\title{
EVOLUCIÓN HISTÓRICA Y TRANSFORMACIONES RECIENTES DE LA AGRICULTURA EN TIERRA DE MEDINA. LA ESPECIALIZACIÓN VITÍCOLA EN LA DENOMINACIÓN DE ORIGEN RUEDA. SERRADA COMO EJEMPLO
}

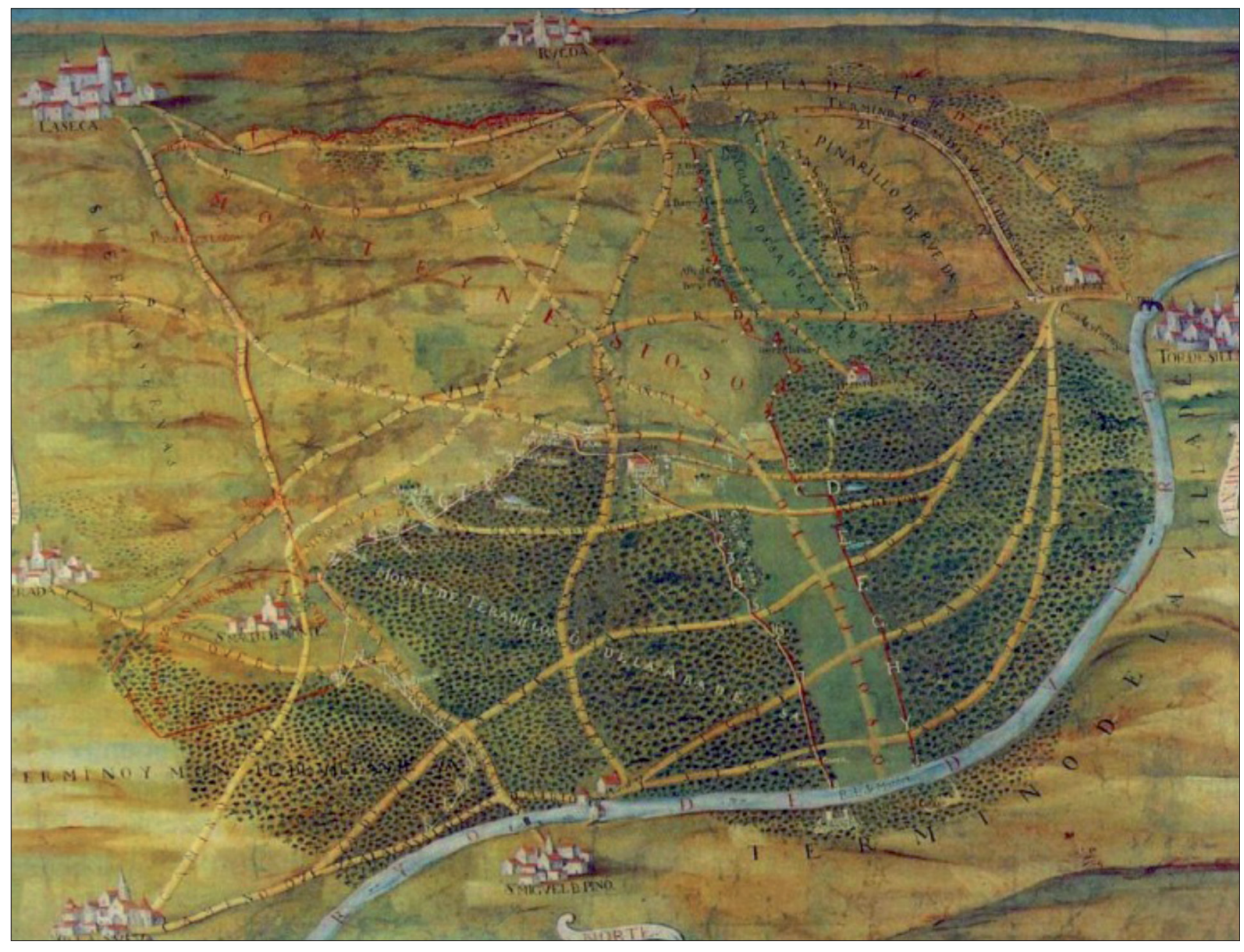

\section{Tomo I}

Trabajo de Tesis Doctoral.

Dirección: Dr. D. Fernando Molinero Hernando.

Doctorando: D. Miguel Esteban de Íscar.

Departamento de Geografía. Universidad de Valladolid.

Marzo de 2015. 


\section{EVOLUCIÓN HISTÓRICA Y TRANSFORMACIONES RECIENTES DE LA AGRICULTURA EN TIERRA DE MEDINA. LA ESPECIALIZACIÓN VITÍCOLA EN LA DENOMINACIÓN DE ORIGEN RUEDA. SERRADA COMO EJEMPLO}

\section{Tomo I}

Trabajo de Tesis Doctoral.

Dirección: Dr. D. Fernando Molinero Hernando.

Doctorando: D. Miguel Esteban de Íscar.

Departamento de Geografía. Universidad de Valladolid. 
Ilustración de portada: Carta topográfica de los términos de Serrada, La Seca y Tordesillas. Óleo sobre lienzo. A. Navarro. Año 1780.

(Ministerio de Cultura. A. R. Ch. V. PLANOS Y DIBUJOS. ÓLEO 0010). 


\section{ÍNDICE}

ARCHIVOS CONSULTADOS Y ABREVIATURAS UTILIZADAS

MEDIDAS TRADICIONALES UTILIZADAS EN ESTA OBRA Y EXTENSIBLES

A BUENA PARTE DE LA TIERRA DE MEDINA

AGRADECIMIENTOS

PRESENTACIÓN, OBJETIVOS Y MÉTODO

CAPÍTULO I. LOS CONDICIONANTES FÍSICOS

DE UN ESPACIO DE TERRAZAS Y CAMPIÑAS AL SUR DEL DUERO MEDIO 27

1. Una localización al sur del Duero medio 29

2. Un relieve de terrazas y campiñas modeladas por los ríos

a. Un relieve de terrazas modeladas por los ríos.

b. El espacio de campiñas de la Tierra de Medina.

3. El clima como condicionante de los cultivos 44

a. La incidencia de las temperaturas en el desarrollo de los cultivos.

- Un ejemplo de helada en viñedo por irradiación nocturna

b. Unas precipitaciones que condicionan el óptimo desarrollo de la actividad agraria.

- La prevención del mildiu, fundamental para garantizar el buen desarrollo de los cultivos. Un ejemplo de estudio en viñedo

4. Montes, suelos y cultivos 80

a. Los montes que dieron paso a las tierras de labor.

b. El suelo, condicionante de los cultivos.

c. El declive de una riqueza vegetal y faunística.

\section{CAPÍTULO II. UNA OCUPACIÓN HUMANA DESDE TIEMPOS}

REMOTOS CON UN APROVECHAMIENTO AGRARIO DE LOS RECURSOS

1. Las huellas prehistóricas y la impronta de las primeras culturas 83

a. La presencia de grupos humanos paleolíticos al sur del Duero.

b. Los primeros agricultores y ganaderos.

- El material cerámico prospectado en el pago de Las Carretas, atribuible a la Edad del Bronce, como ejemplo. 
c. La cultura celtibérica.

d. La presencia romana y la impronta de su cultura.

2. De la época altomedieval al nacimiento y ocupación del espacio por los primeros pobladores cristianos

a. La incierta presencia del pueblo visigodo en el espacio comarcal.

b. El nacimiento de los primeros poblados cristianos al sur del Duero. La Moya, Serrada y San Martín del Monte como ejemplos al norte de la comarca.

- La Moya, una heredad en territorio de Septem Ecclesias, al norte de la Tierra de Medina.

- Serrada, una aldea en los confines de la Tierra de Olmedo.

- La protección de San Martín del Monte por el Monasterio de Santa Clara.

c. La época bajomedieval y el señorío de Serrada en tiempos de los Reyes Católicos.

- La donación de Serrada a Pedro de Silva y a Mencía de Meneses.

- La venta de Serrada en 1487 a Diego Ruiz de Montalvo.

- La fundación de mayorazgo sobre Serrada en 1506 por Ruiz de Montalvo.

\section{CAPÍTULO III. EL CRECIMIENTO DEL TERRAZGO LABRADO EN LOS SIGLOS XVI Y XVII. LA ESPECIALIZACIÓN VITÍCOLA EN EL NORTE DE MEDINA}

1. El aumento del terrazgo labrado en detrimento del espacio comunal.

El caso de las sernas en los montes de propios de Medina

a. La importancia económica de las sernas de Medina del Campo.

b. El reflejo del aprovechamiento de las sernas en el terrazgo.

Del paisaje montaraz al predominio vitícola.

2. La roturación y organización del terrazgo en el norte comarcal en los siglos

XVI y XVII. Ejemplos de roturaciones y aprovechamientos en Serrada

a. El empuje vitícola del siglo XVI.

Un ejemplo de expansión del viñedo en La Moya y Serrada.

- La concesión de mil obradas del mayorazgo de los Montalvo para la plantación de vińas en Serrada.

- La venta a censo del mayorazgo de los Vega de la Moya para plantar majuelos.

- La importancia del viñedo en las disputas por límites y términos:

La Concordia de 1640.

b. Las tierras de pan llevar. El predominio aplastante del arrendamiento.

El ejemplo de Serrada y La Moya.

c. El aprovechamiento de prados y montes.

3. Los sistemas de cultivo y la rentabilidad de las tierras de sembradura y viñedo.

Análisis de una explotación en el siglo XVI

a. Las tierras de sembradura en la segunda mitad del siglo XVI.

Sistemas de cultivo, producciones y rentabilidad.

- El sistema de cultivo.

- La recolección del pan.

b. El viñedo en la segunda mitad del siglo XVI.

Sistemas de cultivo, producciones y rentabilidad.

- La plantación del majuelo. 
- Las labores de arada y cavadura.

- La poda.

- La vendimia, el lagar, las bodegas y las cubas

- La transformación de mostos y la comercialización del vino.

- Una rentabilidad que supera a las tierras de pan.

c. Análisis de una explotación en el siglo XVI.

\section{CAPÍTULO IV. LA CONSOLIDACIÓN DEL ESPACIO AGRARIO EN EL SIGLO XVIII. UN ACERCAMIENTO AL ESTUDIO DE LA RENTABILIDAD AGRARIA}

1. Un terrazgo de tierras de sembradura en cultivo de año y vez

a. La ordenación de los aprovechamientos en hojas de cultivo.

b. El aprovechamiento del terrazgo a mediados del siglo XVIII.

- La gran disparidad de calidades de las tierras de sembradura.

c. La mejora de los sistemas de producción y rentabilidad del cultivo.

- La intensificación del cultivo. El incremento de los retelos.

- El aumento de las labores, del abonado y de la rotación con leguminosas.

- Unas producciones diversas atendiendo a la calidad de la tierra pero, en general, bajas.

- El calendario de trabajos en las tierras de sembradura del siglo XVIII.

2. La importancia del vińedo en el siglo XVIII en Tierra de Medina

a. La especialización vitícola en el norte de la Tierra.

- Ejemplos de las últimas plantaciones en terrenos comunales.

b. El mantenimiento de las técnicas de cultivo. El calendario vitícola.

- Labores de poda, vástigas, plantación e injerto.

- El desmate, el excavo, la cubierta, el reacobijo y los escardes.

El eterno temor a la grama.

- Las vueltas de rama, marzo y mayo. Los sistemas de tracción animal.

- Los avatares metereológicos y el final del ciclo: La vendimia.

- A modo de conclusión: un calendario vitícola con labores en todo el año.

c. El incremento de productividad por el aumento del vińedo de primera calidad.

- Ejemplos de explotaciones vitícolas al norte de Medina.

d. La elaboración del vino. Producciones y mercados a mediados de siglo.

3. La reducida extensión pero importante papel de montes y prados

a. La crítica situación de unos montes que dieron paso a tierras de labor.

- El aprovechamiento y ordenación de pinares y pimpolladas.

Un ejemplo en Villanueva de Duero.

b. La necesaria conservación y aprovechamiento de los pastos.

- Los problemas de los derechos de pasto en los terrazgos comunales. Ejemplos al norte de Medina.

- El incremento y encarecimiento de los arrendamientos particulares.

- Los conflictos en el aprovechamiento de la hoja de las vińas.

4. Una estructura de la propiedad desequilibrada

a. La Seca. Un terrazgo de tierras sernas, labradas por los propios vecinos.

b. La importante propiedad nobiliaria y eclesiástica en Serrada. 
c. Una pequeña villa con los días contados: San Martín del Monte.

d. Rubí de Bracamonte. La importancia del arrendamiento

para dimensionar unas explotaciones predominantemente cerealistas.

5. Un acercamiento al estudio de la rentabilidad agraria

en la segunda mitad del siglo XVIII

a. Un ejemplo de pequeña propiedad: la labranza de Pedro de Íscar en 1743.

b. Un ejemplo de labradores acomodados a finales de siglo: la familia Moyano.

c. Un ejemplo de explotación vitícola capitalizada y rentable:

El Hospital de la Resurrección de Serrada.

- Una comercialización que se adelanta a su tiempo: Del productor al consumidor.

d. Una de las mayores haciendas de la comarca: La casa conventual de San Pablo.

\section{CAPÍTULO V. ORGANIZACIÓN SOCIAL Y VIDA COTIDIANA EN LA EDAD MODERNA. SERRADA, LA MOYA Y SAN MARTÍN DEL MONTE COMO EJEMPLOS DISPARES DE COMUNIDADES CAMPESINAS}

1. El desmembramiento de las comunidades de villa y tierra en los siglos XVI y XVII ..... 348

a. La compra del Privilegio de Villa por Diego Ruiz de Montalvo como ejemplo.

- Las justificaciones de la venta del privilegio de villazgo de Serrada.

- Las tensiones del vecindario y los pleitos por el tanteo del señorío.

b. El fin del lugar de La Moya.

- La vida y trabajos de sus últimos moradores.

- El controvertido poder de sus últimos alcaldes.

- La pervivencia de conflictos derivados de antiguos usos y aprovechamientos comunales.

c. Los avatares de los quince vecinos de San Martín del Monte.

- Las repercusiones de la compra a censo perpetuo del término de San Martín del Monte.

- Las últimas roturaciones y el reparto de tierras y prados entre vecinos.

- Los pleitos con La Seca por el aprovechamiento de sus prados.

2. Una sociedad estamental con una presencia nobiliaria y religiosa

muy importante en el espacio agrario

a. El estamento nobiliario: el ejemplo del marqués de Torreblanca.

b. La importancia del estamento clerical.

El elevado número de casas conventuales en Serrada.

- Una numerosa presencia concretada en notables patrimonios.

- Rentas y diezmos como fuente de riqueza.

Los dominicos como principales perceptores en Serrada.

- Ejemplos y características de casas religiosas asentadas en la villa.

- La casa de la capellanía de Andrés Rodríguez Zorrilla.

- La casa de Francisco Cabo, canónigo de la Catedral de Valladolid.

- La casa convento de las monjas del Corpus Christi.

- La casa del presbitero Pedro Alonso del Arenal.

- La casa grande del Obispo.

3. Las consecuencias espaciales del dinamismo agrario del siglo XVIII.

Serrada como ejemplo 
a. El crecimiento de población y su reflejo en el casco urbano.

- Las casas, lagares, bodegas y paneras de los labradores locales.

- Ejemplos del acomodo de las familias labradoras.

- Las viviendas de los jornaleros.

- Las casas de artesanos, cirujanos, herreros y demás oficios.

- La construcción del Ayuntamiento.

b- La evolución dispar y situación de las iglesias de La Moya, Serrada

y San Martín del Monte.

- El poblado de la Moya y la iglesia de Santa María de los Remedios.

- La falta de impulso de la villa de San Martín del Monte.

De sus continuadas penurias a su abandono y hundimiento final.

- Las dificultades de Serrada por levantar su iglesia.

La accidentada edificación de San Pedro de Serrada.

4. La vida cotidiana. Una necesaria organización interna para garantizar la armonía entre vecinos

a. Las normas de buen gobierno.

b. La casa del concejo. La panera del pósito. La cárcel.

- Localización y características de las casas del concejo en Serrada y San Martín del Monte.

- La importancia de las paneras del pósito en la economía rural.

- La cárcel.

c. Las rentas y la guarda de montes, campos y pastos.

d. Las necesidades de abastos y otros servicios públicos.

- Comprar en la abacería, beber en la taberna, adquirir carne o aprovisionarse de sal.

- Hacer acopio de sal, comprar tabaco o disponer de nieve o hielo.

e. Las necesidades del cuerpo y de la mente: los médicos, los maestros y el escribano.

- La preocupación por la salud y los cirujanos sangradores.

- El maestro de primeras letras.

- El escribano.

- El pago de las contribuciones y el peso de los impuestos.

\section{CAPÍTULO VI. LA CRISIS DEL ANTIGUO RÉGIMEN}

Y LA OBRA DESAMORTIZADORA. CULTIVOS Y RENDIMIENTOS

1. Del Antiguo Régimen al brusco despertar del siglo XIX. La guerra de la Independencia ... 437

a. La incidencia de la Ilustración y las crisis que anteceden a la invasión francesa.

- Las ideas ilustradas en Serrada. La familia Moyano Rodríguez como ejemplo.

- Las luces y sombras de finales de siglo. Las crisis agrarias que anteceden a la invasión napoleónica.

b. La Guerra de la Independencia. Repercusiones en Serrada

y en San Martín del Monte.

c. Las consecuencias del desastre. El reinado de Fernando VII.

- La participación de serradenses en la restauración política y las tensiones y choques durante el absolutismo fernandino.

2. La pervivencia de estructuras precapitalistas en el primer tercio del siglo XIX

El mundo campesino al final del Antiguo Régimen en Serrada. 
a. Las tierras de pan llevar. El predominio del arrendamiento, los flojos rendimientos y el cultivo de año y vez.

- Rentas, producciones y beneficios en las tierras de pan llevar.

b. El cultivo del viñedo al final del Antiguo Régimen.

La irregularidad de las cosechas y el estancamiento de los precios.

- La labranza de las viñas. Labores, producciones y rentabilidad.

- El ejemplo de una explotación vitícola en crisis a finales del Antiguo Régimen.

- La atonía del sector vitícola a finales del primer tercio del siglo XIX.

- Ni el huevo que flota ni el dichoso glaucómetro: Mis mostos son los mejores.

c. Los ganados y el aprovechamiento de los pastos a finales del viejo régimen.

- La hoja de las viñas y las rastrojeras al final del Antiguo Régimen.

- Los pastores y el ganado lanar a comienzos de siglo.

3. El desmantelamiento del Antiguo Régimen. La obra desamortizadora

a. Las primeras medidas desamortizadoras llevadas a cabo durante

el Trienio Liberal (1820-23).

b. La desamortización de Mendizábal. Serrada como ejemplo.

- La desamortización de la Hacienda del Convento de San Pablo, orden de los dominicos.

- Los Conventos de Monjas Brígidas y de Trinitarios Descalzos, un paso más en la desamortización del clero regular.

- La subasta de los bienes seculares. Adiós al patrimonio de curas, cofradías e iglesias.

- La redención de censos y cargas. El foro del Monte de La Moya y la hacienda del Hospital de la Resurrección.

- Los bienes rústicos y urbanos de la comunidad del Sancti-Spiritu.

c. La desamortización de Madoz.

- Llegó la hora de prados y montes.

d. Las consecuencias del proceso desamortizador.

\section{CAPÍTULO VII. LOS CAMBIOS DERIVADOS DE LA REVOLUCIÓN LIBERAL. EL INICIO DE UN CAPITALISMO AGRARIO MONOPOLIZADO POR LA CLASE PROPIETARIA EN LA SEGUNDA MITAD DEL SIGLO XIX}

1. La incidencia de la nueva organización administrativa en tierras vallisoletanas

a. La Diputación Provincial como nuevo órgano de gestión, vigilancia

y control de la vida municipal.

- La nueva adscripción de Serrada al partido de Medina y la definitiva fijación de límites en su ampliado término municipal.

2. Los escasos cambios en las estructuras de propiedad y cultivo de la tierra.

El predominio del arrendamiento como principal forma de tenencia

a. Un terrazgo cultivado por medianos y pequeños labradores.

b. El marqués de Torreblanca y Falces como principal rentista de la villa.

c. La familia De Rojas como gran propietaria absentista y arrendataria.

d. El arrendamiento y gestión del Despoblado de San Martín del Monte.

3. El dinamismo agrario de mediados de siglo

a. Los factores que alientan el despegue: La integración de las producciones

en los mercados, la revolución de los transportes y la política proteccionista. 
b. Evolución y caracteres de los aprovechamientos agrarios en la segunda mitad del siglo XIX.

c. Los pastos y el ganado como soporte básico de la actividad agraria.

- La ordenación de los pastos atendiendo a las necesidades de los cultivos y del ganado de labor.

- Las dificultades del mantenimiento de la ganadería lanar.

4. La evolución y rentabilidad de los cultivos en la segunda mitad del siglo XIX 548

a. La importancia del terrazgo vitícola. El análisis de una explotación vitícola.

- La plantación y crianza de las cepas en los primeros años.

- De las labores de producción a la entrada de los mostos en las bodegas.

- Del pisado de la uva a la transformación de los mostos.

b. Las tierras de sembradura. Cultivos, rendimientos y precios.

- El análisis de una explotación cerealista.

- De la preparación de la tierra al tapado de la simiente.

- De la siega y trilla a la guarda del grano en las paneras.

5. Valoración y resultados de la intensificación agraria.

La superación definitiva del sistema económico del Antiguo Régimen

\section{CAPÍTULO VIII. LA CRISIS AGRÍCOLA Y PECUARIA DE FINALES DE SIGLO.}

1. Los síntomas de la crisis y el agotamiento agroganadero de finales de siglo

a. La toma de posiciones ante la crisis. El abandono de los hombres de negocios. El caso de José María de Rojas.

b. Del endeudamiento de los labradores a las exigencias de los arrendatarios.

c. Una estructura de la propiedad insuficiente para hacer frente a la competitividad que exigen los mercados.

d. Las dificultades de las labranzas en la última década del siglo: la caída de los precios y la pérdida del valor de la tierra.

- La precaria situación de la ganadería lanar.

2. La llegada de la filoxera y la ruina de las explotaciones vitícolas

a. La década dorada de las buenas sacas a regulares precios. 1877-1887.

b. La crisis, el descenso de precios y la adulteración de los vinos.

c. La llegada de la filoxera.

d. Una población no exenta de crisis periódicas y que acusa las dificultades agrarias.

3. La vida municipal en el siglo XIX. Labradores y jornaleros

a. El control político por la clase propietaria.

b. La clase jornalera. De la pobreza secular a la desesperación de finales de siglo.

c. La vida cotidiana. De la solución de los problemas a los problemas sin solución.

- La cabeza rectora: el Ayuntamiento de la villa.

- La relación entre vecinos. Negocios y trabajos. Alegrías y penas.

- Los negocios entre vecinos.

- Momentos de celebraciones y alegrías.

- La otra cara de la moneda. Momentos de dolor y de luto.

La impotencia ante la ignorancia, la sinrazón, el dolor y la muerte.

d. Mirando al futuro. La necesidad de carreteras y la importancia

del agua y de la salud. 
- Caminos y carreteras. El malogrado intento por conectarse a la red ferroviaria.

- La preocupación por la salud pública. La importancia del agua.

El alejamiento de los cementerios de las poblaciones.

- El permanente interés por disponer de maestro de primeras letras.

La escuela de niñas.

\section{CAPÍTULO IX. LA PRIMERA MITAD DEL SIGLO XX. EL FIN DE LA AGRICULTURA Y GANADERÍA TRADICIONALES}

1. Las dificultades agrarias a comienzos del siglo XX.

Los intentos por superar la crisis finisecular

a. Las dificultades de los labradores y el hambre de los braceros.

El asociacionismo agrario. Serrada como ejemplo.

- Las agrupaciones obreras. La Sociedad de Socorros Mutuos "La Paz Social".

- Las agrupaciones de propietarios: La Asociación de Labradores,

la "Liga de Campesinos" y "el Sindicato".

- La "Liga de Campesinos".

- Un ejemplo de incipiente cooperativismo:

La Cooperativa Católico-Obrera de Consumos".

- La Asociación de Labradores de Serrada.

- La "Hermandad Sindical Local de Labradores y Ganaderos".

b. El juego político y la vida municipal. Los intentos por superar la crisis finisecular

- La política municipal en las primeras décadas del siglo XX.

- Unos presupuestos orientados a cubrir las necesidades más perentorias de la población.

- La carrera política y de mediación de Medina Bocos.

- El eterno problema del agua y la salubridad pública.

El nuevo cementerio. La llegada de la luz eléctrica.

- Los niños en la escuela, los soldados en la guerra, los bailes en el Salón y los toros en la plaza.

c. Del enfrentamiento ideológico y la falta de expectativas a la guerra civil.

2. El fin de la propiedad nobiliaria en Serrada

tras quinientos ańos de pervivencia y dominio

a. La venta de los bienes adscritos al antiguo mayorazgo de Serrada

por el marqués de Falces.

b. La compra de las tierras a los herederos de Giraldo y su reparto entre los vecinos de Serrada.

- Los antecedentes de una venta influida por la política agraria de la II República.

- La compra de las propiedades de los herederos de Giraldo

y su reparto en lotes.

- La cuantificación técnica, jurídica y económica de la compra

y reparto realizado.

3. La crisis de la agricultura tradicional. Evolución de los cultivos

y ejemplos de explotaciones en la primera mitad de siglo

a. La lenta, tardía y débil reconstrucción del viñedo.

La pérdida del pulso vitícola en un contexto de crisis general. 
- Producciones en viñedo filoxerado en los primeros ańos del siglo XX.

- Los efectos de la filoxera en la hacienda vitícola de la familia Cantalapiedra.

- La superación de la adversidad. Un ejemplo de replantación de viñedo con barbados americanos.

- El combate de la piral, del mildiu y del oídio a principios de siglo.

b. Las tierras de sembradura y la crisis del modelo tradicional.

- La importancia de las tierras de sembradura en la "batalla del trigo" de los años cuarenta y cincuenta.

- El cultivo de la patata y la remolacha como complemento al aprovechamiento vitícola y cerealista. El surgimiento del regadío y la llegada de la mecanización.

- El desarrollo del regadio, impulsor de los nuevos cultivos.

- La llegada de la mecanización y el empleo de fertilizantes, factores indispensables para afrontar los nuevos cambios.

- La estructura de la propiedad a mediados del siglo XX.

c. Análisis de una labranza a finales de la década de los cuarenta:

Pío de Íscar Hinojal y Paula Moyano Moyano.

- La adquisición de tierra, una "obsesión" del labrador castellano.

- Caracteres de la explotación y cultivos en la primera mitad del siglo XX.

\section{CAPÍTULO X. LA SEGUNDA MITAD DEL SIGLO XX.}

EL SORPRENDENTE EMPUJE INDUSTRIAL, EL IMPULSO DEL REGADIO Y EL RENACER DEL VIÑEDO COMO FACTORES EXPLICATIVOS

1. Las transformaciones agrarias y la evolución de los cultivos

entre los años setenta y ochenta

a. Caracteres y problemas estructurales de las explotaciones agrarias.

- La corrección de un desequilibrio secular. La Concentración Parcelaria.

b. El regadío como base de una agricultura moderna y orientada al mercado.

2. Serrada como ejemplo de las transformaciones agrarias

que tienen lugar en el espacio comarcal

a. Los cultivos de regadío como motores de la actividad agraria.

b. Los avances en la mecanización, fertilización

y productividad de los nuevos cultivos.

c. La falta de Concentración Parcelaria. ¿Una oportunidad perdida?

3. Un acercamiento al análisis de las explotaciones y a su rentabilidad económica 802

a. Explotaciones agrícolas y características a mediados de los años 80 .

a. Un acercamiento al estudio de la rentabilidad agraria en las explotaciones de Serrada de 1985, año previo a la incorporación del sector a la CEE.

- Un ejemplo de gran explotación.

- La mediana explotación. El sacrificio y el trabajo familiar como única salida.

4. Los nuevos motores del desarrollo. El sorprendente empuje vitivinícola.

Serrada y La Seca como ejemplos

a. De la crisis de la filoxera a la consolidación de la industria vitivinícola

- Los últimos cosecheros particulares, la bodega de Martín Hinojal y el espectacular crecimiento de Hijos de Alberto Gutiérrez.

- La Sociedad Cooperativa Agrícola Castellana. 
b. La importancia económica y social de la fábrica de muebles de cocina Lino Alonso

c. La fábrica de quesos como tercer motor industrial de Serrada.

5. La evolución demográfica del último siglo. La singularidad de Serrada en una comarca caracterizada por el envejecimiento y la despoblación

a. El descenso de la población, causado por un fuerte y continuado éxodo rural. La singularidad de Serrada en el contexto comarcal.

b. La modernización del comportamiento demográfico.

c. La estructura de la población. Serrada como ejemplo en el norte de la comarca medinense.

d. Una comarca al límite de la despoblación.

e. El acusado envejecimiento y los recientes aportes inmigratorios como factores a tener en cuenta en el espacio local y comarcal.

\section{CAPÍTULO XI. TRANSFORMACIONES RECIENTES EN EL NORTE DE LA TIERRA DE MEDINA. LA INCIDENCIA DE LA PAC Y EL EMPUJE DEL VIÑEDO}

1. La importancia del carácter agrario en el espacio comarcal.

La evolución de los cultivos en las últimas décadas

a. Los cultivos de regadío como dinamizadores de las explotaciones agrarias.

- La pérdida de importancia de la remolacha en los regadíos comarcales

y el incremento de los cultivos hortícolas.

b. Los cultivos de secano, complemento del regadío y viñedo

en las explotaciones de la comarca.

2. El impacto de la aplicación de la P.A.C. y sus repercusiones

en las explotaciones agrarias

a. La importante cuantía y repercusión de las ayudas recibidas.

b. La incidencia de la PAC en la distribución de los cultivos.

3. El empuje del vińedo y de la industria vitivinícola al amparo

de la Denominación de Origen Rueda

a. La situación del sector vitivinícola en el norte comarcal en los ańos setenta y ochenta. Los antecedentes de la Denominación de Origen Rueda.

b. El nacimiento de la Denominación de Origen Rueda y su papel fundamental en el dinamismo económico de la comarca.

c. El extraordinario crecimiento de la D.O. Rueda en las últimas décadas.

- Una industria vitivinícola muy dinámica en los momentos presentes.

d. La evolución del cultivo y de las explotaciones vitícolas. Serrada, La Seca y Rueda como ejemplos en un espacio donde el vińedo vuelve a ser el cultivo por excelencia.

- La pervivencia del cultivo tradicional hasta la década de los años ochenta.

- El espectacular aumento de superficie del vińedo desde la década de los noventa hasta la actualidad.

- Las nuevas prácticas culturales derivadas de la revolución técnica.

- El aumento de superficie de las explotaciones vitícolas.

\section{CAPÍTULO XII. LA AGRICULTURA E INDUSTRIA VITÍVINÍCOLA EN SERRADA EN LA ACTUALIDAD. ANÁLISIS DE EXPLOTACIONES TIPO Y CARACTERES \\ DE LA INDUSTRIA VÍNICA. LAS CONSECUENCIAS ECOLÓGICAS Y CULTURALES DE LAS TRANSFORMACIONES AGRARIAS}

1. El declinar del regadío y el auge del viñedo, como caracteres

fundamentales de la agricultura local. 
a. Un cultivo de regadío tradicional en dificultades por sus grandes oscilaciones de precios: la patata.

- El retroceso de un cultivo de regadío tradicional.

- La sociedad Augusto Pajares, S.L., como ejemplo de empresa productora y comercializadora en Serrada.

- La evolución de un cultivo con costes de producción muy elevados y fuertes oscilaciones de precios.

b. Análisis y evolución de una explotación familiar típica, 1960-2014.

- La evolución de los cultivos. La expansión del regadío.

- La influencia de la PAC y la especialización vitícola.

c. Evolución y caracteres de una gran explotación en el norte de la comarca.

- Un crecimiento espectacular en capital tierra resultado de las actividades agrarias, comerciales e industriales.

- La rentabilidad de los cultivos, clave para entender su evolución.

2. El surgimiento de nuevas bodegas, que acompañan a las históricas, como prueba del dinamismo vitivinícola actual

a. El espectacular crecimiento de Agrícola Castellana

b. La modernización productiva y vocación vitivinícola de Hijos de Alberto Gutiérrez

c. Bodegas Val de Vid, S.L, un ejemplo de bodega volcada en los mercados exteriores

d. La necesidad de unirse para afrontar el futuro: Diez Siglos de Verdejo, S.L.

e. La sorprendente visión empresarial de Miguel M. Gutiérrez: DALMADEL, S.L.

y Servicios Vinícolas HUGAD, S.L.

f. La apuesta de primeras marcas nacionales por la D.O. Rueda. El ejemplo

de Bodegas Marqués de Cáceres en Serrada.

3. Las consecuencias ecológicas y culturales de las transformaciones agrarias.

La pérdida de biodiversidad y de patrimonio histórico

a. La pérdida de humedales y la degradación de los hábitats asociados a los mismos.

b. La transformación del paisaje y la pérdida de biodiversidad asociada a la agricultura.

- El empleo de plaguicidas y fitosanitarios, principales responsables de la pérdida de biodiversidad. Los ejemplos de la avutarda, el chotacabras y el alcaraván.

- La mecanización, tecnificación y modernización de cultivos, responsables de un nuevo dibujo paisajístico. La conducción en espaldera del viñedo como ejemplo.

c. El reconocimiento de un patrimonio cultural de indudable valor.

- La importancia de la arquitectura tradicional y de los archivos familiares, claves para conservar el patrimonio cultural.

- El valor de un paisaje transformado por el ser humano.

- El mantenimiento de las tradiciones, otro ejemplo de patrimonio cultural diferenciador de las comunidades rurales. 


\section{Archivos consultados y abreviaturas utilizadas}

A.G.A.: Archivo General de la Administración.

A.H.P.V.: Archivo Histórico Provincial de Valladolid.

A.M.A.: Archivo del Ministerio de Agricultura. Madrid.

A.C.P.: Archivo de la Catedral de Palencia.

A.D.V.: Archivo de la Diputación de Valladolid.

A.G.D.V.: Archivo General Diocesano de Valladolid.

A.C.S.: Archivo Catedralicio de Salamanca.

A.C.V.: Archivo de la Catedral de Valladolid.

A.M.V.: Archivo Municipal de Valladolid.

A.G.S.: Archivo General de Simancas.

A.R.Ch.V.: Archivo de la Real Chancillería de Valladolid.

A.H.N.: Archivo Histórico Nacional. Madrid.

B.N.: Biblioteca Nacional. Madrid.

A.G.P.M.: Archivo General de Protocolos de Madrid.

A.D.P.H.V.: Archivo de la Delegación Provincial de Hacienda de Valladolid.

A.M.M.: Archivo Municipal de Medina del Campo.

A.R.P.M.C.: Archivo del Registro de la Propiedad de Medina del Campo.

A.M.H.C.R.R.: Archivo del Ministerio de Hacienda. Catastro de Riqueza Rústica.

A.U.V.: Archivo Universidad de Valladolid.

A.M.L.S.: Archivo Municipal de La Seca.

A.M.V.D.: Archivo Municipal de Villanueva de Duero.

A.M.S. Archivo Municipal de Serrada.

A.C.R.D.O.R.: Archivo del Consejo Regulador de la Denominación de Origen Rueda.

A.B.H.A.G.: Archivo Bodegas Hijos de Alberto Gutiérrez..

A.F.M.L.A.: Archivo Fábrica de Muebles Lino Alonso.

A.F.M.: Archivo Familia Muelas.

A.C.A.L.S.: Archivo Cámara Agraria Local de Serrada.

A.A.C.S.C.: Archivo Agrícola Castellana, Sociedad Cooperativa.

A.F.A.M.: Archivo familia Alonso Moyano.

I. R. A.: Instituto de Reforma Agraria.

C.O.S.A.: Cámara Oficial Sindical Agraria.

IRYDA.: Instituto de Reforma y Desarrollo Agrario.

SENPA.: Servicio Nacional de Productos Agrarios.

INDO.: Instituto Nacional de Denominaciones de Origen.

C.R.D.O.R.: Consejo Regulador de la Denominación de Origen Rueda.

Ms.: Manuscrito.

Leg.: Legajo.

Ob. cit.: Obra citada.

Carp.: Carpeta.

Pág. o págs.: Página o páginas.

Nota: en el caso de otros archivos de menor entidad, sobre todo familiares, se han especificado sus nombres conforme se han consultado los fondos que alberga.

En el proceso de transcripción se ha cuidado la fidelidad al texto original, respetando tanto su contenido como su estilo. La grafía original se ha mantenido en su mayor parte, siguiendo el sistema actual de separación de palabras y acentuación. 


\section{Medidas tradicionales utilizadas en esta obra y extensibles a buena parte de la tierra de Medina}

\section{Medidas de superficie}

a. Tierras de sembradura

Obrada. Equivalente a 400 estadales cuadrados. Cada estadal cuadrado equivale a $14,15 \mathrm{~m}^{2}$, es decir, a un cuadrado de 4,5 varas castellanas de lado. Una obrada equivale a 0,5659 ha (5.659 metros cuadrados).

\section{b. Tierras de viñedo}

Aranzada. En Serrada, La Seca o Rueda acogen 420 cepas; en la Moya, en el siglo XVII, se cifra en 500 cepas cada aranzada; en Villanueva y Valdestillas encontramos aranzadas de 440 cepas. La aranzada equivale, de forma aproximada, a tres cuartas de obrada, o 0,42 ha.

\section{Medidas de capacidad}

\section{a. En cereales}

Carga. Equivalente a cuatro fanegas.

Fanega. Medida de capacidad de unos 55,5 litros aprox. El peso de cada fanega depende de la granazón del cereal estimándose, por regla general, que la fanega de trigo pesa unos 44 kilogramos; la de la cebada caballar, unos $33 \mathrm{~kg}$ y el centeno, otros $44 \mathrm{~kg}$. Hemina. Equivalente a $1 / 8$ de carga o media fanega.

Celemin. Equivalente a 1/12 parte de fanega.

\section{b. Otros sólidos}

Arroba. Equivale a $11,502 \mathrm{~kg}$.

Libra. Es una 1/25 parte de arroba, o 0,460 kilogramos.

Onza. Equivale a $1 / 2$ de libra, o 287 gramos.

\section{c. Líquidos}

Moyo. Equivalente a 16 cántaras o 258,128 litros ${ }^{1}$. Cada cántara equivale a 16,133 litros. Azumbre. Equivalente a 1/8 de cántara, o 2,016 litros.

Cuartilla. Es 1/4 de cántara, o 4,033 litros.

Cuartillo. Equivalente a $1 / 4$ de azumbre, o 1,008 litros.

Está comúnmente aceptado que de $23 \mathrm{~kg}$ de uva ( 2 arrobas) se obtiene un cántaro de mosto (16 litros).

\section{Medidas de longitud}

Pie. Equivale a 0,278 metros.

Vara castellana. Equivale a tres pies, o 0,836 metros.

Cuarta. Son cuatro varas, o 3,345 metros.

Legua. Equivale a 5.572,7 metros lineales.

\footnotetext{
${ }^{1}$ En tiempo histórico las cosechas de uva también se cuantifican en moyos, o conjunto de ocho "cestos" repletos de uva, con una capacidad aproximada de ochenta kg cada uno. En cada carro se transportan ocho cestos por lo que se identifica un moyo con un carro que, por otro lado, era lo que venía dando una aranzada de producción un ańo con otro.
} 



\section{Agradecimientos}

Me es imposible citar en breves líneas a cuantas personas e instituciones han colaborado en este trabajo, cuyos inicios se remontan a 1984. En estos treinta años soy deudor de los profesores del Departamento de Geografía de la Universidad de Valladolid en aquellos años ochenta, no sólo por la formación y el aprendizaje recibido, sino también por las vivencias compartidas, siempre entrañables y duraderas.

A ellos deben sumarse muchos compañeros que he tenido en la tarea docente, geógrafos e historiadores de enorme valía y vocación, que me han dedicado su tiempo y ayudado a comprender mejor la interacción entre el espacio, el tiempo y el ser humano. Sus consejos, generosidad y disposición sobrepasan cualquier palabra de agradecimiento. A lo largo del presente estudio aparecen sus nombres y la deuda que esta obra tiene con todos ellos es impagable.

Analizar la evolución de una comunidad agraria, en un espacio concreto y a lo largo del tiempo, era un trabajo pendiente de abordar en el citado Departamento. Desde aquellos años nunca nos ha faltado la ilusión y la disposición para llevarlo a término, a quien escribe y al doctor Molinero Hernando, director de la presente tesis. Dicho proyecto requería reflexión, años de investigación, mayor formación y madurez en mi caso y, además, una vez acotado el espacio, una indispensable búsqueda de fuentes más allá de los archivos convencionales, en los que me he sentido como en mi propia casa, especialmente en el Archivo Histórico Provincial de Valladolid.

Igualmente, apenas puedo encontrar palabras para mostrar mi gratitud a cuantos vecinos de Serrada y comarca me han ayudado en las tareas de prospección de campo y abierto sus casas para buscar documentos que pudieran arrojar luz sobre el análisis de sus explotaciones agrarias en tiempo histórico. ¡Cuántos tópicos sobre el campesinado castellano he podido comprobar por falsos y qué enorme generosidad me han mostrado a lo largo de estos años!

Por último, he de manifestar que compaginar la docencia, la actividad agraria y la investigación académica, ha sido tan sacrificado como motivador para poder realizar el trabajo. La ayuda de mi familia ha resultado esencial en este empeño. Es razón suficiente para que les dedique esta tesis. A mis padres, por inculcarme desde niño la pasión por el campo y la necesidad del trabajo diario para conseguir cualquier meta; a Pilar, mi mujer, por su apoyo, sacrificio y paciencia infinita a lo largo de estos años; también a mi hermano, Ángel Carmelo, por realizar muchas tareas agrícolas sin mi ayuda, a fin de que pudiera disponer de más tiempo para la investigación. En este sentido nos conformaríamos con que nuestros hijos, al igual que los de su generación, tuvieran la inquietud por conocer el pasado de las comunidades agrarias de las que formaron parte sus antepasados, dando por hecho, no sin cierta tristeza, que muchos de ellos apenas añorarán la tierra, estén cerca o lejos de ella, elemento vital sobre el que ha girado nuestra vida y, desde siglos, la del mundo rural que hemos estudiado. 


\section{Presentación, objetivos y método}

Esta obra es fruto de un largo camino de trabajo y evolución profesional. En el otoño de 1984, como estudiante de cuarto curso de Geografía en la Universidad de Valladolid, el Dr. Molinero Hernando, profesor de Geografía Agraria, me propuso llevar a cabo una investigación sobre Serrada (Valladolid), pueblo del que soy natural. Nos llamaba la atención la vitalidad socioeconómica de determinados núcleos rurales del centro y sur de la provincia, frente a otros que, ya por entonces, presentaban una preocupante situación y un incierto porvenir. El propio título de aquel primer acercamiento era revelador en este sentido: "Serrada, la dinámica singular de una comunidad agraria de Tierra de Medina".

Sin resultar pretencioso, siempre pensé que aquel primer trabajo debía ser revisado, ampliado $\mathrm{y}$ analizado en profundidad. En este sentido han sido varios los factores que me han impulsado a acometer dicha tarea. En primer lugar, fruto de la actividad agraria que compagino con la docente en la comarca de Medina, me ha interesado estar actualizado y documentado sobre los importantes cambios del propio sector. En segundo lugar, impartir la asignatura de Historia en estos años ha añadido a mi formación geográfica de base una elemental preparación histórica, esencial para adentrarse en esta disciplina y, especialmente, en el apasionante mundo de los archivos públicos y particulares. No deseo extenderme en destacar mi debilidad por el mundo campesino tradicional y por las profundas transformaciones que ha sufrido a lo largo del siglo XX.

El problema era entonces determinar un marco espacial que me permitiera reconstruir de forma rigurosa la evolución de estas comunidades campesinas desde sus inicios hasta los momentos presentes. Veinte años después, me he vuelto a sentir alumno de mis antiguos "maestros" del Departamento de Geografía e interesado lector, nuevamente, de sus valiosos estudios regionales que vieron la luz en aquellos años setenta y ochenta ${ }^{2}$. Aun así, mis dudas en relación con el espacio que había que acotar eran permanentes. Mi interés por investigar la evolución del norte de la Tierra de Medina, tomando como referencia Serrada y sus términos limítrofes, crecía tanto más cuanto que en estas décadas volvía a ser centro de sus quehaceres el viñedo de una forma tan dinámica como ya lo fuera en anteriores siglos, pero me resultaba demasiado heterodoxo encuadrar la investigación como

\footnotetext{
${ }^{2}$ La obra del profesor y maestro de geógrafos D. Jesús GARCÍA FERNÁNDEZ es de obligado reconocimiento. Desde muy temprano sus clases magistrales, apuntes inéditos y obra publicada sirvieron de base científica y estímulo investigador a no pocas generaciones de geógrafos. Entre los estudios que destacan en relación con el espacio agrario regional cabe mencionar: Sobre la "agricultura de grupo" en Castilla la Vieja, el caso de un pueblo organizado en régimen cooperativo. Valladolid, Universidad de Valladolid, Departamento de Geografía, 1970; Organización del espacio y economía rural en la España atlántica. Madrid, Siglo Veintiuno, 1975; Desarrollo y atonía en Castilla. Barcelona, Ariel, 1981; Castilla (entre la percepción del espacio y la tradición erudita). Madrid, Espasa-Calpe, 1985,...

Su preocupación por ahondar en el estudio del espacio regional, bien en sus áreas de llanura como en las de las montañas de la región, “... que todavía son más ignotas que aquellas”, tal como dejó escrito en el prólogo del I Congreso de Geografía de Castilla la Vieja y León (Burgos, mayo de 1981) será continuado por no pocos de sus discípulos, a su vez, maestros de generaciones de estudiantes de Geografía. Baste citar, en este sentido, algunos nombres y obras, imprescindibles para el conocimiento del agro regional: ORTEGA VALCÁRCEL, J.: La transformación de un espacio rural: las montañas de Burgos. Estudio de Geografía Regional. Universidad de Valladolid, 1974; MOLINERO HERNANDO, F.: La tierra de Roa. La crisis de una comarca vitivinicola. Universidad de Valladolid, 1979; MANERO MIGUEL, F: Valdivieso: Una comarca de la Montaña de Burgos. Valladolid, Universidad de Valladolid, 1972; PEÑA SÁNCHEZ, M.: Crisis rural y transformaciones recientes en Tierra de Campos: estudio geográfico del sector noroeste. Valladolid, Universidad de Valladolid, Departamento de Geografía, 1975; MARTÍN GALINDO, J. L.: Arcaísmo y modernidad en la explotación agraria de Valdeburón. Valladolid, Departamento de Geografía, Instituto Juan Sebastián Elcano, 1969; CABALLERO FERNÁNDEZ-RUFETE, P.: Propiedad y explotaciones agrarias en un sector del suroeste vallisoletano. Valladolid, Universidad de Valladolid, 1987; ALARIO TRIGUEROS, M: Significado espacial y socio-económico de la Concentración Parcelaria en Castilla y León. Universidad de Valladolid, 1990; BACHILLER MARTÍNEZ, J. M.: Transformaciones socioeconómicas y ordenación del territorio en el sudoeste soriano. Universidad de Valladolid, 1993; BARAJA RODRÍGUEZ, E.: Expansión del cultivo remolachero y de la industria azucarera en la Cuenca del Duero. Universidad de Valladolid, 1994.
} 
un estudio regional en tan minúsculo soporte físico. También, por qué no decirlo, me retraía la existencia de otras investigaciones muy meritorias que ya habían realizado geógrafos e historiadores de prestigio sobre aspectos concretos o generales de la comarca en que deseaba profundizar la investigación ${ }^{3}$.

Sin embargo, cuantas prevenciones anoto se transformaron en energías positivas en los últimos años. El pasado 2005, con motivo de la realización de los cursos teóricos de Doctorado, hice partícipe nuevamente de mis inquietudes a mi tutor, el Dr. Molinero Hernando. Como hiciera hace más de veinte años, no dudó en animarme a seguir adelante. El descubrimiento de documentación rigurosa y de distintas épocas sobre Serrada y el norte de la Tierra de Medina en archivos públicos, e inédita en archivos privados en relación a cultivos, rendimientos, costes de producción... me decidió a iniciar un proceso de análisis preciso y continuado sobre la evolución de la vida campesina en este reducido espacio. A ello se unió el descubrimiento de vestigios prehistóricos cuyo estudio puede contribuir a completar lo ya conocido en el centro de la Meseta. La existencia, en las 2.495 ha que componen el actual término de Serrada, de dos antiguos despoblados, así como de la permanencia muy duradera de importantes señoríos laicos y religiosos sobre dicho terrazgo, nos proporcionaba un aliciente ańadido para indagar en el pasado de las sociedades campesinas que a ellos estuvieron sujetas. La investigación fue tomando forma y fue leída en octubre de 2006 en la Universidad de Valladolid como trabajo de investigación tutelado de Tercer Ciclo, bajo la dirección del citado Dr. Molinero Hernando. Llevó por título Evolución histórica y transformaciones recientes en el norte de la Tierra de Medina.

En dicho trabajo son protagonistas las comunidades campesinas que, a lo largo de distintas épocas, hicieron suyo el espacio; los aspectos estructurales que condicionaron su existencia y cómo evolucionaron técnicas de cultivo, condiciones de vida y relaciones con el entorno próximo o lejano. Estudiamos la actividad agraria y a sus protagonistas desde tiempos pretéritos hasta los momentos presentes; desde aquellos "...pobres e lazerados e viejos e cansados... que cavando e trabajando con sus cuerpos... para su solo mantenimiento non les basta..." hasta que sus "descendientes" actuales dirijan modernizadas explotaciones agrarias o ya no les unan al campo más ataduras que el lugar que les vio nacer".

En la presente investigación trataré de ampliar y completar lo realizado interesándome, especialmente, por la evolución y cambios experimentados en la estructura de la propiedad de la tierra, analizando ejemplos de dicha evolución y de la forma en que han ido arraigando los distintos cultivos. Es mi intención estudiar, bien una explotación real en cada una de las distintas épocas históricas, bien una explotación tipo, de acuerdo al material archivístico recabado al efecto. Soy consciente de la dificultad que conlleva tamaña labor, pero sólo así podré acercarme de forma precisa al mundo real campesino de estos espacios al sur del Duero medio.

El objetivo que me propongo estudiar es, pues, la evolución del mundo campesino en un espacio concreto a lo largo del tiempo; las interrelaciones entre hombres y medio y cómo las distintas

\footnotetext{
${ }^{3}$ Destaca y ha sido un referente obligado en todos los estudios posteriores que han abordado el análisis de las sociedades rurales la obra de A. HUETZ DE LEMPS: Vignobles et vins du Nord-Ouess de l'Espagne. Burdeos, Institut de Geographie, Faculté des Lettres, Burdeos.1967, 2 vols.; El viñedo de la Tierra de Medina en los siglos XVII y XVIII. Estudios Geográficos, no 74. Traducción: J. García Fernández.1959 y Principales aspectos de los viñedos del Sur de la Cuenca del Duero. Estudios Geográficos, no 86. 1962. Del mismo modo y, en concreto, en lo que atańe a la comarca medinense, es de destacar la obra Historia de Medina del Campo y su Tierra, coordinada por Eufemio Lorenzo Sanz. Valladolid, 1986. El presente trabajo es deudor de aquellos apartados que hacen referencia al sector agrario, especialmente de las notables aportaciones de H. PASCUAL GETE. Su Memoria de Licenciatura: El viñedo en la antigua "Tierra de Medina del Campo". Departamento de Geografía, Universidad de Valladolid, 1973, ha sido otra obra de notable interés que hemos consultado.

${ }^{4}$ Cortes de los antiguos reinos de León y Castilla, publicadas por la Real Academia de la Historia. Tomo III, Madrid, 1986, Cortes de Valladolid de 1447, pág. 498. (Citado por MARTÍN CEA, J. C.: El Campesinado de la Cuenca del Duero (S. XIII-XV). Junta de Castilla y León, Valladolid, 1986, pág. 38.
} 
coyunturas económicas y de evolución técnica generan cambios en las comunidades humanas y en el propio espacio rural. Sólo adentrándonos en la economía doméstica de las familias de labradores y jornaleros, en su vida cotidiana, en la dimensión de sus explotaciones y relacionando la rentabilidad de sus quehaceres con el marco económico que caracteriza a las distintas etapas históricas, podremos comprender las variaciones del terrazgo cultivado, el arraigo de unos u otros aprovechamientos, la salida o llegada de grupos humanos a las distintas poblaciones que se reparten por el espacio estudiado y, en fin, entender de forma integral el cómo, el cuándo y los porqués de los cambios vividos.

Como veremos, en este análisis de las sociedades campesinas de la Tierra de Medina, de su evolución histórica y transformaciones recientes, entre los distintos aprovechamientos que trataremos destaca el del vińedo, especialmente en el norte de la comarca. Centrará nuestra atención por haberse constituido a lo largo del tiempo como un verdadero motor del desarrollo rural, atracción para inversores foráneos en distintas épocas, protagonista indispensable a la hora de analizar dinámicas demográficas y económicas y, en la actualidad, cultivo fundamental que ha vuelto a impulsar la vida de los municipios que se reparten en el norte del espacio estudiado. He aquí una de las claves para entender el espacio agrario que hemos estudiado y que constituye nuestra tesis fundamental: la agricultura ha evolucionado conforme ha variado la demanda y rentabilidad de los distintos aprovechamientos a lo largo de los siglos y ello ha influido, de forma decisiva, en la ocupación y transformación del espacio por el hombre.

La Tierra de Medina nos ha servido de marco espacial para estudiar diacrónicamente los cambios producidos a lo largo del tiempo en su espacio agrario y, en concreto, la evolución de su agricultura desde que se empuñaran por primera vez azadas para desbrozar el terreno y sembrar cereales. Desde entonces, y hasta la actualidad, las sociedades agrarias que han labrado y poblado sus campos han ido dejando su huella tanto en el terrazgo labrado como en los espacios incultos que aún hoy permanecen indemnes al arado. Al profundizar en esta evolución, tomando a Serrada como ejemplo, hemos estudiado en detalle la labor del campesino en tiempo histórico, el peso de la tradición y su obsesión por disponer de tierra en propiedad para dejar a los suyos un mejor camino de futuro... Estas estructuras históricas son las que sustentan el esqueleto de un paisaje agrario que, desde hace décadas, parece rendirse a la tecnología pero sigue fiel a los primeros aprovechamientos en su dibujo parcelario y con similar dependencia de los condicionantes físicos. El ser humano que lo habita, igualmente, es heredero del quehacer histórico y de unas estructuras productivas que han ido modernizándose pero, en muchas campańas, sigue tan inseguro ante los mercados como necesitado de buenas cosechas.

Un vez delimitado el espacio, precisado sus características físicas y llegados los grupos humanos que dejaron sus huellas, hemos iniciado un análisis detallado de la evolución que se produce en este espacio agrario desde comienzos de la Edad Moderna. Lejos del tópico del inmovilismo de las comunidades campesinas, cada siglo nos ha sorprendido con importantes transformaciones, que han ido modelando el paisaje y ańadiendo nuevos elementos al legado histórico: las grandes roturaciones del espacio montaraz en los siglos XV y XVI; el arraigo del viñedo en los suelos de terraza y el reparto en hojas de cultivo de las tierras de pan en el siglo XVII; el desembarco de las órdenes religiosas en el siglo XVIII; la incidencia del proceso desamortizador en el siglo XIX; las crisis de fin de siglo y la hecatombe que provoca la filoxera a comienzos del XX; los profundos cambios y transformaciones que se viven en el siglo XX...

Aun a riesgo de ser reiterativo es imposible entender nuestra agricultura de hoy si no conocemos su pasado y el de las comunidades que hicieron suyo cada aranzada de viñedo, cada obrada de sembradura, cada bodega que excavaron. El método seguido, en este sentido, no podía ser otro que el método histórico basado en la obtención de información contrastada, procedente de variadas fuentes archivísticas y el apoyo en estudios, publicados e inéditos, de historiadores de prestigio relacionados con el tema que planteamos. 
Como precisaré en el siguiente apartado introductorio, el marco espacial en el que he trabajado sobrepasa el marco jurisdiccional que tradicionalmente configuraba la llamada Tierra de Medina. Aún así, como veremos a lo largo del trabajo, cabe diferenciar dentro de ella y desde un punto de vista agrario, la especialización vitícola que ha caracterizado históricamente el sector de terrazas situado al norte de la Tierra, del espacio de campiñas al sur de la Villa de las Ferias, por lo general, con una vocación más cerealista y más dependientes de la cabecera comarcal. Por otra parte, me resulta cuando menos atrevido calificar de regional un trabajo que, básicamente, se centra en la actividad agraria de un espacio "comarcal". Sin embargo, no es menos cierto que no han sido estos avatares metodológicos los que más me han preocupado a la hora de desarrollar la investigación. En este particular siempre me he sentido confortado una y otra vez leyendo la presentación y justificación que el profesor Ortega Valcárcel hacía, al respecto, al comienzo de su modélica tesis doctoral: "la entidad región ha sido aplicada lo mismo a dimensiones continentales que a minúsculas parcelas territoriales; a un espacio natural que a un conglomerado histórico, político administrativo. La región, muchas veces, cuando se trata de definirla, resulta ser todo y nada al mismo tiempo. Es inútil ir en su busca; es tan huidiza como los criterios que la definen"s.

Y, de la misma manera, si también, quizá en exceso, he buceado en el tiempo histórico para explicar la realidad geográfica, ha sido porque desde siempre me lo inculcaron todos mis profesores del Departamento de Geografía en la primera mitad de los años ochenta, tanto en sus clases como en su obra escrita y, sea fruto de aquella formación, sea por mi actividad docente ligada también a lo "histórico", lo siento como algo único e interrelacionado con el espacio y el hombre, el tiempo y lo geográfico, el pasado y el presente. El propio Huetz de Lemps, en 1967, conjugaba ambos factores de forma indisoluble para explicar la realidad vitícola del noroeste español: "La diversidad de condiciones atmosféricas y la complejidad de la evolución histórica no son suficientes para explicar toda la originalidad de los viñedos del noroeste de España... Los viticultores han tenido que luchar por mantener y desarrollar sus plantaciones frente a numerosos enemigos, y las plagas han sido, en ocasiones, menos temibles que las rivalidades humanas...".

Soy consciente, por último, de los riesgos que conlleva una investigación como la que propongo, realizada sobre un marco geográfico relativamente reducido. Para evitar caer en localismos estériles, en todo momento he relacionado los hechos estudiados con los acaecidos en los espacios limítrofes. La información que hace relación a personas o hechos muy detallados se ha situado en líneas al pie, al entenderlo más práctico que en anexos finales. Con todo, me siento reconocedor de tal exceso aunque, si mutamos los hombres y topónimos que se repiten en este trabajo por otros de la vieja Castilla de las llanuras, encontraremos semejanzas notabilísimas hasta extender y hacer válidas las tesis expuestas a horizontes mucho más amplios. Aún así, me considero deudor de la ortodoxia que debe presidir el método y análisis del estudio geográfico regional ${ }^{6}$. Espero que se disculpe tamaña falta por mi querencia en detallar, quizá en exceso, la evolución de la comunidad agraria de la que formo parte y los cambios que ha experimentado su terrazgo labrado. Con estos planteamientos, hemos procedido al estudio de la Tierra de Medina que, desde su origen, ha gozado de una personalidad muy definida.

La Comunidad de Medina, que acogía en tiempo histórico hasta medio centenar de lugares poblados, limitaba al oeste con el reino de León; al sur con la comunidad de Arévalo, al este con la de Olmedo, y al norte con las tierras de la merindad del Infantazgo de Valladolid. ${ }^{7}$ La repoblación medieval organizaba las tierras al sur del Duero en Comunidades de Villa y Tierra, que integraban administrativamente la llamada Extremadura castellana. La Villa de las Ferias siempre

${ }^{5}$ ORTEGA VALCÁRCEL, J.: La transformación de un espacio rural: las montañas de Burgos..., ob. cit., pág. 9.

${ }^{6}$ HUETZ DE LEMPS, A.: Vinos y viñedos de Castilla y León. Valladolid, Junta de Castilla y León, 2001, pág. 15.

${ }^{7}$ MARTÍNEZ DÍEZ, G.: "La Comunidad de Villa y Tierra de Medina”, en Historia de Medina del Campo y su Tierra. Coordinador: Eufemio Lorenzo Sanz, vol. I, Ayuntamiento de Medina del Campo y otros, Valladolid, 1896, pág. 159 y ss. 
se ha constituido como centro administrativo, político y económico del espacio bajo su jurisdicción. Actualmente sigue desempeñando tal función, si bien algunos de los núcleos de población más periféricos como Alaejos, Sieteiglesias o Pollos, varían su dependencia atendiendo a razones de cercanía o existencia de vías de comunicación que los vinculan también a otros centros comarcales y de servicios, tales como Tordesillas, Toro o Salamanca.

Si se atiende a criterios geográficos, el espacio se inscribe en las llanuras y campiñas meridionales que se extienden al sur del Duero y que, pese a su apariencia, encierran no poca complejidad morfogenética, sea si tratamos de explicar los relieves aluviales inversos, recortados por el Adaja, Zapardiel, Trabancos y arroyos afluentes del Duero al norte de la Tierra, sea si queremos precisar el modelado sobre arcillas arenosas y arenas miocenas que se extienden por el sur de la provincia. Con todo, el espacio vinculado a Medina del Campo desde un punto de vista agrario y poblacional rebasa, a nuestro entender, el propio marco "histórico" que se acaba de mencionar, especialmente y por distintas causas, en su sector nordeste y sureste. En el primer caso los términos de Serrada, Villanueva de Duero, Valdestillas, Ventosa y Matapozuelos continúan hasta el río Adaja el entramado de terrazas de gravas que distinguen a Rueda y La Seca y que son aprovechadas por el viñedo, confiriendo a este norte comarcal una acusada personalidad ${ }^{8}$. Distinto es el caso de los pequeños núcleos al sureste y suroeste de la "histórica" Tierra de Medina. Pueblos como Ataquines, Ramiro, Lomoviejo, Torrecilla de la Orden o Salvador de Zapardiel han sentido siempre a la citada villa como su centro "natural" de servicios, más en los momentos actuales, pues el envejecimiento parece comprometer el futuro y la agricultura cerealista, predominante en ellos, está lejos de crear dinamismos endógenos, fijar población e incentivar crecimiento demográfico alguno.

Estas consideraciones, teniendo presente el marcado carácter agrario del espacio mencionado, nos han llevado a ampliar el área de estudio, por homogéneo e interesante, en cuanto a las dinámicas agrarias contrapuestas que en él se perciben, hasta 38 municipios que suman 158.124 ha de las 814.961 ha que catastra la provincia de Valladolid. Medina del Campo es, para la mayor parte de ellos, su centro comarcal por antonomasia, con suficiente talla urbana, poblacional y de servicios para que todos se sientan atendidos en sus necesidades vitales, factores estos siempre argumentados como necesarios en la organización del territorio9. De hecho, en el año 2012 la Villa de las Ferias sumaba 21.594 habitantes de un total comarcal de 38.375, prueba de su poder aglutinador en las últimas décadas y reflejo, por lo demás, de un éxodo rural que ha vaciado de pobladores buena parte del espacio estudiado.

${ }^{8} \mathrm{La}$ vinculación del espacio con los aprovechamientos agrarios ha sido uno de los criterios que, tradicionalmente, ha servido para la "comarcalización" y administración del espacio provincial. En este sentido, a mediados del siglo XX se abandonan los criterios de partido judicial y en los balances y memorias de administración agraria o comercial se adoptan los expuestos por Vicente Bielza Laguna, delegado Provincial de Estadística, en relación con la provincia de Valladolid. Bielza Laguna define la "Comarca Natural" como un conjunto de territorios que presentan aproximadamente los mismos caracteres físicos y, por consiguiente, donde se dan los mismos productos. En este sentido la clasificación por comarcas atiende, de acuerdo a su criterio, a la yuxtaposición de elementos integrantes, tales como la orografía, la hidrografía, condiciones atmosféricas, la flora, la agricultura, la fauna y el ser humano. De esta manera diferencia en la provincia de Valladolid ocho comarcas naturales: Tierra de Campos, Montes de Torozos, Campiña del Pisuerga, Páramos del Esgueva, Campo de Peńafiel, Tierra de Pinares, Tierra de Medina y Tierra del Vino. Reduce la comarca de Tierra de Medina a $681,6 \mathrm{~km}^{2}$, frente a una Tierra del Vino que se extiende por $1.308 \mathrm{~km}^{2}$. Los municipios que Bielza determina como integrantes de la comarca medinense son: Bobadilla del Campo. Brahojos, El Campillo, Carpio, Cervillego de la Cruz, Fuente el Sol, Gomeznarro, Lomoviejo, Medina del Campo, Moraleja de las Panaderas, Muriel, Nueva Villa de las Torres, Pozal de Gallinas, Ramiro, Rubí de Bracamonte, Salvador, San Vicente del Palacio, Velascálvaro, Villaverde de Medina y La Zarza. (BIELZA LAGUNA, V.: Las comarcas naturales de la provincia de Valladolid, 1953).

9 CABO ALONSO, A., MANERO MIGUEL, F. (dir.): La Articulación del Territorio, tomo VII, en Geografía de Castilla y León, Ámbito, Valladolid, 1989, pág. 27 y ss. 

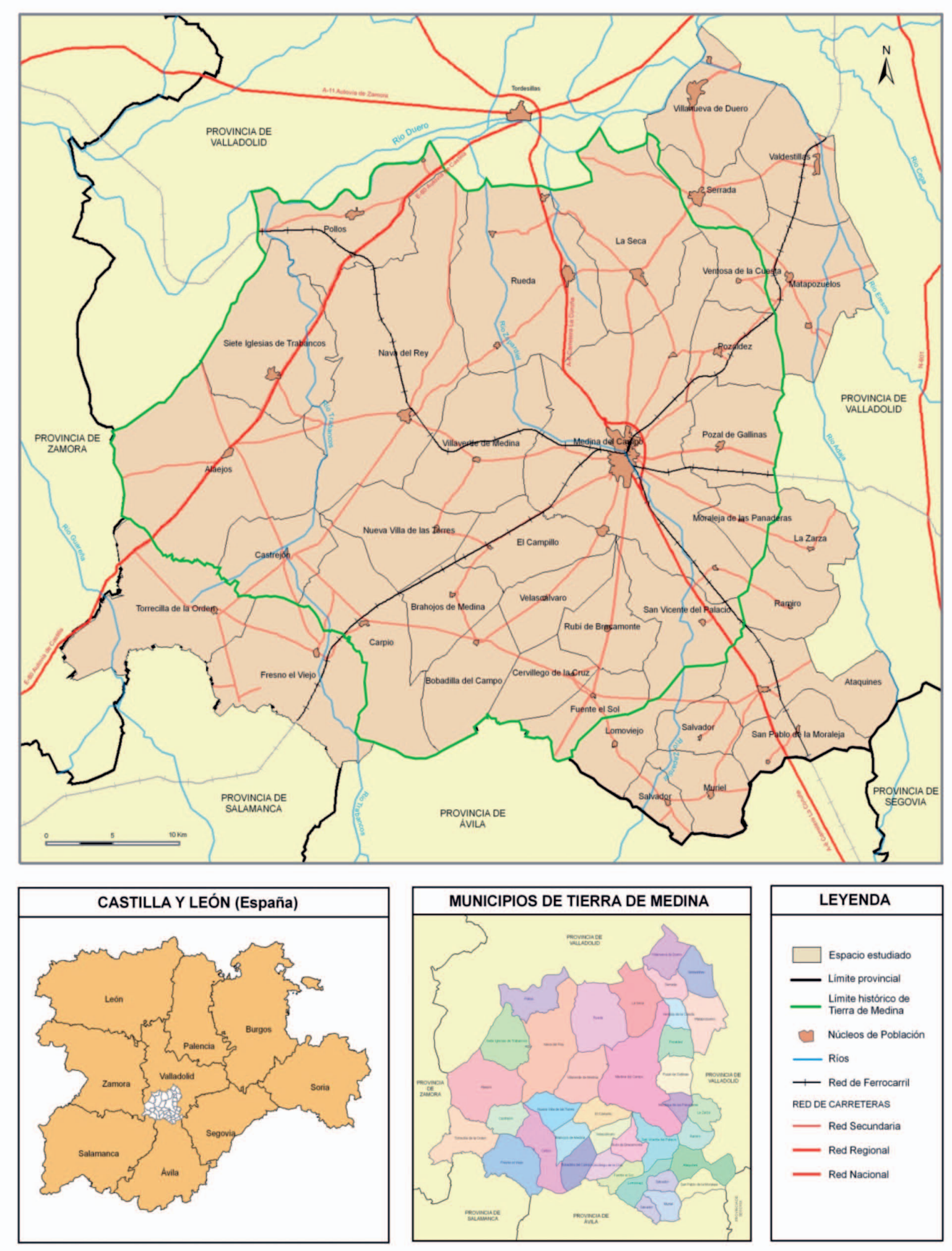

Figura 1. Mapa de localización y división administrativa del espacio estudiado. 
Los criterios señalados y cartografiados coinciden, en buena parte, con la delimitación de la llamada Comarca Sur, creada en 1977 por la Secretaria General Técnica del Ministerio de Agricultura, con el fin de mejorar la organización administrativa y de gestión del espacio agrario ${ }^{10}$. Según estadísticas agrarias actuales, especialmente las referidas a las ayudas de la P.A.C., la parcial coincidencia facilitará al menos, aunque no compartamos los criterios delimitativos efectuados, la tarea en la interpretación de los valores globales que caracterizan al territorio analizado. No entra entre nuestros objetivos, en ningún caso, la delimitación precisa del espacio comarcal, tanto más cuanto que nos proponemos analizar las interrelaciones entre los grupos humanos y el espacio a lo largo del tiempo y los posibles límites pueden variar, y de hecho han variado, conforme se ha modificado la relación del ser humano con el espacio que le ha sustentado.

Nos encontramos, como se desprende de la figura adjunta, en un espacio marcadamente rural y agrario, a excepción del centro de servicios comarcal, cada vez más urbano y terciarizado. Teniendo esto presente, y dado que el objetivo del presente trabajo se centra en las transformaciones vividas en el mundo campesino, el conocimiento del medio físico es indispensable para explicar las interrelaciones entre hombres, cultivos y ganados. Si los condicionantes de suelo y clima no han sido muy generosos en este centro de la Cuenca del Duero, de cara a obtener cosechas regulares a lo largo del tiempo, en el sector de terrazas que ocupan los términos mencionados debió de hacerse frente a las dificultades con sacrificios ańadidos. Pero lo que en principio fue rechazado por los hombres, en beneficio de retamas y baldíos, se convirtió desde los albores de la Edad Moderna en la esencia que dinamizó la vida de estos lugares. Entre las gravas y numerosos pagos sin sustancia pronto arraigaron las cepas, en especial su variedad verdeja, y el viñedo se adueñó ininterrumpidamente de la mayor parte del terrazgo hasta convertirse en el corazón económico de todos los pueblos del norte de la Tierra de Medina. De hecho, durante los siglos XVI y XVII, se produjo una intensa roturación de los espacios que aun quedaban vírgenes al arado, al tiempo que se consolidaban distintos señoríos en los términos y lugares ya citados. El norte de la Tierra de Medina fue así especializándose en el cultivo de la vid y en la elaboración de unos vinos blancos que pronto alcanzaron el reconocimiento de los habitantes de la montaña, de los consumidores de la llanura y del paladar de la corte madrileńa.

Por el contrario, los lugares al sur de la comarca arrumbaron la podadera en beneficio de yuntas y arados que preferían surcar tierras de pan llevar, por lo demás más numerosas y aptas en sus pagos para el cultivo cerealista que los cascajales norteńos ${ }^{11}$. La rentabilidad de los propios cultivos en los distintos siglos, el declinar de las ferias de Medina, el surgimiento de otras redes comerciales y, por supuesto, la idoneidad edáfica para obtener el máximo rendimiento en cada término, contribuyeron a ir perfilando la distinta especialización productiva entre el norte y el sur del espacio analizado ${ }^{12}$.

\footnotetext{
${ }^{10}$ En el estudio que se lleva a cabo en la segunda mitad de los ańos setenta, con el fin de establecer un marco territorial operativo, la propia Secretaria General Técnica del Ministerio de Agricultura expone las no pocas dificultades por delimitar comarcas uniformes y adaptadas a la labor diaria de planificación y control. Hasta entonces las provincias se habían dividido en unidades menores para mejorar la organización de los distintos trabajos. Se habían delimitado, por ejemplo, comarcas de Ordenación Rural, comarcas de Extensión Agraria, comarcas del mapa Agronómico Nacional, comarcas trigueras, comarcas olivareras... En mayo de 1977 Gómez Irureta, a la sazón Secretario General Técnico, "con el fin de esclarecer en lo posible este difícil tema, e ir asentando criterios más firmes para futuras revisiones" da luz verde a una comarcalización agraria que, en el caso de la provincia de Valladolid, diferencia cuatro comarcas que, en la actualidad y atendiendo a criterios de administración y planificación agraria, siguen vigentes: Tierra de Campos (195.550 ha), comarca Centro (246.345 ha), comarca Sur (193.627 ha) y comarca Sureste (179.439 ha). (MINISTERIO DE AGRICULTURA. Secretaria General Técnica. Comarcalización Agraria de España. Documento de trabajo no 8, Madrid, 1977). No han sido pocos, posteriormente, en lo que atañe a nuestra Comunidad Autónoma, los estudios para establecer unos criterios válidos para la definición de comarcas atendiendo a criterios geográficos que resultaran eficaces para la prestación de servicios, sea el "Estudio y propuesta de comarcalización de Castilla y León" de 1985; la "Base de Datos Municipal de la Comunidad Autónoma de Castilla y León" de 1987; el estudio titulado "Modelo funcional de la territorialización de servicios" de 1994 o las directrices y trabajos al respecto que acompañaron los precedentes, y derivaciones de la aprobación de la Ley de Ordenación del Territorio de la Comunidad de Castilla y León. (SANTOS Y GANGES, L., PEIRET I CARRERA, A.: Articulación regional y comarcas en Castilla y León: Las directrices de ordenación del territorio. Boletín de la A.G.E., no 32, 2001, págs. 177-190).
} 
En este sentido, no hemos podido sustraernos a analizar la vida de estas comunidades campesinas, ligadas eternamente a la tierra y sus quehaceres. Tampoco nos hemos olvidado del contexto espacial y temporal que ha marcado su pulso vital, conforme lo hacían las cada vez más maltrechas comunidades de villa y tierra y los propios reinos peninsulares. En el estudio de las pervivencias propias del antiguo régimen nos detendremos de modo particular en las estructuras productivas de mediados del siglo XVIII. El Catastro de Ensenada, siempre tan apreciado por el investigador, y la consulta de centenares de protocolos notariales en el Archivo Histórico Provincial de Valladolid, nos posibilitaron delimitar con cierto rigor el mundo campesino en el espacio estudiado.

A continuación se abordarán los profundos cambios vividos en los siglos XVIII y XIX, la incidencia de la Ilustración y las crisis que anteceden a la revolución francesa, la situación del mundo campesino al final del viejo orden, las consecuencias del proceso desamortizador y la expansión agraria y demográfica de mediados de siglo.

Como el resto del agro peninsular, el mundo rural del espacio acotado se sumergirá en una situación nada fácil a finales del siglo XIX. La crisis agrícola y pecuaria hace desistir incluso a los hombres de negocios que tenían al mundo campesino como objeto de sus inversiones desde el proceso desamortizador. El endeudamiento de los labradores, la precaria situación de la ganadería lanar, la llegada de la filoxera y la ruina de las explotaciones vitícolas pondrán contra el tablero a unos y otros. Nunca como hasta entonces se había visto mutar la quietud de las sociedades campesinas por tanta tensión y desasosiegos. El control de la clase propietaria en el marco del liberalismo y de la España de la Restauración contrasta con el hambre de los braceros y la falta de expectativas en unos pueblos que contemplan atónitos cómo el trigo ya no sube de precio, conforme avanza la primavera, y el insecto acaba por secar hasta las cepas más robustas.

Nos encontramos en los albores de un nuevo siglo que, si por algo se caracterizará, será por sus constantes y profundas transformaciones. Es aquí donde unos y otros pueblos acaban por diferenciarse, de acuerdo a su especialización productiva, estructura de la propiedad, mayor o menor cercanía a los espacios urbanos, impulso del vińedo o auge del regadío, por citar algunos de los distintos factores que comenzaron a diferenciar tanto los pueblos del norte y sur de la comarca de Medina como del resto de la región.

En las últimas décadas del siglo XX, el mundo rural dejará de ser rural en la forma que lo había sido hasta entonces. "Tempora mutantur, nos et mutamur in illis", que dicen los clásicos. Nuevos cambios técnicos, financieros, de cultivos, productivos y de mentalidad verifican en el nuevo siglo XXI el inexorable paso del tiempo. Hasta las viejas cepas, retorcidas y cargadas de estaciones y memoria, son sustituidas por otras conducidas por la mecanización, la productividad y la rentabilidad. Será en este cultivo, en el viñedo, amparado en la Denominación de Origen Rueda desde 1980 y que también hemos creído conveniente estudiar, al margen de que sus límites rebasen la Tierra de Medina, donde se encuentren de nuevo y con éxito parte de estos pueblos, como ya lo hicieran, en tiempo histórico, hace largos siglos.

${ }^{11}$ HILARIÓN PASCUAL, en su memoria de licenciatura sobre los viñedos de la antigua Tierra de Medina, se muestra flexible a la hora de fijar posibles límites comarcales: "El ámbito espacial en el que la Tierra de Medina, en virtud de su uniforme o similar realidad geográfica, llegó a constituir una auténtica unidad fisonómica -en cuanto a la estructura de su paisaje y en cuanto a su economía rural y a la sociedad que de ella derivaba-que podemos llamar comarca, pero que no elimina la posible existencia de una cierta variedad subyacente. En consecuencia, el ámbito geográfico de la comarca de Tierra de Medina puede tener unos limites que amplien o que recorten los que son propios del espacio jurisdiccional". (PASCUAL GETE, H.: La Tierra de Medina. Siglos XVI al XVIII. Los viñedos de la antigua Tierra de Medina. Memoria de licenciatura, Universidad de Valladolid, 1973, págs. 4-5, inédito).

${ }^{12}$ De hecho, como ya se ha apuntado anteriormente, los distintos aprovechamientos y usos agrarios han servido de diferenciación entre unas comarcas y otras. Hilarión Pascual, en su espléndida memoria de licenciatura, toma el relevante papel que tiene el viñedo en buena parte del espacio como el criterio fundamental a la hora de fijar los límites de la "comarca vitícola de Tierra de Medina”. (PASCUAL GETE, H.: La Tierra de Medina..., ob. cit., págs. 5-7). 

CAPÍTULO I

LOS CONDICIONANTES FÍSICOS DE UN ESPACIO DE TERRAZAS Y CAMPIÑAS AL SUR DEL DUERO MEDIO 


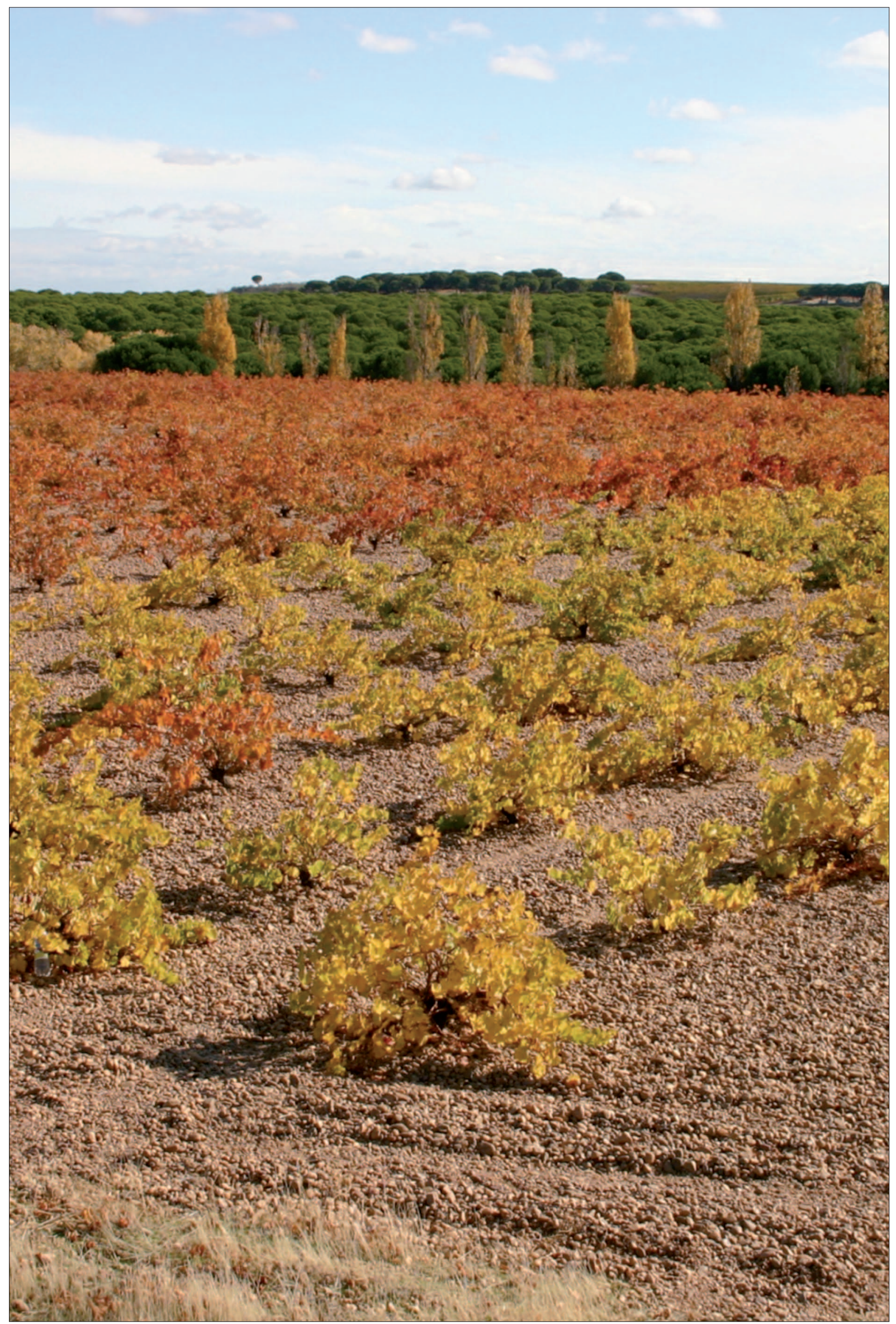

Imagen 1. Paisaje otoñal de viñedos a marco real sobre terrazas de gravas en La Moya, Serrada. Foto: 06/11/2011. Todas las imágenes de esta obra han sido realizadas por el autor, salvo las que se indiquen de forma expresa. 
A diferencia de la orla montañosa que bordea la meseta, de por sí muy sugerente para el hacer de los geógrafos, buena parte de las planicies centrales apenas han sido estudiadas por especialistas en geografía física. Los motivos pueden imaginarse varios y contrapuestos: quizá en su aparente simplicidad no han merecido la atención debida; o, por el contrario, cuando ante el primer acercamiento investigador el tópico de lo simple se torna compleja morfogénesis, los proyectos se han sustituidos por otros más gratificantes. En este caso, siempre con la modestia de quien se sabe inexperto en analizar el puzle de montańas, valles, páramos y campiñas que conforman la cuenca sedimentaria del Duero, se intentará un breve acercamiento a los componentes físicos del espacio estudiado, toda vez que representan un condicionante básico para la actividad humana que en ellos se ha desarrollado.

No se puede iniciar ninguna aproximación al estudio de las sociedades campesinas si se ignoran las características del territorio que ocupan y las variables que han influido a lo largo del tiempo. Nadie mejor que aquellos que aun siguen ligados a la tierra para conocer el efecto de la helada en primavera, la falta de lluvia en abril y mayo o el riesgo de pedrisco si se pone el tiempo de tormentas en agosto. Si estos elementos inciden decisivamente en el desarrollo de los cultivos y pueden poner en grandes apuros la actividad agroganadera en la actualidad, en otro tiempo situaron a comunidades enteras al borde del hambre y de la muerte. Aquí y en todo el centro de la denominada "meseta norte". A lo largo del tiempo, todos los que habitaron estas tierras supieron que nada tenían seguro hasta que la cosecha estuviera recogida en paneras y bodegas. Cuántas veces los fríos se llevaron parte del fruto al inicio de los primeros brotes y los calores de junio las cosechas antes de su completa maduración. Relieve, clima y suelo forman el soporte sobre el que las sociedades rurales tradicionales levantaron casas, roturaron tierras o apacentaron ganados. Se debe iniciar la investigación partiendo del espacio delimitado, de su localización e interrelación con las áreas circundantes y detenerse, aunque sea de una forma sencilla y somera, en analizar estos condicionantes antes de abordar el estudio histórico. Sólo así se comprenderá mejor la interrelación de los grupos humanos con el espacio que les ha alimentado durante siglos.

\section{Una localización al sur del Duero medio}

Como tantos otros espacios castellanos, la Tierra de Medina es fruto de un largo y complejo devenir histórico. Excede nuestro propósito, por el momento y como se ha apuntado, extendernos en tratar de delimitar los límites exactos que la conforman, tanto más cuanto que a lo largo de las distintas épocas históricas, entidades que hoy se entienden como propias de esta comarca, han pertenecido a otras adscripciones administrativas y jurídicas ${ }^{13}$.

Por otro lado, los actuales flujos comerciales y económicos, en los que la acción humana es el principal agente dinamizador, han impedido en las últimas décadas la fijación de límites comarcales estrictos e inamovibles. De ahí el mantenimiento en el estudio tanto de municipios situados al oeste del espacio, como Alaejos o Sieteiglesias, más alejados del efecto de atracción medinense y vinculados a la red viaria que les une con Salamanca o Toro; de Pollos, siempre más cercano administrativamente 
a Tordesillas; o de aquellos municipios situados al norte y noreste del espacio, tales como Serrada, Valdestillas o Matapozuelos, donde la cercanía a Valladolid reduce la influencia medinense. Como ha sido referido, todos estos municipios, junto con otros limítrofes que riega el Duero, forman la llamada Comarca Sur, realidad que tampoco podemos eludir, toda vez que la administración autonómica y la nueva Política Agraria Común las dota de personalidad propia a efectos agrarios ${ }^{14}$.

En cualquier caso, lo que es incuestionable es que al sur del Duero medio, entre Tordesillas, Medina y Olmedo, ha latido durante largos siglos el corazón de la vieja Castilla, sus importantes mercados feriales y tantas otras decisiones reales. La propia villa de Medina del Campo se constituye en referencia económica obligada en los primeros siglos de la Edad Moderna. Difícilmente Fernando de Antequera imaginó, al poner en marcha sus renombradas ferias francas, que tal espacio se convertiría en encrucijada de caminos y mercaderes. Más cuando hasta entonces las más importantes vías de comunicación apenas si la tocaban tangencialmente ${ }^{15}$. A partir de entonces Medina articulará en torno a sí misma buena parte de la red caminera del centro de Castilla, casi a mitad de recorrido entre Salamanca y Valladolid o Ávila y Palencia. Medina del Campo será considerada "el mejor sitio que hay para ferias... por estar en medio de todo" ${ }^{16}$.

De hecho, a mediados del siglo XVI el Repertorio de Juan Villuga otorga a Medina del Campo un puesto de primer orden en la red caminera de Castilla, aunque no será por mucho tiempo. El traslado de la Corte a Madrid de forma permanente, el agotamiento de Castilla y del imperio o los flujos comerciales con América y con el resto de Europa marginan el interior peninsular hasta nuevo aviso. Los principales linajes nobiliarios y familias burguesas son los primeros que abandonan la ciu-

${ }^{13}$ En tiempo histórico y en buena parte del espacio estudiado se superponían la jurisdicción civil y la eclesiástica. La civil integró cincuenta entidades reducidas, por despoblación, a veinticuatro términos actuales: Alaejos, Bobadilla del Campo, Brahojos, Campillo, Carpio, Castrejón, Cervillego, Fuente el Sol, Gomeznarro, Moraleja de las Panaderas, Nava del Rey, Nuevavilla de las Torres, Pollos, Pozal de Gallinas, Pozaldez, Rodilana, Rubí de Bracamonte, Rueda, San Vicente del Palacio, La Seca, Siete Iglesias, Velascálvaro, Ventosa de la Cuesta y Villaverde de Medina, si bien, alguna de éstas, como Alaejos, Castrejón o Bobadilla fueron desvinculándose con el tiempo.

La jurisdicción eclesiástica, dependiente de la Abadía de Medina, y que gozaba de autonomía propia, dada la indeterminación de la divisoria que separaba Medina y Olmedo se ordenaba a través de las llamadas parroquias medianas que, cada Jueves Santo del año, cambiaban su jurisdicción eclesiástica entre la Abadía de Medina del Campo y el Obispado de Ávila. Aunque en distintas relaciones van variando las parroquias sujetas a esta peculiaridad, el conjunto de ellas fueron: Cervillego, Fuente el Sol, Gomeznarro, La Mezquina, Miguel Serracín, Montecillo, Moraleja, Pollos, Pozaldez, Rubí de Bracamonte, San Martín del Monte, Santiago de la Olga, Tobar, Valverde, Vidales y Villafuerte. Al mismo tiempoconviene apuntar las tensiones históricas por el control de aldeas y términos entre los límites entre la Tierra de Medina, Olmedo y el Infantazgo de Valladolid. De hecho, por ejemplo, algunos de los términos que se estudian, tales como Valdestillas, Matapozueloso Serrada pertenecieron a la Comunidad de Villa y Tierra de Olmedo, en tanto que Villanueva de Duero lo era de la Merindad del Infantazgo de Valladolid, por no hablar de los litigios históricos entre Tordesillas y Medina por el control de las pequeñas aldeas situadas en las márgenes del Duero. que servía como límite divisorio. MARTÍNEZ DÍEZ, G: "La Comunidad de Villa y Tierra de Medina", en Historia de Medina del Campo y su Tierra. Coordinador: Eufemio Lorenzo Sanz. Volumen I, Ayuntamiento de Medina del Campo y otros, Valladolid, 1896, pág. 159 y ss. Igualmente, en este sentido, y para precisar estas cuestiones, se hace imprescindible la obra de MORALEJA PINILLA, G.: Historia de Medina del Campo. Medina del Campo, 1946.

${ }^{14}$ La denominada Comarca Sur la forman los municipios de Alaejos, Ataquines, Bobadilla del Campo, Brahojos, Campillo, Carpio, Castrejón, Castronuño, Cervillego, Fresno, Fuente el Sol, Gomeznarro, Lomoviejo, Matapozuelos, Medina del Campo, Moraleja de las Panaderas, Muriel, Nava del Rey, Nueva villa de las Torres, Pollos, Pozal de Gallinas, Pozaldez, Rodilana, Rubí de Bracamonte, Rueda, Salvador de Zapardiel, San Míguel del Pino, San Pablo de la Moraleja, San Román de la Hornija, San Vicente del Palacio, La Seca, Serrada, Siete Iglesias, Tordesillas, Torrecilla de la Abadesa, Torrecilla de la Orden, Valdestillas, Velascálvaro, Ventosa de la Cuesta, Villafranca de Duero y Villaverde de Medina.

15 PASCUAL GETE, H.: “Las condiciones físicas de Medina del Campo y su Tierra”, en Historia de Medina del Campo y su Tierra..., Valladolid, 1896, pág. 20 y ss.

${ }^{16}$ Ibídem, pág. 22, citando a MARCOS MARTÍN A.: Auge y declive de un núcleo mercantil y financiero de Castilla la Vieja. Evolución demográfica de Medina del Campo durante los siglos XVI y XVII. Universidad de Valladolid, Secretariado de Publicaciones, Valladolid, 1978, pág. 21. 
dad, dejando sus palacios y propiedades en manos de administradores a los que rara vez se les encargará reinvertir las rentas que gestionan en el espacio comarcal. La descapitalización será para muchos de sus términos la antesala de un éxodo rural inevitable. Ponz apenas si cree la postración en que está sumergida la Villa cuando la visita en $1783^{17}$ :

"No se puede entrar sin desconsuelo a hablar de la Villa de Medina del Campo, y más de quien tiene idea de lo que fue antiguamente, residencia de muchos Monarcas, teatro de grandes sucesos, y población de catorze mil vecinos. Hoy está reducida a poco más de mil. Desaparecieron sus famosas ferias, sus muchas riquezas, la comodidad, y limpieza de calles, y casas, y solo queda la apariencia de destrucción y ruina...”

Del sopor dieciochesco la saca una nueva vía de comunicación: el ferrocarril. Medina del Campo olvida su abandono a mediados del XIX al convertirse en uno de los más importantes nudos ferroviarios de la mitad septentrional de España. Tres siglos después de su apogeo histórico, el nudo ferroviario devuelve a la decadente villa ferial el papel indiscutible de motor económico comarcal. Por entonces la nueva organización administrativa y judicial había integrado muchos de sus antiguos despoblados en los términos y villas que hoy se conoce y éstos, extinguidas las antiguas Comunidades de Villa y Tierra, formarán parte, a todos los efectos, de la Tierra de Medina, de la que siempre se sintieron integrantes, tanto por sus intereses económicos como por la vinculación que tuvieron socialmente al núcleo cabecero sus principales próceres y propietarios.

La nueva infraestructura viaria hará recuperar a Medina su papel de encrucijada de comunicaciones, atracción de industrias y asentamiento y crecimiento de una población cada vez más demandante de bienes y servicios. La línea férrea no sólo pondrá a Medina en contacto con Madrid o Venta de Baños sino también, de forma directa, con Salamanca, Zamora o Segovia. El tránsito de pasajeros de los apeaderos menores hacia Valladolid o el núcleo comarcal no será menor. Por si esto fuera poco, la confluencia y potenciación de otras vías de comunicación reforzará aún más, si cabe, la centralidad de la antigua villa ferial a lo largo del siglo XX. La hasta hace unos años N VI, hoy A6, Madrid-La Coruña; la otrora N 620, actualmente A 62, Burgos-Portugal en su sector oeste, junto a la confluencia de las arterias comarcales C-112 (Cuéllar-Toro) y C-610 (Valladolid-Piedrahita) pondrán a Medina del Campo en una situación de privilegio que no siempre se refleja en un dinamismo industrial acorde con este potencial, quizá por su vinculación en demasía al agro que la circunda, al mercado dominical que la oxigena o también, por qué no apuntarlo, por la abundancia de rentistas acomodados, faltos de decisión inversora y escasez de capitales proclives a asumir riesgos en los momentos más transcendentes.

Pero esto no será tampoco una excepción en el territorio regional. Muchas de las antiguas villas cabeceras, convertidas en núcleos intermedios a lo largo del siglo XX, apenas si han tenido capacidad para ensamblar territorialmente su espacio dependiente e impulsarlo económica y demográficamente. Al sur del Duero acompañan a Medina en esta tarea Olmedo e Íscar, en la provincia de Valladolid; Cuéllar, Coca, Cantalejo o Santa María la Real en Segovia; Arévalo o Fontíveros en Ávila; Fuentesaúco en Zamora y Peñaranda de Bracamonte en Salamanca, por citar los centros comarcales más cercanos a la Tierra de Medina, espacio intermedio, por lo demás, entre sus respectivas capitales provinciales. No hay duda de que han sido esta precariedad urbana y la ausencia de una red de ciudades mínimamente densa y jerarquizada, unida al tímido y desigual empuje industrial que las ha caracterizado a la mayor parte de las mencionadas a lo largo del último siglo, las verdaderas causas de esta incapacidad de reacción económica y demográfica que caracteriza, y puede extenderse, a la mayor parte del espacio regional ${ }^{18}$.

Todas ellas, al margen del devenir histórico, tienen un denominador común: un profundo componente agrario. La Tierra de Medina no se ha apartado, en este sentido y en general, de las contingencias

${ }^{17}$ PONZ PIQUER, A.: Viage de España, o Cartas en que se da noticia de las cosas mas apreciables y dignas de saberse, que hay en ella. Ibarra impresor, Madrid, 1772-1794, tomo XII, carta quinta, pág. 145.

${ }^{18}$ CLEMENTE CUBILLAS, E., LÓPEZ TRIGAL y PASTOR ANTOLÍN, L. J.: La Articulación del Territorio, en “Geografía de Castilla y León”. CABO, A. y MANERO, M. (dir.), Ámbito,Valladolid, 1989, pág. 30. 
vividas a lo largo de la historia por el agro regional. Sin embargo, fruto de las distintas condiciones edáficas que diferencian el norte y sur de la comarca, unidas a componentes históricos y a la mayor influencia que ejerce Valladolid en los pueblos más cercanos a su área de influencia, sí cabe diferenciar, como se verá, dos dinámicas distintas con honda tradición histórica: por una parte, los sectores de terraza del norte de la Tierra, obstinados desde siglos en hacer fructificar en sus pagos de gravas el vińedo, cultivo que se refugia en ellas cuando la dinámica de los mercados es desfavorable y que rebasa su ámbito ocupando tierras medianeras, aptas para pan, cuando las coyunturas de rentabilidad en el comercio de los caldos superan a leguminosas y cereales. Este aspecto, junto con el tradicional arraigo del regadío desde las primeras décadas del siglo XX y el surgimiento de importantes industrias agroalimentarias ha proporcionado una singularidad a este espacio respecto al resto de la comarca. La Seca, Rueda y Serrada son, en este sentido, abanderados de dicho esfuerzo vitícola. Esta última villa es el único municipio, de los treinta y ocho que se estudian que, exceptuando el centro comarcal, supera la población que tenía a comienzos del siglo XIX.

El sur de la comarca, por el contrario, ha experimentado un acusado vaciamiento demográfico desde mediados del siglo XX. El predominio aplastante de la agricultura cerealista de secano, el menor peso del regadío en la mayor parte de los municipios del sur del espacio y su alejamiento respecto a la capital provincial serán factores determinantes para explicar la falta de vitalidad y el envejecimiento de muchos de sus pueblos. Pero todo, como veremos, tiene su explicación. Nada mejor, para ello, que ir desgranando los factores que han contribuido a su evolución, comenzando por los físicos.

\section{Un relieve de terrazas y campińas modeladas por los ríos}

El espacio acotado se caracteriza visualmente por sus amplios horizontes y paisajes despejados. Si dejamos a nuestros ojos dirigirse hacia el sur, la planicie no parece acabar nunca; si miramos hacia el norte y noroeste, la horizontalidad está matizada por las cuestas que enlazan con los páramos que, desde Tordesillas, siguen al Duero y al Pisuerga, rubricando el tablero meseteño. El horizonte acaba por romperse, por tener un límite, cientos de kilómetros al sur y sureste entre las siluetas, difuminadas por la lejanía, de las sierras desniveladas de la Cordillera Central. Es esta imagen de inabarcables y altas llanuras la que se ha introducido en el inconsciente colectivo como característica general de Castilla, aun cuando, como es sabido, la diversidad de la región rebasa con mucho tal percepción. García Fernández, en su profundo conocimiento del espacio castellano, no duda en citar las palabras de Unamuno para caracterizar estas campiñas al sur del Duero: "Y en derredor una vasta campiña de pan llevar, con acá y allá las manchas verdinegras de los pinares, y en el fondo, uniendo la tierra al cielo, la sierra coronada de nieve. Y sube de la tierra una gran serenidad, a juntarse con la serenidad grandísima que baja del cielo"19.

Este abierto paisaje, descrito tan poéticamente por Unamuno o en cierto modo malquisto por Ortega y Gasset, en palabras de García Fernández, se inscribe en la parte central de la cuenca sedimentaria del Duero, formada durante el Terciario por colmatación de sedimentos, tras el hundimiento de parte del Macizo Central Ibérico durante la orogenia alpina, que reactiva las líneas de falla tardihercinianas a finales del Cretácico y principios del Paleoceno. En su relleno alternaron fases lacustres, palustres y marinas dejando constancia de una diversidad de rocas que delatan un origen dispar, sea las procedentes de las rocas paleozoicas de la parte occidental de la cordillera Cantábrica o de las mesozoicas carbonatadas de su parte oriental, sea de la erosión de los macizos metamórficos de la Cordillera Central o las calizas y rocas siliciclásticas del Cordillera Ibérica ${ }^{20}$.

${ }^{19}$ GARCÍA FERNÁNDEZ, J.: Castilla (Entre la percepción del espacio y la tradición erudita). Madrid, 1985, pág. 121.

${ }^{20} \mathrm{No}$ entra entre nuestros objetivos el estudiar de forma detallada la evolución geológica y geomorfológica del espacio estudiado, más allá de cuantas consideraciones estén relacionadas con el aprovechamiento agrario o puedan influir sobre el mismo. Con todo, los recientes estudios del I.G.M.E. y la publicación en 2007 de las hojas 399 (Rueda), 427 (Medina del Campo) y 371 (Tordesillas), clarifican notablemente cuanto hasta el presente se ha divulgado sobre el particular. 
En concreto, durante el Mioceno y parte del Plioceno, la sedimentación terciaria es endorreica. Especialmente importante, en este sentido, en esta acumulación de Terciario detrítico en el centro de la cuenca que se estudia, es la existencia en profundidad de niveles arenosos y de gravas, entremezclados con otros arcillosos o arcillo-arenosos permeables o semipermeables que conforman la base geológica del gran acuífero terciario que, al sur del Duero, recibe el nombre de acuífero de los Arenales, imprescindible en el aprovechamiento agrario, tal como en los capítulos siguientes se detallará.

El proceso de relleno y el carácter endorreico de la cuenca termina con la formación de las llamadas calizas de los páramos. Cuando la meseta se bascula hacia el oeste se instala un régimen exorreico en el Plioceno superior-Pleistoceno inferior que desmantela los materiales calizos centrales y detríticos marginales, configurándose una primitiva red fluvial, caracterizada por distintos encajamientos y líneas de erosión y transporte que será la gran protagonista del vaciado de la cuenca y de sus formas de relieve, relacionadas siempre con la tectónica y el clima ${ }^{21}$. La complejidad de los bancos de sedimentos terciarios y su espesor, cercano al millar de metros en el centro de la cuenca, es tan grande como difícil de interpretar ${ }^{22}$. Sin embargo, al norte del espacio estudiado, donde el recubrimiento cuaternario de depósitos aluviales de gravas y arenas ha atraído el interés de la actividad minera para la extracción de áridos, los cortes generados por dicha actividad en sectores cercanos al Duero sobre materiales miocenos muestran un perfil, aparentemente caótico, de bancos detríticos permeables, entremezclados con otros impermeables. Muchos de estos depósitos parecen seguir canales que se estrechan o ensanchan de forma variable y anárquica, desapareciendo el componente permeable de forma repentina, dando la apariencia de lentejones o abanicos rodeados de matriz arcillosa que, en muchos casos, son disecados por aportes posteriores ${ }^{23}$. Su espesor abarca desde centímetros hasta la decena de metros, entremezclándose los bancos de arena con aquellos de gravas de desigual granulometría, en ocasiones barridos de forma violenta por nuevos aportes ${ }^{24}$. La extracción de áridos, en las últimas décadas, testifica la diversidad de estos depósitos.

Con todo, a pesar de la magnitud del relleno terciario, su parte visible apenas supera los cien metros, dada la escasa incisión hidrográfica del Duero en su curso medio. Esta comienza a jerarquizarse durante el Cuaternario, vertebrada en torno al río castellano y sus afluentes, que forman pequeños valles y vacían los anteriores materiales en amplios sectores. Las formaciones cuaternarias derivan principalmente de los procesos erosivos causados por la red fluvial, sin olvidar el acompañamiento eólico, toda vez que actúa sobre materiales blandos y deleznables del Terciario infrayacente, por otra parte fundamental para el desarrollo agrícola.

${ }^{21}$ PÉREZ GONZÁLEZ. A: "La depresión del Duero", en “Territorio y Sociedad en España”. Geografía Física, Vicente Bielza de Ory, (coord.), Taurus, Madrid, 1989, pág. 162 y ss.

${ }^{22}$ En el sector norte del espacio estudiado, en concreto, en el término municipal de La Seca, se conoce con exactitud la estratigrafía del subsuelo gracias a un sondeo realizado por Foret en 1981 y que cortó los materiales siguientes: De superficie hasta los $412 \mathrm{~m}$ : serie areniscoso-lutítica, atribuible al Mioceno; de 412 a $1033 \mathrm{~m}$ : serie areniscosa-lutítica, con yesos en la parte alta, atribuible al Oligoceno; de 1033 a 1153 m: calizas del Cretácico superior; de 1153 a 1188 m: serie fundamentalmente arenosa, de facies Utrillas (Cretácico); de 1188 a $1237 \mathrm{~m}$ : (fin del sondeo): zócalo paleozoico. Mapa Geológico de España a escala 1:50.000. (Memoria). Hoja no 399, Rueda, I.G.M.E., Madrid, 2007, pág. 11.

${ }^{23}$ SÁNCHEZ SAN ROMÁN, F. J.: Los grandes acuiferos de la Cuenca del Duero. Universidad de Salamanca, Departamento de Geología.

${ }^{24}$ Los bancos de gravas y arenas que conforman la parte más superficial del acuífero han sido explotados por la iniciativa privada hasta su agotamiento desde las primeras décadas del siglo XX, por medio de pozos excavados en las vegas de los distintos pueblos de Tierra de Medina. El descenso del nivel freático a la par que la expansión del regadío ha necesitado de sondeos que llegan a alcanzar más de ciento cincuenta metros en algunos sectores. La sobreexplotación de esta unidad hidrogeológica ha conllevado desde hace una década una regulación más rigurosa por parte de la Confederación Hidrográfica del Duero en relación con los permisos y volumen de extracción de agua de acuerdo a los usos solicitados. No podemos dejar de referir las decenas de manantiales que se hacen constar en la Memoria explicativa de la hoja de Medina del Campo del Mapa Geológico de Espańa del año 1956, así como las imágenes de las lagunas que se expendían al sur de Villaverde de Medina, al norte de Fuente el Sol o en tantos otros pueblos del espacio estudiado y que, prácticamente irrecuperables por cuanto explicamos, ya forman parte del pasado. 
En el nuevo proceso de denudación, la red fluvial, consecuencia del régimen exorreico, de la tectónica y del clima, irá variando su curso, encajándose hasta su curso actual y dejando en resalte todo un elenco de terrazas que, entre los interfluvios del Trabancos y el Adaja, están magníficamente conservadas. Las más altas se localizan a la altura de Sieteiglesias de Trabancos, Nava del Rey y Rodilana, a una altitud de 800 metros, superando los 140 metros sobre la llanura de inundación actual. Todo indica, de acuerdo con esta disposición, que el río Duero fue desplazándose hacia el norte una veintena de kilómetros desde el inicio de su encajamiento en el Plioceno superior ${ }^{25}$. Posteriormente o al tiempo que sucedía este desplazamiento, la propia red hidrográfica fue recortando y desmantelando parcialmente dichos depósitos, que han quedado colgados respecto a los cursos fluviales actuales.

Se pueden diferenciar, no obstante, desde un punto de vista morfoedafológico, dos formas de relieve que se extienden, respectivamente, al norte y sur de la tierra medinense: el espacio de terrazas inversas y el espacio de campiñas suavemente alomadas que se extienden al sur de aquellas hasta enlazar con las de Peñaranda y Arévalo.

\section{a. Un relieve de terrazas modeladas por los ríos}

Sin olvidar el componente eólico, ha sido la morfogénesis fluvial la principal responsable de estas formas de relieve tras un proceso previo de importante acumulación. Los cursos fluviales, posiblemente múltiples, poco profundos y con gran movilidad lateral, fueron rebajando los niveles superiores de sedimentación. Al oeste del espacio estudiado, en los términos de Torrecilla, Alaejos y Sieteiglesias, se conserva la que Pérez-González (1982) estudia como "superficie de Alaejos", que se extiende hacia el oeste y rebasa el Duero hacia el norte enlazando con la "superficie de Valderaduey". Herrero Hernández, en la memoria que acompaña a la hoja no 399, identifica estas superficies como "superficie estructurales", degradadas como consecuencia del desmantelamiento de una "discontinuidad estratigráfica de edad miocena que originó una superficie que enlazaba con el resto del relieve existente". Dicha superficie, al NO de Sieteiglesias, se encaja en la terraza del Duero a 74-80 m sobre su curso, por lo que, en palabras del citado autor, "el ciclo morfogenético regional es más complicado del que se derivaría de la simple alternancia: aluviación-incisión-aluviación-incisión, etc. ${ }^{26}$

$\mathrm{Al}$ oeste de la misma los ríos Trabancos, Zapardiel, Adaja y Eresma, acompañados por arroyos de menor entidad, fueron encajándose por erosión remontante en los distintos niveles de terrazas del Duero, formando pequeños valles ortogonales que mueren en el río principal, caracterizado, por lo demás, por una asimetría muy notable.

Aunque un acercamiento a su estudio permite observar hasta seis niveles de terrazas, los estudios geológicos elevan a catorce su número, con espesores que en la mayoría de los casos se sitúan entre dos y tres metros, aunque en ocasiones pueden acercarse a los siete ${ }^{27}$. Estas acumulaciones de gravas y arenas, fruto del arrastre fluvial, recubren los materiales miocenos infrayacentes, suavizan las pendientes entre los distintos niveles de terrazas y forman un manto que recubre ampliamente las terrazas

${ }^{25}$ PINEDA VELASCO, A.; SALAZAR RINCÓN, A.; HERRERO HERNÁNDEZ, A: Mapa Geológico de España a escala 1:50.000. Hoja no 399 (Rueda), I.G.M.E., Madrid, 2007, memoria, pág. 42-43.

${ }^{26}$ PÉREZ-GONZÁLEZ, A. (1982): "El Cuaternario de la región central de la Cuenca del Duero y sus principales rasgos geomorfológicos", en Actas de la 1a Reunión Regional sobre la Geología de la Cuenca del Duero (Salamanca 1979). Temas Geológico-Mineros, I. G. M. E., VI, (2), Madrid, pág. 733.

27 Pérez González establece en 1979 y 1982 hasta catorce niveles de terrazas, incluyendo la llanura de inundación. Tomando como cotas medias lasexistentes entre la casa y aceńas de Zofraguilla, en la desembocadura del Zapardiel hasta el punto 799, situado al NO de Villaverde de Medina, este autor fija las siguientes: la llanura de inundación $+3-5 \mathrm{~m}$ (TD 14); + 8-12 m (TD 13) + 18-22 m (TD 12); + 24-30 m (TD 11); + 40-48 m (TD 10); + 54-56 m (TD 9); + 62 m (TD 8); + 74-80 m (TD 7); + 82-84 m (TD 6); + 96-100 m (TD 5); + 102-107 m (TD 4); + 110-114 m (TD 3); + 126-134 m (TD 2); y + 141-144 m (TD 1). Este modelo ha sido seguido como válido, salvo leves modificaciones en los estudios del I.G.M.E. para la confección de las hojas no 399 y 427 (Rueda y Medina del Campo, respectivamente. PÉREZ-GONZÁLEZ, A. (1982): «El Cuaternario de la región..., ob. cit., pág. 722. 

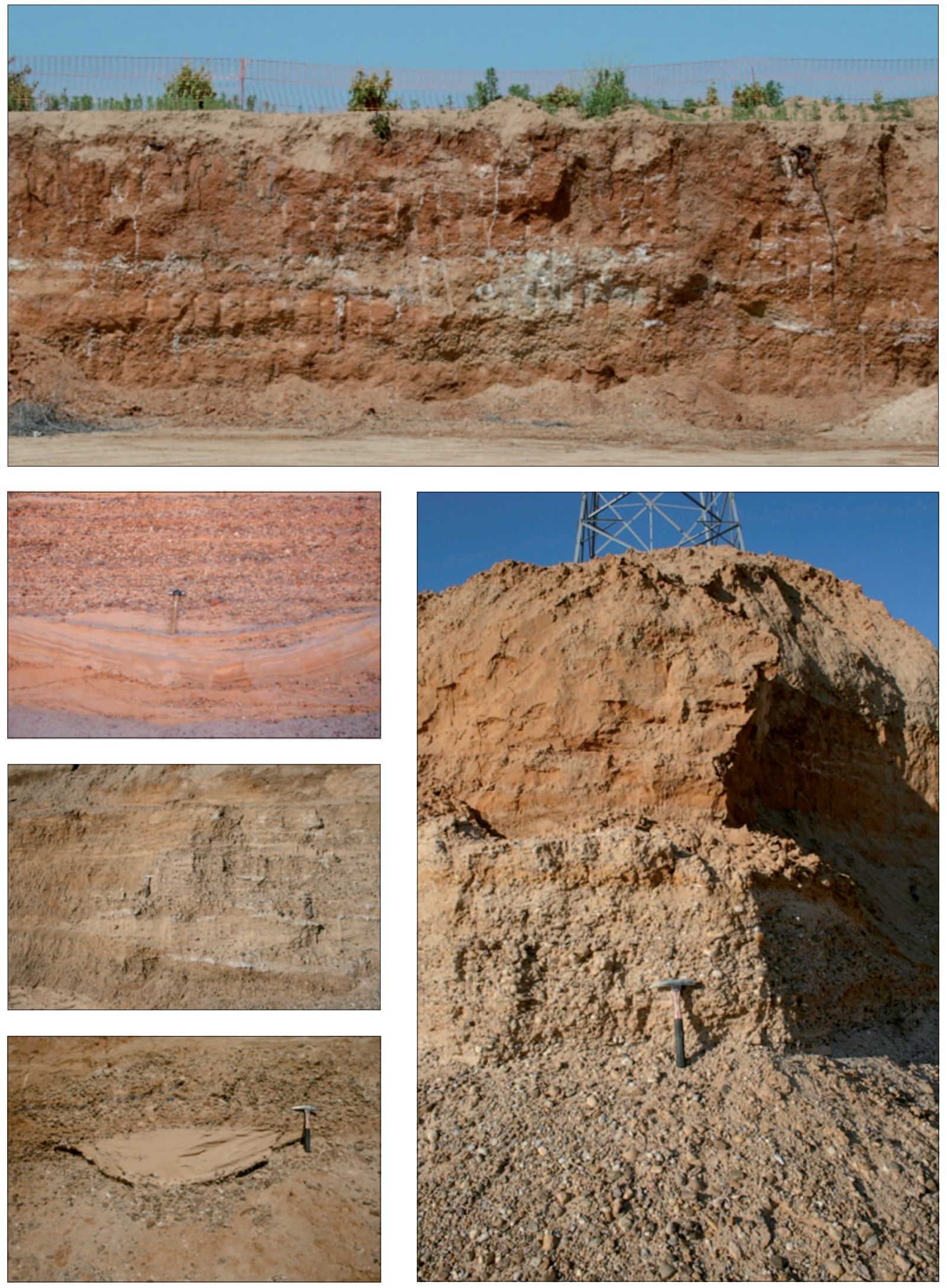

Imagen 2. Alta terraza fluvial sobre sedimentos miocenos (Medina del Campo, imagen superior) y estratificación de depósitos terciarios (Villanueva de Duero y Serrada, cuatro imágenes restantes). Fotos: 22/06/2005. En la imagen superior pueden apreciarse, tanto las oxidaciones e impregnaciones calcáreas infrayacentes a las gravas más superficiales, como el importante desarrollo radicular del vińedo, adaptado a estos suelos de gravas. En el resto de las imágenes se observan con claridad los distintos lentejones terciarios de gravas y arenas, intercalados entre matriz arcillosa, que caracterizan el proceso de colmatación de la cuenca. 
más bajas, ya en contacto con la llanura de inundación. García Fernández denomina este complejo conjunto como "el gran área de acumulación del centro de la cuenca sedimentaria" en la que han participado tanto los aportes del propio Duero como los ríos que nacen en la Cordillera Central, especialmente el Cega, Adaja, Eresma y Zapardiel ${ }^{28}$. Lo sorprendente de la enorme acumulación ha de ser explicado, como va referido, por múltiples factores, sin descartar fuera este espacio un área de represamiento del conjunto de ríos anteriores al perder competencia por causas complejas, en un régimen lacustre o palustre y con unos periodos de fuerte escorrentía, quizá en el tiempo previo en que el Duero trataba de abrirse paso hacia su desembocadura.

En este proceso las formas de relieve resultantes son extraordinariamente diversas. En el interfluvio entre el Trabancos y el Zapardiel, dichas terrazas, especialmente las más altas, se encuentran muy desmanteladas, toda vez que a la acción erosiva de ambos ríos en su curso final ha de sumarse la del arroyo del Monte, que discurre entre ellos de sur a norte, a lo largo de los términos de Nava del Rey y Pollos, hasta su desembocadura en el Duero. De hecho, la terraza más alta del Duero ha sido desmantelada en su totalidad y la segunda en altitud (TD 2, cuantificada por Pérez González a + 126-134 m y por el I.G.M.E. a + 135-141) se encuentra muy disminuida (ermita de la Concepción, al NE de Nava del Rey, con $801 \mathrm{~m}$ de altitud en su punto culminante y pago de Cuatro Caminos al oeste, a $796 \mathrm{~m}$ ). El resto del conjunto, a su vez diseccionado de sur a norte por el arroyo Valhenoso en aquellas cercanas al Trabancos, y por el propio Zapardiel en su margen izquierda, se solapa por arrastres, resultando difícil su delimitación, hasta que en niveles inferiores (TD 9 y TD 10 a 50 y 40 metros sobre el cauce del Duero) presentan una mayor extensión y nitidez, ya en término de Pollos y en el norte de los términos de Nava y Rueda.

A la datación geológica por los especialistas de las terrazas más antiguas como del Pleistoceno Inferior, ha de añadirse la localización en algunas de ellas de material lítico que puede indicar o ser prueba fiable de la ocupación humana más antigua en este sector central de la meseta. En concreto, en el yacimiento de La Castella, a + $101 \mathrm{~m}$ sobre el Duero, en la terraza TD 5, en término de Nava del Rey, el profesor Benito Álvarez ha estudiado varias piezas en posición estratigráfica que datan de finales del Pleistoceno Inferior, en el periodo normal Bunhess, en torno a 700.000 ańos $^{29}$. Al este de las anteriores, entre los interfluvios del Zapardiel y Adaja-Eresma, a pesar de haber colaborado también en su desmantelamiento otros cursos fluviales de importancia, como el arroyo del Perú y el arroyo de Serrada, que sigue posiblemente el anterior curso del Adaja, antes de que fuera capturado por el Eresma, las terrazas se conservan y se observan en algunos pagos de forma extraordinaria, al tiempo que, como se verá, su conservación ha posibilitado de forma permanente en tiempo histórico el aprovechamiento continuado del viñedo.

Las terrazas más altas en este sector se conservan en pequeños cerros aislados al norte de Medina del Campo: Cuesta del Aire y ermita de San Cristóbal a 805 m de altitud y 145 m sobre el cauce actual del Duero. A partir de ellas se extiende hacia el norte un amplio graderío a distinto nivel y buena extensión, tal como el que se sitúa a este y oeste desde Rodilana a La Seca, formado en el Pleistoceno Inferior (TD 2, TD 3 y TD 4 de Pérez González, a 135, 119 y 108 m sobre el nivel del río).

A estas terrazas siguen otras acumulaciones, al norte de Rueda-La Seca, datadas como Pleistoceno Medio y Superior, que están disecadas de forma notable por los arroyos de la Morejona y del Perú, para volver a mostrar un gran empaque cuando dichos arroyos se unen y encajan al aproximarse a su desembocadura, en torno a 40 y 60 metros sobre la llanura de inundación ${ }^{30}$.

${ }^{28}$ GARCÍA FERNÁNDEZ, J.: Geografía y Paisaje. Llanuras y montañas de Castilla y León. Universidad de Alicante, Universidad de Valladolid, 2012, pág. 98.

${ }^{29}$ BENITO ÁLVAREZ, J.M.: Aportaciones al conocimiento del Achelense en la Meseta Norte. Universidad de Salamanca, Tesis doctoral, 2001, inédita, págs. 98-125.

${ }^{30}$ Mapa Geológico..., ob. cit., memoria, pág. 22-23. 


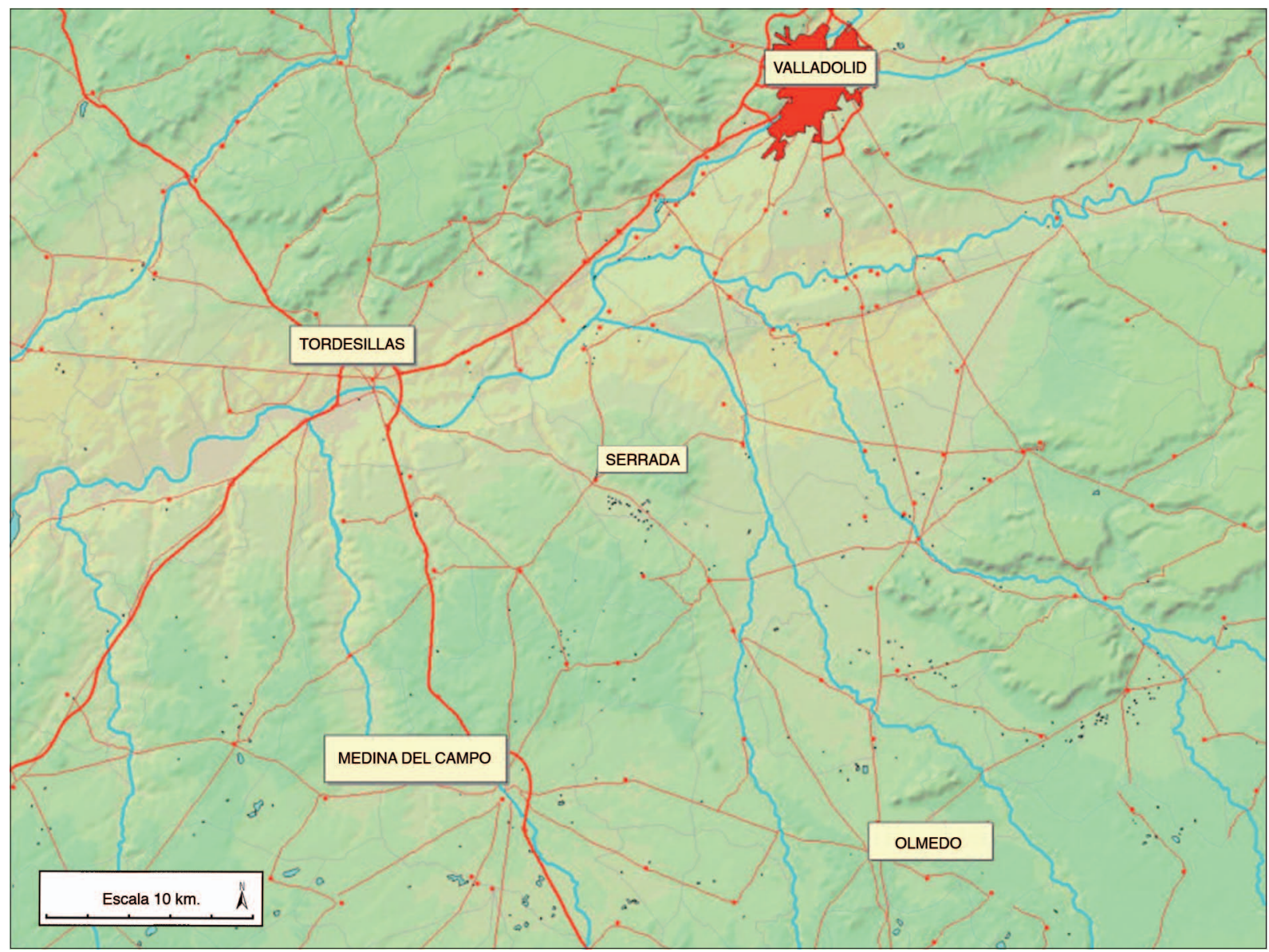

Figura 2. Esquema topográfico general del Duero Medio. Fuente J.C. y L.

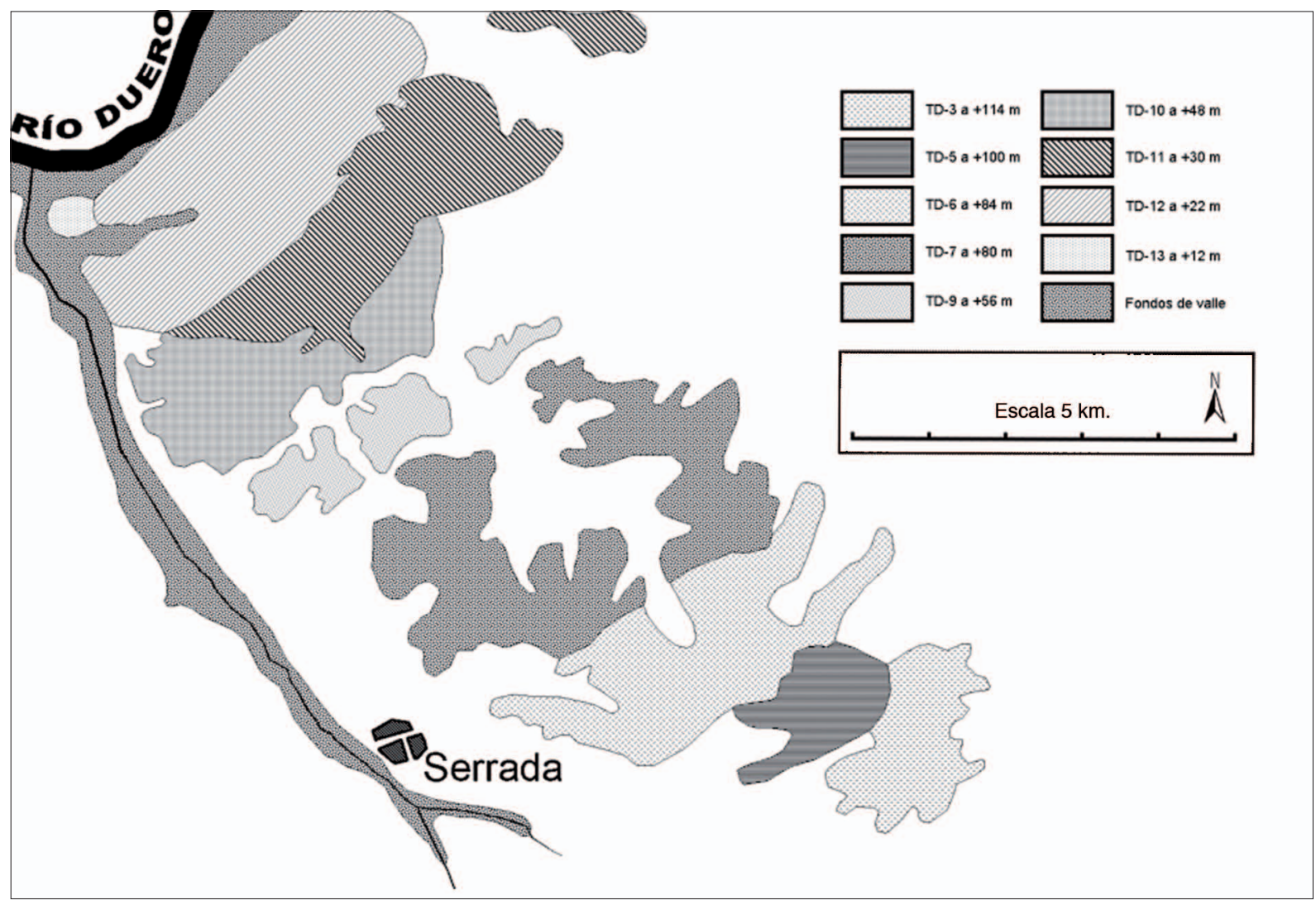

Figura 3. Ejemplo de niveles de terrazas entre Serrada-Villanueva y el río Duero. 

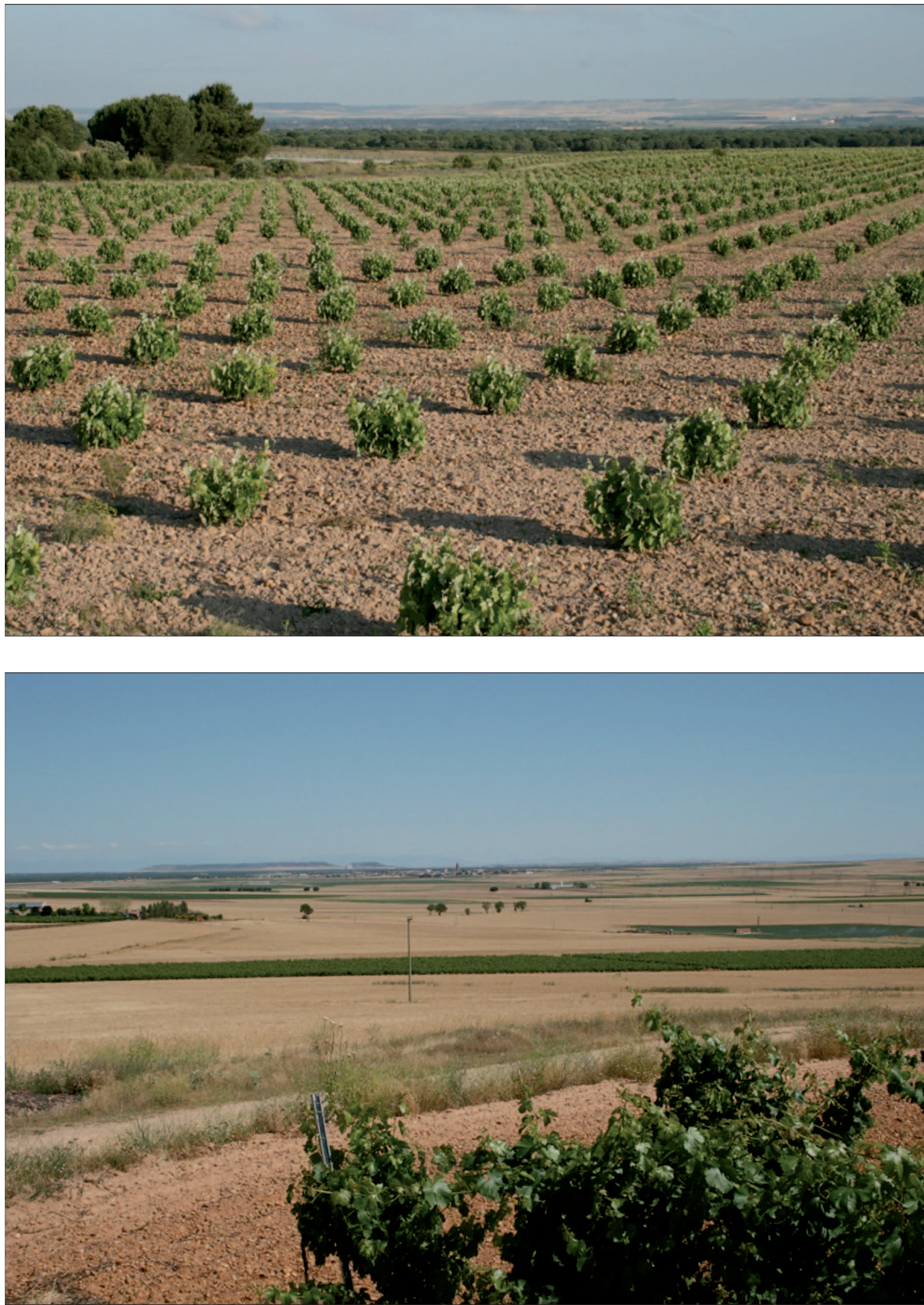

Imagen 3. Ejemplo de terraza baja en Villanueva de Duero (arriba) y terraza alta dominando el amplio valle, en Serrada (abajo). Foto: 09/06/2008 y 03/07/2008. La acción erosiva durante el Cuaternario, en su etapa del Pleistoceno, especialmente la fluvial, originó distintos niveles de terrazas, unidas por pequeños valles, entre los interfluvios Zapardiel y Adaja-Eresma, al sur del Duero medio. En la imagen se aprecia el amplio valle producido por el antiguo Adaja y, al fondo, el nivel de páramos de Portillo y la silueta difuminada de la Cordillera Central. 
Tanto en estas últimas como en las más antiguas, salvo en los sectores mejor conservadas y que pueden superar los tres metros, en la mayor parte su espesor se ha reducido considerablemente, fruto de la incisión lineal de los pequeños arroyos, por procesos de deflación eólica, o por pérdida de sustancia toda vez que, al encontrarse sobre arcillas miocenas impermeables, cuando la terraza permeable se satura de agua, esta rebosa y escapa, arrastrando material hacia las partes más bajas, que da lugar a vallecillos que enlazan con los labrados por los arroyos o arroyuelos más activos.

Distinto es el caso, por último, del valle y las terrazas cortadas por el arroyo de Serrada, que sigue el término municipal del mismo nombre, también conocido como arroyo del Berral o arroyo de San Martín, por ser también propio del despoblado del mismo nombre. En este caso, como se aprecia en la imagen anterior, el valle formado asombra por sus grandes dimensiones y sólo puede ser explicado si lo formó el antiguo cauce del río Adaja, antes de que fuera capturado por el Eresma en el Pleistoceno Superior ${ }^{31}$. Este hecho estaría relacionado con otros cambios de redes del sistema Adaja-Eresma en el Pleistoceno Medio y Superior, debidos a procesos geotectónicos, a cambios climáticos o a ambos factores a la vez ${ }^{32}$. Estos valles no funcionales formados por los anteriores ríos confluirían en el Duero entremezclados por distintos brazos y con periodos cálidos y húmedos intercalados con otros más áridos, como lo prueban la matriz arenosa enrojecida y con impregnaciones calcáreas que se aprecia en numerosos sectores ${ }^{33}$.

El escalonamiento de las terrazas, entre los arroyos del Perú y el mencionado de Serrada, que discurren con dirección S SE-N NO, se encuentra muy bien conservado, especialmente en el término de La Seca, y más erosionado al noreste, donde los cursos variables del Adaja y el Eresma lo han desmantelado en buena parte, aunque en los términos de Serrada, Villanueva de Duero y Valdestillas aún se conserva, si bien solapadas las terrazas unas con otras, las más cercanas al Duero y, de forma más nítida, las medias, como las denominadas TD 5, TD 6 y TD 7 que Pérez González sitúa entre 100 y 74 metros sobre el nivel actual del Duero. En estos sectores, a lo largo de los pagos de Montaña o El Francés, en término de Serrada, dando vista a las Arenosas de Villanueva y al Duero mismo, se puede comprobar que las terrazas más elevadas se encuentran desmanteladas y en su lugar, a cotas más bajas, aparecen otras, o el resto de aquéllas, asociadas a importantes acumulaciones arenosas de matriz más fina, vinculadas al arrastre fluvial y eólico que, en consonancia con los vientos dominantes del SO, llevan en suspensión el barrido de amplias superficies de la terrazas más altas, acumulando estas arenas más jóvenes y más blancas en hondonadas, laderas y pequeños vallecillos que salpican los distintos términos municipales.

\section{b. El espacio de campińas de la Tierra de Medina}

Desde las terrazas más altas y antiguas, situadas inmediatamente al norte de Medina del Campo, se abre hacia el sur una amplia superficie de gran monotonía litológica que presenta no más de cien metros de diferencia altitudinal, si exceptuamos el punto culminante de Ataquín Alto, al SO de Ataquines, que se eleva a $841 \mathrm{~m}$ y que constituye el resto de una antigua terraza fluvial.

El escaso relieve y las diferentes superficies de erosión que enlazan con aquellas de origen estructural, muy difícilmente distinguibles, complican la interpretación de las formas de relieve. En ocasiones se cartografían como superficies estructurales degradadas, como las que aparecen en la confluencia de los términos municipales de Rubí de Bracamonte, Fuente el Sol y San Vicente del Palacio y que dan la apariencia de antiguas terrazas. En cualquier caso, estas superficies de erosión, sean al sur de Medina, sean las de Alaejos o Carpio, rebasan el espacio estudiado hasta extenderse por las superficies de Coca, Arévalo, Olmedo y la Tierra de Pinares segoviana. Por ellas se extiende,

\footnotetext{
${ }^{31}$ Ibídem, pág. 35.

32 PÉREZ GONZÁLEZ. A: La depresión del Duero..., ob. cit., pág. 173.

${ }^{33}$ GARCÍA FERNÁNDEZ, J.: Geografía y Paisaje. Llanuras y montañas..., ob. cit., pág. 100.
} 
igualmente, un importante modelado eólico, que enmascara los sedimentos miocenos, vinculados al nivel de disección más bajo, consecuencia de la acción fluvial en la etapa fría del Pleistoceno, que en su última fase, ha ampliado los valles hasta enlazar con los contiguos y reducir al mínimo los interfluvios, apenas perceptibles en muchas ocasiones. En palabras de García Fernández, "estas campiñas al Sur de Medina del Campo constituyen una de las llanuras más perfectas de la Castilla del Norte"34. Han sido labradas por los cursos del Trabancos, Zapardiel y Adaja, caracterizados por un escaso caudal, toda vez que los primeros nacen en la Sierra de Ávila, a una altitud de entre 1.100 y 1.200 metros y en unos de los sectores con menores precipitaciones de la región. El propio Adaja, que tiene su cabecera en el tramo oriental de la vertiente norte de La Serrota, se caracteriza igualmente por precarias precipitaciones. A diferencia de la llamada "Tierra de Pinares" segoviana, en estas campińas de Medina, los recubrimientos de arenas eólicas son más discontinuos y someros, lo que ha permitido un mayor aprovechamiento agrícola desde tiempos medievales, aunque con un gran derroche de esfuerzo humano y una búsqueda de especies herbáceas de gran rusticidad como el trigo candeal, por ejemplo.

Al SO del espacio estudiado, en los términos de Castrejón, Torrecilla, Fresno y Carpio, nos encontramos una superficie de erosión en la que afloran materiales miocenos con suelos muy erosionados, sin apenas formaciones superficiales y que va descendiendo desde los $791 \mathrm{~m}$ de Los Tesillos, al SO de Fresno hasta por debajo de la cota de $750 \mathrm{~m}$ en El Campillo, conforme avanza en dirección SO-NE el arroyo de la Golosa, hasta su desembocadura en el Zapardiel, tres kilómetros al este de Medina del Campo. Distintas observaciones de campo y trabajos de cartografía geológica y geomorfológica ponen de manifiesto que parte de estas superficies se corresponden con niveles del substrato que presentan diferente resistencia a la erosión y que tienen un origen estructural ${ }^{35}$. Apenas las recubren en algunos sectores arcillas y limos en depósitos endorreicos, especialmente cuando el avenamiento de los pequeños arroyuelos es deficiente y forman pequeños lavajos o lagunas, tal como ocurre entre los municipios de Carpio y Brahojos.

El espacio sur y sudeste de la comarca estudiada presenta distintas caracterizaciones, siguiendo el curso del Zapardiel. Aquí el río ofrece un amplísimo y poco profundo valle con un importante relleno asociado a acciones fluvio-eólicas de las últimas etapas áridas y frías del Pleistoceno Superior (tardiglaciar). Los arroyos del Simplón, Malpaso, del Ramo o Valenoso discurren del SO-NE, buscando al Zapardiel, dejando regueros de material limoso y mal avenado donde afloran un sinnúmero de lavajos, lagunas o bodones, desde hace años temporalmente secos, toda vez que aquellos que, además del agua de la lluvia, se alimentaban de las capas superficiales del acuífero de los Arenales, al descender el nivel freático varias decenas de metros, se han desconectado del sistema hídrico, tal como le sucede al propio río que, como ocurre con el Trabancos, de ser recargadores por infiltración, han pasado a ser influentes (perdedores) del acuífero. De hecho, los caudales del Zapardiel y sus arroyos son efímeros, debidos solamente a la escorrentía superficial, cuando esta se produce, sea en tormentas estivales, sea en lluvias persistentes en otońo-invierno, manteniéndose secos el resto del año ${ }^{36}$. Lejos quedan, en este sentido, las palabras de Miguel de Cervantes en su Viaje del Parnaso, cuando manifiesta que las aguas del Zapardiel son "famosas por su pesca".

${ }^{34}$ GARCÍA FERNÁNDEZ, J: “La explotación tradicional en la “Tierra de Pinares” segoviana”, en Investigaciones Geográficas. Anales de la Universidad de Alicante. Instituto Universitario de Geografía, septiembre-diciembre de 2004, pág. 8-9.

35 PINEDA VELASCO, A.; SALAZAR RINCÓN, A.; HERRERO HERNÁNDEZ, A; MARAREO BENITO, Y: Mapa Geológico de España a escala 1:50.000. Hoja no 427 (Medina del Campo), I.G.M.E., Madrid, 2007, memoria, pág. 41.

36 SÁNCHEZ SAN ROMÁN, F. J.: Los grandes acuiferos de la cuenca del Duero. Universidad de Salamanca, Departamento de Geología, Salamanca, 2004. 

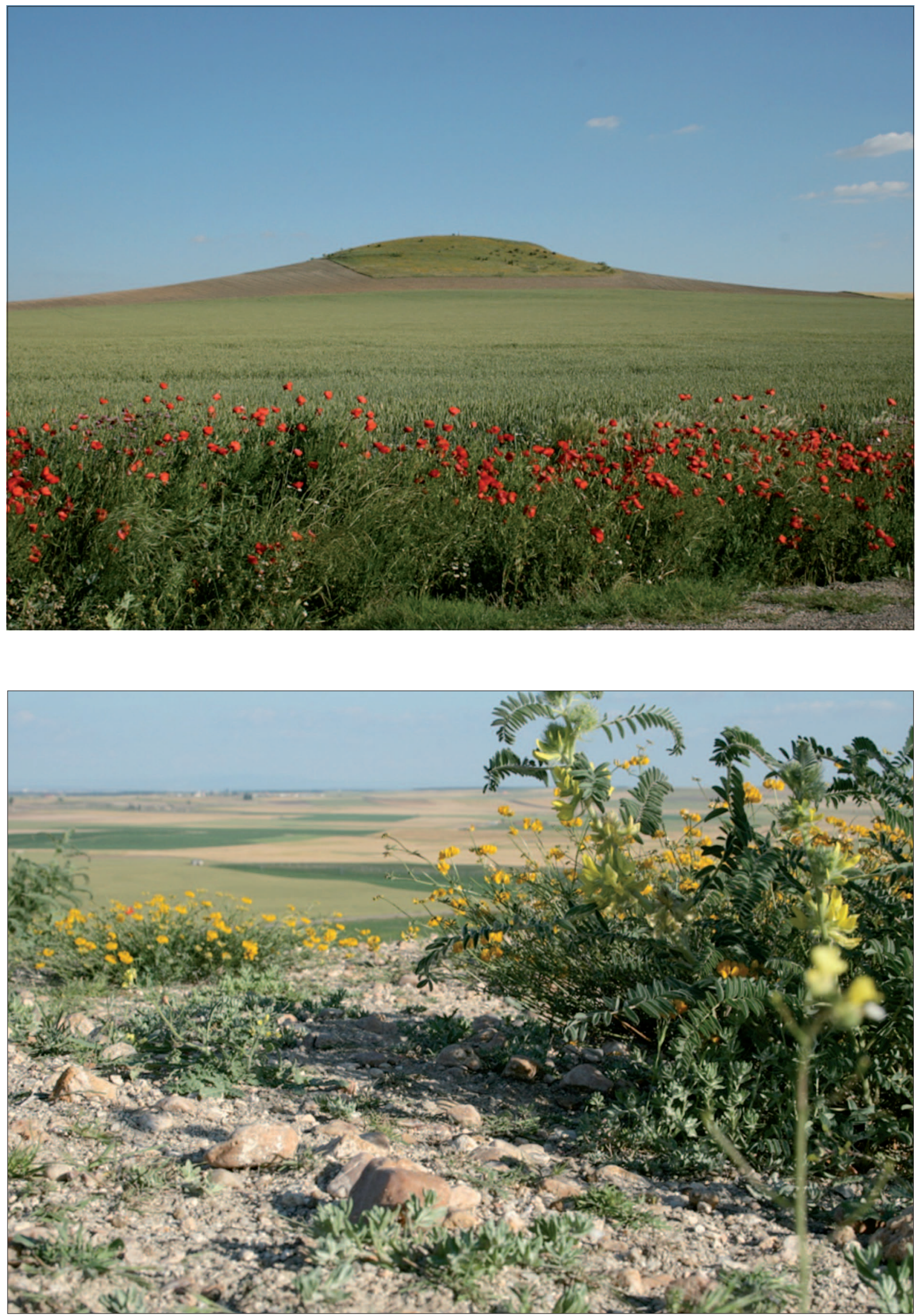

Imagen 4. Vista general del Ataquin Alto y detalle en su culminación de esta antigua terraza fluvial. (Foto: 12/06/2008). Estos restos de antiguas terrazas fluviales, que se elevan a más de ochocientos metros de altitud, rompen la monotonía en las campiñas al sur de Medina del Campo, caracterizadas por su horizontalidad. Obsérvese, en la imagen inferior, los cantos rodados de cuarcita, ventifactos, por la acción del viento. 


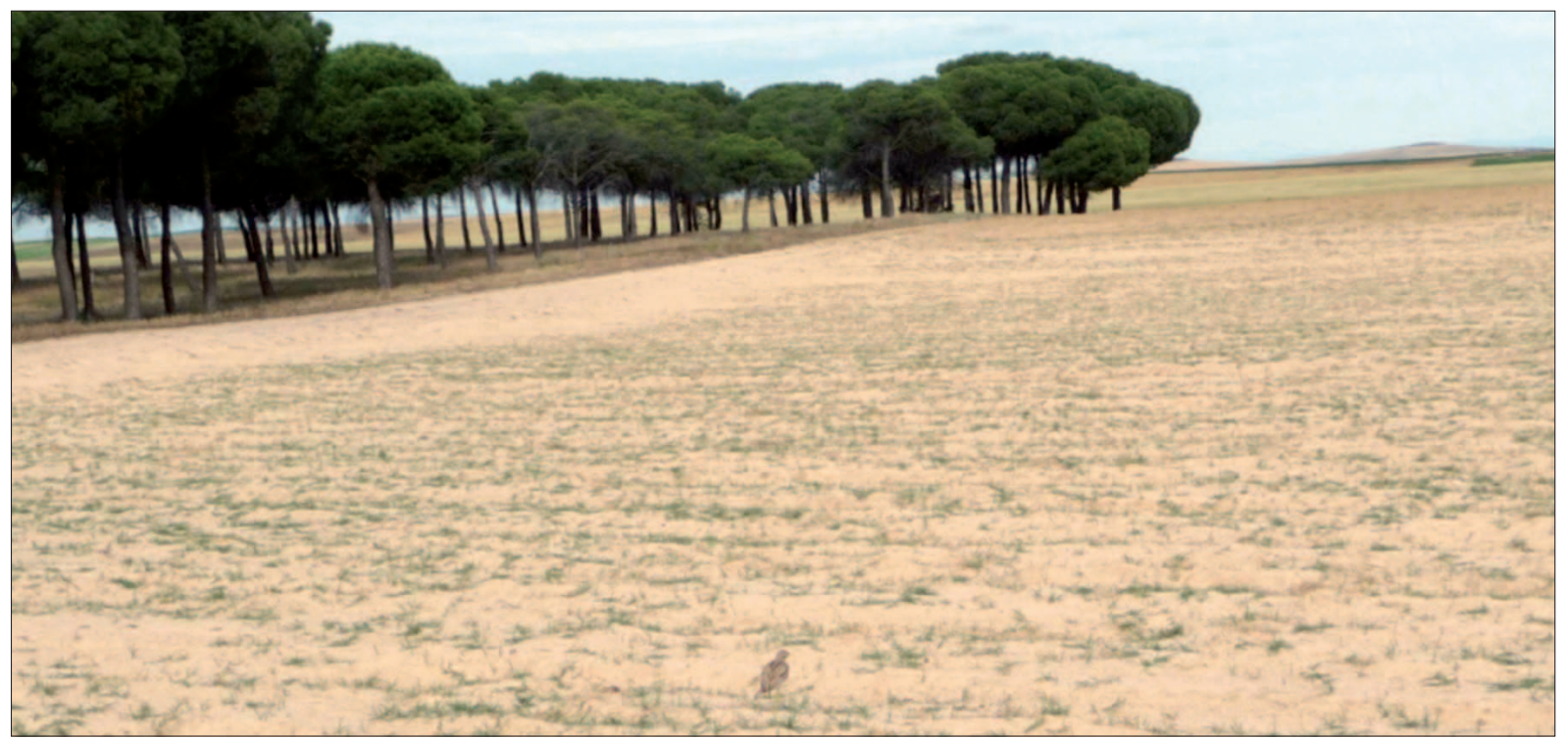

Imagen 5. Arenas eólicas fijadas por rodales de pinares en las campiñas del sur. En primer plano, un alcaraván. (Foto: 11/06/2011). Los recubrimientos de arenas eólicas se extienden, intermitentemente, por buena parte de las campinas del sur de Medina, condicionando el desarrollo de los cultivos.

Antes de que estos arroyuelos alcancen al Zapardiel, sin embargo, los depósitos de arenas y limos se ensanchan notablemente, a la par que las lagunas y lavajos se mantienen rodeados de algunos prados verdinales durante las estaciones más secas, como es el caso de las Lagunas Reales, las que surten el Balneario de las Salinas o los lavajos Toribia y Rabioso. Estas superficies de acumulación arenosa se extienden hasta el sur de Pozal de Gallinas, llegando al río Adaja, siendo cartografiadas geomorfológicamente como superficies de depósito que dan la impresión de enlazar con los niveles de terrazas de este río, en los términos de Ataquines, Ramiro, La Zarza y Pozal de Gallinas ${ }^{37}$.

En todos estos depósitos de arenas, también en aquellos que enlazan las terrazas fluviales del norte de la comarca, se advierte un marcado influjo eólico, dando lugar a depósitos dunares como los que se observan un kilómetro al oeste de la laguna del Simplón, en la carretera que va de Medina a Bobadilla o como meras acumulaciones dispersas, con orientación SO, de acuerdo a los vientos dominantes y que, estériles para los cultivos herbáceos, por superar el metro de espesor, han sido fijadas por rodales de pinares.

Estas importantes acumulaciones parecen concebirse en un clima frío, de tipo periglaciar, con fuertes vientos del oeste. Por un lado los propios ríos las transportarían desde la Cordillera Central pero en las estaciones frías, a la par que experimentaban una disminución de caudal por el hielo, el viento era otro agente de transporte que debemos considerar. Estas arenas blancas, con escasas oxidaciones y encostramientos constituye, en palabras de García Fernández, "la última fase de sedimentación en esta dialéctica contradictoria de etapas de denudación y acumulación que ha regido su desmantelamiento"38.

${ }^{37}$ PORTERO, J.M.; CARRERAS, F.; OLIVÉ, A.; GUTIÉRREZ ELORZA, M.; MOLINA, E. y otros: Mapa Geológico de España a escala 1:50.000. Hoja no 428 (Olmedo), I.G.M.E., Madrid, 1982, memoria, pág. 42-43.

${ }^{38}$ GARCÍA FERNÁNDEZ, J.: Geografía y Paisaje. Llanuras y montañas..., ob. cit., pág. 119. 

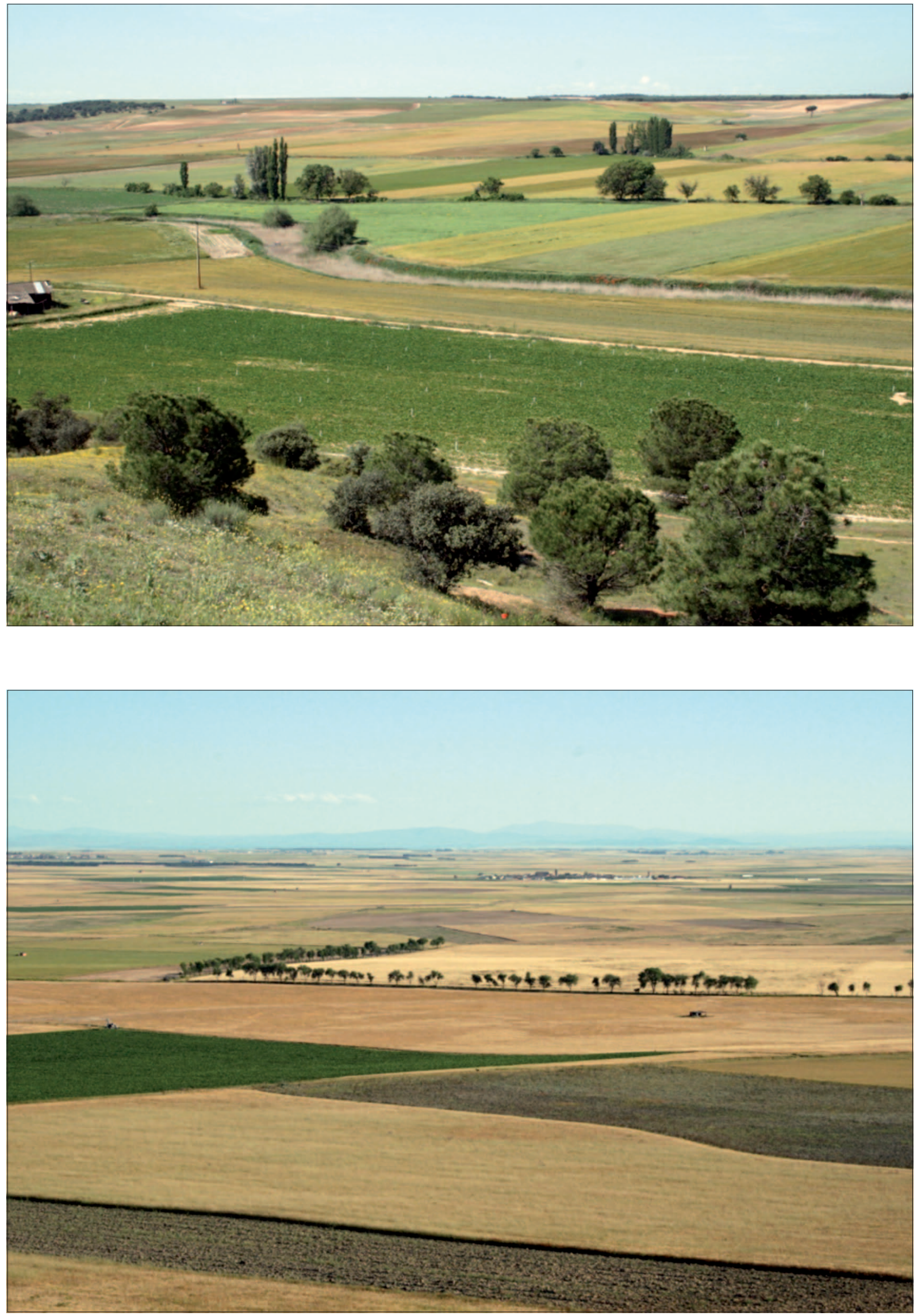

Imagen 6. El río Zapardiel a su paso por Foncastín (arriba) y paisaje de campiñas al sur de la Tierra de Medina (abajo). Foto: 04/06/2008 y 12/06/2008. La simplicidad de las formas de relieve esconde, sin embargo, una gran complejidad si atendemos a su morfogénesis. El paisaje agrario, como vemos, es el resultado de la interacción entre el hombre y el medio a lo largo del tiempo. 


\section{El clima como condicionante de los cultivos}

La Tierra de Medina vallisoletana, a una altitud de entre 700 y $800 \mathrm{~m}$ sobre el nivel del mar, participa de las condiciones físicas generales del sector central de la cuenca del Duero, en el marco de un clima mediterráneo interior. Como todo el centro de la cuenca sedimentaria, se enmarca en la Castilla de las llanuras, alejada de la influencia atemperante del mar y rodeada de una orla montańosa que, junto al factor altitudinal, reduce las precipitaciones, eleva la oscilación térmica y es responsable de un largo y riguroso invierno ${ }^{39}$. En este sentido ha sido siempre la crudeza del invierno, junto con la llanura, uno de los elementos más aprehensibles en la percepción y valoración del complejo ecológico ${ }^{40}$. Dicha configuración morfológica es responsable, igualmente, de la existencia de unos veranos suaves, salvo breves periodos calurosos, y de un régimen de precipitaciones escasas, si atendemos a la vegetación natural, a las necesidades de los cultivos y a las apetencias de los hombres que habitan o han morado en este espacio.

Como puede apreciarse en los climogramas adjuntos, representativos del espacio estudiado, la temperatura media anual de las tres localidades es de $12,4^{\circ} \mathrm{C}$, una temperatura media de $4^{\circ} \mathrm{C}$ en enero y $21,5^{\circ} \mathrm{C}$ en agosto y una amplitud térmica de $17,5^{\circ} \mathrm{C}^{41}$. Desde noviembre a marzo la temperatura media no supera los $10^{\circ} \mathrm{C}$ lo que nos indica la rigurosidad de los inviernos, largos y con periodos de frío donde las heladas condicionan la vida vegetal. Éstas, como seguidamente veremos, se hacen sentir hasta bien entrada la primavera, estación fugaz con cambios de tipo de tiempo que parecen devolvernos al invierno o asomarnos al verano en los meses de abril y mayo, según se tercie. El verano, cálido, está atemperado por la altitud y, en las tres estaciones mencionadas, no se superan los $22^{\circ} \mathrm{C}$, salvo los meses de julio en Rueda $\left(22,2^{\circ} \mathrm{C}\right)$ y Ataquines $\left(22,4^{\circ} \mathrm{C}\right)$. En el otońo las temperaturas descienden considerablemente, siendo la media de septiembre $18,4^{\circ} \mathrm{C}$ y de octubre $12,9^{\circ} \mathrm{C}$. Las noches vuelven a ser frías y las heladas, frecuentes a comienzos de octubre y numerosas en la segunda quincena, nos aproximan nuevamente al invierno.

Las precipitaciones, igualmente, son representativas del centro de la cuenca del Duero, oscilando entre los $396 \mathrm{~mm}$ de Villanueva y los $401 \mathrm{~mm}$ de Ataquines. La mayor parte de ellas se producen en primavera y otońo, con un mínimo estival, por debajo de $20 \mathrm{~mm}$ de media, en julio y agosto. Como puede apreciarse en los gráficos, estas bajas precipitaciones, generalmente asociadas a tormentas estivales, coinciden con las máximas temperaturas. El amarillo de los rastrojos, el ocre de los barbechos y el verde del viñedo han sido los colores predominantes del paisaje agrario, en esta estación, hasta la llegada del regadío en el último siglo. Diciembre, enero y febrero, no obstante, reciben el 26,8\% del total de precipitaciones, con valores que oscilan entre los $27 \mathrm{~mm}$ en febrero de Villanueva y Ataquines y los 44 y $46 \mathrm{~mm}$ en diciembre de Rueda y Villanueva de Duero. Aunque en principio pudiera parecer que esta distribución de temperaturas y precipitaciones no es muy favorable para el desarrollo de la actividad agraria, la realidad es que tanto en tiempo histórico, como en la actualidad, el arraigo de cereales y vińedo ha sido un hecho que ha posibilitado un notable dinamismo en las comunidades agrarias que han ocupado estas tierras.

Especialmente se ha de destacar el vińedo, adaptado tanto a los suelos más pobres como a la precipitaciones que reciben. Como veremos, a estos condicionantes físicos se han adaptado variedades rústicas en el caso de los cereales, como el trigo Candeal o la cebada caballar del país. Mención aparte

39 GARCÍA FERNÁNDEZ, J.: El Clima en Castilla y León. Ámbito, Valladolid, 1986, pág. 31 y ss.

${ }^{40}$ GARCÍA FERNÁNDEZ, J.: Castilla (Entre la percepción...), ob. cit., pág. 127.

${ }^{41}$ Las estaciones escogidas, por significativas atendiendo a su situación, son Villanueva de Duero, al norte del espacio estudiado (680 m de altitud), Rueda (724 m de altitud) y Ataquines, al sur del espacio (802 $\mathrm{m}$ de altitud). Sus temperaturas medias anuales son $12^{\circ} \mathrm{C} ; 12,7^{\circ} \mathrm{C}$ y $12,5^{\circ} \mathrm{C}$, respectivamente; el total de precipitaciones suman $384 \mathrm{~mm}, 396$ $\mathrm{mm}$ y $401 \mathrm{~mm}$, respectivamente. Las series utilizadas, facilitadas por el Observatorio Meteorológico de Valladolid, se inician a comienzos de los años setenta en las estaciones referidas y abarcan hasta el año 2007. 


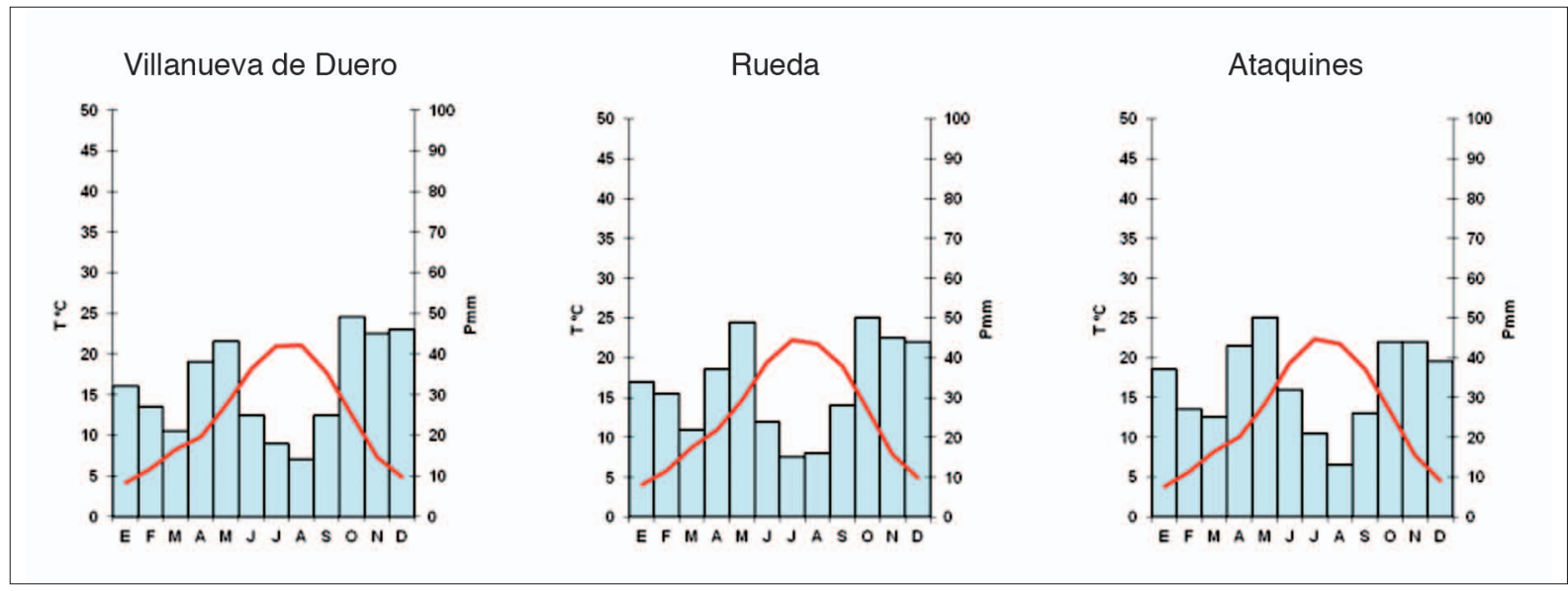

Figura 4. Climogramas de distintas estaciones del espacio estudiado.

Fuente: Centro Meteorológico Zonal del Duero, Observatorio Meteorológico de Valladolid.

merece el Verdejo, vinífera que hace de la necesidad virtud en las altas terrazas de gravas, resecas a finales del verano. Esta variedad consigue en septiembre cargar de azúcares su fruto, garantía para una buena elaboración y conservación, al tiempo que las bajas temperaturas nocturnas, que comienzan a registrarse en estas fechas, en pleno proceso de maduración, suman un aporte aromático diferenciador y clave de su éxito, tanto en el pasado como en los momentos presentes.

Ha sido, pues, la rusticidad de estas determinadas variedades de cereales, leguminosas y viñedo, una de las claves de la adaptación a estos condicionantes climáticos, ligados, como veremos, a los edáficos. La aparición del regadío, esencial para entender la evolución agraria del último siglo, también ha debido atender a la distribución de temperaturas como factor limitativo en el desarrollo de los cul$\operatorname{tivos}^{42}$. La patata y la remolacha han sido los aprovechamientos básicos, entre los cultivos de regadío, que se han adaptado con éxito a dichos condicionantes. Con tan solo tres meses libres de heladas (junio, julio y agosto), la práctica agronómica y la selección de variedades ha sido fundamental en la superación, tanto de las heladas primaverales como de los fríos otoñales ${ }^{43}$. A los anteriores productos, incluyendo el cereal regado, se han ido sumando otros, atendiendo a coyunturas y políticas de mercado, dimensión de explotaciones, etc., tales como la alfalfa, los cultivos hortícolas y el maíz.

\section{a. La incidencia de las temperaturas en el desarrollo de los cultivos}

Como acabamos de exponer, reflejo de la altitud, latitud y relieve que caracteriza al espacio estudiado, así como del que se deriva de la Meseta en la que se sitúa, los inviernos son fríos y largos, ya que la media de las mínimas es inferior a $0^{\circ} \mathrm{C}$ en sus meses centrales. La morfología de la cuenca del Duero contribuye mucho a estas bajas temperaturas. El enfriamiento del aire de los espacios circundantes a más altitud, especialmente durante las noches, provoca, al ser más pesado, su acumulación en este centro regional, dando lugar a periodos en que las temperaturas son continuadamente bajas, normalmente acompañadas por nieblas densas que contribuyen, aún más, a acentuar la sensación de frío.

A escala más local, este fenómeno se acentúa en los sectores de menor altitud, sobre todo en los espacios de campiñas del sur, donde los fenómenos de inversión presentan una alta frecuencia. De hecho, si el gradiente altitudinal se calcula en $0,4^{\circ} \mathrm{C}$ cada $100 \mathrm{~m}$ en el invierno, para Medina del

\footnotetext{
${ }^{42}$ MOLINERO HERNANDO, F.: El regadio..., ob. cit., pág. 72.
}

${ }^{43}$ Un ejemplo es la evolución del rendimiento de la remolacha en Castilla y León, que ha alcanzado 108 tm/ha en la campaña 2012/13. La fecha de siembra es fundamental a la hora de alcanzar altos rendimientos. Las 89 tm/ha alcanzadas en la campańa 2013/14 se consideran muy buenas, teniendo en cuenta que la siembra fue muy tardía debido a la adversa meteorología, con 39 días de retraso respecto al ańo anterior, que supuso una pérdida del $20 \%$ del potencial productivo. Fuente: Revista AIMCRA, Plan 2014, informe final, págs. 6-7. 


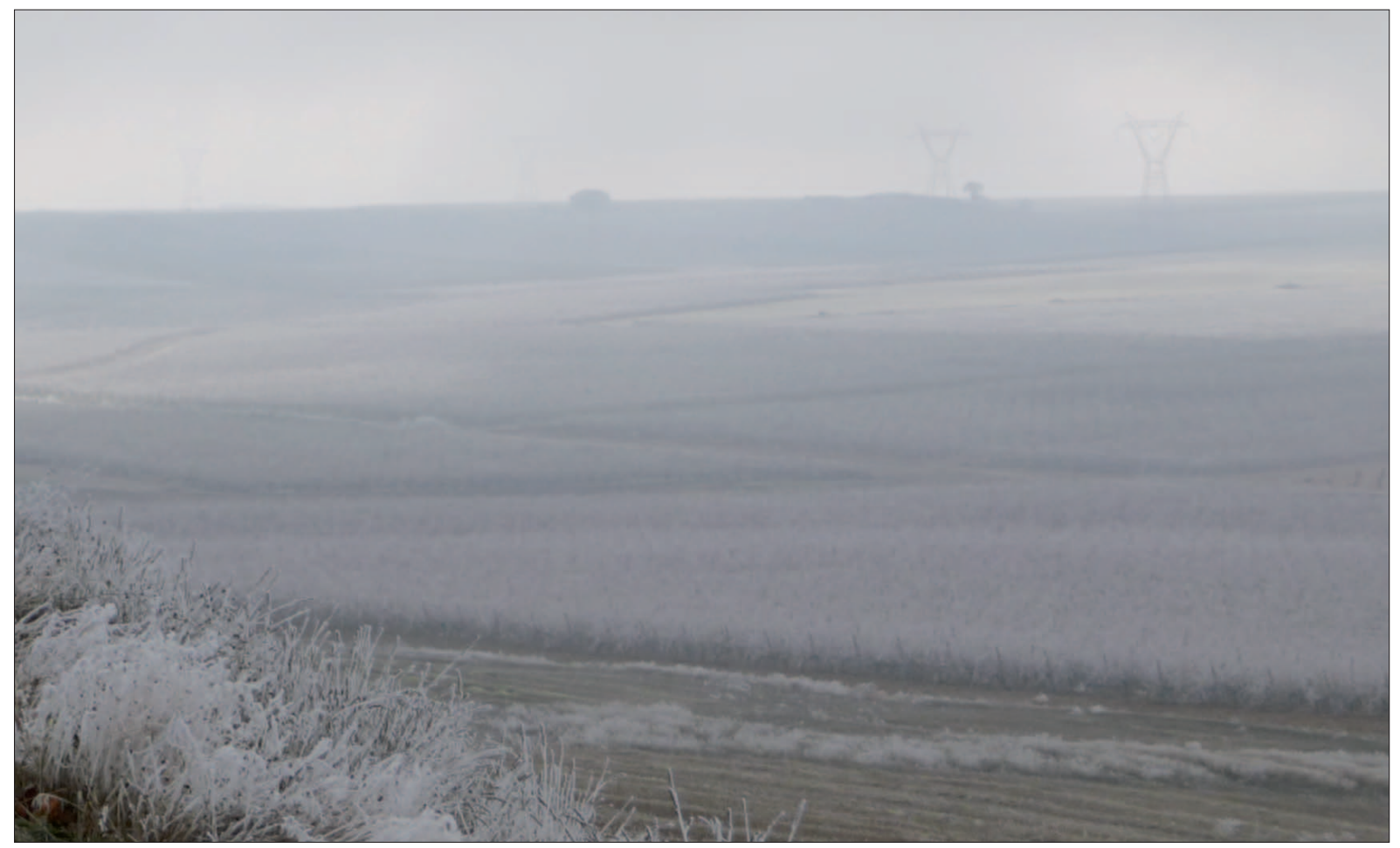

Imagen 7. Amanecer entre niebla, con fuerte helada y escarcha, en las terrazas y valles del norte de Medina. Foto: 09/12/2013. Con temperaturas inferiores a $0^{\circ} \mathrm{C}$ durante la madrugada y buena parte del día, apenas si levantó la niebla unas horas, al atardecer, consecuencia del tipo de tiempo anticiclónico que caracterizó a la Península en la citada fecha y a la morfología de la cuenca del Duero.

Campo la medida señalada es de 2,9 $\mathrm{C}$. El campo, al alba, se cubre de una niebla espesa que inunda toda la comarca, bajando por los pequeños valles hasta llegar al Duero y haciéndose resistente, en el mejor de los casos, durante buena parte de la mañana, cuando no se torna desafiante y permanece dejando entrever el sol a primeras horas de la tarde sobre los sectores más altos y, más cerrada y persistente, hasta ocultarle día tras día, en campiñas y valles. Los que, por motivos de trabajo, recorren al amanecer de norte a sur este centro regional, no acaban de acostumbrase, por el desasosiego que les produce, cuando se adentran en estos bancos de niebla cada vez más persistentes, desafiantes y fríos a la altura de Puente Duero, para esperanzarse en las terrazas más altas de la Seca o Rueda, queriendo ver el sol entre la niebla, sin conseguirlo. Al descender a la campiña medinense, con el termómetro en sus niveles más bajos, observan cómo se precipita la niebla en forma de cencellada, dejando cada mańana un tenue tapiz blanco, tan repetitivo como frágil, y dependiente del sol conforme traza su elíptica. Son amaneceres en los que el campesino tradicional, sabiendo dormida y helada la tierra, daba tregua a la esteva y al legón para empuñar la podadera. Eran y son mańanas frías y duras que atrasan los sembrados y sumergen en profundo sueño a las cepas, liberándolas parcialmente del riesgo de helada, ante un despertar anticipado. Lo uno por lo otro, a decir de los antiguos labradores.

A ello debemos añadir la llegada, en este periodo, de olas de aire polar continental, que provocan el descenso térmico a mínimas absolutas inferiores de $-5^{\circ} \mathrm{C}$, y que, cuando persisten varias jornadas ininterrumpidas, pueden ocasionar daños en cultivos como la remolacha, si aún no se ha recogido la cosecha, e incluso en el cereal de ciclo largo sembrado en el otoño ${ }^{44}$. No se debe olvidar, en este sentido, que las nuevas variedades no están tan habituadas a estos avatares de rigor invernal como los tradicionales trigo candeal o cebada caballar, mejor adaptados en su rusticidad a estas extremas exigencias térmicas, a la par que a los suelos sueltos y cascajosos, tan abundantes en este espacio. Si bien con las técnicas y semillas actuales en los secanos la sementera puede atrasarse hasta bien entrado noviembre, el labrador tradicional, temeroso de que los primeros fríos y lluvias lo cojan con la simiente en la panera, se apresuraba desde finales de septiembre a darle tierra en los barbechos para dedicar el 

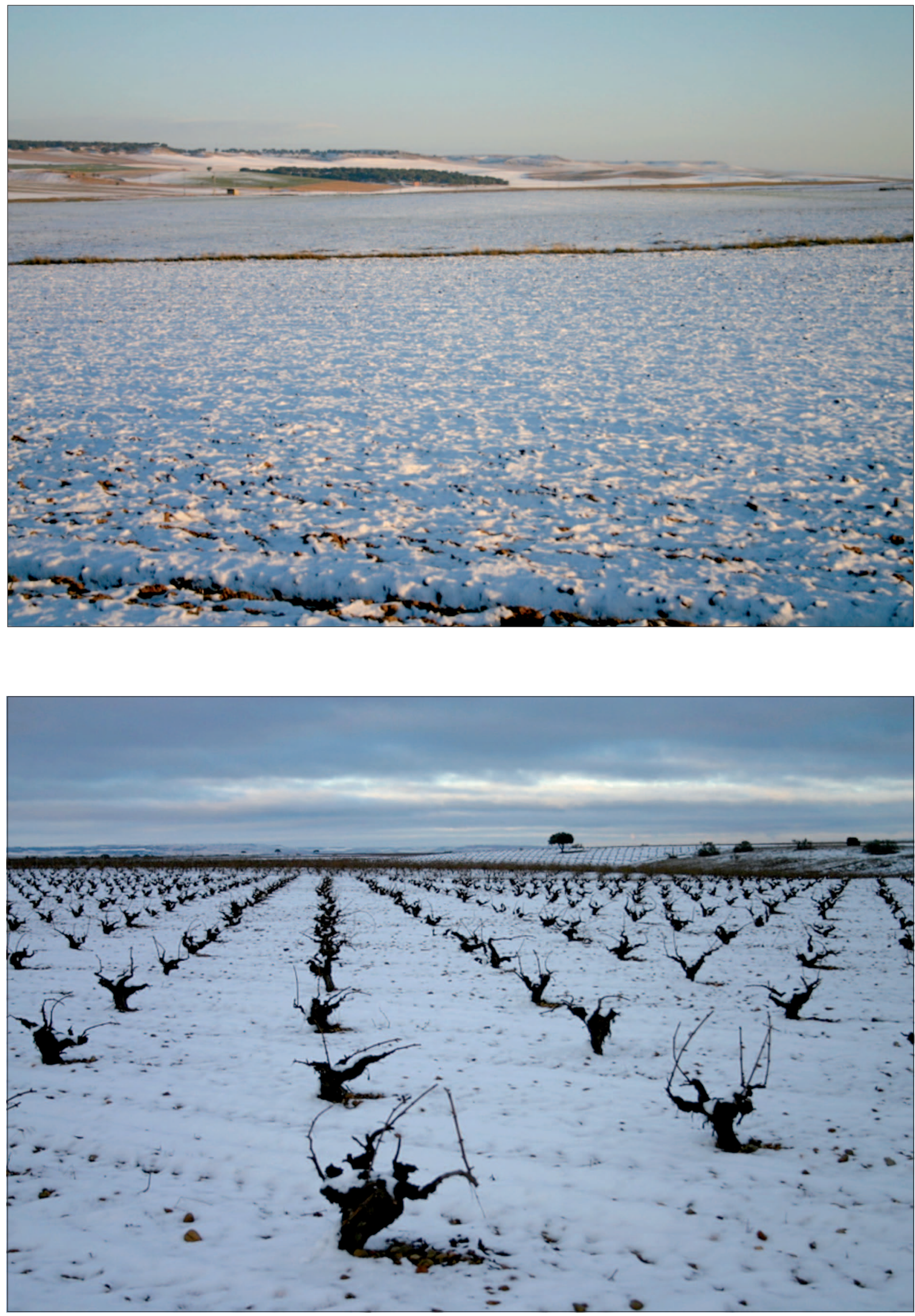

Imagen 8. Atardecer invernal al norte de la Tierra de Medina. Tierras de pan llevar en Rueda (arriba) y viñedo Verdejo a marco real en Serrada, (abajo). Foto: 15/12/2008. El frío se hace sentir en la comarca en los meses invernales. Las heladas son frecuentes y las nevadas, como es el caso de la imagen, aunque limitan la actividad agraria, dan esperanzas al labrador, a decir del refranero tradicional: "año de nieves, año de bienes". 
mes de octubre a "retelar" las pajas con cebada ${ }^{45}$. De esta manera, a finales de octubre, ya verdegueaban los campos entre los amarillos y púrpuras de los majuelos y era frecuente ver, especialmente en tiempo de vendimia, a los burros con bozal o cebadera para evitar que hicieran daño en las hojas de pan. Sólo así se encaraba noviembre con garantías, toda vez que "por San Martín (once de noviembre) ya sólo siembra el ruin", siguiendo el criterio de los más precavidos.

Pero no ha sido en general el frío invernal el que ha determinado la actividad agraria y los cultivos en el espacio estudiado. En el sector norte de terrazas, especialmente si su terrazgo cuenta con pagos de majuelos, la preocupación máxima por las bajas temperaturas se centra en las que tienen lugar en primavera, dependiendo también del grado de brotación de los cultivos, especialmente del vińedo. El riesgo se incrementa de acuerdo a la mayor o menor benignidad de los meses de febrero y marzo, factores, por lo demás, tenidos en cuenta y tratados de paliar con técnicas culturales asociadas a la vid, sea retrasando en lo posible la poda -poda tardío y siembra temprano y cogerás uva y grano-, sea con prácticas culturales de acobijo o tapado de las cepas. No hay que olvidar, en este sentido, que el periodo libre de heladas es tan sólo de 164 días en la comarca de Medina del Campo, abarcando desde el 6 de mayo al 17 de octubre y que, entre estas fechas, se encuentran los meses más críticos de brotación y floración de cultivos tales como patatas, remolacha o el mencionado viñedo. Las heladas son una realidad, año tras año, al menos durante cinco meses, derivadas de coladas de aire ártico, de vaguadas de aire polar continental, consecuencia de "gotas frías" o, con mayor frecuencia, de procesos de irradiación nocturna ${ }^{46}$.

El refranero puede parecer desmedido, pero no lo es tanto si recorremos el campo rayando el alba a finales de abril o en la primera semana de mayo. Más de un día, por lo general, la percepción de frío deja de ser subjetiva al comprobar cómo las cebadas brillan blancas de escarcha ante los primeros rayos del sol. Y no es raro que los charcos de los caminos, caso de que haya llovido, se cubran de una fina película de hielo. También en estos pequeños detalles se diferencia el campo de la ciudad.

${ }^{44}$ No es el frío invernal, por lo general, el causante de pérdidas sustanciales de cosechas a lo largo del tiempo, a no ser que se acompañe de humedades, que ocasionan el enfriamiento y pasmado de los cultivos herbáceos en bajos o suelos de poca sustancia. Es sabido por todos los que moran en estos pueblos de la meseta castellana que el frío llega cada invierno y que casas, ganados y personas deben estar prevenidos y bien pertrechados. Si la población lo acusaba en tiempo histórico, no es tanto por el frío como por las menguadas despensas de los más desfavorecidos. Un menor número de jornales limitaba más la vida a los jornaleros que el descenso del mercurio. Con todo, las bajas temperaturas registradas en Valladolid en 1864 ( $\left.-14^{\circ} \mathrm{C}\right)$, en 1871 $\left(-15^{\circ} \mathrm{C}\right)$ y en $1885\left(-21^{\circ} \mathrm{C}\right)$ y la crudeza del invierno de $1945 / 46 ; 1962 / 63 ; 1970 / 71$ o del mencionado de 1885 , forman parte del registro atmosférico habitual. Las fortísimas heladas de enero de 1985 llegaron a ocasionar pérdidas en la cosecha de remolacha, con la consiguiente repercusión en las economías agrarias familiares, como consecuencia del efecto continuado de la mencionada y duradera "ola de frío". Sin embargo, como señala García Fernández (El clima..., pág. 192), las pérdidas económicas, en lo tocante al mundo agrario, se hicieron notar en el sector remolachero, fruto de un retraso desmesurado en la saca por culpa de un otońo lluvioso que no facilitó la extracción de la raíz en unas tierras demasiado embarradas. Tampoco se debe olvidar que, aún en aquellos años, buena parte de las explotaciones familiares disponían de sistemas de recolección y transporte muy inferiores en agilidad y capacidad a los existentes en la actualidad. No podemos olvidar ahora, casi veinticinco años después, el tiempo vivido como alumno en el aula Juan de la Cosa, en la Facultad de Filosofía y Letras de Valladolid, sin calefacción tras haber estallado sus tuberías por el hielo. Cómo olvidar las explicaciones de los profesores García Fernández o Calonge en relación con la génesis de dicha dinámica atmosférica, o las de los profesores Molinero y Cascos Moraña sobre sus efectos en el medio. Aún se recuerda en estos pueblos la angustia de muchos labradores, que salían con sus pequeños tractores a las cuatro de la madrugada camino de la fábrica, a fin de descargar el producto a primera hora, pues, al subir el sol y subir la temperatura, acababa por deshelarse, produciendo tanto disgusto el verlo, dado el lastimoso estado que presentaba la raíz, como la pérdida económica derivada del rechazo del producto. Con todo, las consecuencias en la actividad agraria de aquellos contratiempos siguió alargándose en las siguientes semanas, pues se añadió el consecuente retraso en la siembra de la cebada en dichas parcelas, agravado por la persistencia de un régimen anticiclónico que provocó la necesidad de sacar los tubos de lluvia para asegurar la nascencia y evitar que dicho retraso derivara en la mengua de la siguiente cosecha de cereal, dado lo ajustado de los tiempos y márgenes en que se movían las pequeñas explotaciones familiares de la comarca en aquellos años.

${ }^{45}$ Aunque el verbo retelar no está recogido en la diccionario de la RAE, le utilizamos toda vez que su uso es muy corriente en el mundo rural que estudiamos. Con este localismo se expresa la repetición de cultivo, sin barbechar, en las tierras que salen de pajas, una vez segado el cereal.

${ }^{46}$ CALONGE CANO, G.: Climatología de los inviernos en Valladolid. Universidad de Valladolid, 1984, pág. 332 y ss. 


\section{Cuadro 1. Registros de heladas tardías en el sector central de la Cuenca del Duero}

\begin{tabular}{|c|c|c|c|c|c|c|c|c|}
\hline Estación & $\begin{array}{c}\text { Periodo } \\
\text { de registro }\end{array}$ & $\begin{array}{l}\text { No de años } \\
\text { con registros } \\
\text { en dicho } \\
\text { periodo }\end{array}$ & $\begin{array}{c}\text { No de años con } \\
\text { helada registrada } \\
\text { desde el } 15 \\
\text { al } 30 \text { de abril }\end{array}$ & $\%$ & $\begin{array}{l}\text { No de ańos } \\
\text { con helada } \\
\text { registrada en } \\
\text { el mesde mayo }\end{array}$ & $\%$ & $\begin{array}{l}\text { No de años con } \\
\text { coincidencia de } \\
\text { helada en la segunda } \\
\text { quincena de abril } \\
\text { y en mayo }\end{array}$ & $\%$ \\
\hline Rueda & $1978-2007$ & 27 & 10 & 37,3 & 9 & 33,3 & 6 & 22,2 \\
\hline $\begin{array}{l}\text { Villanueva } \\
\text { de Duero }\end{array}$ & $1977-2007$ & 31 & 23 & 74,1 & 15 & 65,2 & 12 & 38,7 \\
\hline Ataquines & $1970-2007$ & 37 & 25 & 67,5 & 22 & 59,4 & 18 & 48,6 \\
\hline $\begin{array}{l}\text { Medina } \\
\text { del Campo }\end{array}$ & $1960-1988$ & 29 & 16 & 55,1 & 16 & 55,1 & 16 & 55,1 \\
\hline Arévalo & $1962-2005$ & 30 & 14 & 46,6 & 6 & 20 & 5 & 16,6 \\
\hline Valladolid & $1973-2007$ & 35 & 16 & 45,7 & 11 & 31,4 & 5 & 14,2 \\
\hline
\end{tabular}

Fuente: Centro Meteorológico Zonal del Duero, Observatorio Meteorológico de Valladolid.

Cuando el observatorio de Valladolid capital, situado apenas veinte kilómetros al norte del espacio comarcal, anota temperaturas de uno o dos grados, a los habitantes de las áreas rurales del sur de la provincia no les hace falta salir de casa a comprobar el accidente metereológico; saben que más de un viñedo adelantado presentará síntomas de la helada pocas horas más tarde, especialmente los situados en las terrazas arenosas a menor altitud y en el fondo de los pequeños valles orientados al norte. Idéntico riesgo y similares consecuencias afectarán a las parcelas sembradas de remolacha. Se trata de la denominadas "heladas en el suelo", debidas a situaciones dinámicas tales como coladas polares y árticas o situaciones de gota fría que ocasionan, en noches despejadas, tan fuerte irradiación nocturna que el vapor de agua en las capas más bajas llega al grado de congelación. Aunque su cuantificación es difícil por la falta de registros, de los existentes se deriva un aumento de un $41,4 \%$ respecto a la media convencional ${ }^{47}$.

No son heladas que provoquen la pérdida total de la cosecha, pero si la aminoran, y, si se repiten, la pueden reducir considerablemente, especialmente en el caso del viñedo. Sabedor de su peligrosidad, el campesino tradicional, caso de tener tierra disponible, siempre prefirió para este cultivo las terrazas más altas y mejor venteadas que los bajos arenosos y fríos donde agarra más el frío y siempre son más propensos a estas amanecidas con hielo en los charcos y escarcha en los campos. De hecho, estos son factores fundamentales a la hora de explicar la distribución en hojas del espacio labrado en tiempo histórico e, incluso, como se analizará en capítulos posteriores, resultan claves para entender la regresión espacial de determinados cultivos cuando por causas económicas se reducía su margen de rentabilidad ${ }^{48}$.

${ }^{47}$ GARCIA FERNÁNDEZ, J.: El clima..., ob. cit., págs. 115-117.

${ }^{48}$ Como se verá en siguientes apartados, las prácticas culturales en los distintos cultivos siempre tuvieron muy en cuenta estas contingencias meteorológicas. En lo que respecta al vińedo en relación a las mencionadas heladas de suelo, el cambio que desde hace unas décadas se está dando en el sistema de conducción de las cepas se torna fundamental para paliar este tipo de heladas. Piénsese que, en las plantaciones de viñedo en espaldera, el alambre de formación de la planta se sitúa a 0,8 $\mathrm{m}$ de altura, al tiempo que la aísla del suelo, suficiente para aminorar o anular el efecto de las heladas más débiles. Distinto es el caso de las importantes extensiones de olivo que, desde hace una década, se están cultivando en la comarca. Aunque en tiempo histórico en este centro de la meseta se registraron plantaciones y almazaras, nunca cuajó como cultivo y aprovechamiento significativo. En la actualidad las modernas técnicas agronómicas y la selección de variedades pueden hacer frente a las bajas temperaturas sin que, al parecer, se resienta en exceso el árbol. De momento las plantaciones se sitúan en pagos bien venteados y su crecimiento no parece estar afectado por la dureza invernal de estas tierras. En la próxima década, cuando estén en plena producción, se podrá analizar con mayor rigor la rentabilidad y adaptación de los nuevos compañeros del cereal y el viñedo en los secanos medinenses. 


\section{- Un ejemplo de helada en vińedo por irradiación nocturna}

Las heladas más problemáticas para el agro, como decimos, son las que se producen a comienzos de la primavera, especialmente cuando esta sucede a inviernos benignos o, habiendo sido fríos, cuando el mes de marzo se presenta con temperaturas más altas de lo normal para este mes ${ }^{49}$. Hay que destacar la alta frecuencia de los ańos con heladas, tanto en la segunda mitad de abril, que superan en la mitad a los años registrados en los puntos de medición situados en el espacio estudiado, como las habituales de mayo, mes en el que en Medina del Campo y en Ataquines hiela un año de cada dos. En estas dos estaciones, igualmente, y en dicha proporción, se anotan heladas coincidentes el mismo año, tanto en la segunda quincena de abril como en mayo, prueba de lo frías que son las mańanas al comienzo de la primavera en el centro de la cuenca. Las heladas, en buena parte producidas por irradiación nocturna, son frecuentes hasta bien entrado mayo. "Hasta el cuarenta de mayo no te quites el sayo" es la expresión más popular que indica la variabilidad de la primavera castellana y la persistencia de un frío que se resiste en estas enclaustradas y altas tierras meseteñas.

Aunque, como se ha expuesto, muchas de ellas tienen efectos reducidos o locales, siguen representando el accidente meteorológico más seguido por los agricultores en estas fechas. En los ejemplos adjuntos puede comprobarse su efecto en viñedo en los años 2010 y $2013^{50}$. El primer caso corresponde a un viñedo localizado en Villanueva de Duero, pago de Las Laderas del Rey, situado en el fondo de un pequeño valle con suelo arenoso y grava, resguardado entre laderas arcillosas, con orientación $\mathrm{NO} / \mathrm{SE}$, a $725 \mathrm{~m}$ de altitud, entre terrazas a $750 \mathrm{~m}$ de altitud $^{51}$.

En el gráfico puede comprobarse la importante pérdida de calor que supera los $12,6^{\circ} \mathrm{C}$ entre las 20,00 horas del 5 de mayo y las 7,30 horas del 6 de mayo, en que se registran 1,30 C. Estas bajas temperaturas al amanecer, al igual que los $0,3^{\circ} \mathrm{C}$ registrados un día antes en la estación de medición a $750 \mathrm{~m}$ de altitud, son consecuencia de un tipo de tiempo anticiclónico, cielos despejados, fuerte irradiación nocturna y viento en calma. En el fondo del valle la temperatura baja por debajo de los $0^{\circ} \mathrm{C}$, propiciando bancos de aire muy frío a nivel del suelo que, al amanecer, al estar resguardados entre laderas que acentúan su estabilidad, generan y mantienen la escarcha pegada a la materia vegetal hasta que el sol quema los brotes, como puede advertirse en la imagen adjunta, tanto más cuanto que el ascenso de temperaturas es muy rápido $\left(1,3^{\circ} \mathrm{C}\right.$ a las 7,30 horas y $10,55^{\circ} \mathrm{C}$ a las 12,30 horas).

${ }^{49}$ En estos casos una savia impetuosa empuja una brotación precipitada y las heladas, especialmente si se producen en la segunda quincena del mes, resultan fatales para muchos cultivos. De ahí la expresión "abril siempre fue ruin, al principio, a la mitad y al fin" aunque, como vemos, no toda la culpa la tiene abril, sino, en parte, el caprichoso marzo. Así lo testimonia la percepción popular: "cuando marzo mayea, mayo marcea". Y las heladas en primavera son palabras mayores para la gente del campo pues son conscientes que pueden llegar a aminorar la cosecha de forma seria dos de cada diez años. En la tabla adjunta se indican, a modo de ejemplos, algunas de estas variables de heladas tardías en observatorios del espacio estudiado o cercano a él. García Fernández en su libro "El clima en Castilla y León" apela igualmente a la percepción popular para ser más elocuente en relación a la variabilidad del mes de marzo. En este mes los golpes de frío pueden paralizar o dańar los primeros brotes. De ahí que refiera el dicho "los hielos por la Encarnación (25 de marzo) los últimos hielos son, sino sale el año respondón", que, a decir verdad y siguiendo sus palabras, "la mayoría son respondones". GARCIA FERNÁNDEZ, J.: El clima..., ob. cit., pág. 188.

${ }^{50}$ Los datos han sido proporcionados por la Estación de Avisos Agrícola de Toro, que se encuentra dentro de la Red de Vigilancia Fitosanitaria creada por la Consejería de Agricultura y Ganadería de la Junta de Castilla y León. Se fundamenta en la Orden AyG/622/2004, de 26 de abril, de la Consejería de Agricultura para, en la medida de lo posible, recoger y analizar información al objeto de detectar la aparición de agentes parasitarios nocivos para los vegetales, evaluar los riesgos y adoptar las medidas de información y control oportunas. En el ejemplo estudiado se han utilizados los datos recogidos en las estaciones controladas por la Estación de Avisos de Toro, en concreto, las de La Seca 1 (parcela 153, polígono 4, latitud 410 25’ 18,64” N y longitud 4o 55' 32,47” O); La Seca 2 (parcela 5068, polígono 1, latitud 41.26' 27,37" N y longitud 40 56' 5,97" O) y Villanueva de Duero (parcela 174, polígono 8, en la parte alta de la parcela, situada a una latitud de $41^{\circ} 28^{\prime} 52,03^{\prime \prime} N_{y}$ longitud de 4o 51' 17,39” O). Nuestro agradecimiento a Santiago Cepeda Castro, ingeniero agrónomo, técnico de la Estación de Avisos Agrícolas de Toro, Junta de Castilla y León.

${ }^{51}$ Este primer ejemplo se localiza a 350 metros de la estación de toma de datos Villanueva de Duero, situada a una latitud de $41^{\circ} 28^{\prime} 52,03^{\prime}$ N y longitud de 40 51' 17,39” O, localizada en la parte culminante del valle en el pago del mismo nombre, a la mencionada altitud de $750 \mathrm{~m}$, altitud. El resto de las estaciones, situadas igualmente en las terrazas más amplias en que se asientabuena parte del viñedo al norte de Rueda se sitúan tambiéna 750 m de altitud. 


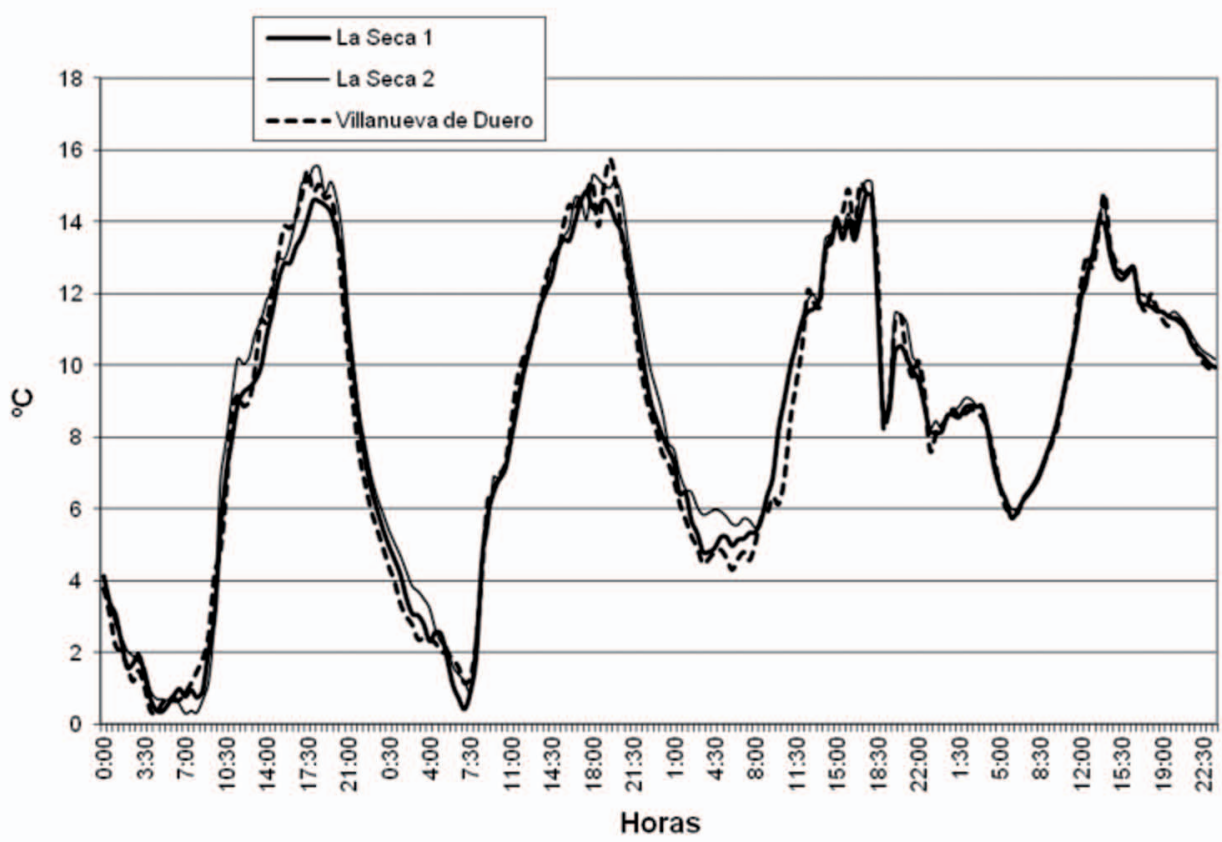

Figura 5. Gráfico de temperaturas correspondiente a los días 5, 6, 7 y 8 de mayo de 2010.

Fuente: Estación de Avisos Agrícola de Toro. Junta de Castilla y León.

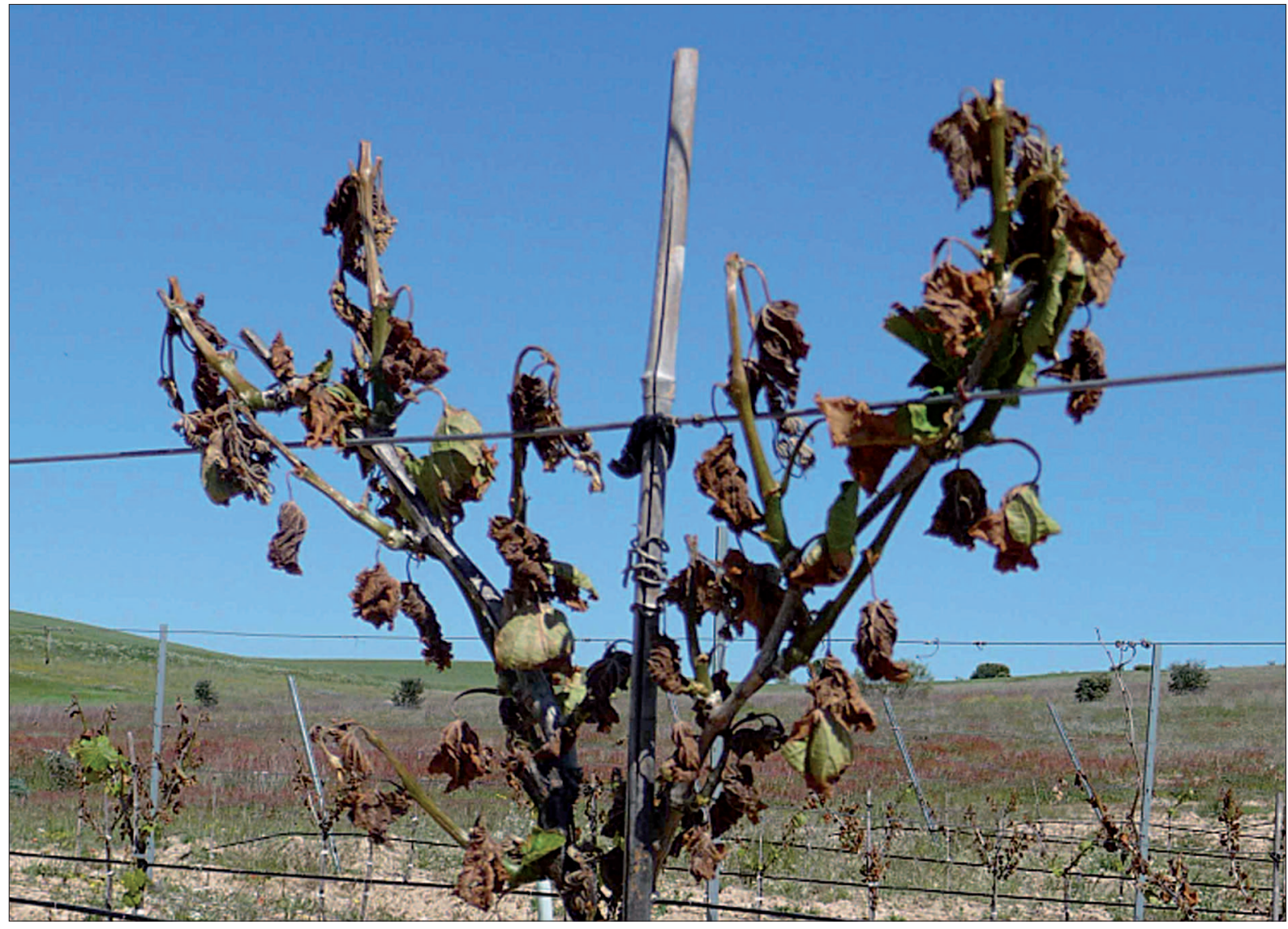

Imagen 9. Efecto de la helada del 5 y 6 de mayo de 2010, días después de haberse producido, Villanueva de Duero. Foto: 16/05/2010. Las heladas que se producen en el viñedo, una vez la cepa muestra los primeros racimos, aminoran la cosecha de forma muy notable, toda vez que el rebrote se caracteriza por la abundancia de tallos y la ausencia de fruto. 


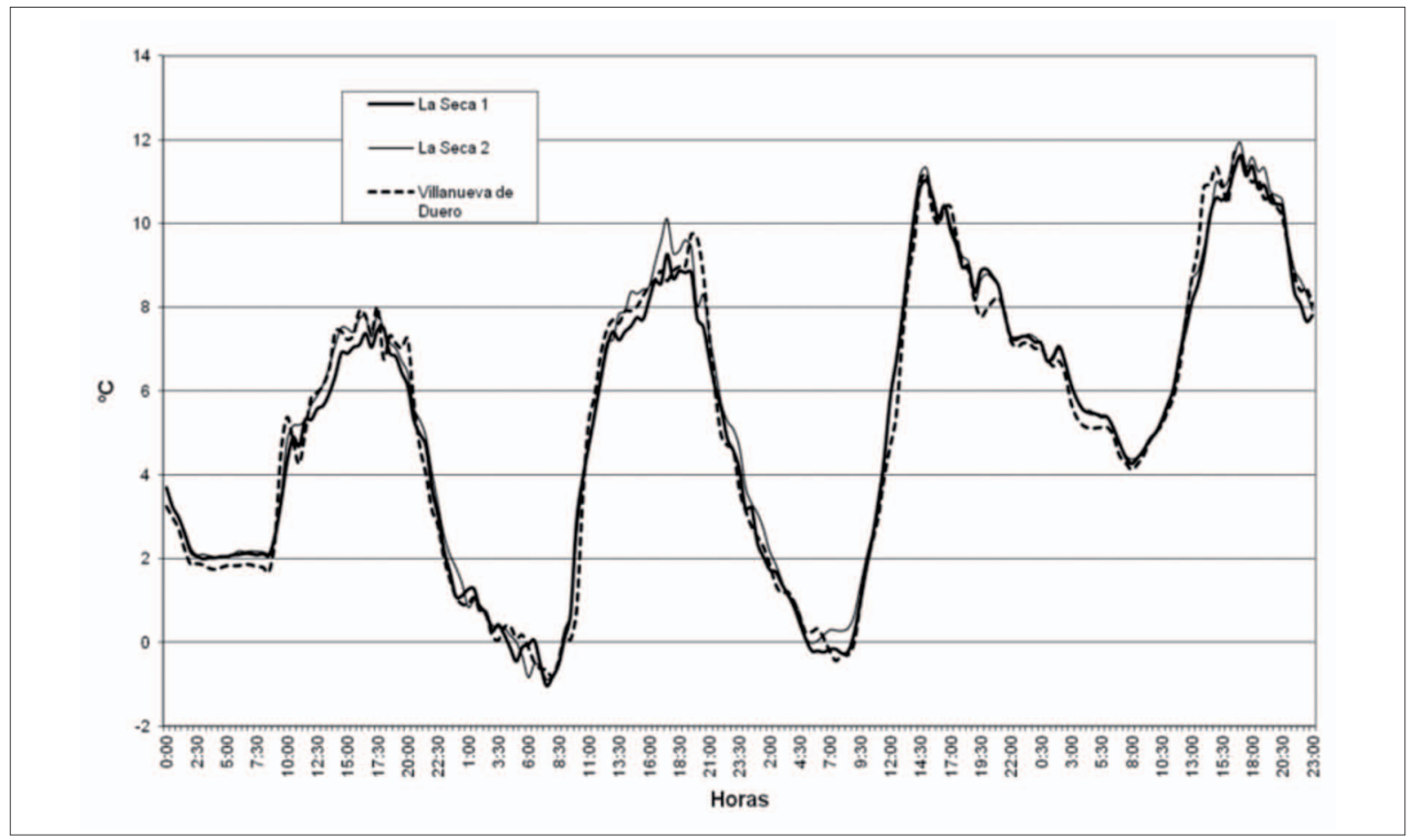

Figura 6. Gráfico de temperaturas correspondiente a los días 5, 6, 7 y 8 de abril de 2013.

Fuente: Estación de Avisos Agrícola de Toro. Junta de Castilla y León.

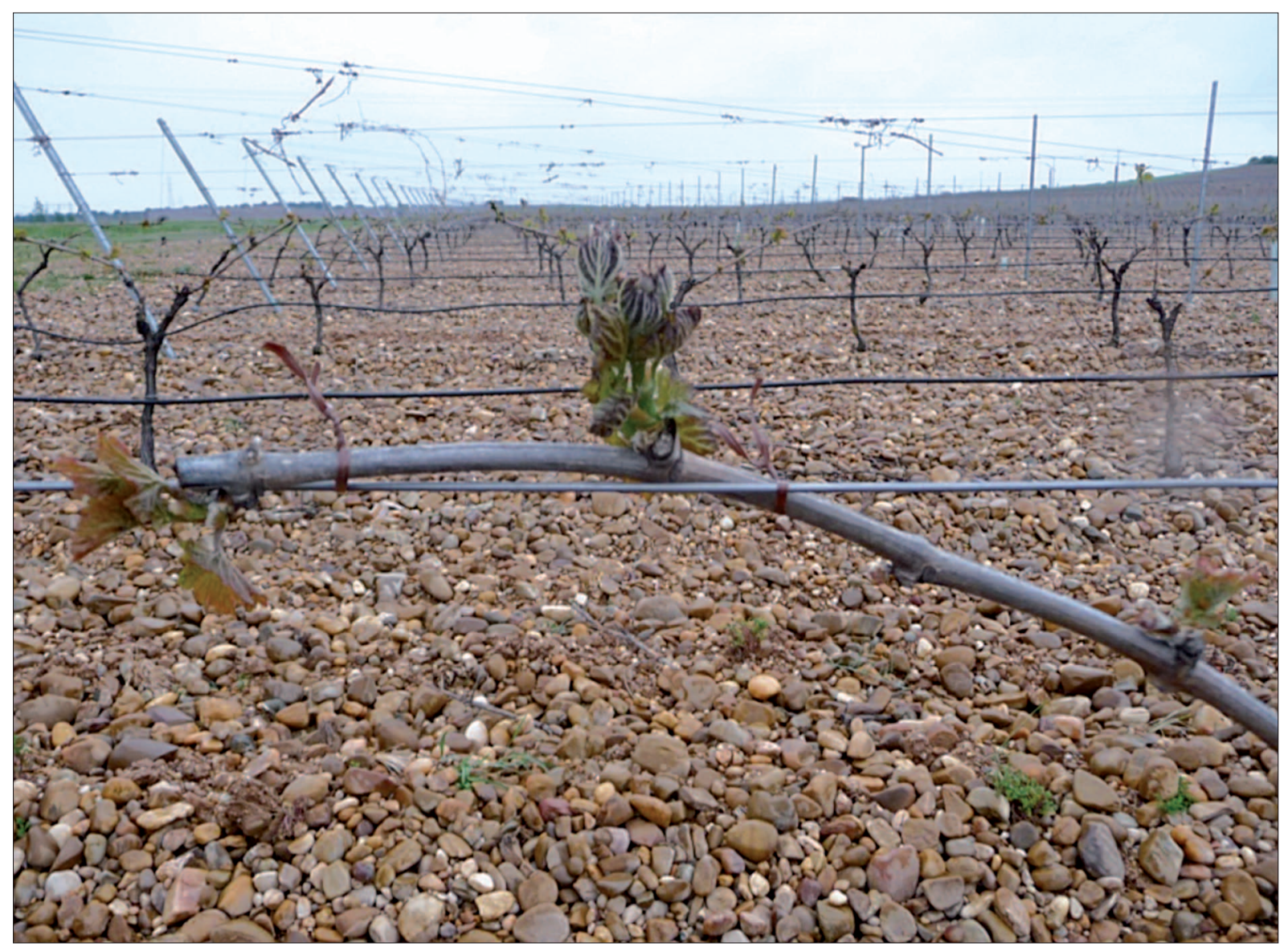

Imagen 10. Débil y desigual efecto de la helada en los primeros brotes, Villanueva de Duero.

Foto: 09/04/2013. Los efectos de estas heladas son tan variables como las circunstancias atmosféricas, tipos de suelo o labores dadas a los majuelos. Hasta los viticultores más experimentados no se explican los porqués de los dispares efectos de estas heladas en unos u otros pagos de viñedo. 
Las prácticas agronómicas adquieren un papel importante en la prevención de las heladas más débiles, tales como dejar arados los viñedos a principios de abril y no tocarles hasta San Isidro, a fin de que la corteza, formada en la tierra con las lluvias que puedan caer en este tiempo, impida la salida de humedad del interior del suelo y su congelación en estos amaneceres que relatamos. Las arenas, con más porosidad y siempre más frías, acusan su debilidad ante los suelos arcillosos. Tan importante como ello es la diferencia entre las cepas plantadas a marco real, pegadas a la tierra y por tanto más heladizas, de las plantaciones en espaldera que se encuentran más aireadas y cualquier pequeño movimiento del aire antes de la salida del sol, seca o desprende la escarcha de las hojas o racimos, evitando la helada.

Todas estas contingencias, entre otras, hacen variar los efectos del hielo primaveral en los cultivos de forma muy diversa. Basta comprobarlo en el segundo gráfico que, con temperaturas por debajo de $0^{\circ} \mathrm{C}$ en la estación citada, apenas se chamuscaron algunos brotes en la primera semana de abril de 2013.

El descenso de temperatura por debajo de $0^{\circ} \mathrm{C}$, como puede apreciarse, es más importante que en el primer ejemplo pero sus efectos en el viñedo apenas se dejaron sentir. En efecto, la temperatura baja en la estación de La Seca I hasta los $-1,04^{\circ} \mathrm{C}$ a las 7,30 horas del 6 de marzo de 2013 y a $-0,82^{\circ} \mathrm{C}$ a las 8,00 horas del mismo día en la mencionada estación de Villanueva. Al día siguiente se repiten valores negativos, en concreto, $-0,27^{\circ} \mathrm{C}$ en La Seca y $-0,44^{\circ} \mathrm{C}$ en Villanueva. El aumento de temperatura en las horas siguientes, tras salir el sol, fue muy rápida, pues se alcanzaron los $11^{\circ} \mathrm{C}$ a las 14,30 del segundo día, pero el ligero viento y nubosidad alta al amanecer atenuó una helada difusa tanto en las terrazas altas como en las bajas, tal como muestran los brotes de la espaldera de la imagen.

Como decimos, la existencia o no de nubosidad o viento en las primeras horas de la mañana, y sus múltiples variaciones locales, se tornan fundamentales en las repercusiones que tienen en el rendimiento de los cultivos, de acuerdo a la orientación, altitud y tipos de suelo del parcelario labrado. Los rendimientos finales dependen, en parte, de estos factores ${ }^{52}$.

Junto a estas bajas temperaturas registradas en buena parte del año y que acusan no sólo los meses invernales sino también las breves estaciones intermedias de otoño y primavera, se encuentran unos veranos con temperaturas medias de $18,4^{\circ} \mathrm{C}$ en junio, $21,7^{\circ} \mathrm{C}$ en julio y $20,9^{\circ} \mathrm{C}$ en agosto, similares a las registradas en todo el centro de la cuenca. En general, su duración no supera los noventa días, comprendidos entre mediados de junio y septiembre, no exentos de periodos de gota fría que refrescan y acortan el tiempo caluroso. El dicho "en agosto frío al rostro" es revelador de estos veranos breves y más bien suaves, salvo cuando la persistencia del anticiclón de las Azores o la llegada de aire sahariano eleva las temperaturas medias a cotas más altas, hasta alcanzar medias de máximas de $26,0^{\circ} \mathrm{C}, 29,1^{\circ} \mathrm{C}$ y $30^{\circ} \mathrm{C}$ en junio, julio y agosto, respectivamente. A ello se une una configuración del relieve de la cuenca sedimentaria del Duero corresponsable de una aridez importante en los meses estivales ${ }^{53}$. Como efectos adversos, si anteriormente se acusaba en el viñedo la influencia perniciosa de la helada primaveral, en el cereal se producen ahora similares incertidumbres. Si la siembra es temprana y se dan unas condiciones óptimas, puede adelantarse la cosecha y las heladas tardías representan una seria amenaza; si, por el contrario, se retrasa la siembra, se corre un riesgo mayor, pues en las jornadas finales de mayo y junio las altas temperaturas llegan a alcanzar cotas elevadas $\left(20,2^{\circ} \mathrm{C}\right.$ y $25,6^{\circ} \mathrm{C}$. de temperaturas medias máximas y temperaturas superiores a $30^{\circ} \mathrm{C}$ en sus máximas absolutas), que asuran la cosecha, provocando un importante descenso de la producción.

\footnotetext{
52 Nada mejor, aunque se trate de una situación excepcional, que reseñar las heladas que tuvieron lugar en el norte comarcal los días 27 y 28 de mayo de 1914. El Ayuntamiento de La Seca dejó constancia de ello en su Libro de Actas: "Que siendo de gran consideración los daños causados por las heladas de los días veintisiete y veintiocho de mayo último en todos los majuelos del término municipal, lo cual constituye una grave calamidad pública... se solicita el perdón de la contribución que al citado pueblo pueda corresponder... las que participa la instrucción de expedientes por los pueblos de Rueda y Ventosa de la Cuesta solicitando el perdón de sus contribuciones por la pérdida de la mitad de la cosecha de cereales, legumbres y vino, el primero, y total de vinos, mitad de algarrobas y cuarta parte de guisantes, muelas y cebada, el segundo", (A.M.L.S. Libro de Actas, sesión extraordinaria, fecha 2/6/191.

${ }^{53}$ CASCOS MARAÑA DE, C. S.: Contribución al estudio de los tipos de tiempo en los veranos de Valladolid. Institución Cultural Simancas, Valladolid, 1982, pág. 210.
} 

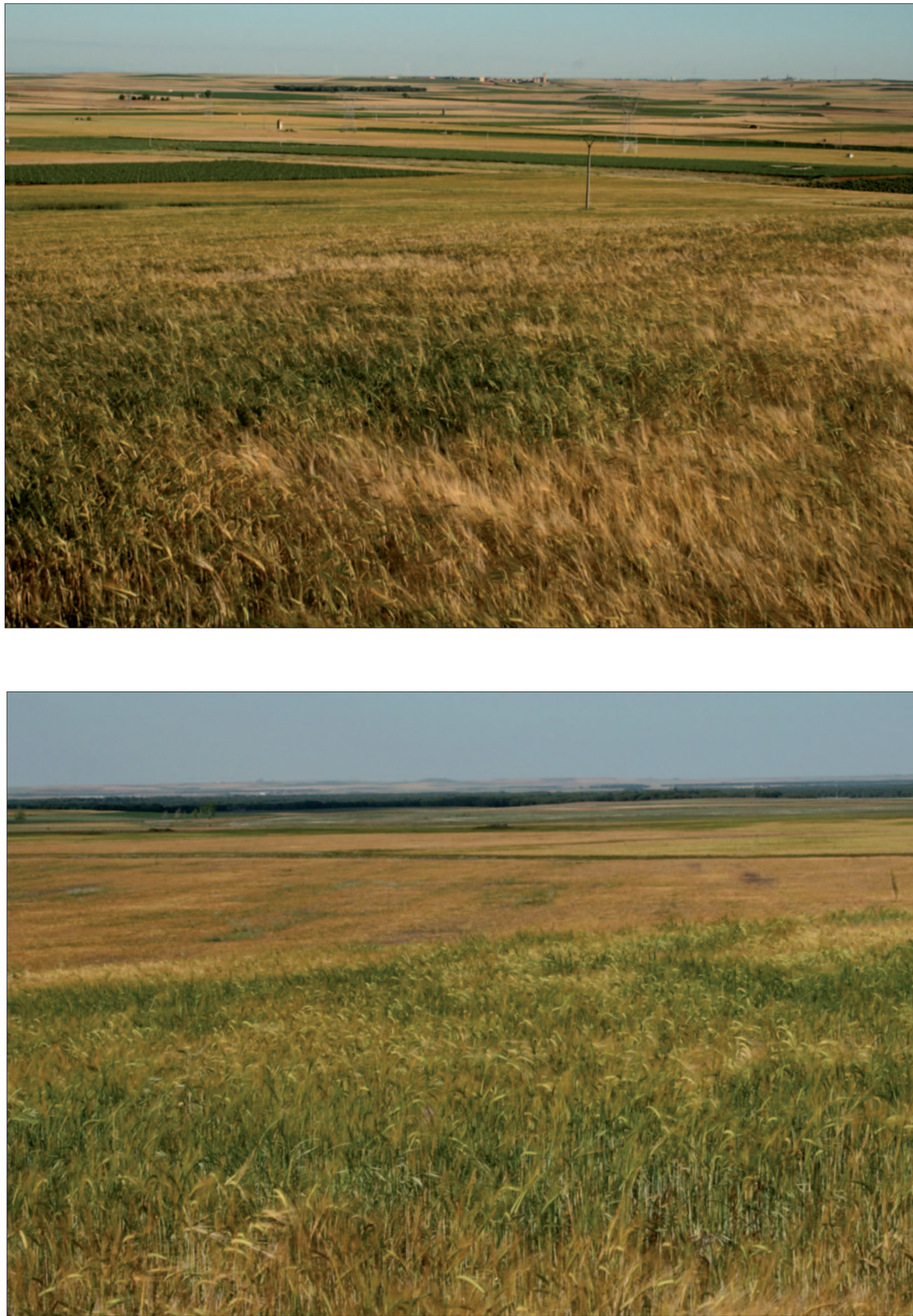

Imagen 11. Las condiciones meteorológicas propiciaron una excepcional cosecha de cereal en el año 2008, tanto al norte de la comarca (Serrada, arriba), como al sur de Medina (Rubí de Bracamonte, abajo). Foto: 12/06/2008. "Abril y mayo tienen la llave del año" es un refrán que alude a la importancia que precipitaciones y temperaturas tienen en el desarrollo de los cultivos. La lluvia es esperada por todos y, si es generosa en los meses citados, también lo es la cosecha. 

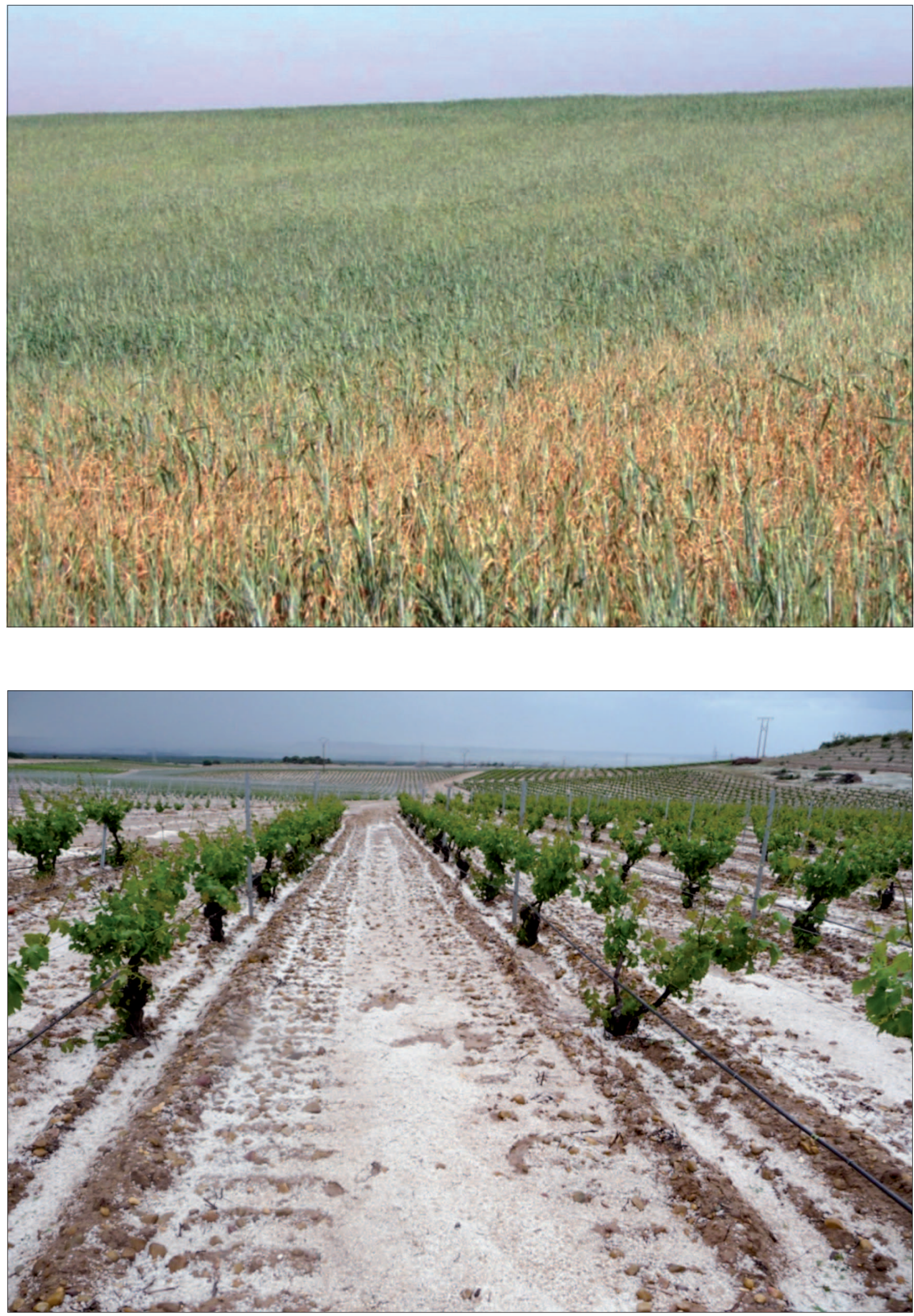

Imagen 12. Efectos de la sequía en el cereal (imagen superior), y del granizo en el viñedo (imagen inferior). Foto: 02/06/2005 y 24/05/2009. A diferencia de las anteriores imágenes, cuando el agua escasea en mayo, o el granizo hace acto de presencia, los cultivos de cereal o de vińedo, entre otros, se resienten en su desarrollo, con diferentes grados de pérdida de cosecha atendiendo a los factores explicados. 
A pesar de todas estas incidencias sobre los cultivos, las temperaturas que tratamos permiten, en general y a lo largo de todo el ciclo vegetativo, un buen desarrollo del viñedo, del cereal, y de los cultivos de regadío. Junto a ellas no podemos ignorar la influencia de las precipitaciones en su desarrollo, especialmente en los cultivos de secano.

\section{b. Unas precipitaciones que condicionan el óptimo desarrollo de la actividad agraria}

Indisolublemente unida a la temperatura, el agua se torna fundamental para el desarrollo de los cultivos. Si se sigue el criterio de los habitantes de este espacio la lluvia es escasa, en los cultivos de secano, en dos de cada tres campañas, especialmente en los momentos más cruciales del calendario agrario. Analizando su distribución anual en las localidades cercanas con estaciones y registros fiables, se observa que apenas se superan los $400 \mathrm{~mm}$ en Rueda, Medina del Campo o Ataquines, por poner ejemplos representativos. La indigencia de las precipitaciones es otra característica de esta Castilla de las llanuras ${ }^{54}$. Hay que tener en cuenta, además, que parte de las citadas precipitaciones se producen en los meses invernales, cuando buena parte de la actividad vegetativa está paralizada y, si se añade la incidencia de la evapotranspiración en el resto del año, se comprenderá hasta qué punto representan, temperaturas y precipitaciones, factores condicionantes tanto de los cultivos como de la propia ocupación humana.

Es verdad que, en lo que respecta a su repercusión en las cosechas, no es tan importante el volumen de precipitación anual como su distribución en los periodos críticos de crecimiento, floración y maduración del fruto. El agua ha sido vital en la economía agraria tradicional, tanto en los cultivos de secano como en el aprovechamiento ganadero de pastos y montes. Desde los primeros contratos de arrendamiento documentados en el siglo XVI, se fijan con precisión tanto las labores que han de dispensarse a tierras y cultivos como la obligatoriedad de la entrega de rentas más allá de contingencias fortuitas, sean sequías, pedriscos o langosta que afecten a los campos. No en vano el concejo de Lomoviejo de 1752 "...paga en cada año a los señores cura y beneficiado veinte y dos reales por razón de conjurar los nublados... "\$5. Dependía de los meteoros la supervivencia de cosechas y ganados. Era el cielo el que dictaminaba las bondades de las cosechas y, en el peor de los casos, cuando "o no llovía o no quería llover", era San Isidro y la Virgen del Rosario los que trataban de remediar la agónica situación que presentaba el campo. Así sucedió, al menos, en la primavera de $1776^{56}$ :

\footnotetext{
"Se acabaron de acubrir las vińas el día diez de abril y lo más de ello con bastante trabajo por la falta de agua y hallarse bastante atrasadas... Por amanecer del día diez de abril se laron mui bien las viñas... Se puso rogativa a San Isidro por la falta de agua oy día dieciocho de mayo y llovió dos o tres tardes mui bien, de suerte que se recuperó bastante el campo y aun nos libró de una piedra muy gruesa y abundante que cayó en el término vecino...”.
}

Los meses de mayo y junio siempre han sido cruciales y el campo se examina cada semana, atendiendo a temperaturas y precipitaciones, tal como reflejan las imágenes anteriores. Las lluvias son siempre bienvenidas, especialmente cuando, favorecidas por las últimas borrascas de circulación zonal y por gotas frías derivadas de las coladas de aire polar, ártico o marítimo dejan moderadas precipitaciones y, en suelos consistentes, casi asegurada la cosecha a principios de junio. No por citar ejemplos de incidencias negativas vamos a ignorar que, en la mayor parte de los años, temperaturas y precipitaciones se conjugan con cosechas regulares que han permitido vivir de la actividad agroganadera a estas comunidades desde hace siglos. Otra cosa es que la variabilidad e irregularidad de las precipitaciones, en su distribución a finales de primavera y principios del verano pueden ocasionar mermas en las cosechas. La situación central del espacio estudiado, como se ha dicho, se torna capital ante unas

\footnotetext{
${ }^{54}$ GARCÍA FERNÁNDEZ, J.: El Clima..., ob. cit., pág. 199.

55 A.H.P.V. Libro Maestro de Seglares, caja 120, fol. 30.

${ }^{56}$ Archivo familia Muelas, copia, s/c.
} 
precipitaciones vitales para la buena granazón de la cosecha. Valgan, en este sentido, las apreciaciones de García Fernández en su libro "El clima en Castilla y León": "Son muchos los días en que en este sector el cielo está anubascado, en particular en el paso de frentes fríos de las borrascas de situación más aquilónica, pero las lluvias son esparsas e inapreciables, o caen en muy parca cuantía” ${ }^{57}$.

Consecuencia de lo anterior es que a finales de mayo y principios de junio los secanos al sur del Duero, especialmente los que se extienden por los suelos más arenosos del sur de la provincia, si no ha llovido a tiempo, presentan tal grado de estrés hídrico que basta una semana de calor en la primera quincena de junio para que o sus rendimientos apenas si rebasen los $1.000 \mathrm{~kg} / \mathrm{ha}$, representativos de la cosecha $2014^{58}$. La cobertera vegetal se marchita presurosa teniendo a ocres y amarillos por colores predilectos. He aquí la razón por la que el barbecho haya tenido tanto predicamento y el trigo candeal, la cebada caballar del país y el centeno hayan sido los cultivos mejor adaptados, ante tantas limitaciones y condicionantes. Sólo excepcionales primaveras como la del año 2008 se salieron de la norma y posibilitaron medias de $3.500 \mathrm{~kg} / \mathrm{ha}$ de cereal en los pagos más livianos del sur comarcal, pero "un grano no hace granero", a decir del saber popular. Es la falta de precipitaciones en los momentos de mayor necesidad para los cultivos, ańo tras ańo, la mayor preocupación de los habitantes y la causante, principalmente, de la reducción de rendimientos en sus explotaciones cerealistas.

En este sentido, estudios realizados sobre intervalos de tiempo sin precipitación (rachas secas), en el sector central de la Cuenca del Duero, donde el volumen de precipitación anual desciende por debajo de los $400 \mathrm{~mm}$, ponen de manifiesto que la duración media de las rachas observadas (días con precipitación menor o igual a $0,1 \mathrm{~mm}$ ) se acerca a los diez días y que, si atienden a periodos de mayor duración, sus valores se asemejan o sólo son superados por observatorios de la mitad meridional de la Península ${ }^{59}$. En el caso de las de mayor duración Alaejos, al oeste del espacio comarcal, presenta niveles muy altos y una duración media esperada de 6,2 días secos en abril; 6,1 en mayo y 8,9 en junio.

Es evidente que dichos periodos han de ponerse en relación con lo acaecido en los días anteriores o posteriores a las distintas acotaciones, pero la sequía se hace realidad, por unas u otras causas, año tras año y, en los sectores con menos precipitaciones del sur y suroeste comarcal, cercanos a Castronuño, puede abarcar hasta cuatro meses, desde junio a septiembre, alcanzando la evapotranspiración potencial valores cercanos a $700 \mathrm{~mm}$, con la consiguiente incidencia en el ciclo vegetativo de los cereales y del vińedo, adaptado a la aridez estival ${ }^{60}$. De hecho, en el mencionado Alaejos se constatan entre los años 1662 y 1700 cincuenta y nueve salidas procesionales de las que cuarenta y dos tienen como fundamento la falta de agua. Cuando llueve a tiempo, como en abril de 1668, no faltan las salidas "en agradecimiento de gracias por las mercedes que Dios nos abia hecho por abernos ynbiado tan copiosa agua'r1.

En contraste a estas peticiones de tiempo histórico, nos ha parecido oportuno, al igual que anteriormente hemos realizado en el apartado de las temperaturas, incluir un ejemplo de la incidencia de estos factores, especialmente de la humedad, asociada a temperaturas benignas en el desarrollo de los cultivos y de las nuevas formas de actuación del hombre ante estos condicionantes que tratamos.

${ }^{57}$ GARCÍA FERNÁNDEZ, J.: El Clima..., ob. cit., pág. 329.

58 Esta cifra se ha obtenido de la media de distintas explotaciones del sur provinvial en cultivo de trigo de secano sembrado sobre barbecho en la citada campaña de 2013/14.

59 LUENGO UGIDOS, M. A.; CEBALlOS BARBANCHO, A.; MARTÍNEZ FERNÁNDEZ, J.; YUSTE YUSTE, C.: "Las rachas secas en el sector central de la Cuenca del Duero" en Investigaciones Geográficas, no 27 (2002), págs. $65-82$.

${ }^{60}$ Ibídem, pág. 71.

${ }^{61}$ OJEDA NIETO, J.: Alaejos. Un pueblo de Castilla en el siglo XVII. Diputación Provincial de Valladolid, 2000, pág. 17. 


\section{- La prevención del mildiu, fundamental para garantizar el buen desarrollo de los cultivos. Un ejemplo de estudio en vińedo}

Esta plaga o enfermedad producida por un hongo (Plasmopara vitícola), se extiende por Europa, proveniente de América, en el último tercio del siglo XIX. Aunque pronto afecta a la mayor parte de los cultivos, su incidencia en los viñedos europeos será una fuente de preocupación permanente, toda vez que las plantas afectadas pueden perder, en breve tiempo, sus muestras de racimos a finales de la primavera y comienzos del verano. En este sentido, los valores de temperatura y humedad son claves para su desarrollo. En aquellas parcelas afectadas en años anteriores, con hongos presentes, cuando las temperaturas se sitúan en torno a $15^{\circ}$ y $20^{\circ} \mathrm{C}$, con tipos de tiempo lluviosos, existencia de nieblas, rocíos matinales o humedad relativa alta, el riesgo de las primeras infecciones es muy alto. Los tratamientos preventivos son fundamentales a la hora de evitar la infección pues las oosporas o gérmenes durmientes, al entrar en vegetación, generan una reproducción de las esporas iniciándose un nuevo proceso de propagación. Si a eso añadimos que el micelio o aparato radicular se desarrolla en los tejidos tiernos, la erradicación es prácticamente imposible, toda vez que su eliminación dañaría el propio tejido en que se aloja el hongo.

En el cuadro adjunto, en el que se recogen los valores de temperatura y humedad del mes de mayo de 2007 en la estación de Villanueva de Duero, puede comprobarse que se dan condiciones para su desarrollo ${ }^{62}$. Las temperaturas medias mensuales se sitúan en torno a $14^{\circ} \mathrm{C}$ y, lo que es más importante, apenas hay días con registros de temperaturas por encima de $25^{\circ} \mathrm{C}$ que consigan ralentizar o paralizar la vida del hongo. A ello se une una humedad relativa, foliar y del suelo bastante alta, consecuencia de la sucesión en dicho mes de distintos tipos de tiempo lluviosos que dejaron 111,6 mm de precipitación acumulada. De hecho, uno de los problemas que se vivieron en la D.O. Rueda en dicho mes de 2007 fue que, a pesar de asentarse buena parte del viñedo sobre suelos con buen drenaje, era complicado entrar con maquinaria en el campo para tratar de forma preventiva tanto al mildiu como el oidio, la otra enfermedad criptogámica asociada a estas condiciones meteorológicas. De ahí que algunas bodegas, sabedoras del peligro que corría la futura cosecha, optaran, excepcionalmente, por tratar el vińedo con medios aéreos para que la planta recibiera el producto adecuado en el tiempo idóneo. La figura que recoge el proceso de germinación e infección en los meses de mayo y junio del citado año, elaborada por los servicios técnicos de la Consejería de Agricultura de la Junta de Castilla y León, trata de ser representativa de la agricultura y ganadería actual, necesitada de cuantos avances técnicos previenen enfermedades o plagas ${ }^{63}$.

\footnotetext{
${ }^{62}$ Estación de Avisos Agrícola de Toro, Consejería de Agricultura y Ganadería de la Junta de Castilla y León.

${ }^{63}$ En este sentido,como trataremos al analizar la evolución del vińedo en la D.O. Rueda, los distintos estudios que realizan los servicios técnicos son fundamentales para garantizar el buen desarrollo de los cultivos. Sirva como ejemplo el estudio anual del vuelo de la polilla y las recomendaciones que reciben los viticultores, mediante circulares, para su tratamiento.

No obstante, al margen del apoyo institucional y de los estudios y seguimientos que se llevan a cabo por parte de estas instituciones, por Asociaciones Agrarias, casas comerciales, etc., la generalizada utilización de Internet por los agricultores, especialmente por los más jóvenes, les hace estar sobre aviso de cualquier contingencia meteorológica. En relación al ejemplo del mildiu que comentamos, por lo demás conocido y temido por todos los viticultores desde el siglo pasado, sirvan las palabras colgadas en la red el 22 de mayo de 2014 por un usuario interesado en estos temas: ¡PELIGRO: oídio y mildiu a la vista en el vińedo! Enviado por Aitor Fernández el jueves, 22 mayo, 2014 a las 7:18. ¡Peligro! Riesgo alto de ataque de oídio y mildiu en el viñedo. La borrasca que ha entrado esta semana en Espańa y que dejará lluvias en prácticamente toda la península completa el cuadro de condiciones adecuadas para la proliferación de los hongos que originan estas graves enfermedades de la vid (http://laseptimauve.bligoo.es/enfermedades-mildiu-oidio-hongos-vid-vinedos-tratamientos-soluciones-azufre-cobre, fecha. 16/07/2014).

Igualmente importante es la utilización de la información meteorológica para efectuar los tratamientos con eficacia. Actualmente, por ejemplo, puede decirse que no hay viticultor que no consulte las páginas del tiempo antes del inicio de cualquier tarea agrícola, especialmente si se trata de tratamientos fitosanitarios. En verano, por citar otro ejemplo, resulta esencial conocer la previsión horaria del viento, especialmente durante la noche, previa al tratamiento con azufre micronizado para prevenir o combatir el oídio.
} 


\section{Cuadro 2. Valores de temperatura, humedad y viento que propiciaron el desarrollo del mildiu en mayo de 2007. Estación de Villanueva de Duero}

\begin{tabular}{|c|c|c|c|c|c|c|c|c|c|}
\hline Fecha & $\begin{array}{l}\text { Temp. } \\
\text { max. }\end{array}$ & $\begin{array}{l}\text { Temp. } \\
\text { mínima }\end{array}$ & $\begin{array}{l}\text { Temp. } \\
\text { media }\end{array}$ & $\begin{array}{l}\text { Humedad } \\
\text { relativa } \\
\text { media }\end{array}$ & $\begin{array}{l}\text { Humedad } \\
\text { foliar } \\
\text { media }\end{array}$ & $\begin{array}{c}\text { Lluvia } \\
\text { acumulada }\end{array}$ & $\begin{array}{l}\text { Humedad } \\
\text { del suelo } \\
\text { media }\end{array}$ & $\begin{array}{l}\text { Dirección } \\
\text { del viento } \\
\text { dominante }\end{array}$ & $\begin{array}{c}\text { Velocidad } \\
\text { del viento } \\
\text { media }\end{array}$ \\
\hline $01 / 05 / 2007$ & 13,62 & 4,39 & 8,13 & 75,45 & 125,81 & 0,2 & 100,28 & $\mathrm{NO}$ & 6,69 \\
\hline $02 / 05 / 2007$ & 15,49 & 6,61 & 10,29 & 80,77 & 196,63 & 2,4 & 150,14 & SE & 9,73 \\
\hline 03/05/2007 & 16,73 & 7,46 & 11,2 & 84,93 & 84,7 & 17,3 & 36,39 & $\mathrm{NE}$ & 8,32 \\
\hline $04 / 05 / 2007$ & 17,53 & 8,33 & 13,02 & 69,68 & 217,56 & 0 & 78,19 & $\mathrm{~N}$ & 5,57 \\
\hline 05/05/2007 & 15,24 & 5,91 & 11,01 & 68,42 & 225,28 & 0,3 & 101,53 & $\mathrm{~N}$ & 10,36 \\
\hline 06/05/2007 & 19,14 & 4,7 & 11,73 & 60,43 & 240,27 & 0 & 200 & $\mathrm{NE}$ & 6,11 \\
\hline 07/05/2007 & 24,45 & 7,13 & 15,15 & 56,68 & 247,48 & 0 & 198,61 & $\mathrm{~N}$ & 3,6 \\
\hline 08/05/2007 & 25,89 & 9,34 & 18,2 & 51,65 & 246,11 & 0 & 200 & $\mathrm{~N}$ & 3,56 \\
\hline 09/05/2007 & 26,96 & 9,48 & 18,82 & 48,07 & 247,36 & 0,1 & 118,19 & $\mathrm{~N}$ & 3,4 \\
\hline $10 / 05 / 2007$ & 25,37 & 11,73 & 18,96 & 48,72 & 247,57 & 0 & 150,28 & $\mathrm{SO}$ & 8,79 \\
\hline $11 / 05 / 2007$ & 23,55 & 8,1 & 15,85 & 50,4 & 247,66 & 0 & 108,79 & $\mathrm{SO}$ & 5,83 \\
\hline $12 / 05 / 2007$ & 24,43 & 8,89 & 16,72 & 55,14 & 246,33 & 0 & 147,22 & SO & 6,72 \\
\hline $13 / 05 / 2007$ & 18,24 & 9,49 & 14,39 & 59,36 & 242,27 & 0 & 185,97 & $\mathrm{SO}$ & 9,42 \\
\hline $14 / 05 / 2007$ & 17,61 & 4,62 & 10,85 & 64,91 & 160,58 & 0,2 & 106,94 & $\mathrm{NO}$ & 10,39 \\
\hline $15 / 05 / 2007$ & 20,52 & 3,89 & 12,49 & 54,4 & 231,89 & 0 & 200 & $\mathrm{~N}$ & 5,02 \\
\hline $16 / 05 / 2007$ & 23,54 & 7,58 & 15,88 & 54,34 & 233,32 & 0 & 200 & $\mathrm{~N}$ & 5,85 \\
\hline $17 / 05 / 2007$ & 26,17 & 9,23 & 17,14 & 60,93 & 226,23 & 0 & 137,08 & $\mathrm{NE}$ & 6,38 \\
\hline $18 / 05 / 2007$ & 28,24 & 12,38 & 20,16 & 63,3 & 204,26 & 0 & 180,28 & NE & 8,64 \\
\hline $19 / 05 / 2007$ & 26,91 & 12,96 & 18,24 & 72,48 & 176,97 & 0,3 & 191,39 & $\mathrm{NE}$ & 8,66 \\
\hline $20 / 05 / 2007$ & 16,56 & 12,34 & 14 & 93,41 & 25,03 & 24,6 & 92,5 & E & 5,87 \\
\hline $21 / 05 / 2007$ & 18,71 & 11,41 & 14,21 & 90,35 & 80,62 & 7 & 57,22 & E & 7,96 \\
\hline $22 / 05 / 2007$ & 24,86 & 10,87 & 16,1 & 79,76 & 208,46 & 15 & 112,5 & E & 12,23 \\
\hline $23 / 05 / 2007$ & 19,2 & 10,68 & 13,09 & 91,06 & 81,74 & 6,7 & 47,36 & $\mathrm{E}$ & 9,2 \\
\hline $24 / 05 / 2007$ & 17,63 & 9,56 & 12,92 & 91,28 & 48,38 & 12,1 & 14,03 & $\mathrm{~N}$ & 4,38 \\
\hline $25 / 05 / 2007$ & 20,58 & 7,95 & 13,45 & 84,68 & 91,11 & 17,9 & 29,44 & $\mathrm{~N}$ & 3,41 \\
\hline $26 / 05 / 2007$ & 16,92 & 10,67 & 12,6 & 93,04 & 25,61 & 7,5 & 9,72 & SO & 3,54 \\
\hline $27 / 05 / 2007$ & 17,07 & 8,59 & 12,99 & 80,77 & 136,5 & 0 & 43,19 & $\mathrm{NO}$ & 9,17 \\
\hline $28 / 05 / 2007$ & 17,88 & 4,62 & 11,2 & 64,3 & 237,64 & 0 & 129,31 & NO & 9,24 \\
\hline 29/05/2007 & 21,22 & 6,72 & 13,68 & 68,06 & 246,35 & 0 & 200 & $\mathrm{O}$ & 5,76 \\
\hline $30 / 05 / 2007$ & 21,1 & 11,54 & 15,6 & 73,72 & 243,26 & 0 & 200 & $\mathrm{NO}$ & 7,5 \\
\hline $31 / 05 / 2007$ & 18,78 & 8,87 & 13,39 & 65,06 & 245,64 & 0 & 199,58 & $\mathrm{NO}$ & 6,61 \\
\hline Media & 20,65 & 8,58 & 14,24 & 69,54 & 184,47 & 111,6 & 126,65 & $\mathrm{NO}$ & 7,03 \\
\hline
\end{tabular}

Fuente: Estación de Avisos Agrícola de Toro. Junta de Castilla y León.

Como puede apreciarse en la figura adjunta ${ }^{64}$, teniendo presente los valores del cuadro anterior, los valores de humedad de hoja en combinación con la temperatura (parte superior de la figura, en color morado), generan el desarrollo del hongo ${ }^{65}$.

${ }^{64}$ La gráfica se ha realizado en la Estación de Avisos de Toro utilizando la información proporcionada por las estaciones de medición y el programa Peronospora, Lufft, versión V1. Al igual que manifestamos en los anteriores ejemplos de helada somos deudores de la información proporcionada por Santiago Cepeda Castro, ingeniero agrónomo, técnico de la Estación de Avisos Agrícolas de Toro, Junta de Castilla y León.

${ }^{65}$ El 19 de julio, el pico gris que se superpone al morado en la parte superior de la gráfica (asociado al eje de la derecha, producción de esporas en millones). 


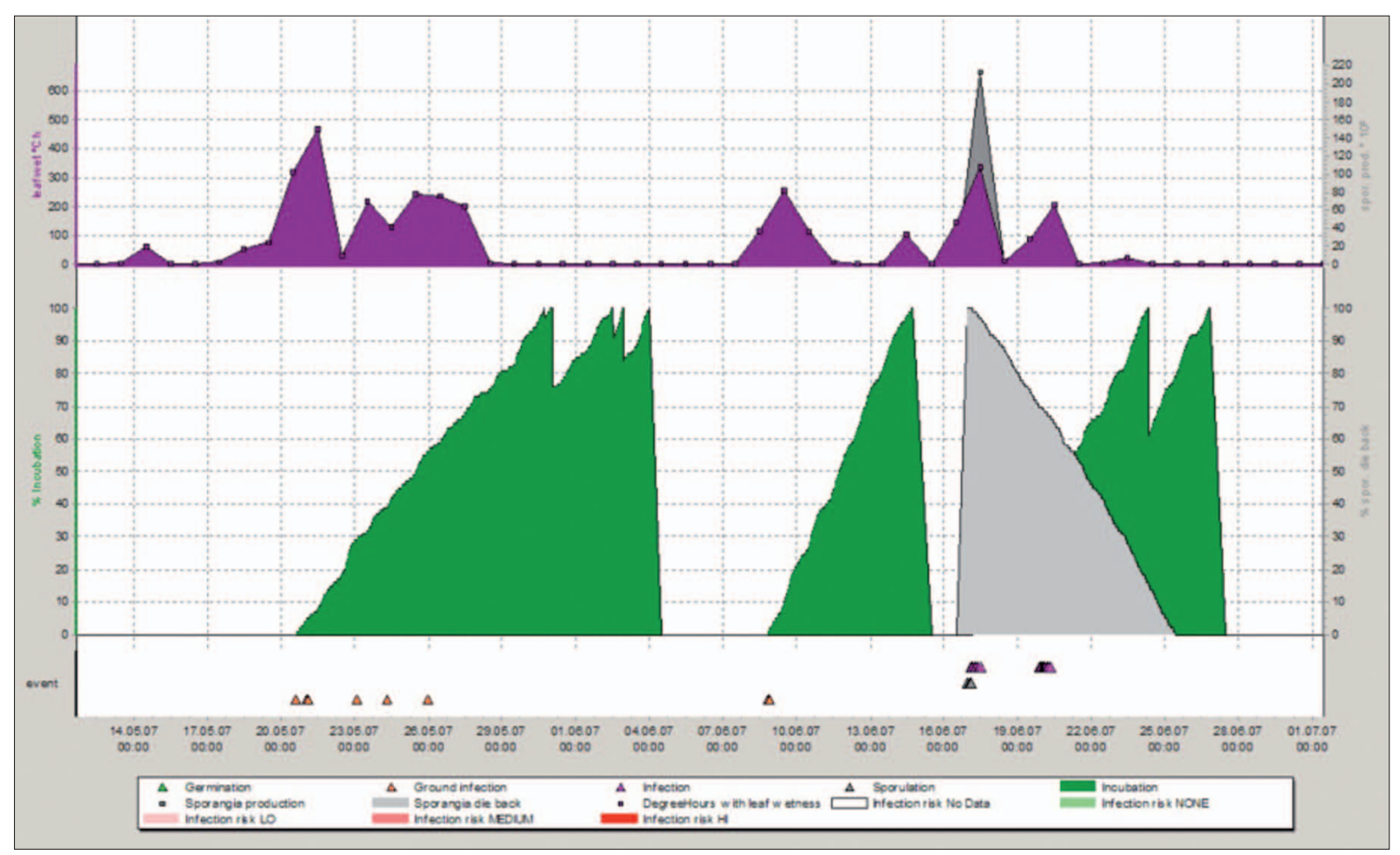

Figura 7. Desarrollo de la infección del mildiu en mayo y junio de 2007. Fuente: Estación de Avisos Agrícola de Toro, Junta de Castilla y León.

El 21 de mayo (triángulo morado), nos marca la primera infección, procedente del suelo, de la oospora de invierno, presente en estado de hibernación, que madura generando una primera infección primaria, consecuencia directa de la combinación de temperatura con humedad relativa, que alcanza en dicha fecha un $90,35 \%$. En el periodo que tratamos, no obstante, se producen varias infecciones primarias encadenadas, procedentes del suelo. La gráfica verde, en consecuencia, ilustra el porcentaje de desarrollo del hongo que se desarrolla en el interior de la hoja, y cuando llega al 100\%, o casi al $100 \%$, se hace visible.

El año del ejemplo, al registrarse varias infecciones, coincidentes con el periodo de floración, y manifestarse visiblemente en hoja, generaron enorme preocupación entre los profesionales del sector, sabedores del peligro consiguiente de pérdida importante en la producción. De hecho, el 9 de junio, como puede comprobarse en dicha figura, se vuelven a dar condiciones que se manifiestan en nuevas infecciones procedentes del suelo. Unos días más tarde, a partir del 17 de junio, como puede observarse en color gris, que indica el \% de esporas que mueren, una vez que el hongo ha llegado al 100\% de desarrollo, y es visible en las hojas, la combinación de rocío, temperaturas mínimas, etc., generan nuevas infecciones secundarias. La gráfica marca como, a partir de las condiciones de infección secundaria (17 de junio), se producen esporulaciones que van disminuyendo con el tiempo (eje de la derecha, con \% de esporas muertas), al tiempo que los triángulos rosas nos indican las infecciones encadenadas del 20/21 de junio. La aparición de manchas verdes de infección puede acarrear consecuencias letales en el tejido vegetal de la planta, especialmente en los racimos.

\section{Montes, suelos y cultivos}

No le ha sido fácil a la sociedad campesina dominar el terrazgo que estudiamos si nos atenemos a la lenta ocupación humana en tiempo histórico, especialmente en época romana y altomedieval. Un factor explicativo es la dureza de las condiciones metereológicas y la dispar calidad de sus suelos, poco fértiles en los amplios sectores de gravas del norte de la comarca y de bajos rendimientos en las arenas 

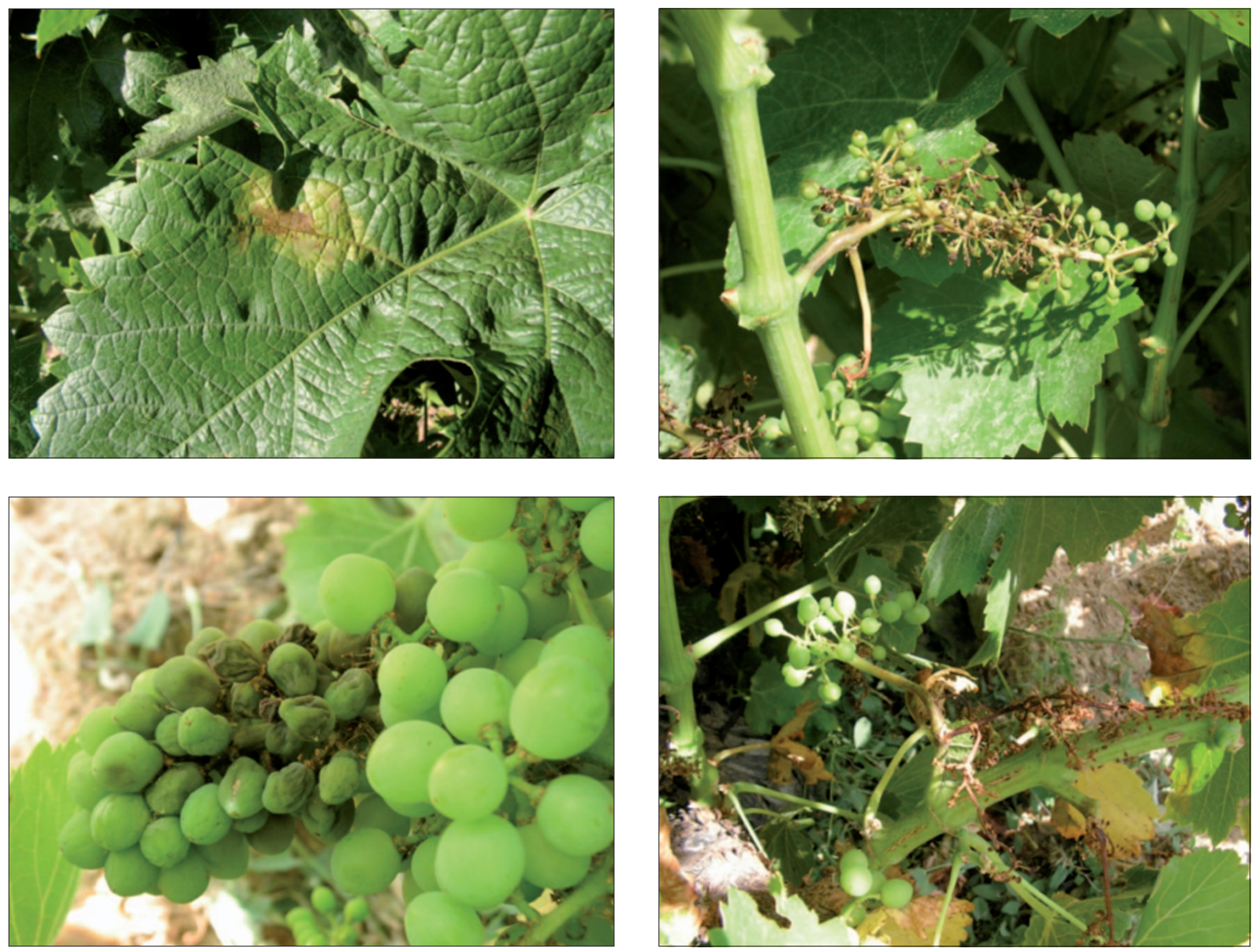

Imagen 13. Hoja con mancha de mildiu y racimo afectado tras su floración, (arriba). Racimo y tallos con infección severa del hongo, (abajo). Autor de las imágenes: Santiago Cepeda, 17/07/2007.
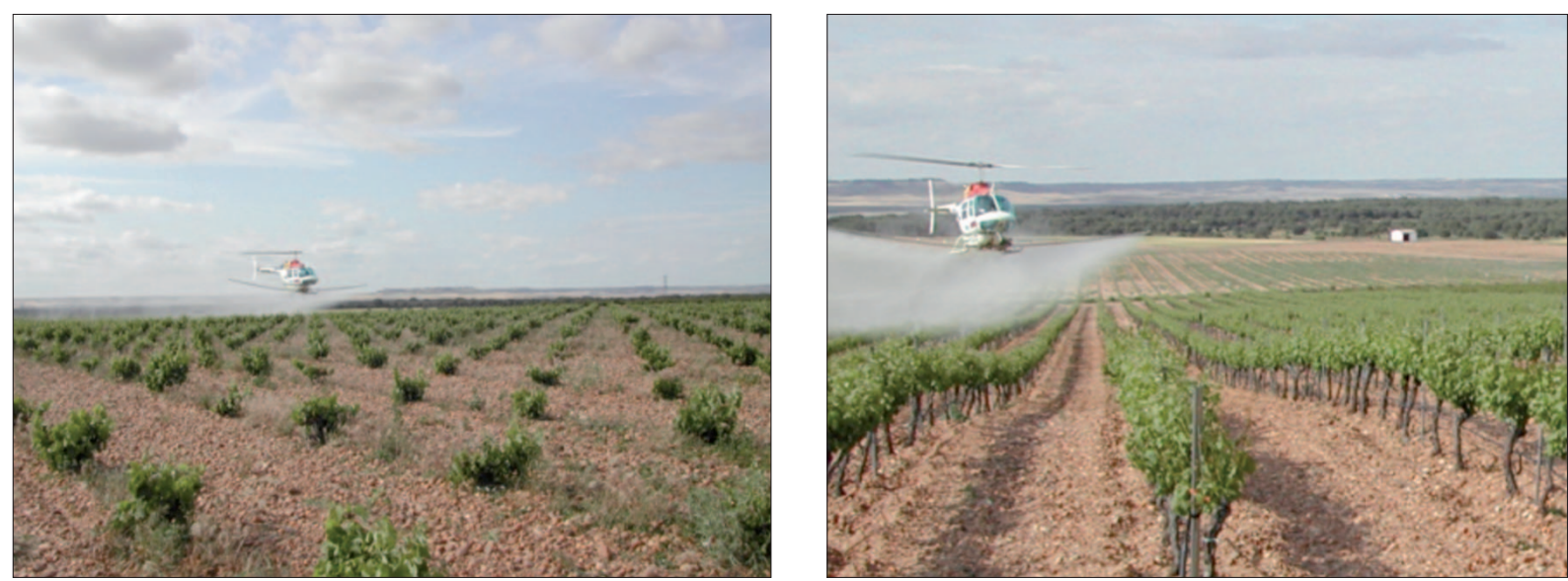

Imagen 14. Tratamiento aéreo antimildiu llevado a cabo en la D. O. Rueda en 2007 sobre viñedo en vaso de Jerez (izquierda) y viñedo de espaldera de Verdejo (derecha). Foto: 31/05/2007. Aunque la mecanización y los avances tecnológicos han revolucionado la agricultura en las últimas décadas, muchos tratamientos se basan en derivados de productos que comenzaron a aplicarse hace un siglo, tal es el caso de la acción fungicida y bactericida del cobre, para combatir el mildiu y otras enfermedades.

de los términos más al sur. Otro factor no menos importante ha sido la falta de cursos fluviales de entidad que aporten comunicación y defensa a sus márgenes, feracidad a la tierra o pesca a sus aguas. Sólo el Duero, al norte del espacio estudiado, presenta suficiente entidad. Los verdes pastizales salpicados de labajos y charcas, en los que rebosaba el importante acuífero de los Arenales, representan una riqueza 
menor, cuando no se convertían las áreas menos drenadas en focos infecciosos de paludismo, entre otros males. En la actualidad, el agotamiento del nivel freático los ha condenado a su desaparición y son historia, al igual que los numerosos rebańos que en ellos han pastado a lo largo del tiempo. Es uno de los muchos tributos que pagan estas comunidades agrarias tras el último medio siglo de intensas rotaciones de regadío y de transformación del mundo rural.

\section{a. Los montes que dieron paso a las tierras de labor}

Como decimos, montes y cultivos dirimen una desigual contienda desde que la acción antrópica inicia la transformación de sus bases económicas. El paisaje que hoy se contempla es el resultado de un terrazgo plenamente ocupado, transformado y explotado por el hombre, especialmente en los últimos mil años. Lejos quedan las palabras del viajero alemán Jerónimo Munzer que, para indicar lo poblada de árboles que estaba la Península, lo ilustraba con el ejemplo de una ardilla que podría viajar de norte a sur sin tocar el suelo. Hoy se diría que, con suerte, alguna noche podría descansar subida en algún árbol ${ }^{66}$. Esos montes, como sus aledaños, formaban una mancha continua entre las campiñas de Medina y el Duero. Su cobertera vegetal estaba compuesta predominantemente por encinas, acompañadas en ocasiones por pinos y en algunos sectores muy puntuales, por robledales e incluso alcornocales, mezclados con espacios más abiertos donde predominaban retamares, tomillares y escobares ${ }^{67}$. La presencia del pino en estas áreas del Duero medio ha sido siempre muy discutida como vegetación potencial. Análisis polínicos y antracológicos, realizados en yacimientos prehistóricos, refieren su presencia en distintas áreas vallisoletanas, así como el aprovechamiento de su madera y frutos, por lo que es posible que alternara con la encina, pero con mucha menor presencia a la que hoy ostenta. En concreto, piñones de pino piñonero se han hallado en el yacimiento de la II Edad del Hierro en Medina del Campo, datado hace 2.500 ańos $^{68}$. El pino albar (Pinus pinea) se adapta tanto a los suelos de arenas y gravas de gran espesor como a la aridez y calores del verano de estas altas llanuras. Distinto es el caso de los alcornocales existentes en Foncastín, Tordesillas, Torrecilla de la Abadesa o Villaester, cuya existencia actual, aunque ocuparon en el pasado áreas más extensas, es solo testimonial y relicta ${ }^{69}$.

\footnotetext{
${ }^{66}$ En el norte del espacio es muy posible que fuera factible la aseveración de Munzer. Serrada, San Martín del Monte, La Seca y tantos otros poblados y despoblados nacieron, como se verá en capítulos posteriores, al explotar sus moradores unos recursos montaraces que, prácticamente, sin solución de continuidad, se extendían desde el mismo Duero hasta las campińas al sur de la cuenca. De hecho, aunque no se desea entrar en polémicas etimológicas, es muy posible que haya sido la propia actividad asociada a su corta y roturación de donde proceden, por ejemplo, los anteriores topónimos. El de San Martín del Monte es más que evidente; el de Serrada, o "la Serrada", tal como se anota en los escritos que se conservan sobre sus primeros siglos de vida, bien pudiera derivar del verbo latino "serrare", aserrar, lugar de corta, sierra y tala de los montes y bosques apuntados. También el nombre de La Seca puede asociarse a cuanto se dice. Recuérdese que en latín "seco, seca, secare" es cortar, serrar, talar y "la Seca" y "la Serrada" fueron en idéntico tiempo y espacio, además de lugares vecinos, lugares de roturas y cortas para un posterior cultivo.

En buena parte de los documentos bajomedievales consultados la terminología empleada para referirse a este lugar es "la Serrada” y el artículo acompaña al nombre sea cual sea el contexto. "En la Serrada en la eglesia..." (A.C.P., armario 3. Libro Becerro de Beneficios. Año 1346); "Venta de la villa de la Serrada y de su jurisdición cebil y criminal..." (A.R.Ch.V.P.C. Zarandona y Walls (F), caja 2711.1, año 1487). En relación a "la Seca”, el artículo "la” precederá al sustantivo en todas las épocas históricas.

${ }^{67}$ La presencia del roble debió de serescasa en tiempo histórico. En los términos de Rueda y Nava del Rey se constatan topónimos que aluden a esta formación y que, deforestados, fueron sustituidos por tierras de sembradura y viñedos: "Una viña, en el pago de el Rebollarejo, dista de la población media legua" (A.H.P.V. Hacienda, Catastro de Ensenada, Respuestas Particulares, Rueda, caja 238, fol. 930v.)

${ }^{68}$ CALONGE CANO, G.: "Rasgos básicos del medio físico correspondiente al territorio vacceo del valle medio del Duero", en Arqueología y Medio Ambiente, El primer milenio a. C. en el Duero medio. DELIBES DE CASTRO, G.; ROMERO CARNICERO, F. Y MORALES MUNIZ A. (edit.), Junta de Castilla y León, 1995, pág. 67.

${ }^{69}$ ORIA DE RUEDA SALGUEIRO, J. A.: “Un mosaico de ecosistemas”, en El Bosque actual, (I), del Atlas Forestal de Castilla y León. Junta de Castilla y León, 2007, pág. 118.
} 
Medina, Olmedo y el Convento de Santa Clara, en Tordesillas, vigilan siempre una riqueza vegetal propia, ambicionada por los lugares bajo su jurisdicción. De su conservación y explotación racional dependen en buena parte sus ingresos, especialmente en el caso de Medina. El equilibrio parece imposible para unas sociedades campesinas que anhelan más tierra que cultivar, más pastos para sus ganados, más leña para calentar sus hogares, levantar sus casas o mantener sus hornos de pan, tejas o cal y que tiene, invariablemente, un claro perdedor: el monte.

Las primeras presuras cristianas se datan en torno al año 900 en tierras de Alcamín, junto a Tordesillas $^{70}$. Los cultivos se extienden a costa de los montes existentes en sus términos, siempre sujetos a no pocos intereses contrapuestos: el sobrepastoreo y las cortas indiscriminadas los dañan de forma irremediable. Y qué decir del fuego, si Alfonso X el Sabio dictó para los incendiarios que “...al que lo fallaren faciendo fuego que lo echen dentro de él...”. No faltan pagos en los confines de los términos municipales, lindando con montes concejiles o tierras sernas en que los topónimos recuerdan su práctica ${ }^{71}$ :

"Una pieza de tierra de sembradura de secano en el pago de los Quemadillos y Valdeculebro, dista de la población una legua... Consiste en ochenta y dos obradas y media; produze una año sí y otro no. Linda por el norte con el río Zapardiel; por el poniente con la raia de sernas de Medina; por el sur con la cañada de Mollorido...”

A partir del siglo XV, recogiendo antiguas costumbres y ordenanzas regias y dado el progresivo aumento de hombres y ganados, comienza a regularse su explotación mediante dictados reales. Así, por ejemplo, el nueve de mayo de 1409 el rey Juan II da una provisión "prohibiendo a los hombres de la corte cazar, pastar e cortar leña en el monte de las monjas, que está entre el Duero, Medina del Campo, cerca del lugar de San Martín y Santa Clara..."72. En los siglos siguientes todo un conjunto de ordenanzas tratarán de regular el uso y disfrute del pasto y madera en estos espacios que, como veremos, verán reducida su superficie a la mínima expresión, dado el afán roturador de los lugares poblados.

El proceso no es exclusivo de esta comarca, sino general en la mayor parte de la región. Desde el siglo XIII se constata la preocupación de reyes como Alfonso VIII o Fernando III para que tierras roturadas sean devueltas al monte. Este último, en relación con el conflicto entre los vecinos de Dueńas y Cevico dispuso que "todo lo al quanto rompieron amas las partes de muerte de mio avuelo a aca en el monte, mando que lo dexen todo para monte"73. La ordenanza de montes de la ciudad de Zamora del año 1448 indica en su capítulo 87 que "los pueblos se multiplican si los montes se guardasen y conservasen para proveimiento de ellos..." ". Las "Ordenanzas de los pinares de la Villa de Cuellar", fechadas en 1492, ponen de manifiesto esa enconada lucha histórica del hombre frente al arbolado en la que "los dichos pinares comunes se dextruxen a cabsa que muchos vecinos de las dichas villas e de sus tierras tienen oficio de cortar en los dichos pinares comunes"75. Los pleitos son continuos en la Tierra de Medina. La sentencia arbitral dada en Medina en 1451 entre su concejo y el Convento de Santa Clara y San Martín del Monte da fe de ello ${ }^{76}$ :

${ }^{70}$ REGLERO DE LA FUENTE, C. M.: Espacio y poder en la Castilla medieval. Los Montes de Torozos (siglos X-XIV), pág. 158.

${ }^{71}$ A.H.P.V. Hacienda. Catastro de Ensenada. Respuestas Particulares. Rueda, caja 239, fol. 2231.

72 CASTRO TOLEDO, J.: Colección Diplomática de Tordesillas. Institución Cultural Simancas, Valladolid, 1981, pág. 102.

${ }^{73}$ REGLERO DE LA FUENTE, C.M.: Espacio y poder en la Castilla medieval. Los Montes de Torozos. (Siglos XXIV), pág. 162.

${ }^{74}$ RAMOS SANTOS, J.M.: Intervención humana y transformación de los paisajes forestales en la Cuenca del Duero en la Edad Moderna. Papeles de Geografía, enero-diciembre, 41-42. 2005. Universidad de Murcia, Murcia, págs. 218, citando a Canto de la Fuente, C.; Carbajo Martín, V.A.; \& Moreta Velayo, S. (1991). Ordenanzas municipales de Zamora, siglos XV-XVI. Diputación de Zamora, Zamora.

75 CALONGE CANO, G.: Atlas Forestal de Castilla y León. Tomo I, Junta de Castilla y León, pág. 117.

${ }^{76}$ CASTRO TOLEDO, J.: Colección diplomática...,ob. cit., pág.357. 


\begin{abstract}
"Mandamos que los vesinos e moradores que moran e moraren en el dicho lugar de Sant Martín que agora e de aquí adelante para siempre jamás que pascan e puedan pasçer de noche e de día las yeruas e beber las aguas por todos los términos e montes de la dicha villa de Medina del Canpo e su tierra con tres mill cabeças de ganado ovejuno e cabruno, non faciendo danno en panes en vinnas nin en prados dehesados...

Otrosy que los vesinos... puedan cortar e roçar yniesta e cantuesos e escobas e lenna por todos los términos de la dicha villa de Medina del Canpo, para quemar, con que se calienten los pastores e guisen de comer, mientra que andodieren en dichos montes e términos"
\end{abstract}

El aprovechamiento de sus recursos y las cada vez más intensas roturaciones en los montes Pedroso e Inestoso, que se extienden al norte de la Comunidad de Villa y Tierra, son el pan nuestro de cada día para unas aldeas que despiertan en este tiempo. En las campiñas del sur, el contrate entre la masa arbolada y las tierras de sembradura es cada vez mayor a favor de las segundas. Los montes de Madrigal, Bobadilla y Escargamaría, representados en la carta topográfica adjunta subsisten a mediados del siglo XVIII tras no pocos litigios y cortas, pero nunca serán lo que fueron a finales del medievo. La presión demográfica puede con ellos y no es porque desde el propio nacimiento de estos lugares sus concejos no tuvieran normas para guardarlos.

Medina del Campo, villa cabecera de una amplia Comunidad de Villa y Tierra, con abundantes bienes comunes, lucha lo indecible a lo largo de los siglos por que de su administración se deriven saneadas rentas para hacer frente a los gastos de la villa. Los lugares sujetos a su jurisdicción nunca opinan lo mismo y los montes, por unas u otras circunstancias, acaban perdiendo consistencia. Y cuando pertenecen al común de las aldeas y tienen lugar épocas adversas, arbitrariedades señoriales o necesidades pecuniarias, hasta los pies más robustos de encinas y pinos se echan a temblar cuando tañen las campanas a reunión de concejo. Alea jacta est, dirían caso de poder hablar. A veces los pleitos por denuncias de talas ni siquiera llegan a su final, pues los procesos acaban siendo más onerosos que el valor de lo presentado a la justicia. Las denuncias del comendador de Fresno en 1497 ante los Reyes Católicos, para que se impida la venta del monte de encinas y retamar propio del lugar, es una prueba fehaciente del desastre que se avecina entrado el tiempo moderno ${ }^{77}$ :

\footnotetext{
"Otrosy, muy poderosos Señores, vuestras altesas sabrán que la dicha Encomienda de Fresno e Conçejo della tyenen un monte conçejil e un retamar, para nuestro serviçio de los ganados en los ynviernos e con que aquellos se puedan guareçer en los tiempos de las nieves, del qual non se puede cortar, salvo con mucha pena por ser muy pequeńo y agora, vuestras altesa sabrán quel dicho conçejo, para tener dineros con que sostener y favoreçer y ayudar a los dichos malhechores e delincuentes, han vendido çierta parte del e tyenen por dicho de vender más. Y porque sy en esto se ovyese de dar logro, redundaría tanto daño al bien público de la dicha villa que de todo punto se despoblaría e non se podrían traer ganados algunos, e pagarían e recibirían mal e daño las biudas e los que son ynoçentes... pues quel dicho monte y retamal es el principal proveymyento asy para la dicha Encomienda como para el dicho Conçejo e vesynos del e suplico... sea guardado segund e por la vya e forma e so las penas que syenpre se guardó”.
}

Sea por abusos de autoridad en unos casos, sea por interés colectivo en otros, el caso es que los montes acaban talados o descuajados. Doce años después de las anteriores denuncias, el propio lugar solicita licencia a la reina Juana para que "una dehesa de monte que nos avemos e tenemos... la podamos ronper para llevar pan"78. Son los propios concejos los principales enemigos de unos montes que, por paradoja, son necesarios tanto para sus ingresos como para el sustento de sus ganados y personas. Las necesidades de liquidez y el hambre de tierra matan de forma inexorable la gallina de los huevos de oro. Los lugares y villas acaban quedándose sin montes, sin pastos y sin ingresos procedentes de estos espacios que siempre desearon preservar. Al oeste del Trabancos, el retroceso de las masas arbóreas y arbustivas no es menor. En el término de Alaejos son también, el concejo, el señor de la villa, los vecinos

77 A.G.S. Cámara de Castilla (pueblos), leg. 8. Fresno. Año 1497, no 91, trascripción de GONZÁLEZ SÁNCHEZ, V.: Fresno el Viejo. Una de las nueve villas de "Valdeguareña". Diputación Provincial de Valladolid, Valladolid, 1996, pág. 26.

${ }^{78}$ A.G.S. C. Castilla (Pueblos), leg. 8, no 95, en GONZÁLEZ SÁNCHEZ, V.: Fresno el Viejo..., ob. cit., pág. 40. 

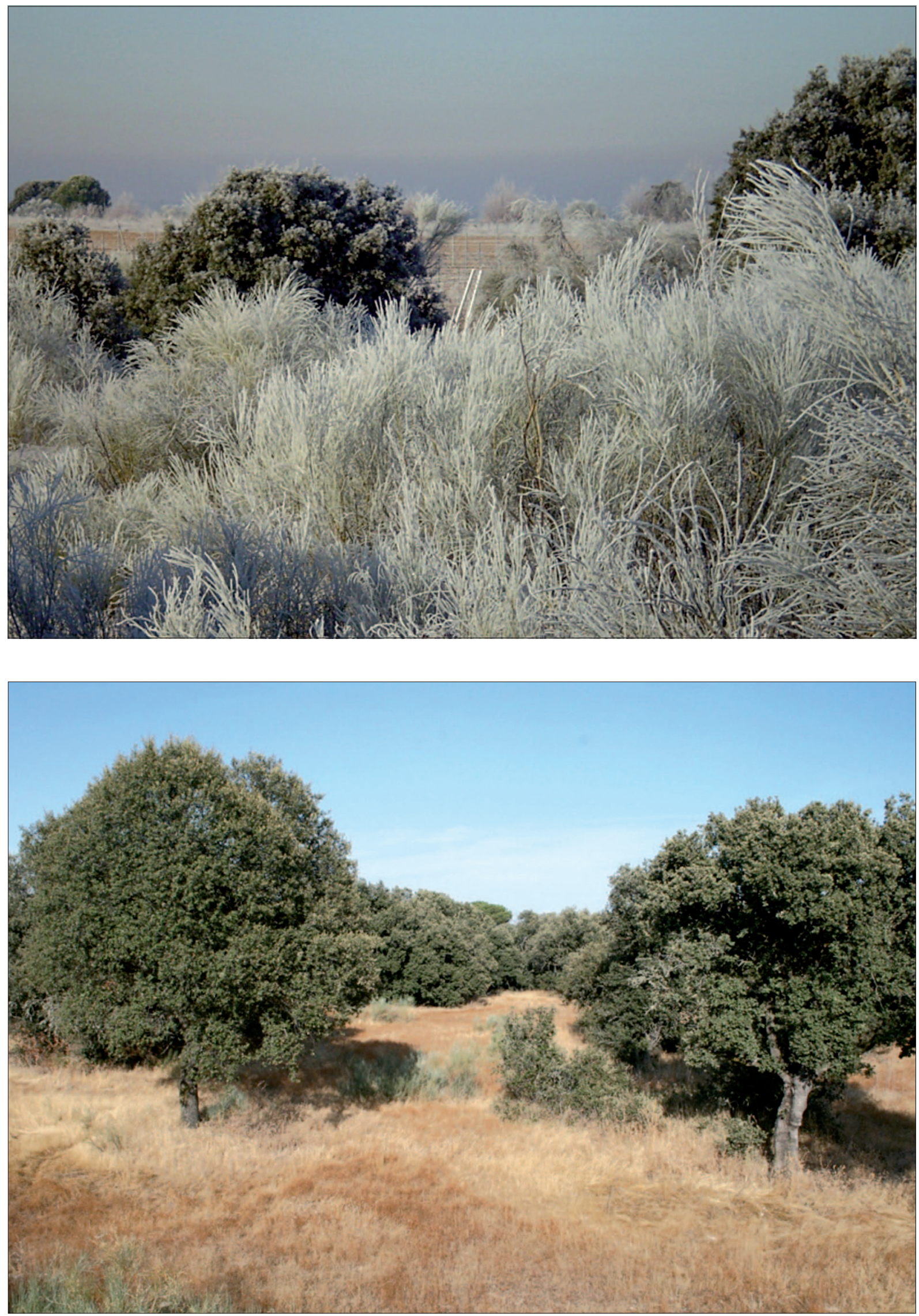

Imagen 15. Invierno y verano en montes de encina y retamas al norte (Villanueva de Duero) y sur (Medina del Campo) del espacio estudiado. Foto: 23/01/2008 y 02/09/2008. Los montes de encinas y retamas se extendían por buena parte del espacio estudiado. Las roturaciones y las repoblaciones de pinos, en tiempo histórico, han relegado a la encina a un lugar secundario entre las formaciones arbóreas que, no obstante, se resiste a desaparecer. 

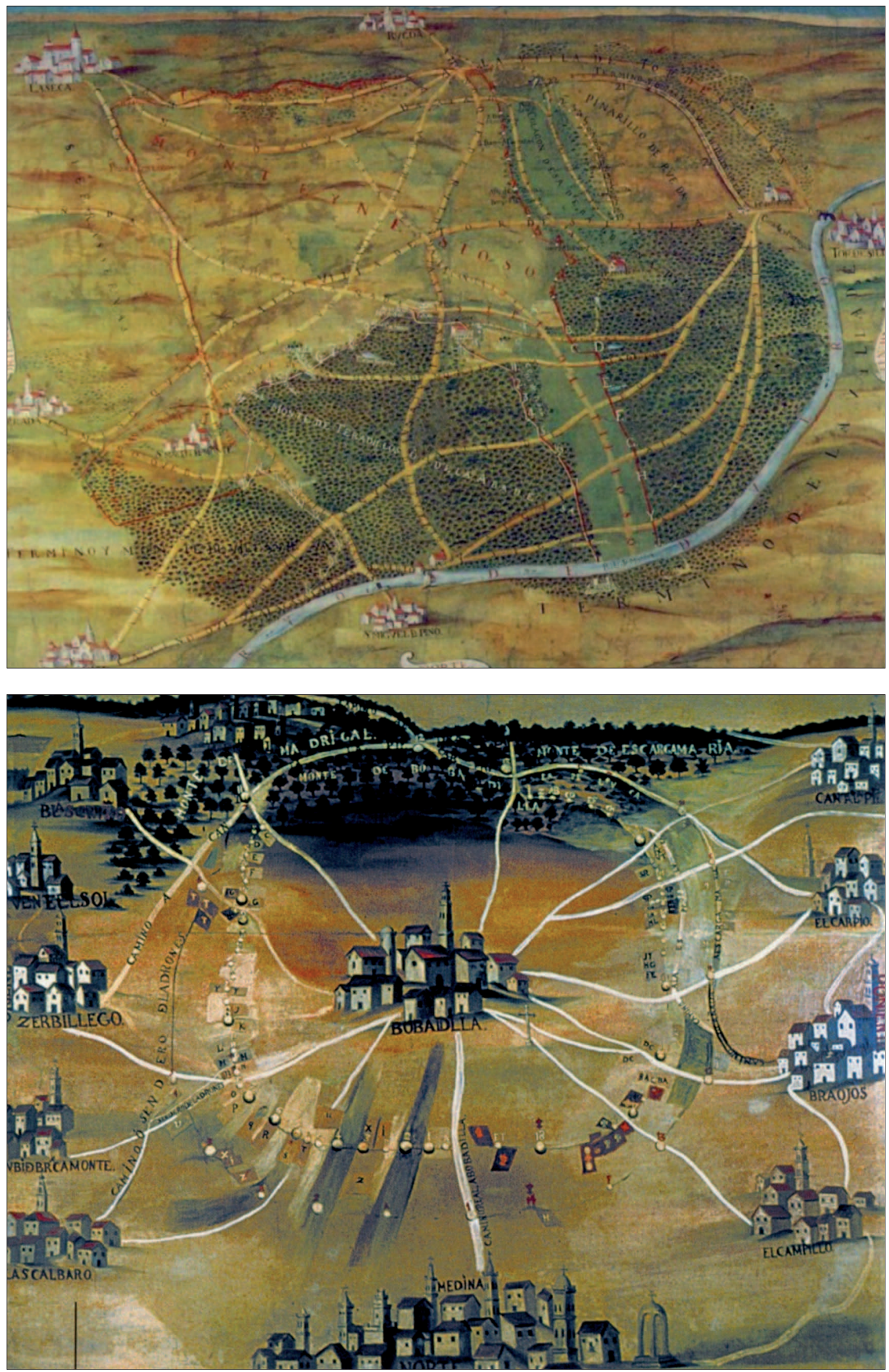

Imagen 16. Ejemplos de la situación del monte en el siglo XVIII: Carta topográfica de los términos de Serrada, La Seca y Tordesillas y de los términos de Bobadilla del Campo y localidades próximas en el siglo XVIII. Fuente: Ministerio de Cultura. A. R. Ch. V. Planos y dibujos, óleos no 0010 y nº 643. 
y los acontecimientos extraordinarios quienes merman su superficie. Cuando la necesidad asoma es el concejo quien arrienda "pedazos del dho monte de por diez años y çinco panes" sin que los sectores mejor conservados frenen al arado. Las cortas se realizan sin impedimento en "monte alto y del valor dellos se aderezaron y rrepararon çiertas hermytas... aunque heran monte brabos". Y cuando suceden acontecimientos extraordinarios, como en este caso lo será la guerra de las comunidades, los desastres no tienen freno. En los montes de Alaejos y Valdefuentes entrarán "con todas sus carretas (vinieron y) talaron un monte... a la villa de Valdfuents syn dexar en el un solo pie q la dha villa perdio mucho porq. no tenía otro remedio de sus ganados". Las importantes cortas "talaro(n) y cortaro(n) del dho monte... 11.088... encinas antes más que menos"79.

Una continua ocupación será irreversible tanto en los sectores de terrazas como en las campiñas del sur en los siglos siguientes pese a que los poderes públicos tratan de frenar el ansia del hacha y del arado. Los propios reyes dictan en noviembre de 1503 en Segovia restituir al uso común las tierras tomadas para satisfacer la penuria de pastos para el ganado. Y es que éste cobraba especial importancia en el abastecimiento de lana y carne a la Villa de las Ferias en los siglos XV y XVI. Pero también lo era la madera y el pan. Difícil equilibrio cuando se incorpora la competencia vitícola. Será el apogeo de las roturaciones serniles que se estudiará más adelante y que tienen un claro perdedor en el norte de la Tierra: el monte Inestoso. Las repoblaciones de pinos inician su andadura reforzando su existencia, aunque pudieron haber sido extendidos por manos romanas en los suelos más sueltos, prontamente agotados por el esquilmo pastoril y ante las exiguas cosechas cerealistas que se obtenían de su aprovechamiento ${ }^{80}$.

Lo que parece probado es que los montes de la comarca medinense, como los de buena parte del sector central de la meseta, presentan un grado de deterioro bastante notorio a fines de la Edad Media. Muchos encinares se han convertido en carrascales impenetrables; en otros casos, roturaciones o cortas indiscriminadas han reducido muchas áreas de gran riqueza forestal a montes descuidados y otros rompimientos, abandonados al cabo de poco tiempo por estériles, que se convierten en baldíos y retamares con escaso aprovechamiento. El crecimiento demográfico y el desarrollo vitícola a lo largo de la Edad Moderna, como se tendrá ocasión de comprobar, son letales para buena parte de los montes que permanecen intactos. La preocupación que se suscita entre autoridades y vecinos es manifiesta, si se atiende a la multitud de pleitos entre partes que registra la Chancillería de Valladolid. El pino es comenzado a verse como un remedio a tantos males por su rápido crecimiento en relación a la encina y por la versatilidad de su madera. Los propios Reyes Católicos dictan normas que tratan de adaptarse a la nueva realidad, completando las existentes. Se precisa con minuciosidad cómo y cuándo se han de realizar cortas, penas y plantíos. En 1538 unas nuevas Ordenanzas amplían la Real Provisión que la reina Juana y el emperador Carlos extienden a todos los lugares de la corona de Castilla y que es prorrogada en el ańo $1557^{81}$. La dureza de los castigos parece ser el mejor remedio para proteger el monte. El propio emperador, si no constara la necesidad de las haciendas locales o reales, conjuga el interés económico con el ecológico, en relación a los montes de la Tierra de Medina. En el siguiente memorial, emanado de su Consejo, se describe tanto su lamentable estado como las actuaciones encaminadas a devolverles su antiguo esplendor ${ }^{82}$ :

79 OJEDA NIETO, J.: Alaejos. Un pueblo..., ob. cit. págs. 33-35. Las citas proceden, respectivamente, y siguiendo la trascripción del autor, del A.H.N., sección Consejos, leg. 1339-21 y del A.G.S., Cámara de Castilla, leg. 144-82.

${ }^{80} \mathrm{La}$ importancia que alcanzan estas masas de pino piñonero - Pinus pinea - en estas arenas con vistas al Duero, y que por lo demás servirían para fijarlas evitando una intensa erosión, sobre todo eólica, se refleja en distintos pasajes a partir del siglo XVI. Sirva como ejemplo la carta ejecutoria de 1787 entre La Seca y las monjas de Santa Clara, donde se cita “...el pino más grande que linda con el camino del puerto...”. En este pleito, como ya se tendrá ocasión de comprobar, se encargará al pintor Antonio Navarro un mapa preciso para juzgar el litigio, donde puede apreciarse la menguada extensión que alcanzaba el monte Inestoso. La encina irá dejando paso mayoritariamente al pino, si bien esta última, se resiste a desaparecer. Era el ocaso de un esplendor pretérito.

${ }^{81}$ RAMOS SANTOS, J.M.: Intervención humana..., ob. cit., págs. 209-223.

82 BLANCO SÁNCHEZ, A.: Sobre Medina del Campo y la Reina agraviada. Caballeros de la Hispanidad, Medina del Campo, 1994, citando como fuente el manuscrito 9-5527 de la Real Academia de la Historia. 
"I.-Que las orillas del río Zapardiel... se pongan álamos almuces (sic) y sauces, que sería cosa provechosa y deleitosa II.-Item, que el pinar que puso Francisco del Nero siendo corregidor, pues por la experiencia parece que está muy bueno y lo da bien aquella tierra, se junte, que está en dos partes, y se pueblen y siembren muchas manchas que en él hay vacías y se acreciente alrededor porque tiene gran disposición y aparejo para hacerse hermoso pinar a dos leguas de Medina.

III.-Item, de aquel cabe La Seca un cuarto de legua hasta pasado el camino que va a San Martín hasta las vertientes a Duero, hay el monte que dicen Henestoso, muy espeso de carrascos en que habrá casi una legua que en poco tiempo, en cardándose, se haría un buen monte porque labradores dijeron que el monte que está cabe Pollos, que dicen Palancar, poblado de encinas, le vieron no ha mucho como ahora está el Hinestoso.

IV.-Los vecinos de La Seca y otros lugares comarcanos se agraviarán de guardar este monte Henestoso porque le tienen cabe casa para sus ganados y aprovechamientos, pero en las vertientes a Duero y en el monte de Rueda y en los llanos de Valverde que alpadan (sic) con el monte de Valdemuelles que es todo hiniestas y retamas y habrá en ello dos leguas muy buenas para pastos, con cañada hasta el río Duero, con que no reza bien (...) en mandar guardar el monte Henestoso.

V.-Hay otro monte en Valdemuelles, cabe Pollos, que dicen el Palmar, en que habrá tres cuartos de legua de buenas encinas y carrascos altos, algo maltratado de mal guardado, y en él se han dado alguna parte de mercedes que talan el monte y lo arrastran (sic). Convendría que aquella parte mejor y el monte se amojonase y guardase haciendo en ella una casa para la guarda como lo está el de Rebollar y desde allí podrá guardar éste y el Enestoso con el monte de Valdemuelles".

Similar preocupación por mejorar la gestión del uso y ampliar la superficie del arbolado tienen en estas mismas fechas los vecinos de Tordesillas, al norte de Medina, pues "para remediar la mucha desorden que habia y hay en estos nuestros reinos de montes y pinares y otros árboles..." y "sin perjuicio de las labranzas", el regimiento de Tordesillas, siguiendo la Provisión de 1538, promoverá plantaciones de pinares al sur del Duero, que sigan el curso del Zapardiel y en dirección a la raya de Medina del $\mathrm{Campo}^{83}$. Lo realizado es limitado y las roturaciones son constantes en los siguientes siglos. Antonio Ponz, cuando recorre el camino entre Tordesillas, Rueda y Medina, no cesará de reclamar la repoblación como forma de revitalizar y generar riqueza en unas tierras peladas por la desidia donde pueden criarse "toda suerte de árboles, a excepción de las especies que requieren tierras cálidas..." ${ }^{\text {. }}$.

\section{b. El suelo, condicionante de los cultivos}

Una vez ganado al monte terrazgo agrícola, va a ser el suelo el que imponga su ley, tanto para las necesidades de los hombres como del ganado. La distribución de los cultivos y el grado de intensidad en su explotación ha variado a lo largo del tiempo, de acuerdo a avatares económicos y técnicos. Cuando no se respetan los condicionantes edáficos o no se solventan sus limitaciones, de poco le valen al campesino plegarias y procesiones. En tiempo histórico muchos montes se rompen para, al cabo de varios años, ser abandonados por improductivos. Sus suelos, en muchos casos sueltos y pedregosos, apenas soportan media docena de exiguas cosechas de morcajo (mezcla de trigo y centeno). Al no ser compensada su baja capacidad de retención hídrica con precipitaciones frecuentes en primavera, los cultivos herbáceos sufren tal grado de estrés hídrico que las cosechas merman hasta ser ruinosas. No pocos lugares, que nacen en el seno de estos espacios montaraces, se computan como despoblados, tiempo después de haberse labrado. El continuum suelo-agua-plantaatmósfera se rebela contra los hombres caso de que estos no aporten agua, técnicas agronómicas o aprovechamientos adaptados a tales necesidades. Sabido es que, desde las primeras roturas, el sistema de año y vez es la norma general, tanto en las tierras de segunda y tercera calidad como en la mayor parte de las de primera. Y ni siquiera parece suficiente a tenor de los rendimientos que se obtienen. Invariablemente, y hasta bien entrado el siglo XX, “...las tierras se siembran cada segundo año, dejando

${ }^{83}$ RAMOS SANTOS, J.M.: Intervención humana..., ob. cit., pág. 219.

${ }^{84}$ PONZ PIQUER, Antonio: Viage de España..., ob. cit., vol. XII, carta quinta, pág. 162. 
el de intermedio para su descanso..." 85 . Como excepción se anotan "...algunos herreñales o cortinales, que estos se siembran todos los años..." ${ }^{86}$. Y "los frutos que anualmente se cojen... son trigo, zebada, zenteno, garrobas y vino" 87 .

Poco más cabe añadir hasta que llegue la mecanización e industrialización del agro. La distribución en hojas del espacio labrado es lo que caracteriza al dibujo paisajístico del campo castellano, al tiempo que una necesidad para la buena armonía entre ganados y cultivos. Las Respuestas Generales del Catastro de Ensenada de mediados del XVIII son elocuentes por realistas. Tomemos las aportadas por el lugar de Lomoviejo, situado al sur de la comarca medinense ${ }^{88}$ :

“(En Lomoviejo) se hallan las especies de tierra siguientes: la de huerta de regadío, con el artificio de noria, produce hortaliza sin intermisión; las tierras blancas de sembradura de secano sin plantío alguno que fructifican cada segundo ańo del grano que se las siembra, por necesitar uno de descanso; la de sembradura de vińas que anualmente produce vino; la de prados de regadío y de secano que también producen pastos sin intermisión, y algunas tierras yermas por naturaleza...”.

De hecho, muchos suelos, desprotegidos de las encinas que los cubrían, quedan a merced de una aridez que los convierte en secarrales buena parte del año. No siempre los esfuerzos repobladores logran arraigar en ellos árbol alguno, pese a la buena disposición del Pinus pinea. De ahí la repetida argumentación de "no hay plantio de árboles de ninguna calidad por aberse esperimentado en las ocasiones que se ha hecho su insubsistencia" 89 o que, "aunque el año pasado de setecientos cuarenta y ocho, en virtud de orden de Su Majestad, se hizo un plantio de árboles... no a producido por no ser aparente la tierra, aunque se ha trasplantado y reformado..."

Menguado el monte en el espacio estudiado, será el viñedo el que colonice, a partir del siglo $\mathrm{XVI}$, tanto las desnudas terrazas del norte como las superficies degradadas y pedregosas del sur o las llamadas superficies de erosión del oeste. Es el único aprovechamiento continuado que se adapta a estas exigentes condiciones edáficas y climáticas. De hecho, como se verá, acaba disputando al propio monte el terrazgo en coyunturas vitícolas favorables. Y, cuando estas se tornan críticas, se refugia en las endebles terrazas del norte a la espera de tiempos mejores.

En relación con este aspecto, se diferencian varios tipos de suelo. Al norte de la comarca, los suelos de gravas se extienden de forma mayoritaria acompañados por los francos y francolimosos que recubren el fondo de los pequeños valles; en las campiñas meridionales, los arenosos cubren buena parte del terrazgo en los pueblos al sur de Medina. Pueden clasificarse unos u otros, en general, como cambisoles, luvisoles o arenosoles, atendiendo a su diversa génesis, sustrato geológico y evolución.

Los primeros se extienden, por las terrazas que se escalonan al sur del Duero hasta Medina del Campo. Son suelos que acogen de forma temprana el vińedo, al no adaptarse a ellos cereales y leguminosas. Se distinguen por tener una escasa proporción de arcillas y limos, reducida capacidad de retención de humedad y ser pobres en materia orgánica ${ }^{91}$.

${ }^{85}$ A.G.S. Hacienda. Catastro de Ensenada, Respuestas Generales, Libro 647, Carpio.

${ }^{86}$ Ibídem, Rodilana.

${ }^{87}$ Ibídem, Carpio.

${ }^{88}$ A.G.S. Hacienda, Catastro de Ensenada, Respuestas Generales, Libro 4, Lomoviejo.

${ }^{89}$ A.G.S. Hacienda, Catastro de Ensenada, Respuestas Generales, Libro 647, Nava del Rey.

${ }^{90}$ A.G.S. Hacienda, Catastro de Ensenada, Respuestas Generales, Libro 648, Serrada.

${ }^{91}$ Este tipo de suelos se clasifican como cambisoles eútricos, desarrollados a una altitud en torno a los 720-740 metros y presentan un drenaje externo malo e interno regular. Su evolución los ha hecho conferir un horizonte superior de color pardo amarillento predominantemente arenoso, con abundantes gravas redondeadas y no alteradas de cuarcita. Sus datos analíticos refieren hasta un $77 \%$ de arenas; un $12 \%$ de limos y $9,5 \%$ de arcillas, con un pH de 6 y bajos porcentajes de materia orgánica. FORTEZA BONNIN, J.; LORENZO MARTÍN, L. F; NAJAC BALLESTEROS, N.; CUADRADO SÁNCHEZ, S. y otros. Mapa de suelos de Castilla y León, Junta de Castilla y León, 1988, pág. 55. 
Las características antes descritas los hacen poco adecuados, tanto para cultivos de secano como de regadío, bien por sus determinaciones fisicoquímicas, bien por su escasa retención de humedad. A esta última consideración debe añadirse el hecho de que, al encontrarse muchos de ellos en la parte culminante de las terrazas, a cotas de 730-740 metros de altitud, los niveles freáticos se encuentran a profundidades imposibles para la extracción de agua por los medios tradicionales de elevación.

Sin embargo, como puede apreciarse en las imágenes adjuntas, la presión humana a lo largo del tiempo y sus propias características morfoedáficas han hecho, como se viene insistiendo, que encuentren en la vid un aliado vegetal adaptado a sus condiciones y al clima mediterráneo interior frío que caracteriza a este espacio. A lo largo del siglo XVI y primera mitad del XVII, no pocas facultades reales abren las puertas a su expansión a gran escala en el norte comarcal. Un ejemplo es la que sigue, dictada en 1612 en tiempos de de Felipe III' .

\footnotetext{
“Don Felipe, por la gracia de Dios, rey de Castilla, de León, de Aragón...por quanto por parte de vos, Juan Rejón Samaniego, en nombre... de Don Juan Antonio de Montalvo... nos ha sido hecha relación que teniendo el dicho buestro menor de su mayorazgo entre los vienes del quatro mil obradas de tierras de pan llebar en término del lugar de Serrada, jurisdizión de la villa de Olmedo, de las quales havía mas de mil que por ser flacas y pedregosas había muchos ańos que no se arrendaban, y que heran mui a propósito para plantar viñas, y se allaran personas que las tomasen a zenso...”.
}

Ni fueron las primeras ni las últimas. El viñedo ha sido el cultivo que ha fijado población, ha dado sustento y ha evitado que estas tierras "flacas y pedregosas" permanecieran inertes desde el punto de vista agronómico, toda vez que los cultivos de secano, en buena parte de ellos, se mostraban incapaces de hacer frente a la pobreza mineral de sus suelos y a los calores primaverales que asuraban sus cosechas. El propio carácter pedregoso del suelo ha dado nombre a pagos asociados a las cepas ${ }^{93}$. Este arbusto, adaptado a la aridez, ha sido el aprovechamiento que se ha extendido desde siglos por estas terrazas de gravas y arenas, proporcionando a sus habitantes un elemento fundamental en su dieta y constituyendo, en la economía de mercado que se inicia en los pasados tiempos feriales, uno de los elementos más dinamizadores de la Tierra de Medina ${ }^{94}$.

Los suelos francos y francolimosos ocupan, por el contrario, los fondos de valle en los que se asientan los municipios, drenados tradicionalmente por arroyos discontinuos que discurren entre prados y charcas camino del Duero. Se extienden también, aunque variando considerablemente su morfología de acuerdo a múltiples factores, por las laderas que enlazan las terrazas con los suaves declives que acaban en vallecillos que recorrieron arroyos en otro tiempo. Han sido estos suelos y la cercanía del acuífero que rebosaba en superficie en algunos sectores los que han contribuido, junto con el mencionado viñedo, a escribir la historia agraria de muchos de los pueblos del norte de Medina, tales como Serrada, La Seca, Ventosa, Matapozuelos, Rodilana... Tierra y agua como elementos fundamentales de la ocupación humana. Y es que sus suelos, equilibrados en su textura si se atiende a su análisis físico, y con unos niveles idóneos para el aprovechamiento agrícola en sus componentes químicos, han aportado buenas cosechas de cereal y

92 A.H.P.V. Hospital de la Resurrección, caja 4, leg. 1, nº 16.

${ }^{93}$ Ejemplos de ello se registran en el Catastro de Ensenada en el término de Rueda: "Una viña en el pago de Cantosal, distante de la población una legua" o "una viña en el pago de carrespedreras, dista de la población un cuarto de legua..."(A.H.P.V. Hacienda, Catastro de Ensenada, Respuestas Particulares, Rueda, caja 238, fol. 944 r. y fol. 837v, respectivamente).

${ }^{94}$ De la varietal verdeja, espartana en sus necesidades y generosa en sus virtudes, nada tenemos que ańadir que los labradores no sepan, los cosecheros de antaño no hayan comprobado y los bodegueros de la Denominación de Origen Rueda no estén difundiendo por medio mundo. 


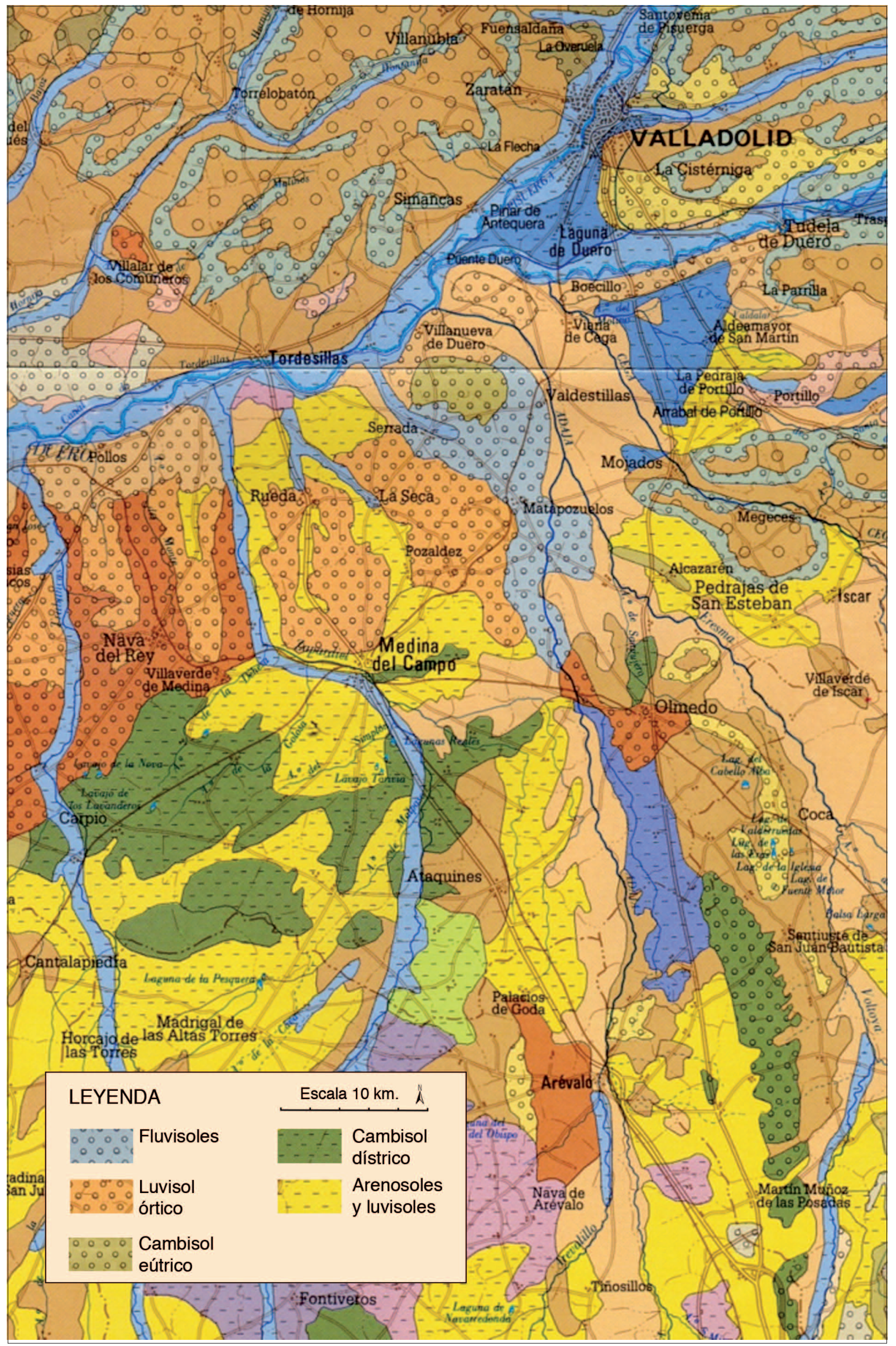

Figura 8. Mapa de suelos al sur del Duero medio. Fuente: Mapa de Suelos de Castilla y León. 

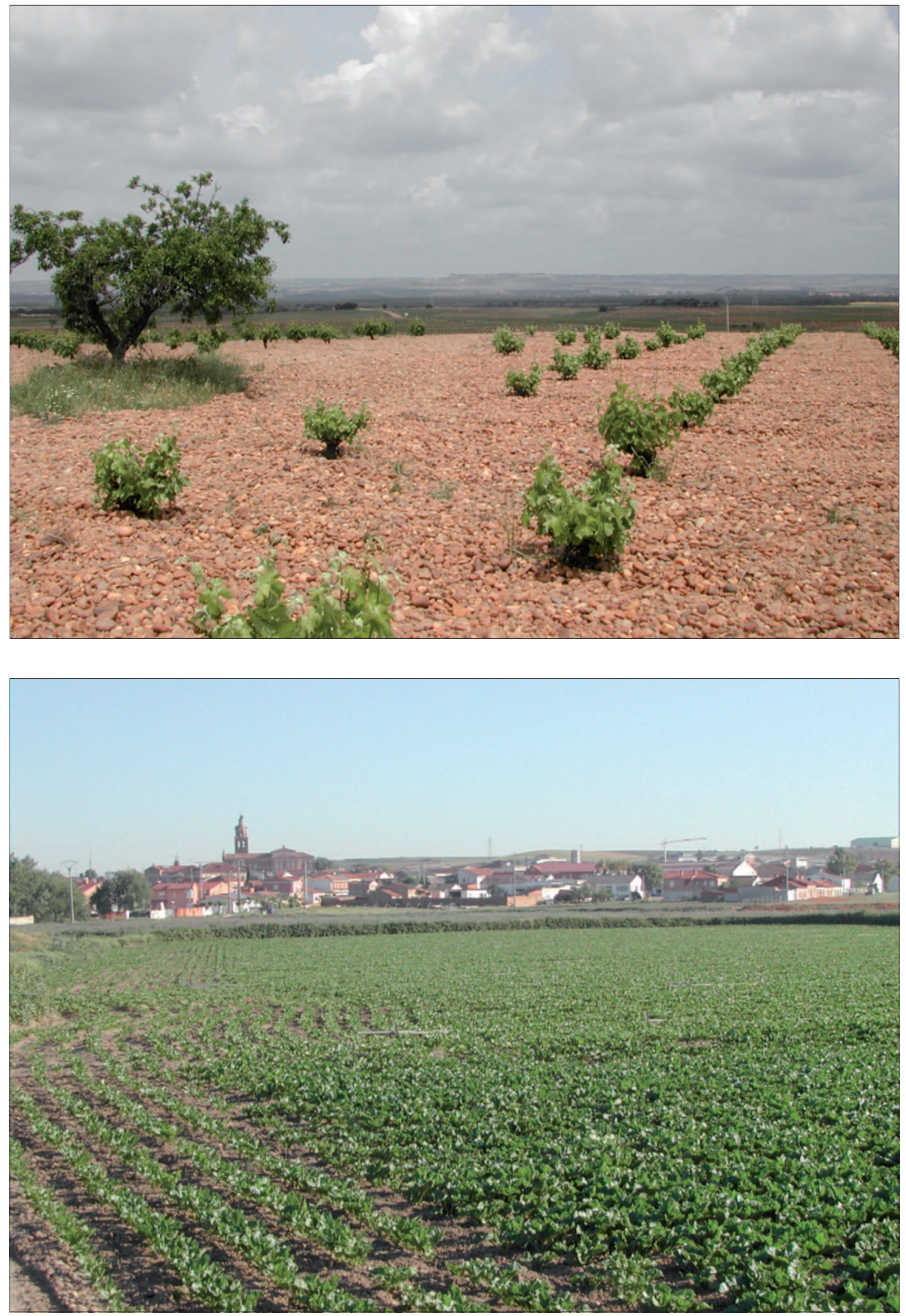

Imagen 17. Ejemplos de suelos de terraza (arriba) y fondo de valle (abajo). Serrada. Foto:12/06/2008 y junio de 2005. Los cultivos, y hasta el propio asentamiento humano, han estado condicionados por el tipo de suelos. Obsérvese, en las imágenes, el contraste entre las gravas de cuarcita y las tierras de vega. 

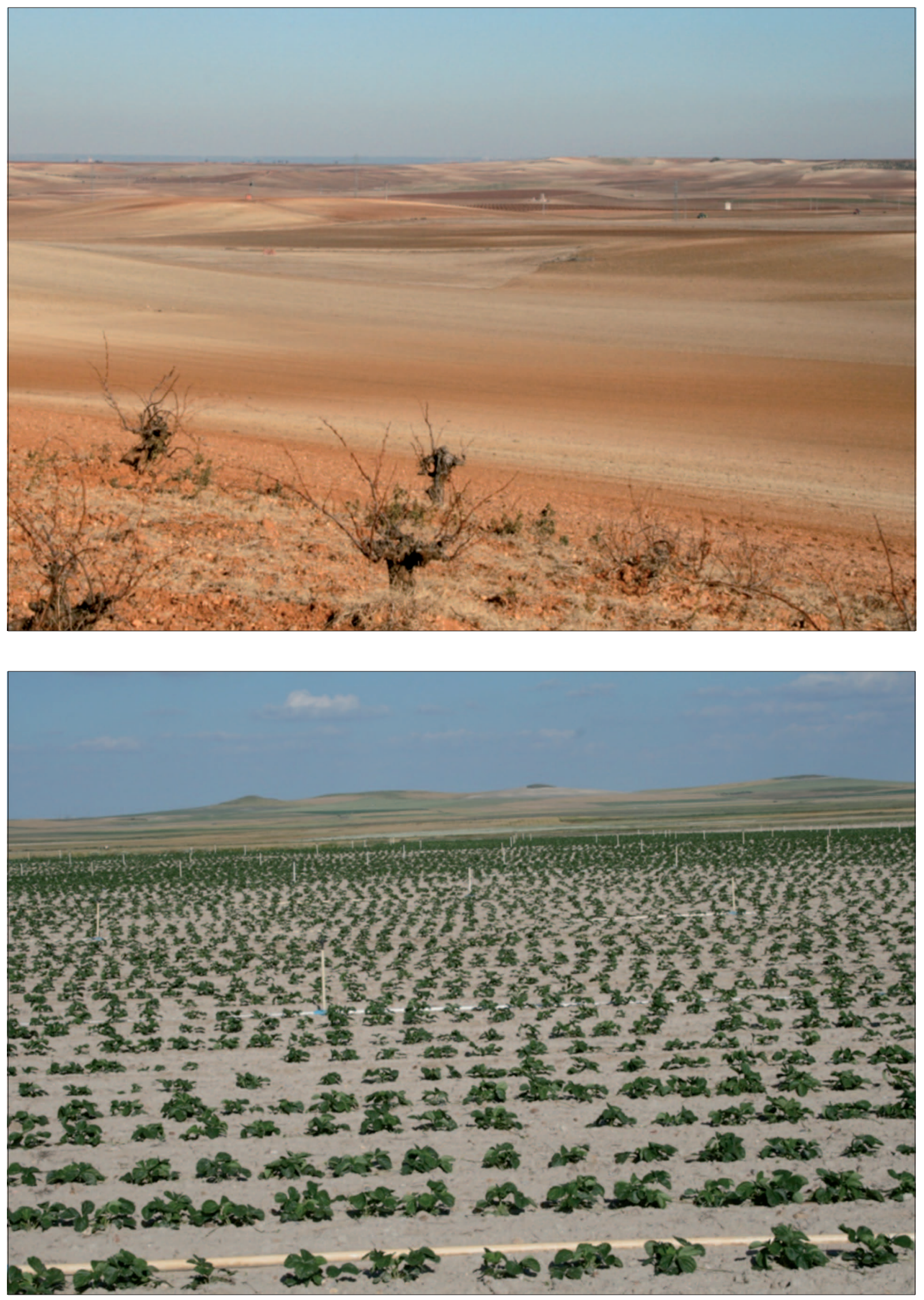

Imagen 18. Ejemplo de suelos arcillosos en los términos de La Seca y Rodilana (arriba) y arenosoles macroporosos en San Vicente del Palacio (abajo). Foto: 16/11/2007 y 12/06/2008. El desmantelamiento de las terrazas de gravas ha dejado al descubierto, en algunos pueblos, como Rodilana, materiales miocenos de gran fertilidad; en otros términos, por el contrario, los recubrimientos de arenas han condicionado seriamente la rentabilidad de cereales y leguminosas. El regadío ha abierto nuevas posibilidades y aprovechamientos, tal como muestra la imagen inferior. 
legumbres en tiempos pasados y, gracias al impulso del regadío, de patatas y remolacha, indispensables para la supervivencia de las pequeńas y medianas explotaciones familiares en los últimos cincuenta años ${ }^{95}$.

Este tipo de suelos recubren también buena parte del terrazgo al sur de las terrazas en los términos de Alaejos, Sieteiglesias, Nava del Rey, Torrecilla o la propia Medina, siendo clasificados como luvisoles. Muchos de ellos mantienen regulares producciones, afrontando con entereza las rachas secas que en los arenales situados más al sur se llevan los frutos de forma inmisericorde. Ello es posible debido a unos mayores componentes arcillosos en sus horizontes superiores e inferiores, con pocos poros, muy finos, que limitan la pérdida de humedad, mantienen una mayor disponibilidad de agua útil y, por tanto, ralentizan el marchitamiento de la planta. Los porcentajes de materia orgánica, a pesar de ser bajos, junto con el papel que desempeñan las fracciones texturales más reducidas, se tornan factores fundamentales para comprender la dinámica de la humedad en ellos ${ }^{96}$. Son terrazgos que se comportan firmes en húmedo y duros en seco, difíciles de cogerlos a tiempo con el arado, pero de regulares rendimientos para las menguadas precipitaciones que reciben en abril, mayo y junio.

Distinto es el caso de los recubrimientos arenosos del sur comarcal, característicos de términos como Medina del Campo en sus pagos meridionales o, entre otros, de San Vicente del Palacio, Rubí de Bracamonte, Fuente el Sol, Gomeznarro, Moraleja de las Panaderas... No ocupan la totalidad de sus pagos, pero caracterizan el paisaje vegetal que los recubre por endeble ante los primeros calores e improductivo en sus sectores más livianos. Se trata de arenosoles macroporosos, tal como refleja la imagen anterior, de escasa capacidad de retención de agua, muy permeables, con bruscas variaciones en la reserva hídrica como consecuencia de un excelente drenaje y evaporación después de las lluvias, que ocasionan un elevado déficit hídrico para una vegetación que sufre marchitamiento desde fechas inusualmente tempranas. Sólo primaveras agradecidas como la de 2007 o muy lluviosas, como la del año 2008, logran producciones altas de cereal y leguminosas que animan al labrador a seguir en su actividad. Hasta bien entrado el siglo XX, en muchos de estos pueblos se conservó la división en hojas de forma muy nítida, al igual que el sistema de año y vez, y la siembra de centeno, trigo candeal y cebada caballar en mayor medida que en el resto de la comarca, prueba de lo limitado de sus recursos edáficos.

Estos condicionantes nunca permitieron excesos en tiempo histórico y las propias comunidades locales siempre fueron sabedoras de ello. En algunos casos los pagos más sueltos fueron aprovechados como pastizales, como ocurre con Moraleja de las Panaderas que "tiene por propios los pastos que incluye este término y una crecida porción de tierras incultas por naturaleza por ser de arena muerta...", según catastra en $1752^{97}$.

\footnotetext{
${ }^{95}$ Los suelos francos de los que se habla se extienden por el fondo de los valles originados por las corrientes fluviales que disecaron las terrazas del Duero. Se conocen en el mundo campesino como vegas y fueron formadas por acumulaciones aluviales cuaternarias. Su análisis físico es bastante equilibrado, con un ligero predominio de la arena (50\%) sobre el limo (40\%) y la arcilla (10\%), lo que les confiere una gran feracidad agrícola. Su análisis químico les otorga un pH en torno al 7,7 y unos niveles de sodio, potasio, magnesio y calcio de cambio muy favorable para todo tipo de cultivos herbáceos, aunque su explotación continuada los ha hecho perder de forma considerable sus primitivos valores, especialmente de materia orgánica, actualmente y por lo general, por debajo del uno por ciento. Los suelos francoarenosos suelen ser característicos del espacio de enlace entre las laderas que forman las terrazas con el fondo de los valles. De ahí que su porcentaje de arena pueda llegar hasta el 75\%, bajando el limo hasta el 20\% y la arcilla al 5\%, aproximadamente. Pese a ello, suelen darse unos $\mathrm{pH}$ y valores de componentes químicos similares a los suelos francos mejorando el drenaje, pero perdiendo capacidad de retención de humedad conforme el componente arenoso aumenta. Su valor agrícola es también muy estimado y, al igual que los anteriores, la corrección mediante abonado orgánico y químico de aquellos valores que descienden por el intenso cultivo los permite mantener una elevada productividad año tras año.

${ }^{96}$ CEBALLOS BARBANCHO, A.; MARTÍNEZ FERNÁNDEZ, J.; HERNÁNDEZ SANTANA, V.; MORÁN TEJEDA, C. y CASADO LEDESMA, S.: "Variabilidad espacio-temporal de la humedad del suelo en el sector semiárido de la cuenca del Duero (España)", en Revista C \& G., 19 (3-4), 63-77.
} 
El propio concejo de Rubí certifica que "su terrazgo es bien infimo y endeble..." y que "por lo mismo... de ser el referido término bastante endeble y seco, no hay en él plantio de árboles..." 98 . Similares palabras testifican Cervillego de la Cruz o San Vicente del Palacio. Sólo la presión demográfica fuerza su aprovechamiento, aunque siempre se las considera de tercera y con escaso rendimiento. La propia toponimia lo delata: "otra tierra a carramoraleja, a los arenales, que hace obrada y media de la tercera calidad..."; "otra (tierra) a el vallejuelo, al vajar los cascajales..."99. Similares circunstancias pueden apuntarse en las áreas mal drenadas y salinas, comúnmente aprovechadas como pastizales, cuyos suelos sufren continuos encharcamientos que provocan la asfixia radicular de la planta, caso de ser aprovechado el suelo por cultivos herbáceos. Sólo las ayudas de la P.A.C., a finales de la pasada década de los ochenta, logran desterrar el barbecho y aumentar la superficie labrada a costa, en ocasiones, de estas tierras que, fuera de los periodos de mayor ocupación, fueron pastizales temporales o baldíos improductivos. Nada sería más ilustrativo que pudieran hablar muchos de estos salgüerales y arenales del sur provincial sobre el repentino cambio vivido en las últimas décadas. "El tiempo volverá a dar la razón a los antiguos", parecen decir en muchas primaveras, al observar como "su secura" y su carácter "ínfimo" les impide fructificar convenientemente fruto alguno.

En sus sectores más prominentes, sobre antiguas terrazas fluviales, también arraigó en tiempo histórico el viñedo y, en la actualidad, ante la falta de rentabilidad de los cultivos de secano y la desaparición del cultivo de la remolacha, vuelve a ser introducido en algunos pueblos. Los propios topónimos van de la mano de su aprovechamiento, al tiempo que aluden al componente arenoso del soporte mineral como, por ejemplo, "otra viña, al pago de la Cantera..." ${ }^{100}$. Arenales, en fin, que fueran gestados bien por recubrimientos eólicos, bien por aportes fluviales, han condicionado sobremanera los esquilmos tanto en el pasado como en la actualidad, variando su superficie de acuerdo a la técnica, al agua disponible o a la demanda de cereal o leguminosas en el mercado. No deja de ser alentador en los momentos presentes observar cómo estas tierras, tradicionalmente poco consideradas, son reclamadas, si bien de forma puntual, por empresas muy capitalizadas para la implantación de cultivos hortícolas, como la zanahoria o la planta de fresa, frambuesa y fresón, por citar algunos ejemplos. La reintroducción del viñedo en estos suelos que ya lo conocieron atenderá, como también se ha apuntado, tanto a la rentabilidad de los cultivos tradicionales que en ellos se asientan como a la propia dinámica del actual mercado vitivinícola.

A las anteriores consideraciones debemos ańadir otros factores, tales como la importancia de los suelos mal avenados de estas campiñas del sur, tradicionalmente encharcados buena parte del año y que acogieron buenos pastizales en tiempo histórico.

Las oscilaciones del nivel del acuífero generaron una migración de sales hacia la superficie, provocando una elevada salinidad, con la consiguiente merma de su aptitud agronómica. Las roturaciones y drenajes de las superficies menos insanas hicieron retroceder notablemente el espacio ocupado por navas, lavajos y bodones, lugares refugio de una vegetación y fauna rupícola y abrevadero natural de los ganados. En tiempo histórico, en algunos municipios, se caracterizaban por su esterilidad, caso de Ataquines y La Zarza, con diez y setenta obradas de salgüerales, respectivamente, en $1752^{101}$.

\footnotetext{
${ }^{97}$ En otros, como el despoblado de Bayona, que suma 750 obradas, es muy significativa la apreciación de que “...cuatrocientas cuarenta y una obradas de tercera calidad... sólo se disfrutan y siembran de zenteno cada año veynte obradas, porque por ser de muy mala calidad y haver experimentado, no dan fruto; las dexan olgar, y alternativamente las van disfrutando, sin que puedan exceder a las vein te obradas en cada un año...”. A.G.S. Hacienda. Catastro de Ensenada, Respuestas Generales, Libro 647, Moraleja de las Panaderas y Bayona.

${ }^{98}$ Ibídem, Rubí de Bracamonte.

${ }^{99}$ A.H.P.V. Hacienda, Catastro de Ensenada, Libro Maestro de Seglares, caja 120, Lomoviejo, fols. 226 y 604, respectivamente.

${ }^{100}$ Ibídem, caja 236, Rubí de Bracamonte, fol. 56.

${ }^{101}$ A.G.S. Hacienda, Catastro de Ensenada, Respuestas Generales, Libro 548 y 648, respectivamente.
} 
En otros, el arado ha ido ganando la partida, aprovechando los sectores limosos más fértiles. No son pocos los topónimos que aluden tanto a su estado primigenio como a la fauna que en ellos habitaba: "otra tierra, al sendero de los pradillos de las Navas"; "otra tierra a el lavajo de zigüeña..." 102 , "una pieza de tierra de sembradura de secano en el pago del Grullero...", "otra de sembradura de secano en el pago de las Navas" 103 .

Estas transformaciones se han cobrado su tributo. El incremento del terrazgo labrado y la sobreexplotación del acuífero de los Arenales han conllevado la desaparición de determinadas especies animales y vegetales, así como de las propias charcas y lagunas, fundamentales en otro tiempo para alimentar a una importante cabaña ganadera, imprescindible en la economía tradicional y en la vida de estos pueblos hasta bien entrada la segunda mitad del siglo pasado.

\section{c. El declive de una riqueza vegetal y faunística}

Como bien apunta Hilarión Pascual al estudiar las condiciones físicas de la Tierra de Medina, hacer un balance de la vegetación comarcal es indagar en la historia de su deforestación ${ }^{104}$. No se va a abundar en lo analizado anteriormente. Las escasas masas arbóreas existentes en la actualidad corresponden predominantemente al pino, producto, a su vez, de las repoblaciones llevadas a cabo por el hombre sobre las áreas anteriormente deforestadas. Como se ha estudiado, importantes masas forestales fueron objeto de intensas roturaciones a partir del siglo XVI, caso del monte Valdevite en Siete Iglesias, Valdemuelle en Nava, Montico en Rueda e Inestoso y Pedroso, situados al norte y oeste de La Seca, entre otros.

En cuanto a la riqueza que atesoraban humedades y pastizales, la podemos dar por extinguida en buena parte de los términos, dado el agostamiento permanente que presentan y la roturación de parte de ellos. Especies vegetales como la menta silvestre o el té, por poner un ejemplo, propias de estos humedales en otro tiempo, y que formaron parte habitual de la dieta campesina, sólo ocupan hoy un lugar en la memoria de los mayores. Y similares características regresivas presentan las formaciones arbustivas y subarbustivas como zarzales, retamares, escobares, tomillares y especies menores que apenas sobreviven en los escasos eriales existentes, a la vera de caminos y cañadas donde el ambicioso arado y el tránsito de maquinaria reducen de forma inexorable su supervivencia, en otro tiempo más extendida y numerosa. Por último, y asociado al declive de la cobertera vegetal, hay que constatar las repercusiones que ha tenido en la fauna el devenir histórico y los últimos decenios del siglo XX, en que las transformaciones espaciales y económicas han reducido las especies faunísticas a niveles muy inferiores respecto a tiempos pasados.

Lejos quedan, en este sentido, los testimonios de cronistas y escribanos regios, aduladores de las gestas de reyes que, en sus largos tiempos de holganza, se entregaban por estas tierras del Duero a la caza del oso y del jabalí. A la desaparición del primero hace siglos le siguió la reducción del segundo a niveles mínimos, conforme aumentaban las roturaciones de los montes y tierras incultas. De la misma manera podría hablarse de depredadores como el lobo. Como se ha indicado es la toponimia, en este caso, quien constata su pasada existencia, aunque de su recuperación al sur del Duero constan testimonios de su avistamiento, cercanos a los cauces del Adaja y del Eresma o de ataques a ganado ovino en el valle del Trabancos. Distinto es el caso de la avutarda, reina de las aves esteparias. Su precaria situación en estas campiñas ha sido uno de los factores que han contribuido

${ }^{102}$ A.H.P.V. Hacienda, Catastro de Ensenada, Libro Maestro de Seglares, caja 120, Lomoviejo, fols. 172 y 310.

${ }^{103}$ Ibídem, caja 236, fols. 62, 106 y 537, respectivamente.

${ }^{104}$ PASCUAL GETE, H.: "Las condiciones físicas de Medina del Campo y su Tierra”, en Historia de Medina del Campo y su Tierra. Coordinador: Eufemio Lorenzo Sanz, vol. I, Ayuntamiento de Medina del Campo y otros, Valladolid, 1896, pág. 61 y ss. 
a la declaración como Zonas de Especial Protección para las Aves (ZEPA) del espacio denominado "La Nava-Rueda", que acoge 7.176,03 ha y de la llamada "Tierra de Campiñas" que, con 139.444 ha, se extiende por buena parte del suroeste de la comarca, integrando también áreas de Ávila y Salamanca ${ }^{105}$. En el primero de los espacios destacan, entre las aves esteparias, las poblaciones reproductoras de avutarda, con 92 aves, además de sisón y cernícalo primilla. Otras especies, ligadas sobre todo al pinar de la Nava, integrado en el citado espacio, son el milano real, milano negro, azor, alcotán y gavilán, por citar las rapaces más importantes ${ }^{106}$. En la "Tierra de Campiñas", donde en algunos sectores los ríos Trabancos y Zapardiel mantienen franjas con vegetación palustre y bosques de ribera bien conservados, las especies por las que se ha declarado ZEPA son la cigüeña común, milano real, aguilucho cenizo, cernícalo primilla, grulla común, sisón, avutarda, ortega y ganga común. La avutarda destaca entre las demás por censar 2.195 aves en 1998, constituyendo uno de los núcleos poblacionales más importante de Castilla y León ${ }^{107}$.

Fuera de estos espacios más singulares, la tecnificación y mecanización del agro han provocado el descenso y práctica desaparición de distintos tipos de rapaces, aves esteparias o carroñeras, abundantes en otro tiempo, pero difícilmente compatibles en la actualidad con la agricultura y ganadería modernas. El empleo de plaguicidas y productos químicos en general, junto a la sobreexplotación de acuíferos y la consiguiente desecación de charcas, fuentes y prados, ha rubricado también el final de otras especies menores, aunque no menos importantes, como ranas y sapos, aves lacustres, mariposas y otros insectos, a los que hoy les resultaría imposible la vida en muchos de los términos tratados. Las especies que han sobrevivido a la intensa alteración y ocupación humana del territorio son de índole menor, estando regulada su presencia por la práctica tradicional de la caza, tal es el caso de la liebre, el conejo, la perdiz o, en otros casos, como ocurre con águilas y cernícalos, zorros, aves nocturnas y esteparias como el alcaraván, sufriendo las consecuencias de la pérdida de biotopos benefactores y, por tanto, muy alejados, como se ha dicho, de la presencia e importancia que tuvieron en otro tiempo.

Como conclusión, se puede resumir que las condiciones atmosféricas y los distintos tipos de suelos han permitido a las comunidades agrarias, a lo largo de los siglos, satisfacer sus necesidades alimentarias y crecer al tiempo que lo hacían sus cultivos y ganados. Distintos grupos humanos, a lo largo del tiempo, se han asentado preferentemente a lo largo de los ríos, o en posiciones de privilegio, ocupando de forma temprana los términos próximos de Simancas, Tordesillas, Valdestillas, Medina o Matapozuelos. De ahí que haya sido en estos núcleos donde se han asentado, con mayor intensidad, las primeras sociedades de las que se tiene noticia. Y por todos estos condicionantes físicos, que han impuesto su ley de forma imprevisible durante generaciones, se debe valorar sobremanera la capacidad de las distintas comunidades rurales que habitaron este espacio por adaptarse a este medio difícil, hacerlo producir y asegurarse de forma continuada el sustento.

${ }^{105}$ SANZ-ZUASTI, J.; ARRANZ SANZ, J.; MOLINA GARCÍA, I.: La Red de Zonas de Especial Protección para las Aves (ZEPA) de Castilla y León. Junta de Castilla y León, 2004, pág. 29.

106 Ibídem, pág. 292-293.

${ }^{107}$ Ibídem, pág. 312. 


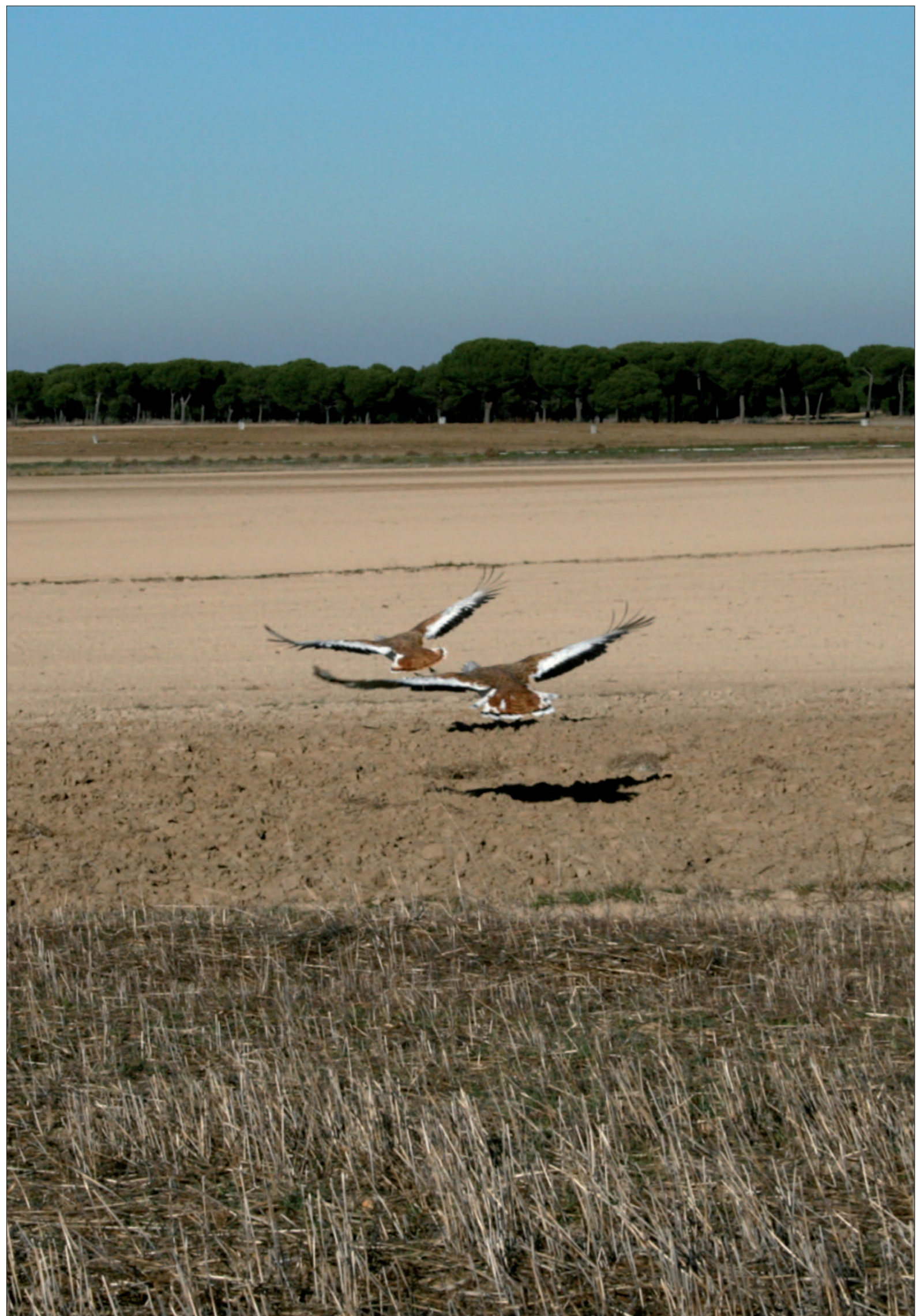

Imagen 19. Avutardas (Otis tarda) iniciando el vuelo en las campiñas meridionales. Rubi de Bracamonte. Fecha. 05/11/2007. En progresiva disminución desde los años sesenta, distintos programas y actuaciones medioambientales han conseguido que esta ave, la de mayor peso de Europa, aumente en número y no sea difícil de ver, tanto en las campińas del sur, como en los pagos más solitarios de norte de Tierra de Medina. 

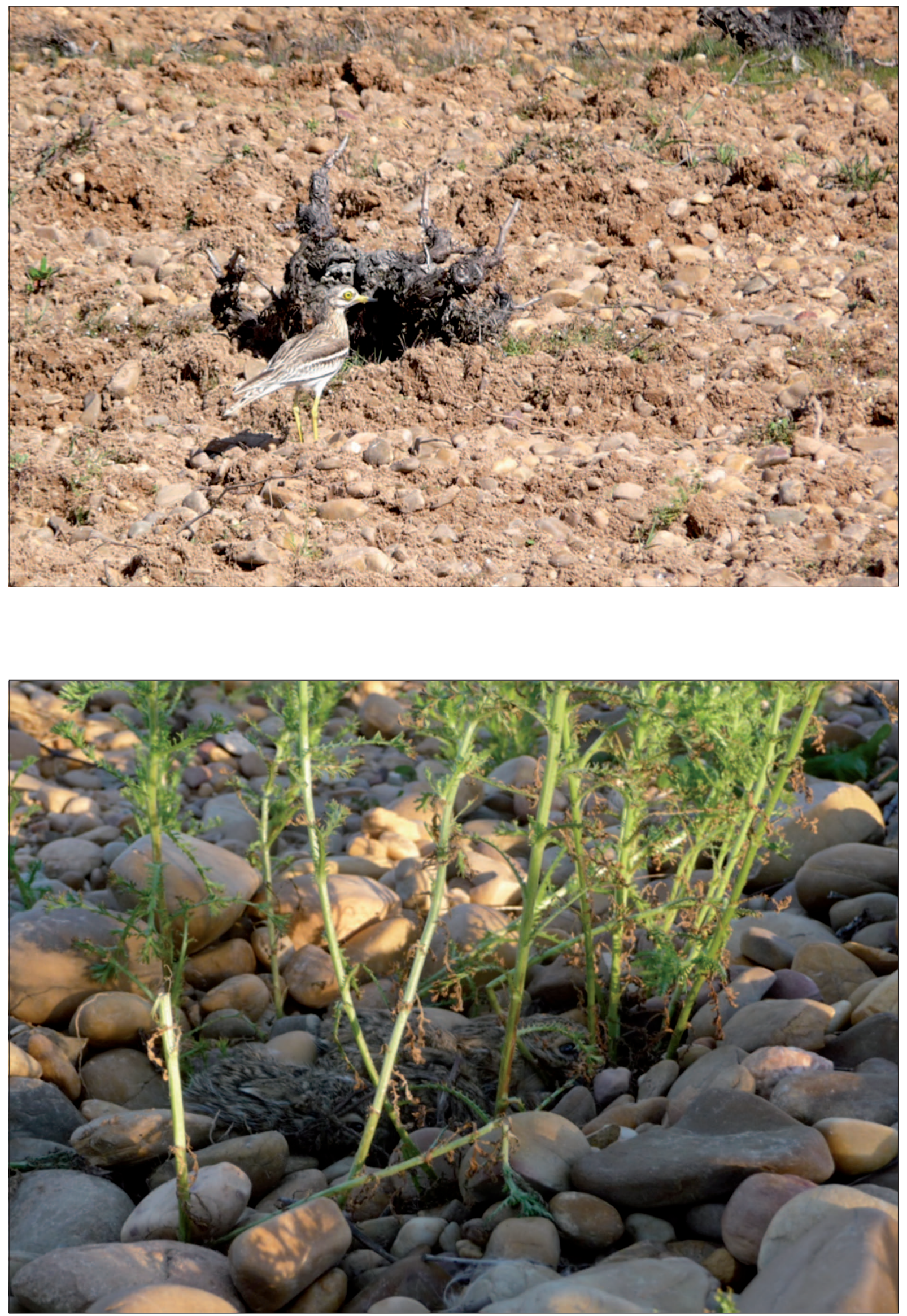

Imagen 20. Alcaraván (Burhinus oedicnemus), y excepcional camada de cinco gazapas (Lepus granatensis). Foto: 07/04/2010 y 20/05/2013. Tanto las aves esteparias como el resto de la fauna del espacio estudiado muestran una gran adaptación a un medio de tonos terrosos, desprovisto de vegetación parte del año, consecuencia de la actividad agraria. 

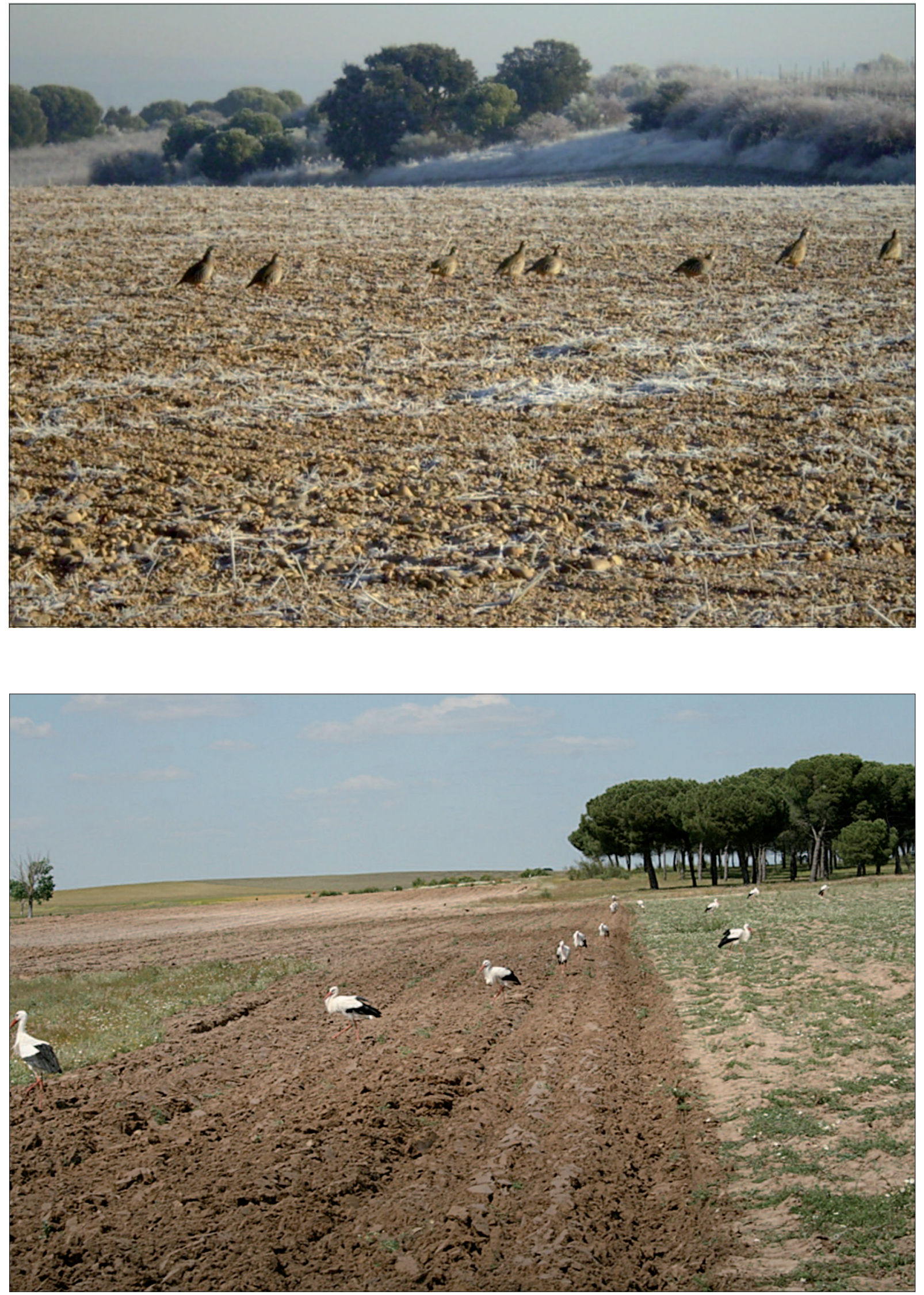

Imagen 21. Grupo de perdices comunes (Alectoris rufa) y cigueñas comunes (Ciconia ciconia) en tierras de cultivo. Foto: 23/01/2008 y 12/06/2008. Buena parte de la fauna existente en la comarca aprovecha o sobrevive, de alguna manera, siguiendo el curso de las cosechas o las labores que necesitan los distintos cultivos. La cigüeńa, como podemos apreciar en la imagen, desaparecidos lavajos y arroyos, se alimenta, entre otras presas, de roedores e invertebrados que deja al descubierto el paso del arado. 


\section{CAPÍTULO II}

UNA OCUPACIÓN HUMANA DESDE TIEMPOS REMOTOS Y UN APROVECHAMIENTO AGRARIO DE LOS RECURSOS 


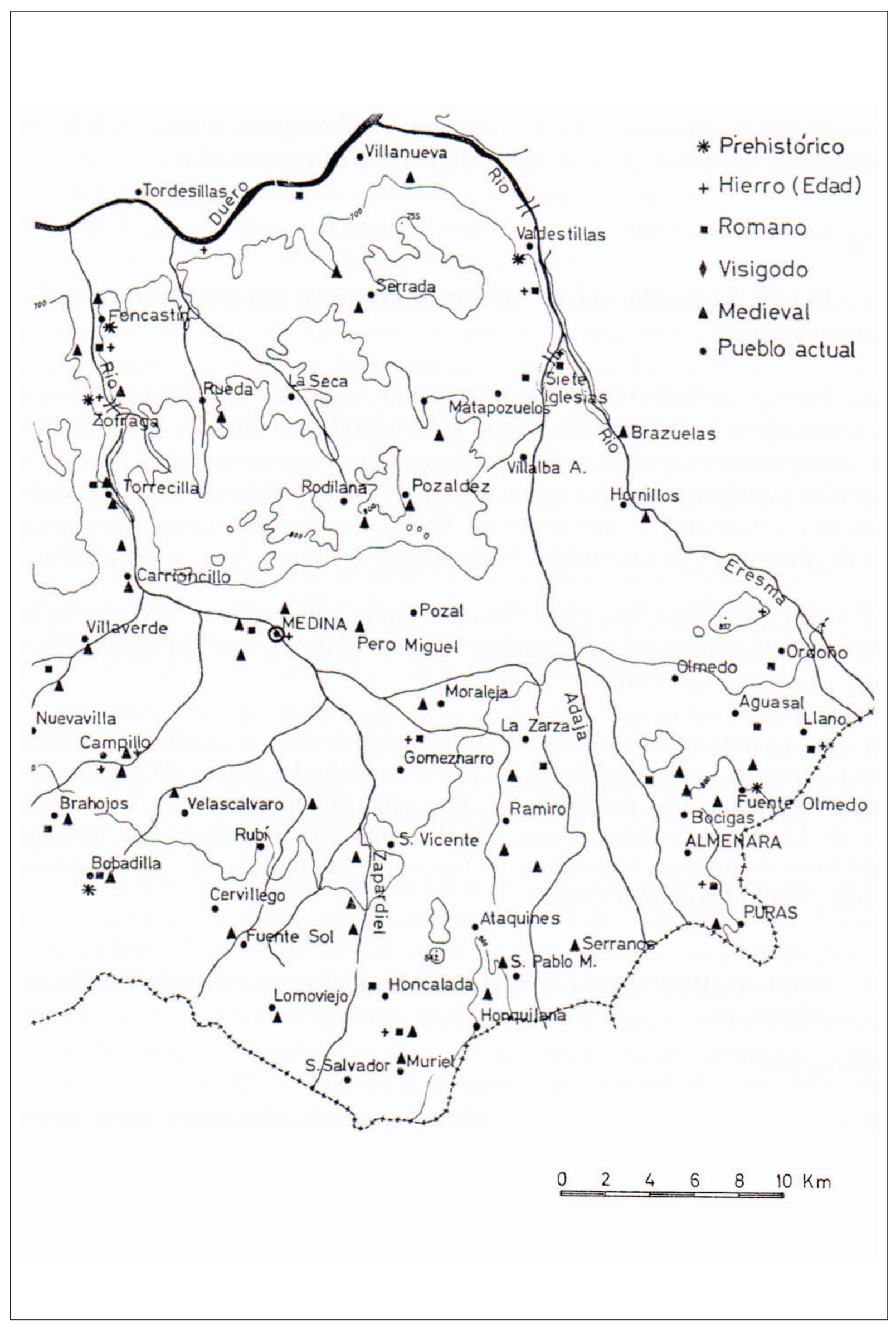

Figura 9. Principales yacimientos y restos arqueológicos en la Tierra de Medina.

Fuente: Tomás Mañanes. Arqueología 2002. 


\section{Las huellas prehistóricas y la impronta de las primeras culturas}

Los términos de los municipios de la Tierra de Medina, así como sus comarcas limítrofes, han sido habitados desde épocas muy remotas. En el Paleolítico la presencia humana debió de ser bastante eventual pues, a pesar de la inmensidad del tiempo que comprende esta etapa de la Prehistoria en la península Ibérica -desde 900.000 años hasta 8.000 años a. C.-, y teniendo en cuenta la amplitud del valle del Duero, los yacimientos encontrados con restos de homínidos antepasados del hombre actual, o con culturas materiales a ellos asociadas, son muy escasos.

La horizontalidad del terreno y la inexistencia de salientes rocosos y cuevas naturales pudiera haber sido un impedimento para un asentamiento permanente en estas tierras centrales del Duero, sobre todo cuando las condiciones metereológicas eran más rigurosas. Sin embargo, no estamos lejos del importantísimo yacimiento de Atapuerca, en Burgos, que se está convirtiendo, a la luz de los descubrimientos que en él se hacen año tras año, en el gran templo del registro humano del sur de Europa. La vida de las distintas especies de homínidos que en él se han encontrado desde hace casi un millón de años, se trate de Homo Antecesor, H. Heidelbergensis. H. Neanderthalensis u H. Sapiens, estuvo siempre basada en la caza de animales y en la recolección de todo tipo de alimentos. Baste, a modo de ejemplo, el hallazgo, en la pasada campaña de excavación de 2014, de una lasca de antigüedad de 1,3 millones de años, que se suma a los últimos descubrimientos de ejercicios anteriores, y que confirma la presencia humana, en este espacio, desde tiempos muy remotos.

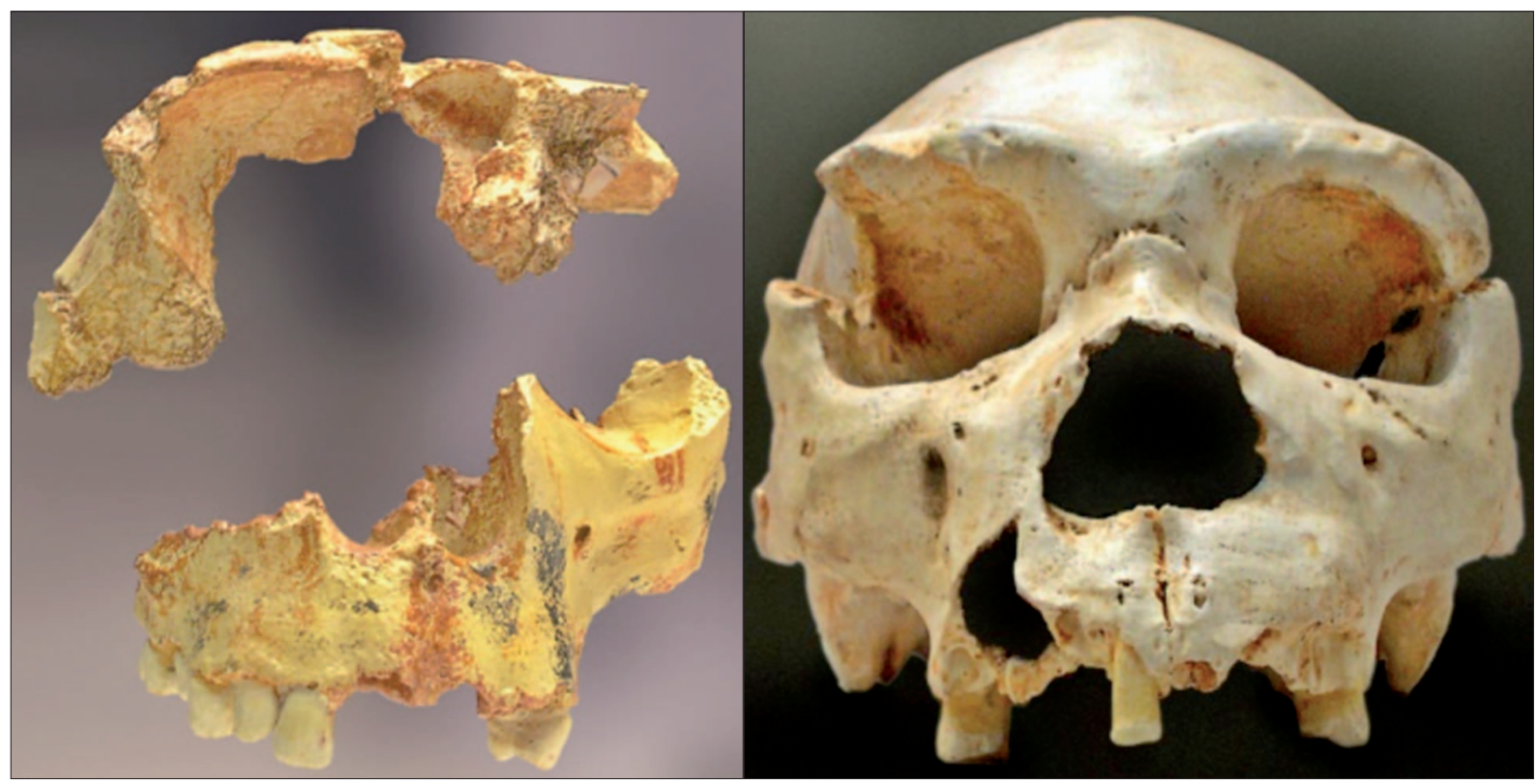

Imagen 22. Restos craneales de Atapuerca: Homo Antecessor de Gran Dolina y Homo Heidelbergensis de Sima de los Huesos. Foto: José Manuel Benito, junio de 2006. 
En sus recorridos, cuando llevaban a cabo expediciones de caza y recolección, dejaron restos de útiles que se han encontrado dispersos por toda la meseta. A diferencia de otras tierras más arenosas o arcillosas, en los términos al norte de la comarca, las superficies fluviales fósiles, formadas por gravas de cuarzo y cuarcita, les dejaron a mano una materia prima básica para tallar sus herramien$\operatorname{tas}^{108}$. No resulta difícil encontrar en los distintos niveles de terraza cantos tallados mono o bifaciales, lascas, percutores y núcleos, y otros artefactos de cuarcita. Aunque fuera de contexto arqueológico, su relación con las terrazas cuaternarias del Duero y sus características técnicas, permiten establecer una hipótesis de trabajo y una comparación con piezas encontradas en situación similar, en secuencias del Duero, del Pisuerga, del Tormes u otros afluentes vecinos.

\section{a. La presencia de grupos humanos paleolíticos al sur del Duero}

Somos conscientes de lo limitado del muestreo realizado, toda vez que sus resultados no forman parte si no de un mero acercamiento a tan interesantes como poco conocidos hallazgos. No obstante, estudios rigurosos llevados a cabo sobre el conocimiento de las culturas achelenses en la meseta norte y, en particular, en las tierras de Nava del Rey, Castronuño y Pollos, entre otros lugares de la provincia, permiten relacionar las muestras recogidas con las de las citadas investigaciones ${ }^{109}$.

Como se puede apreciar en los gráficos e imágenes adjuntas, se trata de herramientas similares, realizadas por el mismo tipo de individuos. Sus características y técnica de talla confirman la presencia de estos homínidos anteneandertales que vivieron entre 700.000 y 200.000 ańos, es decir, durante

${ }^{108}$ La exploración que se ha llevado a cabo a lo largo de los distintos niveles de terraza en este sector ha sido muy somera y parcial (no se plantea, en ningún momento, un estudio en profundidad), pero pone en evidencia lo prometedor del terreno, atestiguando una variada industria del Paleolítico inferior, que merecería un análisis profundo a cargo de un experto. En el análisis y conclusiones de las muestras recogidas coincidimos y somos deudores de los efectuados por el profesor Benito Álvarez en los cercanos yacimientos de El Castillejo y Teso de la Morcilla (Alaejos), La Toribia (Pollos), El Cascón, El Pesebrón y La Castella (Nava del Rey). BENITO ÁLVAREZ, J.M.: Aportaciones al conocimiento del Achelense en la Meseta Norte. Universidad de Salamanca, Tesis doctoral, 2001, inédita.

Tanto en este apartado, como en los siguientes, el material arqueológico prospectado y utilizado ha sido fotografiado y dejado en su contexto, siguiendo el consejo de las autoridades competentes en la materia tras el hallazgo, por el autor, del primer material tallado en 2005. En todos los casos se ha indicado su procedencia. No faltan muestras de hallazgos casuales, fuera de contexto arqueológico, realizados por los vecinos del espacio estudiado que, cuando se ha conservado y nos lo han mostrado, se les ha recomendado lo dejen en su contexto o lo pongan en conocimiento de la autoridad competente.

En este sentido, recordamos hoy, más de treinta años después, los concursos de cantos singulares que organizaba José Luis Medina (Serrada, 1909-2003), pintor y maestro de artistas, vecino de Serrada, a comienzos de los años setenta. Decenas de niños, tras salir de la escuela, recorríamos las terrazas de gravas en búsqueda de algún canto llamativo al objeto de conseguir el correspondiente premio. Entre las encontradas por su rareza, fueran o no entregadas en los concursos, recordamos "puntas de rayo", hachas de piedra, hachuelas, etc., que hoy refuerzan nuestro convencimiento de un espacio más poblado por estas culturas prehistóricas de lo que en principio puede creerse.

Junto a ello y al igual que en otros espacios, la mecanización agraria y la falta de cultura arqueológica de la que hablamos, nos ha conducido a una pérdida de patrimonio incalculable e irrecuperable. Los yacimientos de El Lomo, en Valdestillas, o Casa Calderón, en término de Villanueva, cercano al despoblado de San Martín del Monte, son algunos ejemplos. Hemos de agradecer la desinteresada información facilitada por Daniel Serna, ceramista de Valdestillas, conocedor del yacimiento de El Lomo, donante de material encontrado al Museo Arqueológico Provincial y de las familias Alonso Moyano, Hidalgo, Román, De Rojas, etc., de Serrada, en cuyas propiedades se han prospectado y fotografiado restos de estas culturas. En cualquier caso, cuanto material se ha fotografiado y estudiado, tras una ardua búsqueda por casas particulares o prospección de campo, además servir, con la prudencia debida, de complemento a la tesis que se estudia, se pone a disposición de los especialistas en esta época en la medida puedan relacionarlo con yacimientos o descubrimientos realizados de forma más rigurosa y científica.

${ }^{109}$ BENITO ÁLVAREZ, J.M. y BENITO DEL REY, L. (2002): “Secuencias inferopaleolíticas en la cuenca media del Duero” en SPAL, Revista de Prehistoria y Arqueología, no 9, (año 2000: homenaje al profesor Vallespí), Universidad de Sevilla. 


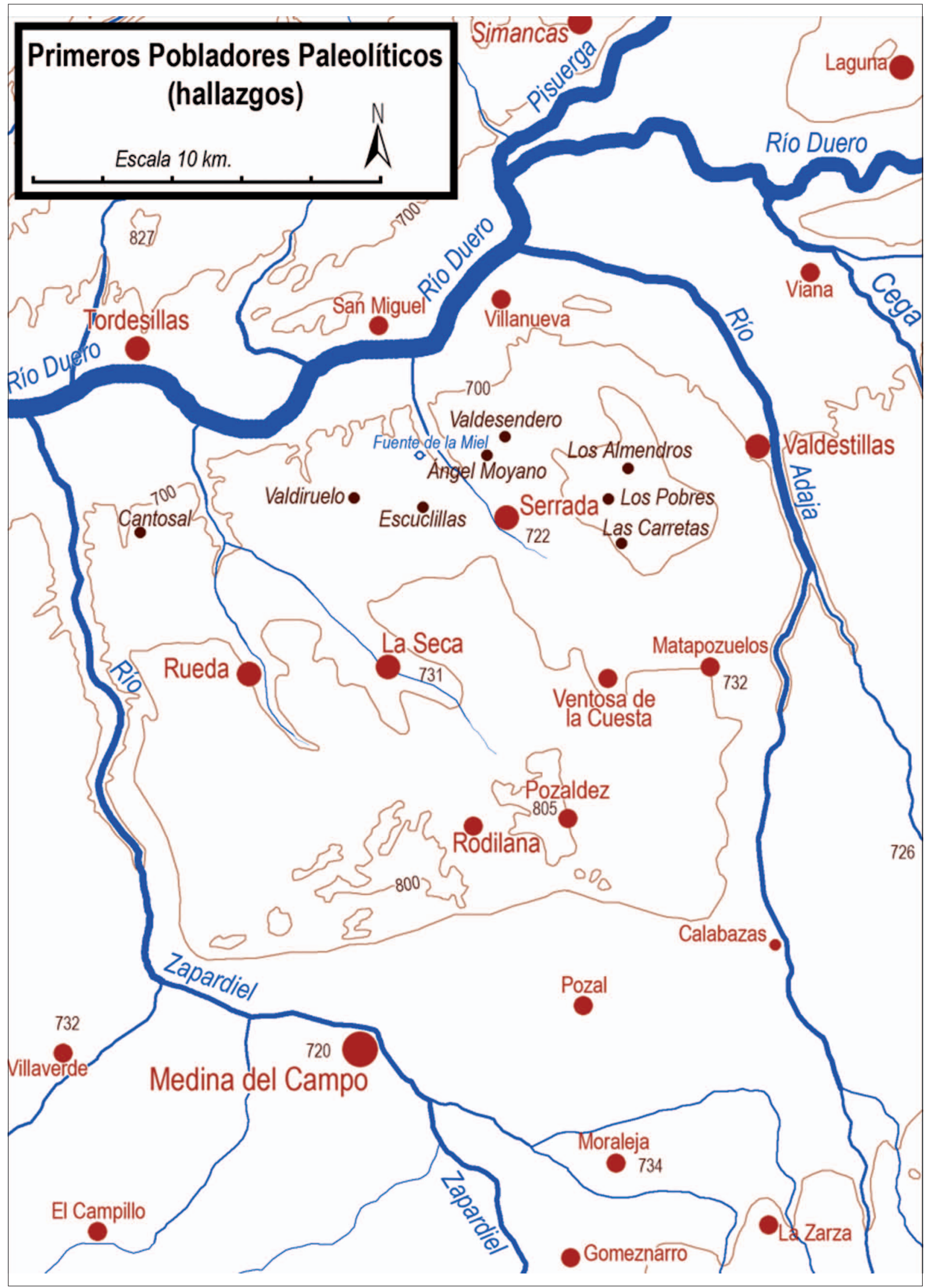

Figura 10. Mapa de localización de hallazgos paleolíticos en el norte de la Tierra de Medina.

En el mapa únicamente se han representado los pagos y lugares en los que se ha encontrado material tallado tras una somera prospección. Los interesantes resultados pueden servir de aliciente para extender el estudio al conjunto de terrazas al sur del Duero medio, toda vez que el material prospectado es tan abundante como diverso e interesante para merecer dicho trabajo. 
el Pleistoceno Medio. En el caso que se analiza, se ha encontrado material lítico consistente en bifaces, lascas, núcleos y cantos tallados en los términos de Serrada (pagos de Las Carretas, Los Almendros, Los Pobres y Ángel Moyano); Villanueva de Duero (El Recio, El Rosarillo...) y La Seca (Cotarrón, Las Comas y Escuclillas). A estos pagos, en los que se ha prospectado y encontrado este tipo de herramientas han de sumarse, en general, la mayor parte de las terrazas de gravas que se extienden al sur del Duero medio. En todas ellas, con más frecuencia conforme nos acercamos a los cursos fluviales más importantes, la presencia de cantos tallados de cuarcita son muy numerosos y testifican, como manifestamos, una presencia inequívoca de grupos de homínidos que recorrían estos espacios para aprovechar sus recursos.

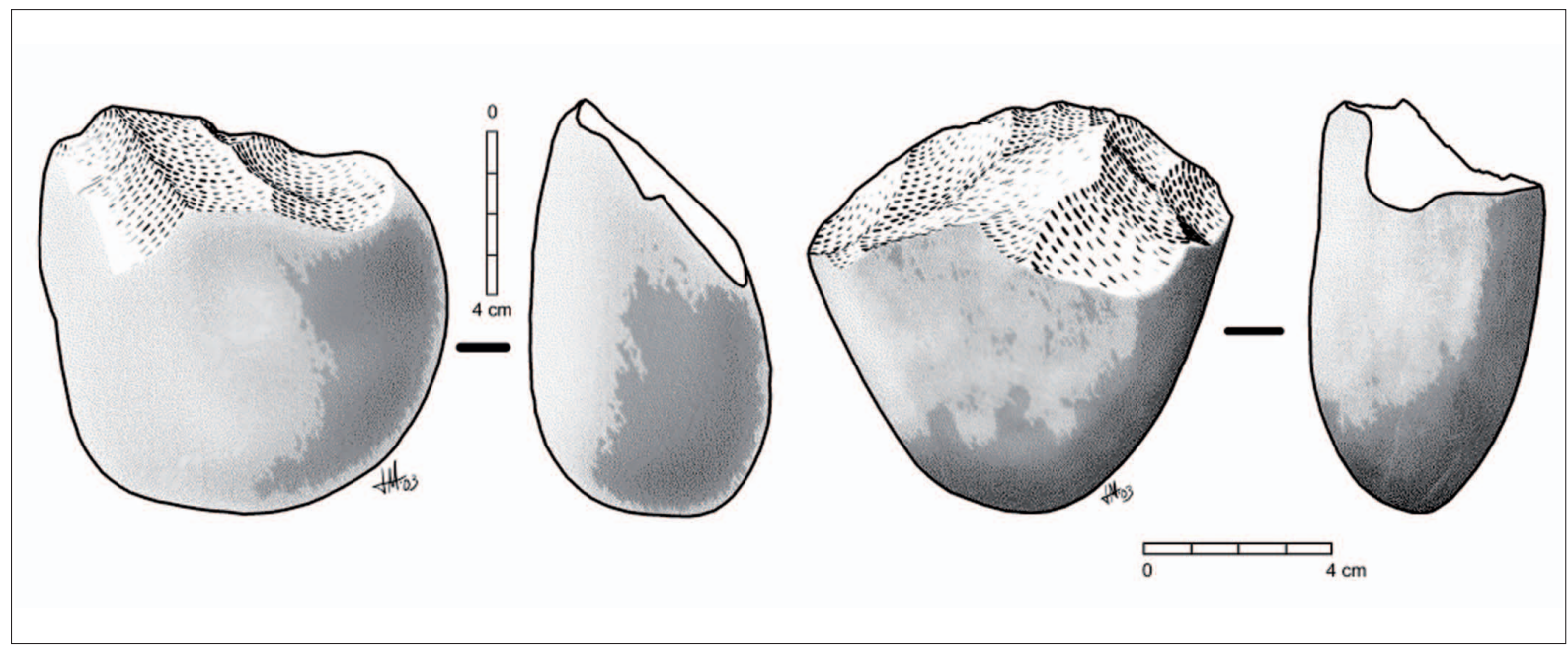

Figura 11. Cantos tallados monofaciales. Pago de las Escuclillas. La Seca.

El estudio geológico mostró que los hallazgos se circunscriben a depósitos datados en el Pleistoceno Medio, abarcando todo el periodo, aunque con hiatos entre algunas terrazas:

- La Terraza denominada en la bibliografía citada como nivel TD7, a una cota de $765 \mathrm{~m}$ de altitud y +80 metros sobre el nivel del Duero, ha deparado dos sitios con un buen número de piezas. Se trata de Las Carretas y Los Pobres (ver mapa). Se trata de pequeñas colecciones con cantos tallados, bifaces, lascas y núcleos, en general de aspecto primitivo. Si bien, los bifaces presentan rectificación de aristas por medio de una somera retalla con percutor duro y, aunque los núcleos son toscos, uno de ellos tiene fuertes reminiscencias Levallois. Todos estos rasgos podrían apuntar al inicio del Pleistoceno Medio, posterior a El Espinar (Toledo) ${ }^{110}$, a +85 metros sobre el cauce del río Tajo, pero comparable a lugares como El Montico (León), en la terraza a +85 metros sobre el río Bernesga ${ }^{111}$, o al vecino pago de El Pesebrón (Nava del Rey, Valladolid), a +87 metros sobre el Duero ${ }^{112}$, por poner algunos ejemplos.

- La terraza TD8, a +65 metros sobre el Duero, podría ser el lugar donde descansaran las piezas de pago de Los Almendros (aunque no es seguro, pues esta terraza no está bien atestiguada en la zona). En este lugar la industria es claramente un achelense pleno, con características algo más evolucionadas que los sitios anteriormente nombrados.

${ }^{110}$ AGUIRRE, E. (1991): "Les premiers peuplements humains de la Péninsule Ibérique. Les Premiers européens", en Actes du 114 Congrès national des Sociétés Savantes, París, pág. 144.

${ }^{111}$ CASTELLANOS, P. (1986): El Paleolitico Inferior de la Submeseta Norte -León-. Diputación Provincial de León, Institución Fray Bernardino de Sahagún y C.S.I.C. León, págs. 33 y ss.

${ }^{112}$ BENITO ÁlVAREZ, J.-M y BENITO DEL REY, L. (2002): Secuencias..., ob. cit., pág. 137. 
- La terraza TD9, a +56 metros sobre el Duero, es, aparentemente, la más rica en indicios. A los pagos de Ángel Moyano y Valdiruelo hay que añadir el más rico de Escuclillas, cuya industria se caracteriza por núcleos de extracciones centrípetas y Levallois, bifaces de cuidada hechura, rematada con percutor blando (de asta o de madera), algunos hendidores, raederas, muescas y denticulados. Estamos ante un Achelense típico comparable con cualquiera de los muchos que se reparten por la península, siendo el más próximo el de La Toribia, en Nava del Rey ${ }^{113}$. Los bifaces de este yacimiento responden a un perfil achelense, con rectificación de bordes de forma mayoritaria, de silueta almendrada y relativamente simétrica, lo que se traduce en unas siluetas objetivamente identificables ${ }^{114}$.

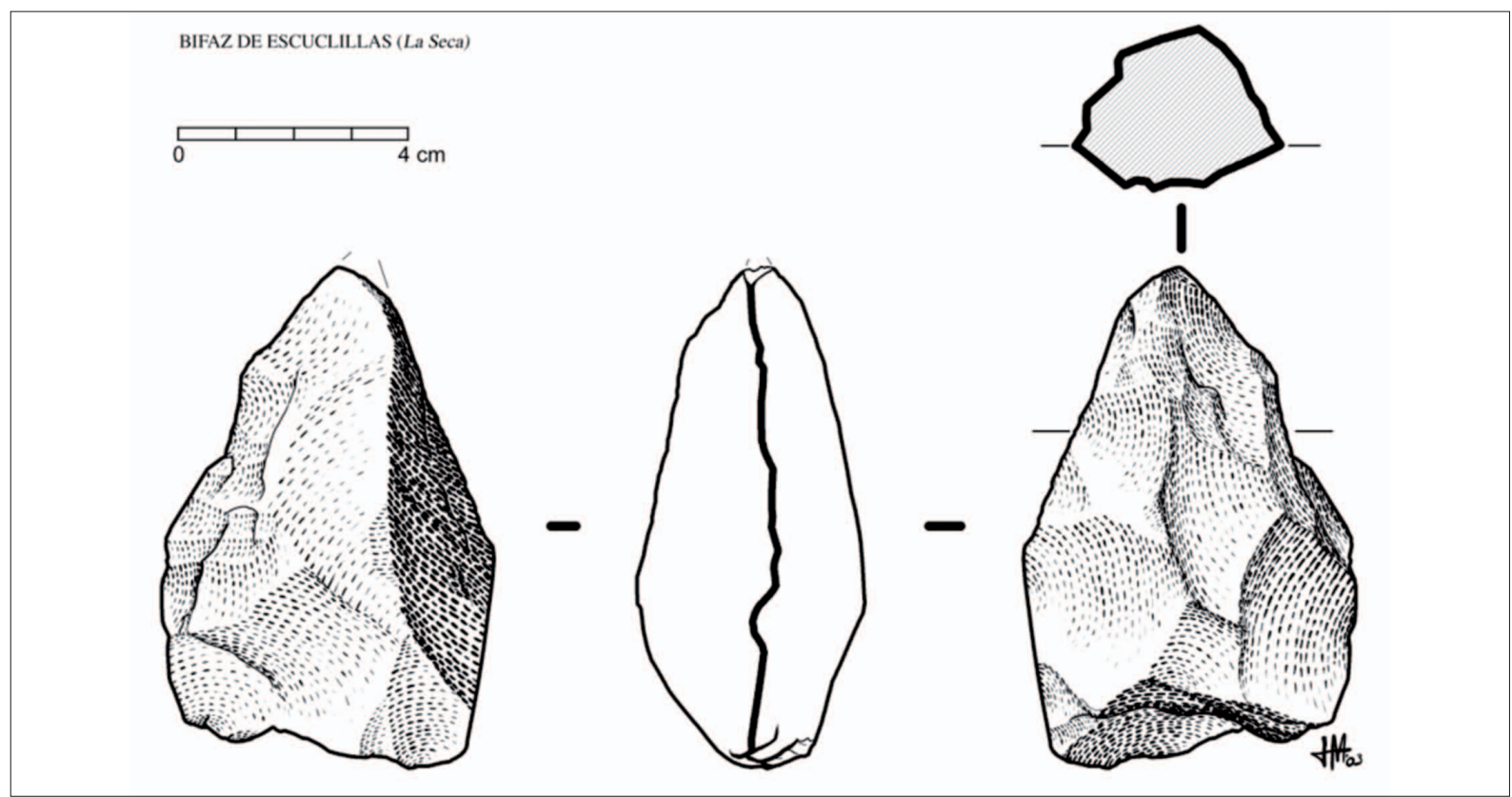

Figura 12. Bifaz. Pago de las Escuclillas. La Seca. Achelense Medio.

- La Terraza TD 10, a +43 metros sobre el Duero: en la terraza inferior a La Toribia se recogió abundante industria en el pago de Cantosal-Buenavista (Rueda, Valladolid). La colección es, en casi todos los aspectos, propia de un Achelense Pleno. Comparado con otros lugares, hay más bifaces y están más cuidados, han sido rectificados en más ocasiones y el percutor blando se reconoce claramente. Otro cambio interesante es el aumento sustancial de la aparición de triedros, que sólo son superados por bifaces y cantos tallados. Este aspecto está muy relacionado con yacimientos de la provincia de Zamora, en los alrededores de Toro. En efecto, en la gravera de Valdelama, donde hay muchas piezas en posición estratigráfica, los triedros son una parte importante de la industria, junto con bifaces de hechura bastante cuidada ${ }^{115}$.

Todos los hallazgos que se han efectuado incluyen artefactos con signos de rodamiento y desgaste que indican que se trata de zonas sumamente afectadas por diversos procesos erosivos. En ningún caso se han hallado piezas en posición estratigráfica, lo que obliga a avisar de que las piezas están en posición derivada, y no existe, necesariamente, una relación exacta entre la terraza en la que se

${ }^{113}$ BENITO ÁLVAREZ, J.-M y BENITO DEL REY, L. (2002): Secuencias..., ob. cit., pág. 138.

${ }^{114}$ BENITO ÁlVAREZ, J.M.: Aportaciones..., ob. cit., pág. 211.

115 BENITO ÁlVAREZ, J.-M y BENITO DEL REY, L. (2002): Secuencias..., ob. cit., pág. 140. Los citados autores relacionan este lugar de Valdelama, en Toro, con Pinedo (Toledo). Pinedo está ubicado en una terraza relativamente baja del Tajo $(\mathrm{a}+22 \mathrm{~m})$, y sin embargo suele situarse en el Achelense antiguo. En cambio, los citados autores sostienen una cronología relativamente reciente para Pinedo, al final del Achelense Medio. 
asientan y la edad de la industria ${ }^{116}$. Como conclusión de este apartado se pueden apuntar tres hechos incuestionables:

- Que los seres humanos del Paleolítico Inferior estuvieron en estas tierras y, aunque el muestreo realizado es somero, todo parece indicar que un estudio intensivo daría buenos resultados.

- Que todas las piezas se enmarcan en el Pleistoceno Medio, concretamente en el Achelense, sin que se pueda asegurar nada más concreto, a pesar que puede que exista una larga secuencia en las terrazas cuaternarias.

- Que, al comenzar el Pleistoceno Superior, desaparecen los indicios, hay un hiato, un vacío cronológico, por lo que es más que posible que la presencia humana se redujese o desapareciese totalmente, al menos hasta la llegada de los primeros agricultores y ganaderos, tal vez en el tercer milenio antes de Cristo.
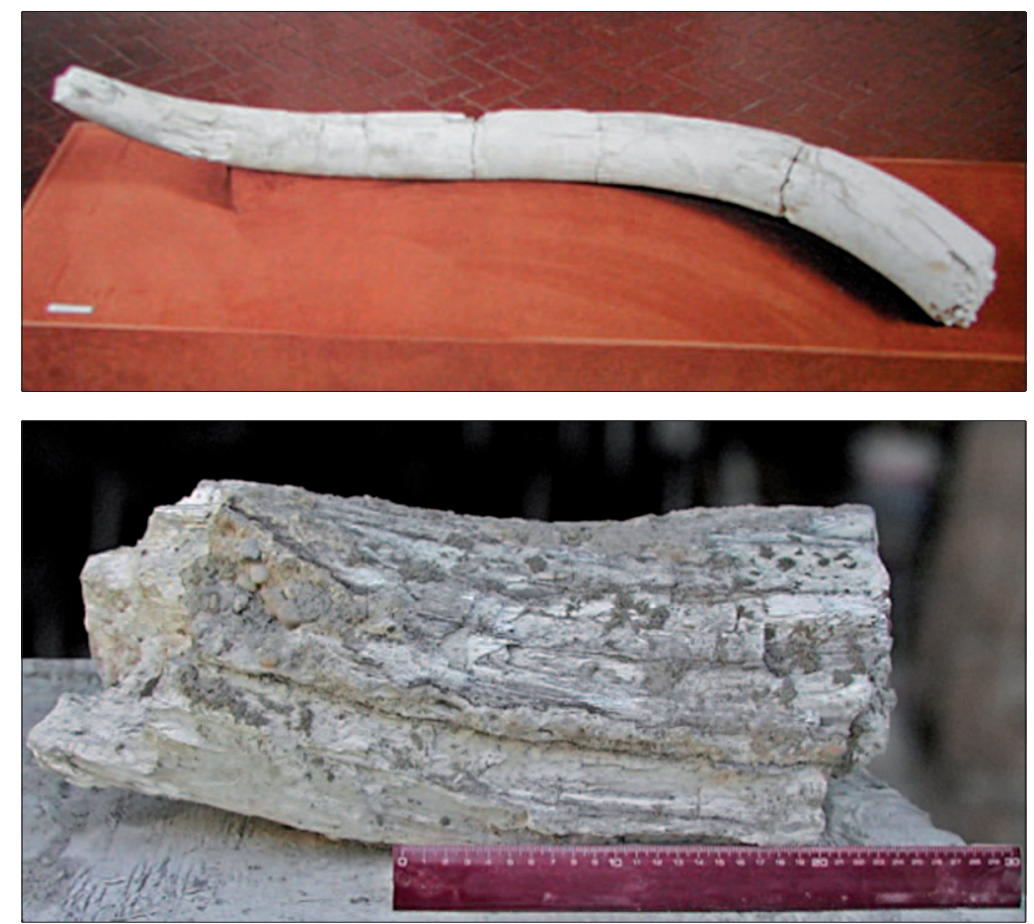

Imagen 23. Defensa de Palaeoloxodon Antiquus. Villanueva de Duero, imagen superior: Museo Arqueológico Provincial de Valladolid, catálogo del museo, inv, 11066, marfil, 210 cms, 600.000-100.000 a. C., imagen inferior: Fragmento de defensa de Elephas antiquus localizada en Rueda. (Colección particular). Los estudios antropológicos y paleontológicos realizados en la Sierra de Atapuerca ponen de manifiesto la variada fauna existente durante las oscilaciones climáticas del Pleistoceno. Leones, tigres de diente de sable o hienas competirían con los homínidos estudiados, tanto por la carrońa, como por los distintos herbívoros: jabalíes, ciervos, bisontes, grandes rinocerontes, mamuts, etc. El paisaje varía atendiendo a las etapas glaciares o interglaciares que se suceden en este tiempo.

Fuente: http://www.atapuerca.org/ y http://www.museoevolucionhumana.com. (Fecha. 3/08/2014).

116 Sólo de un muestreo más exhaustivo, que rebasaría los objetivos de esta tesis, pudiera derivarse el hallazgo de piezas en posición estratigráfica. Cabe citar las halladas y estudiadas en La Castella (Nava del Rey) a 101 metros sobre el Duero, en la terraza TD 5 y que, como se ha anotado en el anterior capítulo, podría constituir una prueba de la ocupación humana más antigua de este sector del valle de Duero. (BENITO ÁLVAREZ, J.M.: Aportaciones..., ob. cit., pág. 102). 

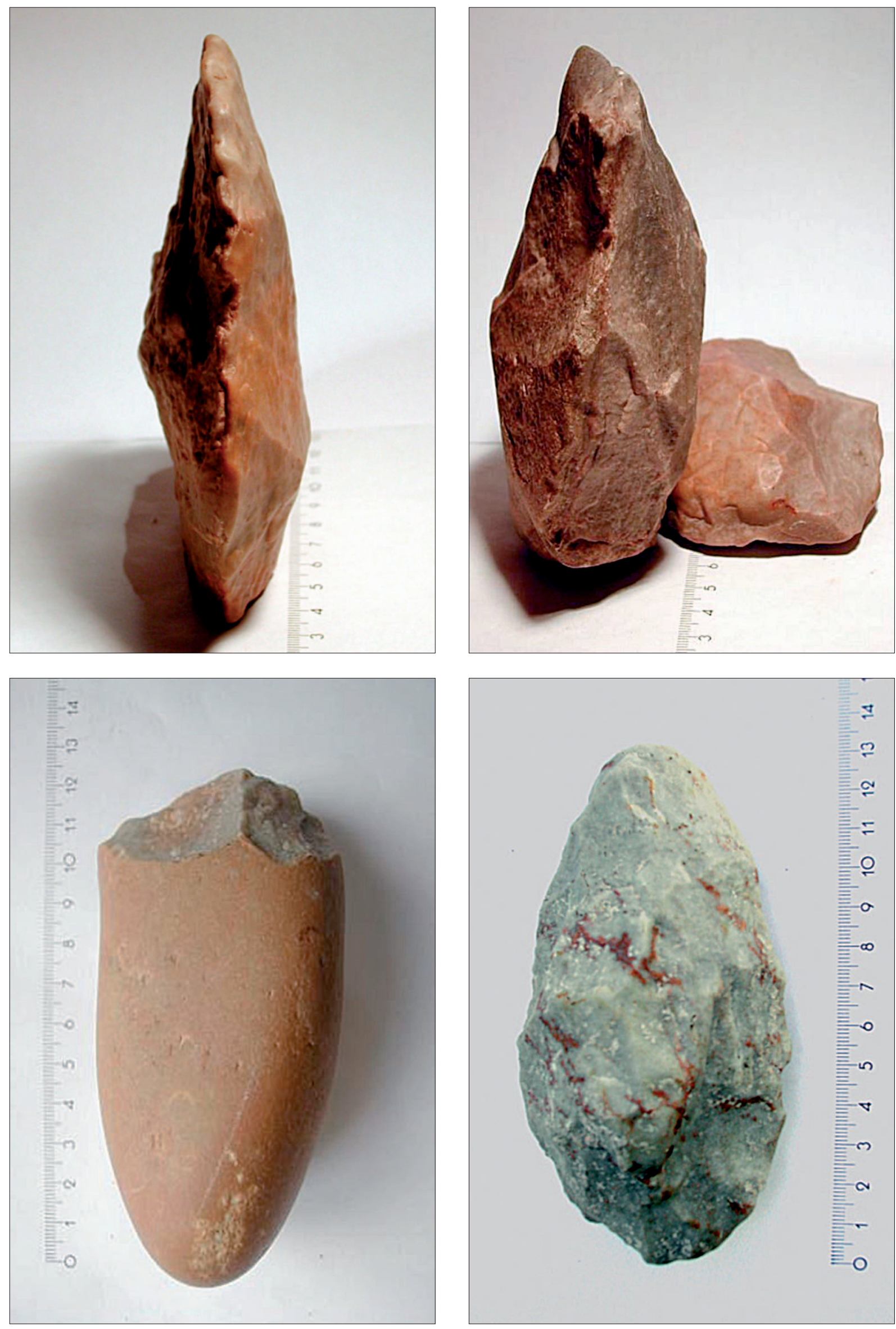

Imagen 24. Ejemplos de bifaces y percutor prospectados en suelos de terraza del pago de Escuclillas, en La Seca, y bifaz encontrado en Matapozuelos, (abajo, derecha, colección particular). Fotos: junio de 2005. 


\section{b. Los primeros agricultores y ganaderos}

Con el fin del último glaciar, hace 10.000 años, como es sabido, los grupos de cazadores-recolectores fueron derivando en el Próximo Oriente hacia formas de vida productoras, basadas en el cultivo de la tierra y en la domesticación de las primeras especies animales, la invención del tejido y la cerámica y una serie de nuevas herramientas más acordes con la nueva economía y el proceso de sedentarización. El cambio fue tan trascendente que se conoce con el nombre de Revolución Neolítica.

Sin embargo, las pruebas demuestran que estas tierras interiores quedaron al margen de estas novedades. Tuvo que transcurrir mucho tiempo para que dichas transformaciones, sobre todo por influencia externa, y en una pequeña parte por evolución cultural propia, llegaran al interior de la Meseta. Estos primeros agricultores y ganaderos buscaron, poco a poco, los lugares más idóneos para sembrar sus cereales o apacentar sus rebaños. El primer Neolítico Meseteño aparece, fundamentalmente, en áreas de relieve accidentado (como Diego Álvaro, Ávila o La Vaquera, en Segovia, por ejemplo) a principios del cuarto milenio ${ }^{117}$. Se tienen noticias inequívocas de sucesivas culturas en comarcas circundantes: las capas inferiores del yacimiento de La Cañadilla en Torre de Peñafiel para el Neolítico ${ }^{118}$; el sepulcro de corredor de filiación dolménica en Los Zumacales (Simancas, Valladolid); el calcolítico precampaniforme de Casaseca de las Chanas (en el cercano valle del Guareña, Zamora) y la inhumación campaniforme de Fuenteolmedo enlazan con ocupaciones relativamente estables en Valdestillas, Matapozuelos y, más tardíamente, Medina del Campo. Pero en lo que se refiere a las tierras que interesan en ese breve estudio, las vegas del sur del Duero en Tordesillas; las riberas del Adaja en Valdestillas y los valles de los arroyos subsidiarios en los interfluvios Trabanco-Zapardiel-Adaja..., el resultado es muy difuso: el poblamiento se confundiría con el Calcolítico (2500-2000 a. C.) y los comienzos de la llamada Edad del Bronce, extendida entre 2000 y 1000 ańos antes de Cristo ${ }^{119}$.

Siguiendo el curso del Adaja entre Matapozuelos, Valdestillas y Villanueva hasta llegar al Duero por San Martín y Tordesillas, remontando arroyuelos desde esta última villa hasta Rueda, siguiendo el arroyo de Serrada, el Zapardiel desde Medina por Rueda y Foncastín hasta su desembocadura, o el Trabancos desde Castrejón hasta Pollos, los distintos materiales hallados dan fe de quienes, por entonces, fueron los primeros en roturar terrenos para producir cosechas, tejer fibras para vestirse, moldear el barro, tornearlo y cocerlo en vasijas cerámicas para guardar sus alimentos y, en fin, levantar las primeras cabañas y poblados estables en los lugares que hoy habitamos. Los escasos pero significativos restos encontrados y los distintos trabajos arqueológicos llevados a cabo lo testifican ${ }^{120}$. Desde entonces, estas tierras no dejaron de ser pobladas y recorridas por los grupos humanos hasta nuestros días. Sin embargo, si se exceptúan los pagos de El Lomo, en Valdestillas, y Siete Iglesias, en Matapozuelos, no hay más que hallazgos dispersos, propios de una población itinerante o muy escasa, tal vez dedicada a la ganadería y a la agricultura del cereal (sin olvidar la caza), pero cuya esencia real necesitaría una investigación más profunda.

En los muestreos realizados en los términos del norte de la comarca, y atendiendo a los estudios llevados a cabo por especialistas en la materia, conviene señalar distintos hallazgos como la hoja de

${ }^{117}$ DELIBES de CASTRO, G. (1985): "El Neolitico. Los comienzos de la agricultura y la ganadería en la Meseta”. En Historia de Castilla y León, tomo I: La prehistoria del valle del Duero, pág. 26-27

${ }^{118}$ MARTÍN MONTES, M. A. y PÉREZ RODRÍGUEZ-ARAGÓN, F. (1996): Un nuevo asentamiento neolitico al aire libre en la Meseta norte: La Cañadilla de Torre de Peñafiel (Valladolid). BSAA, LXII.

${ }^{119}$ GALVÁN MORALES, R.: "Evolución Prehistórica de la Tierra de Medina”, en Historia de Medina.., ob. cit., pág. 75 y ss.

${ }^{120}$ MAÑANES PÉREZ, T. (2002): Arqueología del área Central de la Cuenca del Río Duero: de Simancas a Coca. Diputación de Valladolid, pág. 56 y ss. 

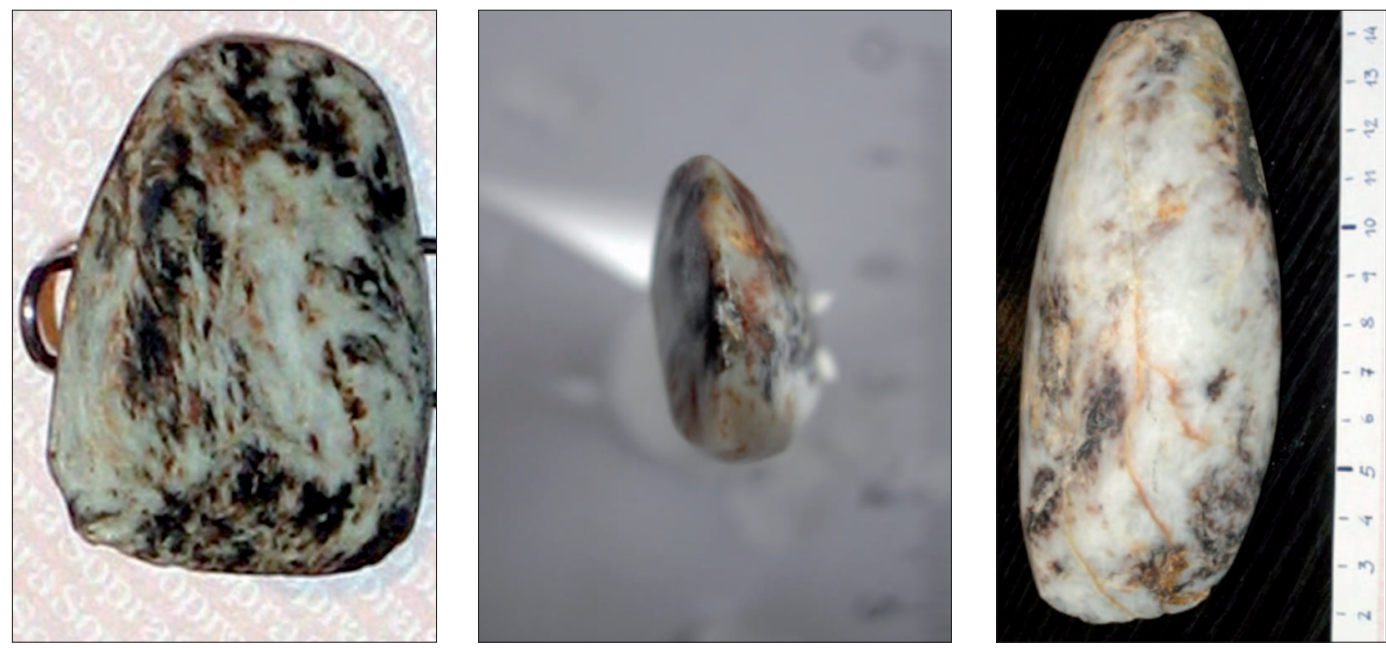

Pequeñas azuelas pulimentadas, pago de El Cascajo, Serrada, (izquierda y centro), y La Lavadera, La Seca, (imagen derecha) (Colección particular).

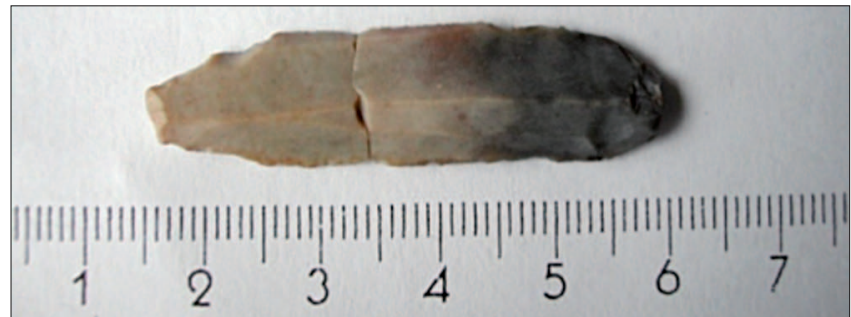

Hoja de sílex, pago de San Martín, Serrada. (Colección particular).
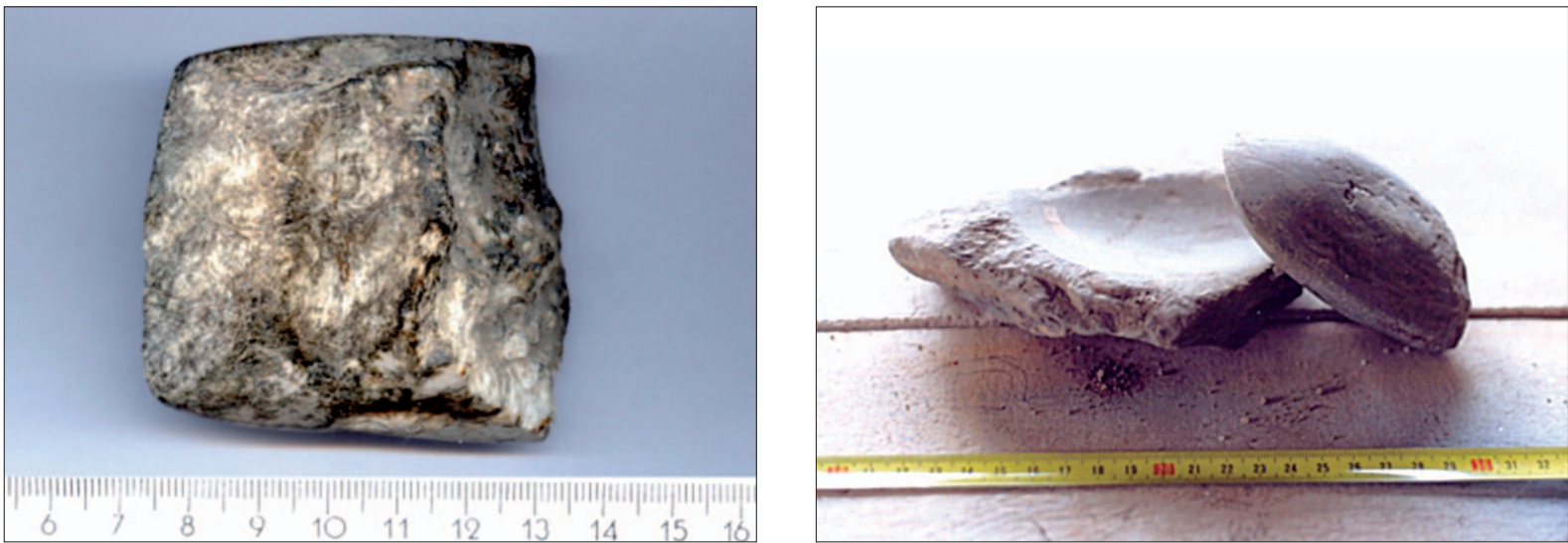

Fragmento de hacha neolítica, pago de San Martín, Serrada, (izquierda). Afilador neolítico, pago de El Lomo, Valdestillas, (derecha). (Colección particular).

Imagen 25. Ejemplos de material calcolítico y neolítico encontrado en el espacio de estudio.

sílex de San Martín ${ }^{121}$, que se interpreta como un pequeño cuchillito ritual, destacado por la calidad de su talla, típica por otra parte en este tipo de piezas; varias azuelas pulidas encontradas en los términos de Serrada, La Seca y Villanueva (las más pequeñitas, pueden tener, más que un uso cotidiano, un carácter funerario o ceremonial) y una azada neolítica o calcolítica, técnicamente denominada "herminette".

${ }^{121}$ Por los pagos de San Martín y de la Fuente de la Miel, en los términos de Serrada y La Seca, respectivamente, siguiendo el curso del pequeño arroyo, distintos vecinos han encontrado en décadas pasadas las denominadas popularmente "piedras del rayo", conocidas así por creerse originadas en tormentas. Son similares a las herramientas citadas, algo más grandes de tamańo y, generalmente, muchas de ellas, de color negruzco. Pudieran tener también una adscripción neolítica-calcolítica. 
Ésta y algunas azadas pulidas de tamaño mayor que las azuelas, encontradas en los alrededores de Serrada y la Fuente de la Miel, hablan de trabajos agrícolas, sin sospecha de que puedan proceder de ajuares funerarios, como ocurre con el resto del material. En efecto, la herninette, representada en la figura adjunta, es, sencillamente una azada tallada con percutor de piedra (sin pulimento), a base de grandes lascados, con una zona de corte relativamente estrecha que, en este caso, conserva numerosas huellas de uso en una tarea pesada y violenta, y con un cuerpo estrecho que sirve de enmangue $^{122}$. Una vez enmangada, su empleo tiene que ver con el trabajo de la tierra, bien para desbrozarla, bien para labrarla. Es difícil precisar con exactitud su cronología. Ha sido encontrada fuera de contexto arqueológico en unos términos completamente roturados, sin sectores rocosos que hubieran posibilitado la existencia y conservación de tumbas o monumentos megalíticos, lo que impide ser más precisos.

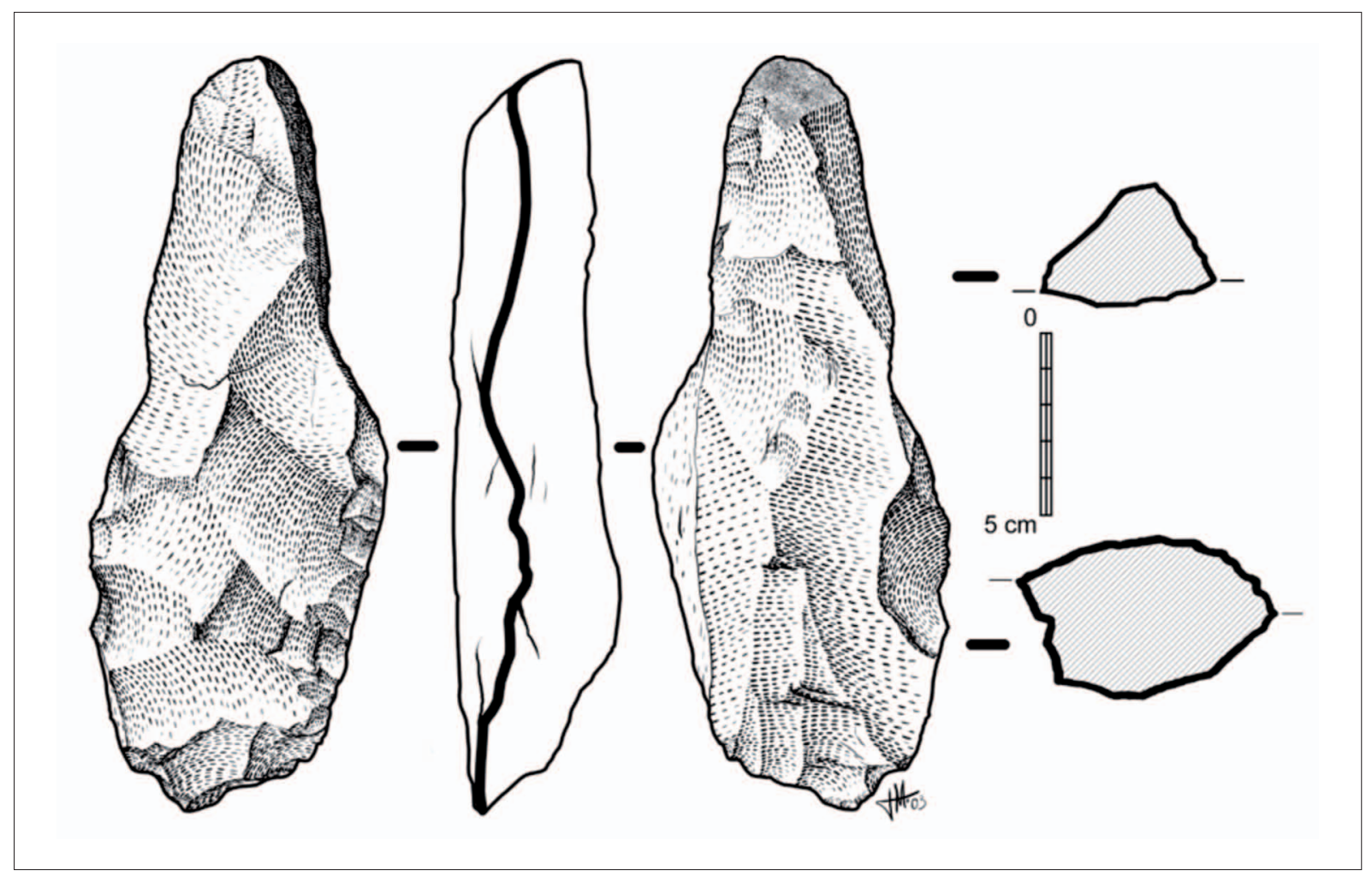

Figura 13. Azada tallada. Pago de Fuente de la Miel-San Martín, Serrada, (colección particular).

También merece un comentario aparte el pago de El Lomo, en Valdestillas, donde la presencia de dientes de hoz, con un claro lustre de cereal y alguna punta de flecha, pueden inducir a pensar en una ocupación ininterrumpida desde el Calcolítico, la Edad de Bronce, la Edad de Hierro y la época romana. Como se viene reiterando, en el curso cercano al Duero entre los interfluvios AdajaZapardiel-Trabancos y, en la medida de los hallazgos recabados y que pueden servir de ejemplo, en el sector comprendido entre Matapozuelos, Valdestillas, Villanueva de Duero, La Seca, el Despoblado de San Martín del Monte, La Peña y Tordesillas, la presencia de grupos humanos, sean neolíticos, calcolíticos, del bronce o del hierro, estos en el primer milenio antes de Cristo, ha sido casi permanente a tenor de los restos dispersos encontrados. El hecho de haber sido un terrazgo muy fértil, intensamente cultivado y, especialmente, haber estado sometido a los efectos de la mecanización de la agricultura moderna, ha impedido la conservación in situ de posibles yacimientos de estas épocas. Con todo, estos pueblos aprovecharon durante varios miles de ańos la fertilidad de sus arroyuelos y vegas.

122 PIEL-DESRUISSEAUX. J. L. (1986): Outils préhistoriques. Forme, fabrication, utilisation. Masson, Paris, pág. 172 y ss. 


\section{- El material cerámico prospectado en el pago de Las Carretas, atribuible a la edad del bronce, como ejemplo}

Iniciado el segundo milenio, la aparición del bronce genera toda una serie de transformaciones ligadas a una progresiva sedentarización, una mayor división social del trabajo y nuevas creencias religiosas ${ }^{123}$. En este contexto cabe mencionar el resultado de la labor prospectada llevada a cabo en el pago de Las Carretas, a dos $\mathrm{km}$ al este del casco urbano de Serrada ${ }^{124}$. Todo indica la existencia de actividad agrícola y ganadera asociada a los prados, charcas y tierra fértil del valle en que se asienta esta localidad, tal como se ha estudiado en otras áreas cercanas ${ }^{125}$. El anterior material lítico prospectado o referido de colecciones particulares, fotografiado in situ tras prospecciones sobre el terreno, etc., puede ser considerado, en este sentido, una prueba fehaciente de esta actividad. Como las numerosas "piedras de rayo" o hachas dolménicas de basalto u ofita encontradas hace décadas a lo largo de las tierras lindantes con el arroyo y prados mencionados, objetos que han sido utilizados como adorno, misterio o juego, por su rareza y vistosidad y que, desafortunadamente, solo hemos podido constatar por testimonios orales. Unas u otras pueden estar relacionadas con los yacimientos funerarios cercanos de tipo Ciempozuelos, tales como los estudiados en Fuente-Olmedo ${ }^{126}$.

En cualquier caso, tal como se puede apreciar en las imágenes adjuntas, nos encontramos ante cerámicas sin decorar. Todos los fragmentos, rescatados de una bolsada de tierra cenicienta a un metro de profundidad, y extraídas por el arado de un tractor, presentaban en una gran parte roturas recientes por el paso de la maquinaria. Pertenecen a distintas vasijas de diferente función, pastas y método de cocción. Por lo heterogéneo de los restos nos encontramos ante un pequeńo basurero con cenizas y escoria en el que se han identificado fragmentos de, al menos, diez vasijas y partes de un crisol.

Las vasijas de menor tamaño presentan, desde el punto de vista técnico, una elaboración muy cuidada: pastas decantadas y muy bruńidas, con acabado fino y sin imperfecciones externas o internas. Sólo unos pocos trozos de recipientes de mayor tamaño presentan huellas del alisador en su interior, o algunas imperfecciones en su acabado, como vacuolas, siendo su superficie algo más áspera que el resto del material. Los tamaños de las vasijas oscilan, desde los de dos cazuelas de cuerpos convexos (dos fondos de entre 12 y $14 \mathrm{~cm}$ de diámetro), hasta los de la más grande de alrededor de 1 metro de altura y un diámetro máximo de aproximadamente 0,80 metros.

${ }^{123}$ GALVÁN MORALES, R.: "Evolución Prehistórica de la Tierra de Medina”, en Historia de Medina...., ob. cit., pág. 80 .

${ }^{124}$ La cerámica fue encontrada en el pago de las Carretas, en Serrada, en una visita de prospección llevada a cabo después de una labor de desfonde preparatorio para plantación de viñedo tras el comentario casual de un tractorista que había visto fragmentos cerámicos. El material fue recogido en 2005 evitando su destrucción, segundos antes del paso de maquinaria desterronadora que los hubiera pulverizado. En su estudio somos deudores de la profesora Inmaculada Sáez Saiz, especialista en este campo. La localización se encuentra a una latitud de 41 27’24” N y una longitud de 40 50'10 O. Se trata del borde de una terraza alta de gravas con amplias vistas al fondo del valle por el que en tiempo histórico discurría un arroyo intermitente rodeado de pastizales y salpicado de lavajos. A escasas decenas de metros se localiza una cañada que enlaza con la red caminera que pone en contacto con los términos vecinos de Valdestillas (yacimiento de El Lomo, con material abundante de todas estas culturas), Villanueva de Duero (yacimiento tardorromano de Casa Calderón), Matapozuelos y Tordesillas (yacimiento vacceo de La Peńa) y, a 17 km al sur, se encuentra el yacimiento de La Mota (Medina del Campo).

125 DELIBES DE CASTRO, G.: El vaso campaniforme en la Meseta Norte española, en "Studia Archaeologica”, Valladolid, 1977, pág. 161.

${ }^{126}$ MARTÍN VALLS, R. Y DELIBES DE CASTRO, G.: La cultura del vaso campaniforme en las campiñas meridionales del Duero: el enterramiento de Fuente-Olmedo. Monografías del Museo Arqueológico de Valladolid, 1974. 


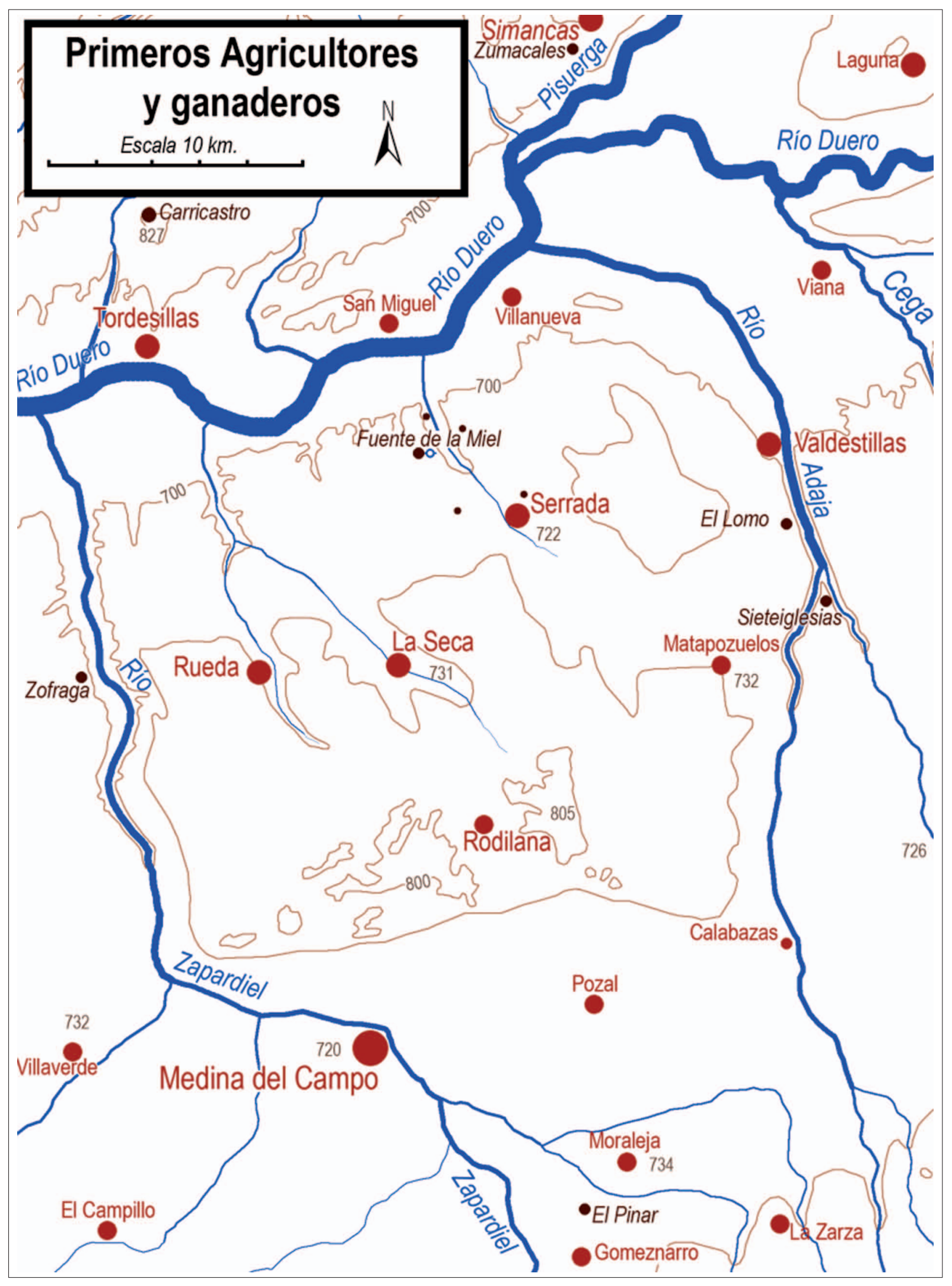

Figura 14. Mapa de localización de hallazgos de los primeros agricultores y ganaderos en el norte de la Tierra de Medina. $\mathrm{Al}$ igual que en la figura del mapa que representa la localización del material tallado, en el que nos ocupa únicamente se han localizado, en un sector al norte del espacio estudiado, los principales pagos en los que se ha prospectado y encontrado material arqueológico relacionado con los primeros agricultores o ganaderos asentados entre los interfluvios Zapardiel y Adaja. Los hallazgos, igualmente, pueden relacionarse con los descubiertos y estudiados por expertos e, igualmente, de una profundización en este campo pudieran derivarse resultados prometedores. 


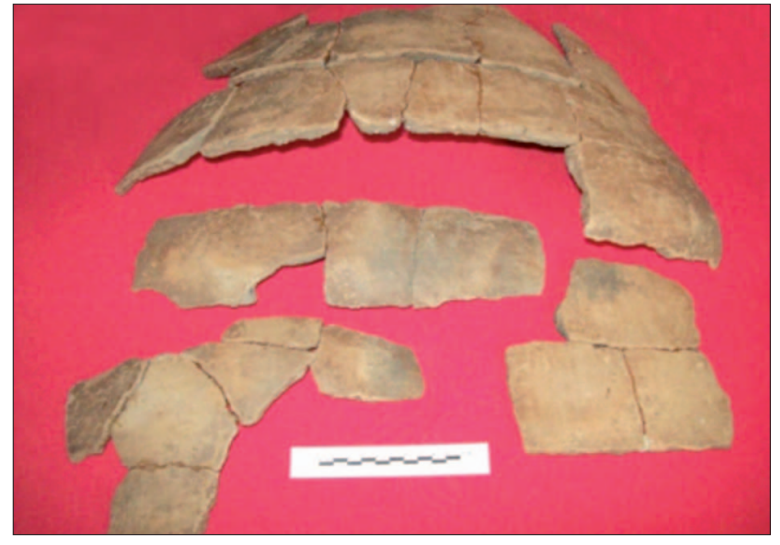

$1-\mathrm{a}$

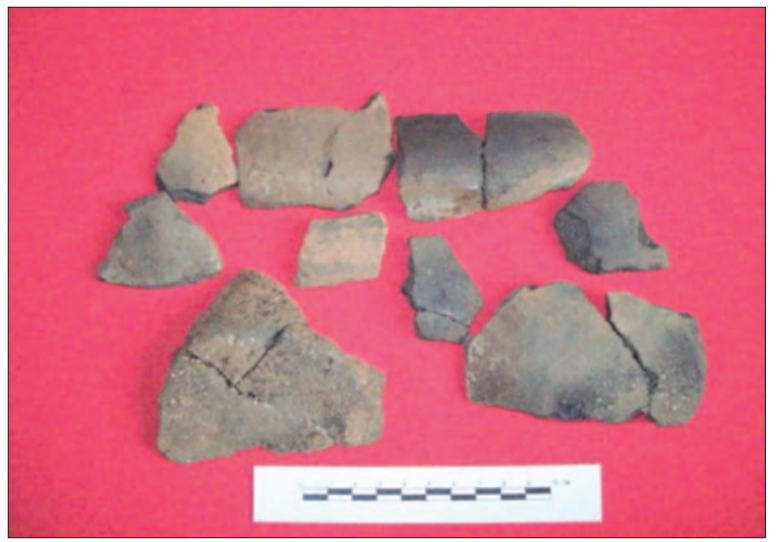

$1-\mathrm{c}$

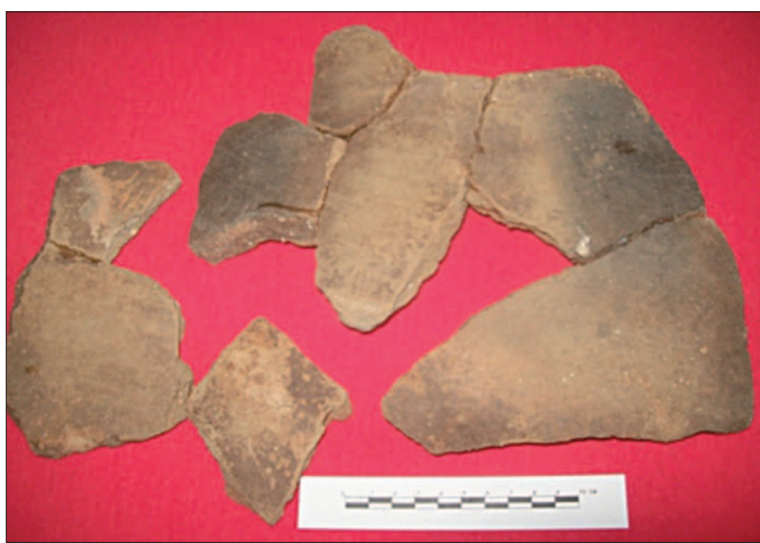

$1-\mathrm{e}$

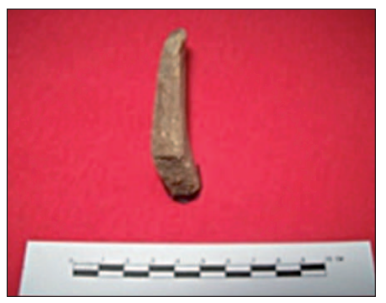

$2-\mathrm{a}$

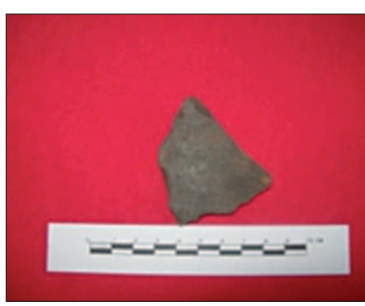

$2-\mathrm{b}$

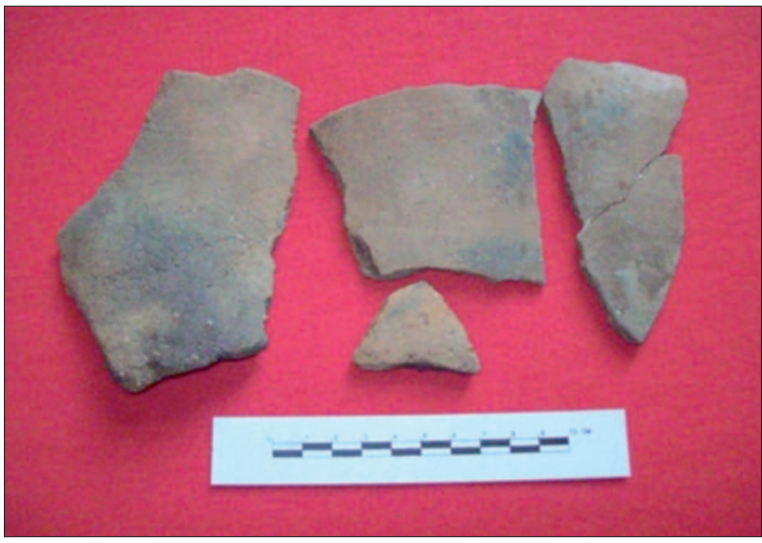

$1-b$

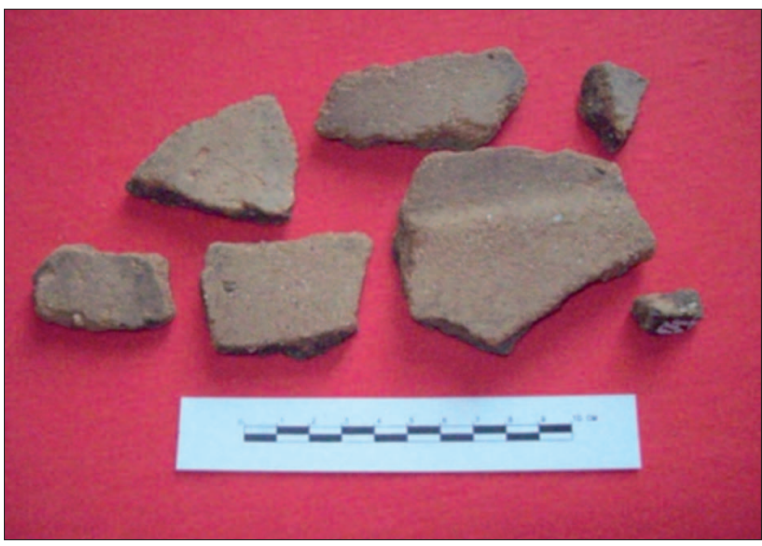

$1-d$

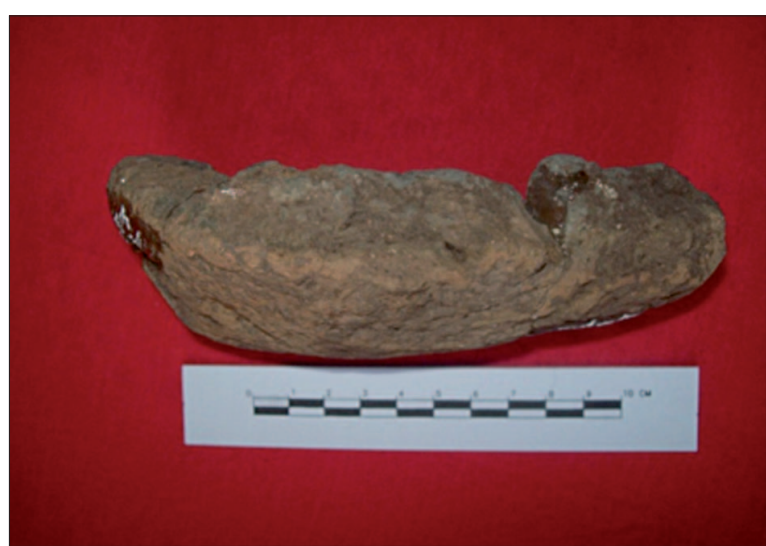

$1-f$

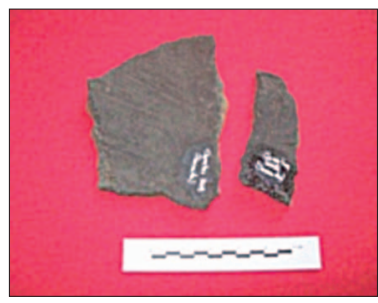

$2-\mathrm{c}$

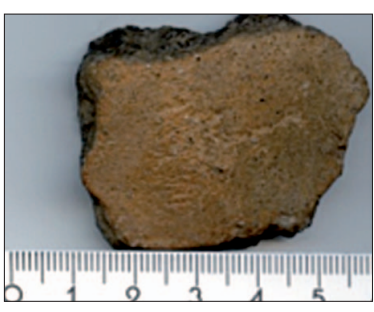

$3-\mathrm{a}$

Imagen 26. Ejemplos de cerámica de la Edad del Bronce prospectadas en el pago de Las Carretas, Serrada. (Fotos: Inmaculada Sáez, 01/07/2014). Fragmento cerámico hallado en La Fuente de la Miel, La Seca. (Imagen inferior derecha. Foto: agosto de 2006. 
Siguiendo la publicación de Rodríguez Marcos ${ }^{127}$, se han identificado los distintos restos de este pago con los tipos que sitúa en el Calcolítico Final-Bronce Inicial en la Ribera del Duero (pág.263274). Hemos reconocido las vasijas de la fig. 189 (tabla tipológica de la cerámica lisa del Calcolítico Final-Bronce Inicial en la Ribera del Duero de Valladolid), los números 4B, 5Ba, 6A, 7 y 8; en el apartado de otros recipientes y objetos de barro, un crisol ${ }^{128}$.

Dentro del apartado 4B, los materiales que disponemos pertenecen al menos a cuatro recipientes de paredes y tamańos distintos (imagen 2-b). Son de perfil muy recto y exvasado y pertenecen a la zona del cuerpo. Uno de ellos es un borde de pastas bastante bien decantadas y de cocción oxidante al interior y exterior, y de un grosor en el cuerpo de $10 \mathrm{~mm}$ y hasta $0,6 \mathrm{~mm}$ en el borde. Señalar que, como se ve por las medidas, el borde se adelgaza y se exvasa ligeramente. El fragmento de vasija de paredes más gruesas presenta una cocción oxidante al exterior (tonalidad anaranjada) y reductora al interior (negra). Los de la vasija de paredes más finas son de cocción oxidante (tonalidad marrón) tanto al interior como al exterior y pastas muy bien decantadas, con restos de engobe al exterior (imagen 2-b y 2-c). Encuadra este tipo dentro de los yacimientos calcolíticos de ámbito meseteño.

Otro fragmento pertenece a la parte superior del cuerpo de una vasija de pastas muy decantadas, con cocción reductora al exterior y cocción oxidante al interior, muy pulida, sobre todo al interior y con desgrasantes micáceos y silíceos. Por su cuerpo globular y su ligero exvasado en la zona del cuello nos recuerda al grupo del 5Ba, aunque sólo con el fragmento y sin dibujo, es difícil precisar.

Dentro del apartado 6A tenemos unos treinta fragmentos de un enorme recipiente, del que se conservan partes de la zona del hombro y del cuerpo con tendencia ovoide. Como se ve en la imagen 1-a, el tamaño de la vasija es considerable, de al menos un metro de altura y de un diámetro máximo de $0,80 \mathrm{~cm}$, con paredes de entre 0,7 y $15 \mathrm{~mm}$ de grosor. Las roturas antiguas coinciden con la fractura de las uniones de los distintos pańos. Los desgrasantes son medianos y grandes, acorde con el tamaño de la vasija, en su mayoría de sílice y algunos micáceos; las pastas están alisadas por dentro y por fuera, de tonos oxidantes al exterior y de cocción reductora al interior.

Hay una serie de fragmentos pertenecientes a dos recipientes de pastas finas y decantadas, de entre 0,7 y $0,4 \mathrm{~mm}$ de grosor, en las que abunda la mica y granitos de sílice, con cocción reductora, aunque en parte del exterior presenta oxidación de las paredes hasta darles una tonalidad marrón. Tenemos fragmentos de dos fondos planos y restos del cuerpo (imagen 1-c). Los fondos parecen sumamente desgastados por el uso. Los cuerpos presentan una convexidad y una rotura en la zona que correspondería al arranque del cuello. Creemos identificar el tipo de vasija representado en la pág. 142, fig.89, la forma $\mathrm{n}^{\circ}$ 1, igualmente del yacimiento del Pico del Castro, citado por Rodríguez Marcos. Él los encuadra en los recipientes de perfil en $S$ de la forma 6, con "cuellos bien marcados y desarrollados" o a la forma 7. Compartimos el fondo plano, dimensiones parejas de los fondos, la convexidad de las paredes, aunque los materiales rescatados y la falta de dibujos no nos dan más pistas de las vasijas. Hay un total de 15 fragmentos de estas dos piezas.

Un segundo grupo de fragmentos, entre 8 y 14, de la zona del cuello y el cuerpo de la vasija son de pastas grisáceas al interior y más parduzcas al exterior, con restos de cocción reductora con paredes entre 0,6 y $12 \mathrm{~mm}$ de grosor (imagen $1-\mathrm{e}$ ). Son, aparentemente, de similares medidas a la vasija anteriormente descrita (imagen 1-a), aunque en menor número. Dentro del tipo 8 se recuperaron cinco fragmentos, de la zona del cuerpo, y uno de la unión del cuello y el cuerpo. El único fragmento que responde a este grupo tiene pastas cocidas en atmósfera oxidante y color anaranjado, con desgrasantes micáceos y silíceos de tamaño medio y tacto algo áspero. La unión del cuerpo y del cuello se marca con un rehundimiento que limita ambas partes (imagen 1-d). El grosor de las pasta

${ }^{127}$ RODRÍGUEZ MARCOS, J. A.: Estudio secuencial de la Edad del Bronce en la Ribera del Duero (provincia de Valladolid), dentro de las monografías de la Junta de Castilla y León, Arqueología en Castilla y León, 7.

${ }^{128}$ Ibídem. 


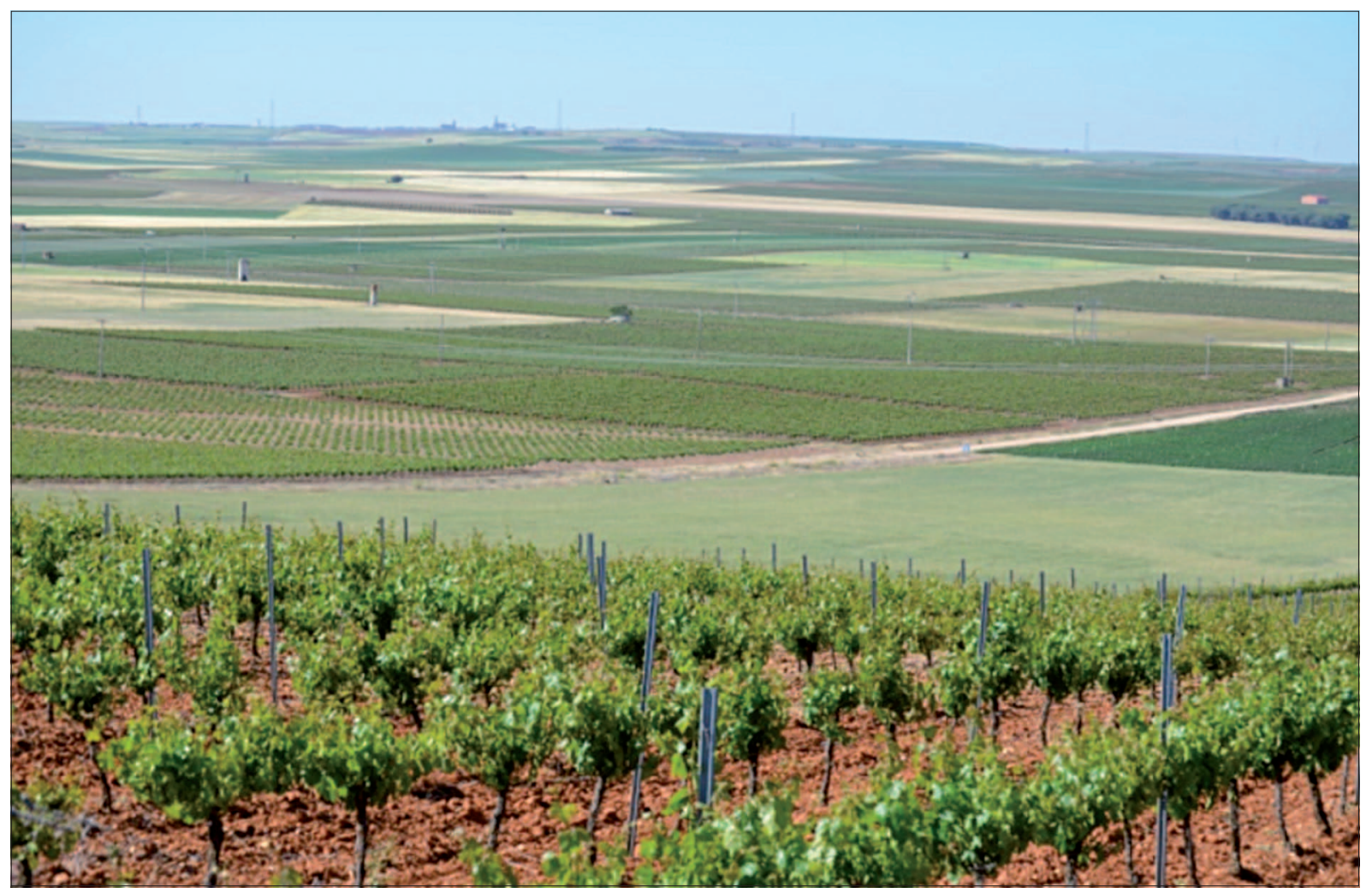

Imagen 27. Vista panorámica desde el pago de Las Carretas, en Serrada. (izquierda, 18/05/2014). En primer plano, plantado de vińedo, se sitúa el lugar en el que se encontró el material estudiado. Buena parte de los yacimientos descritos en este capítulo presentan una localización similar: lugares prominentes cercanos a cursos fluviales, amplia visibilidad, existencia de pasos o vías de comunicación naturales, pastos abundantes y tierra fértil. Desde el lugar en que se ha tomado la imagen pueden verse, en los días despejados, desde las siluetas de la Cordillera Central y páramos de Portillo, al este, hasta la línea de páramos de Tordesillas-Simancas, al oeste.

oscila desde el centímetro de la zona del cuerpo y los $0,7 \mathrm{~cm}$ del cuello. Entendemos que el fragmento descrito es muy similar al dibujo de la pieza 27 de la fig. 88, pág. 141 del trabajo anteriormente citado de Rodríguez Marcos, perteneciente a las piezas recuperadas en el yacimiento el Pico del Castro, de Quintanilla de Arriba.

Por último hablar de ¿un fondo y parte de la pared? de una vasija hecha de manera muy tosca a mano. Simplemente han amasado el barro dándole la forma del fondo de vasija de extraordinario grosor (más de $20 \mathrm{~mm}$ ) y porosidad, y que creemos que ha sido utilizada para la reducción de mineral, dado lo quemada que está en su interior. La tosquedad de la vasija, el grosor de las paredes y las huellas que el fuego ha dejado nos hacen pensar que nos encontramos con un crisol para fundir minerales de cobre (imagen 1-f). La pieza recuperada estaba fragmentada en tres partes. En total tendría unas dimensiones de unos $3 \mathrm{~cm}$ de altura en la pared y un arco de circunferencia de unos $18 \mathrm{~cm}$.

Teniendo en cuenta que se encontró al borde de una terraza alta de gravas con amplias vistas al fondo del valle por el que en tiempo histórico discurría un arroyo, nos daría un emplazamiento idóneo para la explotación agrícola del entorno, en la actualidad campos de vińedo, cereal y regadío. Además, se constata que, a escasas decenas de metros, se halla un cańada que enlaza con la red caminera que pone en contacto con los términos vecinos de Valdestillas (yacimiento del Lomo, con material abundante del Calcolítico, la Edad de Bronce, la Edad de Hierro y la época romana, Villanueva de Duero (yacimiento tardo romano de Casa Calderón), Matapozuelos y Tordesillas (yacimiento vacceo de La Peńa) y, a $17 \mathrm{~km}$ al sur, se encuentra el yacimiento de La Mota (Medina del Campo). 
En cualquier caso, no hay que olvidar que los restos encontrados eran material de desecho y, por ello, cabría suponer que el asentamiento de un poblado no se encontraría lejos, por el momento, no localizado ${ }^{129}$. La intensa roturación del espacio desde hace siglos y la mecanización de la actividad agraria, desde hace décadas, es un factor limitativo en este sentido. No se ha recogido material óseo o metálico, únicamente los fragmentos cerámicos anteriormente descritos. Hemos de hacer hincapié en el hallazgo del crisol, muy afectado al interior por el fuego y una escoria, entre un revuelto de tierra cenicienta y negruzca extraída por la reja del arado a un metro de profundidad.

En conclusión, tanto el emplazamiento de los hallazgos como la tipología de los mismos nos hacen pensar que este material, encontrado de forma conjunta y perteneciente a un mismo momento, quedaría perfectamente encuadrado entre el 1850-1500 a. C., y, por tanto, en el período Campaniforme-Bronce Antiguo inicial, vinculado a pobladores estables que practicarían la agricultura y la ganadería.

A partir del primer milenio antes de nuestra era, nuevos aportes humanos llegarán desde el norte y noreste procedentes del continente europeo. Serán los pueblos indoeuropeos y, entre ellos, grupos celtibéricos que se asentarán en este valle medio del Duero, fundiéndose con la población autóctona. A los que se asentaron en este amplio sector del centro de la cuenca del Duero se les conoce por las fuentes clásicas con el nombre de vacceos.

\section{c. La cultura celtibérica}

Como se ha dicho, el espacio que hoy forma esta provincia, así como sectores próximos a ella, fueron territorio plenamente celtibérico (en sentido amplio) y lugar de asentamiento de la cultura vaccea. Los pueblos célticos indoeuropeos llegaron a la Península a mediados del primer milenio, aportando elementos étnicos, culturales y técnicos, sobre todo, el hierro. Junto a la poderosa influencia de los iberos, constituyeron la cultura celtibérica, que modifica sustancialmente los hábitos de las civilizaciones que aquí se asentaban. La introducción de este metal provocó el abandono de la industria lítica y la relegación parcial del bronce, e incrementó notablemente la presencia humana sobre el territorio, dando lugar a una sociedad más belicista, tal como reflejan los restos de poblados fortificados y armas ofensivas y, además, introdujo estas tierras en una dinámica más productiva, intensificando la explotación de la tierra y el aprovechamiento de pastizales y superficies montaraces.

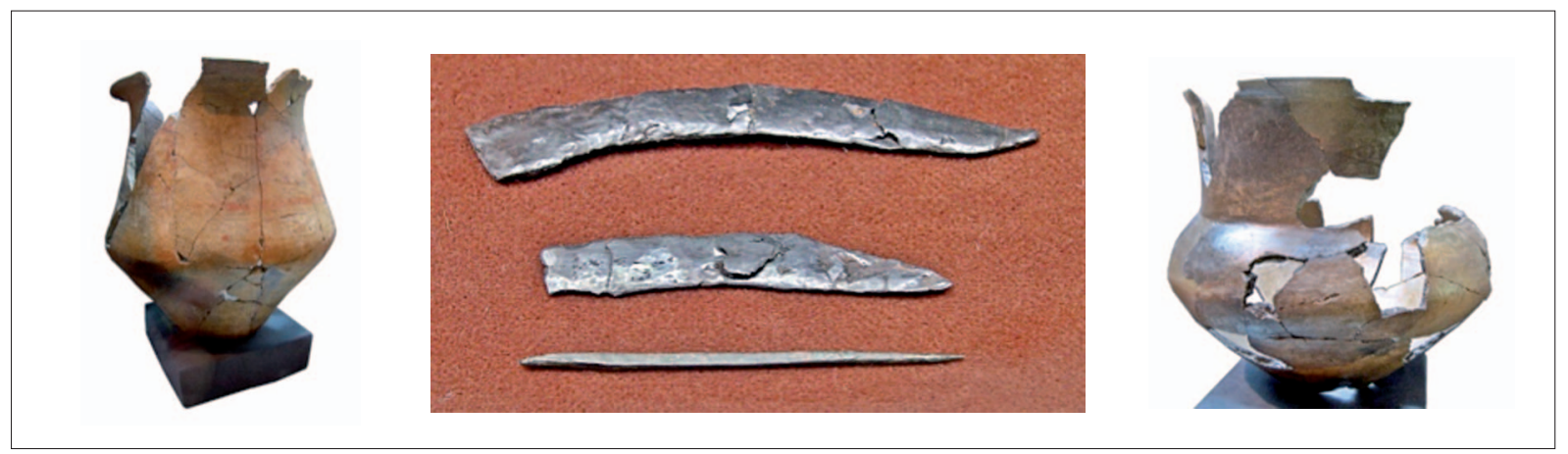

Imagen 28. Materiales procedentes del Cerro de la Mota, Medina del Campo. (Museo Arqueológico de Valladolid). Foto: José Manuel Benito, junio de 2006.

${ }^{129}$ En el pago de Fuente La Miel se ha localizado un fragmento del cuerpo de una vasija realizada a mano, de características y pastas similares al lote descrito en del Pago de las Carretas, por lo que podríamos asociarle al emplazamiento del Bronce Antiguo del que hablamos, pero del que sólo hemos conocido este fragmento fotografiado. El resto puede que haya sufrido la destrucción y desaparición que se evitó con el lote localizado en el pago de las Carretas, en Serrada. Como se ha reiterado, la abundancia de fragmentos cerámicos, correspondientes a estas épocas prerromanas, es fácil encontrarlas siguiendo el curso del Adaja-Eresma hasta llegar al Duero, entre Simancas y Tordesillas. 
Los diferentes estudios y excavaciones en la comarca hacen referencia a poblados situados al amparo de cerros, motas o espigones fluviales, fácilmente defendibles y con un amplio dominio visual. Destacan los poblados del cerro de la Mota, en Medina (entre el Zapardiel y el arroyo de la Adajuela); o La Peña, en Tordesillas, defendido por el Duero; el pago llamado de Siete Iglesias en Matapozuelos, entre el Adaja y el Eresma o El Lomo de Valdestillas. Se trata de yacimientos de cierta entidad, donde se han practicado excavaciones o se ha encontrado abundante material de superficie como cerámica, restos de viviendas, ajuares y hogares adosados a sus muros, entre otros materiales, prueba, todo ello, de una notable presencia de la cultura celtibérica en la tierra medinense ${ }^{130}$.

Las piezas que muestran las imágenes adjuntas son molinos de vaivén, o barquiformes, para moler cereales. Han sido hallados en los términos de Serrada-La Seca en el mencionado pago de la Fuente de la Miel hasta el Duero, pasando por el despoblado de San Martín del Monte. Tan sólo distan estos parajes escasos kilómetros del yacimiento de La Peńa en Tordesillas o Casa Calderón, mirando al Duero. Algunos son de dimensiones nada despreciables. También se localizan a lo largo del Adaja, entre Valdestillas y Matapozuelos. La mayor parte de ellos tienen un soporte granítico, cuarcítico y areniscoso, pero en todos los casos la materia prima para su fabricación o uso ha sido traída desde puntos muy distantes, que en algunos casos rebasan el centenar de kilómetros, prueba de la existencia de contactos e intercambios comerciales y culturales entre pueblos afines.

Nos encontramos, por tanto, ante sociedades muy organizadas y complejas ${ }^{131}$. La abundancia de estas piedras de moler da pie a pensar que el cultivo cerealista se extiende ampliamente por el valle del Duero. Son piezas barquiformes, similares a las encontradas en el yacimiento vallisoletano de Soto de Medinilla, datado en la primera edad del Hierro, fases culturales de Soto I (siglos VIII y VII a. C.) y Soto II (siglos VI y V a. C.), o los datados como Soto o Cogotas de Valdestillas. Impresionantes por su tamaño, igualmente, son los restos que, en las últimas décadas, siempre de forma casual y realizando tareas agrícolas, han aflorado en tierras de El Puerto, entre San Martín y Casa Calderón. Ello pone de manifiesto que los vacceos desarrollaron ampliamente la agricultura, desbrozando montes y vegas para hacerlos producir cosechas. Había que dotarse también de azadas, recipientes para guardar excedentes, hoces... El diente de hoz adjunto, encontrado en Valdestillas, iría engarzado, junto con otros muchos, en un soporte de madera. En la imagen adjunta se puede apreciar su corte, desgastado y bruñido del cereal que ha cortado.

Similar importancia podemos señalar de la cerámica asociada a los anteriores hallazgos. La cultura celtibérica (en sentido amplio) aporta una cualificación técnica que en nada envidia a pueblos posteriores. Los vacceos tamizan la arcilla hasta conseguir una finura difícilmente alcanzable. La cuidada cocción la dota de una calidad final extraordinaria. El tono anaranjado y la decoración con espirales o motivos geométricos la confieren un aspecto final de indudable belleza ${ }^{132}$.

Se adjuntan algunas muestras encontradas entre Valdestillas, La Peña y San Martín. Es más que probable que bajo el suelo de sus casas y calles se escondan secretos de estas épocas celtibéricas que se están tratando ${ }^{133}$.

${ }^{130}$ GALVÁN MORALES, R.: “Evolución Prehistórica...”, en Historia de Medina...., ob. cit., pág. 75 y ss.

${ }^{131}$ Un estudio muy completo de esta cultura puede consultarse en ROMERO CARNICERO. F., SANZ MÍNGUEZ, C. y ESCUDERO NAVARRO, Z. (eds.): Arqueología vaccea. Estudios sobre el mundo prrromano en la cuenca media del Duero, Junta de Castilla y 1993.

${ }^{132}$ Es un tipo de cerámica muy común en toda la Meseta norte, que, según las investigaciones, se difundió a partir del 300 a. C., o quizá un poco antes: MARTÍN VALLS, R. (1985): "La Segunda Edad del Hierro. Las culturas prerromanas", en Historia de Castilla y León, Tomo I: La Prehistoria del valle del Duero, pág. 125.

${ }^{133} \mathrm{Al}$ tratarse de un acercamiento a estas primeras culturas que han hecho suyo el espacio que estudiamos se ha optado por no citar de forma detallada cuantos estudios profundizan sobre el particular. No obstante, como obra que actualiza y renueva los estudios tradicionales de la arqueología vaccea, debe citarse la publicada por ROMERO CARNICERO, F., SANZ MÍNGUEZ, C., ESCUDERO NAVARO, Z., (eds.): Arqueología vaccea. Estudios sobre el mundo 

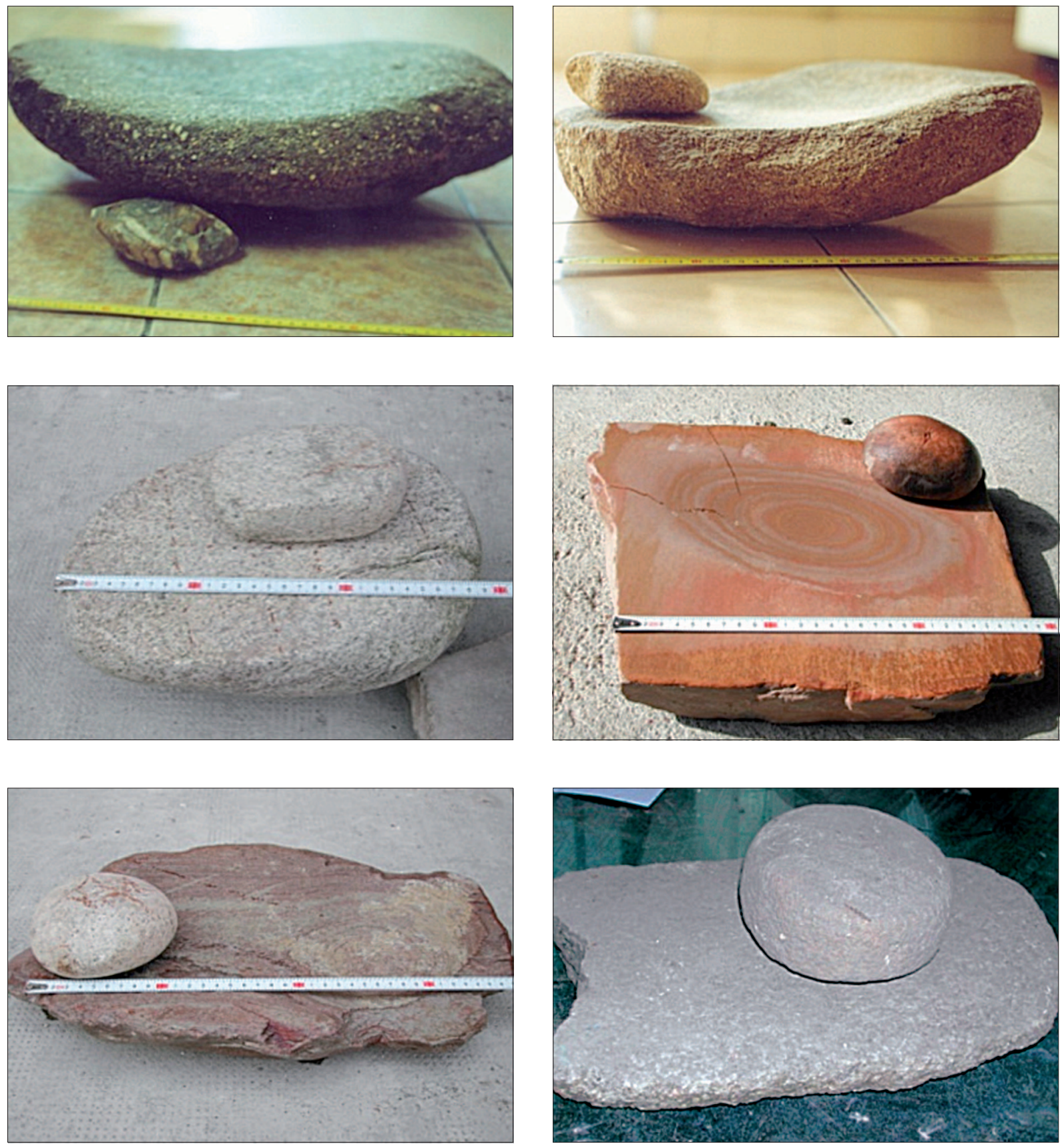

Imagen 29. Ejemplos de molinos celtibéricos. Pagos de San Martín y Fuente de la Miel (todas las imágenes, salvo la inferior derecha, que fue hallada en El Lomo, Valdestillas). Colecciones particulares. Foto: julio-agosto de 2006.

Su cultura, sus aportaciones técnicas, sus costumbres, sus dioses y sus hábitos formaron el sustrato ibérico prerromano en estas áreas del Duero medio, en el siglo III antes de nuestra era. Una nueva civilización estaba a punto de asentarse en estas tierras.

\section{d. La presencia romana y la impronta de su cultura}

El desembarco romano en la península Ibérica, en función de los intereses estratégicos de Roma en sus luchas con Cartago, trajo consigo una política expansionista de ocupación, control y explotación del solar ibérico. No fueron noticias gratas para los pueblos celtibéricos asentados en estas tierras. Se les acababa el tiempo. A las primeras bases costeras cartaginesas y territorios del sur del Guadalquivir sucederá, en una segunda fase, (206 a 83 a. C.), una política de control de fronteras y 

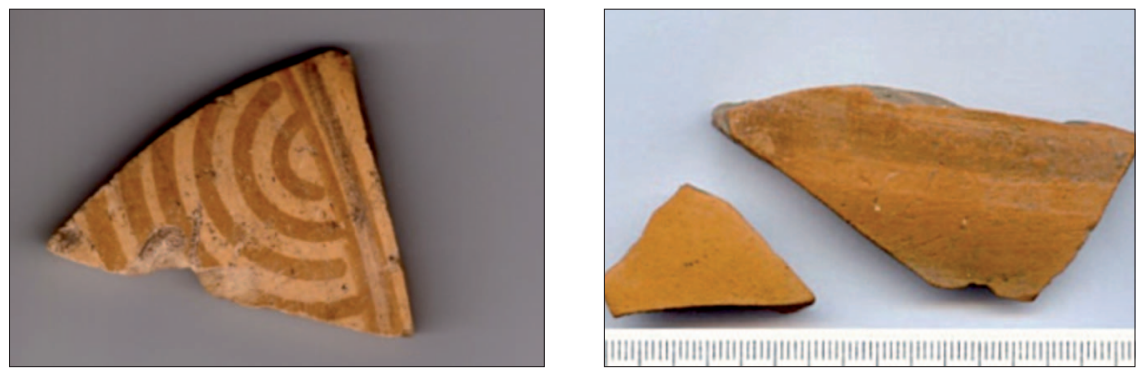

Ejemplos de cerámica vaccea. La Peña (izquierda) y San Martín (derecha). Colección particular.
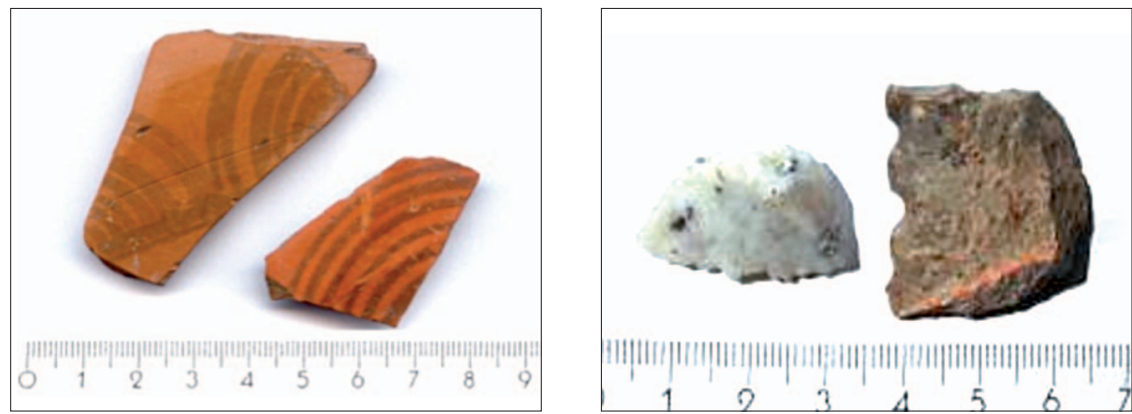

Ejemplos de cerámica y dientes de hoz del yacimiento de El Lomo. Valdestillas. Colección particular.

Imagen 29. Material cerámico y dientes de hoz pertenecientes a la cultura celtibérica. Fotos: junio-agosto de 2006.

administración territorial. Los asentamientos y culturas que habitaban el centro y sur de la actual provincia de Valladolid, van a ver profundamente alterada su vida y costumbres, como tantos otros pueblos prerromanos, a finales del siglo III a. de C. Los abusos de los administradores romanos, las incursiones lusitanas en las tierras del Guadiana en busca de botín y las respuestas represivas de Roma, llevaron a una escalada bélica entre los diferentes pueblos peninsulares y la capital del imperio. Las azadas se iban a convertir en lanzas. Al pueblo vencido le será arrebatada su preciada libertad, vestida de cadenas.

Así, en lo que a nuestro entorno atañe, al tiempo en que se desarrollan las Guerras Lusitanas y tras el declive de éstas una vez sea asesinado Viriato en el 139 a. C., Roma intensifica su política del control interior de la Meseta, continuando sus enfrentamientos con los pueblos peninsulares en las llamadas Guerras Celtibéricas (154-133 a. C.). Su objetivo es la toma del principal centro político y militar: Numancia. La alianza entre celtiberos y vacceos, y el apoyo que estos últimos otorgarán a los primeros mediante refuerzos y abastecimientos, extenderá la guerra al centro de la Meseta. No obstante, el sector que nos ocupa es relativamente marginal en el territorio vacceo. Sólo Cauca (Coca, Segovia) es una población importante, quizá, en menor medida, Nivaria (¿Matapozuelos?), pero sólo como lugar de paso de la ruta principal hacia Septimanca (Simancas).

Las fronteras entre vacceos y vettones son realmente difusas. Para Lomas, estarían en la "divisoria de aguas de los afluentes de la margen derecha del Tormes mejor que el propio rio, pues creemos que en tiempos prerromanos no serian los ríos sino las alturas las que servirían como fronteras naturales". Desgraciadamente, no nos es posible saber cuál de los interfluvios actuó de frontera: Guareña-Trabancos o Trabancos-Zapardiel. Seguramente ambos, pues los vacceos, algo más avanzados que los vettones, estaban en franca expansión en el siglo III a.C., llegando a ocupar ocasionalmente Salamanca ${ }^{134}$.

${ }^{134}$ Unas de las cosas que hicieron los romanos tras su victoria, para castigar la rebeldía vaccea, fue privarlos de sus avances y restituírselos a los vettones (LOMAS SALMONTE, F. J. (1983): Pueblos celtas de la Península Ibérica. En Historia de España Antigua, tomo I, Protohistoria, Editorial Cátedra, págs. 92-93). 
A decir verdad, este espacio apenas es de nadie y, cuando más tarde los romanos establecieron las fronteras entre la provincia Lusitania y la Citerior/Tarraconense, aquella se fijaba cerca de estas tierras. Otro aspecto a tener en cuenta en relación con la organización del territorio es que los vacceos tenían un régimen económico y social diferente al de los celtíberos, más jerarquizados y cercanos a la idea de estado. En efecto, los vacceos poseían, según recoge Lomas de Diodoro ${ }^{135}$, una cultura colectivista agraria, con una producción prioritariamente cerealista y, secundariamente, una rica ganadería. Ni la tierra ni el ganado eran propiedad privada, sino comunal, y se repartía anualmente por lotes a las familias. Políticamente, los vacceos tenían mayor dificultad para tomar decisiones unitarias, pues carecían de una autoridad centralizada; sin embargo, se vieron envueltos en numerosas reyertas en las guerras contra o entre los romanos. Durante la conquista ${ }^{136} y$, concretamente, en las Guerras Celtibéricas, los vacceos apoyaron a los celtíberos, sobre todo con suministros. Esto obligó a los romanos a realizar expediciones punitivas para cortar el abastecimiento de Numancia. En el 151 a. C., el cónsul Lúculo arrasó Cauca (Coca) y, rebasando el Duero, continuará su avance por territorio vacceo hasta llegar a Intercatia y Pallantia (Palencia). De nuevo, en el ańo 143 a. C., Metelo arrasó los campos vacceos. Entre estos ańos es seguro que los habitantes de los poblados que por aquí se asentaban apenas recogieron cosechas, basta parafrasear a Catón el Censor que, en una de sus campañas militares, aseguró al senado que la guerra en Hispania se alimentaba sola, con las ricas cosechas indígenas.

La caída de la emblemática ciudad fortificada en 133 a. C. abre las puertas a la definitiva ocupación romana del centro de la cuenca del Duero y convirtió a los vacceos de esta tierra en dediticii o súbditos absolutos: no sólo sus bienes, sino ellos mismos, pasaban al control directo del Senado y el Pueblo Romano, dependiendo administrativamente del cónsul de la Hispania Citerior (Tarraconense), además de pagar un impuesto anual fijo y despojarles de territorios que habían ganado en su expansión hacia el suroeste (a costa de los vettones).

Las revueltas de los pueblos meseteńos continuaron y, de hecho, los vacceos intervinieron en las Guerras Sertorianas (82-72 a. C.), lo que provocó un nuevo saqueo de Cauca por parte de Pompeyo en el 73 a. C. De nuevo los vacceos eligieron el bando perdedor. Aunque no vuelven a intervenir en grandes conflictos, hay noticias de pequeñas revueltas en la zona, aún en el año 61 a. C. Desde entonces, completamente derrotados, empezaba un nuevo tiempo, nuevas creencias, economías monetarias y esclavistas, centralizadas estructuras de poder, aportes técnicos, influencias e ideologías lejanas. Aquí, sin embargo, en las terrazas y pequeños valles que ocuparán con el tiempo Serrada, La Seca, Valdestillas, Villanueva, Ventosa y Matapozuelos, y sin menoscabar la importancia de las campińas del sur, el arado volverá a surcar las mejores tierras, el ganado seguirá aprovechando sus excelentes pastos y los hombres, los que permanecían de antes y los que ahora llegarán de tierras lejanas, volverán a ocupar los antiguos poblados o darán nueva vida a nuevos asentamientos.

Quizá por estos años de inseguridad, del estudio de los restos romanos se desprende una escasa presencia en estas épocas altoimperiales, circunscrita a las vecinas localidades de Valdestillas y Matapozuelos ${ }^{137}$. Más tarde, durante la época bajoimperial, a partir del siglo III después de Cristo, el proceso de crisis política y económica derivará en un proceso de ruralización y progresiva servidumbre que concentra la ocupación rural romana en torno a las "villæ rustici", tales como Almenara de Adaja, Villa del Prado, tal vez Villaverde de Medina, etc., configurándolas como nuevos centros de poder, casi autosuficientes en el aprovechamiento de los recursos. Los asentamientos de El Lomo (Valdestillas), el propio de Sieteiglesias (Matapozuelos) y el de Casa Calderón en Villanueva de Duero, junto al

${ }^{135}$ LOMAS SALMONTE, F. J., ob. cit., págs. 93-94.

${ }^{136}$ MANGAS MANJARRÉS, J. (1985): “La conquista del valle del Duero por los romanos”, en Historia de Castilla y León, tomo II: Romanización y germanización de la Meseta Norte, págs. 8-25.

${ }^{137}$ MAÑANES PÉREZ, T.: "La Tierra de Medina del Campo en las épocas romana y visigoda", en Historia de Medina...., ob. cit., pág. 95 y ss. 
Duero y a trescientos metros de la raya del término con Serrada en el reiterado pago de San Martín, serán los que extiendan su influencia sobre el espacio comarcal y el instinto práctico de los romanos los hará decidirse por continuar la ocupación.

Lo que parece innegable es que los pobladores tardorromanos habitaron y explotaron estas tierras de Medina y aprovecharon sus pastos con sus ganados. En el norte comarcal, limítrofe al Duero, la incipiente red caminera se articulará entre los asentamientos localizados en Valdestillas y Matapozuelos hasta los poblados dependientes de Casa Calderón, lugar por el que vadearían el río, al igual que por La Peña y Tordesillas, para enlazar con la vía que les pondría en contacto con Septimancas (Simancas).

Estas vías de comunicación serán pasos menores, nunca de importante tráfico de hombres o mercancías, pero necesarios para el acortamiento de recorridos o la conexión de los asentamientos más cercanos. En el nuevo contexto, la introducción de distintas técnicas agrícolas facilitó la explotación de los recursos. Prueba de ello son los molinos adjuntos, encontrados en Valdestillas, Casa Calderón y La Peña, distintos de los anteriormente estudiados y que suponen todo un avance técnico ${ }^{138}$.

Importante era, asimismo, la fina cerámica que servía de soporte a sus vajillas, también hallada en los lugares citados. Son fragmentos de Terra Sigilata Hispánica, arcilla muy fina y trabajada por expertos alfareros, con su color rojizo característico. Los restos encontrados en Valdestillas están decorados con ruedas y motivos de círculos y ángulos. Los de Casa Calderón son lisos, del mismo tipo, aunque también aparecen restos decorados y, al igual que en el anterior ejemplo, proliferan mezclados con cerámica vulgar, de pasta negruzca y de difícil datación toda vez que no consta poblamiento medieval en estos sectores ${ }^{139}$.

El análisis de los fragmentos fotografiados, tanto por el color de las pastas como por los motivos, que siguen los modelos establecidos por Ma Ángeles Mezquíriz, es lo que nos ha permitido precisar el momento histórico al que pertenecen y que nos lleva a situar dichos yacimientos en el entorno de la amplia red de villas agrícolas localizadas en la provincia de Valladolid y que se hace extensiva a casi todo el Norte de la Meseta.

Este material pertenece, de acuerdo con la clasificación de Mezquíriz de Catalán ${ }^{140}$, a los siglos IV y V después de Cristo. Estos siglos parece que se corresponden, en el caso de Castilla y para la provincia de Valladolid, con unos siglos de cierto equilibrio económico ${ }^{141}$, de manera que renace con gran fuerza la vida de estos latifundia, como atestiguan los excepcionales mosaicos de Pedrosa de la Vega y de Dueñas, en Palencia, o los bellos pavimentos de Almenara de Adaja o los del segundo nivel de la Villa del Prado en Valladolid. Los tipos identificados siguiendo la clasificación establecida por Mezquíriz de Catalán se corresponde con la T.S.H.T., más concretamente con la forma 37 para estos siglos IV y V, de acuerdo con los motivos decorativos identificados en el término de Valdestillas: decoración de círculos concéntricos con botón central, puntas de flecha dentro de dos semicírculos concéntricos y decoración de picos separados por una línea. Se ha reconocido un fragmento de borde que lleva bajo el labio una decoración de bastones, así como dos fragmentos de dos fondos anulares, el más grande con el pie más marcado, que podrían corresponderse con alguno de los vasos descritos en las láminas 37 y 38 de la obra citada.

${ }^{138}$ Se trata de una piedra circular cóncava y otra convexa con una abertura central por donde se echaba el grano. La fricción que produce el giro de la superior sobre la inferior deja triturado el cereal.

${ }^{139}$ Desde el punto de vista arqueológico la intensa explotación agrícola del terreno ha conllevado la pérdida de buena parte del patrimonio arqueológico. En el espacio estudiado, desde la llegada de la mecanización, los tractores, con sus arados, mezclaron los distintos niveles. El empleo de maquinarias desterronadoras pulverizaron los restos. Testimonios de quienes han trabajado estos pagos desde hace décadas hablan de abundantes restos de cimentaciones y sepulcros intactos de piedra, molinos circulares, etc., que extraían y apartaban para evitar roturas en la maquinaría.

${ }^{140}$ MEZQUÍRIZ DE CATALÁN, Ma . Á.: Terra Sigillata Hispánica, tomos I y II, The William Bryant Foundation, Valencia, 1961.

${ }^{141}$ PALOL, P. y WATTENBERG, F., Carta Arqueológica de España, Valladolid, Servicio de Publicaciones de la Diputación Provincial de Valladolid, Valladolid, 1974, pág. 41. 


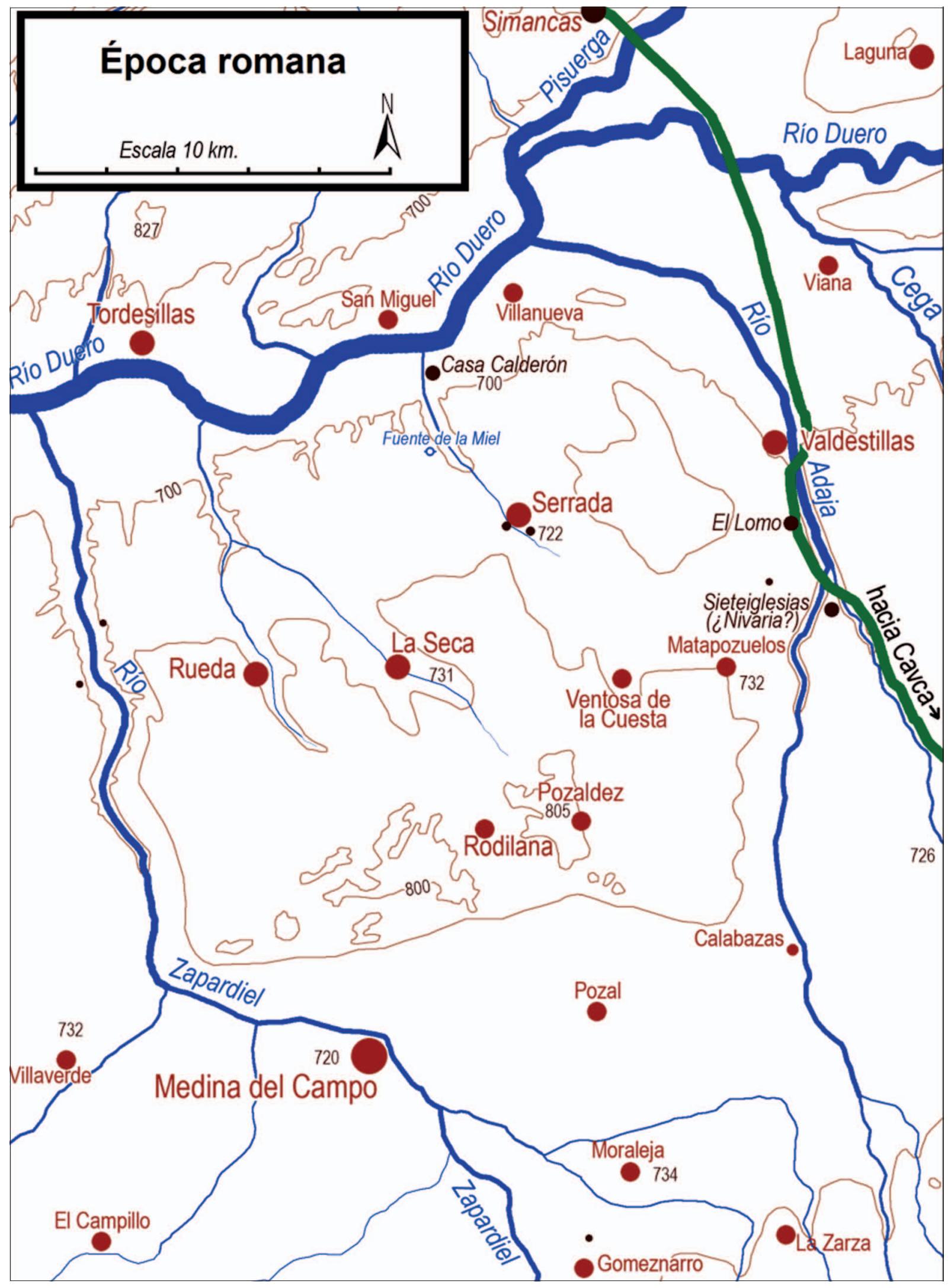

Figura 15. Mapa de localización de hallazgos y asentamientos romanos en el norte de la Tierra de Medina. Como se ha reiterado al pie de las figuras de los mapas anteriores, únicamente hemos localizado algunos de los emplazamientos de los materiales encontrados en tareas de prospección, sin menoscabo de otros materiales y estudios que abarcan espacios más amplios. Ver bibliografía. 

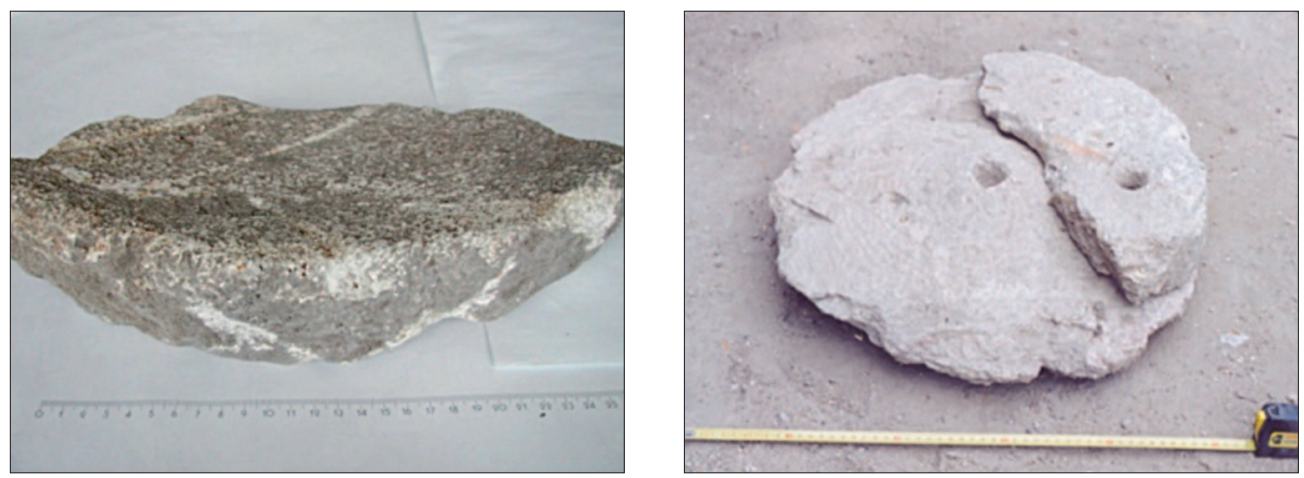

Fragmentos de molinos circulares de Casa Calderón (Villanueva), izquierda, y de El Lomo (Valdestillas), derecha.
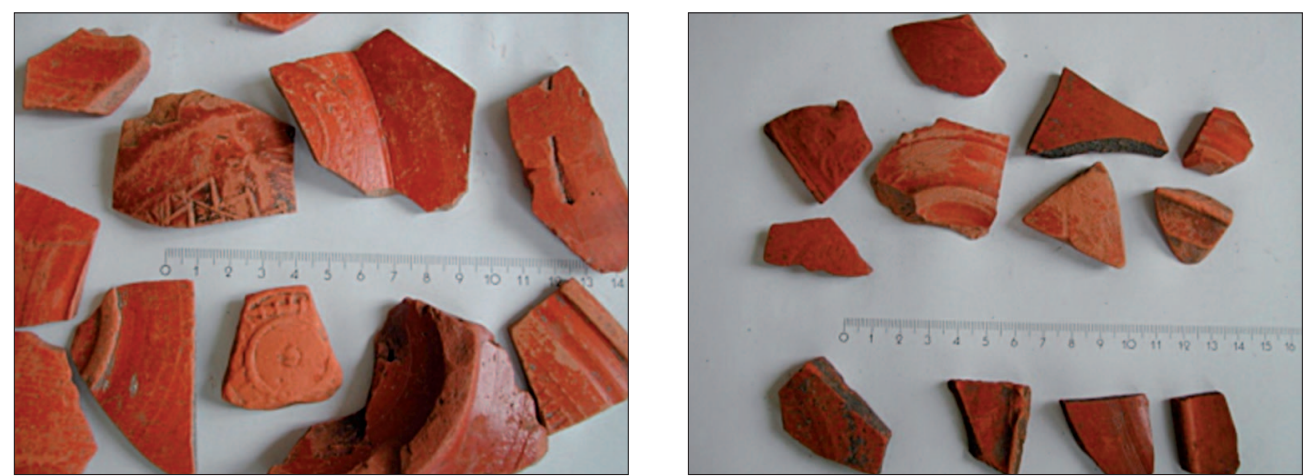

Terra sigilata prospectada en El Lomo (Valdestillas), izquierda, y en Casa Calderón (Villanueva), derecha.


Anverso y reverso de un sestercio de la época de Trajano (98-117 d. C.), izquierda, y anverso y reverso de un antoniniano, Victorino, (268-270 d. C) emperador, derecha, (colección particular). Foto: junio-agosto de 2005.

Imagen 30. Ejemplos de restos de época romana encontrados en el espacio estudiado. En la página siguiente, puente con vestigios en su base que la tradición remonta al mundo romano, en Matapozuelos. 


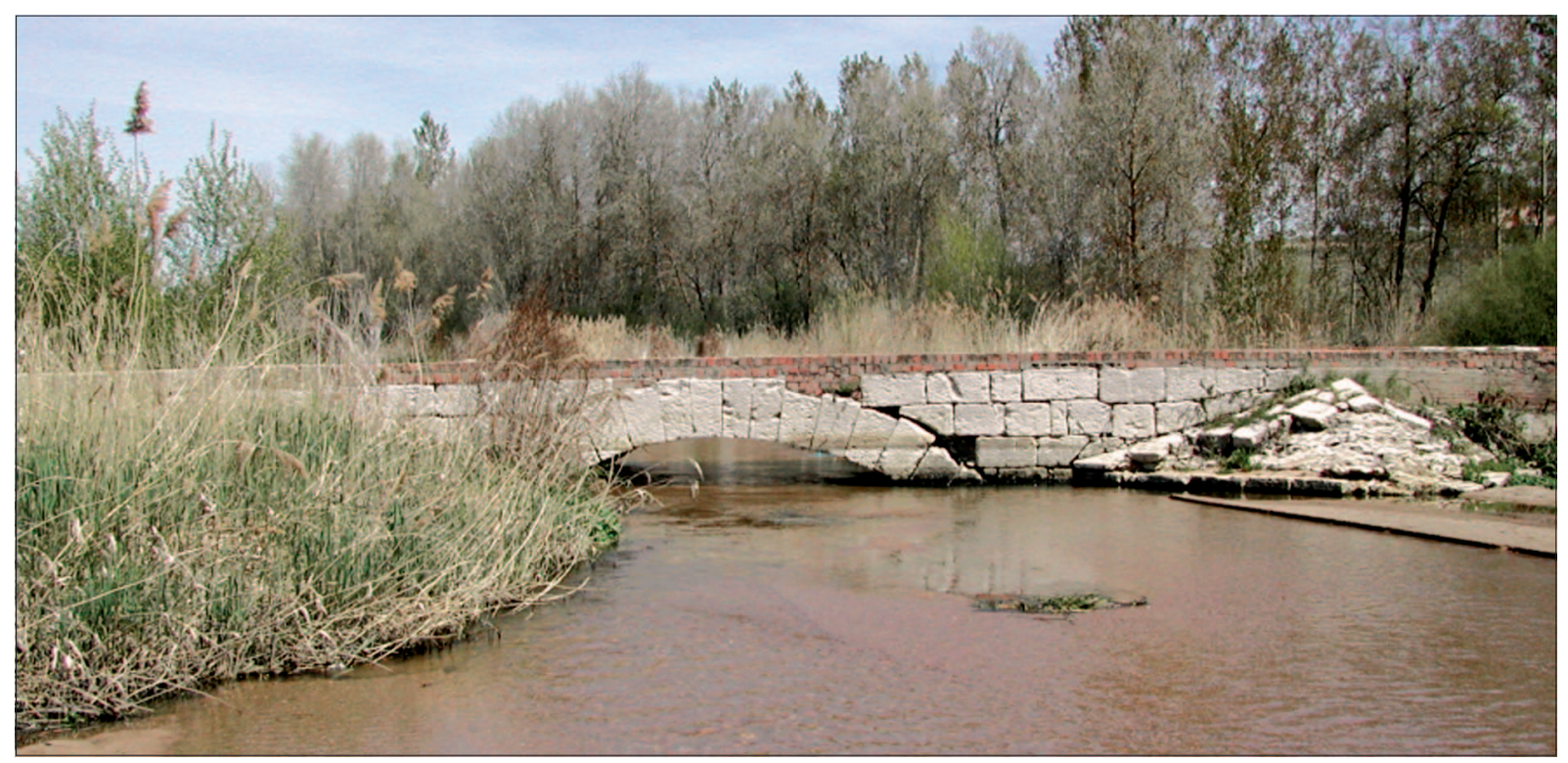

Puente sobre el río Adaja, en la confluencia de este río con el Eresma. Matapozuelos. Foto: junio de 2005.

Los motivos decorativos que distinguimos, a excepción del fragmento del borde, se corresponden con zonas del galbo y fragmentos muy pequeños. Las características generales son: vasijas con un pie muy bajo, como los dos fondos reconocidos en las fotos, casi desaparecido, pared curva sobre la que va la decoración y borde muy abierto con una especie de reborde más grueso, como es el caso del ejemplo estudiado. La pared es, por lo general, es bastante delgada y cubierta por un barniz ligero y poco brillante en la mayoría de los $\operatorname{casos}^{142}$. Se documentan también un borde, probablemente de una olla u orza, de pastas negras junto a otros dos fragmentos del cuerpo y, quizás del fondo, pertenecientes a la cerámica común romana de Casa Calderón, en Villanueva de Duero y, por lo tanto, del mismo período histórico. En este pago también se localiza un pequeńo lote de cerámica T.S.H.T, en fragmentos más pequeños y rodados, en los que no distinguimos decoración alguna, a excepción de unas líneas paralelas hechas a peine que recorren el hombro de la vasija; se identifica un fondo y un borde con características similares a las piezas de Valdestillas anteriormente descritas.

El profesor Mañanes, igualmente, identifica y estudia cerámica de este tipo en sendos lugares, al tiempo que analiza hallazgos de terra sigilata en Bobadilla, Brahojos, Campillo, Carpio, Castrejón, Foncastín, Gomeznarro, Honcalada, Medina, Villaverde, La Zarza, etc., lo que prueba la notable presencia romana y el aprovechamiento de los recursos en una vida predominantemente rural en toda la Tierra de Medina. La agricultura se configuró eterna compañera de viaje en este espacio. Buena parte del valle medio del Duero había sido lugar de asentamiento vacceo y los cereales y la ganadería eran las actividades más importantes, sin descartar el cultivo del viñedo, tal como se desprende de la presencia del vino en los rituales funerarios. Roma impulsa el cultivo por todo el mediterráneo y es muy posible que los asentamientos romanos en el espacio que estudiamos albergaran lagares y prensas para su elaboración ${ }^{143}$. Cereales y ganados. ¿Serían los romanos los primeros en plantar viñas en estos pagos? No hay certeza de ello, pero es muy posible que así fuera. La llegada de las invasiones bárbaras o las abundantes revueltas y saqueos que tuvieron lugar durante los siglos IV y V de nuestra era provocaron que muchas villas quedaran reducidas a cenizas. La civilización romana, sin embargo, perduraría para siempre.

${ }^{142}$ En relación a la forma 37 de la clasificación llevada a cabo por Mezquíriz, la autora en su Tomo I, en las páginas 115 a 118, expone las características generales de la misma. Al describir la Forma 37 Tardía, explica que son todos aquellos vasos decorados que, a partir del siglo III, tienen un perfil curvo en la parte decorada de la pared, pues en las formas más antiguas que comienzan en el siglo I, hasta el siglo IV, hay una gradual evolución de la que conocían diferentes ejemplares y que se sistematizaron tras las excavaciones llevadas a cabo en Pamplona.

${ }^{143}$ PIQUERAS HABA, J.: La vid y el vino en España. Universidad de Valencia, 2014, pág. 45. 


\section{De la época altomedieval al nacimiento y ocupación del espacio por los primeros pobladores cristianos. La Moya, Serrada y San Martín del Monte, como ejemplos al norte de la comarca}

La inseguridad y la ruptura de las estructuras sociopolíticas romanas continúan a partir del siglo $\mathrm{V}$ por los peligros asociados a la entrada, sin control efectivo por parte de Roma, de pueblos extraños al imperio, que recorrieron la Meseta y amplios sectores peninsulares. Por si no fuera suficiente la inestabilidad que estas invasiones provocaban entre la población autóctona, los movimientos y revueltas de las Bagaudas -protestas y saqueos protagonizados por parte de colonos empobrecidos, esclavos y pequeńos propietarios descontentos- generan un estado de incertidumbre y temor en aquellos sectores, como el que nos ocupa, en que no existían estructuras sólidas de poder o villas con recursos humanos y económicos, capaces de organizar la defensa y control del territorio circundante.

La reacción romana ante semejante marasmo ibérico no iba ser sino de debilidad. El pacto con los visigodos, pueblo bárbaro romanizado, para el control territorial de la Península a cambio de asentamiento en la Galia mediterránea, resultaría una visión de corto alcance. Los visigodos acabarán asentándose en Hispania para ejercer sobre ella un control político que se extiende desde el siglo V al año 711, fecha de inicio de la dominación islámica, y que se conoce como época visigoda, nada fácil de reconstruir dada la carencia de fuentes al respecto.

De la misma manera, entre vacíos e interrogantes, se desgranan los siguientes siglos, de probada presencia islámica, por parte de los pueblos bereberes que ocupan el centro de la meseta. Su llegada tuvo lugar tras la conquista y dominación de la Península, que inician los ejércitos de Tariq y Muza, aprovechando la desintegración de la débil y electiva monarquía visigoda, representada en sus últimos momentos por los reyes Rodrigo y Vitiza. En virtud de los pactos entre los nuevos invasores y la nobleza hispano visigoda, el control peninsular fue muy rápido salvo en el sector cantábrico, donde pronto surgen incipientes núcleos de resistencia y el germen de los primeros reinos cristianos.

Los siglos IX y X de nuestra era se presentan, igualmente, poco agradecidos para las fuentes escritas. Estas tierras de la campiña medinense están poco pobladas, son enormemente desconocidas para el investigador y la historiografía la sitúa en el amplio y despoblado territorio que conforma la Extremadura castellana, localizada entre los reinos cristianos del norte y las pobladas y ricas tierras islámicas, al sur del Tajo.

Cuesta creer, sin embargo, que en esta decena de siglos, desde las épocas tardorromanas a la ocupación cristiana del Duero, no existieran, aunque fuera de forma muy discontinua en el tiempo y desigual en la intensidad de la ocupación, pobladores que aprovechasen los recursos naturales de estos parajes, gentes que se beneficiaran, transcurrido un tiempo prudencial, tras los peligros o pestes, de las infraestructuras y terrazgos labrados o desbrozados por aquellos que murieran o marcharan.

En este capítulo, finalmente, se abordará el nacimiento de unas comunidades cristianas que ocupan de forma progresiva estas tierras de nadie al sur del Duero, para hacerlas suyas de forma duradera. Se trata de sociedades profundamente campesinas, al arbitrio de nobles y clérigos, pero también de sequías, hambrunas y pestes. Como ejemplo de todas ellas nos serviremos de los lugares de La Moya y Serrada, pertenecientes históricamente a la Comunidad de Villa y Tierra de Olmedo, y de la pequeńa villa de San Martín del Monte, a la Tierra de Medina, pero vinculada al Monasterio de Santa Clara de Tordesillas, todas ellas situadas en el norte de la comarca estudiada. En su elección pesa que representan distintos orígenes y destinos: Serrada como lugar señorial perteneciente hasta comienzos del siglo XX a uno de los más importantes linajes medinenses; La Moya como ejemplo temprano de lugar poblado que se torna en despoblado a comienzos del siglo XVII y, por último, San Martín del Monte como pequeña villa al norte de la Tierra de Medina, donada al Convento de Santa Clara de Tordesillas, y que sucumbe para siempre tras la invasión napoleónica. Se entiende que pueden ser representativos de cuantos lugares inician en estos tiempos medievales la ocupación del territorio, el cultivo de la tierra y el aprovechamiento de sus pastos. Por lo que deja entrever la documentación de archivos y otras fuentes, basta mutar los nombres 
de la nobleza que sigue, atribuir a otros monasterios y cargos catedralicios las decisiones tomadas y cambiar el nombre a lugares, campesinos y villas para que puedan verse reflejados el resto de los términos de esta Tierra de Medina y de buena parte de Castilla. Analicemos, brevemente, todos estos aspectos.

\section{a. La incierta presencia del pueblo visigodo en el espacio comarcal}

Las campiñas medinenses, si nos atenemos a los hallazgos arqueológicos, no han sido un lugar preferente de asentamiento visigodo. Se han localizado restos, en lo que respecta al territorio vallisoletano, a lo largo del valle del Duratón hasta su desembocadura en el Duero (hallazgos encontrados en Curiel y Quintanilla de Arriba), a la vera del Pisuerga (necrópolis de la Flecha), a lo largo del valle del Esgueva (necrópolis de Piña de Esgueva) y en los sectores del centro-oeste provincial: San Cebrián de Mazote, Wamba, Pollos... Al este de la comarca, en la Tierra de Pinares y, especialmente, a lo largo de los ríos Eresma, Cega y Pirón los asentamientos también fueron, a tenor de los restos hallados, numerosos: necrópolis del Cantosal en el área de Coca; Las Peguerillas en Íscar; La Cotarra de San Miguel y el Vado de Brazuelas en Alcazarén; siguiendo el margen del Eresma hasta Olmedo... ${ }^{144}$. Resulta verosímil, a la luz de los restos e investigaciones conocidas, que estas poblaciones, fueran visigodas propiamente dichas o descendientes de los hispanorromanos, no continuaran, en mayor o menor medida, con sus aprovechamientos agropastoriles en estos espacios del sur del Duero. Es probable que los pagos citados en el norte comarcal, desde Serrada hasta San Martín por la Fuente de la Miel, siguiendo el arroyo hasta el Duero, sus verdes pastizales y la tierra fértil de sus vegas, pudieran haber sido ocupadas, en algún momento, por pueblos germánicos en estos siglos altomedievales.

Aunque dejamos entre interrogantes la ocupación del terrazgo que estudiamos, lo que no cabe duda es que en estos tiempos se sientan buena parte de las bases jurídicas que regulan las relaciones sociales con respecto al uso de la tierra. La Lex Visigothorum o Liber Iudiciorum redactado durante el reinado de Recesvinto y promulgado en 654 recopila la legislación anterior y se aplica tanto a hispanorromanos como a visigodos. En sus libros y leyes, siguiendo la tradición romana, se ordena un paisaje agrario en el que constan prados, mieses, viñas, olivares, campos, tierras y vergeles. Entre los aprovechamientos el viñedo aparece individualizado como uno de los cultivos más importantes ${ }^{145}$. Su protección la regulan un conjunto de leyes que precisan los tipos de cercados, hitos o derecho de paso entre las cepas ${ }^{146}$.

De igual manera se precisan los tiempos de recolección, sea la siega o la vendimia, que se reconoce entre mediados de septiembre y octubre, considerándola fiesta en el calendario anual. En este tiempo la actividad del hombre se centra en la recogida de la cosecha hasta el punto de que se paralizan juicios o pleitos entre ellos: “...Mandamos guardar del tiempo de las vendimias XV. días por andar de setiembre, fasta XV. dias andados de octubre... En los días de coger el pan y el vino, los omnes que fazen tal cosa, porque deven prender muerte, deven recebir la pena... "147.

No nos extenderemos, sin embargo, en buscar raíces en este tiempo tan falto de vestigios. Tanto más cuanto que hasta los siglos IX y X de nuestra era se presentan, incluso para los historiadores, enormemente desconocidos e insertos en el amplio y despoblado territorio que conformaría la

${ }^{144}$ MAÑANES PÉREZ, T.: "Villa y Tierra de Íscar a partir de la conquista romana”, en ARRANZ SANTOS, C.: Villa y Tierra de Íscar. Valladolid, 1995, págs. 78-82.

${ }^{145}$ PIQUERAS HABA, J.: La vid y el vino..., ob. cit., pág. 50.

${ }^{146}$ L.V., Libro X, tíyulo III, ley II: “De conlisis et evulsis limitibus:...Si quis autemdum arat, vel vineamplantat, terminum casu non voluntate convellerit; vicinis praesentibus restituat terminum, et postmodum ex hoc nullum damnum aut periculum vereatur." (Fuero Juzgo, Libro X, título III, ley II: "de los fitos arrancados e quebrantados:...E si algun ome, mientra que ara, o ponne vinna si arranca el fito sin su grado delantre los vecinos, torne el fito en so logar, e nom aya nengua calonna."). GALLEGO FRANCO, H.: "La cultura del vino en la España visigoda: Un análisis de las fuentes jurídicas", en Actas del I Encuentro de historiadores de la vitivinicultura española. Departamento de Historia Antigua. Universidad de Valladolid. Serie: Encuentros de primavera en El Puerto, no 2, Javier Maldonado Rosso y Alberto Ramos Santana, (eds.)

${ }^{147}$ Ibídem, pág. 200. 
Extremadura castellana, entre los reinos cristianos del norte y las pobladas y ricas tierras islámicas al sur del Tajo. Con similar incertidumbre anotamos el yacimiento de los Cotarros, excavado en 1934 por el Seminario de Estudios de Arte y Arqueología de la Universidad de Valladolid. Se trataba, en apariencia, de una reducida necrópolis situada en una pequeña elevación del terreno rodeada de charcas a escasos dos centenares de metros al sureste del casco urbano de Serrada ${ }^{148}$.
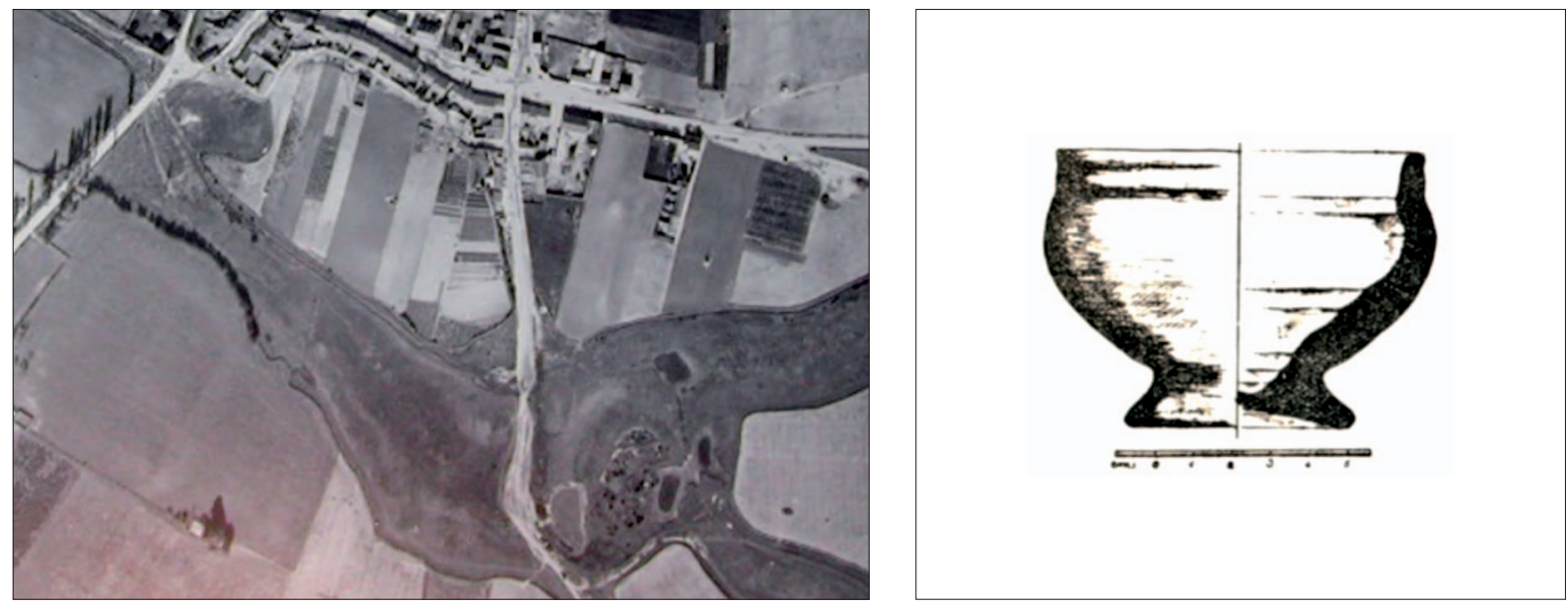

En la parte inferior derecha de la imagen puede apreciarse el resalte del terreno, entre charcas, en que se localiza el yacimiento. Foto vuelo 1956. Perfil de vasija (imagen derecha),
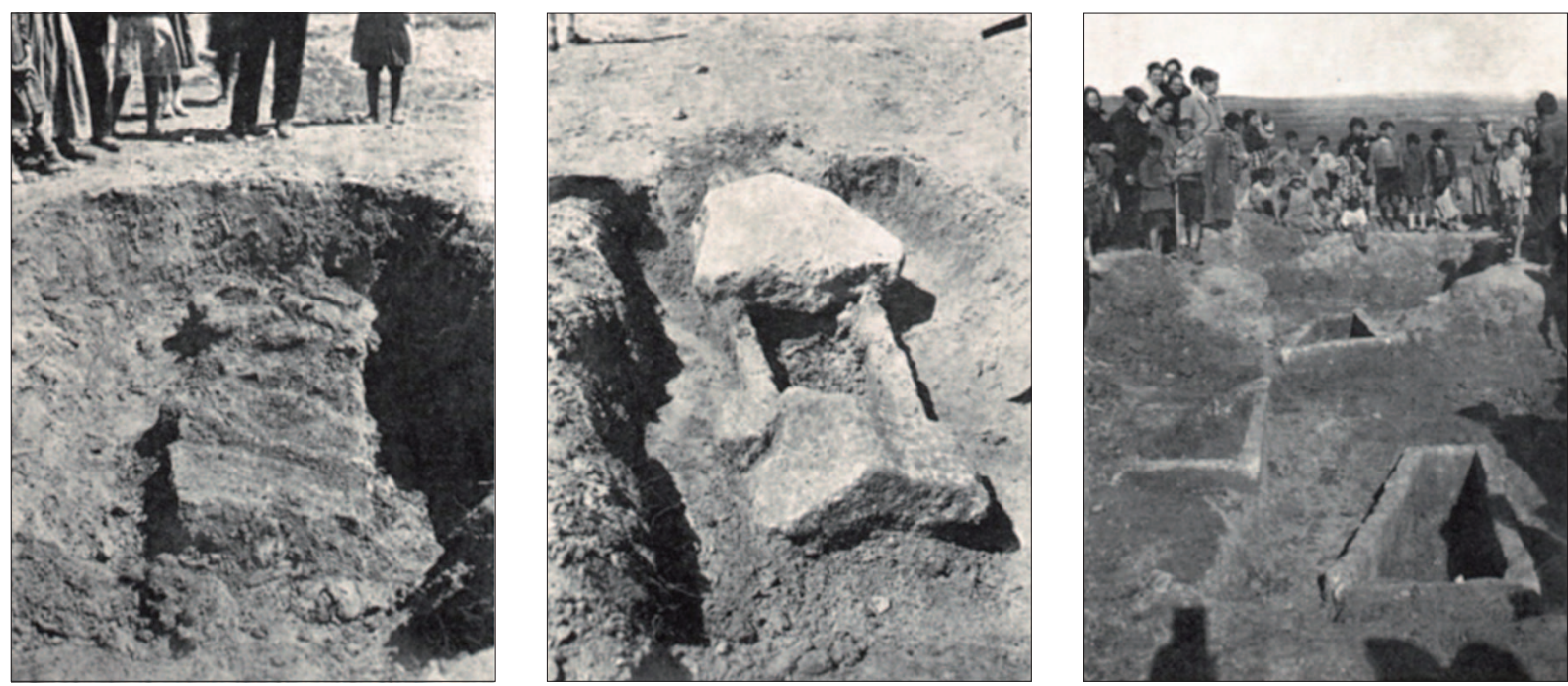

Imagen 31. Localización del yacimiento de Los Cotarros. Foto aérea, año 1956 (página anterior).

Imágenes de la excavación del yacimiento en 1935. Fotos: Seminario de Estudios de Arte y Arqueología, curso de 1934-1935.

${ }^{148}$ En 1878 el Ayuntamiento de Serrada comunica al gobierno de la provincia el hallazgo de un vecino que haciendo adobes y, "cabando en el sitio llamado Los Cotarros... ha descubierto y sacado en pedazos una caja de piedra con tapas de los mismos $y$ dentro de ella algunos despojos de restos humanos". (A.H.P.V. S.H. 22-VI, año 1878). En dicha comunicación se hace referencia a que en dicho lugar "continuamente salen escombros y restos de viviendas en descomposición.", prueba inequívoca de que la citada prominencia del terreno albergó en su día si no un antiguo poblado sí una pequeña necrópolis. En los años treinta del siglo XX, los serradenses, con sus carros, año tras ańo, siguieron sacando tierra de los Cotarros. Se denominaba así a la elevación del terreno que existía al final de lo que puede asemejarse a un pequeńo espigón entre los dos prados (el del Pradejón y el de la Estacada), localizado en frente de la tierra que se conoce con el nombre de La Picona del señor Valentín Alonso. Estaban en terreno comunal y con el barrero del marqués y señor del lugar habían tenido no pocos problemas. En Los Cotarros salía una tierra rojizoparduzca inmejorable para dar de llana los hastiales y las medianerías de las casas. Los montículos fueron mermando hasta que, al sacar mayores cantidades al objeto de aplanar y encauzar un arroyo maloliente, justo donde se asienta ahora el polideportivo, volvieron a salir a la luz nuevos sarcófagos de piedra. Corría el año 1934. Nuevamente, el Ayuntamiento, presidido entonces por el alcalde Alberto Gutiérrez Estébanez, elevó el hecho a la Comisión de Monumentos de Valladolid. El Seminario de Estudios de Arte y Arqueología será el encargado de llevar a cabo el estudio. 
¿Quiénes o qué cultura se aventuraba a hacer descansar a sus muertos entre humedales y prados encharcados? Bien es cierto que se encontraban, como se puede apreciar en las imágenes, situados en un lugar prominente y a salvo de inundaciones. En la fotografía aérea de 1956 se aprecia perfectamente este pequeño accidente topográfico. De ahí el topónimo. Lo insuficiente del resalte, lo insano del lugar en el momento de su descubrimiento, la falta de ajuar y las escasas semejanzas a las elevaciones que acogen los enterramientos visigodos de Pińa de Esgueva o Amusquillo, por poner algún ejemplo, hicieron pronunciarse con extrema cautela a quienes llevaron a cabo la excavación. Por otro lado, de tratarse de enterramientos de repoblación cristiana, es igualmente extraño que tal lugar sagrado no permaneciera en la memoria colectiva. Al menos como una tenue referencia en las delimitaciones del lugar de Serrada y sus límites cuando prados y tierras son objeto constante de litigios entre el seńor del lugar y la villa de Olmedo desde tiempos bajomedievales.

Ello nos hace pensar que su origen se remonta a tiempos altomedievales. P. de Palol y F. Wattenberg, en su Carta Arqueológica, citando la excavación y estudio realizada por el Seminario de Arqueología, manifiestan el posible carácter visigodo del hallazgo ${ }^{149}$. En la propia memoria de excavación, sin embargo, no se llega a ninguna conclusión definitiva ${ }^{150}$. Hay una falta absoluta de ajuar, un extraño emplazamiento y una falta de caracteres diferenciadores de las tumbas excavadas. Se trata de cajas de piedra de 1,70 $\mathrm{m}$ de longitud y $0,52 \mathrm{~m}$ de ancho en la cabecera con una especie de baquetón de apoyo. Las tapas a dos vertientes. Todas ellas en granito "más bien flojo", en palabras de los arqueólogos. De las seis sepulturas que se analizaron, señala J. Barrientos, se encontraron, "en cada una de ellas, varias inhumaciones señalando paquetes de huesos a los pies. "Señala el autor del texto que describe la excavación cómo, otra sepultura, estaba formada por muros de ladrillo, que formaban en la cabecera una especie de caja para colocar la cabeza. Como único ajuar recogido se testimonia la presencia de una pequeña vasija de barro negruzco con granos de mica, tosca, hecha a torno, de esbelto galbo y con pie. Sus dimensiones eran $8 \mathrm{~cm}$ de altura, $8 \mathrm{~cm}$ de diámetro de boca y $6 \mathrm{~cm}$ en el de la base y con un grueso de $5 \mathrm{~mm}$ Según refiere la citada memoria fue encontrada por las gentes del lugar al remover el terreno y en una sepultura ${ }^{151}$. Ante tan escasas pruebas y vestigios ciertos, quizá proceda, si se desea llegar a una conclusión definitiva, llevar a cabo una reexcavación con el objetivo de descubrir alguna sepultura intacta que, de acuerdo con las nuevas técnicas prospectoras y de investigación arqueológica, daten con precisión el hallazgo.

\section{b. El nacimiento de los primeros poblados cristianos del sur del Duero. La Moya, Serrada y San Martín del Monte como ejemplos al norte de la comarca}

La invasión islámica de la Península Ibérica pone fin a la decadencia, intrigas y debilidad de la monarquía electiva visigoda. El año 711 representa el inicio de una rápida ocupación peninsular por el mundo musulmán que, a través de acuerdos, capitulaciones y tributos, controla la práctica totalidad del solar ibérico, salvo núcleos aislados de resistencia hispanovisigoda, refugiados en los sectores de las montańas cantábricas y pirenaicas, poco atractivas, por lo demás, para los nuevos invasores.

En estas tierras de la Meseta norte que recorre el Duero se asientan, en virtud de los repartos y acuerdos de los conquistadores, tribus y clanes bereberes, integrantes de ejército de Tarik, que aprovechan de forma agrícola, pero sobre todo pastoril, los recursos de estas planicies. No se tiene constancia de la pervivencia de núcleos hispanovisigodos en los territorios cercanos a los hoy habitados,

${ }^{149}$ WATTENBERG, F. y PALOL DE, P.: Carta Arqueológica de España. Valladolid, 1974, págs.142-143.

150 Seminario de Estudios de Arte y Arqueología. Facultad de Historia. Universidad de Valladolid. Boletín de trabajos, $1^{\circ}$ trimestre, fascículo VII, curso de 1934-1935, pág. 413.

${ }^{151}$ Ibídem. 
pero es posible que, a pesar de la conmoción originada por los recién llegados, pudieran subsistir pequeños grupos rurales en distintos sectores.

La situación política en Al-Andalus derivará, en virtud de las desigualdades provocadas por los repartos de poder y tierra entre las diversas facciones islámicas, en tensiones y luchas internas. De hecho, los bereberes se levantarán contra la oligarquía árabe en 741, siendo vencidos por fuerzas sirias enviadas por el califa de Damasco. Las derrotas sufridas, junto a las sequías y hambres que se constatan por estas fechas en la parte central de la Cuenca del Duero, provocan el abandono y el despoblamiento de buena parte de los asentamientos bereberes. Poblaciones islámicas cercanas como Al-garyn (Alcazarén), Íscar, Villa de Ahmad (Villabrágima), Villa al-barbar (Villalbarba), Ataquines, las tribus Azdaya (Adaja), asentadas a lo largo del citado río al que dan nombre, dan paso a despoblados o, cuanto menos, a una notable disminución de efectivos.

$\mathrm{Al}$ tiempo que se suceden estas crisis internas en Al-Andalus, y, aprovechándose de ellas, los núcleos cristianos del norte, libres de la presión militar y poblacional musulmana, inician una progresiva ocupación de los valles cercanos y tierras próximas. En lo que a las tierras meseteńas respecta, la ocupación y posterior repoblación parte del reino astur. Ordoño I (850-866) extenderá su reino al sur de la Cordillera Cantábrica, repoblando las tierras de Astorga y León. Alfonso III (866-910) dominará y fortificará el espacio al norte del Duero. Sahagún, Zamora, Toro, Simancas y Tordesillas protegerán, entre otros enclaves, la llegada y asentamiento de pobladores venidos del norte junto a elementos mozárabes que se integran, junto con los anteriores, formando la base de una nueva sociedad y otorgando personalidad jurídica a la repoblación cristiana.

La llegada de colonos y repobladores cristianos generó, no obstante, tensiones con la población autóctona. Un ejemplo cercano que trata de evitar estas dificultades fue la permuta que el mencionado rey Alfonso III llevó a cabo en el año 909 con Sarracino, Falcon y Dulquito sobre Alkamín, enclave inmediato a Tordesillas ${ }^{152}$. Todo parece indicar que el río es superado y los colonos van ocupando las tierras de Medina, Portillo e Íscar en las siguientes décadas. Pero la vida no iba a ser fácil a estos primeros pobladores. Superados los conflictos internos, Adb al Rahman III (912-961), proclamado califa, lleva a cabo distintas expediciones contra los reyes cristianos del norte ${ }^{153}$. Las crónicas dejan una estela de desolación y ruina al paso de sus ejércitos. La empresa del año 938 para poner fin al atrevimiento cristiano será relatada por Al Razi, contemporáneo de la aceifa ${ }^{154}$.

${ }^{152}$ VILLAR GARCÍA, L. M.: La Extremadura Castellano-leonesa. Guerreros, clérigos y campesinos (711-1252). Consejería de Educación y Cultura, Junta de Castilla y León, Valladolid, 1986, pág. 63.

${ }^{153}$ Adb al Rahman III impondrá su poder pacificando las rebeliones y reforzando su autoridad religiosa con la adopción del título califal de "Príncipe de los Creyentes." Su fortaleza le llevará a iniciar expediciones contra los reyes cristianos del norte. En cuanto a la incursión que nos afecta, ampliamente debatida por los historiadores, se estima que siguió la tradicional ruta romana desde Somosierra hasta entrar por tierras segovianas en territorio repoblado por cristianos en el sureste vallisoletano.

154 “Al-Nasir il Din Allah penetró con sus tropas en territorio enemigo, recorriéndolo unos días de etapa en etapa, siguiendo el itinerario acostumbrado, destruyendo sus bienes hasta que bajó sobre M.d.m.h. (¿Olmedo?-¿Medina?) el jueves a cinco pasados de Sanwal del ańo mencionado (25 julio); se la encontró desierta, ya que habían huido sus gentes, abandonándola llena de riqueza y víveres. Los musulmanes saquearon todo esto aunando sus esfuerzos para destruirla (igualando lo alto con lo bajo) arrasándola totalmente. Hallaron en sus mazmorras cierto número de cautivos musulmanes que pusieron en libertad. Permanecieron allí los musulmanes dos días, trasladándose luego al Hins Skr (castillo de Íscar) que fue hallado abandonado, lo arrasaron y asolaron las propiedades de sus gentes. Desde allí marcharon al Al Qasrayn (Alcazarén) donde talaron sus panes, trastocaron sus mojones y borrarn sus vestigios. Desde allí marcharon a la etapa que está sobre el río Yiqah (Cega) de ahí a Hisn Burtil Asim (castillo de Portillo). Esto fue el viernes 13 de Jauwal (2 de agosto) y los musulmanes empezaron a usar las moradas de sus gentes...”. CHALMETA, P.: Simancas y Alhandega, Hispania, XXXVI, 132, págs. 364-369. 
Sin embargo, la fortaleza de Simancas, defendida por leoneses, castellanos y navarros, bajo la tutela del rey leonés Ramiro II, resiste en 939. O, al menos, de acuerdo a las distintas fuentes, el resultado pareció incierto a unos u otros. Aprovechando el puente romano como si se tratara de su mismo brazo, es posible que alentara la ocupación de tierras más al sur, pero sus esfuerzos son vanos. Los ejércitos de Almanzor la toman y saquean en 983. Pocos pobladores se aventurarán a levantar poblados hasta que muera el victorioso caudillo en el año 1002.

Nos encontramos en estas fechas en una especie de frontera invisible, de tierra de nadie, expuesta a mil peligros, pero también llena de incentivos. Los reyes castellanos, una vez descompuesto el califato de Córdoba en 1031, inician una decidida expansión hacia el sur. Alfonso VI de Castilla (10721109) toma Toledo en 1085. Las tierras que van dejándose atrás deben ser pobladas para asegurar la retaguardia de las nuevas fronteras. El arado debe hacerlas producir fruto y los ganados, multiplicarse con sus pastos. Las tierras de sembradura y las vinnas comenzarán a dibujar un paisaje agrario desde el primer momento. Sólo así los reinos podrán poblarse, consolidarse y fortalecerse. Pero para ello son indispensables los hombres. Se alienta su llegada desde las más pobladas tierras del norte mediante leyes y dictados que otorgan privilegios y propiedades. Fernando I, rey de León, cuando refiere el límite sur de la diócesis palentina que se extiende por estas áreas, cita nuevamente a Portillo, Simancas y Tordesillas entre otros lugares. Todo parece indicar que, desde mediados del siglo XI, grupos de pobladores vuelven a asentarse en estas tierras desde las villas cabeceras, que actúan como cabezas de puente con las tierras al sur del Duero.

Desde Portillo, el conde Martín Alonso, teniente de su castillo en 1074, también dirige la ocupación hacia estas tierras de Olmedo y Medina ${ }^{155}$. La fortaleza de los reinos cristianos anima la llegada de otros pobladores. Caballeros villanos, bajo dirección real y nobleza de mayor rango premiada por sus servicios a la corona, dirigen y organizan jurídicamente estas nacientes Comunidades de Villa y Tierra, fundamentalmente desde el reinado de Alfonso VI. La toma de la taifa de Toledo en 1085 inicia una etapa en la que numerosos colonizadores, bien alentados por los poderes nobiliarios y religiosos, bien de forma espontánea, van ocupando las tierras que hasta entonces no estaban exentas de peligros. Con todo, se estima que la Tierra de Medina ya estaba parcialmente colonizada antes de la caída de Toledo ${ }^{156}$. A pesar de no disponer de documentación escrita y sin poder precisar fecha exacta, es muy posible que, a lo largo de este siglo XI, comenzaran a levantarse las primeras casas y se diera nombre a lugares como La Moya, San Martín del Monte, Serrada, La Seca, La Perdiz o Zofraga. En abril de 1144 esta última villa realenga, en territorio de Medina, será donada por el emperador Alfonso VII, su mujer Berenguela y su hijo Sancho a la Sede eclesial salmantina y a su obispo Berenguer ${ }^{157}$. Ya por entonces se anotaban viñas en estas tierras de Rueda y la forma en que los eclesiásticos alentaban su cultivo: "Et qui nostram hereditatem plantauerit uineam, quando fuerit criada, habeat ibi sua medietad”. El obispo de Salamanca otorgará fuero a Zofraga en 1177, para diferenciarla jurídicamente del resto de los lugares ${ }^{158}$.

No tardaron en surgir las ambiciones por el control jurídico de sus tierras, pastos y hombres. Raimundo de Borgońa puebla la tierra de Olmedo hasta aproximarse al Zapardiel; Medina ansiaba llegar al Duero; Tordesillas, controlar los pequeños lugares al sur del histórico río. La inestabilidad que se vive durante la minoría de edad de Alfonso VIII no contribuye a calmar los ánimos entre las

${ }^{155}$ RUIZ ASENCIO, J. M.: "Medina del Campo en la Alta Edad Media (siglos VIII-XIII)", en Historia de Medina..., ob. cit., pág. 131 y ss.

${ }^{156}$ VILLAR GARCÍA, L. M.: La Extremadura Castellano-leonesa..., ob. cit., pág. 110.

${ }^{157}$ MARTÍN, J. L. (dir.): Documentos de los Archivos Catedralicio y Diocesano de Salamanca. (Siglos XII y XIII). Universidad de Salamanca, 1977, pág. 95-96 y Gonzalo Martínez: Las Comunidades..., ob cit., pág. 529.

${ }^{158}$ GONZÁLEZ DÍEZ, E.: El régimen foral vallisoletano. Diputación Provincial de Valladolid, 1986, pág. 75. 


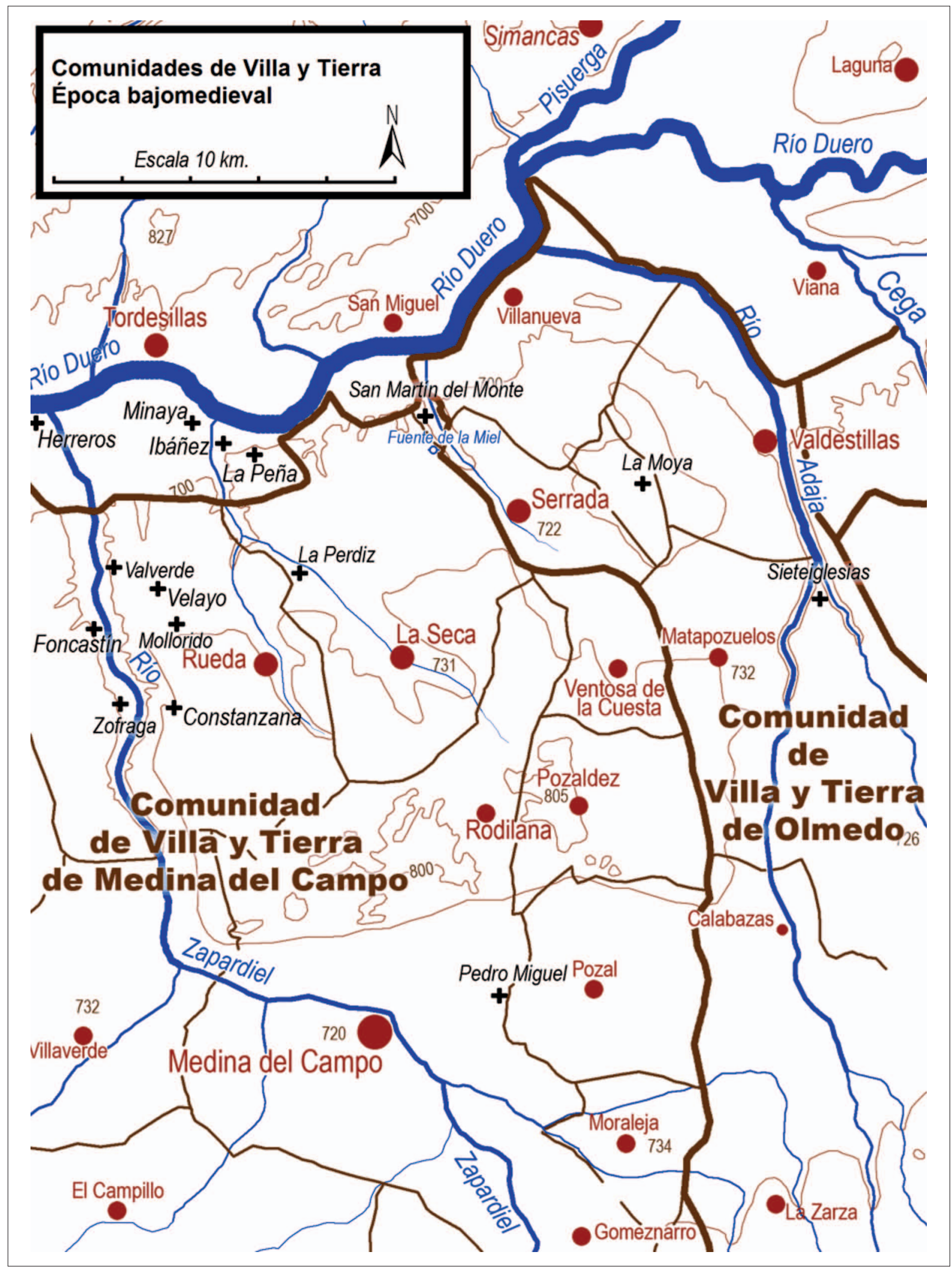

Figura 16. Limites y emplazamientos de los poblados cristianos al norte de la Tierra de Medina. Época bajomedieval. Las villas cabeceras pleitearon lo indecible, siglo tras siglo, por controlar hasta la última aldea de su término. Si al norte y este de la comarca se han señalado o se analizarán algunos ejemplos, al sur y al oeste suceden conflictos similares. Obsérvese los despoblados existentes en los términos de poblaciones que han llegado a nuestros días, fruto de la evolución histórica que tratamos. 
distintas jurisdicciones. Los pleitos entre términos seguirán durante siglos ${ }^{159}$. En 1258 Alfonso X pondrá fin a tantas desavenencias, pero una cosa es segura: por estas fechas, campesinos y ganaderos de diverso origen llevaban varias generaciones afanándose en dominar el terrazgo que se extendía al sur del Duero. Sirvan como ejemplo el nacimiento y vicisitudes de tres lugares al norte de la llamada Tierra de Medina, inmediatos al sur del Duero y tan dispares como interesantes por su evolución posterior. Se trata de La Moya, Serrada y San Martín del Monte.

\title{
- La Moya, una heredad en territorio de Septem Ecclesias, al norte de la Tierra de Medina
}

Como se acaba de referir, desde los inicios del siglo XI se tiene constancia de la existencia de poblaciones o heredades cristianas que serán permanentes en los siguientes siglos. La Moya es una de ellas. Cuando Sancho III el Mayor erige la diócesis palentina en 1035 y fija sus límites, cita tierras y términos claves en el proceso estudiado ${ }^{160}$ :

\begin{abstract}
"Et do alia parte ubi gignit amne Pisorice et uadit usque ad castrum Pennafidelis el ipsum castrum cum terminis suis antiquis et Portellum cum terminis suis antiquis et Septem Ecclesias cum terminis suis antiquis usque ad flumen Duris".

(Y doy otra parte donde nace el río Pisuerga y fluye hasta el pueblo de Peñafiel y el pueblo mismo con sus antiguas tierras y Portillo con sus antiguos términos y Siete Iglesias con sus antiguas tierras hasta el río Duero)".
\end{abstract}

Septem Ecclesias o Sieteiglesias se configura, desde estas tempranas fechas, en un enclave de importancia, situado en la confluencia del Adaja y el Eresma. Su posición en un enclave históricamente estratégico se encuentra, además, a medio camino exacto entre Simancas y Olmedo, a escasas tres leguas y cuarta de cada uno de ellos $(18 \mathrm{~km})$. En este mismo siglo XI parece ocuparse, de forma permanente, tanto Olmedo como las tierras de Medina del Campo, Íscar, Coca y Cuéllar ${ }^{161}$. En la fijación de límites que el rey Fernando I hace en 1059 de la diócesis palentina, todo parece indicar que Septem Ecclesias estaba integrado en estas fechas por Simancas o Portillo antes, quizá, de la repoblación de Olmedo y al sur del límites de la diócesis: “...Tarego, leo Ceuic, Couellas, Castrouert, Corel, Pennafidel, Mamblas, Cabezon, Portello, Septemancas, Oter de Sellas, Tronco (Trabanco), Mozot (Mazote)”'162. En relación con ello, casi un siglo después, en 1143, el papa Inocencio II ratifica las donaciones efectuadas a dicha sede. Entre otros muchos lugares aparecen, siguiendo una continuidad geográfica "Portello, Septem Ecclesias, Anaiago, Sanctus Michael de Maluauisco, Sepmancas, Oterdesellas,... "’63.

${ }^{159}$ Un ejemplo es la pretensión del concejo de Toro sobre los límites y derechos de los concejos de los nueve villas de Valdeguareña, adscritas a la orden de San Juan: Cañizal, Fresno, Fuentesaúco, Fuente la Peña, La Bóveda, Tarazona, Torrecilla, Vallesa y Villaescusa. En 1487 el Comendador se enfrenta al concejo de Toro sobre "razón de çiertos términos de la dicha çibdad de Toro, sus partes questán cabe la villa de Torrecilla de la Horden de San Juan quel dicho Comendador dize ser suyos...” (A.G.S. R.G.S. Tordesillas, 26 de marzo de 1487, fol. 83, citado por GONZÁLEZ SÁNCHEZ, V. Fresno el Viejo..., ob. cit., pág. 14). En otros casos los pleitos se enquistan en relación con los apartamientos concedidos. Cuando Enrique IV entrega Alaejos al obispo Fonseca en 1452 le hace donación también del término de Villar "sobre que fasta agora hera y es contienda y debate entre la my villa de mdina y el dho lugar de alahejos el qual dho termyo del villar en sus..., tierras y pastos y... aguas (en el caso) que perteneciese o pertenezca ala dh. ${ }^{a}$ my villa de medina yo lo hesimo de l. ${ }^{a}$ my villa de medina y su tierra. (A.R.Ch. V.: P.C. Fenecidos, Pérez Alonso, C. 1004-1, citado y transcrito por OJEDA NIETO, J.: Alaejos..., ob. cit., pág. 15).

${ }^{160}$ MARTÍNEZ DÍEZ, G.: Las Comunidades de Villa y Tierra de la Extremadura Castellana. Editora Nacional, Madrid, 1983, pág. 516.

${ }^{161}$ La repoblación de todas estas plazas es atribuida, de acuerdo con varias fuentes escritas, al rey Alfonso VI (10721109). Ibídem, pág. 516, citando, en este sentido, a Lucas de Tuy (Chronicon mundi, ed. Schott, Hispania Ilustrata, t. IV, pág. 101), y Rodrigo Jiménez de Rada (De rebus Hispaniae, 6, 22, ed. Lorenzana, pág. 136).

162 Ibídem, pág. 516.

${ }^{163}$ ABAJO MARTín, T.: Documentación de la Catedral de Palencia (1035-1247), Fuentes Medievales Castellano Leonesas, Palencia, pág. 41, (A.C.P., arm. 3, leg. 8). 
En 1146 el citado rey dona a la diócesis el diezmo de todos los derechos reales que poseía en estas tierras ${ }^{164}$. Entre los distintos lugares de cabecera se encontraba Septem Ecclesias y, dentro de la misma, las heredades de La Moya. En el año 1158 la infanta dońa Sancha, hija del conde Ramón de Borgońa y de la Reina dońa Urraca, hermana del Emperador Alfonso VII, dona dicha heredad y sus términos a la Santa Colegiata de Valladolid ${ }^{165}$ :

"Dios es el sumo bien del cual proceden todas las cosas buenas. Bajo su nombre yo, Sancha, hija del conde Raimundo y hermana del Emperador Alfonso, me pareció bien dar la Moia a la Iglesia de Santa María de Valladolid y al Abad Miguel y a los clérigos que sirven allí a Dios. Con compromiso para que allí siempre se haga memoria de mis padres y en el aniversario de mi hermano el Emperador Alfonso. Esta heredad arriba nombrada, es decir, la Moia, situada en el territorio de Semptem Ecclesias.

Concedo a la antes dicha Iglesia Santa Maria de Valladolid con todas sus pertenencias, salidas y entradas, pastos, montes, sernas y libero de mi dominio totalmente ahora y por siempre. Yo la reina Sancha mande hacer esta carta y por mi mensajero, es decir, Pelayo Pérez, mande enviar en mano del Abad Miguel y con mi mano este signo como confirmación.

Dada la carta con esta heredad arriba nombrada el dia 15 de las calendas de marzo de la era 1196. (Año 1158). Y si alguno viniera, o yo mismo viniese a romper esta donación, sea maldito y excomulgado y separado de la Santa Madre Iglesia y llore en el infierno con Júdas el traidor. Estos son los que lo vieron y oyeron: Muño González, Pedro Ibáneez, Domingo Esteban, Román Pérez, Pedro Comeso, Adrián Gordo, Adrián Adriánez, Rostrudo, Martín López del Templo, de los clérigos Arnaldo, prior, Domínguez Ibáñez, sacristán, Juan Cantor, Don Cipriano."

En la carta de donación se refieren pastos, montes y sernas, aunque nada manifiesta sobre si el lugar se encontraba poblado en aquel tiempo. Nos encontramos en unos momentos de articulación del territorio, tanto jurídico como de explotación de los recursos existentes en estos espacios montaraces al sur del Duero. Incluso, cuando las fuentes documentales conservadas son más explícitas, son sumamente simples y escuetas. En el fuero de Zofraga, sin embargo, "iuxta Zapardelum rivum sitam”, a pocas leguas al suroeste de La Moya y Serrada, fechado en 1144 y por el que Alfonso VII aumenta el patrimonio de la sede episcopal de Salamanca, se constata el inicio de una organización jurídica y agrícola del terrazgo. En el documento se fijan los quińones que recibirán los pobladores, las prestaciones que han de realizar al señor en concepto de sernas o procuraciones e, incluso, el esquema de gobierno y derechos penales vigentes en un territorio que se remite judicialmente al fuero de Medina del Campo: "pro homicidio, pro rapina et pro furto faciatis secundum forum de Medina"166.

${ }^{164}$ MAÑUECOS VILLALOBOS, M.: Documentos de la Iglesia... de Valladolid, siglos XI y XII. Valladolid, 1917, pág. 222.

165 A.G.D.V. Archivo catedralicio. Leg. 37, no 43, (ant. sig: Leg. 10, no 58). Trascripción de Jonás Castro Toledo: Documentos de la Colegiata de Valladolid.

166 Fueros y Cartas Pueblos de Castilla y León. El Derecho de un pueblo. Junta de Castilla y León. Salamanca, 1992, pág. 32-33. Por la importancia del citado fuero de Zofraga trascribimos su texto:

1177, Medina del Campo. In nomine Domini nostri Ihesu Christi.

Ego Vitalis, per gratiam Dei Salamantinus episcopus, do et concedo uobis Concilio de Suffraga et uestris successoribus forum quod habuistis in tempore predecessoris mei domni P., tunc salamantini episcopi postea acobitani archiepiscopi, ut scilicet:

[1] Pro homicidio, pro rapina et pro furto faciatis secundum forum de Medina.

[2] Et habeatis per forum II alcaldes et unum excusatum et unum iudicem; et excusatum baraget la uoz del senior et iudicem prende.

[3] Quando in Medina Rex terre iactabit pectum per fossatoria, uos dens mihi meisque successoribus tantum quantum dimidiam partem dederit el postern de Medina per fossatoria et non per alterum pectum.

[4] Singulis annis faciatis mihi tres obras: unam ad arandum, alteram ad seminandum, terciam ad triturandum.

[5] Unam mihi ac successoribus meis annuatim dens procurationem.

[6] Habeatis per forum los posterns dos dos [sic] quinnones: singulos ex partem aldee et singulos de utraque pane del rio; et uestros ortos.

[7] Et qui nostram hereditatem plantauerit uineam, quando fuerit criada, habeat ibi sua medietad. 

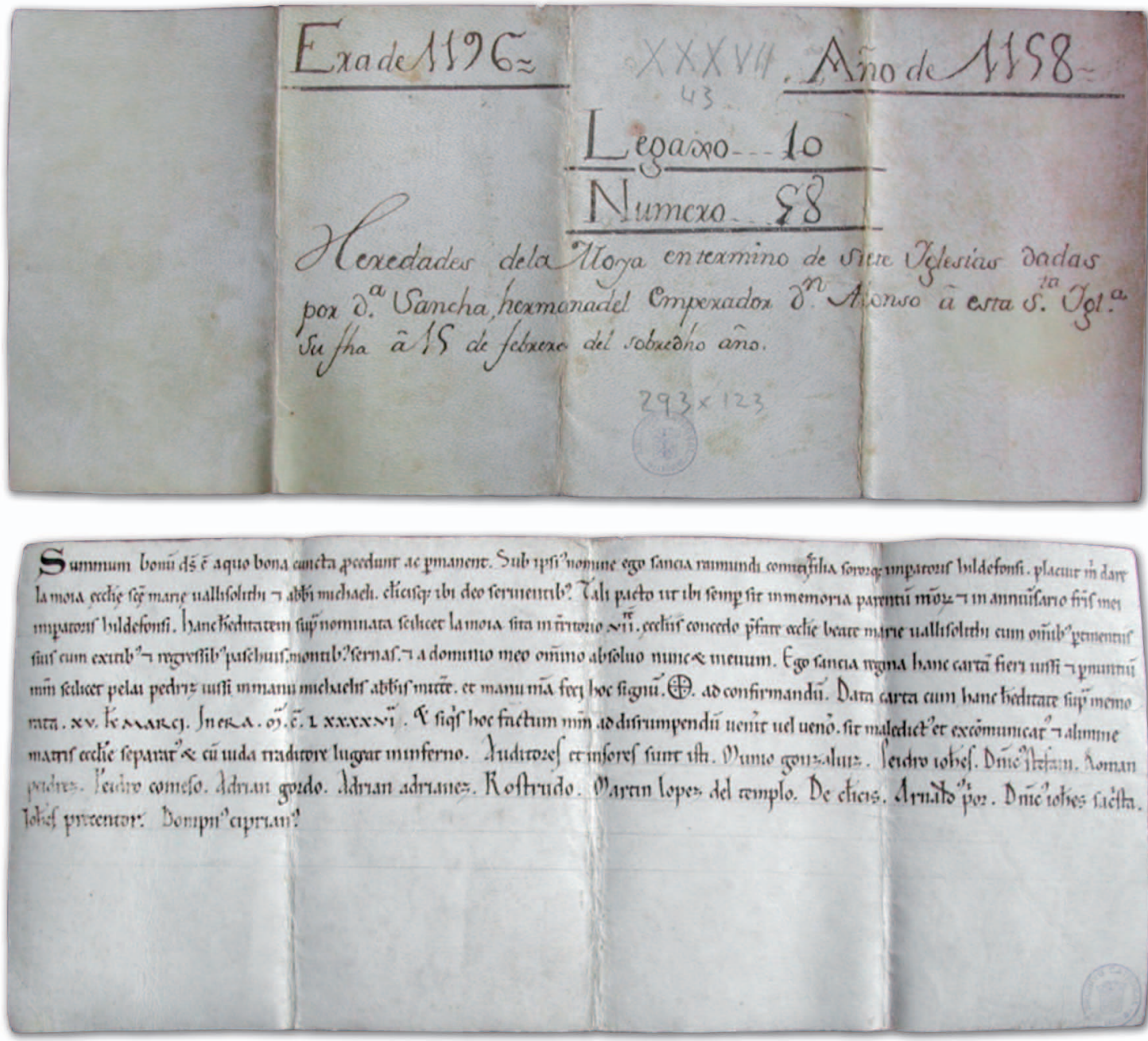

Imagen 32. Anverso y reverso del documento de donación de la heredad de La Moya, año 1158, (A.G.D.V.). Foto: $03 / 05 / 2005$.

Sin infravalorar a Serrada y a San Martín del Monte que, como La Moya, es más que posible que iniciaran su andadura por aquel tiempo, lo que parece fuera de toda duda es que Semptem Ecclesias testimonia un temprano recorrido en el tiempo ${ }^{167}$.

[8] Et si in laboribus nostris dampnum feceritis, nostrum iudicem recipiat pignus de uobis et uos steteritis a directo ante uestros alcaldes.

[9] Et alcaldes et iudicem et excusatum sint excusatos que non pectent.

[10] Et quando feceritis nobis nostras ser[nas] dent vobis ad manducandum panem et uinum et carne de carnero et carne de porcho; et si in tempore quadragesimale euenerit, dent uobis piscato.

[11] Et por enforcion detis mihi Ia emina de ceuada et media emina tritici et tres panes per Nathal.

Facta fuit autem hec carta Medine, era $\mathrm{M}^{\mathrm{a}} \mathrm{CC}^{\mathrm{a}} \mathrm{XV}$.

http://humanidades.cchs.csic.es/ih/paginas/fmh/zofraga.htm. Fecha 6/09/2014.

${ }^{167}$ Los vecinos de Matapozuelos han peregrinando durante siglos a su ermita de Sieteiglesias, sita sobre el antiguo poblado de Semptem Ecclesias, situado entre la confluencia del Adaja y Eresma, lugar, por otro lado, sobradamente conocido por albergar importantes asentamientos prehistóricos. Los más devotos atribuyen también al lugar un carácter eremítico. Sin atrevernos a tanto, es seguro que estos pagos ribereńos, que seguían la vía romana que llegaba a Simancas, fueron madrugadores a la hora de levantar sus primeras casas e iglesias. El hoy despoblado de Brazuelas, cerca del río, por la Cobatilla, y la Moya, es posible que iniciaran su andadura en tiempos parejos. Estamos hablando de tiempos muy pretéritos, con escasas fuentes donde contrastar hechos. 


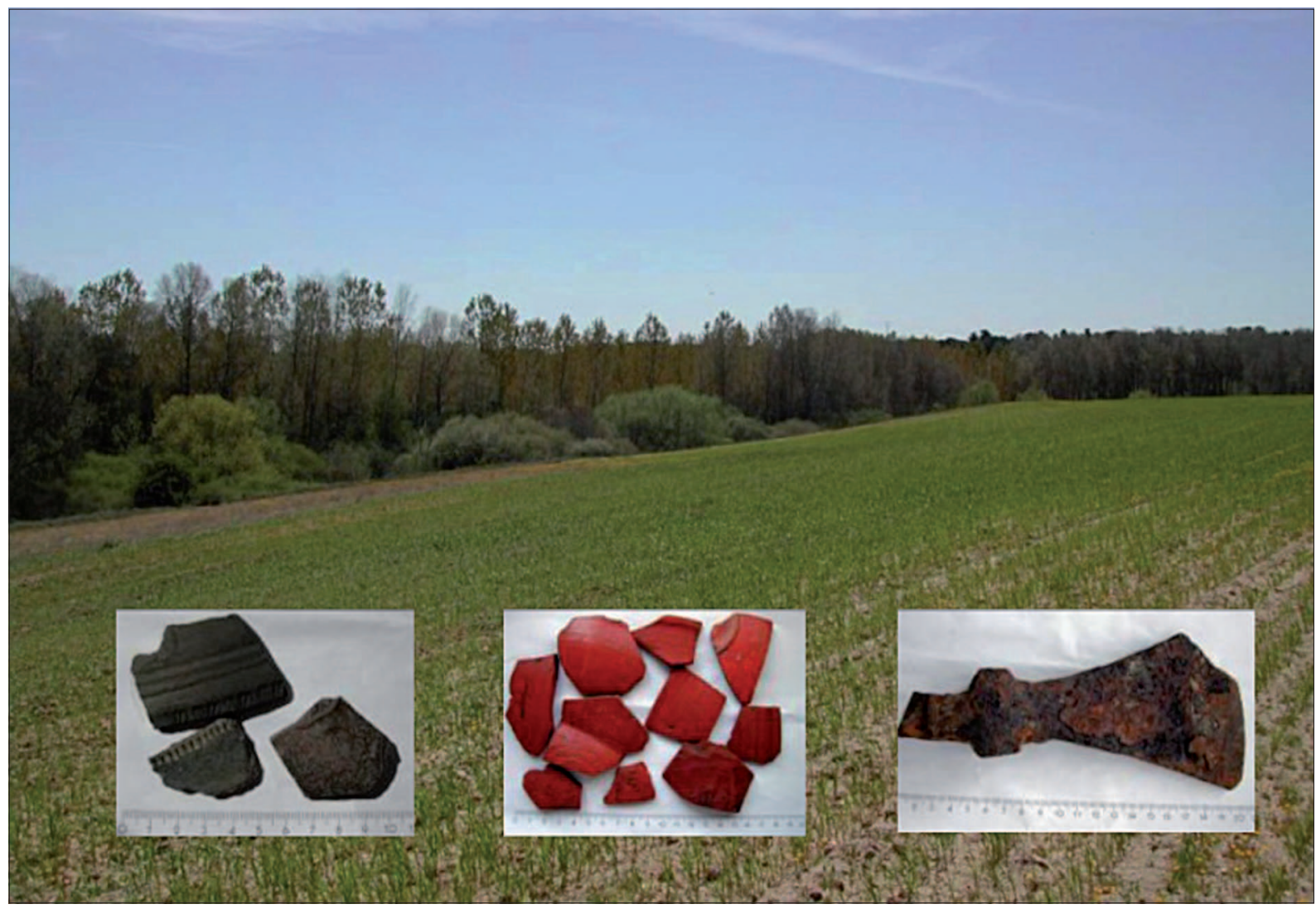

Imagen 33. Vista aproximada de la localización de Semptem Eclesias, en la confluencia del Adaja y Eresma. Su ubicación, entre ambos ríos, fue un paso estratégico para entender la ocupación humana desde tiempos prehistóricos hasta la repoblación cristiana en el norte de la Tierra de Medina. Imagen de localización y materiales prospectados: cerámica prerromana (izquierda); terra sigilata (centro) y hacha de hierro (derecha), indeterminado. Foto: paisaje, junio de 2005; restos, junio-agosto de 2005).

Llama la atención las coincidencias de numerosos núcleos de poblamiento prehistórico o prerromano con estos incipientes núcleos cristianos bajomedievales. La vertebración del territorio por antiguos caminos y vados naturales, así como la cercanía de fuentes, ríos y arroyos, ha sido desde tiempos remotos atractivo para el asentamiento humano y el aprovechamiento de recursos. Aunque la marea repobladora se extiende como una mancha de aceite al sur del Duero en estos siglos, los poblados de Tordesillas, Simancas y Toro, en las márgenes del citado río, Zofraga a la vera del Zapardiel, Siete Iglesias en la confluencia del Adaja-Eresma o La Perdiz, San Martín del Monte y Serrada en los bordes de arroyos, testimonian esta repetición del interés de los hombres por unas similares ocupaciones del espacio.

En lo que respecta a La Moya, como puede apreciarse en la siguiente imagen, las labores agrícolas han hecho aflorar restos de fragmentos calcáreos irregulares que, a buen seguro, fueron traídos por los primeros pobladores desde la superficie de páramos de Sepmancas. Aparecen dispersos por una toponimia evocadora de su ocupación: Las Cruces, los Ranchos, los Paredones, la Ermita, la propia Moia... La dispersión en pagos, que abarcan varios kilómetros cuadrados, lleva a pensar que se trata de restos de las primeras edificaciones cristianas, que tienen a La Moya como núcleo principal de poblamiento. Sea como fuere, el caso es que los vestigios remiten a tiempos muy remotos ${ }^{168}$.

${ }^{168}$ En lo que respecta al poblado de La Moya, se debe destacar su emplazamiento intermedio entre Serrada y la referida Septem Ecclesias (coordenadas 410 28 “2” N y 40 49’ 26” O), junto a la cańada de Buena Vista, que enlaza tres kilómetros más al sur con la cañada de Las Merinas o cordel de Salamanca a Valladolid. Es preciso anotar que, si bien por estas fechas no existía la cańada como tal, el trazo viario sería hoyado por hombres y bestias para comunicarse entre los núcleos habitados en las diferentes épocas en que se ha constatado presencia humana. 
Con el discurrir del tiempo, todo parece indicar que la pérdida de vitalidad de Septem Eccesias y la influencia y pujanza de Olmedo situará a la Moya bajo su influencia ${ }^{169}$. Eclesialmente, dependerá del arciprestazgo de Portillo y de la diócesis palentina.

En este contexto, es muy posible que colonos o renteros, procedentes de la referida Semptem Eclesias, desbrozaran los montes y matorrales e iniciaran el cultivo de trigo y cebada al tiempo que plantaban las primeras vińas, seguramente posteriores a la carta de donación, que las omite: “...pastos, montes, sernas". El levantamiento de edificaciones y su constitución con entidad propia, dependiente del citado poblado, les exigía el pago de diezmos y cargas tanto al señor del castillo de Semptem Eclesias, vasallo del rey Sancho III, como a la diócesis palentina erigida por el mencionado monarca. A lo largo del siglo XII, la pujanza de Olmedo, como núcleo cabecero, extiende su jurisdicción y provocará que La Moya y Serrada se integren en su Comunidad a efectos civiles y fiscales, siendo su corregidor quien nombre alcaldes y autoridades. Los rendimientos, escasos de por sí en aquel tiempo, serían aún menores en estos pagos donde son amplias las superficies de mediocre calidad, hecho que se agravaría por la escasez de arroyos necesarios para el ganado en años de sequías prolongadas. Como señala el profesor Villar García, cada aldea se corresponderá con un territorio y estos elementos forman parte de una misma definición entre quienes pueblan y explotan el espacio ${ }^{170}$.

En el caso que nos ocupa, esta vida agrícola y pastoril no iba a derivar, transcurridos los siglos, en una mayor pujanza de esta aldea de La Moya. No se constata un aumento del vecindario o noticias de bonanza en este lugar olmedano. Todo lo contrario. La economía de sus pobladores rayaba en la mera subsistencia, una vez detraídas de sus rentas los diezmos y gravámenes a que estaban obligados. La Moya, como todas las aldeas nacientes en estas Comunidades de Villa y Tierra, estaba sujeta al arbitrio de una política de donaciones, ambiciones y cambios entre señores y reyes. En este sentido, la importante familia de los Fonseca, acaparadores de cargos, obispados y regidurías en buena parte de la Castilla isabelina y carolina, iba a dejar sentir su influencia en estas tierras. El monasterio de La Mejorada de Olmedo se verá beneficiado por la cesión de juros y donaciones de tan acaudalada familia. La reina Juana eximirá de huéspedes a Juana de Fonseca, según carta de privilegio fechada en Tordesillas en 1517 donde se exime también a sus renteros de la Moya, evidencia de las numerosas propiedades que detentaba en estos lugares ${ }^{171} / 172$ :

"Carta de privilegio en que la Reina doña Juana confirma una su provisión real eximiendo de huéspedes a Hernando de Vega (de la Cámara del Rey), y a su mujer dońa Juana de Fonseca, en las villas de Tordesillas y Olmedo, y a sus renteros en los lugares de La Moya, Valdestillas, Matapozuelos, Velilla, Villavieja, Villamar y Bercero”. Sevilla. 2 de junio 1511. Traslado en Tordesillas, 21 de octubre 1517”.

No será fácil a sus vecinos la vida pese a encontrase a la vera de rutas sobradamente holladas en aquel tiempo. Se cree a sus primeros ocupantes más ganaderos que labradores y, a tenor de la documentación consultada, más renteros que propietarios a lo largo de los siglos en que el lugar estuvo poblado.

\footnotetext{
${ }^{169}$ La Comunidad de la Villa y Tierra de Olmedo, a la que pertenecerá el poblado de La Moya y el lugar de Serrada, se organizaba en torno a la citada villa y sus iniciales lugares que formaban su alfoz: Aguasal, Almenara, Bocigas, Fuente Olmedo, Llano de Olmedo, Puras y La Zarza. En torno a este núcleo inicial se disponían, al norte y al sur, los restantes pueblos entre los que se encontraban en su sector noreste, Serrada, Villanueva de Duero, Valdestillas, Matapozuelos, Villalba de Adaja y Ventosa de la Cuesta. Como se puede apreciar en el mapa adjunto, el Adaja y el Duero al norte fijaban el límite con la Merindad del Infantazgo de Valladolid; al este se extendía la Comunidad de Villa y Tierra de Portillo, la villa episcopal de Mojados y las Comunidades de Íscar y Coca; al sur, las tierras olmedanas limitaban con las de Coca y Arévalo y al oeste, la amplia Comunidad de Villa y Tierra de Medina.

${ }^{170}$ VILLAR GARCÍA, L. M.: La Extremadura Castellano-leonesa..., ob. cit., pág. 309.

${ }^{171}$ BLANCO SÁNCHEZ, A.: Sobre Medina del Campo y la reina agraviada. Colección caballeros de la Hispanidad, no 1, pág. 246 y ss. Medina del Campo, 1994.

${ }^{172}$ A. G. S. Patronato Real. Catl. II, 125 y 126, ob. cit., pág. 246.
} 


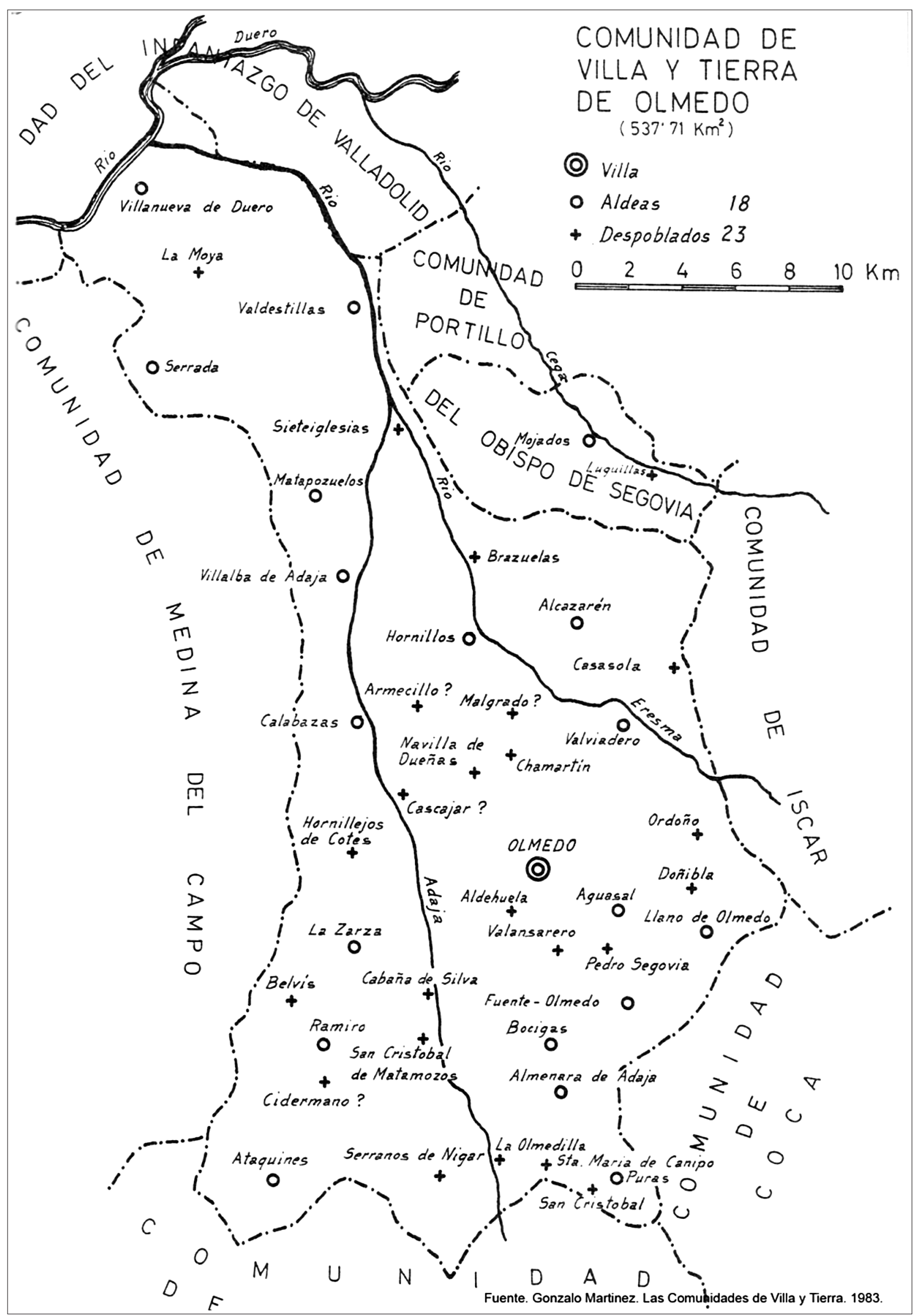

Figura 17. Comunidad de Villa y Tierra de Olmedo. Gonzalo Martínez Diez, 1983. La organización política de la Extremadura castellana, en las tierras tomadas a Al-Andalus en los siglos XI y XII, se basaba en estas Comunidades de Villa y Tierra, donde el concejo de la villa cabecera tenía competencias sobre el poblamiento y el ordenamiento jurídico de las aldeas pertenecientes a su territorio. 

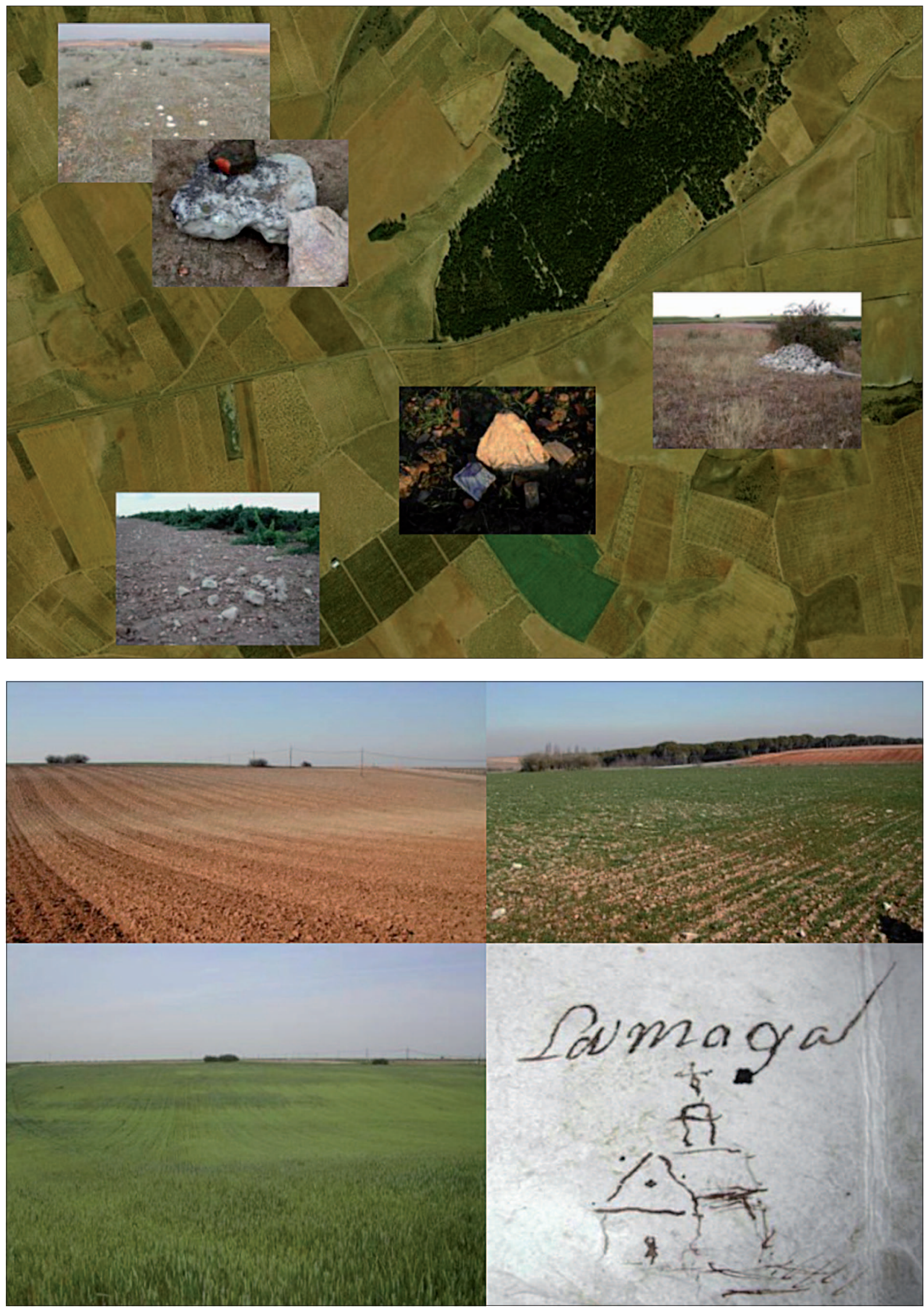

Foto aérea y localización de restos en el Despoblado de La Moya. Fuente: Junta de Castilla y León. Fotografías de restos: año 2005.

Imagen 34. Ubicación del antiguo lugar poblado y restos de edificaciones en La Moya. Imagen superior: vuelo J. C. y L., 1999; restos: foto, junio de 2005). Imagen inferior: Terrazgo sobre el que se alzaba el lugar, restos y dibujo de su iglesia en el año 1675. Fotos superiores: abril de 2004 y primavera de 2005; Foto inferior: dibujo, Privilegio de villazgo de Serrada, (A.M.S.) 


\section{- Serrada, una aldea en los confines de la Tierra de Olmedo}

Cercana a la Moya, Serrada nace, igualmente, inmersa en esta encrucijada de ambiciones entre Tierra de Olmedo y Tierra de Medina. A la primera pertenecían los lugares de La Moya y Serrada y, a la segunda, San Martín del Monte ${ }^{173}$. Como en el caso de La Moya, "La Serrada" se puebla, posiblemente, a partir del siglo XI, localizándose el asentamiento en un cruce de caminos, transitado con anterioridad. A casi medio camino entre Valladolid y Medina, en el camino que llevan los de Olmedo y Matapozuelos a Tordesillas, a la vera de un arroyo que riega abundantes pastos y linda con fértiles tierras. He aquí el secreto de un éxito que no disfrutó La Moya. Dejando estos aspectos al margen, las similitudes son numerosas: espacios abiertos ocupados por montes degradados de retamas y encinas, población campesina, apenas propietaria, sujeta a los vaivenes de las donaciones laicas y eclesiásticas y donde, caso de Serrada y San Martín, pasan de ser lugares de realengo a poder señorial y eclesiástico, respectivamente.

Como en tantos otros lugares de estas Comunidades de Villa y Tierra, además de las obligaciones de pago de foros y rentas a sus respectivos señores, los pobladores habían de aceptar la reglamentación de sus poblaciones cabeceras en lo tocante a cortas de madera y retamas, pastoreo de tierras comunales, permisos para efectuar roturas de sembradura o plantación de vińas..., sin olvidar las obligaciones religiosas y, particularmente, el diezmo ${ }^{174}$. En el Libro Becerro de Beneficios que guarda el Archivo Catedralicio palentino, fechado de 1346, no se refieren solamente los numerosos poblados vecinos tratados, sino el abultado número de clérigos que servían en sus parroquias y los diezmos que estas debían recabar y partir. Se puede leer en el citado pergamino ${ }^{175}$ :

"En La Serrada en la eglesia de sanct Pedro deue auer un preste, dos graderos, que son con la media ración del cura dos raciones menos sesma.

E los diezmos deste logar pártense en eta manera

E aquí ay de estimación VII

En La Moya en la eglesia de santa María deue auer un preste, un subdiáchono, dos graderos, que son con la media ración del cura dos raciones e media sesma

E los diezmos deste logar pártense en esta manera

E aquí ay de estimación diez mrs X".

\footnotetext{
${ }^{173}$ A ello se deben añadir los cambios y jurisdicciones eclesiásticas sobre los citados lugares que nacían entre imprecisos límites. Ventosa de la Cuesta, por ejemplo, era una aldea de Medina, pero inserta en jurisdicción de Olmedo; Serrada, Valdestillas y Matapozuelos eran aldeas de Tierra de Olmed,o dependientes eclesialmente de Palencia e integradas en su arciprestazgo de Portillo; Villanueva de Duero, por citar todos los pueblos limítrofes, dependía religiosamente del arciprestazgo de Peńafiel. En Tierra de Olmedo, al igual que Serrada, se hallaba el ya mencionado poblado de La Moya, que pertenecía también al arciprestazgo de Portillo, integrado en el citado obispado palentino. San Martín del Monte, por su parte, figuraba en el elenco medianil de 1265 como una de las dieciséis parroquias medianas que alternaban anualmente entre las diócesis de Salamanca y Ávila. Aunque en el catálogo de 1458 no figurará, sí se anota en el computo paroquial solicitado por Felipe II como parroquia del vicariato de Medina, inserto en el obispado de Salamanca. En este último documento, San Martín del Monte figuraba con tan sólo 12 vecinos, al lado de otras parroquias del término de Medina como La Seca o La Perdiz, entre otras. (MARTÍNEZ DÍEZ, G.: La Comunidad de Villa y Tierra de Medina, en Historia de Medina..., ob. cit., pág. 159 y ss.)

${ }^{174}$ El diezmo, o la obligación de entrega por parte del campesino de la décima parte de los frutos recogidos a las iglesias y clérigos que las sirven sitas en cada lugar, constituirá una de las principales detracciones del ingreso campesino. Su regulación jurídica aparece recogida en las Siete Partidas que establecen "que de todos los frutos que los homes lievan de las tierras et de los árboles, también de las cosas que fueren sembradas como plantadas, et otrosí de los frutos de los ganados, et de las rentas de todas las otras heredades... que diesen los diezmos de todo entregamente..." (MARTÍN CEA, J. C.: El Campesinado castellano de la Cuenca del Duero (siglos XIII-XV). Junta de Castilla y León, Valladolid, 1986, pág. 64).
}

${ }^{175}$ A.C.P. Arm. 3. Trascripción en: Jesús San Martín Payo. Publicaciones de la Institución "Tello Téllez de Meneses." Centro de Estudios Palentinos, no 7, pág. 90. 
Obsérvese la similitud de servidores religiosos y la menor cuantía de estimación monetaria de Serrada respecto a La Moya, prueba de la importancia de esta última en aquel tiempo. Hasta entonces, sus escasos vecinos, que difícilmente pasarían de la decena, habrían iniciado la roturación de su feraz "Vega" para hacerla producir panes, y plantado, como en todos los lugares vecinos, las primeras cepas. El cultivo del cereal y el viñedo aparecen asociados desde el inicio de la repoblación en toda esta Extremadura castellana, alternando el espacio cultivado con otros vírgenes a cualquier aprovechamiento. El terrazgo conoce la entrada del arado conforme llegan pobladores y situaciones favorables de cosechas que incrementan la población en estos lugares. En 909, en la citada permuta de Alkamín, al norte de la Tierra, se refiere el espacio “tam cultum quam etiam et incultum” 176 y, en las roturaciones, el pan y el vino son la base de la alimentación. En el fuero de Zofraga, por ejemplo, en 1144, son estos alimentos, más la carne, los que reciben los campesinos al trabajar las sernas del señor: "Et quando feceritis nobis nostris sernas, dent vobis manducandum panem et vinum et carne"177. Villar García, en su estudio de la Extremadura Castellana, sostiene que el cultivo de cereales era el dominante, pudiendo multiplicar su superficie en siete u ocho veces la destinada al vińedo que, no obstante, parece crecer a partir de la segunda mitad del siglo XII ${ }^{178}$. En los siglos siguientes, las propiedades particulares de tierras de pan llevar, viñas, aceñas, bueyes, corrales, casas, bodegas o solares se repiten con profusión en cartas de ventas y donaciones y prueban, al margen de la mayor conservación documental, un incremento muy notable de la actividad económica en todas estas aldeas. Tomemos como ejemplo la referencia archivística de la venta de una casa sita en Valverde por su propietario, vecino de La Perdiz, en los términos de La Seca y Rueda ${ }^{179}$ :

“1377, abril, 26. Tordesillas.

Venta hecha por Martín Fernández, hijo de Juan Martín de Dueñas, y Marina González de Rueda, su mujer, vecinos de La Perdiz, aldea de Medina del Campo, al convento de Santa Clara, de una casa que tenían en Valverde, aldea de Medina, linderos las Iglesias de Santa Cruz y Santa María y la calle pública, en precio de 70 mrs Pasó ante Pedro Fernández".

Las épocas de sequías y hambrunas, junto con el peso de los impuestos, convertirán muchos de estos lugares en despoblados, antes, incluso, de que asomen los tiempos modernos. A muchos de sus vecindarios tan sólo les quedaba la protección divina: Santa María Magdalena en Mata Pozuelos; Santa María en Valdastiellas y en Brazuelas; San Pedro en La Serrada, San Salvador en Sepmancas... Por entonces todos sus habitantes, reunidos en concejos abiertos, nombran regidores, se reparten las tareas colectivas, se preocupan de tener asegurada la visita de algún cirujano sangrador, bien cumplidas las mandas piadosas, resueltas por vías amistosas mejor que por la justicia las diferencias con concejos vecinos y acordado, en fin, el pastoreo de los prados comunes adscritos a las Comunidades de Villa y Tierra a las que pertenecían, fueran de Medina, Olmedo o de las tierras del Infantazgo de Valladolid. Nos encontramos al comienzo de una larga andadura en que el campesinado, como es sabido, era el encargado de alimentar al resto de la sociedad. Una de las leyes incluida en "Las Siete partidas", obra magna de Alfonso X el Sabio (1221-1248) que recoge la tradición romana pero teniendo en cuenta la tradición operante en Castilla, así lo constata ${ }^{180}$ :

${ }^{176}$ CASTRO TOLEDO, J.: Colección Diplomática..., ob. cit., pág. 2.

177 VILLAR GARCÍA, L. M.: La Extremadura Castellano-leonesa..., ob. cit., pág. 353.

${ }^{178}$ Ibídem, pág. 354.

${ }^{179}$ CASTRO TOLEDO, J.: Colección Diplomática..., ob. cit., pág. 114.

${ }^{180}$ MARTÍN CEA, J. C.: El Campesinado castellano de la Cuenca del Duero (siglos XIII-XV). Junta de Castilla y León. Valladolid. 1986. Pág. 38, citando a "Las Siete Partidas del rey Don Alfonso el Sabio cotejadas con varios códices antiguos por la real Academia de la Historia”, Madrid, 1807, ed. facsímil de la Ed. Atlas, Madrid, 1972, tomo II, partida II, tít. XX, ley IV, pág. 193. 
"Criar debe el pueblo con muy grant demencia los frutos dela tierra labrÁndola et enderezándola para haberlos Della, ca desta crianza se ha de mantener la otra..., et Della se goviernan et se ayudan ellos et todas las cosas vivas...; et por ende todos se deben trabajar que la tierra do morasen sea bien labrada...; ca unos lo han de facer por sus manos, et otros que non lo supieren ó non les conveniere deben mandar commo se faga”.

De esta manera se sanciona y reglamenta el funcionamiento de obligaciones y deberes que regulará la vida de estas comunidades durante largos siglos. Las fanegas de trigo, cebada o pan mediado que comienzan a salir a centenares de estos lugares al sur del Duero, camino de Tordesillas, Portillo, Medina y Olmedo, como núcleos de residencia del estamento nobiliario o eclesiástico que las tutela, no hacen sino rubricar el modelo jurídico establecido. Los pechos, sin embargo, asfixiarán siglo tras siglo a unas comunidades rurales demasiado sobrecargadas de rentas, diezmos e impuestos ${ }^{181}$. Sus quejas pocas veces serán escuchadas. Como será común en todos los reinos en relación a la percepción y distribución de los diezmos, en la diócesis de Salamanca, a la que pertenecían Medina del Campo y los pueblos de su Tierra, el rey Alfonso IX ordena en fecha de 31 de diciembre de 1229 que los diezmos con sus tercias fuesen pagados en la misma era antes de ser recogidos, al igual que mandaba se entregasen los correspondientes a los de las viñas y otras heredades existentes en sus términos, con serias advertencias, de ser incumplida dicha obligación ${ }^{182}$ :

“...Pero si alguien, no habiendo cumplido de este modo tal obligación, encerrase los granos en su casa, pague de multa seis maravedíes además de satisfacer todos sus diezmos, con juramento ante tres vecinos, de que ha pagado lo que en justicia debía pagar. Esto es lo que mandamos con todo rigor de ley, no obstante cualquier disposición o costumbre en contrario. Del mismo modo mandamos que todo aquel que labre viñas u otras heredades (fuera del lugar en que vive), entregue la mitad de su diezmo a la iglesia en cuyo término se encuentren tales vińas y heredades, no obstando nada en contrario. Lo cual mandamos para bien de las conciencias de todos nuestros súbditos y por la salvación de sus almas así como para sostenimiento de las iglesias y de su clero. Lo cual no respecta solamente a las tierras de más abajo del Duero sino a todas las tierras y comarcas que están sobre el Duero y a todos nuestros dominios y tierras productivas. Dada en Alba de Tormes en el último día de diciembre del año 1229"

En lo que respecta a Serrada, la primera constancia documental de su existencia corresponde al elenco parroquial de la diócesis de Ávila con fecha de 1250. No se tienen pruebas escritas que testimonien su vida en fechas anteriores, pero es fácil advertir que sus pobladores iniciales se asentarían al tiempo que sus vecinos de La Moya o San Martín. La existencia del arroyo intermitente señalado y las abundantes charcas existentes en sus prados naturales serían un factor de primer orden para atraer a pastores y campesinos de tierras norteńas, una vez pacificada por los reyes cristianos esta frontera del Duero.

Su situación entre los límites septentrionales de la Tierra de Medina y de Olmedo hará oscilar su vida económica entre ambas, si bien su pertenencia jurídica a la Comunidad de Villa y Tierra de Olmedo la vincula a su jurisdicción, autoridades, pago de tributos y otras cargas. Anteriormente a estas fechas, se constatan, sin embargo, movimientos de renteros y servidores de unos lugares a otros, sea siguiendo dictados de sus respectivos señores, sea por conveniencias de tierras o bienes. Son estos siglos XII y XIII de vertebración territorial y política en los que Serrada se consolida como aldea

${ }^{181}$ En los Cuadernos de Cortes de estos siglos, tal como recoge Martín Cea en la obra antes citada, se registran estas solicitudes de rebaja o espaciamiento de tributos ante la precaria situación por la que pasan los pecheros: “...non sola mente se sacan delos que tienen de quelos pagar mas de muchos pobres e lazerados e viejos e cansados que non han otra cosa, saluo aquello que cavando e trabajando con sus cuerpos lo han por su jornales e que para su solo mantenimiento non les basta...". (MARTÍN CEA, J. C.: El Campesinado castellano..., ob. cit., pág. 38 citando a "Cortes de los antiguos reinos de León y Castilla, publicadas por la Real Academia de la Historia”. Tomo III, Madrid, 1866, Cortes de Valladolid de 1447, pág. 498).

${ }^{182}$ A.C.S., caja 39, leg. 1, n 9, copia en latín del s. XIII, traducción al castellano y citado por GONZÁLEZ SÁNCHEZ, V.: Carpio. Historia de una villa de la Tierra de Medina, Diputación Provincial de Valladolid, 1999, pág 163-164. 
perteneciente a la jurisdicción de Olmedo, pero poblacional y económicamente influenciada también por Medina del Campo y Tordesillas. No en vano las ambiciones de Medina y Olmedo por el control territorial, anteriormente expuesto, siguen trascendiendo en siglos posteriores. Así, en julio de 1498 se fecha en Valladolid una "comisión para que el licenciado Rodríguez de Coalla, contador mayor de cuentas y del Consejo, termine de entender en el debate de términos entre Olmedo y Serrada"183, lo que indica las dificultades por encontrar unos límites precisos en estas áreas donde confluyen los extremos de tierras olmedanas, medinenses y del Infantazgo de Valladolid ${ }^{184}$.

Serrada por otra parte, como La Moya o San Martín, centra su vitalidad en el aprovechamiento agroganadero de su reducido término. La superioridad de su potencial agrícola respecto a La Moya y San Martín ejerce una notable atracción e influencia sobre estos núcleos que le harán ganar población a su costa con el paso del tiempo. Reflejo de esa riqueza son las rentas a las que debía hacer frente, una vez vencida la cosecha, para las distintas arcas eclesiales o señoriales. Enrique III donará en 1398 las tercias de los arciprestazgos de Cevico y Portillo, al que pertenecían La Moya y Serrada, a la Universidad de Valladolid"185. En el privilegio se especifica "todo que montasen e rendiesen las dichas tercias de los dichos arciprestazgos de Portiello... para en cuenta e en pago de los veint mill maravedis que el dicho Estudio tiene salvados en las tercias de dicho obispado de Palencia para mantenimiento e salario de los dotores e bachilleres e letores e oficiales del dicho Estudio"186. Sus archivos constatan rentas, diezmos y alcabalas obtenidas de las cosechas de su terrazgo. La red caminera analizada ponía en contacto aldeas y lugares con los mercados y ferias de entidades mayores como Medina, Olmedo, Rueda o Tordesillas. La cercanía al Duero por el camino de San Martín a la barca o a las aceñas de la peña y de la misma Tordesillas era otro itinerario obligado para la molienda del cereal. Lugareños de Serrada poseían propiedades en dichas instalaciones molineras y el comercio e incluso la venta de tales participaciones delata una actividad económica fuera de toda duda ${ }^{187}$ :

1393, septiembre, 25. Tordesillas.

Venta hecha por catalina González, mujer de Rui fernández de Serrada, vecina de dicho lugar de Serrada, al convento de Santa Clara, de un cuartillo de ochavo de aceña que tenía en la que fuera de las de la parada de yuso de la puente de Tordesillas en el río duero, linderos la aceña Cierva, y de este cuartillo vez de ferrand González de Velliza y vez de Gonzalo Gil el Viejo, en precio de 1000 mrs Pasó ante Ferrand García.

1408, noviembre, 27. Tordesillas.

Venta hecha por Rui Fernández de Serrada y Catalina González, su mujer, vecinos de Tordesillas, al convento de santa Clara, de un cuartillo de ochavo de aceña que tenían en la de afuera, que está en la parada de aceñas en el río Duero cerca del puente de dicha villa, en precio de 2450 mrs. Pasó ante Gil martínez, escribano de Tordesillas".

${ }^{183}$ R. G. S., vol. XV, 1829, folio 103.

${ }^{184}$ Las desavenencias entre seńores, concejos locales, comunidades de Villa y Tierra e, incluso, obispados, por fijar con exactitud hasta dónde llega la jurisdicción de cada cual, no cesan en estos siglos bajomedievales de ocupación inexorable del espacio. En 1258 será un privilegio de Alfonso X el que ponga fin y sentencie una cuestión entre términos entre Tordesillas y Medina del Campo, a tenor de lo cual se amojonan los límites. Los de Medina razonaban que "poco allende de la puente de Oterdesillas conttra Medina que era ttodo so término, fueras ende el aldea que dizen Zofraguilla...", cuestión ésta que en nada compartían los de Tordesillas. Los mojones, en fin, se fijaron "sobre la aldea de la Peña", siguiendo por Valdeferros hasta Valdelasna, Valbuena y "la aldea que dizen la Perdiz y pusimos seis mojones fastta la carrera que ba de la Perdiz a la aldea de la Peña..."(CASTRO TOLEDO, J.: Colección..., ob. cit.,. pág. 26).

${ }^{185}$ Las tercias equivalían dos novenas partes de los diezmos eclesiásticos. En su origen habían sido concedidas por el papa a los monarcas que, al perpetuarse con el paso del tiempo, estos las cedían en reconocimiento de mercedes o apoyos a diversas instituciones.

${ }^{186}$ MARCOS MARTÍN, A.: La Hacienda de la Universidad de Valladolid en la época moderna. Historia de la Universidad de Valladolid. Volumen I. Universidad de Valladolid, 1989, págs. 311 y siguientes.

${ }^{187}$ CASTRO TOLEDO, J.: Colección Diplomática..., ob. cit., pág. 185 y 227. Institución Cultural Simancas, 1981. 
La importancia e influencia del convento de Santa Clara rebasaba el Duero hasta extenderse por el norte medinense. La conservación de su archivo permite constatar, en los siglos bajomedievales, la abundancia de pequeńos labradores y ganaderos que venden, compran y donan bienes de su propiedad en todos estos espacios al sur del Duero. En algunos casos, incluso, de pueblos olmedanos. Es el caso, en 1377, de la venta hecha por Gutiérrez Gómez, vecino de Alcazarén, que vende al convento" "sesenta yugadas en 26 tierras de pan llevar, por labranza de un par de bueyes, año y vez, y seis aranzadas de viñas plantadas que tenía en la labranza de dicha aldea, en precio de 600 mrs", lo que indica la proporción de tierras y viñas de esta labranza, así como el empleo de bueyes en el laboreo de la tierra ${ }^{188}$. En realidad, la distribución del terrazgo desde sus inicios se organiza de acuerdo con el potencial del campesino, la titularidad de la tierra, la facilidad o no del laboreo del terrazgo y la aptitud de los suelos para los distintos cultivos. En todos los lugares, por ejemplo, se anotan los huertos cerca de las poblaciones: "una huerta cercana de la puerta de Valverde..."; "una huerta con dos norias y todos sus árboles y suelo que tenía en dicha villa (Tordesillas) cerca de Santa Marina, linderos la cava y muro de la villa"; "una huerta con una casa que se contiene en ella dentro de la villa de Medina del Campo a do dicen la cal de Herreros, linderos el rio Zapardiel..." "189. Las tierras de sembradura y las viñas atienden preferentemente a la fertilidad de los distintos pagos que componen el término, estando los más feraces, por lo general, cerca de las poblaciones y situados los majuelos en aquellas tierras de menor sustancia, tal como a veces se desprende de los documentos que los citan en estos siglos XIV y XV, sean "al Pedroso", al "Cerruelo", a "los Pobres" o "ençima de Santa Crus, en el teso, ..." y que, conforme nos acercamos a la Edad Moderna, encontramos en mayor número ocupando nuevos terrenos rotos al monte y también en manos de pequeños labradores y renteros ${ }^{190}$.

En cualquier caso, en el espacio estudiado, hablamos de aldeas poco pobladas en este tiempo. Si la Moya, como se ha visto, apenas rebasó la media docena de vecinos y San Martín del Monte, la decena, a Serrada, en los pleitos entre los Dávila y los Montalvo por la jurisdicción sobre la villa, tan sólo se le adjudican dieciocho vecinos "y todos muy pobres..." que, aunque no deje de ser una exageración del procurador de la parte de los Dávila para tratar de eludir el pago de lo recibido con anterioridad por la venta del lugar, es muy ilustrativo. El término se delimita en el año 1525, haciendo referencia a medio siglo antes, en 2.598 obradas (1.470 ha), y nada mejor que leer un fragmento del litigio para entender las dificultades y pobreza de unos campesinos siempre al arbitrio de los estamentos privilegiados ${ }^{191}$ :

“... no tiene sino una Iglesia como una hermita y las casas de los labradores caídas e muy pequeñas, que no valen nada, y en el dicho lugar no ay ni arroyo ni fuente ni monte ni vińa ni un árbol, que es el lugar muy estéril y dentro de las cinco leguas de Valladolid.... y el dicho lugar de Serrada tiene agora veynte y ocho bezinos con biudas y menores, y todos muy pobres, y quando se dio la sentenzia contra el dicho marqués y sus hermanos podra aver en el dicho lugar diez y siete o diez y ocho vezinos, de manera que sola la jurisdizión de Serrada es la que se a de pagar...”.

Esta organización del espacio, en fin, necesitará de una regulación cada vez más compleja por parte de los concejos locales y, conforme se detraen mayores cantidades de obradas a prados y montes comunales, las necesidades del ganado de labor y de renta irán generando una estricta regulación de

${ }^{188}$ Ibídem, pág. 115.
${ }^{189}$ Ibídem.
${ }^{190}$ Como ejemplo se cita el anotado por Castro Toledo en su Colección Diplomática: "1464, diciembre, 3. Tordesillas. Venta hecha por Alfonso Fernández el Viejo, vecino de San Martín del Monte, por sí y en nombre de sus hijos, al convento de Santa Clara, de unas casas que tenía en dicho lugar con dos corrales, linderos suelos de dicho vendedor y la calle del rey, y más dos viñas que tenía en término de dicho lugar a do dicen el cerruelo, linderos la una de éstas viñas de Alfonso Sánchez, pastor, y viña de Juan Calvo, y la otra lindaba con viña de Alfonso Martínez de Serrada y vińa de los herederos de Juan de la Puente, en precio de 2.300 mrs Pasó ante Pedro Martínez”. (Ibídem, pág. 4219).

${ }^{191}$ A.R.Ch.V. P.C. Zarandona y Walls (F), caja 2711.1. 
tiempos y aprovechamiento del terrazgo, tanto del labrado como del inculto. La disposición en hojas será una consecuencia de esta mayor presión sobre la tierra y, como se verá a continuación en el caso de San Martín del Monte, origen de continuos conflictos entre las partes.

\section{- La protección de San Martín del Monte por el Monasterio de Santa Clara}

A tenor de las fuentes documentales existentes, San Martín del Monte despierta al mundo cristiano de forma tan madrugadora como los lugares anteriores. Su situación geográfica así lo sugiere. El camino de la Barca por San Miguel del Pino hacia Tordesillas o Simancas, y el camino o cañada de Rueda a Valladolid no ha sido un paso menor a lo largo del tiempo. El vado existente sobre el Duero en este sector ha servido durante siglos de comunicación entre ambas orillas. El paso de la barca entre San Martín y San Miguel del Pino ha permanecido activo hasta comienzos del siglo XX. Buena parte de la red caminera de este sector norte de las campiñas medinenses confluía en este lugar ${ }^{192}$. Es impensable que los primeros pobladores que pasaron el Duero desde Tordesillas no aprovecharan el vado natural sobre el Duero y el vallecillo apartado, de abundantes pastos, por donde discurría, en sus últimos centenares de metros, el arroyo de Serrada ${ }^{193}$. De ahí la posibilidad de que, a mediados del siglo XI, honrasen a San Martín en este terrazgo de montes de encina y vestigios del pasado. Si Serrada se localizaba en el Poniente de la Tierra de Olmedo, esta pequeña villa lo hacía en un reducido espacio de apenas 350 obradas al norte de la Tierra de Medina, entre los términos de Serrada, La Seca, Tordesillas y Villanueva ${ }^{194}$. Desde 1265 en que aparece documentada, no dejará de respirar hasta 1818. Doscientos años antes lo había hecho La Moya y otros muchos lugares que hoy se conocen como Despoblados. Si se insiste en ello, es por hacer constar la tremenda fragilidad de estas minúsculas aldeas, siempre al azar de las cosechas, de la guerra, la peste y las hambrunas. De hecho, nunca rebasará la pequeña villa los quince vecinos en sus momentos de mayor esplendor. En

${ }^{192}$ El poblado de San Martín del Monte se localizaba al O-NO del actual municipio de Serrada, a una distancia de 3400 metros. (Mapa 1/50.000, hoja 399: Lat. 41 29’ 7,86”; long. 4o 53’ 53,36”). Restos de cimentaciones de su Iglesia, huesos humanos, fragmentos de cerámica y otros hallazgos, afloran unas decenas de metros al sur del camino de San Martín al camino de La Barca, al pie de la actual torreta metálica de conducción eléctrica, lugar aproximado donde se levantaba la Iglesia y se ubicaba el cementerio. No obstante, se ha advertido la presencia notoria de más restos unos centenares de metros al SE., claro indicio de que, junto al reducido casco urbano, existirían pequeńos caseríos cercanos. Unos dos mil metros aproximadamente más al S-SO. y en la misma área en la que se han localizados molinos barquiformes y otros restos anteriormente estudiados, han aflorado en las últimas décadas, realizando tareas agrícolas, abundantes restos medievales, consistentes en molinos circulares, restos de cimentaciones, sepulturas, brocales de pozos, etc., que denotan la existencia de ocupación medieval que, en estudios posteriores, deberá ser valorada.

193 Juan Bayón Clemente, en su "Historia de la Antigua Villa de Rueda", cita el vado de San Martín del Monte, por el que se atravesaría el Duero tras la destrucción del puente de Tordesillas por Alfonso I (739-757). Ello fue debido a la necesidad de frenar posibles incursiones islámicas en las que el río jugaba un papel de muro defensivo. El anterior puente estaba situado quinientos metros aguas abajo. Este hecho reforzaría la tesis de la temprana repoblación de San Martín del Monte y la existencia de una importante confluencia viaria en busca del citado paso. La toponimia de los caminos y cañadas así lo constata: "Camino de Villanueva a la barca", " Camino de Rueda y La Seca al camino a la Barca y a las aceñas a San Miguel del Pino”, “Camino de San Martín a la Barca”. La situación de la necrópolis tardorromana de Casa Calderón, situada al borde del arroyo de Serrada que desembocaba en dicho paso, no sería ajena a la importancia de situarse junto a un vado natural, al igual que anteriores poblamientos prerromanos.

${ }^{194} \mathrm{Su}$ importancia en el ayer contrasta con el desconocimiento, casi general, de las gentes que habitan los pueblos mencionados. Quizá los factores que le dieron vida - el monte y el río- son hoy elementos protectores de su intimidad, como lo fueron en su pasado histórico. Esto y haber sido sus aledańas tierras, camino del puerto, propiedades de familias aristocráticas ajenas al entorno comarcal. Sin embargo, ya se ha relatado en capítulos anteriores la importante ocupación humana que, desde la Fuente de la Miel, se adentra por San Martín buscando al Duero en Casa Calderón. Herramientas paleolíticas, molinos neolíticos y asentamientos romanos constatan unas tierras ya viejas, repetidamente ocupadas por hombres y ganados. Y el río y el monte como vía de entrada y escape. Tordesillas y Simancas en su cabecera norte, como atalayas desde las que se divisaban decenas de kilómetros al sur. A sus señales, avisando de peligros, escaparían, presurosos a refugiarse en sus muros, quienes se repartían en sus aldeas y tierras al sur del Duero. 
el elenco medianil de 1265 figura como una de las dieciséis parroquias medianas que alternaban anualmente entre las diócesis de Salamanca y Ávila. Aunque dependiente jurídicamente de Medina, pronto su rumbo tomará otro camino. En 1363, mediante privilegio otorgado por el rey Pedro y las infantas Beatriz e Isabel, se funda el Real Monasterio de Santa Clara de Tordesillas.

El Monasterio de las Claras se constituye, como ha quedado referido, como uno de los más importantes centros económicos y de influencia política del Duero medio, engrandeciéndose por donaciones reales, por sus propias adquisiciones de bienes y por las rentas eclesiásticas recibidas de las tierras de su jurisdicción, sin olvidar las limosnas y donaciones de fieles devotos, que contribuían a fortalecer aún más su ingente patrimonio ${ }^{195}$.

En lo que a San Martín respecta, al Monasterio de Santa Clara le será otorgada la jurisdicción sobre Tordesillas y su tierra, recibiendo como seńorío la Bailía de San Miguel del Pino que comprendía, junto con otras villas y lugares, la villa mencionada. Pese a pertenecer a la Comunidad de Villa y Tierra de Medina, pasa a jurisdicción eclesiástica y será la propia abadesa quien disponga y nombre alcaldes, escribanos, merinos y oficiales en el ańo 1401. Aunque llevaban sus vecinos trabajando este terrazgo varios siglos, el rey Pedro cambia el rumbo de su Historia. O, al menos, el camino que habían de seguir para cumplir con el pago de rentas e impuestos ${ }^{196}$.

\footnotetext{
"Sepan quantos esta carta vieren commo yo, la infante donna Beatris, fiia del mucho alto e muy noble sennor don Pedro, por la gracia de Dios rey de Castiella, de León, de Toledo, de Gallisia, de Seuilla, de Cordoua, ..., es mi entencion de dar e faser consagrar la mis casas principales, que yo he en Oter de Siellas, en que el dicho sennor rrey don Pedro posa quando es en el dicho logar, ...Primeramiente todos los pechos, fueros e derechos e heredades que a mi pertenescen en qualquier manera en el dicho logar de Oterdesiellas e sus aldeas, .... E doles mas, la mi Baylia de Sanct Miguell del Pino con Sanct Martín del Monte e Torresiella, que pertenescen a la dicha baylia, con todos / sus logares e vasallos e heredades e montes e guardas. ...Fecha esta carta en Seuilla, dos dias de enero era de / mill e quatrocientos e vn annos."
}

El texto es un ejemplo de jurisdicción monacal por concesión regia, muy propio, por otra parte, de estos siglos bajomedievales. Clero y reyes, como poseedores de tierras y hombres, se benefician de las numerosas cargas tributarias que pagana los pecheros, necesarias para el buen funcionamiento del sistema feudal. Se repite nuevamente el esquema en los casos que se han estudiado y que vuelven a ratificar las palabras del profesor Valdeón Baruque: "El hecho más significativo en la historia del campesinado de Castilla y León en la Edad Media es su progresiva caida de dependencia, independientemente de la posición económica de los labriegos" ${ }^{197}$. La propia infanta Beatriz, hija del rey Pedro I, autorizada por su padre, se preocupa en la donación tanto por detallar los poderes que tendrá la abadesa sobre las tierras y jurisdicciones regias otorgadas, como de concretar lo temporal y espiritual. En enero de 1379 el rey Enrique II, en su guerra contra el reino de Navarra, envía carta al Infantazgo de Valladolid, con objeto de abastecerle de 40.000 cargas de cebada y 20.000 de harina, precisando las cantidades en los distintos pueblos y aldeas de la Tierra de Tordesillas. También, en febrero del mismo año, recuerda la obligación de los arciprestazgos de Tordesillas, Torrelobatón, Portillo, Matapozuelos y Simancas, entre otros, de hacer llegar las tercias de pan y vino que deben entregar en Valladolid a Pedro Fernández Sanchón, recaudador del obispado de Palencia. Pero junto a las obligaciones, en ocasiones también se dan concesiones: Juan II premia, en agosto de 1443, al Concejo de Tordesillas y a San Miguel del Pino, Torrecilla y San Martín del Monte, "sean cristianos, judios o moros, con la declaración de francos y exentos de pedidos y moneda forera por diez años."

${ }^{195}$ CASTRO TOLEDO, J.: Colección Diplomática..., Institución Cultural Simancas. Estudio introductorio, Valladolid, 1981.

${ }^{196}$ Ibídem, pág. 78-80.

197 VALDEÓN BARUQUE, J.: "Señores y Campesinos en la Castilla Medieval”, en El Pasado Histórico de Castilla y León”, vol. I, Burgos, 1983, pág. 62. 

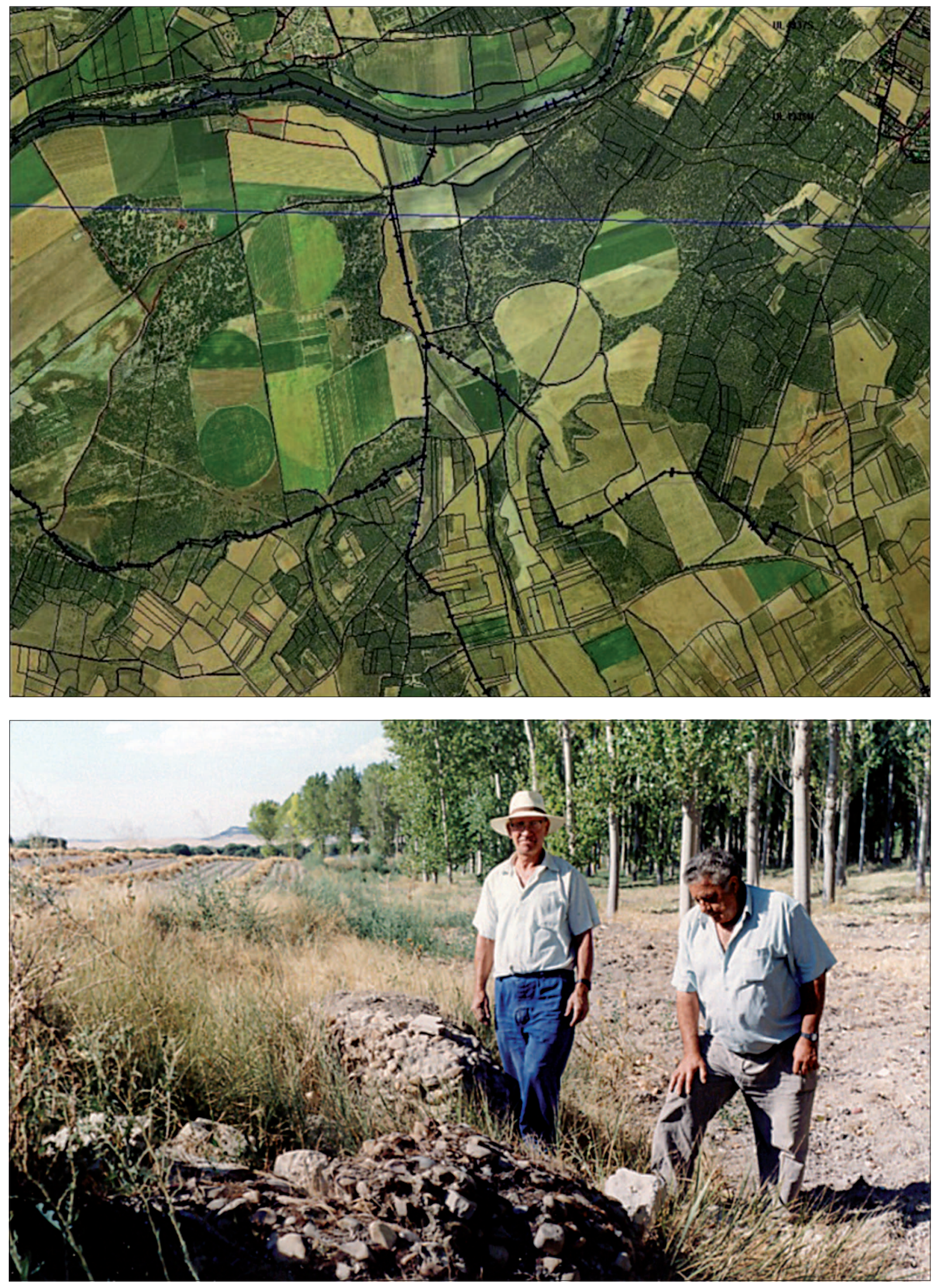

Imagen 35. Foto aérea de la confluencia de los términos de Serrada, La Seca, Villanueva de Duero y Tordesillas. (Foto: Junta de Castilla y León, año 2002, imagen superior). Restos de cimentaciones de la iglesia de San Martín del Monte, (Foto: imagen inferior, agosto de 2004. Mi agradecimiento a Felicísimo de Rojas y Ángel Hidalgo por mostrarme cuanto conocían en estos ańos sobre el mencionado despoblado). 
Esta consideración vuelve a ser confirmada por el rey Juan II, mediante una albalá a los contadores mayores y carta del mismo rey en enero de 1444, donde precisa la solicitud realizada por Tordesillas para que fueran prorrogadas por otros cinco años las exenciones otorgadas. En sus argumentaciones, se señala la necesidad de aligerar las cargas impositivas por los cuantiosos gastos que trae consigo la estancia de la corte en la villa, pues de lo contrario, si tuvieran que pagar los impuestos que la tradición exige, los lugares se despoblarían y perderían.

San Martín del Monte tendrá problemas burocráticos para beneficiarse de tales exenciones, puesto que en el obispado de Ávila, al que pertenecía a mediados del siglo XIV, no figuraba de lo salvado por la confirmación. Para ello, mediante provisión real de mayo de 1446, el rey Juan II manda guardar las franquezas concedidas a San Martín del Monte a los recaudadores, y monedas del obispo de aquella ciudad. Pero San Martín del Monte, como lugar perteneciente al Monasterio de Santa Clara, gozará de protección frente a terceros. La propia abadesa así lo constata en carta de licencia de 17 de abril de 1451. La respuesta de concejo de San Martín no se hace esperar. El 19 del mismo mes otorga poderes al escribano del rey Andrés Gómez de Medina "para poder comprometer con el concejo de Medina del Campo todos los pleitos que tenían sobre pacer y andar los ganados de dicho lugar a beber agua, cortar y rozar la leña por los términos de dicha villa de Medina". Y es que, como se acaba de estudiar, la convivencia entre ganaderos y labradores levanta ásperas discusiones entre los derechos de unos y otros por el aprovechamiento de los montes. No hay que olvidar que las roturas del monte Inestoso al norte de Medina enfrentan a los vecinos de Rueda y La Seca repetidas veces. Los pleitos, además de dilatados en el tiempo, eran caros. San Martín del Monte y el convento por una parte, y Medina del Campo por otra, deben someterse el 25 de septiembre de 1451 a la sentencia arbitral, que trascribimos al pie, firmada por los jueces de Medina del Campo Ruy Fernández Morejón y Juan Ruiz de Ríomayor ${ }^{198}$.

El documento nos acerca de primera mano a la vida campesina de este norte de Medina en la segunda mitad del siglo XV. La regulación del pasto, la corta de retamas y escobas, el respeto absoluto que los ganados deben tener a sembrados y viñedos so pena de su pérdida, aleja cualquier provisionalidad en el funcionamiento de estas sociedades y lugares a mediados del siglo XV. Del mismo modo la sentencia anterior pone de manifiesto la enorme importancia de la cabaña ganadera en estos espacios al norte de Medina. Adviértase, en este sentido, que la cifra de tres mil cabezas de ganado, que menciona y permite la sentencia como límite para el aprovechamiento de los montes, además de indicar un gran potencial ganadero y económico, señala cuál podría ser la principal actividad de los moradores de estas pequeñas poblaciones.

198 "Mandamos que los vesinos e moradores que moran e moraren en el dicho lugar de Sant Martín que agora e de aquí adelante para siempre jamás que pascan e puedan pascer de noche e de dia las yeruas e beuer las aguas por todos los términos e montes de la dicha villa de Medina del Campo e su tierra con tres mill cabecas de ganado euejuno e cabruno, non fasiendo dapno en panes nin en vinnas nin en prados dehesados, segund andan e pacen los ganados de los vecinos e moradores de la dicha villa de medina e su tierra e aldeas, e puedan dormir e tener majada e parir en los dichos términos e montes, segund dicho es.

Item que los pastores que andudieren con los dichos ganados non puedean traher nin coger ganados algunos de fuera parte del dicho lugar en guarda nin en otra manera, aunque en el dicho lugar non aya las dichas tres mill cabecas; e si lo trayeren e sabido fuere en qualquier manera, que ge lo tomen e lo ayan perdido e sea para las personas que ge lo montaren.

E otrosy que los pastores que guardaren el dicho ganado que puedan traher e trayan por los dichos términos e montes de la dicha villa de Medina del Campo e su tierra sus bestias e asnos en que tayan sus fatos e mantenimientos syn pena alguna.

Otrosy que los vesinos e moradores del dicho lugar de Sant Martín, que agora son o serán de aquí en adelante para siempre jamás, puedan cortar e rocar yniesta e cantuesos e escobas e lenna por todos los términos de la dicha villa de Medina del canpo, para quemar, con que se calienten los pastores e guisen de comer, mientra que andolieren en los dichos montes e términos...

Otrosy que los ganados de la dicha villa de Medina e su tierra puedan pascer e pascan en los términos del dicho lugar de Sant Martín, guardando pan e vino e prados dehesados del dicho lugar de Sant Martín e, sy entraren en los dichos prados, que los vesinos e moradores del dicho lugar de Sant Martín los puedan montar, segund montan e prendan a los otros vesinos del dicho lugar de Sant Martín”.

CASTRO TOLEDO, J.: Colección Diplomática..., ob. cit., pág. 356 y ss. 
El profesor Piqueras Haba señala este tiempo de donaciones laicas y eclesiásticas, como un momento crucial en la formación del terrazgo vitícola, impulsado por monasterios y nobleza donde, "los vińedos los plantaron los campesinos, vasallos o aparceros, en las tierras que el clero regular y secular solían recibir de forma gratuita de los reyes y de la alta nobleza”. El fuero de Zofraga es claro en este sentido, pues, como analizaremos posteriormente, anima al campesino a plantar vińas para luego disfrutarlas por mitad. Los pleitos estaban servidos desde esta época, dado el interés entre las partes por controlar su riqueza. En alguno de ellos, incluso, se detecta la presencia de judíos, que valoran los majuelos como garantía de préstamo, lo que denota la importancia del cultivo y su valor ${ }^{199}$.

Esta ganadería ovina continuará desarrollándose en las décadas y siglos posteriores, al amparo del importante mercado ferial que se desarrollará en Medina del Campo. El paso de la barca y el uso de las aceńas para la molienda era otra de las actividades que se realizaría a diario y que hoy sólo figura en los topónimos de los mapas y en la memoria de la sabiduría popular. En la época estudiada, hace seiscientos años, las márgenes del río Duero entre San Miguel del Pino y San Martín del Monte eran muy frecuentadas por vecinos de La Seca, Serrada, Rueda o las distintas aldeas que jalonaban sus inmediaciones. Los caminos al convento de Santa Clara eran frecuentados para acudir al monasterio a pagar rentas, vender bienes o solicitar aprovechamientos ganaderos o agrícolas en sus múltiples propiedades y jurisdicciones. El poder de la abadesa y su influencia era algo incuestionable. Y los favores de los reyes de Castilla para con el Monasterio o para con la alta nobleza adicta, muy frecuentes. No en vano nos encontramos en la apoteosis de la nobleza tras el advenimiento de la dinastía de los Trastámara. Como consecuencia de tantos favores y mercedes reales, surgirá una nueva nobleza de segundones castellanos (los Mendoza, Ayala, Álvarez de Toledo, Manrique...), aragoneses (los Luna), navarros (Estúñiga...), portugueses (Pachecos, Acuñas, Pimentel...) o franceses (Bearn, Bracamonte...).

En diciembre de 1455, un privilegio y confirmación de Enrique IV otorga validez a la continuación de la franqueza, exención de pedidos, monedas, monedas foreras y medio servicio, otorgados por Juan II en ańos anteriores. Sin embargo, la cortedad del término hacía que estos renteros de Santa Clara dispusieran de labranzas que apenas fueron, a lo largo del tiempo, suficientes para asegurar su subsistencia. Se hace muy difícil cuantificar en estos siglos la cantidad de tierra necesaria que asegure la manutención a una familia campesina. Clemente Ramos mantiene que, con rendimientos de tres por uno, una explotación debería disponer de entre catorce y quince hectáreas. Las siembras en la mitad de ellas por el tradicional sistema de año y vez podría asegurar la subsistencia en años de cosechas normales. En cuanto al consumo de vino, por ejemplo, este autor sitúa el consumo diario por debajo de los 0,5 litros y las extensiones detentadas por familia campesina son tan variables como los rendimientos que se cosechan ${ }^{200}$. Con todo, los rendimientos pueden valorarse entre el medio centenar y los casi dos hectolitros por aranzada. El sistema de aprovechamiento del terrazgo se realizaba repartiéndose en suertes iguales las tierras de la abadesa a la que pagaban el foro escriturado. Unas tierras por lo demás ansiadas por otros pobladores de lugares cercanos, como los vecinos de Villanueva de Duero, Serrada o La Seca, hasta el punto que estos llegaron a entrar, arar y sembrar parte de las suertes que disponían los vecinos de San Martín. El litigio estaba servido ${ }^{201}$.

${ }^{199}$ PIQUERAS HABA, J.: La vid y el vino..., ob. cit. pág. 228.

${ }^{200}$ CLEMENTE RAMOS, J.: La economía campesina en la Corona de Castilla (1000-1300). Barcelona, 2003, pág. 135. Otro ejemplo de favor real que, poco a poco, irá haciendo perder vigor a la unidad jurídica de la Comunidad de Villa y Tierra de Medina será la donación por parte del regente Fernando de Antequera, después rey de Aragón tras el Compromiso de Caspe de 1412, de la villa de Fuente el Sol a don Álvaro de Dávila como merced por su ayuda en tal nombramiento. Álvaro Dávila, perteneciente a uno de los linajes más importantes de Castilla había contraído matrimonio con Juana de Bracamonte, hija mayor de Mosén Rubín de Bracamonte, Almirante mayor en Francia, participante en la ayuda francesa a Enrique II frente a Pedro I y llegado a Espańa tras los acuerdos entre Castilla y Francia frente a Inglaterra. Fernando I de Aragón confirmará su donación el 20 de mayo de 1413. (SOBRINO MATA, E.: Fuente El Sol. Memoria de una villa señorial. Diputación de Valladolid, Valladolid, 2002, pág. 63). 
Y, como en la actualidad sucede, unos compraban y otros vendían. Las transacciones de propiedades de los vecinos de las aldeas y lugares de la Tierra de Medina y Tordesillas eran continuas y muy numerosas al citado convento de Santa Clara, lo que demuestra su poderío económico. La abadesa concreta numerosas participaciones en las importantes aceñas que jalonan el Duero además de casas, bodegas, lagares, tierras de pan llevar y viñas por doquier. Se ha referido anteriormente alguna de estas compras monásticas en tierras de San Martín. En otras ocasiones, se trataba de permutas y trueques entre vecinos de distinto término e, incluso, con los bienes del convento, siempre que satisficieran a ambas partes ${ }^{202}$. Una economía campesina de limitados recursos y la presencia todopoderosa de los estamentos privilegiados, en fin, condicionaban la vida de estas pequeñas aldeas en estos siglos bajomedievales.

\section{c- La época bajomedieval y el señorío de Serrada en tiempos de los Reyes Católicos}

En este proceso continuado de dominación señorial hay que de tomar nuevamente como ejemplo el caso de Serrada, para ilustrar, antes de pasar a analizar los tiempos modernos, las crisis políticas y sus repercusiones sobre el campesinado al final del medievo, especialmente durante el reinado de Enrique IV. La crisis generalizada del siglo XIV iba a situar a toda la sociedad contra el tablero. Ahora no eran los peligros islámicos. Se trataba de la peste, las malas cosechas, el hambre, la guerra..., que trastornaban la quietud de estas pequeñas comunidades campesinas hasta, en ocasiones, hacerlas desaparecer. Se hablaba de un castigo divino y seguramente así lo sintieron los más desvalidos, verdaderos paganos de las continuas intrigas nobiliarias que por este tiempo se desataron. Enrique de Trastamara, apoyado por importantes sectores nobiliarios, se levanta en guerra fratricida frente a su hermanastro Pedro I, al que asesinará en 1369.

Comienza de esta manera una dinastía que ha de pagar generosas mercedes a los distintos bandos nobiliarios que lo habían apoyado ${ }^{203}$. Enrique III donará en 1398 las tercias de los arciprestazgos de Cevico y Portillo, al que pertenecían La Moya y Serrada, a la Universidad de Valladolid ${ }^{204}$. Sus archivos constatan rentas, diezmos y alcabalas, obtenidas de las fructíferas cosechas salidas de su terrazgo ${ }^{205}$.

${ }^{201}$ El litigio estaba servido y los escribanos y procuradores dispuestos a obrar. El 21 de abril de 1457 se constata lo anteriormente expuesto en término de Olmedo, "cerca de Aldeanueva, junto a la fuente de Linares, entre el río Duero y el camino de Aldeanueva a Tordesillas". Los vecinos de San Martín denuncian que personas de la villa de Olmedo -se referían a Serrada o Villanueva, puesto que La Seca pertenecía a la villa de Medina- cultivan tierras del convento, presentando como testigos a cuatro vecinos de Aldeanueva, uno de Villavieja y tres de La Seca. El alcalde de Olmedo, Juan Ruiz de la Fuente, interviene en contra de los ocupantes, mandando que dejasen libres las tierras ocupadas, so pena de 20.000 maravedís, entre otras.

${ }^{202}$ En marzo de 1409, se constata un trueque entre dońa Juana García de Guadalajara, abadesa del convento de Santa Clara, y García Martínez, vecino de San Martín del Monte, por el cual aquella le da una tierra que dicho convento tenía en termino y labranza de San Martín, que es fondón de la cabeza de Poheles, linderos tierra del convento, tierra de Fernán Martín y tierra de Toribio Martín, por otra tierra que dicho García Martínez tenía en dicho termino entre las viñas de dicho lugar, linderos viñas de Juana Fernández, mujer que fue de Fernán Velasco, viña de Diego Martín y viña de hijos de Juan Martín de Villavieja. Trueque por trueque y pasando ante Gil Martín. (CASTRO TOLEDO, J.: Colección Diplomática de Tordesillas..., ob. cit., pág. 228.).

${ }^{203}$ VALDEÓN BARUQUE, J.: Los Trastámaras. El triunfo de una dinastía bastarda, Valladolid.

${ }^{204}$ MARCOS MARTÍN, A.: “La Hacienda de la Universidad de Valladolid en la época moderna”, en "Historia de la Universidad de Valladolid”, vol. I, Universidad de Valladolid, 1989, págs. 311 y siguientes.

205 En el privilegio se especifica "todo que montasen e rendiesen las dichas tercias de los dichos arciprestazgos de Portiello... para en cuenta e en pago de los veint mill maravedis que el dicho Estudio tiene salvados en las tercias de dicho obispado de Palencia para mantenimiento e salario de los dotores e bachilleres e letores e oficiales del dicho Estudio". Las tercias equivalían a las tres novenas partes de los diezmos eclesiásticos. En su origen habían sido concedidas por el Papa a los monarcas que, al perpetuarse con el paso del tiempo, estos las cedían en reconocimiento de mercedes o apoyos a diversas instituciones. 

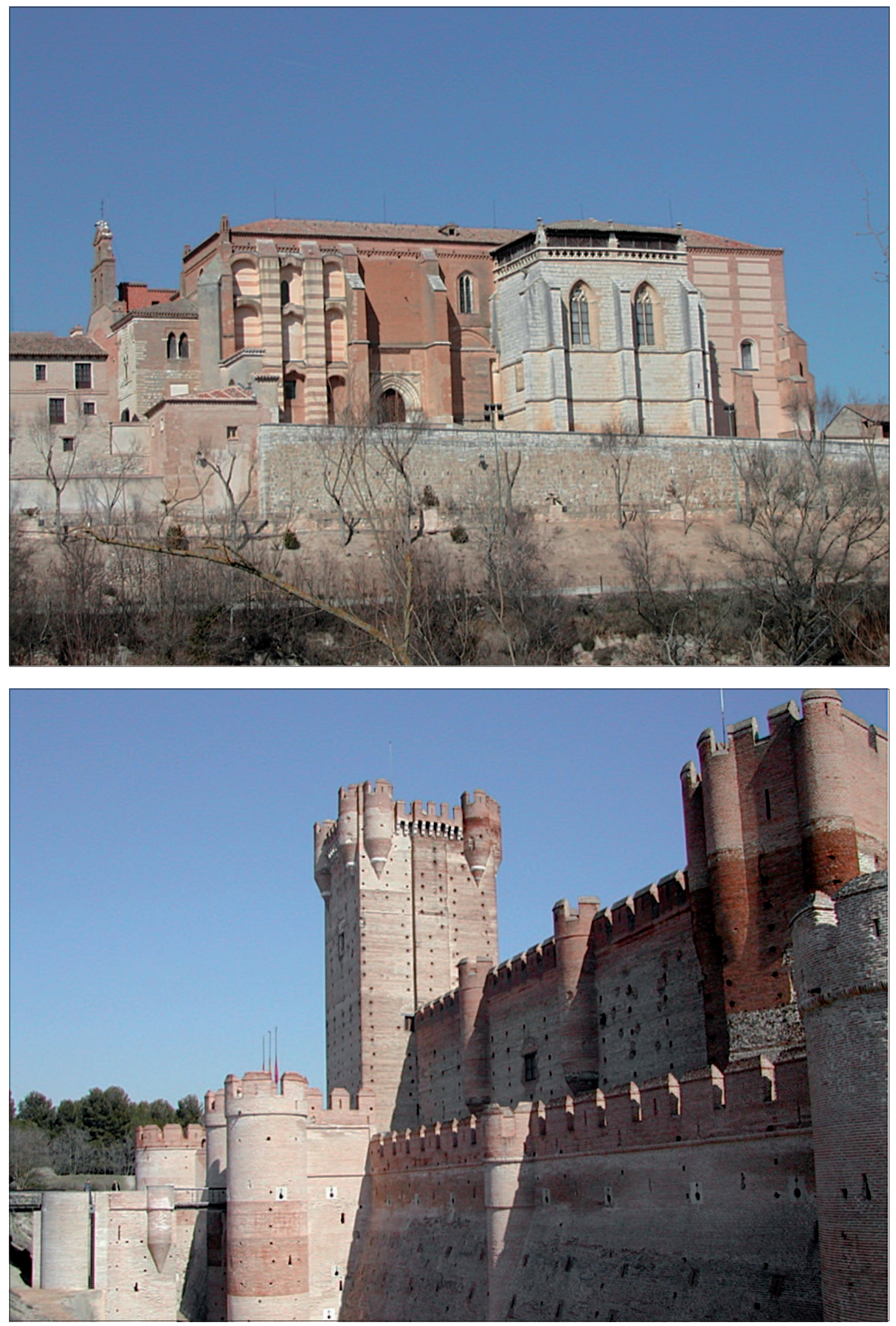

Imagen 36. Convento de Santa Clara (Tordesillas, arriba) y Castillo de la Mota (Medina del Campo, abajo), símbolos del poder eclesiástico y civil en el espacio estudiado. Fotos: junio de 2005. 
Aldeas enteras, rentas y jurisdicciones por doquier restaban fuerza al patrimonio real y llegaban a manos de unos insaciables nobles deseosos de más riqueza y poder. La nobleza salía, de esta manera, enormemente reforzada de la crisis ${ }^{206}$. Los campesinos y las tierras que trabajaban se convertían una vez más en moneda de cambio para los estamentos privilegiados, inmersos en continuas intrigas y querellas. El ejemplo del rey Juan II y su valido Álvaro de Luna, o el polémico reinado de Enrique IV, depuesto simbólicamente en la farsa de Ávila en 1465, no hacen sino corroborar la crisis de un sistema medieval que toca a su fin. Será su hermana Isabel, y su matrimonio con Fernando de Aragón, quien inicie un nuevo tiempo, una vez superada, mediante el tratado de Alcaçovas de 1479, la guerra sucesoria con Juana la Beltraneja y su aliado, el rey Alfonso V de Portugal.

Demasiados intereses para que estuvieran indiferentes tanto la nobleza de cuna como los nuevos acrecentados. Medina y Olmedo no permanecerán ajenas a tantas intrigas y ambiciones. En la que será pujante villa ferial, los viejos linajes, tales como los Pollino, Pedro Benito, Castellanos, Morejón y otros, toman posiciones en el nuevo tiempo de intervencionismo regio; en Olmedo, por su parte, los Vivero, Daza, Ulloa o Villahermosa conservan tanto abolengo como el que envuelve la legendaria vida del famoso caballero de Olmedo, Don Rodrigo de Vivero y Silva, "la gala de medina, la flor de Olmedo", emparentado, como se verá, con los primeros señores de Serrada. Nunca sospecharían los pobladores de este pequeño lugar, al poniente de la jurisdicción de tan ilustre cabecera, que también ellos y las tierras que labraban iban a ser objeto de donación y merced real. Serrada será donada a uno de sus más fieles vasallos, entroncado con la nobleza olmedana para, poco tiempo después, ser vendida y consolidarse como señorío y mayorazgo en manos de otra de las familias medinenses más distinguidas, colaboradora de los propios Reyes Católicos: la familia Ruiz Montalvo.

\section{- La donación de Serrada a Pedro de Silva y Mencía de Meneses}

Se acaba de relatar cómo, en la segunda mitad del siglo XV, Castilla sigue inmersa en una agitación política en que se mezclan intereses opuestos. Aunque el rey Enrique IV vence al bando rival en la segunda batalla de Olmedo en 1467, sus contradicciones personales y su debilidad política dificultan sobremanera el final de su reinado. Al igual que sus antecesores abonaba los apoyos que recibía con generosas prebendas. Serrada, como tantos otros lugares de la Tierra de Medina, entra de lleno en este juego de intereses. Hay que recordar que numerosos lugares habían pasado a manos señoriales, gracias a la generosidad de unos u otros reyes. Bobadilla del Campo, por ejemplo, fue dada por Fernando IV, el Emplazado a Juan Fernández en 1304; Fuente el Sol, a Álvaro Dávila en 1413 por Fernando de Antequera; Alaejos y Castrejón, a Alfonso de Fonseca en 1452 por Enrique IV207. El 18 de septiembre de 1464 la reina Juana, su esposa, como señora de la villa de Olmedo y tras la preceptiva licencia otorgada por su esposo el rey Enrique, hace donación del lugar de Serrada a Pedro de Silva y a su esposa Mencía de Meneses ${ }^{208}$.

\footnotetext{
${ }^{206}$ VALDEÓN BARUQUE, J.: Los conflictos sociales en el reino de Castilla en los siglos XIV y XV. Historia de los movimientos sociales, Siglo XXI edts.

${ }^{207}$ El rey Enrique IV dona, como decimos, de forma similar otros lugares de la Tierra de Medina, tal es el caso en 1452 de los términos de Alaejos, Castrejón y Valdefuentes, situados al oeste de esta Comunidad de Villa y Tierra y donados al obispo de Ávila, don Alfonso de Fonseca: “Don Enrrique por la graçia de dios príncipe de Asturias hijo primogénito..., por hazer bien y mrd. a vos el rreverendo padre don Alfonso de Fonseca, obispo de avila, del concejo del dho señor Reyno por los muchos y leales y seńalados servy ${ }^{\circ}$ s... fago vos mrd y gracia y don. ${ }^{a} . .$. , del my lugar de alahejos...,

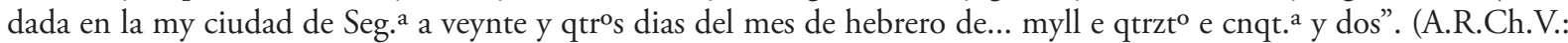
Pleitos Civiles. Fenecidos, Pérez Alonso, C. 1004-1. Copia del pleito de 1537, tomado de OJEDA NIETO, J.: Alaejos..., ob. cit., pág 15).

${ }^{208}$ La trascripción de la donación sigue las mismas normas protocolarias que en otras donaciones y mercedes otorgadas en estos tiempos: "18 de Setiembre de 1464. Dońa Juana por la gracia de Dios, Rreyna de Castilla e de León, por mí tratados los muc(...) e leales y continuos seruiçios que vos Pedro de Sylua, guarda e vasallo del Rrey, mi seńor, e del su
} 
Coincide la fecha, prácticamente, con las negociaciones que, en los últimos meses de 1464, se estaban llevando a cabo en Medina del Campo por parte de Enrique IV frente a representantes del bando rival, capitaneado por el arzobispo de Toledo, Alfonso Carrillo ${ }^{209}$. De hecho, la merced realizada será prontamente ejecutada mediante toma de posesión y anuncio público ante el concejo del lugar, firmándose el acta de dicha reunión el 12 de octubre de 1464210. Era una donación más por parte del rey para atraer mayores apoyos a su causa. Pedro de Silva se había distinguido como capitán de guerra a su servicio ${ }^{211}$.

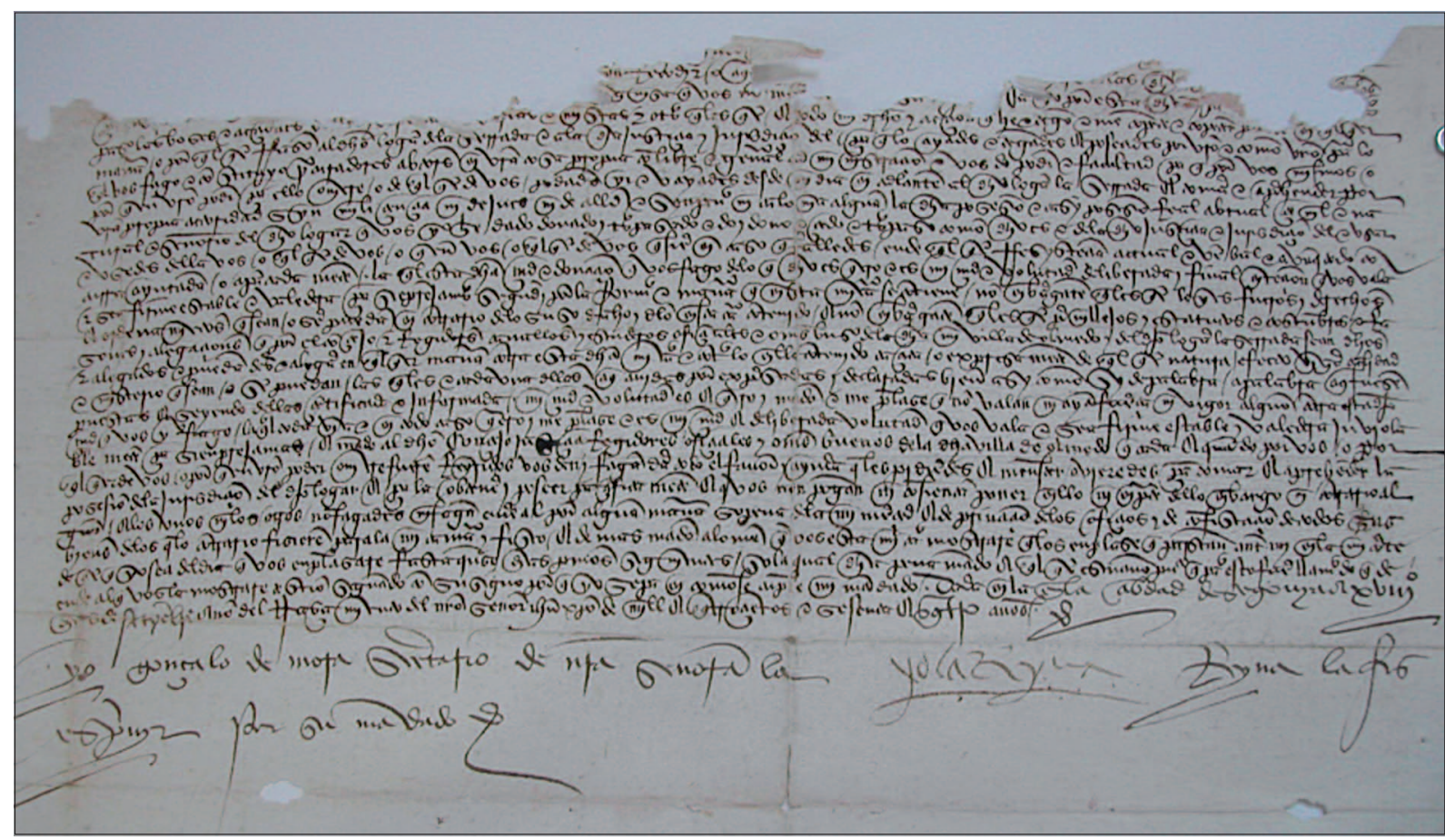

Imagen 37. Fragmento del documento de donación de Serrada por la reina Juana y el rey Enrique IV a Pedro de Silva y a Mencia de Meneses, 18 de Septiembre de 1464. (A.R.Ch.V.). Foto: 09/09/2003.
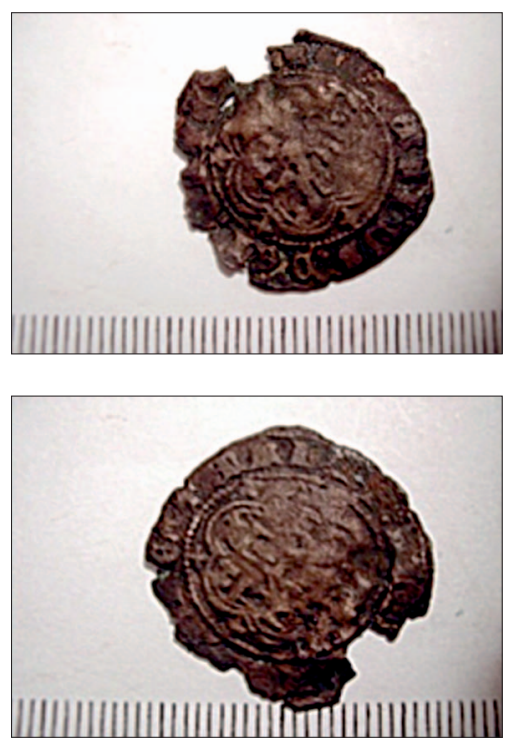

1- Anv. / Rev.
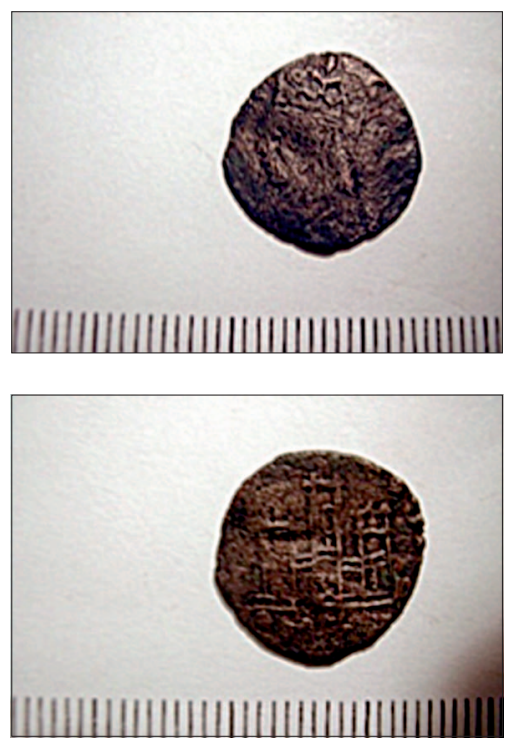

$2-$ Anv./ Rev.
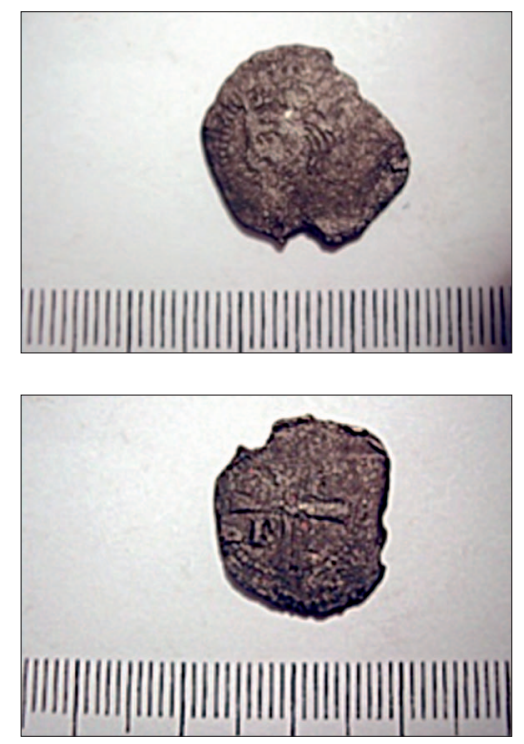

$3-$ Anv. / Rev.

Imagen 38. Anversos y reversos de monedas encontradas en el espacio estudiado de época bajomedieval: coronado de Alfonso XI (1312-1350), izquierda; cruzado de Enrique II (1339-1379) centro; Blanca de Enrique III (1390-1406), derecha ${ }^{212}$. Colecciones particulares, foto: junio de 2005. 
Como acabamos de relatar, siguiendo la historia de la casa de los Silva, el matrimonio de Pedro de Silva con Mencía de Meneses, doncella de la reina Juana, procedente de lo más granado de la nobleza portuguesa, le hace partícipe de las intrigas y vaivenes que se viven en la corte por estos años. De hecho, según se relata en la Crónica Anónima de Enrique IV, cuando la reina escapa del castillo de Alaejos en 1468, donde estaba custodiada por Alonso de Fonseca, arzobispo de Toledo, y las malas lenguas atribuyen su embarazo a unos u otros nobles entre los que Beltrán de la Cueva es el más nombrado, es esta doncella de confianza quien la acompaña ${ }^{213}$ :

\begin{abstract}
"Estándola esperando el dicho don Pedro de Castilla e con Luys Hurtado de Mendoça, mayordomo mayor que fue del rey don Juan, con diez de cavallo con los quales la estava esperando doña Mençía de Meneses, mujer que fue de Pedro de Silva, morador en Olmedo, los quales todos se fueron con la reyna a la villa de Cuéllar, donde estaba el duque don Beltrán de la Cueva, la qual dava al duque algunas causas de su venida negando la verdadera causa: de lo qual el duque ovo grande enojo e yncrepava mucho a la reyna por aver cometido tan gran liviandad, de lo qual todo el rey don Enrique seyendo çertificado, estando en la villa de Madrid, ovo gran sentimiento".
\end{abstract}

Consejo y vos doña Mençía de Meneses, su muger (...) vedes fecho e fasedes de cada día e por rrespecto de vuestras personas (...) e quiticado vos remunerar en alguna parte e manera los dichos vuestros buenos y (...) seruiçios por esta mi carta de mi propio motu e çierta ciencia e (...) de qui quatro vsar e vsó en esta parte y por virtud de la licencia e acturidad (sic) que el (...) me dio e otorgó para lo que en esta mi carta será contenido la (...) e supliqué e della vsando por esta mi carta vos fago (...) e donaçión (...) ble que es dicha entre biuos para sienpre jamás del mi logar [de la] Serrada con la justicia e jurisdicción çeuil y criminal alta y baxa y [mero]misto... e derechos y penas e colonias e vasallos del logar fasta (...) término e jurisdiçión de la mi villa de Olmedo y la yo aparte e (...) y della (...) para vos e para vosotros herederos e suçesores después de vos (...) vo e cada vno de vos que fuerdes i por bien touiéredes por (...) heredad (...) con el término que fue e está limitado e apartado e amojonando (...) Alfonso García Cherino e el liçençiado Juan Días de Altaçer (...) bachiller Dada en la çibdad de Segouia a VXIII días de Setyenbre, año del nasçimiento del nuestro señor Ihesu Cripto de mill e quatroçientos e sesenta e quatro años. Yo la Rreyna. (Rubricado) Yo Gonçalo de Mora, secretario de nuestra señora la Rreyna la fis escriuir, por su mandado". Un mes más tarde, en reunión de concejo celebrado en dicho lugar, el escribano y notario público da fe de la carta real. Los serradenses han dejado de tener al rey y a la reina por sus señores. El lugar olmedano había pasado a manos nobiliarias. A partir de este 12 de octubre de 1464 serán Pedro de Sylva y su esposa Mencía de Meneses quien ostentarán su jurisdicción, por siempre jamás, para ellos y sus hijos, de todos los términos y heredamientos amojonados en dicho lugar. (A.R.Ch.V. P.C. Zarandona y Walls (F), caja 2711.1, trascripción: Juan Carlos Alonso).

${ }^{209}$ VALDEÓN BARUQUE, J.: "Medina del Campo en los siglos XIV y XV", en Historia de Medina..., ob. cit., vol. I, pág. 211.

${ }^{210}$ A.R.Ch.V., P.C. Zarandona y Walls (F), caja 2711.1.

${ }^{211}$ SALAZAR Y CASTRO, L.: Historia de la Casa de Silva, donde se refieren las acciones más señaladas de sus señores..., Madrid, 1685, segunda parte, libro VII, capítulo primero, pág. 131 y ss.

http://books.google.es/books?id=YgPSamKesLUC\&pg=PA313\&dq=pedro+de+silva+y+mencia+de+meneses. (Fecha: 10/08/2014).

${ }^{212}$ La moneda no 1 corresponde al numerario de Alfonso XI (1312- 1350). Es una moneda de vellón que sigue el tipo de monedas conocidos como coronados o cornados. Este rey era hijo de Fernando IV y Dońa Constanza de Portugal y hasta 1325, con 14 ańos, no gobierna por sí solo. No acuńó vellón hasta 1330. Estos cornados los labra siguiendo la ley y la talla de su padre Fernando IV, pero son de inferior calidad. En ellas se representan el busto coronado del rey a la izquierda en el Anverso, y un castillo de tres torres en el reverso. Los dos van rodeados de una gráfila de puntos circular, que cierran las leyendas y el busto del monarca o el castillo. La leyenda es: Anv.- ALFONS REX; / Rev.- CASTELLE ET LEGIONIS. Las cecas en las que acuńa son hasta 9 , y creemos reconocer encima de las almenas, a la izquierda de la torre central una "B", que respondería a la inicial de la ceca de "Burgos". La siguiente moneda, se corresponde también con una moneda de vellón emitida durante el reinado de Enrique II (1368 -1379). Este tipo se le denomina "Cruzado". Son acuñaciones de leyes y tallas muy bajas en relación a sus emisiones contemporáneas.

Este cruzado lleva en el Anverso un busto coronado del monarca a la izquierda, enmarcado por una gráfila de puntos. La leyenda es ENRICVS REX LEGIONIS. En el Reverso Cruz patada y las letras E-N-R- I entre los brazos de la cruz, que se rodea por una gráfila circular de puntos; en la leyenda ENRICV REX CASTELLE, aunque desconocemos la ceca. Su valor de un maravedí - diez dineros novenes-. 


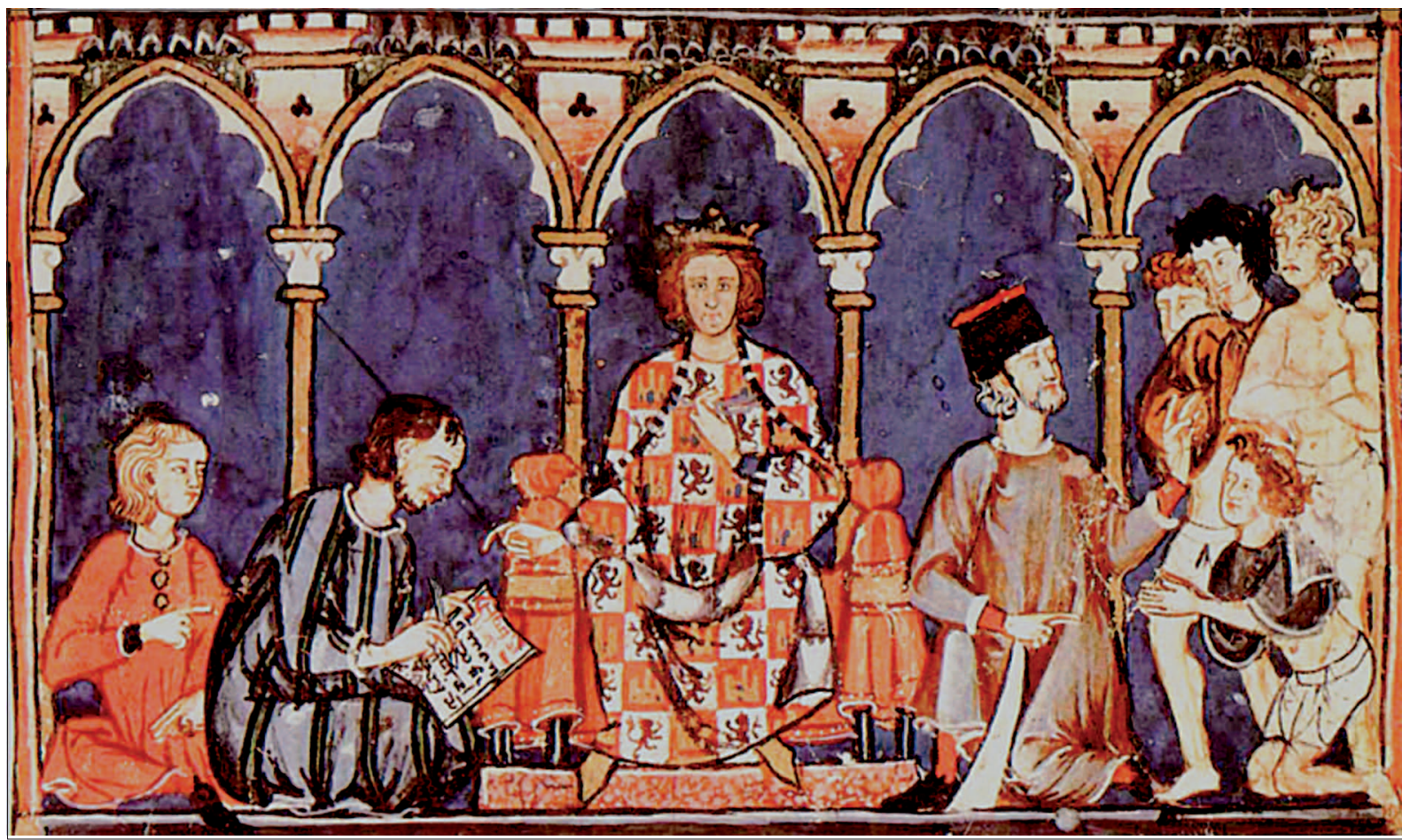

Imagen 39. Ilustración perteneciente al Libro del Axedrez, Dados e Tablas. Esta obra, escrita por encargo de Alfonso X el sabio, recoge el simbolismo de las figuras y movimientos del juego del ajedrez, toda una metáfora de las intrigas políticas de estos siglos. (Biblioteca del Monasterio del Escorial. Madrid.

La moneda fotografiada en tercer lugar se corresponde al numerario de Enrique III. Este monarca castellano emite moneda con un valor fiduciario más alto valor nominal que el primitivo "dinero o novén” debido a la inflación producida durante el reinado de la casa Trastamara, que le va a obligar a realizar este tipo de acuńaciones. Las blancas de Enrique III (1390-1406), a la que pertenece el ejemplar fotografiado en tercer lugar, presentan los emblemas de Castilla y León: castillo en el anverso y león en el reverso. Ambos motivos se encuentran inscritos en seis lóbulos y delimitados por una gráfila circular de puntos. En la intersección de cada lóbulo, una pequeña cruz. Las leyendas correspondientes serían: Anv.-ENRIQCVS DEI GRACIA REX; Rev.- ENRIQCVS DEI GRACIA REX; Estas “blancas”, equivalen a cinco de las anteriores. La marca de ceca no se distingue, aunque estos tipos suelen llevar hasta seis marcas de ceca: Burgos, Coruña, Cuenca, Segovia, Sevilla, Toledo y marcas C o Corona, sin ceca conocida. Los períodos que representan estos hallazgos medievales se corresponden a momentos turbulentos de la Baja Edad Media, bien por minorías (la de Alfonso XI), bien por cambios de dinastía, con guerra civil incluida (Enrique II). El caso de Enrique III, el monarca se enfrenta a serios problemas de inflación que hereda de los reinados de la Casa de Trastamara. Dentro de las acuñaciones de vellón de Alfonso XI, el cornado es su tipo numerario más común junto con los novenes, según los hallazgos casuales recogidos por Inmaculada Sáez y estudiados en su Memoria de Licenciatura (SÁEZ SAIZ, Inmaculada, "La Circulación Monetaria del vellón en el reino Castellano-Leonés de Fernando I a los Reyes Católicos", Memoria de Licenciatura de la Facultad de Filosofía y Letras, de la Universidad de Valladolid, dirigida por el Profesor D. Alberto Balil Illana, 1982, 362 páginas; sin publicar). Creemos también identificar que esta moneda fue emitida en la ceca de Burgos, una de las más destacadas entre el resto de las ya citadas. A pesar de que no comienza a emitir hasta Alfonso VII no dejará de hacerlo de manera regular a lo largo de toda La Edad Media. Según nuestros datos, es la que mayor número de monedas ha emitido tanto en tesorillos como en hallazgos casuales. La zona de expansión que se marca en el mapa coincide con los límites del reino, a excepción del sureste de la península. Refleja la importancia de la ciudad como centro económico y político, favorecida por los reyes castellano-leoneses.

Enrique II es el monarca que marca el inicio de la Dinastía Trastamara. Se sabe de sus acuńaciones, en gran parte gracias a la documentación encontrada en el Archivo de la Corona de Aragón sobre las falsificaciones que hizo Pedro IV de Aragón de su monetario. El cruzado encontrado es uno de las acuńaciones en vellón de Enrique. También su numerario es localizado con frecuencia en los hallazgos de los que se ha tenido constancia. Enrique III tiene una representación mucho más escasa dentro de los tesorillos y hallazgos casuales aunque se ha podido detectar en casi todas sus piezas la pertenencia a la ceca de Burgos.

${ }^{213}$ Crónica anónima de Enrique IV de Castilla, 1754-1474 (Crónica castellana). Edición crítica y comentada de Ma Pilar Sánchez Parra, 1991, capítulo III, pág 247.

http://books.google.es/books?id=KHdJ00PfNgC\&pg=PA248\&dq=pedro+de+silva $+y+$ mencia + de + meneses $\&$ hl $=$ (Fecha 10/08/2014). 




Imagen 40. Documento que da fe de la reunión del concejo de Serrada para dar cuenta del nuevo señor del lugar. Año de 1464. Ministerio de Cultura. (A. R. Ch. V.), PL. Civiles. Zarandona y Wals (F), caja 2711.0001. Foto: 09/09/2003. 
$\mathrm{Al}$ margen de estos u otros hechos, en lo que respecta a la donación de Serrada, Olmedo, como decimos, no se va a quedar impasible ante la pérdida de una de sus aldeas, por pocas o muchas rentas que proporcionara. Y menos cuando las traiciones de unos y otros nobles acababan por perjudicar a la propia villa o a quienes la regentaban ${ }^{214}$.

Las intrigas entre los partidarios del rey Enrique y los de su hermano Alfonso envenenan las relaciones entre unos y otros nobles. El hijo de Pedro de Silva, de igual nombre, junto con Antonio de Arévalo, continos del rey Católico, cuando son convocados a la guerra contra Francia rińen con su capitán Alonso de Fonseca y regresan desde Almazán a sus casas. Las distintas familias nobiliarias tejen toda una maraña de favores, matrimonios o envidias. En el caso que nos ocupa, por ejemplo, la familia de los Silva se emparentan con los Viveros, de los que desciende Juan de Vivero, el "Caballero de Olmedo", que será asesinado como consecuencia de las disputas por las regidurías de dicha villa, entre otras consideraciones ${ }^{215}$. En lo que al propio lugar de Serrada respecta, la aldea se convierte por donación real en un dominio señorial que durará más de cuatrocientos años.

\section{- La venta de Serrada en 1487 a Diego Ruiz de Montalvo}

En menos de treinta años los vecinos de este lugar de Olmedo van a tener por señores a la flor y nata de la sangre azul castellana, desde reyes a nobles con alcurnia y distinción. Y es que en 1487 María de Silva, hija de Beatriz de Silva, segunda señora de Serrada, otorga poder a su padre Pedro Dávila, previa licencia de su marido Rodrigo de Vivero y Guzmán, para su venta al regidor e importante servidor real Diego Ruiz de Montalvo ${ }^{216}$.

Se hace difícil establecer las causas concretas que movieron a Pedro de Ávila a vender su señorío de Serrada. Desde que Pedro de Silva abriera por la noche la puerta de San Pedro a los partidarios de Alfonso, los Silva no van a ser bien vistos en Olmedo, pese a sus intentos de relación y parentesco. Por la parte compradora no debe pasar desapercibido el deseo de estas familias nobles que aspiran a engrandecer su nombre y patrimonio con seńoríos equiparables a los de los más rancios linajes. En Serrada encontraban el aliciente de derechos de jurisdicción, no siempre adscritos a los señoríos en

${ }^{214}$ El propio cronista Enríquez del Castillo narra los hechos que acaecieron después de que el rey llegara a Segovia, alumbrando nuevos datos de este primer señor de Serrada y de sus actuaciones contra el rey que le había hecho merced: "E pasados algunos días después que el rrey fue llegado a la cibdad de Segovia, vino allí Pedro de Fontiveros, diziendo que por los cavalleros tiranos traya cierta contratación, pero aquello hera falso, porque el fin de su venida fue concertar con Pedrarias de Ávila la trayción e vendida de aquella cibdad, que por su secreto mensajero les avia proferido de dar, e así como su venida hera agena de lo que fingía traer, se torno sin conclusión alguna, porque ya las cosas de paz e sosiego se yvan de contino enpeorando, las novedades crescían de contino e las trayciones se multiplicavan. Vn onbre de baxo estado que se llamava Pedro de Silva, aviendo rrescibido mercedes de la rreyna, cuya hera la villa de Olmedo, e teniendo la governación delta por su mandado, porque hera casado con una donzella suya, pospuesta su vergüenza, ensuziando su linage y envileciendo su persona, en nonbre de traydor, vendió a los tiranos desleales e dioles entrada por un postigo del muro que estava junto con su casa, donde luego los cavalleros con su rrey que dezían, se movieron allí aposentar...”. (SÁNCHEZ MARTÍN, A.: "Crónica de Enrique IV, de Diego Enríquez del Castillo". Edición crítica, Universidad de Valladolid, 1994).

${ }^{215}$ BLANCO SÁNCHEZ, A.: Sobre Medina el Campo y la reina agraviada. Ed. Caballeros de la Hispanidad, Medina del Campo, 1994, pág. 445 y ss.

${ }^{216} \mathrm{La}$ carta de venta precisa las condiciones de la compraventa y quién es la parte compradora, nada desconocida, por otro lado entre los linajes y regidores medinenses: “/ $(f .1 r)$ 1487. Pedro de Ávila bendió a Diego Rruiz de Montaluo. No 4. (Cruz). Venta de la villa de la Serrada y de su jurisdición cebil y criminal y de todos sus términos, montes, prados, binas, heredades, casas y casares en fabor de los siguientes: Diego Rruiz de Montalbo, doña Leonor de Torres, su muger, fecha a 25 de Otubre de 1487 años. / (f.2r) (Cruz) 25 de Otubre 1487. Sepan quantos esta carta de venta vieren como yo Pedro de Ávila, señor de Villafranca e de las Nabas, vesyno de la noble çibdad de Ávila, por mí e en nonbre e por virtud del poder que he e tengo de doña María de Ávila, mi hija, e fija legítima e heredera vniversal que fyncó e queriendo de doña Beatriz de Sylva quien la aya santa gloria, mi primera muger, esposa en el de Rrodrigo de Bivero el qual dicho poder espresó en papel e synado de escriuano público, segund que por él paresçía, su tenor es el syguiente: 
venta y, además, el lugar estaba próximo a su vecindad medinense, en el centro de esta Castilla que basculaba entre Valladolid, Medina, Tordesillas y Olmedo, centros neurálgicos en aquellos tiempos. Los Montalvo eran conocedores de la escasez de renteros que por aquel entonces poseía el citado lugar, pero confiaban en su influencia para alentar la llegada de otros nuevos que pudieran generar mayores rentas para vigor del señorío. No debe olvidarse que nos encontramos en tiempos del gran auge ferial de Medina. La nobleza, en Serrada y en otros lugares cercanos, a pesar de su pequeña entidad, habían encontrado el aliciente de titularse señores, detentar derechos jurisdiccionales y codearse tanto con los viejos linajes como con los nuevos acrecentados. En la escritura se precisa lo que se vende ${ }^{217}$ :

“...Que la mejor forma e manera que puedo e devo de derecho, vendo a vos Diego Ruiz de Montalvo, regidor e vezyno desta noble villa de Medina del Campo, e a vos dońa Leonor de Torres, vuestra muger, por vos e para vuestros herederos e subcesores, por juro de heredad, para siempre jamás, la mi villa de la Serrada... diócesis e obispado de Palencia, con sus vasallos e jurisdición cebil e criminal, alta e baxa e mero misto ynperio, e con todos sus términos e montes e prados e pastos e casas e solares e eriales e tierras e vyñas, e aguas estantes e corrientes e manantiales, con todas sus heredades e con todos sus derechos e husos e costumbres e servidumbres pertenescientes... e pueden e deben pertenecer e qualquier manera e por qualquier razón, titulo, derecho... de hecho como de derecho que los dichos vasallos e vezinos del dicho lugar han y tienen y les pertenecen...según que mejor e mas cumplidamente lo tuvieron e poseyeron la dicha doña Beatriz, su muger e Pedro de Sylva, su padre, e los otros sus antecesores e segund que mejor e mas conplidamente lo yo he tenido e poseydo e lo tengo en posesión...”

En el texto consta lo que por este tiempo se ambiciona: vasallos, jurisdicciones, montes, prados, casas, solares, eriales, tierras, vińas, aguas... Un millón trescientos mil maravedíes fue el precio ajustado en la venta y pagado por el nuevo señor. Diego Ruiz de Montalvo en estos años disfrutaba de la confianza de los mismos Reyes Católicos. Estaba casado con Doña Leonor de Torres, hija de Juan Torres, tercer señor de Alcobilla. Desde estos años se asiste a una meteórica vida llena de cargos y honores. En febrero de 1494 la reina Isabel y su esposo el rey le hacen entrega de la fortaleza de Monleón, en la vecina Salamanca; en noviembre de ese mismo año se encontraba de alcaide en Logroño; regentó con anterioridad la de Toro, más tarde la de Segovia... A pesar de sus numerosas responsabilidades, su preocupación por proteger su señorío y vasallos de Serrada, hasta en ocasiones excederse,

Sepan quantos esta carta de poder vieren, como yo doña María de Ávila, fija de Pedro Dávila, mi señor, e de doña Beatriz de Sylva, mi seńora madre, que Dios aya, con lizençia de Rrodrigo de Bivero, mi esposo,... otorgamos e conosçemos que damos e otorgamos todo nuestro poder conplido libre e llenero... a vos el virtuoso e noble cavallero el señor don Pedro Dávila que está ys presente para que por nos y en nuestro nonbre podeys vender e vendays y enpenar y enpeñeys y enageneys todos qualesquier bienes muebles e rraýzes e basallos e fortalezas e juridiçiones espeçialmente vos damos el dicho poder para que < por> nosotros y en nuestro nonbre podades vender e trocar e cambiar e enpeńar toda la parte e derecho e posesyón e tenençia e propiedad e seńorío que nosotros avemos e tenemos en la villa de la Serrada ques çerca de la villa de Holmedo e de la puente de Valdastillas(sic) [e]n todo lo a la dicha villa de la Serrada, anexo e pertenesçiente de los que fueron e fyncaron de la dicha dońa Beatriz, que Dios aya...”. (Trascripción: Juan Carlos Alonso).

La fecha de venta es de 25 de octubre de 1487 y es muy posible que confluyan distintos factores. Por una parte, como avecindado en esta época en Olmedo, lo suponemos al corriente de las intenciones de su regimiento de reclamar jurídicamente la segregación de una de sus aldeas a pesar de la confirmación recibida por sus servicios a la villa. Por otra, Pedro Davila está inmerso en pleitos y litigios, siempre costosos, que pueden indicar su necesidad de recursos. En los años de 1487, 1490, 1503 y 1509, constan numerosos pleitos con vecinos de Olmedo y Ataquines sobre posesiones, restitución de bienes y curadurías, deudas por arrendamientos y usura, etc., que pueden indicar esta necesidad de liquidez, sin menoscabo de la situación y necesidades de su hija María de Silva y su esposo Rodrigo de Vivero. Quién sabe, por último, si las relaciones políticas y personales de estas partes compradoras y vendedoras, al servicio de los mismos reyes, influyeron igualmente en la escritura de venta. Si todos estos factores pudieron concurrir en la parte vendedora, otros tantos deben pesar en el deseo de la familia de los Montalvo de Medina del Campo por hacerse con el control de esta aldea olmedana. Se señala, en primer lugar, la disponibilidad de liquidez por parte de Diego Ruiz de Montalvo que, como regidor de la villa de Medina e importante colaborador y detentador de cargos al servicio de los Reyes Católicos, podía afrontar compras y sumas de cuantía elevada. (A.R.Ch.V.P.C. Zarandona y Walls (F), caja 2711.1).

${ }^{217}$ Ibídem. 


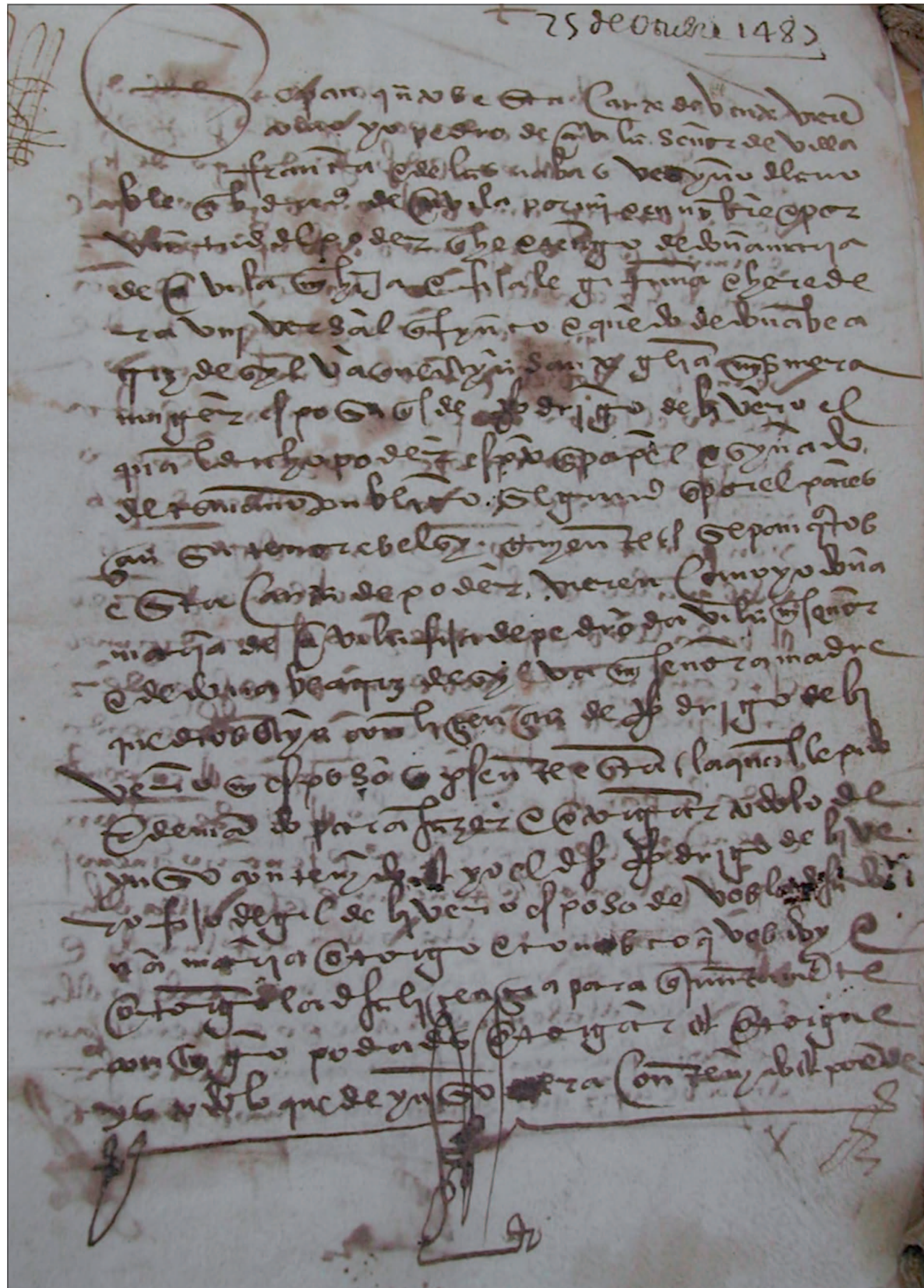

Imagen 41. Carta de venta del lugar de Serrada por parte de Pedro de Ávila a Diego Ruiz de Montalvo.

25 de Octubre 1487. (A.R.Ch.V.P.C. Zarandona y Walls (F), caja 2711.1). Foto: 09/09/2003. 
dada su preponderancia política, llama la atención. En este sentido, y como primer documento referente al señorío de Serrada en manos de esta familia, lo encontramos pocos meses después, fechado el 30 de enero de 1488 en Zaragoza. Esta dirigido "a Luis González de Sepúlveda, para que este determine la demanda de Diego Ruiz de Montalvo, contino, contra ciertos vecinos de Matapozuelos, Valdestillas, Aldeamayor, etc, que habian hecho daño a renteros suyos del lugar de Serrada"218.

\section{- La fundación de mayorazgo sobre Serrada en 1506 por Ruiz de Montalvo}

No habían sido pocas las batallas y conflictos que, por estas fechas, había librado el nuevo señor de Serrada. En su propia villa ferial sus actuaciones le habían hecho ganar un mar de enemigos ${ }^{219}$. Son tiempos en que estos prohombres se deslizan entre ambiciones personales, ocupación de cargos y traiciones políticas. Tanto la propia reina Isabel hasta 1504, año en que fallece, como Fernando como Regente posteriormente, habían mostrado sobrada mano izquierda para, a pesar de tantos intereses creados entre familias nobiliarias, poderes locales y eclesiales, sentar las bases de un Estado moderno presidido por su autoridad. Las distintas familias nobiliarias no se conformaban solamente con adquirir tierras, rentas y jurisdicciones, deseaban por encima de todo perpetuarlas eternamente a través del mayorazgo. Los bienes preservados por tal figura jurídica, que rubricaba el propio rey, pasarán indivisibles de generación en generación a través del primogénito varón o, en su defecto, la primera de las hijas, a la que sucederá, nuevamente, su primogénito. La nobleza blindaba de esta manera su poder por los siglos de los siglos. Los campesinos que habitaban Serrada, como en tantos otros lugares, por el contrario, quedaban condenados a ser siempre renteros de unas tierras que, en su mayoría, hasta apenas unas décadas, no han sido de su propiedad. La fundación la lleva a cabo, junto a su esposa Leonor de Torres, en el año $1506^{220}$.

${ }^{218}$ El documento muestra cómo muy pronto Diego Ruiz se preocupa por gestionar cuantos aspectos atañen a su nuevo seńorío y defender las necesidades de sus vasallos. No dejará en el futuro de asombrar, en una persona de tan alta condición, el gran celo e interés que se toma a lo largo de su vida por preservar la integridad y defender las causas de los habitantes de su seńorío de Serrada, dada su ajetreada vida al servicio real. Pero pronto empezarán nuevos disgustos para la familia Montalvo. Se trata de los constantes litigios sobre los límites, derechos de pasto sobre terrenos concejiles, alcance de derechos jurisdiccionales o tierras y montes propios de la Comunidad de Villa y Tierra. Si se sumaran los gastos en justicia que, a lo largo de estos siglos, pagaron cuantos concejos poblaban la Tierra de Medina por estas cuestiones, en más de un caso se pensaría que se compraron dos y tres veces los bienes disfrutados. (A.G.S. R.G.S., vol. V, 2208, fol. 179).

219 BLANCO SÁNCHEZ, A.: Sobre Medina el Campo..., ob. cit, pág. 432 y ss.

${ }^{220}$ En dicha institucionalización se reflejan con claridad los intereses nobiliarios y, en este caso, los referentes a los Montalvo y a sus propiedades de Serrada: "Los antiguos que tuvieron consideración a perpetuar su nombre y la honra de su linaje ovieron por buen consejo, de dar a sus hijos los mayores la mayor parte de su hacienda e condicionarla e vincularla para que veniese en sus descendientes de mayor en mayor, y desta manera, (...) e por ende yo Diego Ruiz de Montalvo, vecino y regidor desta noble villa de Medina del Campo, e yo doña Leonor de Torres su legítima mujer, señores de la villa de Serrada, queriendo seguir el consejo de los antiguos e discretos pasados, considerando que Iohan Gutiérrez de Montalvo, nuestro hijo mayor, fue primero en el nacimiento, (...), determinamos de facer y constituyr un mayorazgo de nuestros bienes a servicio de Dios, e de los reyes nuestros señores, e de sus sucesores e herederos en estos Reynos. E queriendo usar e usando de una licencia e facultad que por Su Alteza nos fue concedida e es otorgada para efecto, el thenor de la qual es este que se sigue: Dońa Juana, por la gracia de Dios reyna de Castilla, (...) etc. Por quanto por parte de vos, Diego Ruys de Montalvo, vecino e regidor de la villa de Medina del Campo, e dońa Leonor de Torres, vuestra mujer, me fue fecha relacion por su petición asiento que vosotros queriades facer mayorazgo en Iohan Gutierrez, vuestro fijo mayor de la vuestra villa de Serrada con sus términos e jurisdición cevil e criminal, alta e baxa e meromisto ynperio e con todas las cosas a ello anexas e pertenecientes y de las casas principales que teneys en la dicha villa de vuestra morada, que son en la calle que decen de las quatro calles, con un lagar e cortinal que esta junto con las casas segund que oy día vosotros las teneys e poseeys... E yo, por fazer bien e merced a vos, los dichos Diego Ruys de Montalvo e dońa Leonor de Torres, vuestra muger, e acatando los muchos e leales servicios que me aveys fecho e faredes de aquí en adelante.... vos podades facer e fagades.... mayorazgo de la dicha villa de Serrada con todos sus términos, e jurisdiciones e meromisto ynperio, e todo lo otro a ello pertenesciente, e de las dichas casas principales con su lagar e cortinal en el dicho Iohan Gutierrez, vuestro fijo mayor.." (A.R.Ch.V. Pergaminos, caja 48.7. Copia del mismo también se halla en: A. H. P. V. Prot. 6688. Juan Bayón Clemente, autor de la "Historia de la Antigua Villa de Rueda", también cita parte del mismo en su obra). 
La constitución de mayorazgo blindaba ante posibles fragmentaciones las propiedades y derechos asociados, vinculándolos al primogénito varón por siempre jamás. En el propio privilegio se señala cómo dicho mayorazgo no podrá ser vendido, ni enajenado, ni perdido por cualquier causa por grave que esta sea. Se señalan incluso aquellas de las que pudieran derivarse su anulación, anotando respuestas salvaguardadoras pues "es mi merced que si alguno o algunos que tovieren el dicho mayorazgo, cometieren delito que sea crimen lesa majestatis o de heregia contra natura por donde según las leyes e premáticas de mis Reynos merescen perder sus bienes, que en tal caso los aya perdido e pierda assí como si los dichos bienes no fuessen de mayorazgo" ${ }^{221}$. Es un tiempo de descubrimientos en que Castilla es la protagonista. Isabel I y Fernando de Aragón sientan las bases del estado moderno. Para ello apaciguan los antiguos bandos en lucha, imponen su autoridad en ciudades y municipios y avanzan en la gestación de una administración central222.

Más allá de estas cuestiones, necesarias por otra parte para conocer en detalle la evolución de las comunidades que habitan en estos lugares, en estas décadas de finales del XV y principios del XVI los conflictos entre vecinos, y las diferencias que enfrentan a concejos con las villas a las que pertenecen, son continuos. La presión de los labradores sobre las tierras comunales, cada vez más crecientes; las necesidades del ganado sobre unos pastos menguados por el arado, aún mayores; el deseo de riqueza y rentas por parte de los señores, no parecen encontrar techo. Una nueva época muy distinta a la del nacimiento de estas aldeas. El dinamismo ferial medinense genera una importante demanda de productos agrarios que sólo el rompimiento de los montes comunales y terrenos baldíos puede satisfacer. La población se dispara y la presión sobre el terrazgo se incrementa como nunca lo había hecho hasta entonces. Se estima que Medina en 1561 contaba con más de tres mil vecinos. Los lugares que se situaban al norte, como Rueda, La Seca, Ventosa o Pozaldez, solicitan o reclaman permisos para roturar montes comunales. El propio Ruiz de Montalvo interviene en dichos repartos. En el año 1500 los propios Reyes Católicos otorgan licencia para que el Monte Inestoso, que, según sus palabras, "va del camino de Rodilana al lugar de Serrada hasta Ventosa ... e hasta San Martín e Monte de la Abadesa de Tordesillas, que es bueno para labrar pan" lo labren dichos vecinos por espacio de doce años ${ }^{223}$.

${ }^{221}$ Esta primera parte del privilegio en pergamino de la reina Juana está fechada en Segovia el 31 de agosto de 1505, señalándose la firma del rey como gobernador y administrador del reino de Castilla y de Miguel Pérez Almazán como secretario de la propia reina Juana. A la licencia otorgada le sigue la propia escritura del mayorazgo por parte de los dichos Diego Ruiz y Leonor de Torres: "Por ende, yo el dicho Diego Ruys de Montalvo e yo, la dicha dońa Leonor de Torres, su muger, con su licencia e expreso consentimiento, para que juntamente conmigo podays facer e otorgar lo contenido en esta carta... disponemos e ordenamos que la nuestra villa de Serrada con sus términos e jurisdicción cevil e criminal mero misto ynperio, rentas, pechos e derechos, con sus casas e casares, huertos e mesón e palomar e con todo lo otro a la dicha villa anexo e perteneciente segúnd que lo nosotros avemos e tenemos en las casas principales que nos avemos e tenemos en esta dicha villa de Medina e en una de las cuatro calles della con sus cortinales e bodegas e cubas e lagar e con todos sus derechos e pertenencias e usos e costumbres...lo aya e herede todo el dicho Iohan Gutiérrez de Montalvo, nuestro fijo mayor, por mayoradgo e a titulo e condición de mayoradgo por bienes ynajenables e ynperesquritibles para sí e para su fijo mayor e subcesores e dessendiente...”. Y rubricando las posibilidades de perpetuar indivisiblemente sus bienes "sine die" establecen, como posibilita esta institución nobiliaria, perpetuar el mismo en los primogénitos varones nacidos en línea masculina de su hijo mayor Iohan Ruiz de Montalvo. En caso de no tener éste descendencia, disponen quién, cómo y cuándo deben otorgarse derechos y hacer ostentación de sus armas ${ }^{220}$. Como se ve, todo será para su primogénito Juan Gutiérrez de Montalvo. Se inicia de esta manera una vinculación extraordinaria y muy duradera entre los vecinos de Serrada y el fecundo linaje medinense. Se otorga y firma la carta en Medina del Campo ante el escribano Gómez Gutiérrez a tres días del mes de marzo de 1506. (A.R.Ch.V. Pergaminos, caja 48.7).

${ }^{222} \mathrm{Su}$ política de unificación territorial y unitarismo religioso será otro aspecto no menos importante que hay que tener en cuenta. La Tierra de Medina late con más fuerza que nunca. En estos años Medina goza de la protección real que asienta en ella su Corte, y sus ferias traspasan las fronteras. El castillo de la Mota ve reforzar y ampliar sus muros de acuerdo a las demandas de la nueva artillería y se levanta la torre del homenaje. En este 1504 Juana, más recluida que huésped en la Mota por la ausencia de su esposo, lleva a cabo más actuaciones de desesperada que de cuerda con tal de marchar a Flandes. No imagina la trágica vida que la espera. Su madre no podrá acompañarla en sus largos desvelos. La reina Isabel muere en noviembre de 1504.

${ }^{223}$ MORALEJA PINILLA, G.: Historia de Medina del Campo. Medina del Campo, 1971, pág. 74. 
El ímpetu será tal que tres años después manifiestan que se ha "rompido tanto que ya no cumple tener ganado porque diz que no tiene donde pacer", por lo que muchos campesinos deberán dejar de meter el arado en beneficio del ganado. La falta de tierra hace saltar chispas entre los concejos. Los pleitos que se inician en 1539 entre La Seca y Rueda son sólo un ejemplo. La verdadera guerra surge con la ampliación del terrazgo cultivado mediante las tierras sernas, esto es, aquellas propias de Medina y su Tierra, roturadas y usufructuadas por los vecinos de los concejos que las acogen a cambio de un canon anual.

A nadie se le escapa que junto a las tierras de pan hay algo más: el viñedo. La fácil salida de los caldos en los mercados medinenses dispara las plantaciones. El mercado ferial es, además, el mejor escaparate para difundir por toda Castilla la calidad de unos blancos que desde entonces se convertirán en el motor económico de buena parte de la Tierra de Medina. Una riqueza que será mimada y vigilada por unos y otros. De hecho, la Villa de las Ferias contaba con una rigurosa normativa en cuanto a la compra de vińas y el control y venta de vinos, mostos y vinagres. En las ordenanzas de 1503 regula precios, abastecimientos y penas. Una riqueza vitícola que tenderá a desplazarse hacia el norte de la Tierra. Llegará un poco más tarde, pero acabará siendo su estandarte por los siglos de los siglos. Los suelos de gravas de las terrazas fluviales serán su asiento y a sus bodegas llegarán los arrieros desde los puntos más lejanos de Castilla.

Entretanto, Serrada, que sirve como ejemplo, no gana para pleitos ${ }^{224}$. Tampoco en esto se diferencia del resto de lugares de Olmedo y Medina. La nobleza lleva intrigando largo tiempo y en los albores del nuevo tiempo, cuando la monarquía trata de imponer su autoridad, todos desean estar bien posicionados. Al margen de estas cuestiones, que exceden el marco del presente trabajo, lo que ha de resaltarse en que, a partir del primer tercio del XVI, se inicia un crecimiento de población y aumento del terrazgo labrado en el lugar de Serrada de forma similar al resto de los lugares vecinos. La demanda de productos por parte de las ferias medinenses pudo incrementar la vitalidad de las tierras situadas al norte de Medina e iniciar, de forma imparable, la plantación de vides para abastecer de caldos a mercaderes, monasterios, ciudades y reyes. Se abre un nuevo periodo en el transcurrir de las pequeńas aldeas estudiadas.

${ }^{224}$ Diego Ruiz de Montalvo, nieto con igual nombre del comprador del lugar en 1487 y Olmedo, no había dicho la última palabra. La villa del caballero reclamaba la jurisdicción sobre su aldea y el control de pastos y tierras "por romper y arar”. La justicia daba la razón a Olmedo. El acto por el que se quitan los símbolos de poder al señor de Serrada y se entregan a los representantes olmedanos no son propios de ser leídos. Merecen ser representados. Ningún testigo que presenció los hechos olvidó las miradas que se dirigieron los Montalvos y los de Olmedo: “...Y ansimismo el dicho Luys de Torres y el dicho Diego Ruiz de Montalbo salieron de la casa donde estaban en el dicho lugar de Serrada y fueron a la picota del dicho lugar y la hizieron derrocar e ansi se derroco. E ansymismo fueron a una cuesta que estava cerca del dicho lugar donde estava la horca y la derrocaron. Y el dicho Luys de Torres dixo que le diexe por testimonio como avia cumplido la dicha carta executoria...”. No fueron estos símbolos sagrados de poder y justicia sólo lo que restituyeron a Olmedo. Esta villa también toma como propia de su tierra "un prado grande que hera del dicho lugar, el qual hera vaxo del dicho logar hazia la villa de Tordesillas,... que se llamaba el prado de abaxo,... y que tenía por linderos el camino Real que yba de la villa de Olmedo a la villa de Tordesillas e de la otra parte, debaxo hacia Tordesillas, el término del lugar de San Martín del Monte..."Se mide, catastra y pinta el término y se reparten los pagos que no habían conocido la entrada del arado. Las piezas se encontraban dispersas entre las dos mil quinientas y noventa y ocho obradas de tierra que por entonces catastraba Serrada. Mal día tuvo Montalvo. Su abuelo lo había pagado por el señorío, vasallaje y meromixto imperio del lugar y ahora la justicia se lo quitaba. El pleito contra los Dávila no se haría esperar. Les reclamaría "sobre que le pagase lo que le avia salido incierto". En este sentido conviene reproducir, en palabras del contador López de Zúniga, propuesto por los herederos de los Dávila, la descripción de Serrada en torno a 1525. Está claro que no desean sobrevalorarla pero, ante el juez, la prudencia frenaría cualquier intención de descalificación total. (A.R.Ch.V. P.C. Zarandona y Walls (F), caja 2711.1). 


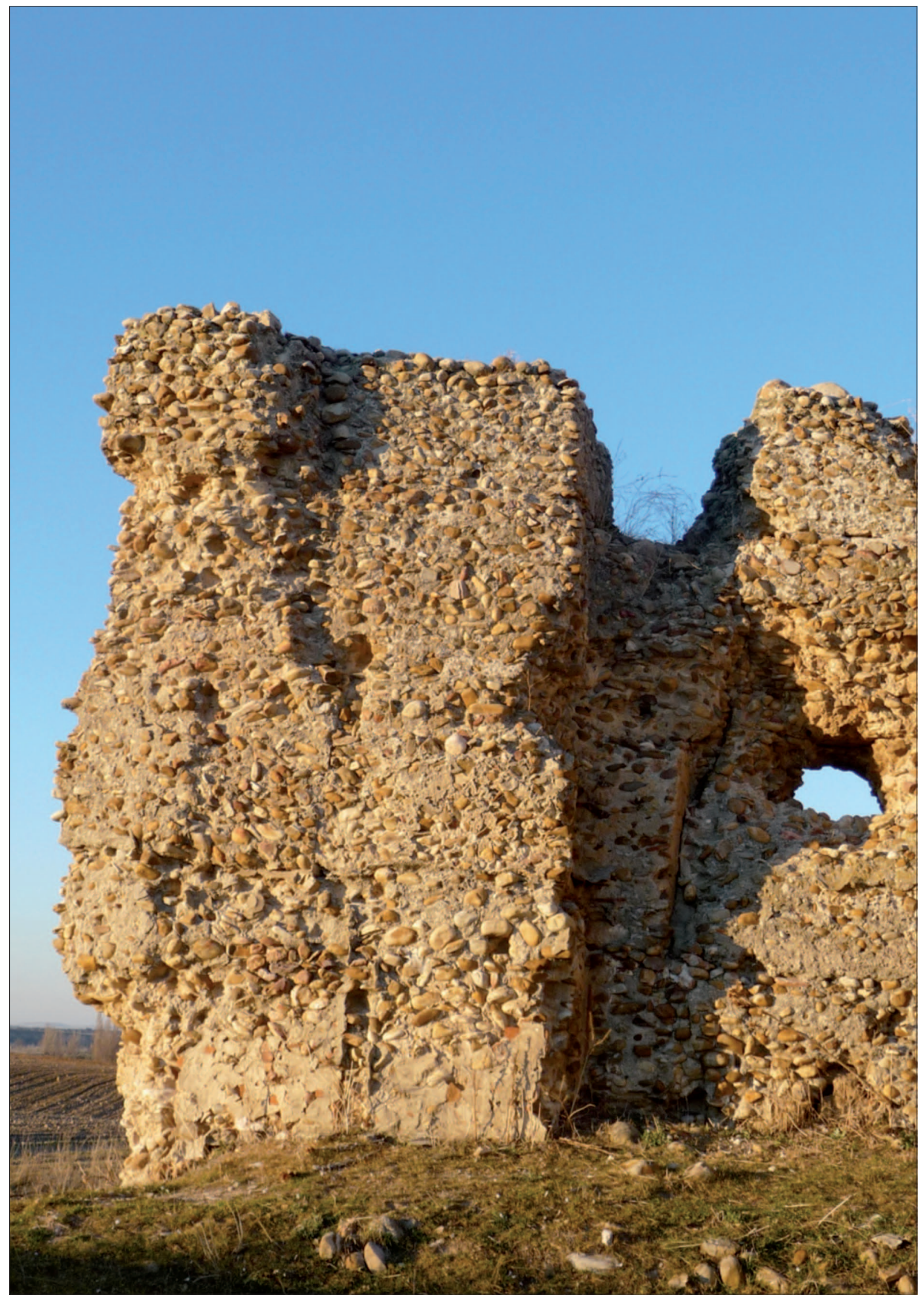

Imagen 42. Restos de la fortaleza defensiva medieval en Eván de Abajo, lugar que, como Serrada, formará parte del mayorazgo del marqués de Torreblanca y Falces. Foto: 04/12/13. Todo un conjunto de fortificaciones fronterizas se extienden por la que fuera Comunidad de Villa y Tierra de Medina. Muchas de ellas se levantaron consecuencia de las guerras entre castellanos y leoneses en el siglo XII. Están realizadas con tapial de cantos rodados y, en ocasiones, se alternan hiladas de ladrillos. 


\section{CAPÍTULO III}

EL CRECIMIENTO DEL TERRAZGO LABRADO EN LOS SIGLOS MODERNOS. LA ESPECIALIZACIÓN VITÍCOLA EN EL NORTE DE MEDINA. LA RENTABILIDAD DE LOS CULTIVOS EN EL SIGLO XVI 


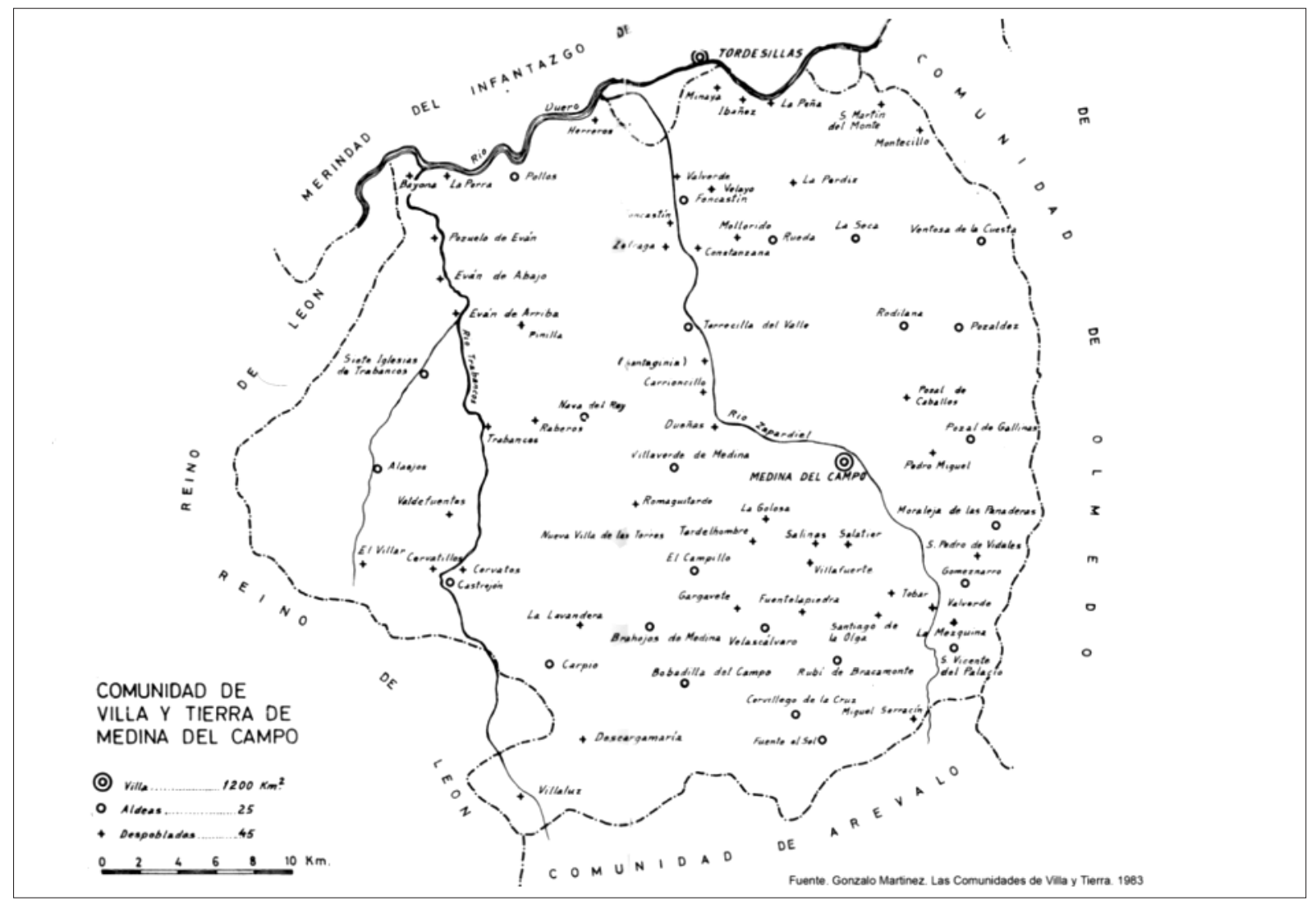

Figura 18. Comunidad de Villa y Tierra de Medina del Campo. Gonzalo Martínez Díez, 1983.

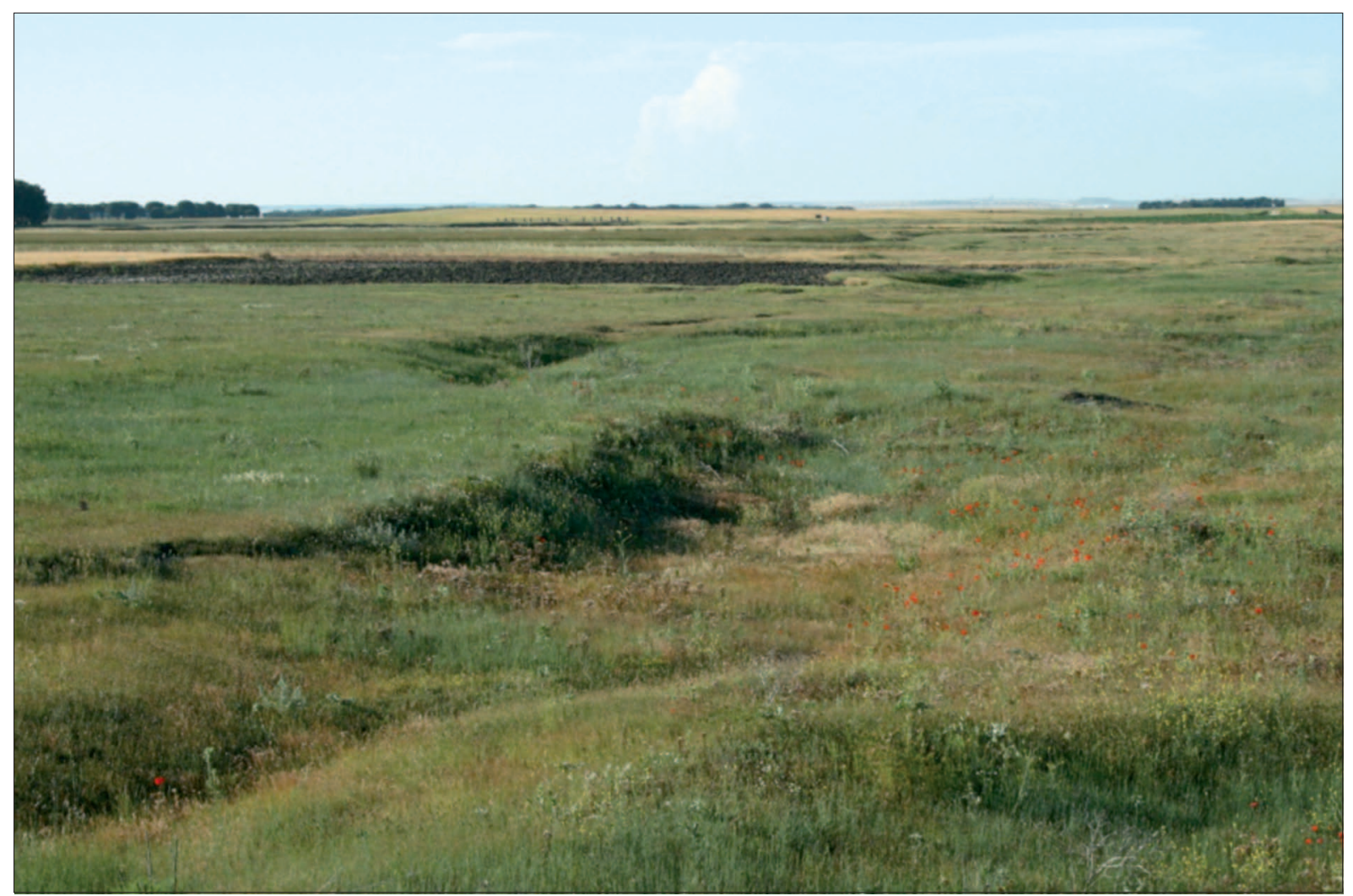

Imagen 43. Prados al sur de Medina regados por el Zapardiel, muy valorados, en tiempo histórico, por el ganado de renta y labor. Foto: 12/06/2008. Obsérvese, en la imagen, cuantos condicionantes hemos señalado en estas campiñas del sur: llanuras casi perfectas, rodales de pinos que fijan los recubrimientos de arenas, roturaciones que llegan hasta el mismo cauce, descenso del nivel freático hasta hacer desaparecer el mismo río y charcas que están secas hasta en las estaciones de invierno y primavera. 
La Edad Moderna representa, para buena parte de los lugares de las Comunidades de Villa y Tierra analizados, una etapa de crecimiento a todos los niveles. Aunque algunas pequeñas aldeas tendrán que cerrar sus puertas para siempre al no poder superar los periodos críticos, que también los hubo, la mayor parte de los núcleos poblados experimentaron una expansión económica y demográfica sin precedentes.

Al tiempo que se producen estos hechos, el fenómeno roturador es imparable en cada uno de los lugares y villas. La expansión económica del siglo XVI, acompañada de un importantísimo crecimiento demográfico, va a necesitar cuantas tierras pudieran ser labradas. El amplio terrazgo que engloba los términos de La Seca, Ventosa, Pozaldez, Rodilana, Nava y Rueda, hasta llegar a los pastizales de San Martín del Monte y al mismo Duero, serán "ocupados" por labradores, más allá de los permisos serniles ${ }^{225}$. Estamos hablando de los montes Pedroso, Inestoso, Valdescaleras, Valdemuelles... En las campiñas del sur y oeste de la comarca se repiten similares vicisitudes. Los abusos del arado generan toda una regulación de coteos y sernas y la restitución, en ocasiones, al monte de parte de las tierras y labradas mediante dictados reales, dadas las necesidades de una cabaña ganadera que ve disminuir rápidamente sus pastos tradicionales $226 / 227$.

En cualquier caso, los tiempos modernos representan el principio del fin de la vegetación natural que aún quedaba en pie en estos espacios de terrazas al norte de Medina o, para ser más exactos, de la poca que quedaba, toda vez que la que refieren los documentos escritos de la época es una vegetación degradaba por presión antrópica ${ }^{228}$.

${ }^{225}$ Las roturas de montes comunales o baldíos son característicos en toda esta Extremadura castellana desde la llegada de los primeros pobladores. Fenómenos similares se han registrado o se tomarán como ejemplos en la Tierra de Olmedo, sea en los casos de la Moya, Valdestillas, Matapozuelos, sea en otros lugares.

${ }^{226}$ El "rompimiento" del monte o de terrazgos de Propios que no llevan esta consideración ha ido asociada a la demanda de tierra por parte de los cultivadores en cada una de los lugares desde su nacimiento. El fenómeno se acrecienta a finales de la Edad Media, tanto por el propio dinamismo económico de las aldeas, como por el efecto de control señorial del terrazgo y la institucionalización del mayorazgo sobre grandes superficies por parte de la nobleza. Tanto a los medianos labradores, como a los pequeños renteros o braceros, sólo les quedaba como único camino para incrementar sus recursos meter el arado o la azada en los bienes comunales y, entre ellos, en los amplios montes de Villa y Tierra.

${ }^{227}$ En otras ocasiones, incluso, ante la falta de equidad en los repartos serniles por parte del corregidor, que beneficia en exceso a la oligarquía local, son los mismos reyes los que tienen que ordenar un nuevo reparto o paliar, en lo posible, el descontento de pueblos enteros que se sienten marginados respecto a sus vecinos. Es el caso de los labradores de Ventosa y Pozaldez que se quejan en 1494 de que no se les ha permitido cultivar parte del monte Inestoso en relación a los de La Seca y Rueda. (VAL VALDIVIESO, Ma. I.: Medina del Campo en la época de los Reyes Católicos, en Historia de Medina y su Tierra..., ob. cit., pág., 250 y ss.)

${ }^{228}$ Villar García, en su completo trabajo sobre la Extremadura Castellana, mantiene la tesis de una práctica ausencia de cobertera arbórea, por presión y actuación antrópica desde épocas antiguas, en los valles y campiñas comprendidos entre el Duero y sus afluentes Adaja, Eresma, Zapardiel, Trabancos y Guareña, limitado al sur por la isohipsa de los 800 metros. La toponimia repobladora, advertida por Hopfner y Wattengerg, es escasa en formaciones arbóreas de entidad y abundante en especies mediterráneas arbustivas o subarbustivas degradadas. En lo que respecta a los límites de este trabajo, salvando "el monte de encina de las Monjas", muy estimado desde finales del siglo XIV por el monasterio de Santa Clara, lo cierto es que los retamares y escobares son las especies que más se repiten en la mayor parte de los pagos que se extienden por este norte comarcal. 


\section{El aumento del terrazgo labrado en detrimento del espacio comunal. El caso de las sernas en los montes de Propios de Medina}

La ocupación del espacio en estos pequeńos lugares al norte de Medina puede ser representativa del resto de la comarca. Especial singularidad merece el caso de los terrazgos denominados "montes, sernas y mercedes", pertenecientes a Medina del Campo, centro de la Comunidad de Villa y Tierra del mismo nombre. Se extienden, en concreto, por los términos de Pollos, Sieteiglesias, Nava del Rey, Torrecilla del Valle, Foncastín, Rueda, La Seca, Ventosa, Rodilana, Pozaldez y los despoblados Mollorido, Zofraga y Herreros. Su importancia y trascendencia agraria radica en su importante extensión y en ser considerados desde tiempos inmemoriales como bienes comunes de Medina del Campo, que, gracias a las rentas que rinden año tras ańo, equilibran los abultados presupuestos de este centro cabecero. De ahí que la villa de las Ferias eche el resto en pleitos dilatadísimos con los concejos locales, cada vez que estos duden de la legalidad de tales cargas, especialmente cuando tengan lugar los procesos de exención en los siglos modernos. No se va a entrar a valorar la génesis y significado del término serna, polisémico y complejo en tiempo histórico, al no ser el objetivo del presente trabajo ${ }^{229}$. Nos centraremos en analizar la transformación que sufre dicho terrazgo a lo largo de los siglos hasta convertir este importante espacio, prácticamente montaraz e inculto en tiempos bajomedievales, en labrantío a lo largo de los siglos XVI, XVII y XVIII.

A falta de pruebas documentales, se estima que la explotación sernil en los espacios comunes de la Comunidad de Villa y Tierra se remonta a su propio origen. El espacio agropastoril que excedía al terrazgo labrado fue considerado, tomando naturaleza jurídica, de uso común y adscrito a la villa cabecera. Lo conformaban importantes encinares, carrascales, retamares y otros espacios incultos que se extendían desde Medina hasta el mismo Duero, amén de notables manchas de pastos a lo largo del Zapardiel, Trabancos y otros arroyos, indispensables para el ganado como pastos y abrevaderos de los distintos lugares que se levantan en sus cercanías. A la par que los pleitos enfrentan a Olmedo, Medina, Tordesillas, Toro o Arévalo por la delimitación de sus respectivos territorios desde tiempos bajomedievales, las propias aldeas fueron concretando, por razones agrarias, de posesión o donación real y fiscal, sus propios términos. Más allá de lo que fuera tomado en principio como "presura" por parte de los primeros pobladores, o labrado y consentido por los reyes o señores legitimados para su organización y poblamiento, generalmente en torno al lugar poblado, no parece aventurado afirmar que el resto del espacio fue lo que, andando el tiempo, se consolida como un espacio común de montes y pastos, dependiente jurídica y administrativamente de la villa de Medina del Campo, tomando el nombre de "sernas" las roturas realizadas en el espacio común por manos particulares para aprovechamiento como tierras de sembradura, a cambio de un canon anual.

Fuera de la delimitación de la propia comunidad de Villa y Tierra, pero dentro del espacio estudiado, se han encontrado labrantíos con igual denominación y similares caracteres. En el término de Fresno el Viejo, perteneciente a la Encomienda de San Juan, se apea en 1833 un coto redondo denominado "La Serna", de una superficie de 450 obradas, que "ha estado en todos los tiempos en concepto de propio y perteneciente a la Encomienda de Fresno..." 230.

${ }^{229}$ El profesor Pascual Gete ha analizado los distintos significados del término "serna", sea referido al trabajo como prestación en las tierras del señor, sea en su acepción como referencia a determinados caracteres culturales, como tierras de sembradura, como sinónimo de parcela o su equivalencia a una unidad económica de explotación o a sus variados significados jurídicos. En relación con la práctica de roturación y cultivo que tiene lugar en los montes de Propios de Medina del Campo, el autor mantiene un significado distinto, pues "se trata siempre de tierras de cultivo, e inicialmente sólo de sembradura, pero de propiedad concejil de la Villa de Medina y de libre usufructo por parte de los vecinos de toda la Tierra de Medina, aunque por ello - al menos desde el siglo XV-tengan que pagar un canon al concejo capitalino". (PASCUAL GETE, H.: Las tierras "sernas" de Medina y su Tierra: peculiaridad jurídica y transcendencia socioeconómica de una antigua propiedad concejil en el antiguo régimen, en "Historia de Medina..., ob. cit., pág. 372-373).

${ }^{230}$ A.H.P.V. Pt. 14012, fo1s. 1-88. Año 1833, citado por GONZÁLEZ SÁNCHEZ, V.: Fresno el Viejo. Una de las nueve villas de "Valdeguareña". Diputación Provincial de Valladolid, 1996, pág. 141-142. 
En esta fecha, al igual que los montes y sernas de Medina, estaba plenamente roturado, pero, como aquellos, también se denuncia que "algunos vecinos se han extralimitado y obrado contra el derecho de propiedad de la Encomienda, vendiendo a extraños y aun de unos vecinos a otros... y otros plantando de majuelos, como si fueran tierras propias, sin haber obtenido permiso ni licencia alguna... "231. En otros términos al sur y al oeste de Medina, donde desde siglos tempranos donaciones reales los separaron jurídicamente de aquella villa, la roturación del terreno inculto, aun presentando variaciones locales, se caracteriza por similares detracciones al monte para ampliación de las labranzas existentes o la creación de otras nuevas a lo largo del siglo XVI y XVII. En el caso de Alaejos, separado en 1452 por Enrique IV de la Tierra de Medina, el monte evoluciona de su papel " $p .{ }^{a}$ sus pastos abrigadero de sus ganados e p. " las labores e aparejos dela labranza" a ser reguladas sus cortas "conforme a la premática dada en Burgos por los católicos reyes", para acabar menguado por las talas excesivas, ventas del concejo o desastres extraordinarios como los que acaecieron durante la guerra de las Comunidades ${ }^{232}$. En este término, limítrofe al monte, se extendían más de dos mil hectáreas de las llamadas tierras "cáñamas", de aprovechamiento comunal y propiedad concejil que se "rreparten entre los vecno deesta villa de en diez en diez años", de acuerdo con la hacienda de cada vecino, hasta su venta en 1585233 .

En unos u otros casos, como se ha tratado en capítulos anteriores, los problemas se suscitan entre las partes cuando la inicial tierra labrantía no cubre las necesidades, a finales del medievo, de unas aldeas en crecimiento y de un mercado ferial necesitado de pastos, madera, cereal, legumbres y vino, en las épocas de mayor concurrencia. Las intrusiones del arado o los excesos del hacha, por necesidades vitales en los siglos anteriores, se convierten en litigios graves desde el siglo XIV. Los propios reyes tratan de armonizar intereses sin conseguirlo y Medina del Campo se muestra inflexible ante la más mínima ocasión que derive en una merma de su jurisdicción y renta. Un temprano ejemplo es la oposición de Medina y la alteración de límites que se efectúa en el lugar de Herreros, despoblado localizado en el actual término de Pollos, cuando Sánchez Yáńez de Medina obtiene la gracia del rey en septiembre de 1368 "con la facultad de que poblase con veinte vecinos exonerándoles del pago de los derechos de fonsa, fonsadera, martiniega y de todo género de tributos, la qual gracia se confirmó por los Señores Reyes... en 28 de septiembre del año 1389"234. La villa de Medina contradijo la delimitación de términos "por ser propios y privativo suyos los términos del Palancar y Valdemuelles", donde se otorgaba tal concesión.

Los mismos Reyes Católicos, aun reconociendo los derechos medinenses sobre dichos terrenos comunes, no aciertan a conciliar los intereses entre las partes. En mayo del año 1500 mandan al corregidor de la villa que "...del dicho monte Inestoso, que va del camino de Rodilana al lugar de Serrada hasta Ventosa... e hasta el lugar de San Martín e monte de la Abadesa de Tordesillas, que es bueno para labrar para pan, ge lo debes a los vecinos de la tierra de esa dicha villa, para que lo labren por tiempo de doce años, dando a cada par de mulas o bueyes o yeguas, cuatro obradas... e mandamos que den de renta una fanega por obrada... quedando la dicha tierra, después de alzado el fruto por común a todos los vecinos" $^{235}$. Poco tiempo después había sido tanto lo roturado que las protestas de los ganaderos y de los concejos por la merma de los montes hicieron a los reyes emitir otra carta, en noviembre de 1503, que decía que "se ha rompido tanto que ya no cumple tener ganado porque diz que no tiene donde pacer...", por lo que debían integrarse al uso común "todas las tierras que fallaredes tomadas" 36.

\footnotetext{
${ }^{231}$ Ibídem.

${ }^{232}$ OJEDA NIETO, J.: Alaejos...., ob. cit., pág 33-34.

${ }^{233}$ Ibídem, pág. 38-39.

${ }^{234}$ A.M.M.C., caja 170-5, fol. $12 \mathrm{v}$.

${ }^{235}$ MORALEJA PINILLA, G.: Historia de Medina del Campo. Medina del Campo, 1971, pág. 74.

${ }^{236}$ Ibídem.
} 
Las restituciones al común de la Comunidad de Villa y Tierra que gestiona Medina serán constantes a lo largo del siglo XVI por parte de los pueblos que las habían usurpado, aun cuando se sospecha que avanzaban más rápidamente los nuevos rompimientos que lo que las ejecutorias judiciales mandaban reintegrar al uso común.

\section{a. La importancia económica de las sernas de Medina del Campo}

Para la Villa de las Ferias tan importante o más que estas roturas del monte es asegurarse la percepción de las rentas que han de pagar los cultivadores. Desde comienzos del siglo XVI, se asiste, como se ha dicho, a un incremento demográfico que se traduce en un aumento muy notable del terrazgo labrado, una necesidad creciente de liquidez por parte de los concejos para equilibrar sus gastos y, en consecuencia, no pocos litigios entre deudores y villa cabecera. Buena parte del presupuesto de Medina depende de los ingresos de estos bienes de Propios, por lo que la regulación de su cobro trata de evitar la picaresca campesina en dilatar los pagos o eludir la posesión tomada en caso de malas cosechas. Los apeos de sernas serán costosos por lo extenso y variado del terrazgo, pero es el único medio para recabar la renta anual a sus tenedores. El proceso de coteo y pago toma carta jurídica desde la ejecutoria dada en Burgos el 12 de abril de 1508 por la reina Juana ${ }^{237}$. Desde entonces estas ordenanzas se repiten una y otra vez, como prueba documental de la pertenencia de estos montes como bienes de Propios de Medina, y como forma anual de controlar lo sembrado y recabar el pago anual. Muchos campesinos eluden los cánones cuando los apeos se hacen "después

${ }^{237}$ A.M.M.C. Caja 255-3. Traslado escritural del año 1519 de las ordenanzas dictadas el 12 de abril de 1508 por la reina Juana sobre las sernas de Medina del Campo. Por su importancia y constante referencia por las partes en litigio a lo largo de los siglos, se transcribe la totalidad de las ordenanzas pese a su extensión. (Trascripción de Juan Carlos Alonso): “Doña Juana, por la gracia de Dios, rreyna de Castilla, de León, de Granada, de Toledo, de Galiçia, de Sebilla, de Córdoba, de Murçia, de Jaén, de los Algarues, de Algeçira, de Gibraltar, de las Yslas de Canaria y de las Yndias, yslas y tierra firme del mar oçéano; prinçesa de Aragón y de las Dos Siçilias, de Iherusalén; archiduquesa de Avstria; duquesa de Borgońa y de Brabante y condesa de Flandes y de Tirol, ecétera, señora de Vizcaya y de Molina, ecétera.

Por quanto por parte de uos el concejo, justiçia y rregidores, caualleros, escuderos, ofiçiales y omes buenos de la villa de Medina del Campo, e de uos los conçejos y omes buenos de los lugares de su Tierra me fue fecha rrelaçión por vna petiçión, diziendo que entre uosotros a auido algunos debates y diferençias sobre el apear de las tierras de los montes desta dicha villa que se dizen las sernas e sobre la paga de la rrenta dellas que hera vna de la mayor y más prinçipal rrenta de Propios que esta dicha villa y el conçejo della tiene e diz que agora por bos quitar de los dichos pleitos e debates y por que la rrenta de las dichas sernas rredunda en mucha homrra y probecho desa / $(f .1 v)(\ldots)$ villa herades convenidos e ygualados que el apear de la dichas tierras y en la paga execuçión e pedimiento dellas se guardase la forma de çiertas hordenanças de que ante los del $\mathrm{mi}$ Consejo fue fecha presentaçión. Por ende que me suplicauades y pedíades por merçed mandase ${ }^{237}$ ver el dicho asiento e conçierto por vosotros fecho sobre lo suso dicho y le mandase aprobar y confirmar para que sea guardado, cumplido y executado de aquí adelante como en el se contenía, ynterponiendo a ello mi autoridad y decreto rreal o como la mi merçed fuese los quales dichas hordenanças fueron vistas por los de mi Consejo y fue acordado las deuía confirmar, su thenor de las quales es este que se sigue:

Primeramente que por quanto los arrendadores, rrecavdadores y rreceptores de la sernas desta dicha villa que len apear e medir las tierras de las dichas sernas después de pan coxido y desto se siguen muchos dańos ansí a la villa como a la tierra, por que muy acostumbradamente acaheçe llegar los dichos apeadores a muchas tierras que ni ellos ni los vezinos allí çercanos no saben quien las sembró ni a coxido en pan dellas y muchos de los que las tales tierras labraron viendo que no se sabe ni alla quien diga el que las labra, encubre y calla avellas labrado y de aquí rresulta la dicha villa perder la rrenta de las tales tierras o cargallo a los conçejos y pediles a quien no lo deue lo qual todo es muy dańosso y agrauiado. Por ende se asienta y conçierta que los tales apeadores, arrendadores y rreceptores que son fueren / $(f .2 r)$ o serán de las dichas sernas sean tenudas y obligados a haçer el dicho apeo en todo el mes de hebrero e março de todas las tierras que estubieren sembradas por que entonçes no acaezerá en abrirse ninguno ni negarlo que tubiere labrado es tenido el fruto por coxer como después del pan coxido y puesto en su casa y que los dichos arrendadores y rrecaudadores, fieles y rrecebtores que fueren a haçer el dicho apeo no le puedan haçer sin llebar consigo vn escriuano de cada conçejo donde apeare y queste dicho escriuano haga otro apeo comforme al que hizieren los dichos arrendadores, rrecaudadores y rrecebtores y después de acabado el dicho apeo en cada lugar los conçierten el vno con el otro y el escriuano de la villa que los dichos arrendadores, rrecaudadores e rrecebtores lleuaren firme el apeo que hiziere el seuicio del tal conçejo para que quede en el conçejo y escriuano del conçejo firme así 
de pan coxido", por lo que "no saben quien las sembró ni a coxido en pan dellas y muchos de los que tales tierras labraron viendo que no se sabe ni alla quien diga el que las labra, encubre y calla avella labrado". Medina, por estas y otras circunstancias, veía perder notables rentas año tras año. De ahí que las ordenanzas dictadas por la reina Juana obliguen "a haçer el dicho apeo en todo el mes de hebrero e março de todas las tierras que estubieren sembradas por que entonçes no acaezerá en abrirse ninguno ni negarlo que tubiere labrado es tenido el fruto por coxer" 238 .

mesmo el apeo que los dichos arrendadores y rrecaudadores y rreçebtores hubieren de traer para sí el quel dicho escriuano o escriuanos quel dicho concejo o conçejos de los lugares de la dicha tierra enbiaren a apear con el escriuano que el dicho concejo, justicia y rregidores desta dicha villa enbiare, pague el dicho conçejo o conçejos de los dichos lugares de la dicha tierra cada vno. El que cada vn conçejo enbiare por su parte y que pareçiendo ansí firmados estos dichos apeos como dicho es, tenga tanta fee el vno como el otro y quando / $(f .2 v)$ acaesçiere hallar alguna tierra de que no parezca dueńo que los dichos arrendadores, rrecaudadores e rrecebtores la dexe encargada al conçejo en cuyo término estubiere para quel dicho conçejo tenga cargo de saber cuya es e de poner rrecaudo en ella y pagar la rrenta y quel tal concejo lleue el <tal> pan que estubiere sembrado en las dichas tierras pues a de pagar las rrentas dellas.

$\$$ Otrosí por quanto la rrenta de las dichas sernas se suele coxer el año adelante después de pan coxido y desto se sigue muchos ynconvinientes ansí a la villa como a la tierra por que las rrentas se coxen muy mal y los devdores rreçiben fatiga de pagallas después que tiene el trigo vendido y gastado y por escusar esto y otras cosas que de aquí adelante se podrían seguir se asienta que los dichos arrendadores, rrecaudadores o rrecebtores, fieles sean obligados a rrequerir por ante escriuano público a todos los deudores de las dichas sernas particularmente o estando cada vn concejo junto a canpana tańida e encomiençe el dicho ${ }^{237}$ rrequerimiento mediado el mes de agosto amonestando que todos vengan a pagar hasta en fin de mes de setiembre y que desde el dicho día encomençare a rrequerir sean obligados a començar a rresçibir la rrenta que les traxeren.

$\$$ Otrosí que los dichos labradores de las sernas y otras / (f. 3r) qualesquier personas de la dicha tierra que en ellas labrare sean tenudos abligados a pagar la rrenta dellas hasta en fin del $^{237}$ dicho mes de setiembre que hera el próximo siguiente después que las senbrare y que si alguno o algunos dellos no la pagaren en este dicho tiempo que los dichos arrendadores, fieles y rreçebtores tengan de espaçio y término para lo cobrar por justicia y poder dar a executar quatro meses primeros siguientes que serán otubre e noviembre e diziembre y henero y que la tal execuçión se aga por vía de justicia segúnd es vso e costumbre lleuando derechos el escriuano veinte e çinco marauedís, el aguaçil seis marauedís e no más que son derechos acostumbrados y que se guarde en las dichas execuçiones que se hizieren los términos de la ley en el rrematar de los (...) a la rraiz según rraiz e al mueble segund mueble según quel derecho lo dispone conviene a saber a la rraiz dando tres pregones de en diez en diez días que son treynta días y al mueble dando los dichos tres pregones de tres en tres días que son nuebe días y que quando algún deudor de la dicha rrenta no deviere más quantía de vna fanega de trigo si de allí no pasare que está tal execución no la ${ }^{237}$ pueda façer alguaçil o escriuano más que la agan los andadores según que lo tenemos de vso y de costumbre que de çiento e veynte marauedís abaxo no pueda haçer execuçión saluo el dicho $/(f .3 v)$ andador y que si den tiempo deste término destos dichos quatro meses no pidiere execuçión los dichos arrendadores y rrecaudadores, ofiçiales e rrecebtores de la dicha rrenta que el dicho término pasado no puedan pedir <ni haçer> execuçión en alguno ni algunos de los dichos vezinos de la dicha tierra saluo a quien en algo les deuiere que lo pidan entel juez por vía de demanda e rrespuestas.

$\$$ Otrosí que ninguno de los dichos arrendadores, rrecaudadores y rreçebtores de las dichas sernas non puedan hazer prender a ninguno de las dichos deudores de los que fueren abonados y tubieren con que pagar más de que primero le busquen sus bienes y si los hallaren e dieren fianças de saneamiento execute en ellas y quando el tal deudor no yubiere de que pagar e el escriuano diere fee que no le halla la haçienda ni fianças que basten a su devda que entonçes el dicho rrecaudador, arrendador, fiel y rreçeptor le pueda haçer prender hasta pagado de lo que les deuiere.

$\$ Y$ por esta mi carta confirmo y apruebo las dichas hordenanças que de suso van yncorporadas y vos mando que en quanto mi merçed e voluntad fuere las guardeis y cumplais y executeis en todo y por todo según que en ellas según y contra el tenor y forma de lo en ellas contenido no vayades, ni pasedes, ni consintais / ( $f .4 r)$ yr ni pasar agora ni de aquí adelante en ningún tiempo ni por alguna manera e los vnos ni los otros non fagades ni fagan ende al por alguna manera so pena de la mi merçed e de diez mill marauedís para la mi Cámara a cada vno de bos que lo contrario hiziere e más mando al ome que esta mi carta mostrare que vos enplaze que parezcades ante mí en la mi Corte doquier que yo sea del día que vos enplazare asta quinze días primeros siguientes so la dicha pena so la qual mando a qualquier escriuano público que para esto fuere llamado que de ende al que vos la mostrare testimonio signado con su signo por que yo sepa en como se cumple mi mandado.

Dada en la noble çiudad de Burgos a diez días de mes de abril, año del naçimiento de nuestro saluador Ihesu Cripto de mill e quinientos y ocho años. Conde Alférez. Leçençiatus Móxica. El doctor Palaçios Rrubios. Lliçençiatus Polanco. Lliçençiatus Aguirre. Yo Bartolomé Rruiz de Castańeda, escriuano de cámara de la rreyna, nuestra señora, la fize escrevir por su mandado con acuerdo de los de su Consejo. Y en las espaldas de la dicha carta de su alteça estaua el sello rreal y las firmas e nombres siguientes. Rregistrada: lliçençiatus Ximénez, Castañeda chançiller".

${ }^{238}$ Ibídem. 
Similares prevenciones serán tenidas en cuenta a la hora de cobrar las rentas. Las deudas contraídas, las malas cosechas o la propia necesidad del campesinado son causa de "que las rrentas se coxen muy mal y los devdores rreçiben fatiga de pagallas después que tiene el trigo vendido y gastado". Para evitarlo, se regula su pago mediado el mes de agosto y a lo largo de septiembre, antes de pasar a procedimientos judiciales, siempre costosos para las partes en litigio. En el fondo subyace, siglo tras siglo, la imperiosa necesidad del concejo de Medina de contar con unos ingresos tan abultados como esenciales en sus presupuestos anuales. Cuando las nuevas villas eximidas eleven a la Real Chancillería sus demandas contra tales cargas, Medina acudirá con el peso de la costumbre, las ejecutorias ganadas al respecto y con cuanto presupuesto se necesite para inclinar la balanza de la justicia a su favor. El sueldo de médicos, escribanos, procuradores, maestros, regidores, pregoneros o guardas está en juego; con las fanegas del trigo recabado en La Seca o Pollos se satisfacen diezmos y pagos de censos contraídos con anterioridad y, sin estas aportaciones anuales, difícilmente se pueden atender las necesidades del Hospital General y de tantos otros gastos ordinarios y extraordinarios a los que se enfrenta Medina año tras año.

Demasiado dinero, por otra parte, para evitar la tentación de lucrarse indebidamente por parte de los administradores de estos caudales. No en vano se constatan numerosos procesos para aclarar o regular convenientemente estas rentas. A finales del siglo XVIII, cuando los montes sernas alcanzan plena ocupación por parte del campesinado de los distintos concejos locales, José de Mier Cosío, en calidad de comisario apoderado en la administración de estos recursos, lo denuncia de forma expresa ${ }^{239}$ :

"Con motivo de la entrada de caudales en los mayordomos sin intervención ni más quenta y razón que la quellos han querido dar se han experimentado diferentes quiebras y pérdidas, así en ellos como en los Propios; unos por alcances legales, y otros con usurpación a los Propios adatando partidas, ya por los mismos mayordomos percividas; otras que no ha havido, y otras acrecentándolas; y jamás suponiendo costas”.

La situación motiva la actuación de un comisionado real para aclarar la situación y agilizar la información entre las partes, para recabar las rentas con los menores gastos posibles para Medina y la mayor comodidad para los sernistas. Se manifiesta "que parece conveniente para en lo sucesibo evitar este desorden, y que sean los Propios manejados con la claridad y Pureza correspondiente, y que los colonos hallen prontamente las noticias que necesitan y se les deben dar"240. Para ello se apuesta por el establecimiento de una oficina con oficiales capaces, el control riguroso de los caudales, la realización de apeos y la existencia de un reglamento eficaz y claro para efectuar los cobros de estas rentas de tierras y majuelos.

El canon que había que satisfacer se mantuvo constante durante siglos, a pesar de no pocas protestas y parciales concesiones por parte de Medina en casos de penuria. Los cultivadores de sernas, situados a la izquierda del río Zapardiel (términos actuales de Nava del Rey, Siete Iglesias y Pollos), satisfacen media carga de trigo (dos fanegas) por cada obrada de 500 estadales, una vez recogido el fruto. Las tierras a la derecha del citado río, mirando a Valladolid, por lo general más livianas y de suelos de terraza, pagan la mitad, a saber, una fanega por cada obrada sembrada. Esta parte comprende los términos de La Seca, Ventosa de la Cuesta, Rodilana, Pozaldez y Rueda. Dentro de este terrazgo se habían detraído por la corona, especialmente durante los reinados de la reina Juana y el rey Carlos I, numerosas tierras donadas como "mercedes" a servidores fieles y a los que se reduce el canon en la mitad de la renta estipulada. Medina no tarda en presentar sus quejas al sentirse perjudicada, toda vez que dichas mercedes son subarrendadas a colonos por parte de sus titulares. Consigue, al menos, que, una vez que vacasen dichas concesiones, pasen de nuevo al dominio medinense, aunque este supuesto será efectivo en contadas ocasiones ${ }^{241}$.

${ }^{239}$ A.M.M.C. Caja 167. “Años 1792, 93, 94 y 97, papeles varios puestos en los años indicados por D. Josef de Mier Cossío relativos al aumento y veneficio de los Propios", fol. 23v.

${ }^{240}$ Ibídem.

${ }^{241}$ MORALEJA PINILLA, G.: Historia..., ob. cit., pág. 77. 
El canon, en cualquier caso, es puesto en duda por los cultivadores de los distintos lugares, por considerarlo muy abultado, dispar en relación a la diferente fertilidad de los pagos de los términos a los que hacía referencia, y siempre injusto e improcedente cuando los lugares adquieran sus privilegios de villazgo y se liberen de la jurisdicción medinense. Las ejecutorias ganadas y los memoriales vistos, relativos al pago de sernas, testimonian los derechos inmemoriales de Medina por sus "montes, sernas y mercedes" ${ }^{422}$. Los pleitos son tan numerosos como intrincados. En ocasiones, incluso, se detectan ejecutorias "sobre que se paguen rentas de tierras sernas aunque no se siembren”, prueba de la inflexibilidad de Medina en su afán de recaudación ${ }^{243}$, especialmente cuando se detecta que algunos pueblos, como La Nava, cotean y rayan los montes sin labrarlos, a fin de que nadie los ocupe en detrimento del concejo medinense. Pese a que los lugares insisten recurriendo y suplicando sentencias ante el Consejo de Castilla, el final de los procesos coincide en el pago del canon establecido desde tiempos inmemoriales. Un ejemplo es lo librado por carta ejecutoria del año 1628 , tras no pocos recursos a la sentencia de vista dada con anterioridad ${ }^{244}$ :

“...se condenó a los concejos a que desde entonces en adelante, assí delas tierras sernas como de los Montes y Mercedes pagasen a Medina por cada 500 estadales desde el Río Zapardiel a la parte de Valladolid una fanega de trigo, y desde el Río Zapardiel a la parte e Salamanca media carga de la misma especie...”.

Especial importancia tienen los pleitos que vuelven a enfrentar a Nava del Rey con Medina, tras adquirir aquella su privilegio de villa y negar los derechos de Medina sobre su término. Su esfuerzo jurídico será en vano. Llueve sobre mojado. En la propia ejecutoria, ganada por Medina a Nava con fecha de 24 de noviembre de 1679 sobre la venta hecha por la corona a Nava de los montes del Palancar y Valdemuelles, privativos de Medina del Campo, se incluyen anteriores sentencias que fallaron a su favor, imponiendo "perpetuo silencio para que no les puedan más pedir ni demandar cosa alguna cerca de lo en su demanda contenido, e por esta nuestra sentencia asi lo pronunciamos e mandamos"245. De hecho, en la propia ejecutoria, se halla inserta una copia de un pleito que se siguió hasta el estado de prueba iniciado en Valladolid en el año 1504 "en razón de si los vecinos de la villa de Nava del Rey havían de pagar una o dos fanegas de trigo por cada obrada que labraban en tierras sernas" y del que se derivó una concordia posterior ${ }^{246}$.

Similar litigio enfrenta a Medina con Rodrigo Calderón, marqués de Siete Iglesias, por su pretensión de propiedad sobre los citados montes de Baldevite, Palancar y Valdemuelles. Medina, una vez más, se defiende sin paliativos y hará escuchar su voz en Madrid en 1614 ante el Real Consejo, tal como recoge el Memorial de Sernas ${ }^{247} / 248$ :

${ }^{242}$ Un ejemplo es la ganada por Medina al concejo de La Nava en 1594, de la que se derivan cuantas obligaciones se vienen exponiendo. En el "Memorial de los papeles que se han visto en razón de las tierras sernas, montes y mercedes, privativos de la Villa de Medina del Campo" puede leerse:”De tiempo inmemorial a quella parte la dicha Villa de Medina avia sido, y era, Señor de todas las tierras que se dezían, y nombravan las Sernas, montes, y exidos, cañadas, pastos, y abrevaderos, y todo lo a ello anexo, y perteneciente para poder llevar de cada obrada de tierra que se sembrasse en cada un ańo, desde el Río Zapardiel azia la Ciudad de Salamanca, media carga de trigo de cada quinientos estadales, puesto, y pagado en la Alóndiga de la dicha Villa de Medina. Y assimismo una fanega de trigo, de cada fanega de trigo de cada quinientos estadales de las tierras de merced, pagado en la conformidad que va dicho, y de cada quinientos estadales de tierra de la parte del Río Zapardiel azia Valladolid una fanega de trigo pagado según va dicho". Fuente: "Memorial de los papeles que se han visto en razón de las tierras sernas, montes y mercedes, propios de la Villa de Medina del Campo". A.M.M.C., caja 256.

${ }^{243}$ A.M.M.C. Caja 170-5, fol. 8

${ }^{244}$ Ibídem, caja 254-35, fol. 7

245 Ibídem, caja 170-5, fol. 13.

${ }^{246}$ Ibídem, fol. 14.

${ }^{247}$ A.M.M.C. Caja 256. "Memorial de los papeles que se han visto en razón de las tierras sernas, montes y mercedes, propios de la Villa de Medina del Campo", pág. 3-4.

${ }^{248}$ El término "rejas vueltas" indica que el terrazgo se labra o aprovecha yendo y viniendo a diario desde el pueblo donde vive el labrador, sin necesidad de pernoctar fuera de su casa. 


\begin{abstract}
"La dicha Villa (de Medina) y tierra havía tenido, y poseído siempre por suyo para pasto común y abrevadero de sus ganados los montes, prados y Valles de Baldevite, Palancar, Valdemuelles y Mollorido, y todos los demás valles, y de Hessas que toca a los dichos términos, y lo estava en término y jurisdicción de la dicha Villa de Medina del Campo, y su tierra sin que jamás huviesse avido cosa en contrario, y siendo como era rejas bueltas para el pasto común de los ganados de dicha Villa, y tierra...”.
\end{abstract}

Dos años después, en 1616, por carta ejecutoria se desestima la pretensión del señor de Siete Iglesias, imponiéndole perpetuo silencio y "declarando que todos los dichos términos, pastos y montes eran propios de la dicha Villa" ${ }^{24}$. Los pleitos y controversias también se centran en el aprovechamiento del terrazgo. Las antiguas ordenanzas articulan aprovechamientos herbáceos en sistemas de año y vez, sea trigo, cebada o centeno, eludiendo otros, como el viñedo. Las propias ordenanzas de la reina Juana silencian este aprovechamiento que, paradójicamente, es el que predomina con el paso de los siglos en dichos montes, siendo, además, la principal fuente de rentas para Medina. A falta de razonamientos explícitos sobre este particular, se observa un cierto temor por parte de Medina al identificar los majuelos como propiedades permanentes y, en consecuencia, correr el riesgo de pérdida de posesión sobre dicho terrazgo. De ahí la oscilación entre momentos de persecución de jóvenes plantaciones, especialmente cuando eluden la licencia correspondiente, con otros en que los mayordomos se felicitan por lo que rinde en rentas cada año dicho cultivo.

En este sentido, Medina muestra especial susceptibilidad cuando los majuelos se plantan en términos litigantes contra ella por la posesión del terrazgo, caso de La Nava. Un ejemplo es la ejecutoria que, en enero de 1622, se dicta contra distintos vecinos de esta villa por plantío de vińedos en tierras sernas. La justificación y temores no pueden ser más claros ${ }^{250}$ :

\footnotetext{
"Porque teniendo como la dicha Villa de Medina tenía por suyos propios todos los términos de la dicha Villa, y su suelo en que entra la dicha Villa de la Nava, puesto que se había eximido de la jurisdicción, y acostumbrados, e siempre romper, y labrar las tierras que llaman sernas que están en dicho suelo para las sembrar, pagando la dicha villa de Medina el tributo en obrada de sembradura, las partes contrarias de poco tiempo a aquella parte, queriendo apropiar para sí las dichas sernas las habían metido de viñas como si fueran heredades suyas propias, y especialmente lo habían hecho los susodichos, porque pidió que se les castigase, y que las plantas se quitasen y arrancasen”.
}

La sola posibilidad de que el terrazgo de viñedo se considere como propio del cultivador que detenta el vuelo previene al concejo medinense, siglo tras siglo. Las licencias se dan con cuentagotas. La inercia de los términos sernistas, situados todos al norte de la Tierra, es potenciar y especializarse en este cultivo. Difícil tesitura para una Medina deseosa, por un lado, de evitar la competencia a sus vińedos en retroceso y, por otro, eternamente recelosa de posibles apropiaciones en un cultivo identificado con la propiedad individual. El incremento de rentas y la perseverancia de los labradores acaban obligando a Medina a aceptar la nueva realidad, toda vez que buena parte de las antiguas roturas se habían abandonado por improductivas y no generan renta alguna.

A finales del siglo XVIII, la renta procedente de los majuelos plantados en tierras sernas supera el $70 \%$ del total percibido por Medina, prueba del arraigo del cultivo en los suelos de los antiguos montes tratados ${ }^{251}$. Aun así, la falta de licencias por parte de Medina a solicitudes de plantación, los pleitos contra majuelos existentes que en ocasiones se saldaban con ejecuciones de descepe, como el

${ }^{249}$ Ibídem.

${ }^{250}$ A.M.M.C. Caja 256. "Memorial de los papeles que se han visto en razón de las tierras sernas, montes y mercedes, propios de la Villa de Medina del Campo", pág. 7-8.

${ }^{251}$ En 1794, por ejemplo, el mayordomo de Propios y encargado del libro cobratorio de majuelos certifica que en los términos de Rodilana, La Seca, Rueda y Pollos se contabilizan 4.844 obradas y 299 estadales que rinden otras tantas fanegas de trigo que a 27,5 reales cada una suman la importante suma de 133.225 reales. (Ibídem, caja 20-43. Certificación del apeo de majuelos de 1794 en Rodilana, La Seca, Rueda y Pollos). 
acaecido en 1763, y otras actuaciones cobratorias, alientan la animadversión de los tenedores de sernas hacia Medina y viceversa. Por un lado, esta villa vigila e interpone pleitos contra quienes sospecha eluden el pago en los majuelos jóvenes al "ser costumbre no pagarla en los quatro años primeros de hueco por no producir en ellos los majuelos", caso del pleito contra Rueda de $1768^{252}$ y, por otro, se prohíben en 1785 a La Seca nuevas plantaciones en los montes Inestoso y Pedroso, argumentado intención "maliciosa, hija del aborrecimiento que sus vecinos profesan a esta villa", puesto que existen pleitos sin resolver en dicho sentido, aun cuando de ellas se derivan rentas muy notables ${ }^{253}$.

Todo este desgaste jurídico tiene completa justificación si se atiende a la cuantía económica que alcanzan las rentas anuales y al celo que siempre empeñó Medina por la conservación de esta fuente de ingresos. Piénsese que, en el año de 1490, las rentas de sernas ascienden a 320.000 maravedíes, representando el 52\% del total de rentas arrendadas del concejo de Medina ${ }^{254}$. En 1762, por ejemplo, la suma total de ingresos por Propios y arbitrios alcanza la suma de 92.770 reales, de los cuales 72.600 reales, que representan el 78,25\% del total de ingresos, pertenecen al capítulo de ingresos por sernas ${ }^{255}$. De las anteriores cantidades el presupuesto detrae 52.562 reales, para gastos ordinarios y fijos, y 13.461, para los extraordinarios, por lo que aún queda como sobrante 26.745 reales, prueba de la importancia de tales aportaciones procedentes de estos bienes de Propios.

El agotamiento del terrazgo labrado obliga a muchos sernistas a abandonar sus roturas, volver sobre ellas cuando la fertilidad se recupera o las vicisitudes de la labranza lo aconsejan y ello, unido a las distintas coyunturas económicas y demográficas, explica la variabilidad de las cantidades registradas, sin olvidar los impagos y las cesiones y ventas de Medina o de los propios reyes de parte del citado espacio, a lo largo de los siglos. Para hacerse una idea más aproximada de su importancia económica, se ha escogido la fecha de 1792, antes de que llegue la crisis finisecular del XVIII, y momento último de ocupación plena del espacio de Propios de Medina tras la expansión agraria del siglo XVIII. En dicho año, tal como figura en el cuadro adjunto, el total de lo percibido en razón de rentas de sernas llega a 1.696 cargas (6.784 fanegas de las que 4.843 fanegas proceden de los majuelos y 1.941 fanegas las rinden tierras de sembradura) ${ }^{256}$.

$\mathrm{Al}$ igual que en el ejemplo anterior, conviene resaltar, tal como se desprende de los datos adjuntos, que el 88,29\% de los ingresos de Propios de Medina del Campo de 1792, y que ascienden a 186.630 reales, proceden de las rentas de los sembrados y majuelos en tierras sernas. Su cuantía cubre de forma sobrada todos los gastos de la villa, desde el sueldo del corregidor al carbón gastado en los braseros del ayuntamiento. Se puede pedir a Medina que perdone la renta en caso de pedrisco, que legalice plantaciones de majuelos, que muestre algo de misericordia con labradores empobrecidos, que sea benevolente en los nuevos rompimientos sin licencia, pero nunca que renuncie a sus derechos serniles.

${ }^{252}$ Ibídem, caja 170, fol. 17.

${ }^{253}$ A.M.M.C, caja 254-40.

${ }^{254}$ En 1505 se recaban "dos mil cargas de trigo"; en 1532, suman 2.272 cargas llegando en 1535 a 2.510 cargas; en 1701, se anotan 1.525 cargas y 1.458 cargas dos ańos después (A.M.M.C., caja 255-26), para incrementarse en 1713 hasta 2.856 cargas ( $502.656 \mathrm{~kg}$ de trigo!). En unos y otros ańos, en fin, estas cantidades son vitales para el desenvolvimiento de Medina, pero no dejan de sustraer una o dos fanegas de trigo por obrada a los campesinos lugareños, ańo tras ańo. De acuerdo con los datos aportados por Moraleja para valorar la cantidad de mrs, se puede tomar como referencia que este año un toro de lidia costaba cien reales o 3.400 maravedíes, luego las rentas de sernas equivaldrían a 184 toros de lidia. (MORALEJA PINILlA, G.: Historia de Medina..., ob. cit., pág 194). Recuérdese que una carga equivale a cuatro fanegas. Dos mil cargas de trigo equivalen a 8.000 fanegas, o lo que es lo mismo, si consideramos $44 \mathrm{~kg}$./fanega en caso de trigo bien granado y limpio de impurezas, a 352.000 kilogramos.

${ }^{255}$ Una vez efectuada la "verificación de hallarse sembradas y plantadas de majuelos a cuio fin se haze Apeo de ellas todos los años por todas las cuales perzibe 4.840 fanegas de trigo (1.210 cargas) y ban reguladas a quinze reales cada una”A.M.M.C., caja 256-54.

${ }^{256}$ MORALEJA PINILLA, G.: Historia de Medina..., ob. cit., pág. 80. 
De hacerlo, sería echar agua a las ascuas que calientan sus presupuestos. Los pleitos y ejecutorias dan fe de ello ${ }^{257}$. Apagados los ecos de sus históricas ferias, es de estas tierras sernas de las que depende su vida hasta la llegada de la industrialización y el ferrocarril a mediados del siglo XIX.

Cuadro 3. Rentas correspondientes a los Propios de Medina del Campo, ańo $1792^{258}$

\begin{tabular}{|c|c|c|c|c|c|c|c|}
\hline & \multirow[b]{2}{*}{ Pueblos } & \multicolumn{3}{|c|}{ Renta en fanegas } & \multirow{2}{*}{\multicolumn{2}{|c|}{$\begin{array}{c}\text { Total } \\
\text { fanegas/celemines/cuartillos }\end{array}$}} & \multirow{2}{*}{$\begin{array}{c}\text { Reales y mrs } \\
\text { (a } 27 \text { rs/fanega) }\end{array}$} \\
\hline & & Fanegas & Celemines & Cuartillos & & & \\
\hline Renta de & Rodilana & 330 & 6 & 3 & & & \\
\hline majuelos & La Seca & 3.290 & 5 & 1 & & & \\
\hline plantados en & Rueda & 827 & 6 & 1 & & & \\
\hline \multirow[t]{3}{*}{ tierras sernas } & Pollos & 396 & 0 & 2 & $4.844 \mathrm{far}$ &., 3 cuart. & 133.275 rs $14 \mathrm{mrs}$ \\
\hline & \multirow[b]{2}{*}{ Pueblos } & \multicolumn{3}{|c|}{ Renta en fanegas } & \multicolumn{2}{|c|}{ Total } & Reales y mrs \\
\hline & & Fanegas & Fanequs Celemines Cuartillos & Cuartillos & fanegas & uartillos & (a 27 rs/fanega) \\
\hline \multirow{6}{*}{$\begin{array}{l}\text { Renta de tierras } \\
\text { de sembradura } \\
\text { en tierras sernas }\end{array}$} & La Nava & 1.064 & 9 & 0 & & & \\
\hline & Rueda & 105 & 0 & 0 & & & \\
\hline & Pollos & 485 & 0 & 0 & & & \\
\hline & La Seca & 174 & 3 & 0 & & & \\
\hline & Sieteiglesias & 110 & 0 & 0 & & & \\
\hline & Foncastín & 3 & 0 & 0 & & & 53.405 \\
\hline \multirow{12}{*}{\multicolumn{2}{|c|}{ Otras rentas diferentes }} & \multicolumn{3}{|c|}{ Réditos, haberes y arrendamientos } & & Reales & Total rs \\
\hline & & \multicolumn{4}{|c|}{ Réditos de censos perpetuos sobre casas } & 362 & \\
\hline & & \multicolumn{2}{|c|}{ Haber del Peso Real } & & & 1.000 & \\
\hline & & \multicolumn{4}{|c|}{ Arrend. de carnicería y matadero } & 500 & \\
\hline & & \multicolumn{4}{|c|}{ Arrend. del Pozo de Nieve } & 500 & \\
\hline & & \multicolumn{4}{|c|}{ Arrend. del almacén de aceite } & 300 & \\
\hline & & \multicolumn{4}{|c|}{ Arrend. de yerbas. } & 990 & \\
\hline & & \multicolumn{4}{|c|}{ Arrend. de río y lagunas } & 700 & \\
\hline & & \multicolumn{4}{|c|}{ Arrend. de piña y piñón } & 300 & \\
\hline & & \multicolumn{4}{|c|}{ Arrend. de la casa mesón } & 300 & \\
\hline & & \multicolumn{4}{|c|}{ Correduría de vinos y vinagres } & 2.500 & \\
\hline & & \multicolumn{4}{|c|}{ Arrend. de portazgo } & 5.500 & 12.952 \\
\hline \multirow{3}{*}{\multicolumn{2}{|c|}{ Otros arbitrios }} & \multicolumn{4}{|c|}{ Reales facultades y otros } & Reales & Total rs \\
\hline & & \multirow{2}{*}{\multicolumn{4}{|c|}{$\begin{array}{l}\text { Real facultad para médicos en venta de vinos } \\
\text { Por la mr. En libra de vaca y carnero }\end{array}$}} & 8.800 & \\
\hline & & & & & & 3.000 & 11.800 \\
\hline \multicolumn{7}{|c|}{ TOTAL RENTAS DE MAJUELOS Y SEMBRADURAS EN TIERRAS SERNAS } & 186.630 \\
\hline \multicolumn{7}{|c|}{ TOTAL OTRAS RENTAS DIFERENTES } & 12.952 \\
\hline \multicolumn{7}{|c|}{ TOTAL OTROS ARBITRIOS 11.800} & \\
\hline SUMA TOTAL I & RENTAS DE P & ROPIOS & & & & & 211.382 \\
\hline
\end{tabular}

Fuente: Archivo Municipal de Medina del Campo (A.M.M.C.). Fondos sernas. Elaboración propia.

${ }^{257}$ La voluminosa documentación sobre sernas que custodia el Archivo Municipal de Medina del Campo y del que se ha consultado una mínima parte en el presente trabajo, prueba la especial querencia de Medina por preservar su principal fuente de ingresos. Asimismo son abundantes los pleitos y ejecutorias que alberga el Archivo de la Real Chancillería de Valladolid sobre el particular. Así, por ejemplo, en 1509 se registran ejecutorias sobre deudas por arrendamiento de tierras concejiles o sobre el cobro por el aprovechamiento de montes y ejidos (A.R.Ch.V. Ejecutorias, caja 236.3 y 542.53, respectivamente); en 1622 se tiene constancia de ejecutorias contra Nava del Rey sobre acusarles de haber plantado vińas en tierra de sernas (Ejecutorias, caja 2327-33) o contra Nava, La Seca y otros lugares en 1630 sobre la paga de las mismas (Ejecutorias, caja 2534-36). Los pleitos son largos y voluminosos, especialmente cuando lo que se disputa es la conversión de tierras labrantías en viñedos. Sirva como ejemplo los registrados en: PL. Civiles. Pérez Alonso (F), caja 2061-3/2063-1 de fecha 1617/1624) o los de apropiación indebida de estos bienes de Propios de Medina (PL. Civiles. Pérez Alonso (F), caja 52-2; Pérez Alonso (F), caja 765-1). Unos años más tarde, cuando la invasión napoleónica trastoca la costumbre y pone contra las cuerdas al Antiguo Régimen, los valores y rendimientos de las sernas medinenses siguen siendo muy relevantes. En 1817 las cargas anuales se estiman en 96130 reales sobre 126.000 reales en que se computan los ingresos de Propios donde las rentas de sernas siguen siendo su mayor parte. (A.M.M.C., caja 254-35). 
Cuadro 4. Cargas anuales y fijas que tienen los Propios de Medina del Campo, año 1792

\begin{tabular}{|c|c|}
\hline Descripción de las cargas & (Rs) \\
\hline Letanías y funciones de iglesia & 5.078 \\
\hline Salarios a capitulares & 911 \\
\hline Hospital General (200 fanegas de trigo a 15 rs/fanega) & 3.000 \\
\hline Derechos de funciones a la iglesia Colegial. (32 fanegas a 15 rs/fanega) & 480 \\
\hline Diezmos de las tierras sernas que corresponden a la iglesia Colegial ( 40 fan. a 15 rs/fan.) & 600 \\
\hline Diezmos de tierras sernas al Cabildo mayor de curas y beneficiados (20 fa. A 15 rs/fan) & 300 \\
\hline Réditos de censos perpetuos sobre dos casas incorporadas al Ayuntamiento & 86 \\
\hline Abogados, consultas y censos de los pobres de la cárcel & 240 \\
\hline Capitular comisario de cartas & 120 \\
\hline Al que conduce los bancos a las funcione de villa & 60 \\
\hline Al pregonero & 180 \\
\hline Al caballero corregidor & 6.600 \\
\hline $\mathrm{Al}$ alférez mayor & 117 \\
\hline A nueve regidores a $3000 \mathrm{mrs}$ & 794 \\
\hline Al capellán que celebra las misas de Ayuntamiento & 442 \\
\hline A los dos escribanos de Ayuntamiento & 2.200 \\
\hline $\mathrm{Al}$ agente de Madrid & 1.100 \\
\hline Al procurador de causas de Medina & 117 \\
\hline A los dos porteros de Villa & 1.100 \\
\hline Al mayordomo de Propios ${ }^{259}$ & 4.000 \\
\hline A la persona que gobierna el reloj. & 500 \\
\hline A la que toca la queda & 100 \\
\hline Al fiel de repeso de carnicería & 730 \\
\hline Al maestro de Gramática & 1.650 \\
\hline Al monasterio de San Isidro de Dueñas por el voto de San Boal & 130 \\
\hline Al guarda de los pinares & 600 \\
\hline Al guarda de las alamedas & 800 \\
\hline Al guarda del prado Chopal & 250 \\
\hline Para quindenios de Mercedes & 68 \\
\hline Para los medidores de granos & 300 \\
\hline Para el agrimensor de sembrados & 700 \\
\hline Para los mostradores de sembrados & 300 \\
\hline Para papel sellado y común que se ofrezca en los apeos y libro cobratorio & 5 \\
\hline Al contador que lleva la razón de lo que debe pagar cada rentero de sembrados & 200 \\
\hline Al escribano de Ayuntamiento por salir a los apeos de sembrados & 500 \\
\hline Para carbón de los braseros de Ayuntamiento y carnicerías & 400 \\
\hline Réditos de censos al redimir & 13.507 \\
\hline Réditos de once censos perpetuos sobre efectos de Propios & 2.050 \\
\hline Para viudas, reparos de casas de Ayuntamiento y otras obras públicas & 3.000 \\
\hline Para el salario de dos médicos & 7.700 \\
\hline Por el $2 \%$ del rendimiento de Propios y $19 \%$ de los 211382 rs y 11 mrs del año en curso & 40.159 \\
\hline Para gastos extraordinarios y eventuales & 3.000 \\
\hline TOTAL & 104.174 \\
\hline \multicolumn{2}{|l|}{ RESUMEN DE RENTAS DE PROPIOS Y CARGAS } \\
\hline Haberes de Propios y cargas anuales & (Reales) \\
\hline VALOR DE PROPIOS Y ARBITRIOS & 211.382 \\
\hline CARGAS ANUALES Y FIJAS & 102.710 \\
\hline CONSIDERACIÓN DE AUMENTO DE CARGAS & 12.406 \\
\hline SOBRANTES & 96.265 \\
\hline
\end{tabular}

Fuente: Archivo Municipal de Medina del Campo (A.M.M.C.). Fondos sernas. Elaboración propia.

${ }^{258}$ A.M.M.C. Caja 167, fols. 19 y ss.

${ }^{259}$ Desglosado de la forma siguiente: 1.180 rs por lo correspondiente al $15 \%$ al millar de acuerdo al producto de los Propios según el reglamento de 1762 que ascendían a 92.770 reales y 2.819 rs y 28 mrs por la administración y práctica de diligencias en el cobro de la renta de sernas. 
Cuadro 5. Rentas procedentes de majuelos y tierras en sernas de Medina, año $1815^{260}$

\begin{tabular}{|c|c|c|c|c|c|c|c|}
\hline \multirow{2}{*}{ Pueblos } & & \multicolumn{3}{|c|}{ Rentas procedentes de majuelos } & \multicolumn{3}{|c|}{ Rentas procedentes de sembrados } \\
\hline & & Fanegas & Celemines & Cuartillos & Fanegas & Celemines & Cuartillos \\
\hline La Seca & Propietarios & 3.241 & 3 & 3,5 & 6 & 5 & \\
\hline Agregados & Serrada & 30 & 8 & 2,5 & & & \\
\hline al terrazgo & San Martín & 2 & 6 & & & & \\
\hline de La Seca & Cigales & 3 & 7 & 2 & & & \\
\hline \multicolumn{2}{|c|}{ Total La Seca y agregados } & 3.276 & 24 & 8 & 6 & 5 & \\
\hline Rueda & 1.190 & 7 & 3 & 47 & 10 & & \\
\hline Agregados & Salamanca & 9 & & & & & \\
\hline al terrazgo & Madrid & 3 & 10 & & & & \\
\hline de Rueda & Íscar & 5 & 5 & 1,5 & & & \\
\hline \multicolumn{2}{|c|}{ Total Rueda y agregados } & 1.207 & 22 & 4,5 & 47 & 10 & \\
\hline Pollos & 428 & 8 & 2 & 74 & 6 & & \\
\hline Agregados & Tordesillas & 22 & 10 & 3,5 & & & \\
\hline a Pollos & Villanueva & 1 & 11 & 2,5 & & & \\
\hline \multicolumn{2}{|c|}{ Total Pollos y agregados } & 451 & 29 & 8 & & & \\
\hline Nava del Rey & 332 & 7 & 1 & 211 & & & \\
\hline Rodilana & 223 & 6 & 2 & & & & \\
\hline Agregados & Ventosa & 23 & 8 & 1,5 & & & \\
\hline \multirow[t]{2}{*}{ de Rodilana } & Pozaldez & 13 & 7 & 2,5 & & & \\
\hline & Valladolid & 14 & 3 & 0,5 & & & \\
\hline \multicolumn{2}{|c|}{ Total Rodilana y agregado } & 273 & 24 & 4,5 & & & \\
\hline \multicolumn{2}{|l|}{ Siete Iglesias } & & & 13 & 9 & 2 & \\
\hline \multicolumn{2}{|l|}{ TOTALES } & 5.548 & 4 & 2 & 353 & 6 & 3 \\
\hline
\end{tabular}

Fuente: Archivo Municipal de Medina del Campo (A.M.M.C.). Fondos sernas. Elaboración propia.

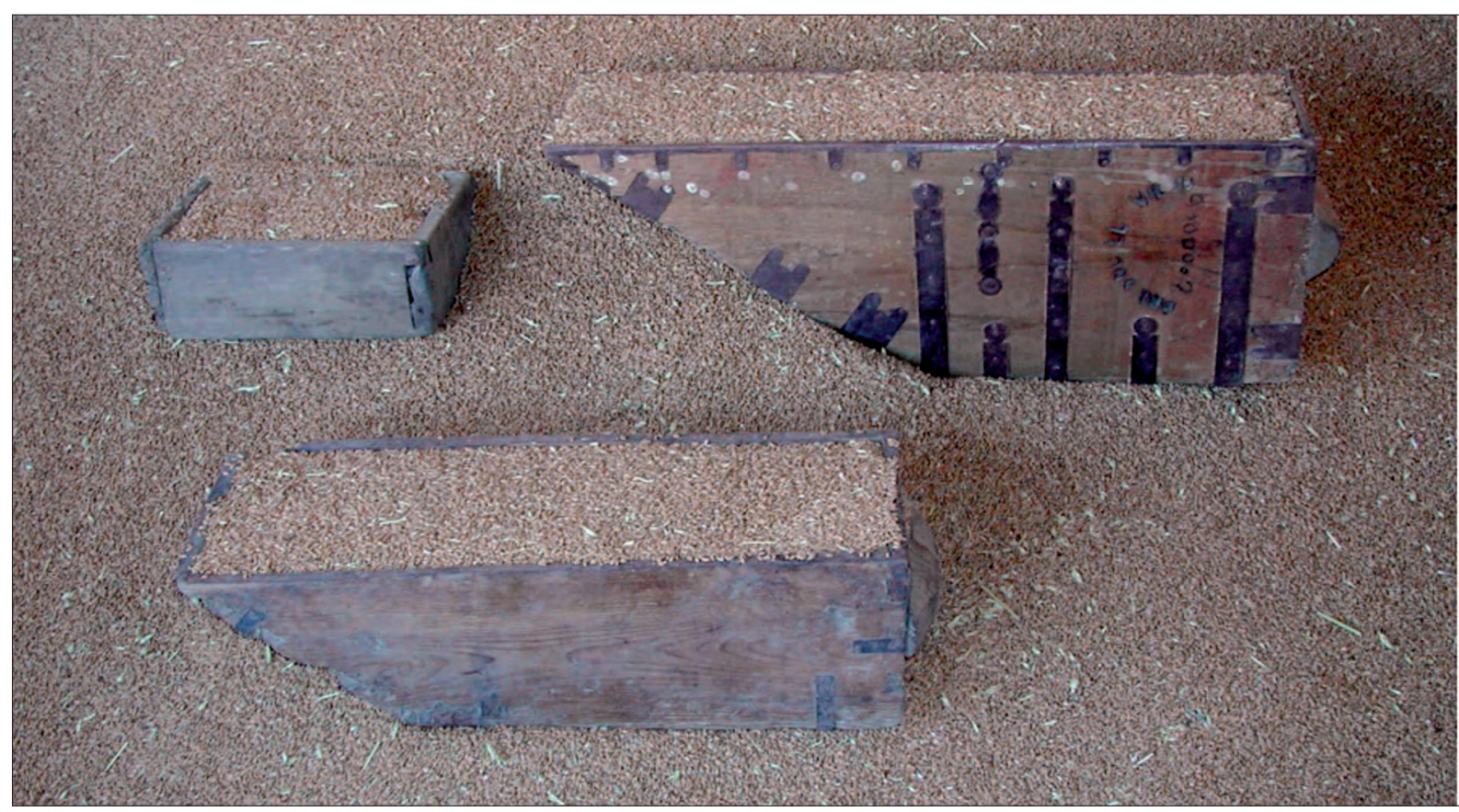

Imagen 44. Medidas tradicionales en que se acordaban el pago de rentas. En la imagen, medio celemin y media fanega (arriba) y hemina (abajo). Foto: julio de 2006.

${ }^{260}$ Ibídem, caja 254-34. Recuérdese que el peso de una fanega de trigo bien granado suele pesar $44 \mathrm{~kg}$ y que una hemina es equivalente a media fanega. Un celemín es la doceava parte de una fanega. 


\section{b. El reflejo del aprovechamiento de las sernas en el terrazgo. Del paisaje montaraz al predo- minio vitícola}

A pesar de la abultada documentación existente en los archivos de Medina del Campo sobre sernas, se hace difícil cuantificar su dimensión exacta y cartografiar sus límites en los distintos términos municipales. La pérdida de los mapas que acompañan los distintos apeos que tuvieron lugar, la controversia continua entre las partes sobre límites y rentas, la cesión de parte del terrazgo a particulares a lo largo de los siglos, el apartamiento de montes y pinares por parte de Medina del primitivo terrazgo de Propios, etc., son factores que nos han limitado en este aspecto. Con todo, lo que no cabe duda, como se ha tratado de exponer en el anterior epígrafe, es de su extraordinaria importancia, en la economía y la sociedad de los siglos modernos, para los términos por los que se extienden estos bienes de Propios de la Comunidad de Villa y Tierra de Medina.

Moraleja Pinilla fija en 36.000 obradas el terrazgo que ocupaban estos bienes comunes ${ }^{261}$. Pascual Gete anota 16.000 obradas a comienzos del siglo XVI, de las que la mayor parte están roturadas a mediados del XVIII ${ }^{262}$. La documentación consultada, especialmente de finales de este siglo, cuando coinciden varios mayordomos y comisarios de Propios que tratan de poner claridad en tan intrincadas cuestiones, catastran en torno a 20.000 obradas de 500 estadales $\left(14.147 \mathrm{ha}^{263}\right)$ de tierra ocupada por vińedos y sembraduras, a las que se ha de añadir aquellas incultas que siguen siendo montes, que invariablemente tratan de eludir la legalidad ${ }^{264}$, otras "privatizadas" de una y otra forma a lo largo de los siglos y los pinares, prados y montes inmediatos al sur de Medina, que se dejaron de anotar como bienes de "sernas, montes y mercedes", pero que, en los siglos bajomedievales, sí parece que tuvieron tal carácter, por lo que es muy posible que su verdadera dimensión se acerque a la cifra que estimó Moraleja, pensamos tomada del "Estado que manifiesta todas las fincas que tienen los Propios de este pueblo...” de comienzos del XIX, cuando los llevadores de rentas, tras la invasión napoleónica y el comienzo de las leyes desamortizadoras fueron declinando sus deberes anuales con la villa de Medina.

${ }^{261}$ MORALEJA PINILLA, G.: Historia de Medina..., ob., cit., pág. 88.

262 PASCUAL GETE, H.: Las tierras “sernas”..., ob. cit., pág. 374.

${ }^{263}$ La conversión se ha llevado a cabo teniendo en cuenta la equivalencia de una obrada de 400 estadales a 0,5659 ha, medida tradicional en la mayor parte de la Tierra de Medina.

${ }^{264}$ Las formas y maneras en que campesinos y ganaderos, a título particular, y los concejos locales, a nivel general, tratan de eludir el peso de los tributos daría para una tesis doctoral sólo en el tema de las sernas de Medina. Con todo, se estima que el número de obradas registradas en apeos y pago de rentas está entre un diez y un 20\% por debajo de lo realmente ocupado. En ocasiones, incluso, de forma tácita entre las partes, cuando los apeadores, especialmente en tierras de exiguos rendimientos, "redondean" a la baja los estadales de cada obrada o, confabulados con los concejos por pertenecer a ellos, "ignoran" parte del terrazgo labrado como propio de sernas. Es el caso del pleito contra Rueda del año 1773 en el que se habían dejado excluidas 656 obradas.

En el "Expediente para informar sobre instancia en el Consejo de los deudores de sernas vecinos de Pollos" de 1796 (A.M.M.C., caja 254-13), en que los tenedores de este pueblo adeudan por rentas atrasadas la importantísima cifra de 209.804 reales, los argumentos entre las partes resumen lo siempre debatido y litigado desde tiempos bajomedievales. Así, las protestas de los distintos concejos por la fijación inmemorial de las rentas tan desiguales que hay que pagar a un lado y otro del Zapardiel, como ocurre en el caso de Pollos que, al situarse "de la parte del Zapardiel hacia Salamanca" y pagar el doble que pueblos como La Seca o Rueda, son constantes. Argumentan que "había una infinita desproporción con la bondad y producto de la tierra, pues esta es de ínfima calidad y apenas puede llegar su fruto a cubrir los indispensables gastos y barbechera, y simiente en los sembrados y labores en el viñedo y de la respectiva recolección”.

Aunque el corregidor de Medina les baja la pensión a una fanega en 1793, esta villa no duda en argumentar que tal cuestión "hace más de tres siglos que se determinó" y que ello no causa ni ha causado la decadencia de sus labradores sino, en todo caso, "causas distintas como el luxo, la diversiones impropias de los labradores, falta de cuidado en el cultivo u otras semejantes...”. Medina, además, se siente, incluso, víctima, al entender que, a diferencia de otros renteros de bienes particulares que pagan más rentas por similares tierras, Medina cobra las rentas a un precio fijo cuando hay ańos en que lo regulado por el mercado es muy superior, es muy liberal en caso de malas cosechas y los sernistas pueden escoger o abandonar el terrazgo a discreción "sin que Medina se haya quexado, ni quexe de esto, contentándose con 
Cuadro 6. Resumen de tierras sernas pertenecientes a Propios de Medina. Año $1792^{265}$

\begin{tabular}{lccrrrr}
\hline \multirow{2}{*}{ Pueblos } & \multicolumn{2}{c}{ Majuelos } & \multicolumn{2}{c}{ Tierras } & \multicolumn{2}{c}{ Total obradas } \\
\cline { 2 - 8 } & Obradas & Estadales & Obradas & Estadales & Obradas & Estadales \\
\hline Rodilana & 1.176 & 490 & 1 & 62,5 & 1.178 & 12,5 \\
\hline La Seca & 2.588 & 2 & 1.941 & 325 & 4.529 & 327 \\
\hline Rueda & 1.085 & 320 & 17 & 450 & 1.103 & 27 \\
\hline Pollos & 410 & 100 & 880 & 400 & 1.291 & 0 \\
\hline Siete Iglesias & 0 & 0 & 503 & 230 & 503 & 230 \\
\hline Nava del Rey & 0 & 0 & 10.493 & 130 & 10.493 & 130 \\
\hline TOTAL & 5.260 & 372 & 13.838 & 97,5 & 19.098 & 469,5 \\
\hline
\end{tabular}

Aumento anual que se ha dado en majuelos resultantes de los Apeos"267

\begin{tabular}{lcccc}
\hline Pueblos & Obradas & Estadales & Total de obradas & Total de estadales \\
\hline Rodilana & 131 & 21,5 & & \\
La Seca & 948 & 107 & & \\
Rueda & 524 & 290 & 1.622 & 368,5 \\
Pollos & 18 & 450 & & \\
\hline
\end{tabular}

Fuente: Archivo Municipal de Medina del Campo (A.M.M.C.). Fondos sernas. Elaboración propia.

En anteriores apartados se ha tratado de forma general el proceso de progresiva deforestación que ha tenido lugar en el espacio estudiado en beneficio de la tierra cultivada. En estos siglos modernos es cuando se procede, por parte de los distintos concejos y labradores, a romper el monte a gran escala. Como se acaba de analizar, el arbitraje de Medina y el interés económico fueron capitales para entender el fenómeno roturador y el nuevo paisaje moldeado por el hacha, el arado y el pastoreo.

percibir el canon referido de sólo aquellos terrazgos que realmente disfrutan”. Medina, por lo demás, es consciente de que los apeos reflejan menos terreno del real pues, como dice, siempre se muestra generosa en la "equidad en la medida, esto es, que si habían de coxer de 500 estadales suelen hacerlo de 600, o más”. Ello genera, especialmente cuando los atrasos son abultados y las necesidades presupuestarias de Medina acuciantes, agrias disputas entre las partes. En el exhaustivo informe de 1801 del contador Puche, se alude nuevamente a estas cuestiones aun cuando se es consciente de la dificultad de cobrar a los morosos y de ejecutar apeos con precisión y regularidad, dado lo costoso de los mismos. En relación a ello "Además (Medina del Campo) tiene el dominio directo de 36.000 obradas de tierra en los Pueblos de Rodilana, La Seca, Rueda, La Nava, Pollos y Siete Iglesias, y por cada obrada paga el llevador ocho reales por obrada que siembra, y por un quinquenio debe valer 160.000 rs de vellón, atendiendo a que estos tres últimos pueblos deven satisfacer 16 rs por cada quinientos estadales, deviendo advertir que de muchos ańos a esta parte se cobra muy poco por oponerse los llevadores a dicho pago”. (A.M.M.C., caja 254-34).

${ }^{265}$ A.M.M.C., caja 167, fol. 17. El cuadro recoge los datos derivados del "Apeo General ejecutado por el Corregidor D. Justo Martínez de Baños en testimonio de Juan García Núñez en virtud de órdenes del Supremo Consejo en los años de 1791 y 1792 ".

${ }^{266}$ La superficie anotada corresponde a tierras labrantías (8.204 obradas y 164 estadales); tierras tituladas de Merced ( 1.623 obradas y 182 estadales); el pinar plantado por la villa de Nava (305 obradas); tierras tituladas propias (147 obradas y 344 estadales) y una vińa titulada propia de 2 obradas y 440 estadales. Se ignora la causa de que, en el cuadro resumen del apeo, no se registren majuelos en este término y se sospecha que lo están como registros de tierras labrantías.

${ }^{267}$ La pensión en los pueblos de Rodilana, La Seca y Rueda es de a fanega por obrada; las viñas majuelos contribuyen todos los años según su cavida. Las tierras sólo pagan el año que están sembradas.

Las tierras tituladas de Merced pagan a Medina una mitad de su cavida. Las tierras nombradas propias están en posesión de no pagar. El pinar sembrado por la villa de La Nava nada paga aunque ocupa tierras contribuyentes. Las 400 y más obradas de Rueda se omitieron, y es quasi todo el terrazgo plantado de majuelos. Debe aumentarse la renta según el último Apeo 1.622 fanegas, 8 celemines y 2 quartillos en la clase de majuelos, y en las tierras lo que resulte del anual reconocimiento que podrá hacerse con más distinción y conocimiento mediante dicho apeo”. 


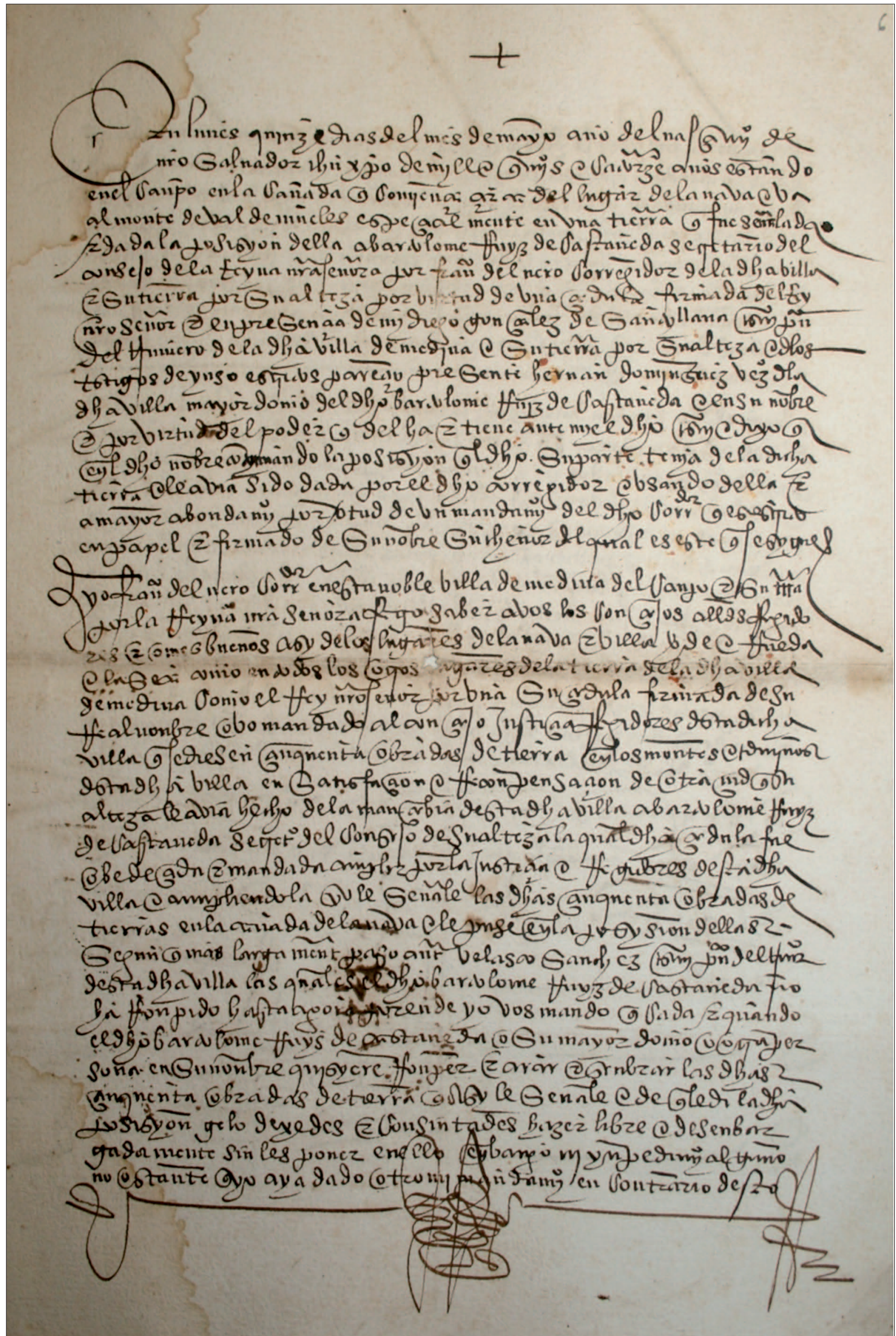

Imagen 45. Toma de posesión de la merced de Castañeda concedida en el monte Valdemuelles por la reina Juana y el Emperador Carlos en el año 1514. (A.M.M.C. Caja 18, exp. 234-136, fol. 6). Foto: 17/07/2008. 
Sin embargo, no hay que olvidar que, desde tiempos bajomedievales, en los distintos lugares los concejos locales disponen de normas de ocupación y aprovechamiento tanto de los espacios concejiles como de los particulares. Sea propiedad señorial, monástica, del común o de pequeños y medianos labradores, buena parte del terrazgo se labraba o aprovechaba con los ganados.

Respecto al importante terrazgo de tierras sernas que se extienden por el norte de la Tierra, es en esta época cuando se convierten en centro de atención, tanto para sus detentadores como para quienes desean ampliar sus propiedades y cultivos. Un primer impulso para que los labradores sacien su hambre de tierra, como se anotaba en el anterior epígrafe, lo dan los Reyes Católicos al permitir, en el año 1500, la toma de cuatro obradas por cada par de mulas "quedando la dicha tierra, después de alzado el fruto por común a todos los vecinos"268. A pesar de que la medida preservaba la propiedad de los montes, lo amplias que debieron ser las roturas y las protestas de los ganaderos, que se sentían sin pastos, obligaron unos años más tarde a revisar la concesión. La ampliación del terrazgo labrado, sin embargo, no podía hacerse si no era a costa del terreno inculto. Y éste era, en su mayor parte, de propiedad concejil: pastizales, montes bravos, retamares, baldíos, cańadas y abrevaderos.

En este mismo año de 1500, en una Real Facultad expedida a pedimiento de los vecinos de Pozaldez, se hace relación de haber labrado el monte Pedroso a cambio de entregar a Medina una fanega por obrada, pero, como "ya estava cansado y havia otro que llamaban Ynestoso por romper", solicitan y consiguen la licencia para llevar a cabo nuevas roturas a cambio de idéntico canon anual ${ }^{269}$. Distinta actitud muestran los vecinos de Nava en este tiempo. Su canon es el doble, de acuerdo a lo que disponen las antiguas ordenanzas. Los pleitos que los obligan al pago de la renta de las tierras "que hasta entonces habian roturado como de las que rompiesen en adelante" 270 envenenan las relaciones entre sus concejos. Es de suponer que los vecinos de esta villa se sintieran agraviados por los continuas "mercedes", concedidas por el emperador Carlos entre 1528 y 1550, que detraen, de importantes superficies de terrazgo, sernas en las que el beneficiario paga la mitad del canon establecido ${ }^{271}$. Muchas de ellas acaban formando parte de mayorazgos y son cultivadas mediante subarriendo por vecinos de la Nava. Un ejemplo es la merced de Castañeda, de la que se reproduce la toma de posesión. Fue concedida en 1528 por el rey Carlos I a Bartolomé de Castañeda y Juan Ramírez. De una extensión de cincuenta obradas se sitúa en el término de Nava al monte Valdemuelles, y "linda con merced de Diego Velázquez de Espinosa por dos partes..., y con tierra manchón de Jiménez, y tiene dos ramas que salen al camino de Pollos que va a Medina del Campo, que lindan con dicho camino..., y cañada que llaman del Vellosillo y con merced de Escobar"272, que prueba que en este pago se detrajeron al monte importantes superficies para este fin.

Estas concesiones suponen un importante retroceso de los montes en este término, especialmente en el citado de Valdemuelles. No en vano las mercedes que subsisten y se apean a finales del XVIII ascienden a 1.623 obradas y representan el 15,6\% del total de superficie sernas en el citado término. En

\footnotetext{
${ }^{268}$ MORALEJA PINILLA, G.: Historia de Medina..., ob., cit., pág. 74.

${ }^{269}$ A.M.M.C., caja 18, exp. 234-36. "Relazión sobre que recayó la formación del Real Reglamento del año de 1762 para los Propios y Arvitrios de Medina”, fol. 4r.

${ }^{270}$ Ibídem, fol. $4 \mathrm{v}$.

${ }^{271}$ En estos años estas "mercedes” se concedieron “con particularidad a los licenciados Santiago Zuazo, Blanco, Aguirre, Acuña, Herrera, Ronquillo, Francisco Gómez de Vergara del Consejo de S. M.; a Rodrigo de Dueñas, al Comendador mayor de León Francisco de los Cobos y a Juan Bázquez de Medina, secretario de S.M. con la obligación de pagar a la villa de Medina del Campo el terrazgo que se acostumbraba...” (A.H.M.C., caja 170-5, fol. 15). A finales del siglo XVIII constan demandas contra distintos colonos de algunas de ellas, como la merced del Doctor Aguilar, del Doctor Medina, de Lugo, del Rosario, la merced de Briones, de Pedro Alonso, la de Bernardino Velásquez, buena parte de ellas labradas por colonos afincados en Nava del Rey.

${ }^{272}$ A.M.M.C., caja 18, exp. 234-136. En 1673, detenta esta merced Mariana de Segura, viuda de Juan de León y Castańeda como tutora de su hijo Antonio León y Castańeda, sucesor del mayorazgo. En 1726 la encontramos en manos de Juan León y Castañeda, abad y vicario de Medina del Campo.
} 
este mismo monte, pero en término de Pollos, este lugar solicita en 1546 cien obradas por espacio de diez años y una renta de media carga de trigo por cada obrada de quinientos estadales. Los montes del Palancar y Valdemuelles ven así, en la segunda mitad del siglo XVI, reducir buena parte de su superficie.

A diferencia de Alaejos y sus tierras comunes, que se reparten en suertes entre sus vecinos hasta su venta, como también ha sido estudiado, "las sernas, montes y mercedes" de Medina del Campo son el lugar idóneo de expansión para los lugares de pertenecientes a la Villa y Tierra, pero en manera alguna son gratis. La salida de rentas que jamás se reinvierten sobre los terrazgos labrados fue una práctica común tanto en los bienes de mayorazgos como en estos comunes de Medina. La tensión y el cruce constante de litigios, como se ha reiterado, es la norma durante siglos. Por entonces el principal sustento era el pan y de ahí la vigencia de las ordenanzas antiguas ratificadas en 1508 por la reina Juana. Pero no es menos cierto que se había iniciado la plantación de majuelos en dicho terrazgo con el consiguiente conflicto de intereses ${ }^{273}$. En el pleito que surge en 1522 y que se extiende durante buena parte del siglo entre Medina contra Alaejos y Siete Iglesias, sobre viñas plantadas en tierras concejiles en este último término, por causa de haberse vendido viñas en término de Siete Iglesias a vecinos de Alaejos, Medina ratifica su posesión sobre dichos bienes de Propios. A través de los testimonios, autos y sentencias contenidas se desprende que, sobre estos bienes comunes y de tiempo inmemorial, se solían plantar viñas que acompañaban las tierras de pan, pero siempre con la licencia debida ${ }^{274}$ :

"Quel que quiere plantar algún pedaço de lo concejil de vińa antes que la plante es obligado a registrarla antel scrvo de la dicha $v^{a}$ de siete iglesias, después ques villa, y antes desto, antel scrvo del ayuntamiento de $\mathrm{m}^{\mathrm{a}}$ del canpo, para que siempre quede memoria de como la vińa esta plantada en lo concejil, y cualquiera que ocupa

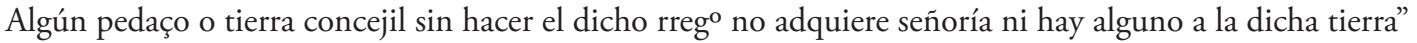

Por entonces muchos lugares tenían plantadas vińas en terrazgo común, aunque, a tenor de los testimonios, predominaba lo labrado a lo plantado:

"El primero testigo dixo que... a visto que algunos vecinos de la dicha villa de siete yglesias y de otros lugares de la juridizión de la dicha villa de medina del canpo tienen plantadas algunas viñas en tierras públicas e concejiles de la dicha villa de siete iglesias e de otros lugares de la juridición de la dicha villa de medina del canpo...”

Lo temprano del momento y la escasa entidad que representan los majuelos respecto al terrazgo común no impide que Medina quiera dejar clara su posesión sobre unas viñas plantadas sin licencia sobre sus bienes de Propios y vendida a "extraños" a su jurisdicción. Es un aviso ante las evidencias que aumentan año tras año en otros lugares y que, de generalizarse, sería la extinción de sus privilegios.

Las roturaciones son una constante a lo largo del siglo XVI en los montes de Propios de Medina. La necesidad de tierra rivaliza con la ley y la costumbre, década tras década, y los pleitos son el espejo de estos intereses encontrados. En 1574, en el citado término de Siete Iglesias, se forma pleito ante las intrusiones que varios vecinos llevan a cabo en las cańadas de Valdeyuste, Valdevite, Valdelabrojo, así como en la realenga de Tras el Sotillo. Los labradores "con poco temor de dios y en gran menosprezio de la justicia... avian rronpido y arado un pedazo de la dicha cañada y al presente la tenían sembrada"275. Poco más podrán hacer que acatar la sentencia y devolver al pasto y tránsito común lo usurpado, pese a que nunca faltan alegaciones para evitar las sanciones, en este caso argumentando que dichas cañadas son concejiles y de aprovechamiento común de sus vecinos y que "las dichas cañadas estavan

${ }^{273}$ A.M.M.C., caja 234-36, fol, 5. Siguiendo con la información que se recoge en el citado memorial, en 1515 se da cuenta de otra ejecutoria por querella que tuvo Medina del Campo contra vecinos de la Nava, por haber plantado vińas en tierras sernas, pretendiendo que las descepasen, siendo condenados por la justicia ordinaria y que confirmó la Real Chancillería, tras la apelación pertinente, en sentencias de vista y revista, librándose ejecutoria que se practicó.

${ }^{274}$ A.M.M.C., caja 146, carpeta 2424.

275 Ibídem. 
llenas de langosta que si se criara destruyera todo el término y todos los otros lugares comarcanos y fue muy necesario ararlas y de mucho provecho sembrarlas para destruyr la dicha langosta". Evidentemente, la justicia no atenderá tales argumentos y, junto a las penas en dinero y pérdida de animales de labor, avisa caso de que algún vecino trate de ampliar su labranza en detrimento del terrazgo común ${ }^{276}$ :

"Y en que de aquí adelante ellos, $\mathrm{u}$ alguno de ellos, u otra persona alguna, no rompan, aren ni siembren en la dicha cańada, so pena de diez mill mrs y perdidas las mulas con que rompieren, araren y sembraren y rreduce lo sembrado a pasto común como antes lo hera para que lo puedan pastar y pastan el concexo e veçinos de la dicha villa"

Los bienes concejiles son, en cualquier caso, una salida para pequeños labradores y jornaleros, deseosos de ampliar sus menguadas heredades, pero también para medianos y grandes propietarios como forma de aumentar sus labranzas. Muchos de los aprovechamientos y rompimientos que se hacen en las sernas y montes de Medina se realizan al margen de la legalidad. Es esta villa la que denuncia las roturas o las apea para el cobro de rentas ante hechos consumados. Los rompimientos se prodigan en los pagos de más sustancia hasta la pérdida de su fertilidad, en que vuelven a su estado inicial o son plantados de majuelos. Cuando en el siglo XVI lo ocupado se hace de forma moderada y las cosechas y precios son favorables, la mayor parte de estas roturas se registran y sus tenedores pagan el canon correspondiente; pero, cuando en los siglos XVII y XVIII se generalizan y se entremezclan las ejecuciones contra deudores, se multiplican por cientos los renteros, se extiende la exención de las villas negando la jurisdicción de Medina sobre sus términos, abundan los pleitos contra concejos y las plantaciones de majuelos sin permiso, el divorcio entre Medina y su Tierra es total.

En la averiguación que se practica en Nava en 1623 sobre los rompimientos efectuados en los montes del Palancar, Valdevite y Valdemuelles, la declaración de Albín Blanco, guarda de dichos montes, no puede ser más esclarecedora. En los cinco últimos años desde la citada fecha, trece vecinos de Nava habían roturado 101 obradas que sembraban de cebada y trigo. Entre los labradores figuran regidores y procuradores y cuatro vecinos que, con doce o más obradas cada uno, se estima que regentan labranzas de entidad. La marea roturadora parece incontenible ${ }^{277}$.

No hay que olvidar que Nava había comprado su exención en 1559 y sentía como terrazgo propio cuanto abarcaba su jurisdicción y término. Fue un factor que impulsó la ocupación hasta que la reacción pleiteadora de Medina impuso la ley según las viejas normas. Un caso similar sucede en La Seca que, tras eximirse en 1629, lleva a cabo cortas tan intensas en el monte Inestoso que no tardan en ser denunciadas y que acercan a su situación forestal en $1630^{278}$ :

"Juan de la Mora, en nombre de la villa de Medina del Campo... nos hiço relación que siendo la dicha villa de la Seca de la jurisdizión de la dicha villa de Medina del Campo se havía eximido y dentro de la moxonera que se havía señalado se comprendía el monte de su parte que llaman Ynestoso, y contenía más de legua y media

\section{${ }^{276}$ Ibídem.}

277 He aquí una selección de la citada averiguación: "En la villa de medina del campo a tres días del mes de agosto del año de mill y seiscientos y veintitrés ańos..., para averiguación de los rompimientos echos en los montes del palancar, baldebito y baldemuelles y los demás desta villa, pasto común de los ganados de billa y tierra, presentó por testigo a albín blanco, vezino de la villa de pollos, guarda de los dichos montes y... siendo preguntado..., dixo que lo que sabe es que bartolomé recuero, vezino de la villa de la nava del rrey tiene rronpido seis obradas de tierras poco más o menos en el dicho monte del palancar a do dizen el bellosillo, y abrá que lo rompió dos meses poco más o menos, pegada a una tierra suya; y que pedro martín, vezino de la dicha villa de la naba y rrexidor della tiene rronpido en el dicho monte al mismo pago del bellosillo ocho obradas de tierra poco más o menos, y abrá un año lo rompió y este lo a tenido sembrado de cebada..., y que joan gonzález... tiene rronpido en el dicho monte al dicho pago de baldeorexas ocho obradas poco más o menos, y lo rronpido abra un ańo poco más o menos, y este ańo la a tenido sembrada de trigo y cebada..., y que esto todo lo sabe como tal guarda ques de los dichos montes de más de treinta y tres años a esta parte, y lo ha visto todo lo que se ba dicho romperse con las mulas y criados de los que ba dicho, y declaró ser de sesenta y tres años poco maá o menos...”.A.M.M.C., caja 149, carp. 2433.

${ }^{278}$ A.M.M.C., caja 149, carp. 2436. 
de término, y estava el dicho monte muy poblado de encinas y carrasca, y tenía en medio del una casa de cantería... en que vivían sus alcaldes y guardas de a pie y de a caballo... Los dichos justicias y vecinos de la dicha villa de la Seca, después de que habían comprado su jurisdicción, havían talado el dicho monte cortando más de doce mil enzinas de pie..., habiendo echo particular granxería vendiéndolo en la dicha villa, y lo avían llevado a vender a Tordesillas, Pozaldez y otros lugares de la comarca..., habían echo gran feria y trato y cambrones y otros instrumentos de caça; havían muerto toda la que havía en el dicho monte. Y havía llegado a tanto su exceso que con mano poderosa de justicia havían derrivado las dichas casas principales y azesorios. Y se havían provechado de todos sus materiales con fin de que en el dicho monte no obiese personas que le guardassen y pudiesen conseguir el que se acavase de cortar y destruir... Y siendo la serna del dicho monte de su parte y su tierra para que la pastasen sus ganados no davan lugar si no es que los prendían, matavan y maltratavan los pastores y vendían la yerba a diferentes personas como si fuera suya propia”

$\mathrm{Al}$ igual que ocurre en los lugares más al norte de la comarca, adscritos en estos siglos a la comunidad de Villa y Tierra de Olmedo, tales como La Moya, Matapozuelos o Serrada, la expansión del viñedo en la primera mitad del XVII necesita de autorizaciones legales para su plantación, sea en las tierras "flacas e pedregosas", propiedad de los distintos mayorazgos que controlan la propiedad en tales términos, sea en las de "sernas, montes y mercedes" que tratamos. Para ello se arbitran en 1665 ventas a censo perpetuo, que posibilitan el desarrollo del viñedo de forma legal y en amplias superficies. Las licencias dan un respiro a muchos concejos, siempre en litigios con Medina por la reiterada controversia en aceptar o no al viñedo como forma de aprovechamiento en sus bienes de Propios. Bien es verdad que, en este caso, la legalidad obedece más a hechos consumados y necesidades presupuestarias que a la interpretación que siempre se hizo de las antiguas ordenanzas de la reina Juana, en las que nada se decía de los majuelos, pues, en aquel tiempo, como ha quedado dicho, las roturas que se hacían en los montes eran mayoritariamente para sembraduras de cereales y leguminosas ${ }^{279}$ :

"Y ahora, ha entendido esta Villa, que habiéndole hecho (el apeo) en La Seca, se han hallado en las tierras que quedan en él comprendidas, y por propios de esta Villa, muchas plantadas de viñas, y majuelos con las quales no se puede entender la disposición en que dio forma la Señora Reyna Doña Juana, por ser solamente quando se sembrasen, y porque se dé a esta hazienda el cobro que conviene, y para que se pueda acudir y cumplir con las muchas cargas, y obligaciones con que se halla,... Dan poder a los dichos señores... para que en nombre desta Villa confieran, traten, ajusten y den a censo perpetuo todas las tierras que assí en el término referido de La Seca se hallaren plantadas de vińas, y majuelos, como en los de Rueda, Pozaldez, Ventosa, Poçal de Gallinas, la Nava del Rey, Pollos, Siete Iglesias, Herreros, Heván de arriba, Heván de abajo y en las demás partes donde esta Villa tiene sernas, y se hallaren plantadas en la forma referida...”

De esta manera se "legalizan" para bien de los tenedores de sernas y de las arcas de Medina las plantaciones existentes que, al rendir canon de forma anual, acaban siendo más "productivas" que las tierras de sembradura de año y vez ${ }^{280}$.

\footnotetext{
“Otorgamos, que por la dicha Villa de Medina del Campo,... Damos en venta, a fuero, a censo perpetuo enfitéutico, desde luego para siempre jamás, a Roque de Pedrosa, vecino de la villa de La Seca, ... nueve arançadas de majuelo plantadas en tierras sernas propias de Medina del Campo en dos pedazos; el uno al pago de Valdelagúndez, que hace cinco arançadas, que linda con el camino de San Martín y majuelo de Thomé Rico y majuelo de Inés Vidal. Y por parte de Arriva el sendero del Monte. Y el otro pedazo haze quatro arançadas questa al camino de Serrada, y linda con el dicho camino y majuelo de Pedro Bayón de Pedrosa y con majuelo de Miguel de Ayllón, y los dichos majuelos que ban puestos por linderos están ansimismo plantados en tierras de sernas".
}

${ }^{279}$ A.M.M.C., caja 125. Sernas, Censo perpetuo para la villa de Medina del Campo, año 1665.

${ }^{280}$ Ibídem. La renta estipulada se fija en dos reales y medio por aranzada de cuatrocientas veinte cepas, a pagar "por los días de nuestra Señora de Agosto" de cada año. Como es costumbre, se prohíbe gravar sobre estos bienes cualquier otro censo, aniversario, capellanía o carga alguna. Caso de su venta, esta debe contar con el consentimiento de Medina que, no obstante, puede tomarlo "por el tanto para sus propios y, no lo queriendo, se le ha de pagar la veintena del precio”, amén de que el Mayordomo de Propios otorgue la licencia para hacer el traspaso y enajenación. 
Ahora bien, una real carta ejecutoria, fechada en Madrid el 24 de mayo del año 1674, librada a pedimiento de Medina del Campo del pleito que siguió con Rueda, La Seca y Ventosa "sobre que dichas villas y sus vecinos particulares dejasen libres y de tierra labrantía, como lo estaban, más de seis mil obradas de terreno que habian plantado de majuelos", pone sobre aviso del importante crecimiento del cultivo a costa de las sernas al norte de la tierra en este siglo XVII ${ }^{281}$. Aun cuando en la citada fecha la cifra de seis mil obradas rebase la realidad para sobrevalorar la causa del litigio, acerca al auge del vińedo en los citados lugares y explica cómo las plantaciones dejan inoperantes los apeos generales anteriores de tierras sernas. De hecho, a través de la documentación registrada se advierte que, desde los apeos generales de 1642 y 1643 hasta el de 1665, el aumento de estas plantaciones “ilegales" es muy elevado. Su magnitud repercute positivamente en la hacienda medinense, toda vez que muchas de ellas se legalizan en 1661, a cambio del canon correspondiente, previniéndose "a que se arrancasen los plantados en adelante dejando el terreno como antes estaba, precisando a dichas villas de Rueda, La Seca, Ventosa y sus vecinos a que no plantasen en lo sucesivo maxuelos alguno en terreno de sernas sin licencia y consentimiento de la de Medina"282.

Cien años después, sin embargo, volverán los enfrentamientos. La Nava, La Seca y Rueda solicitan a Medina permisos para nuevas plantaciones, sea reducción de rentas en los términos a la izquierda del Zapardiel, sea que los majuelos no paguen renta en sus primeros cuatro ańos siguientes al plantío, al entender que los gastos de cultivo en esos ańos deben ser tenidos en cuenta por Medina pues, desde que entran en producción, rinden canon todos los años. Pese a los constantes litigios, los majuelos se multiplican década tras década al igual que los llevadores. De acuerdo a las ordenanzas de la reina Juana de 1508, las rentas han de pagarse a Medina desde mediados de agosto hasta fin de septiembre "por los labradores, puesto que en aquel tiempo no habia majuelos y se cobraba en especie de trigo; hoy, de años hace, es la mayor parte de rentas sernas de maxuelos" 283.

Todo ello se inserta en los debates para la cobranza de sernas. El propio juez conservador de Propios de Medina manifiesta en 1792 que "por quanto las rentas de las dichas tierras sernas se suelen coger el año adelante despué de pan cogido, y de esto se siguen muchos inconvenientes asi a la Villa como a la tierra por que la renta se coja muy mal, y los labradores reciven fatiga de pagarles después que tienen el trigo vendido, o gastado por escusar esto, $y$ otras cosas... ${ }^{284}$.

En el informe sobre los Propios, que se redacta en 1760, señala que en Medina se regula en $2.138 \mathrm{fa}-$ negas de trigo lo que rinden los sembrados, y en 2.072 fanegas, las generadas como rentas por los majuelos. Unos años más tarde, en 1776, tal como refleja la gráfica adjunta, son 2.459 y 3.982 fanegas las recaudadas, respectivamente. Las sernas dimensionan muchas labranzas, palian el hambre de tierra de jornaleros y pequeńos propietarios y, no se olvide, suponen en algunos términos buena parte del terrazgo labrado, tal es el caso de La Seca, donde representan más del $60 \%$ o, en Rueda, que representan en torno al 30\% ${ }^{285}$.

${ }^{281}$ A.M.M.C., caja 164.

${ }^{282}$ Ibídem.

${ }^{283}$ Ibídem, caja 254-1, año 1799. Expediente sobre el procurador del común de La Seca que se retire el juez ejecutor que entiende en el pago de sernas: "Que por las mismas ordenanzas se dice y manda se haga el apeo de sembrados en los meses de febrero y marzo, esto es porque ya en fin de enero está hecha la sementera y manifiestos los frutos de trigo, cebada y centeno; pero pasado febrero ¿̇se cesa ni debe cesar en el apeo?; no, por cierto, por que estando arreglado lo que se debe pagar por cada obrada de tierra que se roturase y labrase, de hay es que sembrándose los abenales, garbanzos, guisantes y otras semillas pasado febrero, se quedarían por pagar; y así se apea en mayo, o abril, tiempo en que está demostrado para no causar perjuicio, y así se entiende y debe entenderse quando se establecieron las ordenanzas solo heran sembrados y el canon hera trigo, era el tiempo oportuno para su paga los meses de agosto y septiembre, y para el apremio a los morosos los meses siguientes hasta fin de enero, porque hallaráin al labrador que apremiado, no podía pagar en trigo pasado enero sería por tenerlo de nuevo empanado en las tierras, y por consiguiente pagaría por junto en la subcesiba cosecha... Para con la Seca nunca le a havido (inconveniente) por ser todo su canon por majuelos y no llegar al corto número de veinte obradas y fanegas todos sus sembrados...”.

${ }^{284}$ Ibídem, caja 254-1, año 1799. Expediente sobre el procurador del común de La Seca que se retire el juez ejecutor que entiende en el pago de sernas.

${ }^{285}$ PASCUAL GETE, H.: Las tierras “sernas”..., en "Historia de Medina...”, ob. cit., pág. 392. 
El cuadro adjunto da una idea tanto de los numerosos que son los renteros en 1776, como de las importantes rentas que recibe Medina de estos aprovechamientos en sus bienes de Propios.

\section{Cuadro 7. Importe de tierras sernas de Medina del Campo, ańo 1705}

\begin{tabular}{|c|c|c|c|c|c|c|c|c|}
\hline \multicolumn{5}{|c|}{ Villas y superficie y renta a pagar } & \multicolumn{4}{|c|}{ Total renta } \\
\hline & Estadales & $\begin{array}{c}\text { Obradas } \\
\text { (de } 500 \\
\text { estadales) }\end{array}$ & Estadales & $\begin{array}{c}\text { Renta } \\
\text { (heminas } \\
\text { de trigo) }\end{array}$ & Cargas & Heminas & Celemines & Cuartillos \\
\hline Nava del Rey & 989.120 & $1.978,24$ & & 4 & 989 & & & \\
\hline Siete Iglesias & 25.000 & 50 & & 4 & 25 & & & \\
\hline Pollos & 75.525 & 151,05 & & 4 & 75 & 2 & 1 & 3 \\
\hline La Seca & 542.010 & $1.084,02$ & & & 135 & 4 & & \\
\hline Rueda & 106.000 & 212 & 50 & 2 & 25 & 7 & 1 & \\
\hline Rodilana & 91.100 & 182 & 100 & 2 & 22 & 6 & 2 & 0,5 \\
\hline TOTAL & 1.828 .755 & $3.657,51$ & & & 1.225 & 25 & 5 & 1 \\
\hline
\end{tabular}

Fuente: Archivo Municipal de Medina del Campo (A.M.M.C.). Fondos sernas. Elaboración propia.

\section{Cuadro 8. Relación de lo que hacen las tierras labradas de sembradura, año 1705}

\begin{tabular}{|c|c|c|c|c|c|c|c|}
\hline \multirow[b]{2}{*}{ Pueblos } & \multirow{2}{*}{$\begin{array}{r}\text { Superficie } \\
\text { (estadales) } \\
\text { Estadales }\end{array}$} & \multicolumn{2}{|c|}{$\begin{array}{c}\text { Superficie } \\
\text { (obradas de } 500 \text { estadales) }\end{array}$} & \multirow{2}{*}{$\begin{array}{l}\text { Renta } \\
\text { (heminas } \\
\text { de trigo) }\end{array}$} & \multicolumn{3}{|c|}{ Total renta (fanegas) } \\
\hline & & Obradas & Estadales & & Fanegas & Celemines & Cuartillos \\
\hline Nava del Rey & 995.985 & 1.992 & 15 & 4 & 3.984 & & \\
\hline Rueda & 106.050 & 212 & 50 & 2 & 212 & 1 & 1 \\
\hline Siete Iglesias & 25.000 & 50 & & 4 & 100 & & \\
\hline Rodilana & 91.100 & 182 & 100 & 2 & 182 & 2,5 & \\
\hline La Seca & 542.000 & 1.084 & & 2 & 1.084 & & 1 \\
\hline Pollos & 75.525 & 151 & 25 & 4 & 303 & 1 & \\
\hline TOTAL & 1.835 .660 & 3.671 & 190 & & 5.865 & 4,5 & 2 \\
\hline
\end{tabular}

Fuente: Archivo Municipal de Medina del Campo. Fondos sernas. Elaboración propia.

\section{Cuadro 9. Rentas en trigo de sembrados y majuelos en tierras sernas, año $1776^{286}$}

\begin{tabular}{|c|c|c|c|c|c|c|c|c|}
\hline \multirow[b]{2}{*}{ Pueblos } & \multicolumn{3}{|c|}{ Rentas en trigo de sembrados } & \multicolumn{3}{|c|}{ Rentas en trigo de majuelos } & \multicolumn{2}{|c|}{ Total rentas } \\
\hline & No de renteros & Fanegas & Celemines & No de renteros & Fanegas & Celemines & Fanegas & Celemines \\
\hline Nava del Rey & 102 & 1.384 & 11 & & & & 1.384 & 11 \\
\hline Pollos & 53 & 537 & & 94 & 776 & & 1.313 & \\
\hline Foncastín & 2 & 6 & & & & & 6 & \\
\hline Siete Iglesias & 10 & 63 & & & & & 63 & \\
\hline Eván de Abajo & 1 & 2 & & & & & 2 & \\
\hline Rueda & 29 & 152 & 5 & 150 & 671 & & 823 & \\
\hline Rodilana & 2 & 3 & 2 & 116 & 350 & 10,25 & 353 & 12,25 \\
\hline Ventosa de la C. & 2 & 4 & 9 & 21 & 34 & 7,50 & 38 & 16,5 \\
\hline La Seca & 100 & 275 & 3 & 478 & 2.070 & 11,75 & 2.345 & 11,75 \\
\hline San Martín del M & 1 & 10 & & 2 & 5 & 7 & 15 & 7 \\
\hline San Miguel del P. & 1 & 20 & & & & & 20 & \\
\hline Serrada & & & & 5 & 52 & 2,25 & 52 & 2,25 \\
\hline Pozal de Gallinas & & & & 1 & 5 & 5,5 & 5 & 5,5 \\
\hline Pozaldez & & & & 2 & 16 & 2 & 16 & 2 \\
\hline TOTAL & 303 & 2.459 & 2,25 & 869 & 3.982 & 10 & 6.440 & 8,25 \\
\hline
\end{tabular}

Fuente: Archivo Municipal de Medina del Campo (A.M.M.C.). Fondos sernas. Elaboración propia.

${ }^{286}$ A.M.M.C., caja 254. En 1778 la renta de los sembrados ascendió a 2.329 fanegas, siete celemines y dos cuartillos y la de los majuelos 1.982 fanegas, 10 celemines y un cuartillo. En total la suma de las rentas en tierras sernas ascendieron a 6.312 fanegas, cinco celemines y tres cuartillos. 
De hecho, en La Seca, además de situarse por encima del resto de los pueblos tanto en renteros como en sernas en relación al total del término, la fiebre plantadora no parece acabar nunca. En 1785 su alcalde mayor es consciente de la importancia del cultivo para un municipio de cuatro mil almas que respira cepas y vino por los cuatro costados y donde "apenas se encuentra un mendigo que sea de su naturaleza y vecindario, ni tampoco un palmo de tierra sin cultivar, a excepción del pago que llaman el Monte Ynestoso y Pedroso, donde se hallan como dos mil novecientas cincuenta obradas de tierra... toda yerma y perdida"287.

Nos encontramos al final del camino roturador, en el tiempo de la difusión de las ciencias útiles y el fomento de la agricultura en la España de la Ilustración. Son décadas, por lo demás, que anteceden al fin de la expansión vitícola de la edad moderna. Nos encontramos, una vez más, inmersos en los eternos debates sobre la plantación de vides en tierras sernas y las protestas de pueblos vecinos que sienten que el incremento de majuelos en otros términos, a costa de "Propios comunes", les pueden perjudicar. Siguiendo los pleitos sobre el particular, estamos ante los últimos retazos de superficie forestal en Tierra de Medina o, para ser más precisos, ante los últimos baldíos y retamares que siglos anteriores llevaron el titulo de montes. El alcalde mayor de La Seca no puede ser más elocuente al respecto ${ }^{288}$ :

"Que aunque el expresado terreno se titula monte, ni lo es, ni aparece señal en todo su ámbito de haberlo sido: toda ella es tierra calba sin árbol, cepa, ierba, ni otra planta alguna no a propósito para pan, porque si algo se siembra, que lo es mui poco, se reduce a un centenal u otro, mui raxo y malo...”.

Sus argumentos sobre lo aparente de esta tierra "guijosa y ligera”, idónea para viñedo, no logran convencer a Medina, de momento, pese a que se le ofrece sin tapujos lo que sabe anhela por encima de todo: incrementar sus rentas de Propios.

\begin{abstract}
"Que si se plantaran de viña... habría de nuevo plantío como quatro mil aranzadas de majuelo... que pueden fructificar un ańo con otro, según el cómputo más moderado, ciento treinta mil cántaras de mosto, las que reguladas sólo a cinco reales vellón cántara, valen seiscientos cincuenta mil rs.... Por esta quenta, que es bien perceptible y clara, se hecha de ver lo que pierde este vecindario industrioso..., lo que pierde la Iglesia de Dios en sus diezmos, y lo que pierde V.M. de tributos..."
\end{abstract}

Como se analizará en próximos capítulos se trata de los momentos de mayor apogeo vitícola del espacio estudiado. Medina del Campo catastra en 17523.191 ha; Villaverde 3.636 ha; Rueda 2.955 ha; Nava del Rey 1.220 ha; La Seca 2.128 ha... Las producciones son muy abultadas y la competencia entre los gremios viñeros de los distintos pueblos a través de ordenanzas de vinos trata de proteger los intereses de cada uno. Tan importante es vender lo que cada término produce como evitar que otros saturen el mercado. En Medina siempre pesaron más las rentas que generaban los majuelos para sus presupuestos que la influencia de los intereses del gremio de vińeros para la contención de las plantaciones. Similares argumentos manifiesta el alcalde de La Seca ante estos baldíos en los que sus administrados no pueden meter legalmente el arado "al paso que los demás circunvecinos están a su arbitrio plantando, como lo ha hecho, y hace Rueda, Tordesillas, Serrada, y Medina del Campo"289. Pese a lo ilustrado de la solicitud y la contundente negativa de Medina, los hechos consumados superan nuevamente las pláticas de unos y otros. En un informe del Ayuntamiento de Medina de final de siglo se anota que "la Seca tiene quasi plantado todo el terreno sernas de modo que hasta San Martín del Monte y el Monte de las Monjas tienen ya plantado, ques mucho más que lo apeado año de 1792".

${ }^{287}$ A.M.M.C., caja 254-40.” Representación hecha a S. M. por el Alcalde mayor de la Villa de La Seca solicitando permiso para plantar de maxuelos el terrazgo de los Montes Ynestoso y Pedroso pagando un canon correspondiente".

${ }^{288}$ Ibídem.

${ }^{289}$ Ibídem, fol. 33. 
Pocos años más tarde, en 1798, cuando las crisis de finales de centuria hagan tambalearse muchas explotaciones y las haciendas locales se encuentren en estado crítico, se generan los enésimos debates en Medina que nos sitúan ante un terrazgo plenamente ocupado y donde en algunos términos lo plantado de majuelos parece retroceder por la crisis. En un auto escrito bajo el mandato de Justo Martínez de Baños, corregidor y juez privativo conservador de Propios de Medina, se critica a quienes se oponen a que otros planten viñas en estos terrazgos sernas, especialmente en relación al plantío solicitado en este tiempo por Nava del Rey, y al que se oponen "cosecheros de cien cántaras de vino (que) no quisieran hubiera más en toda Castilla para lucrar a su veneficio y saciar su ansia ${ }^{290 "}$.

De hecho, en los debates sobre la conveniencia de parar dicho plantío o darle autorización para beneficio y aumento de las rentas de él derivadas, se manifiesta tanto la situación vitícola como la culminación roturadora del espacio sernas. La historia se repite una vez más en esta tierra de Medina y el siguiente testimonio ilustra tanto la situación que vive el sector vitivinícola, el fin definitivo de la superficie montaraz, como la apuesta por el interés crematístico de una hacienda local al borde del colapso $^{291}$ :

"Lo primero porque La Nava planta en sernas tierra roturada. La Nava cinquenta años hace era bodega de más de 300.000 cántaras de vino; hoy no llega a 180.000, con que hasta que planten hasta la cosecha antigua parece no perjudica a ninguno. La Seca a plantado quasi todo el terreno del monte Ynestoso que no ha devido ni aun roturar sin licencia del consejo por ser tierras montes y Medina no tan solo no lo ha impedido como devio, sino es que ha hecho Apeos, les ha cargado desde el primer año del plantío y cobrado. A Rueda vendió Medina para los cuarteles el término del Montico más de 600 obradas. Los mismos de Ayuntamiento de Medina que no quieren que otros planten lo han estado haciendo todos estos años y en el actual".

Pero no sólo los presupuestos están al borde del abismo. Sobre el mundo vitivinícola se ciernen no pocos interrogantes. Distintos pareceres antes de que llegue la crisis así lo constatan. De la misma manera que se advierte que "enviniendo dos o tres años abundantes no tan sólo no plantarán sino es que mucho de lo plantado se abandonará en todos los Pueblos", se dice que "lo cierto es que parece imposible se consuma tanto vino como se coge sólo en esta circunferencia, y ello es que cada año, y de algunos asta parte, bale caro y tiene buen precio"292.

Las imágenes adjuntas testifican este auge. En el plano de Rueda de finales del XVIII puede comprobarse que el espacio roturado se ha ido extendiendo por todo el término, desde el lugar poblado hasta el mismo Duero, en la vecina Tordesillas. Consecuencia de ello es la construcción de numerosas bodegas en cada uno de los pueblos que tratamos, muchas de ellas de grandes dimensiones, atendiendo a la superficie vitícola de cada hacienda. En la que reproducimos de Pozaldez pueden observarse, a lo largo del cañón de la bodega, la disposición de las cubas, de gran capacidad, todas ellas de roble con arcos de hierro y asentadas sobre poínos.

La evolución del terrazgo labrado había llegado a su máximo histórico. Y también el número de cepas plantadas. La ocupación de los "montes, sernas y mercedes" de Medina era casi total, como refleja el mapa adjunto de Rueda de $1793^{293}$.

${ }^{290}$ A.M.M.C., caja 167, "Papeles varios puestos..., ob. cit., fol. 37.

${ }^{291}$ En este año de 1798 la renta que los Propios de Medina obtenía de los majuelos ascendía a 4.861 fanegas. De ellas 826 procedían de Rueda; 3.315 de La Seca, 309 de Rodilana y 411 de Pollos. El terreno de Nava destinado a plantíos se estimaba en 3.443 obradas, sin incluir las tierras de merced. De estas producían como tierras de sembradura unas 600 obradas. De ahí la querencia por proveerse de 2.843 fanegas anuales en Nava, caso de que prosperasen los permisos para plantíos solicitados.

${ }^{292}$ Ibídem, fol. 37.

${ }^{293}$ A.M.M.C., caja 168. Papel suelto incluido en la "Pieza 3a para la conclusión del Apeo de tierras y maxuelos sernas del término de Rueda y titulado: Plano y Pintura del terreno de sernas en término de la Villa de Rueda". 


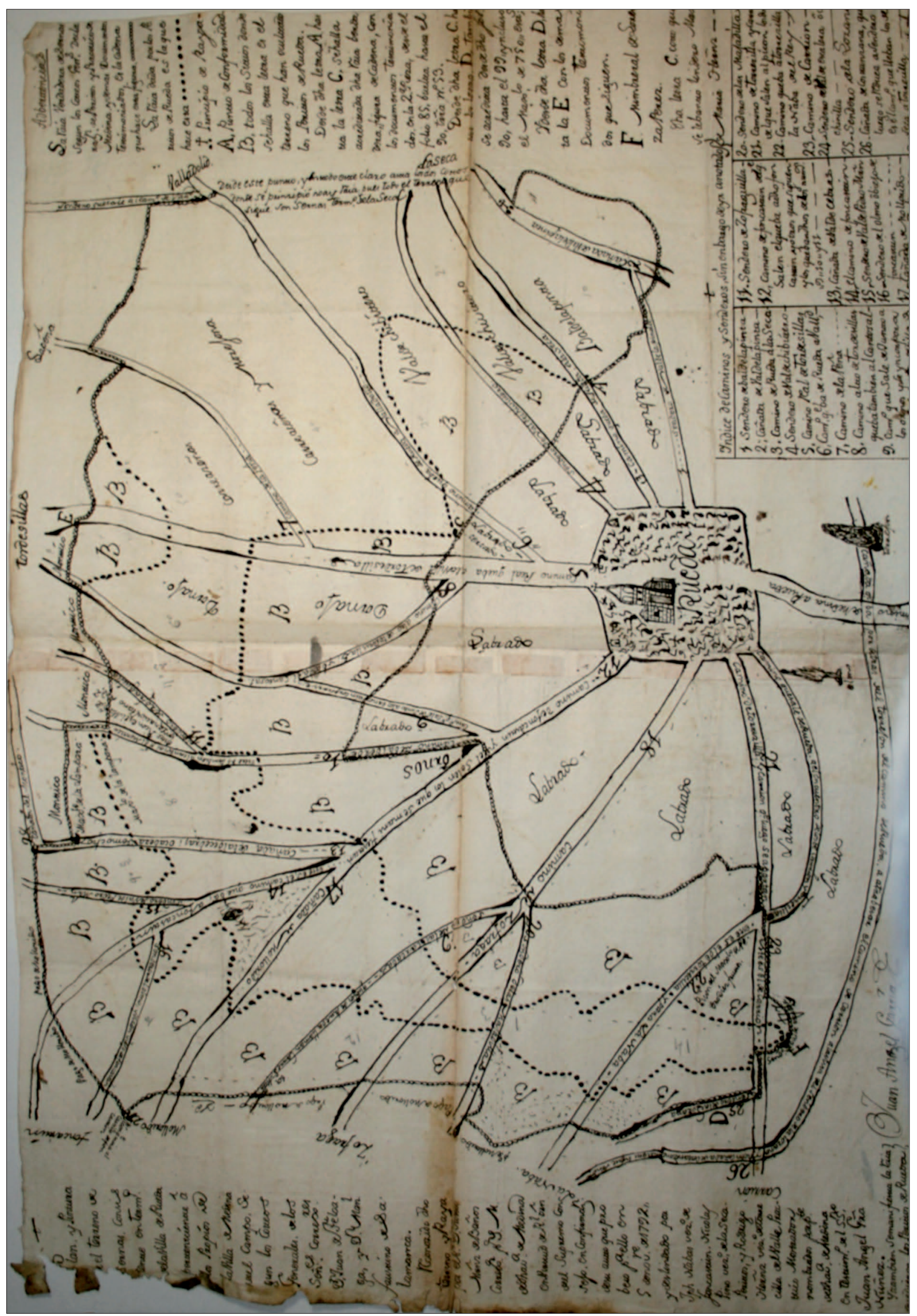

Imagen 46. "Plano y Pintura del terreno de sernas en término de la Villa de Rueda", año 1794, (A.M.M.C. Caja 168). En la ocupación del espacio se observan las distintas aureolas roturadas en torno al lugar poblado, unidas por caminos que son recorridos mediante el sistema de "rejas vueltas", es decir, yendo y viniendo a diario desde el pueblo, sin pernoctar fuera de su casa. 


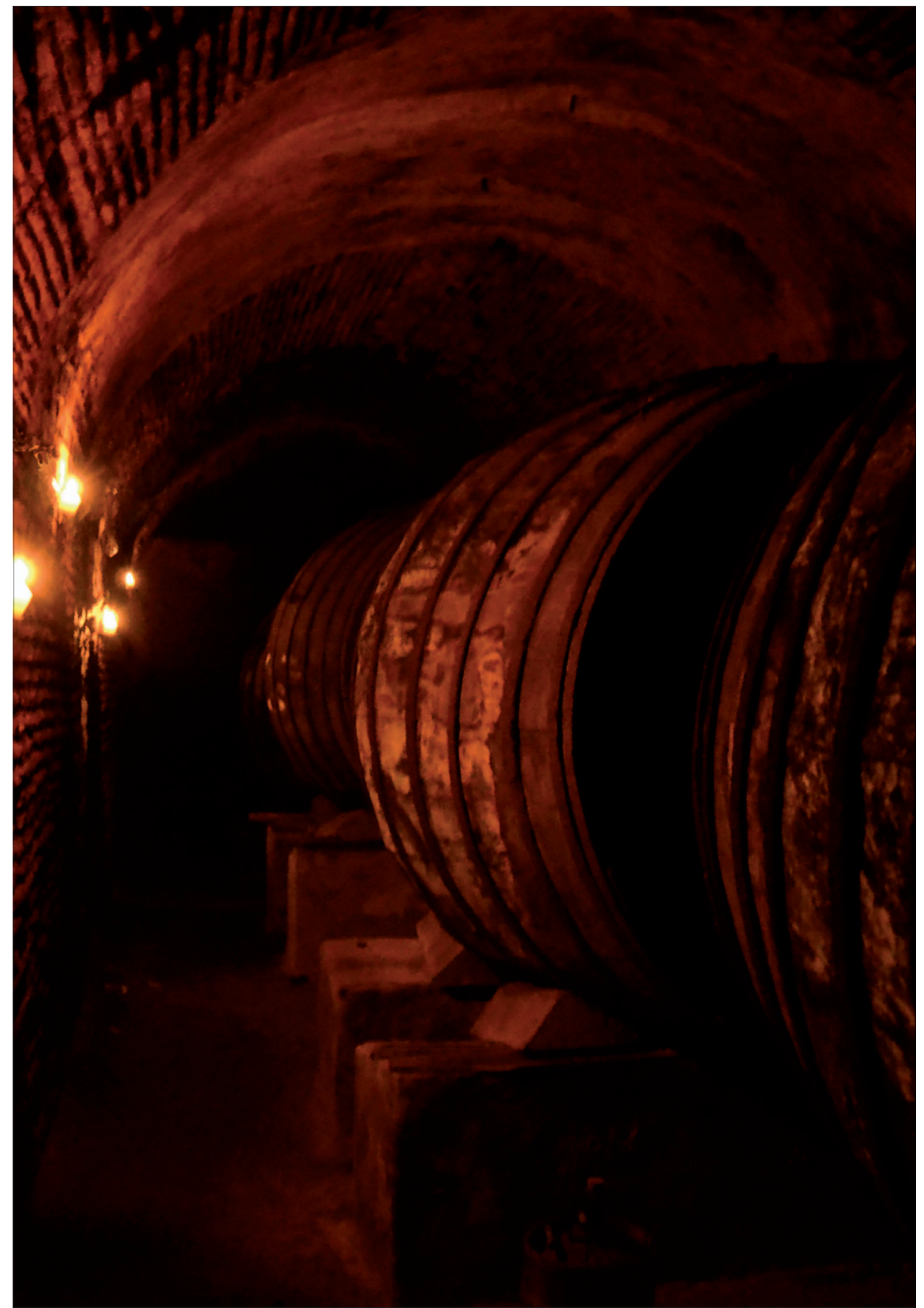

Imagen 47 Interior de bodega subterránea, con cubas de roble e iluminada con velas, a la manera tradicional. (Familia Bocos Cantalapiedra. Pozaldez). Foto: 02/09/2014. Buena parte del subsuelo de la comarca, especialmente el existente bajo las casas de los labradores, está horadado de bodegas donde se produce la fermentación de los vinos. Las buenas prácticas de elaboración y conservación han sido claves para entender su éxito. 
Como puede apreciarse, si se sigue la leyenda que delimita el terrazgo sernas, éste se sitúa en la mitad norte del actual término de Rueda, dejando a esta villa al sur de dicho espacio. La delimitación que se señala en este apeo y mapa de 1794 coincide con la que determina el de 1665, que continúa por los términos vecinos situados al norte de la Tierra de Medina hasta llegar al Duero, límite jurisdiccional de Tordesillas. Este espacio septentrional de suelos de terraza fue ocupándose, como se ha estudiado, conforme se agotan las posibilidades del terrazgo labrado propio del lugar y al tiempo de coyunturas vitícolas expansivas que reclaman los suelos sueltos y pedregosos que se extienden incultos en estos montes que tratamos.

La disposición en aureolas de las distintas partes labradas, sea de lo "labrado" propiedad de los vecinos de la villa, sea de las tierras sernas ocultadas, apeadas con anterioridad o existentes en los límites periféricos, denota una ocupación economicista del espacio, más temprano cuanto más cercano al lugar poblado, de rejas vueltas y que sigue la red de caminos, cañadas o senderos trazados de forma radioconcéntrica. En ocasiones, sin embargo, el propio concejo debió solicitar a Medina la roturación de manchas enteras de monte, como "El Montico", en que se sembraban cada año unas 155 obradas, con el acuerdo de pagar "... en años pares a diez y seis celemines y en los nones a quinze", aunque no sin problemas y pleitos para su entrega, como constatan los informes de débitos de $1786^{294}$.

La delimitación del espacio de sernas no separa parcelas, hojas de cultivo, majuelos ni tierras de sembradura. Tanto en el apeo de 1665, como en este de 1794, se detectan tierras y majuelos que forman parte tanto del terrazgo propio de Rueda como del de sernas. La "raia" los divide como si sus propietarios hubieran efectuado ampliaciones en siglos anteriores a costa de dichos montes. Un ejemplo se encuentra al comienzo de sendos apeos ${ }^{295}$ :

"Prosiguióse por el dicho majuelo del Licenciado Antonio de Molina, dexando parte del en Sernas, y se hizo un coto en la linde del dicho majuelo, y en el camino que llaman de Baldelapinta, que va azia la villa de la Seca”. Apeo General de 1665.

"Dirigieron la raia desde el camino que ba de Rueda a la Seca con dirección a Gállego, yncluiendo la maior parte del majuelo de Don Joseph Pimentel, atravesando la tierra de Dña Marcelina Baion hasta encontrar un linderon saliendo derecho al camino de Valladolid...” Reconocimiento de la raya de sernas de Rueda. Año 1794.

Del mismo modo y a diferencia de los términos cerealísticos del sur comarcal, e incluso del terrazgo labrado propio de estas villas más al norte, no se ha detectado la tradicional división en hojas ni en los primeros siglos en que predominaban las sembraduras sobre las plantaciones ni, por supuesto, a partir del XVII en que se impone la especialización vitícola.

En uno u otro apeo se constata, en este sentido y como ha quedado expuesto, lo numerosos que son los majuelos. En el cuadro anterior que resume las "Rentas en trigo en majuelos y sembrados de 1776 " se anotan únicamente en Rueda 26 renteros que entregan 29 fanegas de trigo procedente de sernas de sembrados y hasta 150 titulares detentadores de sernas de majuelos que rinden a Medina 671 fanegas anuales. Ello lleva a afirmar que el terrazgo sernas de Rueda es mayoritariamente vitícola a fines del XVIII y, a la luz de lo representado en el anterior plano y pintura, se encuentra completamente roturado.

Similar evolución presenta Nava del Rey por estas fechas. Se echa en falta, sin embargo, la representación gráfica de su terrazgo sernas aun cuando se cuenta con la descripción detallada de lo representado. En 1793, no obstante, y a tenor del resumen adjunto, puede advertirse la importancia del espacio labrado respecto al total de estos Propios de Medina.

${ }^{294}$ A.M.M.C., caja 21-49, fol. 7.

295 A.M.M.C., caja 171 (Coteo General y deslinde y amojonamiento con distinción de rayas de las tierras de sernas de la Villa de Medina del Campo) y caja 168 (reconocimiento de la raya de sernas de Rueda). 


\section{Cuadro 10. Resumen del Apeo en tierras sernas de la villa de Nava del Rey, año $1793^{296}$}

\begin{tabular}{lrc}
\hline Tipo de aprovechamiento & Obradas (de 500 estadales) & Estadales \\
\hline Tierras sernas que se labran & 8.084 & 164 \\
Arenales, juncales, aguanales e incultos & 190 & 452 \\
Tierras tituladas Mercedes & 1.623 & 344 \\
Tierras tituladas propias que poseen particulares & 145 & 440 \\
Pinar puesto por la villa & 305 & 400 \\
Viña de particular & 2 & \\
\hline TOTAL & 10.351 &
\end{tabular}

Fuente: Archivo Municipal de Medina del Campo (A.M.M.C.). Fondos sernas. Elaboración propia.

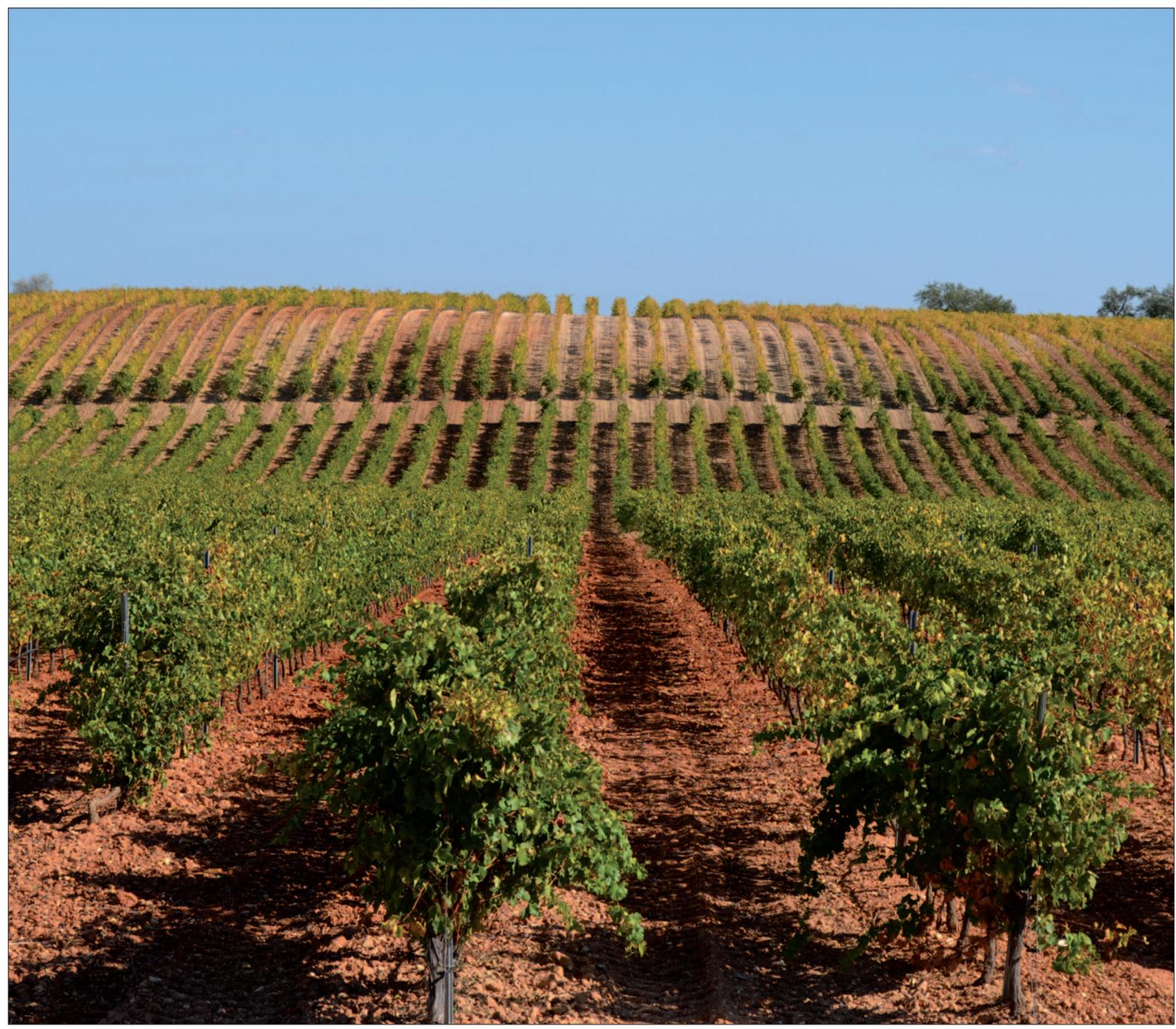

Imagen 48. Plantación de viñedo en Nava del Rey. Foto: 18/10/2014. Antiguos pagos sernas, como Barco Rodrigo, Cascón, Valdeculebro, Valdelasno,Valdeladrones u otros, sitos en el mencionado término, vuelven a acoger la varietal Verdeja, que en tiempo histórico diera tanta fama a los blancos de esta villa.

${ }^{296}$ A.M.M.C., caja 168. 


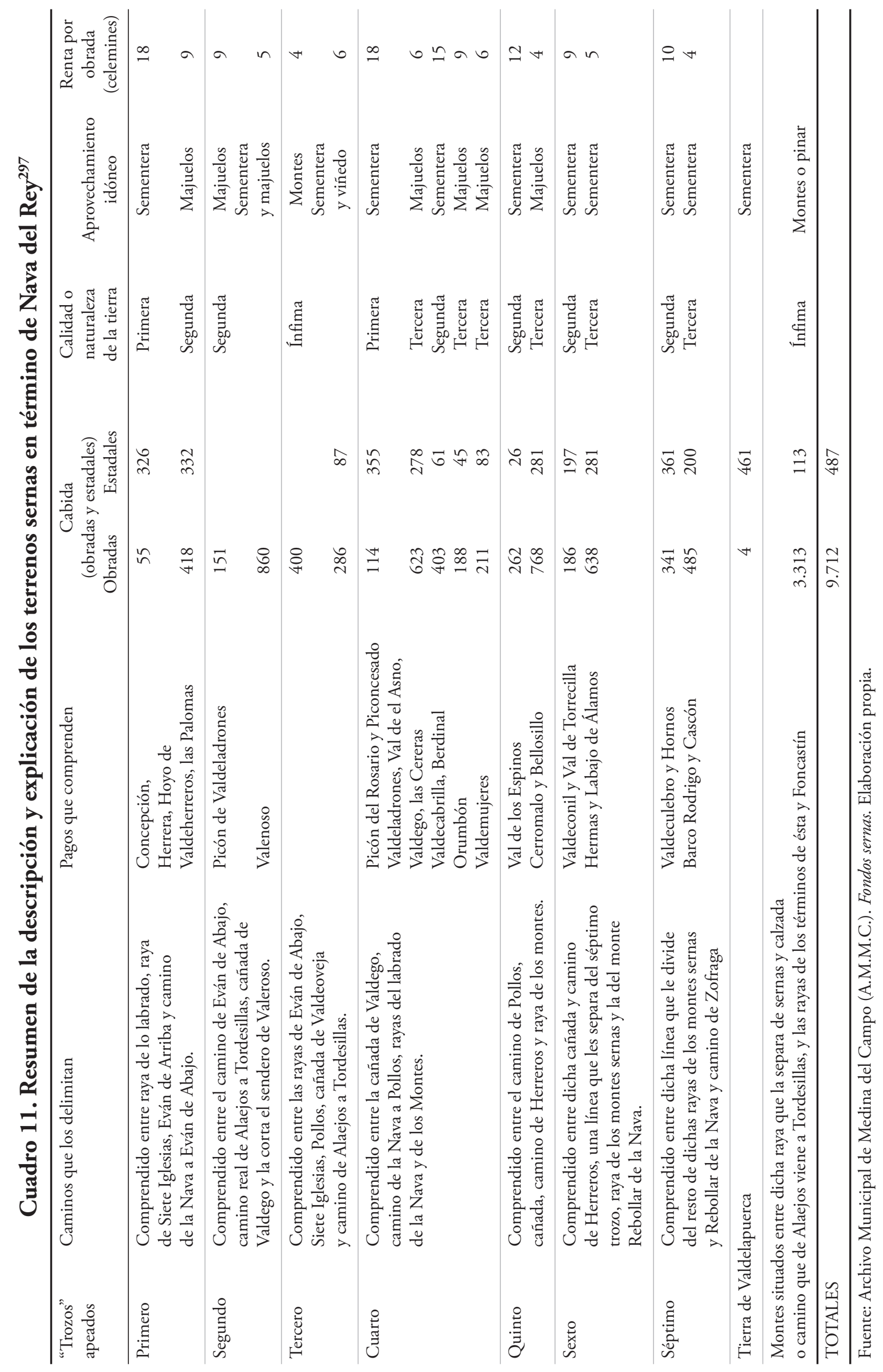




\section{La roturación y organización del terrazgo en el norte comarcal en los siglos XVI y XVII. Ejemplos de roturaciones y aprovechamientos en Serrada}

El proceso de roturación llevado a cabo en los siglos XIII, XIV y XV, atendiendo al mayor o menor potencial de los lugares poblados, se generaliza en toda la Tierra de Medina a lo largo del siglo XVI. Hasta entonces los espacios incultos eran aprovechados por la ganadería, actividad vital desde los primeros tiempos de ocupación ${ }^{298}$. Las roturaciones y la ocupación del terrazgo más fértil por los cultivos cerealísticos y del de menor calidad, por el viñedo, no se hacen esperar. Sin embargo, a diferencia de términos vecinos, como Rueda o La Seca, que obtienen permisos y coteos para hacer roturas en el Monte Pedroso e Inestoso, en Serrada la vinculación de la práctica totalidad del término al mayorazgo de los Montalvo retrasa casi un siglo la plena expansión vitícola. Bien es cierto que, al mediodía del término, las tierras y montes de sernas se encuentran a tan sólo unos centenares de metros de su "raya" con la Tierra de Medina, por lo que sus labradores también participan en la toma de tierras de sembradura y en la plantación de cepas en los citados suelos. Pero donde se afanan por introducir el arado es en sus pagos al norte y nordeste del término, fuera de la jurisdicción de Serrada y de la propiedad de su señor, en pagos de La Moya, pertenecientes a Propios de Olmedo y, en ocasiones, en tierras agotadas prontamente por el cereal, que vuelven a cubrirse de retamas y matas de encina.

En los últimos siglos bajomedievales definir con precisión el avance del arado a costa del monte resulta, por el momento, muy aventurado. Aún a comienzos del siglo XVI, como refiere la ejecutoria ganada por Olmedo a Diego Ruiz en 1524, el juez cotea límites e indaga entre los vecinos por las tierras labradas y por romper existentes décadas atrás. Todos manifiestan que el terrazgo estaba "rompido y por romper". Junto a estos suelos tampoco se pueden olvidar los prados y dehesas concejiles, imprescindibles para el ganado y que se extienden ampliamente, siguiendo el camino real de Olmedo a Tordesillas, en raya con el término de La Seca, hasta San Martín del Monte, en los límites entre Olmedo y Medina. Las probanzas y testimonios de los testigos confirman, en fin, la existencia de amplias superficies vírgenes de aprovechamiento alguno a comienzos del siglo XVI que no sea el pastoreo o la corta de retamas. El escribano testifica en la ejecutoria el inexorable proceso roturador: ${ }^{299}$

\footnotetext{
“...dixo que según parescía por las dichas probancas e ynformación, en todo el dicho campo e termino susodicho, desde raya e coto de Olmedo a la raya e coto del término de Medina del Campo, estar ronpido e por ronper al tiempo quel dicho Diego Ruiz de Montalbo compró el dicho lugar de Serrada (fechado la carta de venta en 1478). E algunos de los testigos hablaban e deponyan en mucha cantidad de tierra del dicho término y otros en menos. E unos dizen que en algunas partes estaba ronpido y en otras por ronper, y otros entre ronpido e no ronpido, por manera que en el dicho campo no avía cosa en que poder executar que quedase por sí e sobre sí sin estar entre arado y ronpido..."
}

Como señala el texto, buena parte de estos terrenos incultos serán roturados a lo largo del siglo XVI como temporales tierras de pan llevar y vueltos a abandonar, dadas las débiles cosechas que producían estos suelos cascajosos, pero, de hecho, desde fines del XVI y a lo largo del XVII, las superficies eriales se reducen a extensiones meramente simbólicas. Muchos de los pagos que se han mencionado en esta obra tomaron nombre o siguieron consolidándose en estos siglos: La Frontera, El Rompido, El Coto, Roturas, Sernas, La Raya,... En toda la Tierra de Medina y Olmedo se repiten sin cesar los pagos que aluden a montecillos, carrascares, rebollares, encinares, retamares, etc., de tantas superficies ganadas al monte en este tiempo. Ni es fácil ni rápido domeñar el terrazgo. $\mathrm{Al}$ contrario. Será una labor costosa, a impulsos de coyunturas económicas favorables.

${ }^{297}$ A.M.M.C., caja 170-1. No se ha podido determinar con exactitud la fecha de esta descripción, aunque se cree de la segunda mitad del siglo XVIII.

${ }^{298}$ MOXO DE, S.: Repoblación y sociedad en la España cristiana medieval. Madrid, 1979, pág. 75.

${ }^{299}$ A.R.Ch.V.P.C. Zarandona y Walls (F), caja 2711.1. 


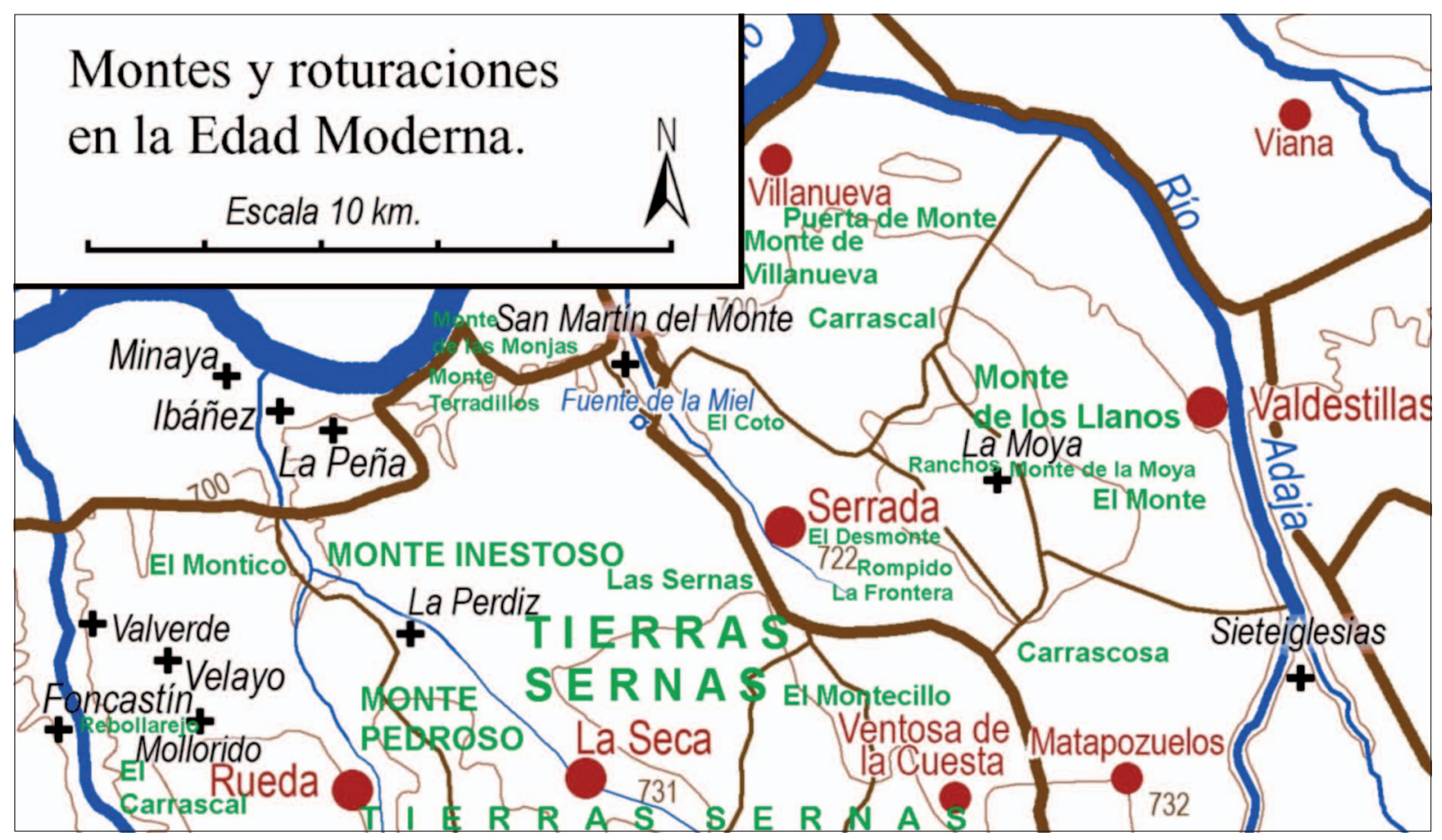

Figura 19. Localización de los principales montes y topónimos alusivos a formaciones vegetales al norte de Medina en la Edad Moderna.

Los factores que contribuyeron al proceso se han anotado. A partir del siglo XV, el auge de los mercados feriales supone una mayor salida a productos como la lana, el trigo y el vino. Piénsese que la agricultura castellana y la economía en general durante el siglo XVI se caracterizan por un notable crecimiento. El alza de los precios agrícolas, provocada por el aumento de la demanda, genera un enorme interés por la tierra como medio de producción ${ }^{300}$. Todos los lugares en torno a Medina pretenden apropiarse de cuantos montes y espacios incultos puedan. Lo mismo sucede en los terrazgos de Propios de Olmedo.

Esta villa, como Medina con las suyas, se enzarza en pleitos por el control y recepción de las rentas que generan el aprovechamiento de estos montes y, en la concesión de sus roturas, Serrada o La Moya no están ajenas. Por sus términos se extiende el llamado Monte de los Llanos, acogedor de importantes retamares, que, desde la raya de Villanueva y siguiendo los pagos de Valdelacasa, continuaba por la cañada de Buenavista en dirección a La Moya, donde ocupaba buena parte de su jurisdicción, extendiéndose por el término vecino de Valdestillas. Un ejemplo de la lucha jurídica entre Olmedo y las aldeas de su tierra, por el control y aprovechamiento de dicho terrazgo, tiene lugar cuando el concejo de Serrada otorga poder en 1590 a los procuradores Alonso Herrero y Andrés Garrido para efectuar un nuevo concierto con Olmedo, en relación con el citado Monte de los Llanos ${ }^{301}$.

${ }^{300}$ ANÉS ÁLVAREZ, G.: Las crisis agrarias en la España moderna. Madrid, 1974, pág. 92.

${ }^{301}$ En concierto en cuestión se redacta en los siguientes términos: "Sepan quantos esta carta de Poder vieren como nos, el concejo y onbres buenos del lugar de Serrada, tierra e jurisdizión de la Villa de Olmedo, juntos y ajuntados a voz de campana tañida, según que lo avemos de uso y de costumbre de nos ajuntar, estando especialmente Epocial de Rojas el biejo, alcalde, y Francisco de Rojas, regidor perpetuo del dicho lugar, y Simón de Vallelado, Luis de Logroño, Antonio de Yscar, Francisco Blanco, Francisco Navarro, Francisco de Vallelado, Francisco Prieto, Alonso Casado, Alonso Blanco, Blas Blanco, Francisco Alvar, Francisco de Yscar, todos vecinos del dicho lugar, por nos y por los demás vecinos que hay ausentes e por venir....otorgamos y concedemos por esta presente carta para que... podáis efetuar el concierto questa tratado y concertado entre le ayuntamiento, justicia y regidores de la villa de Olmedo y el dicho cavildo, nuestra parte en razón, de ques sin perjuicio de derecho que dicho ayuntamiento y cabildo de la tierra tienen de gozar y destribuir lo procedido y que procediere del Retamal que se dice de los Llanos, y lo a el anexo, que es propio de la Villa e tierra..., por agora se aya de arrendar y arriende el dicho terrazgo a pasto y lavor, y usando de las licencias que para ello ay del Rey 
Este monte, como se aprecia del concierto anotado al pie, se constituía como un bien de Propios del que se beneficiaban tanto la propia villa de Olmedo, como los lugares de su Tierra, que aprovechaban sus recursos o se beneficiaban de las rentas de quienes por él apostaban, bien para cortas de retamas, pasto o roturas para labrantíos. Era evidente que los escasos vecinos de La Moya no abarcaban con sus mulos o bueyes tanta extensión de terreno, por lo que siempre estuvieron acompañados por renteros o labradores de Serrada, Ventosa, Valdestillas y Matapozuelos. Unos y otros, sea aprovechando con sus ganados el pasto de dicho monte, sea roturando tierras baldías u otras pertenecientes a él, fueron haciéndose con el dominio total de las tierras de esta parte del término. A este tipo de bienes comunes se debe añadir aquellos pertenecientes al mayorazgo de los Vega, que se extendía por la Moya, Matapozuelos y Valdestillas. Al ser tierras arrendadas y no todas de mediana calidad, muchas de ellas se confunden con los montes y baldíos existentes. Prueba de ello es la constancia de tierras "que están al presente por romper", arrendadas a distintos vecinos por parte de Antonio de Vega, pertenecientes a su mayorazgo que, en 1596 y según sus palabras, "fundaron mis antecesores ansi en la dicha Villa de Tordesillas y lugares de su jurisdición y comarca y términos del lugar de la Moya, Baldestillas, Serrada y Matapozuelos e Aldeanueva, y en los demás partes y lugares que yo tengo las dichas heredades anejas al dicho mi mayorazgo" 302 .

La presencia de estos mayorazgos acerca la historia de La Moya a Serrada, en la medida en que también había fundado mayorazgo Diego Ruiz de Montalvo, vinculando para su linaje buena parte del término, como hicieron lo propio en La Moya los padres de Antonio de Vega, Hernando de Vega y Juana de Fonseca, sometiendo a la población campesina en ellos asentada a la condición de renteros durante siglos. Las escasas propiedades que disfrutan son aquellas situadas en espacios marginales, roturados en los escasos montes y baldíos que aún quedan indemnes, de escasa calidad y poco adecuados para los cultivos trigueros, pero aptos para fijar en ellos cepas que, a la postre, derivan en la principal fuente de riqueza de estos pueblos.

Desde la época de los Reyes Católicos la presión que ejerce la población sobre estos espacios incultos y montaraces es grande. Prueba de ello son las continuas ordenanzas y los pleitos entre ganaderos y labradores, sin menoscabo de las actuaciones del Honrado Concejo de la Mesta para vigilar pastos, cañadas y veredas. Los pleitos entre el concejo de Serrada o las tensiones derivadas de la intromisión del arado en territorios acotados por la Mesta, son igualmente una constante a lo largo del tiempo, y cańadas o prados objeto de largos litigios ${ }^{303}$. Lo mismo se puede decir cuando en 1604 Gonzalo de Santoantón, vecino de Valdestillas, se querella contra Epocial de

nuestro señor para Poder ussar de los adbitrios que quisieren para le pagar lo que a sido repartido,......que de ello se hiciere sea poder repartir y Reparta la tercia parte para el ayuntamiento de la dicha villa, y las otras dos tercias partes para el dicho cavildo de la tierra de la dicha villa y lugares que están y se comprehenden en él, e para que sobre ello podáis e hazer y otorgar las escripturas, contrato y acuerdos y conciertos .... e podáis traer y hacer pregón del dicho terrazgo para le arrendar a trigo o dinero como os pareciese y recevir las posturas y conceder los prometidos que bien vistos fuere.... y podáis hacer y sentar los remates que fueren necesarios y partir y dibidir el dicho terrazgo.... e tomar las fianzas que vien visto os fuere apartando la dicha dos tercias partes para el dicho cavildo y lugares que del se comprehenden y cotear y amojonar el dicho terrazgo para que ninguna persona se pueda entrar...”.(A.H.P.V. Pt. 11838, fol. 811).

302 A.H.P.V. Pt. 11843, fol. 212.

${ }^{303}$ En fechas tan tardías como 1746, cuando la Mesta ya ofrecía un notable declive en relación con lo que antes había ostentado, aún se refieren litigios que ponen de manifiesto la débil línea que separaba los montes y pinares de tierras y majuelos. Un caso que destaca es el que se sigue entre el concejo de Serrada y el juez de la Mesta en el citado año. Al parecer, desde 1725 se habían realizado plantaciones de vińas en virtud de reales órdenes de su majestad, que en Serrada habían contado con el permiso del marqués de Torreblanca. Se habían realizado en el pago del Pinar, junto al nuevo plantío llevado a cabo por dicho concejo, siguiendo instrucciones reales a fin de promover la forestación de las distintas partes del reino. Al tener noticias el juez de la Mesta que "algunos vecinos desta villa que an plantado bińas en esta jurisdicion y pago del pinar, lindero de el, además, del nuevo plantio, se an entroducido alargar sus heredades de 
Meba y Epocial de la Fuente y Sebastián de Vallelado, todos ellos vecinos de Serrada, "en razón de le aber tomado parte de la leña de retama del monte de la tierra de la villa de Olmedo puesta en el lugar de la Moya..." 304 .

Valorando el proceso, se puede afirmar, a la vista de los datos ofrecidos, que las tierras de pan y los majuelos reducen a la mínima expresión estos espacios montaraces. Es la época en que pueblos como La Seca, Rueda o La Nava alcanzan gran dinamismo y un crecimiento espectacular y otros, como Serrada, pujan por no quedarse atrás. Los más débiles, como es el caso de La Moya, experimentan un retroceso paulatino que los lleva a su desaparición. San Martín del Monte, por último, consigue mantener su docena de vecinos a duras penas y a la sombra de las monjas claras tordesillanas. Pero en todos ellos, y así se puede constatar en los diferentes coteos y amojonamientos, realizados a lo largo de los siglos XVI y XVII, la superficie labrada es muy grande y, entre ella, la ocupada por el vińedo cada vez mayor.

$\mathrm{Al}$ sur de estos límites, los antiguos espacios por donde se extendían el Monte Inestoso y Pedroso, hasta llegar a Medina, donde acostumbraban a practicar la caza la alta nobleza y la realeza castellana, ya eran historia en estas fechas de finales de la Edad Moderna. Si de por sí estaban muy degradados, a tenor de las fuentes escritas que los mencionan por vez primera, la presión agrícola y ganadera acabó con ellos. Únicamente jóvenes manchas de pinar, siguiendo decretos reales en las tierras poco aptas para el cultivo, tratan de recuperar infructuosamente el antiguo monte o, al menos, asegurar unos mínimos de madera y leña para las necesidades de los distintos concejos. Era el tributo que tenían que pagar las sociedades de aquel tiempo.

\section{a. El empuje vitícola del siglo XVI. Un ejemplo de expansión del vińedo en La Moya y Serrada}

Los repobladores cristianos se acompañan de vińas a la par que de tierras de sembradura. El pan y el vino fueron siempre indispensables en las economías de subsistencia del centro de la Meseta. Cuando las cosechas se tuercen y hay que procurarse dinero prestado, son las viñas lo primero que se demanda en las hipotecas. En el censo que constituye en 1546 Juan Ramos, vecino de La Moya, con el señor Antonio de Vega, vecino regidor de la villa de Tordesillas y sucesor en el mayorazgo familiar del citado lugar, acepta responder al préstamo con su casa y con las siguientes piezas de majuelos ${ }^{305}$ :

“...Un majuelo que yo tengo en el término del dicho lugar, a do dicen la Cañada en que hay en él tres arançadas que a por linderos de la una parte mejuelo de vos, el dicho señor Antonio de Vega e de la otra parte los Llanos, e sobre una vińa a do dicen camino de Sant Sebastián, en que ay en ella ocho arançadas, que a por linderos de la una parte el dicho camino de Sant Sebastián, e de las otras partes tierras de vos, el señor Antonio de Vega..."

Las viñas se extienden de manera ininterrumpida entre las pequeñas propiedades particulares y aquellas pertenecientes a nobles y clérigos. Un ejemplo se encuentra en la información que se des-

biñas hasta llegar con ellas a el referido pinar, en corta cantidad, lo que puede ser en perjuicio del pasto comun apropiarse por suio lo que no es y para obrar perjuicios en ejecución de las Reales Ordenes...”, ordena el arranque de las citadas cepas lo que lleva al concejo de la villa a solicitar su indulto, testimoniando con ello la imposible convivencia entre el monte y el arado en estos siglos. (A.H.P.V. Pt. 8216, fol. 131).

${ }^{304} \mathrm{~S}$ debe advertir que la retama no sólo tiene valor en sí misma como combustible, sino en tanto que su desbroce facilita la regeneración del pasto de los montes o el desarrollo de pinos y encinas. Así se manifiesta en concejo de 14 de enero de 1616 en relación al "pinar el qual tiene mucha planta de retama y a mucho tiempo y ańos que nunca se corta y está muy fuerte y reberdezida que a en perjuyzio del dicho pinar y es necesario cortarle para la utilidad y provecho que se sigue para que la dicha retama se reparta entre los vecinos de este dicho lugar por suertes...” (A.H.P.V. Pt. 11861, fol. 28, año 1614).

${ }^{305}$ A.H.P.V. Pt. 4398, fol. 252-268. 
prende del apeo realizado en La Moya en 1588 sobre las tierras de la iglesia de Santa María de los Remedios y las propiedades anejas beneficiales. Al estar repartidas por todo el término y hacer constar los propietarios linderos y el aprovechamiento de cultivos, acerca de primera mano la realidad existente en este lugar y que se puede hacer extensible al resto de los pueblos. Buena parte de las piezas propiedad de la citada iglesia lindan con el mencionado "Monte baldio de los llanos" y, en ocasiones, con las "rreturas del dicho concejo de Valdestillas", lo que indica que en estas fechas de finales del XVI tampoco había concluido el proceso roturador en el término vecino. La mayor parte, sin embargo, están próximas a las tierras del mayorazgo de Antonio de Vega, labradas en arrendamiento y sembradas de cereal. Unas y otras se entremezclan con piezas particulares donde constan aprovechamientos de vińas. Estos, en ocasiones, dan nombre a los propios caminos como el "camino que ba a las labranzas de las Binas de los Serbales". En La Moya, como en tantos otros lugares, las viñas vienen de antiguo. Las tierras linderas, declaradas en 1588 en uno de los citados bienes de beneficio de la iglesia de dicho lugar, así lo ponen de manifiesto: ${ }^{306}$

"Primeramente fueron a una tierra que deslindaron por del beneficio de la dicha Yglesia, que esta al barco debajo del pozo biejo, que aze una obrada poco más o menos. Linda con tierras por dos partes de don Antonio de Vega, vecino de Tordesillas, que solían ser Biñas, y por la parte de arriba, majuelo de Bartolome de Moralexa, vecino de la Moya"

Queda claro que, si en 1588, donde se labraban panes, antiguamente habían sido viñas, la plantación de estas puede perfectamente remontarse un siglo antes. Si muchas de estas tierras no lindan con majuelos, es por el propio carácter rentista de las citadas tierras de mayorazgo, arrendadas en plazos cortos y que impiden la plantación de cepas. Esto ocurre igualmente con las tierras roturadas del Monte de los Llanos, si bien, con el tiempo, se plantan muchas de ellas de vińedo, ocasionando no pocos problemas a sus llevadores cuando, mediado el siglo XVIII, el concejo de Serrada negocia su compra y Olmedo considera las viñas como plusvalías propias, en detrimento de quienes se sienten legítimos posesores de suelo y vuelo. Aparte de esta consideración, el empuje vitícola en La Moya es innegable a lo largo del siglo XVI y durante buena parte del XVII. Y este dinamismo obedece en muchos casos a vecinos de Serrada que, habiendo ocupado y plantado buena parte de su término, extienden los majuelos a tierras de La Moya e incluso bajan a la cercana Valdestillas: ${ }^{307}$

\footnotetext{
"Sepan quantos esta carta de venta vieren como yo, Elbira de Roja, biuda, mujer que fui de Francisco de Rojas, difunto, que soy del lugar de Serrada, jurisdición de la Villa de Olmedo, otorgo y conozco por esta carta que bendo e doy en benta real por juro de heredad para agora y para siempre jamás, a vos, Francisco de Rojas, mi hijo, questáis presente para vos y para vuestros herederos y sucesores presentes e por venir, y para la persona o personas que de bos o de ellos obieren título, razón y causa el saber: aranzada y media de bińa que yo tengo en término y jurisdición del lugar de Baldestillas, .... por precio y quantía de seis mil maravedíes...” Año 1576.
}

Este empuje vitícola del siglo XVI va asociado, en todos los pueblos del norte de la Tierra de Medina, a un incremento de la producción que se cifra del orden del sesenta por ciento en la segunda mitad de siglo, ligada a la subida de los precios de los caldos con relación al cereal y a la creación de mercados estables de salida, como lo eran las propias ferias medinenses o, más tarde, la corte de Madrid. Tanto las pequeñas aldeas como las villas de cabecera regularon siempre vendimias y sacas y entradas de vinos en las poblaciones, sobre todo en aquellas que, por su importancia, se prestan a que pudieran introducirse vinos clandestinos y fuera de tiempo en los mercados. Entre las más co-

${ }^{306}$ A.H.P.V. Pt. 11837, fol. 739

${ }^{307}$ A.H.P.V. Pt. 11838 , fol. 486. 
nocidas y antiguas se encuentran las ordenanzas del concejo de Medina del Campo de $1503^{308}$. Comienzan a sentarse las bases de una regulación jurídica que acompaña al vino siglo tras siglo. En 1593, por ejemplo, el concejo de Medina prohíbe que se eche nata al vino tinto "caiga pena de doscientos maravedies" y en julio de 1672, por fe pública del escribano Alonso de Montero, otorga validez en concejo a las ordenanzas aprobadas con fecha de 12 de abril de 1540 y que recogen las dictadas en tiempos de los Reyes Católicos que se acaban de reproducir. Se había articulado un mercado de caldos que rebasaba las jurisdicciones cercanas hasta llegar a tierras de León, Asturias y las "Montañas" de Santander y Burgos. Serán consumidores fieles de estos blancos durante siglos ${ }^{309}$.

Esta demanda es creciente e ininterrumpida a lo largo de estos siglos XVI y XVII y provoca una mayor expansión del viñedo, que va acompañada de la excavación de nuevas bodegas y de la ampliación de las existentes. En los inventarios de bienes y testamentos, otorgados en las últimas décadas del siglo XVI, en todas estas villas al norte de Medina se encuentran, además de tierras, abundantes viñas, bodegas, cubas o cántaras de vino ${ }^{310}$. Sirva como ejemplo el inventario de un vecino de Serrada de 1593 que, como otros muchos, pone de manifiesto la emergente economía vitícola de estos pueblos del norte de Tierra de Medina ${ }^{311}$ :

\footnotetext{
"En las casas que están en dicho lugar de Serrada, con otras mas pequeñas junto a las que el dicho Francisco de Rojas compro de Francisco Prieto, vecino del dicho lugar, que linda las casas principales con las dichas casas del dicho Francisco de Rojas.... " se toman como cuerpo de bienes:

"Yten. Una cuba en la bodega de las dichas casas de veinte y dos moyos, poco mas o menos, tasada en nueve mil maravedíes.

Yten. Otra cuba en la propia bodega de nuebe moyos, tasada en nuebe ducados.

Yten. Otra cuba en la dicha bodega tasada en seis mil maravedíes, de doze palmos.

Yten. Otra cuba en la dicha vodega de cinco moyos, bieja, tasada en quatro ducados. Son todas de roble.”.
}

${ }^{308}$ Dichas ordenanzas regulan ventas y entradas de vino en la villa, vendimias, precios, etc. Dada la afluencia de gentes en las ferias y la llegada de los Reyes Católicos, por ejemplo, se pregona el precio y calidad que deben tener los vinos que se vendan en la villa: "Luego los dichos seńores conçejo, justiçia e regidores desta dicha villa dixeron que por quanto ante ellos an venido grandes rreclamaçiones e quexas, asý de vecinos desta villa commo de fuera della, que la gran deshorden que de los preçios que de los vinos se venden, e asymismo la grand neçesydad del vino que ay e se espera aver, asý por la venida de Sus Altezas commo por la feria, que podría faltar el vino, e, sy non faltase, los preçios serían tan sobidos que todas las gentes rreçibirían mucho agrauio. Por ende, queriendo proveer e rremediar en lo susodicho, dixeron que mandauan e mandaron e hordenavan e hordenaron que ningund vezino desta villa non pueda vender vino a más preçio de a diezeséys maravedís el acumbre e ende abaxo. E demás mandaron a todas e cualesquier presonas, asý desta villa commo de fuera della que quisyeren traer vino de fuera de la dicha villa, que lo puedan traer syn que puedan caer por ello en pena nin calumnia alguna, con tanto quel dicho vino que asý truxieren non lo puedan vender más que al dicho preçio e ende abaxo" (A.M.M.C. Libro de Acuerdos, caja 267-3, fol. 73-74, trascripción: Juan Carlos Alonso).

${ }^{309}$ Las escrituras que conciertan estos trasvases en 1608 así lo ponen de manifiesto: "Andrés Gutiérrez, vecino de Billartierra del Duque del Ynfantado y Juan Gutierrez, vecino de Billacantiz, jurisdición de Reynosa, y Juan Diez Montero, vecino de Soto, jurisdición de la dicha villa de Reynosa.... se abian conbenido y conzertado con Gonzalo de Santo Antón, vecino desta villa, de le llebar desde ella en sus carros, con sus bueyes, a la ciudad de Burgos, ciento y ochenta y siete cantaras de bino blanco de la cosecha del año pasado de mil y seiscientos y siete ańos, y dárselo puesto en la dicha ciudad para el sábado por la mańana, a una ora el sol salido, que se contaran veynte y quatro días deste presente mes de otubre deste ańo de la fecha desta, ques el propio dia que en la dicha ciudad se aze el mercado a donde se a de vender el dicho vino porque el dicho Gonzalo de santo Antón les aga de dar y pagar de parte por cada una cantara tres reales menos un quartillo...”. (A.H.P.V. Pt. 11856, fol. 112).

${ }^{310}$ Es el caso del vecino de Serrada Francisco de Rojas, que llevó a su segundo matrimonio con María del Castillo, "tres moyos de bino encubado, poco más o menos...". En este mismo caso, en la partición de bienes que hace con su suegra Juana de Velasco en 1591, una vez fallecida María del Castillo, detalla una importante labranza compuesta por 55 obradas de tierras de pan llevar y cerca de 25 aranzadas de majuelos, buena parte de ellos en tierras de La Moya.

${ }^{311}$ A.H.P.V. Pt. 11841, fol. 357. 
Vinos y bodegas son codiciados muy pronto por el estamento clerical. La riqueza vitícola de estos pagos y lugares no queda a salvo de las ambiciones de las distintas órdenes religiosas. El proceso afecta a toda la Tierra de Medina que se convierte en blanco de compras de viñedos, casas y bodegas, amén de recibir religiosamente diezmos o primicias. Los testimonios de compras y ventas relacionadas con el preciado líquido son numerosos. Un ejemplo es el caso de la carta de venta que otorgó en 1604 Francisco Belasco, cura del lugar de Serrada a favor del clérigo Juan García Rodríguez ${ }^{312}$ :

“...Conviene a saber, unas casas con sus corrales, caballeriza y paxar y bodega con una cuba de ocho moyos, pocos más o menos, con todo lo demás a ellos anexo y perteneciente y de la forma y manera que yo las ube y compre de Francisco Alonso, vecino de Valladolid...”.

Como se aprecia en los textos seleccionados, todo lo parejo al viñedo y al vino es muy valorado por la sociedad de este tiempo. La demanda es alta y la venta de vino no parece tener grandes dificultades por estos años. De ahí que se arbitre una de las medidas jurídicas más importantes para la expansión vitícola de Serrada y que beneficiará tanto a renteros como a señores.

\section{- La concesión de mil obradas del mayorazgo de los Montalvo para la plantación de viñas en Serrada}

Coincidiendo con la mayor demanda de caldos que se deriva de la breve estancia de la corte en Valladolid entre 1600 y 1609, con los mercados abiertos y la demanda existente, se arbitra una extraordinaria medida que impulsa definitivamente el cultivo del viñedo. Se trata de la facultad para romper y plantar majuelos a censo perpetuo con derecho de veintena en tierras eriales del mayorazgo de los Montalvo ${ }^{313}$. A través de este proceso legal, se aparta del directo uso del mayorazgo una parte del mismo, con el fin de poner las tierras en venta a censo perpetuo "para plantar mil obradas de tierras de las del dicho vínculo y mayorazgo". Para ello tiene lugar el "apregonamiento" de las mismas, tras avisos a los alcaldes vecinos. La venta se realiza a los mejores postores a "tres reales y medio de renta y censo perpetuo en cada un año a cada obrada de cuatrozientos estadales". La escritura manifiesta esta intención por parte de Juan de Samaniego, curador y tutor del dicho Juan Antonio de Montalvo y de la Quadra, y pone de manifiesto, tanto el auge del vińedo, como la necesidad de tierra para sus renteros y reales para sus arcas:

\footnotetext{
"Por quanto por parte de vos, Juan Rejón Samaniego, en nombre, y como tutor y curador adliten de don Juan Antonio de Montalbo y de la Quadra, vecino de la villa de Medina del Campo. Nos ha sido hecha relación, que teniendo el dicho vuestro menor de su mayorazgo entre los bienes del quatro mil obradas de tierras depan llevar, en término del lugar de Serrada, jurisdicción de la villa de Olmedo, de las quales avia más de mil que por ser flacas y pedregosas, havía muchos años que no se arrendaban, y eran muy a propósito para plantar de vińas, y se hallarían personas que las tomasen a censo perpetuo para este efecto...”
}

Esta información es corroborada por el propio corregidor de Medina. El Consejo de Cámara confirma la existencia de tales "dichas tierras inútiles y pedregosas... que a más de treynta años que no se arriendan, ni se han sembrado por ser areniscas, y no buenas para pan, ni centeno, ni otra cosa...", por lo que se aprueba la venta en detrimento del mayorazgo. Se justifica además la decisión "por no aver viñas en todo el término del dicho lugar de Serrada por faltar tierras y no aver más que las del dicho mayorazgo y que

\footnotetext{
${ }^{312}$ A.H.P.V. Pt. 11852 , fol. 422.
}

${ }^{313}$ La concesión se aprueba en Madrid el 18 de noviembre de 1612 y está firmada en escritura publica por Tomas de Angulo, secretario del rey Felipe III y en su nombre. Las escrituras se extenderán siguiendo la real cédula por Pedro Muñiz, escribano del número de Medina del Campo a partir de 1619. Son aprobadas por Pedro de Lizardi, señor de Piña de Valdesgueva, en nombre de Juan Antonio de Montalvo y Quadra, seńor de Serrada y en posesión de su mayorazgo. 
se hallaría por cada obrada de las dichas tierras de censo perpetuo, diez reales cada año de renta, quedando la propiedad y directo dominio de las dichas tierras y la veyntena para el dicho mayorazgo...".

El texto confirma la necesidad de nuevas plantaciones que, aunque existían tanto en Serrada como en sus términos limítrofes, no cubren las demandas de vino ni la potencialidad de un mercado en auge. A nadie se le oculta, además, la ocasión de los Montalvo para incrementar sus rentas a costa de terrenos improductivos, dado su carácter pedregoso y estéril para panes ${ }^{314}$. Los majuelos, una vez plantados, quedan hipotecados de por vida en manos de estos campesinos. Disfrutan de sus frutos, previo pago de las rentas y réditos, pero no de la propiedad, que sigue en manos del señor. En todo caso, este y sus sucesores serán los que otorguen las licencias de venta entre censatarios, recibiendo "la veyntena parte del precio que les dieren por la dicha tierra y viña que en ella se ha de plantar, advirtiendo y se advierte, y ha de entender, que la persona a quien se hiziere la dicha venta ha de ser lega, llana y abonada, con cargo deste censo, y de cumplir todas las dichas condiciones", obligándose, como sus anteriores cultivadores, a los pagos pertinentes.

Esta importante medida impulsa definitivamente el cultivo del viñedo en Serrada, ocupando extensas terrazas de gravas y poniendo en manos de sus vecinos estas mil obradas, que son roturadas y dedicadas al cultivo de la vid. Consta, a través de traslados de escrituras del año 1644, que son numerosos los vecinos que se obligan al pago de distintas cantidades de reales a favor del mayorazgo, en relación con estos censos concedidos ${ }^{315} / 316$. Pero el censo será visto con recelo por partes ajenas a los contrayentes. Se reanudaban por enésima vez las tensiones con Olmedo.

El mapa adjunto de 1550 y, unas páginas más adelante, el del ańo 1650, reflejan la progresiva roturación del monte y su ocupación por viñas y tierras de sembradura, atendiendo a la calidad de los suelos y a la distinta propiedad de los mismos, tal como hemos estudiado ${ }^{317}$. Se observa con claridad la disposición del terrazgo de sembradura sobre los suelos aluviales más fértiles, colindantes con el arroyo y bordeado de prados, por otra parte imprescindibles para el ganado. Al norte de este fértil terrazgo se extienden los suelos de gravas que, roturados y abandonados por su falta de fertilidad para producir cereales o leguminosas, serán ocupados por el viñedo, de acuerdo a las coyunturas de mercado

${ }^{314}$ La necesidad, por parte de labradores y jornaleros, de hacerse con algunos pedazos, una vez conseguida la facultad real, hará que muestren efectivo interés en las distintas posturas llevadas a cabo, pero sin alardes monetarios, puesto que no ofrecerán más de tres reales o tres reales y medio. Sólo un tal Juan de Yepes subirá la postura a cuatro reales menos un cuartillo. Las arcas de Ruiz de Montalvo, en cambio, incrementan su cuantía en "tres mil y quinientos o quatro mil reales de renta".

${ }^{315}$ Un ejemplo de escritura es la del vecino Domingo Caballero. Toma a censo cuatro obradas "al camino de la Seca" por precio de "catorze reales que balen cuatrozientos y sesenta y seis maravedís" de renta y censo perpetuo en cada un año. Se obliga al pago de esta cuantía en los primeros días del "mes de diziembre del año que bendra de myl y seiscientos y veinte y tres años” y, durante los siguientes cuatro años, estará obligado a tener plantados en las citadas tierras los referidos majuelos " $y$ lo ha de yr continuando, fin de dexar dello mano; de manera que al fin de dicho tiempo este asentada y pressa la dicha viña, do de no, el dicho don Juan Antonio de Montalvo e los dichos sucesores pueden hazer plantar y meter en la dicha tierra las dichas viñas a costa del dicho Domingo Caballero cobrando del y sus bienes el dinero necesario para este efeto...", lo que pone de manifiesto la obligatoriedad de plantar de vides el terrazgo tomado a tal efecto.

${ }^{316} \mathrm{O}$ al menos sirve al titular del mayorazgo para poder exigir jurídicamente a los censualistas mayores obligaciones. Prueba de ello es que, en el año 1644, hasta veintiocho vecinos de La Seca, que habían firmado sendas escrituras a censo perpetuo para plantar viñas, a razón de tres reales y medio, otorgan poder escritural para iniciar acciones judiciales contra Juan Antonio de Montalvo, al querer obligarles a renovar sus contratos censales hasta el punto de que, al no seguir sus deseos, "les vende los frutos y otras cosas semejantes en nuestro perjuicio". En relación con quienes, al final, deciden ser censualistas, se contabilizan hasta cincuenta y cuatro vecinos. Todos detallan su pago en la escritura seńalada y fechada el 10 de septiembre de 1644 . Se obligan a "que de diez en diez años o abiendo nuevo posehedor a las dichas heredades sobre que están fundados, o abiendo nuevo posehedor al dicho mayorazgo, los reconocerán para los reconocimientos que hicieren para el dicho mayorazgo...”. La cláusula tiene razón de ser en este tiempo. Don Juan Antonio de Montalvo Quadra y Avellaneda muere en el año 1647, dejando por heredero y poseedor del mayorazgo a Diego de Montalvo Quadra y Abellaneda, de quien es tutora y curadora su madre, Doña Teresa de Aliprando. (A.H.P.V. Pt. 6487, año 1644, fol. 194). 
y distintas disposiciones jurídicas. La presión sobre la tierra por parte de jornaleros y labradores acaba en estos siglos con los montes comunales y los eriales de los mayorazgos citados. Tanto la nobleza absentista como los concejos ven, tal como se ha descrito, una ocasión de oro por incrementar sus rentas en unos suelos donde solo el vińedo puede llegar a ser rentable. La imagen adjunta nos aproxima a lo que será el paisaje vitícola desde el siglo XV hasta finales del XX: vińedos plantados a marco real mediante sistema en cuadrículas de once pies de lado (tres metros de ancho, aproximadamente), que permiten a la cepa dar fruto en estos suelos aun en condiciones de primaveras de escasas precipitaciones y veranos calurosos siempre, claro está, se atienda a cada cepa con podas adecuadas al potencial edáfico que la sustenta y no se escatimen las labores de brazo y arado a lo largo del año.

\section{- La venta a censo del mayorazgo de los Vega de la Moya para plantar majuelos}

La mayor parte de los mayorazgos nobiliarios y heredades monásticas, que se extienden por los pueblos vecinos, solicitan licencias para hacer producir rentas a los terrenos más pobres. Los renteros encuentran una ocasión para hacerse con algunas obradas que dedican a la plantación de majuelos. $\mathrm{Al}$ igual que Diego Ruiz respecto a Serrada, sucede en La Moya. Buena parte de su término era propiedad de Hernando de Vega, regidor de Tordesillas y esposo de Juana de Fonseca. Habían fundado mayorazgo por facultad real concedida por la reina Juana de 1509 en Mayorga, el 23 de abril de 1517. Entre sus bienes se encontraban ${ }^{318}$ :

"La heredad de tierras, viñas, casa, palomar, prados, huertas, pozos, dineros de rentas que tenían en la Moya, Valdestillas, Aldeanueva y Serrada, con todo lo que habían comprado, e fecho, así en la Moya, como en Valdestillas, Aldeanueva y Matapozuelos, con todo lo que habían plantado, y todos los otros bienes que tenían y les pertenecían, con prohibición de su enajenación... y que después de nuestros días e fin e muerte de nos e cada uno de nos, que lo haya y herede y suceda en el dicho mayorazgo el dicho Antonio de Vega, nuestro hijo legitimo de legítimo matrimonio...”.

El conjunto de la propiedad, en el entonces lugar poblado de La Moya, sumaban quinientas obradas de tierra, además de casas, paneras y ejidos. Entre las posesiones adscritas figuran, además de las referidas, las casas principales, sitas en la plaza del corro de San Pedro de Tordesillas, tres juros con una renta de cuatrocientos ducados y un majuelo en La Peńa de catorce mil cepas. Como hicieran los Montalvo con sus posesiones en Serrada, los Vega arriendan sus propiedades a los escasos vecinos de la Moya y a renteros de los pueblos próximos. Prueba de ello son las cuentas y rentas que pagan anualmente quienes las labran. En el año 1581 figuran, entre otros, los siguientes ${ }^{319}$ :

“...Házese el cargo que cobró de Llorente Domínguez, vezino de la villa de la Bentosa, de la renta que labra en la Moya, de la dicha paga de cinco cargas y una fanega de pan por mitad de trigo y cebada.

Yten. Se le haze cargo que cobró de Hernando Nabarro, vezino de Serrada, de la paga del dicho año de ochenta y uno, de tres cargas y una fanega y nuebe zelemines de trigo y tres fanegas de cebada.

Házese el cargo que cobró de Juan de Rojas, vezino del dicho lugar de Serrada, de la paga de ochenta y un año, de seis cargas de pan por mitad trigo y cebada.

Házese el cargo que cobró de Francisco Blanco, vezino del lugar de Serrada, de la paga del año ochenta y un año, de una carga de trigo...”.

${ }^{317}$ La fuente utilizada para la elaboración de los mapas que siguen de 1550 y 1650 ha sido, básicamente, la derivada de la información contenida en los apeos, compraventas, inventarios de bienes, etc, que registran los protocolos notariales (A.H.P.V.) y en la de los distintos pleitos habidos en estos siglos, que afectan a los lugares estudiados (A.R.Ch.V). Es de justicia, en relación a la cartografía del presente epígrafe y siguientes capítulos, mostrar nuestro agradecimiento al profesor y compañero Miguel Ángel Martín Hernando, por su ayuda, paciencia y generosa disposición en cuantos aspectos cartográficos le hemos consultado.

318 A.H.P.V. Pt. 5533, traslado escritural, fol. 33.

${ }^{319}$ A.H.P.V. Pt. 4533, fol. 129 y ss. 


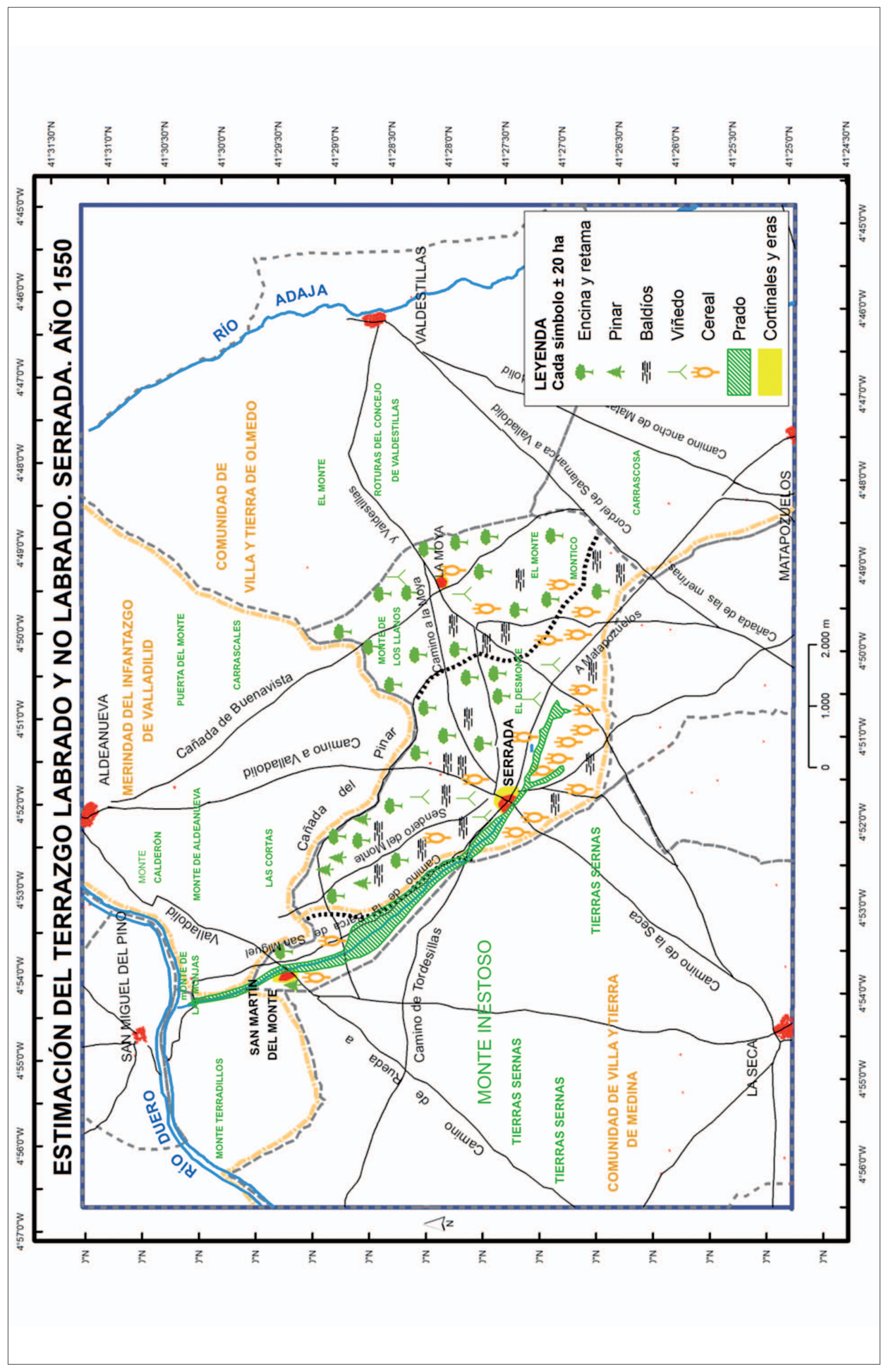



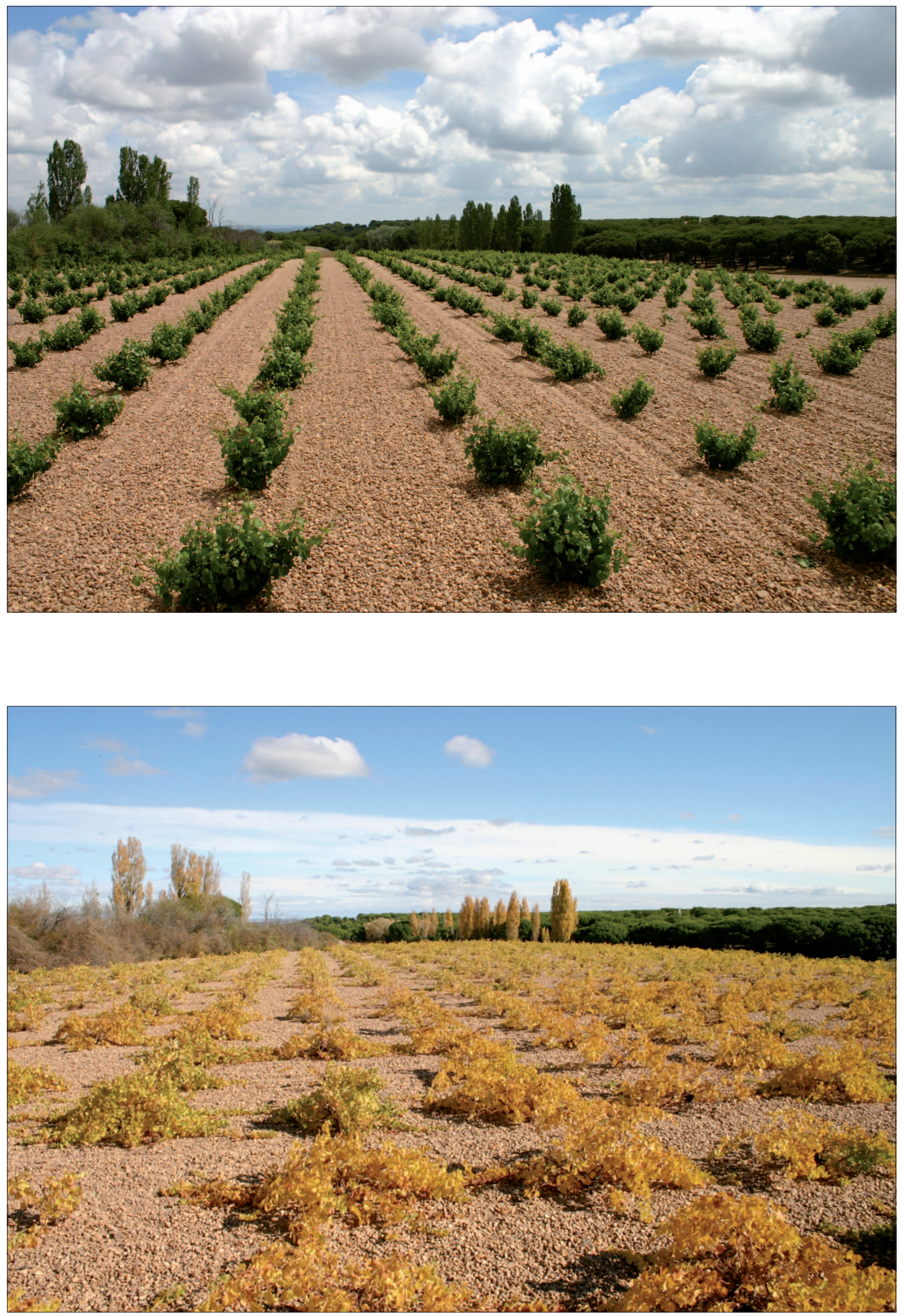

Imagen 49. Primavera y otoño en pagos de La Moya. Serrada. Similares viñedos sobre gravas se plantaron en los siglos XVy XVI en el Monte de los Llanos, una vez roturado, y en todos aquellos que se extendian al norte de Medina. Foto: 03/06/2012 (arriba) y 06/11/2011 (abajo). 
Sin embargo, la escasa entidad poblacional de este lugar y lo alejado de los pueblos circundantes, junto a la escasa aptitud de la mayor parte de las tierras para producir panes, van a hacer desistir a muchos renteros de meter sus yuntas en las tierras de su término. Los eriales se alternan con las superficies labradas y las retamas vuelven a crecer en los terrenos que apenas dieron nunca trigo ni cebada. El propio lugar poblado se apaga sin remedio. Pero, como sucediera en Serrada, también el crecimiento del viñedo iba a cambiar la cara de buena parte de sus pagos. El 22 de mayo de 1629 Diego de Vega y Ayala, sucesor en el mayorazgo, ganaba provisión para "vender quinientas yugadas de tierras que tenía del dicho mayorazgo en el lugar de la Moya, jurisdicción de la villa de Olmedo, o la parte que de ellas le pareciese, a censo perpetuo, con derecho de veintena, para plantar de viñas ${ }^{320}$. Sin embargo, sólo van a venderse setenta y dos obradas a Pedro Morales y otros vecinos de la villa de Matapozuelos y pueblos vecinos. Los Vega no tardan en reaccionar para procurarse nuevas rentas al calor de la expansión vitícola en este norte de la Tierra de Medina. En la información que se acompaña en 1644 para ganar la preceptiva cédula real para vender dichas tierras a censo al quitar, un testigo manifiesta ante el corregidor de Tordesillas ${ }^{321}$ :

\footnotetext{
"Que el dicho mayorazgo tiene hasta quinientas obradas de tierras en la jurisdicción de la villa de Olmedo, a do llaman la Moya, el qual hera antes lugar, y con la infelicidad de los tiempos quel dicho lugar de la Moya se a despoblado, a cuya causa las tierras que están en el dicho término y terrazgo de la Moya y son del dicho mayorazgo, no se arriendan ni hay persona que las aya querido arrendar, por ser para pan llevar flacas y muy ruines, por lo qual pareciese a este testigo de gran utilidad y aumento para dicho mayorazgo y sus sucesores ... para que las tierras del dicho terrazgo se vendan a zenso al quitar a las personas que las tomaren para plantar de majuelos y vińas".
}

El aumento que había experimentado la superficie del viñedo en el siglo XVI en Rueda, La Seca o la Nava, llega con fuerza en el XVII a las terrazas de gravas de Serrada, La Moya, Villanueva o Valdestillas. Y de ello se benefician tanto los grandes propietarios como los pequeños renteros. El vino es, desde entonces, el motor de estas poblaciones, desde lo alto de los pagos de gravas donde arraigan las cepas, hasta las entrañas de la tierra donde fermentan y reposan sus mostos. El impulso vitícola se extiende por toda la comarca. Los testigos de 1644 manifiestan que también los vecinos de Matapozuelos "con muchas viñas que an plantado de pocos años a esta parte... buscan otras tierras donde plantar" ${ }^{\prime 22}$. En esta villa también la nobleza propietaria se beneficia de la fiebre plantadora. Francisco de Menchaca, poseedor del mayorazgo familiar que se extendía por este término, vende a censo en 1642 cuantas tierras son apropiadas para plantar viñas ${ }^{323}$ :

\footnotetext{
"Sepan quantos esta carta de poder bieren como yo, Don Francisco de Menchaca, caballero del ábito de Santiago, vezino de la ciudad de Salamanca, doy mi poder... a Joseph de Vitoria, escribano de la villa de Matapozuelos para que en mi nombre, y en virtud de la licencia y facultad que su Majestad, Dios le guarde, se ha serbido de concederme para bender a censo al redimir las tierras de mi mayorazgo a propósito para plantar de viñas, por no lo son para llevar pan, que están en los términos y labranzas de la dicha villa de Matapozuelos y Villalba de Adaja y sus confines...”.
}

Es un proceso general en la comarca. En Rueda, por ejemplo, el convento de Santa Ana de Medina da a censo perpetuo, en 1682, cien obradas que posee en la citada villa y comarca para que sean plantadas de majuelos. Como los anteriores, se reserva el tanteo y veintena, pero se diferencia en exigir a las personas que tomen las tierras a censo el pago de tres celemines de trigo por obrada,

\footnotetext{
${ }^{320}$ A.H.P.V., Pt. 5073, fol. 177 y ss.

${ }^{321}$ Ibídem, fol. 189.

${ }^{322}$ Ibídem, fol. 183.

${ }^{323}$ A.H.P.V., Pt. 5094, fol. 214.
} 
en tanto los majuelos no produzcan ocho cántaras de mosto por aranzada "y en dando los dichos ocho cántaros... han de dar al dicho convento todos los diezmos... con más de real y medio por alanzada de viñas pos reconocimiento del directo dominio"324. Que los censos aprobados graven perpetuamente a sus tomadores o puedan redimirles iba a variar el éxito o no de las concesiones ${ }^{325}$. No es necesario leer entre líneas para darse cuenta de quiénes son los grandes beneficiados en la venta a censo de estas tierras pedregosas y de débiles rendimientos. La familia nobiliaria de Tordesillas apenas obtenía cincuenta y cinco fanegas de centeno de sus tierras de La Moya. Le faltará tiempo para solicitar al rey nuevas licencias de venta. La nueva concesión tiene fecha de $1648^{326}$ :

"Don Felipe (IV) por la gracia de Dios, Rey de Castilla, etc. Poe quanto por parte de vos Don Diego de Vega y Ayala me ha sido hecha relación que habéis sucedido en el mayorazgo de D. Francisco de Vega, vecino de la villa de Tordesillas, a quien por una mi carta y provisión de veinte y dos de mayo de mil y seiscientos y veinte y nueve, di facultad para vender a censo perpetuo con derecho de cincuentena quinientas yugadas de tierras para plantar de viñas que tenía del dicho mayorazgo en el lugar de la Moya..., y en virtud de ella se vendió setenta y dos obradas..., y las cuatrocientas y veinte y ocho restantes se quedaron por vender, las quales son tan flacas y de tan poco valor que no hay quien las quiera... Suplicándome sea servido de daros facultad para vender las dichas cuatrocientas y veinte y ocho yugadas de tierras, juntamente con los dichos censos perpetuos, haciéndolos redimibles... Doy y concedo licencia y facultad a vos, el dicho D. Diego de Vega y Ayala..., en Madrid a treinta y uno de marzo de mil seiscientos y cuarenta y ocho años. Yo el Rey".

Aunque la presión demográfica hace tomar a los vecinos de los pueblos mencionados muchas de ellas, aún en 1790 quedaban otras por labrar. La presión vitícola tenía también ciertos límites. De hecho, en la citada fecha, Pascual de Vega, sucesor en el mayorazgo, vende a censo enfitéutico o foro con licencia real a Francisco Moyano Rodríguez 156 obradas, repartidas en dieciocho pedazos, en precio de trece reales la obrada. Eran las que restaban por vender. El nuevo comprador, natural de Serrada y hermano del obispo Buenaventura Moyano, dispone de capital suficiente para esto y

${ }^{324}$ A.H.P.V. Pt. 8042, fol. 122. Estos censos, como otros estudiados, obligan de forma férrea a sus tenedores. El que nos ocupa es un censo perpetuo enfitéutico con las calidades de licencia, tanteo y veintena. Al margen de la carga de renta como reconocimiento del directo dominio por parte del convento, cuando dichas viñas se vendan "han de dar al dicho convento la veintena parte de toda la cantidad en que fueren vendidas, aviendo de requerir a dicho convento antes que se otorgue la venta y hacerle saber la cantidad en que estubieren concertados para que si quisiere de licencia para que corra dicha venta y concierto y sino la quisiere dar pueda usar el derecho de tanteo"

${ }^{325}$ Es el caso del mayorazgo antedicho de los Vega de La Moya. Se justifica la falta de interés por parte de los labradores en tomar las tierras del citado mayorazgo unos ańos antes por haber sido mediante censo perpetuo de tres reales y medio de renta por obrada y "no querer los labradores echarse una carga tan grande sobre sus haciendas", conviniendo que "es más útil hacer redimibles los censos dados y que se dieren de nuevo" tanto para el propio mayorazgo como para los propios cultivadores. Pero, como en estas mismas fechas sucede en Serrada por parte de los Montalvo, las cartas que se firman entre labradores de este pueblo o de Matapozuelos con los Vega de Tordesillas serán a censo perpetuo de tres reales y medio por obrada. El terrazgo de La Moya va así cubriéndose de majuelos que colman la demanda de tierras por parte de los labradores y rentan buenos dividendos a unos propietarios que, de otra manera, verían dicho lugar, además de despoblado, inculto y montaraz. Las condiciones a las que se obliga en 1645, por poner un ejemplo, Agustín de Villán, vecino de Matapozuelos, respecto a ocho obradas que "están en el límite de la Moya, al Horcajo", son similares a las pactadas en los anteriores casos comentados: "Yten. Que habiéndose plantado las dichas viñas se han de sustentar y conservar por el dicho Agustín de Villán y sus herederos y sucesores, labrándolas de las labores, ordenanzas y necesarias de forma que vayan en aumento y no en disminución, todo a su costa...Yten. Que las dichas tierras e viñas que en ellas se han de plantar han de quedar y quedan a riesgo y ventura del dicho Agustín de Villán y de sus sucesores, de tal manera que aunque estén vacías y no se coja ni tenga de ellas ningún aprovechamiento por sucederse sobre ellas los casos fortuitos a que están sujetas, como son piedra, niebla, langosta, pulgón, pestilencia, bochorno, fuerça, guerra u otro cualquier, no por eso a de haber ni se pueda poner descuento ni dilación e la paga y cumplimiento de lo contenido en esta escritura...Yten. Que después de haber plantado las dichas viñas en las dichas tierras, el dicho Agustín Villán e sus herederos e sucesores quando quisieren las puedan dejar al dicho don Diego de Vega y demás sucesores ... dejando las dichas viñas bien labradas y separadas e no perdidas, pagándole los réditos corridos hasta dicho dí..." (Ibídem).

${ }^{326}$ Ibídem. 
mucho más. Aunque nos salgamos del tiempo tratado, sobre los citados bienes se generalizará toda una legislación de redención y venta que pulveriza los bienes del mayorazgo tordesillano entre multitud de pequeños propietarios pero, por entonces, una cosa queda clara: los majuelos también se habían adueñado del terrazgo de La Moya.

\title{
- La importancia del viñedo en las disputas por límites y términos: La Concordia de 1640
}

Como se viene anotando, las tensiones y pleitos de las aldeas y lugares con sus villas cabeceras sobre hasta dónde llegan los límites y jurisdicciones de unos y otros fueron constantes a lo largo de toda la Edad Moderna. El control jurídico conlleva la percepción de rentas sobre los nuevos espacios roturados, especialmente atractivas cuando sobre ellas enraízan las cepas. Los afanes de Medina por cobrar las rentas de sus tierras sernas y los intentos de los cultivadores por retrasar sus obligaciones dan fe de ello. En Serrada la expansión vitícola del XVI y primera mitad del XVII vuelve a poner sobre la mesa las viejas diferencias que separan a los señores del lugar con los procuradores de la Tierra de Olmedo ${ }^{327}$. A nadie se le escapa que la concesión en el año 1.616 de mil obradas a censo enfitéutico para vińas o las cientos de aranzadas, que se están plantando en los baldíos y montes limítrofes, alientan a desempolvar antiguas disputas territoriales para luchar por su control jurídico, con el fin de poder reintegrarse nuevas rentas. El viñedo se convierte así en el centro de los pactos y en moneda de cambio que sacia los bolsillos de unos y otros. De hecho, los procuradores y hacedores de la Universidad de la Tierra de Olmedo, reunidos en mayo de 1637, tratan el ofrecimiento de concordia de Juan Antonio de Montalvo, sintiéndose aliviados por la posibilidad de acuerdo, pero recordando que el viñedo es el nuevo centro de todos los intereses ${ }^{328}$ :

\begin{abstract}
"Dixeron que bien sabían que les hera notorio e largo y costoso Pleyto que esta villa y sus lugares habían traydo de diez años a esta parte con Don Juan Antonio de Montalbo Quadra y Abellaneda, vecino de la villa de Medina del Campo, sobre ciertas heredades de tierra que con facultad real había vendido a becinos de las villas de Matapozuelos, la Ventosa y la Seca y otras partes para plantar de majuelos y dado a censo perpetuo en término del lugar de Serrada, jurisdición de esta villa y sobre su término, del cual dicho Pleyto los vecinos de la tierra se habían encargado gozando los frutos de diez años sobre que habían hecho cierta concordia con el Ayuntamiento de esta Villa y pasados habían de quedar las propiedades que se sacase del dicho Pleyto, sus frutos y aprovechamientos por de esta villa y su tierra en conformidad de las concordias que tienen y se refieren”.
\end{abstract}

El seguimiento del pleito había superado en ducados la renta percibida. El pacto cierra la nueva demanda que había puesto por vía de restitución en la persona de su hijo, menor de edad, contra lo ejecutado anteriormente ${ }^{329}$. De esta manera, el señor de Serrada recupera los pagos de los Llanillos

${ }^{327}$ El proceso de concordia se inicia cuando Juan Antonio Montalvo, Quadra y Avellaneda, señor de Serrada, ofrece un pacto a los procuradores de la Tierra de Olmedo, que ponga fin a tantos pleitos y gastos entre las partes sobre los límites de su mayorazgo de Serrada, y sirva para reordenar y separar las propiedades de unos y otros. Al parecer, el señor de Serrada había iniciado un nuevo pleito, toda vez que entendía que las ejecutorias mencionadas, en las que se otorgó a Olmedo parte de su terrazgo en dicho lugar, "excedió en mucha cantidad de tierras y término que tocaban a él y se lo dio a esta villa (Olmedo) en que estaba engañado que esta villa se sirbiesen de nombrar personas que vieren los dichos términos y cartas executorias y que esta villa tome lo que es suyo y no aya pleyto ni diferencia”. A través de ella los prados de Serrada quedarán también por Propios del Concejo y vecinos del lugar de Serrada. En el proceso se recuerdan "las cartas executoras viejas ganadas por ella (la villa de Olmedo) contra Diego Ruiz de Montalvo y Christobal de Montalbo, antecesores del dicho Don Juan Antonio de Montalbo en el año de mil y quinientos y cinquenta y ocho, la qual salió a executar Pedro de Vibanco, receptor de la dicha Real Audiencia”(Ibídem).

328 Ibídem, fol. 3.

${ }^{329}$ Nunca se había percibido tanto interés por parte de los pueblos olmedanos respecto al nuevo cultivo en estas tierras alejadas de su villa principal, pero mucho menos se imaginaría al señor de Serrada contar las cepas que cede o que desea recibir: "Sépase como yo, Don Juan Antonio de Montalbo, Quadra y Abellaneda, señor de la Villa de 
y el campo de la Loma de San Martín que habían sido reintegrados a Olmedo a través de las cartas ejecutorias de 1558 y de 9 de mayo de 1626. En el citado terrazgo "se incluyen algunos majuelos que están plantados en las tierras que el susodicho vendió y dio a censo perpetuo a razón de tres reales y medio por obrada con derecho de beintena en virtud de facultad Real". De esta forma se legaliza definitivamente tal concesión, disponiendo Montalvo de pagos adyacentes donde pudiera rentabilizar nuevos vińedos. A las citadas tierras, que superan varios cientos de obradas, se unen, tal como se refleja en otro pasaje de la concordia, el otro pedazo junto al pinar de Aldeanueba (actual Villanueva de Duero) "que hará como seiscientas obradas poco más o menos que nunca se an labrado ni son a propósito para plantarse y no estar en parte donde se pueda hacer". Un siglo más tarde serán igualmente roturadas para arraigo de las vides ${ }^{330}$.

\section{- Las últimas plantaciones en terrenos comunales. El monte de los Llanos de La Moya}

En líneas anteriores ha quedado reflejado el interés, muchas veces estéril, de los renteros y labradores de Serrada o La Moya por meter el arado en el llamado Monte de los Llanos, inmediato al poblado de La Moya. Tierras de sembradura, eriales, vińas y retamas, se alternaban al calor de la llegada de nuevos renteros o dispares coyunturas económicas. La concesión de mil obradas a censo perpetuo por Juan de Montalvo, señor de Serrada, en 1612 y con el fin exclusivo de plantar vides, extendió la mancha del verdejo por buena parte de las más flojas tierras de su mayorazgo y, al tiempo que estas producían rentas al señor y subsistencia a los campesinos, libraron del hacha y la reja a los últimos espacios incultos durante un siglo más. En el mapa adjunto de 1650 se cartografía tanto los nuevos viñedos como la pervivencia de los últimos montes. A mediados del siglo XVIII, sin embargo, la suerte estaba echada por estos llanos "flojos de sustancia" que se repartían entre las divisorias de Serrada, La Moya, Matapozuelos y Valdestillas. Así recordaba el Ayuntamiento de Serrada la roturación de sus últimos montes ${ }^{331}$ :

Peña de Valdesgueba, vecino de la ciudad de Valladolid digo, que por cuanto de muchos años a esta parte ... hemos traído pleyto con la Villa de Olmedo y lugares de su tierra sobre pedazos de términos en el lugar de Serrada ... y biendo que los pleytos son costosos y de mucho daño, y quan dudosos son, me he compuesto con la dicha villa y tierra de Olmedo en que me han de dar y dejar para mi en propiedad y posesión y para mis herederos y subcesores los majuelos que están plantados hacia el dicho lugar de Serrada, en linde del camino Real que ba de la dicha villa a Tordesillas, que lindan con heredades propias mías y con otros majuelos qu tengo dados a censo perpetuo. Que hará todo como sesenta y quatro aranzadas de viñas; y las tierras que labra Gerónimo Maestro, vecino del dicho lugar de Serrada que rentan quince fanegas de trigo; y otyro pedazo de tierras que esta junto al Pinar de la villa de Aldeanueba que nunca se a labrado ni plantado y otras cosas. Y en pago y trueque de los susodicho y medio tomado para la dicha composición, doy a la dicha villa y tierra de Olmedo ciento y setenta alanzadas de viñas en el término de las Carreruelas y Cuesta Blanca; y en linde con ellas mucha cantidad de tierras heriales que hacen mas de quatrocientas obradas, cerca todo de la villa de Matapozuelos, con lo que quedan partidos y distintos los términos y juntos con lo que cada uno tiene, con que no habrá duda ni pleyto adelante en que se consigue mucho útil hambas partes". (Ibídem, fol. 5-6).

${ }^{330}$ En la precisión que se anota de las plantaciones objeto de permuta se concretan hasta 104 obradas plantadas y repartidas entre vecinos de Ventosa (55 obradas) y Matapozuelos ( 49 obradas), fragmentadas en un total de veinte piezas localizadas entre el camino de las Carretas y "al camino que lleban los de Ventosa a la Moya”. A la definitiva separación de las jurisdicciones y propiedades, se unía, de forma novedosa, el interés por concretar cada palmo de viñedo, prueba evidente de los réditos y beneficios que nadie pensaba pudieran dar estas tierras. Definitivamente, en la segunda mitad del XVII, el viñedo se extiende por las terrazas más al norte de la Tierra de Medina, mirando ya a los mismos Duero y Adaja, consolidándose de forma masiva a lo largo de la primera mitad del XVIII. Después de casi dos siglos, por último, parece casi imposible que Olmedo y los Montalvo sellen sus diferencias y reordenen sus términos en torno al vino. Y además que lo hagan firmando la concordia el día de los Santos Inocentes. ¿Podrían vivir en las siguientes décadas sin acudir a las salas de justicia?

${ }^{331}$ A.M.S., caja 72, carp. 878, folio 5. 


\begin{abstract}
"Que en término del lugar Despoblado de la Moya, jurisdición de la misma, como distante de ella 1.000 pasos para por una parte y 200 por otra poco más o menos, existía y existe un terreno de 400 o más obradas titulado los Llanos del Monte, el cual estubo inculto y sin producir cosa alguna el largo espacio de dos siglos, y más, fundadamente dicho desde tiempo inmemorial, cuya procedencia, aunque se ignora, debió ser sin duda propio, común o concejil del citado lugar Despoblado hasta que por los años de 1750 o 1760 diferentes vecinos que represento, dedicados al mayor fomento de la agricultura, biendo tan próximo a su vecindario un terreno que yacía en completo abandono y sin dueño conocido, procedieron a desmontar la infinita maleza de que estaba cubierto y enseguida a roturarle y plantarle de vińedo, por manera que estendiéndose esta operación a mayor número de vecinos, consiguieron en dichos años poner en estado fructífero dicho terreno" .
\end{abstract}

Si de por sí las roturaciones conllevaban tensiones y pleitos, en este caso los ecos de los beneficios de los caldos pronto llegarán al conjunto de pueblos que componían la llamada Universidad de la Villa y Tierra de Olmedo. Tiempo faltó a los procuradores generales de la misma para llamarse a posesión del mencionado terreno. Entendían como propio el espacio común de La Moya, antigua aldea perteneciente a su jurisdicción y, por tanto, beneficiarios de las rentas o usufructos que pudieran generar sus terrazgos. A las primeras protestas siguieron costosos pleitos en la Real Chancillería. Los roturadores, "deseosos de cortar los gravosos costes de la pendencia contra una Corporación y a no perder lo que habian tenido en la rotura y plantio", transigieron y otorgaron escritura de censo enfitéutico a favor de dicha Universidad y Tierra, obligándose al pago de 1.510 reales anuales de foro, aplicables al pago de 120 fanegas de trigo y otras tantas de cebada, aun cuando los moradores de La Moya, "refugiados posterior a Serrada", nunca habían contribuido con cantidad alguna por el disfrute del pastoreo en tales espacios ${ }^{332}$. Se había constituido el llamado foro del Monte de los Llanos.

Dejando al margen estas consideraciones, lo cierto es que el 14 de marzo de 1766 se firma escritura de censo enfitéutico por varios vecinos de Serrada, a favor de dicha institución ${ }^{333}$. A los antiguos plantíos se suman otros nuevos hasta alcanzar las 400 obradas que, plantadas de cepas, se integran definitiva y jurídicamente al de por sí importante terrazgo vitícola, aliviando, por lo demás, la escasez de bienes en propiedad de la mayor parte de los cultivadores de Serrada que contraían, de esta manera, la obligación personal a pagar el foro en las tierras hipotecadas al pago del citado canon. En las siguientes décadas, hasta la redención de censos, casi un siglo más tarde, todas las escrituras de compraventa de estas tierras del Monte de los Llanos recogen, tanto la instancia por la parte compradora al procurador más antiguo de la Tierra de Olmedo, en que se le ofrece el bien objeto de compra por si desea hacer uso de su derecho de tanteo, como, en caso contrario, la notificación por este de haber recibido la veinteava parte del valor de venta abonado por el comprador a dicha institución, indispensable para dar validez a la nueva escritura ${ }^{334}$.

\title{
b. Las tierras de pan llevar. El predominio aplastante del arrendamiento. El ejemplo de Serrada y La Moya
}

Las tierras de sembradura constituyen la otra cara de la moneda y, si las uvas tienen su importancia, nada produce más satisfacción en estas economías precapitalistas que una panera llena de trigo. La disposición de granos siempre fue la gran preocupación, tanto de los labradores y jornaleros como de los concejos de los distintos lugares y villas. Hay que asegurarse las casi 4,5 o 5 fanegas de

332 Ibídem, folio 5 .

333 A.F.A.M. (s/c).

${ }^{334}$ Un ejemplo es el que sigue: "Muy señor mío: Pongo en noticia de Vmd. Como procurador más antiguo de la tierra de Olmedo, que en el día estoy combenido con Don Fernando Rodríguez, Beneficiado de Preste de esta villa de Serrada, en darle en benta quatro aranzadas de maxuelo sitas en el término y jurisdición del Despoblado de la Moya a precio de un mil seiscientos reales de vellón cada una. Y teniendo éstas el foro, veintena y tanteo a favor de dicha tierra, lo hago presente a Vmd. Para que si usando de su derecho quisiere tomarlas por el tanto, lo haga; y de no servirse poner al pie de esta su lizencia para otorgar la competente escritura a el espresado D. Fernando, y poner el rezivo de los trescientos treinta reales que se importa la veintena, que entregara el dador, favor que espera de Vmd este su servidor. Serrada y agosto, diez y nuebe de 1793. Don Zenón Díaz (rúbrica)”. (A.H.P.V. Pt. 8226, fol. 54). 
trigo en que se estima el consumo medio por persona y año. Las propias comunidades organizan paneras colectivas para mantener unas reservas de grano esenciales en épocas de penuria y que aseguren la existencia de simiente para afrontar con garantías la sementera siguiente. La propia villa de Medina regula el pago de las rentas de sus sernas en fanegas de trigo y los renteros de Serrada o la Moya es en este producto en el que pagan las rentas a sus señores 335.

La nobleza mencionada, siguiendo en estos siglos XVI y XVII prácticas casi feudales, tiene como único interés en sus posesiones o villas asegurarse rentas que permitan vivir holgadamente. Con tener las paneras bien repletas por Nuestra Señora de agosto y sus corrales con buenas cargas de leña, han cubierto el objetivo asignado a sus mayorazgos. Parece que no ha transcurrido el tiempo desde épocas bajomedievales. Si cae o no piedra, ventisca o langosta, es más una desgracia de los renteros que un problema de los señores. De hecho, el absentismo en sus posesiones es casi total.

El Caballero de la Orden de Alcántara y regidor perpetuo de Tordesillas, Fernando de Vega, apenas pisa la Moya. Otorga poder para administrar los arrendamientos y recoger las rentas del lugar citado a personas de su confianza que, por lo general, son labradores vecinos de este lugar o pueblos cercanos. En la carta de arrendamiento reproducida al pie y fechada en 1588, se arriendan seis obradas por cuatro ańos y dos frutos y una renta de dos cargas de trigo, equivalente a 1,33 fanegas por obrada $^{336}$.

Respecto al mayorazgo de los Montalvo, fundado en 1506, el propio señor de Serrada, vecino de Medina del Campo, arrienda las tierras más feraces repartidas en "suertes" o "tierras que llaman rentas," de cuarenta obradas cada una, a los vecinos del lugar. Estos pagos se localizan limítrofes a los prados que recorre el arroyo que riega, de este a oeste, el término y serán en los siglos siguientes la base de aprovisionamiento de cereales de todos los labradores de esta villa que mantengan hacienda propia. Su fertilidad, a diferencia de otros terrazgos limítrofes, es tal que desde su roturación no se dejarán de cultivar un solo año. Hasta la primera mitad del XVII, el señor arrienda el conjunto del terrazgo de sembradura por un tanto común y son los propios labradores los que se comprometen a repartirse la tierra labrada en rentas o medias rentas, a cambio de la correspondiente paga. En 1647, por ejemplo, salvo las tierras que hemos estudiado y que "tiene bendidas de por vida", Juan de Montalvo arrienda a dieciséis vecinos "todo el termino de dicho lugar de Serrada, heredades de pan llevar... por espacio de diez años... y por precio y quantía los cinco años de nobenta cargas de trigo, los otros cinco de cien cargas de trigo...", regulados alternativamente ${ }^{337}$.

335 Son los descendientes en el derecho de mayorazgo de Diego Ruiz de Montalvo, señor de Serrada; aquellos que hacían lo propio con los derechos de Antonio de Vega, titular del mayorazgo que se extendía por la Moya y las monjas claras de Tordesillas, dueñas de la jurisdicción de San Martín del Monte. Junto a ellos, conviene tener presente a la llamada Universidad de la Tierra de Olmedo, que verá cómo sus montes y baldíos de los Llanos pasaban a integrar el terrazgo labrado -piénsese que en 1752 llegaban a 117 obradas de tierras de sembradura que arrendaban renteros de Serrada- y, por último y en mucha menor medida, las propiedades de las Iglesias respectivas y tierras beneficiales a ellas asociadas.

${ }^{336}$ Se recuerda que una carga son cuatro fanegas. Los términos del arrendamiento son los que siguen: "Sepan quantos esta carta de arrendamiento vieren como yo, Pedro Fernández, vecino del lugar de la Moya, jurisdizión de la villa de Olmedo, otorgo y conozco por esta carta que arriendo fiado y en renta y en arrendamiento a vos Francisco de las Heras, vezino de la villa de Valdestillas, a saber: un pedazo de tierras de las tierras que yo traigo en renta de la hermita de Sansebastian, que abía en ellas seis obradas, poco más o menos, poco o mi mucho, lo que en ellas obiere, que lindan de la una parte con el camino que ba a la Moya y tierra de don Antonio de Vega, vecino de Tordesillas, la qual vos arriendo y doy en renta por tiempo y el plazo a quatro ańos, dos frutos cogidos, que se entiende ańo y bez, que corren desde oy día en adelante, y por precio y quantía de dos cargas de trigo, bueno, seco, linpio, tal que sea de dar e tomar en cada una paga, y me lo abéis de dar y pagar por el día de Nuestra Señora de agosto de cada un año, y que sea y comienze la primera paga, que de las dichas dos cargas de trigo me abéis de hacer, el día de nuestra seńora de agosto primero que berna del año benidero de mil y quinientos y ochenta y nueve ańos, por las dichas tierras al presente están abarbechadas y senbradas en este año...”.

A.H.P.V. Pt. 11837, fol. 18.

337 A.H.P.V. Pt. 11144, fol. 8. 
Se añade a este compromiso que, si alguna de las tierras vendidas quedase libre, los renteros tienen la obligación de labrarla con una renta anual e indefinida hasta la finalización del contrato de las cien cargas de trigo cada año, lo que viene a salir, aunque no se dispone de forma exacta la superficie arrendada, a 0,81 y 0.90 fanegas por obrada, alternativamente, cada año.

A partir de esta fecha se individualizan las rentas por labrador. Nada mejor que leer la escritura que se firma en enero de 1657. Anota hasta once suertes. Es Doña Teresa de Aliprando, viuda de Don Juan Antonio de Montalvo, Quadra y Avellaneda, quien avala el arrendamiento ${ }^{338}$ :

“A Juan Garzía de Santiago, una renta; a Domingo Martín e Ysavel Navarro, de mancomún, una renta; a Juan
Román, una renta; a Francisco de la Vega, una renta; Roque Álvarez, media renta; Pedro Álvarez, media renta;
Andrés Garzía, media renta; Francisco Ballalado, media renta; Francisco Alonso, media renta; Francisco Rezio,
media renta; Andrés Sisón, media renta; Andrés Platón, media renta; Pedro Ynoxal, media renta; Alonso González,
media renta; Francisco Garzía Montańa, media renta; Pedro de Castro, media renta; Juan Alonso, media renta...”.

La suma de todas asciende a once rentas que suman 440 obradas, quedando constancia de una más reservada al mayorazgo. El precio de la renta de cada una asciende a ocho cargas y una hemina y tres celemines de trigo, equivalentes a 0,81 fanegas por obrada. Como es costumbre, se especifica que ha de ser "buen trigo, seco, linpio, bien medido, de dar e tomar, por los días de nuestra Señora de agosto de cada un año", puesto desde las eras en las paneras de la casa palacio existente en Serrada. Se concretan, además, medidas tales como que los eriales que forman parte de las rentas deben ser labrados. En el terrazgo mencionado queda excluida "...la guerta, ni la tierra del bosque, ni el pinar, y solo a de tener aprobechamiento de cortar cándalo y latas en dicho pinar los dichos renteros y no otro alguno...".

Todas las posibles contingencias quedan recogidas. En caso de que algunos renteros se ausenten, han de dejar persona que labre y pague lo estipulado y, si murieran, han de ser los otros renteros los que deben proseguir el cultivo y los pagos convenidos. Estos, por último, se determinan libres de diezmo y al margen de cualquier contingencia de langosta, pedrisco u otras desgracias fortuitas o intencionadas.

En 1675, por concluir este proceso de individualización del reparto del terrazgo arrendado entre renteros, Diego de Montalvo, Quadra y Avellaneda, comprador del villazgo en este mismo año, deja constancia en la escritura de arriendo tanto los renteros y rentas como sus antiguos poseedores. El precio sigue fijándose únicamente en trigo "de lo mejor que cogeremos" a razón de ocho cargas (32 fanegas) por renta ${ }^{339}$.

Conforme pase el tiempo, los Montalvo escrituran sus arrendamientos, pormenorizando cada aspecto en las relaciones contractuales con sus renteros. Nada mejor que la lectura del contrato de arrendamiento del año 1709 , reproducido al pie, para saber de quién es la propiedad, qué cuidados y labores han de hacerse, cuál es el papel que cada uno tiene encomendado en la sociedad, quiénes son los que pagan y a qué paneras se llevan las rentas ${ }^{340}$.

${ }^{338}$ Esta rama de descendientes del regidor medinense pronto ostentará el título de Marqués de Torreblanca. Luis de Montalvo, nieto de los anteriores, casará con Feliciana de Olmos Girón, II Marquesa de Torreblanca. Su padre Diego de Montalvo Quadra y Avellaneda había comprado en 1675 el derecho de villazgo de Serrada.

${ }^{339}$ A.H.P.V. Felipe Gutiérrez de Valdés, La Seca, año 1675, fol. 140-144.

340 "Sépase por esta pública escriptura de arrendamiento, como yo, D. Diego de Montalbo Olibera y Bellosillo, vezino de la villa de Medina del Campo, en virtud de poder que tengo de mi hermano D. Luis de Montalbo Quadra y Abellaneda Aliprando y Mercado, Marqués de Torreblanca, Señor de las villas de Piña de Baldesgueba, Tabales de los Oteros y desta de Serrada, Balberde y las demás de su estado, posehedor de los mayorazgos de los Montalbos, de cuio poder ago exibición, que paso por testimonio de Joseph de Espinosa, escriuano de Su Magestad y vezino de la villa y corte de Madrid, su fecha en dicha corte en los treynta días del mes de marzo del año pasado de setecientos y siete, de que el presente escriuano da fee. Y de el mando, otorgo, que doy en arrendamiento al presente escriuano: Andrés Alonso, Diego de Híscar, Simón de Castro, Pedro de Híscar, Joseph Alonso Santos, Joseph Alonso Recio, Juan Garzia, Santos Moyano, Francisco Rico, Santiago de Inojal, Diego Híscar menor, Pedro Navarro, Joseph Moyano, Antonio Alonso, Andrés García, Bernardo Alonso, María Alonso, Andrés Alonso Román, Gregorio García, Pedro Alonso, Joseph Alonso García, todos vezinos desta dicha villa de Serrada, 
Como puede apreciarse, en este año de 1709 la renta ha subido a 32 fanegas de trigo y 4 de cebada, añadiendo dos carros de leña que han de llevarse a su casa palacio de Medina del Campo. Por primera vez parte de la renta no se fija en trigo, lo que explica el avance de la cebada como cereal básico en la alimentación del ganado de labor. En la carta se precisa la división en hojas y la prohibición de retelos, que se estudiará. A partir de este momento se encuentran contratos que, afecten a buena parte de los renteros o sean más particulares, desligan las relaciones personales en favor de consideraciones más mercantilistas.

un cortijo de tierras de labor para sembrar questan dibididas y partidas por iguales partes sin engaño en honce partidas que se yntitulan honze Rentas en el término y jurisdición de esta dicha villa de Serrada.

Sus linderos son los términos de la billa de Bentosa y Matapozuelos y el termino de la villa de la Seca y los demás que con ellas confinan, por tiempo y espacio de nueve años y ocho panes, en precio y quantía de treynta y dos fanegas de trigo y quatro de zevada, y de dos carros de leńa cada huna de dichas honze Rentas y lo correspondiente a la media Renta. $\mathrm{Y}$ al quanto que sera la primera paga para el día de Nuestra Seńora de agosto que bendrá del año de setezientos y honce y suzesibamente an cada un ańo para el referido día y la última paga será para el dicho dia de nuestra señora de agosto que bendra del año de setezientos y diez y nuebe.

Y las dichas trynta y dos fanegas de trigo y quatro de cebada por cada una de las dichas honze Rentas que pagarán en cada año de los ocho referidos, puestas a costa y misión de los dichos renteros en la villa de Medina del Campo en casa y poder de dicho Marqués de Torreblanca o quien a suio tubiere, y que el referido trigo a de ser linpio, seco y además selepto y semental que cogieren los dichos renteros, exzeptuándoles lo que nezesitaren para sembrar.

Y que los dichos dos carros de leña pagando el dicho Marqués o quien su poder tubiere la leña en los Pinares de las villas de Portillo o Baldestillas, dichos renteros an de conduzir los dichos dos carros de leńa en cada una de las once rentas a la dicha billa de Medina, y a la casa de dicho Marqués. Con condición que las dichas tierras se an de traer y aberbechar a dos ojas de suerte que el último ańo de este arrendamiento a de quedar una oja de bacío para que en ella abarbechen los arrendadores que sucedieren en adelante.

Y que ninguno de los dichos arrendadores, en todo el tiempo de este arrendamiento, no ara de poder dar ninguna de las dichas tierras a renta ninguna persona que no sea de los comprehendidos en esta escriptura, por causa de no poderlas labrar ni por otra alguna que se le ofrezca, ni tampoco darlas para sembrar melones ni garbanzos ni otra ninguna semilla a ninguna persona si no es que sea entre los susodichos.

Que las dichas honze rentas se an de barbechar y sembrar a las ojas y bezes que se an barbechado y sembrado antiguamente. Y que si por causa de haber labrado las mismas rentas el arriendo antezedente los mismos otorgantes u otros se hubieren entrado por algún fin de su conbeniencia a le bolber algunas de las dichas tierras las ayan de quedar y poner a las dichas ojas y bezes que estaban antiguamente. Y porque esta clausula ba mirando a la ygualdad de los renteros y que al azerlo alguno de ellos recae en perjuicio de otro pueda el perjudicado querellarse del que se metiere en la reboltura de las dichas tierras y pedir testimonio desta clausula para justificazión de la dicha querella.

Y que para igualdad de las dichas once Rentas y las que se dibidieren por medias o por quartos a costa de los dichos otorgantes se han de poner hitos y señales. Y que durante el dicho arrendamiento no se a de poder pedir desquento, baja ni moderazion del precio deel por ningún caso que suceda de esterilidad por pocas o muchas aguas, piedra, fuego, niebla, peste, guerras, langosta, ni por otro ninguno que suceda pensado o no pensado, porque lo arriendo a todo riesgo, peligro y bentura.

Y con todos los casos que expresa la ley de la recopilación y por lo que en contrario se pretendiere, dijere o alegare no ha de ser oydo en juicio ni fuera deel porque desde luego y en dichos precios ba bajada la esterilidad que pueda tener y renunciada la ley deel gano y norma i normísima y de las demás que en este caso puedan baler y aprobechar.

Y que además deel precio deste arrendamiento cada bez que contrabinieren qualquiera de dichos arrendadores las claúsulas y condiciones antecedentes an de pagar dos fanegas de trigo a dicho marqués o a quien ubiere su poder.

$Y$ con estas condiciones en birtud de el dicho poder que tengo para arrendar y administrar la hacienda y rentas de dicho Marqués las arriendo y seran ziertas i seguras las dichas once rentas de tierras como propias que son de los mayorazgos que goza dicho Marqués y no se las quitare en el dicho tiempo pena de les dar a los susodichos y a quien su derecho representare otras tantas tierras tales y tan buenas, en tan buen sitio y precio y en defecto deello les pagare todas las costas, daños, yntereses y menoscavos que se les hizieren y recrezieren cuia liquidación difiero en su juramento y les reliebo de otra prueba.

E nos, los susodichos, cada uno por lo que nos toca que es así, yo el presente escriuano, por una renta en cada un año de los dichos ocho referidos me hobligo de pagar las dichas treynta y dos fanegas de trigo, quatro de zevada y conducir los dos carros de leña.

(Siguen las firmas de los renteros y la aceptación de todas y cada una de loa condiciones del presente contrato de arrendamiento.)

En Serrada, a honze días del mes de diziembre de este año de mil setezientos y nuebe, siendo testigos Juan Lorenzo Moyano y Lorenzo de Pedrosa, vezinos de la villa de la Seca y el Br. Andrés García, cura beneficiado de preste de esta dicha villa y los otorgantes a quien yo, el escriuano doy fe, conozco, firmo el que supo y por el que no ante testigo a su ruego de que doi fee.

D. Diego Montalbo Ribera y Vellosillo (rúbrica). Antonio Rodríguez (rúbrica) D. Andrés García (rúbrica). Por mí y ante mí, Francisco de Pedrosa (rúbrica)". (A.H.P.V. Pt. 8214, fol. 109). 
Los textos y ejemplos entresacados acercan a las características que marcan la explotación de la tierra y las estructuras de propiedad durante siglos y que, adelantando conclusiones, conviene anotar. Primero: La falta de titularidad de la tierra por sus directos cultivadores e incluso, como en el caso que nos ocupa, la abundancia de formas de subarriendo que gravaban aún más la economía de la población campesina. Segundo: La vinculación de los bienes arrendados a la práctica de determinadas labores por parte del arrendador, para garantizar la fertilidad de la tierra aun cuando esta no fuera cultivada por el que suscribe la escritura de arriendo. La tierra es un bien si está correctamente cultivada. Tercero: El establecimiento de lazos de dependencia entre arrendador y arrendatario, pues, al estar en manos del segundo buena parte del terrazgo, la dependencia de los renteros respecto a los todopoderosos señores es prácticamente total ${ }^{341}$. Cuarto: la falta de inquietud, por parte de estos rentistas absentistas, por introducir mejoras en sus haciendas o revertir parte de los beneficios de las mismas en el equipamiento o mejora de instalaciones agrícolas o ganaderas.

En el mapa adjunto puede advertirse la presión sobre los espacios incultos y la distribución de cultivos atendiendo a las características del terreno. El avance del espacio cultivado respecto al anterior mapa es innegable. El viñedo se ha extendido por las terrazas de gravas y las tierras de sembradura ocupan, casi en su totalidad, las tierras más feraces. Abandonados eriales vuelven a roturarse y las reducidas manchas de monte pasan a mejor vida. Con todo, obsérvese como espacios baldíos se siguen entremezclando con los ya escasos montes, una vez han sido roturados y posteriormente abandonados a la espera del arraigo definitivo del vińedo. Con las imágenes adjuntas hemos querido ilustrar lo relativamente pronto que las retamas y encinas, por ejemplo, colonizan antiguas parcelas de viñedo o sembradura. En pocas décadas un terrazgo labrado puede convertirse en un intrincado retamar o encinar salpicado de pinos, atendiendo al pastoreo, tipo de suelo o cercanía a masas forestales. Las comunidades rurales nunca desestimaron estos recursos, también vitales en sus economías domésticas.

Con todo, es el cultivo del viñedo el que experimenta un mayor crecimiento en el siglo XVI, adaptándose tanto a los suelos más pobres como al marco jurídico que regula la tenencia de la tierra y el vuelo de la misma. El vino se consolida como un producto básico en la economía comarcal y un sólido camino de futuro, que alimenta a una población creciente vinculada a las cepas y al vino, sean jornaleros, labradores, albañiles o carreteros.

Aunque excede del propósito presente trabajo, muchas aldeas de Tierra de Medina u Olmedo, como La Moya, no superan la crisis del XVII y su terrazgo será labrado por vecinos de los pueblos cercanos. Con todo, como se verá en posteriores mapas, en cada siglo tierras de cultivo, eriales, pinares y poblaciones experimentarán no pocas transformaciones atendiendo a la rentabilidad de los distintos cultivos y a la dinámica de las comunidades rurales.

${ }^{341}$ Como antes se ha señalado, los propietarios de buena parte del terrazgo labrado ni siquiera viven en el lugar por donde se extienden sus mayorazgos, pese a disponer de casas o palacios. La vida campesina en estos siglos depende más del cielo y de voluntades ajenas que de las propias fuerzas. Un año con otro una obrada de trigo daba ocho fanegas. Entre la décima parte que como diezmo se entrega a la Iglesia, la fanega por obrada de renta al señor y el resto de pagos tributarios, se consume la mitad de la cosecha. Pero ahí no acaban las penurias campesinas. Se siembra una obrada, pero hay que dar tres vueltas de arado a otra de barbecho. Las huebras no son gratis. Ni la siega, ni el acarreo, ni la trilla. Aunque los pagos más feraces, como la Vega, dan más de ocho fanegas, hay que tener en cuenta que muchas de sus obradas van de cebada para alimento del ganado. Y debe guardarse otra fanega y media para siembra.

A la luz de las obligaciones escrituradas por unos y otros, quien más y quien menos tenía que pagar algún rédito de préstamos contraídos por sequías o pedriscos. Así que, un año con otro, apenas salen las cuatro o cinco fanegas que se necesitan por persona y ańo para alimento. Si se muere una mula, y no puede reponerse, con la consiguiente repercusión en la vida del pequeño o mediano rentero, al año siguiente a lo mejor va detrás algún miembro de la familia. Y morirse cuesta lo suyo. Al menos si se quiere uno enterrar como Dios manda. Muchos labradores dejan en el testamento que sus herederos saquen a la venta algún cuerpo de bienes para pagar funeral, entierro, ofrendas, misas u obras pías. Claro que este último problema no afecta a los jornaleros. La mayor parte de ellos, a tenor de lo que consta en los libros de difuntos, apenas si necesitaron caja. 


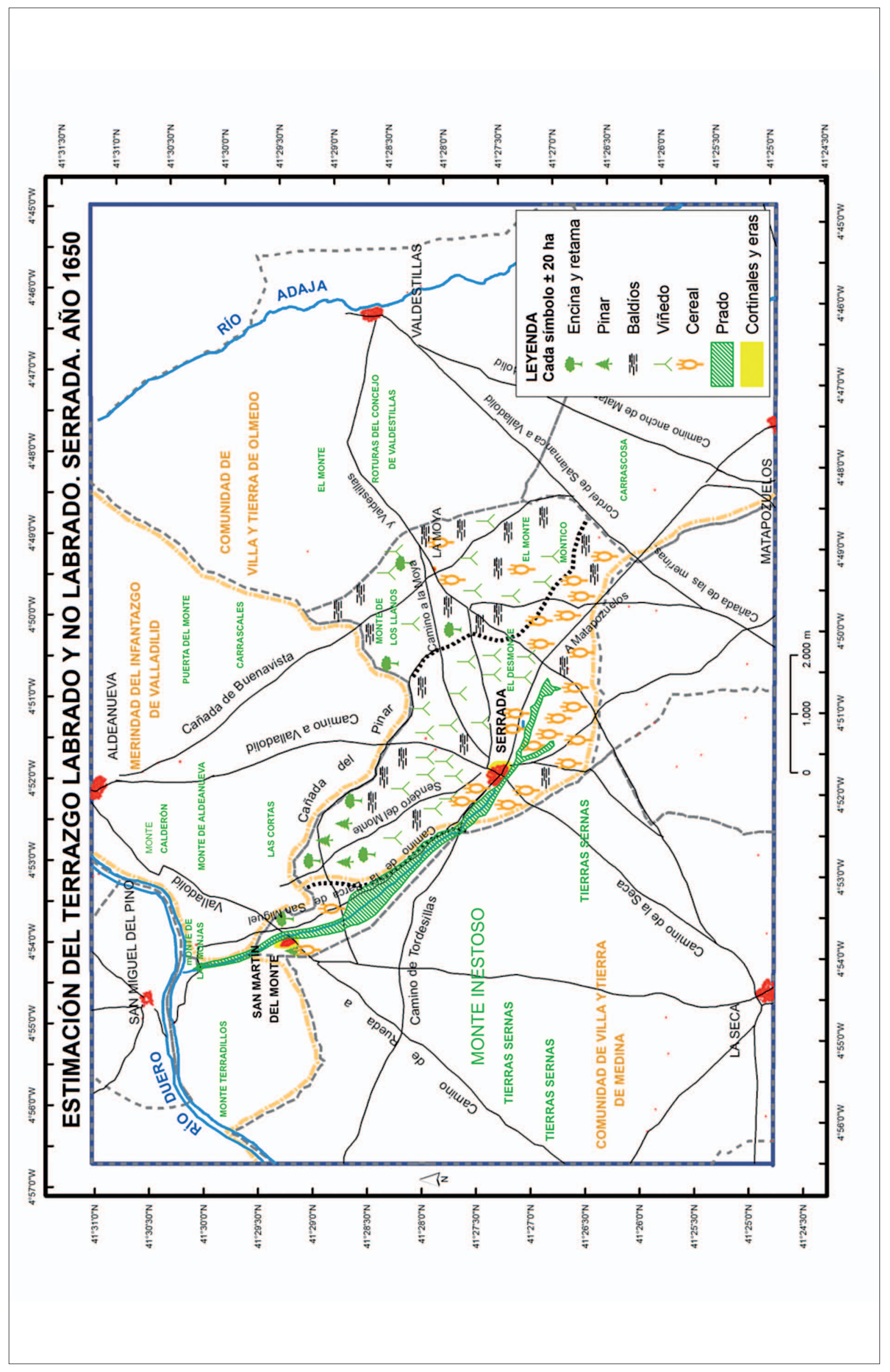



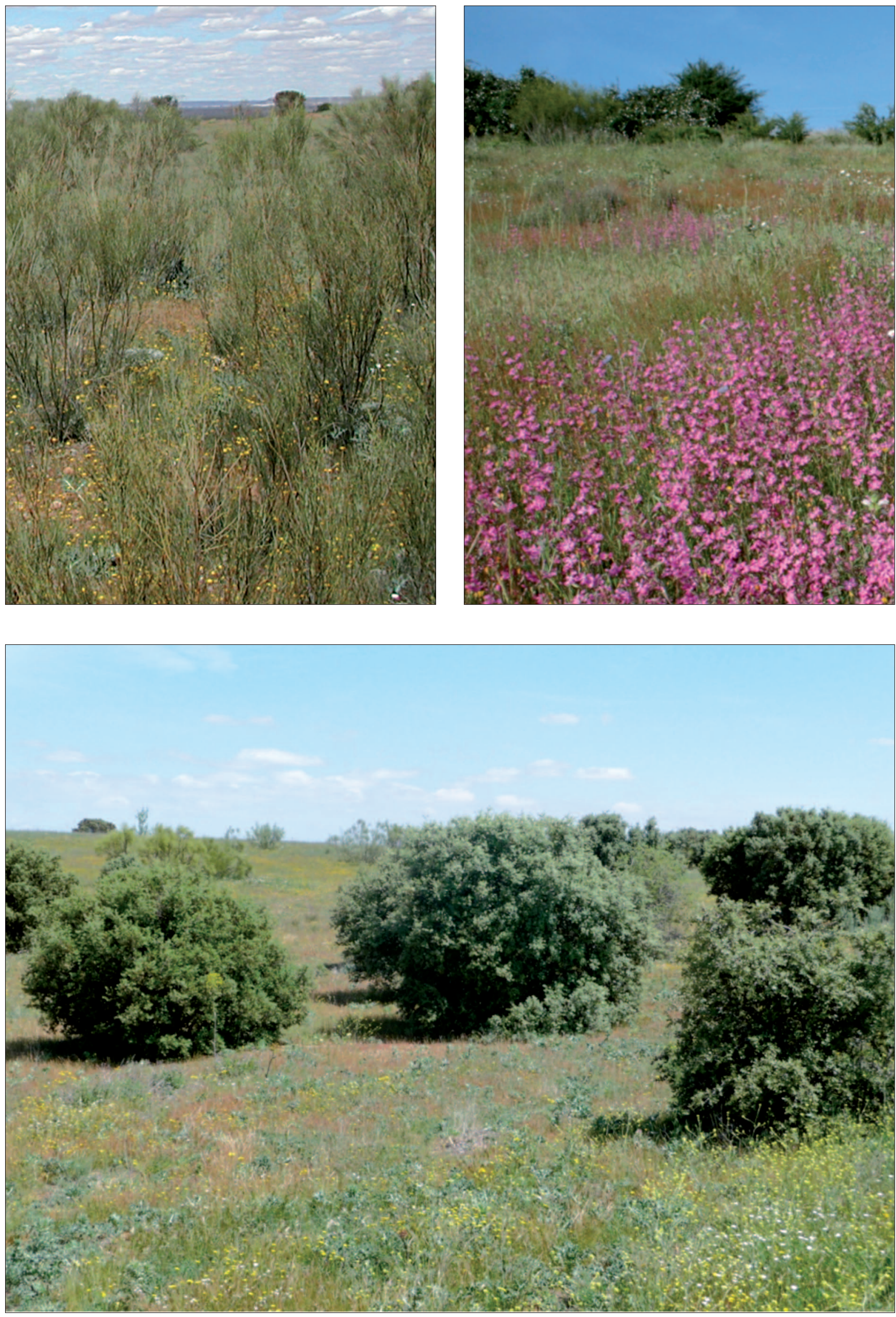

Imagen 50. Como en tiempo histórico las retamas, la flora autóctona y las encinas colonizan baldios anteriormente roturados y sembrados. Términos de Villanueva de Duero, (arriba) y Serrada, (abajo). Fotos: Imágenes superiores, 08/05/2006 y 07/06/2008; inferior, primavera de 2010. 


\section{c. El aprovechamiento de prados y montes}

Lo expuesto anteriormente explica la evolución del espacio inculto, ocupado por retamares, baldíos, encinares, pinares y prados. Como ha quedado expuesto, desde las primeras ocupaciones cristianas de los siglos XII y XIII, hasta la consolidación de estas pequeñas aldeas y lugares en los siglos siguientes, montes y prados se alternan situándose los primeros en las terrazas más altas y dejando a los segundos el fondo de los pequeños valles que las recorren. Su extensión es tan amplia que, en el ámbito estudiado, rebasa las necesidades de las escasas decenas de vecinos que pueblan La Moya, Serrada o San Martín del Monte. Idéntico planteamiento puede generalizarse en los terrazgos limítrofes. Hasta el reinado de Isabel y Fernando no se ha detectado tensión alguna entre cultivadores y ganaderos, pues al escaso vecindario le sobran tierras y pastos. Además, pese a lo marginal de su situación, alejados de las principales cañadas que articulan la trashumancia castellana, el entendimiento entre la oveja y la reja era total. Es en los siglos XVI y XVII cuando se incrementan los desbroces de las mejores tierras y comienza la expansión vitícola, el momento en que no dan abasto las salas de justicias para determinar a quién pertenece tanto terreno común y qué derechos asisten a nobles, concejos locales o Comunidades de Villa y Tierra sobre su uso y explotación ${ }^{342}$.

Los montes también equilibran los recursos de los concejos. En el caso de La Moya y Serrada, las manchas abiertas de encinas y retamas que se extienden desde San Martín del Monte, siguiendo la raya con Villanueva, hasta enlazar con la cańada de Buenavista y La Moya, van a convertirse en una importante reserva para pasto y leńa ${ }^{343}$. Encontramos a los propios vecinos explotando su vuelo o aprovechando retamas ${ }^{344}$. En 1602 el alcalde ordinario de Serrada otorga poder al procurador del común para tratar con Antonio de León, "vecino de la villa de Tordesillas a razón de la hierba del prado deste dicho concexo que pretende pastar" 345 .

Con todo, por lo que reflejan los protocolos notariales de esta época, en estos sectores y en el último tercio del siglo XVI, las tierras de pan llevar y las cepas se van adueñando de los pagos más fértiles o apropiados para cada cultivo, de forma inexorable. Sirva como ejemplo el arrendamiento firmado en 1602 entre Diego de Medina, curador de Catalina Casado y Pedro de Torres, vecinos de

${ }^{342}$ A la contraposición de intereses entre las Comunidades de Villa y Tierra con los concejos locales se suman las tensiones entre éstos y los derechos de la Mesta y los vecinos por la utilización del terrazgo. Los conflictos dirimidos en tiempos bajomedievales parecían ahora un juego de niños. Anteriormente, cuando se trataba el fenómeno roturador, se ponía como ejemplo el litigio entre Serrada y el Honrado Concejo por el interés de este en hacerse con el control de las eras, pinares y prados de Serrada. Los vecinos de este lugar tampoco se encontraban solos en su resistencia. La mayor parte de las aldeas y lugares al sur del Duero eran centro de intereses opuestos. En nuestro caso, los lugares que componen el llamado Cabildo de la Tierra de Olmedo solían arrendar sus espacios comunales "a pasto y lavor y usando de las licencias que por ello ay del Rey nuestro señor". El retamar "que se dize de los Llanos y lo a el anexo ques propio de villa y tierra" estaba siendo arrendado por Olmedo y su cabildo para, con sus rentas, contribuir al pago de arbitrios reales y gastos concejiles. Las rentas se dividían "la tercia parte para el ayuntamiento de dicha villa y las otras dos tercias partes para el dicho cabildo de la tierra de la dicha villa y lugares que están y se conprehenden en él”. (A.H.P.V. Pt. 11838, Valdestillas, año 1590).

343 De hecho, además de los habitantes del lugar, acudían a su aprovechamiento vecinos foráneos. En 1598 el concejo de Serrada, presidido por su alcalde Francisco Alonso, otorga poder a Alonso Blanco, procurador del común, para gestionar el cobro de la renta del monte de los Llanos de la Moya "que se arrendaron a Esteban de Porres y a Juan de Castro y otras sus consortes, vecinos de la ciudad de Valladolid, por cuya suma fueron executados los susodichos”. (A.H.P.V. Pt. 11846, fol. 194).

${ }^{344}$ Juan Alonso el Mozo, vecino de Serrada, se obliga en 1602 a pagar al concejo y a Francisco Bizán, su mayordomo, "veinte y cinco ducados los cuales debo y son por razón de la leña de retama que está en el pinar que dicho concejo tiene”. Tomás García y Francisca Moyano, su mujer, se obligan asimismo a pagar a Juan Alonso el Viejo y a Antonio Blanco "siete ducados de valor de trescientos setenta y cinco maravedís que debemos y son por razón de una suerte de retama que nos bendieron en los montes de los Llanos de la tierra de Olmedo”. A.H.P.V. Pt. 11850 y 11852, fol. 367 y 262 , respectivamente.

${ }^{345}$ A.H.P.V. Pt. 11850 , fol. 460. 
Serrada. Montes y tierras se entremezclan. La renta en trigo delata que son las mejores tierras a las que se ponen cerros. No lejos están las vińas en los suelos de gravas. Las siete obradas, repartidas en tres pedazos tienen las siguientes lindes ${ }^{346}$ :

"Con el prado del concexo y con tierras de Don Diego de Montalbo y otro pedazo esta do dizen Valdelacasa, que linda con el monte de los Llanos y con tierra de Juan Navarro: y el otro pedazo está en el dicho Baldelacasa que linda con el monte de las cabezas y con tierra de Antonio Blanco... por precio todas las dichas tierras de siete cargas y media de trigo".

No ocurre lo mismo con los pastizales, siempre frescos y vivos por su encharcamiento temporal, e imprescindibles para el cada vez más numeroso ganado de labor y renta. La longitudinal mancha de herbazal, que recorre el término, es muy valorada por todos y se considera el soporte alimenticio del ganado de labor. De su regulación y vitalidad depende la fuerza para seguir roturando. El arroyo que las comunica sirve de hilo conductor a los distintos pedazos. Como los anteriores espacios, todo está regulado y tiene un dueño que vela por su aprovechamiento. Nada mejor que comprobarlo en una escritura firmada en 1604 entre el concejo de Serrada y Andrés Martín sobre la guarda de estos prados, de sus ganados y del término en general $^{347}$ :

"En el lugar de Serrada, tierra y jurisdizión de la villa de Olmedo, a catorze días del mes de febrero de mil y seiscientos y quatro ańos, por ante mi Antonio de Medina, escribano real y del numero de la villa de Valdestillas, parescio presente Andrés Martín, vecino que dixo ser de la Mata, estante en el dicho lugar de Serrada, e dixo que en el se havía rematado el oficio de guarda del campo y guarda del ganado mayor que los vecinos del dicho lugar tienen; y mas treinta y cinco bueyes o alimañas que se an de acoger en los prados quel dicho lugar tiene por este ańo de seiscientos y quatro; que se a de entender asta el día de Todos Santos; ... y ansimismo el dicho término y el pan que dentro del está sembrado al presente y se sembrare...”.

Se conocen con cierta precisión sus extensiones, dadas las continuas referencias que los pleitos y ejecuciones hacen, atribuyendo su propiedad a unos y otros, aunque es Olmedo quien, a pesar del deseo de los Montalvo, goce casi siempre de su disfrute como bienes comunales que forman parte de su Tierra ${ }^{348}$. La concordia de 1640 entre el señor de Serrada y Olmedo otorgaba, amén de un nuevo reordenamiento de las propiedades y disfrutes del terrazgo entre las partes, la propiedad de la totalidad de los prados al concejo de Serrada de forma plena. Por el contrario, el resto de pastos y montes que se reparten de forma abundante en distintos sectores de Serrada y La Moya permanecen como bienes comunales de Villa y Tierra, teniendo tanta potestad en su disfrute los vecinos de Serrada como los de Matapozuelos o Valdestillas, por poner un ejemplo, siempre que sea a rejas vueltas, es decir, regresando con los animales al lugar poblado tras la jornada de trabajo ${ }^{349}$ :

346 A.H.P.V. Pt. 11850, fol. 385, año 1604.

${ }^{347}$ A.H.P.V. Pt. 11850 , fol. 364.

${ }^{348}$ Recuérdese el apartado en que se trató la pérdida y reparto con esta villa del terrazgo por romper y arar, en que el juez ejecutor asigna en 1524 y 1526 gran cantidad de pagos incultos a Olmedo, otorgando igualmente a esta villa los distintos prados del lugar de Serrada. Hasta entonces, en lo que se refiere a los pastizales, aunque la posesión era de Diego Ruiz de Montalvo, señor del lugar, como bienes adscritos a su mayorazgo, parte de los prados eran guardados por el concejo de Serrada que los habían adehesado y arrendado sin impedimento de su señor.

${ }^{349}$ En este sentido la concordia no dejaba sombra de dudas: "Que el pasto de los Prados del dicho lugar de Serrada de que ansimismo se dio posesión a esta villa y su tierra en virtud de la que antiguamente tenía an de quedar y quedan por Propios del Concejo del dicho lugar y de sus vezinos para que los ayan y gocen según en la forma y manera que los an gozado y disfrutado hasta agora, pastando sus yerbas y beviendo sus aguas con sus ganados, arrendándolos a quien y por el precio que les pareciere, cobrando la renta y penas de ellos por Propios del Concejo del dicho lugar, sin que en hellos el dicho Don Juan de Montalbo ni sus subcesores ayan de tener parte ni aprobechamiento ninguno en la propiedad mas que tan solamente en el pasto de ellos con sus ganados si caso fuere que el susodicho se fuese a vivir a el dicho lugar en el tiempo que los demás vecinos y no mas.”. (A.M.S., caja 69, carp. 722, Concordia sobre posesión de prados). 


\begin{abstract}
"Que el pasto de todo el término del dicho lugar de Serrada a de quedar y quede por pasto común y rejas bueltas para los ganados de todos los vecinos de esta dicha villa y del dicho lugar de Serrada y de los demás lugares de la xurisdición y villas del Partido, según en la forma y manera que lo a sido hasta agora, y lo son y an sido todos los términos de esta dicha villa y lugares de la xurisdición y villas del Partido, sin que en esta se haya de hacer no haga ninguna nobedad porque todo el término del dicho lugar de Serrada a de quedar y queda y se de clara para pasto común y rejas bueltas"
\end{abstract}

A los términos nada imprecisos de estas últimas escrituras sobre la posesión del pasto y la guarda del término en estas fechas, se debe añadir las necesidades de regulación de sus aprovechamientos. El pastoreo se ordena conforme lo hace el terrazgo en hojas, aunque, salvo en las tierras de la Vega, arrendadas por el señor de Serrada a sus vecinos, lo cultivado en las terrazas de gravas, dado lo fragmentado y disperso de las tierras de cereal constatadas en la primera mitad del siglo XVI, y la particular dinámica que introduce el pasto del viñedo, dificultará la ordenación regular que se observa en otros espacios netamente cerealísticos. Por otro lado, desde fechas muy tempranas, se observa en toda la comarca la preocupación por la guarda y custodia de las uvas y, en 1609, el concejo de Valdestillas otorga poderes y se ganan provisiones "para que los ganados coman la oja de las biñas y su balor en que se arrendaren o bendieren se de de limosna al Ospital para sus necesidades"350.

Es el comienzo del tira y afloja entre ganaderos, vińeros y concejos sobre el aprovechamiento, no sólo del pasto que crece en los majuelos durante el otońo y las primeras semanas del invierno, sino también de la hoja y pampanera, una vez finalizada la vendimia. En próximos siglos se verá cómo la expansión de este cultivo trae no pocos litigios y controversias ante la necesidad de los pastores de aprovechar estos nuevos pastos, ganados al antiguo monte comunal, y las reticencias de muchos labradores hacia las ovejas, toda vez que pisan los majuelos y muerden sus varas y pulgares. Al final se imponen los intereses económicos de los concejos, que ven en este aprovechamiento pastoril una ocasión para sacar a remate la hoja y pámpana de sus viñas y obtener unos recursos añadidos a sus siempre exiguas arcas. El viñedo, pues, también va a condicionar el aprovechamiento por los ganados del espacio analizado.

\title{
3. Los sistemas de cultivo y la rentabilidad de las tierras de sembradura y viñedo. Aná- lisis de una explotación en el siglo XVI
}

En el espacio tratado y hasta los siglos XV y XVI, se hace poco menos que imposible analizar con cierto rigor las dimensiones, cultivos y rentabilidad de las labranzas campesinas. Bien es cierto que se puede vislumbrar, a la luz de investigaciones realizadas en otras áreas cercanas y a través de documentación archivística, datos parciales que, prudentemente hilvanados, acercan a esa vida, casi siempre precaria, del campesino bajomedieval. Documentos de los siglos XII, XIII y XIV constatan la existencia de un terrazgo labrado que se abre paso entre superficies montaraces, para retroceder cuando la fertilidad de los suelos decae o pestes y guerras ponen a este eslabón más débil de la sociedad al borde de la muerte. No hay que olvidar que “...aquellas gentes, como hombres simples..." caerán en la más absoluta dependencia de los poderosos y es esta servidumbre "...la más vil et la más despreciada cosa que entre los homes puede ser; porque el home... se torna por ella en poder de otro... " una de las características más importantes que lo definirán siglo tras siglo ${ }^{351}$.

${ }^{350}$ A.H.P.V. Pt. 11857 , fol. 174.

${ }^{351}$ MARTÍN CEA, J. C.: El Campesinado castellano..., ob. cit., pág. 28-29, citando a Crónicas de los reyes de Castilla”, Crónica de Juan II, Ed. Atlas, Biblioteca de autores españoles, Madrid, 1953, tomo II, pág. 393 y "Las Siete Partidas del rey Don Alfonso el Sabio cotejadas con varios códices antiguos por la Real Academia de la Historia”, Madrid, 1807, ed. facsímil de la Ed. Atlas, Madrid, 1972, tomo II, partida II, tít. XX, ley IV, pág. 193. 
vinarevo 6

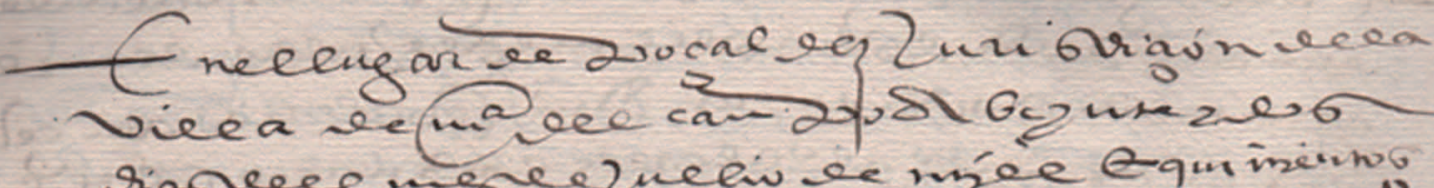

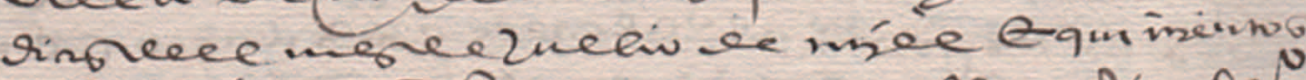

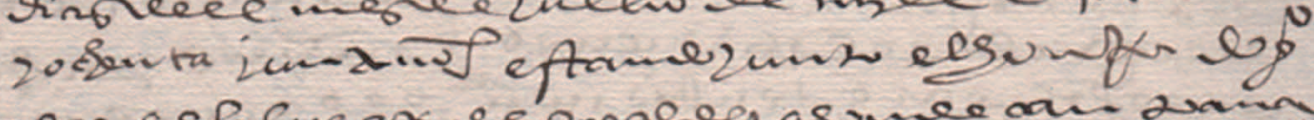

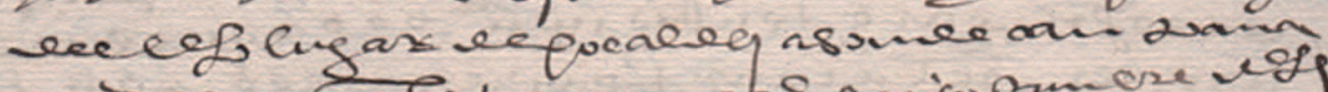

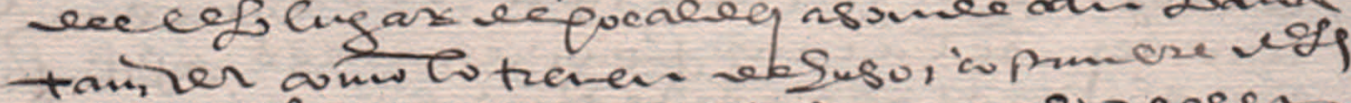

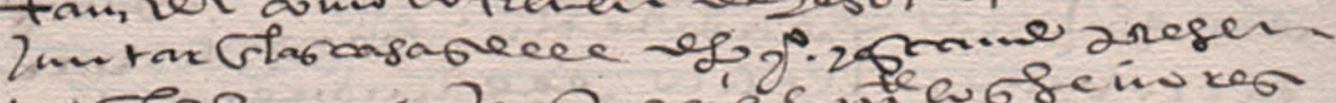

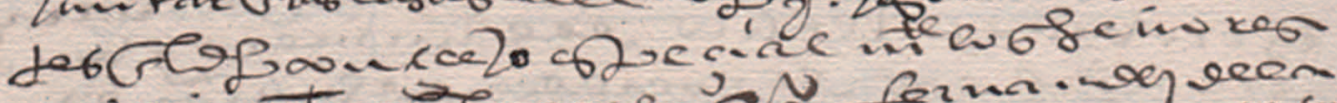

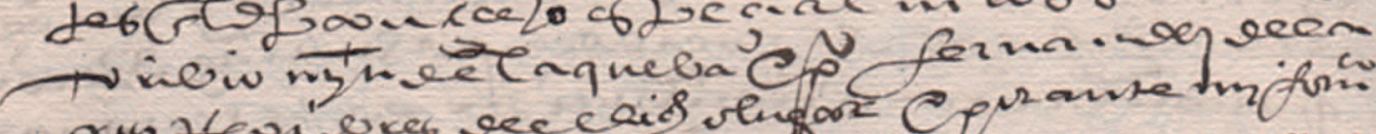

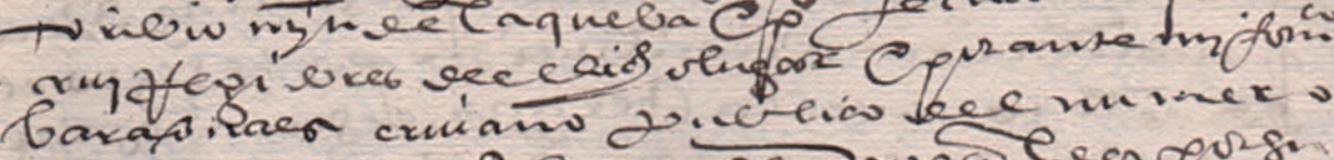

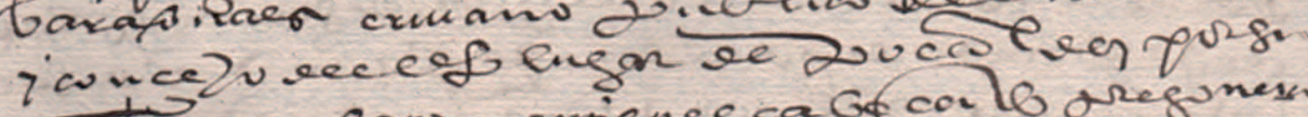
nang. maneakon amignee ca of conlo aregunesw

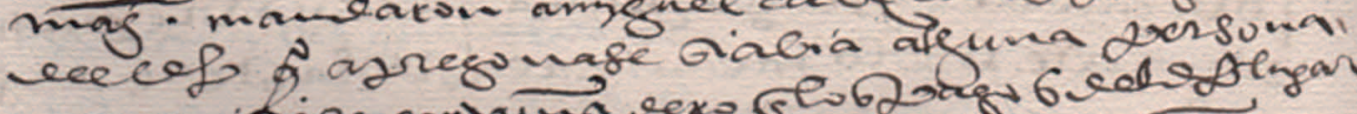

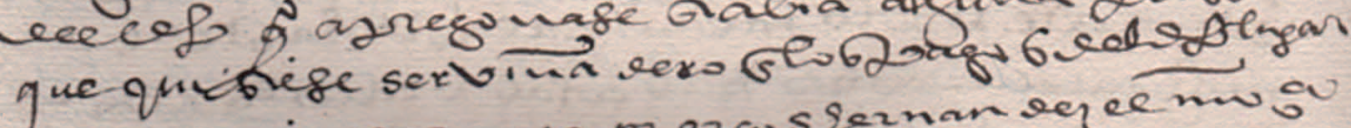

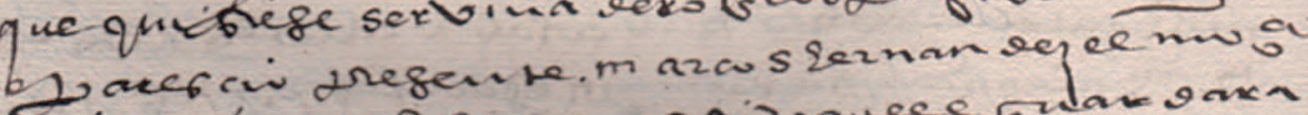
ve ano ece offligar. erizoquece 5 lar gaxa

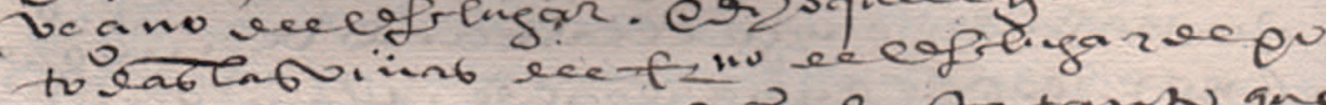

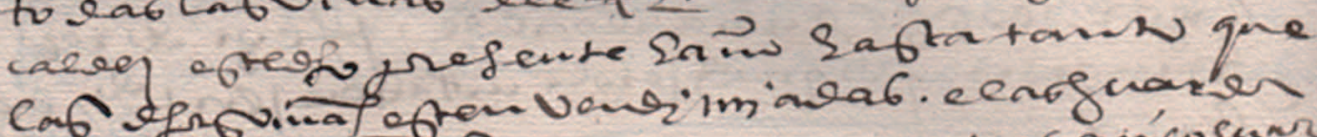

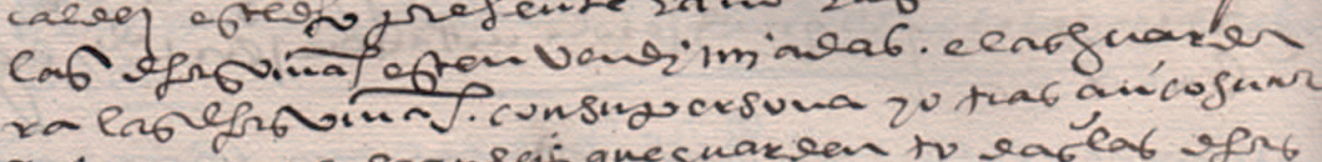
rabque cunec scangerb que guareen to rafear igns

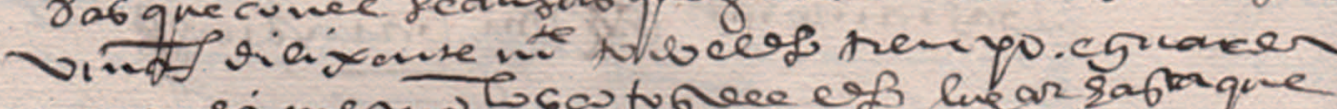

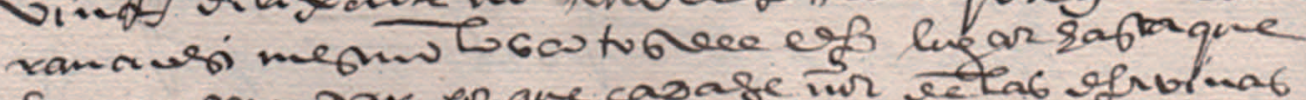

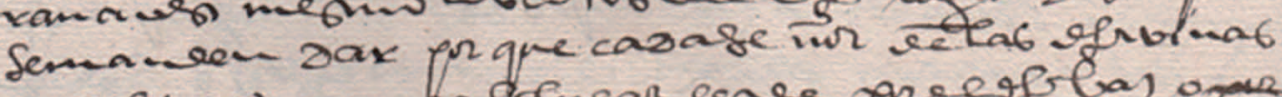

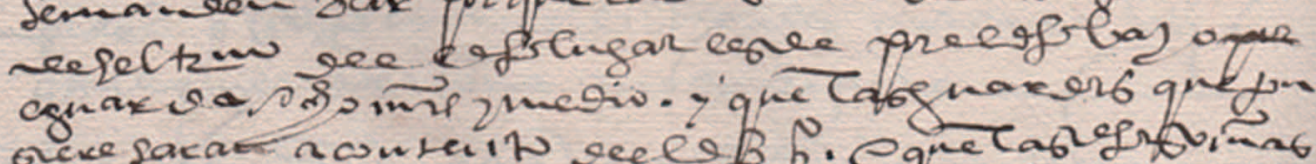

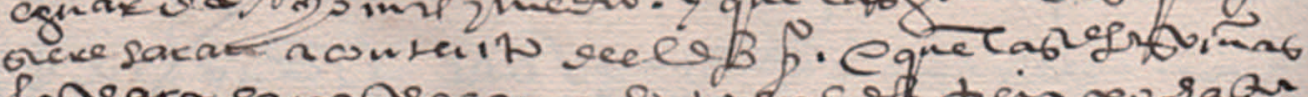

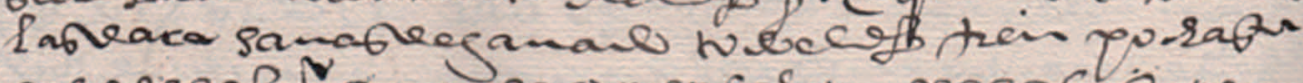

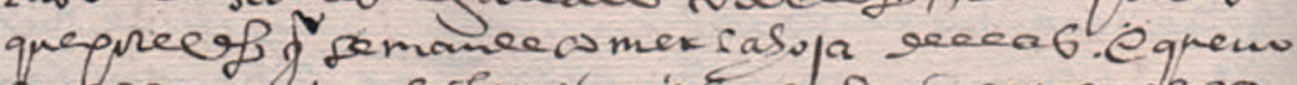

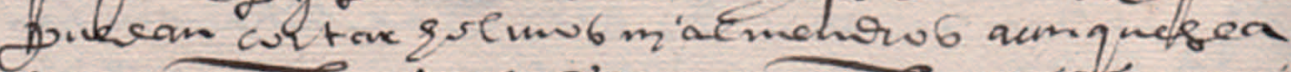

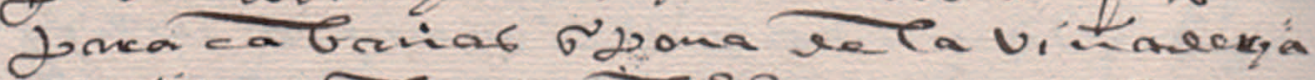

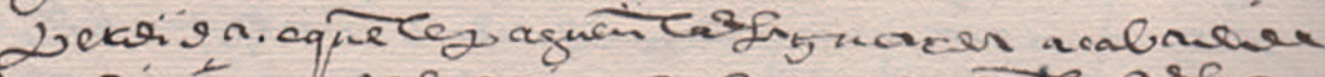

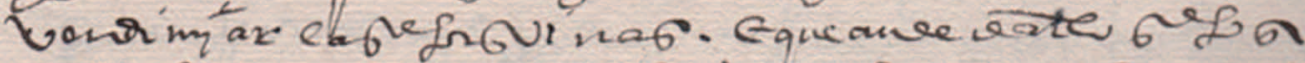

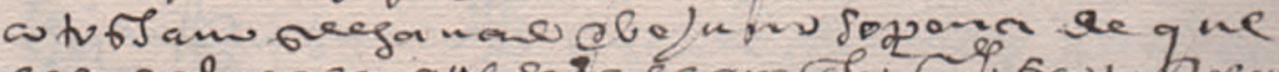

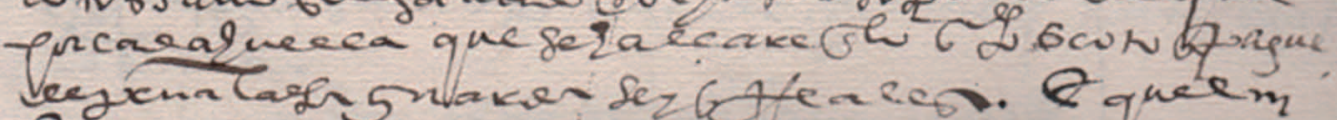

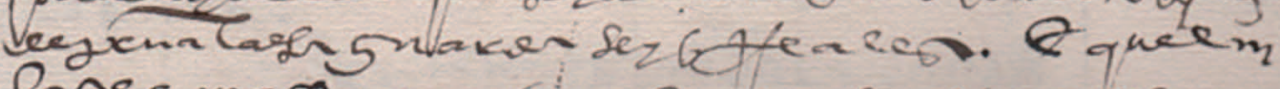

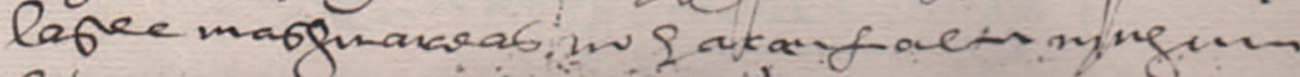

Imagen 51. Concierto sobre la guarda de las viñas en Pozaldez. Año 1581. (Archivo familia Bocos Cantalapiedra). Foto: 03/03/2014. Los concejos locales desarrollan, a lo largo de los siglos, toda una compleja regulación de la guarda de los frutos y aprovechamiento de la hoja y pámpana, una vez recogido. La guarda de las viñas se vigila con especial atención, como se reproduce en el ejemplo de la imagen adjunta. 
Si como se ha estudiado, delimitar la cuantía de lo labrado era misión casi imposible, incluso para la justicia de aquel tiempo, precisar hoy rendimientos de producción y rentabilidad es caer en la temeridad. No obstante, en el siglo XIV se constatan compras y ventas de tierra, aceñas, vińas, casas y animales de labor, que ponen de relieve la existencia de numeroso campesinado con bienes en la Tierra de Medina y en sus proximidades. Bien es cierto que con demasiadas ataduras señoriales, deudas y cargas impositivas. La venta hecha en 1377 por Gutiérrez Gómez al convento de Santa Clara de Tordesillas de "sesenta yugadas en 26 tierras de pan llevar, por labranza de un par de bueyes, año y vez, y seis aranzadas de viñas plantadas que tenía en la labranza de dich a aldea...", es un ejemplo de la cuantía y parcelación de la tierra, al tiempo que vislumbra una posible relación entre tierras de pan y de viñas y el empleo de los bueyes como animales de tracción en tales fechas ${ }^{352}$. En este mismo siglo Martín Cea cifra una productividad en los cereales, en heredades explotadas por los monjes de Silos, de 1 a 4 para el trigo, 1 a 3,5 para la cebada y la avena y 1 a 3,7 para el centeno, que se entiende representativa en el espacio estudiado ${ }^{353}$. Si se tiene en cuenta que una tercera parte debe destinarse a simiente, resulta poco menos que imposible estirar los dos tercios restantes para cumplir con el diezmo, rentas, alimentación, deudas, vestido y utillaje agrícola, tanto más cuando algunos autores cifran en dos tercios el peso impositivo que sume irremediablemente al campesino en la miseria ${ }^{354}$.

La existencia de numerosas fuentes escritas en el siglo XVI, en el que se centrará este análisis, permite un acercamiento más riguroso a la explotación de la tierra en este espacio. A lo largo de los siglos XIV y XV las roturaciones van dibujando un terrazgo que los centros cabeceros de Villa y Tierra, concejos locales o señores, cuidan por su propio interés. El hambre de tierra, como forma de dimensionar las explotaciones y conseguir excedentes comercializables, es un hecho incontestable. La propiedad de la tierra es el objetivo último de todo labrador que se precie, a pesar de que su cultivo vaya en detrimento de un espacio comunal que igualmente necesita. El caso de los montes sernas analizados es un ejemplo. Por otro lado, la necesidad de liquidez de los concejos y la misma Corona impulsan la venta de baldíos por doquier ${ }^{355}$. La propia nobleza acude presurosa en busca de nuevas rentas y segrega parte de sus mayorazgos para ventas o arrendamientos. Qué duda cabe que, cuanto más próximos y dinámicos son los mercados, el fenómeno es más intenso. Resultado de todo ello es la configuración de unidades de explotación que, con terreno propio o arrendado, luchan por ser rentables en una centuria en la que el crecimiento de la población y el dinamismo urbano alientan la especialización de los cultivos atendiendo al tipo de suelos, condiciones atmosféricas y comercialización del producto.

En este sentido, los siglos XV y XVI consolidan un paisaje agrario de tierras de pan y vino en la comarca medinense a costa del monte. Los nombres de parcelas y pagos identifican y concretan una toponimia que, en su mayor parte, sigue hoy vigente. Las producciones aumentan conforme lo hacen las nuevas roturas y aumenta la población. Las técnicas, aperos y sistemas de cultivo permanecen inalterables o, para ser más exactos, se perpetúan en estos siglos. Entresaquemos algunos ejemplos que sirvan para cuantificar la dimensión y caracteres de las explotaciones agrarias en este siglo XVI.

${ }^{352}$ CASTRO TOLEDO, J.: Colección Diplomática..., ob. cit., pág. 115. Institución Cultural Simancas. 1981.

${ }^{353}$ MARTÍN CEA, J. C.: El Campesinado castellano..., ob. cit. pág. 62-63.

${ }^{354}$ CARRASCO TEZANOS, A.: Propiedad campesina y medianos propietarios en Castilla central entre los siglos XVy XVI. Ediciones Universidad de Salamanca Stud, hist., Ha mediev., 22, 2004, pp. 109-149 y PÉREZ-DÍAZ, V. "Transformaciones de una tradición. Campesinos y agricultura en Castilla entre mediados del siglo XVI y mediados del siglo XX". En Antiguo Régimen y liberalismo. Homenaje a Miguel Artola. 1: Visiones Generales. Madrid, 1994, pp. 95-101.

355 ALVAREZ NOGAL, C.: Incentivos económicos y derechos de propiedad en la Castilla del siglo XVI. Cuadernos económicos de ICE, end_of_the_skype_highlighti No 70, 2005, (ejemplar dedicado a: Nuevas tendencias en historia económica), págs. 77-96. 


\section{a. Las tierras de sembradura en la segunda mitad del siglo XVI. Sistemas de cultivo, produc- ciones y rentabilidad}

En el norte de la comarca medinense, donde se alternan terrazas de gravas y suaves laderas con pequeños valles y vegas, las tierras de pan se localizan en los suelos aluviales de estos últimos, dejando las terrazas al monte, al viñedo o a baldíos roturados de forma discontinua, de acuerdo a la necesidad del pequeño campesino. El aumento de la producción es directamente proporcional al terreno labrado, que se organiza en hojas, para facilitar el aprovechamiento de rastrojeras, pampaneras y barbecheras. Esta organización es más nítida en el paisaje y será también más duradera en el tiempo en las campiñas meridionales del sur de Medina, toda vez que la vid se recluye en pagos situados en relieves residuales.

En estas terrazas, donde la disección de los distintos niveles deja materiales miocenos y fondos de valle con buenas aptitudes cerealistas, los cultivos se entremezclan en mayor medida, si bien, conforme se baja en altitud y se amplía el valle y vega cultivada, el espacio cerealista se divide nítidamente en hojas: sembradura y barbecho. Cuando avance el siglo XVI y, bien por roturación de montes de Propios, bien por concesiones de la nobleza, las tierras "flacas e pedregosas" se planten de majuelos, las hojas del vińedo se agrandan y uniforman en espacios concretos. De hecho, en los inventarios de bienes consultados, en los que se concreta la vecindad de los bienes raíces, la mayor parte de las tierras declaradas lindan con tierras y las viñas, con viñas. No faltan, en ocasiones, alusiones a una u otra hoja: "linda... con el camino que va a las biñas..." 356.

Si el aumento del terrazgo labrado es indiscutible, tal como se ha tratado de constatar documentalmente, el sistema de cultivo, producciones y rentabilidad parecen ancladas en el tiempo, desde la Baja Edad Media y hasta el siglo XIX. Los numerosos inventarios de bienes, contratos de arrendamientos y conciertos de labores, consultados en los siglos XV, XVI y XVII, repiten invariablemente las mismas labores, idéntica prevención sobre la forma y manera de llevarlas a cabo, a fin de evitar la esterilidad de la tierra, y, en fin, los mismos tipos de arado, rejas y baluartes con que secularmente son labradas. Únicamente donde se constata un cambio es en el sistema de tracción, pues, a lo largo del siglo XVI, las mulas comienzan a sustituir a los bueyes o, al menos, su presencia es más frecuentes en los inventarios de bienes del campesino mediano de este siglo. Sirva como ejemplo los que siguen de 1591 en Serrada ${ }^{357}$ :

"Yten. Un par de bueyes de arada tasados en nueve mill mrs.

Yten. Dos yugos de arada, el uno de mulas y el otro de bueyes y dos arados con cinco rejas de yerro que fue tasado todo en dos ducados.

Yten. Dos burras tasadas en quatro mill maravedies."

"Primeramente tres bueyes que fueron tasados en cincuenta y nueve ducados que valen beynte y dos mill y ciento y veynte y quatro mrs.

Yren. Dos yeguas la una de color rroja y la otra un poco castańa hija desta que anbas fueron tasadas en diez y seis mil y quinientos maravedis.

Ytem. Una bestia color rrucia que fue tasada en diez ducados.

Yten. Dos garańones asnales que fueron tasados anbos a dos en honze mill maravedies.

Yten. Un roçin color negro tasado en tres mill maravedies.”

La ampliación del terrazgo cultivado incrementa las distancias. Lo fragmentado de las explotaciones y lo liviano de parte de los suelos condicionan la rentabilidad de los bueyes frente al ganado mular $^{358}$. La mula, además, se impone por su agilidad y mejor manejo, tanto en el transporte como, sobre todo, en las labores de vińedo que requieren continuas vueltas entre las calles y saetines en que

356 A.H.P.V. Pt. 11840, fol. 270.

${ }^{357}$ A.H.P.V. Pt. 11839 , fols. 236 y $262 \mathrm{v}$

${ }^{358}$ ANES, G. (1970): Las crisis agrarias en la España moderna. Madrid y "The agrarian 'depression' in Castile in the seventeenth century», en I. A. A. Thompson y B. Yun (ed.), The Castilian crisis of the seventeenth century. Cambridge: Cambridge University Press, pág. 67. 1994. 
se ordenan las cepas. De hecho, el aumento de su precio en este siglo es una prueba evidente de su demanda ${ }^{359}$. No obstante, el ganado boyal seguirá estando presente en la mayor parte de las medianas y grandes haciendas. Piénsese que, en el año 1604, los labradores de Serrada disponen de 35 bueyes, cifra nada despreciable en un lugar de poco más de 36 vecinos, tal como recoge la obligación que firma el guarda del ganado mayor en dicha fecha ${ }^{360}$.

Otra característica del terrazgo es su extraordinaria parcelación, resultado de las roturas que se llevaron a cabo, con o sin licencia, y que en ningún caso se hicieron de forma individual sobre grandes superficies, puesto que se trataba de una ampliación de la heredad y no de la constitución de una labranza en sí misma. Las continuas divisiones hereditarias y compraventas también contribuyeron a ello, al igual que la prevención en tener en distintos lugares y calidades del término sembrados de trigo, cebada y centeno, para contrarrestar, en lo posible, adversidades metereológicas que puedan afectar a la totalidad de una heredad, caso de que esta esté concentrada en una parte del término.

\section{- El sistema de cultivo}

Desde siglos, el cultivo de año y vez es el único posible si de la tierra se desea obtener algún sustento. Cualquier variación se anota en los acuerdos entre partes, si se trata de las tierras de sembradura. En el que sigue de 1590, tomado como ejemplo, al margen de que la renta se estipula en moneda, queda claro que el arrendamiento es "...por tiempo de quatro años y dos frutos que se entienden de año y bez..." ${ }^{361}$ :

"Sepan quantos esta carta de arrendamiento vieren como yo... doy en rrenta y arrendamiento a vos andrés rredondo... tres obradas de tierras, poco más o menos... en tres pedazos.. y vos las arriendo a todo rriesgo y ventura y caso fortuyto ansí del cielo como de la tierra, de agua, piedra, niebla, esterilidad con todos los demás casos mayores y menores que dichos frutos de las dichas tierras acaezcan o acaezer puedan que por alguno dellos no ha de ser visto... y pagades por dicho arrendamiento por tiempo de quatro años y dos frutos que se entienden de año y bez y por precio de veynte y dos ducados que balen ocho mil y doscientos y cincuenta mrs..”

La siembra de otras semillas, al margen del cereal, es común en muchas localidades y los arrendamientos lo especifican o lo prohíben, atendiendo al interés de las partes. En ocasiones, el permiso desea un consumo propio más que comercial. En 1598 Rodrigo Manrique, de Rodilana, arrienda las tierras de la iglesia del lugar a Francisco Delgado el Mozo "...con condición que en las dichas tierras pueda yo, el dicho Françisco delgado el moço, senbrar un corro de melonar..."362. Los aprovechamientos se detallan cuando se salen del sistema bienal en sentido estricto. Incluso se anotan qué malas hierbas deben quitarse. El arrendamiento que en 1588 rubrican Benito Moro y Alonso de Aragón en la Vega de Villaverde, sobre una tierra de cuatro obradas para sembrar de melones, precisa que debe estar libre para el día de San Miguel y que los renteros "...en la dicha tierra abeys de ser obligados a me sacar todas las mielgas y gatunas que en ella ubiere..."363.

Igualmente, los cultivos se concretan si se sale de lo habitual. Juan de Alaejos arrienda una tierra de obrada y media en esta misma villa con la condición de "...que la podays senbrar de melones... y quitados los melones la senbréis... de trigo y lo coxays el verano venidero de ochenta y nuebe..." 364 . Salvo estas semillas, previamente consentidas, los retelos son palabras mayores. Sin salir de esta villa y ańo,

${ }^{359}$ ALVAREZ NOGAL, C.: Incentivos económicos..., ob. cit., pág. 83.

360 A.H.P.V. Pt. 11852 , fol. 385.

${ }^{361}$ A.H.P.V. Pt. 11838, fol. 498.

${ }^{362}$ A.H.P.V. Pt. 6572, fol. 125.

363 A.H.P.V. Pt. 8287, fol. 10.

364 A.H.P.V. Pt. 8287, fol. 20. 
se encuentra un caso al respecto. Elvira López arrienda a Antonio Pérez todas las tierras que posee, a fanega por obrada, con la condición de que "...lo que esta senbrado agora ... no podays rebolber tierra ninguna so pena de pagar la renta de cada una obrada que rebolbiéredes la renta doblada..." "365, lo que prueba lo importante que es la barbechera como garantía de tener la tierra descansada, para que pueda rendir cosecha al año siguiente. Aún hoy, se oye decir a los agricultores que dejan barbecho, convencidos del sistema bienal, que "vale más un pan que dos panecillos", aludiendo a las menguadas cosechas que rinden las tierras cuando se las revuelve o "retela" 366 . Sólo de forma muy excepcional se encuentran a finales de este siglo XVI acuerdos que permiten repetir tierras de pan. Es el caso de Domingo Maeso, que arrienda tres obradas en 1591 a Pedro Pérez por un año con la condición de “...que las tengo de poder rebolver lo que yo quisiera y con esta condición me obligo de dar y pagar de renta en cada una obrada... media carga de trigo..."367.

Este equilibrio en los aprovechamientos generales también concierne a su variedad en el caso de los cereales. Conforme se reducen pastos y montes comunales y aumenta el ganado mular, la cebada va incrementando su cultivo, aunque sigue siendo el trigo el cereal más preciado y sobre el que pesan la mayor parte de las transacciones destinadas al mercado. No olvidemos que muchas laderas que enlazan las terrazas de gravas con el fondo de los valles disponen de unos suelos apropiados para pan, siempre que se haga buen barbecho, y ello será muy estimado por los labradores de estas épocas. Analicemos en detalle las tierras de sembradura y los rendimientos declarados por los herederos de Francisco Martín en La Moya de $1590^{368}$.

\section{Cuadro 12. Fruto, rendimiento y precios obtenidos en las tierras de sembradura de Francisco Martín. La Moya, año de $1590^{369}$}

\begin{tabular}{lccccccc}
\hline Aprovechamiento & $\begin{array}{c}\text { Obradas } \\
\text { sembradas }\end{array}$ & $\begin{array}{c}\text { Producto } \\
\text { recogido } \\
\text { (cargas) }\end{array}$ & $\begin{array}{c}\text { Rendimiento } \\
\text { por obrada } \\
(\mathrm{kgs})\end{array}$ & $\begin{array}{c}\text { Quedan tras } \\
\text { el diezmo } \\
\text { (cargas) }\end{array}$ & $\begin{array}{c}\text { Precio } \\
\text { cada carga } \\
\text { (reales) }\end{array}$ & $\begin{array}{c}\text { Totales } \\
\text { (reales) }\end{array}$ & $\begin{array}{c}\text { Reales por } \\
\text { obrada }\end{array}$ \\
\hline Trigo & 17 & 40 & 414 & 36 & 48 & 1.728 & 101,64 \\
Cebada & 8 & 33 & 544 & 30 & 24 & 720 & 90 \\
Centeno & 5 & 10 & 352 & 10 & 26 & 260 & 52 \\
\hline Total & 30 & 83 & 436 & 76 & & 2.708 & 81,21 \\
\hline
\end{tabular}

Fuente: Archivo Histórico Provincial de Valladolid. Protocolos Notariales. Elaboración propia.

Francisco Martín es representativo de los labradores medianos del citado lugar ${ }^{370}$. En 1588 tiene poder y facultad de Antonio de Vega para arrendar tierras de su mayorazgo. En 1590, sin estimar la superficie de barbecho que pueda tener, labra 33,9 ha, amén de 8 aranzadas de vińedo que registra como

365 A.H.P.V. Pt. 8287, fol. 135.

${ }^{366}$ Revolver, retelar o rebujar las tierras que salen de pajas para sembrarlas en otońo, tras un pase somero de arado, de algarrobas, por ejemplo, o volver a repetir cultivo sobre ellas, son expresiones utilizadas en tiempo histórico en la comarca que estudiamos. En relación con estas tareas los verbos hacen referencia al hecho de cubrir o envolver la tierra con la simiente.

${ }^{367}$ A.H.P.V. Pt. 8287, fol. 137.

368 A.H.P.V. Pt. 11838 , fol. 143 y ss.

${ }^{369}$ De acuerdo a la tabla de equivalencias de medidas tradicionales que figura al comienzo del presente estudio, se recuerda que una carga equivale a cuatro fanegas. La fanega de trigo tiene un peso de $44 \mathrm{~kg}$, la de cebada caballar del país, $33 \mathrm{~kg}$, y la de centeno, 44. Con estos parámetros, de cada obrada (0,5659 ha) de trigo, tal como se ha anotado en la tabla, se han obtenido $414 \mathrm{~kg}(731,5 \mathrm{~kg} / \mathrm{ha})$; la obrada de cebada ha rendido $544 \mathrm{~kg}$. $(961,3 \mathrm{~kg} / \mathrm{ha})$, mientras que en la de centeno se obtuvieron $352 \mathrm{~kg}(622 \mathrm{~kg} / \mathrm{ha})$.

En cuanto al valor monetario, conviene saber que por estas fechas un ducado suma 375 maravedíes y un real 34 maravedíes.

${ }^{370}$ A.H.P.V. Pt. 11837, fol. 79. 
viñas propias. Dispone de once moyos de vino encubados de la cosecha anterior, tasados a 62 reales, y en sus paneras guarda 14 cargas de cebada, a 24 reales cada carga, y 7 de trigo, a 40 reales. Como animales de labor, detenta una mula, un rocín y dos burras. Poco tiempo después de esta declaración adquiere una vińa de cuatro aranzadas por 70 ducados $(26.250 \mathrm{mrs})$ y dos obradas de tierra por $10.512 \mathrm{mrs}$.

\section{- La recolección del pan}

Los rendimientos de cultivo declarados son los usuales en estos siglos, fanega arriba, fanega abajo, si bien existen enormes variaciones tanto por la metereología y la calidad de las parcelas, como por las labores y cuidados que en ellas se realizan. Obtener una media de $414 \mathrm{~kg}$ de trigo por obrada, 544 de cebada y 352 de centeno, tal como logró en 1590 Francisco Martín en tierras de La Moya, es meritorio y no se estiman rendimientos superiores en el resto de la Tierra de Medina. Sirva como ejemplo la producción y gastos de recolección de cinco obradas de trigo propiedad de Gabriel Pérez vecino de Villaverde de Medina en el mismo año de $1590^{371}$ :

Cuadro 13. Producción y gastos de recolección de cinco obradas de trigo. Villaverde, 1590

\begin{tabular}{|c|c|c|c|c|c|c|}
\hline & Cargas & Heminas & Celemines & Total en fanegas & Total en $\mathrm{kg}$ & $\begin{array}{c}\text { Rendimiento } \\
\text { kg/obrada }\end{array}$ \\
\hline Producción & 11 & 5 & 2 & 46,50 & $2.046,16$ & 409,23 \\
\hline Pago de diezmo & 1 & 1 & 2 & 4,6 & 205,33 & \\
\hline Pago de primicia & & 1 & & 0,5 & 22 & \\
\hline Siega, acarreo, trilla, & & & & & & \\
\hline limpia y meter en casa & 3 & & & 12 & 528 & \\
\hline Queda neto & & & & 29,33 & 1.290 & 258,16 \\
\hline
\end{tabular}

Fuente: Archivo Histórico Provincial de Valladolid. Protocolos Notariales. Elaboración propia.

Como puede apreciarse, los rendimientos de trigo por obrada son muy parejos en relación al anterior ejemplo: 409 kg en Villaverde y 414 kg en La Moya. Llama la atención, sin embargo, cómo los pagos del diezmo, primicia y recogida del fruto se llevan por sí solos el 37\% del total de la producción. Cuando a ello se sumen, como se verá, el resto de gastos de producción, la mengua de kg vaciará la panera de los productores hasta límites difíciles de imaginar, sea cual sea el rendimiento por obrada del cereal.

Estas producciones se alcanzan sin reparar en dichos gastos, pues barbechar siempre fue una tarea onerosa. O se dan tres vueltas a tiempo en estas tierras al sur del Duero o no se coge cosecha al año siguiente. En los contratos de arrendamiento que el señor de Serrada hace en 1581 de sus tieras de vega, las más feraces con diferencia de todo el entorno, se estipula que los renteros las "an de lebantar al fin del mes de febrero" y que a las que tocaren barbechar deben darles las consabidas "tres bueltas" ${ }^{372}$. Inventarios, obligaciones y conciertos así lo registran. Un ejemplo es el que se firmó en agosto de 1593 en la villa de Serrada ${ }^{373}$ :

\footnotetext{
${ }^{371}$ A.H.P.V. Pt. 8288, fol. 533. Tanto en este cuadro, como en los sucesivos que hagan referencia a beneficios netos debe tenerse en cuenta que, aunque se incluyan como gastos de producción las distintas labores de los cultivos, buena parte de ellas las realiza el titular o la propia familia, por lo que, en realidad, no son pagos realizados sino la valoración de su propio trabajo. Esta apreciación es vital para alcanzar beneficios en las pequeñas y medianas haciendas; en las de mayor entidad el titular dirige la explotación y todas las labores manuales las realizan criados y jornaleros contratados al efecto.

Por otro lado, debemos recordar que las medidas de capacidad en cereales son la carga, equivalente a cuatro fanegas y la fanega, cuya medida de capacidad es de unos 55,5 litros aprox. El peso de cada fanega depende de la granazón del cereal, estimándose, por regla general, que la fanega de trigo pesa unos 44 kilogramos; la de la cebada caballar, unos 33 $\mathrm{kg}$ y el centeno, otros 44. La hemina. equivale a 1/8 de carga o media fanega y el celemín a 1/12 parte de fanega.

372 A.H.P.V. Pt. 11836.

${ }^{373}$ A.H.P.V. Pt. 11841 , fol.397.
} 
“...se apreció y baluó por los dichos nombrados quarenta obradas de tierras, que al presente estan abarbechadas de tres bueltas cada obrada, que las dichas abarbechadurías fueron baluadas y tasadas en quarenta ducados que balen quinze mil maravedíes...”.

Para llevar a cabo estas tareas en la mayor parte de las haciendas, al margen del trabajo que realizan los propios labradores, se contratan huebras para acabarlas a tiempo. En las grandes y medianas labranzas no faltan criados que van detrás de la pareja de bueyes o mulas y apenas salen de las barbecheras. A finales de esta centuria del seiscientos, un año de trabajo para "serbir... desde el dia de san miguel de setiembre... a san miguel de setiembre del año que viene... e andar trabajando... con un par de bueyes..." cuesta cuarenta ducados (15.000 mrs o 441 reales) que, para hacerse una idea, y de acuerdo a los ejemplos que se acaban de entresacar, es el gasto de barbechar cuarenta obradas o lo que rinden en bruto 4,34 obradas de trigo, cantidad, pues, nada despreciable ${ }^{374}$. O se dispone de tierra fértil en abundancia o el campesino medio debe ir sujetando la esteba, si no quiere correr el riesgo de arruinarse tras una mala cosecha. Piénsese que, al margen de estos gastos, en estas villas buena parte del mejor terrazgo es de mayorazgo y, del monto total de la cosecha, una parte se entrega como renta al seńor de la villa.

Distinto es el caso del resto de las tareas que lleva el cereal. La siega y trilla ocupa a la familia propietaria y reclama más brazos para poder llevarla a cabo sin dilaciones que la pongan en peligro. Para asegurar en lo posible que los trabajos se ejecuten con seriedad, se conciertan, en ocasiones, escrituras entre partes que garantizan que la labor se realiza en tiempo y forma.

En la segunda mitad del XVI, segar una obrada de pan viene a costar 15 reales, al margen de la entrega de determinada cantidad de vino, queso y tocino, tal como reflejan distintos ajustes de conciertos consultados $^{375}$. Estas escrituras, por lo general, se firman sobre la totalidad de las tierras de sembradura de las medianas y grandes labranzas, sea trigo, cebada o centeno el grano a recoger y se alzan por un tanto la obrada, toda vez que forman las cuadrillas hombres, mujeres y niños que se reparten las distintas

${ }^{374}$ A.H.P.V. Pt. 11839, año 1590, fol.637. Escritura de conçierto entre Francisco Hernandez y Simón Calvo. “..E dijeron quellos son conçertados en esta manera. En que dicho Simon Calbo se obliga de serbir y que serbira al dicho Francisco Hernández moreno un ano que comenzo a correr e corre desde el día de San Miguel de setienbre pasado deste presente año de mill e quinientos y nobenta y un anos acta el día de san miguel de setiembre del año que biene en la aministración y labores dela acienda quel dicho Francisco Hernández tiene en esta dicha billa y en las binas que tiene en los términos della y en todo lo demás que fuere ser serbido... Y demas de lo susodicho el dicho Symón Calbo se obliga de andar trabajando y que trabajara con un par de bueyes del dicho Francisco Hernández y les a de dar de comer con qual costo que los dichos bueyes hizieren en la dicha comida de ser por quenta del dicho Francisco Hernández con que por rrazón del dicho serbiçio el dicho Francisço Hernández moreno a de dar y pagar al dicho Symón Calbo y a quien su poder oliere cuarenta ducados de valor de trecientos y setenta y cinco mrs cada uno...”

375 Pt. 11839, año 1591, fol. 474. Escritura que otorgaron po Gil y Bernabé de Montejo sobre la beneficiaçion del trigo. En la villa de Valdastillas jurisdicción de Vallad a beynte y siete días del mes de Junio de mill e quinientos y nobenta y un años por ante mi antonio de medina scriuano rreal del $n^{\circ}$ de la dicha villa parecieron presentes de la una parte Pedro Gil y de la otra Bernabé de Montejo el mozo anbos vos de la dicha villa e dijeron queran conbenidos y concertados en esta manera. Que el dicho bernabé de Montejo a de segar.... al dicho Pedro Gil beynte y quatro obradas de pan que tiene sembradas en tierras que tiene de la jurisdicción desta dicha villa, mas o menos, por que en ellas obiere asy de trigo como de cebada y zenteno de las quales no a de alzar mano asta no acabar desde el día quel dicho Po Gil le diere abiso y los dichos panes en tendieren condición para se poder segar para cuya beneficiaçión con su persona a de meter la gente necesaria y se le a de dar por cada una obrada quince reales y demás dellos media cántara de bino y un quarterón de queso y otro de tocino y una carretada de paja en todo trillada todo lo qual se le a de ir dando y pagando como fuere trabajando y para quenta del dinero que montare ha de dar seis heminas de trigo en grano que se a de contar a rrazón de cincuenta y seis reales por carga y para la dicha siega a de darles de hordinario dos... sin su persona... Quisiere que baya a la dicha siega a trabajar en ella Po Gil ... le a de poder ynbiar y se le a de pagar todos los días que trabajare descontando del principio al lo que se montaren en los dichos días y declararen las personas que andubieren en la dicha siega que merece el dicho Po Gil y acabada la dicha siega se a de medir las tierras contandose unas y otras a raçon de cuatrocientos palos por obrada y de las que ubiere se a de quitar obrada y media que le interese le a de perder el dicho bernabe de Montejo y la declaración quel dicho pan no se a de cortar muy alto ni muy bajo que se a de ser en buena perfección a bista y contento de onmbres que entiendan y cogerse y apanarse con mucho cuidado y si en esto hubiere 
labores, de acuerdo a su fortaleza física. Como se puede comprobar en las notas al pie, desde estos siglos se concede gran importancia a la comida que el propietario debe entregar a los jornaleros, por lo general con escasos recursos para hacer frente a un trabajo tan exigente. El vino está presente en buena parte de las obligaciones firmadas. Amador del Torneo obliga a segar en La Seca a Pedro Pérez todo el pan que tubiere "...así trigo como cebada y centeno a raçón cada una obrada de labrado de doce reales y media cántara de bino... ${ }^{376}$. Las labores se concretan de forma minuciosa, pues se trata de uno de los momentos más cruciales del año. En el primer caso, "dicho pan no se a de cortar muy alto ni muy bajo, que se a de ser en buena perfección a bista y contento de ombres que entiendan y cogerse y apanarse con mucho cuidado" $\mathrm{y}$, firmada la escritura con fecha de 27 de junio de 1591, "no a de alzar mano asta no acabar desde el día quel dicho Po Gil le diere abiso y los dichos panes en tendieren condición para se poder segar"377.

Aunque es de entender que se venía haciendo secularmente en el espacio estudiado y, por ende, en toda Castilla, son estas fechas las que alumbran documentos escritos que dejan constancia notarial de lo que cuesta cada labor y cómo debe ejecutarse. La siega de la cebada se inicia desde finales de junio para, terminada esta, proceder con el trigo y centeno. El pan alzado debe trasladarse a las eras para su aparvado, trilla y limpia. En 1590, el escribano Antonio de Medina da fe en Valdestillas de un concierto entre partes para acarrear, parvar, trillar y limpiar el pan segado procedente de 26 obradas, repartidas entre los términos de La Moya y la citada Valdestillas, por cuantía de 24 ducados (9.000 maravedís) que, repartidos entre dichas obradas, suman otros 10 reales por cada obrada. Por su detalle e interés merecen ser reproducidas ${ }^{378}$ :

daño le a de pagar el dicho bernabé de Montejo consola la declaración de los apeadores y personas que fueren nombradas... Cualquier causa que subceda e pueda subcedere hubiere falta en segar todo el dicho pan de las dichas tierras y en amorenarlo y allegarlo en ellas aciendo ausencia estando para lo poder segar de doce días naturales quel dicho Pedro gil pueda darlo a segar a quien quisiere y por bien tubiere y por lo que más costare de lo que dicho es quel dicho perdo Gil lo pueda cobrar y cobre del dicho bernabe de Montejo..."

${ }^{376}$ A.H.P.V. Pt. 6472, fol.52. En este sentido, el 24 de junio de 1596 Fernando Pocero se obliga a segar en La Seca a Esteban Andrtés y a Marcis Pérez "ocho obradas de trigos y centenos... a precio cada una obrada de a once reales y media cántara de vino...” (A.H.P.V. Pt. 6468, fol.205).

377 Ibídem.

378 A.H.P.V. Pt. 11838.Año 1590.Fol. 494. 26 de julio. Escritura de concierto entre herederos sobre la benefiçiaçion del pan. En la villa de Valdastillas a beynte y seis días del mes de jullio de mill e quinientos y nobenta años por ante mi Ant ${ }^{\circ}$ de medina escriuano rreal y del numero della ... aparecieron $\mathrm{p}^{\circ}$ Gil y Po Caballero como maridos y conjuntas personas de Ysavel e Ana Belazquez sus mujeres de la una parte y Alo Garc ${ }^{a}$ y y andrés garrido el moço como maridos y conjuntas personas de maría y catalina belázquez sus mujeres de la otra, todos $\mathrm{v}^{\mathrm{o}} \mathrm{s}$ de la dicha villa e dijeron que dicho difunto al tiempo de sus fin y muerte dejo sembradas beynte y seis obradas de tierras poco mas o menos de trigo cebada y centeno, todo lo cual esta pro indiviso y se a de costear y beneficiar por quenta de todos sus herederos. Agora para beneficiar estan conbenidos y conçertados con los dichos Po y Xristoval Caballero en esta manera: de que el dicho pan lo an de traer en rrama desde las tierras donde al presente esta segado a la hera desta dicha villa donde lo an de tender aciendo dello las parbas necesarias las quales y cada una de ellas an de trillar, barrer y amontonar poniéndolas en toda perfección segund y como es costumbre en esta dicha villa para las poder limpiar la qual dicha beneficia se a de començar desde oy día de la fecha desta escritura en adelante y cada seis días de los que fueren de trabajo se an de hacer dos parbas trilladas e barridas y amontonadas sin aloca mano, de lo suso dicho a esta tanto quel dicho pan se acabe de poner en toda perfección y en esta orden se a de tener en la dicha beneficiaçion no ynpidiendo el tiempo lo que dicho es con agua o con otros casos del cielo e de la tierra, porque sucediendo los dichos casos sea de aguardar que aga tiempo para lo poder a secar y este llegado sea de tener la dicha horden de hacer las dichas dos parbas cada seis días y de la limpia del dicho pan a de ser por quenta de todos los susodichos y para con la dicha beneficiaçion y del trabajo que los (fol. v) Dichos $\mathrm{p}^{\mathrm{o}}$ Ballest ${ }^{\mathrm{o}} \mathrm{y} \mathrm{p}^{\mathrm{o}}$ Gil an de poner en acarrear y trillar, barrer y amontonar el dicho pan se les a de dar beynte y quatro ducados que balen nueve mill mrs pagados del monton que todos los dichos quatro herederos en los quales los dichos $\mathrm{p}^{\circ}$ Gil y $\mathrm{p}^{\mathrm{o}}$ Ballestero an de contribuyr pro rrata la parte que cada uno le conpetiere de manera quel dicho Alonso ga $\mathrm{y}$ andrés garrido an de pagar tan solamente quatro mil quinientos mrs los quales an de pagar a los dichos $\mathrm{p}^{\circ} \mathrm{Gil}_{\mathrm{y}} \mathrm{p}^{\circ} \mathrm{Ba}-$ llestero y para la cobranza los suso dichos y cada uno dellos...Y es declaración que las alimanas que trillaren y acarrearen el dicho pan no an de poder comer del dicho pan..." 
“...el dicho pan lo an de traer en rrama desde las tierras donde al presente está segado a la hera desta dicha villa donde lo an de tender, aciendo dello las parbas necesarias, las quales y cada una de ellas an de trillar, barrer y amontonar, poniéndolas en toda perfección segund y como es costumbre en esta dicha villa para las poder limpiar, la qual dicha beneficia se a de començar desde oy día de la fecha desta escritura en adelante, y cada seis días de los que fueren de trabajo se an de hacer dos parbas trilladas e barridas y amontonadas sin aloca mano, de lo suso dicho a esta tanto quel dicho pan se acabe de poner en toda perfección y en esta orden se a de tener en la dicha beneficiaçion, no ynpidiendo el tiempo lo que dicho es con agua o con otros casos del cielo e de la tierra, porque sucediendo los dichos casos sea de aguardar que aga tiempo para lo poder a secar, y este llegado sea de tener la dicha horden de hacer las dichas dos parbas cada seis días y de la limpia del dicho pan a de ser por quenta de todos los susodichos...”

Recogido el pan y una vez satisfecho el diezmo, llega la hora de pagar rentas y débitos en trigo, pan mediado o moneda. Contratos de arrendamientos y obligaciones fijan, en la mayor parte de los casos, la costumbre de que lo estipulado se ha "de dar y pagar por el día de nuestra Señora de agosto de cada un año... ${ }^{3} 79$. También hay casos, toda vez que por estas fechas no se ha terminado de meter el grano en la panera, o se han entregado tierras barbechadas listas para ser sembradas, u otorgado el derecho a sembrar melones en ellas, que los dineros serán "pagados la mitad dellos para primero de setiembre y la otra mitad al dicho cumplimiento para el día de todos los santos... en la qual dicha suma ba comprendidas las araduras que al presente tienen las dichas tierras... en el qual dicho tiempo abeis bos el dicho Andrés redondo de poder sembrar en las dichas tierras y en cualquiera dellas melones y las demás semyllas a vra. voluntad..."338.

Pero pagar no siempre será posible. No todos los renteros, y se habla de renteros porque buena parte de las haciendas campesinas están constituidas de acuerdo a toda una tipología de arrendamientos, pueden afrontar, amén del diezmo, el pago de las pequeńas deudas, huebras debidas, salarios, réditos de censos, alcabalas, servicios reales, misas de aniversarios..., que cumplen por este tiempo, con lo que el endeudamiento puede ir creciendo hasta que la muerte lo remedie y los contadores, tras verificar los bienes, saquen en almoneda pública cuanto se necesite para poner fin a los abultados cuerpos de deudas y, en muchos casos, certificar el fin de una labranza.

En el cuadro adjunto, que resume las cuentas que rindieron Alonso e Isabel Corroto en 1589 al resto de herederos de la hacienda de sus padres, podemos comprobar las siembras, producciones y gastos que lleva una labranza de 20 obradas de sembradura ${ }^{381}$. Se observa, en relación con el anterior ejemplo de Francisco Martín, que los rendimientos por obrada son un $25 \%$ más bajos $(329 \mathrm{~kg}$ frente a $436 \mathrm{~kg}$ por obrada), sea por la calidad de las tierras, las condiciones metereológicas o las labores que hayan realizado. Los gastos registrados, igualmente, se tasan de forma más económica que los valores encontrados en otros acuerdos hallados por estas fechas, posiblemente relacionados con la menor producción recogida.

A pesar de estos condicionantes se pueden, no obstante, hacer ciertas valoraciones. Dejando al margen la importante carga de reales que se van en deudas y donaciones religiosas para pagar las obligaciones pendientes de los difuntos padres, lo que resulta claro es que, con estas producciones y precios, los gastos igualan a los ingresos. Si a los 1.121 reales que suman la cosecha de grano y paja, restamos los gastos de producción declarados, más 281,74 reales de simiente y 367,64 reales de tres vueltas de barbechera y dos en sementera, esta labranza suma unos gastos, satisfecho el diezmo, de 1.106 reales, por lo que quedan unos ingresos netos, en dichas 20 obradas de sembradura, de 15 reales, cantidad simbólica con la que apenas se pagarían la guarda del pan, alcabalas y servicios reales. La baja producción recogida cercena cualquier posibilidad de beneficio. Si estos herederos no cogen buena cosecha, tienen los días contados. No tardan en sacar los bienes en almoneda pública. Sólo trabajando directamente la heredad, si acompaña la metereología y no se tienen demasiados censos pendientes, el campesino del XVI puede vivir con una labranza de veinte obradas de sembradura, acompañadas de otras tantas de barbecho.

\footnotetext{
379 A.H.P.V. Pt. 11837, año 1588, fol. 18.

380 A.H.P.V. Pt. 11838, año 1590., fol. 498.

${ }^{381}$ A.H.P.V. Pt. 11838, fol. 108.
} 


\section{Cuadro 14. Fruto e ingresos obtenidos en 20 obradas de tierras de sembradura y en el vińedo de los Hdos. de Alonso e Isabel Corroto, año 1589}

\begin{tabular}{|c|c|c|c|c|c|c|c|}
\hline Aprovechamiento & $\begin{array}{c}\text { No de } \\
\text { obradas } \\
\text { sembradas }\end{array}$ & $\begin{array}{l}\text { Producto } \\
\text { recogido } \\
\text { (cargas) }\end{array}$ & $\begin{array}{c}\text { Rendimiento } \\
\text { por obrada } \\
(\mathrm{kgs})\end{array}$ & $\begin{array}{l}\text { Quedan tras } \\
\text { el diezmo } \\
\text { (cargas) }\end{array}$ & $\begin{array}{c}\text { Precio } \\
\text { cada carga } \\
\text { (reales) }\end{array}$ & $\begin{array}{l}\text { Totales } \\
\text { (reales) }\end{array}$ & $\begin{array}{c}\text { Reales por } \\
\text { obrada }\end{array}$ \\
\hline Trigo & 10,75 & 20 & 327 & 18,25 & 43 & 784 & 72,9 \\
\hline Cebada & 9 & 30 & 396 & 27 & $24 / 23$ & 624 & 69,3 \\
\hline Centeno & 0,25 & 1,65 & 264 & 0,37 & 26 & 10 & 40 \\
\hline Total cereales & 20 & 66,65 & 329 & 45,62 & & 1.418 & 70,9 \\
\hline INGRESO CEREALES & 987 & & & & & & \\
\hline Paja & & 7 carros & & & & 134 & 6,7 \\
\hline Vino & & & & 11 moyos & 54/moyos & 594 & \\
\hline INGRESOS PAJA & & & & & & & 134 \\
\hline INGRESOS VINO & & & & & & & 594 \\
\hline INGRESOS TOTALES & & & & & & & 2.146 \\
\hline
\end{tabular}

Gastos declarados en trabajos de recogida del fruto

\begin{tabular}{lccc}
\hline Labores/productos & No de obradas & Total (rs) & Reales/obrada \\
\hline Siega & 20 & 255 & 11,02 \\
10 cántaras de vino & 20 & 55 & 2,75 \\
2 libras de tocino y 3 de queso & 20 & 4 & 0,2 \\
Acarrear, trillar y llevar paja y pan & 20 & 128,29 & 6,41 \\
Vendimia & & 84,14 & \\
Otros salarios & & 15 & 541,43 \\
\hline TOTAL GASTOS
\end{tabular}

Pago de deudas, donaciones y otros gastos

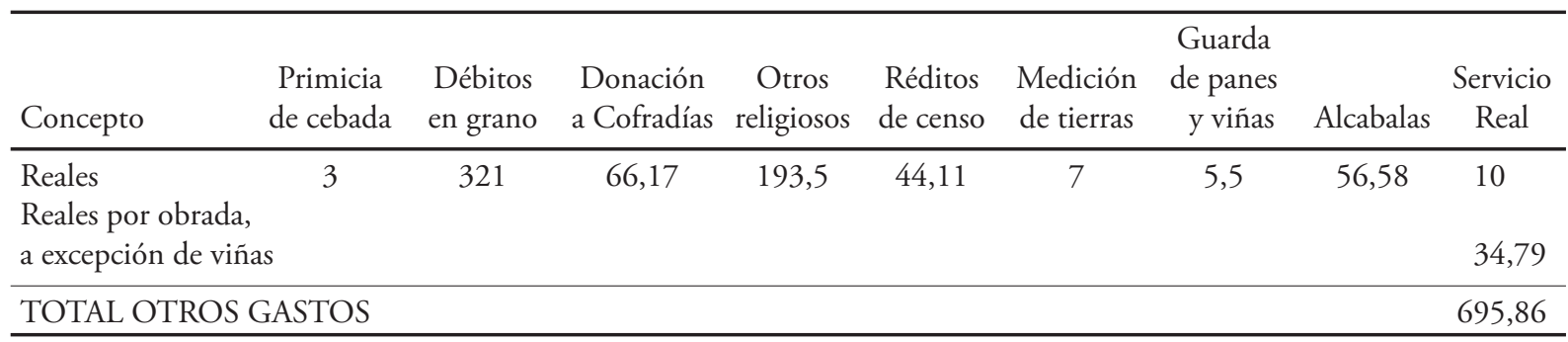

Resumen de gastos e ingresos a falta de deudas (reales)

\begin{tabular}{lr}
\hline INGRESOS TOTALES (PAN Y PAJA) & 1.121 \\
GASTOS BARBECHERA, SIMIENTE Y SIEMBRA & 649,38 \\
GASTOS RECOGIDA DEL FRUTO & 457,29 \\
INGRESOS NETOS & 15 \\
\hline
\end{tabular}

Fuente: Archivo Histórico Provincial de Valladolid. Protocolos Notariales. Elaboración propia. 


\section{Cuadro 15. Estimación de gastos, producción e ingresos de una obrada de sembradura de trigo en cultivo de ańo y vez en Tierra de Medina ${ }^{382}$. Años 1575-1600}

\begin{tabular}{|c|c|c|c|}
\hline \multicolumn{2}{|c|}{ GASTOS } & \multicolumn{2}{|c|}{ INGRESOS } \\
\hline Labores realizadas & Reales & Producción & Reales \\
\hline 3 vueltas en barbechera & 11 & 9,25 fanegas de trigo & 108 \\
\hline Arada, siembra y tapado & 9 & Paja & 8 \\
\hline Simiente (1,5 fanegas) & 18 & & \\
\hline Siega (incluyendo vino) & 15 & & \\
\hline Acarreo, trilla y limpia & 10 & & \\
\hline Diezmo y primicia & 12 & & \\
\hline Rentas de capital y otros & 23 & & \\
\hline TOTAL GASTOS & 98 & TOTAL INGRESOS & 116 \\
\hline BENEFICIO NETO & & 18 & \\
\hline
\end{tabular}

Fuente: Archivo Histórico Provincial de Valladolid. Protocolos Notariales. Elaboración propia.

El cuadro adjunto recoge una estimación completa de las labores, gastos e ingresos en una obrada de sembradura en el que se puede confirmar cuanto exponemos. La posesión de la tierra se torna fundamental para salir airoso a final de ańo. Piénsese que, en el primer ejemplo comentado, Francisco Martín coge a $414 \mathrm{~kg}$ de trigo por obrada, pero ha de entregar un par de fanegas por obrada de buena parte de ellas como renta al mayorazgo de los Vega de La Moya.

Como se ha tratado y se continuará constatando a lo largo de este estudio, el pago de rentas es uno de los mayores lastres que soporta el campesino castellano en estos siglos. Aun sin esta carga, la rentabilidad de las tierras de sembradura viene dada por el propio esfuerzo del campesino en su heredad. Es en su trabajo diario y, si acompaña el tiempo, donde radica el beneficio. Como reflejan los datos del cuadro adjunto, si se dan las labores a realizar sólo en años de excepcional cosecha y precios altos, la actividad es rentable en términos estrictamente monetarios. Prueba de ello es la importante presencia en los protocolos notariales de cuentas de curadores depositarios de bienes tras el fallecimiento de progenitores. En ellas se registran las rentas generadas por tierras y viñas heredadas por menores o viudas. Pocas veces estas labranzas se llevan directamente, dando a hacer las labores. Se prefiere su arrendamiento hasta que el menor pueda hacer frente a la heredad, caso de que no tenga que ser vendida, pues, en cuanto se tuercen las haciendas, la descapitalización del campesino conduce irremediablemente a la disolución y atomización de bienes muebles y raíces. De ahí la obsesión del campesino por conseguir más tierra, a poder ser propia, para producir más y subir los beneficios. La producción se incrementa conforme lo hace la superficie a lo largo del siglo XVI, no porque aumenten las fanegas por obrada sembrada. Como también ha quedado expuesto, se pueden anotar algunos reales derivados de semillas puntuales en las barbecheras, pero su representatividad es insignificante en el cómputo total. Siempre que la superficie

${ }^{382}$ En las labores y precios apuntados, se ha tomado como referencia la media de los precios concertados entre partes y registrados notarialmente en distintos lugares de la Tierra de Medina entre los años 1575-1600. La producción de trigo y paja se estima en tierras trigueras, esto es, de calidad media y alta. En el registro de rentas de capital, se engloba una valoración estimada del coste de amortización de capital, deudas censales inherentes a la propiedad y otros gastos, tales como la guarda y vela del pan en el campo, alcabalas y otros gastos varios siempre posibles como, por ejemplo, el escarde de gatuńas, mielgas, grama u otras hierbas que, en ocasiones, se registran en las tierras de barbechera antes de la sementera. Como se ha explicado, debemos considerar que el aporte del trabajo familiar es fundamental para asegurar la rentabilidad del campesino, así como otros elementos no computados, tales como otros productos de autoconsumo, al margen de los cereales, sean de origen animal o vegetal, fundamentales siempre en su supervivencia. Ello no resta importancia, no obstante, a lo vital que resulta realizar las tareas "a tiempo", o que la cosecha sea "bendecida" por unas condiciones atmosféricas favorables. No es necesario advertir que, en el caso de administradores o curadores encargados de llevar las heredades de menores de edad, pocas veces se rinden beneficios, por tener que dar todas las tareas a realizar y por otras causas, facilmente imaginables. 
cultivable sea abarcable, el viñedo se presenta como un complemento en tanto mantiene ocupado al campesino y a los animales de labor a lo largo del año ${ }^{383}$. A falta de propiedad los majuelos, se plantan en terrenos de Propios o de mayorazgos a precios asequibles. Se trata de sumar reales a las ganancias de las tierras de sembradura, aunque procedan de trabajos propios más que de beneficios netos de explotación.

\section{b. El viñedo en la segunda mitad del siglo XVI. Sistemas de cultivo, producciones y rentabilidad}

El vińedo se consolida a lo largo del siglo XVI en el norte de la Tierra de Medina como un cultivo complementario al cereal, en una economía campesina que se abre definitivamente al mercado. El cereal es el aprovechamiento por excelencia en las tierras de mayor calidad y el perdedor, como se ha estudiado, es el monte e, indirectamente, la ganadería, que ve reducidos los antiguos y vastos espacios montaraces que se extendían por doquier.

El crecimiento económico y demográfico que vive Castilla posibilita en buena medida este arraigo. El vińedo necesita brazos y capital para hacerlo prosperar y, cuando no se dispone de este, caso de jornaleros y pegujaleros, brazos para arrancar de las tierras más estériles algún real para acabar el ańo. No hay que olvidar, en fin, que este arbusto requiere tiempo para conseguir fruto e importantes inversiones en la transformación, conservación y venta de los mostos y vinos.

Si nos extendimos en el análisis del medio físico al comienzo de estas páginas, no fue por ningún tipo de ortodoxia académica. Era un imperativo agronómico. Desde tiempo histórico y, especialmente en estos tiempos modernos, las gentes que necesitaron sobrevivir extrayendo del medio sustento para sí y para sus ganados constataron el enorme potencial de estos suelos de gravas. Las razones han sido analizadas: el suelo no produce otro aprovechamiento, muchos pertenecen a bienes de Propios o a mayorazgos con posibilidad de acceder a su labranza y su altitud libera al arbusto de las heladas primaverales, en mayor medida que los suelos arenosos de las campiñas del sur. La documentación consultada da fe de la importancia que adquiere el vińedo en determinados pagos, la necesidad de abrir caminos para su laboreo y el progresivo agrupamiento del arbusto en hojas de cultivo caracterizadas por su idoneidad edáfica. No tardan los litigios entre concejos y propietarios por la regulación de esta creciente riqueza. Un ejemplo es la petición que se realiza en 1494 al corregidor de Medina para que haga justicia a vecinos de Zofraga, Torrecilla del Valle y Carrioncillo que han hecho un camino que atraviesa un pago de viñedo, a fin de ir por él a la villa de Medina, cuando disponen de uno antiguo que atraviesa dicho pago ${ }^{384}$.

${ }^{383}$ Tras la sementera del pan se inician las labores de excavo, arada de rama y poda en los vińedos antes de levantar las pajas en febrero. Luego se sigue por la aradura de marzo en las vińas y la segunda vuelta en las barbecheras antes de la aradura de mayo en el vińedo. La tercera vuelta en los barbechos mete al campesino en la recogida del pan antes de la vendimia que se realiza en octubre cuando la mayor parte de los sembrados están verdegueando. Un nuevo ciclo vuelve a iniciarse.

${ }^{384}$ Se trata del pago de Torrubio, en tierras de Propios de Medina: "Don fernando e dońa ysabel etc a vos el corrro $\mathrm{ju}^{\mathrm{o}}$ prs de barradas nro corrr ${ }^{\circ}$ de la vi ${ }^{\mathrm{a}}$ de $\mathrm{m}^{\mathrm{a}}$ del canpo o a vro allde en el dho ofiçio e a cada vno de vos a quien esta nra nra [sic] ca $^{a}$ fuere mostrada salud e gra ${ }^{a}$ sepades que por pte de los vs ${ }^{\circ}$ desa dha villa que tienen vińas en el pago de toRuvyo ques termi ${ }^{\circ}$ desa dha vi ${ }^{\mathrm{a}}$ nos fue fecha Relaçion por su petiçion disiendo que agora nuevamente en el dho pago se han puesto muchas vińas e los $\mathrm{vs}^{\mathrm{o}}$ de los lugares de çofraga e toReçilla del valle e carrionçillo despues que las dhas viñas se han puesto a causa de tener entrada $\mathrm{pa}^{\mathrm{a}}$ comer con sus ganados las dhas vińas dis que han dexado e dexan el camyno Real que hasta aqui tenian por do venyan a esta dha vi a e por do van e vienen a sus labranças e dis que han fecho un camyno nuevo por medio del dho pago e dis que como quiera que han seydo Requeridos $\mathrm{pa}^{\mathrm{a}}$ que no hagan el dho camyno por ser en mucho daño e perjuysio suyo dis que no lo han querido ni quieren haser ponyendo a ello sus escusas e dilaçiones yndevydas lo qual dis que sy asy pasase ellos Resçibirian grand agrauyo e dańo e nos suplicaron çerca dello les mandasemos proueer por manera que los vs ${ }^{\circ}$ de los dhos lugares vayan por el camyno que antiguamente solian yr pa las dhas viñas e que no abran nuevo camyno en su perjuysio o como la nra mrd fuere e nos touymoslo por bien por que vos mands ${ }^{\circ}$ que luego veades lo suso dho e llamadas y oydas las ptes...”. Transcipción: F. Javier Vela Santamaría. (A.G.S., RGS, R.G.S., leg, 149410,74) 
Otro ejemplo, unos siglos más tarde, es la representación hecha a su majestad por el Alcalde mayor de la Villa de La Seca, solicitando permiso para plantar majuelos en el terrazgo de los montes Ynestoso y Pedroso, pagando el canon correspondiente. En este caso se argumenta la conveniencia de estos suelos sueltos y pedregosos como los más aparentes para viñas, porque evitan que los majuelos se críen en tierras de pan llevar "y por eso se ven tantos plantíos en tierras gruesas, fertilísimas, y que darian pan en abundancia, de que resultan daños notorios en este Pueblo" "385; de otra parte, por cuestiones edáficas, pues en estas tierras ligeras el viñedo se cría mejor y envejece más tarde que "en tierra de sustancia...", donde se ha experimentado que "a pocos años se envejecen y no fructifican a menos que no se replanten de continuo las cepas, que es lo que a cada paso se nota en esta villa...". Por último, porque el monte, en el estado en que se halla, "por ser guija y arena", no produce pasto alguno, "mostrándose por lo común... áridos y secos", mientras que, de plantarse, una vez alzado el fruto, se aprovecharían sus hojas y hierbas otońales por el ganado, antes de su arada invernal de rama ${ }^{386}$.

\section{- La plantación del majuelo}

En unos u otros lugares, definido este tipo de suelo guijarroso como el más idóneo para el cultivo, los conciertos escriturados entre partes detallan de forma precisa los distintos trabajos. La plantación de nuevos majuelos se realiza a mediados de febrero sobre tierras bien labradas, barbechadas y limpias de grama. El marco es en cuadrícula o marco real, teniendo a la aranzada como unidad de medida y en la que se plantan entre 400 y 500 cepas, atendiendo a los distintos lugares, pero siendo lo más común 420 cepas (1.100 cepas/ha). Para ello se abren hoyas en el lugar que han de colocarse los majuelos o sarmientos escogidos, que, prendidos y si no se agostan, formarán las futuras cepas. Estos trabajos, por ejemplo, se detallan de forma precisa en la escritura firmada en Valdestillas en 1574 entre Diego Román y Santa Cruz Merino. La plantación de una aranzada de cuatrocientas veinte cepas, sin contar los trabajos preparatorios, viene a costar unos 25 reales $^{387}$ :

385 A.M.M.C., caja 254-40, "Representación hecha a S. M. por el Alcalde mayor de la Villa de La Seca solicitando permiso para plantar de maxuelos el terrazgo de los Montes Ynestoso y Pedroso pagando un canon correspondiente".

${ }^{386}$ Ibídem. En Serrada y La Moya, por su parte y como se ha tratado, los mayorazgos de los Montalvo y de los Vega, respectivamente, abren la posibilidad a comienzos del XVII de incrementar las plantaciones mediante el otorgamiento de censos perpetuos. Una vez conseguida la facultad real, labradores y jornaleros pujan por hacerse con algunos pedazos pero sin alardes monetarios, pues no ofrecen en las pujas más de tres reales o tres reales y medio por obrada. Sólo un tal Juan de Yepes sube la postura a cuatro reales menos un cuartillo. Las arcas de Ruiz de Montalvo, en cambio, incrementan su cuantía en "tres mil y quinientos o quatro mil reales de renta". Un ejemplo de escritura lo tenemos en el vecino Domingo Caballero. Toma a censo cuatro obradas "al camino de la Seca" por precio de "catorze reales que balen cuatrozientos y sesenta y seis maravedis" de renta y censo perpetuo en cada un año. Se obliga al pago de esta cuantía en los primeros días del "mes de diziembre del año que bendra de myl y seiscientos y veinte y tres años" y durante los siguientes cuatro años estará obligado a tener plantados en las citadas tierras los referidos majuelos de la siguiente manera: “...y lo ha de yr continuando, fin de dexar dello mano; de manera que al fin de dicho tiempo este asentada y pressa la dicha vińa, do de no, el dicho don Juan Antonio de Montalvo e los dichos sucesores pueden hazer plantar y meter en la dicha tierra las dichas viñas a costa del dicho Domingo Caballero cobrando del y sus bienes el dinero necesario para este efeto..." (A.H.P.V. Pt. 6487. Año 1644, fol. 194).

En el terrazgo de La Moya, donde hay pagos con suelos muy pobres el campesino, sabedor de que las rentas no se perdonan y las cosechas nunca son seguras, esperará tiempos mejores y “...de quinientas yugadas de tierras para plantar de vinas que tenía el dicho mayorazgo se vendieron setenta y dos obradas..., y las cuatrocientas y veinte y ocho restantes se quedaron por vender, las quales son tan flacas y de tan poco valor que no hay quien las quiera... "386. La fiebre plantadora tardará unas décadas más en llegar en el norte de la Tierra. (A.H.P.V. Pt. 5073, fol. 177 y ss.).

${ }^{387}$ A.H.P.V. Pt. 11836, fol. 21. El marco real es el sistema de plantación del que se tiene constancia en estos pagos desde épocas bajomedievales. La unidad de superficie utilizada es la aranzada. En La Moya se catastran 440 cepas por aranzada y en Serrada 420 cepas. 
"En Valdestillas a diez dias del mes de febrero de myl e quinientos e setenta y quatro años... parescio presente Santa Cruz merino, vecino deste dicho lugar, e dixo que tomaba y tomo a destajo de diego román... a hacer cuatrocientas oyas para plantar en ellas viñas, las quales hara tal tan buenas como las que el dicho diego román tiene hechas en una tierra que tiene en término deste dicho lugar que esta do dizen la cańada de Valderramos..., las quales cuatrocientas oyas a de dar hechas y acavadas dentro de quinze dias primeros siguientes de la fecha desta escriptura..., con que por razón de las hazer y atollar el dicho diego román le a de dar por cada una dellas a dos mrs por cada una dándole el dicho diego román majuelos para el dicho efecto...”

En los primeros años, los jóvenes majuelos llevan múltiples tareas de picado y mullido de la tierra, a fin de conservar el tempero y evitar que se agosten. Cuando esto ocurre hay que sustituir el majuelo seco por una nueva planta. Esta tarea se llama reoyar y también está documentada desde el siglo XVI. En Matapozuelos, en febrero de 1585, se ajusta dicha operación “...para que aoyaran un majuelo... que sean de tres quartas de ondo la que menos y enpeçarán a aoyar de su ruego e no deçarán mano della asta le acabar... "388. Estamos hablando, de acuerdo a las equivalencias al uso, de hoyas de $63 \mathrm{~cm}$, que llevan su tiempo y esfuerzo en los terrenos de gravas analizados. Como se ve, la pujanza del viñedo irá unida a la necesidad de brazos que cuiden cada aranzada, estación tras estación y año tras año. Nunca un cultivo alimentará tantas bocas por unidad de superficie. En esta primera fase de formación, es importante su vigilancia frente al ganado, especialmente cuando se alzan los frutos y se aprovechan las rastrojeras y pampaneras. Son frecuentes las denuncias por parte de los guardas de campo. En La Seca y, entre otros acaecidos a fines del XVI, se denuncia el daño sufrido en una nueva plantación ${ }^{389}$ :

"En el lugar de La seca, jurisdicción de medina del campo, a siete días del mes de setiembre de mil e quinientos y nobenta y ocho ańos..., Juan de frutos el moço y Rodrigo cepedón el viexo, apreciadores del concejo del dicho lugar, dijeron que abían bisto un majuelo de francisco nabarro el moço, ... que esta a la perdiz... el qual tenía ciento y cincuenta majuelos comidos y tenían de daño cuatrocientos maravedíes...”

La plantación de un majuelo es una inversión de futuro y complemento a las tierras de sembradura. La crianza estimada de una aranzada puede alcanzar, si no se descuida ninguna tarea, los $5.453 \mathrm{mrs}$ (160,41 reales), que es el precio en que puede ser tasada una vińa adulta y que viene a indicar que el coste mayor del vińedo, tanto en este tiempo como en la actualidad, es el invertido en sus primeros ańos. Ahorrar unos reales en los trabajos que recoge el cuadro adjunto es siempre la peor opción. A pesar de que pueda ser mal año, aquí sí que se puede aplicar el dicho de que el remedio es peor que la enfermedad. Piénsese que, como se verá más adelante, desgramar una aranzada de viña, en la segunda mitad del XVI, puede costar cincuenta reales, que es casi la mitad de su valor. En las jóvenes plantaciones, si la grama se apodera de la cepa, todo lo invertido puede darse por perdido. En Rueda en el año 1587, por ejemplo, se pacta una escritura para desgramar un majuelo de dos aranzadas a siete maravedís y medio la cepa, lo que supone 92,6 reales la $\operatorname{aranzada}^{390}$ y en Valdestillas, el 28 de octubre de 1589, se firma otra en la que el majuelo "daremos desgramado a cepa viba y grama muerta desde oy desta en adelante... por raçón de siete mrs cada una... y se a de contar salto por cepa..." "391. En Villaverde de Medina también se encuentra en 1588 cómo, además de la grama, deben de quitarse mielgas y gatuñas, que indican el tipo de malas hierbas que crecen en las viñas. Es el caso de la obligación que firma Marcos Jimeno respecto a una aranzada de viña para que "...me la cabeys y saqueys toda la grama, mielgas y gatunas della os tengo de dar por cada cepa tres mrs...."392.

388 A.H.P.V. Pt. 10585 , fol. 161

389 A.H.P.V. Pt. 6470, fol. 348.

${ }^{390}$ A.H.P.V. Pt. 8085, fol. 82. Francisco de Vergara y consortes se obligan ante Pascual Benito a “...desgramar... dos alançadas... a siete maravedies y medio por cada cepa y nos las hemos dejar linpias y desgramadas y recorridas una bez y hecho por el tiempo que se suele desmatar y lo hemos de dar desgramado desde aqui asta primero día del mes de mayo...".

${ }^{391}$ A.H.P.V. Pt. 11837, fol. 609.

392 A.H.P.V. Pt. 8287, fol. 10. 


\section{Cuadro 16. Estimación del coste de plantío y crianza de una aranzada de majuelo. Serrada-La Seca-Rueda, año 1595}

\begin{tabular}{|c|c|c|c|c|c|c|c|c|}
\hline \multirow[b]{2}{*}{$\begin{array}{l}\text { Trabajos } \\
\text { realizados }\end{array}$} & \multicolumn{2}{|c|}{ Primer año } & \multicolumn{2}{|c|}{ Segundo año } & \multicolumn{2}{|l|}{ Tercer año } & \multicolumn{2}{|c|}{ Cuarto año } \\
\hline & $\begin{array}{l}\text { No de labores } \\
\text { y caracteres }\end{array}$ & $\begin{array}{l}\text { Coste } \\
\text { (rs) }\end{array}$ & $\begin{array}{l}\text { No de labores } \\
\text { y caracteres }\end{array}$ & $\begin{array}{l}\text { Coste } \\
\text { (rs) }\end{array}$ & $\begin{array}{l}\text { No de labores } \\
\text { y caracteres }\end{array}$ & $\begin{array}{l}\text { Coste } \\
\text { (rs) }\end{array}$ & $\begin{array}{l}\text { No de labores } \\
\text { y caracteres }\end{array}$ & $\begin{array}{c}\text { Coste } \\
\text { (rs) }\end{array}$ \\
\hline $\begin{array}{l}\text { Plantas } \\
\text { y plantación }\end{array}$ & $\begin{array}{l}\text { Señalo y ahoyo. } \\
\text { Majuelos, } \\
\text { zarollo, relleno } \\
\text { y acorrullo }\end{array}$ & 25 & & & & & & \\
\hline Rehoyos & & & $\begin{array}{l}\text { Primer rehoyo. } \\
50 \text { hoyas. } \\
\text { Majuelos, relleno, } \\
\text { recorte y tapada }\end{array}$ & $\begin{array}{r}2,9 \\
4\end{array}$ & $\begin{array}{l}\text { Segundo rehoyo. } \\
25 \text { hoyas. } \\
\text { Majuelos, rellenos, } \\
\text { tapado y recortado }\end{array}$ & $\begin{array}{ll} & 1,4 \\
\text { s, } & \\
0 & 7\end{array}$ & $\begin{array}{l}\text { Tercer rehoyo. } \\
\text { Majuelos, } \\
\text { relleno, recorte } \\
\text { y tapadura. }\end{array}$ & 1 \\
\hline $\begin{array}{l}\text { Vueltas de arado. } \\
\text { Incluyendo } \\
\text { barbechera } \\
\text { previa el } \\
\text { primer año }\end{array}$ & $\begin{array}{l}6 \text { vueltas de } \\
\text { arado. (Pago } \\
\text { de salario } \\
\text { con ganado } \\
\text { propio) }\end{array}$ & 18 & $\begin{array}{l}3 \text { vueltas de } \\
\text { arado. (Pago } \\
\text { de salario } \\
\text { con ganado } \\
\text { propio) }\end{array}$ & 9 & $\begin{array}{l}3 \text { vueltas de } \\
\text { arado. (Pago } \\
\text { de salario } \\
\text { con ganado } \\
\text { propio) }\end{array}$ & 9 & $\begin{array}{l}3 \text { vueltas de } \\
\text { arado. (Pago } \\
\text { de salario } \\
\text { con ganado } \\
\text { propio) }\end{array}$ & 9 \\
\hline Picaduras & cinco & 12 & cuatro & 10 & cuatro & 10 & $\begin{array}{l}\text { Tres picaduras } \\
\text { y recorte de } \\
\text { podadera }\end{array}$ & 8 \\
\hline $\begin{array}{l}\text { Tapadura } \\
\text { de invierno }\end{array}$ & & 2 & - & 2 & - & 2 & - & - \\
\hline $\begin{array}{l}\text { Vino gastado } \\
\text { por los jornaleros }\end{array}$ & & 12 & - & 9 & - & 9 & - & 9 \\
\hline COSTES ANUAL & & 69 & 32,94 & 31,47 & 27 & & & \\
\hline
\end{tabular}

Fuente: Archivo Histórico Provincial de Valladolid. Protocolos Notariales. Elaboración propia.

Como se ha dicho, si se descuidan las labores, los nuevos majuelos son pasto de la grama y, entre reoyo y desgramado, la suma de reales sólo puede ser afrontada por hacendados con posibles, cuyas rentas no proceden sólo de las tierras. Es el caso del concierto firmado entre Josep de Castro, escribano del número, y Juan Sánchez en 1602 en relación con 12.000 cepas (28,5 aranzadas) en el pago de la Hormiga. Por describir con precisión la tarea, merece la pena su transcripción. Cada cepa tendrá un coste de 6,64 mrs y, si se suma el vino aportado que le sube $0,45 \mathrm{mrs}$ por aranzada, nos situamos en precio respecto a los anteriores ejemplos ${ }^{393}$ :

“...digeron que se abían conbenido y conçertado en... desgramar a grama muerta y a zepa viva y a reoyar un majuelo... do dizen la ormiga, en que ay doze mil zepas..., y el dicho desgramar a de ser a golpe rompiendo toda la tierra del dicho majuelo..., comenzando desde fin deste presente mes de otubre asta mediado março..., metiendo en el dicho majuelo en cada un día que fuere de travaxo ocho o diez obreros continuos llebandolos y no se pudiendo aber desgramado para el dicho tiempo lo que quedare se a de desgramar el invierno luego siguiente..., el qual dicho Juan Sanchez de la Bańeza a de dar desgramado del nueve mil zepas asta fin del mes de março, y estas las a de dar recorridas en el ańo siguiente..., y en este presente año se a de dar acabado de reoyar y dar metido de los dichos majuelos lo que cabiere..., y las zepas que quedaren por desgramar se an de mullir..., por todo lo qual el dicho Josep de Castro a de dar pagar al dicho Juan Sánchez de la Bañeza doscientos y doze ducados y mas tres moyos de bino...”.

${ }^{393}$ A.H.P.V. Pt. 11850 , fol. 697. 


\title{
- Las labores de arada y cavadura
}

Enraizado el majuelo, son las vueltas de arado en sus primeros años y las fatigosas labores de picadura las que hacen de la inicial plantación una viña productiva ${ }^{394}$. En este tiempo se estipulan como obligatorias tres vueltas de arado: la de rama de invierno, marzo y mayo que, al tiempo, facilitan las tareas de excavo y acobijo de las cepas. En la mayor parte de las haciendas son los propios labradores con sus mozos o criados los que las realizan con ganado propio. Cuando se tratan las labores de las tierras de sembradura se documenta el salario anual de un mozo de mulas o bueyes en 441 reales. Para determinar el coste salarial por aranzada arada con ganado ajeno se dispone de múltiples testimonios. Un ejemplo es el pleito librado entre la familia Lozano sobre los frutos de cincuenta y dos aranzadas en el término de Torrecilla, a finales del XVI, que lo cifran en tres reales por aranzada ${ }^{395}$. Al haber sido realizada la labor con bueyes y toda vez que se estudian ejemplos con mulas, entresacamos un fragmento ${ }^{396}$ :

\begin{abstract}
"A la sétima pregunta dixo que sabe e vio este testigo que Baltasar Domínguez, vecino del dicho lugar, estando en serbiçio del dicho Loçano el año pasado de mil e quinientos e noventa y cinco, con un par de bueyes del sudo dicho Loçano en una bina maxuelo quel dicho Cosme Loçano tiene..., que hará quatro arançadas poco más o menos, que la aradura de cada una dellas a justa y común estimacion balía y podía baler tres reales que son doce reales todas..."
\end{abstract}

En las grandes heredades, muchas de ellas nobiliarias, se suelen concertar en ocasiones ajustes a yunteros que, en el último tercio del XVI, oscilan entre ocho y diez reales cada huebra. Adviértase en el concierto que sigue, de 1598, firmado por Inés de Montalvo, de Medina del Campo, con distintos vecinos de Rueda, para labrar las 84 aranzadas de viñas que poseía en el pago de los Llanos, el empleo de mulas en estas tareas. Los bueyes van quedando reservados para las tierras fuertes de sembradura, pues en el viñedo, cuando las labores se conciertan a destajo, la mula se desenvuelve con mucha más eficiencia ${ }^{397}$ :

“...los dichos Hernando nabarro y sus consortes se obligaban de que las ochenta y quatro arançadas de binas... que tiene la dicha dońa Ynes de Montalvo en los Llanos, guarda y vela de la dicha villa de medina..., con sus mulas... las an de arar de rrama, março y mayo en los tiempos y de la forma y manera a que se suelen y acostumbran arar las dichas biñas, y por la dicha labor se les a de dar y pagar... por cada una huebra de rama a ocho reales y cada huebra de março y mayo a diez reales...”.

Las labores de brazo que han de acompañar a las anteriores huebras y que alumbran los archivos detallan con precisión el trabajo que hay que ejecutar, sabedores propietarios y jornaleros de que el cultivo agradece la ejecución, cuando se realiza generosamente y, caso contrario, lo puede echar a perder o la grama arruinar la cosecha. Una prueba es la obligación que contraen varios vecinos de Rueda, el 5 de diciembre de 1583, para excavar 80 aranzadas a dos reales y medio cada una de ellas ${ }^{398}$ :

${ }^{394}$ Aunque en la actualidad el término majuelos designa indistintamente cualquier plantación de viñedo sea cual sea su edad, en tiempo histórico la palabra majuelo designa el sarmiento de una nueva plantación y, por extensión, la viña joven, aun cuando esta dé fruto en sus primeros años. Cuando la viña es adulta, la plantación se denomina por este nombre.

395 En Rodilana por estos años también se tasa en tres reales la aranzada arada por mulas. En cuentas de inventarios de bienes figura que "tengo dadas en cuenta desta deuda desta mula tres bueltas los majuelos ...que cada arançada se paga a tres reales... todas las tres bueltas a los dichos tres reales..."(A.H.P.V. Pt. 6572, fol. 223). En 1589 en Villaverde de Medina Juan Redondo se obliga ante Gabriel Sánchrz a labrar de rama, marzo y mayo sus viñas “...con que me abeys de dar y pagar por cada alançada que os arare de a raçon de cuatrocientas cepas tres reales y un quartillo de cada alançada de cada una labor...”. (A.H.P.V. Pt .8287, fol. 253.

\footnotetext{
${ }^{396}$ A.H.P.V. Pt. 6470, fol. 1 y ss.

${ }^{397}$ A.H.P.V. Pt. 6470, fol. 346.

398 A.H.P.V. Pt. 8083, fol. 26.
} 


\begin{abstract}
"Conozemos nos Juan de Rincón y Andrés y Tomé de Madrigal, epocial martín, vecinos del lugar de Rueda, todos juntos de mancomún... nos obligamos descabar y que escabaremos ochenta alanzadas poco más o menos...que son de Juan Rejón de Sylba, por precio cada una alanzada de dos reales y medio, y a de tener el escabo un pie de hueco barrido y que a de dar la cabeza de la zepa toda en blanco asta el cuello de abajo... y desde que las empezaren no an de salir dellas asta las acabar..."
\end{abstract}

Estas labores de excavo son fundamentales para tener la cepa a salvo de la grama, airearla y sanearla con los fríos del invierno y, al tiempo, recoger junto a su pie el agua de lluvia que necesitará al año siguiente. Son tareas duras y exigentes, pues el terreno está endurecido tras seis meses sin que lo haya surcado el arado y los sarmientos dificultan introducir el legón para abrir hueco en torno al cuello de la cepa. Tras esta tarea, en el siglo XVI, nos consta una cavadura en marzo, que entendemos previa al acobijo o tapado de la cepa, para protegerla de las primeras heladas primaverales y mantener atemperado el terreno, antes de la bina de mayo. Estas tres importantes y seculares labores las ajusta Diego Gómez el 9 de enero de 1595, en una viña de Cristóbal de Cabezón ${ }^{399}$ :

“... que son conçertados... a escavar, cabar y binar... una bina del dicho Xpoval de caveçon... que hace doze arançadas... a raçon de a doze reales cada arançada, y en todas las dichas tres labores quatro cántaras de bino, las quales dichas labores el dicho diego gómez se obliga de dar a las dichas vińas en esta manera: escabar mediado este dicho mes de henero, y a de dar acabada desta dicha labor ahora fin de hebrero, y cavar desde principio de março, y darlas acabadas en todo el dicho mes de marzo, y binarla desde mediado mayo...”.

No obstante, hay que hacer constar que no siempre se registra en marzo "acubrir" o acobijar las cepas y que, como se ha dicho, se repite la palabra "cavar o cavadura.". Será en siglos posteriores cuando se generalice el término acobijar. En La Seca se encuentra en un arrendamiento de 1598, en que se detalla que el rentero debe ararlas de rama, marzo y mayo... y “...acobiçarlas..." ${ }^{400}$. Para precisar esta tarea, es conveniente reproducir la obligación que se firma por parte de Pedro Gonzalo y Santiago Rodríguez en Villanueva de Duero, el 13 de diciembre de 1605, respecto a las viñas de Juan de Hera en que sí se detalla el tiempo de esta operación ${ }^{401}$ :

“...dijeron que se obligaban... que escabaran y acubrirán todas las vińas... en esta manera: que las escabaran desde primero de henero... asta mediados de febrero y las acubrirán desde mediado febrero asta mediado março a precio de cada alançada a seis reales menos quarto y en todo ello mas del precio cinco cántaras de bino nuevo y anejo...”.

Dependiendo del terreno, capitalización de las labranzas o rentabilidad del cultivo, estas tareas, amén del desmate y otras operaciones para limpiar el terreno de forma manual, se realizan anualmente o cada varios años, a tenor de lo que reflejan los distintos documentos consultados de estos siglos. Lo que sí parece cierto es la gran preocupación que se cierne si se descuidan, pues, si se extiende la grama, puede que cueste más su erradicación que la propia vińa. De hecho, esta gramínea de raíces profundas y ramificadas requiere una vigilancia, una vez erradicada, en los siguientes años y que recibe el nombre de desmate. No faltan casos en estos y siguientes siglos en que se encuentran viñas perdidas por esta causa. El concierto que se firma el 23 de noviembre de 1573 en Valdestillas, para

${ }^{399}$ A.H.P.V. Pt. 11843, fol. 9. El mismo propietario ajusta al siguiente año estas labores a doce reales, pero sin vino: “... a raçon cada una arançada de a doze reales sin bino ni otra cosa, las quales dichas... se obligarom de dar a las dichas vinas en esta manera: excavar mediado el mes de henero, y an de dar acavada dicha labor a fin de febrero, y a cavar desde principio de março, y acavadas de cavar en todo el dicho mes de março, y binarlas desde mediado mayo hasta fin del plaço del año primero venidero de mil e quinientos e noventa y seis..." (Ibídem, fol. 637).

${ }^{400}$ A.H.P.V. Pt. 6469, fol. 409.

${ }^{401}$ A.H.P.V. Pt. 8185, fol. 326. 
desgramar cuatrocientas cepas de viña, es otro ejemplo que indica lo persistente de esta planta en viñas adultas y lo vigilantes que tienen que estar los campesinos para erradicarla, si desean mantener productivo el viñedo ${ }^{402}$ :

“...el dicho Juan gos toma a destajo y a su riesgo cuatrocientas cepas a desgramar de una vińa que el dicho Juan moreno tiene... por precio y quantia de cincuenta reales..., las quales cuatrocientas cepas el dicho Juan $\mathrm{g}^{\mathrm{o}} \mathrm{s}$ de desgramar con el canpo de cada una dellas desde aquí al dia de navidad..., y después de acavado el dicho Juan $\mathrm{g}^{\circ} \mathrm{s}$ de desgramar las dichas cuatrocientas cepas a de tornar a recorrer las dichas cepas y dentro de dos años primeros siguientes las a de acabar de desmatar según y como se acostumbra en esta dicha villa..."

De hecho, el arado se emplea conjuntamente con el legón para evitar las malas hierbas y tener atemperada la cepa. He aquí lo que diferencia este cultivo del cereal. Ninguna viña es igual a otra y, si se atiende al tiempo y cuidado con que haya sido tratada, mucho menos. En el XVI, como en posteriores siglos, los acuerdos entre partes reflejan esta multiplicidad de factores. En el trato firmado en Valdestillas en el año 1590, entre Gaspar de Castro y Juan Román, se detallan las labores que hay que realizar. Merece la pena su reproducción en tanto se acuerda poner horquillas para sujetar las varas, técnica de emparrado que solo muy raramente se encuentra en tiempo histórico en estas tierras ${ }^{403}$ :

“... están conçertados en quel dicho Juan Román toma a escabar y binar e horquillar la bina quel dicho Gaspar tiene en termino desta dicha villa do dicen el estocano, la qual dicha vina a de quedar acabada de escabar de todo punto a fin del mes de febrero, y antes y en todo el mes de março a de quedar cabada, y como se fuese cabando se a de ir orquillando a costa del dicho Juan Román, poniendo el susodicho y aciendo las dichas orquillas y llevándolas a la dicha vina, y el binar a de ser a principio del mes de mayo; las quales dichas tres labores y orquillar que de suso van declaradas las a de hacer todas tres y cada una dellas según y como se hicieren y dieren en la vina de la dehesa que tiene Epobal de cabeçón, a término desta dicha villa, la qual se da por muestra..., e de a de dar y pagar catorze reales por cada una aranzada, y mas le a de dar a razén de cinco reales por cada un millar de orquillas que le bende ansi por llebarlas y ponerlas..., puestas y asentadas en las cepas y baras dellas que se an de aorquillar en tiempo de la caba y bina porque se an de asentar en la dicha viña en ambas las dichas dos labores de caba y bina...”

La anterior vińa es excavada en febrero, cavada en marzo y binada en mayo. La diversidad de situaciones y necesidades se plasma en condiciones concretas en cada contrato de labor o arrendamiento, atendiendo al estado de la viña, duración del mismo y confianza entre partes. No es lo mismo el acuerdo entre vecinos con algún parentesco que con propietarios no residentes. Hay ejemplos en Serrada o Valdestillas en que las labores se expresan, en general, siguiendo la costumbre y manera en que se hacen en el lugar. Un ejemplo es la que se firma en 1591 sobre tres aranzadas con la condición de "dar las labores necesarias descabar y podar y cabar conforme a la costumbre desta dicha villa” ${ }^{\prime \prime 04}$. Cuando la grama está presente, siempre se deja constancia del desgramado o desmatado caso de que esta rebrote. Es el caso de Francisco Santos que firma un acuerdo en 1590 sobre una vińa de dos aranzadas por dos años, a 13 reales cada una, que ha de pagar por el día de Todos los Santos "a la qual dicha viña abeis de dar las labores... descabar, cabar y podar.. según la costumbre de esta villa... y desgramar la dicha villa de todo que tubiere necesidad... de suerte que quede limpia de dicha grama..." ${ }^{305}$.

${ }^{402}$ A.H.P.V. Pt. 11836, fol. 100. Desde tiempos andalusíes, entre las tareas de este mes de noviembre se encontraba la de desgramar. Gabriel Alonso de Herrera en su obra Agricultura (1513) cita a Wafid en relación a "soltar los puercos para que coman la grama de las viñas”. ESCARTÍN GONZÁLEZ, E: El vino en el Islam clásico. Universidad de Sevilla, 2005, pág. 27, citando a Cipriano Cuadrado Redondo en su "Introducción” al tratado de Agricultura de Ibn Wafid, pág. 43.

403 A.H.P.V. Pt. 11838, fol. 615.

${ }^{404}$ A.H.P.V. Pt. 11839, fol. 87.

${ }^{405}$ A.H.P.V. Pt. 11838, fol. 268. 
En La Seca, La Nava y Rueda, donde la especialización vitícola es mayor por estas fechas que en La Moya, Villanueva o Serrada y hay grandes labranzas de propietarios absentistas, se detallan los tipos de arada y las labores se fijan con exactitud. Es común que se precisen las vueltas de arado que hay que darles al cabo del año, a saber: rama, marzo y mayo, así como las operaciones de desgramar y desmatar. También se suele fijar un número de vástigas que echar por cada aranzada, que indican la preocupación por renovar las cepas que van muriendo, los saltos que no agarran en las viñas nuevas o aquellas que, por descuido, se lleva el arado ${ }^{406}$. María Caballero arrienda a Pedro Bayón en La Seca cuatro vińas, que suman once aranzadas, por tres ańos a razón de doce reales cada una, con la condición de que "arare las dichas viñas de rama, março y mayo, y desmatare lo que en ellas esta desgramado ahora y dejare en cada arançada tres bastigas y las escabare...". En el que firma Andrés Maestro en Ventosa, en 1599, respecto a 4,5 aranzadas y cuatro años a razón de 15 reales, se detalla asimismo que "durante el qual araré las dichas viñas de rama, março e mayo, y dejaré en cada arançada tres bástigas y las escabaré a tercero año, so pena de pagar cien mrs en cada labor que cada un año a cada arançada dejaré de dar..., y respecto a tener alguna grama las dichas binas las tengo que recorrer y quitárselo en quenta de la dicha renta" 407 . Se reproduce, por último, toda vez que fija precios concretos en estas labores, el acuerdo, fechado en Rodilana en 29 de octubre de 1591, entre Juan Domínguez y Francisco Delgado. Se arriendan dos aranzadas y media a 17 reales cada una ${ }^{408}$ :

“...la primera aradura a de ser de rama, y de março y de mayo; si faltare alguna labor a de pagar por cada aradura tres reales, y cada arançada que no escabare dos reales, y las a de dejar la podadera tallo y cordera u dos tallos y las dichas binas se le da por dos ańos y dos frutos...

\section{- La poda}

Si protocolos de este tiempo detallan las anteriores tareas con tanto detalle, los trabajos de poda, como aparecen en el anterior contrato, no van a ser menos. Un excavo mal hecho o una huebra deficiente puede tener remedio, pero hablar de poda son palabras mayores. En la memoria colectiva de estos pueblos ha permanecido como uno de los pocos trabajos en que la pericia y la inteligencia tienen más importancia que la fuerza bruta.

Desde un punto de vista técnico, y como se verá a través de los documentos hallados, las podas son más bien cortas o, para ser más exactos, más restrictivas que las que se realizan en el XIX y principios del XX, de lo que se tiene constancia oral. Ello, indudablemente, ante la falta de abonado, alarga la vida de la cepa, que rinde poca producción, pero de gran calidad. Al margen de dejar algún pulgar en los que se pueda al año siguiente calzar alguna vara, lo normal es que se pode a una vara y una cordera, atendiendo a la edad y al vigor del viñedo. Estas técnicas tan específicas, aun cuando en este tiempo siempre se habla de viñas o vino blanco, sin atender a varietales, prueban que es la cepa verdeja la que está arraigada y, al tiempo, consolida una poda muy particular para extraer el máximo potencial de su fruto.

En este sentido, en los contratos de arrendamiento se fijan con exactitud las varas o pulgares que ha de dejar el podador. El firmado en Nava del Rey en 1572 es claro al respecto ${ }^{409}$ :

${ }^{406}$ Echar vástigas es la operación consistente en enterrar un sarmiento largo y fuerte, dejado el año anterior, desde una cepa "madre" a un hueco perdido. Deberá ser profundo para evitar que el paso del arado le rompa. El sarmiento enraizará al tiempo que se fortalece por ser alimentado también desde la cepa madre. Su extremo formará una futura cepa. Suele estar acorpado de tierra y, a veces, sujetado por una estaca para que vaya adquiriendo verticalidad y forme una nueva cabeza de cepa. Una vez que se estima fuerte, se corta el sarmiento de la cepa de la que procede. Por extensión, se denomina vástiga a los sarmientos largos que sirven para recoger y atar los manojos, una vez que la vińa ha sido podada.

${ }^{407}$ A.H.P.V. Pt. 6471, fols.41 y 352 respectivamente.

408 A.H.P.V. Pt. 6572, fol. 60.

${ }^{409}$ A.H.P.V. Pt. 13338 , fol. s/n. 
“...las quales tengo de labrar e hacer las labores necesarias conforme a las condiziones de los menores... que se tienen de rama, março y mayo; las he de escabar, e cabar a su tiempo, e no he de dejar mas de dos baras en cada cepa de las dichas vińas, una nueba y otra vieja y debo de ararlas y hechar todas las rastras que hubiere..."

Estas precisiones constan en buena parte de los arrendamientos de vińas y, en caso de incumplimiento, debe hacerse frente a nuevas obligaciones ${ }^{410}$. En ocasiones se precisa incluso el precio en que se incrementa la renta, caso de que el rentero desee dejar más madera para incrementar la producción. Sirva como ejemplo el que se firma en 1669 en Lomoviejo a favor de Francisco Rebollo, vecino de Ataquines, que arrienda a Pedro Sanz las viñas de la capellanía que fundó Martín Sánchez, vecino de Fuentelsol ${ }^{411}$ :

“... con condizión que a de dar las dichas bimas en cada un año a tres bueltas, y podarlas, escabarlas y mullirlas, y no dexar más, que están solamente tallo y cordera, y si más dexare a de pagar a medio real por bara a estilo de menores..."

Solo excepcionalmente se encuentran podas más largas que entendemos en majuelos de gran vigor. Y aun así, con cautela. Es el caso del arrendamiento que tiene lugar en La Seca en 1598. Aunque es una tarea menor, se debe tras la poda mencionar la recogida de sarmientos, porque es el combustible más preciado en las casas del campesino de estos siglos. No faltan los manojos en los inventarios de bienes de medianas y grandes haciendas. Aunque el trabajo de entrelazar los sarmientos y atarlos con las vástigas más largas es una labor áspera, se ha encontrado en estos siglos documentación que atribuye el trabajo a la mujer como acompañante del podador. Así y como referencia sobre el particular, "...un podador poda y una sarmentera ata cada dia comúnmente y de ordinario cien manojos y esto se trata de prática entre labradores de viñas...”, lo que sitúa en torno a tres cuartas partes de una aranzada podada por un podador a dos reales diarios y 150 manojos obtenidos de ella que, a cuatro ducados el millar, proporciona unos ingresos brutos de 100 maravedís por aranzada y netos de $74,5 \mathrm{mrs}$, si se descuenta el medio real al día que cuesta el salario de una sarmentadora ${ }^{412}$.

\section{- La vendimia, el lagar, las bodegas y las cubas}

Definidos los trabajos y sus precios, es hora de recoger el fruto, salvo que se hubieran producido "casos fortuytos ansi del cielo como de la tierra que sobre ellas acaezca..., ansi de piedra, niebla, helada e langosta...", frases obligadas en cualquier concierto de arrendamiento o venta de uvas o mostos ${ }^{413}$. Respecto a robos o actos "de mano airada", los concejos, desde que se tiene constancia documental, arbitran la figura de los guardas de campo, tanto para panes como para viñas. Las guarderías salen a postura pública a comienzos del año y la vigilancia se extrema, conforme se acerca la cosecha.

${ }^{410}$ Luis Gómez, vecino de Nava del Rey, arrienda en 1572 dos aranzadas y una cuarta por tiempo de dos años, a razón de veinte reales la aranzada. En él se fijan condiciones similares a los arrendamientos expuestos, pero se fija medio real, caso de que no heche las tres rastras o vástigas por aranzada: "...que las a de arar tres veces de rama, março y mayo, y escabarlas y he de dexar por cada cepa una bara y una cordera y hechar en cada harançada tres rastras en cada un año, e no lo haciendo pague medio real a vos, el dicho Luis Gómez..." (A.H.P.V. Pt. 13338, fol. s/n).

411 A.H.P.V. Pt. , fol. Año 1669. En otras ocasiones se recoge la posibilidad de obligar a quitar al rentero aquellas varas o corderas dejadas de más. Es el caso del arrendamiento firmado en Rodilana, en que se detalla que debe dejarse “...en cada zepa tallo y cordera u tallo u calçon u dos baras y si mas dexare sean obligados a se lo quitar...”. (A.H.P.V. Pt. 6572, fol. 164).

${ }^{412}$ A.R.Ch. V. PL. CV. P. Alonso (F), caja 964.4, fol. 138v.

${ }^{413}$ Estas coletillas figuran en todos los arrendamientos, sea cual sea su tiempo y lugar para que la renta se satisfaga por parte del rentero, al margen del resultado de la cosecha. En el caso de las tierras de sembradura, se suele añadir a lo expresado contingencias de fuego y mano airada, ya que el cereal seco en las tierras de sembradura corre más riesgo que el fruto de las cepas. 
En 1573 se firma en Pozaldez la "a veynte y cinco dias del mes de abril... la guarda de los panes y viñas... hasta el día de Santiago" 114 . En el viñedo, además, conforme se acerca la cosecha, los concejos ajustan la guarda de los distintos pagos. En el anterior lugar, por ejemplo, el seis de agosto de 1574 "se remató el pago del castillo en Rui gómez para guardar las viñas"115. Los guardas, amén de vigilar el fruto, deben velar por las manojeras existentes en el campo, pues se constata que en muchas villas no todos los sarmientos que se atan se llevan al lugar poblado. En la segunda mitad del XVI, las posturas se cierran en torno a "...seis maravedís cada arançada y que a de dar quenta de las manoxeras nuevas que se alzen y de las que al presente esten en el canpo..." $" 16$.

La fecha de la vendimia, igualmente, se fija de común acuerdo. Son los componentes de los llamados gremios de viñeros los que supervisan la evolución de la maduración del fruto y fijan el inicio de la recogida. Las ordenanzas de cada lugar son rigurosas en los procedimientos y entrada o salida de mostos de las poblaciones. En cualquier caso y aunque depende de la metereología, en esta comarca no se dan antes de iniciado el mes de octubre. De ello se derivan en estas terrazas de gravas unos frutos cargados de azúcares, prestos a una rápida fermentación. En el ejemplo que sigue, localizado en pagos vitícolas de primer orden, son los días de la festividad de San Lucas (18 de octubre) en los que se desarrolla la vendimia. En ocasiones, atendiendo al tiempo, puede alargarse hasta los primeros días de noviembre. De hecho, las ordenanzas de Medina de 1539, que permiten a los vecinos de la villa con viñedos en los lugares de la Tierra meter su uva hasta el día de San Martín, hacen constar que "...algunas veces e muchas veces açaecen que las bendimias no se acavan antes de san Martín..." (11 de noviembre $)^{417}$.

Las producciones se presentan con enormes variaciones de acuerdo a los factores relatados y atendiendo a la edad de las cepas. En los majuelos nuevos, de los que se tiene constancia documental en este tiempo, se reflejan tanto sus cortas producciones como la menor valoración de su uva respecto a las vińas viejas ${ }^{418}$. La recogida de la uva es la actividad en que la comunidad campesina trabaja al completo, desde los niños de corta edad hasta los mayores. En las haciendas medianas ya aparece la figura del “...mayordomo... que... en cada un ano hace las vendimias de sus binas..." y está pendiente de coordinar a los obreros contratados que cortan el fruto, a los cargadores que lo suben a los carros, a los trotadores que a lomos de sus caballerías lo trasladan carga por carga y a los carros o "carretadas... a quatro cargas en cada carreta..." que propias o ajenas participan en la recogida ${ }^{419}$. Aunque excepcionalmente se encuentra alguna variación en la relación carga de uva/moyo de mosto ${ }^{420}$, seguramente derivado de la calidad de la uva y su capacidad de "mostear", a finales del XVI en Tierra de Medina de "cada carga de uba me a de dar quatro cántaras de mosto poco más o menos y estos se trata plática entre los labradores... que comúnmente puede dar..."121. Las producciones se determinan por cargas de uva o su equivalencia en mostos. Son frecuentes las expresiones "...cogio en cada una arançada como a moyo por arançada"

${ }^{414}$ A.F.B.C. Libro de Acuerdos del Concejo, año 1573.

415 Ibídem.

416 A.H.P.V. Pt. 11838, fol. 17.

417 A.H.P.V. Traslado escritural, Sección Histórica.

${ }^{418}$ En el pleito que mantienen la familia Lozano a finales del XVI, de las declaraciones de los testigos respecto a la producción de las 38 aranzadas mencionadas, el encargado de vigilar y hacer la vendimia testifica que "no ubo mas de beynte cargas de uba... y benia a salir quatro moyos de mosto... y se bendio cada un moyo de mosto a tres ducados y lo que procedio de las dichas vinas majuelos balia menos de la dicha cantidad por ser de majuelos...”. Otro testigo, sin embargo, manifiesta haberse cogido "treynta y cinco cargas y media de uba... que podrian benir a salir nueve moyos de mosto..., que las dichas cargas de uba de las dichas binas... eran buenas cargas y bien llenas y la uva sana y entera..."..

${ }^{419}$ A.R.Ch. V. PL. CV. P. Alonso (F), caja 964.4.

${ }^{420}$ Ibídem.

${ }^{421}$ A.R.Ch. V. PL. CV. Alonso Rodríguez (F), caja 2938.5, fol. 164.

${ }^{422}$ Ibídem. 
atendiendo a las equivalencias con el sistema métrico decimal, deriva a unas producciones en torno a $368 \mathrm{~kg} /$ aranzada o $963 \mathrm{~kg} / \mathrm{ha}^{423}$. Nada mejor que trasladar los gastos y salarios de la vendimia de 1597 , que tuvo la familia Lozano en sus treinta y ocho aranzadas de vińas y majuelos, sitos en el Barco, entre Rueda y Medina ${ }^{424}$ :

"Primeramente doze obreros a real y medio para vendimiar que fue vispera de señor san Lucas.

Mas quatro burros para trotar a dos reales y quartillo.

Dos trotadores a dos reales y quartillo.

De quien ayudo a descargar en el lagar este dia un real.

Dia de san Lucas diez obreros a real y medio son quinze reales.

Este dia tres burros a dos reales e quartillo.

De un trotador dos reales y un quartillo.

El domingo de antes de san Lucas ocho obreros a real y medio.

Mas tres burros a dos reales y quartillo.

Mas un trotador dos reales y un quartillo.

$\mathrm{Al}$ mayordomo que anduvo alla tres dias a dos reales.

De hacer el pie que se hecho en una cabeçada y del alquiler del lagar (cinco reales)

Del alquiler de deziseys cargas de zestos a quartillo quatro reales.

De lo que me ocupe y del alquiler de una mula de todo (mil setecientos reales) por la suma de atrás monta quatro mil e seyscientos e cuarenta y un maravedis.

Mas que se a gastado en las labores de las vimas como parece en un memorial que tengo presentado en el pleito y lo esta en la carta executoria que monta deciseys mil e ochocientos y quinze maravedís.

En conjunto, de acuerdo con las declaraciones de las partes, y siempre con la prevención de toda declaración judicial, parece ser que, siendo un buen año el mencionado de 1597 en dicho pago, a diferencia de 1598 en que las viñas se helaron y apedrearon, veinte aranzadas dieron a moyo, pero las dieciséis restantes “...no estaban tan vien labradas, se cogio e pudo coger a medio moyo..." ${ }^{225}$. Para recorrer y recoger la uva de estas treinta y seis aranzadas. se tardaron tres días y se pagaron 30 obreros a real y medio, cuatro trotadores a dos reales y cuartillo, diez burros a dos reales y cuartillo y un mayordomo a dos reales. Aunque la estimación del coste de vendimiar una aranzada depende de múltiples factores, si se da todo el trabajo, incluido la pisa y alquiler del lagar, se llega a cifras que pueden variar entre 3,79 reales por aranzada o los 4,87 y 6,8 por moyo. En la declaración que acompańa y se ha analizado en las tierras de sembradura de Isabel Corroto en Valdestillas en 1589, se valoran los gastos de vendimia en 7,64 reales el moyo de mosto, prueba de la variabilidad de situaciones que acompaña al trabajo de cortar y transportar la uva, sea el alquiler del lagar o el salario del encargado de supervisar las operaciones y rendir cuentas, pues, en el caso que nos ocupa, monta su cuantía 1.700 maravedís de un total de $4.641 \mathrm{mrs}$ en que se valora el gasto de recolección y pisa.

Los lagares, como las bodegas y las cubas, pueden ser propios o arrendados para la ocasión. Todo el entramado de bodegas subterráneas que hoy se conoce en el espacio estudiado es el resultado de un devenir histórico que, especialmente en los siglos XVII y XVIII y al calor de plantaciones a gran escala, van horadando el subsuelo. En el siglo XVI y a la luz de los inventarios de bienes que recogen los protocolos notariales, solo los labradores más pudientes cuentan con lagar y bodega propia donde pisan su uva y la de vecinos allegados. El resto se transforma en mosto en lagares arrendados

${ }^{423}$ De cada cuatro cargas de uva se obtiene un moyo de mosto. Un moyo tiene dieciséis cántaras y, por tanto, a 16 litros cada una, suman 256 litros. Siguiendo la costumbre en las elaboraciones de que cada dos arrobas sale una cántara (de $23 \mathrm{~kg}$ de uva se obtienen 16 litros), se viene a determinar que una carga de uvas equivale a $92 \mathrm{~kg}$ en el sistema métrico decimal.

${ }^{424}$ A.R.Ch. V. PL. CV. Alonso Rodríguez (F), caja 2.938.5, fol. 65. Se trata de un pleito entre Beatriz Lozana, heredera de Luisa Lozano, con Cosme Lozano, vecinos de Valladolid, sobre los gastos y labores hechos en las viñas que tenía arrendadas.

425 Ibídem. 
o en pequeños "lagares de mano", al alcance de los menos capitalizados. No faltan tampoco quienes, en vez de pisar la uva, la venden en mosto desde el majuelo ${ }^{426}$. En La Seca de 1596, Marina Sanz se obliga a entregar a Pedro Velasco "...todo el mosto que coxiere y procediere de las viñas... el qual se a de pisar en el lagar del dicho Pedro Velasco... a diez y ocho reales por cada un moyo..." ${ }^{227}$. En Villaverde, Antonio Hernández, vecino de Medina del Campo, compra en 1591 la importante cantidad de ochenta moyos y el derecho a guardarlos en cuatro cubas de la bodega del propietario, al precio de un ducado el moyo (11,02 reales) ${ }^{428}$.

La mostería, en cualquier caso, obliga a coordinar esta tarea colectiva. Muchos yunteros echan huebras acarreando uva a los primeros y en sus instalaciones pisan también el fruto de sus cepas. En la mayor parte de los lugares y villas, los concejos conciertan acuerdos para que se realice con diligencia y buen hacer el traslado del mosto en pellejos desde los pilones de los lagares a las cubas, más cuando no todas las bodegas disponen de lagar y se requiere rapidez en beneficio del futuro vino. Es una tarea que pervivirá y tendrá su regulación año tras año en las villas más vitícolas hasta comienzos del siglo XX. Por su detalle, se selecciona la firmada en 1590 en Valdestillas entre el concejo de este lugar y doce mosteros, representados por Martín Ballesteros, Gregorio Bermejo, Alonso Gil y Blas Merino $^{429}$ :

“...dixeron questn conçertados y conbenidos con la justiçia y regimt ${ }^{\circ}$ desta dicha villa quellos con otros ocho compañeros... servirán al dicho $\mathrm{g}^{\mathrm{o}} \mathrm{y} \mathrm{v}^{\mathrm{o}} \mathrm{s}$ del en echar y recoxer todo el mosto que se cogiere en ella..., el qual dicho mosto llebaran desde los lagares donde se benefiçiase a las bodegas e a las demas partes donde les fuere dicho por los dichos $\mathrm{v}^{\mathrm{o}} \mathrm{s}$ en toda la dicha bendinia..., de manera que siempre a de aber el dicho numero de... doze honbres... cada día mientras durare la dicha vendimia..., y acabada la dicha bendimia la dicha justicia y regmt ${ }^{\circ}$ a de ser obligada a nonbrar persona de su parte, y ellos an de honrar otra de la suya, las quales dichas dos personas an de contar y moderar los preçios que cada moyo de mosto mereciese de llebarlo desde el tal lagar donde se llebare asta la bodega donde se recogiere..."

Como se ha dicho, conforme las plantaciones se extienden por el norte de la tierra, nuevas bodegas y lagares se añadirán a los existentes. Su construcción va ampliándose a lo largo de generaciones, conforme lo exige la necesidad de meter nuevas cubas. A finales del XVI, se dispone de un concierto en que se detalla cómo ha de excavarse una nueva bodega en Matapozuelos ${ }^{430}$ :

“...que en el dicho sitio an de ronper la peńa... y su ronpimiento an de ronper treinta pies a la larga sin salir del dicho sitio..., y si fuere necesarios en la entrada de la dicha bodega hazer escalera la an de hazer a la dicha bodega le an de dar doze pies de ancho...; de alto hasta el suelo della otros doze pies quedando en todo en su partición en la forma e manera de suso declarada..., a raçon de onze reales por cada pie de los dichos treinta pies de largo con el ancho e alto de los dichos doze pies declarados...”

Respecto a las cubas, se observa en los inventarios de estos siglos la existencia conjunta de cubas nuevas y viejas, de tasación y cabida variada, que oscilan, a finales del XVI, entre los 120 reales en que se tasan las de 12 o 16 moyos, atendiendo a su estado, a los 40 reales las pequeñas de 4 moyos (3.072, 4.096 y 1.024 litros, respectivamente). Reproducimos un concierto para hacer una cuba nueva y asentarla en una bodega de Rodilana en diciembre de 1594. Como puede comprobarse, para poder meter en la bodega una cuba nueva de gran capacidad se necesitan 345 reales $(11.730 \mathrm{mrs})$

\footnotetext{
${ }^{426}$ Andrés Pérez de Torales se obliga en el año 1590, ante Juan de Alaejos, a darle “...veynte moyos de mosto de lo que yo coxiere estas bendimias primeras de la viña majuelo que yo tengo...”. (A.H.P.V. Pt. 8288, fol. 306).

${ }^{427}$ A.H.P.V. Pt. 6468, fol. 359.

${ }^{428}$ A.H.P.V. Pt. 8289, fol. 509.

${ }^{429}$ A.H.P.V. Pt. 13338, fol. 589.

${ }^{430}$ A.H.P.V. Pt. 11845 , fol. 108.
} 
que es tanto como decir una pareja de bueyes o tres aranzadas de viña. He aquí la razón fundamental de que no todas las labranzas dispongan de estos bastos y, cuando se tienen, se alarga su vida lo más posible, aun a riesgo de perjudicar al propio vino ${ }^{431}$ :

"Francic ${ }^{\circ}$ diez... me obligo por mi persona y bienes a traer a $\mathrm{Dg}^{\circ}$ Basurto de $\mathrm{R}^{\mathrm{a}}$ un basto de cuba de catorze palmos de largo que a de azer de veintitrés a veinticuatro moyos que son catorze palmos..., y me obligo de traer... a contento de buen mantillo y madera blanca, por precio y quantia de a quinze reales cada moyo de la cuba, y a de ser... biniendo el carretero con el basto y si entretubiere el desbasto sea a costa del dicho do Basurto todos los dias que se detubiere...”.

En los inventarios notariales, se anota una gran cantidad de cubas usadas y viejas que han de repararse cada año para albergar el mosto. En las reparaciones, por falta de dinero, no siempre se renueva la madera y son la estopa y la pez los productos que tapan grietas entre las tablas o los arcos, incluso a riesgo de transmitir malos sabores a los vinos. Son comunes las cuentas en que se valoran estos trabajos, además del obligado lavado antes de la vendimia ${ }^{432}$ :

"De un pegote para la cuba un real, y de una vara de estopa para el otro real, y de pez real $\mathrm{y} \mathrm{m}^{\circ}$, ques todo tres reales y $\mathrm{m}^{\mathrm{o}}$.

Yten. Se adreçó este año un cubillo q'es de pie medio que costaron arcos y pez y vimbres y las manos de los cuberos doscientos y quince mrs".

El capital invertido incentiva su arrendamiento, caso de no ser usados los bastos por el propietario, pues la no utilización de la cuba agota su vida útil. No faltan arrendamientos de lagares, bodegas y cubas. El precio de estas varía de acuerdo con la capacidad y estado del basto y si está unido su alquiler al de toda la bodega. Así, por ejemplo, en 1590, se arriendan dos cubas en Villaverde que hacen cincuenta moyos (12.800 litros) por cinco ducados "... y me obligo de vos dar la llabe de la dicha bodega para que otra persona alguna no pueda entrar en la dicha bodega sino fuere vos..." ${ }^{\text {"333. }}$

\section{- La transformación de mostos y la comercialización del vino}

Las vendimias tardías y las reducidas producciones por aranzada nos sitúan ante unos mostos que no tienen problemas en el proceso de fermentación pues, en buena lógica, proceden de una uva muy madura y azucarada. Detallar el proceso en este tiempo es tarea casi imposible, pues las fuentes son escasas y, cuando se logra su consulta, se muestran incompletas y parcas en el detalle. No obstante, permiten entender que la fermentación se realiza en las cubas y allí permanece el vino nuevo hasta su venta. Son comunes en estos siglos las expresiones “...que el bino mosto... lo encerró y encubó..." "ł34. En ocasiones, constan procesos de trasiegos, pero sólo de forma muy puntual y, a veces, diferenciando este vino como de más calidad. En 1595 Francisco Navarro en La Seca “...trasegó... una de vuestras cubas... treynta y tres cántaras de vino blanco las quales estubieran asta agora en la dicha cuba..." $" 35$. La presencia de tinajas junto a las cubas en las bodegas es un indicador de su utilización, tanto en el envasado como en estas tareas ${ }^{436}$. En el pleito tratado sobre la cosecha de la familia Lozano en el año 1597, un testigo manifiesta que el mosto, que valía menos por proceder de majuelos, “...al

\footnotetext{
${ }^{431}$ A.H.P.V. Pt. 6572, fol. 256.

432 A.H.P.V. Pt. 11839 , fol. 761.

433 A.H.P.V. Pt. 8287, fol. 380.

${ }^{434}$ A.H.P.V. Pt. 6470, fol. s/n

435 A.H.P.V. Pt. 6470, fol. 114.

${ }^{436}$ A.H.P.V. Pt. 11841, fol. 358. En las bodegas que Francisco de Rojas tiene en sus casas de Serrada en 1593 junto a cuatro cubas que suman 48 moyos de capacidad se tasan dos tinajas grandes y tres pequeñas.
} 
presente... no se a trasegado ni trasiega l/ni vendell bino alguno de lo de la dicha cosecha..." ${ }^{\text {"37. }}$. A finales del XVI, los trasiegos se realizan previamente a la venta del vino cuando se les da claro, pero no cuando acaba la fermentación. O en contadas ocasiones.

Este proceso de clarificación es otra tarea ligada al mencionado trasiego. Las impurezas del vino, que no decantan por gravedad, son eliminadas por arrastre, mezclando el vino, por lo general, con tierras yesosas o clara de huevo. Al tiempo de este proceso suelen utilizarse otros productos, sea leche, nata, huevos, etc., a fin de mejorar colores y sabores. Un mundo de secretos entre cosecheros y ordenanzas al respecto, a fin de mejorar o aderezar el vino antes de su saca. Baste, como ejemplo, el testimonio que dejó anotado en las cuentas Juan de Sigüenza en diciembre de 1591438:

\footnotetext{
"Que gastó en leche que se traxo de medina del campo y de huebos para adreçar y dar color a la cuba que se bendió a los segobianos, treynta y dos reales.

Que le costó una cuba para aber de trasegar este vino para le dar color por no tener cuba donde lo poder pasar, cuarenta y dos reales.

Que gastó en dar color a la cuba de diez moyos de que en el cargo se hace mención para la venta diez docenas de huebos que costaron quatroçientos y ochenta mrs".
}

Aquellos vinos de calidad que no se venden o no se necesita vender permanecen añejados unos años más. Si se conservan, el precio compensa la espera. En grandes cantidades o por menudo. En Matapozuelos, Juan de Menchaca vende en 1574 novecientas cántaras a Juan de la Maña y consortes, en las que se especifica "tresçientas cántaras de trasanejo, tresçientas de anejo y tresçientas de nuevo... a precio de seys reales más quartillo y el dicho bino an de sacar y tener sacado de las cubas los susodichos para el dia de San Juan de Junio y el bino nuevo se a de medir enpezando de la cuba que hace decisiete moyos y acabar en la otra que tiene bino nuevo..." ${ }^{3} 39$.

Caso distinto son las cubas que se venden a distintos compradores hasta ser acabadas. En este sentido, el establecimiento de precios en las tabernas de Valladolid, a comienzos del siglo XVII, es muy revelador de un tipo y otro de vino. Los Alcaldes de la Casa y Corte de Su Majestad deciden en 1604 que, para vender vino nuevo, se pida autorización; que el vino añejo no se venda a más de 32 maravedís la azumbre y el trasañejo, a más de 56 maravedís ${ }^{440}$. Será un campo abonado para la picaresca. De hecho, en 1626 los cosecheros de Medina del Campo se quejan del perjuicio que se deriva de la venta de vinos nuevos como si fueran ańejos o trasańejos ${ }^{441}$. Un año más tarde, en 1627, la ciudad de Valladolid fija el precio del vino nuevo a $32 \mathrm{mrs}$, el ańejo a 40 y el trasańejo a 60 maravedís, prueba del valor que alcanzan en el mercado unos y otros caldos ${ }^{442}$.

Estudiar la regulación de precios, entradas y salidas de vino de las poblaciones y tránsito del mismo, excede del propósito de este estudio. No obstante, son de destacar las ordenanzas que pregona el Concejo de Medina en la Plaza Mayor, en septiembre de 1503, sobre la venta del vino ante las próximas ferias de octubre y la llegada de los Reyes Católicos y su séquito. En ellas se detalla el precio y calidad del caldo. Por su importancia y trascendencia posterior reproducimos un fragmento ${ }^{443}$ :

\footnotetext{
${ }^{437}$ A.H.P.V. Pt. 6470, fol. s/n

438 A.H.P.V. Pt. 11839 , fols.759/ 761.

${ }^{439}$ A.H.P.V. Pt. 10584, fol. 113.

${ }^{440}$ HUETZ DE LEMPS, A.: Vinos y Viñedos de Castilla y León. Tomo I., Junta de Castilla y León., pág. 201.

${ }^{441}$ Ibídem, citando referencia A.H.N., leg.24987, no 10, fol. 4 vo

${ }^{442}$ Ibídem, citando referencia B.N. Ms. 11281, fol. 51.

${ }^{443}$ A.H.M.M.C. Libro de acuerdos de 1503, caja 267-3. fol. 73v-74r. 1503, (transcripción: Juan Carlos Alonso).
} 


\begin{abstract}
“(Cruz). /1Conçejo. En primero de setienbre de I mill DIII años. Hordenança del vino. /\$ Este día, estando en conçejo, justicia e rregidores /3eçétera, en las casas nuevas, a canmpana rrepicada eçétera, e estando en el dicho conçejo el señor /5corregidor e (el e) Pero de Mercado e Rrodrigo de Bouadilla e /Pedro de Sant Andrés e Gonzalo Rrodríguez de Montaluo e /7Françisco Díez, rregidores de la dicha villa, eçetera. /Luego los dichos señores conçejo, justiçia e rregidores /9desta dicha villa dixeron que por quanto ante ellos /an venido grandes rreclamaçiones e quexas, /nasý de vezinos desta villa commo de fuera della, /que la gran desborden que de los preçios que los /13vinos se venden, e asymismo la grand /neçesydad del vino que ay e se espera aver, /15asý por la venida de Sus Altezas commo por /la feria, que podría faltar el vino, e, sy /17non faltase, los preçios serían tan sobidos /que todas las gentes rreçibirían mucho /19agrauio. Por ende, queriendo proveer e /rremediar en lo susodicho, dixeron que man-/21dauan e mandaron e hordenavan e hor/denaron que ningund vezino desta dicha villa non /23pueda vender vino a más preçio de /a diezeséys maravedís el açunbre (sic) e dende /25abaxo. E demás mandaron a todas /e qualesquier presonas, asý desta villa commo /27de fuera partes della que quisyeren traer vino /de fuera de la dicha villa, que lo puedan /29traer syn que puedan caer por ello en /pena nin calumnia alguna, con tanto quel /31dicho vino que asý truxieren non lo puedan /vender más de al dicho preçio e dende abaxo. /33Lo qual mandan que sea desde oy dicho día / fasta el día de Todos Santos primero que /viene deste año, con condiçión que todo el /vino que metieron sea [a]nexo e non nuevo, / so pena quel que lo contrario fíziere /de todo lo susodicho por cada /39vez que le fuere fallado caya en pena de (f. $74 \mathrm{r}$ )/dos mill maravedís y perdido el vino".
\end{abstract}

Estas primeras ordenanzas de las que se tiene constancia documental revisan y atienden el mercado de caldos, de acuerdo a la situación de la oferta y la demanda. El concejo atiende al interés general y evita tensiones sociales, caso de que se dispare el precio del vino, si el consumo supera las existencias. De ahí la frase de "...los preçios serían tan sobidos que todas las gentes rreçibirían mucho agrauio... “. En 1539 sucede lo contrario. Los cosecheros se van a la ruina si no dan salida a sus cosechas. Las ordenanzas vuelven a ser celosas del bien común, recordando que nadie, sea cual sea su condición, “...pueda meter ni meta vino ninguno en mosto cocido ni de otra manera ni binagre..." para que, de este modo puedan dar saca los vecinos de Medina su propio vino, que "se an puesto y plantado mucho número de viñas y maxuelos de que mucha abundancia dan de binos y tanto y tan bueno como lo ay en cualquier ciudad, villa o lugar destos rreynos...". El texto hace hincapié en la necesidad de control para que las viñas que se han puesto se críen y sostengan. Se denuncia que algunas personas han metido vinos tintos y blancos, ocasionando perjuicios que la justicia debe perseguir. Se prohíbe que nadie "pueda meter ni meta vino ninguno assi tinto como blanco ni en mosto ni en uba para hacer mosto ni binagre ni en esta villa ni en sus arrabales desde oy dicho día en adelante en cada una año perpetuamente por siempre jamás...", salvo a vecinos de Medina con viñedo en los lugares de la Tierra que pueden meterlo hasta el día de San Martín ${ }^{444}$. El celo de cada población en la defensa de sus intereses desata toda una fiebre de normas, ordenanzas y pleitos entre poblaciones e intereses particulares.

\title{
- Una rentabilidad que supera a las tierras de pan
}

Los anteriores aspectos reiteran el potencial del cultivo y, en concreto, su rentabilidad. Como hemos visto en los cuadros anteriores, los beneficios superan a las tierras de cereal, posibilitan más jornales a las familias campesinas y hacen producir fruto a tierras que, de otro modo, estarían ocupadas por retamas y encinas.

En el anterior epígrafe el beneficio neto de una obrada de sembradura le estimamos en 18 reales del último tercio del siglo XVI, contando gastos de barbechera y entendiendo el cultivo a dos hojas sin olvidar, como siempre reiteramos, que buena parte de los trabajos que se anotan como gastos lo realiza la propia familia campesina. La diferencia no deja ninguna duda a estas comunidades del norte de la Tierra de Medina. Con un terrazgo de gravas y bien posicionadas respecto a las áreas de consumo, la apuesta por este cultivo es clara. Tanto para propietarios como para jornaleros.

\footnotetext{
${ }^{444}$ A.H.P.V. Traslado escritural, Sección Histórica.
} 
Como puede apreciarse en el cuadro adjunto, en relación a los anteriores, los gastos de jornales que lleva una obrada durante dos años para producir pan se estiman en 45 reales mientras que ascienden a 40,5 reales cada año en el viñedo incluyendo el vino gastado por los jornaleros. El viñedo dobla en jornales al trigo y le dobla en beneficio si atendemos a la unidad de superficie en que se anota este aprovechamiento. Si transformamos obradas (0,5659 ha) y aranzadas $(0,4244 \mathrm{ha})$ en ha nos resultan unos beneficios de 31,8 rs/ha en el caso de las tierras de sembradura frente a 61,26 rs/ha en el viñedo. A esta diferencia debemos ańadir que el vińedo produce todos los ańos y, en consecuencia, con la mitad de superficie se consigue el doble de beneficios. Aun considerando el importante desembolso de su crianza, que asciende a 160 reales hasta que da fruto, su longevidad productiva, caso de estar bien cuidado, hace que la inversión no sea tan onerosa como la simiente anual que se necesita en las tierras de pan cada año de su siembra.

\section{Cuadro 17. Estimación de gastos, producción e ingresos de una aranzada de vińedo.} Tierra de Medina ${ }^{445}$. Años 1575-1600

\begin{tabular}{|c|c|c|c|}
\hline Labores & Tipo de actividad & Precio por aranzada (en reales) & Total gastos (en reales) \\
\hline \multirow[t]{11}{*}{ Labores de producción } & Vuelta de rama & 3 & \\
\hline & Desmate & & \\
\hline & Excavo & 2,5 & \\
\hline & Poda & 3 & \\
\hline & Vuelta de marzo & 3 & \\
\hline & Acobijo & 2,25 & \\
\hline & Vuelta de mayo & 3 & \\
\hline & Reacobijo y bina & 2 & \\
\hline & Desmate de mayo & & \\
\hline & Vino gastado (media cántara) & 2 & \\
\hline & Atar sarmientos & 0,75 & 21,5 \\
\hline \multirow{4}{*}{$\begin{array}{l}\text { Labores de vendimia } \\
\text { y lagar }\end{array}$} & Vendimiadores & 2 & \\
\hline & Cargadores, trotadores... & 0,25 & \\
\hline & Lagareros, pisa y lavado de cubas & 0,25 & \\
\hline & Vino gastado & 0,5 & 3 \\
\hline Otros gastos & Diezmo, rentas de capital y otros. & 16 & 16 \\
\hline TOTAL GASTOS & 40,5 & & \\
\hline \multirow{3}{*}{$\begin{array}{l}\text { Producciones y } \\
\text { venta del vino }\end{array}$} & 1 moyo (16 cántaras) & & \\
\hline & a 4 reales cántara & 64 & \\
\hline & 150 manojos & 2,5 & 66,5 \\
\hline TOTAL INGRESOS & 66,5 & & \\
\hline BENEFICIOS NETOS & 26 & & \\
\hline
\end{tabular}

Fuente: Fuente: Archivo Histórico Provincial de Valladolid. Protocolos Notariales. Elaboración propia.

Unos y otros factores, en fin, explican la apuesta por este cultivo desde estos siglos y el interés tanto de jornaleros por hacerse con alguna aranzada como de grandes productores por disponer de haciendas y controlar desde la producción hasta la comercialización del producto. El propio terrazgo en el que se asientan las vides ha sido, como se ha estudiado, ambicionado por el campesinado fuera cual fuera su potencial. Concejos, clero y nobleza no desaprovecharon la ocasión de obtener importantes beneficios de estas heredades sin apenas rendimiento hasta que en ellas arraigaron las vides.

${ }^{445}$ En las labores y precios apuntados, se ha tomado como referencia la media de los precios concertados entre partes y registrados notarialmente en distintos lugares de la Tierra de Medina entre los ańos 1575-1600. 


\section{CAPÍtULO IV}

LA CONSOLIDACIÓN DEL ESPACIO AGRARIO EN EL SIGLO XVIII. UN ACERCAMIENTO AL ESTUDIO DE LA RENTABILIDAD AGRARIA A FINALES DEL ANTIGUO RÉGIMEN 


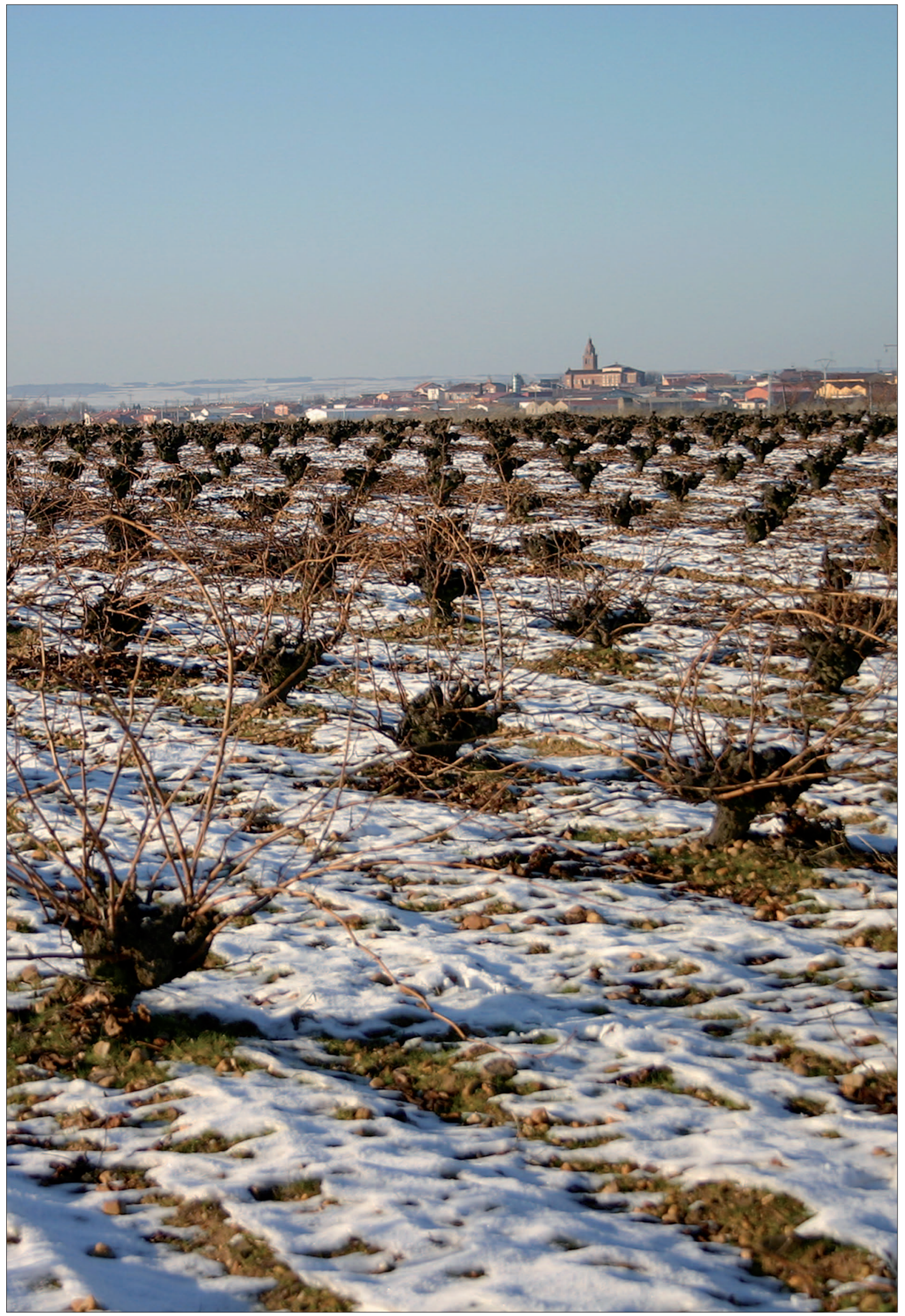

Imagen 52. Paisaje de viñedo plantado a marco real, en invierno. Serrada, al fondo. Foto: 16/12/2008. El aprovechamiento del espacio por el ser humano se explica, a lo largo del tiempo, tanto por los condicionantes físicos como por la rentabilidad de los cultivos. 
En el siglo XVIII quedaban muy lejos la gloria de los descubrimientos, la imperial Castilla y sus tercios invencibles. Hasta la propia dinastía de los Austrias se había agotado en la persona del enfermo Carlos II (1665-1699). La centuria se inicia con la muerte del rey, abriéndose un amplio abanico de pretendientes a la corona de Espańa que se enzarzan en un conflicto nacional e internacional por la sucesión a la corona. Serán los Borbones franceses, en la persona de Felipe V (1700-1746), quienes se instalen en el trono hispano e impongan una monarquía centralista y reformista, en aras de la modernización de la administración y la necesidad urgente de iniciar el camino de la industrialización. En Europa, avanzado el siglo, comienzan a difundirse las nuevas ideas ilustradas que, a la larga, transforman el viejo y pesado esquema del Antiguo Régimen. En nuestro caso, tanto Fernando VI (1746-1759) como Carlos III (1759-1788), se rodean de competentes ministros como Ensenada, Campomanes, Jovellanos o Floridablanca. Todos se esfuerzan en poner orden en la maltrecha y confusa Hacienda, en impulsar las manufacturas y el comercio o, en fin, en tratar de resolver los graves males que afectan al mundo agrario.

En esta Castilla interior, sin embargo, eran más sueños y buenas intenciones que realizaciones y progreso. La crisis poblacional del siglo XVII y la pérdida de cosechas habían dejado a los pueblos medinenses menguados de habitantes y en continuos sobresaltos. Relata Gerardo Moraleja cómo en Medina, ante la dificultad de cumplir con el donativo que se cobra en 1719, para liquidar las deudas de la Guerra de Sucesión, a muchos vecinos se les vende la cama en que dormían de forma pública, cosa que no pudo hacerse con otros muchos, porque ni siquiera la tenían ${ }^{446}$.

El siglo XVIII se inicia y transcurre en estos pueblos con el peso de lo rural de forma aplastante y sin ningún tipo de concesión a innovaciones en el seno de una sociedad profundamente campesina, sujeta a mil penurias y gravámenes, con una rígida estructura feudal que gira en torno a dos poderes omnipresentes y poderosos: la nobleza, como señores de villas y principales propietarios, y la presencia de órdenes religiosas que ejercen un control e influencia muy notable entre labradores y jornaleros. Una nobleza e Iglesia que continúan en este siglo poseyendo gran parte de la riqueza agraria de estos municipios, vinculados a dichas instituciones religiosas y a los mayorazgos nobiliarios antedichos y detrayendo, como se verá, importantes recursos en metálico o en especie, que limitan cualquier atisbo de capitalización y mejora, a jornaleros y pequeńos propietarios.

En los siglos precedentes ha quedado patente la presión campesina sobre el terrazgo de villas y aldeas. A finales del siglo XVII y principios del XVIII se puede afirmar que la mayor parte del espacio de Tierra de Medina se encuentra cultivado o lo ha sido. Se trata, pues, de un espacio predominantemente agrícola. El Catastro de Ensenada corrobora a mediados de la centuria que la presión sobre el terrazgo ha sido tal que hasta arenales y suelos sin sustancia se catastran y labran como tierras centeneras de escasos rendimientos. En muchos pueblos se ha acabado con montes pertenecientes a Propios de concejos o de sernas de Medina. En la ordenación de cultivos, seguirán pesando las condiciones atmosféricas, la rentabilidad y aptitudes de los suelos, la salida o cercanía del mercado y el lastre del arrendamiento, pero, a diferencia de pasados siglos, se observa un mayor dinamismo en las medianas labranzas que se esfuerzan por dimensionarse y capitalizarse para ser más competitivas.

${ }^{446}$ Gerardo Moraleja: Historia de Medina..., ob. cit, pág. 193. 


\section{Un terrazgo de tierras de sembradura en cultivo de ańo y vez}

El aumento de la superficie cultivable como forma de incrementar la producción de alimentos, para atender a una población creciente, hizo de la Tierra de Medina a lo largo del XVIII un espacio en el que predominan las tierras de sembradura por encima del resto de cultivos. Las manchas de encinares y retamares que se extendían por doquier son recuerdos del pasado. En el Catastro de Ensenada, en relación a la Tierra de Medina, se da fe de hasta 180.304 obradas de un total de 267.559 obradas como tierras de pan, lo que representa el $67,38 \%$ del total catastrado y el 78,41\% si atendemos a la superficie labrada ${ }^{447}$.

Cuadro 18. Aprovechamiento del terrazgo en Tierra de Medina, año 1752

\begin{tabular}{llcc}
\hline Tipos de superficie & Aprovechamiento & Obradas & $\%$ \\
\hline Superficie labrada & Tierras de sembradura & $180.304,75$ & 67,38 \\
& Viñedo & 49,432 & 18,47 \\
& Mimbrerales & 9 & 0,003 \\
& Cortinales & 78,5 & 0,029 \\
& Huertas & 120,25 & 0,044 \\
\hline Superficie no labrada & Eras & 213,5 & 0,079 \\
& Prados & $14.380,5$ & 5,37 \\
& Pinares y montes & 16,488 & 6,16 \\
\hline TOTAL & Eriales, caminos, casco población & $6,532.5$ & 2,44 \\
\hline
\end{tabular}

Fuente: Catastro del Marqués de la Ensenada. Respuestas Generales. 1752. A.G.S.

Libros correspondientes a los municipios relacionados. Elaboración propia.

El cultivo de secano en sistema bienal o de año y vez, constatado en anteriores siglos, continúa vigente como el sistema más idóneo para hacer producir las tierras de sembradura. En las Respuestas Generales del citado catastro, se constata en la totalidad de estos pueblos. Carrioncillo, por ejemplo, declara que "solo se recoge trigo, zebada, zenteno, garvanzos, garrobas, abena y vino" y en relación a las tierras, que "ninguna de las que se siembran produce más que una sola cosecha al año, entendiéndose que las de pan llevar es con uno de intermedio de descanso, a excepción de un cortinal que se siembra para verde todos los años" $"$ "48.

Aunque no todos los lugares se refieren a ello por evidente, los vecinos de Salvador de Zapardiel, por ejemplo, certifican que, si las tierras de sembradura de secano producen cada segundo ańo, es “...porque por su devilidad necesita de un año de yntermedio de descanso ${ }^{449}$. Atendiendo a la calidad de la tierra, presión demográfica y coyunturas de precios, la holganza puede alargarse más tiempo. Se ha visto en las sernas y montes de Medina en pasados siglos y se seguirá constatando en esta centuria. Tierras de sernas que catastran vecinos de La Seca en 1752 las anotan de su propiedad, pero las refieren baldías. Pedro Tejedor declara dos obradas en las "no paga cosa alguna porque no ha producido de diez años a esta parte" 450 ; Manuel de Pedrosa "por las tierras expresadas (ocho obradas) no paga cosa alguna porque están desiertas" ${ }^{351}$. Estas villas al norte del espacio estudiado, no obstante, son las menos pues, como se verá, el viñedo las hará fructificar en su mayor parte. Más allá de otras consideraciones,

${ }^{447}$ Esta magnífica fuente documental, junto con la información que proporcionan los distintos protocolos notariales de las distintas localidades, permiten un análisis detallado de las actividades y cultivos en el espacio estudiado.

${ }^{448}$ A.G.S. C.E, Carrioncillo.

${ }^{449}$ A.G.S. CE., R.G. L. 8462.

${ }^{450}$ A.H.P.V. Hacienda, Libro maestro de seglares, caja 273, fol.415 v.

${ }^{451}$ Ibidem, fol. 565 v. 
la calidad de la tierra es, en cualquier caso, determinante. En el despoblado de Bayona se catastran 441 obradas de tercera calidad, de las que cada año sólo se disfrutan y siembran de centeno 20 “...por ser de muy mala calidad, y haver experimentado, no dan fruto, las dexan olgar, y alternativamente las van disfrutando, sin que puedan exceder a las veinte obradas en cada un año.." ${ }^{452}$.

Sólo si acompaña una buena primavera logran ser rentables, tanto en las terrazas del norte como en los arenales del sur. Todas tienen propietario, pero ya estos siglos constatan su esterilidad o agotamiento. Los mismos nombres de los pagos son reveladores. Los concejos de estas villas al sur de Medina testimonian no pocas obradas incultas por naturaleza, por ser de arena muerta que apenas si dan pasto alguno. En la villa despoblada de Tobar se anotan cincuenta obradas "de tierras incultas por ser de tan mala calidad que no se labran". Manuel Martín, por su parte, vecino de Lomoviejo, es propietario de una tierra "que por naturaleza es yerma, al sitio de los arenales, de cabida de seis obradas..."453. Más adelante se precisarán cuestiones relativas a producciones y rentabilidad pero conviene destacar que de las Respuestas Generales se desprenden pocos cambios respecto a pasados siglos. Únicamente se constata que, en la hoja sembrada, se rota en ocasiones el cultivo. Fuente el Sol así lo refleja ${ }^{454}$ :

“...y si en algunas de estas (de segunda calidad) se siembra cebada a causa del benefizio extraño con que se las mejora, se la echa (de simiente) dos fanegas...”.

Y Rueda, en su respuesta número doce, también lo manifiesta de forma expresa en las tierras de regadío y lo sugiere en el resto ${ }^{455}$ :

"Las tierras de regadío un año de trigo, otro de cevada y otro de linaza, y a este tenor, que viene a ser por terceras partes.

Las de secano de primera calidad, la mitad de trigo y centeno, por mitad; una quarta parte de cevada y la otra quarta parte de titos por iguales partes.

Las de segunda, la mitad de centeno, una quarta parte de trigo y otra de cevada.

Las de tercera, tres cuartas partes de centeno y la otra de avena”

El sistema bienal con barbecho está muy arraigado. Para la inmensa parte de los labradores, todo lo que no descanse la tierra es pérdida de cosecha al año siguiente. Sólo el abonado y el agua liberarán al campesinado de estas ataduras. Resulta, en este sentido, ilustrativo el pensar de los vecinos de Salvador de Zapardiel ${ }^{456}$ :

“...una obrada de tierra de sembradura de secano de la primera calidad, cada segundo año produze cinco fanegas de trigo; y si se siembra de cevada por voluntariedad de su dueńo o colono, a causa del benefizio extrańo con que se la mejora, todo el producir de esta especie biene a ser lo mismo que de trigo; previa razón no se debe hazer desto consideración, y si por lo mismo se siembra de garbanzos en el año que tiene o había de tener de descanso, todo lo que produze esta especie pierde de producir en el fruto siguiente, por lo que tampoco se debe azer mérito ni consideración de dicho fruto".

Pese a estas consideraciones, siguen sembrándose algunos garbanzos o melones en los barbechos y, en contadas ocasiones, en algunos pagos, rubia, planta tintórea en que los ilustrados tenían depositada demasiada fe. Es el caso de Ataquines donde de las 1.400 obradas de primera calidad, 1.200 se destinan a trigo y 200 a cebada "con advertencia que de estas un año con otro y por un quinquenio

\footnotetext{
452 A.G.S. CE., R.G. L. 647023.

${ }^{453}$ A.H.P.V. Catastro de Ensenada. Hacienda, Libro maestro de seglares, caja 121, fol.212.

${ }^{454}$ A.G.S. Catastro de Ensenada. Respuestas Generales, Libro 4, fol. 212.

455 A.G.S. Catastro de Ensenada. Libro 493.

456 A.G.S. CE., R.G. L008 469.
} 
las doce se suelen sembrar de garbanzos en los años nones de descanso de trigo"457; de Ramiro "y en las de primera y segunda se suelen sembrar garbanzos"; de Serrada, pues de las 184 obradas catastradas de primera calidad, 130 se destinan a trigo y 54 a cebada, "y se advierte que en los años nones de descanso de los de esta primera calidad se suelen sembrar dos obradas, poco más o menos, de garbanzos"; de su vecino San Martin del Monte donde, por ejemplo, se anota "otra pieza de sembradura, al pago del Rubial, produze una cosech a de trigo, y al año siguiente de melones, es de la primera calidad de termino" 458 o de Matapozuelos, donde la presencia de la citada rubia tiene su importancia pues "de dicha primera calidad quatro obradas que se siembran de rubia"459.

\section{a. La ordenación de los aprovechamientos en hojas de cultivo}

La progresiva ocupación del espacio labrado va a la par de una ordenación racional de los re$\operatorname{cursos}^{460}$. Como se ha estudiado, rastrojos, barbechos y viñedos cobran importancia para su aprovechamiento por el ganado, conforme disminuyen sus pastos. En los siglos XVI y XVII, los concejos regulan las entradas del ganado en los distintos terrazgos con el fin de lograr un aprovechamiento más racional y que evite, por otro lado, los eternos conflictos entre ganaderos y labradores. De forma progresiva, una parte o la totalidad del terrazgo de sembradura se divide en dos hojas de cultivo, la sembrada y la barbechada, que van alternándose conforme al sistema bienal. La hoja de vińas permanece estable en los pagos de gravas y arenas, una vez que estas son agotadas por el centeno o siempre que el vińedo goce de una rentabilidad mayor que el cultivo cerealista.

El proceso de ordenación, a la vista de lo investigado, se constata, en fechas más tempranas, en las campińas meridionales que en las terrazas septentrionales. Con todo, el proceso no se generaliza en toda la Tierra ni en tiempo ni en la totalidad de los términos de muchos pueblos. No se olvide, como una dificultad ańadida, la necesidad de equilibrar por parte de los labradores la superficie de pan y barbecho en las distintas hojas. De hecho, cada hoja suele ocupar dos partes representativas del término, para evitar catástrofes naturales (pedriscos) que puedan afectar a una parte del término coincidente con las tierras de pan y para que todos los propietarios puedan tener parcelas en las distintas hojas de forma más equilibrada.

En las campiñas meridionales se ha constatado, a comienzos del XVII, que la división en hojas es un hecho en muchos términos. En Rubí, Francisco Serracín y Antón Prado arriendan en 1625 todas las tierras que Antonio Verdugo tiene en esta villa "por ocho años y ocho frutos, cada hoxa quatro frutos...". En otro arrendamiento del mismo año, otro rentero se obliga a "pagar de renta las dichas ocho fanegas de trigo cada hoja que las a de labrar tres frutos cada una oja que biene a ser seis pagas". Un siglo después, en 1723, se firma un arrendamiento de toda una heredad de 62 obradas a 31 fanegas de trigo cada año y una duración de ocho años "...que son quatro panes en cada oja... ”’61. Rubí no es un caso aislado. En Lomoviejo hay ventas en las que se determina la localización exacta de las tierras en estas hojas de cultivo. Pedro Sanz vende el 3 de julio de 1671 al licenciado Suárez, beneficiado mayor del lugar, toda una heredad de 40 obradas por valor de 5.000 reales de vellón. Están distribuidas en diez parcelas que suman 17,75 obradas, localizadas en "Panes. Año de Nones" y catorce parcelas que suman 22,25 obradas anotadas en "Rastrojo. Año de Pares". Igualmente, le vende tres vińas valoradas en 5.000 reales localizadas en "Biñas", prueba todo ello de la nítida separación de las hojas en el citado lugar en esta fecha ${ }^{462}$.

${ }^{457}$ A.G.S. CE., R.G. L. 648.

${ }^{458}$ A.H.P.V. Hacienda, Catastro de Ensenada, fol 49, San Martín del Monte.

${ }^{459}$ Matapozuelos.

${ }^{460}$ No es fácil determinar el proceso de ordenación en hojas por falta de documentación histórica pero, a la vista de lo investigado, el proceso ni se da a la par en todos los términos ni, cuando surge, ocupa la totalidad del terrazgo labrado.

${ }^{461}$ A.H.P.V. Pt 8323, fol. 29.

462 A.H.P.V. Escribano: Diego Bueno, Lomoviejo, año 1671, fol. 81. 
En todas estas localidades, cuando se levanta el fruto, el terrazgo "que ocupan una y otra oja su rastrojo es de aprovechamiento común para todo tipo de ganados..." ${ }^{\prime 43}$. Bobadilla del Campo, en la cuarta pregunta del Catastro de 1752, repite de forma invariable lo que manifiestan el resto de poblaciones vecinas ${ }^{464}$ :

“...y por lo que respecta a tierras de cultivo se hallan repartidas en dos hojas: la una nombrada la de pares que se halla de rastrojo y la otra la de nones que actualmente se halla sembrada; es con descanso de un año y produce el siguiente...”.

Las figuras adjuntas son ilustrativas de este reparto. Las campiñas meridionales muestran un predominio cerealistíco y unas hojas muy equilibradas y repartidas por todo el término. Su localización no olvida ni las condiciones edáficas ni una distribución espacial que permita a todos los labradores disponer de parcelas en las distintas hojas en que se divide el término. La atomización parcelaria ayuda, en estos casos, a tal fin y aminora los efectos de pedriscos u otras desgracias, caso de estar concentrada toda la heredad en una parte del término. Las hojas del viñedo ocupan mucha menos extensión y nunca tuvieron la importancia que en los pueblos al norte de la comarca donde este aprovechamiento se extiende progresivamente por las superficies de gravas ocupadas por montes y retamares.

En todos ellos, como puede apreciarse, el espacio de eras y cortinales en torno al lugar poblado es representativo del espacio necesario para la trilla y limpia del grano como, en el caso de los cortinales, de las siembras de cereal para verde. Se observará, igualmente, que todos los términos necesitan y disponen de prados, baldíos y montes, elementos fundamentales para alimento del ganado o aprovisionamiento de leña y madera, imprescindible en las economías de este tiempo ${ }^{465}$.

La incorporación de otros lugares a esta organización y aprovechamiento agrario del terrazgo, a tenor de la documentación consultada, no es tan temprana. Medina del Campo, de acuerdo con las investigaciones de Pascual Gete, incorpora el sistema en hojas a fines del siglo XVII. En los debates que anteceden a las ordenanzas que las regulan, se señala que el sistema en hojas "se guarda en muchos pueblos y villas de la jurisdicción y Tierra de Medina” como, por ejemplo, Velascálvaro y Pozal de Gallinas ${ }^{466}$.

Este hecho tarda más en constatarse en las terrazas al norte, pero también acaba imponiéndose en la mayor parte de los lugares. Una posible explicación es la roturación de los montes y su plantación de majuelos cuando el cereal agota la fertilidad de los suelos. Ello no significa que en las tierras más feraces y de aprovechamiento antiguo no exista dicho sistema. Así se entiende en el término de Serrada que sirve de ejemplo. En el contrato de arrendamiento de 1675 Diego de Montalvo, señor de la villa, arrienda buena parte del terrazgo a sus renteros "por diez años y pagas, años y pagas cada oja..." "467. Unas décadas más tarde, en los contratos se especifica el reparto de forma más explícita. De hecho, el contrato de arrendamiento que se firma en 1709 es claro al respecto. Sólo algunas piezas repiten cultivo y todos los renteros tienen que acatar la tradición antigua de la división en hojas de la superficie labrada ${ }^{468}$ :

${ }^{463}$ A.G.S. CE. R.G. L. 529306.

${ }^{464}$ Ibidem.

${ }^{465}$ Las fuentes tomadas para la realización cartográfíca han sido los distintos protocolos notariales en que se refieren inventarios de de bienes donde constan dicho reparto. Igualmente, en los ejemplos al sur de Medina, se ha recurrido a la información oral de los labradores de mayor edad que recuerdan con precisión los pagos y caminos que servían de límite a una u otra hoja, y que eran coincidentes con la investigación archivística. En el caso de Serrada, al no disponer de fuentes precisas, el reparto es una estimación y en el trabajo cartográfico, una vez más, somos deudores del profesor Miguel Ángel Martín Hernando.

466 PASCUAL GETE, H.: La Tierra de Medina..., ob. cit. . (A.H.N. Consejos, Leg. 28125, exp. n 31 "Nuevas ordenanzas de Medina del Campo aprobadas en 1696”).

${ }^{467}$ A.H.P.V. Pt. 6507, fol. 140.

${ }^{468}$ A.H.P.V. Pt. 8214, fol. 109. 
SAN MARTÍN DEL MONTE, SERRADA Y LA MOYA ESTIMACIÓN DE HOJAS DE CULTIVO. AÑOS PARES. SIGLO XVIII

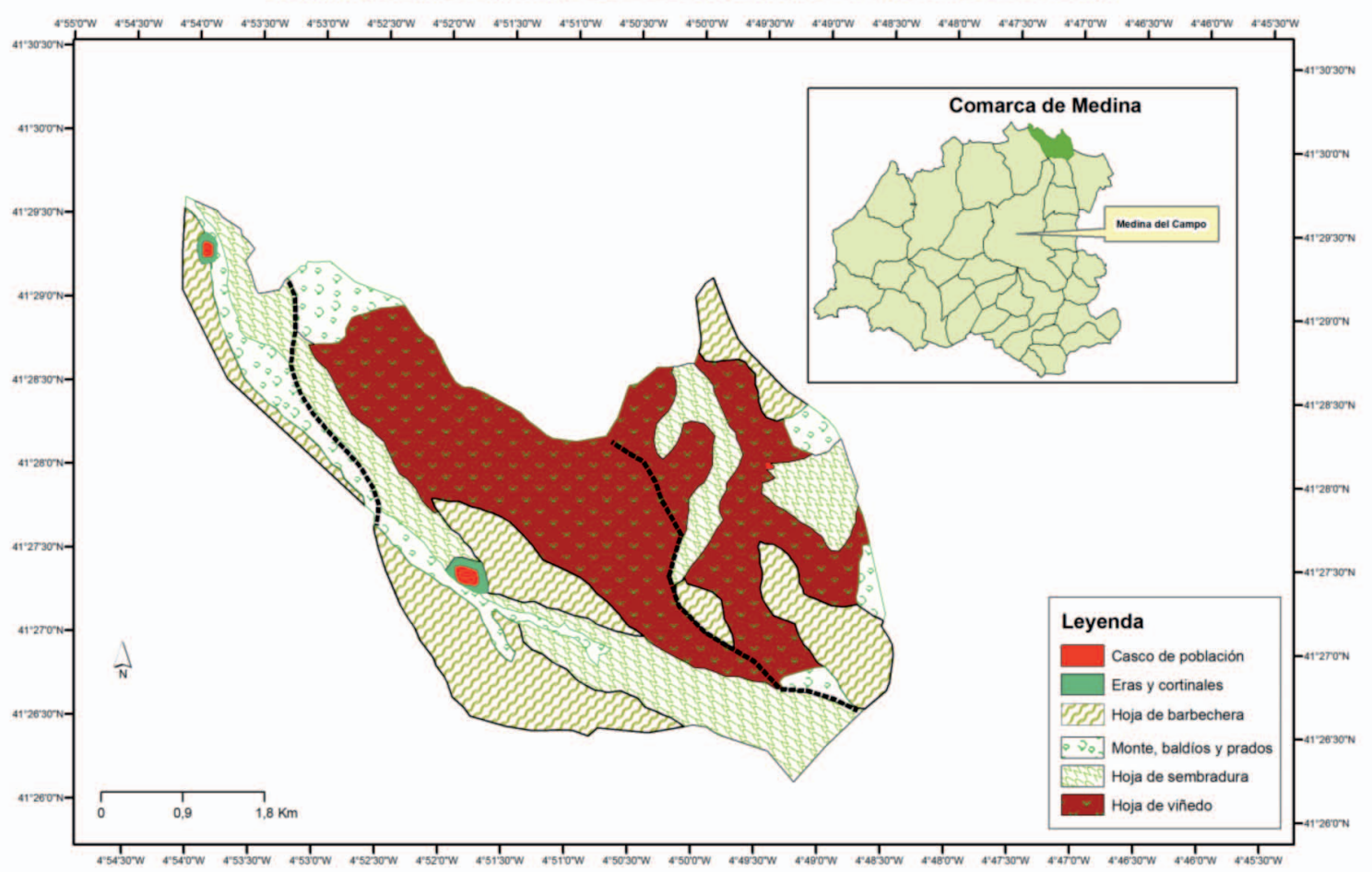

RUBÍ DE BRACAMONTE. SIGLO XVII

HOJAS DE CULTIVO. AÑOS PARES

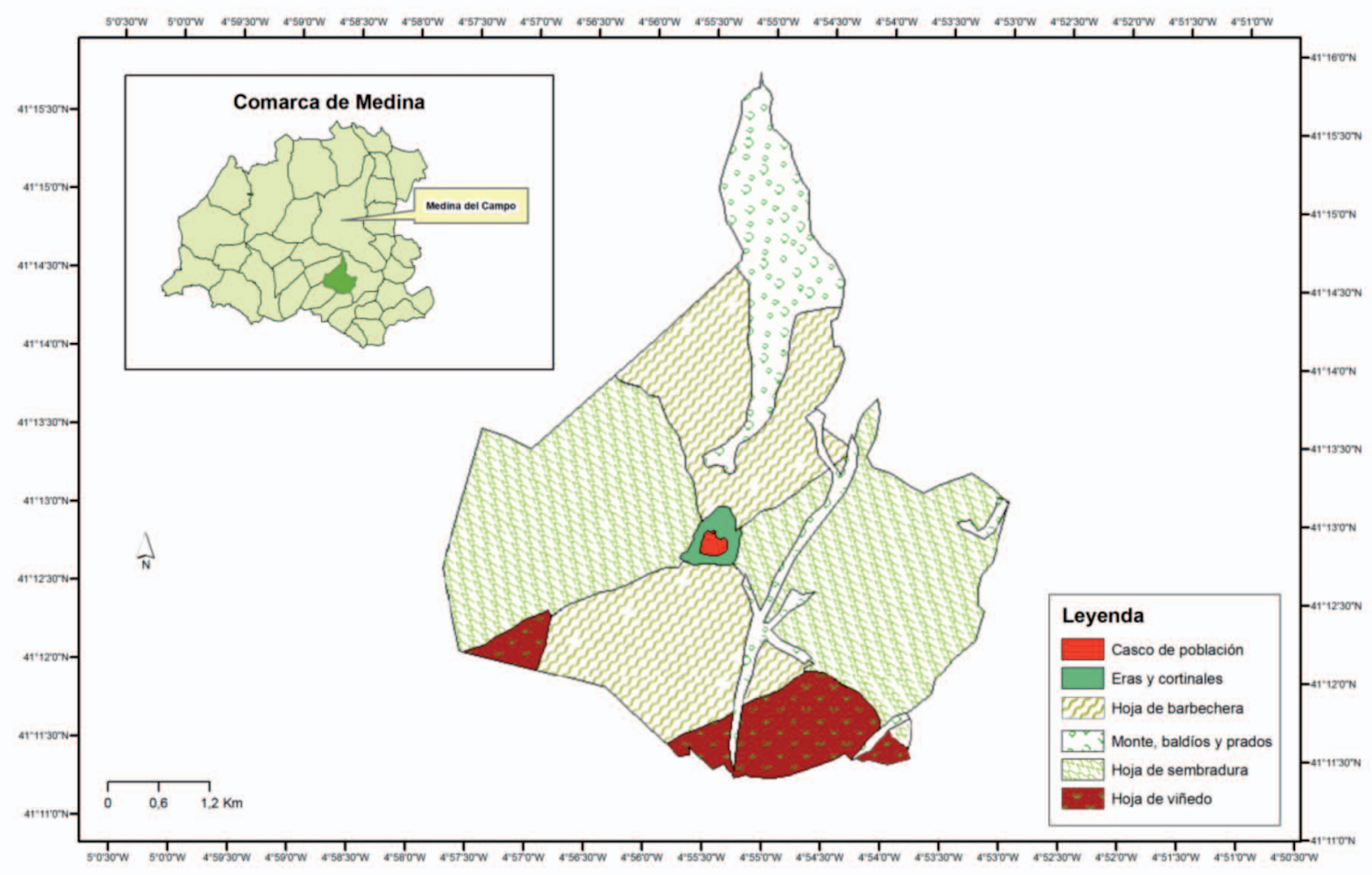

Fuente: Protocolos Notariales. A.H.P.V. y Catastro del Marqués de la Ensenada. Respuestas Generales y Particulares. 1752. A.G.S. Elaboración propia.

Figura 22. Hojas de cultivo y otros aprovechamientos en Serrada y Rubí de Bracamonte. 


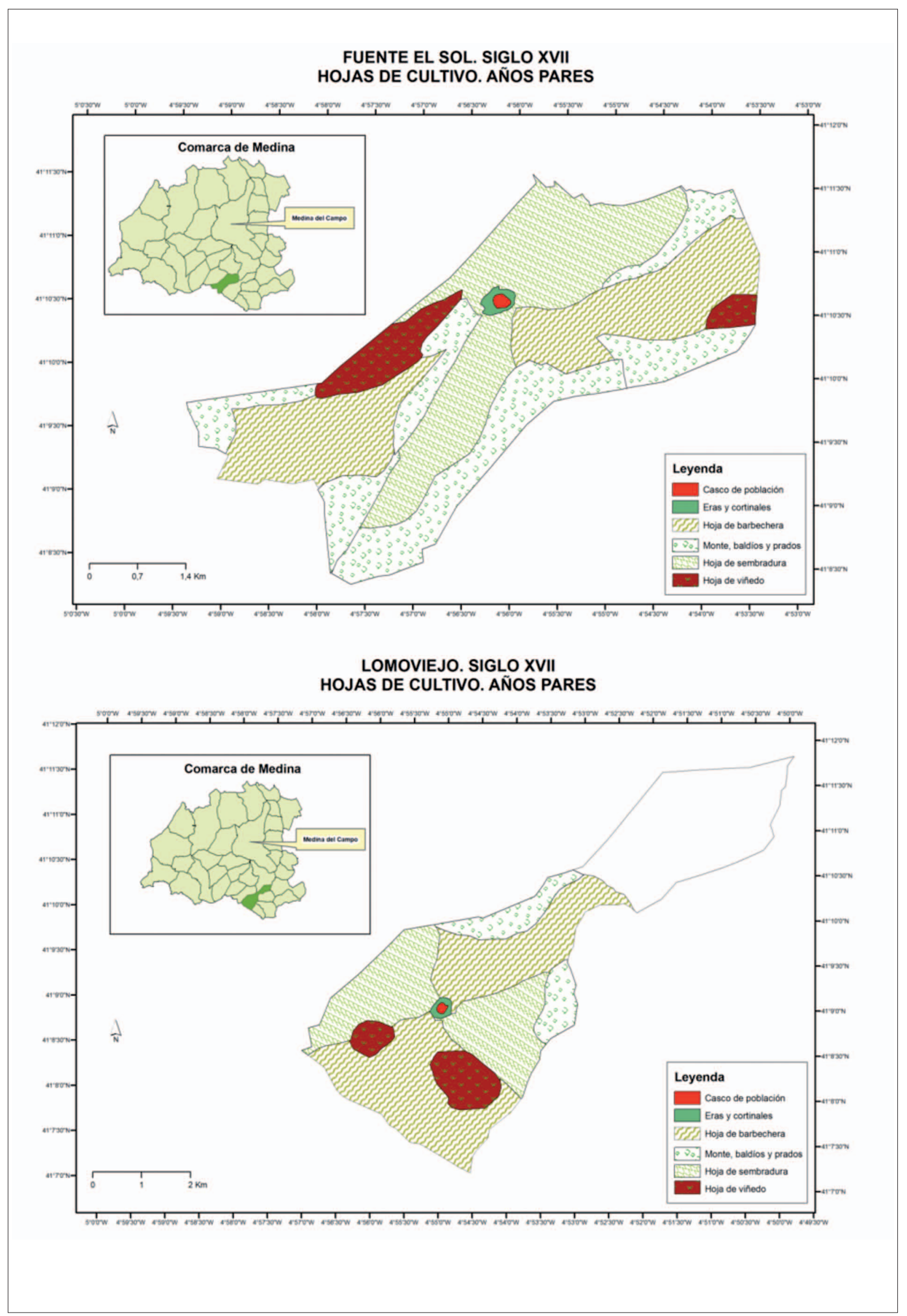

Fuente: Protocolos Notariales. A.H.P.V. y Catastro del Marqués de la Ensenada. Respuestas Generales y Particulares. 1752. A.G.S. Elaboración propia.

Figura 23. Hojas de cultivo y otros aprovechamientos en Fuentelsol y Lomoviejo. 
"Que las dichas honze rentas se an de barbechar y sembrar a las ojas y bezes que se an abarbechado y sembrado antiguamente. Y que si por causa de haber labrado las mismas rentas el arriendo antezedente los mismos otorgantes u otros se hubieren entrado por algún fin de su conbeniencia a rebolber algunas de las dichas tierras las ayan de quedar y poner a las dichas ojas y bezes que estaban antiguamente..."

En 1742, Alejo Manuel de Montalvo, sucesor en el mayorazgo, arrienda tierras con condiciones muy claras en ese sentido ${ }^{469}$ :

"Que las tierras de dicho cortijo se an de traer a dos ojas de suerte que el último año de este arrendamiento que sera el año que viere de setecientos y cuarenta y siete a de quedar una oja de vacío para que en ella abarbechen los arrendadores que le subcedieren”.

A partir de estas fechas, en los contratos se detallan las superficies existentes en cada hoja, prácticamente iguales, por lo general. A la luz de lo investigado, se entiende que la totalidad del término acaba el XVIII repartido en hojas de cultivo. En 1813, se firman numerosas escrituras de arriendo del citado mayorazgo donde se hace constar este hecho y, en 1831, cuando el convento de San Pablo arrienda 25 obradas a Luis Moyano, se hace constar que están "a dos ojas por mitad a doce obradas y media cada una" 470 .

Esta evolución es similar en términos cercanos. Un ejemplo es Pozaldez. En la primera mitad del XVII se prohíbe revolver las tierras y, en los arrendamientos, lo general es hacer constar que se lleven "a año y vez" "71; en la segunda mitad se estipula que las tierras y rentas sean "por ocho años y quatro panes de cada una porque las a de traer a oxa" ${ }^{372}$, para generalizarse en el XVIII la exigencia de llevar las tierras "con buena labranza y de poner(las) para la hoja que corresponda"473.

En los pueblos limítrofes este reparto se encuentra, en el siglo XVIII, en Valdestillas en las tierras de primera calidad, lo que lleva a pensar que estaría extendido también al resto del terrazgo ${ }^{474}$ :

“...de sembradura... de primera calidad setecientas obradas, que cinco partes de siete se sembraran de trigo, y las doscientas de cebada divididas en las dos ojas...”.

De hecho, a finales de siglo, constan escrituras en que esta cuestión se anota como general. En la mencionada villa se firma en 1797 un contrato de arrendamiento, por parte del monasterio de Aniago, en el que arrienda todas las tierras que posee en el referido término, en el que hace constar de forma precisa que las tierras "están y labrase dichas tierras a dos oxas"475. En las villas de términos más extensos situadas al norte, como Rueda o Nava, el reparto aparece en distintos protocolos, pero es dudoso que esté generalizado a todo el término, pese a encontrar expresiones de labrase " 0 oxa" $a$ "77.

${ }^{469}$ A.H.P.V. Pt. 8215, fol. 284.

${ }^{470}$ A.H.P.V. Pt. 8230, fol. 46.

471 A.H.P.V. Pt. 11735, fol. 2 y Pt 11763, fol. 11.

472 A.H.P.V. Pt. 11763, fol. 13.

${ }^{473}$ A.H.P.V. Pt. 11776 , fol. 8.

${ }^{474}$ AG SCE_RG_L646_543.jpg.

475 A.H.P.V. Pt 11890/7. fol. 7.

${ }^{476}$ No es fácil determinar, en ocasiones, si todo el terrazgo está en hojas, pese a que muchos contratos de arrendamiento refieran que las tierras arrendadas deben cultivarse en hojas. En ocasiones la expresión es sinónimo de año y vez y que la parte sembrada debe descansar al siguiente. $\mathrm{O}$ que una misma parcela tiene una parte sembrada y otra en barbecho. Es muy posible que en muchos términos existan pagos donde el agrupamiento de las parcelas sembradas y los barbechos esté más extendido que en otros. En pueblos fuera del espacio que nos ocupa sucede lo mismo. En la Cistérniga, por ejemplo, en un contrato de arrendamiento de 1778, se concreta que las "dichas tierras las hemos de labrar y disfrutar a estilo de la labranza, a dos ojas, en un año la mitad y en otro la otra mitad, y así alternativamente, y al fin deste 
En Nava, por ejemplo, en un arrendamiento de 1728, se fijan condiciones que, una vez cogido el pan en agosto, "queden las de la una oja bazias y de rastrojo para el nuevo arrendador..." 477 , insistiendo en la prohibición de que no se retelen salvo los cortinales arrendados. En su vecina Torrecilla del Valle, el reparto se constata de forma más explícita “...por aver de andar a dos ojas y sembrar en cada una la mitad de dichas tierras... "’78, lo que prueba lo generalizado de este modo de aprovechamiento. En ocasiones, dicha división se hace constar en los contratos de arrendamiento a la hora de fijas rentas, pues no deja de ser un condicionante la situación de las parcelas. En Villanueva, por ejemplo, en un contrato de 1752 y de duración de ocho años, al encontrase todas las tierras en una hoja, el

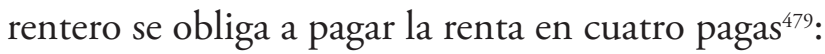

“...las referidas tierras... componen diez y ocho iguadas y quinientos y cinco estadales, las arriendo por espacio de ocho ańos y quatro pagas, por ser tierras que todas ellas están a una hoja, y a precio de catorce celemines de trigo por iguada, que suman y cuentan veinte y una fanegas".

La renta también puede variar atendiendo a que existan más tierras arrendadas en una u otra hoja. Es el caso del firmado en Matapozuelos en 1798. Pedro Martín arrienda cinco obradas en varios pedazos y la renta ha de pagarse en la manera que sigue ${ }^{480}$ :

“...y en cada uno de ellos por estar dichas tierras y lavrarse a dos oxas le ha de pagar en los años pares seis fanegas de trigo... y en los nones quatro fanegas...”.

Igual circunstancia se detecta en 1756 en Rueda cuando se manifiesta en otro contrato que "sembraderes en cada hoja por estar dividida en dos y ser mayor una que otra"

El sistema, en fin, una vez fijado, permanece durante los siguientes siglos de forma inalterable. Sólo la intensificación del abonado y los cambios que se verán en el XIX modifican en muchos pueblos esta forma de organizar el terrazgo. De hecho, en los pueblos más meridionales, eminentemente cerealistas, el sistema en hojas se mantiene hasta el fin del primer tercio del siglo XX. En la cartografía adjunta puede observarse esta forma de división del terrazgo labrado en los términos de Fuentelsol, Rubí y Lomoviejo, representativos del sur comarcal y de Serrada, al norte del mismo.

\section{b. El aprovechamiento del terrazgo a mediados del siglo XVIII}

Las tierras de sembradura dominan ampliamente el terrazgo y ocupan la práctica totalidad del año al campesino. En el conjunto comarcal casi cuadruplican en superficie (3,64 veces) al viñedo, segundo cultivo en importancia, si bien, en este sentido, es notable la diferencia existente entre el sector norte de terrazas, donde el terrazgo de sembradura representa el $47,48 \%$ y el vińedo ocupa el $42,63 \%$, frente a los pueblos más meridionales, en los que los porcentajes son, respectivamente, del $82,97 \%$ para la sembradura y tan sólo del 4,46\% para el viñedo. La comparación de los cuadros adjuntos en las que se ha tomado como muestra algo más de 20.000 obradas al norte y sur de la

arrendamiento hemos de dejar la mitad de dichas tierras calbas y la otra mitad rasas para que el nuevo arrendatario pueda entrar lebantando y abrabechando la oja correspondiente" (A.H.P.V. Hospital de Resurrección, libro 25-5.) De esta manera, como en otros contratos de Tierra de Medina, queda claro que se labran a dos hojas, pero en ningún modo se puede deducir con certeza que la tierra que se siembra esté dentro de la hoja sembrada ni que la que se deja de barbecho esté colindante con otras de la hoja de barbechera del citado lugar.

477 A.H.P.V. Pt 13606, fol. 138.

478 A.H.P.V. Pt 13606, fol. 175.

${ }^{479}$ A.H.P.V. Pt 8203, fol. 512.

${ }^{480}$ A.H.P.V. Pt 11890, fol. 126.

${ }^{481}$ A.H.P.V. Pt 8058, fol. 268 
zona de estudio es reveladora en este sentido ${ }^{482}$. Respecto al resto de superficie labrada, a excepción del vińedo y mimbrerales, sean cortinales o huertas, hay que anotar que en las respuestas generales no siempre se especifican, aun cuando en las particulares se catastran. Representan el 1\% de las tierras de sembradura, caracterizan el paisaje limítrofe a la población y sirven de complemento, tanto para la alimentación en verde del ganado, como para provisión y venta de hortaliza a la población.

Cuadro 19. Aprovechamiento del terrazgo en el norte de Tierra de Medina, año 1752. (Rueda, La Seca, Serrada y Villanueva de Duero)

\begin{tabular}{llcc}
\hline Tipos de superficie & Aprovechamiento & Obradas & $\%$ \\
\hline Superficie labrada & Tierras de sembradura & 11.101 & 47,48 \\
& Viñedo & 9.967 & 42,63 \\
& Mimbrerales & 9 & 0,038 \\
& Cortinales & 0 & 0 \\
& Huertas & 4 & 0,017 \\
Superficie no labrada & Eras & 40 & 0,17 \\
& Prados & 504 & 2,15 \\
& Pinares y montes & 1.063 & 4,54 \\
\hline TOTAL & Eriales, caminos, casco población & 688 & 2,94 \\
\hline
\end{tabular}

Fuente: Catastro del Marqués de la Ensenada. Respuestas Generales. 1752. A.G.S.

Libros correspondientes a los municipios relacionados. Elaboración propia.

Cuadro 20. Aprovechamiento del terrazgo en el sur de Tierra de Medina, año 1752 (Rubí, Fuentelsol, Lomoviejo, Cervillego, Gomeznarro y San Vicente)

\begin{tabular}{llrr}
\hline Tipos de superficie & Aprovechamiento & Obradas & $\%$ \\
\hline Superficie labrada & Tierras de sembradura & 17.971 & 82,97 \\
& Viñedo & 967 & 4,46 \\
& Mimbrerales & & 0,008 \\
& Cortinales & 1.75 & 11,53 \\
Superficie no labrada & Euertas & & 0,32 \\
& Pras & 2.499 & 0,68 \\
\hline TOTAL & Pinares y montes & 70 & 99,96 \\
\hline
\end{tabular}

Fuente: Catastro del Marqués de la Ensenada. Respuestas Generales. 1752. A.G.S.

Libros correspondientes a los municipios relacionados. Elaboración propia.

482 Para evitar reiteraciones en las citas al pie en los cuadros que figuran en este apartado, y cuya fuente han sido los Libros de Respuestas Generales, del Catastro de Ensenada, (A.G.S.) se han utilizado los libros que siguen de los pueblos y despoblados de la Tierra de Medina: libro 649 (Arenillas, Herreros, San Martín del Monte, Terradillos...); libro 646 (Valdestillas, Aniago, Otea, ...); libro 629 (Castronuño...); libro 548 (Alaejos, Castrejón...); libro 4 (fuente el Sol, Onquilana, Oncalada, Lomoviejo,...); libro 5 (Muriel...); libro 648 (Ataquines, La Zarza, La Moya, Matapozuelos, Serrada, Ramiro,...); libro 647 (Villanueva de Duero, Brahojos, Bayona, Carpio, Carrioncillo, Dueñas, Eván de Abajo, Aván de Arriba, Escargamaría, Foncastín, Fuente la Piedra, Gomeznarro, La Seca, La Golosa, Ventosa, Medina del Campo, Moraleja de las Panaderas, Nava del Rey, Pollos, Pozal de Gallinas, Rueda, Pozaldez, Rubí de Bracamonte, Romaguitardo, Torrecilla del Valle, san Vicente del Palacio, Torrecilla del valle, Siete Iglesias, Travancos, Tovar, Velascálvaro, Villaverde, Villaluz, Cervillego, Zofraga...). 
Dentro de ellas, destacan las de regadío, generado por el agua de arroyos o manantiales o bien por la excavación de pequeños pozos. En Villanueva, por ejemplo, hay constancia de "varias huertas de regadio con un arroyo que pasa inmediato a ellas"; en Pollos las hortalizas conviven con árboles frutales y así "...en la citada huerta de ortaliza estan plantados diferentes arboles frutales que se reducen a docena y media de ellos y de corta edad, y tambien estan plantados en ella y alrededor de la balsa donde se recoge el agua para regar, diferentes arboles de negrillo, cuyo numero llegará a veinte"; en las dos huertas de Carpio "hay en la una quatro higueras pequeñas, y en la otra diferentes arboles frutales como son guindos, membrillos, ziruelares y alamos blancos y negrillos". La obrada de hortaliza que catastra la pequeña villa de San Martín del Monte “...produce berza, zebolla, ajos y perejil”, es propiedad del jornalero Francisco González y se describe como sigue ${ }^{483}$ :

"Una pieza de tierra de regido por tres pozos de zigüeñal, de hortaliza. Dista de la población seis pasos...Consiste en una obrada de tierra murada alrredor con su vallado de tierra... Produze todos los ańos, sin intermisión”.

Para completar los sistemas de riego, seguidamente se describen las huertas de Serrada, situadas también junto al casco de población, y en las que el agua de los pozos se extrae mediante noria ${ }^{484}$ :

\footnotetext{
"Una tierra de regadío por noria plantada de hortaliza al camino de La Seca...Consiste en media obrada. Confronta a poniente con huerta de Pedro Martínez, al norte con calle que va a Matapozuelos y al sur con prado de esta villa..."

"Una huerta de regadío por noria, sembrada de hortaliza, situada en la casa que aquí se expresa... consiste en media quarta. Es de la primera calidad".
}

Junto a estas huertas limítrofes con casa y corrales, se extienden cortinales o arreñales que, generalmente, están tapiados o rodeados de setos y vallados. Rubi de Bracamonte catastra, por ejemplo "una pieza de tierra cortinal de sembradura de secano, cercada de ballado, contiguo a la población" y "una pieza cortinal de sembradura de secano, dentro de la población desta villa, zercada de tapia" ${ }^{485}$. Se siembran todos los años y atendiendo a las necesidades del ganado bien se aprovechan a diente, bien acaban segándose pues, al estar bien estercoladas y cuidadas producen todos los años. Baste señalar que en La Seca "en los arreñales o cortinales sembrados todos los años de zebada (se coge) treinta y dos fanegas y de zenteno doze fanegas" cantidades, pues, muy superiores a las medias de las hojas sembradas.

\section{- La gran disparidad de calidades en las tierras de sembradura}

Como se ha señalado, especialmente importante en las tierras de sembradura es su calidad. El campesino se juega la rentabilidad de su hacienda año tras año. De las 180.304 obradas que se anotan en el Catastro de Ensenada, 23.108 obradas (12,81\% ) son de primera; 72.401 (40,15\%) de segunda y $84.795(54,38 \%)$ de tercera. Con estos porcentajes y en secano se comprende la queja de algunos concejos, cuando manifiestan que "...por lo común su terrazgo es bien infimo y endeble, como es notorio" $\$ 86$, caso de Cervillego y que, como puede apreciarse en los cuadros comparativos, es la villa con el menor porcentaje $(7,40 \%)$ de tierras de primera calidad respecto al total de tierras de sembradura. Sin entrar en particularismos, lo que no cabe duda es la gran diferencia entre calidades en estas tierras blancas. Más de la mitad son de tercera calidad y tan sólo un 12,81\%, de primera. Difícil tesitura al sur del Duero pues, como se estudió en los condicionamientos físicos, suman todas las cargas negativas que puede tener el cereal: se refrían con gran facilidad en los inviernos,

\footnotetext{
${ }^{483}$ A.H.P.V. Catastro de Ensenada, Respuestas Particulares, caja 254, fol 116.

${ }^{484}$ Ibidem, fols. 224 y 248 respectivamente.

${ }^{485}$ A.H.P.V. Catastro de Ensenada, Respuestas Particulares, caja 236, fol. 267 y 603 respectivamente.

${ }^{486}$ A.G.S. Catastro de Ensenada, Respuestas Generales, Cervillego.
} 
sufren más las heladas primaverales y, al tener el componente arenoso una mayor proporción en el perfil edáfico, si las lluvias escasean desde mediados de mayo, sitúa a los herbáceos en ellas sembrados al borde del agostamiento.

Los pueblos al norte de la Tierra, como es sabido, eludieron en la medida de sus posibilidades y en mayor proporción la deficiencia de sus peores suelos, dedicándoles al viñedo, pero aun así, en la muestra tomada, sus tierras de primera no superan el $20 \%$ en ningún caso.

Cuadro 21. Ejemplos de calidad de las tierras de sembradura en el norte de Tierra de Medina, año 1752. (Rueda, La Seca, Serrada y Villanueva de Duero. En obradas)

\begin{tabular}{lrrrrrrr}
\hline & $\begin{array}{r}\text { Primera } \\
\text { calidad }\end{array}$ & $\%$ & $\begin{array}{r}\text { Segunda } \\
\text { calidad }\end{array}$ & $\%$ & $\begin{array}{r}\text { Tercera } \\
\text { calidad }\end{array}$ & $\%$ & TOTAL \\
\hline Rueda & 556 & 18,42 & 770 & 25,52 & 1.691 & 56,04 & 3.017 \\
La Seca & 1.000 & 19,53 & 1.500 & 29,29 & 2.620 & 51,17 & 5.120 \\
Serrada & 268 & 17,15 & 528 & 33,80 & 766 & 49,03 & 1.562 \\
Villanueva D. & 190 & 13,68 & 245 & 17,65 & 953 & 68,65 & 1.388 \\
\hline TOTAL & 2.014 & 18,16 & 3.043 & 27,44 & 6.030 & 54,38 & 11.087 \\
\hline TOTAL MEDINA & $23.108,75$ & 12,81 & 72.401 & 40,15 & 84.795 & 47,02 & $180.304,75$ \\
\hline
\end{tabular}

Fuente: Catastro del Marqués de la Ensenada. Respuestas Generales. 1752. A.G.S.

Libros correspondientes a los municipios relacionados. Elaboración propia.

Cuadro 22. Ejemplos de calidad de las tierras de sembradura en el sur de Medina, año 1752. (Rubí, Fuentelsol, Lomoviejo, Cervillego, Gomeznarro y San Vicente. En obradas)

\begin{tabular}{lrrrrrrr}
\hline & $\begin{array}{r}\text { Primera } \\
\text { calidad }\end{array}$ & $\%$ & $\begin{array}{r}\text { Segunda } \\
\text { calidad }\end{array}$ & $\%$ & $\begin{array}{r}\text { Tercera } \\
\text { calidad }\end{array}$ & $\%$ & TOTAL \\
\hline Rubí & 376 & 16,52 & 900 & 39,54 & 1.000 & 43,93 & 2.276 \\
Fuentelsol & 300 & 9,38 & 1.195 & 37,40 & 1.700 & 53,20 & 3.195 \\
Lomoviejo & 400 & 9,09 & 2.800 & 63,63 & 1.200 & 27,27 & 4.400 \\
Cervillego & 200 & 7,40 & 1.500 & 55,55 & 1.000 & 37,03 & 2.700 \\
Gomeznarro & 300 & 15,78 & 800 & 42,10 & 800 & 42,10 & 1.900 \\
San Vicente & 800 & 22,85 & 1.200 & 34,28 & 1.500 & 42,85 & 3.500 \\
\hline TOTAL & 2.376 & 13,22 & 8.395 & 46,71 & 7.200 & 40,06 & 17.971 \\
\hline TOTAL MEDINA & $23.108,75$ & 12,81 & 72.401 & 40,15 & 84.795 & 47,02 & $180.304,75$ \\
\hline
\end{tabular}

Fuente: Catastro del Marqués de la Ensenada. Respuestas Generales. 1752. A.G.S.

Libros correspondientes a los municipios relacionados. Elaboración propia.

No se pueden desligar, desde un punto de vista agronómico, estas tierras y sus calidades de las precipitaciones que reciben. Cuando los labradores del XVIII se quejan de lo liviano de muchos pagos de cada término, no sólo se refieren al suelo, que lo es en gran medida, si se desea hacer fructificar trigo o cebada, sino también a "su secura", esto es, a la escasez de precipitaciones que le hacen, si cabe, más endeble. Se apuntaba en los condicionamientos físicos, y es ahora cuando se debe tener especialmente en cuenta en estos pagos al sur del Duero. Muchas villas apenas recogieron cosecha en los últimos años de la segunda década del siglo. El concejo de Rubí, por ejemplo, “...con el motivo de hallarse esta villa mui aniquilada por la falta de cosechas" y no disponer de trigo para sembrar la barbechera, acude al vicario de Medina solicitando ayuda. Al ser esta parroquia "mediana" de su abadía, se acuerda que la fábrica de la iglesia venda, mediante obligaciones, el trigo que necesitan sus labradores ${ }^{487}$. Las ventas de tierras, escrituras de censos y préstamos, aumentan estos años entre el campesinado con menos recursos.

\footnotetext{
${ }^{487}$ A.H.P.V. Pt. 6653, fol. 92.
} 
Las tierras de tercera, que representan casi el 50\% de las labrantías, se siegan, si llueve bien y a tiempo, en mayo y a primeros de junio. De lo contrario, poca utilidad declaran estos campesinos en sus cosechas. En los cuadros adjuntos de distribución por calidades, en que se han seleccionado cerca de veinte mil obradas y en que se especifican sus cultivos, puede apreciarse que el trigo es el cereal mayoritario, tanto en las tierras de primera como, sobre todo, en las de segunda, en las que representa más del 86\%. Es el cultivo más rentable, en el que generalmente se pagan las rentas y el que proporciona excedentes monetarios, pues, asegurada la alimentación familiar y la simiente, el resto se destina al mercado, siendo su precio muy superior al resto de cereales. Y, si en las de primera se siembra el $55 \%$, es por la necesidad de disponer de cebada para alimentación del ganado, especialmente del mular en las épocas de trabajo. La cebada es exigente en cuanto a suelo y en San Vicente del Palacio se constata de forma expresa al manifestar que "en las que se siembra de cebada son las de primera calidad, porque para esta especie no hay segunda ni tercera...". En las tierras de tercera esta función la desempeñan las algarrobas o la avena. En Pozaldez, en que se especifican leguminosas y cereales menores, se anotan doce obradas de garbanzos en las tierras de primera; veinte de avena y veinte de algarrobas en las de segunda "por usarse en este pueblo para la lavor del campo del ganado que las consume ${ }^{\prime \prime 88}$. Piénsese que en aquellos pueblos que apenas refieren prados, eriales o montes, como es el caso, y si además disponen de abundantes viñas (1.000 obradas), disponer de cebada, avena y algarrobas es vital.

Cuadro 23. Ejemplos de cultivos de cereales y leguminosas en tierras de sembradura de Tierra de Medina $^{489}$. Distribución por calidades. En obradas

\begin{tabular}{lcccccccccrrr}
\hline $\begin{array}{l}\text { Villas y } \\
\text { despoblados }\end{array}$ & \multicolumn{4}{c}{ Primera calidad } & \multicolumn{3}{c}{ Segunda calidad } & \multicolumn{5}{c}{ Tercera calidad } \\
& Trigo & Cebada & Barbecho & Trigo & Cebada & Barbecho & Centeno & Algarrobas & Avena & Barbecho & Total \\
\hline San Martín & 26,6 & 5,33 & 32 & 27,5 & 0 & 30 & 22,66 & 11,33 & 2,5 & 34 & 192 \\
Villaluz & 16 & 6 & 22 & 28 & 3,5 & 31,5 & 20 & 9 & 0 & 29 & 165 \\
Evan de A. & 30 & 20 & 50 & 120 & 5 & 125 & 250 & 49 & 0 & 299 & 948 \\
Carpio & 160 & 65 & 225 & 480 & 120 & 600 & 1.440 & 110 & 0 & 1.550 & 4.750 \\
Serrada & 65 & 27 & 92 & 124 & 0 & 124 & 84 & 25 & 5 & 114 & 660 \\
Matapozuelos & 205 & 85 & 300 & 167 & 117,5 & 300 & 251,25 & 251,25 & 40 & 542,5 & 2.275 \\
La Zarza $^{491}$ & 33,5 & 14,5 & 51 & 300 & 70 & 370 & 217 & 217 & 0 & 434 & 1.008 \\
Romaguitardo & 16 & 9 & 25 & 90 & 10 & 100 & 70 & 30 & 0 & 100 & 580 \\
Rodilana492 & 75 & 225 & 300 & 500 & 0 & 500 & 847,5 & 20 & 0 & 867,5 & 3.335 \\
Sieteiglesias 493 & 60 & 85 & 150 & 500 & 0 & 500 & 300 & 165 & 7 & 472 & 2.244 \\
Villanueva T. & 30 & 7.5 & 37,5 & 200 & 50 & 250 & 340,5 & 75 & 0 & 415,5 & 2.812 \\
\hline TOTAL & 717 & 549,3 & $1.284,5$ & 2.537 & 376 & $2.930,5$ & $3.842,9$ & 962,58 & 54,5 & $4.857,5$ & 18.969 \\
\hline \% & 55,8 & 42,76 & 50,00 & 86,5 & 12,83 & 50,00 & 79,11 & 19,81 & 1,12 & 50,00 & \\
\hline
\end{tabular}

Fuente: Catastro del Marqués de la Ensenada. Respuestas Generales. 1752. A.G.S.

Libros correspondientes a los municipios relacionados. Elaboración propia.

\footnotetext{
488 Catastro de Ensenada, Pozaldez.

${ }^{489}$ En la muestra se han escogido aquellas villas, lugares o despoblados que detallan las distintas superficies por cultivos y calidades en las Respuestas Generales.

${ }^{490}$ En Matapozuelos se anotan, en tierras de primera calidad, veinte obradas de garbanzos y cuatro obradas que se siembran de rubia; en segunda calidad, quince obradas de garbanzos.

${ }^{491}$ En La Zarza se catastra una obrada de árboles frutales.

${ }^{492}$ En Rodilana se anota en las tierras trigueras la siembra de "algún garbanzo" y en las de tercera se reservan veinte obradas "para siembra de alguna algarrova y lenteja".

${ }^{493}$ En Sieteiglesias se anotan cinco obradas de garbanzos en las tierras de primera calidad.
} 


\section{c. La mejora de los sistemas producción y rentabilidad del cultivo}

Desde el último tercio del siglo XVI en que se analizaron las labores y rentabilidad de cada cultivo, hasta el presente del siglo XVIII, apenas si existen novedades técnicas o que afecten directamente a la producción, que puedan considerarse fundamentales más allá de la estudiada división en hojas. A lo largo del XVII se aprecia en muchos términos una mayor presión sobre la tierra y un reparto de cultivos más acorde con la calidad del suelo. La roturación de montes estudiada, el incremento del viñedo y la mayor necesidad de leguminosas, avena y cebada para el ganado, obliga al pequeño campesino a aceptar contratos de arrendamiento caros y exigentes. Señores laicos y conventos arriendan cuanto pueden. La tierra adquiere más valor, especialmente la de primera calidad, porque se necesita y porque escasea.

\section{- La intensificación del cultivo. El incremento de los "retelos"494}

En 1675, el señor de Serrada, por ejemplo, cuando arrienda su mayorazgo, obliga al rentero a no dejar ninguna obrada sin labrar y, después de sembradas, "a hacer y lebantar cauzes por nuestra cuenta y riesgo ansi para la guarda y custodia como para la conservación de dichas tierras", por no citar que, a la hora de pagar la renta por Nuestra Señora de agosto, el rentero, una vez trillada y limpia la mies en las eras, tiene prohibido "lebantar los muelos ni en barrer nada de lo que se cogiere de las tierras", para que el señor o su mayordomo escoja el trigo de mayor calidad" ${ }^{\prime \prime}$. Para hacer frente a estos y otros factores, los labradores, sean o no propietarios, intensifican el cultivo, retelando alguna obrada, más allá del barbecho semillado, caso de melones, garbanzos o algarrobas. Estos retelos se constatan a partir del XVII en contratos de arrendamiento en que se prohíben de forma taxativa o se incrementa la renta, caso de ser aceptados, o se acuerdan rotaciones para que, una vez finalizado el contrato, se dejen las tierras acordes a las hojas y veces que estaban al comienzo.

Distintos ejemplos así lo avalan. En La Seca, se firma un contrato en 1648 por cuatro años y dos panes a precio de tres heminas de trigo cada año pero "si las rebolviese a de pagar una fanega de trigo" En Serrada, el mencionado Diego de Montalvo prohíbe la siembra de garbanzos y otras semillas, sólo acepta la siembra de trigo, cebada y centeno, pero se deja cierta libertad para que puedan ser revueltas, pues se anota que "y no las emos de rebolber los dos años últimos... que fenece dicho arrendamiento". Se entiende que los renteros se acojan a este supuesto solo en caso de necesidad de tierras, pues la condición añadida al supuesto de repetir cultivo es que se pague la misma renta por las revueltas que por la renta principal ${ }^{497}$. Dicha renta asciende, en 1675 , a ocho cargas de trigo (32 fanegas) cada renta de tierras (40 obradas) sembradas en ańo y vez. En 1709, los renteros tienen que hacer frente al pago, en la misma superficie, de 32 fanegas de trigo, 4 de cebada y dos carros de leña, que han de llevar por su cuenta a las casas del marqués de Torreblanca en Medina del Campo. La cuantía se ha elevado de forma considerable respecto a la primera fecha con unas condiciones de laboreo idénticas. La renta seguirá subiendo a la par de la demanda de tierra y cereales. En 1742 y resto de siglo, son 32 fanegas de trigo y 10 de cebada la renta a satisfacer y un hecho novedoso se apunta en el contrato de este año pues "como an estado todas las tierras asi rebueltas se an de bolber a la oja y vez que las corresponde dentro de un año y no lo aciendo los he de poder quitar a cada uno que lo contrario hiciere todas las demás contenidas en este arriendo" ${ }^{\prime 498}$, prueba de que los retelos presionan al sistema bienal, en las tierras de primera, década tras década.

${ }^{494}$ Como se ha indicado en el anterior capítulo, hemos optado por seguir utilizando los verbos "retelar", "revolver" o "rebujar" las tierras que salen de pajas para indicar que se vuelven a sembrar sin hacer barbecho, toda vez que en muchos pueblos de la comarca se siguen empleando estas antiguas expresiones entre los labradores de mayor edad.

495 A.H.P.V. Pt. 6507, fol. 142.

${ }^{406}$ A.H.P.V. Pt. 6489, fol. 147.

${ }^{497}$ Ibídem.

${ }^{498}$ A.H.P.V. Pt. 8215, fol. 285. 
En el resto de poblaciones se repite esta cierta intensificación en el cultivo de la tierra. En la Seca de 1676, se arriendan tierras por cuatro años y dos panes con la condición "de poder rebolber una parte de melones ${ }^{\prime 499}$ y en 1709 constan distintos arrendamientos de tierras, en las que los renteros "an de poder revolberlas y sembrar de los panifos que quisieran"300. En Nava, en los contratos de arrendamiento del llamado mayorazgo de González se fija como primera condición que las tierras no se puedan revolver y que solo se siembren en año y vez o la mitad de ellas, pero a continuación se señala que, caso de sembrarse todas, los renteros deberán pagar "con el doblo dicha renta o la que correspondiere a la porzión que revolvieren y duplicadamente sembraren's01. En otros casos la prohibición es tajante. Así consta en el arrendamiento de las tierras de la capellanía de Juan Pérez en 1728. Aquellas sembradas de pan que finalicen el arrendamiento "queden las de la una oja bazias y de rastrojo para el nuevo arrendador y por ningún acontecimiento ni manera se an de poder ni puedan rebolber..., sino que sean los cortinales que van declarados'302.

\section{- El aumento de las labores, del abonado y de la rotación con leguminosas}

Aunque la calidad de la tierra y las condiciones atmosféricas son fundamentales, desde las primeras décadas del XVIII se constata un incremento de las labores, el abonado y la rotación con leguminosas, lo que puede explicar estos mayores rendimientos. En relación con la cebada, en el Rubí de 1732, en tierras de primera del pago de Mingálvaro, se hace inventario de una heredad donde se precisa que tiene cinco vueltas de arado y que la mitad de la parcela está abonada ${ }^{503}$ :

"Una tierra en dicho término, adentro del sendero de Mingálvaro..., hace dos obradas y ma , sembrada de zebada, que tiene cinco bueltas y media y esta media abonada..."

En este tipo de tierras, como las anteriormente citadas del señor de Serrada sitas en su vega, de cuantas labores se realicen en ellas se obtiene recompensa en frutos, sea el trabajo de arado, sea de abonado. En este sentido, en la segunda mitad del XVIII y siguiente siglo, no hay labranza que se precie que no disponga de rebaños de ovino como necesidad de su labranza, haciendo bueno el refrán de "la oveja con la reja". Sólo así están garantizados los retelos y alejado el dicho "vale más un pan que dos panecillos". Llegado el buen tiempo, especialmente cuando se están aprovechando las rastrojeras, se fijan redes o apriscos que se van desplazando por la parcela, intensificando el abonado a criterio del propietario. Esta operación, si se encarga con ganado ajeno, cuesta su dinero a tenor de los apuntes del libro de administración del convento de San Pablo de Serrada, pero asegura la cosecha en los siguientes ańos. En 1795, en la granja dominica se anota ${ }^{504}$ :

"Mas doscientos setenta y nueve reales de estercolar a redes de ovejas 6 obradas de tierras, a 46 y m la obrada".

Si el tiempo acompaña, estas seis obradas rendirán buena cosecha los siguientes años. En otras ocasiones, el abono se lleva en carros a la propia tierra, el que procede del ganado como el sacado de charcas, arroyos y lavajos. En Serrada, como en otros pueblos, no faltan tareas de limpieza de cauces para evitar aguas estancadas que pongan en peligro la salud del vecindario. El légamo se traslada a

${ }^{499}$ A.H.P.V. Pt 6508, fol. 284.

${ }^{500}$ A.H.P.V. Pt 6398, fol. 358 y 366. En un caso la renta es de tres heminas por obrada y en otro en que se arriendan 25 obradas el rentero ha de pagar 32 fanegas.

${ }^{501}$ A.H.P.V. Pt 13605, fol. 386.

${ }^{502}$ A.H.P.V. Pt 13606, fol. 134 y ss.

${ }^{503}$ A.H.P.V. Pt 6654, fol. 132.

${ }^{504}$ A.H.N. Clero Secular y Regular, Libro 17351, fol. 104v. 
las tierras de sembradura y en otros casos vienen bien las épocas antes de las lluvias para aprovechar este preciado elemento del fondo de los lavajos. En el libro registro de la anterior granja dominica se dejó anotado ambas formas de estercoladura ${ }^{505}$ :

"Estiércol. Data. Más cuatrocientos veinticinco reales en esta forma: 58 reales de 31 carros de basura; los 23 a dos reales y los 8 a real y medio. 237 reales de estercolar con ovejas 6 obradas y media quarta de tierra a 39 reales obrada; 60 reales de 24 jornales a 2 reales y $\mathrm{m}^{\circ}$ para revolver el estiércol, limpiar corrales y sobrado de la panera; y los 70 reales de 28 jornales, a 2 reales y $\mathrm{m}^{\circ}$ para sacar estiércol de un lavajo y derramar en las tierras el que se llevó de casa”.

En 1793, en Valdestillas, se registra un arrendamiento del poseedor de un mayorazgo en Medina de Rioseco donde, amén de la división en hojas, se exige que el rentero abone ocho obradas a su costa donde mejor le acomode, dando parte del hecho al propietario, lo que indica que esta práctica toma cuerpo desde finales de siglo, en la medida en que se dispone de estiércol en las tierras cerealistas del centro de la meseta ${ }^{506}$. De hecho, aparecen precisiones sobre el manejo de estiércol de cara a que sea más efectivo, pues en la granja dominica de Serrada se pagan distintos jornales "para revolver el mudalar"507.

Aunque no consta ningún tipo de novedad técnica en lo tocante a tipos de arado, sí se desprende de los inventarios de bienes consultados en distintos pueblos que, en relación a siglos anteriores, se incrementan las vueltas de arado en muchas tierras de trigo y cebada y que tal hecho se tasa como un valor ańadido. La tierra comienza a valorarse por su calidad y en atención a cómo está labrada. Si en algunas tierras que van de cebada, se han registrado, en la primera mitad del XVIII, hasta seis vueltas de arado es porque es rentable invertir tal esfuerzo, caso contrario, con cuatro o cinco vueltas sería suficiente. El ejemplo de 1728 es revelador en este sentido ${ }^{508}$ :

"En tierra propia... de zinco obradas, dos obradas y media sembradas de trigo con quatro bueltas y otro tanto sembrado de zevada con seis bueltas que tasan cada una a siete reales menos quartillo; y quatro fanegas de trigo de sembradura a quinze reales fanega, y siete fanegas de zevada que tambien tiene de sembradura a nueve reales fanega”.

En este caso se echan de simiente 1,6 fanegas de trigo por obrada y 2,8 de cebada que, como se verá seguidamente, son cifras medias en las tierras de primera calidad.

\section{- Unas producciones diversas atendiendo a la calidad de la tierra pero, en general, bajas}

Respecto a la simiente y producción de estas tierras, se observa en el cuadro adjunto que las medias enmascaran toda una realidad de suelos, cosechas y diversidad de trabajos en las labranzas, pero, en general, puede decirse que se encuentran entre las medias de otras comarcas cercanas en este tiempo. Se sigue a mediados del XVIII con rendimientos muy bajos. En este tiempo, en el $90 \%$ de los pueblos segovianos, investigados por García Sanz, la fanega de simiente en tierras de segunda produce menos de siete fanegas y, su mayor parte, se sitúa entre las cuatro y cinco ${ }^{509}$. Pocos cambios respecto a épocas anteriores, pues, a pesar de la parquedad de fuentes, el citado autor anota en distintas explotaciones eclesiásticas del año 1580 rendimientos de 4,8 fanegas en Villacastín, y 3 y 3,7 fanegas de trigo por

\footnotetext{
${ }^{505}$ Ibidem, fol. 96.

${ }^{506}$ A.H.P.V. Pt 11890, fol. 108.

${ }^{507}$ A.H.N. Clero Secular y Regular, Libro 17351, fol.108.

508 A.H.P.V. Pt. 13606, fol. 637.

${ }^{509}$ GARCÍA SANZ, A.: Desarrollo y crisis del Antigua Régimen en Castilla la Vieja. Economía y Sociedad en tierras de Segovia 1500-1814, Akal, 1977, págs. 158-159.
} 
fanega sembrada y de 4,5 fanegas en el caso de la cebada en Matallana (Valladolid) ${ }^{510}$. En el anterior capítulo, en nuestro caso, anotamos rendimientos en varias explotaciones del año 1590 de $414 \mathrm{~kg}$, $409 \mathrm{~kg}$ y $326 \mathrm{~kg}$ de trigo por obrada y de $394 \mathrm{~kg}$ de cebada que representarían, una vez realizadas las oportunas equivalencias, unos rendimientos por fanega de simiente sembrada de 6,26, 6,2 y 4,9 fanegas para el caso del trigo y de 4,64 fanegas por fanega sembrada en las tierras de cebada.

Cuadro 24. Medias declaradas de simiente, producción y precios en Tierra de Medina, año 1752, (en fanegas/obrada)

\begin{tabular}{lccccccc}
\hline Producto & \multicolumn{2}{c}{ Trigo } & \multicolumn{2}{c}{ Cebada } & Centeno & Algarrobas & Avena \\
\hline Calidad de tierra & Primera & Segunda & Primera & Segunda & Tercera & Tercera & Tercera \\
\hline Simiente & 1,62 & 1,34 & 2,99 & 2,27 & 0,95 & 0,92 & 0,87 \\
Producción & 7,76 & 5,36 & 24,89 & 20,48 & 3,90 & 5,61 & 5,57 \\
Rendimiento por & & & & & & & \\
fanega sembrada & 4,79 & 4 & 8,32 & 9,02 & 4,10 & 6,09 & 6,40 \\
Precio (rs/fanega) & 14,34 & 6,5 & 9,31 & 6,96 & 5 & & \\
\hline
\end{tabular}

Fuente: Catastro del Marqués de la Ensenada. Respuestas Generales. 1752. A.G.S.

Libros correspondientes a los municipios relacionados. Elaboración propia.

A falta de series más completas que aporten una mayor precisión a los rendimientos numéricos, junto a las condiciones atmosféricas, los rendimientos de trigo son similares, pero en la cebada, además de constatarse un aumento importante del cultivo, se observa un incremento del rendimiento, pues pasa de las 4,5 fanegas por fanega sembrada, estudiadas por García Sanz en 1580, y las 4,64 fanegas en nuestro caso de 1590 a unas medias entre 8 y 9 fanegas en Tierra de Medina en 1752.

En el caso del centeno, que ocupa un porcentaje muy importante de las 84.795 obradas de tierras de tercera $(79,11 \%$ en la muestra tomada), sus rendimientos son más bajos que el trigo, en torno a cuatro fanegas por obrada (frente a una de simiente), inferiores a las registradas en 1590 (6 y 8 fanegas por obrada), pero similares a los anotados por García Sanz en 1580 (entre 3 y 4 fanegas por obrada). Estas diferencias pueden deberse a la mayor calidad de las tierras escogidas en nuestra muestra de 1590 y la ocupación, a mediados del XVIII, de tierras muy inferiores que impiden producciones rentables, pues, como se verá, resulta poco menos que imposible obtener beneficio alguno a cuatro fanegas por obrada en hojas de año y vez.

\section{- El calendario de trabajos en las tierras de sembradura en el siglo XVIII}

El año campesino en las tierras de sembradura dispone de pocos días inactivos a lo largo del año ${ }^{511}$. La sementera se inicia en septiembre, tras la vuelta de arado que abre los surcos dejados en la tercia de principios del verano. A mediados de septiembre se siembran los herreńales o cortinales de centeno, cebada o una mezcla de cereales para, en este caso, ser consumidos en verde por el ganado. En esta segunda quincena quedan sembradas las algarrobas e incluso el trigo, si se tarda en dar comienzo la vendimia. De hecho, no faltan normas para impedir el paso por los sembrados cuando da principio la recogida de uva. En las grandes labranzas se mandan yuntas a la hoja de barbechera a la par que trotadores a los vińedos. La sementera no puede retrasarse. Las lluvias otońales son básicas para asegurar la nascencia de leguminosas y cereales. Nada mejor que leer los apuntes de la familia Cillero escritos entre los ańos 1771 y 1800 en que se detallan estas labores ${ }^{512}$ :

\footnotetext{
510 Ibidem, pág. 156.

511 Se toma como base la información que se desprende de la documentación histórica de este siglo, especialmente de la hallada en archivos familiares que albergan apuntes de labranzas. Pese a los avances descritos, las labores y tiempos son similares a los anteriores y a los que se suceden en siglos siguientes.
}

512 A P.Q.M. "Libro de Cuentas y Razones que boy llevando..., ob. cit., s/n. 
"Se dio principio a la sementera martes 22 de septiembre y se sembró el Arreñal de Baldehuetos y llebó mas de una fanega de zenteno.

Día 28 del mismo. Se empezó a sembrar las garrobas... y se llebó media carga... y no se concluió el día por haber llovido demasiado y benirse a casa los mozos...

Día 30. Fue un arao a acabar de tapar las pocas que habian quedado estapadas el dia anterior y se suspendió por empezar la bendimia.

Día 13 de octubre. Se sembraron en dicha tierra media carga de garrobas.

Día 14. Tres heminas en dicha tierra.

Día 15. Dos fanegas en dicha tierra.

Día 16. Media carga de trigo para la tierra de la riverica de D. Fernando...

Día 23... dicho día tres heminas de zebada por estar la tierra mui cargadas..."

La siembra se alarga hasta la primera quincena de noviembre, dependiendo tierras y tiempo. Si está de lluvias, se dejan las tierras más cargadas para sembrar las ligeras o se aprovecha para alzar los rastrojos en aquellas que vayan a retelarse de legumbres o cereal. Lo general es que, a mediados de octubre, muchos años en plena vendimia, verdegueen los trigos. Téngase en cuenta que parte de las mejores tierras han recibido, como ha quedado explicado, hasta cuatro y cinco vueltas de arado, por lo que están bien atemperadas y la semilla germina en estas condiciones y mes con gran rapidez. No faltan inventarios, como el que nos ocupa de 1743 , en los que se relatan estos trabajos, la semilla y su valor ${ }^{513}$ :

"Ytem. Pusieron por deuda ziento y veinte y seis reales que tubo de costa el barbechar quatro obradas y media de tierras para trigo a quatro bueltas, a siete reales cada obrada.

Ytem. Sacaron por deuda sesenta y quatro reales importe de ocho fanegas de trigo que se compraron para sembrar".

El grano se siembra por parte de mozos y criados a voleo, esparciéndolo por los surcos. Detrás, las mulas lo van tapando. Como se ha dicho y, por lo general, se empieza con las algarrobas, el trigo, el morcajo y el centeno para seguir con la cebada ${ }^{514}$. En los meses de invierno consta que se alzan tierras, por lo general con bueyes, en la hoja de pajas y se retelan de avena algunas piezas. La casa granja de San Pablo de Serrada así lo atestigua ${ }^{515}$ :

"Data de avena. Sementera. Primeramente son data diez y seis fanegas que da por gastadas en sembrar las tierras de Serrada en el febrero pasado de este año de 1771.

Enbuelto con zebada. Mas son data nuebe fanegas y tres quartillos que da por enbueltas con la zevada para el ganado..."

Desde el siglo XVII y a lo largo del XVIII, la presencia de leguminosas, sean algarrobas, muelas o guisantes, se incrementa, al igual que la avena, por las necesidades del ganado, especialmente el de labor en las épocas de mayor actividad. En el año de 1794 en la casa granja citada se consumen las siguientes cantidades ${ }^{516}$ :

"Cebada. Ciento ochenta fanegas para las mulas, caballo y burra; veinte fanegas hechas panija para los bueyes; ocho fanegas con los cerdos, y diez fanegas en huebras, para vendimiar.

Centeno. ...siete fanegas y ocho celemines consumidas con bueyes y cerdos.

Garrovas. Venticinco fanegas y celemín y quartillo gastadas con los bueyes, las dos fanegas y media con una yunta para la vendimia y el resto con las de la casa

Avena. Gastadas con las gallinas una fanega y diez celemines.”

\footnotetext{
513 A.H.P.V. Pt. 8216, año 1743, fol. 10.

${ }^{514} \mathrm{El}$ morcajo es trigo y centeno envuelto a partes iguales que se siembra en tierras livianas.

515 A.H.N. Clero Secular y Regular, Libro 17351, fol. 12v.

${ }^{516}$ Ibidem, fol 86.
} 
La alimentación del ganado es cara, sobre todo cuando el pasto escasea. La hacienda dominica llega a gastarse en 1797 hasta doscientos reales "de mielgas para el ganado por falta de forraje" 517 . De ahí la importancia y presión de los retelos para conseguir estas leguminosas y cereales, aun cuando se obtengan menguadas cosechas.

Una buena nascencia es señal de un buen principio. En ocasiones se asegura aquella echando más simiente de la necesaria, aunque luego haya que entresacar el pan con un arico o grada. Así lo manifiestan los vecinos de Bobadilla al echar de simiente quince celemines de trigo en las de segunda calidad, al igual que en las de primera "no porque en realidad la tierra tenga sustancia para criarlo, sino porque acontece no nazen bien y perderse mucho trigo en la sementera y tener la procura de entresacarlos arroiándolos con una lavor se experimenta veneficio sin el qual requisito no suelen produzir cosa considerable..." ${ }^{318}$.

A lo largo de la primavera, los trabajos en las tierras de sembradura se alternan en la hoja sembrada y en la barbechada. En esta es obligada la vuelta de arado o bina que sigue a la alzadura. En los sembrados se quitan las malas hierbas para evitar que se coman la humedad y las espigas. En la hacienda dominica anterior, de un total de 42 obradas de trigo y cebada, se anotan hasta "cuarenta y seis obreros en escardar los trigos, a dos reales obrero", prueba de su importancia y cuantía ${ }^{519}$. La primavera, como siempre, es la que dicta sentencia en el fruto que se va a recoger, aunque es raro el año en que algún pedrisco no afecte a parte del término y es al ir a segar cuando "se advierte que se apedreó muchísimo, pues estaban los surcos llenos de granos sanos y las espigas faltas" ${ }^{20}$. Igualmente y como consustancial a la vida campesina, se deben tener en cuenta las novenas y plegarias para evitar nublados o para hacer llover en los meses de abril y mayo. San Isidro siempre fue bondadoso, como lo demuestran los apuntes familiares de la familia González Cillero en mayo de $1776^{521}$ :

"Se puso rogativa a San Isidro por la falta de agua oy día 18 de mayo y llobió dos o tres tardes mui bien de suerte que se recuperó bastante el campo y aun nos libró de una piedra muy grueso y abundante que cayó en el término vecino..."

En junio vuelven a intensificarse las labores. Las barbecheras por San Juan deben ararse de tercia para que estén bien atemperadas durante el resto de verano. Sólo si las últimas lluvias las llenan de hierba, se cuartean en julio. En la segunda mitad del XVIII se detecta una mayor intensidad en la preparación de los barbechos, aunque se estima que muchas tierras no reciben más que tres vueltas y, si acaso, se completan con un escarde, dado el gasto y el tiempo que lleva tal operación en un mes en el que se da comienzo la recolección del fruto.

Desde la segunda semana de junio consta el comienzo de la recogida de las algarrobas para seguir con la cebada a finales de mes y principios de julio. Segada la cebada, se continúa con el trigo y el centeno desde la segunda quincena hasta acabarlo en agosto. El cuaderno familiar citado es rico en matices en el verano de 1797:

"Día 11 de junio. Fueron los criados de casa y el cachicán a principiar a coxer las garrobas; y al día siguiente fueron 22 personas, hombres y mujeres a veinte y un quarto de xornal cada uno; y tubo dos carros de garrobas las que se traxerosn a la era y se trillaron..."

\footnotetext{
517 A.H.N. Clero Secular y Regular, Libro 17351, fol. 131.

518 A.G.S. CE. R.G. L. 529306.

519 Ibidem, fol. 94.

${ }^{520}$ A P.Q.M. "Libro de Cuentas y Razones que boy llevando..., ob. cit, s/n.

${ }^{521}$ Ibidem, ob. cit, s/n.
} 
En este ańo se anota que el diez de julio se acarreó la cebada; el veintisiete, las muelas y el 11 de agosto, el trigo. Dos años antes, en 1995, por ejemplo, se anota que la siega de la cebada comenzó el 25 de junio " $y$ estaba bastante cerezana, el 27 de julio el trigo y el 9 de agosto los garbanzos ${ }^{522}$. Como se estudió a finales del siglo XVI hay labranzas que dan la siega a destajo y otras que contratan jornaleros. En la que nos ocupa se detallan tiempos, precio y comidas. En relación a la siega de la cebada, de la que se cogieron 292 fanegas, se lee ${ }^{523}$ :

\begin{abstract}
"Se gastaron en segar dichas tierras con quatro obreros escepto un día, doce días y medio, a quatro reales y medio cada uno cada día. Su desayuno por la mañana, sus cebollas por la tarde y una olla y cinco panes a el mediodía, y cinco medios quartillos de vino, que importaron los xornales doscientos veinte reales y medio".
\end{abstract}

Un ciclo acaba y otro empieza. Antes de encerrar en las paneras la cosecha, debe pagarse el diezmo y por Nuestra Señora, como es obligado, las rentas. Los aperos del verano, idénticos a los siglos anteriores y posteriores, vuelven a colgarse en las paneras ${ }^{524}$. En septiembre, la barbechera vuelve a estar a punto para iniciar una nueva sementera.

\title{
2. La importancia del vińedo en el siglo XVIII en Tierra de Medina
}

Como se ha estudiado, el viñedo ha sido un cultivo ligado al quehacer campesino desde que se asienta en estas tierras, pero siempre complementario de las tierras de pan. La dinámica y cercanía a los mercados, la aptitud de los suelos y las distintas opciones por conseguir extraer de la tierra algún esquilmo, explican la pujanza en unas partes y la atonía en otras a lo largo de los siglos.

Tras las tierras de sembradura, es el aprovechamiento por excelencia. Agrupado en pagos, siguiendo un criterio edáfico, componen la "hoja de viñas" o "tierras de vino". A mediados del XVIII, de acuerdo al Catastro de Ensenada, se declaran en el espacio estudiado un total de 49.432 obradas (equivalentes a 65.909 aranzadas o $27.973 \mathrm{ha}$ ), que representan, como puede apreciarse en los anteriores cuadros, el 18,47\% del total de la superficie labrada. No obstante, como ha quedado patente, su distribución en este siglo es muy desigual, si se atiende al sector de terrazas del norte y a las campiñas del sur. En estas se encuentra un viñedo estancado, orientado en buena parte a un consumo local, frente al sector de gravas y terrazas a mayor altitud de los pueblos al norte donde está ligado a unas formas de explotación y comercialización precapitalista. Su crecimiento es muy notable por su rentabilidad desde finales del XVI y a lo largo del XVII, como prueba el interés de labradores, jornaleros e inversores foráneos, sean laicos o eclesiásticos.

La superficie plantada es reveladora de esta pujanza. En las terrazas escalonadas más septentrionales hasta el mismo Duero, es el cultivo por excelencia. Obsérvese que Rueda, La Seca, Serrada y Villanueva, destinan, de las 23.376 obradas que componen sus términos, un total de 9.967 obradas que representan el $42,63 \%$ del término y el $47,27 \%$ del conjunto de tierras labradas. A estas villas se debe sumar, con superficies importantes, Alaejos, con 5.008 obradas (24,6\% de su término); Villaverde, con 3.356 obradas de un total de 6.000 y que es la villa con el porcentaje más alto $(55,9 \%)$; Nava del Rey, con 2.800 obradas (20,14\% de su término) o la propia Medina del Campo, que mantiene 5.500 obradas de un total de 20.300 (27,09\%).

522 Cerezana quiere decir que aun no estaba seca del todo.

523 A P.Q.M. "Libro de Cuentas y Razones que boy llevando..., ob. cit, s/n.

${ }^{524}$ En este sentido no se observan novedades respecto a las estudiadas en siglos anteriores. La granja convento de San Pablo de Serrada renueva en 1794 aperos de era y labranza sin novedad alguna. En relación con aperos de verano, gasta 103 reales, distribuidos de la siguiente manera: 25 rs y mº de 6 sogas carreteras, y 6 lias comunes, ajustadas por junto; 15 rs de dos redes para meter paja; veinticuatro rs de 6 palas; 8 rs de 4 horcas; 6 rs de 4 vieldos; 6 rs de dos gárias; y 23 rs de 2 cribas, un crivo y dos rastros, todo para la hera” (A.H.N. Clero Secular y Regular, Libro 17351, fol. 131). 
Alejadas de estas cifras se encuentran las campiñas meridionales, eminentemente cerealistas. Baste repetir que, de las 23.376 obradas que suman los términos de Fuentelsol, Lomoviejo, Rubí, Cervillego y San Vicente, están plantadas de vides 967 obradas que representan el 4,46\% del total de sus términos. En ellos se detecta la pervivencia de viñedos plantados a manta, sin orden, lo que dificulta las tareas de arada y, es fácil imaginar, repercute en los rendimientos. El caso de Lomoviejo sirve de ejemplo ${ }^{525}$ :

“...otra vińa en dicho pago del Pavo que hace dos aranzadas de la terzera calidad plantada a manta, como las antecedentes..."

"una vińa, a el sitio del Montoro, produze sin intermisión, contiene quatrozientas zepas plantadas a manta, sin horden alguno, que componen una haranzada de terzera calidad...”

En Torrecilla de la Orden también se encuentran estas plantaciones ${ }^{526}$ :

"A la octava pregunta digeron que los plantíos que hay en esta villa es de viñedo; y que están plantadas las unas a manta y las otras a liño y ambos géneros de plantíos están estendidos por toda la tierra”

Al norte de Medina la práctica totalidad de las plantaciones son a marco real, en cuadrícula, y, como en Serrada, el viñedo se ordena "... a cordel línea recta y de zepa a zepa once pies de hueco según práctica de esta villa...” y la aranzada es la unidad de medida que "...se compone de quatrozientas y veinte zepas y ocupa de tierra tres quartas" 527.

En relación con el tipo de uva de las Respuestas Generales, parcas en este sentido, parece desprenderse que la blanca verdeja es mayoritaria y en muchas villas es la plantada en exclusiva, como parece desprenderse de la declaración de Fresno cuando manifiesta que “...se previene no cogerse en este término más que la referida huba blanca.. ${ }^{\prime 528}$ aunque en otros, como en Torrecilla de la Orden, al concretar su precio, se indica que "...la arroba de uva blanca real y medio y cada dos arrobas dan una cántaro de mosto que vale cuatro reales. La arroba de uva tinta dos reales" 329 .

\section{a. La especialización vitícola en el norte de la Tierra}

En capítulos y siglos anteriores se ha constatado la importancia del cultivo del viñedo en este sector del Duero medio y más concretamente en el sector norte de la Tierra de Medina. Desde aquellas tempranas fechas de comienzos del siglo XV en que se referían ventas y trueques donde constaban viñas en estos pagos, hasta 1752 en que se catastra hasta la última cepa, han transcurrido trescientos cincuenta ańos. Tres siglos y medio que desgranan la verdadera historia del vino en esta Edad Moderna. Atrás quedaron ordenanzas que, a lo largo del XVI, regulaban las actividades de corredores y taberneros al calor de las ferias medinenses. El declinar de éstas provocará el reordenamiento del viñedo en la comarca, desplazando más intensamente el cultivo hacia el sector norte de terrazas, donde sobresaldrá el empuje de Nava, Rueda, La Seca y Serrada, entre otros términos ${ }^{53}$. Junto a ello, y

525 A.H.P.V. Hacienda. Catastro de Ensenada, caja 120, fol. 398 y caja 122.

${ }^{526}$ A.G.S., CE RG L, 634 632, fol 647.

${ }^{527}$ Las cepas por aranzada varían de unas villas a otras. Lo común son 420 cepas, caso de La Seca, Ventosa, Rueda, Rodilana, Pozaldez, Serrada, Medina, que ocupan tres cuartas de obrada, pero La Moya y Matapozuelos anotan 500 cepas, y Villanueva de Duero, 440. La aranzada de Pollos, Torrecilla y Nava son, en cambio, de 400 cepas, al igual que las de las villas meridionales como Salvador, Velascálvaro, La Zarza, Rubí, San Vicente o Cervillego. Aun manifestando unas y otras villas que son plantadas a once pies, su equivalencia es de media obrada en muchas de las villas de 400 cepas la aranzada y de tres cuartas de obrada, en la mayor parte de los casos.

528 AGS RG L630 071.

${ }^{529}$ AGS CE RG L 634632 Fol 647.

530 PASCUAL GETE, H.: "La decadencia vinícola de Medina durante los siglos XVII y XVIII", en "Historia de Medina....”, pág. 652 y ss. 
manteniendo las tesis avaladas por Huetz de Lemps ${ }^{531}$, el retorno transitorio de la corte a Valladolid entre 1601 y 1606, en tiempos de Felipe III, otorgará una vitalidad inusitada a los majuelos de la comarca, que verán multiplicar sus cepas para garantizar el consumo de la corte y de cuantos demandaban estos caldos blancos de calidad y duraderos en su conservación. Su fácil salida a los mercados del norte y a los del entorno de la corte madrileńa mantendrá la pujanza de este sector norteño, a pesar del descenso paulatino que acusan las plantaciones de Alaejos y Medina.

Pero, como se ha estudiado en anteriores capítulos, las cepas serán plantadas entre no pocos litigios por parte de señores, instituciones y cultivadores. Nunca han sido buenos tiempos para quienes han carecido de tierra en propiedad. Y, cuando el sector y los mercados despegan, el clero regular y secular amasa cuantas aranzadas, casas y bodegas puede para negociar ventajosamente con el preciado elemento. De ahí la atomización parcelaria y de cultivadores que caracteriza, siglo tras siglo, a estas villas ${ }^{532}$.

El vino, no obstante, se alza como rey indiscutible en unos terrazgos poco proclives a producir panes. En sus Respuestas Particulares, los vecinos de Serrada y La Seca, por poner un ejemplo del sector anteriormente mencionado, constatan que no hay en 1752 casa abierta que no posea algún centenar de cepas, bodega sin cubas y cubas sin vino. Son los momentos de mayor esplendor de los caldos blancos de esta Tierra de Medina, que superan las 20.000 ha plantadas y triplican incluso las existentes dos siglos después. A partir de estas fechas, la progresiva pérdida de mercados y el ataque de la filoxera a lo largo del XIX mermarán, de forma ostensible, la entidad vitivinícola de la comarca. Han sido, por paradoja, estos factores de baja calidad edáfica y unos más bien limitados rendimientos de la variedad verdeja, uno de los fundamentos de su calidad, pureza y vitalidad en estos pasados tiempos $^{53}$. Pero el coste humano y de producción será muy alto. En Serrada y en La Seca casi la mitad de su vińedo se asienta sobre tierras de tercera calidad, que producen unos rendimientos hasta tres veces inferiores al consignado en aquellas de primera, con el consiguiente sobresfuerzo humano y animal en su laboreo para obtener, tan sólo, entre ocho y diez cántaras de vino por aranzada.

\section{b. El mantenimiento de las técnicas de cultivo. El calendario vitícola}

La mayor parte de las técnicas de cultivo estudiadas en el último tercio del siglo XVI, desde la plantación del majuelo a la vendimia, van a continuar a lo largo del siglo XVIII, si bien, como en las tierras de sembradura, al margen de las condiciones atmosféricas, la productividad de unas aranzadas respecto a otras varía, atendiendo al tipo de suelo, edad de la cepas y cuidado recibido.

En el último tercio del XVII, un siglo después del análisis realizado en el anterior capítulo, los trabajos siguen siendo básicamente los mismos. Las condiciones de un arriendo, firmado en 1676 en La Seca, son muy claras al respecto ${ }^{534}$ :

${ }^{531}$ HUETZ DE LEMPS, A.: La Tierra de Medina en los siglos XVII y XVII. Estudios Geográficos, no 74, 1959, pág. 111 y ss.

532 Un ejemplo se aprecia en el repartimiento que se efectúa en 1726 en Serrada para la guarda de vińas entre todos los propietarios del término. En él se hacen constar 102 titulares de majuelos que labran 900 aranzadas en el entonces término. Por entonces el convento de San Pablo sumaba 50 aranzadas; el de la Trinidad Descalza 60; el señor marqués 38, Diego de Montalvo 58... Entre religiosos y foráneos sumaban 515 aranzadas de las novecientas totales. Casi eran más los vecinos que las aranzadas que labraban. Si se exceptúa a Francisco Moyano, que labraba 43; a Bernardo Alonso, con 22; a Manuel Gutiérrez, con 18 y a José Alonso Recio, con trece y media, el resto apenas son titulares de media docena cada uno (A.H.N. Leg. 25129, no 3, pieza 10). Hasta cuarenta y ocho vecinos no superan las cinco aranzadas, prueba del escaso terrazgo disponible y del abultado número de braceros y criados que completaban sus recursos con estas minúsculas heredades.

${ }^{533}$ Muchas de estas áreas de terraza, al estar en resalte y bien venteadas, desafían la helada al tiempo que sus suelos, sueltos y frescos, resistirán mejor los calores estivales, asegurando, si no abundantes, al menos regulares cosechas. Igualmente, y quizá sea uno de los factores básicos de su prestigio y pujanza a lo largo del tiempo, acogen la varietal verdeja, dotándola de exquisitos aromas frutales, que logran sazonar buenos añejamientos y conservar, en los siguientes y difíciles siglos, la pujanza de estos vinos blancos.

${ }^{534}$ A.H.P.V. Pt 6508, fol. 244 y ss. 
"Que la dicha vińa en dicho tiempo la a de lavorear de tres vueltas de arado que son las ordinarias de rama, marzo y mayo, dando cada una en su tiempo con sazón, y la a de desmatar, quitar escobas, y un obrero en cada aranzada, que es obligación de escavar, podar y acobijar, y esto en cada un año, y además de dichas labores a de pagarme la renta... y es condizión que si poder mejorar la dicha vińa por ser de mucha edad la fuere renobando de bástigas..."

El contrato no deja nada al azar y recoge cuantas labores van a seguir presentes a lo largo del siglo XVIII. En esta centuria, año tras año y de forma reiterada, los libros de administración de las distintas haciendas consultadas recogen estas actividades sin apenas cambios sustanciales.

Después de la vendimia, el labrador está ocupado en la sementera y la vigilancia del proceso de fermentación del mosto. Los vińedos hasta la caída de la hoja no llevan actividad y, de hecho, tras la rebusca, de acuerdo con la regulación de cada concejo y gremio de vińeros, pueden ser aprovechados por el ganado hasta finales de diciembre o principios de enero Desde noviembre, una vez que las heladas nocturnas, el viento y la lluvia tiran la hoja, se inician las tareas de desmate, arada de rama, excavo y poda, atendiendo a las características del viñedo y a las posibilidades económicas de cada labranza. Analicemos cada una de ellas:

\section{- Labores de poda, vástigas, plantación e injerto}

La poda es una de las labores más especializadas que lleva el viñedo. La realiza el podador, cortando uno a uno los sarmientos de la cepa con la podadera. Puede ayudarse del hacha para la corta de los tarragones viejos, abundantes en la varietal verdeja. En la hacienda de la familia González Cillero, de la que se tiene constancia documental detallada, desde 1771 hasta 1800 , la poda se extiende desde el mes de noviembre hasta abril. En el año 1778, se pagaron 137,5 obreros por la totalidad del vińedo (media aranzada diaria cada obrero), más cincuenta reales al cachicán “y una podadera cada quatro años, que es dinero, dieciséis reales". La labor tuvo lugar entre las siguientes fechas ${ }^{535}$ :

"Se empezó a podar el maxuelo de la China día seis de abril y se concluio día doce del mismo; y los demás se podaron desde el día venticuatro de noviembre del año antecedente hasta el dia 31 de enero deste"

Este escalonamiento en la poda no ha variado desde entonces. Algunos viñedos se podan temprano, a fin de ararlos pronto y evitar el endurecimiento del terreno tras un invierno lluvioso. Si están podados, puede adelantarse la arada de marzo. En otros, como el caso del viñedo mencionado, se deja para abril, porque "no corría tanta prisa por ser tierra más fría" y, en otros, para retrasar la brotación caso, por ejemplo, de ser laderas orientadas al mediodía, en que se adelanta. Es esencial tratar de aminorar las heladas de primavera, podando tardío, pues, aunque son muchos los factores que entran en juego, la documentación escrita en este siglo da pie a pensar que se tienen muy en cuenta ${ }^{536}$.

Respecto a las técnicas de poda, no se encuentra variación de las apuntadas en el siglo XVI. El número de varas y pulgares depende de la edad del viñedo y del vigor de la cepa, podando “...a dos baras y en otras a tres varas sin dejar otra alguna" 337 . En la mayor parte de los contratos estudiados dos siglos antes, se ajusta la poda más corta, dejando solo "dos tallos" o "vara y cordera", pero, en el siglo

535 A P.Q.M. "Libro de Cuentas y Razones que boy llevando..., ob. cit, s/n.

${ }^{536}$ En 1780, en el caso tomado como ejemplo, la poda empieza el 29 de diciembre y acaba el 20 de marzo; la arancia de marzo se realiza desde el 20 al 31 de este mes, excepto el majuelo de la China que finaliza el 5 de abril; el acobijo se lleva a cabo desde el 23 de marzo al 5 de abril y "por amanecer el día quince de abril cayo una elada que hizo bastante daño a causa de lo muy adelantados". Se había hecho todo con buen criterio y llevaban arados diez días antes de la helada. De hecho, no deja de ser ilustrativo de este desconcierto campesino ante la fatalidad, el comentario con el que acaba de relatar el propietario dicha calamidad: "más daño hizo en tierras fuertes que en los pagos frios, cosa todo contrario".

537 A.H.P.V. Pt. 6469, fol. 450. 
XVIII, no se dispone de suficientes fuentes para precisar que se realiza una poda más larga. Seguramente las tres varas se refieren a viñedos de primera calidad, de lo que pudiera extraerse una mayor producción por unidad de superficie, siempre que la cepa esté bien cuidada y no le falten nutrientes. En la mayor parte de los contratos no se concreta tal cuestión y se fijan las labores "según estilo del país"338.

En un contrato de arrendamiento fechado en 1747 en Serrada, se fijan las siguientes condiciones ${ }^{539}$ :

\begin{abstract}
"Que las dichas viñas las han de hacer en cada una año, las labores de desmate de grama y toda rayz según y como están las tres labores; arado en tiempo y sazón, escabo redondo y acobijo, y la poda según y como en esta villa se practica en sus heredades, de manera que los espresados majuelos se mantengan y no baian en disminuzión”.
\end{abstract}

Los propietarios de vińas valoran el trabajo y pericia del podador pagando el jornal medio real por encima que en otros trabajos, viniendo a podar un obrero media aranzada diaria (210 cepas), ya que la varietal verdeja, a diferencia de otras, presenta abundantes y enmarańados sarmientos que han de cortarse uno a uno con la podadera. El agradecimiento y reconocimiento a los podadores se encuentra vinculado a pequeñas celebraciones. En Serrada, tomando como fuente el libro de contabilidad de la hacienda conventual de San Pablo, no se puede por menos que sacar a la luz una tradición completamente perdida e ignorada en la comarca. Aunque se sale del tema tratado, vale la pena su transcripción ${ }^{540}$ :

"Mari Morena. Mas son data ventiocho reales gastados en la Merienda que se da a los Podadores según costumbre de la Villa, que llaman Mari morena".

Tras la poda, se recogen y atan los sarmientos en manojos que se llevan a los corrales de las casas, para apilarlos en la manojera. Estos trabajos se valoraron en el siglo XVI y en este siglo, donde las superficies de retamas y montes se han reducido, los sarmientos son muy estimados para cocinar y calentar las viviendas en el invierno. El coste de su atadura representa en torno al 10\% de los trabajos de brazo. La granja dominica de Serrada, por ejemplo, paga 896 reales por atar 30.000 manojos en 1768 y los jornales oscilan entre dos y tres reales, similares al resto de las labores que no requieren fuerza o especialización, como escardar o vendimiar. Al igual que en el siglo XVI, aparece la mujer realizando estos trabajos. En el año 1774 la granja dominica paga 246 reales "a las sarmentadoras por hacer 12.300 manojos a dos reales el ciento'341. En la hacienda de Cillero, los manojos suelen acabar de recogerse avanzado el mes de marzo y su estima lo evidencia la precisión con la que son anotados:

"Se acabaron de traer los manojos hoy día 16 de marzo, que traxeron del Grande 1.524; del Picón 242; del de la Estaca 193 y de la China 432. Todos componen 2.391 manoxos...”.

Cuando la manojera no se gasta en el ańo o se dispone de mucho vińedo, se venden o se ahorra el gasto de esta tarea, dándolos a atar a personas allegadas para su consumo o venta. En ocasiones se constata que el propietario se reserva los tarragones para sí, por su mayor poder calorífico ${ }^{542}$ :

"Y además extrajeron en el dia 20 y 21 del mismo 14 haces de tarragones de el maxuelo de la China porque la rama se la di a el tío Barriga, la que bendió a los de la Naba a cinco quartos cada carga".

538 A.H.P.V. Pt. 13607, fol. 309.

539 A.H.P.V. Pt. 8216. fol. 175.

${ }^{540}$ A.H.N. Clero Secular y Regular, Libro 1735, fol. 20.

${ }^{541}$ A.H.N. Clero Secular y Regular, Libro 17351, fol. 20.

${ }^{542}$ Los tarragones son trozos de varas viejas que se cortan con el hacha cuando el podador las desestima por viejas o por estar la poda demasiada alargada. Caso de haber dejado ańos antes algún pulgar, este se deja como nueva vara calzada en viejo y más cerca de la cabeza de la cepa. 
Otra labor importante que se describió en el siglo XVI, vital en el mantenimiento del viñedo, es la obligación de renovar y echar vástigas, tarea que se hace a la par que la poda ${ }^{543}$. En esta operación se observa una mayor intensidad respecto a tiempos anteriores. Con esta práctica se ocupan los huecos que van dejando las cepas muertas, los saltos existentes, aquellas que se arrancan, porque su producción es muy pequeña, o, como seguidamente se verá, para ser extraídas una vez enraizadas y servir de plantones en nuevos vińedos. El tiempo que exige este trabajo viene a cuantificarse en el siglo XVIII en torno a un obrero por aranzada y año. Así, por ejemplo, en 1720 en Villaverde, hay acuerdos de "un obrero de rastras en cada aranzada" ${ }^{44} \mathrm{y}$, en otro arrendamiento de 18 aranzadas de viñas, a 16,5 reales cada una, el rentero se obliga "gastar en ellas cada año deste arriendo nuebe obreros de rastras para que desta suerte las dichas viñas baian en aumento y no bengan en disminución" ${ }^{45}$. Estas frases se repiten en cada pueblo y el importe de esta tarea es muy importante, similar al acobijo, en tiempo y en reales. En el convento de San Pablo de Serrada, por ejemplo, de 6.531 reales gastados en labores del viñedo en el año de 1769, 848 se pagaron por desmatar; 1.030 en excavar, 1.899 por podar, 804 en echar vástigas, 862 en acobijar, 660 de recobijo y 428 en escardar ${ }^{546}$.

Las viejas plantaciones o se van renovando mediante vástigas, o se arrancan para ser plantadas de nuevo con la gran inversión que ello conlleva. En algunas grandes propiedades que disponen de tierra en abundancia, se ha constatado que se renuevan los viñedos viejos y se rotan los cultivos para que las tierras descansen y se fertilicen. En Rueda, por ejemplo, el señor de Foncastin y Zofraga suscribe distintos contratos de heredades de tierras en 1798, con la condición de que los renteros planten de majuelos doce obradas de tierras y decepen otras para labrarlas de pan, sin que por ello se incremente la renta ${ }^{547}$.

La plantación, en el norte de la Tierra, se realiza a marco real, señalado mediante cordeles, con una distancia entre cepas de once pies y, como ha sido estudiado, 420 cepas por aranzada en la mayor parte de los pueblos. Los trabajos siguen realizándose en tierras bien labradas mediante hoyas, en las que se plantan los majuelos. Aunque no se han encontrado fuentes escritas en este siglo que detallen la procedencia de estos plantones, nos inclinamos a pensar que en ocasiones no son sarmientos seleccionados en la época de poda, sino plantones enraizados, que reciben el nombre de "majuelos". Sólo así se entienden los apuntes del administrador de la hacienda dominica de Serrada, cuando anota en los gastos "33 jornales para sacar majuelos para plantar ${ }^{348}$. El inventario a la muerte de Pedro de Íscar anota, como deuda del majuelo nuevo que planta, 40 reales "del coste de reoiar... y atollar y sacar majuelos" 349 .

543 Como se recordará del anterior capítulo, al podar la cepa se escoge un sarmiento rastrero o vástiga, no dañado por el arado, que se deja sin cortar. Cuando al año siguiente ha crecido hasta llegar al hueco o falta de una cepa próxima, se entierra a una profundidad que no llegue la reja del arado y se acoda su final para que se forme una nueva cepa. Al estar alimentado por la cepa madre, su desarrollo es más rápido, al tiempo que la parte enterrada enraíza por sí misma. Posteriormente, unos años más tarde, se corta su arranque desde la cepa madre, convirtiéndose en una cepa independiente. Esta técnica está muy extendida en el siglo XVIII como forma de renovación del viñedo. En relación con ello, se cree relacionado el trabajo de escocerar, aunque falta una mayor investigación de esta tarea. El término lo encontramos por primera vez en este siglo, pero sin especificar en detalle el trabajo. En el año 1771, la hacienda de Gonzalez Cillero contrata estos trabajos en parte del viñedo que "no se habian escocerado en dos años y los demás no se escoceraran asta mayo", destinando 23 jornales para 21,5 aranzadas. En 1779, consta que estos majuelos se volvieron a escocerar en octubre, previo a la arada de invierno (1 de diciembre) y al excavo (entre el 1 y el 15 de este mismo mes). En los contratos de arrendamiento también se fija la tarea. Así, por ejemplo, en 1729, en Nava del Rey se obliga al rentero a echar, al margen de las labores comunes, "un obrero de descozero en cada aranzada"

${ }^{544}$ A.H.P.V. Pt. 8326, fol. 19.

545 Ibidem, fol 49.

546 A.H.N. Clero Secular y Regular, Libro 17351, fol. 6.

${ }^{547}$ A.H.P.V. Pt. 8144, fol. 129.

548 A.H.N. Clero Secular y Regular, Libro 17351, fol. 12v.

${ }^{549}$ A.H.P.V. Pt. 8216, fol. 12. 
O son sarmientos previamente plantados en años anteriores y enraizados, o son las rastras o vástigas prendidas que se excavan, cortan y preparan para nuevas plantaciones. No cabe duda que, dados los altos costes de plantación, toda práctica que evite que se pierdan o agosten es garantía de éxito. Estos "majuelos" también se rehoyan en viñedos viejos, como hace la familia Cillero en marzo de 1778 , lo que ratifica la tesis anterior ${ }^{550}$ :

"Empezaron a cubrir las viñas, sin estar podado el de la China, por tener que entremeter algunos maxuelos en el corro que se desgramó, día 26 de marzo..."

De hecho, no faltan anotaciones, en estos libros de contabilidad, sobre el esmero con que deben ser tratados. En el caso anterior, los majuelos comenzaron a meterse el 8 de abril y "fue el criado a mullir los maxuelos nuebos el dia 20 de julio" 551 . Estas tareas de picado y amullentado se repiten a lo largo del verano para que el coto realizado alrededor de la futura cepa guarde el tempero y no se agosten con los calores del verano. Picados y mullidos, deben conservar el castro o coto sin hierba y atemperado. Todas las haciendas que dan a hacer las labores y tienen majuelos nuevos anotan "jornales a tres reales para amollentar algunos maxuelos nuevos ${ }^{522}$ ". Las labores de arado se repiten hasta "cinco bueltas dadas en el maxuelo nuevamente plantado a razón de seis reales cada aranzada" 353 a fin de tenerlo labrado, fresco y a salvo de escobas, mielgas, gatuñas y grama.

No acaban aquí las labores del XVIII respecto a los majuelos nuevos. Se detectan sin cuidados $\mathrm{y}$ vigilados con esmero en sus primeros ańos. Trabajos como echar vástigas, rehoyar las faltas, meter nuevos majuelos y construir vallados que los protejan del ganado, son anotados en el año 1768 en la hacienda del convento del Hospital de la Resurrección de Serrada ${ }^{554}$ :

"En 21 de febrero de 1768 pagué a dicho Marcelo ciento cincuenta reales por setenta y cinco obreros que abían trabajado para echar bástigas, reoyar el maxuelo nuevo y componer el vallado y espinos en el maxuelo que llaman de las Quartas. En el mismo día pague a dicho Marzelo cuarenta reales por cinco cargas de espinos que se traxeron para cercar dicho maxuelo".

Su poda, como en la actualidad, se retrasa hasta abril, a fin de prevenir los efectos de las heladas. Así lo constata el convento de San Pablo cuando contabiliza "despuntar y mullir en abril el majuelo nuevo, a dos reales y medio obrero" 555 . En 1770 se detalla el coste en una de estas plantaciones ${ }^{556}$ :

"Mas son data novecientos sesenta y siete reales y doze mrs gastados en un majuelo nuevo; los ochocientos treinta y nuebe reales y doze mrs en su primer plantío, y los ciento y veinte y ocho reales de recortarle y descubrirlo".

No es frecuente encontrar en la documentación dieciochesca prácticas de injertos, pero la familia González Cillero la describe y realiza a fin de mejorar la calidad de la uva de determinadas cepas. Para ello, escoge la madera de una parra verdeja existente en Velilla "que da ubas como ciruelas". Por novedoso y reiterarse esta varietal, clave en la fama histórica de estos blancos, se selecciona un fragmento ${ }^{557}$ :

${ }^{550}$ A P.Q.M. "Libro de Cuentas y Razones que boy llevando..., ob. cit. s/n.

${ }^{551}$ Este dato es otro factor que inclina a pensar que los majuelos están enraizados, pues, de lo contrario, plantar sarmientos en abril es condenarlos a que no agarren, puesto que la mejor plantación con sarmientos debe realizarse a finales de febrero y primera quincena de marzo.

552 A.H.N. Clero Secular y Regular, Libro 17351, fol. 123v.

553 A P.Q.M. "Libro de Cuentas y Razones que boy llevando..., ob. cit, s/n.

${ }^{554}$ A.H.P.V. Hospital de la Resurrección, caja 47.

555 A.H.N. Clero Secular y Regular, Libro 17351, fol 31.

556 A.H.N. Clero Secular y Regular, Libro 17351, fol. 6.

557 Ibidem. 
"También se ingertaron día 30 del mismo (marzo) seis zepas, tres en el majuelo Grande y tres en el de la Estaca; las dos de este tiene cada una una púa de parra de Velilla; es a saber, en el liño 12, empezando por esta punta, conforme bamos a la zepa mirando como hacia la Seca, está la púa de Velilla en el liño 14, zepa 7. Otra púa, mirando hacia Tordesillas, del mismo ingerto de Velilla, y cada una de estas dos zepas juntas con la zepa 3 del mismo lińo están de berdejo del mismo maxuelo. Y las tres zepas del maxuelo grande están ingertadas de berdejo y son liño 18 , zepa $1^{\text {a }}$, lińo 27 , zepa $1^{\mathrm{a}} \ldots$..."

Debe entenderse una práctica minoritaria, como la que se describe a fines del XVI en Valdestillas, relativa a la plantación de emparrados o espalderas, pero indica que estas técnicas se conocen y practican en algunos viñedos de esta comarca y siglo.

\section{- El desmate, el excavo, la cubierta, el reacobijo y los escardes. El eterno temor a la grama}

Si las anteriores labores requieren práctica e inteligencia, estas son trabajos duros de brazo y azadón, que se realizan en distintas épocas del año con un mismo fin: labrar la tierra en torno a la cepa y mullir la que no llega el arado. En los inventarios de bienes de los labradores del siglo XVIII, no falta nunca "un azadón y un legón tasado en ocho reales cada uno"558 o "un legón de hierro tasado en seis reales", imprescindibles para llevarlas a cabo ${ }^{559}$.

No todas se realizan anualmente en cada pieza de vińedo, pero en el siglo XVIII se citan con más frecuencia que en anteriores siglos. Es básicamente esta mayor laboriosidad del viñedo lo que lo diferencia de épocas anteriores. Los viñedos se limpian de malas hierbas y otras matas altas, generalmente escobas, para, seguidamente y con el mencionado legón, descubrirlas en invierno para romper el castro, sanearlas y recibir el agua de lluvia (excavo o alumbre); más adelante se acorpan de tierra para protegerlas y atemperarlas (acobijo o cubierta); posteriormente, a la vuelta de mayo, se restituye la tierra de la cubierta que se haya desprendido (recobijo) y, por último, se quitan las malas hierbas durante el verano (escarde).

Salvo el excavo y la cubierta, que, por lo general, se realizan todos los años en todos los viñedos, el resto de trabajos se acometen dependiendo del tiempo disponible, de la rentabilidad y situación económica del propietario, de las características del viñedo y de las labores de arada que tengan de campañas anteriores. En todas las villas estudiadas, en cualquier caso, se repite la preocupación y obligación de "traerlas desmatadas y limpias de toda mala yerba" ${ }^{360}$. Esta operación de desmate es previa al excavo y a la vuelta de invierno. Consiste en limpiar de escobas, gatuñas, mielgas y otras hierbas la viña para seguidamente, por este orden, "alumbrarlas, podarlas y cobixarlas "561. Si se descuidan y las mencionadas hierbas enraízan en profundidad, perjudican hasta la labor del arado que salta o se desvía sin poder arrancarlas de raíz.

Estas tareas, en las medianas y grandes heredades, son llevadas a cabo por jornaleros que, generalmente, se ajustan en los meses de noviembre y diciembre y trabajan al dictado del cachicán o criado de confianza del propietario. Los salarios suelen pagarse a dos reales cada día, aunque, en ocasiones, el ajuste es por huebras:

"Se ajustó tres de diciembre de setecientos setenta y dos el descavo a seis reales y quartillo y media cántara de vino y la cuvierta a seis reales la huebra”.

\footnotetext{
558 A.H.P.V. Pt. 8220, fol. 59.

559 A.H.P.V. Pt. 8221, fol. 270.

${ }^{560}$ A.H.P.V. Pt. 8326, fol. 49.

${ }^{561}$ A.H.P.V. Pt. 13606, fol. 26.
} 
El excavo es un trabajo exigente por el esfuerzo de la propia cava y por estar las cepas sin podar, más cuando la verdeja se caracteriza por su porte rastrero que dificulta la entrada del legón al pie de la cepa. Debe retirarse el castro y los restos del acobijo del ańo anterior y dejar libre el cuello y pie del arbusto. Hay constancia de esta labor en este siglo, desde principios de noviembre hasta finales de febrero. La tarea depende del tiempo y del estado de la tierra. Algo similar puede decirse del acobijo. En 1781, por ejemplo, en la hacienda que sirve de ejemplo, "se acabaron de acubrir las viñas el día 4 de abril y se empezó el día 26 de marzo. Los primeros días muy duros pero luego llovió y se acubrieron muy bien". Estando el terreno seco, el acobijo, como el excavo, agota hasta al jornalero más fuerte, amén de ser menos efectivo. No obstante, en lo que respecta a la protección frente a la helada, las condiciones atmosféricas siempre influyen notablemente, como sucedió el 19 de abril de 1776, pese a encontrarse los majuelos muy atrasados:

"Se acabaron de acubrir día diez de abril y lo mas de ello con bastante trabaxo por la falta de agua y hallarse bastante atrasados; empezaron día primero de abril quatro hombres. Por amanecer día diez de abril se (he)laron mui bien las vińas"

Junto al tiempo y de cara a una mejor ejecución, los excavos y acobijos dependen de si el viñedo se ha arado previamente. En muchos vińedos predominan las tareas de brazo al no darse todas las vueltas de arado, especialmente en el caso de los pequeńos propietarios. Cuando esto ocurre, además de realizar el alumbre o tapado de la cepa, se debe labrar todo el castro endurecido que la rodea, por lo que la operación es más costosa y, si se contrata, más cara ${ }^{562}$ :

"En 3 de abril se empezó la cubierta, sin haverle arado de marzo ni de invierno, y la axuste a 7 reales cada huebra y dos cántaros de vino pero que havían de labrar todo el castro”.

El resto de los trabajos complementarios, sean reacobijos o escardas, tratan de tener atemperada la cepa de cara al verano y que las malas hierbas no consuman los nutrientes y el tempero. La granja dominica de Serrada gasta, en 1793, en trabajos de escarde la importante cifra de 1.287 reales de "quatrocientos veinte y nuebe jornales de esmelgar, desgatuñar y limpiar las viñas, a tres reales"563.

Unas y otras, en cualquier caso, van a la par que las vueltas de arado, tratan de mantener limpio y labrado el vińedo y, especialmente, que la grama no haga acto de presencia.

Como se analizó en el siglo XVI, el temor a esta gramínea por parte del labrador es muy grande. Tratar de erradicarla es una tarea ingrata, porque, pese a esmerarse en su extracción, siempre pueden quedar raíces que la vuelven a hacer resurgir. Se realiza, como en el XVI, mediante cava a azadón rompiendo toda la tierra y extrayendo y separando manualmente la grama desprendida. En la hacienda de González Cillero, el denominado viñedo de la China acusa este problema y, cuando contrata en 1777 el desgrame de un corro que le faltaba, proporciona una valiosa y detallada información de su coste, por lo demás muy alto. Asciende entre 4 y 6 maravedíes la cepa, lo que equivale cada aranzada ( 420 cepas) a 30 jornales $^{564}$.

En otras ocasiones, la ejecución de este trabajo afecta a cepas concretas, en las que la grama se ha apoderado de las mismas y acaba por secarlas. El trabajo es muy laborioso, pues, prácticamente,

562 Ibidem.

563 A.H.N. Clero Secular y Regular, Libro 17351, fol. 83.

564 "Día 1 de noviembre. Ajuste el desgramar el corro de maxuelo que me quedó por desgramar del maxuelo de la China, pues lo ajuste en 70 reales y solamente se desgramó la mitad, y esta mitad la axuste a seis mrs cada cepa y solamente se desgramaron 160 cepas, que son 20 líneos de largo y 8 de ancho, que importó a razón de 4 mrs 18 reales y $28 \mathrm{mrs}$ por haver quedado el ochavo para el recorro de mayo, que es quatro reales y $21 \mathrm{mrs}$, y lo restante que fueron 11 lińos de largo les tube que pagar su jornal de 19 quartos cada día, y les llebó a dos hombres dichos ocho liños ocho días que importaron 35 reales y 26 mrs, y concluyeron día 18 del mismo." (A P.Q.M. "Libro de Cuentas y Razones que boy llevando..., ob. cit, s/n.) 
se debe dejar las raíces de la cepa casi en el aire, a fin de poder extraer toda la grama, amén de cavar a azadón toda la tierra y castro que la rodea. Prueba de su elevado trabajo, es el coste que refleja el convento de San Pablo en 1779 en el que desgramar cada cepa cuesta 0,47 reales: "Mas mil trescientos sesenta y un reales y catorce mrs de desgramar 2.893 cepas'365. De ahí que, en muchas haciendas, se observan distintas acciones de prevención, tales como aislar mediante vallados o cercas el vińedo, para evitar la llegada de la gramínea desde linderas o tierras colindantes.

\section{- Las vueltas de rama, marzo y mayo. Los sistemas de tracción animal}

Junto a las tareas anteriores, las labores de arada se tornan vitales y complementarias de las de brazo para el buen desarrollo del viñedo. Arar de rama, marzo y mayo se tiene por "obligación de hazer... en los tiempos y forma que es estilo en esta villa"368 aunque, como se viene reiterando, ni en todos los majuelos se hacen todos los años, ni se circunscriben de forma estricta a los meses que las enuncian.

La vuelta de rama o de invierno se lleva a cabo antes de la poda, siguiendo los "saetines" o diagonales que dibujan las cepas. Suele hacerse tanto en los suelos cascajosos para evitar su endurecimiento, como en aquellos tendentes al empradizamiento. Aunque es una vuelta obligada en los contratos de arrendamiento, en los libros de administración y apuntes familiares no siempre se da a la totalidad de las vińas ${ }^{569}$ :

\footnotetext{
"Se empezó a arar de yvierno día 25 de noviembre en esta forma: los maxuelos que se araron de yvierno esta vuelta a 13 reales y los otros dos a 14, y los que no se araron de invierno la buelta de marzo a 17 reales y la de mayo a 16, y se araron en este año el grande, el chico, el de la Estaca y el Picón.

Año 1779. Se empezó a arar de invierno con dos arcos el uno de diciembre y se concluyó el día siete. No se aro mas que el Grande".
}

Como se ve en el texto, cuando falta alguna tarea, las siguientes son más caras al presentarse el viñedo más atrasado de laboreo. En ocasiones, para ponerlos al día, se anotan trabajos de recuperación. De ahí que, tras una crisis vitícola en la que el viñedo tiende a descuidarse, su recuperación no siempre es posible. En la hacienda de González Cillero, por motivos que se desconocen, no se da la arada de rama en varios de sus vińedos entre 1785 y 1786 . Al ańo siguiente, "se gastaron en el maxuelo grande 47 obreros a 3 reales cada uno en quitar yerbas grandes", cuestión esta nunca anotada con anterioridad. Este mismo año "se araron todos de invierno". Como en el resto de tareas, el tiempo puede retrasar las vueltas de arado. En la de rama de 1786, es el rigor del invierno el que las condiciona:

”22-23 diciembre. Cayó una nebada de más de quarta cada día por lo que no pudieron trabaxar los obreros en todo lo restante del mes y se mantuvo en la calle y texados hasta el día 15 de enero del año siguiente en cuio día salieron los obreros a el campo".

\footnotetext{
565 A.H.N. Clero Secular y Regular, Libro 17351, fol. 17.

566 Se entiende que se trata de limpiar el viñedo atendiendo al estado de las vástigas enterradas, pero no se asegura este extremo hasta una investigación más rigurosa respecto a esta tarea.

567 A.H.P.V. Pt. 13607, fol. 66v.

568 A.H.P.V. Pt. 13606, fol. 265.

569 El coste de estas operaciones está cuantificado por huebras. En Tordesillas la huebra equivale a 2,5 iguadas o 1.000 cepas, es decir, una huebra viene a tener 2,38 aranzadas.
} 
En las vueltas de marzo y mayo, especialmente esta última, las condiciones del suelo, atendiendo al tiempo, son claves para mantener el viñedo atemperado y sin hierba durante el verano. Las condiciones de humedad de la tierra se tornan vitales. Darlas a destiempo o en malas condiciones es equivocarse. En los apuntes familiares de la hacienda mencionada siempre suelen anotarse estos factores. Estos son algunos ejemplos de la vuelta de marzo y de la bina o arada de mayo, en distintos años y estado del suelo:

“Año 1774. Se empezó a arar de marzo el 24 de febrero en buena sazón.

Año 1776. Se empezó a binar oy día 24 de mayo en muy buena sazón por haber llovido el día anterior un rocío muy bueno.

Año 1778. Se empezó a binar el día 1 de junio estando muy duro por lo que no se hizo lavor de provecho.

Año 1786. Día 17 de junio. Se acabaron de vinar los maxuelos y se araron en buena sazón por haber llovido y en este año no se araron más que esta vuelta”.

Hay haciendas en que estas vueltas se dan a una mano siguiendo las calles y solo se cruzan aquellas partes del vińedo que lo necesitan. La Casa del Hospital de la Resurrección de Serrada, en 1768, paga en la primera vuelta de arado "71 aranzadas a seis rs cada una" y el 24 de marzo en la segunda vuelta precisa "aberse cruzado algunos de ellos a razón de seis reales aranzada" 570. Cuando en cada vuelta se cruza toda la aranzada, el precio se duplica siendo la vuelta de marzo la más completa, pues, al estar la calle despejada de sarmientos y brotes, se dan cuatro rayas que forman tres cerros en cada calle. Es el caso de la Casa de la Encarnación en 1790, en el que la operación llega a 15 reales $^{571}$.

"Arancia. A los aradores de la buelta de marzo que araron a quatro y a quatro, ciento y diez y ocho aranzadas de vińa a quince reales cada una, mil setecientos setenta reales".

Respecto al sistema de tracción, predomina el ganado mular, aunque los bueyes siguen estando presentes, puesto que las haciendas los mantienen y estiman para las tierras profundas de sembradura. Toda tracción se hace necesaria para optimizar los recursos, aun cuando el ganado boyal se defiende peor entre las cepas, especialmente en la vuelta de rama. En la vuelta de mayo de la hacienda mencionada, se hace mención expresa a ambos tipos de ganado ${ }^{572}$ :

"Se empezó a vinar dia 26 de mayo con cuatro arcos: dos de mulas en el grande y dos de bueyes en el de la Estaca en mui buena sazón por haber llovido el día 21 un poco y después llovió bastante el mismo día 26. Acabaron día 31”.

No obstante, todo depende de las dimensiones de las labranzas. En La Seca, pueblo vitícola por excelencia, se catastran 86 bueyes, 171 mulas y 430 asnos, prueba palpable de que cada titular del viñedo ara con los animales que puede. En este caso las pequeñas explotaciones son trabajadas con burros, supliendo su menor tracción con más trabajos de brazo. En estos casos las dimensiones de los arados y demás pertrechos son más pequeńos, con las consecuencias derivadas en la labor realizada. La hacienda dominica de Serrada, por el contrario, posee en 1752 seis mulas de labranza para labrar 215 aranzadas de vińedo. Las 47 obradas de sembradura que labra no logran abastecer

\footnotetext{
${ }^{570}$ A.H.P.V. Hospital de la Resurrección, caja 47.

${ }^{571}$ A.H.N. Libro 17200, parte $1^{\text {a }}$, fol. 9 y ss.

${ }^{572}$ A P.Q.M. "Libro de Cuentas y Razones que boy llevando..., ob. cit, s/n.
} 
el consumo interno. En 1769 se anota un consumo de 474 fanegas de cebada para las mulas. En 1771, cuando se labran 260 aranzadas, se cosechan 98 fanegas de cebada, pero se consumen $302 \mathrm{fa}-$ negas. Además de las algarrobas, la cebada y la avena se mezclan y fortalecen a los animales de labor en los meses de mayor actividad ${ }^{573}$ :

"Zebada envuelta. Mas son cargo treinta y tres fanegas y media que se enbolvieron de avena con la zevada para gastos del ganado".

En 1774 se suma a la hacienda un par de bueyes y es rara la hacienda mediana o grande que no mantiene ganado boyal. Los inventarios de bienes de las familias labradoras del XVIII expresan en detalle el número y valor del ganado de labor, en mayor medida ganado mular, apareciendo en ocasiones sus nombres, pelajes o virtudes, tal es su importancia y valor.

"Aperos de labranza. ... 12 rs de un molino de piedra para garrovas, 10 rs de quatro comederas para bueies, 6 rs de seis rollos para los yugos, 32 de errar ocho bueies, 24 de hacer la raia a las mulas en abril que fueron 8 mulas; 4 rs y 28 mrs de 16 rozales para dichas mulas; 60 rs de 40 dentales a real y medio... Mas cincuenta y siete reales al carretero por hacer veinticinco arados nuebos a real y medio... y componer estebas, yugos,... Mas trescientos y cincuenta y un rs y $24 \mathrm{mrs}$ de yerro y herrero... por aguzar y componer las rejas...”.

Si las mulas se imponen a los bueyes en el viñedo, y puede entenderse como un avance en el laboreo, en lo que no se aprecian cambios es en los tipos de arado y otros aperos. Los inventarios así lo constatan y los encargos y gastos de reparación de estos útiles en las haciendas dan fe de ello. Yugos, carros y arados romanos con su reja de hierro, cama, timón, dental o belortas se repiten de forma invariable ${ }^{574}$.

\section{- Los avatares meteorológicos y el final del ciclo: La vendimia}

Como se ha estudiado, el tiempo condiciona la mayor parte de los trabajos que lleva el viñedo. Las heladas, sequías o pedriscos son letales en su desarrollo vegetativo. De hecho, cuando son importantes y sitúan a los labradores al borde de la ruina, los concejos solicitan ayuda terrenal, al tiempo que las rogativas piden a los santos la intercesión divina para que alivie estas calamidades. El cuadro adjunto recoge las incidencias negativas más destacadas entre 1771 y 1800 anotadas por la familia Cillero.

Los meses de abril y mayo son claves en el año agrícola. La falta de agua en primavera es un contratiempo que dificulta tanto las tareas de brazo como la vuelta de marzo y mayo, al margen del perjuicio que sufren las tierras de sembradura. En nota al pie se recogen cuantas rogativas se hicieron en este sentido, pero son las heladas y el pedrisco el problema más grave para el viñedo. Reducen la cosecha respecto al resto de ańos de forma muy importante. Los pedriscos de 1792, 1793 y 1795, por ejemplo, provocan una disminución del $50 \%$ respecto a la cosecha media del total de años registrados. Este meteoro, al margen de otras coyunturas, provoca variaciones importantes en la producción final.

\footnotetext{
${ }^{573}$ A.H.N. Libro 17200 , parte $1^{\mathrm{a}}$, fol. 10 y ss.

${ }^{574}$ Ibídem.
} 

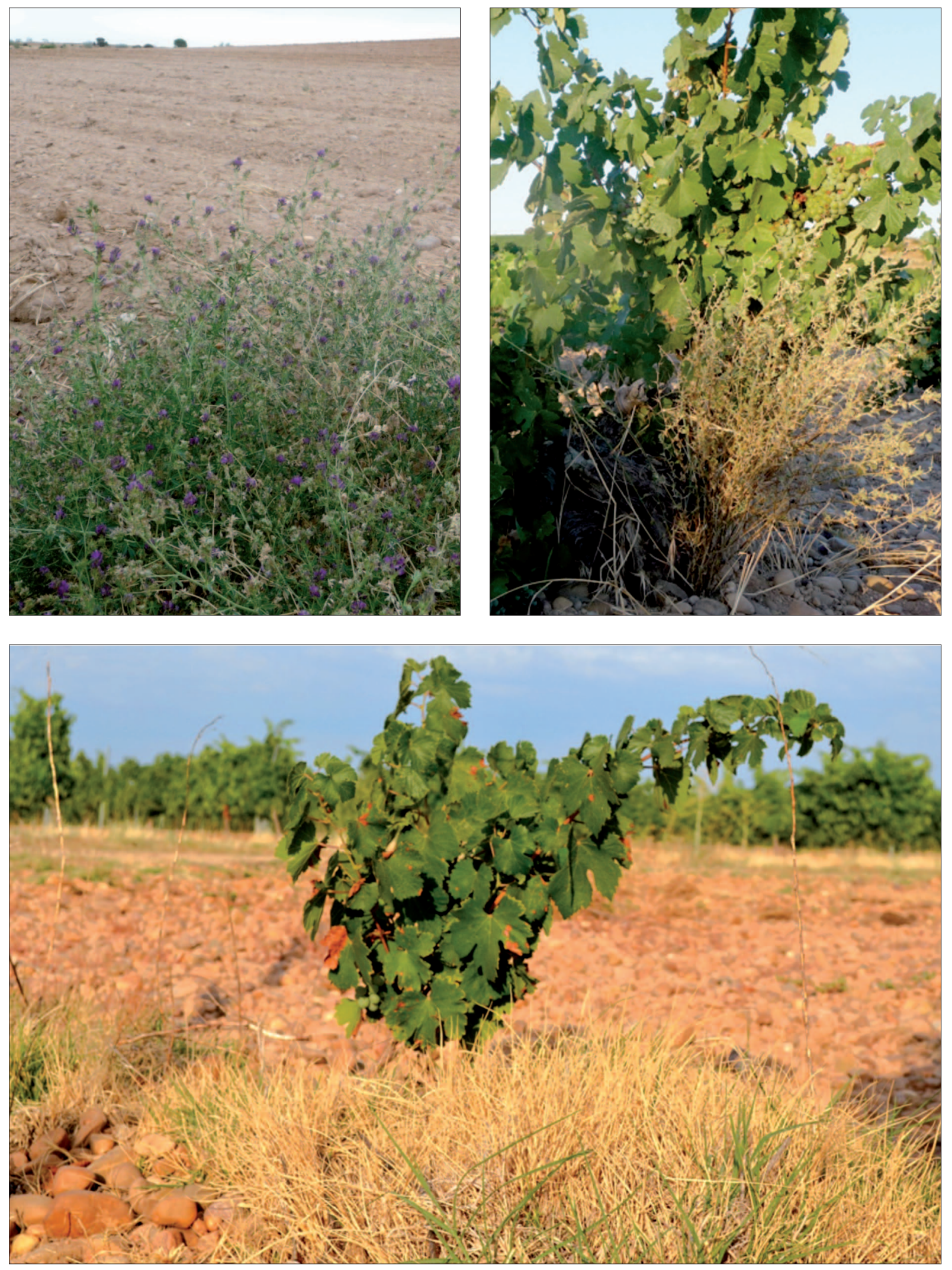

Imagen 53. Las mielgas y gatuñas (arriba, izquierda y derecha, respectivamente, fotos: 25/08/2013) y, sobre todo, la grama (abajo, foto 18/08/2014), han sido las malas hierbas que el campesino se ha afanado en quitar, tanto en los secanos, como en los majuelos. Obsérvese, en la imagen inferior, como la grama ha debilitado a la cepa que acusa, además, la falta de humedad y nutrientes del terreno, tomados por la gramínea en su ciclo vegetativo. 
Si se toman como referencia las cinco cosechas mayores y menores del total de los treinta años registrados, las inferiores suman una media de 64,7 cargas de uva, frente a las 186,6 cargas de los cinco años de mayor producción, lo que supone casi tres veces menos $(2,88)$ de cosecha recogida. El pedrisco de 1773 y de 1781 no afecta a las parcelas propiedad de la familia, pues recoge 129 cargas de uva, pero destroza buena parte del viñedo del norte de la Tierra ${ }^{575}$ :

Año 1773. "Dos de junio. Cayó tan fuerte piedra que en algunos pagos los destruyó bastante y dicho día al medio día cayó otra piedra que en el pago de la Perdiz y Valdecorneta y al pago del llano de la Peña le hizo bastante daño".

Año 1781. "El día 15 de julio por la tarde hubo un nublado mui grande y cayó bastante piedra la que hizo bastante daño en algunos parajes".

Otro ejemplo es el pedrisco de 1793, que merma la cosecha hasta bajar a las 81 cargas, y obliga a recoger la uva apedreada a fin de aprovecharla en lo posible:

"Día 9 de septiembre. Cayó tan fuerte agua y piedra en diferentes pagos y lugares que se apedrearon las vińas y fue preciso algunas bendimiarlas y coger lo que estaba en el majuelo aunque por madurar y traer a los lagares"

Como se ve, la producción del viñedo presenta importantes oscilaciones por múltiples factores ligados a la meteorología, al tipo de suelo, a la vida de la cepa y a los trabajos realizados a lo largo de los años. Como en el anterior ejemplo, en la gráfica de producción del Hospital de la Resurrección, puede comprobarse lo desigual de unos años respecto a otros. Esta es una característica que acompaña al viñedo, tanto en tiempo histórico como hasta hace unas décadas en que el agua, mediante el sitema de riego por goteo, ha permitido limitar o suprimir los efectos de la sequía, principal accidente atmosférico causante de la disminución de la cosecha en estos siglos, al margen de heladas o granizo ${ }^{576}$.

La vendimia, en cualquier caso, es el fin de un ciclo y el principio de otro, vinculado a lagares, bodegas y vino. Como en siglos anteriores, la recogida de la uva comienza cuando concejos y gremios de viñeros comprueban que está bien madura. En los cuadros anteriores se puede comprobar que la mayor parte de los ańos se inicia en la primera semana de octubre. Por estas fechas y con producciones de a 1,20 moyos por aranzada, la uva está pletórica de azúcares, claves en el proceso de fermentación. Las vendimias se suelen autorizar al tiempo en distintos términos para evitar robos entre vecinos. La entrada de uva en la población se controla en las puertas o caminos que las rodean. Para ambas cosas se contratan guardas de campo, que representan un coste añadido a los gastos de producción. En Tordesillas, por ejemplo, la vendimia se publicó en 1781 el miércoles 10 de octubre con una vigilancia muy estricta ${ }^{577}$ :

"Se hizo una bendimia de mui excesivos calores todos los días, y en este año se tomó la providencia de poner guardas a el Puente y a la Puerta del mercado para que solo por estas dos partes entrasen los carros de ubas, y que no traxesen uba alguna ni los bendimiadores ni pasagero alguno”.

${ }^{576}$ A.H.P.V. Hospital de la Resurrección, cajas 42 y 46.

577 A P.Q.M. "Libro de Cuentas y Razones que boy llevando de las cosas que se me ocurren y lavores de las viñas, 1771 1801 ", fol. s/n.

${ }^{575}$ Libro de Cuentas y Razones que boy llevando..., ob. cit, s/n.) 
Cuadro 25. Incidencias meteorológicas, inicio de vendimia y cosecha recogida en los vińedos de la familia González Cillero, años 1771-1800

\begin{tabular}{|c|c|c|c|c|c|c|c|c|}
\hline Años & $\begin{array}{l}\text { Enero- } \\
\text { febrero }\end{array}$ & $\begin{array}{c}\text { Marzo- } \\
\text { abril }\end{array}$ & $\begin{array}{l}\text { Mayo- } \\
\text { junio }\end{array}$ & $\begin{array}{l}\text { Julio- } \\
\text { agosto }\end{array}$ & $\begin{array}{l}\text { Septiembre- } \\
\text { octubre }\end{array}$ & $\begin{array}{l}\text { Noviembre- } \\
\text { diciembre }\end{array}$ & $\begin{array}{c}\text { Inicio } \\
\text { vendimia }\end{array}$ & $\begin{array}{c}\text { Cosecha } \\
\text { (cargas) }\end{array}$ \\
\hline 1771 & & & & & & & 15 oct. & 187 \\
\hline 1772 & & Seq./hel. ${ }^{578}$ & & & & & - & 66,5 \\
\hline 1773 & & & Pedrisco & & & & - & 129 \\
\hline 1774 & & & & & & Lluvias & 15 oct. & 169 \\
\hline 1775 & & & Sequía ${ }^{579}$ & & & & 4 oct. & 192,5 \\
\hline 1776 & & Seq./hel. ${ }^{580}$, & & & & & 7 oct. & 103,5 \\
\hline 1777 & & & Sequía & & & & 4 oct. & 166 \\
\hline 1778 & & & Lluvia/hel. & & & & 5 oct. & 163 \\
\hline 1779 & & & $\mathrm{Hel} /$ seq. ${ }^{581}$ & & & & 24 sep. & 145 \\
\hline 1780 & & Helada & & & & & 18 sep. & 106 \\
\hline 1781 & & & & Pedrisco & Calores & & 10 oct. & 190,5 \\
\hline 1782 & & Fríos & & & & & 14 oct. & 124,5 \\
\hline 1783 & & & & & & & 13 oct. & 174,5 \\
\hline 1784 & & & & & & & 4 oct. & 117,5 \\
\hline 1785 & & & & & & & 30 sep. & 207 \\
\hline 1786 & & & & & & Nevadas & 10 oct. & 166,5 \\
\hline 1787 & & & & & & & 12 oct. & 88 \\
\hline 1788 & & & & & & & 25 sep. & 104,5 \\
\hline 1789 & & & & & & & 8 oct. & 79,5 \\
\hline 1790 & & & & & & & 6 oct. & 108 \\
\hline 1791 & & & & & & & 3 oct. & 127 \\
\hline 1792 & & & Pedrisco & & & & 24 sep. & 66 \\
\hline 1793 & & & & & Pedrisco & & 1 oct. & 81 \\
\hline 1794 & & & & & & & 29 sep. & 111 \\
\hline 1795 & & & & Pedrisco & & & 2 oct. & 48 \\
\hline 1796 & & & & & & & 30 sep. & 62 \\
\hline 1797 & & & Pulgón ${ }^{582}$ & & & & 5 oct. & 102 \\
\hline 1798 & & & & & & & 2 oct. & 95 \\
\hline 1799 & & & & & & & 4 oct. & 118,5 \\
\hline 1800 & & & & & & & 2 oct. & 115,5 \\
\hline
\end{tabular}

Fuente: Archivo familia Muelas. Elaboración propia.

En 1789, se inicia el 8 de octubre, días después de haber comenzado en Rueda y La Seca, lo que genera no pocos problemas con los rebuscadores de uva y con el ganado ovino que entra a comer la hoja:

”Bendimia 1789. Se publicó para jueves 8 de octubre. Hizo buena vendimia solo que hubo muchos desórdenes con los rebuscadores de Rueda y La Seca y las obexas por haber echado ellos mucho antes la bendimia”.

578 "El 21 de abril de 1773 pusieron los padres dominicos plegaria a Nuestra Señora del Rosario por falta de agua y no llovió, y a San Isidro el 23 de abril. El 2 de mayo a Virgen del Rosario, 4 de mayo a Na Señora del Arenal.

579 "Rogativa a San Isidro por falta de agua el 29 de abril y no llovió".

580 "Se puso rogativa a San Isidro por la falta de agua oy día 18 de mayo y llovió dos o tres tardes mui bien de suerte que se recupero bastante el campo".

581 "Se traxo a Mo Santísima en rogativas por falta de agua el día 9 de mayo".

582 “Domingo 21 de mayo. Con el motibo de estar las viñas con bastante pulgón aberse traído el agua de San Gregorio se celebro en Santa María la mayor una misa solemne con asistencia de la Villa, el cabildo y comunidades y cofradías, y después se procesionó solemnemente a la hermita de Santa Marina y desde allí se bendixo el campo con dicha agua y de la que se entrego.... diferentes porciones de agua con que fueron diferentes sacerdotes y religiosos a la tarde de dicho día y otros siguientes a conjurar todos los pagos de vińedo y concluido se bolvió a procesionar a la Iglesia de Santa María y dos días después que fue la víspera de la Ascensión fue a San Vicente con la letanía por estar allí sembrado y se bendijo también con dicha agua y desde la torre de dicha Yglesia por todos los quatro costados bendixo también el campo con dicho agua”. 
La conveniencia de acuerdos entre los pueblos vecinos garantiza la tranquilidad en este sentido, al igual que la existencia de normas claras respecto a que los vendimiadores puedan traer uva o no para su gasto. De hecho varían sus jornales. En cualquier caso, es difícil evitar las irregularidades con el fruto en el campo. En la mencionada Tordesillas, en 1791, "se dio providencia para que los que tubieren maxuelos fuera del término pudieran meter uba desde el día que se bendimiare en aquel término; y en Rueda fue desde el dia 24 de septiembre. Hizo buen temporal"583. Valdestillas, por ejemplo, al observar en 1792 cómo los propietarios de vińas, usando distintas artimańas, venden uva durante la vendimia en los pueblos de Serrada, Valdestillas y Villanueva, solicita que se requiera a las justicias de dichos pueblos "para que haga entender a sus vecinos por medio de edictos... que en la próxima vendimia no compren huva a los de esta citada Valdestillas"384.

Cuadro 26. Cosecha en cargas de uva, fecha de vendimia y producción en los viñedos más representativos de la hacienda del Hospital de la Resurrección, Serrada, 1762-1771585

\begin{tabular}{|c|c|c|c|c|c|c|c|c|c|c|c|c|}
\hline & & 1762 & 1763 & 1764 & 1766 & 1767 & 1768 & 1769 & 1770 & 1771 & & \\
\hline Pagos del viñedo & $\begin{array}{l}\text { No } \\
\operatorname{aranz}\end{array}$ & $\begin{array}{l}4-15 \\
\text { oct. }\end{array}$ & $\begin{array}{l}15-27 \\
\text { oct. }\end{array}$ & $\begin{array}{l}30 \text { sep. } \\
11 \text { oct. }\end{array}$ & - & $\begin{array}{l}30 \text { sep. } \\
10 \text { oct. }\end{array}$ & $\begin{array}{l}3-16 \\
\text { oct. }\end{array}$ & $\begin{array}{l}4-17 \\
\text { oct. }\end{array}$ & - & - & $\begin{array}{c}\text { Cosecha } \\
\text { media }\end{array}$ & $\begin{array}{c}\text { Moyos } \\
\text { por aranz }\end{array}$ \\
\hline Las Cuestas & 5 & 34 & 25,5 & 45 & 32 & 42 & 46 & 25 & 26 & 31 & 24,05 & 1,17 \\
\hline El Monte & 11 & 40 & 27 & 60 & 56 & 72 & 78 & 74 & 74 & 85 & 62,88 & 1,39 \\
\hline La Horca & 2 & 15 & 11 & 21 & 12 & 17 & 14 & 15 & 12 & 13 & 14,44 & 1,76 \\
\hline La Olma & 1 & 8 & 3,5 & 3 & 7 & 11 & 10 & 10 & 13 & 8 & 8,16 & 1,99 \\
\hline Montaña & 5 & 24 & 23 & 32 & 22 & 27 & 15 & 20 & 13 & 18 & 21,55 & 1,05 \\
\hline Eugenia al Pinar & 4 & 14 & 12 & 16 & 17 & 17 & 14 & 29 & 21 & 16 & 17,33 & 1,05 \\
\hline Castro al Pinar & 5 & 32 & 18 & 26 & 25 & 32 & 31 & 43,5 & 22 & 25 & 28,27 & 1,38 \\
\hline Camino Ventosa & 4 & 22 & 9 & 16 & 19 & 21 & 22 & 25 & 25 & 18 & 19,66 & 1,20 \\
\hline Las Cuartas & 8 & & 23 & 27 & 38 & 48 & 56 & 54 & 50 & 42 & 42,25 & 1,29 \\
\hline El Ciego & 6 & 31 & 22 & 32 & 29 & 41 & 37 & 32 & 26 & 27 & 30,77 & 1,25 \\
\hline El de Farruco & 2 & 5 & 4 & 6 & 4 & 6 & 5 & 6 & 6 & 3 & 5,00 & 0,61 \\
\hline El Nuevo & 6 & - & - & - & 4 & 3 & 8 & 5 & 11 & 11 & 7,00 & 0,28 \\
\hline TOTAL & 60 & 225 & 178 & 338,5 & 265 & 337 & 336 & 338,5 & 299 & 297 & 290,44 & \\
\hline $\begin{array}{l}\text { TOTAL } \\
\text { EXPLOTACIÓN }\end{array}$ & 87 & 378 & 254 & 375 & 255 & 447 & 505 & 478 & 414 & 393 & 388,77 & 1,20 \\
\hline
\end{tabular}

Fuente: Archivo familia Alonso Moyano. Elaboración propia.

$\mathrm{Al}$ ser vendimias tardías, la recolección requiere rapidez, pues las lluvias otoñales y las primeras heladas pueden poner el fruto en peligro. Toda la mano de obra disponible se concentra en los vińedos para que, entre una semana y semana y media, pueda estar la uva recogida y pisada en los lagares. Raro es el año en las haciendas vitícolas importantes que la vendimia se alarga más de diez días. Hombres, mujeres y niños forman cuadrillas dirigidas por cachicanes que organizan la corta, carga y acarreo. Un ejemplo detallado es el que se recoge en el libro de contabilidad de la hacienda que el Hospital de la Resurrección tiene en Serrada. Sus 77 aranzadas (71 de viñas viejas y 6 de nuevas) llevaron en el año 1769 los siguientes jornales: ${ }^{586}$

${ }^{583}$ Ibídem.

${ }^{584}$ A.H.P.V. Pt11890/7, fol. 190.

${ }^{585}$ A.H.P.V. Hospital de la Resurrección. Caja 3, leg. 55-81, carp. 18,42 y 47. Al analizar distintos años y comprobar que el peso de las cargas de uva varían de unos años entre los 85 y $92 \mathrm{~kg}$ hemos optado en el cálculo de las medias de producción por valorar cada carga a $92 \mathrm{~kg}$ de uva.

586 A.H.P.V. Hospital de la Resurrección, caja 47. 
"Vendimiadores. Se gastaron doscientos diezinueve obreros para bendimiar el fruto de esta hazienda en diez días que duró dicha vendimia, que a razón de dos reales y medio, dos y quartillo y dos reales a que se pagaron con proporción a su trabajo, importaron y pague cuatrocientos cuarenta y nuebe reales y 16 mrs".

Los trabajos que relatan los documentos de este siglo no difieren de los analizados y que se repiten en siglos posteriores. Los vendimiadores cortan la uva y la echan en cuévanos de mimbre ${ }^{587}$ con los que van llenando los cestos previamente situados en las linderas o calles del viñedo. Al tiempo que siguen vendimiando, los sacadores y cargadores suben los cestos a los carros y caballerías, a fin de que los trotadores los lleven a los lagares. Las grandes haciendas concentran en estos días buena parte de la mano de obra local y muchos pequeños productores, recogida su cosecha, se ponen al servicio de los grandes propietarios para acarrear la uva cobrando por caballería o por carga transportada, en que las huebras de carro se pagan entre 16 y 20 reales diarios dependiendo si se trata de bueyes o mulas. En 1772, la granja dominica de Serrada gasta en vendimia 2.789 reales con el siguiente desglose ${ }^{588}$ :

"Mas son data dos mil setecientos ochenta y nueve reales y dieciséis mrs gastados en la vendimia en esta forma: de siete huebras de mulas a 20 rs, 140 rs; de 3 huebras de bueyes a 16 rs, 48 rs; de treinta y seis jornales de pollinos a tres rs 108 rs Y los restantes de vendimiadores, sacadores, cargadores"

Como puede deducirse, no todas las caballerías arrastran carros. Buena parte de ellas cargan la uva a sus lomos en aguaderas o cestos debidamente preparados para el transporte individual ${ }^{589}$. A tenor de los apuntes de pago, estos animales son conducidos tanto por hombres como mujeres que, en ocasiones, por su edad, prefieren esta tarea de menor esfuerzo físico. En la casa religiosa que posee el Convento de la Encarnación en Serrada, se pagan las siguientes cantidades en la trota de la uva:590

"Burras. En noventa y quatro jornales de burras para la trota pagados a tres reales, doscientos ochenta y dos reales Carro. En catorze jornales de un carro que trotó catorze días a veintitrés reales por día, trescientos veintidós reales”

\section{- A modo de conclusión: un calendario vitícola con labores todo el ańo}

Como se ha visto, desde el desmate y la poda hasta la vendimia no faltan tareas en el viñedo en las distintas estaciones. Muchos de los trabajos se solapan con las vueltas de arado y siempre en los majuelos hay tarea que hacer, de acuerdo a la atención y cuidados que quieran invertirse. Ha parecido

${ }^{587}$ En la documentación consultada es raro el año en que no se compran cuévanos y cestos de mimbre para la vendimia. En 1786, por ejemplo, la hacienda dominica adquiere " 210 reales de 30 cargas de cestos a 7 reales; 20 reales de 20 cuévanos" (A.H.N. Clero Secular y Regular, Libro 17351, fol. 67). Aunque no hemos tratado el cultivo de mimbrerales por no extendernos y ser minoritario, es un elemento obligado en el paisaje de cada pueblo que acompańa a los pagos de viñedo. El Catastro de Ensenada suma en Rueda cinco obradas de mimbres, tres en La Seca y una en Serrada. La hacienda de González Cillero, que nos sirve de ejemplo, corta la mimbre en 1772 los días 14 y 15 de enero "entre tres hombres y un excavador a 3 reales cada uno". Se obtuvieron "58 haces y nos hicieron en dicho año 5 cargas de cestos a real y medio cada carga y llevaron la mimbre que sobro a precio de quince quartos cada haz". (A P.Q.M. "Libro de Cuentas y Razones que boy llevando...).

588 A.H.N. Clero Secular y Regular, Libro 17351, fol. 19v.

${ }^{589}$ En este siglo XVIII encontramos las aguaderas como medio de transporte de la uva al lagar. En 1788 la hacienda de González Cillero las utiliza en vendimia: "a su arrendatario... le pague un cántaro (de diezmo) que fue lo que le correspondió de cinco pares de aguaderas que coxi (del majuelo de la China)”. Las aguaderas son utilizadas como transporte menor en los siguientes siglos. Se componen de cuatro cestos pequeńos de mimbre insertos en una armazón de madera que se adapta al lomo de una caballería. Sus cuatro senos deben de ir llenos de forma proporcional para evitar su basculamiento a uno u otro lado. En el caso del ejemplo citado la aguadera lleva $46 \mathrm{~kg}$ o, lo que es lo mismo, media carga de uva. Los cestos para el transporte de caballerías individuales son más pequeños que los que se usan en los carros y en su parte superior disponen de una media ala que se adapta al lomo del animal y se ata al cesto del otro lado.

${ }^{590}$ A.H.N. Libro 17200 , parte $1^{\text {a }}$, fol. 9 y ss. 
oportuno adjuntar un cuadro resumen de las labores anotadas en 1780 en la hacienda que en Serrada posee el Hospital de la Resurrección de Valladolid, citado anteriormente.

El año agrícola empieza en diciembre, cuando se realiza y paga el excavo, en este caso realizado a destajo a 2,25 reales la aranzada. Dos obreros inician la poda, desde principios de enero hasta mediados de marzo, a dos reales diarios, al tiempo que otro los acompaña realizando tareas de azadón, sea echando vástigas o desgramando. Aunque es invierno la mayor parte de las semanas trabajan los seis días completos, percibiendo en enero a dos reales y cobrando los podadores, a partir de febrero, cuando los días se alargan, es a 2,5 reales. A tenor de las cifras, poda cada obrero 0,82 aranzada/día (344 cepas), lo cual es una media altísima para la época, pues lo normal es podar poco más de media aranzada/día, por lo que resulta lógico pensar que los obreros de azadón que los acompańan realizan tareas complementarias que agilizan la labor.

Una vez podados, se acobijan a destajo al mismo precio que el excavo. Esta tarea de protección, en que la cepa se cubre de tierra desde su pie hasta su cabeza, finaliza antes de que las heladas de marzo puedan helar las gomas o yemas más tempranas y tras la vuelta de marzo, como se refleja en el cuadro, queda el mes de abril con escasa actividad, pues, arados y acobijados los majuelos, lo mejor es no tocarlos y rezar para que el cielo proteja su brotación de las heladas primaverales.

En mayo y junio vuelven las tareas de brazo, sea para escardar, echar vástigas, reacobijar, quitar grama o limpiar el castro de la cepa donde no haya llegado el arado en marzo o en mayo. En ocasiones y dependiendo del terreno, como se ve en el cuadro resumen, deben doblarse las vueltas de arado en algunos majuelos, pues, dependiendo del tiempo y del terreno, los barros pueden empradizarse, la grama campar a sus anchas en las arenas frescas, los cascajos endurecerse...

La vendimia que nos ocupa en este ańo de 1780 la realizan 193 vendimiadores a dos reales de media durante siete días. Recolectan un total de $37.987 \mathrm{~kg}$ de uva, por lo que cada obrero corta una media de $196,8 \mathrm{~kg}$ diarios en una cosecha que se puede calificar como normal para el año, ya que las 87 aranzadas de este ejemplo rinden, antes de diezmo, a 436,6 kg de media o, lo que es lo mismo, a 1,18 moyos de mosto por aranzada ${ }^{591}$ :

\begin{abstract}
"En la vendimia de este año de mil y setecientos y ochenta... se cogieron de ochenta y siete aranzadas de arado... quatrozientas y treinta y ocho cargas y media y dos cobanillos de uba, que rebaxadas de estas cuarenta y tres cargas y media y seis cobanillos que se diezmaron quedaron útiles para el lagar trescientas nobenta y quatro cargas y media y un cobanillo; y de ellas salieron nobenta y dos moyos y doce cántaras y media de mosto, con una que se dio de limosna a los PP. Capuchinos de esta ciudad, por lo que resulta quedaron encerradas en la bodega de dicha villa... mil cuatrocientas ochenta y tres cántaras y media, de los cántaros de cobre medida del lagar, de los que el cerrado hace cinco medias cuartillas....”.
\end{abstract}

En este mismo ańo, las 270 aranzadas que posee la casa conventual de San Pablo producen 1,19 moyos obtenidos de 440,65 kg de uva por aranzada, si bien en este caso no se puede precisar si las 5.168 cántaras declaradas como cosecha fueron o no diezmadas.

$\mathrm{Al}$ margen de las vueltas de arado, transporte de uva y trabajos de lagareo, las tareas de brazo y vendimia suponen 7,55 jornales por aranzada y ańo, lo que indica la importancia del cultivo para dar sustento a la numerosa masa de jornaleros que vive en estas villas. En siguientes epígrafes se abordarán con mayor precisión los trabajos y la rentabilidad del cultivo.

${ }^{591}$ A.H.P.V. Hospital de la Resurrección, cajas 42 y 46, fol. 7. Quizá no sobre recordar las equivalencias utilizadas en la conversión de cargas de uvas a $\mathrm{kg}$ y moyos por aranzada. Seguimos utilizando que de dos arrobas $(23 \mathrm{~kg})$ se obtiene una cántara de mosto (16 litros) por lo que tenemos un rendimiento medio de uva a vino de 0,695). Se recuerda que un moyo de mosto son 256 litros o 16 cántaras. En el caso que nos ocupa la carga de uva ha resultado de 86,63 kg cada una. En los datos apuntados hemos optado por utilizar las cargas de uva antes de ser diezmadas para reflejar más certeramente la cosecha obtenida aun cuando las cántaras de vino para vender son menores. Con todo, como se desprende de la fuente consultada, de las 1.483,5 cántaras se restan "tres moyos y onze cantaras de chorra para la vevida de los obreros, que hazen cinquenta y nuebe cantaras...". 
Cuadro 27. Labores, jornales y precios pagados por el Hospital de la Resurrección, Serrada. Superficie: 87 aranzadas de viñedo, año $1780^{592}$. En rs

\begin{tabular}{|c|c|c|c|c|c|c|c|c|c|}
\hline \multirow[b]{2}{*}{ Mes } & \multirow[b]{2}{*}{ Semana } & \multicolumn{2}{|c|}{ Obreros de poda } & \multicolumn{2}{|c|}{ Obreros azadón } & \multicolumn{2}{|c|}{ Excavo destajo } & \multicolumn{2}{|c|}{ Cobijo y recobijo } \\
\hline & & No obr. & $\mathrm{Rs} / \mathrm{mrs}$ & No obr. & $\mathrm{Rs} / \mathrm{mrs}$ & Aranz. & $\mathrm{Rs} / \mathrm{mrs}$ & Aranz. & $\mathrm{Rs} / \mathrm{mrs}$ \\
\hline \multirow[t]{4}{*}{ Enero } & $1^{\mathrm{a}}$ & 10 & 20 & 5 & 10 & - & - & - & - \\
\hline & $2^{\mathrm{a}}$ & 12 & 24 & 5 & 10 & - & - & - & - \\
\hline & $3^{\mathrm{a}}$ & 12 & 24 & 6 & 12 & - & - & - & - \\
\hline & $4^{a}$ & 11 & 22 & 5,5 & 11 & - & - & - & - \\
\hline \multirow[t]{4}{*}{ Febrero } & $1^{\mathrm{a}}$ & 6 & 14 & 2 & 4 & - & - & - & - \\
\hline & $2^{\mathrm{a}}$ & 11 & 27,17 & 5 & 10 & - & - & - & - \\
\hline & $3^{\mathrm{a}}$ & 11 & 17 & 5 & 10 & - & - & - & - \\
\hline & $4^{\mathrm{a}}$ & 12 & 30 & 6 & 12 & - & - & - & - \\
\hline \multirow[t]{4}{*}{ Marzo } & $1^{\mathrm{a}}$ & 12 & 30 & 6 & 12 & - & - & - & - \\
\hline & $2^{\mathrm{a}}$ & 5 & 12,17 & 6 & 12 & - & - & - & - \\
\hline & $3^{a}$ & 4 & 10 & - & - & - & - & - & - \\
\hline & $4^{\mathrm{a}}$ & - & - & 3 & 6 & - & - & 87,5 & 196,75 \\
\hline \multirow[t]{4}{*}{ Abril } & $1^{\mathrm{a}}$ & - & - & - & - & - & - & - & - \\
\hline & $2^{a}$ & - & - & - & - & - & - & - & - \\
\hline & $3^{\mathrm{a}}$ & - & - & 6 & 12 & - & - & - & - \\
\hline & $4^{a}$ & - & - & 8 & 16 & - & - & - & - \\
\hline \multirow[t]{4}{*}{ Mayo } & $1^{\mathrm{a}}$ & - & - & 11 & 22 & - & - & - & \\
\hline & $2^{a}$ & - & - & 7 & 14 & - & - & - & - \\
\hline & $3^{\mathrm{a}}$ & - & - & 14 & 28 & - & - & - & - \\
\hline & $4^{a}$ & - & - & 10 & 20 & - & - & - & - \\
\hline \multirow[t]{4}{*}{ Junio } & $1^{\mathrm{a}}$ & - & - & 11,5 & 23 & - & - & - & - \\
\hline & $2^{a}$ & - & - & 8 & 16 & - & - & - & - \\
\hline & $3^{\mathrm{a}}$ & - & - & 12 & 24 & - & - & - & - \\
\hline & $4^{a}$ & - & - & 3 & 6 & - & - & - & - \\
\hline Julio & & - & - & - & - & - & - & - & - \\
\hline Agosto & & - & - & - & - & - & - & - & - \\
\hline Septiembre & & - & - & - & - & - & - & - & - \\
\hline Octubre & & - & - & - & - & - & - & - & - \\
\hline \multirow[t]{4}{*}{ Noviembre } & $1^{\mathrm{a}}$ & - & - & 8 & 16 & - & - & - & - \\
\hline & $2^{a}$ & - & - & 10 & 20 & - & - & - & - \\
\hline & $3^{\mathrm{a}}$ & - & - & 11 & 22 & - & - & - & - \\
\hline & $4^{\mathrm{a}}$ & - & - & 9,5 & 19 & - & - & - & - \\
\hline \multirow[t]{4}{*}{ Diciembre } & $1^{\mathrm{a}}$ & - & - & - & - & - & - & - & - \\
\hline & $2^{a}$ & - & - & - & - & - & - & - & - \\
\hline & $3^{a}$ & - & - & - & - & - & - & - & - \\
\hline & $4^{\mathrm{a}}$ & - & - & - & - & 87,5 & 196,75 & - & - \\
\hline TOTAL & & 106 & 241,5 & 183,5 & 367 & 87,5 & 196,75 & 87,5 & 196,75 \\
\hline
\end{tabular}

Resumen de las labores y gastos en la casa de Hospital de la Resurrección, Serrada, 1780

\begin{tabular}{llr}
\hline Labores anteriores & Poda, azadón, excavo, covijo y recobijo. 464,5 obreros & 1.002 \\
\hline Arado & Tres vueltas a 87 aranzadas a 3 rs \\
& 30 aranzadas aradas a cuatro por cuatro, 90 reales & 1.654 \\
\hline Vendimia y lagares & 193 obreros en 7 días, 403,5 rs \\
& $\begin{array}{l}18,5 \text { jornales de trotadores, } 55,5 \text { rs } \\
75 \text { jornales de caballerías, } 225 \text { rs } \\
\text { Gastos de lagares: 486 }\end{array}$ & 1.180 \\
\hline Cachicán y tributos & 1.579 & 5.415 \\
\hline TOTAL GASTOS & & 19.254 \\
\hline INGRESOS & 1483,5 cántaras para la venta. Venta de vino y vinagre & 13.834 \\
\hline INGRESOS NETOS & &
\end{tabular}

Fuente: Hospital de la Resurrección, A.H.P.V. Elaboración propia.

${ }^{592}$ A.H.P.V. Hospital de la Resurrección, cajas 42 y 46, fol. 7. 


\section{c. El incremento de productividad por el aumento del vińedo de primera calidad}

Si en las tierras de sembradura determinar medias y establecer pautas generales es muy arriesgado, en el caso de los majuelos, por la multitud de variables y cuidados que lleva la cepa, es equivocarse a buen seguro. No obstante, a tenor de lo que manifiestan unos y otros pueblos, se puede constatar que, al igual que sucede con las tierras de sembradura, en el vińedo la superficie de primera calidad es reducida, tanto al norte como al sur de la Tierra, no superando en ningún caso el $25 \%$. Las aranzadas restantes se reparten entre la segunda y tercera calidad sin grandes diferencias. Nuevamente se deben anotar los dispares rendimientos obtenidos en unas y en otras pues, si se comparan con los cereales, se acrecientan en el caso del mosto. La media de la aranzada de primera calidad en las terrazas del norte produce 26,5 cántaras; la de segunda 16,75 y la de tercera 9,5 cántaras, siendo la media global del espacio que estudiamos 20, 14 y 8 cántaras, respectivamente, para las tierras de primera, segunda y tercera calidad.

Cuadro 28. Calidad del vińedo en el norte de Tierra de Medina. Año 1752

(Rueda, La Seca, Serrada y Villanueva de Duero).

\begin{tabular}{lrcrcrrr}
\hline & $\begin{array}{r}\text { Primera } \\
\text { calidad }\end{array}$ & $\%$ & $\begin{array}{r}\text { Segunda } \\
\text { calidad }\end{array}$ & $\%$ & $\begin{array}{r}\text { Tercera } \\
\text { calidad }\end{array}$ & $\%$ & TOTAL \\
\hline Rueda & 1.188 & 26,08 & 1.658 & 36,40 & 1.708 & 37,50 & 4.554 \\
La Seca & 750 & 20,00 & 975 & 26,00 & 2.025 & 54,00 & 3.750 \\
Serrada & 340 & 20,48 & 825 & 49,69 & 495 & 29,81 & 1.660 \\
\hline TOTAL & 2.278 & 22,86 & 3.458 & 34,70 & 4.228 & 42,43 & 9.964 \\
\hline
\end{tabular}

Fuente: Catastro del Marqués de la Ensenada. Respuestas Generales. 1752. A.G.S.

Libros correspondientes a los municipios relacionados. Elaboración propia.

Cuadro 29. Calidad del viñedo en el sur de Tierra de Medina. Año 1752

(Rubí, Fuentelsol, Lomoviejo, Cervillego, Gomeznarro y San Vicente).

\begin{tabular}{lrcrcrcr}
\hline & $\begin{array}{r}\text { Primera } \\
\text { calidad }\end{array}$ & $\%$ & $\begin{array}{r}\text { Segunda } \\
\text { calidad }\end{array}$ & $\%$ & $\begin{array}{r}\text { Tercera } \\
\text { calidad }\end{array}$ & $\%$ & TOTAL \\
\hline Rubí & 80 & 22,85 & 120 & 34,28 & 150 & 42,85 & 350 \\
Fuentelsol & 52 & 40,9 & 30 & 23,62 & 45 & 35,43 & 127 \\
Lomoviejo & 60 & 30 & 70 & 35 & 70 & 35 & 200 \\
Cervillego & 15 & 8,82 & 65 & 38,23 & 90 & 52,94 & 170 \\
Gomeznarro & 0 & 0 & 30 & 100 & 0 & 0 & 30 \\
San Vicente & 0 & 0 & 90 & 100 & 0 & 0 & 90 \\
\hline TOTAL & 207 & 21,40 & 405 & 41,88 & 355 & 36,71 & 967 \\
\hline
\end{tabular}

Fuente: Catastro del Marqués de la Ensenada. Respuestas Generales. 1752. A.G.S.

Libros correspondientes a los municipios relacionados. Elaboración propia.

Son diferencias muy notables, pues en muchas ocasiones las de segunda calidad producen la mitad que las de primera y las de tercera, tan sólo un tercio. A finales del XVI, en aranzadas de mediana calidad, es común el criterio que producen, un ańo con otro, un moyo por aranzada (16 cántaras). Como se ve en los cuadros adjuntos, 16 cántaras es la producción media de los viñedos de segunda calidad en La Seca y Rueda, toda vez que los rendimientos son similares en ambos siglos. 
Cuadro 30. Producción por aranzada y precios por cántara en Tierra de Medina. Año 1752

\begin{tabular}{lcccc}
\hline & \multicolumn{3}{c}{ Calidad de la Tierra } & Precio Cántara \\
\cline { 2 - 4 } Términos & Primera calidad & Segunda calidad & Tercera calidad & (Reales) \\
\hline Rueda & 30 & 16 & 12 & 4 \\
La Seca & 28 & 16 & 10 & 4 \\
Serrada & 20 & 14 & 8 & 4 \\
Villanueva de Duero & 28 & 21 & 8 & 4 \\
\hline NORTE MEDINA & 26,5 & 16,75 & 9,5 & 4 \\
\hline Rubí & 20 & 16 & 20 & 5 \\
Fuentelsol & 36 & 28 & 10 & 3 \\
Lomoviejo & 24 & 16 & 11 & 5 \\
Cervillego & 18 & 15 & - & 3 \\
Gomeznarro & 20 & - & 10,75 & 5 \\
San Vicente & 20 & - & 8,42 & 4 \\
\hline SUR DE MEDINA & 23 & 18,75 & 4,79 \\
\hline TOTAL MEDINA & 20,26 & 14 & 5 \\
\hline
\end{tabular}

Cuadro 31. Producciones de uva en La Seca, año 1752

\begin{tabular}{lcccccc}
\hline Calidad & Cargas & \multicolumn{4}{c}{ Producción por aranzada } & Poducción kg/ha \\
\cline { 3 - 5 } del vińedo & de uva & Kilogramos & Cántaras & Litros & Moyos & Product \\
\hline Primera calidad & 7 & 644 & 28 & 448 & 1,75 & 1.739 \\
Segunda calidad & 4 & 368 & 16 & 256 & 1 & 963 \\
Tercera calidad & 3,5 & 230 & 10 & 160 & 0,89 & 602 \\
\hline
\end{tabular}

Fuente: Catastro del Marqués de la Ensenada. Respuestas Generales. 1752. A.G.S.

Libros correspondientes a los municipios relacionados. Elaboración propia.

En el norte de la Tierra, pues, el incremento de productividad es generado por las aranzadas de primera, más numerosas que en siglos pasados, dado que la especialización vitícola de estos pueblos los lleva a plantar de majuelos tierras trigueras de buena calidad. En el cuadro adjunto y tomando a La Seca como ejemplo, pueden analizarse en detalle estas producciones y sus equivalencias ${ }^{593}$.

\section{- Ejemplos de rendimientos en explotaciones vitícolas al norte de Medina}

Como avance del análisis que se hará de distintas explotaciones, en lo que respecta al rendimiento del viñedo en explotaciones reales, vuelve a constatarse su diversidad, atendiendo a las diferentes campañas analizadas. Sin embargo, se aprecian unos rendimientos en explotaciones vitícolas bien atendidas y capitalizadas, que pueden llegar a 1,5 moyos por aranzada (552 kg de uva por aranzada/1.445 kg

\footnotetext{
${ }^{593}$ Se recuerda, tal como se anotaba en el siglo XVI, que de cada cuatro cargas de uva se obtiene un moyo de mosto. Un moyo equivale a dieciséis cántaras y, a 16 litros cada una, suman 256 litros. Siguiendo la costumbre en las elaboraciones de que cada dos arrobas $(11,5 \mathrm{~kg}$ ) sale una cántara (de $23 \mathrm{~kg}$ de uva se obtienen 16 litros, con un rendimiento de 0,69), se viene a determinar que una carga de uvas pesa, en su equivalencia en el sistema métrico decimal, $92 \mathrm{~kg}$. La producción por ha se ha calculado estimando que en una obrada (0,5659 ha) se planta aranzada y media (aranzadas de 420 cepas plantadas a once pies de hueco de cepa a cepa (a $27 \mathrm{~cm}$ el pie son $297 \mathrm{~cm}$ de distancia de cepa a cepa), por lo que una hectárea puede albergar 1.100 cepas.

En este sentido, por la claridad en sus equivalencias, conviene anotar que algunos pueblos, como Bobadilla, que declara recoger por aranzada 10 cántaras en las de primera calidad, 7 en las de segunda y 5 en las de tercera, regula cada carga a tres cántaras y media, en vez de a cuatro. Es interesante su respuesta en relación a estas medidas: “...cada aranzada de viña de buena calidad que se comprende en media obrada de tierra y tiene quatrozientas zepas produze con una ordinaria cultura en cada año tres cargas de uba de dos cestos cada una para carga de carro; que en cada uno van ocho cestos. La mediana produze dos cargas en la misma conformidad y la de inferior carga y media, y cada carga la regulan a tres cantaras y media..."(AGS_CE_RG_L529_309.jpg)
} 
de uva por ha) en viñedos productivos ${ }^{594}$. Las 71 aranzadas viejas del Hospital de la Resurrección de Serrada producen 116 moyos de mosto en 1768 y 104 moyos al ańo siguiente, lo que da unos rendimientos de 1,63 y 1,43 moyos en cada uno de los años mencionados.

Los precisos apuntes de la familia González Cillero que se vienen comentando, tomando como referencia el año 1782 en el que vendimian 124,5 cargas de uva, que se aproxima a las 123 que tienen de media los 30 años de los que se disponen datos, recogen 42,5 moyos totales que, repartidos entre sus 66,5 aranzadas, obtienen una media de 11,01 moyos (371 kg por aranzada/971 kg por ha).

Distinto es el caso de Pedro de Íscar, labrador que fallece en 1743, poco tiempo después de su matrimonio, dejando constancia detallada de su hacienda. Es propietario de 20 aranzadas de las que 7,5 son nuevas plantaciones. Aun descontando su cuantía, caso de que produjeran, obtiene 0,47 moyos por aranzada en 1743 y estiman sus herederos la cosecha de 1744 en 0,55 moyos (204 kg por aranzada $/ 534 \mathrm{~kg}$ por ha). Aunque aparentemente pueden parecer muy bajas, comparándolas con las anteriores, este labrador está en la media que el Catastro de Ensenada fija para el viñedo de tercera calidad en buena parte de los pueblos; por otra parte, a tenor de los pagos en que se sitúan sus viñedos, se corresponden con este tipo de suelos.

Estos datos vienen a corroborar la idea anteriormente expuesta. Tras el análisis de las fuentes consultadas, hay que inclinarse a pensar que las medias de las explotaciones vitícolas del XVIII más capitalizadas mantienen unas producciones estimadas superiores en un 30\% a las del siglo XVI, derivadas, en el norte del espacio estudiado, del incremento de las plantaciones de viñedo en tierras consideradas para el viñedo de primera calidad y, junto a ello, de aspectos derivados del esmero en el laboreo de las cepas, en el caso de las explotaciones vitícolas más capitalizadas, de propiedad clerical y labradores hacendados.

En la granja dominica de Serrada, una de las más importantes de toda la comarca, la mayor parte de los años los rendimientos se cifran entre moyo y moyo y medio. En 1781, por ejemplo, labra 268 aranzadas obteniendo $154.560 \mathrm{~kg}$ de uva, de los que se deriva una media de 1,56 moyos por unidad. Al año siguiente, en 1782, tomado en el anterior ejemplo por ser representativo del último tercio del XVIII, esta hacienda pisa en los lagares un total de $125.120 \mathrm{~kg}$ de los que se obtienen 5.440 cántaras (340 moyos), consiguiendo una media por aranzada de 1,26 moyos.

Cuadro 32. Ejemplos representativos de rendimientos y gastos de vendimia en haciendas vitícolas en Serrada, siglo XVIII

\begin{tabular}{|c|c|c|c|c|c|c|c|c|c|}
\hline $\begin{array}{l}\text { Explotación } \\
\text { vitícola }\end{array}$ & Año & $\begin{array}{c}\mathrm{No}^{\circ} \\
\text { aranz. }\end{array}$ & $\begin{array}{l}\text { Moyos } \\
\text { /aranz }\end{array}$ & Kg/aranz. & $\mathrm{Kg} / \mathrm{ha}$ & $\begin{array}{c}\mathrm{Kg} \\
\text { vend. día }\end{array}$ & No días & $\begin{array}{c}\text { Total } \\
\text { reales/aranz. }\end{array}$ & $\begin{array}{c}\text { Coste } \\
\text { reales } \mathrm{Kg} / \mathrm{uva}\end{array}$ \\
\hline Pedro & 1743 & 12,5 & 0,47 & 172 & 452 & 212 & - & 2,72 & 0,0191 \\
\hline de Íscar & 1744 & 12,5 & 0,55 & 202 & 530 & - & - & - & - \\
\hline Hospital de & 1768 & 77 & 1,50 & 554 & 1.451 & 161 & 9 & 6,00 & 0,0169 \\
\hline la Resurrección & 1769 & 77 & 1,35 & 498 & 1.306 & 174 & 9 & 9,02 & 0,0182 \\
\hline Convento de & 1781 & 268 & 1,56 & 552 & 1.445 & 134 & - & 12,23 & 0,0212 \\
\hline San Pablo & 1782 & 268 & 1,26 & 463 & 1.214 & 151 & - & 10,73 & 0,0229 \\
\hline Familia & 1781 & 66,5 & 1,01 & 371 & 971 & 180 & 12 & 11,68 & 0,0312 \\
\hline Cillero & 1782 & 66,5 & 0,63 & 231 & 605 & 140 & 9 & 8,48 & 0,0360 \\
\hline $\begin{array}{l}\text { Casa de la } \\
\text { Encarnación }\end{array}$ & 1790 & 118 & 0,77 & 285 & 641 & - & 14 & 13,68 & 0,0482 \\
\hline MEDIA & & 106 & 1,03 & 379 & 982 & 169 & 10,6 & 9,56 & 0,0267 \\
\hline
\end{tabular}

Fuente: Protocolos Notariales, A.H.P.V., Clero, A.H.N. y Archivo familia Muelas. Elaboración propia.

${ }^{594}$ Las haciendas analizadas que se detallarán más adelante, al tratar el análisis de explotaciones reales, son las del Hospital de la Resurrección (A.H.P.V., caja 47); la granja dominica de Serrada (A.H.N. Clero Secular y Regular, Libro 17351), los apuntes familiares de González Cillero ("A P.Q.M.: Libro de Cuentas y Razones que boy llevando de las cosas que se me ocurren y lavores de las viñas, 1771-1801", fol. s/n) y el inventario dejado a la muerte de Pedro de Íscar en 1743 (A.H.P.V. Pt. 8216, fol. 1 y ss.).

595 En este caso, los datos de vendimia y jornales corresponden a 1790, pero los datos de producción son de 1808. En los datos del coste reales $/ \mathrm{kg}$ de uva están incluidos los gastos de trota de la uva al lagar. 
Cuadro 33. Cosecha obtenida en un viñedo viejo y nuevo de igual cabida del Hospital de la Resurrección en Serrada, años 1762-1771

\begin{tabular}{lrrrrrrrrrr}
\hline \multicolumn{10}{c}{ En cargas de uva. Superficie: 6 aranzadas } \\
\hline Nombre del pago & 1762 & 1763 & 1764 & 1766 & 1767 & 1768 & 1769 & 1770 & 1771 & Media \\
\hline El Ciego & 31 & 22 & 32 & 29 & 41 & 37 & 32 & 26 & 27 & 30,77 \\
El Nuevo & 5 & 4 & 6 & 4 & 6 & 5 & 6 & 6 & 3 & 5,00 \\
\hline
\end{tabular}

Fuente: Libro del Hospital de la Resurrección. A.H.P.V. Elaboración propia.

Cuadro 34. Equivalencias y medias de cosecha en los viñedos de El Ciego y El Nuevo Hospital de la Resurrección en Serrada, años 1762-1771 196

\begin{tabular}{|c|c|c|c|c|c|c|}
\hline \multicolumn{7}{|c|}{ En cargas y moyos de uva. Superficie: 6 aranzadas } \\
\hline Años & Pagos & Cargas & Moyos/aranz. & Kg/aranz. & $\mathrm{Kg} / \mathrm{ha}$ & $\mathrm{Kg} /$ сера \\
\hline \multirow[t]{2}{*}{1762} & El Ciego & 31 & 1,26 & 465 & 1.217 & 1,10 \\
\hline & El Nuevo & - & - & - & - & - \\
\hline \multirow[t]{2}{*}{1763} & El Ciego & 22 & 0,89 & 330 & 864 & 0,78 \\
\hline & El Nuevo & - & - & - & - & - \\
\hline \multirow[t]{2}{*}{1764} & El Ciego & 32 & 1,30 & 480 & & 1,14 \\
\hline & El Nuevo & - & - & - & - & - \\
\hline \multirow[t]{2}{*}{1766} & El Ciego & 29 & 1,18 & 435 & 1.139 & 1,03 \\
\hline & El Nuevo & 4 & 0,16 & 61 & 160 & 0,14 \\
\hline \multirow[t]{2}{*}{1767} & El Ciego & 41 & 1,66 & 615 & 1.610 & 1,46 \\
\hline & El Nuevo & 3 & 0,12 & 46 & 120 & 0,10 \\
\hline \multirow[t]{2}{*}{1768} & El Ciego & 37 & 1,50 & 555 & 1.453 & 1,32 \\
\hline & El Nuevo & 8 & 0,33 & 122 & 321 & 0,29 \\
\hline \multirow[t]{2}{*}{1769} & El Ciego & 32 & 1,30 & 480 & & 1,14 \\
\hline & El Nuevo & 5 & 0,20 & 76 & 200 & 0,18 \\
\hline \multirow[t]{2}{*}{1770} & El Ciego & 26 & 1,05 & 390 & 1.021 & 0,92 \\
\hline & El Nuevo & 11 & 0,45 & 169 & 441 & 0,40 \\
\hline \multirow[t]{2}{*}{1771} & El Ciego & 27 & 1,09 & 405 & 1.060 & 0,96 \\
\hline & El Nuevo & 11 & 0,45 & 168 & 441 & 0,40 \\
\hline MEDIO & El Ciego & 30,77 & 1,25 & 461 & 1.208 & 1,09 \\
\hline VALOR & El Nuevo & 7,00 & 0,29 & 107 & 281 & 0,25 \\
\hline
\end{tabular}

Fuente: Libro del Hospital de la Resurrección. A.H.P.V. Elaboración propia.

Un hecho que puede hacer variar notablemente los rendimientos medios es la existencia o no de majuelos nuevos. El que se toma como ejemplo en el cuadro adjunto fue plantado sobre uno arrancado previamente. A pesar de ello, en el siglo XVIII el vińedo tarda en producir y en ser rentable una década en muchos casos. Piénsese que "el majuelo nuevo" produce al décimo año de su plantación $168 \mathrm{~kg}$ de uva por aranzada (0,45 moyos/ aranzada o $441 \mathrm{~kg} / \mathrm{ha})$, frente al vińedo en plena producción de "El Ciego", que tiene una producción media de $461 \mathrm{~kg}$ de uva por aranzada (1,09 moyos o $1.208 \mathrm{~kg} / \mathrm{ha}$ ). Son estas cifras medias, con la variabilidad de las cosechas, las que acercan a la verdadera dimensión de la producción de las explotaciones.

Aunque son datos menores y varían atendiendo a múltiples factores, ha parecido interesante incluir en los cuadros anteriores los kg de uva cortados, como media por vendimiador y día, que os-

596 A.H.P.V. Hospital de la Resurrección, caja 3, leg. 55-81, cajas 18,42,47. En este ejemplo hemos optado por valorar la carga de uva en $90 \mathrm{~kg}$ y en 1.100 el no de cepas por hectárea a marco real. La aranzada, en estas villas, tiene 420 cepas. 
cilan, unos ańos con otros dependiendo de la producción, entre los 161 y $174 \mathrm{~kg}$ por vendimiador contratado en el Hospital de la Resurrección, los 115 y 159 kg de la Familia Cillero y los 134 y 151 $\mathrm{kg}$ de uva cortados en los años 1781 y 1782, en la hacienda dominica de Serrada. Los $169 \mathrm{~kg}$ de media por vendimiador y día que refleja el cuadro anterior se entienden como representativos en este siglo. Menor importancia se concede a las medias de reales por aranzada y kilo de uva, pues en este campo las cifras varían atendiendo a la mayor o menor contratación de huebras para la trota de la uva al lagar, dependiendo del ganado de labor y mano de obra disponible en cada hacienda, como se vio al analizar la vendimia.

\section{d. La elaboración del vino. Producciones y mercados a mediados del siglo}

El éxito en la fermentación del mosto es la suma de un conjunto de factores que se inician meses antes de la vendimia. Tan importante es la uva como las tareas que comienzan en el lagar y siguen en la bodega. No obstante, a la luz de lo investigado, se cree que se ha perfeccionado y avanzado en la elaboración, respecto a siglos anteriores, especialmente en las haciendas vitícolas más pujantes. Analicemos los factores que intervienen en el proceso.

\section{- La bodega. La preparación y limpieza de lagares y cubas.}

Una de las preocupaciones que se observa en este siglo es la preparación cuidadosa del lagar y de las cubas en los meses anteriores a la vendimia. Las grandes haciendas los mejoran y amplían a la par que sus aranzadas de viñedos. Sus propietarios son medianos y grandes labradores. La práctica de arrendamientos es frecuente. Lo mismo puede decirse respecto a los lagares de viga y piedra, compartidos en vendimia por arriendo, vínculos familiares o dependencia económica. En el caso de San Martín del Monte, por ejemplo, la existencia de un único lagar, en la calle del mismo nombre, es compartido en propiedad, conjuntamente con su bodega, por Beatriz García y Francisco García:

"Un lagar, situado en la calle que llaman del Lagar, en esta villa de San Martín del Monte, que goza la referida Francisca García....Se compone de piedra, biga, pila y demás pertrechos necesarios...

Tiene en bodega situada en la calle que llaman del Lagar, que a la entrada tiene un corral, cinco cubas que hazen todas treinta y nuebe moyos, de a diez y seis cántaras cada uno, cuia mitad pertenece a la referida Francisca Garzía...”.

Como se verá en detalle en los apartados correspondientes a la vida cotidiana de Serrada, la expansión vitícola está directamente relacionada con estas construcciones que han de tenerse en cuenta en la expansión del casco urbano. Uno es el conocido como "lagar del Obispo", por pertenecer a finales de siglo al obispo Buenaventura Moyano, una vez adquirido por su familia en el siglo XVIII al marqués de Torreblanca, señor de la villa y del que se cuenta con una precisa descripción ${ }^{597}$ :

"Un lagar de viga con sus maderas y todo lo necesario para su servicio, incluso un conducto y cañones de ojalata para llebar desde la Pila el mosto a las cubas; un cubierto además, que tendrá de largo cien pies, en donde hay dos entradas para dicho lagar y la bodega, y además ésta, que se compone de un cañón sólo con nueve cubas de a diez y seis todas, enarcadas de yerro, su escalera, quatro zarzeras, y en una, que es la que enfrenta con la puerta de la Iglesia un pozo, que sirve para dicha bodega y lagar. El dicho cañón de bodega y la escalera es todo bosqueado de fábrica de cal y ladrillo a la mayor seguridad. Se tasa todo lo dicho, uno con otro alzadamente en veinte y quatro mil reales."

${ }^{597}$ A.H.P.V. Pt.8228, año 1801, fol. 61 y ss. 
Otro ejemplo, en este caso eclesiástico, es la casa conventual de San Pablo, que inicia su andadura en 1657, aumenta su bodega a lo largo del XVIII y llega a tener hasta cuatro lagares de piedra. Las obras son una constante década tras década ${ }^{598}$. En 1798, encierra una cosecha de 360 moyos (132.480 kg de 268 aranzadas a 1,34 moyos cada una) y realiza su enésima mejora. Al margen de las "reparaciones en el colgadizo que cubre la bodega" se colocan "quatro piedras, las dos para los pilones $y$ las dos para donde vierte el mosto"399.

La utilización de la piedra en los lagares es una inversión costosa, pero evita que el mosto entre en contacto con tierras o superficies que le transmitan olores y sabores desagradables. En este caso, tanto el suelo del lagar como los pilones donde se recoge el mosto procedente de la prensa, son de este material, fruto de las mejoras realizadas. En 1771, por ejemplo, se gastan 189 reales "para baldosas, para un lagar que se embaldosó". La utilización de la piedra para la fábrica del pilón es menos frecuente ${ }^{600}$. Cillero para preparar la vendimia de 1772 "compuso el Pilón con una capa de cal y arena y un betún de cal y arena y moços de erreros echos polvo oy dia 14 de julio de 1772" pero al lavarle en la vendimia se pasa el agua a una bodega vecina y tiene que impermeabilizarle "gastando primeramente dos cargas de cal, mas 22 cargas de cantos y arena... 'ro1. Como se ha visto, algunos lagares están conectados mediante conductos a sus bodegas para verter el mosto y que llegue a las cubas, facilitando el trabajo de los coritos. Como en el caso anterior, pueden ser de piedra, latón o "aguamaniles de metal del príncipe para los conductos del mosto a cuarenta y ocho reales cada uno", pero esto son lujos de las haciendas más pudientes ${ }^{602}$.

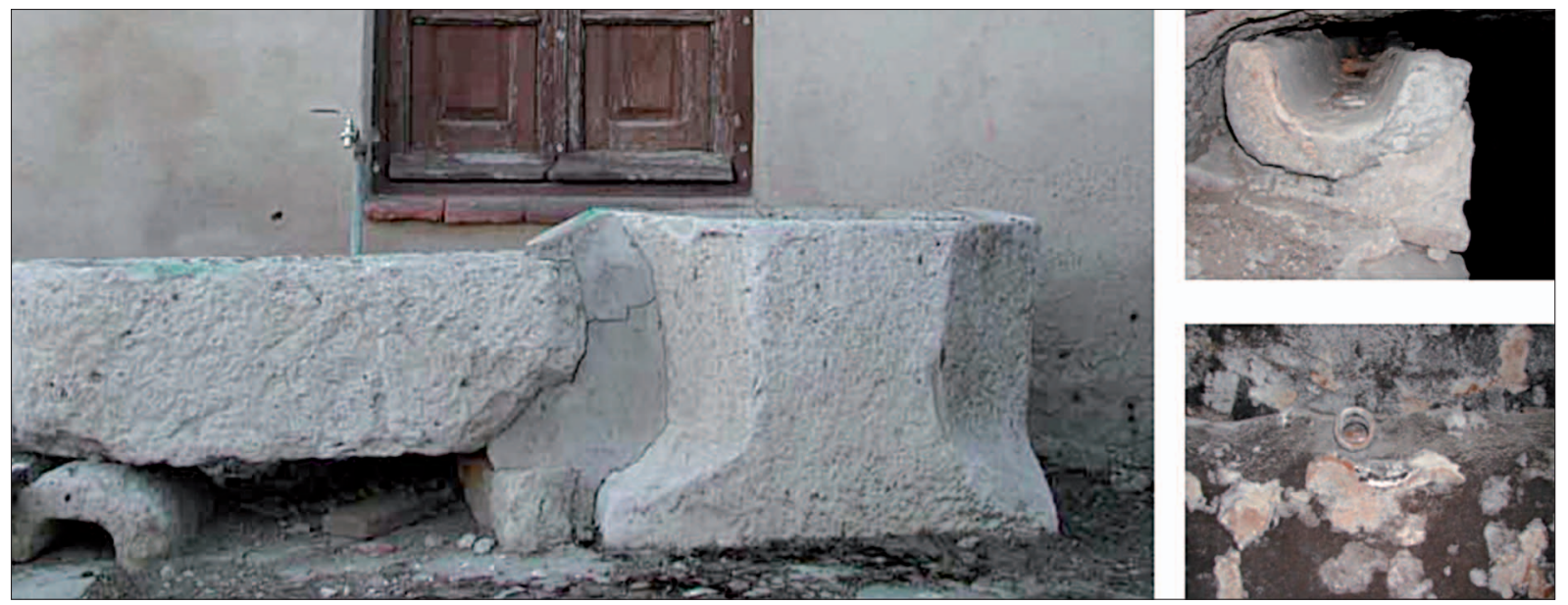

Imagen 54. Brocal del poz, pila de piedra (izquierda) y canaletas en el interior de la bodega. Casa del Hospital de la Resurrección, Serrada, siglo XVIII. Fotos: julio de 2005. La piedra es utilizada en las haciendas más capitalizadas, sean de laicos o religiosos, dado su elevado costo, pese a ser conocido por todos que el mosto no debe entrar en contacto con tierras o materiales menos nobles, que transfieren al vino malos sabores u olores. El piso del lagar, de los pilones en que se vierte el mosto y las canaletas de conducción por el interior de las bodegas, caso de poder económicamente, se construían en piedra.

${ }^{598}$ La construcción y picado de bodegas se ha tratado en anteriores siglos, pero tan importante es su cava como la cimbra mediante bóveda de ladrillo y cal para su mantenimiento y conservación, pues, de lo contrario, pueden arruinarse, especialmente cuando se excavan en terrenos poco compactos. En 1771 la bodega del convento de San Pablo, tomada como ejemplo, invierte 2.622 reales en estas operaciones y cimbra "33 pies y mo de Bóveda a 28 rs el Pie" (A.H.N. Clero Secular y Regular, Libro 17351, fol. 41).

599 Además de lo referido se anota "embaldosar el pilon y taladrar las piedras para los conductos", hacer "650 pies de canal para el encarrado", adquirir "dos mangas de cuero" y gastar 75 jornales a tres reales para "romper la pared de la bodega". (A.H.N. Clero Secular y Regular, Libro 17351, fol. 130).

${ }^{600}$ En la mayor parte de los lagares de viga y piedra, el mosto que sale de la prensa se conduce por una canaleta de piedra hasta una pileta o pilón hecha por debajo del nivel del suelo. De allí se lleva por conductos o se envasa en pellejos para llevarlo a las cubas para que inicie la fermentación.

${ }^{601}$ A P.Q.M.: Libro de Cuentas y Razones que boy llevando..., ob. cit. s/n.

${ }^{602}$ A.H.N. Clero Secular y Regular, Libro 17351, fol. 130. 
Similares circunstancias afectan a las cubas, elemento fundamental en el tema tratado. Los cuberos las revisan y reparan antes de la vendimia, pues cualquier deficiencia puede echar a perder su contenido. Un ejemplo de estos trabajos es el que sigue ${ }^{603}$ :

"Mas seiscientos catorce reales al cubero en esta forma: 352 rs de sacar al Banco tres cubas de a 16; dos de a 14 con algunas tablas nuevas; 20 rs de apretar diez cubas; 48 de empezgar quatro cubas a 12 rs; 14 rs por empezgar un cubeto y echarle tres arcos; 42 rs de 300 mimbres para los arcos; 8 rs de 4 arcos a 2 rs; 100 rs por sacar un cubeto al banco y ponerle algunos arcos y 30 rs por hacer tres herradas para el Pozo".

Muchas cubas son viejas y la utilización de la pez, tan denostada un siglo después, se utiliza como remedio eficaz de impermeabilización, año tras año. Ser propietario de una buena cuba y tenerla a punto es una inversión notable. Una vez revisadas y reparadas, se lavan cuidadosamente. Disponer de agua es fundamental, por lo que muchas bodegas tienen un pozo que sirve tanto para su uso como para la casa y lagar.

\section{- La entrada de la uva en el lagar y el trabajo de mosteros y coritos}

Una vez vendimiada, los trotadores llevan la uva al lagar, por lo que entra en inmejorables condiciones para su pisa y prensa. Estas tareas son llevadas a cabo por los lagareros o mosteros, muchas veces forasteros, que bajan de la montańa al mando de caporales que previamente han sido contratados por los concejos locales para realizar la mostería. Recuérdese que en 1590 se analizó un contrato fechado en Valdestillas, similar al de Rueda, transcrito en las notas al pie, y fechado en $1672^{604}$. Sus salarios suelen fijarse en relación a los moyos de mosto obtenidos, aliciente al tiempo que obligación para hacer bien el trabajo. En 1768, por ejemplo, el Hospital de la Resurrección paga las siguientes cantidades ${ }^{605}$ :

"Lagareros. Mas se pagaron ziento veinte quatro rs a dos lagareros que trabaxaron la uba de esta bendimia por ciento dieciséis moios de mosto que salió della, a real cada moyo y mas ocho rs que se les dio de propina.

Coritos. Mas se pagaron cuarenta y nuebe rs y medio a los coritos por baxar a la bodega sesenta y ocho moyos de mosto, inclusos quinze rs por el coste de tres ollas que les correspondió en tres piladas".

Un año después son 104 moyos y en el pago a los coritos, como en el ejemplo anterior, se les incluye "el importe de una olla que se les da en cada pilada". Cillero, por su parte, paga por piladas prensadas en las que suele entrar la comida. En 1775 acuerda y paga a "lagareros forasteros por 10,5 pisas a 15 reales por no darles de comer, ni cosa alguna y solamente el día que desempilan, una olla”. Su trabajo consiste en pisar y prensar la uva y llevar el mosto a las cubas en las que vaya a realizar la fermentación ${ }^{606}$.

${ }^{603}$ Ibidem, fol. 133

${ }^{604}$ Un contrato de mostería, fechado en 1672, en el que un caporal se compromete a mostear la vendimia de Rueda, permite conocer con exactitud el procedimiento. Bartolomé Álvarez, vecino de la Majúa, del concejo de la Babia, en las montańas de León, acuerda con el concejo de Rueda que "... de antigua costumbre vienen del Concejo de la Babia y del concejo de Laziana, vecinos de dichos concejos y otras personas que residen en ellos todos los años a mostear a esta villa encerrando el mosto que se coge en las bodegas de ella. En conformidad de esta costumbre se tiene obligación a no faltar por tales personas y vecinos a dicha mostería teniendo entre ellos un caporal que govierne y reparta la gente en los lugares para el buen despacho de ellos... ". Ante el fallecimiento del anterior caporal Bartolomé Álvarez solicita se le admita en tal función para lo cual se obliga "con su persona y bienes de cualquier tipo competentes para hazer dicha mostería, recoger el mosto a las cubas sacándolos de los pilos, trasegar lo añejo y hacer todo lo que se acostumbra... Se obliga... de se allar con los hombres y pellejos necesarios para el dicho efecto... y además se pagará todo el mosto y vino que por su negligencia y falta de hombres se perdiese... con la obligación de todos los años ymbiar personas para el mes de agosto o primeros de septiembre de cada año a esta villa para que se de horden del número de hombres que ha de traer a la dicha mostería". A.H.N. Diversos. Concejos y ciudades. Alcaldía Mayor de Rueda, caja 101, año 1672: Nombramiento de un nuevo caporal de mosteros. Transcrito y tomado de la memoria de licenciatura de PASCUAL GETE, H.: La Tierra de Medina. Siglos XVI al XVIII. Los viñedos de la antigua Tierra de Medina, A.H.P.V., sig. 2108.

${ }^{605}$ A.H.P.V. Hospital de la Resurrección, caja 47.

${ }^{606} \mathrm{El}$ nombre de coritos y mosteros viene dado por el trabajo que realizan. Los coritos, por su actividad manejando los pellejos y pellejinas de cuero que les sirven como herramienta de trabajo para trasegar el mosto o bajarlo del pilón a las cubas. Los mosteros o lagareros, por su trabajo con la uva, el lagar y el mosto. 

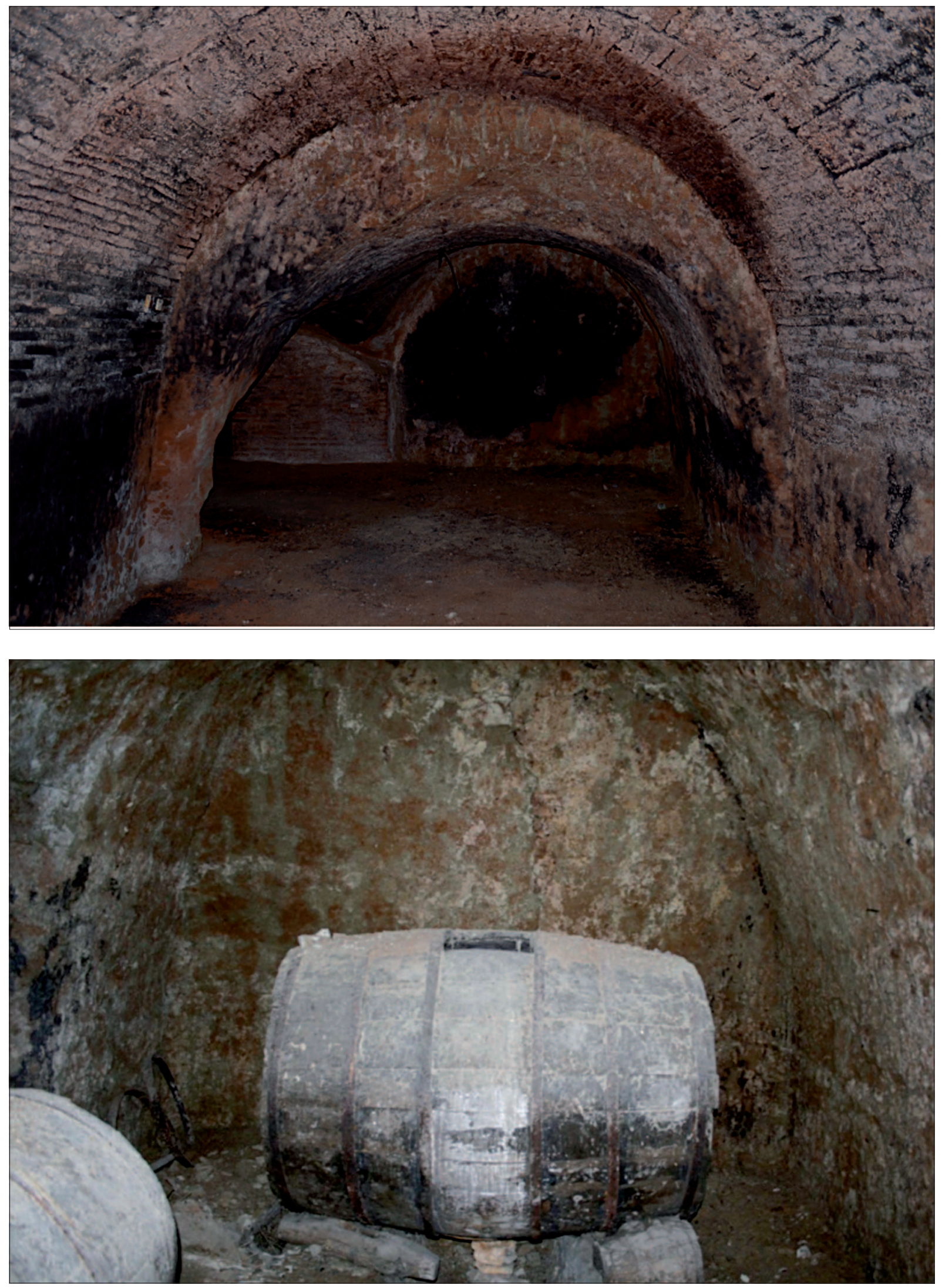

Imagen 55. Interior de bodega con cimbra parcial (Serrada, arriba, foto 25/08/2014) y sin cimbra (Rubí de Bracamonte, abajo, foto: 15/07/2008), que conserva las cubas de siglos pasados. Atendiendo a la roca en la que se excava y a las posibilidades financieras de la hacienda vitícola, las bodegas pueden cimbrarse parcial o totalmente, a fin de asegurar la construcción y evitar derrumbes. Aunque hay excepciones, en las campińas del sur, las bodegas suelen ser de dimensiones más modestas que las existentes al norte de la Tierra. Un ejemplo es la que reproducimos, sin ningún tipo de cimbra y con cubas que no rebasan las cien cántaras (1.600 litros). 
La uva se descarga desde los carros o cestos que transportan los trotadores y, a través de las ventanas o lagaretas, se tira al suelo del lagar donde se pisa. El mosto resultante se desliza por el suelo de piedra hasta la pileta donde se recoge. La pasta que queda se echa con palas de madera dentro de la base que forma la pilada, para ser prensado y extraer el mosto restante. Para ello, se forma un molde con una soga de mimbres en cuyo interior va echándose la mezcla de hollejos, pulpa y rampojos anteriores. Cuando alcanza una altura y volumen proporcionado a la dimensión de la viga y su piedra (puede albergar más de cincuenta cargas de uva $/ 4.500 \mathrm{~kg}$ ), se coloca encima un entramado de madera (marranos y gualderas) a fin de que transmitan proporcionalmente toda la presión y peso de la viga con su piedra suspendida a dicha uva, para que, por compresión, salga el mosto que permanece en dicha pasta.

Como puede comprobarse en la figura adjunta, conforme escurre el mosto entre las mimbres y deja de formar parte de la pilada, el volumen merma, por lo que debe levantarse la viga mediante el husillo de madera para poner más maderos transversales a los anteriores, a fin de que aprovechar toda la presión posible para conseguir extraer la totalidad del jugo de la uva. En las notas al pie se explica en detalle el proceso ${ }^{607}$.

La labor requiere práctica y mucha precaución, dadas las presiones que debe soportar viga, pared y pilada, al tiempo que es importante contar con las cargas de uva necesarias sin dilatarse en el tiempo para evitar el deterioro y oxidación de los mostos, cuando no su fermentación. A la luz de la documentación consultada, tiende a realizarse una pilada al día o cada dos días con la uva vendimiada. Cillero vendimia en 1774169 cargas en ocho días y las prensa en 8,5 piladas; al ańo siguiente recoge 192,5 cargas en nueve días y realiza 10 pisas, etc. Cada una de ellas, de acuerdo con la cosecha recogida, está compuesta de 19 a 20 cargas de uva. En la casa conventual del Hospital de Serrada, en cambio, la uva espera un día para formar cada pilada.

Este hecho tendrá importantes efectos en el proceso de fermentación, pues se produce una importante oxidación que facilita la fermentación, al tiempo que proporciona al futuro vino el "viso" o color dorado que tanto es alabado en estos siglos. Por el contrario, la aceleración de la transformación de las levaduras en alcohol le restará buena parte de su carga aromática, esencial, por ejemplo, en el actual proceso de elaboración.

607 "El lagar es una pieza de 60 pies (unos $16 \mathrm{~m}$ ) de larga, $20(5,5 \mathrm{~m})$ de ancha y de una altura proporcionada. En él, hay una viga de olmo gruesa de dos tercias en cuadro y de 40 a 50 pies de largo (11por 14 metros): El extremo más grueso está entre cuatro postes que llaman merinas y tiene un taladro en que se introduce de parte a parte horizontalmente un barrón de hierro que llaman lobo, cuyos extremos quedan entre las merinas para impedir que la viga, vaya atrás ni adelante, y sobre dichos postes o merinas carga una pared gruesa para contrabalancear la gran fuerza de la viga. A la otra punta tiene un husillo cuyo extremo inferior se asegura en una piedra de una vara de alto y otra de diámetro (una vara equivale a 0,836 metros). Hacia el medio de la viga se levantan hasta un tirante del techo dos postes que llaman gualderas, porque impiden que la viga se ladee a uno y otro lado. El piso del lagar está en declive hacia un pilo de cabida de 300 arrobas (unos $50 \mathrm{hl}$ ) por lo regular, cuadrado y cubierto con tablas o un enrejado de madera.

Molida, pues, la uva con una azadón o mazo largo, se forma un montón de figura de un queso debaxo de la viga y lo más inmediato que se pueda a las merinas: rodease el montón con una soga de mimbres de 22 hasta 34 pies de larga, y encima se ponen juntos tablones de cinco dedos de grueso, algo más largos que el pie o montón de uva; sobre ellos se cruzan unos maderos cuadrados y gruesos de quarta y aun tercia en cuadro, que llaman marranos, en la dirección de la viga, y sobre estos atraviesan otros tres maderos llamados puentes sobre los que descansa la viga para hacer la presión. Mientras se hace todo esto, está levantada la viga por parte del husillo, y baxa por el otro extremo, que se calza por encima para asegurarlo en aquella situación; luego se anda con el husillo en sentido contrario y hace baxar la viga hasta que queda colgada la piedra, y así se comprimen con esta fuerza de palanca de 30 a 50 cargas de uva en cada pie, y hay lagares que exprimen cada vez de 80 a 100 cargas. De cinco en cinco horas se deshace cada pie y se vuelve a formar hasta tres veces para darle otras tantas prensas. Cada carga da de 4 a 6 cántaros de mosto (de 44,5 a 96,5 litros). (A.M.D.: De la agricultura del partido de Medina del Campo (en) Semanario de Agricultura y Artes dirigido a los Párrocos". Año 1801, no 259, (tomo X), págs. 391-392. Transcrito y tomado de la memoria de licenciatura de PASCUAL GETE, H.: La Tierra de Medina. Siglos XVI al XVIII. Los viñedos de la antigua Tierra de Medina, A.H.P.V., sig. 2108). 


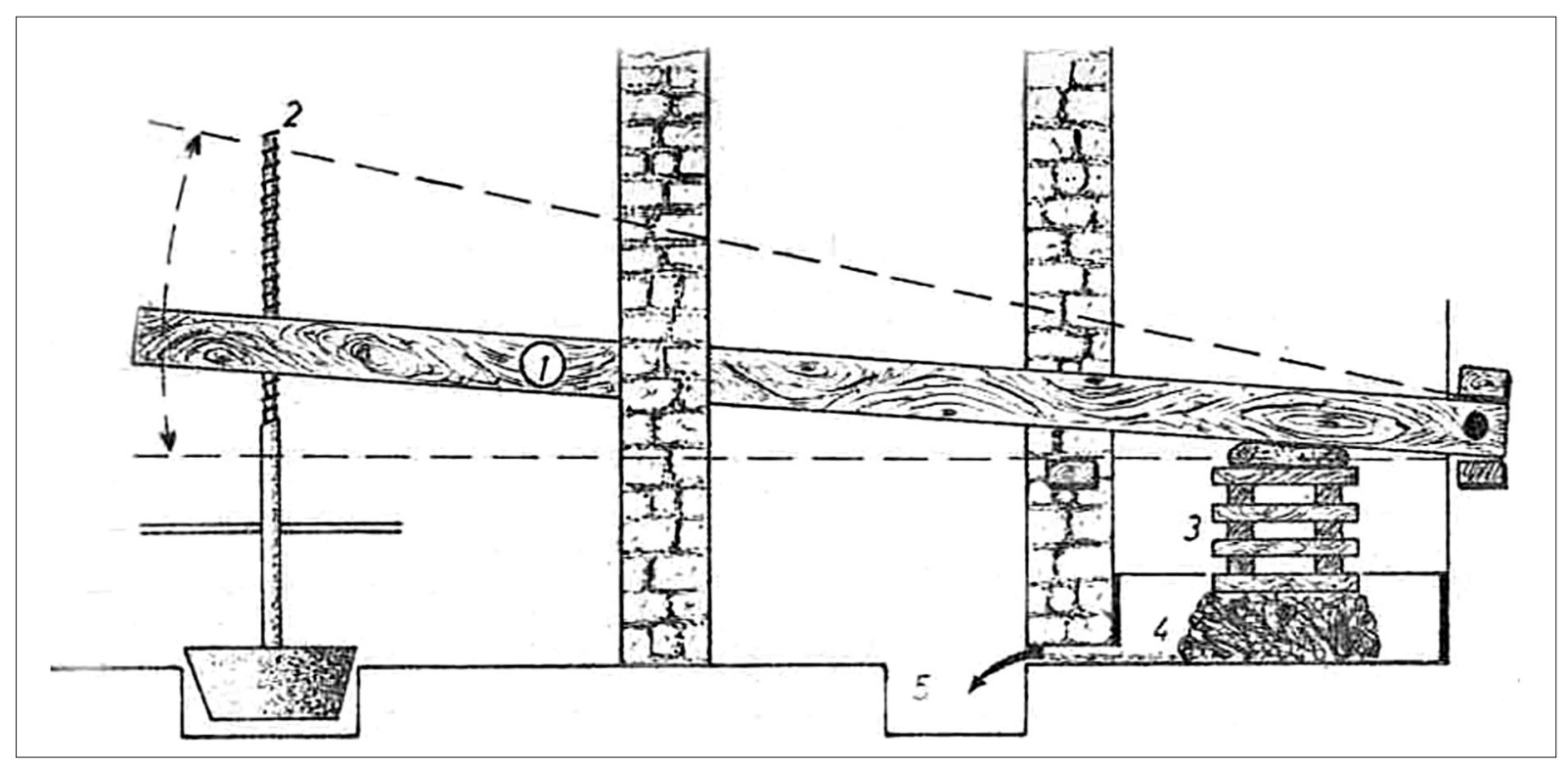

Figura 24. Esquema de un lagar de viga y piedra. 1: viga; 2: husillo con su peso; 3: castillo de madera; 4: pie; 5: pilón.

Cuadro 35. Cosecha de uva y destino del mosto en la Hacienda del Hospital de la Resurrección. Serrada, ańo 1768; comienzo vendimia: 3 de octubre

\begin{tabular}{|c|c|c|c|c|c|c|c|c|}
\hline \multirow[b]{2}{*}{ Viñedo } & \multirow[b]{2}{*}{$\begin{array}{r}\text { Cosecha } \\
\text { (cargas) }\end{array}$} & \multicolumn{2}{|c|}{ Piladas y fecha } & \multicolumn{2}{|c|}{ Cargas y mosto obtenido } & \multicolumn{3}{|c|}{ Destino (cántaras) } \\
\hline & & $\begin{array}{l}\text { No de } \\
\text { pilada }\end{array}$ & Fecha & $\begin{array}{l}\text { Cargas } \\
\text { echadas }\end{array}$ & $\begin{array}{l}\text { Cántaras } \\
\text { obtenidas }\end{array}$ & $\begin{array}{l}\text { A cubas en } \\
\text { Valladolid }\end{array}$ & $\begin{array}{l}\text { A cubas } \\
\text { en Serrada }\end{array}$ & $\begin{array}{c}\text { A cubeto } \\
\text { para labores }\end{array}$ \\
\hline Las Cuestas & 46 & Primera & 6 de octubre & 65 & 276 & 227 & 21,5 & 27,5 \\
\hline El Monte & 78 & & & & & & & \\
\hline La Horca & 14 & Segunda & 8 de octubre & 103 & 352 & 224 & 100,5 & 27,5 \\
\hline La Olma & 10 & & & & & & & \\
\hline El de Matilde & 12 & & & & & & & \\
\hline El Nuevo & 8 & & & & & & & \\
\hline Las Carretas & 21 & Tercera & 10 de octubre & 83 & 336 & 310 & - & 26 \\
\hline El de Vidal & 22 & & & & & & & \\
\hline Montaña & 15 & & & & & & & \\
\hline El de Joaquín & 11 & & & & & & & \\
\hline Matilde y Matías & 8 & & & & & & & \\
\hline Eugenia al Pinar & 17 & Cuarta & 12 de octubre & 83 & 304 & - & 288 & 16 \\
\hline Morena & 16 & & & & & & & \\
\hline El de Castro al Pinar & 31 & & & & & & & \\
\hline Camino Ventosa & 22 & & & & & & & \\
\hline Las Cuartas & 53 & Quinta & 14 de octubre & 77 & 308 & & 296 & 12 \\
\hline El Ciego & 37 & & & & & & & \\
\hline Sigue el de Vidal & 64 & Sexta & 16 de octubre & 80 & 273 & & 256 & 17 \\
\hline El de Farruco & 5 & & & & & & & \\
\hline El de Villanueva & 15 & & & & & & & \\
\hline Total & 505 & & & 491 & 1.849 & 761 & 962 & 126 \\
\hline Diezmo & 50 & & & & & & & \\
\hline Uva comprada & 14 & & & & & & & \\
\hline
\end{tabular}

Fuente: Libro del Hospital de la Resurrección. A.H.P.V. Elaboración propia. 
Extraído el mosto, se baja la viga con el husillo la piedra y se desmonta el castillete de madera para picar y retirar fuera del lagar los restos prensados. Antes de ello, sin embargo, hay constancia en este siglo de una operación que continuará en los siguientes y es echar el agua de lavar el piso del lagar sobre la pilada y dar un último prensado a fin de obtener un mosto aguado que recibe el nombre de chorra o aguapiée08:

"Lagareros. Siete pisas y un repiso y hacer un poco de aguapié que se compuso otra pisa, que son ocho a nuebe reales pisa; cinco reales de labar cinco cubas y cuatro de lavar el lagar. Todo ochenta y uno".

Los restos, denominados orujos, se aprovechan por destilación para elaborar aguardiente, aunque en el siglo XVIII sólo constan operaciones de destilación en las grandes bodegas, como la de San Pablo mencionada, que anota en 1794 "novecientos quarenta reales de ventisiete cántaras de aguardiente, las 25 a 34 rs y las dos a 35 rs" $"$ ". A ella llevan el orujo otros productores para su destilación y es este ramo, el de vinos y aguardientes, el más importante de los que salen a remate anual en estos pueblos vitícolas del norte de Medina.

\section{- La fermentación del mosto y la composición de los vinos}

A diferencia del siglo XIX en que proliferan tratados y cartillas de viticultura, en este siglo XVIII los apuntes sobre el proceso de fermentación siguen siendo escasos. El proceso se inicia y termina en las cubas en que los coritos han echado el mosto. Como estudiamos en el siglo XVI, la capacidad de estos bastos de madera varía atendiendo a la bodega y dimensiones de la hacienda. Una cuba de catorce palmos, frecuente en este siglo, contiene en torno a 24 moyos (384 cántaras o 6.144 litros). La bodega dominica de Serrada, en sus 42 cubas, por ejemplo, tiene 345 cántaras de capacidad media. Pequeńos cosecheros encierran el mosto en cubas más pequeńas. En la imagen anterior de la bodega de Rubí la cuba tiene una capacidad de 100 cántaras.

La fermentación se inicia a las pocas horas de permanecer el mosto en ellas y el alto volumen de azúcares que contiene es una garantía para que el proceso finalice con éxito. No consta ningún tipo de desfangado del mosto, previo a la fermentación, salvo la utilización de "coladores" de los que se puede deducir una filtración grosera antes de su vertido en la cuba.

El tratamiento de los "vinos mostos" se inicia en noviembre, cuando acaba de fermentar y puede considerarse vino nuevo. El primer paso es limpiarlo de las impurezas que tiene en suspensión, utilizando sustancias adherentes que, disueltas previamente, son vertidas en la cuba. Al tiempo se las va removiendo y, conforme se decantan, arrastran por gravedad al fondo las distintas impurezas. En el siglo XVI se anotó, por ejemplo, el gasto de diez docenas de huevos para componer una cuba de diez moyos, al margen de sangrías y tierras. Cillero emplea cada año del último tercio del XVIII espejuelo "para echar en las cubas quando quieren dexar de erbir". Este producto se encuentra generalizado, a lo largo de todo el siglo, en la mayor parte de las bodegas ${ }^{610}$.

La bodega dominica estudiada como ejemplo, desde últimos de noviembre hasta el ocho de marzo de 1772, registra el gasto de los diferentes productos que utiliza para "componer los vinos". Se entiende que es el tiempo en que las bodegas clarifican, trasiegan y mejoran, mediante productos y mezclas la cosecha a fin de tenerla apta para la venta. En 1788, por ejemplo, en una cosecha de 4.664 cántaras (1,08 moyos/aranzada), gasta "quinientos ochenta y tres rs de los Aderentes para aclarar el vino"611.

${ }^{608}$ A P.Q.M.: Libro de Cuentas y Razones que boy llevando..., ob. cit. s/n

${ }^{609}$ A.H.N. Clero Secular y Regular, Libro 17351, fol. 93

${ }^{610}$ El espejuelo es un género de yeso que tiene unas costrillas relucientes y transparentes, especialmente quando les da el sol”. Sebastián de Cobarrubias. Tesoro de la Lengua Castellana”. Ed. De Martín de Riquer de la R.A.E., Barcelona, 1993.

${ }^{611}$ A.H.N. Clero Secular y Regular, Libro 17351, fol. 72. 
Un ejemplo de este gasto y productos empleados es el que sigue ${ }^{612}$ :

"Componer los vinos. Mas son data quinientos cuarenta y ocho mrs de componer los vinos en esta forma: de 31 sangrías, las seis a 16 rs y las restantes a 8,296 rs; de 300 @ de tierra de la Nava a medio real, 150 rs; de una libra de canela, 56 rs, y lo restante de azufre, anís... Mas son data setenta y dos rs de doce fanegas de espejuelo a seis rs fanega".

Estas operaciones tratan de conseguir un color dorado y, a tenor de lo investigado, caso de que no lograrlo vuelven a tratarse, generalmente, mediante sangrías y tierras, momentos previos a su venta. En las bodegas con más recursos, como la citada, se emplea, en algunas partidas, la canela y el anís para conseguir colores y sabores del gusto de consumidores más exigentes. El Hospital de la Resurrección utiliza las expresiones "dar claro y color" con el mismo fin. En 1768, gasta ochenta reales "por diez sangrias que se compraron para dar color en la benta de dichas cubas. Mas se pagaron veinte rs por la tierra y espejuelo que se gastó para dar dicho color"bıs. El 30 de abril del ańo siguiente anotan "dos sangrías de baca para dar color a otra cuba y costaron dieciséis reales" ${ }^{214}$. En 1791 en el concepto "tierras" gasta "30 @ de tierra de la Naba para dar claros..." 15.

Una vez realizado este proceso, el vino se trasiega con "pellejas" a otras, previamente bien limpias, y, al tiempo que se sellan, se desinfectan y reduce el oxígeno existente en su interior, quemando una "pajuela de azufre". El proceso de trasiego se cree generalizado en este siglo y se realiza acabada la composición del vino, previo a ser puesto en venta. Un ejemplo de estos trasiegos y mezclas se encuentra en la bodega del citado Hospital de Resurrección ${ }^{616}$ :

"Para trasegar una cuva de los dos que están envueltas con la añeja, que es la segunda de el cañón grande, que se trasegó en la cuva que esta sola en la sisa de dicho cañón, por que hizo caveza”.

Al tiempo que se realiza este proceso, los cosecheros aforan las cubas, anotan cántaras nuevas y añejas, vino vendido, desbotes y vinagres, así como los precios a que van saliendo las cántaras. Los apuntes familiares de Cillero son ilustrativos en este sentido ${ }^{617}$ :

Cuadro 36. Aforo después de vendimia en la bodega de la familia Cillero, año 1771. (En cántaras)

\begin{tabular}{|c|c|c|c|c|c|}
\hline \multicolumn{6}{|c|}{ Bodega Húmeda } \\
\hline Cubas & Hace & Hueco & Queda & Quita & Líquido \\
\hline 1 & 217 & 30 & 188 & 46 & 141 \\
\hline 2 & 194 & 29 & 165 & 41 & 124 \\
\hline 3 & 310 & 50 & 260 & 65 & 195 \\
\hline \multicolumn{6}{|c|}{ Bodega Alta } \\
\hline Cubas & Hace & Hueco & Queda & Quita & Líquido \\
\hline 1 & 178 & 27 & 151 & 37 & 114 \\
\hline 2 & 216 & 34 & 182 & 45 & 137 \\
\hline 3 & 160 & 26 & 130 & 33 & 101 \\
\hline 4 & 85 & 18 & 67 & 16 & 51 \\
\hline 5 & 418 & 51 & 367 & 91 & 276 \\
\hline 6 & 430 & 52 & 378 & 94 & 284 \\
\hline 7 & 178 & 27 & 151 & 37 & 114 \\
\hline 8 & 98 & 45 & 48 & 12 & 36 \\
\hline 9 & 108 & 13 & 95 & 28 & 72 \\
\hline
\end{tabular}

Fuente. Archivo familia Muelas. Elaboración propia.

${ }^{612}$ A.H.N. Clero Secular y Regular, Libro 17351, fol. 18. La tipografía de la grafía @ es la que por estos siglos se utiliza, de forma idéntica a la empleada en la actualidad, para referirse a la arroba, o unidad de peso (11,5 kg). Recuérdese que de dos arrobas de uva $(23 \mathrm{~kg})$ se obtiene una cántara de mosto (16 litros). 
La crisis de final de siglo, la revolución francesa y la crisis vitícola que se vive en el primer tercio del XIX, hacen decaer sobremanera estas casas de labranza. La pérdida de remtabilidad se acusa sobremanera. Muchos majuelos se arriendan o venden antes de que la Desamortización los cambie de propietario. En ocasiones las ventas refieren viñedos gramosos o descuidados de tareas, a veces, irrecuperables. En el caso que tratamos como ejemplo, el balance global de la cosecha de 1808, obtenida de 118 aranzadas de majuelos propios y labrados con las técnicas de cultivo tradicionales de aquel tiempo es el que sigue ${ }^{618}$ :

"Balance de la cosecha de 1808 . Se encerraron en este año 1.456 cántaros.

Cargo. Valor total: 1.430 cántaros. Salieron de mermas 26 cántaros.

Data. Salieron vendidas 1.185. Para el suministro de la tropa 35; se consumieron en las labores, gasto de la casa y estancia de los religiosos 110 ; quedan existentes 100 . Todo 1.430 cántaros.”.

\section{- Producciones y mercados a mediados del siglo XVIII}

El gran aumento de la producción, en la primera mitad de siglo, se debe al aumento de la superficie plantada, especialmente en las terrazas del norte de la Tierra de Medina. Desde mediados del XVIII y hasta el último tercio de centuria, se alcanzan las máximas superficies de viñedo y de producciones de vino en estas villas, desplazándose el centro de gravedad vitícola hacia el norte de la Tierra. Medina y Alaejos pierden el protagonismo que tenían, pese a seguir detentando 10.508 obradas (14.010 aranzadas). La crisis del XVII hace retroceder los viñedos meridionales al tiempo que se incrementan las roturaciones y plantaciones en las terrazas del norte. A mediados de siglo, la comarca vuelve a superar los 27.000 habitantes, para llegar, de acuerdo a la estimación del Censo de Floridablanca, a 33.000 personas en 1787. Una gran presión sobre la tierra hace que se labren terrenos marginales y se completen las roturaciones allí donde permanezcan sin ocupar. Miles de jornaleros ven en el viñedo un complemento a sus exiguos y temporales ingresos. El estimulo de los precios de los cereales y, en especial, la Pragmática del 11 de julio de 1765, que libera el comercio de granos, cambia la dinámica en las mejores tierras de Alaejos, la Nava o Medina. Viejos vińedos que lo han dado todo dejan paso a tierras de pan más rentables, especialmente cuando en el último tercio del siglo años abundantes de mosto encuentren dificultades en sus sacas ${ }^{619}$. A finales de centuria, como se vio al tratar las sernas, cuando se litiga sobre la concesión o no de permisos por parte de Medina, se advierte que "enviniendo dos o tres años abundantes no tan sólo no plantarán sino es que mucho de lo plantado se abandonara en todos los Pueblos", aunque también se dice que "lo cierto es que parece imposible se consuma tanto vino como se coge sólo en esta circunferencia, y ello es que cada año, y de algunos asta parte, bale caro y tiene buen precio"620.

${ }^{613}$ En ocasiones, se encuentran testimonios que pueden hacer pensar que el espejuelo también se echa en las uvas, al tiempo que se pisa y prensa. Un ejemplo aparece en 1790 en la bodega mencionada del Hospital de la Resurrección: “Espejuelo.Yten. 37 @ de espejuelo para la huba...”. (A.H.P.V. Hospital de Resurrección, caja 42/8

${ }^{614}$ A.H.P.V. Hospital de la Resurrección, caja 47.

${ }^{615}$ A.H.P.V. Hospital de la Resurrección, caja 42/8.

${ }^{616}$ A.H.P.V. Hospital de la Resurrección, caja 42.

${ }^{617}$ A P.Q.M.: Libro de Cuentas y Razones que boy llevando..., ob. cit. s/n.

${ }^{618}$ Ibídem.

${ }^{619}$ PASCUAL GETE, H.: “La decadencia vinícola de Medina durante los siglos XVII-XVIII”, en Historia de Medina del Campo y su Tierra..., vol. II, Valladolid, 1896, pág. 651 y ss.

${ }^{620}$ A.M.M.C. Caja 167. "Papeles varios puestos..., ob. cit., fol. 37. 
No es nuestro objetivo analizar en detalle el mercado de estos caldos ${ }^{621}$. Las montańas del norte, en especial el Principado de Asturias y las montańas de Palencia y Burgos, demandan con intensidad el producto. Campomanes lo señala en 1779 al manifestar que el vino de La Nava, La Seca y Rueda tenía "una gran saca para las montańas de Burgos y Santander" ${ }^{22}$, aunque no es poco el vino que se consume tanto en la propia comarca como en sus limítrofes. Los pueblos al sur de Medina suscriben numerosas obligaciones de venta con tratantes que abastecen las tabernas de los pueblos más al sur. Juan Martín, por ejemplo, vecino de Mamblas, en la jurisdicción de Arévalo, compra en 1730 cien cántaras de vino a Pedro de Coca, vecino de Rubí “...para el consumo de la taberna de dicho lugar” y Alonso Niño firma idéntica operación para Villaflores de Ávila, de donde es natural ${ }^{623}$.

La venta está regulada por severas normas desde el propio inicio de la vendimia. Las ordenanzas de Valladolid de 1423 o las de Medina de 1503, al norte y sur del espacio tratado, no dejan nada al azar y serán imitadas por todos los lugares y villas siglo tras siglo. Como se verá en el siguiente epígrafe, la atomización de la propiedad obliga a los pequeños propietarios, que no disponen de cubas o que tienen necesidades, a vender el producto en uvas o en mosto. Se inicia un comercio que, al igual que las vendimias, se afanan por regular las distintas villas. Un ejemplo es el que recogen las normas de buen gobierno de 1745 de Villanueva de Duero ${ }^{624}$ :

"Que respecto de que el comercio y tráfico general de esta villa, y de que pende su manutención es el de la cosecha de vino bendiendo unos en Mosto por la bendimia, y todos los vinos al trasiego después de encubados, y entre las demandas desta residencia han ocurrido contiendas entre los compradores y bendedores sobre el pago de los precios, y haberse hecho difícil la resolución de los juicios por la inzertidumbre de los precios en que han padezido y padecen los cosecheros menesterosos y los mas pobres, pues sobre bender sus vinos y mostos y entregarlos anticipadamente se hallan después sin precio zierto para la execucion del pago, y socorrer su necesidad".

Como en el resto de villas, el consumo local está perfectamente regulado:

\begin{abstract}
"Los vecinos de esta dicha villa se surten por mayor de las bodegas que hay en ella según el precio a que bende, y también lo pueden hacer por menor, cuio régimen solo se observa hasta fin de agosto o principios de septiembre que cesan en dicha venta por menor porque se pone taberna pública por el concejo y subsiste hasta fin de año".
\end{abstract}

El grueso de la cosecha se destina a un mercado en que arrieros y tratantes de mostos le dan salida. A mediados de siglo, por ejemplo, La Seca, villa de 680 vecinos (entre 2.500 y 3.000 habitantes), registra diecinueve vecinos tratantes de mosto, cincuenta y seis arrieros, siete aguardenteros, cuatro boteros y un cubero; es decir, 87 vecinos (12,7\% respecto al total) están directamente relacionados con la saca de mostos, vinos y aguardientes. No siempre las economías de cosecheros y corredores de vino estaban boyantes. El mercado y el deterioro del producto ocasionaban más de un disgusto y más de un impago, sobre todo, a partir de la segunda mitad del XVIII, cuando la decadencia progresiva de la demanda y los mercados tradicionales van haciendo mella. Es el caso rubricado el 10 de julio de 1799 en el que Matheo de Lito, vecino de la villa de La Seca, confiesa deber a Francisco Bayón, alcalde ordinario de Serrada, setecientos diez reales de vellón, derivados de una compra de 94 cántaras de vino ${ }^{625}$.

${ }^{621}$ En este sentido pueden consultarse las meritorias y citadas obras de A. Huetz de Lemps: Vignoles et vins du NordOuest... y H. Pascual Gete: La decadencia vinicola...

${ }^{622}$ A.H.N. Consejos. Leg. 675, exp. no 18: Informe de Campomanes, citado por PASCUAL GETE, H.: "La decadencia vinícola..., ob., cit., pág. 676.

${ }^{623}$ A.H.P.V. Pt. 6653, fol. 65 y 69.

${ }^{624}$ A.H.P.V. S.H., caja 83.

${ }^{625}$ A.H.P.V. Pt. 8213, fol. 10 y Pt. 8214, fol. 26. 
Cuadro 37. Destino del mosto obtenido en la casa del Hospital de la Resurrección. Serrada. Años 1762-1769

\begin{tabular}{lrrrrrrrr}
\hline Años & 1762 & 1763 & 1764 & 1765 & 1766 & 1767 & 1768 & 1769 \\
\hline Mosto que fermenta en Serrada & 760 & 209,5 & 768 & - & 521 & 1206 & 965,5 & 1076 \\
Mosto que se lleva a Valladolid & 733 & 777,5 & 488 & - & 608 & 352 & 761 & 512 \\
Mosto comprado & 128 & - & - & - & 283 & 42 & 126 & 224 \\
Mosto para las labores & 111 & 105,5 & 96 & - & 114 & 120 & 129,5 & 100 \\
\hline TOTAL & 1.732 & $1.092,5$ & 1.352 & - & 1.526 & 1.720 & 1.982 & 1.912 \\
\hline
\end{tabular}

Fuente: Fuente: Libro del Hospital de la Resurrección. A.H.P.V. Elaboración propia.

La vigilancia de las normas y usos que determinaban los trasvases son igualmente muy interesantes. Es sabido que las justicias locales fijan el precio del vino de acuerdo a la oferta y la demanda existentes en los mercados comarcales y la existencia o no de reservas no vendidas. Las tabernas públicas canalizan parte del mismo al por mayor, pero, especialmente, al por menor, y la observancia y registro de las medidas empleadas era estricta por parte de los concejos locales que, como en el caso de otros servicios, sacan anualmente a subasta la correduría del producto vendible, facilitando, de este modo, la relación entre los arrieros que bajaban de la montaña o de comarcas cercanas y los cosecheros, que atesoran en sus bodegas el principal sustento que rinden sus labranzas.

Las haciendas religiosas, en cambio, no necesitan, en tanta medida, acudir a mercados externos, pues disponen de distribución o tabernas propias. Baste citar como ejemplo el Hospital de la Resurrección de Valladolid, que dispone de haciendas en Serrada y en la Cistérniga. La bodega de Serrada surte de mosto recién pisado y de vino a lo largo del año tanto a la casa madre como a la bodega que tiene en la calle Espadería, desde la que vende directamente al público. He aquí una de las claves del éxito y pujanza de estas explotaciones: controlan a gran escala desde la cepa a la distribución en el mercado urbano con no pocos privilegios en el tejemaneje del mercado de mostos y vinos. No obstante, al final, el beneficio dependerá de la calidad del vino y de la media de los precios en las distintas sacas. Como se verá más adelante, ni todo el vino sale a buen precio ni, a pesar de su fama, todo se conserva en buenas condiciones.

\section{La reducida extensión, pero importante papel de montes y prados}

Como se ha estudiado en el anterior epígrafe, en los siglos modernos se pone fin a la mayor parte de la superficie montaraz de la comarca. Bien es cierto que parte de estos montes estaban degradados y convertidos en retamares y escobares. Si arrinconada quedó la encina en los tiempos bajomedievales, poco tendría que agradecer a estos aires modernos. La presión demográfica, la necesidad de tierras de pan y pastos y la expansión vitícola introducen la reja en la mayor parte de los montes que permanecían intactos. El siglo XVIII certifica la defunción de casi todos ellos. Permanecen únicamente sus nombres para el recuerdo, aunque concejos y particulares se siguen viendo con frecuencia en las salas de la Real Chancillería por abusos en las roturaciones, entradas indebidas del ganado y cortas abusivas por parte de los vecinos. Se acaba de relatar, en este sentido, el destino vitícola de las últimas 400 obradas del monte de los Llanos de La Moya, cuya degradación era notoria a juicio de los vecinos. Y si muchos de estos montes degradados desaparecen definitivamente, el ganado intensificará su presencia en los prados, lo que obliga a una racional explotación de estos por parte de concejos y vecinos. Analicemos estos aspectos.

\section{a. La critica situación de unos montes que dieron paso a tierras de labor}

A mediados del XVIII la realidad es que, si se exceptúan las eras, sólo el 13,97\% del espacio estudiado corresponde a tierras no labradas. De ellas, 16.488 obradas $(6.16 \%)$ se catastran como montes y pinares y 14.380 obradas $(5,37 \%)$, como prados. Se dan muchos casos en que no se catastran montes 
ni pinares, porque, aunque los hubo en abundancia, no queda ni un árbol y los que, como en Pozaldez, se plantan en virtud de la Real Orden de 1748, en vez de prosperar, se secan. La respuesta de esta villa a la sexta pregunta del Catastro se repite de forma muy semejante y elocuente en muchas villas ${ }^{626}$ :

“... que en este término no ay plantío de árvoles algunos de la calidad que expresa ni otra porque en las ocasiones que se ha hecho por la mucha secura se ha experimentado su insubsistencia...”.

De entre todas las localidades llaman la atención, sin embargo, las campiñas meridionales inmediatas a Medina. Como puede observarse en los cuadros de aprovechamiento del terrazgo, Rubí, Fuentelsol, Lomoviejo, Cervillego, Gomeznarro y San Vicente suman 21.657 obradas y catastran tan solo setenta de montes. Prados, salgüerales y baldíos de tercera calidad suman 2.499 obradas y representan, con el 11,53\% de sus términos, la mayor parte de las tierras no labradas. No es que estas villas no tuvieran superficies montaraces, sino que pasaron muy pronto a ser tierras de sembradura. Sus pagos se encuentran en manos concejiles como tierras labrantías arrendadas a los vecinos. El caso de Cervillego es un ejemplo, pues "de ser el referido término bastantemente endeble y seco no hay plantio de arboles..." en la respuesta veintitrés manifiesta que "... a este pueblo le pertenece como propio de su común el directo útil de ciento sesenta obradas labrantías, las que al presente tiene arrendadas en noventa fanegas de trigo en cada una año... '"227. En otras ocasiones, las roturas y talas acabaron en baldíos improductivos, tal como seńala Fresno. De sus 12.500 huebras de tierra, 463 son prados de primera y segunda calidad; 520, "monte altos" y 2.174 huebras de "comeseros...que no se labran por lo ynfructifero dellos y solo sirven de pasto previniéndose que en lo antiguo fueron montes". Respecto al monte, si está poblado de encina, produce cuatro cargas de leña y celemín y medio de bellota por fanega ${ }^{628}$.

Casos similares hay en la propia Medina. Al sur de su término y lindante con los nombrados, en el llamado monte raso de la Espeluca, de 20.300 obradas, se catastran veinte obradas de huerta y "doze mil labrantías de secano y de ellas.. cinco mil y quinientas de plantío de viñedo...".

Las manchas de monte, que en estos pagos meridionales llegan al XVIII mejor conservadas, lo son por estar en manos particulares. Destaca el término redondo de Descargamaría, hoy en término de Carpio, y en 1752 señorío perteneciente a los herederos de Matías de Valparda, tras su compra por 400.000 reales al duque de Arcos. Tiene una extensión de 2.162 obradas, de las que la práctica totalidad (2.159) está cubiertos de "enzina, alta y baja"229. Limita al norte con el monte mencionado de la Espeluca, propio de Medina, y por el sur con montes de Madrigal. De acuerdo a las Respuestas Generales, a mediados de siglo, por "la leña que se corta y saca de dicho monte" se obtienen unos ingresos anuales de 1.500 reales; por "los pastos de yerva" 10.000 reales y por la "cosecha de bellota que producen las enzinas" 200 reales.

Cercano al anterior y de similares características, se encuentra el monte de Bobadilla, propiedad del seńor de la villa, de 900 obradas de extensión, cuyo pasto es particular y privativo, que produce pasto y "algunos años algo de vellota". Como puede apreciarse en la reproducción adjunta, contrasta la desnuda llanura de los pueblos al norte de la citada localidad con las manchas arboladas al sur, tales como el monte de Madrigal, el propio de Bobadilla y el de Descargamaría que se acaba de comentar. Por su extensión merece la pena su descripción general ${ }^{630}$ :

“...novecientas obradas que ocupa el terrazgo de dicho monte y de ellas, según la regulación que ba hecha, de que treinta enzinas ocupa una obrada, consideran que se hallan plantadas ochocientas...”.

\footnotetext{
${ }^{626}$ AGS_CE_RG_L647_420.jpg.

${ }^{627}$ AGS_CE_RG_L647_688.jpg.

${ }^{628}$ AGS_CE_RG_L 630_073.jpg.

${ }^{629}$ AGS_CE_RG_L647_120.jpg.

${ }^{630}$ AGS_CE_RG_L529_308.jpg.
} 
Nava del Rey, una vez roturados los montes de Valdemuelles y Palancar, como Sieteiglesias con Valdevite, acoge en este siglo "mil quinientas de monte raso yntitulado el Rebollar" 331 , propio de los herederos de Juana de Vargas, proindiviso, que se arrendaba para pasto a los vecinos "en diecisiete mil reales de vellon al año y el reseco de la leña que el señor saca para el gasto de su casa lo regulan en quinientos reales al año". ${ }^{32}$ Un siglo más tarde, en 1859, será dividido en suertes, como el monte de Fresno, y adquirido por vecinos labradores de estas poblaciones.

Los siglos pasados, en fin, pusieron en aprietos tanto a las arcas de los concejos como a los estómagos de hombres y ganados. El monte fue el claro perdedor. No se olvide, en este sentido y por ejemplo, que por razón de tierras sernas y plantíos de majuelos, Medina tasa sus rentas de montes sernas, a mediados del XVIII, en la importante cifra de 5.200 fanegas de trigo ${ }^{633}$, estando la mayor parte del terrazgo roturado y lo que falta, sometido a una extraordinaria presión. Recuérdense las palabras del alcalde de La Seca, citadas en el anterior epígrafe, cuando manifiesta en 1785 que en el término apenas se encuentra un palmo de tierra sin cultivar", a excepción del pago que llaman el Monte Ynestoso y Pedroso, donde se hallan como dos mil novecientas cincuenta obradas de tierra... toda yerma y perdida" "634 y que, en aras de favorecer a la agricultura y al vecindario, debe plantarse de vides toda vez que "al presente ni es monte ni, dado su estado, parece haberlo sido" pues “...es tierra calba sin árbol, cepa, ierba, ni otra planta alguna no a propósito para pan, porque si algo se siembra, que lo es mui poco, se reduce a un centenal u otro, mui raxo y malo..." ${ }_{335}$.

Únicamente, al norte de estos terrazgos de Propios de Medina, sigue intacto el importante monte de Terradillos, de las monjas de Santa Clara, que se configura como un estandarte fijador de jurisdicciones. Se extiende siguiendo la margen derecha del Duero por 1.121 obradas, de las que 912 eran de monte propiamente dicho ${ }^{636}$.

Los vecinos de Villanueva fijan su término, en 1752, en relación con dicha existencia: "Las confrontaciones son por la parte del Poniente con el monte de enzina perteneciente al convento de Santa Clara de la villa de Tordesillas, intralímites con la jurisdicción de la de San Martín del Monte..." "37. La ambición de los concejos, presionados por labradores hacendados o jornaleros deseosos de arañar al monte un pedazo de tierra, generará nuevos conflictos, tanto más cuanto que aun por estas fechas muchos límites no están del todo claros. Un ejemplo es el pleito de 1777 entre el convento de Santa Clara y el concejo de La Seca por su fijación ${ }^{638}$. El litigio es, sin duda, muy interesante, pues remarca lo que se viene reiterando en relación a los aprovechamientos y recursos de uso común ${ }^{639}$. Como puede apreciarse en la carta topográfica adjunta, las únicas manchas importantes de arbolado se sitúan inmediatas al sur del Duero, la mayor parte de ellas custodiadas por el Monasterio que las ha

${ }^{631}$ AGS_CE_RG_L647_354.jpg.
${ }^{632}$ AGS_CE_RG_L647_355.jpg.
${ }^{633}$ AGS_CE_RG_L647_256.jpg.

${ }^{634}$ A.M.M.C., caja 254-40.” Representación hecha a S. M. por el Alcalde mayor de la Villa de La Seca, solicitando permiso para plantar de maxuelos el terrazgo de los Montes Ynestoso y Pedroso, pagando un canon correspondiente”.

635 Ibídem.

${ }^{636}$ Atlas Forestal de Castilla y León. Junta de Castilla y León, tomo I, pág. 308.

${ }^{637}$ A.H.P.V. Catastro de Ensenada. Respuestas Generales. Villanueva de Duero, caja 648/22.

${ }^{638} \mathrm{La}$ espoleta fue la detención en 1777 , por oficiales de Tordesillas, de dos hacheros de Valdestillas al servicio del concejo de La Seca, tras cortar cuatro pinos. Seguramente fueron los pinos más caros de la historia a tenor del papel gastado, los procuradores pagados y el óleo pintado por Antonio Navarro a este fin y que ya se ha mencionado en varias ocasiones.

${ }^{639}$ En el pleito el convento de Santa Clara defiende como suyo el terrazgo en litigio, alegando la carta fundacional del Real Monasterio por las "señoras Ynfantas Doña Beatriz y Doña Isabel, hixas del Señor Rey Don Pedro el Justiziero, correspondiente al año 1363...". Se argumenta en los autos la propiedad por donación de "un monte sito entre el río Duero y los Montes de la Villa de Medina del Campo, cercano a San Martín, lugar...". En dicho privilegio se mandaba "que ninguna persona de su corte ni fuera de ella, de ningun pueblo, fueren osadas a entrar en dicho Monte a correr ni tomar, ni cazar caza alguna con perros, furones, tal 
mantenido a salvo de roturas e, incluso, como se ha visto, del pastoreo abusivo. El monte de las Monjas, también denominado de Terradillos o de la Abadesa, gozaba de gran estima entre las aldeas de su entorno por su masa de encinas y pastos para aprovechamiento del ganado.

\section{- El aprovechamiento y ordenación de pinares y pimpolladas. Un ejemplo en Villanueva de Duero}

Siguiendo el curso del Duero y del Adaja, el espacio montaraz se refugia en las terrazas más bajas y arenosas, estériles para panes y heladizas para vides. Las reales ordenanzas de 1748 sobre conservación y aumento de montes y pinares, tuvieron su efecto en estos pagos. Serrada, villa de 182 vecinos, declara solamente 142 obradas de "un pinar de pimpollar... a do dicen las rayas de San Martin del Monte y Villanueva de Duero". Fuera de este espacio arbolado no había en el término más que "dos árboles de álamo negro al camino de Valdestillas que llaman las Olmas" "40. La presión sobre el término pudo con los antiguos montes. En Villanueva, en cambio, la encina logra resistir. En sus normas de buen gobierno de 1745, se insiste que en el entresaco y corta del pinar viejo y encinar "se conserben los pimpollos de pino, matas y tallos de los enzinas para que se conserben y crien nuevo pinar y monte""641.

En relación a cuanto exponemos Villanueva catastra 704 obradas de prados, montes de encina y pinares, unos nuevos y otros de mayor edad. Cabe destacar "un pinar y monte de encina nombrado el viejo y cortas de Cosido", propiedad del común, de 390 obradas de superficie, que limita con el término de San Martín y el referido monte de las monjas. Consta de "setenta obradas de encina que se cortan de doce en doce años... y en el intermedio no da utilidad alguna... ". Lo acompañan 170 obradas de pinar viejo y 220 de pinar "que no produce cantidad alguna por ser nuevo"b42. La explotación de estas masas forestales estaba regulada por reales órdenes, pero la realidad es que no siempre se respetan. En 1749, su concejo otorga poder para pleitear por los dańos hechos en el pinar del concejo y para solicitar que los ganados merinos no entren en las cortas de encina ni en la dehesa ${ }^{643}$. Como en otras localidades, los concejos ven en estos espacios una fuente de ingresos, si crecen convenientemente y están bien conservados. Villanueva en este mismo ańo marca la pimpollada de las Cortas de Cosido a fin de aprovechar la leńa menuda y mejorar la crianza de los pinos $^{644}$ :

\footnotetext{
"Declararon aber marcado todas las matas bajas y gajas que se hallan en dicho pinar torzidas para mucho estorbo a la cría de los que quedan... Asimismo han marcado aquellos pinos torzidos no aparentes para maderas de fábrica... Asimismo dixeron ser de mucha utilidad y probecho descañar los pinos que quedan por ser útiles y probechosos para que se críen para madera de fábrica, quedando en estos siete ruedas en su alero, horca y pendón con lo cual queda bien limpio y sin estorbo de su cría”.
}

correr, vallestas, redes ni en otra manera, ni a cortar, ni llevar leña ni zepas ni vellotas ni otra cosa alguna, ni entrar a pastar las hierbas, ni beber las aguas de el con sus ganados sin lizenzia y mandato de la Abadesa, Dueñas y Combento..." El concejo de La Seca, por la parte contraria, argumenta que, desde tiempo inmemorial, han disfrutado del dicho espacio y ponen como ejemplo el año anterior cuando cortaron árboles para "cierta obra de la Hermita de Nuestra Señora de la Paz, consistente en el mismo termino i monte...". El litigio y las demandas de unos y otros dan lugar a un complejo proceso sobre la fijación exacta de los limites en torno al "mojón denominado de la encina gorda, linia recta a otro mojón y desde este a otro donde hacia una chopa de álamo blanco, ynmediata al rio Duero, frontero a la casa de la huerta titulada del Ajo..." Ante el conflicto y desavenencia entre las partes se manda pintar el óleo referido. En 1782, en fin, se dicta sentencia en la que jugó un papel fundamental, como irresistible prueba, el deslinde practicado en 1629 por el licenciado Montalvo, juez comisionado para la ejecución del Real Privilegio de Villazgo de La Seca en el que se cita que la extensión del monte Terradillos no tiene mas cabida que hasta la casa del mismo nombre "y linea encarnada que gira en el mapa por la mojonera de números blanca desde el diez hasta el diez y ocho, frente a la casa titulada de la Huerta del ajo...” y plasmado en dicho óleo. (A.R.Ch.V. P.C. Zarandona y Wals. (F), sig. C 3280.1, leg. 682).

${ }^{640}$ A.H.P.V. S.H., caja 20.

${ }^{641}$ A.H.P.V. S.H., caja 83.

${ }^{642}$ A.H.P.V. Catastro de Ensenada. Villanueva de Duero, caja 379, folio 711-712.

${ }^{643}$ A.H.P.V. Pt. 8202, fol. 66 y 193.

${ }^{644}$ A.H.P.V. Pt. 8202, fol. 396-397. 
En los siglos anteriores se ha constatado cómo retamas y matas de encina vuelven a ocupar tierras roturadas y posteriormente abandonadas. En este siglo XVIII, a dicha vegetación se suman los pinos, especialmente en las superficies cercanas a los mismos. En 1722, Francisco Reguilón constata que en distintas heredades de viñas de su mayorazgo de Villanueva "que se an perdido y deszepado y por dicha razón se poblaron de pinos..." "645. En las tierras abandonadas, propias del concejo, ocurre lo mismo y bien se procura que vuelvan a ser monte de encina, bien que crezcan los pinos sin la competencia de la encina, que se resiste a desparecer, en lo que en otro tiempo fue su espacio natural ${ }^{646}$ :

\begin{abstract}
"Asimismo declaran que linde a el monte de encina... se halla un pedazo de seis obradas... y en el ay muchas matas de encina y algunos pinos entre ellas que ocasiona no ser pinar ni monte de encina, que es conveniente cortar todos los pinos y que dicho sitio que sea monte de encina

Asimismo declararon aver visto en la referida pimpollada algunas matas de encina; que estas sirbe de bastante estorbo a la cría de los pinos, que tienen por conveniente que se corten a rayz por que no buelba a criar y estorbar los a los pinos de la dicha pimpollada”.
\end{abstract}

Estas manchas arbóreas continúan siguiendo el Adaja hasta el término de Otea y el monasterio de Aniago. Desde fines del XVII y principios del XVIII, no faltaron pleitos entre el monasterio de Aniago, la jurisdicción de Olmedo y la ciudad de Valladolid. Se testifica que, desde 1696, se habían cortado numerosos pinos y encinas, llevando más de seiscientos carros para cocer cal y tejas sin dejar en ellos "orca ni pendón" "47. Las capitulaciones entre Olmedo y Aniago se remontan a 1469 y se manifiesta que "estos vecinos podrán cortar leña en los términos de Olmedo para utilizarla como combustible en sus casas particulares, pero no para venderla" y se concede al monasterio la potestad de cortar al año "sesenta carretadas de leña de cantuesos e yniestas e royuelas" 648 . La presión en estos montes la ejercen tanto los campesinos y el monasterio de Aniago, como la necesidad de madera y leña de la cercana Valladolid. El proceso es siempre el mismo. A las primeras cortas suceden roturaciones y sembrados que esquilman los suelos y, o bien vuelven a cubrirse de retamas y carrascas o bien son plantados de majuelos. En un apeo de 1648 la Cartuja de Aniago declara treinta aranzadas de viñas de las cuales dieciséis fueron, posteriormente, plantadas de pinares ${ }^{649}$. Será el pino, por su crecimiento y porte en relación a la encina, el gran beneficiado en este siglo.

Muchos pueblos así lo manifiestan y catastran importantes superficies. En el sector meridional, destaca La Zarza que declara 680 obradas de pimpollar y pinar en tierras de tercera calidad y Ataquines que acoge 1.937 obradas; en los pagos al norte, límites con los que se toman como ejemplo, se encuentra Aniago y Valdestillas con 600 obradas cada uno y Matapozuelos, con otras 520 obradas. De ahí que Villanueva y Valdestillas encuentran en ellos unos recursos añadidos, tanto en sus términos como en sus limítrofes. Puente Duero, Mojados o Viana siguen aumentando estas manchas de pinares de forma muy importante. Las posturas anuales sobre el aprovechamiento de las pińas o las cortas dan trabajo a jornaleros y recursos a los concejos. Viana, por ejemplo, solicita en 1797 a Luis Manuel de Isla, juez conservador de Montes y Plantíos, la corta de 4.000 pinos del pinar de los Negrales, para hacer frente a una deuda de la villa. Las normas emitidas por el juez conservador son un tratado moderno de aprovechamiento de un espacio forestal ${ }^{650}$.

${ }^{645}$ A.H.P.V. Pt. 8193 , fol. 30.

${ }^{646}$ A.H.P.V. Pt. 8202, fol. 396.

${ }^{647} \mathrm{La}$ expresión procede las ordenanzas antiguas, dictadas por las Cortes, en las que en su quinto dictado en relación a la forma de explotación y cuidado de los montes se ordena que " $n$ i talen los montes ya plantados que se hubieren restituido, salvo si fueren tan grandes, que puedan los pueblos cortar leña; lo qual se deberá executar, dexando en los arboles orca y pendón, para que vuelvan a criar, y no cortándose jamás por el pie, quedando los más pequeños para pasto".

${ }^{648}$ Historia de Villanueva de Duero, Junta de Semana Santa, (inédita), fol. 92 y ss.

${ }^{649}$ Ibídem.

${ }^{650}$ A.H.P.V. Pt. $11890 / 7$, fol. 190 y ss. 

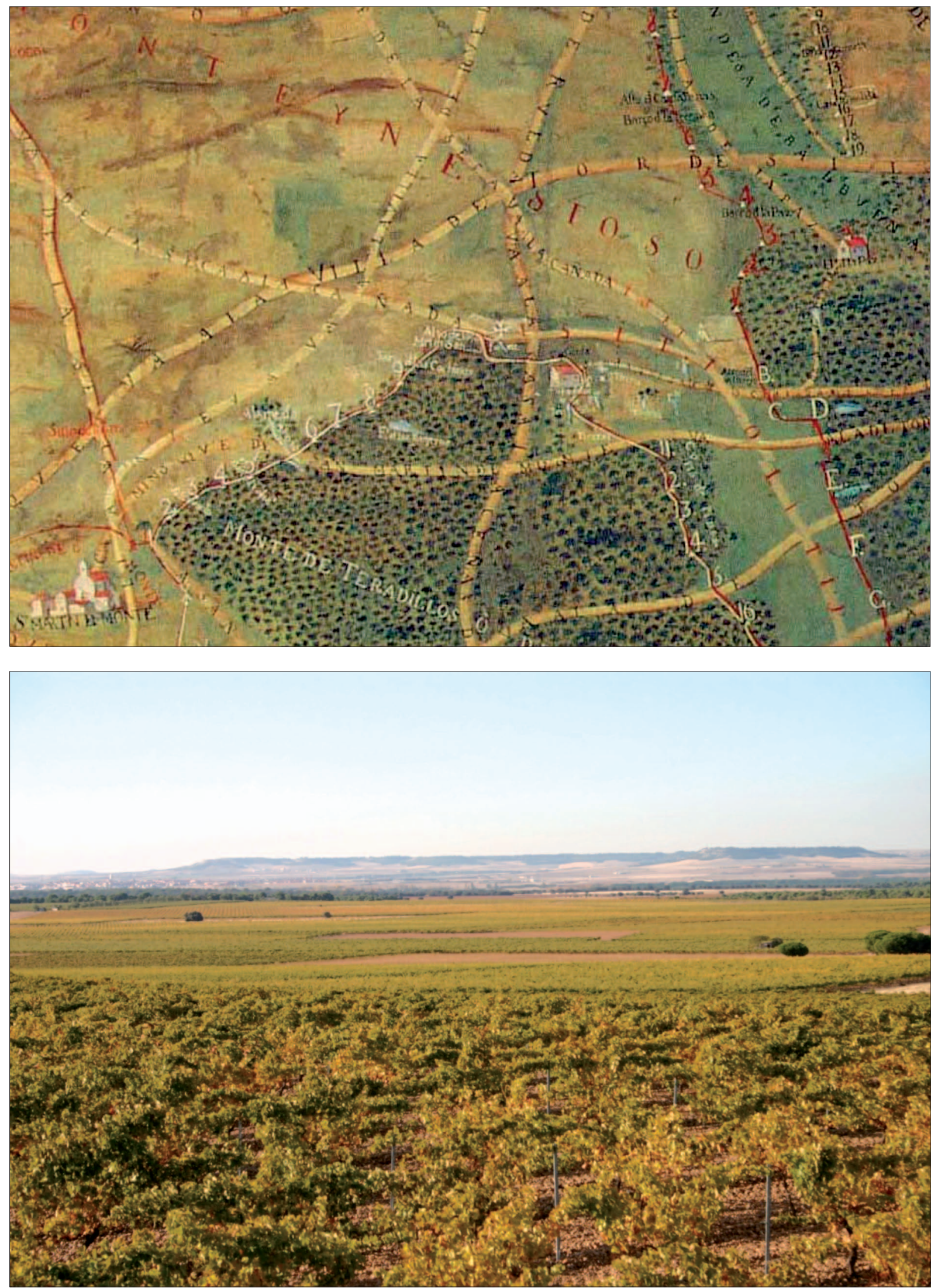

Imagen 56. Situación del terrazgo labrado y montaraz a finales del siglo XVIII al norte de Medina. (arriba, A.R.Ch.V. Óleo 0010). El vińedo sustituye a las encinas y retamas del Monte Inestoso desde la Edad Moderna hasta la actualidad. Abajo, foto: $30 / 10 / 2011$. 

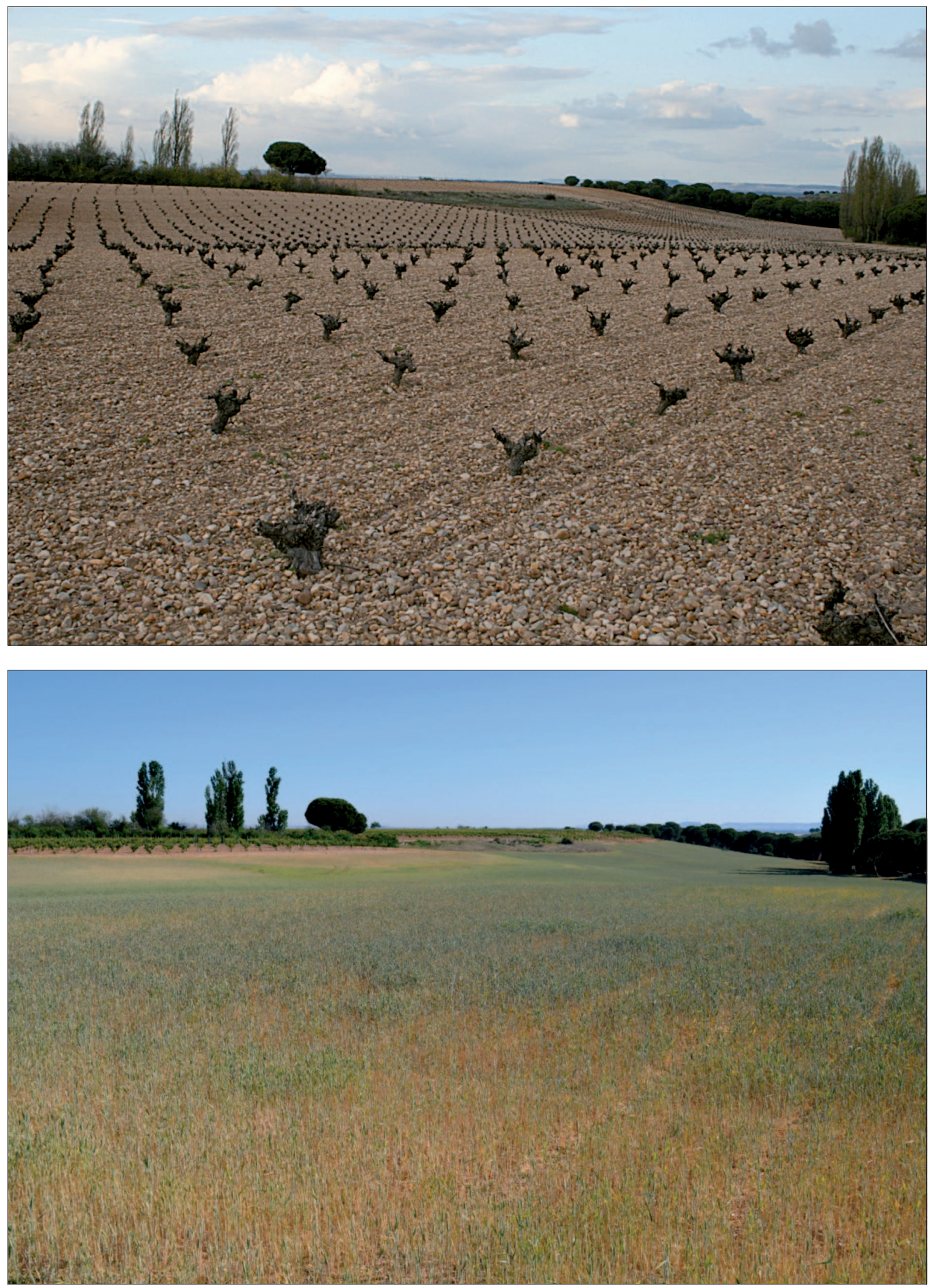

Imagen 57. El viñedo ha sido el único cultivo capaz de hacer producir fruto a estos suelos de gravas. Viñedos en La Moya (arriba). Foto: marzo de 2008. Los años secos hicieron desistir al labrador de otros aprovechamientos. Efectos de la sequía en el mismo terrazgo, (abajo). Foto: 18/05/2014. 

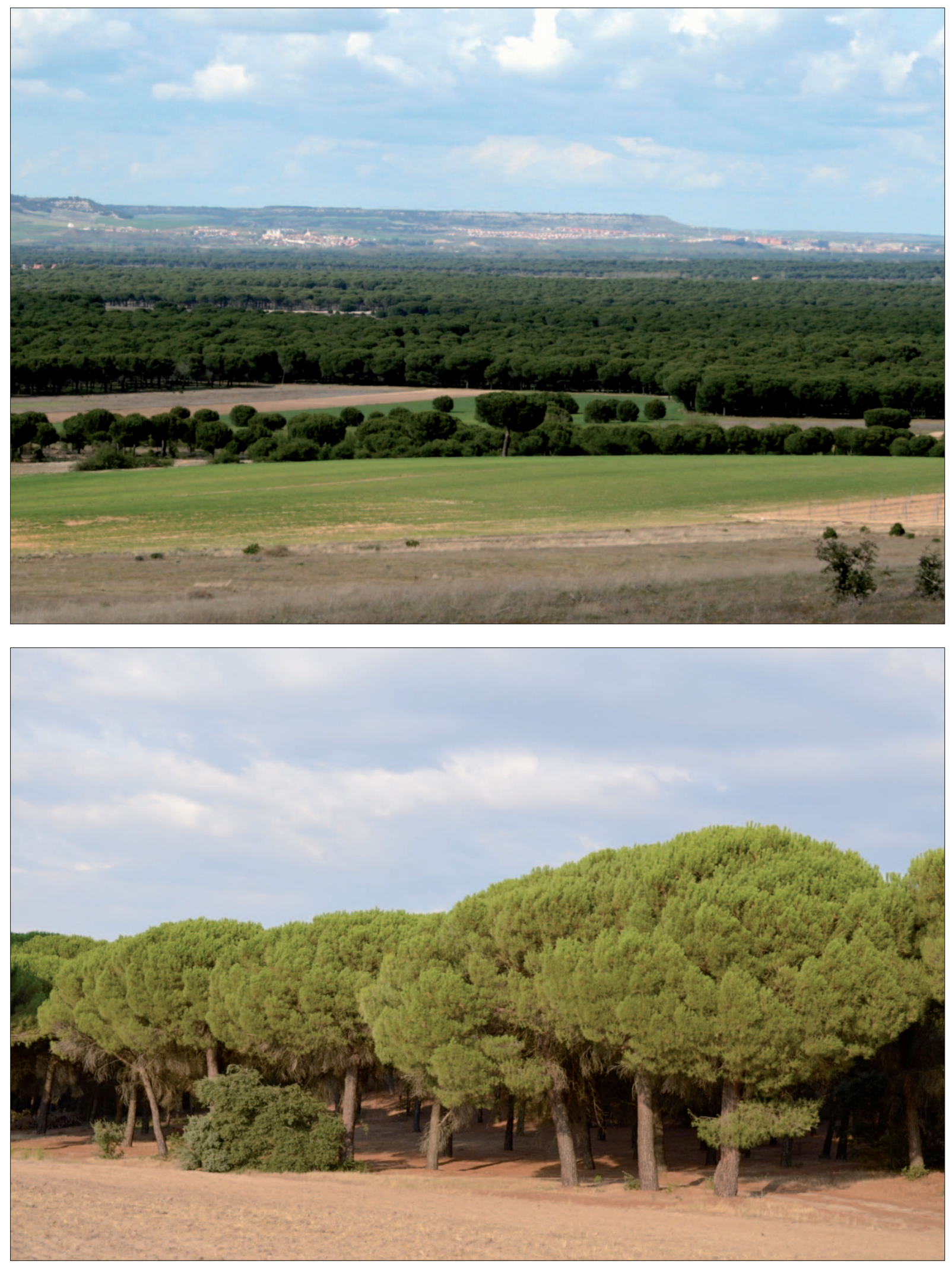

Imagen 58. Las ordenanzas de plantíos del siglo XVIII favorecen la expansión del pino. Pinares de Villanueva de Duero al norte de la comarca (arriba, foto: 12/04/2008) y detalle del Pinar de la Moya, en Serrada (abajo, foto: 18/08/2014). La expansión del pino se realiza a costa de la encina en suelos arenosos poco fértiles. 
Las ordenanzas ilustradas del XVIII, en fin, alientan los plantíos en lo que fueron montes de encinas y retamas, ocasionales tierras centeneras o deficientes vińedos. Parte de los términos despoblados de La Moya y Foncastín son ocupados por pinares a fines del XVIII y comienzos del XIX. Por su importancia merece destacarse este último. En las cédulas de amillaramiento se declaran 3.174 obradas, de las que 724 obradas corresponden a pinares tallares, 36 obradas, de alameda y 229, de prados. A mediados del XX se realiza un minucioso proyecto de ordenación que catastra también 6.000 pies de alcornoque en un espacio vegetal complejo que puede corresponder a un reducto de bosque mediterráneo con encina, pino, alcornoque y quejigo ${ }^{651}$.

\section{b. La necesaria conservación y aprovechamiento de los pastos}

En el anterior capítulo se analizó el aprovechamiento ganadero de estas superficies y se adelantaron no pocos conflictos entre labradores, ganaderos, concejos y derechos comunales de las antiguas villas cabeceras. Distintos problemas con un denominador común: el interés de cada parte por obtener el máximo beneficio. Si el declinar del monte de encina es un hecho en esta centuria del setecientos, no ocurre lo mismo en lo referente a los prados. En primer lugar, porque la naturaleza impone sus reglas en cuanto a humedales y manantiales en aquellos sectores de menor altitud donde, incluso, muchos acuíferos rebosan en superficie; en segundo lugar, porque su conservación es más imperiosa, conforme aumentan las roturaciones y se amplían los cultivos a costa de tierras marginales, pues estas prácticas van asociadas a una mayor necesidad de ganado de labor, a una mayor presión demográfica y, por consiguiente, al mantenimiento de una mayor cabańa ganadera, lo que se traduce en una creciente demanda y ordenación de estos preciados terrazgos.

A mediados de siglo, los prados, clasificados al igual que el resto de aprovechamientos de primera, segunda o tercera, se extienden por cerca de 15.000 obradas en la comarca de Medina, representando el 5,37\% del total de la superficie. A ello se debe ańadir una parte importante de las 6.532 obradas $(2,44 \%)$ que se catastran como eriales, cañadas, caminos o casco de la población, sin olvidar las 213 obradas de eras, pues, en este caso, como en la mayor parte de los pueblos, su aprovechamiento por el ganado es un complemento más.

Cuadro 38. Ejemplos de superficie de prados en el norte y sur de Tierra de Medina ${ }^{652}$ (en obradas, año 1752)

\begin{tabular}{lccrlrrr}
\hline Término & $\begin{array}{c}\text { Superficie } \\
\text { término }\end{array}$ & $\begin{array}{c}\text { Superficie } \\
\text { prados }\end{array}$ & $\%$ & Término & $\begin{array}{c}\text { Superficie } \\
\text { término }\end{array}$ & $\begin{array}{c}\text { Superficie } \\
\text { prados }\end{array}$ & \multicolumn{1}{c}{$\%$} \\
\hline Rueda & 8.147 & 252 & 3,09 & Rubí & 3.000 & 300 & 10,00 \\
La Seca & 9.450 & 50 & 0,52 & Fuentelsol & 3.692 & 300 & 8,12 \\
Serrada & 3.681 & 188 & 5,10 & Lomoviejo & 5.300 & 600 & 11,32 \\
Villanueva & 1.198 & 200 & 16,69 & Cervillego & 3.000 & 199 & 6,63 \\
Valdestillas & 5.000 & 120 & 2,40 & Gomeznarro & 2.755 & 800 & 29,03 \\
Matapozuelos & 5.800 & 500 & 8,62 & San Vicente & 3.910 & 300 & 7,67 \\
\hline TOTAL & & & & 21.657 & 2.499 & 11,53 \\
\hline
\end{tabular}

Fuente: Catastro del Marqués de la Ensenada. Respuestas Generales. 1752. A.G.S.

Libros correspondientes a los municipios aquí relacionados. Elaboración propia.

${ }^{651}$ RAMOS SANTOS, J.M.: Origen y dinámica de la dehesa de Foncastín (Valladolid) entre los siglos XVI y XX: Posibilidades y limitaciones de las formaciones vegetales esclerófilas. Presentado para la mesa temática: Caracterización, dinámica y biodiversidad de los ecosistemas.

(www.secforestales.org/buscador/pdf/4CFE05-555.pdf).

${ }^{652}$ En Rueda se han incluido los prados que declara el despoblado de Zofraga (190 obradas) y el de Foncastín (22 obradas de pastos comunes). En Serrada, los prados de su hoy despoblado de San Martín del Monte, donde se catastran 140 obradas. La Seca declara 160 obradas de tierra yerma que no se han incluido, aunque se aprovechan como pastizales ocasionales. 
En una consideración general, los pueblos meridionales catastran unas superficies de prados mayores que los situados al norte. Ello es debido a la existencia de extensos espacios de bodones, lavajos y salgüerales, poco aptos para el cultivo, que reciben en unos casos la consideración de prados y en otros, de eriales. La Zarza, por ejemplo, catastra a mediados de siglo 680 obradas de pimpollar y pinar, 150 de dehesa, 120 de prados concejiles, 2 obradas de eras, 175 obradas de prados baldíos, 70 de salgüerales y 170 obradas "de eriales que no se cultivan por ser de mala naturaleza". Ataquines, al margen de las 1.937 obradas de pinar que se han referido, anota 111 obradas de prados sanjuaniegos, 50 de comunes y baldíos, 90 de "heriales de mala naturaleza" y 10 obradas de salgüerales. Todos son aprovechados por el ganado, pero su regulación depende de su calidad y de si la propiedad es privada, concejil o común de villa y tierra. Múltiples situaciones y problemas que trataremos a través de algunos ejemplos.

\section{- Los problemas de los derechos de pasto en los terrazgos comunales. Ejemplos al norte de Medina}

La importante superficie de pastos comunes de la villa de Medina, o en el sector norte también de la Tierra de Olmedo, se aprovecha por los ganados de los vecinos del término y demás pueblos de la Tierra. Cuando la cabaña aumenta, los montes se roturan o se cubren de pinares, surgen los conflictos entre jurisdicciones y derechos de pasto y ello ocurre en la mayor parte de los lugares, aunque la costumbre lo tenga bien ordenado. Es el caso de Cervillego, por ejemplo, al sur de la Tierra. Le pertenecen como propios el directo útil de ciento sesenta obradas labrantías que arrienda a sus vecinos y, de su común, distintos prados y ejidos que comparte con ganados vecinos de Medina del Campo y demás pueblos de su partido. Su regulación teórica es la que sigue:

\footnotetext{
"De la inmemorial costumbre este concejo veda y cotea los que han estado y estan destinados para los ganados de labranza desde el día de Nuestra Sa de las Candelas hasta San Juan de Junio de cada una año, y pasado dicho tiempo, sin embargo de ser comunes como llevan dicho, acostumbra y ha acostumbrado arrendar este concejo los pastos de unos y otros, que a su entender se componen todos de doscientas obradas, sin que dexen de pastar en ellos sus ganados y los que quieran de los demás pueblos de Tierra de Medina”.
}

Pero no todo es tan claro ni en Cervillego ni en el resto de los pueblos. Al norte de Medina, por ejemplo, cuando La Seca acaba con los montes sernas donde pastan sus ganados y la superficie labrantía llega a su máximo, las cincuenta obradas de prados que registra no bastan para mantener a su numeroso ganado. El choque por los derechos de los pastizales de San Martín del Monte, situados en su raya septentrional, no se hace esperar. Se extienden siguiendo el arroyo que alinea los prados desde Serrada, San Martín y Casa Calderón hasta el mismo Duero ${ }^{653}$. Junto a este principal manto verde, se deben añadir otros pequeños regatos y manantiales que nutren pradillos en el resto del término. Unos y otros espacios, montes y prados, en manos de los concejos locales, son arrendados o explotados directamente por los vecinos y sirven de vital complemento a la comunidad. La pequeña villa de doce vecinos denuncia en 1702 ante la justicia su precaria situación. Manifiesta sentir unas perdidas de 2.000 reales por los daños continuados que hacen los ganados del pueblo vecino que "...nos an comido y estar comiendo y rozando en dicho prado con mas de trescientas cavezas de ganados mular, cavallar y vacuno y mas de dos mil cavezas de ganado obexuno, todo ello con ánimo de destruirnos y por el odio y mala voluntad que nos tienen, considerandonos yndefensos por pobres y de poco caudal...". ${ }^{554}$ Aunque ganen el pleito, su suerte está echada.

${ }^{653} \mathrm{Si}$ se tiene en cuenta que su término se fijaba en 350 obradas, la posesión por parte de su Concejo de 140 obradas de prados es un dato nada desdeñable, ya que la villa sólo tenía doce vecinos de los que diez se declaran labradores. Seguramente hubieran querido tener más tierras trigueras y más término, pero su ubicación en el tramo final del arroyuelo provocaba encharcamientos y restricciones de cultivo. Lo uno por lo otro, porque el concejo sacaba buenos arrendamientos de estos frescos prados.

${ }^{654}$ Ibídem. 
Serrada, limítrofe con estas villas, pero perteneciente a la villa de Olmedo, se reúne en concejo este mismo año de 1702 para ordenar sus pastos. No eran todo lo buenos que hubieran deseado sus vecinos. Sólo dos obradas son declaradas de primera calidad. Ello implicaba un estricto cumplimiento de las ordenanzas sobre su aprovechamiento para evitar sobrexplotaciones y abusos. El concejo que se celebra el 24 de febrero del citado año ajusta de forma pacífica los intereses ganaderos, de acuerdo a la calidad y capacidad de los mencionados pastizales. Ya se estudiaron no pocos litigios en anteriores siglos. Ahora parece una tregua casi definitiva ${ }^{655}$ :

\begin{abstract}
"Que sin embargo de que dichos prados de arriba y abajo son propios de este concejo y como tales se cotean y guardan cada año por bien de paz y por que dichos ganaderos conserben sus ganados obejunos, permiten y consienten que dichos ganados obejunos entren a pastar dichos prados libremente desde el día de san Andrés de este presente año hasta el día primero de febrero del que viene de 1703, y en la mitad del prado de abajo que está descuidado le pasten hasta mediados del mes de marzo, ocho días más o menos. Y que estando vedados no puedan entrar en ellos y si entrasen se les pueda penar..."
\end{abstract}

A pesar de lo que pudiera parecer en un principio, el concejo de la villa no dejó a las ovejas la hierba de los prados de forma caprichosa. Al parecer, un grupo de ganaderos había ganado una Real Provisión al propio concejo, por la que podían aprovecharla en derecho con sus ovejas.

Más al norte, en término de Valdestillas, se extiende el terrazgo del Montico, también pasto común y abrevadero de todos los pueblos de la jurisdicción de Olmedo. Tras la exención de Valdestillas, se siguen acuerdos del aprovechamiento común con la condición de "no poder pastar mas que de sol a sol, sin poder pernoctar en unos y otros términos y con la condición de quedar siempre para pasto común, abrevadero y descanso de los ganados el pago y terrazgo llamado Montico". En junio de 1786, Valdestillas prende, sin previo aviso, ganados de Serrada y Matapozuelos. Ni las villas cabeceras ni los distintos pueblos ceden sus derechos, cuando hay posibilidades de acrecentar sus rentas. Los pastos escasean y se encarecen. La progresiva sustitución del monte de encinas y retamos por los pinares va también en detrimento del ganado lanar. Conocido es el dicho en estos pueblos de "una retama cría un cordero". He aquí otro aspecto a tener en cuenta, pues del pino no se puede decir lo mismo ${ }^{656}$. En 1793 varios vecinos de Serrada hacen postura y escritura del arriendo del monte de los Llanos o de la Moya por cuatro ańos, obligándose "a dar en cada uno alzadamente por dicho terrazgo zinquenta fanegas de centeno" 657 .

Por último, en Villanueva de Duero, se encuentra un tercer elemento distorsionador, también desarrollado en el presente trabajo en el caso de Serrada, que no es otro que el choque entre los intereses del concejo con los inversores vitícolas forasteros, sean laicos o eclesiásticos, que desembarcan masivamente en este siglo XVIII en estas villas más cercanas a Valladolid, labrando importantísimas extensiones de viñedo, como se estudiará. El conflicto surge cuando el ganado de dichas haciendas y el de las yuntas, contratadas de fuera del término, que vienen a trabajar estas vińas y desean apro-

655 "El Concejo de Junta y Regimiento y vecinos particulares de la villa de Serrada, juntos a son de campana como lo tienen de uso y costumbre, ... (sigue relación de autoridades y vecinos), a quien por parte de dicho teniente y Procurador General se propuso el trato que está echo con los ganaderos de los pastos de los prados de arriba y abajo, los cuales se han de vedar en la forma acostumbrada para el ganado de labranza y ganado menor de los pobres, y que estando vedados no han de entrar los ganados obejunos ni otros, y que éstos han de entrar desde el día de San Andrés (treinta de noviembre), hasta primero de febrero libremente; y que por ello dichos ganaderos han de dar dos libras de zera blanca para alumbrar al Santísimo Sacramento el Jueves Santo de este año, y que dichos labradores no han de dar cosa alguna por no estar en costumbre y otras cosas que se propusieron". (A.F.A.M. Carpeta de asuntos municipales. Acuerdo de ajuste con los ganaderos sobre los pastos, año 1702).

${ }^{656}$ El dicho hace alusión a la hierba que se cría y se mantiene fresca en torno a la retama, durante buena parte del año. Ello no ocurre en el caso del pino, pues, al margen de otros factores, sus acículas cubren toda su base, impidiendo el crecimiento de pasto.

${ }^{657}$ A.H.P.V. Pt. 10674, fol. 136. 
vechar los prados del concejo ${ }^{658}$. Ni la costumbre contempla que aprovechen los prados los forasteros, ni se aceptan los perjuicios que ocasionan, pues "que no son ni tienen vecindad en ella; de que vienen por el prezio en que se ajustan... aziendo estos el agravio a los vecinos vajar los prezios de huebras", sin contar con prácticas que se salen de un buen ordenamiento por parte de estas granjas conventuales, como por ejemplo la propia cartuja de Aniago, que "siembra tierras concejiles y sembrarlas fuera de oxa y otras cosas... "559.

Se entra en un siglo, en fin, donde la expansión vitícola y la completa ocupación del terrazgo necesita un óptimo aprovechamiento de estos recursos naturales. No es fácil el entendimiento cuando, como vemos, entran en juego contrarios intereses económicos.

\section{- El incremento y encarecimiento de los arrendamientos particulares}

Anteriormente se ha estudiado cómo los montes particulares desafían a los siglos en mejores condiciones que los descuajados comunales. En este siglo XVIII se observa una explotación que es posible denominar capitalista en muchos de ellos. Se cuidan y se regulan sus aprovechamientos, obteniendo importantes dividendos. La demanda de los vecinos ante la falta de pastos comunes es la razón principal. Un ejemplo es el citado Monte Rebollar, de Nava del Rey, perteneciente en 1728 a Juana de Vargas Pimentel. En este año, distintos pastores ganaderos de esta villa lo arriendan por tres ańos, desde el día de San Andrés hasta el día de San $\operatorname{Marcos}^{660}$. Su aprovechamiento se limita a pastar con nueve piaras de ganado ovino de 670 cabezas cada una y a satisfacer una renta de 4.500 reales. Por su interés, se entresacan algunas de las condiciones que prueban lo preciso del concierto:

\footnotetext{
"Los susodichos mayorales..., personas y criados... no han de poder traer dentro de dicho monte para tal guarda... caiada ni palo que tenga menos de dos baras de largo...

Que... en el discurso de dichos tres ańos ... no an de poder tener más que nuebe sitios de hogueras que corresponden una a cada peara y que de ello cuidasen y en ella solo an de quemar leńa muerta rebieja, sin que ayan de cortar las verdes...

Que...ni en ellos an de poner lazos, cuerdas, ni otra cosa alguna, ni cazar en dicho monte en forma alguna y para ebitarlo no ayan de tener ni traer escopetas perros perdigueros ni conexeros ni otros algunos que se consideren de caza.

Que...que no an de tener leńa rodeada a los corrales o redes de los ganados... y estos se an de abrigar, cubrir y rodear con retama, escobas o manojos conforme se a estilado y practicado en estos ańos y tiempos...”
}

Similar interés se toma el marqués de Zilleruelo por el mantenimiento del monte de Bobadilla, cuando arrienda los suyos en 1741. Anteriormente se ha citado este enclave, lindante con los montes de Escargamaría y Espeluca, como ejemplo de monte en buen estado de conservación. Sus pastos se arriendan, igualmente, desde San Andrés hasta San Marcos. Estos montes abrigados son muy deseados por el ganado durante el invierno y salen a remate tras edictos que se publican en los pueblos del contorno. Son los administradores de esta nobleza absentista los que se encargan, previos poderes, de llevar a cabo estos conciertos. En estos años hace postura y los toma a renta José de Coca, propietario y ganadero de Rubí de Bracamonte, por 4.400 reales. Son cantidades importantes que se abonan en dos plazos: el primero, el día que entran los ganados y el segundo, el día que salen. Sólo personas pudientes pueden hacer frente a estos arrendamientos ${ }^{661}$.

${ }^{658}$ Entre los pastos que tiene el concejo de Villanueva, está un prado llamado dehesa boyal, que se arrienda de invernia. El vecino que lo disfruta con sus ganados paga un canon por cabeza al concejo. Los prados llamados de Arriba y el de la Vega se reservan para los ganados lanares de los vecinos. Las rentas generadas por todos ellos costean, tanto los gastos concejiles corrientes, como los importantes réditos de un censo, al redimir que pesan sobre dichos bienes.

${ }^{659}$ A.H.P.V. Pt. 8203, fol. 690 y ss.

${ }^{660}$ Se recuerda que el día de San Andrés es el 30 de noviembre y el de San Marcos el 25 de abril.

${ }^{661}$ Una década después de formalizar este contrato, José de Coca declara en el Catastro de Ensenada una hacienda de 131 obradas de sembradura y 19 aranzadas de vińa. En cuanto a ganado, declara poseer cinco mulas, un asno, seis bueyes y cuatro caballos. (A.H.P.V., caja 236). 
Como en el anterior caso, se insiste, entre las condiciones, en no poder hacer cortas de ningún tipo sin previo aviso, en que los pastores sólo hagan lumbre "con la leña muerta perdida del suelo" y, en relación con la fauna, "que no an de poder traer por el monte escopeta ni perros conejeros" recurso cinegético viene de antiguo en estos montes cercanos a Madrigal, Medina y Tordesillas, villas regias hasta el traslado de la corte a Madrid por Felipe II. Los propios reyes ordenaban directrices que velaban por ello. Para evitar que el vecindario entrase a matar "conejos e gazapos e perdices e liebres e tortolas...", en 1477 el rey ordena, en lo tocante a los montes de Madrigal, que "de aqui en adelante... no vos yntrometades de tomar ni cazar ni matar la dicha caza de dicho monte con los dichos perros e hurones e ballestas..." 603 .

Respecto al arrendamiento de prados particulares, las condiciones varían según calidades y duración, pero el interés crematístico sigue siendo el denominador común. En 1713 en Bobadilla, el conocido marqués de Cilleruelo arrienda por 400 reales su prado de la Guadaña, "para la manutención de los ganados de lavor y huelga de los vecinos"664; la marquesa de Campollano, por ejemplo, arrienda en 1729 por ocho años todos los prados y pastos que posee en Fuentelapiedra a Jerónimo García, vecino de Rubí, por 900 reales ${ }^{665}$; en Nava del Rey, Teresa de Rivas, tutora de su hijo Juan de Rivas, arrienda el prado del Zerrellar, propio de su mayorazgo, en el despoblado de Trabancos, desde el día de San Miguel hasta San Juan, a Matías Martín por 240 reales $^{666}$; en 1803, varios ganaderos de lanar, vecinos de Pozaldez, arriendan los pastos del Monte de la Paz, sito en término de La Seca, en 4.500 reales "desde el día de San Andrés hasta el veinte y cinco de marzo del inmediato año de mil ochocientos cinco" ${ }^{\prime 667}$. En otras ocasiones los protocolos notariales dan fe de arriendos y subarriendos que testimonian lo valorados que están estos recursos, imprescindibles para mantener el ganado, tanto en los tiempos de holganza como de trabajo.

\section{- Los conflictos en el aprovechamiento de la hoja de las vińas}

La distribución del terrazgo en hojas de cultivo en muchas villas contribuye a un aprovechamiento más racional de los recursos y reduce las tensiones entre ganaderos y labradores por daños e intromisiones en los cultivos. Las ordenanzas antiguas permiten el aprovechamiento en los distintos pagos, una vez levantado el fruto, y en las barbecheras, de acuerdo a la regulación de los concejos. Donde los conflictos son continuos es en lo tocante a la hoja de las vińas. La fuerza que toman los gremios de vińeros en las villas del norte de la tierra no se lo van a poner fácil al ganado ovino. Un ejemplo es lo que ocurre en La Seca en 1704, donde se mezclan la falta de pastos, la roturación del monte, la mengua de cañadas y la posición contraria del gremio de viñeros a que las ovejas entren sin pagar en los viñedos. Los ganaderos de esta villa otorgan poder para que se arrienden la hoja y espiga una vez levantado el fruto, siguiendo anteriores costumbres, especialmente en los antiguos montes sernas. Alegan que los viñedos están plantados en dichas tierras realengas, que son pasto común de villa y tierra y no de propiedad particular de los vecinos. El monte Inestoso sigue siendo centro de su interés ${ }^{668}$ :

“...donde tenemos derecho a pastar y abrevar... y queden libres las pozas y labaxos que ay y havido en el monte ynestoso... donde se dava agua a dichos ganados, y por averle desmatado y labrado todo dicho monte sin poder entrar ni salir por estar todo labrado y cercados los dichos lavaxos y pozas..."

\footnotetext{
${ }^{662}$ A.H.P.V. Pt. 8347, fol. 5 y ss.

${ }^{663}$ A.G.S..R.G.S. 21 de agosto 1477, tomado de GONZÁLEZ SÁNCHEZ, V.: Carpio. Historia..., ob. Cit. pág.77.

${ }^{664}$ A.H.P.V. Pt. 8347, fol. 13.

${ }^{665}$ A.H.P.V. Pt. 6653, fol. 2.1.

${ }^{666}$ A.H.P.V. Pt. 13606, fol. 622.

${ }^{667}$ A.H.P.V. Pt. 8228, fol. 81.

${ }^{668}$ A.H.P.V. Pt. 6397, fol. 188.
} 
En la mayor parte de los pueblos, constan problemas de entendimiento entre las partes. En Serrada, Francisco Rico y Andrés Leonardo, ambos ganaderos, denuncian en 1739 que, desde tiempo inmemorial, se ha tenido por costumbre pastar en las vińas después de levantado sus frutos. Estos ganaderos se quejan del procurador general del común por el "odio y mala voluntad que nos tiene", bajo el pretexto de dañar a los herederos de viñas ${ }^{669}$. Pero los vecindarios están condenados a entenderse, una vez resueltas las desavenencias económicas. La regulación y posturas sobre la pámpana y hoja será un hecho. En la mencionada Serrada, el 28 de octubre de 1783, los responsables de la junta municipal de propios arriendan públicamente su pampanera ${ }^{670}$ :

"La pámpana y oja pendiente de las viñas de su término por tiempo y espacio de dos meses y medio que darán principio el día veinte y nueve del corriente y feneceran el día trece de enero del ańo que viene... en precio y quantía de mil reales...”.

Y las posturas se repiten año tras año, valorando dicho pasto entre 700 y 100 reales. En Villanueva, en 1749, se firma el remate en 1.200 reales $^{671}$. En el despoblado de La Moya, donde pastaban libremente, no tardará en constituirse el cuerpo o gremio de hacendados para, según las denuncias presentadas en 1796, cambiar la situación y procurar "se arrendase la pámpana y ojas de las viñas"772. El gasto y endeudamiento de los concejos y la mercantilización del espacio agrario acentúan estas prácticas, que continúan vigentes en los siguientes siglos.

\section{Una estructura de la propiedad desequilibrada}

No han sido pocas las limitaciones expuestas en los epígrafes precedentes. La dimensión de las explotaciones, ahora abordadas, sitúa frente a estructuras seculares difíciles de cambiar y que sumen al labrador ante una tesitura complicada de resolver: sin tierra en propiedad es imposible mantener una labranza y completarla con arrendamiento es poner en manos del arrendatario buena parte del beneficio. De ahí que, como se verá, si se resta el trabajo directo de la familia campesina en su heredad, pocas son las labranzas que pueden considerarse rentables, estando la mayoría sujetas a un complemento ganadero de subsistencia o a la realización de huebras o jornales, en las haciendas más importantes de cada lugar.

Para acercarse en lo posible a la explotación real, tomando como base el Catastro de Ensenada, se han escogido los pueblos de La Seca, Serrada y San Martín del Monte, al norte de la Tierra de Medina, y Rubí de Bracamonte, al sur. Al ser entidades menores, se evitan distorsiones de propietarios absentistas que enmascaran los cuadros estadísticos, la superficie labrada por los vecinos de estas villas en los pueblos limítrofes es insignificante y, sobre todo, las respuestas particulares del citado catastro, en el caso de La Seca y Rubí, precisan también la propiedad arrendada y su origen, por lo que el acercamiento a la realidad de cada casa labradora es muy certero.

\section{a. La Seca. Un terrazgo con tierras sernas labradas por los propios vecinos}

La peculiar ocupación del espacio labrado, a través de las llamadas sernas de Medina, estudiadas en el anterior capítulo, configuran un ejemplo que bien se puede considerar excepcional en el espacio comarcal: los vecinos seglares, que representan el $95 \%$ del censo, y a su vez el $95 \%$ de los propietarios, labran el $85 \%$ de la propiedad del término. No existe propiedad labrada significativa en manos de nobles absentistas y el estamento eclesiástico, tan omnipresente en la mayor parte de los lugares, representa tan solo el 5\% de los propietarios y el 15\% de la propiedad.

\footnotetext{
${ }^{669}$ A.H.P.V. Pt. 8215, fol. 39.

${ }^{670}$ A.H.P.V. Pt. 8223, fol. 19.

${ }^{671}$ A.H.P.V. Pt. 8202, fol. 100.

${ }^{672}$ A.H.P.V. Pt. 8227, fol. 79.
} 
Cuadro 39. Distribución de la propiedad en La Seca, año 1752. (En ha)

\begin{tabular}{lrrrr}
\hline & Cereal & Viñedo & Total & $\%$ \\
\hline Concejo & & & 81 & 1,4 \\
Forasteros & 90 & 105 & 195 & 3,4 \\
Eclesiásticos & 200 & 160 & 360 & 6,2 \\
Vecinos Seglares & 886 & 829 & 1.715 & 29,7 \\
Sernas & 2.012 & 1.408 & 3.420 & 59,3 \\
\hline Total & 3.188 & 2.502 & 5.771 & 100,0 \\
\hline
\end{tabular}

Distribución de las tierras sernas en La Seca, año 1752. (En ha)

\begin{tabular}{lrrrr}
\hline & Cereal & Viñedo & Total & $\%$ \\
\hline Forasteros & 27 & 153 & 180 & 5,3 \\
Eclesiásticos & 91 & 64 & 155 & 4,5 \\
Vecinos Seglares & 1.894 & 1.191 & 3.085 & 90,2 \\
\hline Total & 2.012 & 1.408 & 3.420 & 100,0 \\
\hline
\end{tabular}

Fuente: Catastro del Marqués de la Ensenada. Respuestas Particulares. 1752. A.G.S. Elaboración propia.

Cuadro 40. Estructura de la propiedad en La Seca, incluidos los forasteros, en 1752

\begin{tabular}{|c|c|c|c|c|c|c|c|c|c|c|c|c|}
\hline \multirow[b]{3}{*}{$\begin{array}{l}\text { Categoría } \\
\text { (ha) }\end{array}$} & \multicolumn{6}{|c|}{ Seglares } & \multicolumn{6}{|c|}{ Eclesiásticos } \\
\hline & \multirow[b]{2}{*}{$\begin{array}{l}\text { No de } \\
\text { prop. }\end{array}$} & \multirow[b]{2}{*}{$\begin{array}{c}\text { Hectáreas } \\
\text { totales }\end{array}$} & \multicolumn{2}{|c|}{ Tierra } & \multicolumn{2}{|c|}{ Viña } & \multirow{2}{*}{\multicolumn{2}{|c|}{$\begin{array}{l}\text { No de Hectáreas } \\
\text { prop. totales }\end{array}$}} & \multicolumn{2}{|c|}{ Tierra } & \multicolumn{2}{|c|}{ Viña } \\
\hline & & & $\begin{array}{c}\text { No } \\
\text { pedaz. }\end{array}$ & $\begin{array}{c}\text { No } \\
\text { obradas }\end{array}$ & $\begin{array}{c}\text { No } \\
\text { pedaz }\end{array}$ & $\begin{array}{c}\text { No } \\
\text { aranz. }\end{array}$ & & & $\begin{array}{c}\text { No } \\
\text { pedaz. }\end{array}$ & $\begin{array}{c}\text { No } \\
\text { obradas }\end{array}$ & $\begin{array}{c}\text { No } \\
\text { pedaz. }\end{array}$ & $\begin{array}{c}\text { No } \\
\text { aranz. }\end{array}$ \\
\hline Menos de 5 & 274 & 507,35 & 247 & 276,67 & 351 & 828,20 & 7 & 8,12 & 13 & 14,34 & 0 & 0 \\
\hline de 5 a 10 & 52 & 359,29 & 249 & 299,10 & 128 & 447,75 & 2 & 13,44 & 2 & 5,75 & 8 & 24 \\
\hline de 10 a 50 & 144 & 936,56 & 603 & 986,53 & 168 & 891,34 & 7 & 163,19 & 134 & 167,69 & 19 & 165,18 \\
\hline de 50 a 100 & 2 & 109,17 & 83 & 170,00 & 2 & 30,50 & 2 & 173,25 & 90 & 165,21 & 21 & 187 \\
\hline Concejo & 1 & 81,06 & 5 & 143,25 & & & & & & & & \\
\hline Total & 473 & $1.993,4$ & 1187 & $1.875,5$ & 649 & $2.197,7$ & 18 & 358 & 239 & 352,99 & 48 & 376,18 \\
\hline
\end{tabular}

Fuente: Catastro del Marqués de la Ensenada. Respuestas Particulares. 1752. A.G.S. Elaboración propia

Cuadro 41. Distribución de la propiedad entre vecinos seglares en La Seca, 1752.

Tierras propias y en renta, en hectáreas

\begin{tabular}{lrrrrrrrr}
\hline Categoría (ha) & $\begin{array}{c}\text { No } \\
\text { vecinos }\end{array}$ & $\begin{array}{c}\text { Tierras } \\
\text { cereal } \\
\text { propias }\end{array}$ & $\begin{array}{c}\text { Sernas } \\
\text { cereal } \\
\text { arrendadas }\end{array}$ & $\begin{array}{c}\text { Tierras } \\
\text { viñedo } \\
\text { propias }\end{array}$ & $\begin{array}{c}\text { Sernas } \\
\text { viñedo } \\
\text { arrendadas }\end{array}$ & $\begin{array}{c}\text { Totales } \\
\text { (ha) }\end{array}$ & $\begin{array}{c}\text { \% del } \\
\text { total de } \\
\text { vecinos }\end{array}$ & $\begin{array}{c}\% \text { del } \\
\text { total } \\
\text { de ha }\end{array}$ \\
\hline Sin propiedad & 167 & 0,00 & 0,00 & 0,00 & 0,00 & 0,00 & 32,5 & 0,0 \\
Menos de 5 & 239 & 27,20 & 48,23 & 143,35 & 245,90 & 464,68 & 46,5 & 9,7 \\
De 5 a 10 & 67 & 47,90 & 126,18 & 121,90 & 171,39 & 467,37 & 13,0 & 9,7 \\
De 10 a 50 & 130 & 489,11 & $1.344,44$ & 451,85 & 637,05 & 2.922 & 25,3 & 60,9 \\
De 50 a 100 & 12 & 267,44 & 340,72 & 111,51 & 110,42 & 830,10 & 2,3 & 17,3 \\
Más de 100 & 1 & 54,25 & 34,10 & 0,00 & 26,31 & 114,66 & 0,2 & 2,4 \\
\hline Total & 616 & 885,91 & $1.893,67$ & 828,61 & $1.191,07$ & 4.799 & 119,8 & 99,9 \\
\hline
\end{tabular}

Fuente: Catastro del Marqués de la Ensenada. Respuestas Particulares. 1752. A.G.S. Elaboración propia.

Como puede apreciarse en los cuadros adjuntos, 3.420 ha, de un total de 5.771 ha que componen el término, corresponden a tierras sernas propias de Medina que, en un 90,2\%, están en manos de sus vecinos seglares. La Seca crece conforme menguan los montes Pedroso e Inestoso, por donde se extienden los principales pagos de estas tierras. El terrazgo labrado por vecinos forasteros o absentistas es irrelevante $(3,4 \%)$ y el estamento eclesiástico, tan omnipresente en estos siglos, tan sólo detenta el 6,2\% del total y, en su mayoría, se trata de eclesiásticos naturales de la villa. 
Sus vecinos seglares labran un total de 4.799 ha, de las que $3.084(64,27 \%)$ son tierras sernas arrendadas a Medina y $1.714,52$ ha $(35,70 \%)$, propias. De ellas, el porcentaje más representativo corresponde a 130 labradores de entre 10 y 50 ha, que cultivan el 60,9\% del total de ha labradas $(2.922,22 \mathrm{ha})$, de las cuales su mayor parte corresponden a las mencionadas sernas $(1.981,49 \mathrm{o}$ $67,8 \%$ ), por lo que es el arrendamiento la única forma de dimensionar las explotaciones. Llama la atención que 306 propietarios, que representan el 59,5\% de vecinos seglares y suman el 88,14\% del total de vecinos seglares propietarios, labran tan sólo el 19,4\% del total del terrazgo ( 935 ha), en explotaciones inferiores a 10 ha, de las cuales un buen porcentaje es difícilmente rentable, pese a la especialización vitícola.

En el análisis de la tierra en propiedad, se observa la importancia porcentual de las tierras de sembradura. Los seglares, de un total de 1.994,59 ha, siembran en cultivo bienal 1.061,37 ha $(53,21 \%)$, dedicando las restantes $933,22(46,79 \%)$ al vińedo. Como en el resto de la comarca, el terrazgo de pan es fundamental para el alimento de las personas, al tiempo que montes y prados sustentan a los ganados. Conforme la superficie de montes y prados disminuye, en las tierras de primera se incrementa el cultivo de la cebada para alimento del ganado de tiro, especialmente, en las épocas de mayor actividad.

Las tierras sernas, como se ha estudiado, son, a mediados del XVIII, un espacio de expansión del cultivo en el que los labradores completan tanto sus tierras de sembradura como de viñedo. Conforme en el siglo XVIII aumenta la rentabilidad de este cultivo y Medina cede a la plantación de vides, el porcentaje de majuelos aumenta respecto a las tierras de sembradura. Hasta entonces el cereal se sitúa en 1.894 ha $(61,3 \%)$ del toral de sernas en manos seglares frente a 1.191 ha de vińedo $(38,6 \%)$.

Buena parte de las pequeñas explotaciones, constituidas por estas tierras sernas plantadas de vides, son labradas a legón o por arados de burros. Es este animal el que predomina en la mayor parte de las pequeńas explotaciones de menos de 5 ha como animal de tiro. Con la mayor parte de los 430 asnos censados, si se restan 56 animales, propiedad de los arrieros, se labran los majuelos de los más humildes. Las medianas y grandes labranzas acogen preferentemente al ganado mular (171 cabezas) y boyal (86 cabezas), en porcentajes similares al resto de lugares de la comarca.

Cuadro 42. Animales de tiro en La Seca en 1752.

(316 propietarios, el 44\% de la población)

\begin{tabular}{lcccc}
\hline Categoría & No de titulares & $\%$ & Animales & $\%$ \\
\hline Marginal (1 cabeza) & 165 & 52,2 & 165 & 22,6 \\
Pequeña (2-3 cabezas) & 85 & 26,9 & 211 & 28,9 \\
Mediana (4-5 cabezas) & 42 & 13,3 & 184 & 25,2 \\
Grande (6-9 cabezas) & 22 & 7,0 & 149 & 20,4 \\
Muy grande (más de 10 cabezas) & 2 & 0,6 & 22 & 3,0 \\
\hline \multirow{2}{*}{ Total } & 316 & 100,0 & 731 & 100,0 \\
\hline
\end{tabular}

Cuadro 43. Ganado de renta en La Seca en 1752

(29 propietarios, el 4\% de la población)

\begin{tabular}{lcccr}
\hline Categoría & No de titulares & $\%$ & Animales & $\%$ \\
\hline Marginal (menos de 10 cabezas) & 1 & 3,4 & 7 & 0,2 \\
Pequeña (10-100 cabezas) & 10 & 34,5 & 415 & 9,4 \\
Mediana (101-250 cabezas) & 13 & 44,8 & 2.122 & 48,1 \\
Grande (251-500 cabezas) & 4 & 13,8 & 1.181 & 26,7 \\
Muy grande (más de 500 cabezas) & 1 & 3,4 & 690 & 15,6 \\
\hline Total & 29 & 100,0 & 4.415 & 100,0 \\
\hline
\end{tabular}

Fuente: Catastro del Marqués de la Ensenada. Respuestas Particulares. 1752. A.G.S. Elaboración propia. 
Otro aspecto a destacar y que alcanza gran peso en las explotaciones más capitalizadas es la unión de la "reja con la oveja". En las medianas y grandes labranzas, el complemento ovino se torna fundamental para la buena marcha de la actividad agraria. La mayor parte de las explotaciones ovinas de más de cien ovejas son propiedad de labradores. De hecho, de las 4.415 ovejas censadas, 2.287 se reparten entre diez labradores con más de cien ovejas cada uno y cuatro, con más de doscientas. Como se ha estudiado al tratar las técnicas de cultivo estercolar, las tierras de sembradura resultan imprescindibles para garantizar buenas cosechas o practicar retelos en aquellas de primera calidad.

Las explotaciones marginales y pequeñas, se trate de ovejas, de tierras o de viñedos, han sido y son en este siglo XVIII las más numerosas, desde un punto de vista cuantitativo, que no cualitativo. Otra cosa es que sean fundamentales para evitar el hambre en muchos hogares campesinos. Disponer de una cerda de cría, de un burro, unas gallinas o media docena de aranzadas de viña salvan al obrero del hambre y remedian la vida de muchas familias. Es lo que se puede deducir de los centenares de propietarios con casa, va rias hectáreas de viña, un burro y una cuba, remendada y vieja, por lo general. Nunca vivirán de ello, pero gracias a ello pueden vivir.

Cuadro 44. Cubas y capacidad de las mismas en La Seca, año 1752

(292 propietarios, el 43\% de la población)

\begin{tabular}{lcrrrrr}
\hline Categoría & No de titulares & $\%$ & No de cubas & $\%$ & Capacidad (moyos) & $\%$ \\
\hline $1-2$ cubas & 209 & 71,6 & 285 & 37,2 & 4.559 & 32,5 \\
3-5 cubas & 56 & 19,2 & 202 & 26,4 & 3.468 & 24,7 \\
6-10 cubas & 18 & 6,2 & 135 & 17,6 & 2.735 & 19,5 \\
$11-20$ cubas & 8 & 2,7 & 123 & 16,1 & 2.765 & 19,7 \\
$21-40$ cubas & 1 & 0,3 & 21 & 2,7 & 493 & 3,5 \\
Más de 40 cubas & 0 & 0,0 & 0 & 0,0 & 0 & 0,0 \\
\hline Total & 292 & 100,0 & 766 & 100,0 & 14.020 & 100,0 \\
\hline
\end{tabular}

Fuente: Catastro del Marqués de la Ensenada. Respuestas Particulares. 1752. A.G.S. Elaboración propia.

Cuadro 45. Distribución de cubas y capacidades diferenciando seglares y eclesiásticos. La Seca, año 1752

\begin{tabular}{lcccc}
\hline & No cubas & $\%$ & Capacidad (moyos) & $\%$ \\
\hline Seglares & 673 & 87,9 & 11.924 & 85,0 \\
Eclesiásticos & 93 & 12,1 & 2.096 & 15,0 \\
\hline Total & 766 & 100,0 & 14.020 & 100,0 \\
\hline
\end{tabular}

Fuente: Catastro del Marqués de la Ensenada. Respuestas Particulares. 1752. A.G.S. Elaboración propia.

Esto se confirma si se observa el cuadro adjunto de los propietarios de cubas en esta villa, anteriormente expuesto en su comparación con Serrada y Rubí de Bracamonte. Hasta 292 propietarios, que representan el $43 \%$ de los que se registran como propietarios de algún bien, son titulares de alguna cuba. De ellos, 209 titulares de 292 poseen uno o dos bastos, que suman el 32,5\% de la capacidad total de La Seca, cifra nada desdeñable. A diferencia de otras villas donde la concentración vitivinícola es acaparada por grandes haciendas o granjas conventuales, en La Seca el 85\% de la producción de vino está en manos de seglares, repartidos entre medianos y pequeños poseedores. Hasta el 76,7\% de la capacidad total está en manos de 283 titulares, que representan el 96,9\% del total de propietarios de cubas. La capacidad de almacenaje en manos eclesiásticas es tan sólo del 15\% y, como se viene refiriendo, buena parte son hijos de familias labradoras acomodadas con cargos eclesiásticos que regentan en la villa. Unos u otros, no obstante, suman la importante cifra de 14.020 moyos de almacenaje, equivalentes a 3.589.120 litros. 


\section{b. La importante propiedad nobiliaria y eclesiástica en Serrada}

El seguimiento del mayorazgo que fundó Diego Ruiz de Montalvo en 1506 en Serrada pone de manifiesto el enorme peso señorial en esta villa a lo largo de los siglos. En el siglo XVIII, su poseedor, el marqués de Torreblanca, detenta las tierras de sembradura de mayor calidad, pues, como ha sido estudiado, a comienzos del siglo XVII mil obradas de suelos de segunda y tercera, que constituían buena parte del término, son vendidas a censo a particulares, con el propósito de ser plantados de vińas. En 1752 detenta la propiedad de 334,16 ha, que representan el $25,7 \%$ del total ${ }^{673}$. Su importancia radica en que, salvo cuarenta aranzadas (16,97 ha), el resto son las mejores tierras de sembradura, indispensables para sus vecinos que las arriendan en las llamadas "rentas" de cuarenta obradas, "medidas rentas" de veinte o "cuartos de renta" de diez obradas. La importancia cualitativa es enorme. Las "tierras del marqués" representan el 67,49\% de las tierras de pan llevar y hasta el 81,8\%, si se excluyen las tierras eclesiásticas, explotadas directamente en su mayor parte por las distintas granjas conventuales asentadas en la villa.

Este estamento, como más detalladamente se verá, llega a controlar, a mediados de siglo, hasta el $31,2 \%$ del total labrado, representando el 10\% del censo y el 16\% de los propietarios. Estos bienes rústicos, como los importantes urbanos que los acompańan, fueron adquiridos mediante compra desde finales del XVII, conforme crecía la demanda de vino en sus casas madres de Valladolid. Ello explica su preferencia por las vińas (563 aranzadas) frente a las tierras de pan (145 obradas).

Respecto a las tierras del señor de la villa, continúan repartiéndose entre los renteros en las llamadas "rentas", estudiadas en siglos anteriores. El contrato de arrendamiento se firma por cuatro años. El pago por renta de 40 obradas es de 32 fanegas de trigo y 10 de cebada cada año. Las tierras "se an de traer a dos ojas de suerte que el último año... a de quedar una oja de vacío para que en ella abarbechen los arrendadores que se subcedieren y no lo cumpliendo me a de pagar cada uno por cada una de las obradas que estubieren a fuera de dicho oja quatro fanegas de trigo"674. A mediados del XVIII, su distribución entre los principales labradores de Serrada es la que sigue:

Cuadro 46. Arrendamiento del Marqués de Torreblanca en Serrada. Año $1742^{675}$

\begin{tabular}{|c|c|c|c|}
\hline \multirow[t]{2}{*}{ Renteros } & \multirow{2}{*}{$\begin{array}{c}\text { Rentas } \\
\text { (una renta }=40 \text { obradas) }\end{array}$} & \multicolumn{2}{|c|}{ Rentas a percibir (en fanegas) } \\
\hline & & Trigo & Cebada \\
\hline Andrés Rodríguez (presbítero) & 1 & 32 & 10 \\
\hline Atanasio Rodríguez & 1 & 32 & 10 \\
\hline Francisco Moyano (escribano) & $5 / 4$ & 40 & 12,5 \\
\hline Balerio Moyano & $3 / 4$ & 24 & 7,5 \\
\hline Juan Antonio Moyano & $5 / 4$ & 40 & 12,5 \\
\hline Narciso del Castillo & 1 & 32 & 10 \\
\hline Francisco Rico & $1 / 4$ & 8 & 2,5 \\
\hline Andrés García Platón & $1 / 4$ & 8 & 2,5 \\
\hline Andrés Martín & $1 / 4$ & 8 & 2,5 \\
\hline Antonio Moyano & $2 / 4$ & 16 & 5 \\
\hline Lorenzo Alonso & $2 / 4$ & 16 & 5 \\
\hline Alonso Román & $1 / 4$ & 8 & 2,5 \\
\hline Santiago Hinojal & $2 / 4$ & 16 & 5 \\
\hline Eugenio Alonso & $1 / 4$ & 8 & 2,5 \\
\hline Floriana de Ayllón & $2 / 4$ & 16 & 5 \\
\hline Roque de Íscar & $3 / 4$ & 24 & 7,5 \\
\hline Gregorio Díaz & $2 / 4$ & 16 & 5 \\
\hline Gabriel Alonso & $1 / 4$ & 8 & 2,5 \\
\hline TOTAL & 11 & 352 & 110 \\
\hline
\end{tabular}

Fuente: Archivo Histórico Provincial de Valladolid. Protocolos notariales. Elaboración propia.

${ }^{673}$ Para centrase en las tierras labradas y evitar distorsiones entre los propietarios, las propiedades del concejo de Serrada no se han incluido. Posee la totalidad de pinares (142 obradas), prados ( 45 obradas) y eras (16 obradas). En los cuadros adjuntos en que se anota como Fuente: Catastro de Ensenada, Respuestas Particulares, se han consultado los fondos del 
Cuadro 47. Distribución de la propiedad en Serrada, año 1752

\begin{tabular}{lcc}
\hline Propietarios & Superficie (ha) & $\%$ \\
\hline Seglares & 559,31 & 43,1 \\
Marqués de Torreblanca & 334,16 & 25,7 \\
Eclesiásticos & 405,09 & 31,2 \\
\hline Total & $1.298,56$ & 100,0 \\
\hline
\end{tabular}

Fuente: Catastro del Marqués de la Ensenada. Respuestas Particulares. 1752. A.G.S. Elaboración propia.

Como se ha analizado, en este siglo se observa una mayor presión sobre la tierra y los pagos más feraces se retelan alternando barbecho, trigo y cebada en este orden, cuando no se siembra cebada sobre las pajas de este cultivo. Es una práctica frecuente entre los renteros de Serrada, por lo que en este contrato se trata de poner fin a esta práctica, mediante el incremento de la renta en que, como puede verse, la cebada acompaña al trigo, aspecto que lleva a considerar la valoración de esta gramínea en los mercados locales ${ }^{676}$ :

"Que por quanto diferentes renteros an mudado la oja de las tierras y puesto a otra por evadirse de los daños y resultar en el rentero de la tierra siguiente, para que cada uno goze de sus tierras según y como an estado todas las tierras así rebueltas se an de bolber a la oja y vez que las corresponde dentro de un año y no la haciendo los he de poder quitar a cada uno...”.

$\mathrm{Al}$ margen de estas once rentas mencionadas, la casa Montalvo posee otras tierras sueltas en el término, igualmente arrendadas a los vecinos. Conforme los pagos son de segunda y tercera calidad, en la renta que tienen que pagar aparece el centeno que, por ejemplo, en el pago de las Raposeras, que figura en el cuadro adjunto, sólo da este aprovechamiento en año y vez. En estos suelos y en el XVIII, los retelos aún son una temeridad.

Cuadro 48. Arrendamiento de tierras sueltas por el marqués de Torreblanca en Serrada. Año $1743^{677}$

\begin{tabular}{lccccc}
\hline & & & \multicolumn{2}{c}{ Renta a pagar (en fanegas) } \\
\cline { 4 - 6 } Renteros & Pagos & Obradas & Trigo & Cebada & Centeno \\
\hline Andrés Rodríguez Zorrilla & Medianillas & 5 & 12 & 2 & - \\
Narciso del Castillo & El Bosque & 5 & 12 & - & - \\
Narciso del Castillo & Raposeras & 8 & - & - \\
\hline
\end{tabular}

Fuente: Catastro del Marqués de la Ensenada. Respuestas Particulares. 1752. A.G.S. Elaboración propia.

A diferencia de los pueblos vecinos más al sur, que tenían en el espacio de sernas una salida para dimensionar sus labranzas, en Serrada el mayorazgo fue un freno para conseguir tierra en propiedad. Para paliar en parte este inconveniente, y por propia subsistencia, desde siglos tempranos arrendaron tierras del mayorazgo de Vega en la vecina La Moya, al tiempo que aprovecharon el terrazgo común de dicho término. Como se ha estudiado fueron plantando vides tanto en las tierras

A.H.P.V referentes a Villanueva de Duero (caja 379), La Seca (cajas 273/274/275/276), Rueda (cajas 238/239/241), Rubí de Bracamonte (cajas 236/237), y las ya citadas en las notas al pie de Serrada, La Moya y San Martín del Monte.

${ }^{674}$ Ibídem.

${ }^{675}$ A.H.P.V. Pt. 8215 , fol 284 y ss.

${ }^{676}$ Ibídem.

${ }^{677}$ A.H.P.V. Pt. 8215, fol $288-289$. 
del citado mayorazgo como en los comunes de Olmedo al que pertenecía dicho lugar, completamente despoblado a mediados del XVIII. La estimación del terrazgo labrado, representado en el mapa de 1750, que sigue a los cuadros adjuntos, refleja esta distribución que venimos detallando en la que el vińedo cobra enorme protagonismo ${ }^{678}$. Ha sido este cultivo, como en la vecina La Seca, el que ha posibilitado tierra en propiedad y sustento anual al campesino, amén de numerosos jornales en todas las estaciones del año a los vecinos sin propiedad, sean criados o jornaleros. Es importante este aspecto puesto que el $36 \%$ de los censados en Serrada son seglares que no poseen ningún terreno, ni ganado ovino, ni cubas.

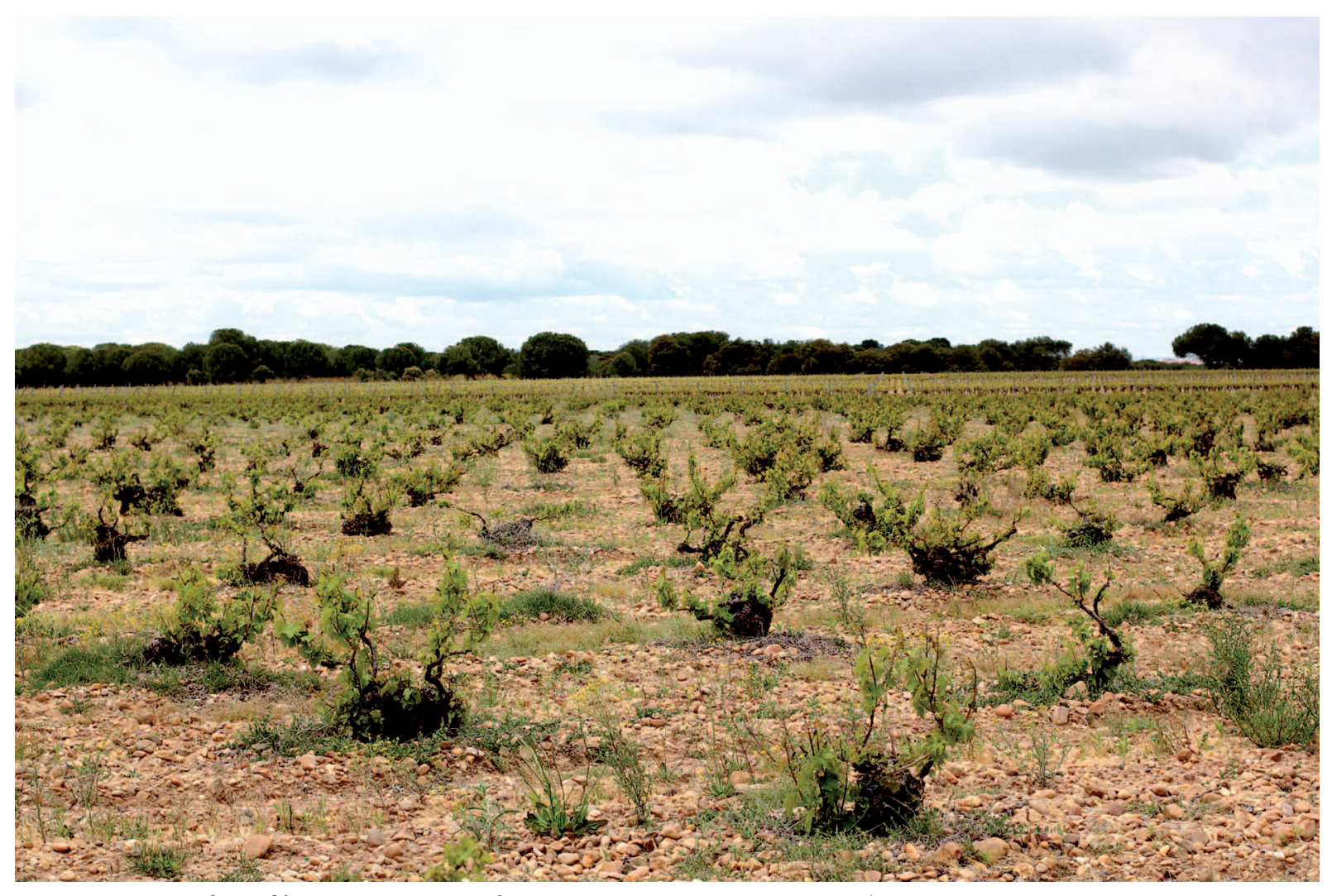

Imagen 59. Viñedo prefiloxérico en término de La Seca, en primavera. Foto: Archivo Javier Sanz, 15/05/2013. Un paisaje conformado por viñedos similares al que reproducimos, sobre gravas, con pinares al fondo, sería el que los labradores del siglo XVIII recorrerían en sus trabajos diarios. Obsérvese la plantación a marco real, las podas cortas, los tarragones en las viejas cepas que, como hemos estudiado, producirían cosechas de a moyo por aranzada, con uvas de excelente calidad.

${ }^{678}$ En Serrada, frente a los estamentos privilegiados, los 113 propietarios seglares, vecinos de la villa, se reparten 124 obradas de sembradura, distribuidas en 59 parcelas de 2,1 obradas de media y que representan el 14,94\% del total y 1.015,25 aranzadas de viñedo, repartidas en 314 pedazos de 3,23 aranzadas de media, que alcanzan el 62,73\% del total del viñedo.

En relación con las tierras labradas de el despoblado de San Martín del Monte, el estamento eclesiástico controla el $32,52 \%$, consistente en 135 obradas de sembradura y 294 aranzadas de vides. Entre los seglares, como puede apreciarse en el cuadro adjunto, destaca Manuel Joaquín de Vega, corregidor de Tordesillas y poseedor del mayorazgo en este tiempo, que, con 117,5 obradas, es el máximo poseedor, con permiso de Olmedo, poseedor de la jurisdicción del lugar y sobre el que extiende sus Propios de 385 obradas, eternamente presionadas por el pastoreo o la roturación vitícola. Los vecinos seglares de los pueblos limítrofes, especialmente los de Serrada que se analizan, poseen en propiedad hasta 59,34 ha, de las que 65,5 obradas son de sembradura y 52,5 aranzadas de viñedo.

La fuente utilizada para la elaboración del mapa de 1752, expuesto a continuación de los cuadros adjuntos ha sido, básicamente, la derivada de la información contenida en el Catastro de Ensenada (Respuestas Generales y Particulares), así como de los apeos, compraventas, inventarios de bienes, etc, que registran los protocolos notariales (A.H.P.V.) y de los distintos pleitos habidos en este siglo que afectan a los lugares estudiados (A.R.Ch.V). 

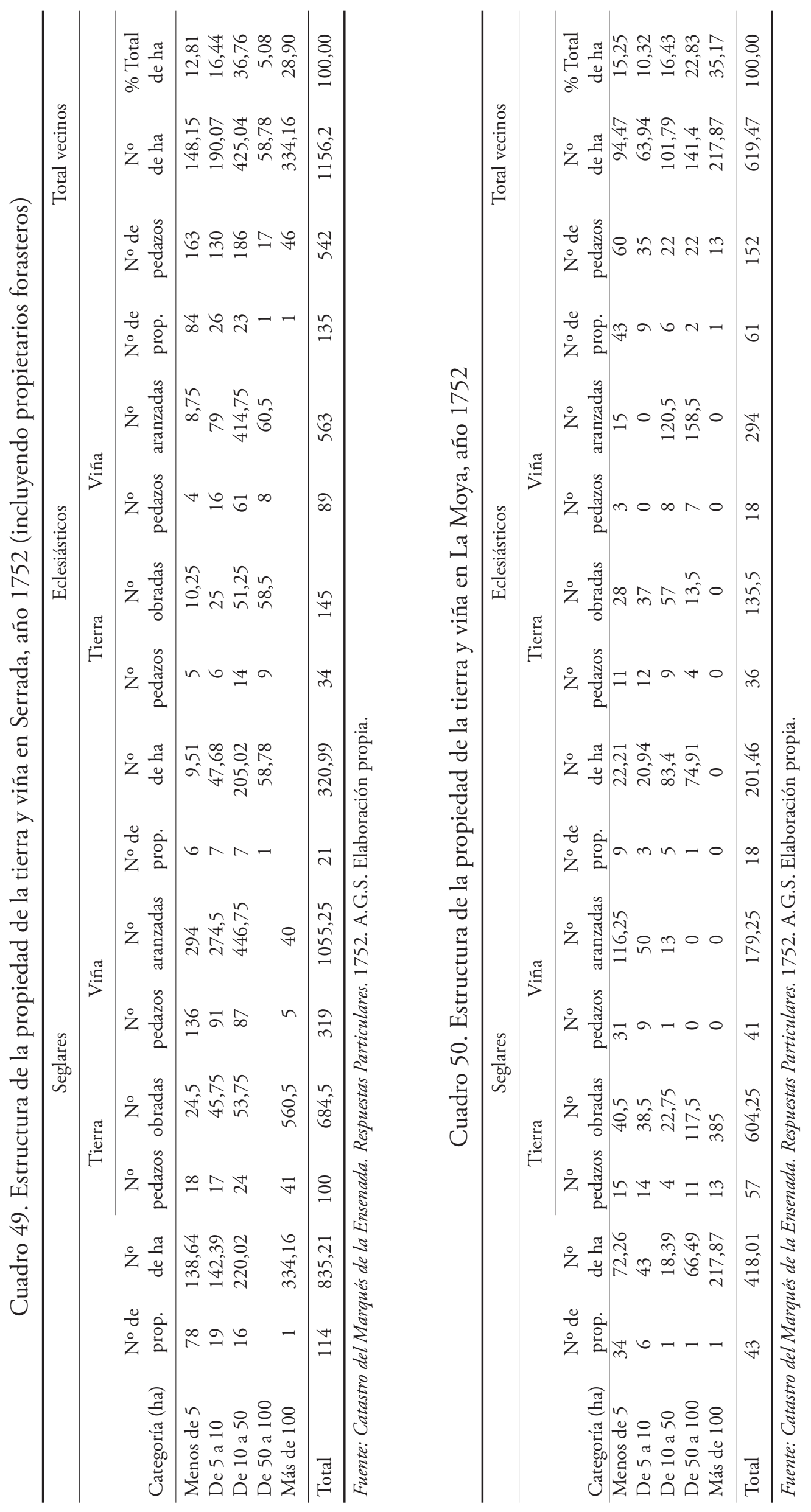


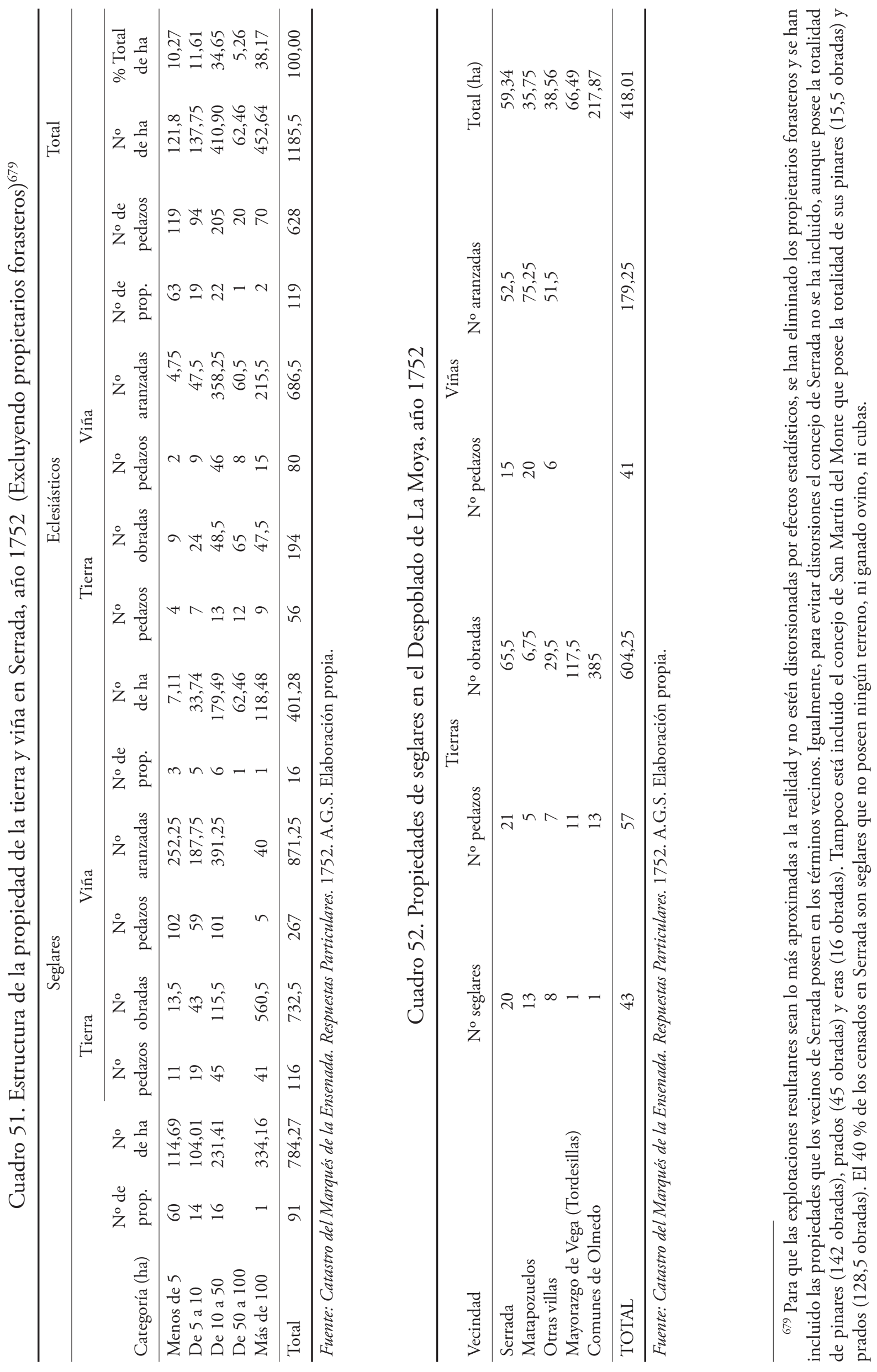


Cuadro 53. Animales de tiro en Serrada, año 1752 (107 propietarios, el 50\% de la población)

\begin{tabular}{lcccc}
\hline Categoría & No de titulares & $\%$ & No animales & $\%$ \\
\hline Marginal (1 cabeza) & 47 & 43,9 & 47 & 17,7 \\
Pequeña (2-3 cabezas) & 33 & 30,8 & 80 & 30,1 \\
Mediana (4-5 cabezas) & 20 & 18,7 & 87 & 32,7 \\
Grande (6-9 cabezas) & 6 & 5,6 & 41 & 15,4 \\
Muy grande (más de 10 cabezas) & 1 & 0,9 & 266 & 4,1 \\
\hline Total & 107 & 100,0 & 100 \\
\hline \multicolumn{1}{c}{ Animales de tiro en Serrada y pueblos, año $1752(117$ propietarios, el 59\% de la población) } \\
\hline Categoría & No de titulares & $\%$ & No animales & $\%$ \\
\hline Marginal (1 cabeza) & 48 & 41,0 & 48 & 15,7 \\
Pequeña (2-3 cabezas) & 37 & 31,6 & 106 & 29,5 \\
Mediana (4-5 cabezas) & 24 & 20,5 & 50 & 34,8 \\
Grande (6-9 cabezas) & 7 & 6,0 & 11 & 16,4 \\
Muy grande (más de 10 cabezas) & 1 & 0,9 & 305 & 3,6 \\
\hline Total & 117 & 100 & 100 \\
\hline
\end{tabular}

Fuente: Catastro del Marqués de la Ensenada. Respuestas Particulares. 1752. A.G.S. Elaboración propia.

En relación con el ganado de renta, en manos de seglares, la propiedad de las 1.411 ovejas se reparte entre 26 propietarios, de los que doce son labradores, pero que solo poseen 411 animales (29,1\% del total). La mediana explotación es la que acapara el 71,7\% del ganado. Son siete explotaciones que superan el centenar de animales y de los que dos son labradores, con 102 y 180 ovejas. El resto son pastores que, como en todos los pueblos cercanos, anhelan más pastos, entrar durante más tiempo en los majuelos y aprovechar las hojas de rastrojera y barbechera de la forma más intensa posible.

Cuadro 54. Ganado de renta en Serrada, año 1752 (26 propietarios, 12\% de la población)

\begin{tabular}{lcccr}
\hline Categoría & No de titulares & $\%$ & No animales & $\%$ \\
\hline Marginal (menos de 10 cabezas) & 9 & 34,6 & 28 & 2,0 \\
Pequeña (10-100 cabezas) & 10 & 38,5 & 372 & 26,4 \\
Mediana (101-250 cabezas) & 7 & 26,9 & 1.011 & 71,7 \\
\hline Total & 26 & 100,0 & 1.411 & 100 \\
\hline
\end{tabular}

Ganado de renta en Serrada y despoblados anexos, año 1752 (26 propietarios, 13\% de la población)

\begin{tabular}{lcrrr}
\hline Categoría & No de titulares & $\%$ & No animales & $\%$ \\
\hline Marginal (menos de 10 cabezas) & 9 & 34,6 & 28 & 2,0 \\
Pequeña (10-100 cabezas) & 10 & 38,5 & 372 & 26,4 \\
Mediana (101-250 cabezas) & 7 & 26,9 & 1.011 & 71,7 \\
Muy grande (más de 500 cabezas) & 0 & 0 & 0 & 0 \\
\hline Total & 26 & 100,0 & 1.411 & 100 \\
\hline
\end{tabular}

Fuente: Catastro del Marqués de la Ensenada. Respuestas Particulares. 1752. A.G.S. Elaboración propia.

Al igual que en el caso de La Seca, un indicador de la expansión vitícola es el número de cubas, su capacidad y beneficios. En Serrada, en este sentido, son propietarios 49 vecinos, que representan el 25\% de la población, y disponen de una capacidad de 2.397,5 moyos (613.760 litros). Son cifras menores que en la villa vecina, que quintuplica el almacenaje y casi duplica el porcentaje de poseedores respecto a la población total. 


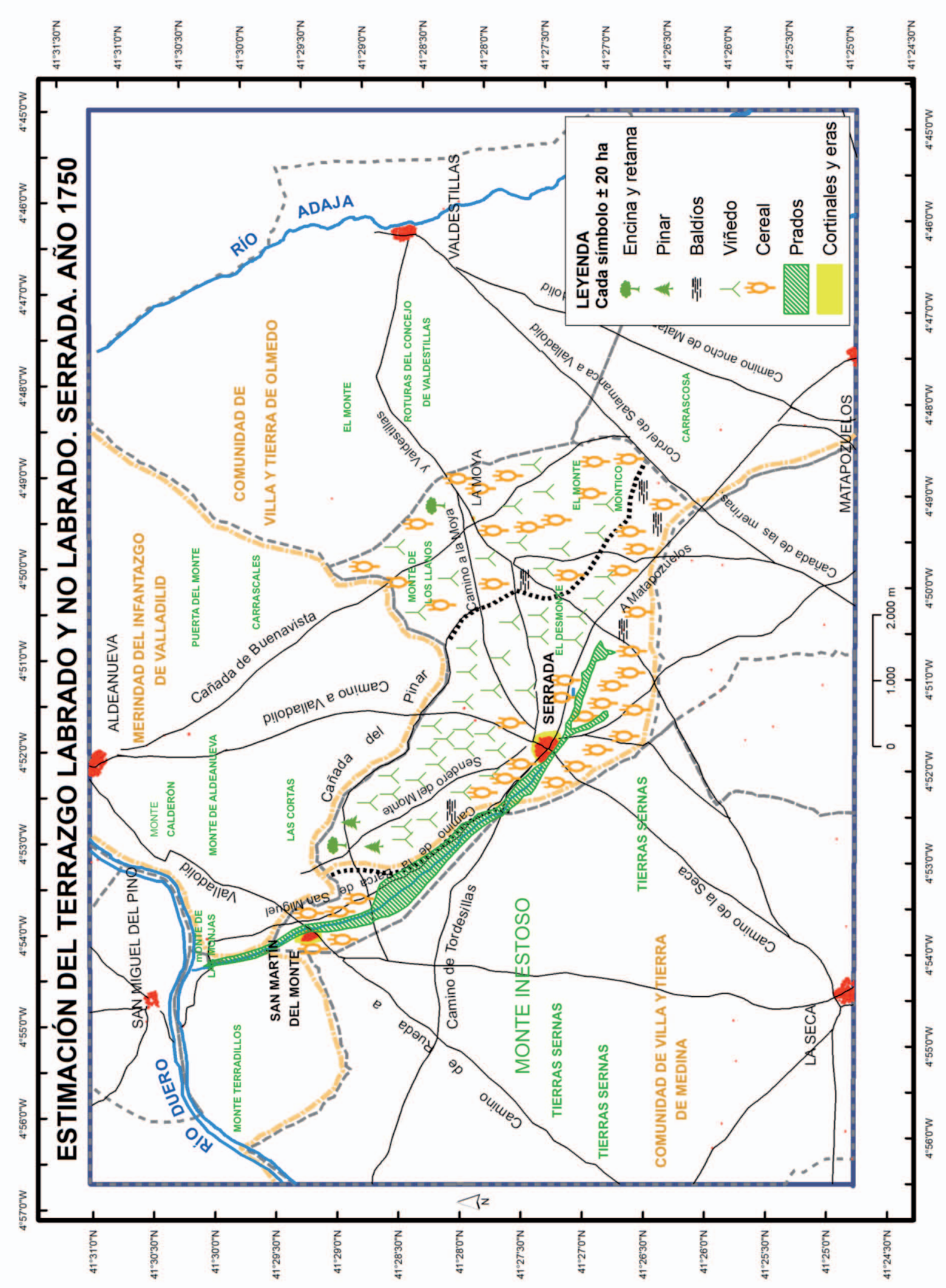



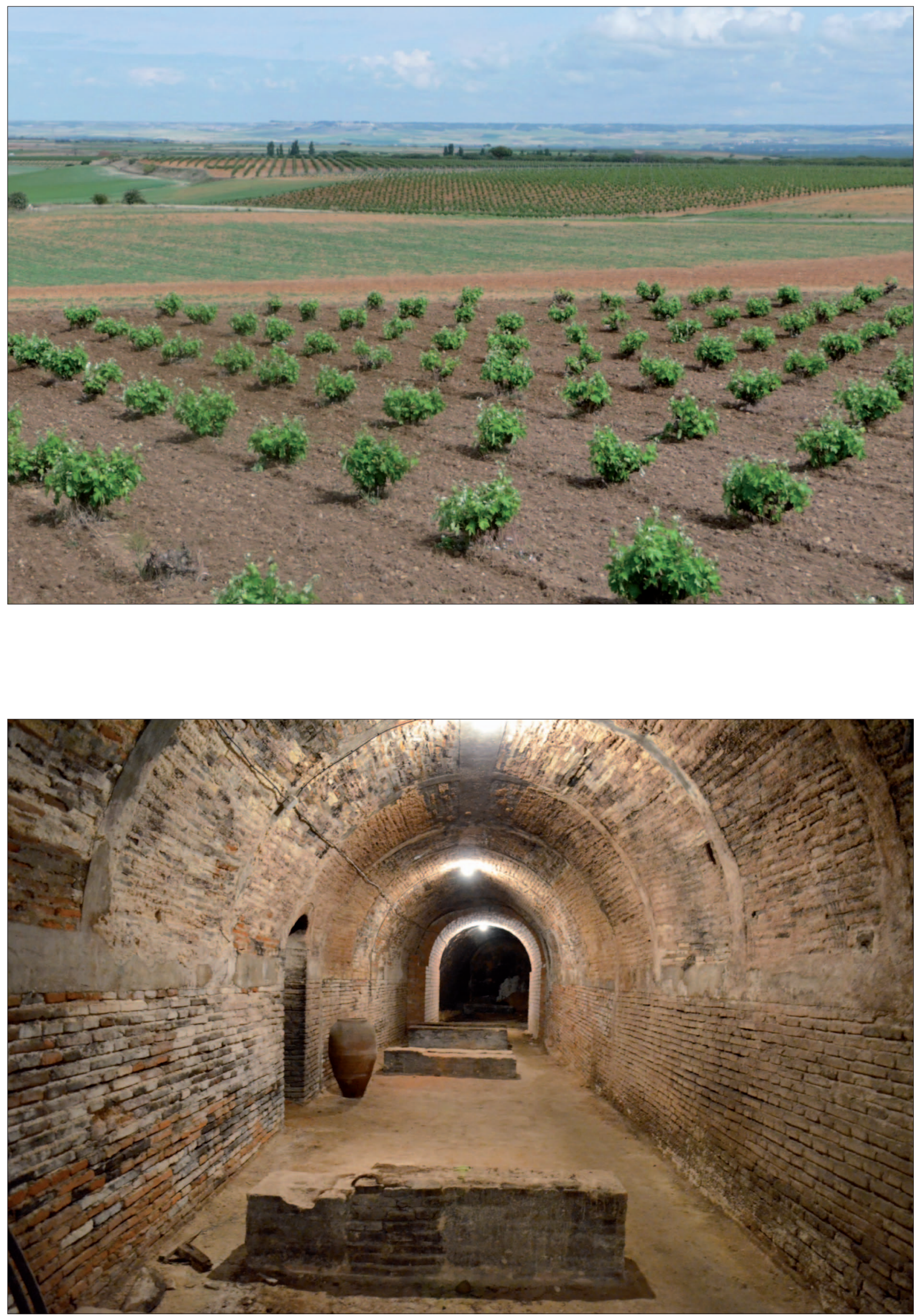

Imagen 60. Paisaje de viñedo (arriba, foto: primavera de 2008), e interior de bodega (abajo, foto: 04/09/2014) que nos acercan a lo que fueron los aprovechamientos relacionados con el viñedo en el siglo XVIII. En muchos pagos se entremezclaron las tierras de pan y las vińas. En este siglo de expansión vitícola se excavaron decenas de bodegas como la adjunta, propiedad de la familia Alonso Capellán. 
Cuadro 55. Cubas, capacidades y beneficios en Serrada y pueblos, año 1752

(49 propietarios, $25 \%$ de la población)

\begin{tabular}{lcccccccc}
\hline Categoría & No de titulares & $\%$ & No de cubas & $\%$ & Capacidad (moyos) & $\%$ & Beneficios (rs) & $\%$ \\
\hline $1-2$ cubas & 26 & 53,1 & 34 & 19,5 & 331 & 13,8 & 995 & 14,1 \\
$3-5$ cubas & 19 & 38,8 & 69 & 39,7 & 787,5 & 32,8 & 2.250 & 31,8 \\
6-10 cubas & 2 & 4,1 & 14 & 8,0 & 136,5 & 5,7 & 408 & 5,8 \\
$11-20$ cubas & 1 & 2,0 & 15 & 8,6 & 235 & 9,8 & 705 & 10,0 \\
$21-40$ cubas & - & - & - & & - & & - & 38,4 \\
Más de 40 cubas & 1 & 2,0 & 42 & 24,1 & 907,5 & 37,9 & 2.722 & 38,4 \\
\hline Total & 49 & 100 & 174 & 100 & $2.397,5$ & 100,0 & 7.080 & 100 \\
\hline
\end{tabular}

Distribución de las cubas y capacidades diferenciando seglares y eclesiásticos en Serrada y despoblados anexos, año 1752

\begin{tabular}{lcccccc}
\hline & No de cubas & $\%$ & Capacidad (moyos) & $\%$ & Beneficios (rs) & $\%$ \\
\hline Seglares & 102 & 58,6 & 997 & 41,6 & $2.878,5$ & 40,7 \\
Eclesiásticos & 72 & 41,4 & $1.400,5$ & 58,4 & $4.201,5$ & 59,3 \\
\hline Total & 174 & 100,0 & $2.397,5$ & 100,0 & 7.080 & 100 \\
\hline
\end{tabular}

Fuente: Catastro del Marqués de la Ensenada. Respuestas Particulares. 1752. A.G.S. Elaboración propia.

La singularidad en este ejemplo es el elevado porcentaje de cubas en manos eclesiásticas. Hasta el 58,4\% del almacenaje está en las bodegas de las casas granjas de las distintas órdenes religiosas asentadas en la villa. Especialmente importante, como se verá, es la casa granja de San Pablo, que se alza como uno de los centros elaboradores más importante de la comarca. Dispone de 42 cubas con una capacidad de 907,5 moyos (232.320 litros), que representan el 38,4\% del total de Serrada. Piénsese, a título de ejemplo, que en La Seca, centro vitícola por excelencia, solo hay un propietario con 21 cubas y 493 moyos, la mitad que la casa citada.

\section{c. Una pequeña villa con los días contados: San Martín del Monte}

Como se ha estudiado, esta pequeńa villa, pese a las limitaciones de suelo y propiedad que tienen sus vecinos, sale airosa de las crisis anteriores al XVIII. El Catastro de Ensenada detalla sus aprovechamientos antes de que los acontecimientos de comienzos del XIX pongan fin a su existencia. De hecho, quizá habría subsistido si no hubiera sufrido los desmanes napoleónicos pero, a la luz de los datos que aporta el citado catastro, de haberlo conseguido habría sido en una situación de extrema debilidad. Estos renteros de Santa Clara, como se ve en los cuadros estadísticos, hacen frente a la reducida dimensión de sus labranzas pero están faltos de terrazgo vitícola, les pesa el censo anual de 27 cargas de centeno y, por si fuera poco, deben sumar la pérdida de sus ingresos de pastos comunes, muy codiciados por La Seca, tras plantar los montes Pedroso e Inestoso. El conjunto de todos estos factores acaban por decidir su futuro.

Sus vecinos labran todo el término sin "necesidad" de forasteros ${ }^{680}$. Los seglares representan el 94\% del censo, a su vez el 92\% de los propietarios y poseen el 97\% de la propiedad. El eclesiástico representado supone el $6 \%$ del censo, a su vez el $8 \%$ de los propietarios y posee el 3\% de la propiedad. Los titulares que labran entre 10 y 50 ha suman un 62,31\% del terrazgo, porcentaje similar al que presenta La Seca $(60,9 \%)$ o Serrada, si se distribuye entre los pequeños y medianos labradores la tierra arrendada al señor de la villa. La diferencia estriba en que, mientras en estas villas vecinas sus titulares medianos labran 21,27 ha entre tierra y vińa, en La Seca, en San Martín la cifra no supera las 14 ha, y son únicamente de sembradura. Para aproximarse con la mayor exactitud a cada hacienda y analizar su situación, en los siguientes cuadros se han diferenciado cultivos y ańadido animales y otros bienes a cada cultivador.

\footnotetext{
${ }^{680}$ Como en los anteriores ejemplos, en aras de simplificar y evitar distorsiones de datos, se han realizado las tablas centrándose únicamente en las propiedades de tierras de sembradura y vińedo. En este sentido conviene anotar que el 25\% de los censados en San Martín del Monte son seglares que no poseen ningún terreno, ni ganado ovino, ni cubas. El concejo de San Martín no se ha incluido, aunque posee la totalidad de pinares (16 obradas) y prados (128 obradas).
} 


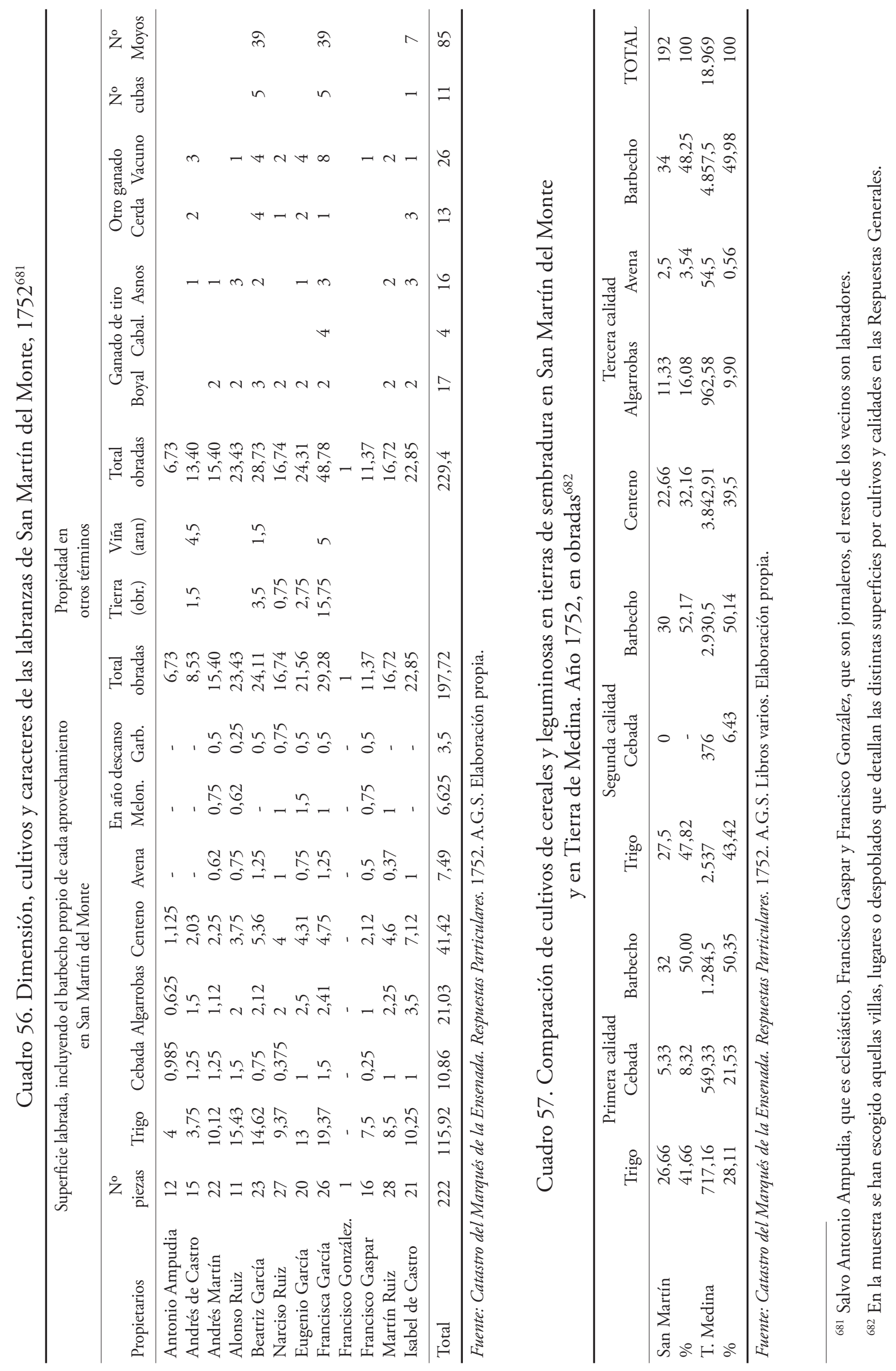


Cuadro 58. Estructura de la propiedad de la tierra en San Martín del Monte, año 1752

\begin{tabular}{|c|c|c|c|c|c|c|c|c|c|c|c|c|}
\hline \multirow[b]{3}{*}{$\begin{array}{l}\text { Categoría } \\
\text { (ha) }\end{array}$} & \multicolumn{5}{|c|}{ Seglares } & \multicolumn{3}{|c|}{ Eclesiásticos } & \multicolumn{4}{|c|}{ Total } \\
\hline & \multicolumn{5}{|c|}{ Tierra } & \multicolumn{3}{|c|}{ Tierra } & \multirow[b]{2}{*}{ No } & \multirow[b]{2}{*}{$\begin{array}{c}\text { No } \\
\text { pedazos }\end{array}$} & \multirow[b]{2}{*}{$\begin{array}{c}\text { No de } \\
\text { s ha }\end{array}$} & \multirow[b]{2}{*}{$\%$} \\
\hline & No & $\begin{array}{l}\text { No de } \\
\text { ha }\end{array}$ & $\begin{array}{c}\text { No } \\
\text { pedazos }\end{array}$ & $\begin{array}{c}\text { No } \\
\text { obrada }\end{array}$ & No & $\begin{array}{c}\text { No de } \\
\text { ha }\end{array}$ & $\begin{array}{c}\text { No } \\
\text { pedazos }\end{array}$ & $\begin{array}{c}\text { No } \\
\text { obrada }\end{array}$ & & & & \\
\hline Menos de 5 & 2 & 5,39 & 16 & 9,53 & 1 & 3,81 & 11 & 6,74 & 3 & 27 & 9,2 & 8,14 \\
\hline De 5 a 10 & 4 & 33,3 & 93 & 59 & 0 & 0 & 0 & 0 & 4 & 93 & 33,39 & 29,5 \\
\hline De 10 a 50 & 5 & 70,4 & 112 & 124,44 & 0 & 0 & 0 & 0 & 5 & 112 & 70,42 & 62,3 \\
\hline De 50 a 100 & & 0 & 0 & 0 & 0 & 0 & 0 & 0 & 0 & 0 & 0 & 0,00 \\
\hline Más de 100 & 0 & 0 & 0 & 0 & 0 & 0 & 0 & 0 & 0 & 0 & 0 & 0,00 \\
\hline Total & 11 & 109 & 221 & 192,97 & 1 & 3,81 & 11 & 6,74 & 12 & 232 & 113 & 100 \\
\hline
\end{tabular}

Fuente: Catastro del Marqués de la Ensenada. Respuestas Particulares. 1752. A.G.S. Elaboración propia.

En el caso analizado, las declaraciones generales del Catastro son prácticamente coincidentes respecto a las particulares, lo cual es de agradecer. De las 350 obradas que componen el término, 192 son de sembradura, 140 de prados, 13 de pinares, una de huerta, media de bosque y cuatro obradas que ocupa el pueblo. En relación a la menor dimensión de las labranzas que aquí se tratan, se debe añadir otro factor importantísimo y es que esta mengua no está compensada con una mayor calidad del terrazgo. De las 192 obradas de secano tan sólo 64 se catastran como de primera calidad, 60 de segunda y 68 de tercera. El trigo es el cultivo por excelencia, pues destinan al mismo 115 obradas de las 197 declaradas, en detrimento de la cebada que tan sólo la ven 10 obradas. Esta reducida cifra puede ser explicada por la necesidad de su siembra hasta alcanzar el mínimo necesario, sea en tierras de primera o segunda.

La tierra está tremendamente parcelada y repartida de forma equilibrada entre sus vecinos. Salvo el jornalero Francisco González y los guardas Lázaro Martín y Antonio Pérez, los restantes once vecinos eran labradores y, amén del cura, labran directamente sus 222 piezas de tierra, repartidas entre los pagos del Rubial y el Espino, que suman 198 obradas de las 350 que totaliza el término. Estas cifras dan 0,89 obradas de media por parcela, muy inferior a las dimensiones de las propiedades de los seglares en los pueblos vecinos: 2,10 en Serrada; 1,58 en La Seca o 1,48 en Rubí. Como se ha anotado, buena parte de ellas son sembradas de trigo cada año, pues, salvando el barbecho, se computan 54,16 obradas, seguidas a gran distancia del centeno (22,66 obradas), las algarrobas $(11,13$ obradas), la cebada con casi 5,33 obradas y la avena con apenas 2,5. Se debe valorar, por último, la importancia de las 5,33 obradas declaradas, sembradas de melones, y las 3,5 de garbanzos y que, junto a la obrada de hortaliza que atiende el mencionado jornalero Francisco González, completan los cultivos existentes.

En cuanto a los rendimientos que declaran, no se apartan de la tónica dominante en esta mitad de centuria. De ahí que, puesto que siglo tras siglo esgrimen la pobreza y la necesidad como una de sus desgracias más duraderas, se está obligado a considerar la falta de tierra, y de tierra en propiedad sin rentas que pagar, como uno de los factores fundamentales que hicieron inviable esta villa.

Puede que este factor no incentivara a sus habitantes a arrendar más tierra fuera del lugar para dimensionar sus explotaciones, o que el censo perpetuo a Santa Clara impidiera la capitalización necesaria para comprar tierra en los pueblos vecinos. Lo que parece cierto es que las deficiencias estructurales explicadas fueron paliadas, en una economía de casi subsistencia, por los ingresos de pastos y el aprovechamiento que de ellos obtenían los vecinos con la cría de ganado vacuno y de cerda que, se entiende, aminoró la precariedad de ingresos que se derivaba de la falta de tierra en propiedad. 
Cuadro 59. Animales de tiro en San Martín del Monte, año 1752 (10 propietarios, el 59\% de la población)

\begin{tabular}{lcccr}
\hline Categoría & No de titulares & $\%$ & No de animales & $\%$ \\
\hline Marginal (1 cabeza) & 1 & 10,0 & 1 & 2,6 \\
Pequeña (2-3 cabezas) & 4 & 40,0 & 10 & 25,6 \\
Mediana (4-5 cabezas) & 4 & 40,0 & 19 & 48,7 \\
Grande (6-9 cabezas) & 1 & 10,0 & 9 & 23,1 \\
\hline Total & 10 & 100 & 39 & 100 \\
\hline
\end{tabular}

Fuente: Catastro del Marqués de la Ensenada. Respuestas Particulares. 1752. A.G.S. Elaboración propia.

Cuadro 60. Cubas, capacidades y beneficios en San Martín del Monte, año 1752

(3 propietarios, el 18\% de la población)

\begin{tabular}{lcccccccc}
\hline Categoría & No de titulares & $\%$ & No de cubas & $\%$ & Capacidad (moyos) & $\%$ & Beneficios(rs) & $\%$ \\
\hline $1-2$ cubas & 1 & 33,3 & 1 & 9,1 & 7 & 8,2 & 0 & 0 \\
$3-5$ cubas & 2 & 66,7 & 10 & 90,9 & 78 & 91,8 & 117 & 100 \\
\hline Total & 3 & 100 & 11 & 100 & 85 & 10 & 117 & 100 \\
\hline
\end{tabular}

Fuente: Catastro del Marqués de la Ensenada. Respuestas Particulares. 1752. A.G.S. Elaboración propia.

Respecto a los animales de tiro que predominan en esta pequeña villa, consta la utilización de bueyes como animales de tiro en todas las casas de labradores. La abundancia de pastos, del monte de encina que pueden aprovechar y la falta de viñedo en la mayoría de las haciendas explica la no utilización del ganado mular, más delicado y exigente en cuanto a su cuidado y alimentación.

Por último y aunque no es significativo en el cómputo agrario del lugar, se catastran once cubas con una capacidad total de 85 moyos, propiedad de Beatriz García y Francisca García con cinco cubas e Isabel de Castro con una cuba. La propia localización de la villa, casi en el fondo del pequeño valle que recorría el arroyo, cercana su desembocadura al Duero, no era el sitio más idóneo para albergar cubas en su subsuelo. De hecho, una de sus dos bodegas se localizaba fuera del lugar poblado, en una de las laderas orientadas al mediodía del citado valle. Quizá fuera esta localización un factor más de su falta de vocación vitícola en aquel tiempo. Se dice en aquel tiempo porque el descenso del nivel del acuífero, la desaparición del arroyo y los nuevos tiempos han hecho que en el lugar donde se levantaban casas, calles, iglesia y cementerio hoy fructifique la varietal verdeja.

\section{c. Rubí de Bracamonte. La importancia del arrendamiento para dimensionar unas explota- ciones predominantemente cerealistas}

A diferencia de las villas situadas al norte de Medina, estos pueblos meridionales carecen a mediados del XVIII de tierra donde poder aumentar la dimensión de las explotaciones o plantar unos centenares de cepas. El vińedo permanece reducido a los pagos más pobres y muchos arenales, ante la esterilidad de sus suelos, quedan abandonados temporalmente. Estos condicionantes de suelos suponen una limitación en la vida de jornaleros y pequeńos propietarios. A mediados del XVIII los prados ocupan en los pueblos al norte un $2,5 \%$ de su terrazgo y los montes y pinares un $4,54 \%$. En estas villas al sur, los montes y pinares tan solo ocupan el $0,32 \%$, mientras que los prados se extienden por el $11,5 \%$ del total del término. 
Cuadro 61. Distribución de la tierra labrada en Rubí de Bracamonte, año 1752

\begin{tabular}{|c|c|c|}
\hline Propietarios & Hectáreas & $\%$ \\
\hline Seglares & $1.125,92$ & 54,5 \\
\hline Eclesiásticos & 814,5 & 39,5 \\
\hline Concejo & 123,65 & 6,0 \\
\hline Total & $2.064,07$ & 100 \\
\hline
\end{tabular}

Fuente: Catastro del Marqués de la Ensenada. Respuestas Particulares. 1752. A.G.S. Elaboración propia.

Salgüerales, bodones y charcas no tendrán más aprovechamientos que los que tienen y poco o nada pueden hacer los más desheredados por disponer de alguna propiedad o esquilmo con que completar sus ingresos. De ahí que los vecinos sin propiedad alcanzan un $60 \%$ del total, cifras mucho más altas que las que se dan al norte, pues en Serrada este porcentaje es del 39,73\% y en La Seca del 32,5\%. A los condicionantes físicos del suelo, se debe añadir, además, la falta de viñedo o de montes donde poder extenderse, toda vez que las tierras del concejo no cumplen este papel al estar en manos de los labradores locales.

Cuadro 62. Estructura de la propiedad de la tierra y vińa en Rubí de Bracamonte, año 1752 (incluidos los forasteros)

\begin{tabular}{|c|c|c|c|c|c|c|c|c|c|c|c|c|}
\hline \multirow[b]{3}{*}{$\begin{array}{l}\text { Categoría } \\
\text { (ha) }\end{array}$} & \multicolumn{6}{|c|}{ Seglares } & \multicolumn{6}{|c|}{ Eclesiásticos } \\
\hline & \multirow[b]{2}{*}{$\begin{array}{l}\text { No de } \\
\text { prop. }\end{array}$} & \multirow[b]{2}{*}{$\begin{array}{c}\text { No de } \\
\text { ha }\end{array}$} & \multicolumn{2}{|c|}{ Tierra } & \multicolumn{2}{|c|}{ Viña } & \multirow[b]{2}{*}{$\begin{array}{l}\text { No de } \\
\text { prop. }\end{array}$} & \multirow[b]{2}{*}{$\begin{array}{c}\text { No de } \\
\text { ha }\end{array}$} & \multicolumn{2}{|c|}{ Tierra } & \multicolumn{2}{|c|}{ Viña } \\
\hline & & & $\begin{array}{c}\text { No } \\
\text { pedaz. }\end{array}$ & $\begin{array}{c}\text { No } \\
\text { obrada }\end{array}$ & $\begin{array}{c}\text { No } \\
\text { pedaz. }\end{array}$ & $\begin{array}{l}\text { No de } \\
\text { aranz. }\end{array}$ & & & $\begin{array}{c}\text { No } \\
\text { pedaz. }\end{array}$ & $\begin{array}{c}\text { No } \\
\text { obrada }\end{array}$ & $\begin{array}{c}\text { No } \\
\text { pedaz. }\end{array}$ & $\begin{array}{c}\text { No } \\
\text { aranz. }\end{array}$ \\
\hline Menos de 5 & 56 & 127 & 85 & 109 & 38 & 155 & 5 & 13,5 & 12 & 18 & 1 & 8 \\
\hline De 5 a 10 & 18 & 128 & 100 & 153 & 25 & 98 & 3 & 22,5 & 32 & 39,75 & 0 & 0 \\
\hline De 10 a 50 & 24 & 615 & 654 & 973,5 & 35 & 151 & 21 & 504 & 620 & 871,7 & 5 & 26,75 \\
\hline De 50 a 100 & 4 & 255 & 269 & 407,2 & 8 & 58,5 & 4 & 27 & 340 & 447 & 6 & 49 \\
\hline Concejo $^{683}$ & 1 & 123 & 135 & 218,5 & & & & & & & & \\
\hline Total & 103 & 1.249 & 1.243 & 1.861 & 106 & 462,5 & 33 & 814 & 1.004 & 1.376 & 12 & 83,75 \\
\hline
\end{tabular}

Fuente: Catastro del Marqués de la Ensenada. Respuestas Particulares. 1752. A.G.S. Elaboración propia.

Como se desprende del cuadro adjunto, los seglares representan el $85 \%$ del censo y el $76 \%$ de los propietarios, poseyendo el $60,5 \%$ de la propiedad, mientras que los eclesiásticos que suman el $15 \%$ del censo y el $24 \%$ de los propietarios poseen el 39,5\% de la propiedad. Detrás de estas cifras, sin embargo, se precisan matizaciones. A diferencia de los ejemplos tratados, el número y propiedad de los seglares forasteros en este término es muy importante. Hasta 53 propietarios de otra vecindad poseen 347 obradas y 151 aranzadas. Entre ellos destacan los integrados en el estamento nobiliario, como José Bernardo de la Torre, con 87 obradas; Ma Josefa de Velasco, con 117; Antonio de Villarroel, con 48 o José Aramburu, con 57. Son parte de estas tierras, conjuntamente con las 1.037 obradas propiedad de religiosos que se catastran arrendadas a laicos $(75,3 \%$ del total de las que poseen), las que dimensionan las labranzas de los vecinos seglares de Rubí.

He aquí otro factor diferenciador respecto a las terrazas del norte de Medina. En Rubí la propiedad religiosa, que se extiende hasta casi un $40 \%$ del término, y se distribuye entre buena parte de las casas conventuales y religiosos de la vecina Medina del Campo, en su mayor parte no se labra directamente. Distintos renteros laicos, vecinos de la villa, toman 1.037 obradas de $1.376,5$ que poseen, por 643,25 fanegas anuales (1,61 fanegas la obrada), que dejan a sus propietarios religiosos una utilidad de 9.231,5 reales al ańo (14,35 reales fanega).

${ }^{683}$ En el Concejo de Rubí no se han incluido los pastos. 
Cuadro 63. Distribución de la propiedad entre los vecinos seglares en Rubí, año 1752

\begin{tabular}{lcccccc}
\hline Categoría (ha) & $\begin{array}{c}\text { No de } \\
\text { vecinos }\end{array}$ & $\begin{array}{c}\text { Tierras } \\
\text { propias }\end{array}$ & $\begin{array}{c}\text { Tierras } \\
\text { arrendadas }\end{array}$ & $\begin{array}{c}\text { Hectáreas } \\
\text { totales }\end{array}$ & $\begin{array}{c}\text { \% del total } \\
\text { de vecinos }\end{array}$ & $\begin{array}{c}\text { \% del total } \\
\text { de ha }\end{array}$ \\
\hline Sin propied. & 81 & 0 & 0 & 0 & 60,0 & 0,0 \\
Menos de 5 & 25 & 63,4 & 6,1 & 69,5 & 18,5 & 5,9 \\
De 5 a 10 & 10 & 68,7 & 1,7 & 70,4 & 7,4 & 5,9 \\
De 10 a 50 & 12 & 134,7 & 204,4 & 339,1 & 8,9 & 28,6 \\
De 50 a 100 & 5 & 120,2 & 293 & 413,2 & 3,7 & 34,8 \\
Más de 100 & 2 & 137,6 & 156,8 & 294,4 & 1,5 & 24,8 \\
\hline Total & 135 & 524,6 & 662 & $1.186,6$ & 100 & 100 \\
\hline
\end{tabular}

Fuente: Catastro del Marqués de la Ensenada. Respuestas Particulares. 1752. A.G.S. Elaboración propia.

En una aproximación más exacta a la realidad de las distintas explotaciones, en el cuadro de distribución de la propiedad seglar se advierte que estos labran más tierras arrendadas (662 ha) que propias $(524,6 \mathrm{ha})$, y que, de no hacerlo, les resultaría inviable la actividad, pues, si se considera al grupo registrado con propiedad entre 10 y 50 ha como el más representativo, si se eliminan aquellas que llevan a renta, disponen como propias de 11,2 ha, que dimensionan hasta 28,25 ha de media por explotación con las 204,4 obradas que toman en arrendamiento a los religiosos absentistas del lugar.

Los condicionantes físicos citados, más los estructurales analizados, dejan a esta villa sin apenas explotaciones de menos de cinco hectáreas, pues tan solo se registran 25 vecinos que labran 69,5 ha, que suponen el 22,7\% de los vecinos propietarios y el 5,9\% del total de ha labradas. Este hecho es completamente inusual al norte de Medina. Recuérdese que en La Seca en este segmento se encuentran 239 vecinos seglares $(68,8 \%)$ de un total de 347 seglares propietarios, que labran 467 ha que representan un $9,7 \%$ del total labrado. En Serrada, por su parte, con menos de cinco ha se encuentran 63 de 119 seglares propietarios (52,9\%), labrando 121,8 ha que suponen el 10,27\% del total labrado.

Difícil tesitura, en cualquier caso, para unos y otros. La falta de tierra en propiedad anula cualquier atisbo de capitalización y de reservas ante imponderables. Muchos arrendadores acaban prestando dinero a sus arrendatarios, tras las malas cosechas, y la espiral genera más y más dependencia y debilidad estructural. Piénsese, a modo de ejemplo, que en Rubí los propietarios seglares declaran como censos y deudas la importante cantidad de 50.826 reales, frente a los 1.500 que declaran los eclesiásticos. De dicha cantidad, la mayor parte (34.367 reales) es adeudada por doce de los diecisiete labradores que arriendan 1.161,25 obradas al mencionado estamento clerical.

Mención especial se debe hacer al viñedo. Se mantiene el existente y las hojas de viña seguirán existiendo dos siglos más, pero sin la dinamización que impulsan los pueblos al norte de Medina. En el caso de Rubí, el viñedo lo detentan los vecinos seglares en su mayor parte (462,4 aranzadas), frente a las 12 de los eclesiásticos, como un complemento a las tierras de sembradura y nunca como fundamento de las mismas.

Lo que sí entienden necesario es el acompañamiento ganadero. De los trece titulares de rebaños que representan el $10 \%$ de la población, siete son labradores que poseen 1.142 ovejas $(85,3 \%)$ de las 1.338 totales. El estiércol es necesario, si se desean revolver tierras o mejorar sus rendimientos, y la práctica de estercolar a red o esparciendo la basura desde los carros se encuentra como actividad frecuente desde mediados de esta centuria. Los animales de tiro se reparten entre 76 propietarios que representan el 55\% de los vecinos censados. Como en el resto de los lugares, asnos propiedad de arrieros, jornaleros y pequeños propietarios constituyen una buena parte. Otro aspecto que hay que destacar es la permanencia del buey como animal de tiro en la mayor parte de las casas labradoras, a diferencia de las mulas que se extienden por las labranzas vitícolas. En Rubí los treinta labradores con propiedad labran sus heredades con 75 bueyes y 26 mulas, lo que prueba la importancia del primero como animal de tiro, aun cuando parte del término lo constituyen tierras livianas en que la mula se desenvuelve sin problemas. 
Cuadro 64. Ganado de renta en Rubí de Bracamonte, año 1752

\begin{tabular}{lcccr}
\hline Categoría & No de titulares & $\%$ & No de animales & $\%$ \\
\hline Marginal (menos de 10 cabezas) & 1 & 7,7 & 6 & 0,4 \\
Pequeńa (10-100 cabezas) & 5 & 38,5 & 130 & 9,7 \\
Mediana (101-250 cabezas) & 6 & 46,2 & 940 & 70,3 \\
Grande (251-500 cabezas) & 1 & 7,7 & 262 & 19,6 \\
\hline Total & 13 & 100 & 1.338 & 100 \\
\hline
\end{tabular}

Cuadro 65. Animales de tiro en Rubí de Bracamonte, año 1752

\begin{tabular}{lcccr}
\hline Categoría & No de titulares & $\%$ & No de animales & $\%$ \\
\hline Marginal (1 cabeza) & 19 & 25,0 & 19 & 6,0 \\
Pequeña (2-3 cabezas) & 25 & 32,9 & 57 & 18,1 \\
Mediana (4-5 cabezas) & 14 & 18,4 & 61 & 19,4 \\
Grande (6-9 cabezas) & 11 & 14,5 & 89 & 28,3 \\
Muy grande (más de 10 cabezas) & 7 & 9,2 & 89 & 28,3 \\
\hline Total & 76 & 100 & 315 & 100 \\
\hline
\end{tabular}

Fuente: Catastro del Marqués de la Ensenada. Respuestas Particulares. 1752. A.G.S. Elaboración propia.

Cuadro 66. Cubas y capacidades en Rubí de Bracamonte, año 1752. En cántaras. (26 propietarios, el 19\% de la población)

\begin{tabular}{lcccccc}
\hline Categoría & No de titulares & $\%$ & Cubas & $\%$ & Capacidad & $\%$ \\
\hline $1-2$ cubas & 22 & 84,6 & 32 & 65,3 & 5.144 & 64,8 \\
$3-5$ cubas & 3 & 11,5 & 10 & 20,4 & 1.649 & 20,8 \\
6-10 cubas & 1 & 3,8 & 7 & 14,3 & 1.145 & 14,4 \\
\hline Total & 26 & 100,0 & 49 & 100 & 7.938 & 100 \\
\hline
\end{tabular}

Distribución de las cubas y capacidades en Rubí de Bracamonte, ańo 1752

\begin{tabular}{lcccc}
\hline & No de cubas & $\%$ & Capacidad & $\%$ \\
\hline Seglares & 37 & 75,5 & 5.950 & 75,0 \\
Eclesiásticos & 12 & 24,5 & 1.988 & 25,0 \\
\hline Total & 49 & 100 & 7.938 & 100 \\
\hline
\end{tabular}

Fuente: Catastro del Marqués de la Ensenada. Respuestas Particulares. 1752. A.G.S. Elaboración propia.

En relación con el resto de ganados, es de destacar la gran importancia que en esta villa tiene el ganado de cerda y el vacuno, especialmente el primero. De un total de 137 vecinos seglares censados, 83 declaran poseer algún animal de cerda, totalizando un total de 284 . En esta distribución no escapan los jornaleros, ni los arrieros, ni los labradores. Meritoria es la cabańa vacuna con 41 reses en manos de 24 vecinos. La existencia de numerosos cortinales y los abundantes prados comunes se entienden como un aliciente para mantener estos ganados que complementan la alimentación de los vecinos y que, si se pueden criar y vender, sirven para aliviar a los más necesitados.

Respecto al $\mathrm{n}^{\circ}$ de cubas y capacidad, por concluir analizando este factor como en el resto de los ejemplos, conviene anotar que el $75 \%$ de dicha capacidad está en manos de seglares y la mayor capacidad se encuentra repartida entre pequeños propietarios. El 68,8\% del total se distribuye en 32 cubas propiedad de 32 titulares. El mayor propietario es el capellán Pedro Rodríguez, con siete cubas, 1.147 moyos y buena labranza, seguido del principal propietario Pedro de Coca, que declara tres cubas con una capacidad de 635 moyos. Salvo excepciones, cubas y bodegas son de pequeñas dimensiones, lo que parece indicar que el consumo tiene un componente local o comarcal, en su mayor parte. 


\section{Un acercamiento al estudio de la rentabilidad agraria en la segunda mitad del siglo XVIII}

Como se trató a finales del XVI, el análisis económico de las explotaciones y su rentabilidad es tan variable como múltiples son los factores que afectan a cada cultivo, desde que la semilla cae en el surco hasta que el grano se guarda en la panera. No obstante, a mediados del siglo XVIII, se dispone de documentación para poder acometer esta tarea con cierta exactitud. Para ello se utilizarán fuentes diversas, sean libros de contabilidad de haciendas eclesiásticas, sean inventarios de bienes en que se precisan trabajos y rendimientos en los distintos cultivos.

No entra entre los objetivos de este trabajo establecer o estimar explotaciones medias, entre otras cosas porque, a la vista de lo investigado, es imposible establecer criterios para poder definirla. La realidad del siglo del XVI, XVIII o del XIX, indica que labranzas grandes o pequeñas son rentables o ruinosas debido a mil factores, imposibles de concretar en teoría, pero decisivos en el acontecer diario. Cuántas veces en los cientos de inventarios o registros notariales consultados la enfermedad del campesino, la muerte de una mula, un pedrisco, el reparto de bienes entre herederos, el avinagramiento del vino o dos malas cosechas seguidas llevaron a haciendas de distinto tamaño a la ruina, mientras que otras semejantes pudieron seguir adelante. De ahí que, aunque se estimen los gastos e ingresos teóricos por unidad de superficie de los distintos cultivos, se opte por seguir mostrando explotaciones reales representativas, con nombres y apellidos, y gastos e ingresos reales para adentrarse en la vida campesina de la Tierra de Medina a mediados del siglo XVIII.

$\mathrm{Al}$ no detallar el Catastro de Ensenada, en el caso de Serrada, las tierras que los labradores llevan a renta del marqués de Torreblanca, pero disponer de diez años antes de los contratos firmados entre partes, se han podido reconstruir con bastante exactitud las dimensiones de las labranzas de diez labradores representativos de esta villa de Serrada, lo que vienen a ratificar cuanto se ha tratado en el anterior epígrafe. En villas señoriales como la citada, donde la presencia religiosa está invirtiendo ingentes capitales desde fines del XVIII, apenas se encuentran labradores que sumen más de 10 ha en tierras propias fruto de la actividad agraria y, cuando aparecen, si se rastrea varias generaciones el origen de sus haciendas, se encuentra que se ha formado bien por herencias, bien por estar próximos familiarmente a escribanos que invierten sus capitales en tierra (el caso de la familia Moyano en Serrada) o a cargos religiosos originarios del lugar con importantes bienes raíces.

Unos y otros, en fin, como en el resto de los ejemplos estudiados, han de recurrir al arrendamiento como forma de dimensionar sus explotaciones, sea en el caso de las sernas en La Seca, en las tierras arrendadas por los vecinos de Rubí a los eclesiásticos forasteros, o al propio señor de la villa. Como se aprecia en los cuadros adjuntos, a mediados del XVIII, las explotaciones que viven de la propia actividad suelen labrar entre 10 y 50 ha, siendo las más importantes por su entidad y tierra labrada las comprendidas entre 20 y 40 ha.

Como puede comprobarse en el cuadro adjunto, de tierra labrada propia y arrendada, la media de los diez labradores que se entiende representativos del conjunto disponen de 11,94 ha en propiedad y llevan 15,83 en renta por lo que labran de media 27,77 ha. No se deben pasar por alto las deudas que se anotan en la mayor parte de los casos, sobre todo cuando se trata de labradores veteranos, con más de diez ańos de actividad. Las diez explotaciones de la muestra declaran en 1752 hasta 21.800 reales de hipotecas, otorgadas por el estamento eclesiástico y que pesan sobre parte de sus bienes raíces. Aunque las medias enmascaran en muchas ocasiones la realidad, si se tienen en cuenta los bienes dotales con que inician su actividad y que se cifran en estos años en torno a $8 / 10.000$ reales en las labranzas medias, el nivel de endeudamiento que arrastran se cifra, entre un $25 / 30 \%$ de los bienes raíces poseídos. Por último y antes de entrar a analizar en detalle distintos ejemplos de labranzas, debe observarse un denominador común que se viene reiterando en estas villas al norte de Medina: no hay labranza que se precie que no disponga de viñedo, de bodega, de cubas y de vino propios, seña de identidad de todos los labradores del espacio estudiado. 

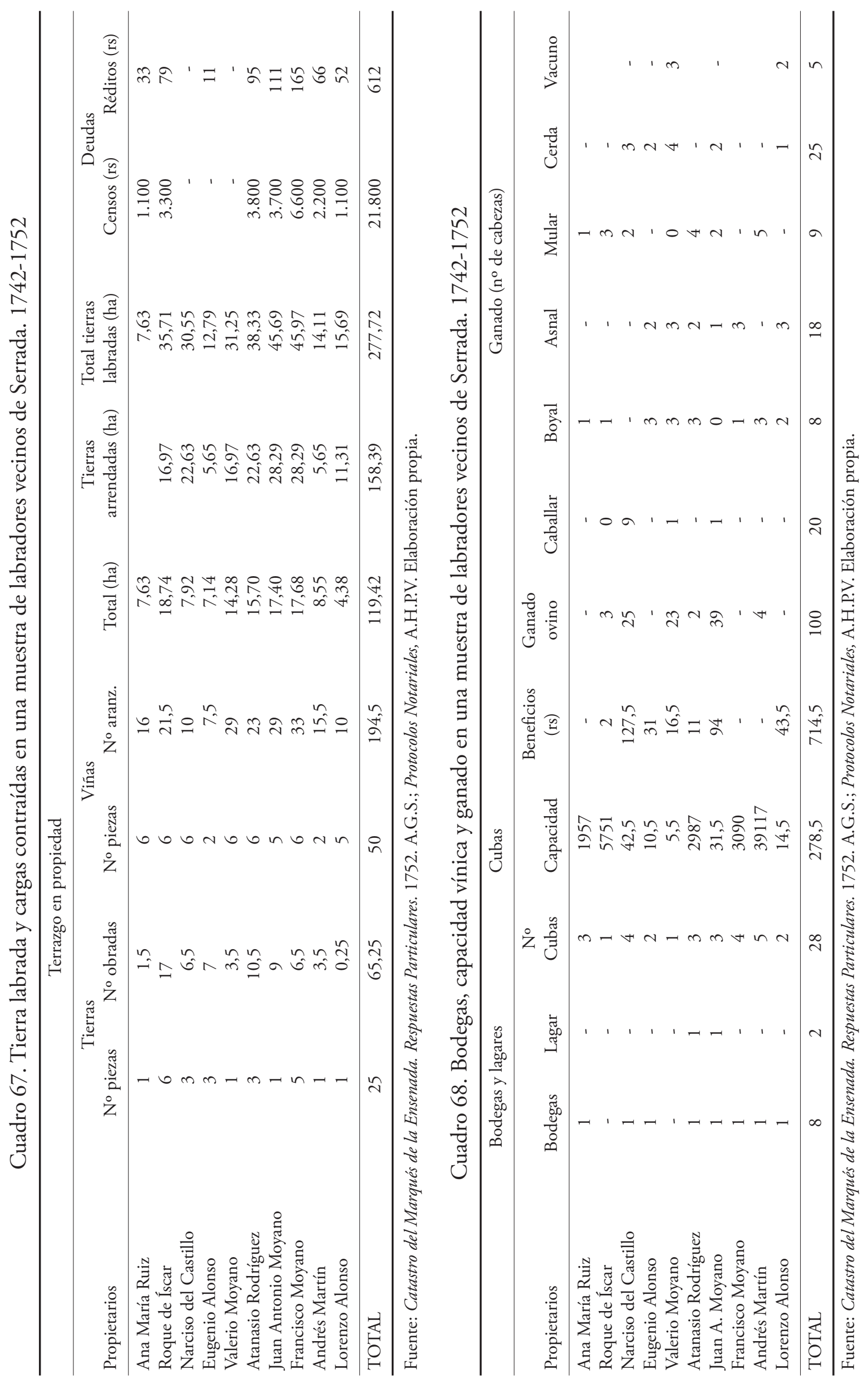


\section{a. Un ejemplo de pequeña propiedad: la labranza de Pedro de Íscar en 1743}

Este vecino de Serrada representa a decenas de pequeños labradores de este siglo que, generación tras generación, han ido detrás de la yunta, como fueron sus padres y como seguirán yendo sus hijos, para sembrar pan en la hoja barbechada y cuidar los majuelos a fin de que "vayan en aumento y no en disminución" 684 .

En las mismas familias, de parecida posición, deudas, muertes y nuevos matrimonios trastocan cualquier realidad $^{685}$. Pedro de Íscar, cuatro años antes de su muerte, firma escritura de reconocimiento de un censo hipotecario que tiene la casa donde habita a favor del Convento de la Merced Calzada, por valor de 100 ducados, al que subroga un majuelo como garantía añadida ${ }^{686}$. Su hermano Roque, en cambio, que emparenta con una hija de Francisco Moyano, escribano de la villa, disfruta de una buena posición, pero muere sin hijos y sus propiedades vuelven a ser repartidas. Los inventarios y los pagos de entierro, testamentarias y demás gastos notariales hacen perder a muchas familias más recursos que el pedrisco y la sequía ${ }^{67}$.

Los bienes raíces son el resultado de la azarosa vida de los ascendientes y de cuantos aspectos se vienen relatando en la evolución del terrazgo labrado. Pedro de Íscar detenta majuelos en Serrada, procedentes del censo de 1612 de las tierras del mayorazgo de Juan de Montalvo, y en el despoblado de la Moya, del censo de la familia Vega de 1629. Muy probablemente los declarados en el pago del Pinar corresponden a las seiscientas obradas que, en la concordia estudiada de 1640 entre el señor de Serrada y Olmedo, se declaran eriales y que, siguiendo protocolos notariales y jóvenes plantaciones, van cubriéndose de vides en la primera mitad y mediados del XVIII.

${ }^{684}$ Los abuelos de Pedro de Íscar (1708-1743) y de su mujer Ana Ma Ruiz (1711-1756) fueron renteros, en la segunda mitad del XVII, de los señores de Serrada Juan Antonio y Diego Montalvo. A algunos de sus antepasados les encontramos en las escrituras de compraventa de Serrada a finales del siglo XV. Se casan entre iguales a fin de constituir nuevas labranzas con el apoyo familiar. En 1711, por ejemplo, consta que su padre otorga a su hermano Blas, para su matrimonio, una legítima de 5.500 reales "en heredades, alaxas, y dinero...", al igual que sus consuegros Andrés Alonso y Catalina de Castro hacen lo propio con su hija Ana, con la suma de 4.400 reales de vellón (A.H.P.V. Pt. 8214, fol. 185). Casar a un hijo con la dote adecuada merma de forma importante la labranza, como seguidamente lo hará la muerte, dada la temprana edad en que los campesinos pasaban a mejor vida. Sirva como ejemplo que Pedro de Íscar fallece a los 35 años; su hijo a los 45; su nieto, Jerónimo de Íscar, rentero del marqués en 1813, a los 69, su bisnieto a los 60.... Unos emparentan con los Moyano, otros con los Alonso y todos se afanan por adquirir más tierra en propiedad, más cepas por criar, más ganado con que completar sus ingresos o saldar sus deudas.

${ }^{685}$ A título de ejemplo y curiosidad, por seguir la línea genealógica desde entonces y hasta quien escribe, Pedro de Íscar (1708-1743) fallece a los 35 años; su abuelo Diego de Íscar (1650-1711) a los 61 años; su hijo Juan Antonio de Íscar (1743-1788) a los 45; su nieto, Jerónimo de Íscar (1763-1812) a los 69; su bisnieto Crisóstomo de Íscar (17931853)a los 60; su tataranieto Pedro Nolasco (1822-1878) a los 56. El hijo de éste, Laureano de Íscar (1848-1919) a los 71 y su hijo Pío de Íscar (1890-1969) a los 79. En el siglo XX, especialmente en su segunda mitad, la esperanza de vida aumenta considerablemente. Así, los hijos de Pío de Íscar y Paula Moyano vivieron todos más de ochenta años: Josefa, 94 ańos; Laureano y Honorata, 80 ańos y su hija pequeńa, María de Íscar Moyano, que es mi madre y una de mis principales fuentes orales en este trabajo, ha fallecido en noviembre de 2014 con 90 ańos.

${ }^{686}$ A.H.P.V. Pt. 8226, fol. 20. Pedro de Íscar tenía un censo sobre la casa, corral y bodega con dos cubas que poseía, sita en la calle o camino que llevan los de La Seca a Valladolid (Calle Real). Dicha propiedad es producto de los repartos que hace con su hermano Roque de Íscar. Pedro se queda con dicha casa y el censo anteriormente fundado sobre ella, que tiene un gravamen del 3\%. Como garantía, amén de la casa, subroga un majuelo de aranzada y media que posee al pago de las Olmas.

${ }^{687}$ Es 1743 encontramos a Roque de Íscar como testamentario y contador de los bienes dejados por su hermano Pedro. 
Cuadro 69. Inventario de bienes a la muerte de Pedro de Íscar, Serrada, $1743^{688}$

\begin{abstract}
Bienes muebles y raíces Reales
-Un banco de respaldo de pino, 17 reales.; dos rejas de arar, 20 rs; una mesa con su cajón, 20 rs; una cama rasa de pino, 3 rs; un jergón de estopa viejo, 6 rs; un arado con sus belortas, 4 rs; un yugo de bueyes con su barrón, 8 rs; un pesebre de pino, 8 rs; una pesebrera vieja, 2 rs; una arca de pino con cerradura, 8 rs; un belón de metal con su mechero, 8 lrs; una media fanega herrada, 6 rs; una caldera vieja de obre, 15 rs;un cazo pequeńo, 2 rs; una tinaja de barro, 8 rs; un salgadero de pino con cerradura y llave, 12 rs; una capa, casaca, chupa de paño de Segovia, todo usado, 120 rs; dos taburetes de pino, 7 rs; un cofre encuerado con cerradura y llave, 22 rs; una taburete de nogal, 8 rs; unos morillos medianos de yerro, 12 rs; un colchón, 40 rs; un jergón de estopa usado, 23 rs;cuatro sábanas de lienzo, 72 rs; cuatro almohadas de lienzo con su lana, 19 rs; una colcha de lana y estopa de botoncillo, 60 rs; siete cuadros de diferentes pinturas con sus marcos, 15 rs; una casaca de mujer forrada, 22 rs; un guardapiés de sempiterna azul, 30 rs; una basquiña de pelo de camello, 20 rs; un guardapiés de lana, 160 rs, una casaca de pańo de color, 50 rs; una casaca de damasco, 60 rs; otra casaca de raso encarnado, 60 rs; ...
\end{abstract}

-Una pollina con su cría, 150 rs

-La cría de un ańo, 50 rs

-Diez fanegas y media de trigo a ocho rs, 84 rs

-Quince fanegas de cebada a cinco reales, 75 rs

-Veinticinco fanegas de avena a tres rs, 75 rs

-Un majuelo de tres aranzadas. Pago de la Horca, 400 rs

-Un majuelo de 2,5 aranzadas. Pago de las Olmas, 800 rs

-Un majuelo de una aranzada. Pago de la Bodeguilla, 420 rs

-Una tierra de cuatro obradas. Pago de La Pradera 1.120 rs

-Casa en calle que va de La Seca a Valladolid, 2.050 rs

-Majuelo de 700 cepas. Pago de Valdesendero, 1.100 rs

-Majuelo de 2,5 aranzadas. Pago del Pinar. 800 rs

-Majuelo de 5 aranzadas. Pago del Pinar, 750 rs

-Majuelo de 4 aranzadas. Pago de Sisón, 3.150 rs

-Barbecho de una tierra de cuatro obradas, con 4 vueltas, 126 rs

-260 rs entregados por Diego Ruiz, su suegro, 260 rs

Cosecha de 1743

-86 cántaras de vino de la cosecha del año pasado de 1743, a 5,5 rs, 473 rs

$-9,5$ fanegas de trigo, rebajado diezmos, 95 rs

-19 fanegas de cebada, rebajado diezmos, 112 rs

$-9,5$ fanegas de algarrobas, rebajado diezmos, 95 rs

-Tres carros de paja, 30 rs

-Fruto pendiente de las viñas, 400 rs

TOTAL CUERPO DE BIENES

TOTAL DEUDAS COMUNES

-Gastos de labranza de 1743 y otras deudas anteriores: 1.539 rs

-Dote de su mujer Ana Ma Ruiz de Castro, 4.090 rs

-Capital que llevó al matrimonio Pedro de Íscar: 9.133 rs

14.762

GANANCIAS: 807. Dividido entre dos: 403,5 rs 807

DEUDAS DE FUNERAL: 692 rs

Fuente: Protocolos Notariales. Archivo Histórico Provincial de Valladolid. Elaboración propia.

${ }^{688}$ A.H.P.V. Pt. 8216. Fol. 1-34. La inclusión de este y otros inventarios de bienes, al margen de precisar los bienes de la familia campesina, nos han de servir para poder comparar los precios de los distintos productos y bienes muebles y raíces, a fin de entender mejor la economía doméstica en estos siglos. 
Cuadro 70. Labores, produccionesy beneficios en tierras de pan llevar. Año 1744. 11,5 obradas en hojas de año y vez. Pedro de Íscar. Serrada

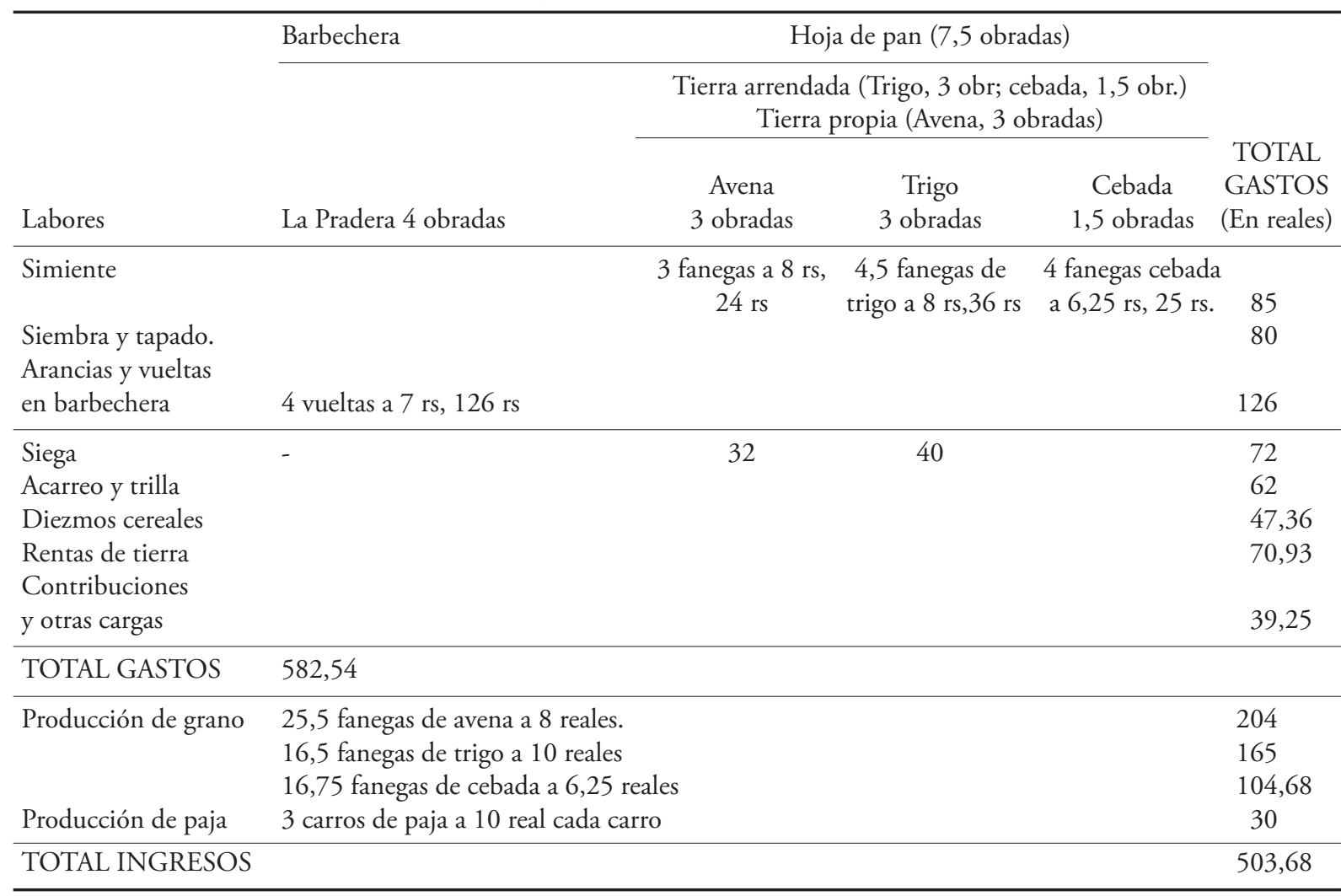

Fuente: Protocolos Notariales. Archivo Histórico Provincial de Valladolid. Elaboración propia.

Cuadro 71. Labores, producciones y beneficios en majuelos. Año 1743 20 aranzadas (12,5 en producción y 7,5 nuevas) Pedro de Íscar. Serrada

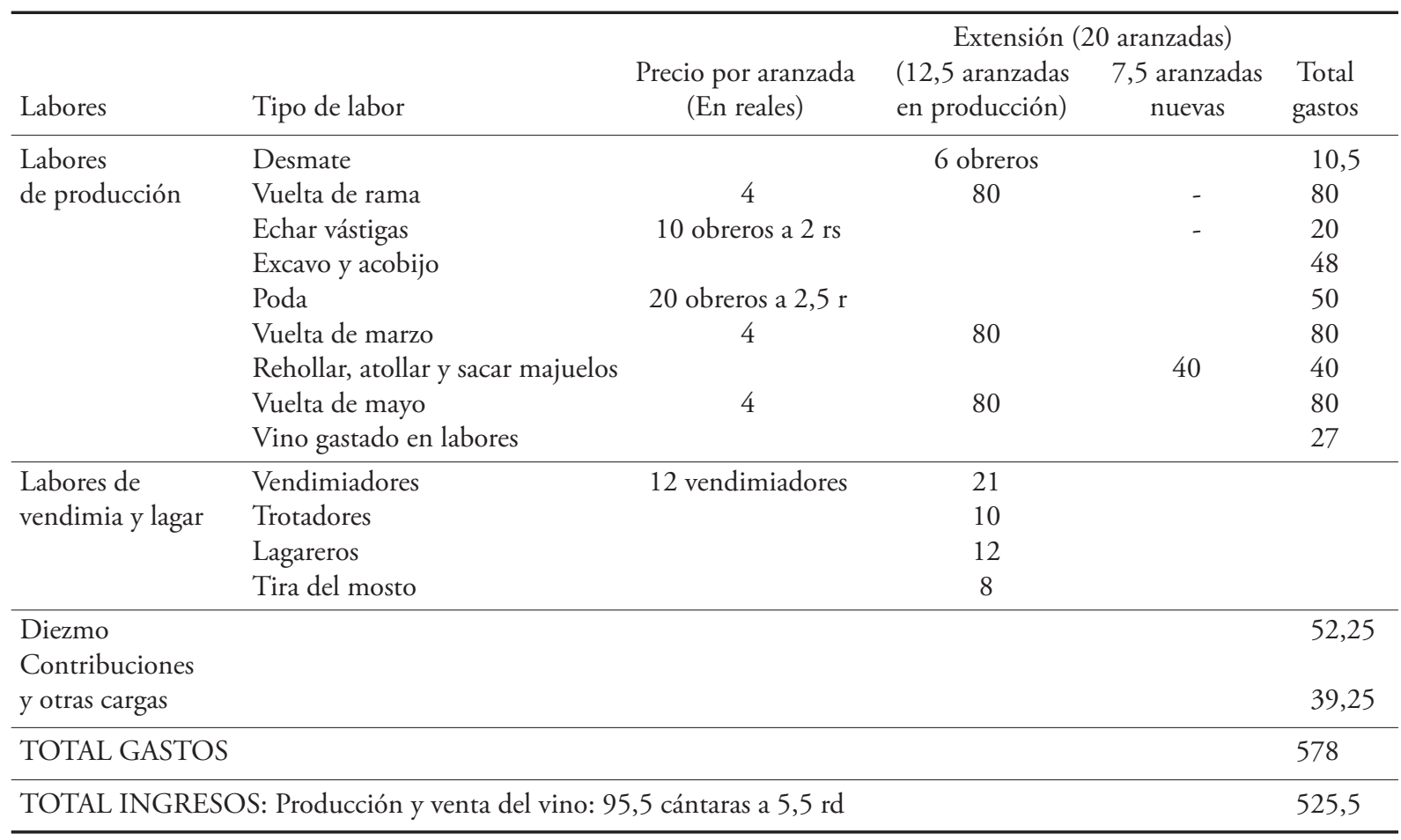

Fuente: Protocolos Notariales. Archivo Histórico Provincial de Valladolid. Elaboración propia. 
Han sido estas ventas a censo de las tierras más flojas o aquellas roturadas pertenecientes al monte de los Llanos del despoblado de la Moya, propias de Olmedo, la única posibilidad de ir adquiriendo tierra en propiedad, al margen de las compraventas de estos pedazos y de los repartos hereditarios. Desde la carta de venta del lugar de Serrada en 1464, todo el término era propiedad del señor y la única posibilidad de labrar la tierra era ser rentero generación tras generación De hecho, todos estos pequeños campesinos, hasta la llegada de la Desamortización, y aun después, siguen arrendando las tierras del señor de la villa para poder vivir o, para ser más rigurosos, son renteros de su señor y tratan de completar sus ingresos, o liberarse de sus ataduras, mediante el viñedo, cultivo en que se especializarán hasta nuestros días.

Es evidente, a la luz del inventario que deja Pedro de Íscar, que sus propiedades no le dan para mantener una familia y que necesita un cuarto o media renta (10 o 20 obradas) de las tierras del marqués. Su temprana muerte le impidió ser rentero. Contrae matrimonio en 1739 a los 31 años y muere en 1743 dejando intacta la dote que recibe. A su padre y a su suegro los encontramos como renteros en 1709 y su hermano Roque, siendo alcalde, toma en 1742 tres cuartos de renta (30 obradas) a Alejo Manuel de Montalvo, señor de la villa en estos años, estipulando la renta en 32 fanegas de trigo y 10 de cebada por cada renta de 40 obradas traídas " $a$ dos hojas" ${ }^{899}$, por lo que es muy posible que complete su labranza con las tierras del marqués, mediante acuerdos con su padre o con su hermano.

Como se puede apreciar en los cuadros adjuntos, las labores que se anotan en las tierras de pan, barbechera y viñedo son las usuales en esta época, tal como se ha estudiado en anteriores epígrafes. En conjunto la labranza presenta unas pérdidas anuales de 131 reales, una vez anotados diezmos, cargas y rentas. Se desconoce cómo fue el año, metereológicamente hablando, pero son los bajos rendimientos en la cebada y en el vińedo los causantes de la falta de ingresos netos. En la avena se superan los rendimientos medios que se anotan en el Catastro, pues recoge 8,5 fanegas por obrada ( 5 fanegas de media en Serrada); en el trigo se declaran 5,5 fanegas, cantidad similar a la declarada en las tierras de segunda, pero en la cebada, tan sólo se recogen 11,6 fanegas, frente a las 40 que se declaran en las tierras de primera y las 20 fanegas en las de segunda.

La cosecha de los majuelos es muy baja. Las 12,5 aranzadas en producción sólo rinden 0,55 moyos (204 kg por aranzada/534 kg por ha), muy inferiores a las producciones de otras labranzas, pero representativas de lo que producían los viñedos de tercera calidad. La viuda de Pedro de Íscar vende la tierra de la Pradera para pagar mandas testamentarias, pero mantiene el viñedo en 1752. Casi diez ańos después, declara los mismos viñedos y clasifica de primera calidad 3 aranzadas; 6,5 de segunda y 10 de tercera. La mediocre calidad del suelo al que se ven abocados los pequeños campesinos puede ser un factor explicativo. Aun así, los rendimientos son bajos. Otro factor, al margen de posibles malas cosechas, puede estribar en que los majuelos en producción son jóvenes. Es de suponer que, tras el matrimonio, al margen de las 7,5 aranzadas que planta al camino del Pinar, el resto no esté en plena producción. Y este es un factor fundamental para que los majuelos den o no dinero ${ }^{690}$. Pedro de Íscar recoge, en las doce aranzadas y media, 7,64 cántaras y ha de pagar los gastos que llevan las otras siete y media que no producen. El viñedo es un pozo sin fondo de trabajo e inversión en el siglo XVIII y en el XIX, si se desea elevar la rentabilidad del cultivo. Por último, el precio en que se tasan los productos en esta época, en relación con el alza que experimentan en la segunda mitad del siglo respecto a los jornales, limita los beneficios en las pequeñas labranzas.

${ }^{689}$ A.H.P.V. Pt. 8215, fol. 284.

${ }^{690}$ Recuérdese que una aranzada de primera calidad produce veinte cántaras; una de segunda catorce y una de tercera, ocho. 
Ahora bien, esto no implica la ruina del pequeño labrador, siempre que tenga salud para llevar personalmente su hacienda. Es evidente que en condiciones normales Pedro de Íscar realiza la mayor parte de las labores, incluida la vendimia, con la ayuda familiar, por lo que, aun con estos rendimientos bajos, su trabajo le reportaría una renta personal de unos 3 reales diarios, cifra que declaran Serrada y otras villas como propias de los labradores frente a los dos reales de los jornaleros.

No se desea insistir, por último, en el peso asfixiante de unas estructuras estamentales que impiden cualquier capacidad de capitalización en estas pequeñas explotaciones. Rentas, deudas y diezmos sumergen al campesino en una espiral de trabajo sin recompensa que acaba por rematar la propia muerte que se lleva, solo en los gastos de funeral, 692 reales. El diezmo es una losa imposible de salvar y una renta de una fanega de trigo por obrada (dos por obrada sembrada) mengua cualquier panera. O llegan ingresos por otros caminos o difícilmente el pequeño labrador con tierras arrendadas puede liberarse de tantas ataduras.

\section{b. Un ejemplo de labradores acomodados a fin de siglo: la familia Moyano}

Se trata de una familia de grandes propietarios, influencia y poder de los siglos XVIII y XIX en este ámbito comarcal. De genealogía hidalga procedente de La Seca, Francisco Moyano regenta la escribanía de Serrada desde 1739 hasta 1754. Desde su llegada ejerce una gran influencia en la vida local, tanto por su oficio de escribano, como por la inversión de su riqueza en la formación de una sólida labranza. Al igual que otros muchos hacendados comarcales en que parte de su patrimonio no procede de la actividad agraria, alterna entre sus hijos la formación académica y el gusto por la tierra. De su primer matrimonio en 1716 con Catalina Luengo, su hijo Juan Moyano encabeza una genealogía de grandes familias labradoras, base de buena parte de las haciendas locales que emparentan con apellidos, ligados a la tierra desde siglos, como son los Alonso, Martín, Hinojal, de Íscar, Fadrique, Obregón, Román, etc. ${ }^{691}$

Aunque de este primer matrimonio no faltan descendientes canónigos y magistrados, es del segundo, con María García, hija de Ares García y Ana de Castro, apellidos locales ligados a la historia de Serrada desde su origen, de donde surge todo un elenco de importantes hacendados y hombres de leyes y clero. De este matrimonio su hijo Miguel Moyano hereda la afición por las leyes y consigue suceder a su padre como escribano de Serrada en 1754. Contrae matrimonio con Beatriz Rodríguez, hija de Atanasio Rodríguez, labrador acomodado, ya mencionado, posibilitando la formación de una de las mayores labranzas de finales de siglo de toda la comarca a través de su hijo Francisco Moyano. Igualmente invierte en formación eclesiástica en su hijo Buenaventura, que, tras importantes cargos, muere en 1802 siendo obispo de Palencia. A su hijo Tomás le da carrera de leyes que le lleva a ocupar cátedra en la Universidad de Valladolid y a ser ministro de Gracia y Justicia durante el reinado de Fernando VII. El resto de descendientes de este matrimonio se une a importantes familias labradoras de Serrada, La Seca o Rueda, siempre en primera posición en cuanto a recursos y cargos políticos y religiosos ${ }^{692}$.

${ }^{691}$ Sin que parezca un tratado genealógico, pero toda vez que clarifica la evolución de la propiedad y de las decisiones que se toman en esta villa respecto a la organización de su terrazgo y recursos, conviene apuntar que, en este siglo XVIII, se gestan las principales labranzas que continúan en los siglos siguientes. Buena parte de ellas han tenido su origen en estos capitales formados a la luz de escribanías y cargos religiosos o de medicina que han permitido a sus titulares comprar tierra y emparentar con miembros de labranzas consolidadas, en la que se cruzan las distintas líneas de los Moyano, aumentando su propiedad e influencia. El alto número de descendientes de Francisco Moyano en sus tres matrimonios no le impide dotar convenientemente a todos ellos y alternar la formación académica al tiempo que la inversión en tierra.

${ }^{692}$ En el epígrafe sobre la vida cotidiana se analiza en detalle buena parte de estas familias labradoras por lo que no hay que extenderse en este apartado. A la muerte de su segunda mujer, Francisco Moyano contrae matrimonio con Ana Rodríguez. Su descendiente Bernardino Moyano casa con Lucía Martín y emparenta con las familias Martín y Fadrique a finales del siglo XVIII. 
Como antes se hizo con Pedro de Íscar ${ }^{693}$, se va a escoger, como representativa de una gran propiedad de la segunda mitad del XVIII, la labranza de Manuel Antonio Moyano, nieto del mencionado Francisco Moyano y de Baltasara Rodríguez, con quien contrae matrimonio en $1762^{694}$.

A mediados del siglo XVIII, estas familias acaparan buena parte del terrazgo labrado en Serrada. Del arrendamiento de 1742 al marqués de Torreblanca, se desprende que 320 obradas de las 440 que se arriendan son llevadas por los distintos miembros de la familia o sus parientes más próximos. Sin llegar a estos porcentajes, el catastro de Ensenada de 1752 los consolida como titulares de buena parte de las tierras de sembradura, viñedos, bodegas y cubas. A la muerte de Baltasara Rodríguez, ya fallecido Manuel Antonio Moyano, del inventario de bienes adjunto se desprende lo acomodado de su situación y lo importante de sus bienes muebles y raíces. Hasta este año de 1791, habiendo dotado abundantemente a sus hijos con tierras, viñas, casas, alhajas o vino, aún declaran como bienes raíces propios 127,5 aranzadas de vińedo (55 ha).

En cuanto a las tierras de sembradura, son renteros, en tierras del marqués de Torreblanca, de 25 obradas entre trigo, cebada y centeno, por lo que hay que pensar que disponen de otras tantas en barbecho hasta completar una renta y cuarta (50 obradas/28,29 ha), que también llevara su padre Atanasio Rodríguez en vida. La tasación del viñedo suma la importante cifra de 169.897 reales, con un valor medio de 1332,5 rs cada aranzada. Que conserven los majuelos sin tierras de sembradura evidencia una neta especialización vitícola y su querencia a conservarla hasta el final de sus días. El nombre de los pagos por los que se dispersan los viñedos refleja, como en el caso de Pedro de Íscar, la ocupación del terrazgo a lo largo de los anteriores siglos. De entre las 127,5 aranzadas, se anotan 27 compradas a foro del mayorazgo de los Vega de Tordesillas en los pagos de la Moya y Valdesuero. Destacan también otras 19 aranzadas foreras de la Tierra de Olmedo en los pagos del Colgadero y la Pradera, que reflejan lo analizado en capítulos anteriores. En esta segunda mitad del XVIII, la presión por la posesión de la tierra con fines vitícolas persiste por parte de estos labradores con recursos. De hecho, en estos años, su pariente Francisco Moyano, acaba por comprar cuanto le falta por vender a Manuel Pascual de Vega y Salzedo, titular del mayorazgo del mismo nombre en La Moya, sea tierras labrantías, baldías, sea solares y ejidos que apenas se mantienen en pie desde comienzos del siglo XVII, época en que este lugar queda despoblado ${ }^{695}$.

El inventario adjunto es completamente distinto del de Pedro de Íscar. Los separan bienes, posición, hidalguía y cincuenta años del siglo XVIII. Respecto al tema agrícola, el último tercio de siglo es muy diferente al de la primera mitad. Los precios de los productos han subido considerablemente, en mayor proporción que los salarios. Si en 1743 se tasa la cántara de vino a 5,5 reales, en 1791 su precio no baja de siete reales, manteniéndose muchos años por encima de los once si el producto es bueno. El trigo, cultivo y alimento de primera necesidad, se vende a 24 reales la fanega, pudiendo subir por encima de los treinta, frente a los 8 reales de la primera fecha. Aunque los jornales han subido y muchos se cifran en tres reales frente los 2,5 anteriores, el margen de maniobra para la clase propietaria es mucho mayor.

${ }^{693}$ Su hermano Roque, alcalde de Serrada, es yerno de Francisco Moyano.

${ }^{694}$ Baltasara Rodríguez es hija, como se ha dicho, de Atanasio Rodríguez e Isabel Alonso. De esta familia salen también cargos religiosos, fundadores de capellanías (Rodríguez Zorrilla) y labradores emparentados con los citados apellidos de Castro, Obregón, Moyano, Alonso... Baltasara Rodríguez tendrá once hijos, pero de los que sobreviven será de Melchor Moyano, nacido en 1770 y casado con María Díaz, y de su descendiente Ventura Moyano, casado con Inocencia Zamora, de quien descienda buena parte de las familias labradoras del XIX y XX, ya que sus otros hijos, o no tienen descendencia o abandonan el pueblo dada su formación y posición (Tomás Manuel Moyano, magistrado). De esta manera, entre los descendientes de Ventura Moyano e Inocencia Zamora, se encuentran dos hijas que toman los hábitos de Santa Clara; León José Moyano, que casa con Gregoria Moyano, cuyos descendientes emparentan con las familias Martín, Hinojal, Gutiérrez...; el licenciado Cándido Moyano, que casa con María Treviño, cuyos descendientes se consolidad como importantes labradores y médicos en la villa de Piñel. Y, por último, Perfecto José Moyano, alcalde de Serrada en el siglo XIX, que contrae matrimonio con Celestina Alonso Moyano, hija del importante hacendado local Gregorio León Alonso y del que descendemos otra parte de los Moyano ligados a la tierra y a sus quehaceres.

${ }^{695}$ A.H.P.V. Pt. 8225, fol. 742. 
Cuadro 72. Resumen del inventario de bienes muebles y raíces de Manuel Moyano Alonso y Baltasara Rodríguez Alonso ${ }^{696}$. Año1791

\begin{tabular}{ll}
\hline Bienes muebles y raíces & Reales $\%$ \\
\hline Casa
\end{tabular}

Casa, lagar y bodega:

-La casa, sita en la calle del Pozo Bueno, compuesta de oficinas bajas, cuadra, pajar y corral,... tasada en 14.065 .

-El lagar existente en dicha casa que es de viga con su piedra, husillo y todo lo demás... 12.320 reales. -La bodega soterraña existente bajo dicha casa que es de dos cañones, el uno de veintiséis varas y el otro de diecisiete, con tres zarceras y escalera,... 3.434 reales

Mobiliario, vestidos y otros:

-Un escritorio de seis navetas grandes de nogal..., 70 rs; seis cortinas de esparragón encarnado nuevas..., 350 rs; doce silletas grandes y doce pequeñas, $240 \mathrm{rs}$; un arca grande de pino con cerradura y llave, 30 rs; nueve sábanas de lienzo, 225 rs; una colcha blanca nueva de botoncillo, 40 rs; una colcha manchega negra, 20 rs; cinco mantas de Palencia usadas, 100 rs; cuatro jergones de estopa nuevos, 160 rs; (...). Unos morillos de peso de veinte libras, 20 rs; una sartén grande, 6 rs; dos asadores de hierro, 6 rs; una sartén de hacer arropa, 12 rs; cuatro candiles de hierro, 4 rs; una chocolatera mediana de cobre, 6 rs; una plancha nueva, 8 rs; un escaño de pino viejo, 12 rs; (...) Vestidos de Tomás: un vestido de pańo fino, 120 rs; otro de verano de pelo camello, 120 rs; una capa color de plomo nueva, 200 rs; cuatro camisas de lienzo Santiago nuevas, 80 rs; (...). Vestidos de Juliana: un baquero de estameña inglesa con barquiña, 100 rs; un jubón y guardapiés, 40 rs; (...)

\section{Ganados:}

Una mula nueva de tres años, 2.400 rs; otra cerrada pelo negro, 1.400 rs; un caballo cerrado viejo, 450 rs; una pollina nueva rucia con su cría, 300 rs; dos cerdos cebados a peso como de seis arrobas cada uno, 480 rs; trs capones en seis reales; un gallo en 3 rs; un pavo en 25 rs; cuatro pares de palomas mansas, $28 \mathrm{rs},(\ldots)$

\section{Aperos:}

-Cinco rejas de arado, 50 rs; dos arados embelortados, 16 rs; dos yugos de mulas, 16 rs; otro de bueyes, 16 rs; una azuela, 2 rs; un carro de mulas, 200 rs; tres orcas a real; seis bieldos a real; un gario a real y medio; dos palas, 4 rs; una hemina con su rasero, 8 rs; dos trillos viejos, 24 rs; (...)

Majuelos: Majuelo del Barco de la Moya viejo: 2.740 cepas, a cuatro reales cepa, 1.960 rd.; majuelo llamado el nuevo al Barco de la Moya, que hace 5.663 cepas a tres rs cepa, 16.989 rd.; majuelo llamado el de Isidro, en término del despoblado de la Moya, de 3.469 cepas, que a 2,5 rs en que está tasado con la carga del foro que tiene, importa 8.672,5 rs; otro majuelo en dicho término y pago del Colgadero, puesto en tierra de la Universidad de Olmedo, que hace 1.680 cepas a 5 rs cepa, importan 8400 rs;...(...) Total majuelos: 127,5 aranzadas de 420 cepas que hacen 53.550 cepas, a 3,17 rs de media... importan 169.907 reales.

\section{Cubas:}

Una cuba de roble de dieciséis palmos con dos arcos de hierro y lo demás de madera y poínos... 800 reales; otra cuba de roble de a catorce palmos con arcos y poínos de madera...430 reales; otra cuba de roble de a dieciséis palmos con arcos y pinos de madera... 660 reales; (...). (Suman en total 9 cubas y dos cubetos tasadas en 5.430 reales).

Vino:

En la bodega propia en el primer cañón y primera cuba, 444 cántaras; eb la segunda, 396 cántaras; en la tercera cuba, 400 cántaras; en la cuarta 306 cántaras; la quinta de junto la escalera, 430. En el segundo cañón, contando desde la última que está junto al pozo, 112 cántaras; (... ) Total vino: 3.918 cántaras, a siete reales cántara, importan 27.426

\section{Granos:}

-Treinta y dos fanegas de garrobas a 15 rs, 480 reales.

-Dieciséis fanegas de cebada a 14 rs, 224 rs

-Ocho fanegas de trigo a 24 rs, 192 rs

-Veinte carros de paja a 20 rs, 400 rs (...)

Fuente: Protocolos Notariales. Archivo Histórico Provincial de Valladolid. Elaboración propia.

${ }^{696}$ A.H.P.V. Pt. 8225, fols. 559 y ss. 
La posesión de la tierra y las rentas vuelven a ser un caballo de batalla entre sus titulares. El marqués de Torreblanca recibe 32 fanegas de trigo y 10 de cebada en los ańos cuarenta por cada 40 obradas de tierra y aumenta sus rentas conforme se anima el mercado triguero, antes de la crisis de fin de siglo. En La Seca, Rueda, Serrada y demás pueblos del entorno se ocupan y labran tierras baldías y eriales, antes despreciados por su escasa rentabilidad. Ya se ha mencionado que Francisco Moyano compra todo lo comprable al mayorazgo de los Vega, en término del despoblado de La Moya; en Serrada se acaban de plantar cerca de cuatrocientas obradas en la cańada del pinar, en las terrazas más bajas y menos productivas, pero rentables con los nuevos precios. Recuérdese que, cuando se estudió la ocupación del espacio de sernas, en el año 1776, un total de 478 renteros pagan 2.070 fanegas de trigo, frente a 100 renteros de tierras de sembradura que pagan 275 fanegas. En Rueda estos porcentajes también se inclinan por el vińedo con un porcentaje de $81,5 \%$ de rentas. O las presiones del alcalde de La Seca en 1785 para poder plantar lo que faltaba en el monte Pedroso e Inestoso, prueba de la fiebre plantadora en este último tercio del XVIII.

No extrańa, ante esta realidad, que toda la hacienda esté plantada de viñedo y que se acuda a las tierras del marqués para abastecerse de trigo para consumo doméstico y cebada y centeno para el ganado de labor. Es la viticultura el centro de los quehaceres en estos pueblos del norte de Medina. Piénsese que majuelos, cubas, lagar, bodega y vino representan hasta el $87 \%$ del cuerpo general de bienes declarado por la familia Moyano Rodríguez en 1791, con 218.507 reales de los 251.118 reales totales.

Cuadro 73. Estimación de labores, producciones y beneficios en tierras de pan llevar, año 1791. Manuel Moyano Alonso y Baltasara Rodríguez Alonso

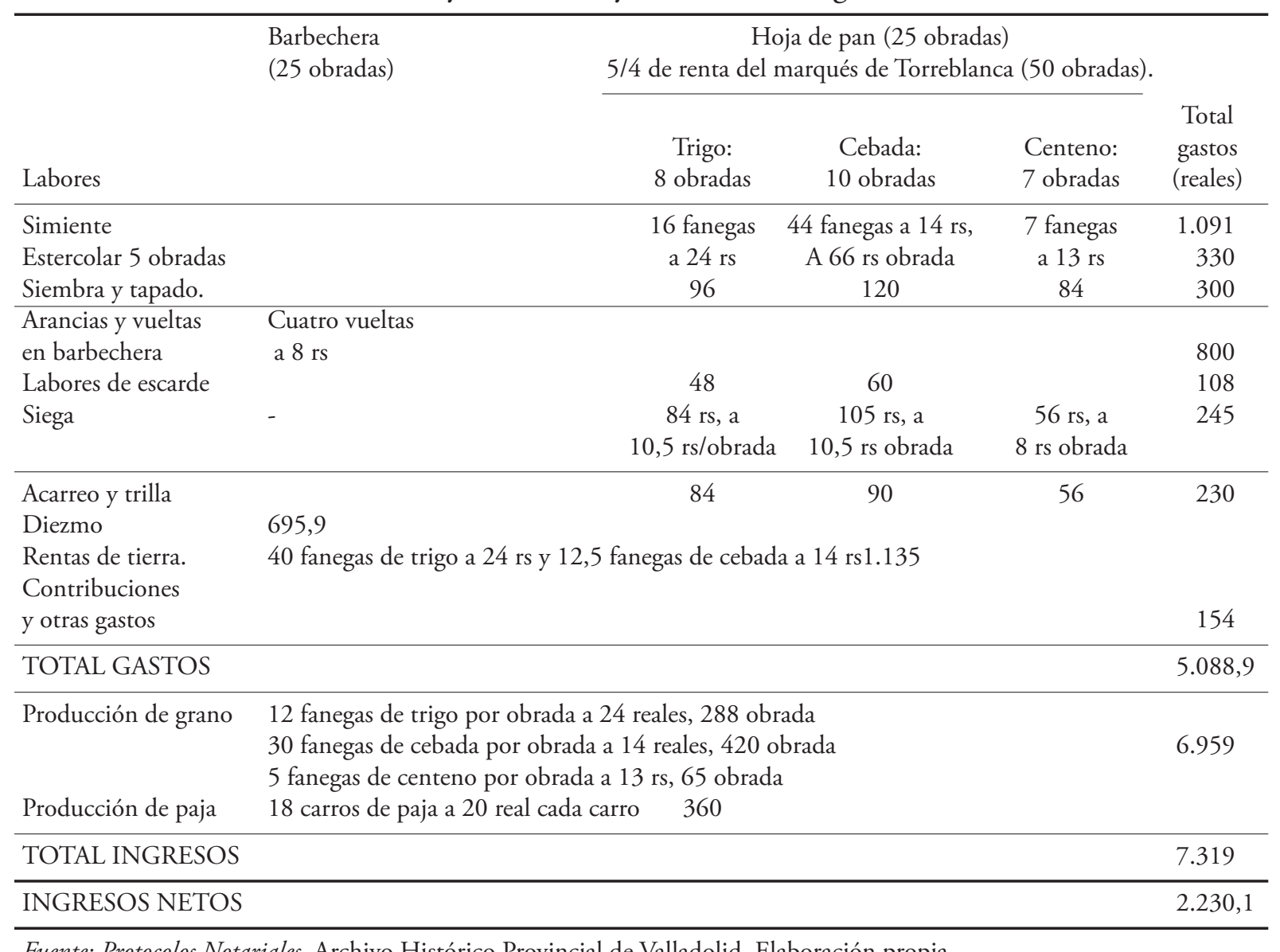


Cuadro 74. Estimación de las labores, producciones y beneficios en majuelos, año $1791^{697}$ 127,5 aranzadas en propiedad. Manuel Moyano Alonso y Baltasara Rodríguez Alonso

\begin{tabular}{|c|c|c|c|}
\hline & Tipo de labor & $\begin{array}{l}\text { Extensión: } 127,5 \text { aranzadas. } \\
\qquad(54,11 \mathrm{ha})\end{array}$ & $\begin{array}{l}\text { Total } \\
\text { gastos }\end{array}$ \\
\hline \multirow{8}{*}{$\begin{array}{l}\text { Labores de } \\
\text { producción } \\
(5.133 \text { rs) }\end{array}$} & Desmate y vallados & 108 obreros a 2,5 rs & 270 \\
\hline & Excavo y vástigas & 135 obreros a 3 rs & 405 \\
\hline & Vuelta de rama & 7 rs aranzada & 892,5 \\
\hline & Poda & 224 obreros a 2,5 y 3 rs & 623 \\
\hline & Vuelta de marzo & 90 aranz a 11 rs y 37,5 a 8 rs aranzada. & 1.290 \\
\hline & Acobijo a destajo & 127,5 aranzada a 2,5 rs & 318,5 \\
\hline & Vuelta de mayo & 7 rs aranz. Se cruzan 32 & $1.116,5$ \\
\hline & Recobijo y escardes & 87 obreros a 2,5 rs & 217,5 \\
\hline \multirow{11}{*}{$\begin{array}{l}\text { Labores de vendimia } \\
\text { y lagar }(2.463 \mathrm{rs})\end{array}$} & Preparar bodega, lagar y cubas & Pegotes, pez, estopa, arcos, salario del cubero... & 191 \\
\hline & Vendimiadores. & 401 obreros a 2,5 rs (3,1 día/obrero/aranz) & $1.002,5$ \\
\hline & Espejuelo & 53,5@ de espejuelo para la uva y canales a 2 rs/@ & 107 \\
\hline & Cargadores & 27,5 obreros a 3 reales & 27,5 \\
\hline & Trotadores y caballerías & 104,5 jornales de caballerías a 3 rs & 313,5 \\
\hline & Lagareros & 141,5 moyos a $1,5 \mathrm{rs} / \mathrm{moyo}$ & 211,5 \\
\hline & Coritos & Bajar 141,5 moyos a bodega y ollas de las piladas & 61 \\
\hline & Aceite & $1,5 @$ de aceite a 62 rs la arroba & 93 \\
\hline & Cachicán de vendimia & Nueve días a 4 reales & 36 \\
\hline & Gastos de manutención & $\begin{array}{l}\text { 1,5 cargas de trigo para lagareros y otros a } 84 \mathrm{rs} / \text { carga } \\
1,5 \text { cargas de cabada para caballerías a } 48 \mathrm{rs} / \text { carga }\end{array}$ & \\
\hline & & Carro y medio de paja a 26 el carro & 237 \\
\hline
\end{tabular}

Carne, pescado, queso y tocino 3 cabras a 24 reales cada una, 72 rs 36 libras de carne a nueve cuartos, 38 rs 7 libras de queso a 16 cuartos, 13 rs 6 libras de tocino a 16 cuartos, 10 rs y $10 \mathrm{mrs}$

Gastos para

la venta (272 rs)

Tierra de la Nava para dar claros.43,5 @ a 5 cuartos cada una 25

Lavar siete cubas para el trasiego 14

Trasegar siete cubas y limpiar heces

Sangrías para la compostura y azufre

Dos arrobas de pasas y dos cuarterones de canela $\quad 78$

\begin{tabular}{ll}
\hline Aceite, velas de sebo, sal y otros & 18
\end{tabular}

Tributos-cargas

\begin{tabular}{llr}
\hline Cachicán & Salario anual de un criado a 3 reales diarios & 1.095 \\
\hline Diezmo & & 3.057 \\
\hline Derechos desbote & Una cántara de cada treinta & 1.019 \\
\hline TOTAL GASTOS & & 13.532
\end{tabular}

TOTAL INGRESOS Producción de 1,11 moyos por aranzada. (408,8 kg de uva por aranzada o $963 \mathrm{~kg} / \mathrm{ha}$ ). Se obtienen 2264,5 cántaras. Se venden a 13,5 rs/cántara de media.

Se pierden por los desbotes en la venta una cántara de cada treinta: 1019 rs

Queda en limpio 29551 reales

INGRESOS NETOS 16.019

Fuente: Protocolos Notariales. Archivo Histórico Provincial de Valladolid. Elaboración propia. 
Este año de 1791 no se han detectado incidencias adversas del tiempo en relación con los cultivos, por lo que hay que inclinarse por rendimientos normales en el viñedo y medio altos en las tierras de sembradura arrendadas, dada su calidad. En estas grandes labranzas capitalizadas, el estercolado se practica como una necesidad para mantener la fertilidad de la tierra y asegurar las cosechas $^{698}$. Se haga a red por los rebańos ovinos o se lleve la basura en carros desde los muladares, los precios en que se tasan estas operaciones son elevados, pues equivalen a dos y tres fanegas de trigo. He aquí cuando toma valor para aminorar estos costes el viejo refrán conocido y ya repetido en esta obra: la oveja con la reja.

Otra operación hasta ahora no registrada como usual en los libros de contabilidad de estos siglos, son las operaciones de escarde en los campos de cereal, no porque no existieran, si no porque no se regulaban como necesarias. A partir de finales del XVIII se registran como imprescindibles en la medida que se quiere aumentar la producción. Los beneficios por obrada sembrada ascienden a 44,6 reales, incluyendo los gastos de barbechera, muy inferiores a los 125,6 que se obtienen de cada aranzada de viñedo. Sin barbechera ascenderían a 89,2 reales. No cabe la menor duda que en las tierras del marqués del ejemplo se retelan algunas obradas y se siembran algarrobas en otras que salen de pajas. Nos se puede afirmar que, con el aporte del abonado, se han sembrado todas las tierras, especialmente las que van de cebada, pero que en el inventario de bienes no se apunten los gastos de barbechera es un indicador de que quizá no tengan barbechera este año. De ahí la necesidad de estercolado y de obtener los mayores ingresos para compensar, al menos, parte de los gastos de producción. Barbechar se hace necesario, pero en estos siglos y en los siguientes es una práctica cara, especialmente cuando los propietarios no perdonan una fanega de trigo de la renta estipulada, sea buena o mala la cosecha.

Con todo, lo que es evidente es que, con estos precios y producciones, el viñedo es más rentable que el cereal. En el año del ejemplo, la producción por aranzada estimada es de 1,11 moyos, un $10 \%$ más que el que se obtenía de media en la primera mitad de siglo. Son los precios del vino los responsables de un saldo positivo que anima a plantar más y más hasta el colapso de fin de siglo. Como en todas las épocas este beneficio se reinvierte en el viñedo. No les falta a los majuelos labor alguna con salarios que, en muchos casos, han pasado de los 2,5 reales día a los tres reales.

Aunque ya se ha estudiado, se observa que, a partir de estas décadas, en la compostura de los vinos, al margen de tierras o sangrías, se añade canela, pasas, anises, etc., a fin de obtener sabores, colores y aromas que hagan más atractivo el producto al consumidor. También aumentan las labores de trasiegos y limpieza de cubas, lo que lleva a pensar en unas elaboraciones más cuidadas y que permiten la conservación de cubas con vino añejo que sirve para encabezar la nueva cosecha y ser vendido a mayor precio.

En conjunto, tierras de sembradura y viñedo proporcionan a la familia Moyano Rodríguez en este año 18.249 reales de beneficio neto, que equivale a un 7,26\% del total del cuerpo de bienes del que son propietarios. Estas cifras de beneficios son similares a las registradas por las granjas religiosas de similar entidad y especializadas en el mundo vitivinícola en estos ańos. El Hospital de la Resurrección, por ejemplo, con un 30\% menos de viñedo, presenta unos beneficios netos en 1780 de 13.838 reales $^{699}$. Son los años de mayores beneficios registrados en todo el siglo. En la nueva centuria se repetirá durante demasiado tiempo el dicho "cualquier tiempo pasado fue mejor".

\footnotetext{
${ }^{698}$ En estos cuadros se han utilizado precios y tiempos medios en cada labor y cultivo. Aunque en el inventario de bienes se ha tasado el vino a 7 reales la cántara, en los precisos libros de las granjas religiosas de la localidad, los precios oscilan entre los once y quince reales, por lo que se ha optado por precios medios. En esta labranza los criados realizarían buena parte de las labores de labor con ganado propio, pero, ante la falta de registros, se ha repercutido, tanto el coste de estos trabajos, como el mantenimiento del ganado de labor y reparación de aperos, en el conjunto de los gastos de producción. En el inventario se declaran 3918 cántaras, próximas a la máxima capacidad de la bodega y que se obtendrían de una cosecha de 1,92 moyos por aranzada, que se entiende extraordinaria para esta época, a no ser que se compute en la bodega vino no vendido de la cosecha anterior. De ahí la estimación más moderada de 1,11 moyos por aranzada.

${ }^{699}$ A.H.P.V. Hospital de la Resurrección, Libro de Cuentas y Pagos, caja 95, no 67-68, fol. 19.
} 


\section{c. Un ejemplo de explotación vitícola capitalizada y rentable: El Hospital de la Resurrección de Serrada}

Desde finales del XVII distintas congregaciones religiosas manifiestan un interés vitivinícola extraordinario en las villas situadas al sur de la capital vallisoletana. En Serrada, como se ha estudiado y se precisará más adelante, el flujo inversor en casas, bodegas y vińedos se incrementa notablemente respecto en las primeras décadas del siglo, se consolida desde mediados hasta el último tercio del XVIII y declina conforme lo hace la centuria y llega la crisis del Antiguo Régimen.

La casa granja del Hospital General de Valladolid declara en el Catastro de Ensenada la posesión de 54 aranzadas de viñedo en Serrada. Poco tiempo después, pasa a sus manos la casa, lagar y bodega que mandara edificar Josef Núñez, importante joyero y financiero de la ciudad. Este había adquirido en 1737 a censo perpetuo al marqués de Torreblanca "quarta y media de tierra para favricar un lagar $y$ bodega" ${ }^{\prime \prime 00}$. Al año siguiente se encuentra como activo comprador de viñedo, dado el interés de estos hombres de negocios por la rentabilidad del cultivo y la distribución de vino en estas décadas ${ }^{701}$.

El Hospital General dispone en Valladolid de 80 camas, botica y una importante plantilla de médicos, cirujanos y sangradores. Se sitúa en el lugar que ocupa actualmente la casa Mantilla y la portada de su iglesia, como se aprecia en la imagen, se inspira en modelos renacentistas italianos ${ }^{702}$. En 1742 el mencionado José Núñez y su esposa Teresa Fernández testan a favor de esta institución para que todos sus bienes pasen tras su muerte a su propiedad, entre los que destacan las haciendas vitícolas de Serrada, La Cistérniga y Valdestillas ${ }^{703}$. En Serrada el Hospital consolida una explotación vitivinícola muy activa a lo largo de todo el siglo, pues, de las 54 aranzadas que catastra en 1752, pasa a las 77 de las décadas de los sesenta y a las 88 al final de la centuria ${ }^{704}$.

${ }^{700}$ El 29 de mayo de 1736 se firma la escritura de venta a censo perpetuo entre Josef Nuñez, mercader de joyería y vecino de Valladolid, y D. Luis de Montalvo Cuadra y Avellaneda, marqués de Torreblanca y de Piña de Esgueva, señor de Serrada, por el que este le vendía a censo perpetuo una cuarta de tierra para edificar casa, bodega y lagar: "Otorgo por la presente que bendo y doy en benta a zenso perpetuo al expresado Josef Nuńez, para el susodicho e sus herederos y subcesores, y quien del o dellos ubiere lexitimo título, en cualquier manera, la quarta y media de la tierra aquí declarada y deslindada con todas sus entradas y salidas, usos, costumbres, derechos y servidumbres della anejo y perteneciente, para que pueda fabricar y fabrique casa lagar y bodega de balor de Duzientos ducados de vellón, y por precio y quantía de real y medio, de la misma moneda, que me ha de pagar en cada un año, y a los demás subcesores y poseedores que fueren de dicho mi mayorazgo...”. La escritura recoge el traslado notarial por el que el rey Felipe III otorga facultades, en 1612, a D. Juan Antonio de Montalvo, para que pueda vender a censo perpetuo mil obradas de tierra en Serrada pertenecientes a su mayorazgo. Como se explicó, el marqués quedaba con el pleno dominio de dichas obradas y los labradores de Serrada las tomaban a censo perpetuo, a cambio de pagar unos réditos anuales de 3,5 reales por obrada. Sólo en este marco legal se posibilita la nueva venta. A.H.P.V. S.H., caja 4, leg. 901, nº 16.

${ }^{701}$ En 1737 compra a Francisco Hinojal e Isabel Valdajos 584 cepas al pago del Pozo Bueno, donde, a pesar de lo apto de sus suelos para el trigo, consta que se estaba extendiendo el viñedo. (A.H.P.V. S.H, caja 4, leg. 1, no 16)

${ }^{702}$ Su creación tiene lugar en 1553 por el empeño de Alonso de Portillo de recoger a todos los enfermos contagiosos. En sus inicios fue la Cofradía de la Resurrección quien se encargaba de su administración para pasar posteriormente a los hermanos de San Juan de Dios. En 1615 fue declarado Hospital General acogiendo a diez de los dieciocho hospitales de la ciudad y su administración corre a cargo del obispado. m@guadi. http://www.valladolidweb.es/valladolid/loqueyanoesta/hospitaldelaresurreccion.htm

${ }^{703}$ A.H.P.V. Hospital de la Resurrección, caja 3, leg. 55-81. Este matrimonio acaudalado deja importantes bienes urbanos y rústicos al Hospital General, dando instrucciones precisas sobre el cuidado de los enfermos y la atención a sus haciendas vitícolas. En relación a Serrada y al Cistérniga, insiste en "dar a las viñas las labores necesarias y correspondientes para que asi le sean útiles y probechosas...”. A continuación de este interés, muestran su cariño por los vecinos de Serrada que trabajan en sus bienes, pues, al tiempo que interceden para que el Hospital ayude a sus familiares si lo necesitan, suplican hagan lo mismo "...si fuese algún vecino de la villa de Serrada...porque como hemos tratadoo con ellos y tenemos alli parte de nuestra hacienda, los tenemos especial afecto...”. (Testamento, caja 1, leg. 2, no 56).

${ }^{704} \mathrm{Su}$ fin llega en 1844 cuando Gregorio León Alonso, importante hacendado local, compra todas sus propiedades a la Junta de Beneficencia en un censo reservativo redimible por importe de 41.567 reales de principal y 1.247 reales de réditos anuales. (A.H.P.V. S.H., caja 3/80, carp. 1, leg.2º, no 55-81). 


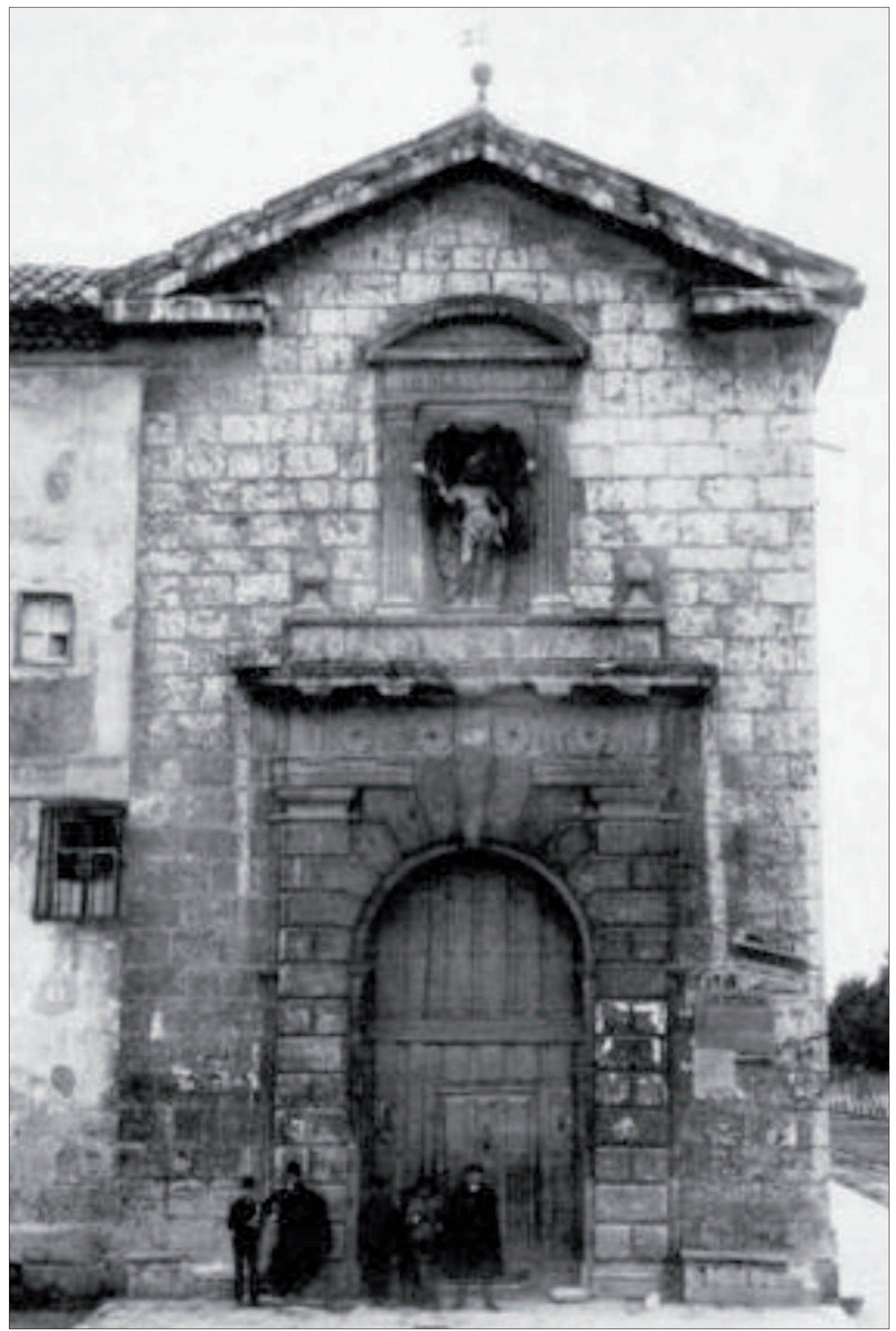

Imagen 61. Fachada del Hospital General de la Resurrección. Valladolid. Siglo XIX. 

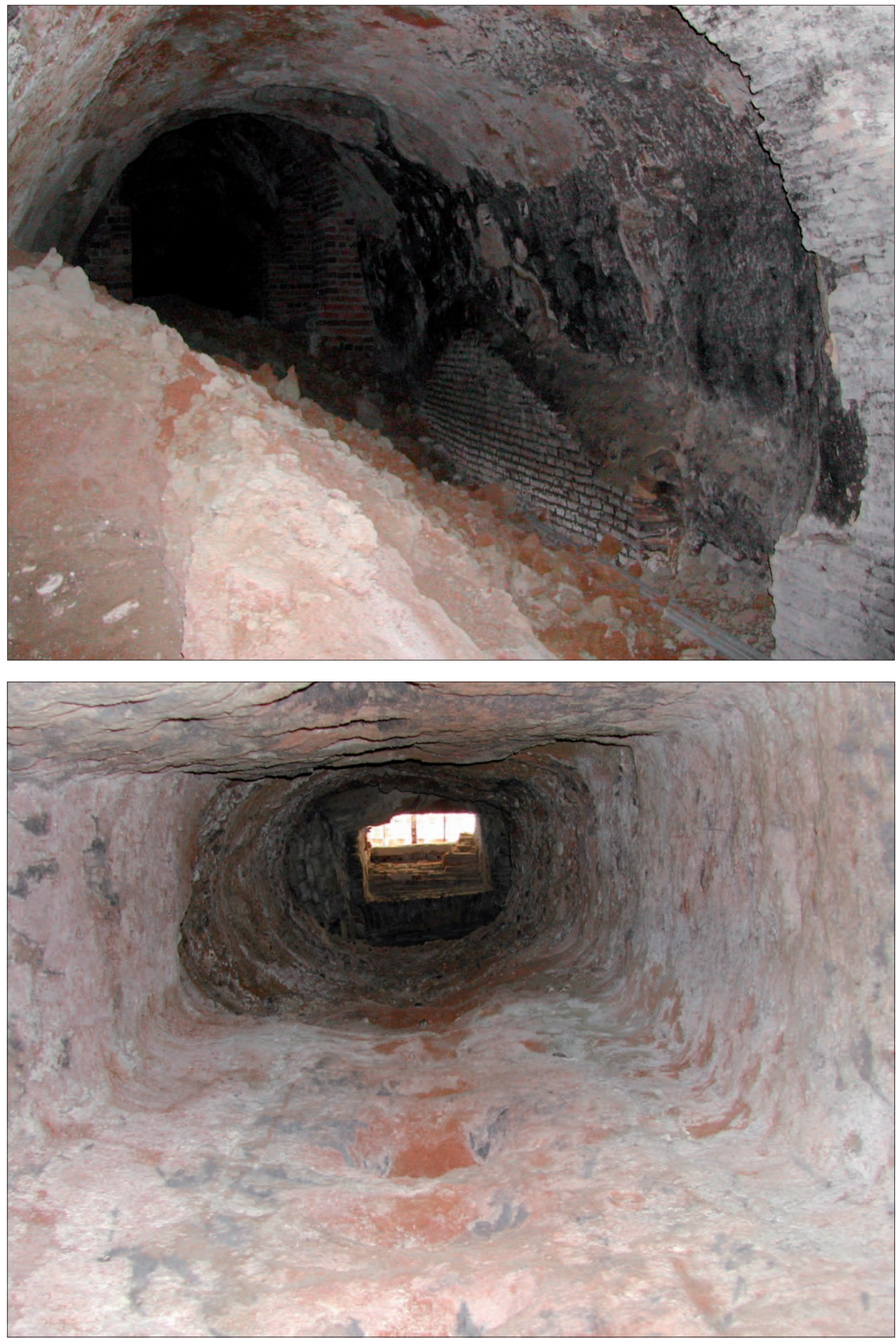

Imagen 62. Vista del cañón principal y del pozo de la bodega del Hospital de la Resurrección, en Serrada. Fotos: julio de 2005. 
Cuadro 75. Labores, costes, producciones y beneficios en majuelos. Hospital de la Resurrección. Serrada. Año $1767^{705}$

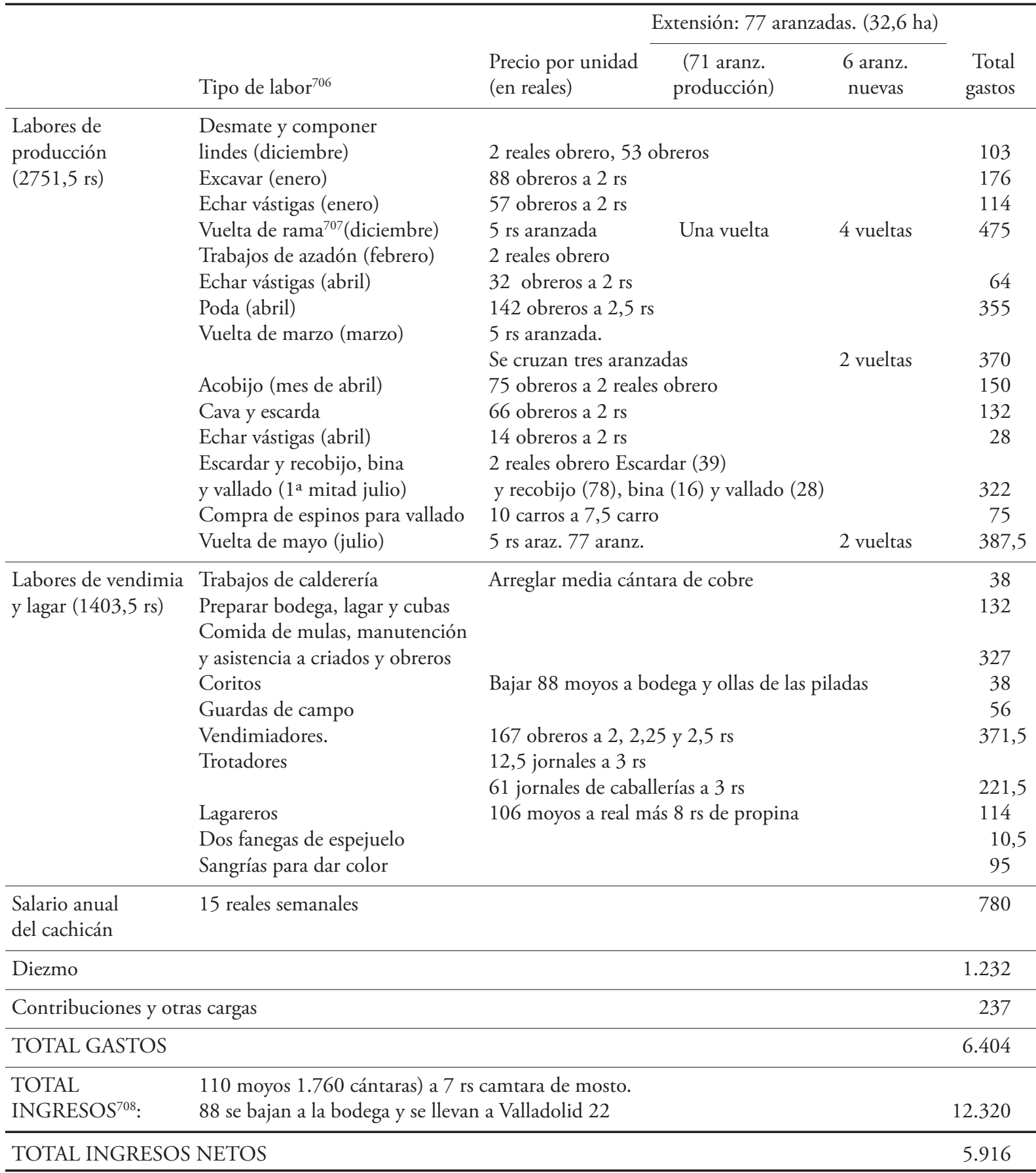

${ }^{705}$ A.H.P.V. Hospital de la Resurrección, cajas 42 y 46.

${ }^{706}$ Entre paréntesis se indica cuando se ha efectuado el pago, por lo que la labor se ha realizado las semanas anteriores.

${ }^{707}$ En el majuelo nuevo de seis aranzadas se habían dado tres vueltas tasadas a cinco reales las dos primeras y a seis rs la tercera.

${ }^{708}$ De acuerdo con las equivalencias manejadas, en las 77 aranzadas se recogen 505 cargas de uva, que a 84,6 kg carga son $42.728 \mathrm{Kg}$. De estos se obtienen, con un rendimiento del 0,695\% (de $23 \mathrm{~kg}$ o dos arrobas sale una cántara o 16 litros), 29.696 litros, o 1.856 cántaras de 16 litros cada una,, que son 116 moyos (16 cántaras o 256 litros). Equivale a una producción en el viñedo de 1,63 moyos por aranzada en los majuelos en producción (603 kg aranzada o 1,43 kg cepa o $1.580 \mathrm{~kg} / \mathrm{ha})$. En el conjunto de las 77 aranzadas, el rendimiento es de 1,50 moyos (552 kg aranzada o $1,31 \mathrm{~kg}$ cepa o $1.447 \mathrm{~kg} / \mathrm{ha})$. 
Cuadro 76. Labores, costes, producciones y beneficios en majuelos. Hospital de la Resurrección. Serrada Año $1768^{709}$

\begin{tabular}{|c|c|c|c|c|c|}
\hline & \multirow[b]{2}{*}{ Tipo de labor } & \multirow[b]{2}{*}{$\begin{array}{l}\text { Precio por unidad } \\
\text { (en reales) }\end{array}$} & \multicolumn{2}{|c|}{ Extensión: 77 aranzadas. (32,6ha) } & \multirow[b]{2}{*}{$\begin{array}{r}\text { Total } \\
\text { gastos }\end{array}$} \\
\hline & & & $\begin{array}{l}\text { (71 aranz. } \\
\text { producción) }\end{array}$ & $\begin{array}{l}6 \text { aranz. } \\
\text { nuevas }\end{array}$ & \\
\hline \multirow{15}{*}{$\begin{array}{l}\text { Labores de } \\
\text { producción }\end{array}$} & \multicolumn{4}{|l|}{ Desmate y componer } & 128 \\
\hline & lindes (noviembre) & \multicolumn{3}{|l|}{2 reales obrero } & 188 \\
\hline & Vuelta de rama ${ }^{710}$ (diciembre) & 6 rs aranzada & 426 & 96 & 522 \\
\hline & Trabajos de azadón (febrero) & 2 reales obrero & 35 & & 35 \\
\hline & \multirow{2}{*}{\multicolumn{4}{|c|}{$\begin{array}{l}\text { Echar vástigas, rehollar majuelo } \\
\text { nuevo, componer vallados (febrero) }\end{array}$}} & \\
\hline & & & 70 & 120 & 150 \\
\hline & Poda (marzo) & & 147 \\
\hline & Vuelta de marzo (marzo) & \multirow{2}{*}{\multicolumn{3}{|c|}{$\begin{array}{l}6 \text { rs aranzada. } \\
\text { Se cruzan seis aranzadas } 462\end{array}$}} & \\
\hline & & & & & 462 \\
\hline & Acobijo (mes de abril) & \multicolumn{3}{|c|}{2 reales obrero } & 170 \\
\hline & \multicolumn{5}{|l|}{$\begin{array}{l}\text { Echar vástigas, desgramar, } \\
\text { limpiar majuelos (mavo) }\end{array}$} \\
\hline & limpiar majuelos (mayo) & & & & 318 \\
\hline & \multicolumn{5}{|l|}{ Escardar y recobijar. } \\
\hline & Se binan 4 aranz. (junio-julio) & \multicolumn{3}{|c|}{2 reales obrero } & 324 \\
\hline & Vuelta de mayo (julio) & \multicolumn{3}{|c|}{6 rs araz. 88 aranz. (arar y cruzar algunas) } & 492 \\
\hline \multirow{19}{*}{$\begin{array}{l}\text { Labores de } \\
\text { vendimia y lagar }\end{array}$} & \multicolumn{4}{|l|}{ Preparar bodega, lagar y cubas } & 14 \\
\hline & Comida de mulas en vendimia & \multicolumn{3}{|c|}{11 fanegas de cebada a 7 reales } & 77 \\
\hline & Gasto de paja & & 35 \\
\hline & \multirow[t]{2}{*}{ Coritos } & \multirow{2}{*}{\multicolumn{3}{|c|}{$\begin{array}{l}\text { Bajar } 68 \text { moyos a bodega } \\
\text { Tres ollas de tres piladas }\end{array}$}} & 49,5 \\
\hline & & \multirow{2}{*}{\multicolumn{3}{|c|}{ Tres ollas de tres piladas }} & 15 \\
\hline & Guardas de campo & & & & 38 \\
\hline & Vendimiadores. & \multicolumn{3}{|c|}{118 obreros a $2,2,25$ y 2,5 rs } & 462,25 \\
\hline & Compra de 5 cuevanos & & & & 4 \\
\hline & \multirow{2}{*}{ Trotadores } & \multicolumn{3}{|c|}{17 jornales a 3 rs } & 51 \\
\hline & & 70 jornales de caballerí & rías a 3 rs & & 210 \\
\hline & Lagareros & 116 moyos a real más & 8 rs de propina & & 124 \\
\hline & Manutención trabajadores & & & & 124 \\
\hline & Asistencia de la cachicana & & & & 24 \\
\hline & Tira del mosto & & & & \\
\hline & Aceite & Tres cuartas de arroba & & & 42 \\
\hline & Doce fanegas de cebada a 10,5 rs & & & & 25 \\
\hline & Preparar cubas y bodega & & & & 65 \\
\hline & Un fanega de espejuelo & & & & 6 \\
\hline & Diez sangrías para dar color & & & & 80 \\
\hline $\begin{array}{l}\text { Salario anual } \\
\text { del cachicán }\end{array}$ & 15 reales semanales & & & & 780 \\
\hline Diezmo 50 cargas & 85 kg cada una, 185,6 cántaras, a 7 & rs cántara & & & $1.299,2$ \\
\hline Contribuciones y & as cargas & & & & 190 \\
\hline TOTAL GASTOS & & & & & $6.650,95$ \\
\hline TOTAL & & & & & \\
\hline INGRESOS ${ }^{711}:$ & 1856 cántaras a 7 reales cántara & & & & 12.992 \\
\hline TOTAL INGRES & NETOS & & & & $6.341,05$ \\
\hline
\end{tabular}

${ }^{709}$ A.H.P.V. Hospital de la Resurrección, cajas 42 y 46.

${ }^{710}$ En el majuelo nuevo de seis aranzadas se habían dado tres vueltas tasadas a cinco reales las dos primeras y a seis rs la tercera.

${ }^{711}$ De acuerdo con las equivalencias manejadas, en las 77 aranzadas se recogen 505 cargas de uva, que a 84,6 kg carga son $42.728 \mathrm{~kg}$. De estos se obtienen, con un rendimiento del 0,695\% (de $23 \mathrm{~kg}$ o dos arrobas sale una cántara o 16 litros), 29696 litros, o 1.856 cántaras de 16 litros cada una,, que son 116 moyos (16 cántaras o 256 litros). Equivale a una producción en el vińedo de 1,63 moyos por aranzada en los majuelos en producción (603 kg aranzada o 1,43 kg cepa o $1.580 \mathrm{~kg} / \mathrm{ha}$ ). En el conjunto de las 77 aranzadas el rendimiento es de 1,50 moyos (552 kg aranzada o 1,31 kg cepa o $1.447 \mathrm{~kg} / \mathrm{ha}$ ). 
Cuadro 77. Labores, costes, producciones y beneficios en majuelos. Hospital de la Resurrección. Serrada Año $1769^{712}$

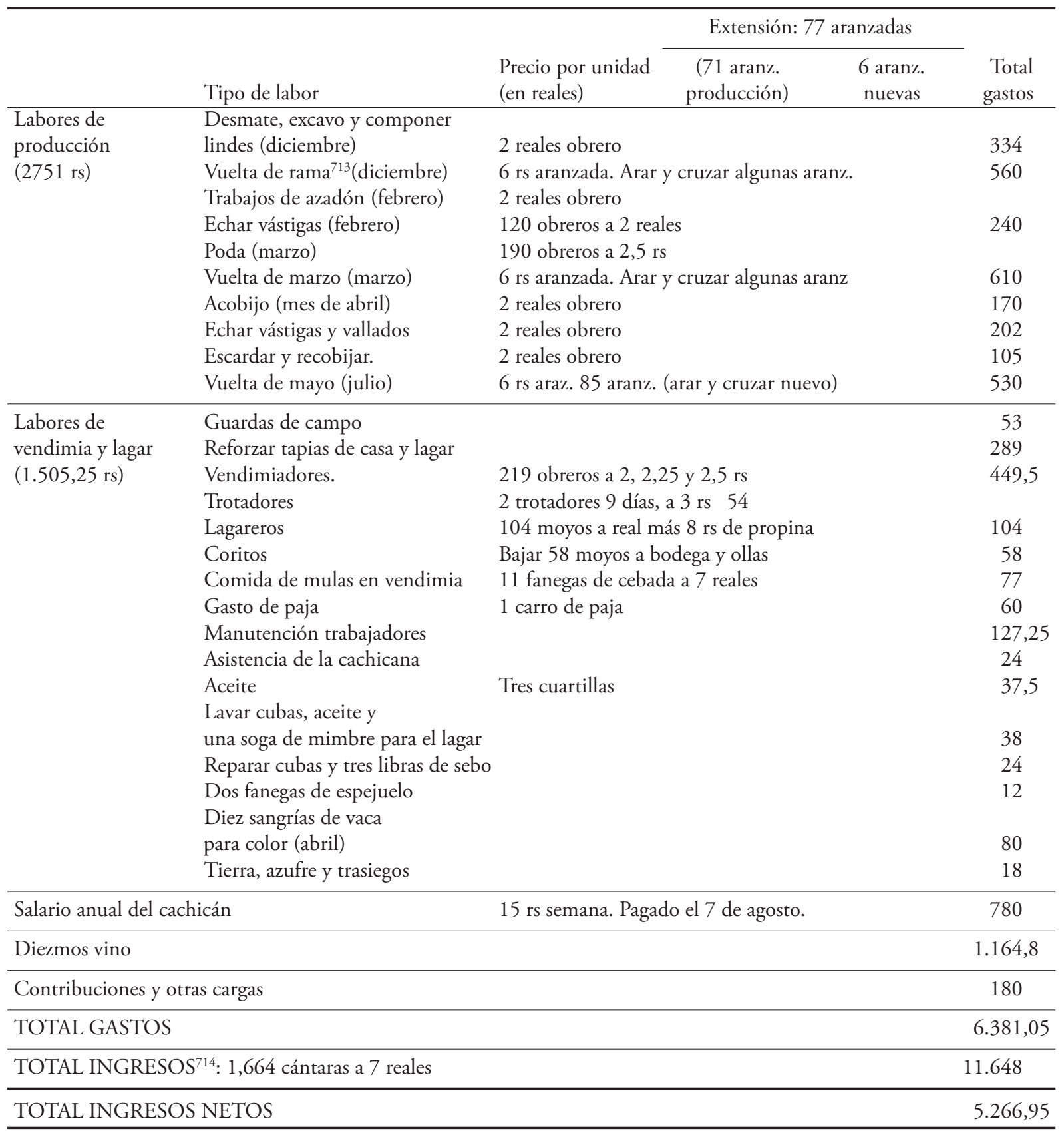

La conservación de los libros de contabilidad de estas granjas religiosas del siglo XVIII ha permitido conocer las labores y rendimientos de los cultivos con notable precisión. En los cuados anteriores se puede corroborar lo ya investigado en relación con los trabajos que lleva el vińedo y que son muy similares siglo tras siglo. En cierto modo es su rentabilidad la que propicia mayores o menores

${ }^{712}$ A.H.P.V. Hospital de la Resurrección, cajas 42 y 46.

${ }^{713}$ En el majuelo nuevo de seis aranzadas se habían dado tres vueltas tasadas a cinco reales las dos primeras y a seis rs la tercera.

${ }^{714}$ De acuerdo con las equivalencias manejadas, en las 77 aranzadas se recogen 478 cargas de uva, a $80,14 \mathrm{~kg}$ carga son $38.307 \mathrm{~kg}$, de los que se obtienen, con un rendimiento del 0,695\% (de $23 \mathrm{~kg}$ o dos arrobas sale una cántara o 16 litros), 26.624 litros, o 1.664 cántaras de 16 litros cada una,,que son 104 moyos (16 cántaras o 256 litros), lo que equivale a una producción en el vińedo de 1,55 moyos por aranzada $(570,9 \mathrm{~kg}$. aranzada o 1,35 kg. por cepa o $1.495 \mathrm{~kg} / \mathrm{ha})$. En el conjunto de las 77 aranzadas el rendimiento es de 1,35 moyos (497,4 kg aranzada o 1,18 kg cepa o $1302 \mathrm{~kg} / \mathrm{ha}$ ). 
cuidados, que las tareas de desmate, desgrame, excavo o acobijo se realicen todos los años, que se les den las tres vueltas, que se echen más jornales de vástigas para evitar saltos en el marco de plantación, que se proteja el cultivo componiendo vallados, etc.

Estas tareas tienen mucho de culturales, pero a nadie se le escapa lo importante de contar con una buena capitalización para formar una buena hacienda, resistir las épocas de crisis y conseguir los máximos beneficios cada cosecha. En este sentido, las casas conventuales estudiadas, como los hombres de negocio que invierten a la luz de coyunturas favorables, llegan capitalizadas, invierten, obtienen beneficios y se van al tiempo que languidecen las cuentas de resultados. He aquí su diferencia respecto a los labradores que, al margen del beneficio con que aumentan o disminuyen sus heredades, siguen atados a la tierra siglo tras siglo.

Como reiteradamente se manifiesta, al margen de la propiedad de la tierra, en la relación entre el campesino y sus cultivos hay un componente esencial: el suelo. De las 20 aranzadas que Pedro de Íscar labra, 3 eran de primera; 6,5 de segunda y 10 de tercera. Los pagos en que se asientan los viñedos del Hospital, salvo los situados en la cañada del Pinar, son de segunda y primera calidad. He aquí un primer factor que explica sus buenos rendimientos medios. No los de los años que se tratan, que superan en un $23 \%$ y $18 \%$ a la media de cosechas obtenida entre 1662 y 1771 , y por tanto se puede considerar muy buena cosecha, sino a la propia media en sí, valorada en 1,16 moyos aranzada o 18,6 cántaras, cosecha intermedia entre las 20 cántaras en que se cifra la media del viñedo de primera calidad y las 14 cántaras de las de segunda. Recuérdese que la cosecha media en los majuelos de segunda calidad de Rueda y La Seca es de 16 cántaras. No hay duda tampoco de que con medias más bajas la granja sería rentable por su forma de comercializar el producto y, por tanto, incluso en los viñedos de tercera se obtendrían buenos rendimientos, pues, al no faltarles labor, el verdejo agradece en su fruto cuanto trabajo se invierte en la cepa.

Como se desprende de los cuadros, los jornaleros no salen de los majuelos en todo el año. En cuanto cae la hoja en noviembre entran a desmatarlos para después ararlos de rama. Tanto en esta vuelta como en la de marzo se cruzan aquellos que lo necesitan. Una y otra vez se invierten obreros en labores de azadón, vástigas, desgrame, escarde... que indican un buen cuidado. Que en mayo se reacobijen para que la cepa quede atemperada y libre de hierbas que le resten humedad es un detalle de buen labrador, o de labrador con posibles, pues no siempre se efectúa cuando se han dado las tres vueltas, excavado y acobijado.

A diferencia del caso anterior, en este ejemplo se precisan los trabajos de vendimia y bodega. El importe de las tareas de producción representa un 51\% del total de gastos en el año1769, los de vendimia y bodega suponen el $28 \%$. De estos, la recogida del fruto se lleva la mayor parte. Se trata de vendimias tardías, en este caso, del 3 y 4 de octubre hasta el 16 y 17 del mismo mes, respectivamente. Con menos de dos kg por cepa, en estas fechas y según de atendidos los majuelos, el fruto presenta una maduración plena de azúcares e incluso inicia el proceso de pasificación, especialmente los racimos orientados al mediodía que, evidentemente, garantizan lo que se busca: buenas y rápidas fermentaciones, elevada oxidación que propicia buen color y alta graduación que garantiza de conservación, evita avinagramiento y posibilita, si no se vende toda la cosecha, un buen ańejamiento. Para conseguirlo, hay que invertir en la limpieza del lagar y cubas, disponer de buenas tierras para clarificar, sangrías para dar color, azufre para desinfectar y trasiegos al realizar estos trabajos. Todos estos factores se detallan y, aunque estas operaciones ya han sido tratadas, que se lleven a cabo sin escatimar un real, indican que hay un fin comercializador de primera línea, como a continuación se verá.

El precio de venta se ha indicado de acuerdo con los precios que señalan los labradores en sus obligaciones e inventarios pero es inferior al que vende el Hospital. No obstante, a 7 reales la cántara de 16 litros y con una producción media en el conjunto de la explotación de 1,5 moyos por aranzada en 1768, quedan 7.510,33 reales o 97,5 reales por aranzada. En 1769, en que baja la producción a 1,35 moyos, el beneficio es de 6.298 reales o 81,79 reales por aranzada. 
Con los gastos de producción manejados, necesarios para mantener el majuelo en primeros niveles, se necesita una cosecha de 0,65 moyos por aranzada (239 kg/aranzada o 563/ha) para evitar pérdidas o, lo que es lo mismo, se debe superar el rendimiento medio del viñedo de tercera calidad porque, de lo contrario, se puede dar el caso de Pedro de Íscar al que, con muchos majuelos de tercera, a medio moyo por aranzada y a cinco reales cántara, los majuelos sólo dan el trabajo que en ellos se invierte y, caso de pedriscos o heladas, el camino del endeudamiento asegurado.

\section{- Una comercialización que se adelanta a su tiempo: Del productor al consumidor}

El Hospital General vende directamente en su bodega de Serrada al por mayor y en Valladolid al por menor de forma acuartillado o por cántaras. Elabora en Serrada, La Cistérniga y Valdestillas y transforma buena parte de la producción in situ en estas villas, pero, desde la vendimia, transporta cada año una parte del mosto a la ciudad. En el caso de la hacienda de Serrada, por ejemplo, en 1767 fermenta 88 moyos en esta villa y traslada 22 moyos a la bodega de la calle Espadería; en 1768 hace lo propio con 752 cántaras que representan el $41 \%$ del total del mosto producido ${ }^{715}$. Al año siguiente son 32 moyos (512 cántaras) equivalentes al 30\% del total ${ }^{716}$. De esta manara no falta mosto ni vino en cualquier época del año, sea para sus necesidades de beneficencia, sea para la venta directa al público.

En los cuadros anteriores se ha fijado el precio del vino a 7 reales la cántara, que es el precio al que se encuentra el mosto en estos ańos. Es también el que aparece en transacciones e inventarios, al tiempo que se entiende apropiado para valorar la cosecha, ya que una cosa es que se encierre el mosto y otra que se transforme en vino vendible y que acompañen los precios. En lo que respecta al ejemplo analizado, en todos estos años no se han detectado cubas perdidas por avinagramientos u otros motivos, lo que lleva a pensar en un buen cuidado, limpieza y saber en todo el proceso, desde que entra la uva en el lagar hasta que sale como vino vendido. Bien por la meticulosa administración que llevan estas casas religiosas, bien por necesario, se puede afirmar que ya entonces llevaban con gran precisión lo que ahora se entiende como trazabilidad, esto es, el conocimiento preciso de todas las labores que lleva el cultivo, desde la cepa hasta la copa, a fin de disponer de la información necesaria para tomar las mejores decisiones en cada momento del proceso.

Como se observa en el cuadro adjunto, del vino que fermenta en cada cuba se conoce el origen, evolución, destino y precio, de tal manera que, en buena lógica, se ha de pensar que estas granjas especializadas y capitalizadas seleccionan vendimias, vińedos y cubas para culminar con éxito la elaboración y venta que, al igual que las tareas de producción y elaboración, llevan sus gastos. De ahí que haya pequeńos productores que prefieran vender el mosto desde el majuelon evitando riesgos. Sin entrar en detalles, baste decir que sólo por el "desbote y bota" en cada cuba, cuando el vino se envasa para su venta, se pierden "a razon de una cántara en cada treinta".

A estas menguas se debe ańadir el mosto final de cada pilada, generalmente de peor calidad, aguapié, chorra y escurriduras, que se fermenta en el llamado cubeto de las labores, gastado en casa por los jornaleros que trabajan en los vińedos o vendido a menor precio y que, igualmente, resta reales en el conjunto final. Junto a ello se han de sumar los gastos anotados de sangrías y tierras para dar color. Desde Valladolid en el año 1768 se envían cinco sangrías por valor de 53 reales más tierra "para dar color a cubas de Serrada", tasadas en 20 reales, al margen de las que se compran en la misma villa. A ello hay que añadir, en este año de 1768, un total de 237 reales que el administrador refleja en su contabilidad por gastos de correduría, fiel medidor y otros.

${ }^{715}$ El transporte de mosto a la bodega del Hospital en Valladolid lo realiza Manuel Fraile, carretero que baja de la Montańa en tiempo de vendimia a realizar estas tareas.

${ }^{716}$ Esta vendimia es el carretero montañés Felipe Fernández el encargado de realizar el transporte con sus carros. 
Cuadro 78. Seguimiento de la cosecha desde su vendimia hasta su venta al por mayor. Hospital General de la Resurrección. Serrada. 1767-1768

\begin{tabular}{|c|c|c|c|c|c|c|c|c|}
\hline $\begin{array}{l}\text { Piladas/ } \\
\text { fecha prensado }\end{array}$ & Viñedos & Cargas $^{717}$ & Cántaras & $\begin{array}{c}\text { Destino } \\
\mathrm{No}^{\circ} \text { cuba }^{718}\end{array}$ & $\begin{array}{c}\text { Vino } \\
\text { en limpio }\end{array}$ & $\begin{array}{c}\text { Fecha } \\
\text { de venta }\end{array}$ & $\begin{array}{c}\text { Precio } \\
\text { (rs/cántara) }\end{array}$ & $\begin{array}{c}\text { Ingresos } \\
\text { brutos }\end{array}$ \\
\hline $\begin{array}{l}1^{\text {a }} \text { pilada } \\
1 / 10 / 67\end{array}$ & $\begin{array}{l}\text { Cuestas }^{719} \\
\text { Olma } \\
\text { Monte }\end{array}$ & 81 & 336 & $\begin{array}{l}\text { Serrada, } \\
\text { cuba } \\
\text { penúltima }\end{array}$ & 315 & $21 / 7 / 68$ & 8 & 2.520 \\
\hline $\begin{array}{l}2^{\text {a }} \text { pilada } \\
3 / 10 / 67\end{array}$ & $\begin{array}{l}\text { Monte } \\
\text { Montaña } \\
\text { Nuevo } \\
\text { Pinar }\end{array}$ & 90 & 323 & $\begin{array}{l}\text { Serrada, } \\
\text { cuba } 2^{\mathrm{a}}\end{array}$ & $301^{720}$ & $31 / 8 / 68$ & $8 \mathrm{rs} / 12 \mathrm{mrs}$ & 2.064 \\
\hline $\begin{array}{l}3^{a} \text { pilada } \\
5 / 10 / 67\end{array}$ & $\begin{array}{l}\text { C. Orca } \\
\text { C.Ventosa } \\
\text { Cuartas } \\
\text { Ciego.Largo }\end{array}$ & 104 & 403 & $\begin{array}{l}\text { A Valladolid, } \\
352 \text { cántaras }\end{array}$ & & & & \\
\hline $\begin{array}{l}4^{a} \text { pilada } \\
6 / 10 / 67\end{array}$ & $\begin{array}{l}\text { Carretas } \\
\text { Vidal }\end{array}$ & 80 & 332 & $\begin{array}{l}\text { Serrada, } \\
\text { cuba } 8^{a}\end{array}$ & 311 & $6 / 7 / 68$ & 9 & 2.712 \\
\hline
\end{tabular}

Fuente: Hospital de la Resurrección. A.H.P.V. Elaboración propia.

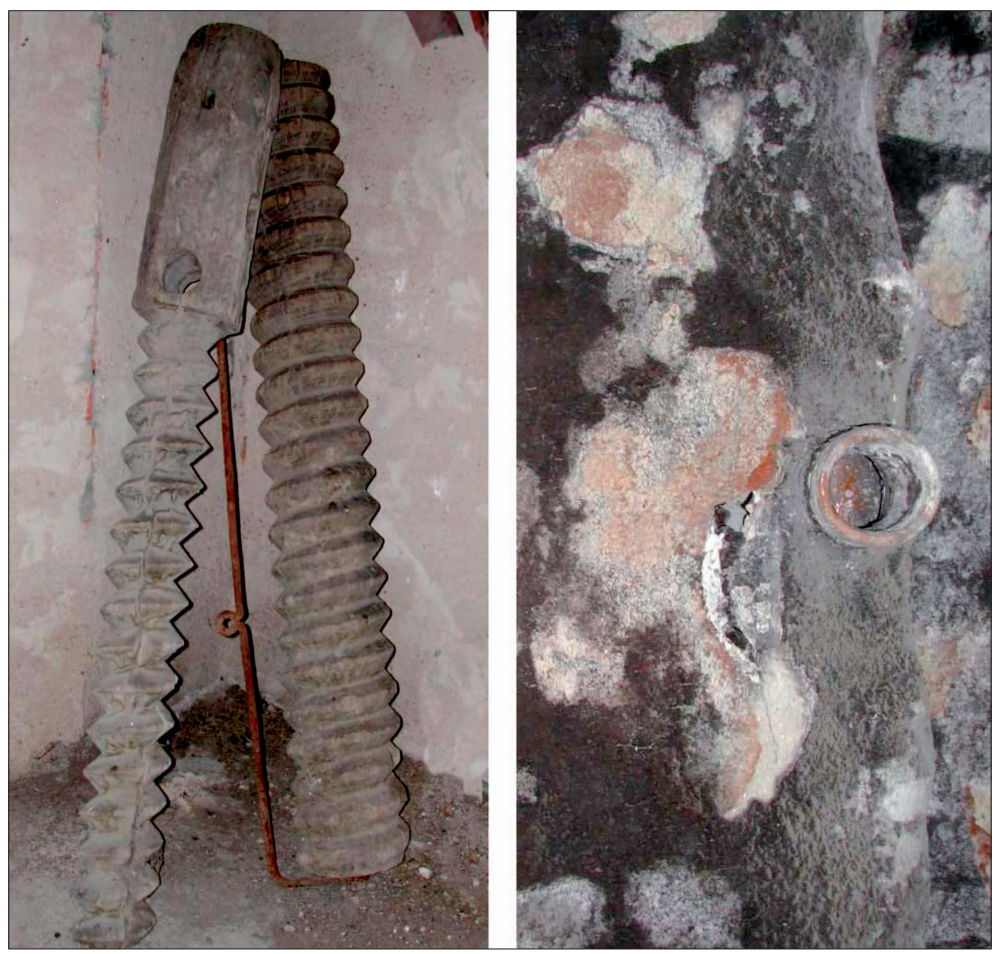

Imagen 63. Husillo del lagar de viga y conductos interiores en la bodega del Hospital de la Resurrección. Serrada. Fotos: julio de 2005.

${ }^{717}$ La transformación de las cargas de uva en mosto varía atendiendo al peso y rendimiento de la uva. En este ejemplo oscilan las cargas entre los 82 y $95 \mathrm{~kg}$.

${ }^{718}$ En Serrada el Hospital llena cinco cubas y el cubeto de las labores. Además, en su bodega elabora una cuba el alcalde de la villa y otra, Marcelo, el cachicán. Se han indicado las cantidades principales en cada cuba.

${ }^{719}$ Este año el majuelo de las Cuestas, puesto de ejemplo en anteriores apartados, tiene una cosecha de 42 cargas, que equivale a $595 \mathrm{~kg} /$ aranzada o 1401/ha. Es un vińedo de buena producción pues consta en 1752 dando uva y este ańo sale a 1,61 moyos por aranzada.

${ }^{720}$ La cuenta de las cubas $2^{\mathrm{a}}$ y $3^{\mathrm{a}}$ se hacen a la par, resultando 464 cántaras en limpio, si bien 163 no son propias del Hospital. 
Para vender, sobre todo, si se quiere vender bien, hay que gastar en la preparación del producto. Si el mosto o el vino sale para Valladolid, el transporte, sin contar trabajos de envase, se tasa a 16 y 17 reales el moyo, que es como decir a real cada cántara, por lo que o se vende bien o las ganancias se aminoran. Basta observar los cuadros de la venta al por menor para comprobar las labores y precios de estos ańos de mediados del XVIII.

Cuadro 79. Detalle de venta de dos cubas en la bodega de los soportales de la Espadería. Hospital General de la Resurrección. Valladolid. Junio de $1762^{721}$

Cuba no 1 de bodega. Aforo: 174 cántaras.

Cuba no 4 de bodega. Aforo: 326 cántaras.

Pasaron a los pobres: 60 cántaras

Quedan de venta: 444 cántaras

Venta acuartillada de 12 moyos y 9 cántaras $^{722}$.

(201 cántaras a razón de 8 cuartos la azumbre. Sale a 13 reales, 6 mrs y 4/7 la cántara).

-En pesetas, 672 rs

-En rs de plata 794.

-En tarines 139.

-En pesos y medios, 280.

-En oro, 317,2.

-En monedas de columnas, 111,8 .

-En cascajo, 256,10

-Más en plata, 3.

-Más una cántara que llevó Dña. Teresa Paniagua, 13,6

Importa 2.611 rs y $21 \mathrm{mrs}$

Venta de la tabernera por menor de15 moyos y tres cántaras.

(243 cántaras, y a razón de 8 cuartos la azumbre. Sale a 13 reales, 6 mrs y 4/7 la cántara).

Importa:3205 rs y $32 \mathrm{mrs}$

TOTAL IMPORTE VENTA: 5.817 rs y $19 \mathrm{mrs}$

\begin{tabular}{|c|c|c|}
\hline Gastos de venta & $\begin{array}{l}\text { Trabajos realizados } \\
\text { Tabernera. } 11 \text { días a dos reales. } \\
\text { Propina del tabernero } \\
\text { Mozo que sacó el vino a la orza y medir el pozal. } 16 \text { días a } 3 \text { rs, más } 2 \text { rs de ayudar a labar cubas } \\
\text { Trasiego de dos cubas } \\
\text { Media arroba de tierra } \\
1 \text { sangría para dar color } \\
\text { Sacar heces y lavar cubas } \\
\text { Por pasar un poco de vinagre al hospital, sacar las heces y lavar las cubas en que estaba } \\
\text { Por trasegar una cuba en la primera venta. } \\
\text { Por azufrar esta cuba. } \\
\text { Derechos de Millones en la primera venta. } \\
\text { Derechos de Facultades en la misma venta. } \\
\text { Derechos de Millones en la segunda venta. } \\
\text { Derechos de Facultades, } 375,18\end{array}$ & $\begin{array}{c}1 \\
8 \\
14 \\
15 \\
6 \\
2 \\
755,2 \\
559,3 \\
503,22 \\
375,18\end{array}$ \\
\hline \multicolumn{2}{|c|}{ Total gastos de venta } & $11 \mathrm{mrs}$ \\
\hline \multicolumn{2}{|l|}{ Ingresos de venta. } & 5.817 rs y $19 \mathrm{mrs}$ \\
\hline \multicolumn{2}{|l|}{ Queda neto } & y $8 \mathrm{mrs}$ \\
\hline
\end{tabular}

Fuente: Hospital de la Resurrección. A.H.P.V. Elaboración propia.

${ }^{721}$ A.H.P.V. Hospital de la Resurrección, cajas 42-46, carp. 22.

${ }^{722}$ Conviene recordar que, redondeando, un moyo son 16 cántaras que totalizan 256 litros a 16 cada cántara. Esta sale de dos arrobas de uva o $23 \mathrm{~kg}$. La media cántara tiene 8 litros; la cuartilla cuatro litros; la azumbre dos litros; el cuartillo (cuarta parte de azumbre o $1 / 32$ parte de cántara) medio litro. Una copa se estima en 1/128 cántaras o 0,12 litros. 
Cuadro 80. Resumen de la venta de tres cubas en la bodega de la Espadería. Hospital General de la Resurrección. Valladolid. Del 11 de abril al 5 de mayo de 1768. En rs.

\begin{tabular}{llr}
\hline Gastos de venta $^{723}$ & Tabernera. 16 días y propina & 41 \\
& Mozo, sacar vino 17 días & 51 \\
& 2,5 sangrías para dar color & 20 \\
& Tabernero y asistenta & 16 \\
& Administración de Millones, Cientos y alcabalas & 1.373 \\
& Administración facultades & 775 \\
\hline Total gastos & & 2.276 \\
\hline Ingresos de venta. 496 cántaras a 11 reales & 5.456 \\
\hline Queda neto & & 3.180 \\
\hline
\end{tabular}

Cuadro 81. Detalle de la venta de dos cubas en la bodega de la Espadería.

Hospital General de la Resurrección. Valladolid. Junio de $1769^{724}$

Venta "a la orza" de la tabernera de diez moyos y dos cántaras y media (162,5 cántaras)

a seis cuartos la azumbre que sale la cántara a once reales, $1 \mathrm{mrs}$ y 3/7. (11,04123 rs/cántara)

Importa $1.794,2$ rs

Venta acuartillado. 188,77 cántaras. Precio de la media cuartilla a doce cuartos.

(Sale la cántara a once reales, 1 mrs y 3/7)

-En pesetas, $508 \mathrm{rs}$

-En rs de plata 372.

-En tarines 101.

-En pesos y medios, 600.

-En oro, 197,2.

-En monedas de columnas, 97,17.

-En cascajo, 208.

Importa $2.083,37$

Total ingresos venta: 3.878, 5 rs (351,27 cántaras al precio anterior)

\begin{tabular}{llr}
\hline Gastos de venta & Trabajos realizados & Reales \\
& Tabernera. 14,5 días a dos reales y 8 rs propina & 37 \\
& Mozo que sacó el vino. 14 días a 3 rs & 42 \\
& Trasiego de dos cubas & 30 \\
& Tierra y azufre & 12 \\
& 8 sangrías para dar color & 64 \\
& Asistencia y cuidado de venta y bodega & 60 \\
& Un recado & 6 \\
& Administración de Millones, Cientos y alcabalas & No constan \\
& Administración facultades & No constan \\
\hline Total gastos & & 251 \\
\hline Ingresos de venta. & & $3.878,5$ \\
\hline Queda neto & & $3.627,5$ \\
\hline
\end{tabular}

Fuente: Hospital de la Resurrección. A.H.P.V. Elaboración propia.

\footnotetext{
${ }^{723}$ Ibídem.

${ }^{724}$ A.H.P.V. Hospital de la Resurrección, cajas 42-46, carp. 19.
} 
En estos dos cuadros se aprecian de forma precisa las operaciones y precios al por menor. Antes de proceder a la venta, se trata al vino con tierras y sangrías para limpiarlo de impurezas y subirle el color. Realizada esta operación, se trasiega a otra cuba limpia en la que se quema azufre a fin de desinfectarla y evitar, en la medida de lo posible, la presencia de aire en su interior que pueda avinagrar el producto.

Todos estos trabajos llevan un coste que no baja de medio real cántara, al que hay que añadir otro real que ha costado el transporte desde Serrada, principal centro de abastecimiento de la bodega. Por encima de cualquier afán mercantilista, lo que se intenta demostrar es que, con los gastos de producción estudiados y este real y medio añadido, ha de subirse el precio respecto al que tiene en origen para poder tener cierta ganancia.

El principal coste de estas ventas, sin embargo, no son estos gastos, sino el importante gravamen que llevan estas ventas al por menor. A falta de una investigación más exhaustiva, en el caso tratado los impuestos suponen en 1762 el 37,68\% del volumen total de ingresos. En el cuadro de 1768 las cargas alcanzan el 39\%. Esto resta importantes beneficios en cada cuba, si es que queda alguno. Si en 1762 se vende en la calle Espadería vino a 13 reales, descontando estos gravámenes, el precio baja hasta 8,16 reales la cántara. En 1763 en Nava del Rey, por ejemplo, el vino tiene un precio en origen de 204 maravedíes (6 reales cántara) y los impuestos representan hasta un $29 \%$ del total ${ }^{725}$. Cuanto mayor es la calidad del vino, mayor son sus impuestos, por lo que ya se puede imaginar el tipo de vino que consumen las clases populares en las distintas ciudades. Se trata de un aspecto que hay que estudiar, pero que sitúa ante una altísima presión fiscal utilizada por ciudades y pueblos para equilibrar sus presupuestos y financiar servicios y trabajos a sus vecinos ${ }^{726}$. El consumidor considera la subida de precios abusiva, pero los taberneros poco pueden hacer más que pagar o asumir riesgos, vendiendo vino ilegal o aguado, práctica por lo demás bastante frecuente en las distintas ciudades. Piénsese que, por ejemplo, en el quinquenio 1657/61, estas cargas representaban el 50\% del precio del vino en Valladolid, similar al que se gravaba en la corte madrileña. Años más tarde, en la respuesta de los obispos castellanos a una carta orden de Felipe V en 1715, se constata esta preocupación hasta considerar al impuesto de los Millones como una de las causas de la decadencia castellana ${ }^{727}$.

Volviendo al tema que tratamos, lo cierto es que la hacienda de Serrada del Hospital General vende todo el vino que produce cada año y rara es la campańa que quedan restos sin vender cuando se inicia la siguiente. Todos los cuadros anteriores reflejan beneficios netos continuados en años de bonanza de cosechas y precios estables. La regularidad de las cosechas, en buena parte por lo cuidado de los viñedos, es la base sobre la que se asientan los beneficios de la venta, se lleve a cabo en Serrada o se traslade el mosto a Valladolid. Se trata de un ejemplo de explotación capitalizada y rentable que controla todo el proceso productivo, desde que el podador selecciona la mejor vara en las cepas del majuelo de Las Cuestas, hasta que la tabernera vende en la calle Espadería la media cuartilla a doce cuartos.

\footnotetext{
${ }^{725}$ HUETZ DE LEMPS, A.: Vinos y Viñedos..., ob. cit., págs. 234-235

${ }^{726}$ Huetz de Lemps en la primera mitad del XVIII anota unos gravámenes entre el 25 y el 30\% en Astorga, Santander, Zamora o Burgos.

${ }^{727}$ ANDRÉS UCENDO, J.I.: Fiscalidad y precios en Castilla en el siglo XVII: los precios del vino en Madrid, 16061700. Departamento de Historia e Instituciones Económicas (Universidad del País Vasco) http://www.um.es/ixcongresoaehe/pdfB2/Fiscalidad\%20y\%20precios.pdf
} 


\section{d. Una de las mayores haciendas de la comarca: La casa conventual de San Pablo}

En el siguiente capítulo se tratarán pormenorizadamente los rasgos de estas granjas religiosas. Se asientan en los pueblos del entorno de la capital a fin de invertir y rentabilizar enormes capitales. Desde mediados del XVII, su presencia en la vida local se intensifica y, en el siglo XVIII, alcanza su máximo apogeo. La importancia patrimonial que alcanza el clero en estas villas es extraordinaria. En Serrada, la casa de San Pablo, orden de los dominicos, se constituye como uno de los más importantes centros productores de vino al sur del Duero. Su origen se remonta a 1657 cuando adquiere a Isabel Navarro, viuda de Jerónimo Maestro, media obrada de tierra por quinientos reales, "para que en la dicha tierra y sitio puedan fabricar y fabriquen casa y lagares y hacer bodega y hacer lo demás que fuese necesario y conveniente al dicho Convento...". No tardan en levantar una impresionante casa de labranza, excavar una amplia bodega y construir cuatro lagares de viga y piedra.

Este patrimonio, en su mayor parte, es adquirido mediante compra a vecinos de Serrada y Matapozuelos en la primera mitad del XVIII. Es raro el año que no adquieren tierras o viñedo en producción. Cuando compran alguna heredad completa, como sucede en 1724 al adquirir los bienes rústicos de Alonso de Requena, casa, bodega y cubas, mantienen las tierras y venden al convento de las Brígidas los bienes urbanos para destinarlos a la casa antigua. Desde 1716 a 1743 invierten la importante suma de 67.440 reales en viñedos en su mayor parte, que se añaden a los empleados en cañones de bodegas, lagares y cubas. Sus edificaciones aumentan en la calle que va a Valdestillas y al Pozo Bueno, hasta el punto de que los vecinos acusan a los dominicos de "embarazar caminos y quitar la comunicación de aires". En 1740, ante el escribano Francisco Moyano, firman un convenio para abrir dos zarceras "para los aires de la bodega"28. Tanto el plano adjunto, como el cuadro que resume el apeo ejecutado en 1787, revelan las dimensiones de esta labranza.

En 1752, el Catastro de Ensenada declara como propiedad de esta casa conventual 34,25 obradas de sembradura en Serrada y 13,5 en el despoblado de La Moya. El grueso de sus bienes, sin embargo, lo forman viñedos, cubas y vino. Poseen entre los dos términos citados 215,5 aranzadas de viñedo y su bodega alberga 42 cubas, con una capacidad de 907,5 moyos (232.320 litros).

Del estudio de sus libros de contabilidad se desprende la conclusión de que se está ante algo más que una casa granja conventual, ante un centro productor de primer orden, con labranza propia y un peso socioeconómico muy importante en la vida local. Por si fuera poco, percibe un tercio entero del diezmo de todas especies diezmables, cifrado su valor en 6.327 reales ${ }^{729}$. Por esta razón y porque poseen sobrada infraestructura, en su lagar pisan la uva y arriendan cubas otros labradores, previo pago de alquiler ${ }^{730}$ :

"Mas cuatrocientos cuarenta y siete reales de rentas de cubas; los 326 rs de Basilio Martín y don Juan Antonio Yscar; 32 rs de manuel Aparicio; y los 89 rs de D. Melchor Moiano. Más trescientos setenta y dos rs de otros tantos moios que pisaron en los lagares de casa, del tercio y otros particulares...”.

Como sucede en otras órdenes religiosas, no todo el vino de la uva que fermenta en la bodega se vende en la casa conventual. Compran y venden de acuerdo a la cosecha obtenida y en sus granjas vecinas. Desde Pollos llega mosto y grano año tras año. Se abastece regularmente a órdenes religiosas de Valladolid. Aunque su producción es de vino blanco, son numerosos los años en que se traen "seiscientas sesenta cántaras de mosto traído al Convento para el vino tinto" 31.

${ }^{728}$ A.H.N. Clero, Libro 17351. fols. sueltos.

${ }^{729}$ A.H.P.V. Catastro de Ensenada, Libro..., fol. 122.

${ }^{730}$ A.H.N. Clero, Libro 17351, fol. 35

${ }^{731}$ A.H.N. Clero, Libro 17351, fol. 65 
Cuadro 82. Apeo del Convento de San Pablo de Valladolid en Serrada. Año $1787^{732}$

\begin{tabular}{|c|c|c|c|c|c|c|}
\hline $\begin{array}{l}\text { Tipo de } \\
\text { aprovechamiento }\end{array}$ & $\begin{array}{l}\text { Nombre de la } \\
\text { pieza o pago }\end{array}$ & $\begin{array}{l}\text { Cabida } \\
\text { en estadales) }\end{array}$ & $\begin{array}{l}\text { Piezas o pedazos } \\
\text { que la forman }\end{array}$ & $\begin{array}{l}\text { Antiguos } \\
\text { Propietarios }\end{array}$ & Vecindad & $\begin{array}{l}\text { Año de } \\
\text { compra }\end{array}$ \\
\hline \multirow{25}{*}{$\begin{array}{l}\text { Tierras y } \\
\text { majuelos }\end{array}$} & \multirow{4}{*}{$\begin{array}{l}\text { Vao del Pico } \\
\text { y Quartillos }\end{array}$} & \multirow[t]{4}{*}{3.537} & 1107 estadales & Fernando Díez Arroyo & Matapozuelos & $15 / 12 / 1733$ \\
\hline & & & $\begin{array}{l}2 \text { obradas y } \\
75 \text { estadales }\end{array}$ & $\begin{array}{l}\text { Jerónimo y } \\
\text { Gregoria Velasco }\end{array}$ & Ventosa & $21 / 05 / 1734$ \\
\hline & & & 2,5 aranzadas & $\begin{array}{l}\text { Josepf Ortiz } \\
\text { y Juana Rico }\end{array}$ & Matapozuelos & $12 / 06 / 1734$ \\
\hline & & & 910 estadales & $\begin{array}{l}\text { Tomás Díez } \\
\text { y María de Îscar }\end{array}$ & Matapozuelos & $09 / 04 / 1734$ \\
\hline & \multirow[t]{5}{*}{$\begin{array}{l}\text { La Cruz del Mal } \\
\text { Ladrón (Olmilla) }\end{array}$} & \multirow[t]{5}{*}{4.740} & $\begin{array}{l}2,5 \text { obradas } \\
\text { y } 46 \text { estadales }\end{array}$ & $\begin{array}{l}\text { Francisco de } \\
\text { Arévalo }\end{array}$ & Matapozuelos & $11 / 01 / 1733$ \\
\hline & & & 1811 palos & Josepf Alonso & Matapozuelos & $02 / 01 / 1733$ \\
\hline & & & 684 estadales & Gregorio Hernández & Matapozuelos & $01 / 02 / 1737$ \\
\hline & & & 1,5 obradas & Bernardo de Villán & Matapozuelos & $07 / 03 / 1737$ \\
\hline & & & $\begin{array}{l}2 \text { obradas } \\
\text { y } 4 \text { estadales }\end{array}$ & Gregorio Velasco & Matapozuelos & $14 / 01 / 1742$ \\
\hline & \multirow[t]{2}{*}{ Pelagallos } & \multirow[t]{2}{*}{2.921} & 8 aranzadas & María Toro & Pozaldez & 28/11/1716 \\
\hline & & & 1,5 obradas & Andrés Alonso & Serrada & $14 / 11 / 1731$ \\
\hline & Simon (Las Cuestas) & 350 & & \multicolumn{2}{|c|}{$\begin{array}{l}\text { Diego Ruiz de Riomayor. } \\
\text { Tomas de Íscar y otros La Seca. Serrad }\end{array}$} & $3 / 8 / 1740$ \\
\hline & \multirow[t]{2}{*}{ Cerrajero y Montico } & \multirow[t]{2}{*}{3.887} & 10 aranzadas & Bernardo Carnicero & Ventosa & $28 / 11 / 1716$ \\
\hline & & & 940 estadales & $\begin{array}{l}\text { Alonso Rodríguez } \\
\text { y otros }\end{array}$ & Pozaldez & $28 / 2 / 1762$ \\
\hline & \multirow[t]{3}{*}{ Antońuela (Cerrajero } & \multirow[t]{3}{*}{ o) 882} & 541 cepas & Isidro Alonso & Serrada & $22 / 5 / 1757$ \\
\hline & & & 491 cepas & Antonio Moyano & Serrada & $22 / 5 / 1757$ \\
\hline & & & 340 cepas & Francisco Rico & Serrada & $22 / 5 / 1757$ \\
\hline & \multirow[t]{2}{*}{ Cerrajero } & \multirow[t]{2}{*}{837} & & Alonso Rodríguez & & \\
\hline & & & & Francisco Barcenilla & Serrada & $28 / 2 / 1762$ \\
\hline & \multirow{2}{*}{\multicolumn{2}{|c|}{$\begin{array}{lr}\text { Cerrajero y } & 2.772 \text { (sobran } \\
\text { Cuartillos } & 62 \text { estadales) } \\
\end{array}$}} & & & Valladolid? & \\
\hline & & & 6,5 obradas & Alonso Requena & Presbitero & $4 / 7 / 1724$ \\
\hline & Carretas & 1.498 & 2180 cepas & Francisco Roman & Serrada & $19 / 3 / 1758$ \\
\hline & $\begin{array}{l}\text { Cruz de los Muertos } \\
\text { (Pozo Bueno) }\end{array}$ & 4.526 & 15 aranzadas & $\begin{array}{l}\text { Francisco Antonio } \\
\text { del Cavo (Canonigo) }\end{array}$ & Valladolid & $14 / 3 / 1758$ \\
\hline & $\begin{array}{l}\text { Heras del Calvario } \\
\text { (Hera y Tierra) }\end{array}$ & 1.118 & 2,5 obradas & $\begin{array}{l}\text { Juan Santos. Manuela } \\
\text { Maestro y otros }\end{array}$ & Serrada & $13 / 6 / 1733$ \\
\hline & Las Raposeras & 2.064 & 5,5 obradas & \multicolumn{2}{|l|}{ Don Alonso de Requena } & Valladolid? \\
\hline \multirow[t]{9}{*}{ Majuelos } & Carretas & 1.140 & & Santos Garcia & Valdestillas & $26 / 12 / 1716$ \\
\hline & El Tinto (Carretas) & 5.444 & $\begin{array}{l}2 \text { aranzadas } \\
\text { menos } 44 \text { cepas }\end{array}$ & Simon de Castro & & \\
\hline & & & 20 aranzadas & Alonso deRequena & Valladoli? & $25 / 2 / 1717$ \\
\hline & Eugenia (Carretas) & 745 & 2,5 aranzadas & $\begin{array}{l}\text { Alonso Crespo, } \\
\text { Eugenia de Iscar }\end{array}$ & $\begin{array}{l}\text { Matilla de } \\
\text { los Caños }\end{array}$ & $3 / 12 / 1716$ \\
\hline & $\begin{array}{l}\text { La Hidalga } \\
\text { (Raposeras) }\end{array}$ & 1.252 & 4 aranzadas & $\begin{array}{l}\text { Maria Bayon, } \\
\text { Bartolomé Minguela }\end{array}$ & Serrada & $1 / 3 / 1719$ \\
\hline & \multicolumn{2}{|c|}{$\begin{array}{l}\text { La Ladera de Matias } \\
\text { (Raposeras) }\end{array}$} & 3,5 aranzadas & $\begin{array}{l}\text { Andres Rodríguez } \\
\text { Zorrilla (Beneficiado) }\end{array}$ & Serrada & $1 / 3 / 1719$ \\
\hline & $\begin{array}{l}\text { Las Zarzas } \\
\text { (Alvarillos) }\end{array}$ & $\begin{array}{r}1.232 \text { y } \\
29 \text { cepas }\end{array}$ & 4 arnzadas & Antonio Rodríguez & Serrada & $1 / 3 / 1717$ \\
\hline & Senderillo & 1.321 & & \multicolumn{2}{|c|}{ Don Alonso de Requena Valladolid? } & $24 / 7 / 1724$ \\
\hline & El Pinar & 1.553 & & \multicolumn{2}{|c|}{ Don Alonso de Requena Valladolid? } & - \\
\hline Total & 43.034 est & estadales & & & & \\
\hline
\end{tabular}

Fuente: Protocolos Notariales. A.H.P.V. Elaboración propia.

${ }^{732}$ A.H.P.V. Pt. 8224, fol. 621 y ss. 
Junto a su impresionante hacienda vitícola, labran 86 obradas de sembradura en sistema bienal, por lo que, junto al viñedo, el conjunto de la explotación suma 162 ha. La hoja sembrada suele repartirse en 43 obradas de trigo, cebada, centeno y algarrobas. En 1791, por ejemplo, siembran 60 fanegas de trigo, 5,5 de cebada, 8 de avena y 3 de algarrobas. Normalmente compran cebada para el gasto de la labranza, pues las tierras son de segunda y tercera, más aparentes para el viñedo. Al trabajarlas con el ganado de casa y no hacer constar huebras, únicamente se conocen fanegas sembradas, gasto de siega y cosecha, por lo que no se puede estudiar su rentabilidad, pero sí manifestar que la mayor parte de la producción se destina al gasto interno, sea de trigo, cifrado en 60 fanegas, sea de cebada y algarrobas para alimento del ganado.

La producción por obrada se estima en siete u ocho fanegas de trigo, muy por encima del que rinden sus tierras de centeno o avena. El propio precio al que ajustan la siega ya es un indicador en este sentido. Hay ańos, como en 1791, en que una obrada cuesta 11 reales y otros, como 1793, en el que el trigo y la cebada se siega a 8,5 reales y la avena a 7 reales. Se observa, y ya se ha constatado anteriormente, el cambio que se produce a lo largo de la segunda mitad del XVIII en las tierras de sembradura: los retelos aumentan en las tierras de primera calidad, la cebada incrementa la superficie de cultivo por las necesidades del ganado y, en las últimas décadas, las leguminosas crecen en cantidad y en variedad. Muchas de ellas se echan sobre pajas para proveerse de pienso y vender el trigo y la cebada en el mercado ante la considerable subida de precios. En esta hacienda, como en la capitalizada de los Moyano, también se observan las prácticas de abonado o estercolado a fin de aumentar la productividad. Otra labor para obtener buenas cosechas son las tareas de limpieza y escarde de los sembrados. En 1795, por ejemplo, los dominicos en sus cuentas no olvidan a "los obreros en escardar los trigos a dos reales", prueba de su interés por este cultivo, especialmente cuando llega a 44 reales la fanega y el morcajo a 34 reales, justo el doble que veinte ańos antes ${ }^{733}$.

Como en el vino, el precio lo fija la calidad del producto, su abundancia o escasez y la necesidad de compraventa entre las partes. En el anterior año de 1795, cuando el trigo está a 46 reales y el morcajo a 34, los dominicos venden "dos fanegas a treinta y quatro reales por ser mediano"34. La propia especulación es decisiva para obtener beneficios o pérdidas en un mismo ańo y cosecha. En 1793, en el que constan operaciones por debajo de los quince reales, los dominicos venden "10 fanegas de zebada llevada del convento a 30 reales fanega que valía en mayo" 35 . Esta práctica de aguantar el grano en las paneras hasta que alcance el máximo precio y venderlo es propia de labranzas muy saneadas y capitalizadas como la analizada. Hasta que llegue la revolución de los transportes y la llegada de grano más barato del aquí producido, los picos alcistas continúan año tras año beneficiando a los más pudientes.

En el viñedo el margen de maniobra es más bien escaso. El producto es perecedero y el avinagramiento, un riesgo demasiado grande. Los gastos fijos del cultivo son importantes e imprescindibles y el atraso de labores lleva a la ruina al propietario, esté la cántara de vino cara o barata. A esto se añaden la helada y el pedrisco, enemigos del cultivo, pero especialmente dañinos con los majuelos. Puede parecer puro mercantilismo o el inicio de una economía capitalista, pero, cuando los vinos bajan de precio, hasta los dominicos pierden dinero y deben ajustar gastos, como se evidencia en los cuadros que siguen. Si varios ańos seguidos son malos, muchos majuelos se pierden y llenan de grama, las deudas se incrementan y el hambre se ceba con los jornaleros. Piénsese que en 1768, por ejemplo, sólo en labores de vińedo se gastan 9.717 rs que suponen, a dos reales diarios, el trabajo de quince jornaleros empleados todo el año ${ }^{736}$. Por el contrario, y antes de que llegue el colapso de fin de siglo, con los precios al alza se roturan hasta las tierras más estériles, aumentan los jornales, se intensifican los cultivos, se anima el mercado y el consumo crece hasta que llegue una nueva hecatombe.

\footnotetext{
${ }^{733}$ Ibídem, fol. 94.

${ }^{734}$ A.H.N. Clero, Libro 17351, fol. 62. Conviene recordar que el morcajo es una envuelta de trigo y centeno.

735 Ibídem, fol. 84.

736 Ibídem, fol. 2.
} 
Cuadro 83. Detalle del vino vendido en la casa conventual de San Pablo de Serrada

\begin{tabular}{ccccccccc}
\hline & Ańo 1775 & & \multicolumn{3}{c}{ Ańo 1785} & \multicolumn{3}{c}{ Año 1795} \\
Cántaras & Precio & Reales & Cántaras & Precio & Reales & Cántaras & \multicolumn{1}{c}{ Precio } & \multicolumn{1}{c}{ Reales } \\
\hline 332 & 10,25 & 3.403 & 233 & 7 & 1.631 & 705,25 & 13,5 & 9.521 \\
226 & 8,5 & 1.921 & 500 & 4,5 & 2.250 & 240 & 13,75 & 300 \\
348 & 8,25 & 2.871 & 1.343 & 4,25 & $5.707,75$ & 415,25 & 14 & $5.813,16$ \\
330 & 9 & 2.970 & 243 & 4,5 & $1.093,16$ & 250 & 14,25 & $3.562,16$ \\
48 & 9,45 & 453,6 & & & & 160 & 14,5 & 2.320 \\
34,5 & 10 & 345 & & & & 143,5 & 15 & $2.152,16$ \\
46 & 9,75 & 448,5 & & & & 118 & 15,5 & 1.829 \\
518 & 8,75 & $4.532,5$ & & & & 62,5 & 16 & 1.000 \\
63 & 8,5 & 535 & & & & 2 & 18 & 36 \\
& & & & & & 5 & 18,5 & 92,16 \\
& & & & & & 17 & 20 & 500 \\
1945,5 & 8,98 & $17.476,6$ & 2.319 & 4,60 & $10.681,91$ & $2.162,25$ & 12,75 & $27.578,44$ \\
\hline
\end{tabular}

Fuente: Libros del Clero. Archivo Histórico Nacional. Elaboración propia.

El cuadro adjunto dice por sí mismo más de lo que se pueda detallar. En la vitivinicultura cada año es un mundo distinto, se trate de Pedro de Íscar, los Moyano, el Hospital General o los dominicos. Las oscilaciones de cosecha, la elaboración, las sacas y el precio de venta fluctúan año tras año, si bien, desde los ańos cuarenta hasta el fin de siglo, la tendencia general es alcista. En esta casa religiosa el año en el que se vende el vino más caro es el de 1795, en que alcanza de media 12,75 reales, salvo el año 1792 en que tan sólo se cogieron 2.784 cántaras (0,66 moyos/aranzada) y en el que el precio compensa en parte las pérdidas, pues se dispara en las 1.315 cántaras vendidas hasta los 15 reales ${ }^{737}$.

Circunstancias similares se observan en los cuadros de los años 1781 y 1791. Al final es el precio de la cántara vendida, junto con el volumen de la cosecha, el que determina que se cierre el año con ganancias o pérdidas. En la primera fecha, con una cosecha de 1,56 moyos, un precio de 13,12 reales cántara y unos gastos de producción de 144 reales por aranzada, se obtienen unos beneficios de 102,5 reales por aranzada. Este año en la granja del Hospital General tuvieron con una cosecha de 1,66 moyos/aranzada unos beneficios netos de 135,8 reales por aranzada. En 1791 la casa de San Pablo, con una cosecha de a moyo por aranzada, y la cántara a 10 reales, aunque el administrador dominico recorta gastos hasta bajar a los 120 reales aranzada, el saldo es negativo. La disminución de cosecha explica el déficit en unos años en que salarios y otros costes son altos. En 1791 el Hospital General recolecta a 1,89 moyos, por lo que, a diferencia de sus vecinos dominicos, también tuvieron beneficios, al igual que la estimación que se hizo en la hacienda de los Moyano, con unos beneficios netos a 125,6 reales aranzada. Se desconocen los meteoros de este año, pero el déficit dominico de 1791 sólo es explicable por un pedrisco en el término despoblado de La Moya, donde la casa de San Pablo concentra buena parte de sus majuelos.

\footnotetext{
${ }^{737}$ Ibídem, fol. 80. En 1795 constan también 285,5 cántaras de vinagre y 27 cántaras de aguardiente, de las que 25 cántaras se venden a 34 rs y 2 cántaras a 35 rs.
} 
Cuadro 84. Labores, costes, producciones y beneficios en majuelos. Hacienda de San Pablo, Serrada, ańo 1781738, (268 aranzadas de viñedo o 113,64 ha)

\begin{tabular}{|c|c|c|c|}
\hline $\begin{array}{l}\text { Tipo de labor, } \\
\text { inversión o gasto }\end{array}$ & Detalle del trabajo & Precio por unidad (en reales) & Total (rs) \\
\hline$(7.787,5 \mathrm{rs})$ & $\begin{array}{l}\text { Desmatar, echar vástigas, } \\
\text { esmelgar, escardar y } \\
\text { hacer manojos } \\
\text { Excavar } \\
\text { Poda } \\
\text { Acobijo } \\
\text { Soldadas de arancias } \\
\text { y personal de casa }\end{array}$ & $\begin{array}{l}1.219 \text { obreros a } 2 \text { rs } \\
3 \text { rs aranzada } \\
635 \text { obreros a } 2,5 \text { rs } \\
3 \text { rs aranzada. } \\
\text { Salario de dos mozos, } 816 \text { rs } \\
\text { Motril, } 120 \text { rs } \\
\text { Otro obrero para las mulas, } 202 \text { rs } \\
\text { Ama de la casa, } 216 \text { rs } \\
\text { Cachicán, } 800 \text { rs }\end{array}$ & $\begin{array}{l}2.438 \\
804 \\
1.587,5 \\
804\end{array}$ \\
\hline $\begin{array}{l}\text { Gastos de salarios } \\
\text { mantenimiento, } \\
\text { mejoras y otros } \\
(4.477 \mathrm{rs})\end{array}$ & $\begin{array}{l}\text { Herrador, herrero, cirujano } \\
\text { y otros } \\
\text { Cerretero } \\
\text { Aperos de labranza e hierro } \\
\text { Compra de dos mulas }\end{array}$ & $\begin{array}{l}\text { Herrar } 3 \text { pares mulas, } 75 \text { rs; caballo y burra, } 39 \text { rs; } \\
\text { Herrero, } 180 \text { rs; cirujano, médico, recogida diezmo... } \\
\text { Hacer } 43 \text { arados, } 142 \text { rs; reparar carros, } 45,5 \text { rs... }\end{array}$ & $\begin{array}{l}613,5 \\
187,5 \\
344 \\
3.332\end{array}$ \\
\hline \multirow{9}{*}{$\begin{array}{l}\text { Labores de } \\
\text { vendimia, la } \\
\text { y bodega } \\
(6.251 \mathrm{rs})\end{array}$} & Cestos y arcos para las cubas & $\begin{array}{l}24 \text { cargas de cestos a } 24 \text { rs; } 12 \text { cobanillos a real; } \\
\text { arcos de madera, salario del cubero... }\end{array}$ & 453,5 \\
\hline & Espejuelo, sogas y otros & 72 arrobas de espejuelo a 1,25 rs; sogas, trabas... & 125,5 \\
\hline & \multicolumn{2}{|c|}{ Manutención y asistencia a criados y obreros } & 1.454 \\
\hline & Coritos & Tirar 420 moyos a bodega & 210 \\
\hline & Vendimiadores. & 1146 obreros de vendimia a 2 rs; & \\
\hline & & 123 obreros de cargadores y cachicanes a 2,5 rs & \\
\hline & & 34 huebras de acarreo de uva, a 20 rs & $3.279,5$ \\
\hline & Lagareros & 420 moyos a real & 420 \\
\hline & Composición del vino & $\begin{array}{l}30 \text { sangrías a } 8 \text { rs; } 12 \text { libras de azufre a } 13 \text { cuartos, } \\
100 \text { fanegas de tierra de la Nava a medio real. }\end{array}$ & 308,5 \\
\hline \multirow[t]{5}{*}{$\begin{array}{l}\text { Gastos varios } \\
(20.165 \mathrm{rs})\end{array}$} & \multicolumn{3}{|c|}{$\begin{array}{l}\text { Matanza: } 22 \text { rd. de una cecina; } 286 \text { de un cerdo; } 196 \text { de } 2 @ \text { de pescado y } 3 @ \text { de sardina; } \\
28 \text { rs de una fanega de lentejas; } 144 \text { rs de } 4 \text { fanegas de sal; } 600 \text { rs de } 9 @ \text { de aceite } \\
\text { y } 2 \text { @ de jabón a } 60 \text { rs.... }\end{array}$} \\
\hline & \multicolumn{2}{|c|}{$\begin{array}{l}54 \text { rs de guarda de las viñas y ovejas; } 90 \text { rs de } 6 \text { carros de leña; } 54 \text { rs de esquilar tres veces } \\
\text { a las mulas, a } 3 \text { rs; } 36 \text { rs de } 2 \text { pellejos para servicio de la bodega... }\end{array}$} & 4.178 \\
\hline & \multicolumn{2}{|c|}{$\begin{array}{l}\text { Comida de las mulas: } 358 \text { fanegas de cabada a } 18 \text { rs, } 6.444 \text { rs; } 24 \text { fanegas que valio } \\
\text { el verde que comieron, } 432 \text { rs; } 8 \text { fanegas de centeno a } 21 \text { rs, } 168 \text { rs,..., }\end{array}$} & 7.044 \\
\hline & \multicolumn{2}{|c|}{$\begin{array}{l}\text { Gasto de casa. } 60 \text { fanegas de trigo, a } 24 \text { rs } 1440 \text { rs; } 20 \text { celemines de garbanzos, } 73 \text { rs; } \\
500 \text { cántaras de vino para casa y jornaleros a } 10 \text { rs, } 5000 \text { rs }\end{array}$} & 6.513 \\
\hline & \multicolumn{2}{|c|}{1.470 del administrador y 960 rs de gastos de su persona y huéspedes. } & 2.430 \\
\hline \multirow[t]{2}{*}{$\begin{array}{l}\text { Cargas } \\
(13.197,5 \mathrm{rs})\end{array}$} & \multicolumn{2}{|c|}{$\begin{array}{l}\text { Desvotes. Siguiendo la costumbre de treinta cántara, una, y de cien otra: } 3.820,5 \text { rs } \\
\text { Diezmo: } 8.816 \text { rs }\end{array}$} & \\
\hline & \multicolumn{2}{|c|}{ Contribuciones, fiel medidor y otras cargas: 561} & $13.197,5$ \\
\hline TOTAL GASTOS & & & 51.878 \\
\hline \multicolumn{3}{|c|}{$\begin{array}{l}\text { TOTAL INGRESOS: Producción } 420 \text { moyos (1,56 moyos aranzada o } 577,25 \mathrm{~kg} / \text { aranzada). } \\
\text { Se obtienen } 6.720 \text { cántaras. Quitado el diezmo quedan } 6.048 \text { cántaras, a } 13,12 \text { rs }\end{array}$} & $79.350,4$ \\
\hline \multicolumn{2}{|c|}{ TOTAL INGRESOS NETOS } & $27.472,4$ & \\
\hline
\end{tabular}

Fuente: Libros del Clero. Archivo Histórico Nacional. Elaboración propia.

${ }^{738}$ A.H.N. Clero. Libro 17351. fol. 52-55. 
Cuadro 85. Labores, costes, producciones y beneficios en majuelos. Hacienda de San Pablo, Serrada, año 1791739. (260 aranzadas de viñedo o 110,35 ha)

\begin{tabular}{|c|c|c|c|}
\hline $\begin{array}{l}\text { Tipo de labor, } \\
\text { inversión o gasto }\end{array}$ & Detalle del trabajo & Precio por unidad (en reales) & $\begin{array}{l}\text { Total } \\
\text { (en rs) }\end{array}$ \\
\hline $\begin{array}{l}\text { Labores de } \\
\text { producción } \\
(9.709 \mathrm{rs})\end{array}$ & $\begin{array}{l}\text { Desmatar, echar vástigas, } \\
\text { esmelgar, escardar y } \\
\text { hacer manojos... } \\
\text { Excavar } \\
\text { Poda } \\
\text { Acobijo } \\
\text { Huebras de arada } \\
\text { Soldadas de arancias } \\
\text { y personal de casa }\end{array}$ & $\begin{array}{l}1040 \text { obreros a } 2,5 \text { rs } \\
3 \text { rs aranzada } \\
891 \text { obreros a } 3 \text { rs } \\
3 \text { rs aranzada. } \\
67 \text { aranzadas en marzo y mayo a } 10 \text { rs } \\
\text { Salario de dos mozos, } 946 \text { rs } \\
\text { Motril, } 220 \text { rs } \\
\text { Ama, } 240 \text { rs, a } 20 \text { rs cada mes. } \\
\text { Criada, } 130 \text { rs }\end{array}$ & $\begin{array}{r}2.600 \\
780 \\
2.673 \\
780 \\
1.340\end{array}$ \\
\hline $\begin{array}{l}\text { Gastos de salarios } \\
\text { mantenimiento, } \\
\text { mejoras y otros } \\
(3.980 \mathrm{rs})\end{array}$ & $\begin{array}{l}\text { Herrador, herrero, cirujano } \\
\text { y otros } \\
\text { Carretero y madera } \\
\text { Aperos de labranza e hierro } \\
\text { Compra de una mula } \\
\text { para la labranza }\end{array}$ & $\begin{array}{l}\text { Herrar } 3 \text { pares mulas y caballo, } 300 \text { rs; esquilarlas tres } \\
\text { veces } 63 \text { rs; herrero, cirujano, médico,... } \\
\text { Hacer } 60 \text { arados, } 142 \text { rs; reparar carros... } \\
\text { Calzar arados, } 8 \text { @ de hierro a } 23 \text { rs... }\end{array}$ & $\begin{array}{r}1.147 \\
526 \\
807\end{array}$ \\
\hline $\begin{array}{l}\text { Labores de } \\
\text { vendimia, lagar } \\
\text { y bodega } \\
(4.737 \mathrm{rs})\end{array}$ & $\begin{array}{l}\text { Espejuelo } \\
\text { Manutención y asistencia a c } \\
\text { Coritos } \\
\text { Vendimiadores. }\end{array}$ & $\begin{array}{l}12 \text { cargas de cestos a } 8 \text { rs; } 18 \text { cobanillos a real; } \\
\text { arcos de madera, } 15 \text { @ de pez a } 7 \text { rs; salario del cubero, } \\
\text { lavar cubas... } \\
80 \text { arrobas de espejuelo a } 1,5 \text { rs para echar en las uvas; } \\
\text { sogas, trabas... } \\
\text { iados y obreros } \\
\text { Tirar } 242 \text { moyos a bodega } \\
983 \text { obreros de vendimia } \\
926 \text { obreros a } 2,5 \text { rs y } 57 \text { obreros a } 3 \text { rs } \\
192 \text { caballerías a } 3 \text { rs } \\
4 \text { huebras de acarreo de uva, a } 20 \text { rs } \\
282 \text { moyos a real } \\
\text { Sangrías, azufre y tierra }\end{array}$ & $\begin{array}{r}2.486 \\
656 \\
282 \\
170\end{array}$ \\
\hline $\begin{array}{l}\text { Gastos varios } \\
(12.895,5 \mathrm{rs})\end{array}$ & \multicolumn{2}{|c|}{$\begin{array}{l}\text { Manutención: Compra de tres cerdos y } 8 \text { castrones para cecina, } 740 \text { rs; } \\
10 \text { @ de pescado, } 375 \text { rs; } 9 \text { @ de aceite a } 60,6 \text { rs; jabón, loza.... } \\
\text { Guardas: } 76 \text { rs al guarda del ganado, } 51 \text { al guarda del campo, } 20 \text { rs al de las viñas } \\
\text { Alimento ganado: } 360 \text { fanegas gastadas a } 12,5 \text { rs; } \\
\text { otras } 79 \text { fanegas de cebada, avena, algarrobas.. }\end{array}$} & $\begin{array}{l}1.661 \\
147 \\
5.487,5 \\
5.600\end{array}$ \\
\hline $\begin{array}{l}\text { Cargas } \\
(11.332 \mathrm{rs})\end{array}$ & \multicolumn{2}{|c|}{$\begin{array}{l}\text { Desvotes. Siguiendo la costumbre de treinta cántara, una, y de cien otra: } 3820,5 \text { rs } \\
\text { Diezmo: } 8.816 \text { rs } \quad 8.816\end{array}$} & 1.955 \\
\hline TOTAL GASTOS: & 42.653 .5 & & \\
\hline $\begin{array}{l}\text { TOTAL INGRESO } \\
\text { Se obtienen } 4.512 \mathrm{c}\end{array}$ & $\begin{array}{l}\text { Producción de } 282 \text { moyos. } \\
\text { taras. Quitado el diezmo que }\end{array}$ & $\begin{array}{l}\text {,08 moyos aranzada o } 399,5 \mathrm{~kg} / \text { aranzada). } \\
\text { lan } 4060,8 \text { cántaras, a } 10 \text { rs }\end{array}$ & 40.608 \\
\hline TOTAL INGRESC & JETOS & & \\
\hline
\end{tabular}

Fuente: Libros del Clero. Archivo Histórico Nacional. Elaboración propia.

Sin entrar en hipótesis, basta observar las producciones y precios en el cuadro adjunto para comprobar lo que se viene estudiando. En el viñedo cada añada está sujeta a una diversidad de condicionantes imposibles de prever, pero decisivos en el cómputo final:

${ }^{739}$ A.H.N. Clero, Libro 17351, fol. 76-80. 
Cuadro 86. Cosecha obtenida y precio medio en la casa de San Pablo, Serrada, ańos 1768-1801740

\begin{tabular}{lccccccc}
\hline Años & $\begin{array}{c}\text { Cosecha } \\
\text { (cántaras) }\end{array}$ & $\begin{array}{c}\text { Moyos por } \\
\text { aranzada }\end{array}$ & $\begin{array}{c}\text { Precio } \\
\text { (rs/cántara) }\end{array}$ & Años & $\begin{array}{c}\text { Cosecha } \\
\text { (cántaras) }\end{array}$ & $\begin{array}{c}\text { Moyos por } \\
\text { aranzada }\end{array}$ & $\begin{array}{c}\text { Precio } \\
\text { (rs/cántara) }\end{array}$ \\
\hline 1768 & 5.160 & 1,51 & 8,03 & 1785 & 5.352 & 1,24 & 4,64 \\
1769 & 5.268 & 1,54 & 4,93 & 1786 & 5.898 & 1,37 & 4,94 \\
1770 & 6.176 & 1,81 & 4,61 & 1787 & 4.664 & 1,08 & 6,45 \\
1771 & 5.024 & 1,47 & 6,21 & 1788 & 5.408 & 1,26 & 12,35 \\
\hline 1772 & 4.112 & 1,20 & 7,18 & 1789 & 4.859 & 1,13 & 8,52 \\
1773 & 6.280 & 1,84 & - & 1790 & 4.272 & 0,99 & 11,17 \\
1774 & 5.427 & 1,50 & 7,67 & 1791 & 4.512 & 1,08 & 10,08 \\
1775 & 4.599 & 1,30 & 8,35 & 1792 & 2.784 & 0,66 & 15,00 \\
\hline 1776 & 5.504 & 1,52 & - & 1793 & & - & \\
1777 & 4.514 & 1,17 & 8,30 & 1794 & 5.320 & 1,27 & - \\
1778 & 6.192 & 1,05 & 4,51 & 1795 & 4.512 & 1,08 & 14,14 \\
1779 & 4.272 & 0,98 & 6,53 & 1796 & 4.800 & 1,15 & 12,86 \\
\hline 1780 & 5.168 & 1,20 & 10,27 & 1797 & & - & 13,67 \\
1781 & 6.720 & 1,56 & 13,12 & 1798 & 5.760 & 1,38 & 7,75 \\
1782 & 5.440 & 1,26 & 11,93 & 1799 & 6.400 & 1,53 & 7,99 \\
1783 & 4.698 & 1,09 & 11,45 & 1800 & 4.400 & 1,05 & 6,60 \\
1784 & 7.072 & 1,64 & 12,18 & 1801 & 3.800 & 0,89 & 11,91 \\
\hline Valor medio & 5.389 & 1,39 & 8,35 & & 4.849 & 1,14 & 9,87 \\
\hline
\end{tabular}

Fuente: Libros del Clero. Archivo Histórico Nacional. Elaboración propia.

Desde 1768 a 1784 la media de la cosecha es de 1,39 moyos/aranzada, vendidas a un precio medio de 8,35 reales cántara. Pese a que no hay descuido en las distintas labores de producción desde 1784 a 1801, la cosecha disminuye a 1,14 moyos de promedio en los ańos siguientes. A los avatares del tiempo hay que añadir la pérdida de vitalidad del viñedo, ya que, aunque en ocasiones se planta algún majuelo nuevo, se entiende que no es suficiente para rejuvenecer el conjunto de la hacienda, más cuando en estas últimas décadas se incrementan los precios hasta alcanzar los 9,87 reales cántara. El resto de labores detalladas estos dos años escogidos son ya de sobra conocidas. Los precios de los jornales han subido de 2 y 2,5 reales por día de unas décadas atrás a 2,5 y tres reales, atendiendo a tipo de labor, con su repercusión en el conjunto de gastos de producción. Los gastos del ganado de labor, con una cebada a 18 reales en 1781, se disparan enormemente.

En este sentido, es interesante comparar los gastos que llevan las tres vueltas de arado, realizadas con las mulas, con el precio que se paga por estos trabajos a terceros. En 1781 en que se detalla hasta el último maravedí, los gastos de arada por aranzada y vuelta equivalen a 10,5 reales, teniendo en cuenta que, en este precio, están los jornales y reales que llevan las tierras de sembradura. En este año la casa del Hospital General, que da a hacer estas labores, paga por aranzada 6 reales. Son dos formas distintas de dar a labrar los majuelos y, a tenor de lo investigado, las casas religiosas que contratan estos servicios de arada presentan unos costes menores por unidad de explotación ${ }^{741}$.

\footnotetext{
${ }^{740} \mathrm{El}$ cuadro se ha realizado tomando como base las declaraciones de cosecha de esta granja religiosa. En los valores medios de cosecha por moyos por aranzada se ha tenido en cuenta, en la medida de lo posible, la superficie de cada ańo. Esta varía desde las 213 aranzadas de 1772, las 225 de 1778, 270 en 1779 y 268 de los años siguientes hasta el año 1790 en que se declaran 260 y 1801 en que la superficie se cifra en 165. (A.H.N. Clero, Libro 17351).

${ }^{741}$ Diez años después, con un nivel de precios similar, la casa conventual de San Pablo da a arar 57 aranzadas en marzo y mayo, a 10 reales cada una. En los cálculos no se ha incluido la renovación de animales, que supone un coste ańadido. En el caso de los dominicos, en 1781 compran dos mulas para la labranza por importe de 3322 reales y en 1791 compran otra por 1.500 reales. Con estos precios y con el grano caro, los gastos de mantenimiento son altos, si bien disponer de ganado propio tiene sus ventajas, más allá de la pura rentabilidad en la arancia del viñedo.
} 
Con estos cuadros del último tercio de siglo se completa el estudio del cultivo del viñedo antes de llegada del nuevo régimen. Gracias a lo detallado del libro de administración consultado, se puede precisar el gasto de la casa y manutención. Criados, cachicán, ama, obreros, vendimiadores... llevan consigo, amén del salario, un ańadido de reales en comida y vino nada despreciable. Piénsese que esta casa dedica 500 cántaras de vino anualmente al consumo interno, equivalente a un 7,4\% del total producido. Como importantes son las cargas finales que lleva la venta del producto, asfixiantes para todos. Si en 1781 representan un 25,4\% del total de gastos consumiendo un 16,6\% de los ingresos; en 1791 suponen un 26,5 del gasto y el 27,9 de los ingresos, toda vez que este año los ingresos son inferiores.

Se puede concluir, sin embargo, que diezmos, desbotes y tributos aparte, el viñedo es más rentable que las tierras de sembradura, especialmente en estos sectores de terraza en los que este cultivo sobresale entre el resto de aprovechamientos. La cepa verdeja produce mostos de primera calidad que se venden sin grandes dificultades antes de la siguiente añada. En los distintos ejemplos, además, se ha puesto de manifiesto la gran cantidad de mano de obra que lleva el cultivo, repartido en todas las épocas del ańo, excepto en verano, en que la siega y trilla completan el calendario de trabajos de criados y jornaleros. Ello les permite disponer de un jornal regular, completado por la posesión de algunas aranzadas con las que obtener un complemento añadido. Respecto a las haciendas vitícolas de estas villas poco más hay que ańadir a lo ya expuesto: el viñedo, una vez pagado el tributo de lo exigente de sus labores, produce todos los años en tierras mediocres y, si acompañan los precios, deja más beneficios que el cultivo del cereal en año y vez. 


\section{CAPÍTULO

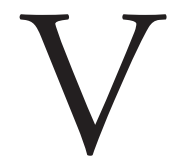

ORGANIZACIÓN SOCIOECONÓMICA Y VIDA COTIDIANA EN LA EDAD MODERNA. SERRADA, LA MOYA Y SAN MARTÍN DEL MONTE COMO EJEMPLOS DE COMUNIDADES CAMPESINAS AL NORTE DE LA TIERRA DE MEDINA 


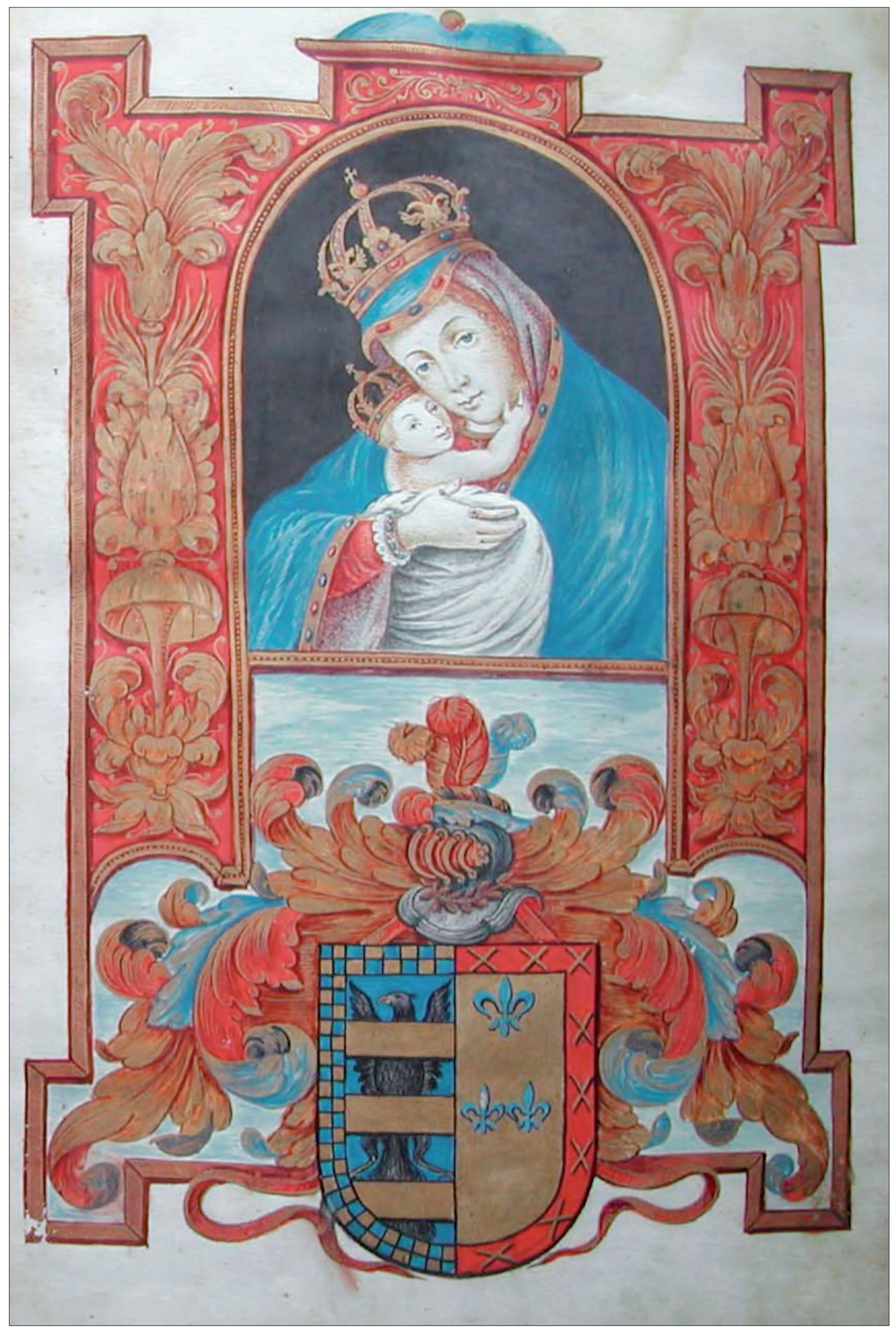

Imagen 64. Ilustración a color y en pergamino con el escudo familiar de la familia Ruiz de Montalvo. Privilegio de villazgo de Serrada, A.M.S. Foto: 17/10/2003. 
No por estudiar en detalle estas comunidades campesinas al norte de Medina, se ha de olvidar el marco general que viven los reinos hispánicos y, por estas fechas, el reino de Castilla en particular. Debemos preguntarnos por las razones de fondo de tantas luchas y disputas por el aprovechamiento de los pastos y la fijación de límites entre aldeas y jurisdicciones. O las causas del porqué La Moya acaba sus días, en el primer tercio del siglo XVII, tras no pocas décadas de agonía. ¡Qué dirían los escasos vecinos de San Martín, cuando se reunían en concejo al abrigo del soportal de su iglesia, fuera de las anotaciones del escribano, sobre los últimos acontecimientos reseñados! ¿Tendrían conciencia colectiva del resquebrajamiento y postración en que se estaba sumergiendo el imperio hispánico de los Austrias? ¿Comentarían la debilidad demográfica y económica de la menguada Castilla que veía cómo, a lo largo del XVII, se desintegraban sus comunidades de villa y tierra que, durante tantos siglos, habían constituido la base de su fortaleza?

Lo cierto es que no corrían buenos tiempos en las últimas décadas del siglo XVI y a lo largo del siglo XVII. Si Felipe II parecía que había agotado todos los recursos, como lo testificaron sus sonadas bancarrotas, y Felipe III trató, al menos, de no agravar la situación, con Felipe IV todo lo imaginable fue sobrepasado. El quebranto económico era de tal magnitud y el déficit crónico de la hacienda tan asfixiante, que ni la desvalorización de la moneda, ni el gravamen de productos corrientes, ni la venta de cargos, ni la contribución de nuevos impuestos o la venta de perdones de delitos sirvieron para otra cosa que no fuera para desmoralizar a la población y generar una nociva burocracia que iba a corroer aún más las estructuras del Estado ${ }^{742}$. La imagen adjunta de resellos encontrados en los términos objeto de estudio testimonia esta política de inflaciones y de deflaciones monetarias que no provoca sino la desesperación de las masas campesinas ${ }^{743}$.

${ }^{742}$ No se puede por menos de entresacar, para acercarse al marco histórico general por el que se ha transitado, las primeras líneas de la carta de venta de las alcabalas de Matapozuelos al Comendador Francisco de Menchaca. Llevan fecha de 1573 y son sólo una muestra del comienzo del ocaso del gigante imperial. Las aldeas también se verán arrastradas en su caída: "Don Phelipe Segundo de este nombre, por quanto para ayuda y socorro a los grandes gastos que se ofrecieron al enperador y Rei mi señor que Santa gloria aya, para la defensa destos mis reinos contra los turcos y moros enemigos de nuestra santa fe católica y otros potentados, y reducir a nuestro servicio y subjetar y allanar y castigar los movimientos del reino de Granada y de los nuestros estados de Flandes, se han gastado gran suma de dineros y la mayor parte de nuestras rentas reales y los socorros, ayudas y servicios ordinarios y extraordinarios que estos reinos y todos los otros mis estados en todas partes han echo y lo que ha venido de las Yndias, y lo que se ha habido de los subsidios y bullas de cruzada y excusado que nuestro muy Santo Padre concedió al emperador mi señor y a mi y las otras cosas extraordinarias, y theniendo agora que proveer de mucha suma de dinero para la sustentación y defensa de nuestros Reinos y fortificación de las fronteras, no aviendo hallado manera alguna menos dañosa e acordado de vender algunas rentas de nuestras alcabalas...".

${ }^{743}$ Las diez monedas de la imagen adjunta son monedas de vellón, seis de ellas reselladas, y todas fuertemente recortadas (sólo han dejado reconocible los símbolos parlantes del castillo y el león dentro de escudo coronado) que caracterizan a las acuñaciones de 8 maravedíes tanto de Felipe III (1598-1621) como de Felipe IV (1621-1665). Este numerario con pequeña o ninguna ley, es equivalente a los maravedíes emitidos por Felipe III. Son monedas que se acuñan con valor de 8 maravedíes que llevan castillo y león dentro de sendos escudos coronados y PHILIPPVS IIII D G / HISPANIARVM REX, y fecha. (GIL FARRÉS, O., Historia de la moneda española. Madrid, 2o ed., 1.976, p.396). Esta autora 


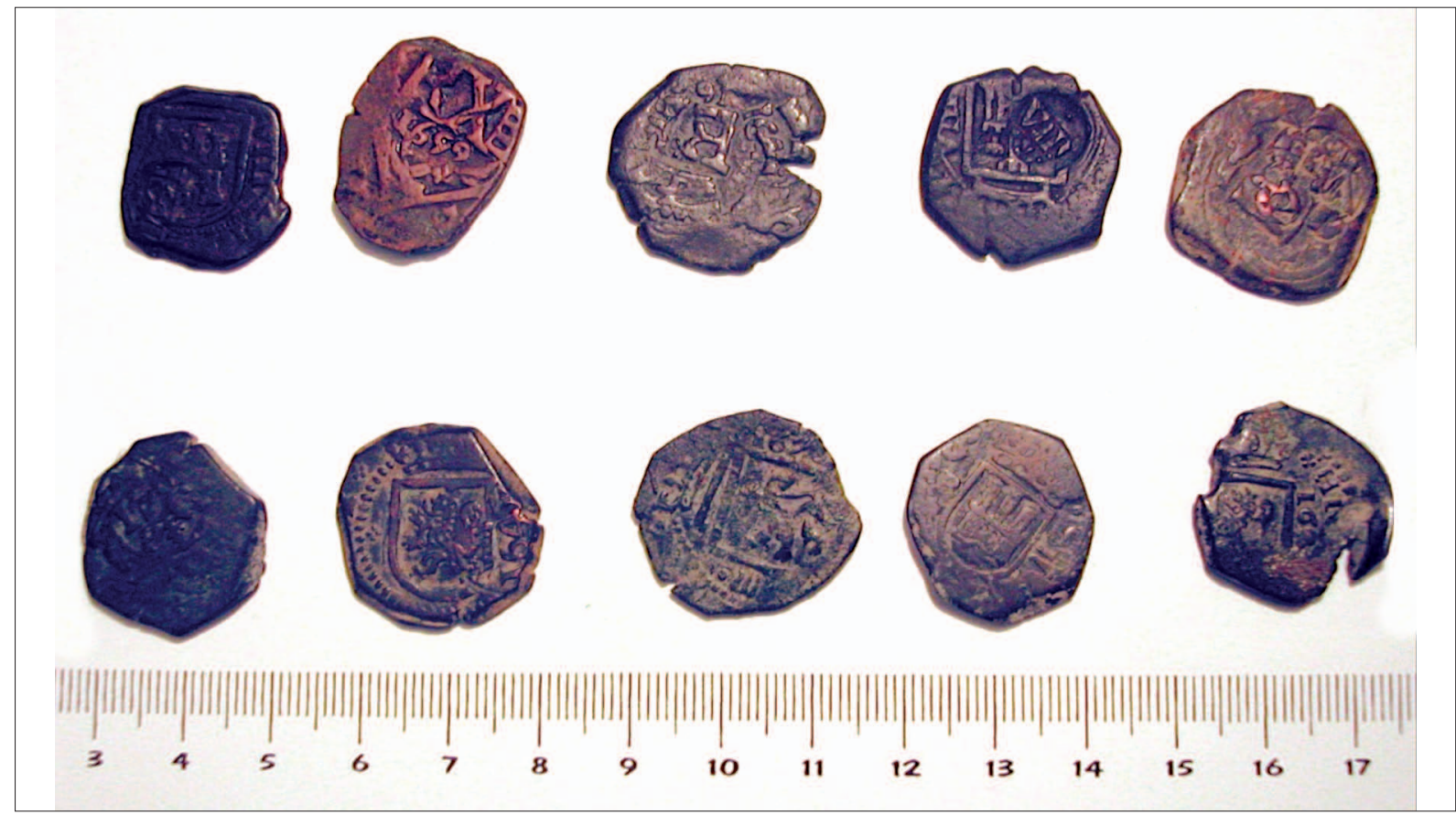

Imagen 65. Monedas de vellón reselladas, maravedies, Felipe IV. Serrada y San Martín del Monte. (Colección particular). Foto: $18 / 04 / 2005$.

La búsqueda de nuevos recursos es una obsesión por parte de la hacienda pública cuando se reinicie, en 1621, la guerra de Flandes. El reinado de Felipe IV (1621-1665) fue testigo, no sólo de la caída del gigante imperial, sino también del alarmante estado en que se encontraba la hacienda pública. Para remediarlo, tal como se ha adelantado al comienzo de este apartado, se generaliza la venta de vasallos y la enajenación de señoríos, como forma de afrontar las crecientes necesidades de liquidez. En reunión de Cortes de 18 de septiembre de 1625 se decide autorizar la venta "hasta veinte mil vasallos de villas y lugares de realengo y de behetría...", iniciando el procedimiento formal que abre las puertas al desmembramiento de las comunidades de villa y tierra y, en particular, a la adquisición del privilegio de villazgo de muchos de los pueblos vecinos.

\section{El desmembramiento de las comunidades de villa y tierra en los siglos XVI y XVII}

La regulación jurídica y las relaciones que mantienen los lugares con sus núcleos cabeceros de Villa y Tierra toca a su fin. En el primer capítulo tratamos, de forma general, el complejo proceso de articulación del territorio que vive el reino de Castilla y de León en los siglos XI y XII. Las distintas aldeas gestionaban su terrazgo de acuerdo a las directrices de la comunidad de la que formaban parte. Los procesos de exención y desmembramiento de estas comunidades, que tienen lugar en estos tiem-

defiende que, en su mayoría, se hicieron por el sistema de molino y que algunas tenían tantos resellos que se convirtieron en auténticas chapas, sin contar las falsificaciones, algunas tan burdas que sorprende que pudieran circular. Los maravedíes se acuñaron en piezas de 2, 4 y 8, llamando al doble maravedí ochavo, y al cuádruple cuarto, nombres que van a ser origen de varias expresiones populares y refranes.

Con relación a la estampación de sellos, resellos o contramarcas que se aplican a estas monedas, lo que se perseguía era alterar su valor nominal, depreciando la moneda a lo largo del siglo XVII, y de manera particular durante el reinado de Felipe IV. Estos resellos muestran la anarquía monetaria, las manipulaciones de un estado completamente endeudado por las guerras, ya en bancarrota a finales del reinado de Felipe II (bancarrotas de 1557, 1560, 1574 y 1596). Felipe III, reduce el peso y el tamaño de las monedas y empeora su aleación haciendo que el vellón acuñado antes de 1602 duplique su valor. Las marcas estampadas sobre las piezas fueron circulares, con un IIII o un VIII coronados y con la seńal de la ceca correspondiente bajo el valor (Burgos, Coruña, Cuenca, Granada, Madrid, Segovia, Sevilla, Toledo, y Valladolid). 
pos modernos, van a la par de ventas y arrendamientos de recursos reales, tales como alcabalas, servicios, etc. La Tierra de Tordesillas, Olmedo y Medina es un ejemplo de cómo rentas de alcabalas acaban, mediante compra, en manos particulares. Francisco de Menchaca compra en 1573 las de Matapozuelos; Antonio de Contreras hace lo propio en 1636 en Villanueva de Duero... La Hacienda real vende cuanto puede, en especie o en papel, para tratar de saldar sus deudas. Hombres de negocios, señores vinculados a los lugares donde poseen mayorazgos o altos funcionarios, cobran sus cargos y pagas sobre las rentas de la Corona, mermando la presencia real en estas tierras y, de paso, rubricando el ocaso de los Austrias, de Castilla y de sus antiguas comunidades de Villa y Tierra.

El proceso de desmembramiento es prácticamente generalizado en toda la Tierra de Medina y Olmedo. Estas villas contemplan su mutilación jurisdiccional con impotencia, tanto más cuanto que son sus principales lugares, aquellos que pueden hacer frente al pago de su liberación, quienes primero deciden emanciparse. Aun así, no hay que engañarse. Las relaciones entre concejos locales y villas cabeceras carecen, en la mayor parte de los casos, de cualquier lazo de fraternidad. En los procesos de exención se pone de manifiesto, o se toma como una justificación más, que las Comunidades distan de presentar la imagen de unidad jurídica y administrativa de otros tiempos. Los conflictos por el aprovechamiento de las tierras comunales, montes y baldíos habían sido un foco permanente de diferencias. Baste señalar la alegría de los 680 vecinos de La Nava tras apartarse de Medina en junio de 1559. En este mismo año tiene lugar el proceso de exención de Valdestillas respecto a Olmedo. Las exenciones y compras de jurisdicciones y villazgos por los propios lugares satisfacen, en parte, las viejas demandas de autonomía jurídica y control de recursos.

La necesidad de plata obliga al Estado a vender todo lo vendible y lo que estuviera por vender. En 1629, Villaverde y La Seca compran su exención de la mano de su concejo, desgajándose de Medina $^{744}$. Rueda aprovecha igualmente la disposición Real de 15 de mayo de 1630, iniciando seis años más tarde su independencia jurisdiccional ${ }^{745}$. Es de destacar que en todos estos casos son los propios vecinos, unidos en concejo, quienes protagonizan tamaña aventura. Pozaldez, sin embargo, no puede hacer frente a los pagos y acaba cayendo en manos del poder señorial. Y es que las familias nobiliarias, al reclamo de conseguir poder jurídico y preeminencia social, acuden también prestas a las ofertas de la corona. En 1558, el Doctor Antonio Velázquez de Santiago, abogado y “oydor" de la Chancillería de Valladolid, se hace con el lugar y las alcabalas de Carpio ${ }^{746}$; un año más tarde, en 1559 , se concierta la venta de Ventosa, que pasa al señorío del escultor Alonso de Berruguete; en 1636, el anteriormente citado Antonio de Contreras, señor de Villanueva de Duero, compra, amén de las alcabalas descritas, la jurisdicción de su término ${ }^{747}$; en 1656, el marqués de Fuente el Sol adquiere para su hijo Luis Rubí de Bracamonte, los lugares de Rabé y Cervillego... Serrada no es tan madrugadora. Su concejo no está por la labor de endeudarse para liberarse de la jurisdicción de Olmedo. En la mente de sus vecinos es posible que estuvieran los casos de Pozal de Gallinas o Villanueva de las Torres, que, tras no poder hacer frente al pago de la exención en 1559 y 1574, respectivamente, hubieron de regresar a jurisdicción medinense ${ }^{748}$.

${ }^{744}$ SUÁREZ ALÁEZ, A.: Historia de la villa de La Seca y A.G.S. Mercedes y Privilegios, leg. 334, fol. 26.

745 MARTÍNEZ LLORENTE, F.: Rueda, de aldea a Villa. Diputación de Valladolid, 1988, pág. 19.

746 GONZÁLEZ SÁNCHEZ, V.: Carpio. Historia de una villa de Tierra de Medina. Diputación Provincial de Valladolid, Valladolid, 1999, pág. 37.

${ }^{747}$ A.G.S. Mercedes y Privilegios, leg. 353, fol. 13.

748 Se anotan algunos de los procesos de exención como ejemplo de la práctica que se generaliza, no sólo en esta Tierra de Medina, sino en todo el reino. Al margen de los aludidos, también se eximen por entonces Carpio, Pollos y Siete Iglesias, para constituir señorío en las personas de Magdalena de Silva, Francisco de Dueñas y Hernando de Vela, respectivamente. Pollos y Bayona, siguiendo a Moraleja, pasaron del señorío de los Dueñas al de Medina, que cede en 1615 a Fernando de Peralta, mayorazgo de Simón Ruiz. Ver MORALEJA PINILA, G.: Historia de Medina..., ob. cit., pág. 334-335. 
Diego de Montalvo ostenta el cobro de las alcabalas y es, con mucho, el mayor propietario del término y quien puede hacer frente a la compra del villazgo. De hecho, lo hace aprovechando una cédula firmada por dońa Mariana de Austria, tutora de Carlos II y gobernadora del reino el 8 de febrero de 1675 .

\section{a. La compra del Privilegio de Villa de Serrada por Diego Ruiz de Montalvo}

Aunque han sido la quietud y la sumisión ante los poderosos dos de los aspectos que han caracterizado al campesinado castellano a lo largo del tiempo, no por ello se ha de dar por sentada su conformidad ante el sistema establecido. En el caso de Serrada, como se ha expuesto, los pleitos entre los Montalvo con Olmedo y los propios vecinos de esta villa o de pueblos limítrofes, fueron enconados a lo largo del tiempo ${ }^{749}$. En el año 1664 continúan y esta vez, como no podía ser de otro modo, por los majuelos dados a censo. Diego Ruiz inicia autos quejándose de que “...de algunos años a esta parte y que por ser de poca cantidad sus débitos de cada año por los censos que sobre las propiedades que gozan tienen, aunque les ha pedido se las satisfagan, no lo hazen...", poniendo el caso en manos de la justicia, para que "les requiera luego paguen la cantidad que cada uno deviere y no pudiendo ser habido les envargen sus vienes y frutos de viñas y maxuelos..." 750 .

El conflicto, que se inicia de forma limitada, se agrava enormemente ${ }^{751}$. Se apunta el hecho porque es en este contexto de pleitos en el que se produce el proceso de exención de Serrada respecto a Olmedo. El protagonista no iba a ser otro que Ruiz de Montalvo, heredero del mayorazgo que fundara su antepasado de mismo nombre.

\section{- Las justificaciones de la venta del privilegio de villazgo}

El privilegio de exención de Serrada eleva a este lugar a la condición de villa señorial, dado que será Diego de Montalvo quien adquiere la nueva categoría jurídica. El proceso de enajenación se inscribe en el amplio marco legislativo que, como se ha estudiado, inician los Austrias Mayores de forma puntual, para generalizarlo sus sucesores, entre los que destacará Felipe IV.

En las cédulas reales y declaratorias que acompañan a la venta de la jurisdicción, se reproduce el marco legal y las justificaciones últimas del propio consejo de Hacienda, organismo fiscal que vela y garantiza la legalidad del proceso. Los textos que preceden al ajuste son iguales o guardan gran similitud a cuantos acompañan las ventas de tantas aldeas que, por estas fechas, se desvinculan de sus viejas ataduras. En lo que a este término atañe, el rey Carlos II repite las causas que justifican las medidas tomadas y que, a la postre, contribuyen definitivamente a desintegrar las comunidades de Villa y Tierra ${ }^{752}$ :

${ }^{749}$ Habiendo estudiado los que se extendieron a la largo del siglo XVI y primera mitad del XVII, vamos a centrarnos en aquellos que, desde la segunda mitad de este siglo acaban por definir los derechos de los Montalvo sobre determinadas rentas en Serrada y la legalidad de la posesión de ciertos pagos del término, cuya titularidad permanece cuanto menos confusa desde las primeras sentencias.

${ }^{750}$ A.R.Ch.V. P.C. Zarandona y Walls (F), caja 2711.1. Dichos censos eran los que se aprobaron para plantar de viñas mil obradas de su mayorazgo y sobre los que gira la concordia de 1640, en que se reordenan, mediante trueque, distintas porciones de tierras y pastos en estos confines olmedanos.

${ }^{751}$ De esta manera y a requerimiento del señor de Serrada a Alonso Platón, alcalde del lugar por estas fechas, y en presencia del fiel de los hechos, Antonio Gómez, se embarga "una cuba de vino mosto que ara diez y ocho moyos", propiedad del deudor Antonio de Requena. Diego Ruiz de Montalvo, no contento con ello y "por cuanto lo embargado no es bastante para pagar la deuda”, insta al alcalde a embargarle la siguiente vendimia para así satisfacer dicho débito.

752 A.M.S. Privilegio de villazgo, vol. 1v. En el estudio de este capítulo en que se trata la compra del privilegio por parte de Diego de Montalvo, se seguirá la trascripción que del mismo ha llevado a cabo Ma del Henar Mieres Panedas, al tiempo que le agradecemos haber puesto a nuestra disposición el trabajo realizado. 


\begin{abstract}
"Por cuanto el año de mil seiscientos y veinte y uno que entro a reinar el rey, mi señor y padre, que santa gloria haya, halló su patrimonio real tan gastado, consumido y empeńado, por haber sido superiores a las rentas ordinarias los grandes gastos que fue preciso hacer en tiempo del seńor rey don Felipe III, mi abuelo, y se hicieron antes en el de los señores reyes sus antecesores en la defensa de la santa fe católica, en todas las partes le fue forzoso para continuar los dichos gastos y los que de nuevo se recrecieron a esta Corona para su defensa y beneficio de la causa pública no sólo consumir las rentas y frutos de cada año, sino también vender en empeño y propiedad mucha parte de las ordinarias y usar de otros diversos medios que se eligieron entonces por menos gravosos, entre los cuales en once de marzo de mil seiscientos y treinta y nueve, con consentimiento del reino junto en Cortes, / (f.2r) resolvió el rey, mi señor y padre, de la venta de ocho mil vasallos de cualesquier villas y lugares realengos de estos reinos..."
\end{abstract}

Como se puede observar, las razones tocantes a la defensa de la fe parecen ser, a juicio del propio rey, las que propician el desencadenamiento de una medida que las propias Cortes han de aprobar ${ }^{753}$. Es en este marco legal en el que se ajusta y concierta con Diego de Montalvo Quadra y Avellaneda, señor de Pińa de Valdesgueva y propietario de las alcabalas y unos por ciento de Serrada, la venta de su villazgo ${ }^{754}$. La exención es otorgada en Madrid el 15 de junio de 1675, mediante dos escrituras aprobadas por la reina gobernadora y dos reales cédulas de 20 de junio del mismo año, por las que se le concede al mencionado Montalvo la jurisdicción, señorío y vasallaje, así como el permiso de nombramiento de justicias en el citado lugar. En estas cédulas preliminares constan, junto a las anotadas justificaciones hacendísticas, toda una serie de precisiones jurídicas que encuadran el marco legal concreto en que se llevará, años más tarde, el proceso ${ }^{755}$. En la carta se dispone que, por cada vasallo del distrito de la Chancillería de Valladolid, se paguen 15.000 maravedíes, mil menos que aquellos pertenecientes a la de Granada. En el caso de que el lugar esté escasamente poblado o tenga menos de cien vecinos, la venta podrá ser por leguas, para así evitar menoscabos a la hacienda real.

De acuerdo con los contenidos de las cédulas reales citadas, Diego de Montalvo acepta las condiciones más favorables, toda vez que Serrada, en el año 1675, contaba con 70 vecinos y no extiende su término más de media legua. El ajuste se valida de acuerdo a cédula de 11 de marzo de 1675, que asume cuantos dictados habían emanado de los reinados de Felipe III y Felipe IV. Se trata del fin de

${ }^{753}$ Actas de las Cortes de Castilla. XLIII. Madrid. 1920, p. 127, citado por Emilio González Diez: "La desmembración de la Tierra de Medina: Señoríos y Villazgos”, en Historia de Medina y su Tierra, vol. II, p.744-745. Se alude a su consentimiento de 1639, en que Felipe IV reafirma la intención de la venta de 8.000 vasallos, y que tienen su precedente en las disposiciones de autorización de 18 de septiembre de 1625, por las que se concedía la venta "hasta veinte mil vasallos de villas y lugares de realengo y de behetria..." y que también recoge igualmente el texto seleccionado. A esta medida se añaden los permisos de venta de otros 20.000, en los años de 1630 y 1638 . Y es que el río de maravedíes al contado parece ser la tabla de salvación de un reino que descubre en el despacho de estas cédulas de venta la salida más fácil a su déficit estructural.

${ }^{754}$ Como se indica en esta primera cédula que inicia el expediente de Serrada, por las manos del factor general Bartolomé de Spínola pasaron las ventas de 20.000 y 12.000 vasallos con fecha de 15 de enero, 31 de marzo y 20 de agosto de 1626, así como de 22 de septiembre de 1627.

755 "Y habiéndolo consultado con algunos ministros mios con particular deseo de valerme de lo menos / (f.7v) dañoso, apretado de la necesidad precisa que obligo a ellos, resolvi el año pasado de mil seiscientos y veinte y cinco, con consentimiento del reino junto en Cortes, de vender y que se vendiesen hasta en cantidad de veinte mil vasallos de cualesquier villas y lugares realengos de estos mis reinos, asi de behetría como de villa que tienen jurisdicción propia o aldeas de cualesquier ciudades y villas, desmembrándolas de ellas y haciéndolas villas de por si y sobre si con jurisdicción civil y criminal, alta, baja, mero mixto imperio, o vendiéndolas a personas particulares, asi eclesiásticas como seglares, contando los vasallos del distrito de la Chancillería de Valladolid, a quince mil maravedies por cada vecino, y los del distrito de la de Granada, a diez y seis mil maravedies, y que si las villas y lugares que se tratasen de vender no llegasen a tener cien vecinos se hubiesen de medir y contando por el de una legua legal de veinte y cinco cuentos de varas cuadradas de los lugares del distrito de la Chancillería de Valladolid cinco mil y seiscientos ducados, y de la de Granada, seis mil y cuatrocientos ducados, y, averiguándose también los vecinos que hubiese en ellos, se eligiese en mi nombre por precio de la venta de estas dos formas fuese de mas beneficio para mi Real Hacienda...". (A.M.S. Privilegio de Villazgo, fol. 9). 
la dependencia de Serrada respecto a Olmedo. El lugar se constituirá "villa de por sí y sobre sî" en manos de don Diego de Montalvo, detentador tanto de su completa jurisdicción como de las rentas derivadas del señorío y vasallaje. Olmedo pierde así su sector más occidental. Comienzan a apagarse, casi definitivamente, los rescoldos entre los Montalvo y la villa del caballero ${ }^{756}$. El 29 de julio del citado año de 1675, como juez de posesión y "por cuanto se hallan en esta dicha villa el señor corregidor $y$ dos regidores de la de Olmedo", les ordena "manden tocar a concejo público para que en él se junten todos los vecinos que hay en dicha villa para hacerles notorio del señorio y vasallaje y de la tolerancia de ella a don Diego de Montalvo Quadra y Avellaneda”. Aunque las mieses en el campo están reclamando brazos y carros para su recogida, aquel lunes, 29 de julio, nadie se movió de la plaza de la naciente villa. Hasta cincuenta y cuatro vecinos estuvieron presentes en el concejo celebrado. Todos aceptaron y ratificaron las cédulas reales que otorgan la posesión del seńorío, vasallaje y tolerancia de Serrada a Diego de Montalvo ${ }^{757}$.

Acto seguido, Joseph Sarmiento de Valladares, juez de posesión, manda levantar, como símbolos definitivos de la nueva jurisdicción otorgada, una horca de madera y una picota con su argolla, en lugar público y ordinario, como fe de la nueva justicia que regirá la villa. El escribano relató el momento de la forma que sigue ${ }^{758}$ :

${ }^{756}$ La comisión de Su Majestad fijará el montante de la operación de venta. Serrada y sus vecinos se tasan en 2.800 ducados de plata que valen 1.050.000 maravedíes. La escritura se otorga en la villa de Madrid, el 15 de junio de 1675, ante Jerónimo Zapata, oficial de la Secretaría de la Real Hacienda, siendo rubricada por el propio rey. Cinco días más tarde, el 20 de junio, la propia reina gobernadora, Doña Mariana de Austria, aprobará y ratificará cuántos términos anteriores se han referido. Serrada inicia una nueva andadura ${ }^{756}$. Ajustado el montante de la operación y firmadas las cédulas de confirmación de los contratos, restaba dar solemnidad publica al despacho de la jurisdicción, señorío y vasallaje, así como de la tolerancia a Don Diego de Montalvo Quadra y Avellaneda. Restaba averiguar con exactitud la vecindad y amojonar y deslindar el término para, caso de no coincidir con las estimaciones realizadas, concretar los dineros que la corona tenía que percibir. Serrada se prepara para la ocasión. Tampoco podría eludir, aunque quisiera, los rigores de la administración. A falta de posada que acoja a tan altos ejecutores de justicia, el 28 de julio de 1675 se insta a Juan García, alcalde ordinario de Serrada, para que diligentemente "tengan posada decente para sus ministros con todo lo necesario de camas y cebada para las mulas de su coche...".

${ }^{757}$ En el acta puede leerse: "Yo. Andrés Márquez de Cepeda, escribano de Su Majestad y receptor de sus Reales Consejos $y$ de este negocio, doy fe que luego incontinente y estando en el dicho concejo le las dichas dos reales cédulas de Su Majestad, hallándose presentes su merced dicho señor juez y el licenciado don Juan Antonio Ortiz Liermo, abogado de los Reales Consejos, don Antonio Suárez de Lara y don Femando de Buitrago corregidor y regidores de la villa de Olmedo, y Manuel Álvarez, escribano del ayuntamiento de ella, y Juan García de Santiago, alcalde ordinario de esta dicha villa, Juan Alonso de Velasco y Francisco Alonso, regidores, Pedro Navarro, el mayor en días, procurador general, Pedro Ynojal, el viejo, Carlos de Obregón, Alonso Moyano, Santos García, Marcos Moyano, Juan Alonso de Andrés, Simón Gutiérrez, Miguel Martín, Martín Sánchez, el mayor, Santiago de Ynojal, Bartolomé Román, Juan Román, Francisco Alonso Juste, Juan Alonso, mayor, Andrés García, Melchor Rojo, Francisco Sánchez, Sebastián Recio, Francisco Dominguez, Antonio Recio, Julián Alonso, Antonio Alonso, Francisco Platón, Mateo de Ortega, Juan Platón. Domingo Rojo, Pedro García, Pedro López, Francisco Marcos, Juan de Mora, Roque Labaxo, Domingo González, Alonso de Abuga, Francisco Leonardo, Juan de Montes, Francisco Rodríguez, Antonio de Íscar, Tomás Alonso, Pedro Román, Roque Minguela, Matías Platón, Francisco Álvarez, Francisco Alonso, el mayor, Francisco García, el mayor, Francisco García Hernando, Pedro de Castro, Pedro Navarro, el menor, Francisco Bayón, Bartolomé Monzón, Basilio Moyano y Andrés Maestro, todos vecinos de esta villa, que se hallaron presentes al dicho concejo, los cuales, habiendo oído y entendido a las dos dichas cédulas reales de Su Majestad, dijeron que l/ ( $f 80 v$ ) obedecian y obedecieron con el respeto debido y que se guarde, cumpla y ejecute lo que por ellas se manda y en su cumplimiento se le dé la posesión del señorio y.vasa laj $y$ de la,.de. la tolerancia. al dicho don Diego de Avellaneda; y el dicho señor corregidor, habiendo preguntado en concejo si habia quien contradijese se diese la dicha posesión, respondieron todos que no, y su merced dijo que las obedecía con el respeto debido como cartas de Su Majestad y, en cuanto a su cumplimiento por guardar su jurisdicción hasta que por Su Majestad otra cosa se le mande, no da el cumplimiento para que siempre conste, defiende su jurisdicción a Su Majestad, y lo firmo juntamente con todos los demás vecinos que supieron, y su merced. Licenciado don Joseph Sarmiento de Valladares, Pedro Ortiz Liermo, Andrés Maestro. Juan Alonso. Francisco Bayón. Antonio Alonso. Pedro Román. Pedro Navarro. Francisco Álvarez. Bartolomé Monzón, Francisco Alonso, Antonio Rico, Juan Platón, Martín Sanz, Francisco Domingue,. Simón Gutiérrez. Ante mí, Andrés Márquez.”. (Ibídem, fol. 79-80).

${ }^{758}$ Ibídem, fol. 87-88. 
"Luego incontinente en cumplimiento de lo que por el auto antecedente se mando y ejecutar lo en el contenido, se puso y levantó una horca de palo al salir de las eras, junto al camino que va de esta villa a la de Vasdestillas, y se puso en ella un cuchillo y se fijó y levantó picota, y se fijó en la calle pública, y puso en ella una argolla, todo ello sin contradicción de persona alguna, a lo cual asistió su merced dicho señor juez y muchos vecinos de esa villa, y para que conste lo pongo por diligencia, de que doy fe, y lo firmé. Andrés Márquez”.

El auto en que notifica sus atribuciones a su corregidor y regidores, cierra una época y abre la puerta a dos siglos de potestad jurídica de la familia Montalvo sobre sus tierras y vasallos de Serrada. Diego de Montalvo, un día después del mencionado concejo abierto, en concreto el 30 de julio de 1675, procede, en virtud de los poderes otorgados, al nombramiento de cuantos cargos públicos se necesitan para el buen funcionamiento y administración de su señorío ${ }^{759}$.

Serrada será villa por sí, gracias a los dineros de Diego Ruiz de Montalvo y a pesar de Olmedo. La enésima resistencia de esta villa se constata en las dilaciones y reticencias que muestran sus regidores ante la requisitoria ordenada por el juez de posesión para efectuar la mojonera. En el texto se advierte igualmente la oposición de San Martín del Monte. El pequeño lugar desea que prevalezcan sus viejos apeos, distintos de los criterios esgrimidos por Serrada en el deslinde efectuado. Y similares posiciones esgrime Matapozuelos. Esta villa contradice el coteo realizado, alegando que, cuando llegaron el día notificado a la raya con Serrada, "a cosa de las ocho y media o nueve de la mañana", estaban ya levantados los mojones y en sitio indebido. Acusaron a Serrada de haber "usurpado a la dicha villa más de tres mil pasos de jurisdicción”60.

Todo indica que la justicia continuará, durante unos siglos más, entendiendo de mojones y linderas $^{761}$. Como otros muchos lugares citados, permanecen latentes las vejaciones o diferencias sufridas durante tiempos pasados. En los distintos documentos consultados, parece como si el apartamiento de estos lugares de sus cabeceras de villa fuera una liberación. La propia acta del concejo llega a recoger que, caso de ser Olmedo quien desee tomar la jurisdicción, "aunque sea necesario, venderán sus haciendas, lo tomaran por el tanteo por no volver a la jurisdicción de la dicha villa de Olmedo, por las muchas molestias y dejaciones que les hacian...".

759 "En la villa de Serrada, a treinta días del mes de julio de mil seiscientos y setenta y cinco años, ante mi, el escribano receptor, y testigos, pareció don Diego de Montalbo Quadra y Avellaneda y dijo que ... en virtud de sus reales cédulas, porque les conviene nombrar alcaldes ordinarios y regidores, procurador general y alcalde de la Hermandad, alguacil y carcelero, mayordomos del concejo y fábrica de la iglesia de esta dicha villa y cogedor de bulas, contadores y tasadores, repartidores y fiel de hechos, atento no haber escribano al presente en esta villa, la cual hizo en la manera y forma siguiente: Primeramente nombró por teniente y alcalde mayor a Juan Alonso; por alcalde ordinario, a Juan Román; por regidores a Juan Alonso de Velasco y a Francisco Alonso, menor en días, volviéndolos a reelegir para este presente año; por procurador general, a Pedro Navarro, mayor en dias, volviéndole a reelegir; por alcalde de la Hermandad, a Miguel Martinez; por alguacil y carcelero, a Francisco Domínguez; por mayordomo de propios del concejo, a Juan de Mora; por mayordomo de fábrica de la iglesia, a Basilio Moyano; por contadores, tasadores y repartidores, a Andrés García y Francisco Alonso, mayor en días, ... Don Diego de Montalvo Quadra y Avellaneda. Ante mi, Andrés Márquez." Todos aceptan y juran en forma de derecho "hacer bien y fielmente lo que tocare a su oficio durante el tiempo que le usare y ejerciere". El traspaso de poderes se efectúa con normalidad. Un pregón, amparando cuantos nombramientos y poderes se han otorgado, extiende a todos la obligación de acatamiento. No se olvida de señalar que a Diego de Montalvo todos los vecinos "le tengan y obedezcan por señor de esta villa y su término", le presten obediencia como vasallos, acaten los dictados de sus justicias y, en virtud de las reales cedulas, al lugar de Serrada "desde ahora en adelante la llamen villa". (Ibídem, fol. 91-92).

${ }^{760}$ Esta raya divisoria entre Matapozuelos y Serrada será objeto de continuos enfrentamientos. Ya se advertía cuando se citaba la exención del pueblo vecino. Matapozuelos protesta y defiende que los mojones han de situarse "uno en la Cuesta de San Pedro, aguas vertientes del monte, y el otro más abajo, en el camino que va de Ventosa a la Moya, y otro en el mismo camino, en la cuesta que llaman del Pendón, y otros en el mismo derecho...”.

${ }^{761}$ Entretanto, se lleva a cabo la medida del término al objeto de, una vez averiguada la exactitud de vecinos y las varas cuadradas que se acogen al mismo, proceder a confirmar la estimación inicial del dinero a percibir por la corona. Las cuerdas se tiran bajo la dirección de don Jorge del Pozo y Meneses. Se inicia la medición en el mismo lugar de arranque del amojonamiento, "estando en el dicho camino que sal de esta villa a la de Villanueva de Duero, que es do dicen Valdesendero, y donde se dividen las jurisdicciones de la dicha villa de Villanueva de Duero, esta y el lugar de la Moya...”. El 


\section{- Las tensiones del vecindario con su señor y los pleitos por el tanteo del señorío y jurisdicción de la villa}

Como se ha dicho, Serrada nunca tuvo recursos sobrantes para poder comprar los derechos de villazgo que la corona ponía a la venta al mejor postor. Las rentas que generan sus propios eran escasas y buena parte del vecindario está formada por braceros sumidos en la necesidad permanente. Pero el que cuantos derechos se enajenan fueran comprados por Diego de Montalvo Quadra y Avellaneda iba a avivar el recelo de quienes se sienten oprimidos por sus abusos o exigencias. Las mejores tierras, las rentas en forma de censos que cobraba por los majuelos, la recaudación de las alcabalas..., todo era de los Montalvo. Por si ello no es suficiente, ahora adquiere la jurisdicción civil y criminal, el nombramiento de justicias... Sólo le falta poseer el aire que respiran. Y en cierta medida también era suyo. La tensión de los que se sienten desfavorecidos por las prácticas arbitrarias de su señor no tarda en manifestarse. Nada mejor que aprovechar el descontento de muchos para lanzarse a pleitear e intentar comprar, por derecho de tanteo, el señorío y jurisdicción adquirido por su señor.

El concejo de Serrada no iba a ser el único que iba a litigar por estos temas. La villa de Villanueva hará lo propio con Diego de Rojas ${ }^{762}$. En febrero de 1726, el concejo de Serrada, presidido por unos alcaldes y regidores que recogen el descontento de parte del vecindario, aprueba la iniciativa pese a no contar con la unanimidad de la villa. Como se desprende de la respuesta de Luis de Montalvo a tal demanda, sólo concurrieron noventa vecinos “...de los quales treinta y tres se opusieron a que se intentase este tanteo, conociendo que no era útil al común de aquella villa sino muy perjudicial..." "63. Luis de Montalvo, sucesor en los derechos de mayorazgo de su padre Diego Ruiz, se siente dueño de la situación. La totalidad de los labradores propietarios que llevan en arrendamiento tierras suyas no desea disgustar al propietario ni empeñar sus capitales para proveerse recursos a censo con que hacer frente a pleitos costosísimos. En el año 1697, el concejo había reconocido la plena autoridad, señorío y vasallaje del comprador del Real Privilegio. Ignacio de Ontiveros, en nombre de Luis de Montalvo, manifiesta a este respecto, en 24 de octubre de 1697, que de dicho documento se deriva que " $n i$ por tanteo ni por más precio, ni por ningún servicio que se hiciera... no sería quitada dicha jurisdicción, señorío y vasallaje..." "64. Para los más esperanzados, "unos pobres" en palabras del señor de la villa, no faltan los recuerdos de tiempos pasados en que la justicia les había dado la razón. Pero por encima de todo, la realidad pone sobre la mesa la falta de recursos para acometer pleitos de dudosa rentabilidad. Así es como lo manifiesta el concejo de Serrada en el año $1728^{765}$ :

"El concejo de Serrada, reunido a son de campana..., acuerdan..., que... no daban el poder para dicho tanteo ni para lo anexo a él, por quanto están beneficiados en lo que pagan de alcabalas a dicho señor marqués, y porque la cantidad que se ha de tomar para dicho tanteo, sus réditos importan más que lo que al presente pagan por no tener propios esta villa. Y que los pleitos son muy costosos y sus fines dudosos...”

cómputo total eleva la superficie de Serrada a "diez y ocho cuentos, cuatrocientos y ochenta y siete mil trescientos y veinte y una varas cuadradas".

La confirmación de vecinos y leguas ratifica las cantidades previamente concertadas de acuerdo a los decretos reales. Diego de Montalvo pagará por leguas, dado que, aunque la cortedad del término es evidente, menos aún llenarían las arcas de la hacienda el cálculo por los 75 vecinos existentes en el lugar. Esta reducida entidad de vecinos y término había constituido un argumento de primer orden para excusar, durante largas décadas, la exención respecto a Olmedo por parte de Serrada. De hecho, el 3 de agosto de 1675, reunidos en concejo, renuncian al tanteo manifestando que " $n o$ se hallan por ahora para ello con disposición ni medios, reservándoles su derecho a salvo para si en algún tiempo lo quisiere la villa de $\mathrm{Ol}$ medo y otra persona que le pueda pertenecer saldrán de esta villa y vecinos a la defensa". No deja de sorprender la animadversión por su villa cabecera. (A.M.S. Privilegio de Villa, fol. 168 y A.G.S. Mercedes y Privilegios, leg. 245. Quinta pieza, fol. 20).

${ }^{762}$ A.H.N. Leg. 23970.

${ }^{763}$ A.H.N. Leg. 25129, no 3.

${ }^{764}$ Ibídem.

${ }^{765}$ Ibídem. Leg. no 3, pieza 2a. 
En el fondo subyace el tremendo peso impositivo que recaía sobre los sufridos pecheros. Sólo en casos excepcionales las comunidades campesinas pierden su tradicional quietud. Piénsese que, al margen de este tipo de tributaciones y derechos señoriales, de rentas de tierra entran en las paneras de la casa palacio de los Montalvo de Serrada ochenta y ocho cargas de trigo, veintidós de cebada y sesenta y seis huebras cada ańo, que se cifraban en torno a los cuatrocientos ducados. Fuera buena cosecha o no se segara y vendimiara. Y otros doscientos ducados por arrendar los pastos, pinar y eras. Más los tres reales por aranzada de los majuelos a censo... en un término que por esta época sumaba novecientas aranzadas. Cuando a ello se añade la prepotencia con que también actúa en lo tocante a lo religioso, sobra imaginar los pensamientos del vecindario. Sirvan, como ejemplo, las críticas que en este tiempo se ponen en manos de la justicia ${ }^{766}$ :

"Asimismo se ha apropiado tener silla en la iglesia al lado del Evangelio, demoliendo para ello un altar del Santo Xpto de la Cruz donde la Cofradía decía Misa los viernes por las ánimas de sus difuntos, en grave perjuicio dellas y de dicha cofradía, por que como no ay Altar no se dizen las Misas, y sólo a quedado el Santo Xpto pendiente de la Cruz, todo lo qual el dicho Don Diego con la maña y poder de tal señor adquiriendo dichas posesiones y derechos sin saber el que tiene para ello...”.

Cuadro 87. Alcaldes, regidores y oficios nombrados por Luis de Montalvo, señor de Serrada. Años 1720-1726

\begin{tabular}{|c|c|c|c|c|c|}
\hline \multirow[b]{2}{*}{ Oficios nombrados } & \multicolumn{5}{|c|}{ Años } \\
\hline & 1720 & 1721 & 1723 & 1725 & 1726 \\
\hline \multirow[t]{2}{*}{ Alcalde ordinario } & & Joseph Alonso & Antonio Díaz & Francisco & Francisco \\
\hline & Andrés Alonso & Pablo Rodríguez & Juan García & Moyano & Moyano \\
\hline Alcalde de la & Atanasio & & & & \\
\hline Santa Hermandad & Rodríguez & Pedro Rojo & Joseph de Castro & Lorenzo Alonso & Joseph Recio \\
\hline \multirow[t]{2}{*}{ Regidores } & Francisco Moyano & Atanasio Alonso & Santiago Inoxal & Tomás Rojo & Atanasio Alonso \\
\hline & Bonifacio Martín & Narciso del Castillo & Atanasio Rodríguez & Francisco Martín & Joseph de Castro \\
\hline Procurador & & & & & Narciso del \\
\hline General & Tomás Rojo & Diego de Íscar & Alonso Román & Atanasio Rodríguez & Castillo \\
\hline Contadores tasadores & & Antonio Rodríguez & Simón de Castro & Santiago Inoxal & Simón de Castro \\
\hline y repartidores & Joseph Santos & Bernardo Alonso & Joseph Alonso & Joseph Moyano & Alonso Román \\
\hline Fiel de hechos & Juan García & Lázaro Gómez & Lázaro Gómez & Lázaro Gómez & Lázaro Gómez \\
\hline $\begin{array}{l}\text { Receptor de } \\
\text { papel sellado }\end{array}$ & Lázaro Gómez & Lázaro Gómez & Lázaro Gómez & Lázaro Gómez & Lázaro Gómez \\
\hline Alguacil & Blas García & Joseph García & Francisco García & Andrés Martínez & Joseph García \\
\hline $\begin{array}{l}\text { Mayordomo } \\
\text { de la Iglesia }\end{array}$ & Santos Moyano & Blas de Íscar & Bernardo Alonso & Joseph Alonso & Joseph García \\
\hline $\begin{array}{l}\text { Mayordomo } \\
\text { de Propios }\end{array}$ & Juan Navarro & Francisco Martín & Francisco Álvarez & Julián de Minguela & Manuel Ruiz \\
\hline Colector de bulas & $\begin{array}{l}\text { Simón García } \\
\text { Francisco de Íscar }\end{array}$ & $\begin{array}{l}\text { Francisco García } \\
\text { Juan Navarro }\end{array}$ & $\begin{array}{l}\text { Pedro Román } \\
\text { Francisco Gutiérrez }\end{array}$ & $\begin{array}{l}\text { Manuel Ruiz } \\
\text { Manuel de Mora }\end{array}$ & $\begin{array}{l}\text { Andrés Martín } \\
\text { Pedro García }\end{array}$ \\
\hline
\end{tabular}

Fuente: Archivo Histórico Nacional. Leg. 25129, no 3.

Difícilmente los vecinos que así se manifestaron labraran sus tierras en los años siguientes. Como aquellos que ocuparon cargos en el concejo y protestaron posteriores elecciones. La mayor parte de los elegidos se caracterizan por ser pudientes labradores. Entre ellos se encuentra, como puede comprobarse en el cuadro adjunto, el escribano Francisco Moyano, llegado de La Seca y dueño de una de las principales labranzas de la comarca ${ }^{767}$ :

\footnotetext{
${ }^{766}$ Ibídem, fol. 48.

${ }^{767}$ A.H.N. Leg. 25129, no 3.
} 
Todos estos desencuentros vecinales con el señor son el pan nuestro de cada día en estos pueblos de Castilla. Unos porque, siendo hijodalgo el señor no los tiene en consideración, y otros porque se sienten marginados respecto a quienes ocupan los cargos más importantes, el caso es que resulta imposible averiguar hasta dónde estaban en la verdad unos y otros. Aunque son muchos los representados, los vecinos restantes acusan sin parar. En este sentido un testigo afirma que sabe, "por haberlo visto," que el marqués ha quitado las tierras a todos los que no son sus parciales, "obligándolos a buscarlas fuera de esta jurisdicción”; otro testifica acusando al marqués de hacer las elecciones de justicias y demás oficios a su antojo, "nombrando a sus criados y parciales sin guardar huecos ni parentescos"768. No hay duda de que algo pasa en la Serrada de estos años para que los vecinos estén tan inquietos y enfrentados con su señor. Demasiados intereses y escasos recursos para acometer el tanteo con éxito. Como en el resto de las villas de la tierra. En el mundo del Antiguo Régimen, los señores siempre fueron señores y los pecheros, pecheros.

\section{b. El fin del lugar de La Moya}

A diferencia de Serrada, La Moya sigue los pasos de cuantas aldeas no ven la llegada del nuevo siglo. Las últimas décadas del siglo XVI y primeros años del XVII testifican su práctica desaparición. No se encuentran documentos de reuniones concejiles ni noticias sobre sus reuniones, pese a que, en diciembre de 1589, Francisco Martín figura como alcalde ordinario de la citada aldea. Se convierte en el último alcalde residente de los pocos vecinos que aun viven en las pocas casas que permanecen abiertas. Todos eran, por aquellas fechas, renteros y nacidos en los pueblos cercanos de Ventosa, Valdestillas y Serrada ${ }^{769}$.

\section{- La vida y trabajos de sus últimos moradores}

Prueba de esta falta de futuro es la ausencia de vitalidad que presenta el lugar por este tiempo. $\mathrm{Ni}$ siquiera constan, en los distintos testamentos consultados, intenciones de enterrarse por parte de sus renteros, pese a que llevan gran parte de su vida viviendo en La Moya. Y los hijos que dejan tampoco siguen labrando las heredades de sus padres ${ }^{770}$. Los pocos que continúan morando en sus casas siguen luchando contra el paso del tiempo para proteger sus símbolos. Lo corrobora la escritura firmada el 2 de septiembre de 1590 entre Francisco Flores, de Tordesillas, siguiendo orden del obispo de Palencia, para "hacer la sacristía que esta mandada hacer en la yglesia de nuestra Señora Santa María de los Remedios del lugar de la Moya y la reedificación y reparo del tejado de la torre de la Yglesia del dicho lugar...".

En este año de 1590 testan, aunque viven casi otras dos décadas, Bartolomé de Moraleja y su mujer, nacidos en Ventosa, donde conservan heredades y desean ser enterrados. No parece, a juicio de la documentación hallada, que sus hijos y herederos residan donde trabajaron sus padres. La

\footnotetext{
${ }^{768}$ Ibídem, fol. 72.

${ }^{769}$ Esta falta de vitalidad del concejo, en los primeros años del XVII, cuando La Moya se encamina a su desaparición, será en cierto modo compensada con una tenue actividad religiosa, encarnada en la persona del cura beneficiado Álvaro Floristán, vecino de Valdestillas, así como por parte de Bartolomé de Moraleja, mayordomo de la iglesia de Nuestra Señora Santa María de los Remedios, en cuanto encargados, respectivamente, del culto y los bienes beneficiales que posee en el citado lugar y Moraleja, como administrador de las heredades correspondientes a la citada iglesia.

${ }^{770}$ En 1590, por ejemplo, se hace inventario de los bienes del ya referido alcalde Francisco Martín, casado en segundas nupcias con Francisca de Astudillo, vecina de Serrada y mujer que había sido de Pedro de Rojas, también de este último pueblo. El alcalde deja constancia de su deseo de ser enterrado en Ventosa, de donde era natural y en donde dispone de casas y bienes. Guardaba en la bodega de la citada casa once moyos de vino producido en La Moya y a su muerte atesoraba una labranza mediana. Tenía sembrado en término de la Moya ocho obradas de cebada, diecisiete de trigo y cinco de centeno. De estas tierras se llegarán a coger, tras su muerte, 40 cargas de trigo, 33 de cebada y 10 de centeno, (una carga equivale a cuatro fanegas). (A.H.P.V. Pt. 11838, fol. 143-147).
} 
Moya se apaga sin remedio. Los últimos años de la vida de Bartolomé de Moraleja dejan constancia de sus actividades como mayordomo de la iglesia, sea otorgando poderes para cobrar la renta que deben distintos labradores a la Virgen de los Remedios, sea labrando a renta las poseídas por el beneficiado Álvaro Floristán ${ }^{771}$ :

“... todas las tierras que son anejas al dicho mi beneficio, en que abra catorze obradas poco más o menos, poco o mucho, lo que en ellas obiere y bos las arriendo a todo riesgo y bentisca y caso fortuito ansí del cielo como de la tierra, de agua, piedra, niebla... por término y espacio de quatro ańos y quatro frutos.... y por precio e quantía de dos cargas y una fanega de trigo en grano en cada un año, que sea nuevo, bueno, seco, limpio de dar y tomar y medido con medida aprobada, puesto sin desquento del principal en las casas y poder de mi, el dicho Alonso Floristán”.

La mayor parte del término labrado, sin embargo, es de propiedad nobiliaria, perteneciente al mayorazgo de Antonio de Vega, caballero, como ya se ha dicho, de la Orden de Alcántara y regidor y alférez perpetuo de la villa de Tordesillas. En 1588, administraba sus bienes el alcalde del lugar Francisco Martín, arrendando tierras y pastos a los vecinos de la aldea y pueblos limítrofes ${ }^{772}$. Destacan los vecinos de Matapozuelos, propietarios de unas o renteros de otras ${ }^{773}$. Los vecinos de Valdestillas tienen una menor presencia como propietarios, pero destacan por los arriendos del noveno y menudos de la iglesia de los Remedios, al menos hasta que fallece su convecino y cura Álvaro Floristán. ${ }^{774}$ Desde entonces, el decaimiento del lugar es inexorable. El nuevo cura beneficiado es vecino de Pozaldez y se llama Domingo de Plaza. En 1603 arrienda a Sebastián de Plaza -posiblemente familiar cercano- los frutos del noveno, por la misma cantidad de 17.000 maravedíes, que consta se remataba anteriormente. Por otra parte, muerto el alcalde Francisco Martín, los protocolos notariales no arrojan ninguna luz sobre sus sucesores, el cura beneficiado de la iglesia prácticamente desaparece y La Moya va perdiendo entidad. Bartolomé de Moraleja pasa a ser apoderado de las tierras de los Vega en La Moya, una vez muerto Francisco Martín, encargándose del arriendo de las tierras del mayorazgo ${ }^{775}$ :

“... ocho obradas poco más o menos que son del dicho don Fernando que tiene y están en el pago que llaman de la Ormiga... y otras seis obradas.... que están en dos partes y cada una tiene tres obradas.... por tiempo y espacio de seis años... y precio y quantía de una carga de trigo nuevo, bueno, que sea de dar y tomar, puesta a mi costa y misión en el granero de las paneras que tiene el dicho don Fernando en las casas de la Moya...”.

Estas paneras y casas que posee regidor de Tordesillas no tienen la vitalidad de tiempo atrás, pero la hacienda le sigue proporcionando sustanciosas rentas. También a Olmedo. Las posturas por las cortas y cargas de retama del monte de los Llanos y los pleitos entre partes dan fe de ello ${ }^{776}$.

${ }^{771}$ A.H.P.V. Pt. 11844, año 1596, fol. 489.

772 A.H.P.V. Pt. 11837, fol. 79.

${ }^{773}$ Es el caso de Martín de Arévalo, que toma las catorce obradas del beneficiado que antes llevaba Moraleja, por espacio de otros cuatro ańos y precio de dos cargas y media de trigo.

${ }^{774}$ A.H.P.V. Pt. 11848 y 11849.

775 A.H.P.V. Pt. 11852 , fol. 40.

${ }^{776}$ En este sentido se debe hacer referencia a los avatares judiciales del principal labrador y mayordomo de la iglesia de la Moya. Juan González de Inaraja, clérigo y beneficiado de Valdestillas moverá pleito en 1606 contra Moraleja sobre los frutos del noveno de los Remedios que administraba. La justicia le embarga ciento cincuenta ovejas y los disgustos no serán pocos. Consta que, por estas mismas fechas, Moraleja vende una mula por 600 reales a un vecino de Ventosa. Bien pudiera ser que dicha cantidad fuera a parar a las bolsas de los procuradores de Valladolid que defendían su caso o a levantar dichas hipotecas. De sobra conocerá el lector quién se quedaba con las burras o los bueyes en caso de litigios y pleitos. El caso es que fueran los ańos o los disgustos, el tres de febrero de 1609 se hace inventario de los bienes que deja en esta vida Bartolomé de Moraleja. (A.H.P.V. Pt. 11859, fol. 130). 
El progresivo deterioro que el tiempo ocasiona a la decena de casas, paneras, corrales e iglesia del lugar es irreparable. Tan sólo hay documentada la vecindad de Pedro Román en mayo de 1611, que había sido condenado a pagar 4.000 maravedíes por penas sobre la caza. Un año después, en diciembre de 1612, se firma escritura en Serrada ante Fernando de Vega y el citado Pedro Román, residente en La Moya, para que este "aya y cobre de los renteros que trajeren sus rentas e arrendamientos" y que "asistiere en dicho lugar al dicho Don Fernando de Vega", a cambio de un salario anual de cinco cargas de trigo en grano. La Moya sigue habitada, quizá por este único vecino, encargado de la vigilancia de las heredades del citado Fernando de Vega, quien, en 1616, le otorga poder para que en su nombre "haga apeo de todas sus tierras y heredades que tiene en los términos del lugar de la Moya, Valdestillas y Matapozuelos anexas a su mayorazgo, conforme al apeo viejo que se hizo a pedimiento de su abuelo Fernando de Vega, del habito de Alcántara"ᄁ7.

Pedro Román sigue habitando La Moya, pero por poco tiempo. Los poderes notariales de sus pueblos vecinos guardan silencios que, como en tantos otros lugares de esta Tierra de Medina o de Olmedo, son sinónimo de su desaparición. El siglo XVII se cobra su tributo entre las aldeas más débiles, entre los pobladores con menos recursos o más cargas y La Moya era una de ellas. La acompañan en su viaje aquellas aldeas que constatan similares números de vecinos. Así, en 1587 se contaban 8 vecinos en Tobar; 4 en Villafuerte y Valverde; 3 en Carrioncillo o Miguel Serracín; 2 en Foncastín o Trabancos y que, como en otros muchos de esta comarca, no alcanzan a ver la luz de la edad contemporánea ${ }^{778}$. Sus términos y bienes serán, como en el tratado, arrendados a vecinos de pueblos limítrofes y el tiempo acabará borrando las huellas que sus moradores dejaron. En el caso de La Moya, ciento cuarenta años después de las fechas antedichas, sólo quedaban en pie los paredones de sus iglesia y el pozo, "el Pozo Nuevo, junto a la Moya", que se hallaba en una tierra de cinco obradas propiedad de la propia iglesia, donde había un picón que venía a dar a la Moya, "junto a una casa que es de doña Juana de Sotomayor, vecina de Tordesillas"779.

\section{- La pervivencia de conflictos derivados de antiguos usos y aprovechamientos comunales}

Despoblado el lugar, son los corregidores de Olmedo los encargados de nombrar alcaldes que velen por el control y administración de la justicia en sus términos. Gozan de poder y facultad "para que con vara de justicia conozcan en todas las causas ziviles y criminales” y las remitan para su conclusión a la villa de Olmedo. Pero no siempre las relaciones entre el Despoblado, más vinculado a Serrada que a otros términos, dado entre otras cosas la mayor presencia de propietarios y arrendadores que en los lugares de su contorno, fueron pacíficas y cordiales o, al menos, no en lo que respecta a los encargados de vigilar su jurisdicción ${ }^{780}$.

777 A.H.P.V. Pt. 11861, fol. 446, año 1613.

${ }_{778}$ MARTÍNEZ DÍEZ, G.: "La comunidad de villa y tierra de Medina” en Historia de Medina..., ob. cit., vol. I, pág. 181.

${ }^{779}$ Dicho pozo seguirá apagando la sed de los arrendatarios del mayorazgo de los Vega o de la Universidad y Tierra de Olmedo. Rentistas o propietarios comenzarán a arrastrar los diezmos de La Moya, una vez despoblada, a la iglesia de San Pedro de Serrada, depositaria de sus bienes beneficiales. El propio término será igualmente acogido por Serrada que, de esta manera, dilata los límites de su terrazgo y cierra las páginas a la centenaria historia de este lugar habitado que, no obstante, dará mucho que hablar en los siguientes siglos por el interés derivado de la representación de su jurisdicción y el aprovechamiento de sus recursos. Se analizarán algunos ejemplos de ello. (A.H.P.V. Pt. 11837, fol. 737, año 1588).

${ }^{780}$ Es el caso ocurrido al alcalde del Despoblado, Juan García de Santiago, vecino de Serrada, cuando en el año 1676 fue despojado de su vara por el corregidor de Olmedo Juan García y entregada al vecino de Matapozuelos, Antonio de Neira: "Pedro del Castillo Rueda, en nombre de Juan García de Santiago, familiar del Santo Oficio, vecino de la villa de Serrada, ante V.A. apelo y me presento en grado de apelación, nulidad, desagravio o en la vía y forma que mas haya lugar de derecho, de cierto Autos de apremio, despojo y honor echos dados y proveydos por el correxidor de la Villa de Olmedo contra mi y a favor de Antonio de Neyra, vecino de la villa de Matapozuelos, por los quales siendo mi parte alcalde ordinario del lugar despoblado de la Moia por nombramiento del dicho Corregidor, y estando en posesión del dicho oficio quieta y pacificamente, y en la prozesion que se acostumbra 
A finales del siglo XVIII, más de un siglo después del conflicto precedente, La Moya es centro de intereses encontrados. No se puede dejar de hacer mención a la denuncia que presenta en 1796 Francisco Javier Matesanz, en nombre de Don Pedro Martín de Mora, presbítero, vecino y ganadero de ovino de Matapozuelos. Este eclesiástico, unido a otros ganaderos, defiende ante los tribunales de la Real Chancillería sus derechos de pastoreo sobre el término de La Moya por pertenecer esta a tierra de Olmedo, aun cuando existen ordenanzas particulares que les impiden comer, por ejemplo, la hoja de los majuelos una vez vendimiados ${ }^{781}$.

La denuncia pone sobre la mesa el viejo debate entre los intereses encontrados de quienes desean continuar disfrutando de antiquísimos derechos comunales, frente a quienes defienden, a finales del antiguo régimen, formas precapitalistas y la explotación mercantil del terrazgo. La Moya, como despoblado carente de vecinos que velen directamente por sus intereses, queda en algunos aspectos al margen de esa modernidad y, cuando las autoridades de Serrada desean poner coto a estos disfrutes, anclados en los viejos tiempos, no tardan en estallar conflictos difíciles de determinar hasta para la propia justicia. De hecho, el presbítero de Matapozuelos trata de acogerse al viejo derecho consuetudinario y a las normativas expedidas el 8 de enero de 1780, que defendían tales intereses. En ellas, se señala que "no se impida la entrada de ganados en las viñas y olibares... que hubiese en cada uno de los Pueblos de sus respectivos partidos; y como esta ha sido siempre la de poder pastar libremente...", por lo que se insta a que Francisco Moyano cumpla lo mandado y no moleste ni a ganados en su pastoreo ni a pastores en su cuidado ${ }^{782}$.

La hoja de la pampanera, una vez levantado el fruto, se había mantenido en el término de la Moya como un bien de Propios de Olmedo. En Serrada, como en La Seca, la expansión vitícola había rebasado cualquier expectativa de siglos anteriores, en detrimento de espacios comunales. Si, además, se anotan las diferencias entre términos y vecinos, se entiende la firmeza del alcalde de Serrada en defender los acuerdos concejiles sobre el arriendo de la pampanera y el empecinamiento de los ganaderos de los pueblos limítrofes, por querer mantener sus usos anteriores. El 24 de septiembre, se agrava el conflicto, dadas las actuaciones por parte de los de Serrada respecto a la entrada de ovejas en La Moya ${ }^{783}$ :

hazer en la hermita de Nuestra señora de la Moya, y sin hacer causa ni motibo alguno de echo de su autoridad, quito a mi presente la vara de tal alcalde, estando en la dicha Ermita con ella haziendo acto de jurisdicción. Y nonbró por tal alcalde ordinario al dicho Antonio de Neira. Sin enbargo de que por mi parte le yzo diferentes protestas para que no le quitase dicha vara por no aver podido nonbrar al susodicho por tener mi representado titulo lexitimo y sin causa no le podía aver revocado por ser contra su persona y crédito, sin envargó lo executó el susodicho...”. Tras las oportunas diligencias y no pocos trámites administrativos, volverá a ostentar la representación de la citada alcaldía. Los autos pondrán de manifiesto cuántos intereses y ambiciones se escondían por el control, no sólo de la jurisdicción, sino también del beneficio derivado de las roturas que aun quedaban de sus montes y de cuantas rentas generaba su terrazgo. (A.R.Ch.V. P.C. Pérez Alonso (F), caja 3225, exp. 3).

${ }^{781}$ Así defiende el religioso, a través de su apoderado judicial, sus intereses pastoriles: “... en lo antiguo eran pastos donde se acogían todos los ganados tanto en ibierno como en las demás estaziones del año, sin que ninguno se le impidiese pastar en el por dicha comunidad, y con el motibo de haberse plantado el crecido terreno de que se compone de majuelos por los vecinos de los pueblos comarcanos, ha llegado el caso de no haber dejado pasto alguno, por cuia razón en todo el año se acogen ni pueden acoger los ganados más que el presente tiempo como en el que, después de lebantado el fruto, habiendo presente a comer la oja de las biñas, cuia costumbre havido xeneralmente sin que ello se haya puesto el menor inconveniente, obstáculo, ni inpedimento por persona alguna, y menos por las xusticias de los referidos pueblos comuneros, pero es el caso que contra dicha costumbre antiquísima e inbiolable, se haya cursado en el presente año por el Alcalde de dicho Despoblado, Don Francisco Moyano, vezino de la villa de Serrada, a dar probidencia mandando que ninguno de los ganaderos puedan llebar sus ganados a pastar dicha oxa, pena de cinquenta ducados, sin que primero acuda a hacer postura a ella y se le remate como en mejor postor o maior posturas...".

782 El pleito estaba servido y los litigios, como ya se ha tenido ocasión de comprobar, se sabe cómo empiezan pero nunca cómo acaban. La parte acusatoria ratifica cuanto se ha relatado el 20 de octubre en la Real Chancillería de Valladolid. Los “maxuelos" habían sido, una vez más, la espoleta del enfrentamiento entre labradores y ganaderos. El descenso del pasto que recortaba el campo a las ovejas y la necesidad de dehesas para paliar esta escasez y siempre más caras, se enfrentaba al interés de los concejos por obtener ganancias de antiguos bienes, ahora "privatizados".

${ }^{783}$ La Audiencia, en nombre del rey Felipe IV, dicta una provisión el 21 de octubre, que ratifica lo expuesto por la parte de los ganaderos, que es alegada con contundencia por Francisco Moyano, como alcalde del Despoblado. Defiende este alcalde que siempre se ha entendido por pastos libres los terrenos no acotados, entre los que no figuran las viñas. 
“:...pasó en dicho día con una tropa de gentes y aprendió como hasta ciento y quarenta reses, maltratándolas con caballerías, para llevarlas a el Pueblo, y conminando a los Pastores con la multa de cinquenta ducados, que les exigirá en el caso de no retirarse con los ganados, y que les llevaría presos, cuio atentado se hace mas punible y de la mayor consideración por ser contra un mandato especial de la Sala en que se mande la costumbre...”.

La formalización de autos, lejos de apaciguar los ánimos, incita a ganaderos de Matapozuelos, Valdestillas y Villanueva a entrar y pastorear las vińas plantadas en La Moya. Francisco Moyano eleva nuevas súplicas, informando de las quejas y denuncias presentadas por Pedro Álvarez, guarda jurado del término del despoblado. Se transcribe al pie la denuncia registrada por el escribano de Serrada por referir aspectos sociales que caracterizaron la vida de la población de los términos tratados ${ }^{784}$.

\section{c. Los avatares de los quince vecinos de San Martín del Monte}

San Martín del Monte representa a aquellas aldeas que, si bien fueron resistiendo los embates de las crisis, tenían sus días contados. De hecho nunca supera la docena y media de vecinos y, en ocasiones, se reducen a la mitad. ¿Escasez de tierra para dimensionar las labranzas? ¿Restricciones de las monjas de Santa Clara para la entrada de ganado en sus montes? Son preguntas que, respondidas afirmativamente, nos acercan a la realidad de esta pequeña villa monástica. A diferencia de La Moya o Serrada, su término no rebasa las trescientas cincuenta obradas, de las cuales se deben descontar los prados y pinares que merman la tierra que labrar e impiden un mayor desarrollo demográfico. Tampoco consta un dinamismo vitícola por parte de sus habitantes, como el que caracteriza a Serrada u otros pueblos del norte de Medina ${ }^{785}$.

Como en los casos de Serrada o La Moya, los pleitos por el control de sus pastos comunales permiten acercarse a su vida en estos siglos XVI y XVII. El conflicto estalla en el último tercio del XVII, enfrentando, nuevamente, a los concejos de La Seca con el de San Martín del Monte.

Señala que en los mismos pueblos de Matapozuelos, Valdestillas y Villanueva, villas originales de los ganaderos pleiteantes, las ovejas no entran en las vińas, si no es con el consentimiento de los suyos y tras oportuno arriendo. Manifiesta que, si en La Moya han seguido entrando, es porque lo han hecho con algún reconocimiento en dinero o en reses entre alcaldes y propietarios y que tal contribución solo sirve para la paga de los guardas de dicho termino, dado que el abandono del lugar trajo consigo el atropello de los bienes por transeúntes y ganados, que no respetaban ni vendimias ni frutos pendientes. Denuncia Francisco Moyano el ansia pastoril del cura de Matapozuelos, conminándole a que se hiciera eco y respetara la reunión concejil, celebrada en Serrada el 12 de abril de dicho año, para formalizar, tal como se venía haciendo en otros pueblos, el uso en arriendo mediante posturas de la hojas de las viñas. En ella, dice, asistieron representantes de Matapozuelos que fueron posteriormente quienes ganaron el citado arriendo por 700 reales. Francisco Moyano afea al cura de Matapozuelos su proceder y alentar conflictos cuando 700 o 1.000 reales, repartidos entre 8.000 o más reses, no impiden a nadie el pastoreo y sí sirven para la paga de los guardas de dicho despoblado. (Ibídem).

784 "En la villa de Serrada a cinco días del mes de noviembre de mil setezientos noventa y seis... Pedro Alvarez, guarda jurado del término y campo de dicho lugar despoblado de la Moya... vio que como a las dos y media de esta dicha tarde andava pastando en las viñas del el ganado lanar ovejuno propio de Juan de Arias, vezino de la villa de Baldestillas a el cargo, y cuidado de su maioral llamado Mariano, alias Espantas, y de Juan Antonio Álvarez, su zagal, los quales con su ganado venian por el maxuelo titulado de los Paredones de San Pablo en dirección a la Casa de la Moya, adonde llegaron. Y como que hubiesen visto a el compareciente, suvieron dicho ganado por el maxuelo nombrado el Blanquizal, y se dirigieron a el termino de dicha villa de Baldestillas. Que también vio dicho compareciente a la citada hora que el ganado ovejuno propio de Agustín García, alias Galán, vecino de dicha villa de Baldestillas, custodiado de su criado zagal José Peral, entraron en las viñas de dicho termino de la Moya por los maxuelos llamados de la Rica de las monjas Brígidas de Valladolid, y llegaron hasta el herial del Pozo de la Moya, y subieron por el maxuelo nuevo linde del propio del Sr. Alcalde, su merced, y en derecho al pago de Cuesta Redonda; y que por haberse hallado como el compareciente se hallo solo, y estando como esta temeroso con las amenazas que le tienen hechas los citados pastores, a quienes conoció muy bien, no se determino a llegarse a ninguno de ellos y pedirles le entregasen prendas, y solo resolvió venirse a esta dicha villa a poner, como lo haze, en notizia de su merced todo referido...”.

${ }^{785}$ En 1752, como se ha visto, tan sólo refieren una bodega compartida por dos labradores, amén de su lagar a ella anejo, y aunque consta alguna otra bodega, sita en las peńas que resguardan a la pequeña villa del cierzo, sus mostos nunca tienen la importancia de pueblos vecinos. 
Los primeros defienden sus derechos sobre el aprovechamiento de pastos en San Martín, por pertenecer éste a la Tierra de Medina; los segundos vedan tales herbazales, por estar incluidos en la escritura a censo perpetuo, firmada con el convento de Santa Clara de fines del XV. En los pleitos y autos, como en otras ocasiones, las partes en litigio trasladan notarialmente antiguas escrituras que permiten reconstruir mejor las razones de unos y otros y la vida común de todos ellos.

\section{- Las repercusiones de la compra a censo perpetuo del término de San Martín del Monte}

Los sucesivos tratados escriturados entre el Real Convento de Santa Clara y el concejo de San Martín, que regulan la relación entre los vecinos asentados en este lugar y las citadas monjas, coinciden en seńalar como su antecedente el firmado el 10 de febrero de 1490 ante el escribano publico de Tordesillas, Alonso González del Torneo. En este acto notarial, más de un siglo después de la donación del lugar a las Claras, se sientan las bases del futuro de la pequeña villa ${ }^{786}$.

Como reproduce la escritura anotada al pie, que alude a la carta de censo inicial, el solicitado monte de las monjas queda excluido del concierto, si bien se da facultad al concejo de San Martín para que cada vecino pueda meter en el monte de encina "tres bueies o obejas o otras vestias sin pagar cosa alguna al dicho conbento, e seis bueies o vacas o otras vestias de huelga pagando sesenta y dos maravedies por cada caveza..." ${ }^{787}$. En una nueva escritura, se precisa el número exacto de vecinos, la cuantificación exacta de sus ganados y de quienes deben entrar o no en el preciado monte de encina ${ }^{788}$. En los propios documentos, se hace constar que los aprovechamientos pastoriles son "por su vida e después de su vida los vecinos que fuesen del dicho lugar para siempre jamás no pudiesen meter ni metiesen en el dicho monte ningunas bacas ni bestias de labor ni de güelga e si la metiesen que pagaren las penas

${ }^{786} \mathrm{El}$ traslado notarial refiere: "Sepan quantos esta publica escriptura vieren como nos, la avadesa, vicaria, provisoras e monjas discretas e conbento del monasterio de Nuestra señora Santa María, estando como estamos ayuntadas a canpana tañida junto con la red de yerro que sale al locutorio... por virtud de los tratados que hicimos e zelebramos... e por virtud de la lizencia que nos fue dada... de la qual dicha lizencia e tratados hazemos presentacion, su thenor de la qual es este que se sigue:

Yo, Fray Juan de Cabrera, ministro provinzial desta provinzia de la Concepción de la horden del Bienaventurado Padre San Francisco, comisario visitador General del monasterio... por quanto yo estoy informado que el consejo e honbres buenos del lugar de San Martín del Monte tomaron a zenso perpetuo de la señora Avadesa e monjas e convento del dicho monastyerio e de Juan Gonzalez de Tosantos, su maiordomo, en su nonbre, que a la sazón hera toda la heredad de pan llevar que dicho monaterio e conbento tenia en el dicho lugar y en sus términos, ansi prados, pastos y ejidos y heras y haceras y casas y solares e guertas e palomares e aguas estantes e manantes e todo lo otro que al dicho monasterio pertenecia en el dicho lugar y en su término, excepto el monte de henzinas que quedo para el dicho monasterio e conbento, prescio e quantía de veinte y nuebe cargas de zenteno en cada un año e tres pares de gallinas, pagado en cada un año para el día de Santa María de agosto, según mas largamente se contiene en la carta de zenso que paso ante Alonso González del Torneo, escriuano público que fue de la dicha villa de Tordesillas en diez del mes de febrero del año que paso de mil y quatrocientos e nobenta años...".

${ }^{787}$ A tenor de la documentación consultada, sin embargo, las monjas no quedan satisfechas del nuevo acuerdo. Se sentirán engañadas "en más de la mitad del justo precio e valor en que habian de ser restituidas...", volviendo a tomar la heredad de San Martín hasta tanto no se acuerden otros términos más favorables. Los vecinos del lugar poco podían hacer, sino plegarse a la voluntad de las monjas. Estas argumentaban que la escritura se había firmado antes que la debida autorización de su provincial y por ello estaba fuera de la legalidad. Seguramente los quince vecinos de San Martín sentían la excusa como una manera de restarles las tierras del pago de Linares. Para evitar pleitos y gastos, puesto que Santa Clara siempre tendría la sartén por el mango, llevan a cabo, por "via de hijuela e conveniencia e transacción e nuevo concierto" una nueva escritura similar a la anterior "excepto las tierras de Linares que quedasen para el dicho monasterio e conbento... e que por razón que el dicho conbento queda con dichas tierras de Linares se bajen de las dichas veinte y nuebe cargas de zenteno en cada un año dos cargas y que quedasen en veinte y siete cargas de zenteno..."(Ibídem).

${ }^{788}$ En concreto ascienden a quince, de los que catorce son varones y a los que hay que añadir "la mujer de Pedro Esteban”. Sus bestias podrán pastar desde el día de San Martín hasta mediado el mes de abril del año siguiente. Dicho acuerdo se firma el 22 de noviembre de 1548, estando presente el representante de San Martín y Baltasar de Fonteba, como mayordomo del monasterio, y ante Paio Cuello, como escribano de Tordesillas. Era un paso más en la vinculación eterna entre San Martín y Santa Clara. 
que se llevan de dicho monte..." Este pequeño detalle no pasa desapercibido en el concejo de San Martín. De hecho, unos días después de haberse firmado el concierto, el 28 de noviembre, en el propio monasterio comparece Sebastián Gutiérrez, en nombre del concejo de San Martín, solicitando que, de cara al concierto referido, se hiciese un nuevo censo de vecinos, no paguen más que las referidas veintisiete cargas de centeno y tres pares de gallinas y se introdujese la siguiente matización, en cuanto al aprovechamiento y usos del monte del monasterio:

“...agora de nuevo suplicaron e pedían por merced a las dichas señoras abadesa e monjas e conbento del dicho monaterio que las mujeres de los vecinos del dicho lugar que agora son e un hijo que cada uno nonbrase pudiese meter en el dicho monte las dichas vacas o bueies e nobillos e vestias de lavor o de guelga..."

Los moradores de San Martín tratan de aprovechar al máximo las cláusulas del concierto y alargar en lo posible el disfrute para sus hijos. El mismo 30 de noviembre del citado año de 1548, se "ayuntaban" conventualmente las monjas de Santa Clara, aceptando las peticiones de los vecinos del término de su propiedad. Todas las partes hacen constar la merced y caridad concedida, "porque los vecinos del dicho lugar son pobres e la principal cosa que tienen para su sustentamiento es poder meter en el dicho monte las dichas tres bacas e bueies e nobillos o bestias de huelga...". Se insiste en la carta, como si se tratara de un contrato de arrendamiento, en la obligatoriedad de los pagos, al margen de cualquier contingencia natural o intencionada, especificando de paso las fechas de pasto de los ganados en el codiciado monte de encina, al que podrán acceder los ganados desde el día de San Martín hasta mediados del mes de abril. Aprobado el permiso del cuidado de los ganados por las mujeres de los vecinos de San Martín así como de un hijo, se determina y se especifica que tal excepción será en su tiempo de vida, pues una vez fallecidos "no podáis meter ni metan en el dicho monte ningunos bueies ni bacas... e si dende en adelante las metieren, que paguen las penas como si no fuesen becinos del dicho lugar.." 89 .

\section{- Las últimas roturaciones y el reparto de tierras entre vecinos}

A mediados del siglo XVII, aún quedan espacios que roturar en los espacios incultos y montaraces que Medina y Olmedo poseían al sur del Duero. Se trataba de espacios cada vez más marginales y poco aptos para dedicarlos a tierras de pan llevar. La necesidad de tierras para plantar viñas o la dedicación de algunos de estos pagos al nuevo cultivo en expansión lleva a meter el arado en las pocas tierras que faltan por romper. Se acaba de ver en La Moya y en Serrada. San Martín del Monte tampoco escapa a la nueva dinámica. La precaria situación por la que pasa el campesinado castellano de mediados del XVII lleva a los regidores y corregidores de Tordesillas a interceder ante las máximas autoridades para aliviar su situación ${ }^{790}$. No dan para mucho más las haciendas que trabajan. La paga anual de las veintisiete cargas de centeno y las seis gallinas al Real convento ya eran de por sí bastante onerosas. Para aliviarse de tantas pagos, acuerdan que tanto las tierras de pan llevar, "rotas y por romper, se partan y dividan entre los vecinos con la carga de proporcionar el mencionado censo perpetuo a Santa Clara. El término labrado se reparte de esta manera en "suertes" o partes por periodos de seis años. Si alguno de los vecinos "por alguna causa no la pudiere labrar y quisiere dexar dello", ha de avisar a los demás

${ }^{789}$ En la carta sigue la aceptación por parte de San Martín de todos sus términos y el compromiso para cumplir cada una de sus condiciones, firmándose ante el perceptivo escribano, el 21 de diciembre de 1551, y siendo testigos el mayordomo de Santa Clara Baltasar de Fontecha, el escribano Hernando de Oviedo y el contador del convento Francisco Méndez. El vecino y representante de San Martín, Sebastián Gutiérrez, al declarar no saber firmar, rogó a los presentes lo hicieran en su lugar dando fe de ello. Se ponía fin a las diferencias en la regulación de la vida de San Martín del Monte con Santa Clara y continuaba una andadura ligada a dichas monjas, que duraría más de quinientos años.

${ }^{790}$ Pedro García, alcalde de San Martín del Monte en 1652, junto con Francisco de Sobrados, Pedro Pascual, Antonio de Berceruelo, Juan Hernández, Andrés de Coca, Pedro Bayón y Domingo Aragón, regidores y vecinos de la citada villa, se reúnen en concejo en febrero del citado ańo poniendo de manifiesto que los ingresos que obtienen de sus propios "están en gran empeño por los serbicios que se pagan a Su Majestad y otros encargos" (A.H.P.V. Pt. 5072, fol. 267-268) 
vecinos de la villa si la quieren labrar para, si no es el caso, podérsela arrendar a otra persona de fuera. De esta manera se apurarán los escasos espacios por romper que aún faltaban por labrar. Los distintos vecinos testimonian ante el escribano su compromiso de tomar o no parte en los repartos ${ }^{791}$ :

"Toma parte.

En la dicha villa de San Martín, dicho día, mes y año dichos, yo el escribano leí el acuerdo en quanto a labrar tierras a Pedro García, alcalde en persona, que dixo quería tomar parte en las tierras, y esto respondido, doy fe. Otra toma parte.

En la dicha villa, dicho día y año, yo el escribano, leí dicho acuerdo a Antonio de Berceruelo, vezino de dicha villa, que dixo quería tomar parte en la tierra, y esto respondió, y dello doy fe.

Otra no toma parte.

En la dicha villa, dicho día y año dichos, yo el escrbano leí dicho acuerdo a Francisco Sobrados, rexidor en persona, que dixo no quería parte en las tierras y que se apartaba del derecho que a ellas podía tener como lo declara dicho acuerdo, y esto respondió, y dello doy fe..."

Junto a ello, se precisan las condiciones que han de regular el arrendamiento de sus pastizales, principal fuente de ingresos de sus propios. En 1647, por ejemplo, acordaron arrendarlos, por dos mil reales anuales, a Sebastián Alonso de Contreras y Mitarte, señor de la villa de Villanueva de Duero. Los límites que se precisan acercan a la importancia del monte y de los pastizales en estos pagos ribereños del Duero ${ }^{792}$.

"Los propios prados altos y baxos que la dicha villa (San Martín del Monte) tiene propios suyos, que lindan por el largo por una parte con el prado de Serrada, y de la otra con monte y prado del Convento Real de Santa Clara de la villa de Tordesillas, cuya es esta dicha villa, y por lo ancho, de la otra parte con monte y término de la villa de Medina del Campo, y de la otra con los términos de Olmedo y Villanueva”.

Entre las condiciones que se acuerdan, se fijan los derechos de los propios vecinos a "poder meter y pastar en el prado baxo durante este arrendamiento las cabalgaduras mayores y menores y ganado vacuno y obejuno que fueren propio suyo". Los prados se tornan fundamentales en la economía de este tiempo, más cuando de lo que se trata es de la necesidad de romper las tierras que permanecían montaraces como las que ahora, a mediados del XVII, vuelven a ganarse para el cultivo después de haber sido labradas en otro tiempo, pero siempre "guardando los límites y cotos de los prados alto y baxo, sin poderse meter ni romper en cosa alguna dellos"93.

\section{- Los pleitos con La Seca por el aprovechamiento de sus prados}

Como se ha reiterado en anteriores páginas, las roturaciones de los siglos XVI y XVII acaban con los montes comunales. A la imprecisión de los límites de los montes y baldíos, se une la avaricia de los pueblos por su control y los pleitos, como ya se ha analizado, estallan por doquier. En el caso tratado, los vecinos de La Seca se otorgan el derecho de pasto en los prados de San Martín del Monte, al entenderlos como bienes de propios de la Tierra de Medina. La numerosa cabaña ganadera se refugia en exceso en estos frescos prados, en opinión de los vecinos de San Martín. Sin duda, las roturaciones del Monte Pedroso e Inestoso y el auge del viñedo conducen forzosamente al ganado a cubrir sus necesidades en esta parte cercana al Duero. El conflicto no tarda en llegar a la justicia ${ }^{794}$.

\footnotetext{
${ }^{791}$ Ibídem.

792 A.H.P.V. Pt.5074, fol. 343.

${ }^{793}$ Ibídem.

${ }^{794}$ San Martín defiende como suyos estos prados y su aprovechamiento, aduce reales provisiones para poderlos arrendar, a fin de "reparos y obras de su Yglesia y casa de ayuntamiento y otras cosas...", y apela a la costumbre inmemorial según la cual la pequeńa villa ha disfrutado de su aprovechamiento. Así lo hace constar en la escritura de poder otorgada por su concejo para la defensa de sus derechos, en el pleito con La Seca, y fechada el 8 de agosto de 1702: “...Decimos que
} 
Era la constatación de las diferencias y los litigios que habían distanciado a ambas villas en el último tercio del XVII. San Martín, a pesar de su pacifico deseo, acude a la justicia casi por una cuestión de honor. Siente pisoteados sus derechos por La Seca, población mucho más fuerte a todos los efectos y que, como se cita en la anterior carta de poder, había ganado cierta sentencia dada por el Alcalde Mayor de la Mesta, en febrero de 1673, que permite el pasto de su cabańa ganadera en los prados de Arriba y de Abajo prohibiendo, además, su arrendamiento por los vecinos de San Martín. De hecho, cuando al año siguiente un procurador de Olmedo trata de llevar a efecto la sentencia, San Martín le muestra una carta real, fechada el 27 de julio de 1674, en la que se les otorga facultad para arrendar el prado de Arriba, para sufragar los gastos de reparación de su iglesia y construir una casa para reunión de su concejo ${ }^{795}$.

San Martín, con tan sólo siete vecinos por estas fechas, trata de cualquier manera de hacer valer sus intereses sin acudir a la justicia. Su pobreza le impide destinar ningún recurso a los costosos pleitos. La precariedad de su iglesia y la falta de casa concejil, pese a que se abulten los términos para así ganar más fácilmente el favor real, manifiestan la difícil tesitura en que se encuentran en estos años ${ }^{796}$. No obstante, en la escritura referida, el concejo de San Martín concede al de La Seca el aprovechamiento de un amplio sector del prado de Abajo, al tiempo que se acotan los límites para evitar el paso y el roce del ganado ${ }^{797}$.

El concierto precisa que los pastizales serán únicamente aprovechados por los ganados de labranza, mulares, caballares, bueyes y cabalgaduras mayores y menores, tanto de día como de noche y durante los meses de junio, julio, agosto y septiembre. Transcurridos estos cuatro meses, el concejo de San Martín podrá aprovechar o arrendar dicho acotamiento, dada la especificidad del ganado con derecho a pasto y se insiste en la prohibición de la entrada de ganados ovejunos y cabríos, dado

teniendo como tiene el dicho concejo por suyos propios dos prados que se yntitulan Prado de Arriba y el de Avaxo, y estando en posesión de arrendarlos de ybernia de más de diez, veinte, treinta, quarenta, ziento y mas años ynmemorialmente, que memoria de hombre no ay en contrario, y estando en quieta y pazífica posesión, abra treinta años poco más o menos que el concejo y vezinos de la villa de La Seca, con siniestra relación, ganaron provisión de los señores del Consejo Real de Castilla para poder meter su ganado de labor en el dicho prado a Arriba, y viendo que este concejo yba a la defensa delta, entre las dos villas yzieron, abra los dichos treinta años, poco más o menos, scriptura de compromiso y conzierto por excusar pleitos y las costas y gastos que en ellos a las dichas villas se podian orixinar...”.A.R.Ch.V., P.C. Quevedo (D), caja 442-2.

795 "Don Carlos por la gracia de Dios, rey de Castilla, de Loen, de Aragón, de las dos Sycilias, de Gerusalén...etc, por quanto por parte de vos, el concexo, xusticia y regimiento de la villa de San Martín del Monte se nos yzo relazión que la fabrica de la Yglesia desa dicha villa muy antigua por cuya causa las paredes y texados amenazan ruyna por estar descubiertos con que el sagrario estava con mucha yndefensión y los vezinos entravan a oir misa con riesgo evidente y a lo referido se añadia la falta de ornamentos que tenía y para remediarlo todo no tenía renta ni fábrica alguna dicha villa propios por tener solo siete Bezinos y muy pobres y asimismo no tenía casa de concexo y le azían en el portal de dicha Yglesia con notoria incomodidad y esa dicha villa tenía un prado cuya mitad llamavan de avaxocon el qual los dichos becinos tenían pastos bastantes para sus ganados como todo constava de la ynformazión de que fagan presentazión para cuyo remedio nos pidió y suplicó mandásemos conzeder a esa dicha villa lizenzia y facultad para poder arendar la mitad de dicho prado que llaman de Arriba para que con lo que procediese del dicho arrendamiento se reparase la dicha Yglesia y se fabricase la casa de ayuntamiento..

Os damos lizencia y facultad para que sin incurrir en pena alguna siendo propio de esa dicha villa el dicho prado que llaman de Arriba y no teniendo en el parte ni aprovechamiento otro alguno concexo o persona particular por tiempo de quatro años primeros siguientes... podáis arendar la yerva de la mitad de dicho prado a las personas que mas diere por ella... de lo qual mandamos dar y damos esta nuestra carta senada con nuestro sello y librada por los del nuestro consejo en la villa de madrid a beynte y siete días del mes de julio de mil seiszientos y setenta y quatro...". (Ibídem. Autos para pleitos entre La Seca y San Martín. Fol. 17 y ss.).

${ }^{796}$ A.R.Ch.V. PL. C. Quevedo (D), caja 442.2, fol. 8.

${ }^{797}$ Es por ello por lo que, para evitar litigios y para que los prados, las vacas y sus ganancias no fueran a parar a manos de procuradores y de la Real Chancillería, se firma una escritura de concierto entre ambas partes, el 8 de octubre de 1674, que ponía fin a las desavenencias y regulaba el pasto en los prados de Arriba y de Abajo, sitos en el lugar estudiado, aunque el procurador olmedano, habiendo excluido el prado objeto de arrendamiento por licencia real, concedía a La Seca el derecho a disfrute del resto. (Ibídem). 
"el daño que hazen al pasto del ganado de labranza y deverse mirar el útil más común y que mas combiene..." "\$98. De hecho, La Seca meterá masivamente sus rebaños, encendiendo los ánimos de los vecinos de San Martín que solicitan amparo a la Real Chancillería. Manifiestan en 1702 sentir unas pérdidas de 2.000 reales por los dańos continuados de los ganados de La Seca que “...se nos an seguido y a este concejo aver comido y estar comiendo y rozando en dicho prado con más de trescientas cavezas de ganados mular, cavallar y vacuno y más de dos mil cavezas de ganado obexuno, todo ello con ánimo de destruirnos y por el odio y mala voluntad que nos tienen, considerándonos yndefensos por pobres y de poco caudal... " "99. Era el enésimo conflicto entre villas por defender el sustento de hombres y animales.

La lucha por la supervivencia y la escasa capacidad para generar excedentes es la principal preocupación y conclusión a que se llega tras el análisis de estas pequeñas comunidades agrarias del norte de la Tierra de Medina. Es verdad que se asiste a un crecimiento y ocupación del espacio de forma muy intensa en el siglo XVI y XVII, que genera un aumento de población y de terrazgo cultivado, pero el desahogo económico de las masas campesinas es mínimo. La proliferación de mayorazgos nobiliarios, las numerosas cargas tributarias de un Estado "imperial", pero en bancarrota, las rentas anuales que debían pagar por el cultivo de tierras ajenas, etc., etc., se llevan buena parte de los ingresos netos de las cosechas del cereal y de las ventas de un vino que parece ser la tabla de salvación en estos espacios de mediocres suelos. La situación crítica por la que pasan los hombres y ganados de Serrada, La Seca, Rueda o Matapozuelos, por citar algunos de los lugares más importantes reseńados, genera no poca tensión entre los concejos locales de cada uno de ellos, más, si cabe, cuanto que las unidades jurídicas que los regularon a todos durante varios siglos se desintegran conforme lo hacía el propio estado universalista de los Austrias. La centenaria Moya, como otras pequeńas aldeas de su entorno, no resiste tantos y tan serios embates. Sucumben. Sus términos y hombres pasan a las mejor posicionadas.

\section{Una sociedad estamental con una presencia nobiliaria y religiosa muy importante en el espacio agrario}

La estructura de la propiedad y la evolución histórica pone de manifiesto la gran desigualdad socioeconómica existente en el mundo agrario. Serrada, La Moya y San Martín del Monte, con sus singularidades, pueden servir de ejemplo de tantas otras comunidades castellanas donde el poder de la nobleza, la influencia de la iglesia y la debilidad del tercer estado caracterizan a las sociedades de este tiempo.

${ }^{798} \mathrm{El}$ acuerdo firmado vela por la guarda de lo escriturado, obligando al concejo de San Martín a la puesta de un guarda sin que La Seca contribuya en cantidad alguna al pago de sus haberes. Este penará, si es de día, con un real a cada res que no respete lo acordado, y dos si fuera de noche, sean sus dueńos de una u otra villa. Pero la escritura nace entre la oscuridad y la falta de consenso por parte lasecana. La sentencia del alcalde de la Mesta hace que este pueblo pastoree con rebaños mayores y menores junto a "los demás de la abadía de Medina", tanto lo acotado como lo exento del concierto. Según refiere Diego Alonso, en nombre del concejo de La Seca, dichos pastos también habían sido rozados por ganados de La Seca desde tiempo inmemorial. Manifiesta que San Martín no tiene licencia para su coteo y adehesamiento y, si la Real Provisión de 20 de junio de 1674 concedió facultad para poder hacerlo al concejo de San Martín en la mitad del prado de Arriba por espacio de cuatro años, ellos mismos reconocían que dicho pasto era común de todos. Por si fuera poco, denuncia que la escritura de 8 de octubre de 1674 no es suficiente para atribuirse tal derecho y más cuanto sólo fue firmada por "tres vezinos y algunos ofiziales sin aver tenido poder para ello" amén de no haber "estado en uso ni observancia pues sin embargo mis partesh an continuado en su posesión de pastar con sus ganados en dichos prados sin limitación de numero de tiempo ni lugar".

799 De hecho, y para no extenderse en demasía, el auto de justicia que dicta el 2 de diciembre de 1702 la Real Audiencia de Valladolid limita a La Seca su derecho de pasto sobre el espacio acotado en la concordia realizada entre estas villas en 1674. Cuarenta años después de los pleitos tratados, encontramos una denuncia hecha por el concejo de San Martín del Monte sobre los procedimientos realizados por la justicia de La Seca contra su alcalde mayor. Al parecer, la parte de San Martín niega los maltratos infringidos a un vecino de La Seca que se encontraba pastoreando con sus bueyes en el prado de la Fuente de la Miel. (A.R.Ch.V. Pl. C. Pérez Alonso (OLV), caja 127.14). 


\section{a. El estamento nobiliario: el ejemplo del marqués de Torreblanca}

Serrada, como sus villas vecinas, no escapa a las consideraciones generales que rigen los destinos de tantos pueblos castellanos. Poco se puede ańadir a lo dicho sobre el seńor que ostenta su jurisdicción. La mayor parte del terrazgo permanecía adscrito a su mayorazgo. A comienzos del siglo XVIII el hijo del comprador del Privilegio, Luís de Montalvo Quadra y Avellaneda, contrae matrimonio con Feliciana de Olmos Girón, segunda marquesa de Torreblanca y une dos importantes linajes nobiliarios: los Montalvo y los Torreblanca ${ }^{800}$. Sin embargo, el espacio analizado no es nada singular en el contexto comarcal. El señorío nobiliario extiende su influencia por buena parte del mismo y llena sus arcas con las rentas que generan sus propiedades. En lo que respecta al marqués de Torreblanca, a mediados del siglo XVIII es propietario en esta villa de 559,5 obradas de tierras de pan llevar, 40 aranzadas de vińedo y tres obradas de prado, además de su casa palacio, con sus correspondientes caballerizas, paneras, corrales, bodega y lagar ${ }^{801}$ :

El poder e influencia de la nobleza permanece inmutable a lo largo de los siglos, desde el año 1506 en que Diego Ruiz fundara el mayorazgo. Rentas y cargas que sumados a otros gravámenes continúan asfixiando las precarias economías de sus renteros que, inexorablemente, desde mediados de agosto, acarrean centenares de fanegas de trigo o pan mediado, a las paneras de la casa palacio de su seńor ${ }^{802}$ :

"Una casa que llaman el Palacio, situada calle que va de la Seca a Valladolid, con vivienda alta y baja, caballerizas, pajares, corral y bodega onda, propia de dicho marqués. Tiene de frente sesenta y dos varas y de fondo veinte y quatro. Se reguló su alquiler en ochenta y ocho reales de vellón al año. Confronta con la iglesia de esta villa y Plaza de ella".

La presencia de la nobleza en sus propiedades, sin embargo, es ocasional en los siglos modernos y completamente absentista posteriormente. Tan sólo se tiene constancia, según reza el libro de bautizados de la parroquia, del bautismo de Francisco de Montalvo y Oviedo, hijo de Diego de Montalvo y Bernarda de Oviedo, en el año $1646^{803}$. La vida cercana a la corte la aleja definitivamente de sus inmensas posesiones, repartidas por la vieja Castilla. Conforme transcurren los siglos, la casa es más centro de administración de rentas que residencia ocasional, aunque sus propietarios tampoco descuidan las reparaciones necesarias en techumbres, lagares y bodegas ${ }^{804}$. De hecho, basta comprobar, en la imagen adjunta, el lateral de dicha casa palacio como prueba de los distintos alzados y usos a lo largo del tiempo.

${ }^{800}$ Su hijo Alejo Manuel de Montalvo, amén de noveno señor de Serrada, será también III marqués de Torreblanca. Es, desde esta época, cuando a los señores de esta villa comienzan a titularse con esta distinción y sus bienes del mayorazgo a llamarse, en palabras del vecindario, "las tierras del marqués". Por si fuera poca su alcurnia, al sucesor de Alejo Manuel de Montalvo, José Nicolás de Montalvo, como nieto en línea directa de Antonio Rodríguez de Eván, le correspondieron los bienes y el título del marquesado de Falces en 1809, por ser el noveno nieto de Alonso Carrillo de Peralta. (ÁLVAREZ MARTÍN, M.: Personajes en Tierras de Medina, Diputación de Valladolid, pág. 73 y ss. y BLANCO, A.: Esplandián Amadis, 500 años. Diputación de Valladolid, 1998).

${ }^{801}$ Como se estudió al analizar la estructura de la propiedad, el marqués de Torreblanca posee el 30,48\% del total de tierras labradas de Serrada y esta participación, de por sí importante, asciende enormemente en lo referente a las tierras de sembradura de primera calidad. La familia nobiliaria tampoco debe preocuparse por encontrar renteros. Pequeños propietarios y medianos labradores necesitan tierras y trigo para su propio alimento o cebada y algarrobas para sus caballerías. Algunas de sus piezas destacan por sus dimensiones y calidad: "Otra tierra, al pago de la Vega. Dista de la poblazión setezientos pasos. Poseída por dicho marqués. Consiste en ziento treinta y zinco obradas y media. Confronta a Lebante con el camino que va desta villa a Valdestillas; a Poniente con el prado del Pradejón, a Norte con el prado que llaman de la Estacada, y al Sur con el sendero que ba de esta villa al pago del Lobo. Son ziento de primera calidad y las restantes de segunda del término de su espezie, y su figura al margen”. (A.H.P.V. Catastro de Ensenada. Respuestas Particulares, caja 278).

${ }^{802}$ Ibídem.

${ }^{803}$ A comienzos del siglo XVIII se lleva a cabo la supresión de un altar en la iglesia, para acomodar un sitio de honor al señor de la villa, por lo que también se le supone, si no residente, asiduo al templo en sus vistas ocasionales. 
Junto al señor de la villa, en este siglo XVIII, ha de hacerse constar a Manuel Joaquín de Vega, vecino de Tordesillas y sucesor en los derechos del mayorazgo que se extiende por La Moya y que abarca quinientas obradas ${ }^{805}$. En el mismo lugar poblado dispone, igualmente, de casa de administración y residencia que, como el resto del lugar, acaba fundiéndose con la tierra con el transcurrir del tiempo. La concesión a censo de la mayor parte del terrazgo, tras el despoblamiento de la Moya, tampoco contribuye a mantener estas edificaciones, tanto más cuanto que la propia familia nobiliaria justifica, siglo tras siglo, la venta de parte de sus posesiones para reparar y sostener sus casas principales de Tordesillas, lugar de residencia en estos siglos.

A diferencia de Rueda, La Nava o La Seca, donde nos consta una notable presencia de pequeña nobleza, en Serrada o en San Martín su número fue más bien escaso. Los distintos censos al efecto así lo atestiguan. En el que se ejecuta en el año 1590, por ejemplo, tan sólo refiere en Serrada a tres hidalgos frente a treinta y seis pecheros. San Martín del Monte, por su parte y en dicha fecha, suma quince vecinos de los que doce son pecheros, dos hidalgos y un clérigo. En La Seca y Matapozuelos, por el contrario, siempre destacaron por la numerosa presencia de familias hijosdalgo aunque conviene apuntar, para evitar equívocos, que muchos de ellos, a pesar de su sangre y raíces, tienen que coger la podadera si no quieren sucumbir de necesidad. En el citado año de 1590 en La Seca fijan su vecindad

${ }^{804}$ A una antigua e inicial edificación, reseñada en documentos del siglo XVI como propia del mayorazgo de los Montalvo, se sucede la gran casona, con paneras, bodega y lagar, que ocupa la práctica totalidad de la manzana que se extiende entre la iglesia, la plaza de la villa y la calle Real, limitando al norte con la casa y lagar hoy llamado lagar del obispo. Su fachada y entrada principal se situaba enfrente del lugar que ocupaban las casas del concejo, espacio que hoy ocupa el actual Ayuntamiento. Los labradores de Serrada han llevado a sus dependencias las rentas durante siglos. Como puede observarse en páginas siguientes, su estructura suma una larga evolución constructiva y distintos usos a lo largo del tiempo. Así, por ejemplo, en 1774, aprovechando la presencia de Bernabé Rodríguez en la edificación de la iglesia, se acometen profundas obras de reparación y ampliación. En lo que respecta al lagar y bodega se precisa de forma exacta dónde y cómo se deben de hacer cimientos, paredes y arcos: "Primera. Condición es que se aya de desmontar todo el lagar con el mayor cuidado que sea posible, poniendo todos los materiales adonde no se echen a perder por tener que serbir, asi texa como todo lo demás que legítimamente serbiere. Yten. Es condición que desmontado y aclarado que sea, se tiraran sus líneas paralelas para abrir los cimientos del lagar y estos serán por los mismos cimientos que oi tiene, de tres pies de anchos y de profundidad asta encontrar la tierra firme, y se mazizaran de cal y cantos pelaos de los de este término ata el superficie de la tierra vien apisonado. Yten. Es condición que antes de mazizar dichos cimientos se aian de azer tres arcos de ladrillos y cal de buena mezcla en la bodega en esta forma: el uno en la frente y testero de dicha bodega y en linea de la pared del septentrión, de tres pies de grueso y bien fortificado contra la tierra que sirve de capa a dicha bodega, por tener que cargar enfrente las paredes de lagar y panera; y otro en el terzio de la bodega; y otro a la subida de la escalera a dicha bodega y en linea con la pared del mediodía y anbos de la misma fábrica y fortificación que el antecedente".

La traza de las edificaciones se lleva a cabo de forma precisa, teniendo muy en cuenta las cargas superiores y la localización y grosor de cimientos y muros. La que detalla esta escritura ha estado en pie hasta hace unas décadas. Sobre una parte de la misma se edificó hace décadas el almacén de "Ibérica de Patatas, SA" y, sobre la casa palacio propiamente dicha, el grupo de viviendas que cierran por la parte norte la plaza de la villa. Estas fueron las condiciones de fábrica en aquel tiempo: "Yten. Es condición que en la armadura de la casa se an de poner dos carreras que cojan toda la armadura al terzio de las andabigas y estas con sus entrantes metidos a cabeza de perro, con pies derechos en los mazizos de la casa, y se aran dos dibisiones en todo el ancho de la casa para dexar quatro piezas las que se tabicaran de yeso y adobes. Yten. Es condición que a de poner las anda bigas que estén podridas nuebas como todos los sobradeles y texas que faltasen, aziendo dos guardillas en cada lado, y tegar toda la casa de nuevo, y poner en cada cuarto su postigo con fijas y picaportes. Yten. Es condición que todos los materiales an de ser de quenta del Maestro como también todos los despoxos de dicha obra aian de ser para su aprovechamiento”.(A.H.P.V. Pt. 8220, fol. 444 y ss.).

${ }^{805}$ En estos años, una vez apartadas muchas de ellas a censo entre distintos cultivadores, aún labra, o posee de forma directa, 117,5 obradas de tierra de sembradura en el Despoblado. Junto con la Universidad de la Tierra de Olmedo (385 obradas) y el Convento de San Pablo (13,5 obradas de sembradura y 158,5 aranzadas de vińa), se constituye como el tercer poseedor del término. Destacan, por su tamaño, las piezas localizadas en los pagos de Barco Moya, a cuarenta pasos del despoblado y de cabida de 50 obradas; otra, de quince obradas en Cuesta Redonda; treinta en el Monte Moya, etc. He aquí la referencia a una de ellas: "Una tierra al pago del Barco. Dista del Despoblado quarenta pasos. Poseída por el referido Don Manuel Joachín de Vega, natural de la Villa de Tordesillas y Corregidor de la de Medina del Campo. Consiste en cinquenta obradas. Confronta a Lebante con el camino que ba de Serrada al Puente de Baldestillas; a Poniente con tierra del Monte de la Moia, al Norte con tierra de Thomas de Íscar y al Sur con el camino que ba de Matapozuelos a Villanueba de Duero. Son de segunda calidad veinticinco obradas y las restantes de la terzera del término de su espezie, y su figura la del margen.”. 
hasta cuarenta hidalgos de un total de 426 vecinos; en Matapozuelos, por su parte, los hidalgos son 46 de un total de 267 vecinos. Pero estos dos casos eran excepciones en la mayor parte de las pequeńas poblaciones campesinas del entorno. El Censo de Floridablanca de 1787 otorga a Serrada 842 habitantes de los que ocho son hidalgos, 39 labradores y 105 jornaleros, entre otras ocupaciones.

De estas poblaciones cercanas proceden ramas familiares que acaban por consolidarse en la villa que estudiamos. Uno de los casos más significativos es el de los Moyano. Proveniente de La Seca, Francisco Moyano accede a la escribanía de Serrada en 1739, siguiéndole en el cargo su hijo Miguel Moyano, dando lugar a una prolífica saga que, amén de importantísimas haciendas, ocupan altos cargos administrativos y eclesiásticos en la vida española de los siglos XVIII y XIX. En las imágenes adjuntas pueden observarse sus armas y distinciones ${ }^{806}$.

Para este estamento ostentar hidalguía y limpieza de sangre era condición sine qua non para su acceso a cargos públicos. La solicitud de confirmación de título es una necesidad para cada familia cuando, por circunstancias diversas, han de trasladarse de un lugar a otro ${ }^{807}$.
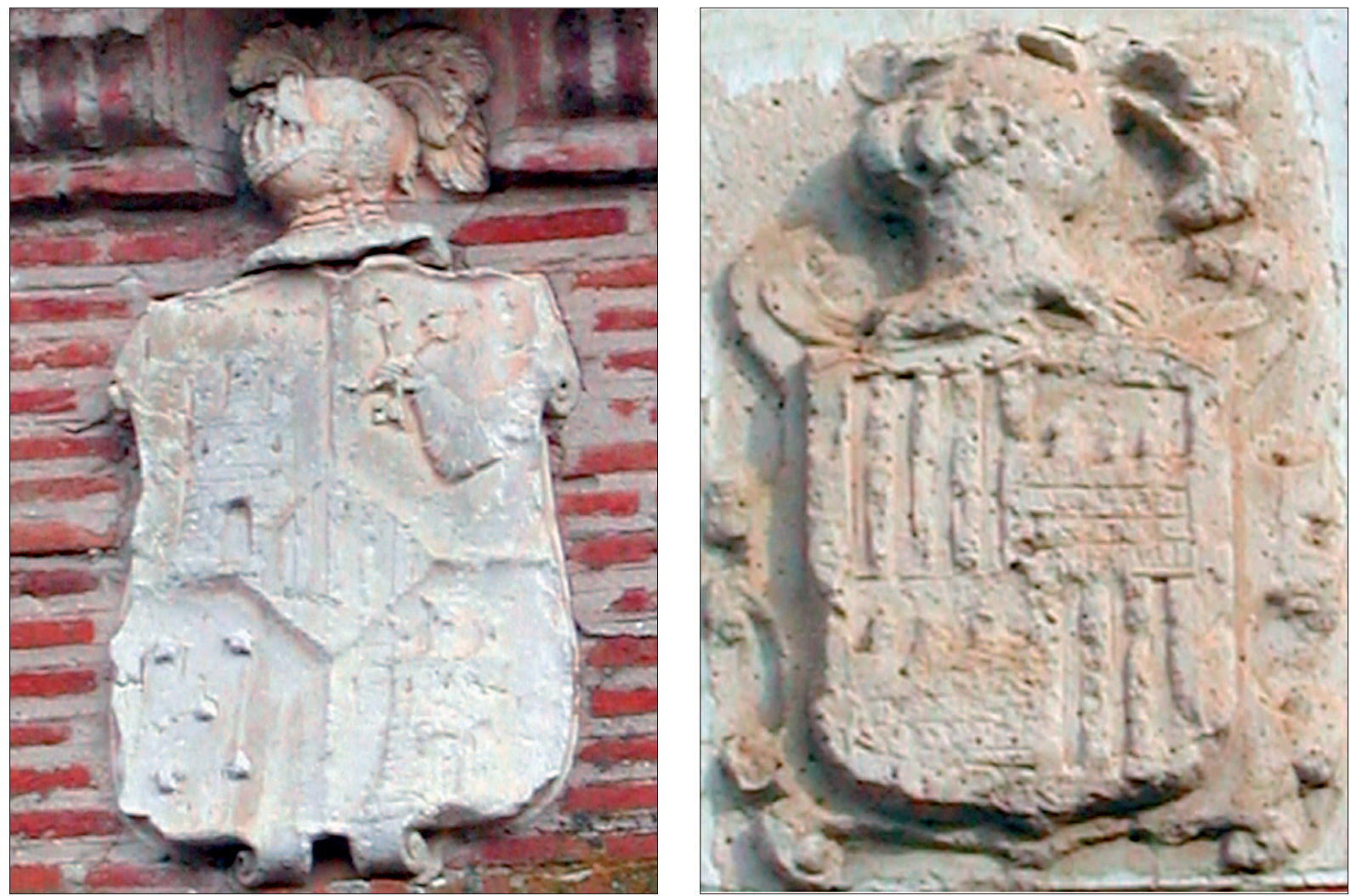

Imagen 66. Escudos de armas de la familia de los Moyano, Serrada. El primer escudo que reproducimos, sito en la calle Antonio Medina, $\mathrm{n}^{\mathrm{o}} 4$, es cuartelado: $1^{\circ} \mathrm{y} 4^{\circ}$, con un castillo donjonado de tres torres; $2^{\circ}$ una mano naciente que porta dos llaves y en el $3^{\circ}$ cinco luceros colocados en sotuer. En el centro figura una pieza con forma de rombo cargada con tres barras. En el segundo escudo, situado en el no 11 de dicha calle, figura en el primer y cuarto cuartel tres barras; en el segundo y tercero un castillo donjonado de tres torres. Ambos escudos tienen coincidencia en las armas en los cuarteles segunda y cuarta y el escusón del escudo de los Moyano.

${ }^{806}$ FERNÁNDEZ FUENTES, R.S.M.: Catálogo Heráldico de la provincia de Valladolid. Diputación de Valladolid, 2013, pág. 288.

${ }^{807}$ En el privilegio de hidalguía, que se otorga en 1778 al citado Miguel Moyano, puede leerse: "Don Carlos, rey de Castilla, etc., por quanto por parte de vos, D. Miguel Moyano, vezino de la villa de Serrada, obispado de Valladolid, me ha sido hecha relación sois descendiente legitimo de la antiquisima familia de los Moyano, de la rama radicada en La Seca... Que sois hijo lexítimo de Francisco Moyano, nieto de Josef Moyano, segundo nieto de Juan Moyano..., que por las memorias que resultan se halla averiguado que la rama de los Moyano radicada en la insinuada villa gozó del estado de Hijosdalgo, así como 


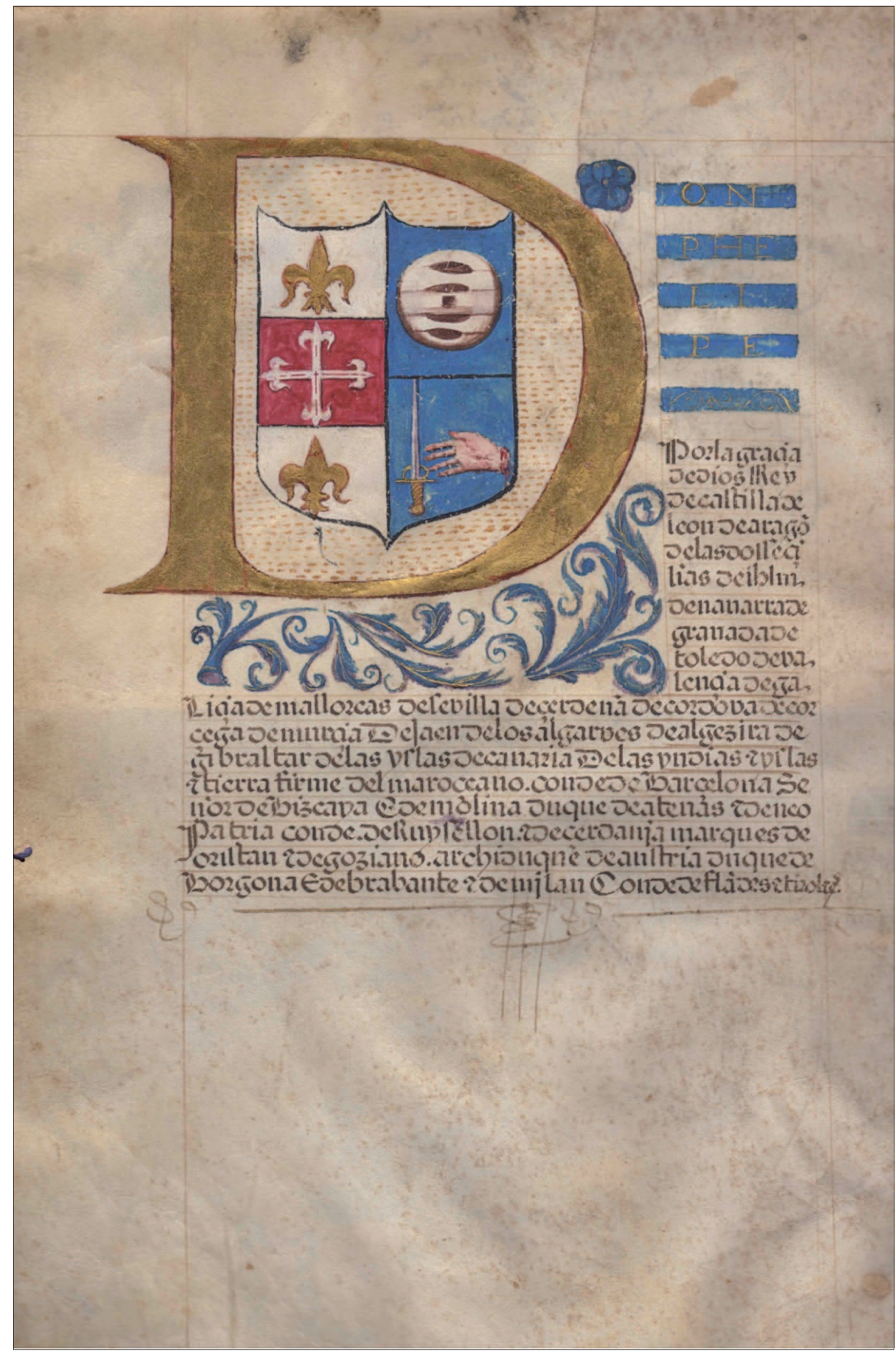

Imagen 67. Título de hidalguía de Juan Obregón, año 1560. (Archivo familia Moyano Rojo, Serrada). 

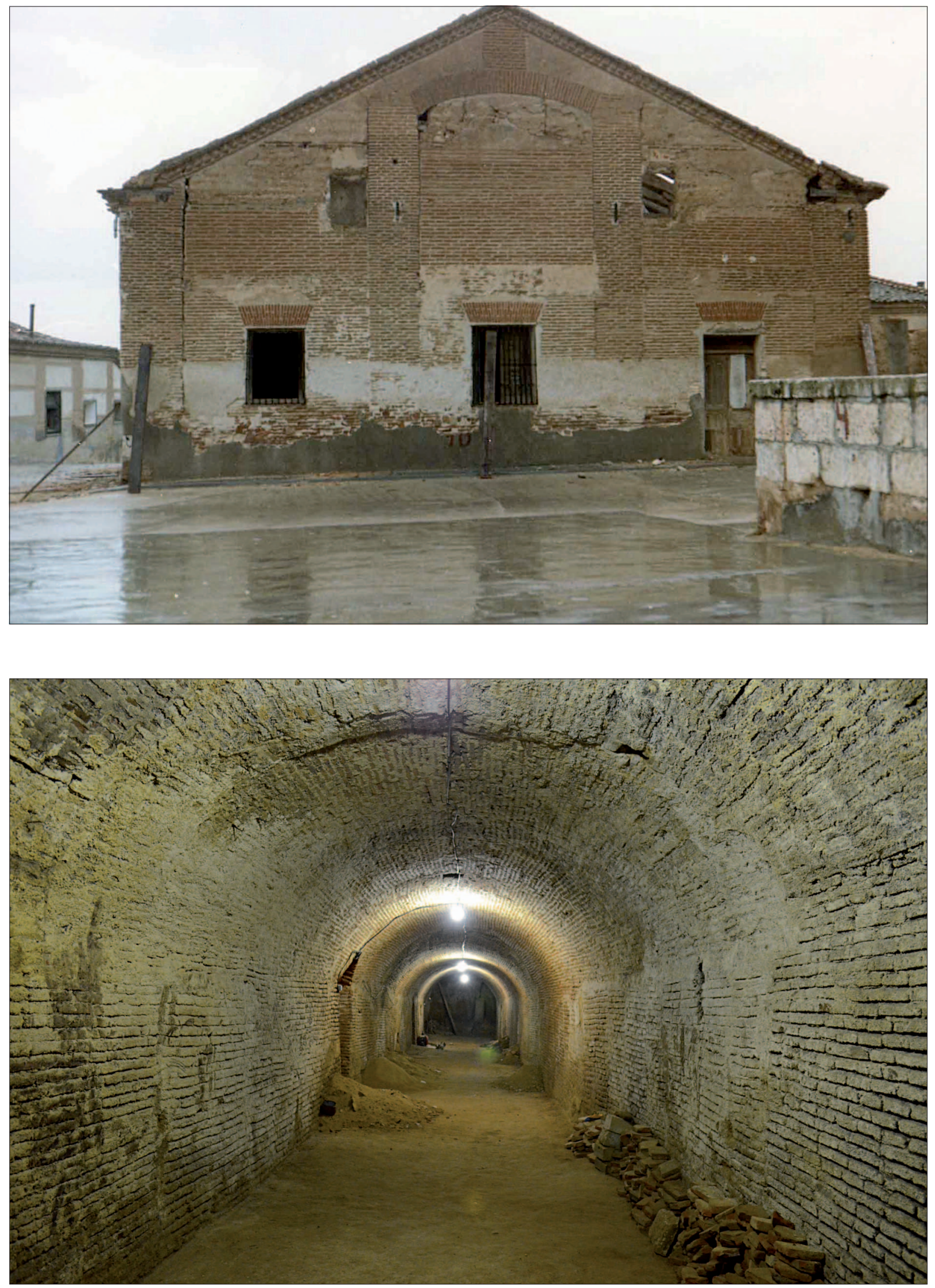

Imagen 68. Fachada y bodega de la casa palacio de la familia Montalvo, en Serrada. Arriba, vista lateral (foto: Archivo familia Román Román, 02/01/1983, año de su demolición); abajo, cañón de la bodega más antigua, situada bajo el lagar adjunto al palacio, hoy denominado Lagar del Obispo, tras su compra por la familia del obispo Moyano. Foto: 15/09/2014. La traza y solidez arquitectónica testifica el poder económico de esta familia nobiliaria que, desde la compra del lugar a fines del siglo XV, también apuesta por la crianza de los vinos a gran escala, dadas las dimensiones de la monumental bodega que reproducimos. 
Aunque la hidalguía era el escalón más bajo de la jerarquía nobiliaria, su condición exime a sus poseedores de cargas y tributos propios de los pecheros, además de la preferencia en detentar cargos y distinciones públicas. No en vano, en 1786, Cenón y José Díaz del Castillo y José Obregón, vecinos de Serrada, presentan sus quejas y litigan contra el señor de la villa, en relación a la falta de nombramiento, por parte del marqués, en los cargos de regidurías locales a que tienen preferencia por ser nobles ${ }^{808}$. En este sentido, la reproducción de la carta de hidalguía otorgada a Juan Obregón en 1560 nos acerca a esta otra familia de hijosdalgos locales, siempre presentes en los concejos y con autoridad en lo tocante la organización de la villa ${ }^{809}$.

\section{b. La importancia del estamento clerical. El elevado número de casas conventuales en Serrada}

La extraordinaria importancia de la iglesia en la Edad Moderna ha sido ampliamente estudiada ${ }^{810}$. Ha llamado la atención, sin embargo, la presencia tan abrumadora que tiene en Serrada y que sobresale entre el resto de los pueblos al norte de Medina. Se gesta desde finales del siglo XVI, incrementa su patrimonio en la segunda mitad del XVII y se consolida enormemente en la centuria del ochocientos ${ }^{811 / 812}$. La fundación entre 1601 y 1609 en Valladolid del convento de los Clérigos Menores, el levantamiento del convento de Premostratenses en 1628 y la construcción del de Las Brígidas entre 1643 y 1647, explica el interés y titularidad de las abundantes tierras y viñas cercanas

lo gozaron los otros en los expresados pueblos, pues resulta que el Don Miguel Moyano, que floreció durante todo el siglo diez y seis, obtuvo la Gracia para recibir el Hábito de San Juan, dejando escrito en la lápida de su sepulcro el mismo escudo y Blasón que hoy permanece con la inscripción latina ex Moyanorum Viteri familia natus... Que vuestros abuelos y demás parientes por el dicho apellido han casado y están enlazados con personas nobles y que gozaron hidalguía en la nominada villa de La Seca y fueron labradores hacendados...”. A.H.N. Consejos. Hidalguías, legs. 8963 (nº 23) y 4582 (nº 123).

${ }^{808}$ A.H.P.V. Pt. 8223, fol. 386, año 1786.

${ }^{809}$ Se trata de Juan González Obregón, abuelo del que obtuvo la ejecutoria: "Estuvo casado, y murió en Guadalcanal, con Maria García; éstos obtuvieron executoria en Ciudad Real, antes de mudarse la Chancillería de Granada; tuvieron de hijo a Francisco Obregón, quien casó en la ciudad de Segovia con María Espinosa, en tiempos que estuvo la Corte en dicha ciudad; tuvo tres hijos, y entre ellos a Juan Obregón, que casó en Pozal de Gallinas, tierra de Medina, quien obtuvo la ejecutoria citada el año referido de 1560. Litigada en la Chancillería de Valladolid en contradictorio juicio con el Fiscal de S. M. y el concejo, en el año de 1570 por Diego Obregón se pidió posesión de tal noble en la villa de La Seca, donde se le admitió sin contradizión alguna, y hoy la tiene en su poder y posesión el tal Josef Obregón, hijo que quedó de Don Justo Obregón, quien casó en esta villa de Serrada y estuvo en posesión de Hijosdalgo hasta su fallecimiento, y lo está el citado D. Josef, su hijo". (A.F.M.R. s/c.).

${ }^{810}$ Hay que recordar que el poder e influencia de la iglesia ha ido parejo con la propia consolidación de las estructuras feudales desde los remotos tiempos del Bajo Imperio. Con el resurgir urbano bajomedieval, adaptará sus estructuras e instituciones a la nueva realidad de las ciudades, sea a través de órdenes mendicantes, Hospitales, casas conventuales o cabildos catedralicios. Su papel asistencial a pobres, enfermos, niños expósitos, etc., acrecentará el fervor popular de clases altas y bajas, ya que unos y otros se ven reflejados en dicha Institución. Favores reales, donaciones y mandas testamentarias incrementarán sus arcas y bienes, extendiendo su presencia en Valladolid y su provincia desde el siglo XI, e incrementando su patrimonio a través de casas de labranza o heredades que dejarán en arrendamiento en siglos posteriores. Así, a la fundación de la Colegiata de Santa María a fines del siglo XI se sucederán de forma ininterrumpida nuevos establecimientos: Templarios en el siglo XII, Franciscanos y Dominicos en el XIII, Trinitarios y Mercedarios en el XIV... Similar importancia alcanzarán en las cabeceras comarcales. En Tordesillas, entre otras, de la mano del Convento de las Claras desde fechas muy tempranas; En Medina, desde la fundación Colegial de 1480 y que alcanzará en este siglo XVIII una dominadora presencia, como lo rubrica el hecho de que es una de las ciudades espańolas donde el peso de la población eclesiástica es mayor, con porcentajes cercanos al 6\%. E igualmente, por citar los cuatro polos religiosos que rodean e influyen eclesial y jurídicamente sobre estos pagos, la villa de Olmedo, también rebosante de conventos e iglesias, repartidos entre las ocho instituciones conventuales habitadas por casi dos centenares de frailes y monjas en 1752, amen de sacristanes, beneficiados y curas que atendían sus siete parroquias.

${ }^{811}$ RUCQUOI, A.: Valladolid en la Edad Media. Génesis de un poder. Junta de Castilla y León, 1987, pág, 101.

812 VALDEÓN BARUQUE, J., y otros. Olmedo según las Respuestas Generales del Catastro de Ensenada. Colección Alcabala del Viento, n 37, Centro de G. C. y C. T, Ayuntamiento de Olmedo, Tabapress, 1991. 
a sus sedes vallisoletanas y, entre otras muchas localidades, en Serrada y en La Moya. La presencia de otras órdenes regulares, anteriormente pujantes, como el convento de San Pablo o el de la Madre de Dios, no ratifican sino el aumento de la presencia religiosa en siglo XVII al que estos pueblos no son ajenos ${ }^{813}$. Igualmente importante es la presencia del numeroso clero secular. Beneficiados, presbíteros, titulares de capellanías o religiosos con abundantes propiedades en estas villas constatan este aumento de población religiosa, que contribuye negativamente en los saldos demográficos de los distintos lugares, ya de por sí debilitados por las crisis y penurias del siglo XVII. Nadie podía imaginar que, cien años después, este inmenso patrimonio se desmoronaría, mediante leyes que pulverizan sus posesiones, en beneficio de hacendados o burgueses pudientes que anhelan su riqueza, sus casas y sus tierras.

\section{- Una numerosa presencia concretada en notables patrimonios}

A pesar de la contracción general que vive Castilla a lo largo del XVII, lo cierto es que estos términos se encuentran, a mediados de la centuria, en su cénit desde el punto de vista de la ocupación del espacio. La expansión vitícola, alentada en otros tiempos desde el escaparate ferial medinense, traslada hacia estos pagos la supremacía de unos caldos que se han ganado merecidamente el reconocimiento de los mercados. Este impulso no pasa desapercibido al estamento religioso, que ve en la inversión en viñas, panes y bodegas una excelente ocasión para acrecentar sus bienes. De esta manera las órdenes regulares toman posición de la Tierra de Medina, Olmedo o Tordesillas, con numerosas casas granjas conventuales que se dotan de tantos recursos como de influencia en el territorio. En el pleito de 23 de marzo de 1737 entre el convento de Trinitarios Descalzos de Valladolid y el concejo de Serrada, el padre administrador Fr. Joseph de Jesús María, afirma que el dicho convento tiene en Serrada "a más de noventa años..., casa poblada, aperos y labranza para la administración, beneficio y cultivo de la hacienda y viñas que asimismo tiene en los términos de dicha villa...", lo que remonta la presencia de esta casa religiosa al menos a la primera mitad del siglo XVII ${ }^{814}$. Sus saneados recursos son invertidos en compras anuales de aranzadas que requieren más capacidad de cubas y bodegas $^{815}$. En el propio memorial de 1690 que se conserva de esta hacienda de Serrada, se advierte a los futuros religiosos, que velen por la propiedad de todas sus pertenencias, atesoradas con no pocas inversiones y esfuerzos. La primera casa "estaba derrotada y derruida y no tenía más de veinte moyos de cubaje ${ }^{316}$. Los trinitarios amplían la bodega y adquieren nuevas cubas, conforme crecen los majuelos en su haber.

No son los únicos que invierten en la villa, ni Serrada es una excepción. Matapozuelos, La Seca, Villanueva, Tordesillas, la propia Medina... son centros de compras e inversiones. Ya por entonces era difícil rivalizar con el convento de San Pablo, de la orden de Santo Domingo. Como se refirió al estudiar la rentabilidad del viñedo, el 8 de septiembre de 1657 había rubricado ante Gregorio de

${ }^{813}$ GARCÍA SIMÓN, A. (ed.): Historia de una cultura. Junta de Castilla y León, Junta de Castilla y León, Consejería de Cultura y Turismo, 1995.

${ }^{814}$ A.R.Ch.V. Pleitos Civiles. Quevedo (F) 3544.1, año 1737.

${ }^{815}$ Los Trinitarios Descalzos adquieren en 1695 una casa adosada a la conventual para ampliar sus instalaciones. El vendedor es Santiago Hinojal y los términos son los que siguen: "Sépase como yo, Santiago Inojal, vezino de la villa de Serrada, como padre y lexitimo administrador de Santiago Inojal, mi hijo legitimo... Bendemos y damos en venta real... al convento de la Trinidad Descalza de la ciudad de Valladolid... una casilla que tenemos en esta dicha villa de Serrada, en la calle que llaman del pozo bueno, que tiene su portal, cozina, aposento, cavalleriza, corral, con todo lo que perteneciese a dicha casilla. Que linda con la dicha calle y queda como se va a dicho pozo a mano derecha y con casas de herederos de Andrés León y Francisca Sánchez, nuestros padres y suegros difuntos de quien heredamos la dicha casilla, y con casas de dicho convento, con todas sus entradas y salidas... por precio y quantía de doscientas y treinta y nueve reales de vellón...". (A.H.N., Clero, Libro 17898 y A.H.P.V., Pt. 6156).

${ }^{816}$ Ibídem. 
Victoria, escribano público de Matapozuelos, la compra en Serrada de media obrada de terreno. La parte vendedora era Isabel Navarro, viuda de Jerónimo Maestro, ambos vecinos de Serrada ${ }^{817}$. Sobre esta media obrada se levanta la granja conventual dominica que tanto influye en la vida local. La casa-granja en absoluto nace sola. La atracción es igualmente irresistible para Brígidas, Trinitarios Descalzos, Hospital de la Resurrección, Clérigos Menores o el Convento de la Madre de Dios de Valladolid que, amén del numeroso clero secular, caracterizan un siglo de notable presencia religiosa. Todos acaban viniendo, comprando, recibiendo donativos y, en definitiva, asentándose en las estructuras productivas y sociales de la localidad.

Entre ellos, el convento de San Pablo es un referente de primer orden. Su afán comprador es espectacular durante el primer tercio del ochocientos. Desde 1717 hasta 1737 alcanzan sus compras 149 aranzadas en la Moya y 53 obradas de tierra y otras 63 aranzadas de vińas en Serrada. El Catastro de Ensenada de 1752, en que constan con exactitud sus heredades, catastra una hacienda que alcanza las 215 aranzadas de majuelos y 47 obradas de pan llevar. Logran configurar la segunda heredad más importante de Serrada, sólo por detrás de las propiedades del mayorazgo de los Montalvo. En breve tiempo construyen una sólida y espaciosa casa de labranza y excavan en el subsuelo cinco cañones de bodega que llenan de cubas. En el primer tercio del XVIII, fueron añadiendo nuevos espacios a lo ya edificado. El conflicto no tarda en llegar, incluso, con el concejo de Serrada. Este se queja de "que dicho convento pasa a fabricar en los egidos desta villa en mucho perjuizio del común, embarazando los caminos y quitando la comunicación de aires porque, quando lo que an principiado a tapiar junto con la casa y demás anejo a ella fuere en dicho sitio de media obrada, no de mucho más, quando sea dicho si no la media obrada..." "\$18. Aún en 1781 compran un corral lindero a Petra García, "que es lo que corresponde hacia la parte del Norte y camino que de las heras del Calvario va para Pozo Bueno, donde se halla la puerta carretera señalada con el número quarto..." ${ }^{19}$. Sus lagares y bodegas son uno de los principales centros de producción vitícola, no sólo del pueblo, sino de buena parte del espacio comarcal ${ }^{820}$.

${ }^{817}$ La escritura de compra reza: "Ysabel Navarro, viuda de Jerónimo Maestro, vezino deste lugar de Serrada, jurisdizión de la villa de Olmedo, digo que por las quentas y particiones que se hizieron entre mis hijos y el dicho mi marido y entre mi de los vienes que entre los dos quedaron, se me fue adjudicada una tierra que está en el término deste dicho lugar, al camino del Pozo Bueno, que linda con el dicho camino y el camino que Ba desde lugar a la Moya, la qual dicha tierra bendo y doi en venta real a el Convento y Religiosos y quien en su derecho tenga en cualquier manera para que en la dicha tierra y sitio pueda fabricar y fabrique casa y lagares y hazer bodega y azer lo demás que fuese necesario y conveniente a el dicho Convento y por bien tuviere, y se la bendo con todas sus entradas y salidas, usos y costumbres y servidumbres quantas tiene y la pertenecen y pueden pertenecer en cualquier manera por libre de todo género de zenso, hipoteca, aniversario, y de otra cualesquier carga tazita ni espresa que no la tiene, por prezio e quantía de quinientos reales que por dicha tierra y sitio me ha dado y pagado el dicho Convento y en su nombre confieso aver recivido de el padre Frai Francisco de Ayuso, procurador del dicho Conbento... Y la otorgo asi ante el presente escribano en el lugar de Serrada, ocho días del mes de setiembre de mil seiscientos y zinquenta y siete años, siendo testigos el Lcdo Antonio del Cura y veneficiado del dicho lugar y Domingo González y Francisco Juáñez, mozos solteros residentes en él, y la otorgante aqui en lo el escribano doy fe que conozco. No lo firmo por no saber. A su ruego lo firmó un testigo. Antonio del Cura (rubrica). Ante mí. Gregorio de Viitoria (rúbrica)”. (A.H.P.V., Pt. 10633, año 1657, fol. 102).

${ }^{818}$ Pt. 10033. Matapozuelos, Gregorio de Victoria, fol. suelto/fol. 102, año 1657. La petición presentada es recibida bajo la autoridad de Antonio de Neira, alcalde ordinario de Matapozuelos por el estado noble, y lleva fecha de 7 de mayo de 1735 , lo que confirma el pleno funcionamiento por este tiempo de la casa conventual. De hecho, en relación con el conflicto, en el apeo de 1788 se señala que en el solar y corrales de la casa se comprenden también "treinta y ocho varas de terreno de largo y treinta y ocho de ancho que el Conzejo y vezinos de esta villa dio y señalo a dicho convento en doze de maio de mil setecientos treinta y cinco, cuio acuerdo y señalamiento paso por testimonio, digo certificación de Lázaro Gómez, fiel de fechos que fue en esta villa...".

${ }^{819}$ Pt. 8224, fol. 636/37, año 1788. Petra García era mujer de Juan Antonio de Íscar y vivirá un autentico calvario, dada la enfermedad de demencia y locura de su marido, que pasará años de cárcel y desaparecido del pueblo. La desgracia familiar le ocasionará numerosos gastos, hasta obligarla a desprenderse de buena parte del patrimonio. (Pt. 8223, fol. 272/327/355, años 1783/86).

${ }^{820}$ Los dominicos acaban levantando toda una nueva manzana, edificada entre el viejo barrio del Pozo Bueno, el de la iglesia y el mencionado pozo, adjunto a las tierras de labor y a las propiedades concejiles de las Heras del Calvario. Nada mejor que seguir las precisiones del agrimensor para precisar su importancia: "Y apearon por de dicho convento una casa que 
La posesión de la tierra es el termómetro que regula el poder y la influencia social, además de garantizar la subsistencia a las familias campesinas. La venta de tierra siempre es el último recurso ${ }^{821}$. No es difícil imaginar los motivos desencadenantes de estas decisiones: mandas testamentarias, inventarios y reparticiones de bienes obligan en algunos casos a desprenderse de bienes muebles o raíces, tanto más cuanto que algunos de los beneficiarios ya no viven en el lugar o pasan por dificultades económicas; repetidas malas cosechas o pedriscos ponen al borde de la ruina a los sectores propietarios más débiles y la venta de tierra era un mal menor ante la posibilidad de ruina definitiva; la obligada devolución de débitos o censos impagados, por poner ejemplos dispares, se torna en ocasiones tan asfixiante que la venta de tierra sella estas decisiones mal calculadas. Es el caso, ya estudiado, de Pedro de Íscar quien, en 1739, firma un reconocimiento de censo, a favor del convento de la Merced Calzada, por valor de 100 ducados. En la escritura subroga distintos bienes a la hipoteca, reconociendo la pérdida de otros bienes hipotecados anteriormente al citado convento ${ }^{822}$.

Son sólo algunos ejemplos entre los cientos que se han registrado y que ponen de manifiesto la diferencia entre las partes compradoras y los eslabones más débiles de la cadena social. En este Antiguo Régimen todo parece a favor del estamento eclesiástico en detrimento del campesinado. Un

tiene y le pertenece en el casco de esta villa, con sus oficinas altas y vajas, oratorio, paneras, cuadras, paxar, corrales y quatro lagares cada uno con su viga y piedra de exprimir la uba; bodega soterraña con cinco cañones llenos de vastos; que toda la dicha casa, corrales y oficinas zitadas se midió por lo exterior y dixo el agrimensor ocupava trescientos y catorce estadales, la qual linda a el oriente con la cañadilla que va a el Pozo Bueno, y queda a la mano izquierda por cuia parte tiene de ángulo treinta y cinco estadales; a el Mediodía con la calle que vaja de las heras del Calvario a la Cañadilla por cuia parte esta la portada principal que tiene de ángulo cinco estadales; a el poniente linda con la calle que sale a el camino de las Olmas que va desta villa a la Moya y Valdestillas, cuias olmas dizen a el frente como se sale de dicha calle y queda la casa a mano derecha, por cuia parte tiene de ángulo diez y ocho estadales, y en el están parte de la habitación principal de la casa y los quatro lagares ya dichos, los dos de que husa dicho Combento para veneficiar el fruto de sus majuelos que corresponden ha el corral de la citada casa, y los otros dos donde se hecha el diezmo de la cilla comun de esta villa que corresponden a la calle; y al norte linda con el camino quee ba delas Heras del Calvario a el Pozo Bueno y queda a mano derecha por cuia parte tiene de ángulo diez y ocho estadales...”.

${ }^{821}$ Los Protocolos notariales rebosan de ejemplos que ratifican cuanto se apunta. A comienzos del siglo XVIII, son los Padres Trinitarios los que, entre otros, adquieren en Serrada y en La Seca distintas propiedades: Simón Labajo, vecino de La Seca, les vende cuatro aranzadas en "La Coma" a 340 reales la aranzada y Teresa Luengo se desprende de otras dos en el mismo pago con carga de sernas. Los años de 1737 y 1738 son particularmente intensos en cuanto a la adquisición de vińas por parte de eclesiásticos. Don Andrés Rodríguez Zorrilla, clérigo presbítero y beneficiado de Preste de la iglesia parroquial de Serrada, compra tierras labrantías a Andrés Alonso, tres aranzadas a Manuel García y Juliana Alonso en 700 reales y un majuelo nuevo de dos aranzadas y media a Juan de Rojas; Melchor de la Peńa, clérigo presbítero residente en Valladolid, hace lo propio adquiriendo en Las Carretas un majuelo de 303 cepas a Marcos Román y María Inojal, en 462 reales; Joseph Sanz del Río, notario mayor del obispado de Valladolid y escribano de su majestad, participa activamente de estas compras en Serrada al adquirir en este año del 1737 majuelos a Pedro Inojal y Agueda Alonso, a Francisco Inojal y Juliana Alonso, a Tomas de Íscar, etc.

En cuanto a las ordenes regulares, destaca la actividad compradora del convento del Corpus Cristhi, que incrementa sus patrimonio comprando en 1738, entre otros, majuelos a Santiago e Isabel Navarro -dos aranzadas y 88 cepas en 462 reales-, a Ventura Eugenio y Joaquín Alonso -distintas parcelas que suman 1.417 cepas en 2.534 reales-, a Andrés Rodríguez -2,5 aranzadas en 2.104 reales-, a María, viuda de Antonio García, a razón de a real y medio por cepa, etc. No podía faltar, por último, el potente convento de los dominicos. Esta orden de San Pablo compra en 1740 a Martín de Vitoria, de Matapozuelos, una tierra de pan llevar y a Diego Ruiz y Tomas de Íscar, tres obradas en el término del Despoblado de La Moya en 1008 reales. En 1743 le toca vender al referido convento 1.033 estadales en 707 reales a Andrés de Íscar, vecino de Serrada. Compras y ventas, en fin, que reflejan el dinamismo económico a la luz de penurias y abundancias de unos y otros, configurando la desigual estructura de la propiedad que se viene refiriendo en este Antiguo Régimen.

${ }^{822}$ A.H.P.V. Pt. 8215, fol. 20. Año 1739. Las escrituras de hipotecas otorgadas por entidades eclesiásticas a los vecinos de Serrada son una constante. Por citar algunos ejemplos, sirva mencionar la escritura de censo al redimir de 2.200 reales, otorgada por el Colegio de San Ignacio a Gregorio Inojal y María Alonso en 1768 o el concedido en el mismo ańo a Basilio Martín a favor del convento de San Pablo en la cantidad de 4.400 reales. Pt. 8224, Serrada, Francisco Quintero, fol. 1068 y 1090 respectivamente. 
río de reales desemboca cada año en sus arcas y paneras, procedente de rentas, diezmos y una administración eficaz, sin contar las donaciones, ayudas y limosnas que conforman otra buena fuente de ingresos. En otras ocasiones se trata de ayudas directas a familiares religiosos, con el objeto de ayudarles en su carrera eclesiástica ${ }^{823}$. Buena parte de estos bienes acaban ajenos a las manos campesinas, bien formando parte de Capellanías fundabas por dichos clérigos, bien en propiedad de iglesias o entidades conventuales. Se trata de importantísimas cantidades que revierten en manos de la Iglesia, permitiéndole comprar las tierras de quienes, en ocasiones, son sus más fervientes fieles. Se reproduce a este efecto un papel suelto, encontrado en el inventario de bienes de la familia de Bentura Alonso Moyano, viuda de Juan Moyano y fechado en el año $1786^{824}$ :

"Recibí de Manuel Moyano, vezino de la villa de Serrada, tres mil reales de vellón, limosna de mil misas que encargo en este convento de San Pablo de Valladolid por el ánima de su hermano Don Melchor Moyano, (con Dios aya), las quales quedan aplicadas por esta comunidad, y para que conste lo firmo en dicho convento. Febrero, 25 de 1786. Son 3.000 reales, Manuel Antón, depositario. (Rúbrica).”.

Resultado de todo ello es la notable presencia religiosa en esta villa. De acuerdo al Catastro de Ensenada de 1752 catastran bienes rústicos y urbanos en Serrada hasta seis granjas conventuales: el convento de Santa Brígida; el convento de Santo Domingo, orden de San Pablo; el de la Madre de Dios; la Trinidad Descalza; la Casa de Encarnación de los Clérigos Menores y el Hospital General de Valladolid. En el Despoblado de La Moya, además de brígidas, dominicos y trinitarios, poseen tierras y vińas el Colegio de San Gregorio y el Real Monasterio de Aniago. A ello debemos ańadir que el término del poblado de San Martín pertenece al convento de Santa Clara de Tordesillas. Y junto a este abundante clero regular, no se puede olvidar al numeroso clero secular, poseedor de bienes patrimoniales o administradores y beneficiarios de capellanías o fabricas de iglesia que acaparan importantes heredades. Sólo en Serrada constan, en el Libro Maestro de Eclesiásticos, hasta trece titulares de bienes, algunos de ellos con numerosas propiedades. Sea como consecuencia de importantes donaciones, sea por compra directa, el caso es que, en el primer tercio del XVIII, el interés por tomar posiciones en el mundo del vino es incuestionable. La familia Cabo es un claro ejemplo ${ }^{825}$. Regulares y seculares poseen, en los términos de Serrada y La Moya, 271,5 obradas de tierra y 857 aranzadas de majuelos, lo que representa respecto al total labrado, de acuerdo a lo declarado en las Respuestas Particulares, el 17,48\% de las tierras y el 40,19\% de las vińas existentes. A estos datos han de sumarse, dado que en manos de eclesiásticos o nobleza se encuentran, 385 obradas

${ }^{823}$ Es el caso fechado en diciembre de 1710. Bernardo Alonso y su mujer María Alonso donan a su hermano, el licenciado Pedro Alonso, "que al presente se allá clérigo de menores" distintos bienes raíces para que, juntos con los de su patrimonio "fuese sacerdote para que como en estado más perfecto sirba a su divina majestad y aga bien y sufragios por las animas del purgatorio y especialmente por las suias las de sus padres y demás difuntos...”. (A.H.P.V. Pt. 8214, fol. 167, año 1710).

${ }^{824}$ A.H.P.V. Pt. 8224, fol. 737, año 1789.

${ }^{825}$ En el año 1723 Petronila Alegre de Requena y su esposo Alonso de Aguado Serna de la Reguera, regidor perpetuo de Valladolid y caballero de la orden de Alcántara, disponen en su testamento que sus bienes sirvan para la fundación y dotación de una capellanía en la parroquial de San Miguel. Entre los bienes adscritos se hayan "ochenta y tantas aranzadas de viñas, una casa con su lagar, bodega y cubas que están en la villa de Serrada, sus términos y contornos...", que, como se recordará si uno se fija en los apellidos de la fundadora, habían pertenecido con anterioridad al doctor Antonio de Requena, catedrático de Medicina en la Universidad de Valladolid y litigante en 1669 frente Ruiz de Montalvo, seńor de Serrada, por el cobro indebido de réditos censales en dichas vińas. En 1730, Francisco Gil de Reinoso, primer capellán, opta por la venta en remate público de los bienes dotales citados anteriormente, que se adjudican, tras no pocas pujas al alza, en la persona de Manuel Antonio de Cabo Redondo, diputado, en estos años, de los gremios y teatros de Valladolid y hermano de Francisco de Cabo, canónigo de la Santa Catedral y titular unos ańos más tarde de los bienes anteriores y de otros muchos adquiridos en esta primera mitad del XVIII en Serrada y en sus términos vecinos. (A.H.P.V. Pt. 2967 , fol. 121 y ss.). 
que la Universidad de la Tierra de Olmedo posee en el Despoblado de La Moya, y 117,5 obradas propiedad del mencionado Manuel Joaquín de Vega, vecino de Tordesillas y corregidor en Medina, también ubicadas en la mencionada Moya, lo que eleva la posesión de la tierra en manos privilegiadas al $27 \%$ del total labrado de panes y al 42,06\% del total de vides, entre ambos términos de Serrada y La Moya.

A esta propiedad rústica se debe ańadir, como decimos, el nada despreciable patrimonio urbano $^{826}$. Conventos y clérigos seculares son propietarios de once casas -no es necesario apuntar su coincidencia con las de mejor traza arquitectónica-, con sus correspondientes bodegas donde reposa uno de los mayores bienes que se ambiciona por estas fechas: el vino. Entre todas ellas destaca, como ya ha sido puesto de manifiesto, el convento de San Pablo, orden de Santo Domingo, que con 47,75 obradas de tierra y 215,5 aranzadas de vińas en 1752, figura en lugar destacado entre las distintas órdenes regulares asentadas en la villa de Serrada ${ }^{827}$.

Viñedos y tierras que las congregaciones administran directamente tratando de obtener la máxima rentabilidad. No ha de pensarse, en este caso, que la acumulación patrimonial de la Iglesia en esta Edad Moderna permanece inmóvil en lo referente al sector vitivinícola. Como se ha estudiado en el anterior capítulo, los libros de contabilidad que se han conservado denotan un conocimiento preciso de las tareas agrícolas y una preocupación por obtener los máximos beneficios. La prosperidad económica que viven estas órdenes monásticas durante el siglo XVIII está fuera de toda duda ${ }^{828}$.

${ }^{826}$ Estas eran algunas de sus principales casas y propiedades: Combento de Santa Brígida de la ziudad de Valladolid. "Una casa en esta dicha villa en el barrio de la Seca, con vivienda baja, caballeriza, corral, lagar y bodega, propia del referido convento. Tiene de frente catorce varas; de fondo treinta y siete. Se regulo su alquiler en sesenta y seis reales de vellón al año. Confronta con las heras de esta villa y con casas de Andrés Martín, vecino de esta villa. Cubas. En la dicha bodega de la casa antecedente hay quatro cubas y dos cubetos y el uno esta inútil, que hacen sesenta y ocho moios y medio, que regulado el alquiler o renta según practica de esta villa, importa al año doscientos y zinco reales y medio de vellón."

Convento de la Trinidad Descalza de la ciudad de Valladolid: "Una casa situada en esta villa al barrio del Pozo Bueno, con vivienda baja, corral, caballeriza, pajar, lagar y bodega honda, propia de dicho Convento. Tiene de frente diez y nueve varas; de fondo sesenta y una. Se regulo sus alquiler en ochenta y ocho reales de vellón al año. Confronta con casa de Gregorio Diaz y con casa de Cristobal Yánez. Cubas. En la referida bodega de la casa antecedente hay quince cubas, que hacen doszientos y treinta y zinco moios, que regulado el alquiler o renta de cada uno a tres reales de vellón, según practica de esta villa, importa setezientos y zinco reales de vellón."

Convento de San Pablo de la ziudad de Valladolid: "Una casa situada en esta villa al barrio del Pozo Bueno, con vivienda alta y baja, corral, pozo, caballerizas, paneras, quatro lagares y bodega, propia de dicho combento. Tiene de frente veinte y una baras; de fondo ochenta. Se regula su alquiler en ziento y veinte y dos reales de vellón al año. Confronta con el camino que de esta villa ba a Pozo Bueno y con casa de Simón Garcia Baion. Cubas. En la referida bodega de la casa antecedente hay quarenta y dos cubas y seis carrales, que hazen novecientos y siete moios y medio, que regulado el alquiler o renta de cada uno, según practica de esta villa, a tres reales de vellón, importan setezientos y veinte y dos reales de vellón”. El convento de San Pablo se anota en este tiempo seis mulas de labranza, una yegua y una pollina, sin olvidar los 18 cerdos que formaban una regular cabaña porcina para la época. Esta granja conventual y la de la Trinidad Descalza, con otras tres mulas y otra yegua, son las únicas que poseen ganado de labor a mediados del siglo XVIII, lo que no significa que el resto de órdenes regulares no labre sus tierras mediante yuntas arrendadas a labradores o jumentos a jornaleros (A.H.P.V. Catastro de Ensenada. Respuestas Particulares, caja 278).

${ }^{827}$ Le siguen, en orden de importancia, el convento de las Brigidas, con 114,25 aranzadas y el de la Trinidad Descalza, con 65 obradas y 60,5 aranzadas. La Casa de la Encarnación de los Clérigos Menores posee 89,5 aranzadas y el Hospital General 54,5. Algunas piezas de majuelo no son nada despreciables, sobre todo las situadas en el Despoblado de La Moya y pertenecientes al convento de San Pablo, orden de Santo Domingo de la ziudad de Valladolid. "Otra viña, al pago de los Paredones. Dista del Despoblado quatrozientos pasos. Poseida por dicho Convento. Consiste en quarenta y cinco aranzadas. Confronta a Lebante con el camino que ba de Matapozuelos a la Moia; a Poniente con tierra de Don Francisco Cabo; al Norte con el camino Real de las Carretas, y al Sur con viña de Don Francisco Cabo. Es de la primera calidad del término de su especie, y su figura la del margen."

${ }^{828}$ MARTÍNEZ RUIZ, E. (dir.): El peso de la Iglesia. Cuatro siglos de Órdenes Religiosas en España. Madrid, 2004, pág. 334. 


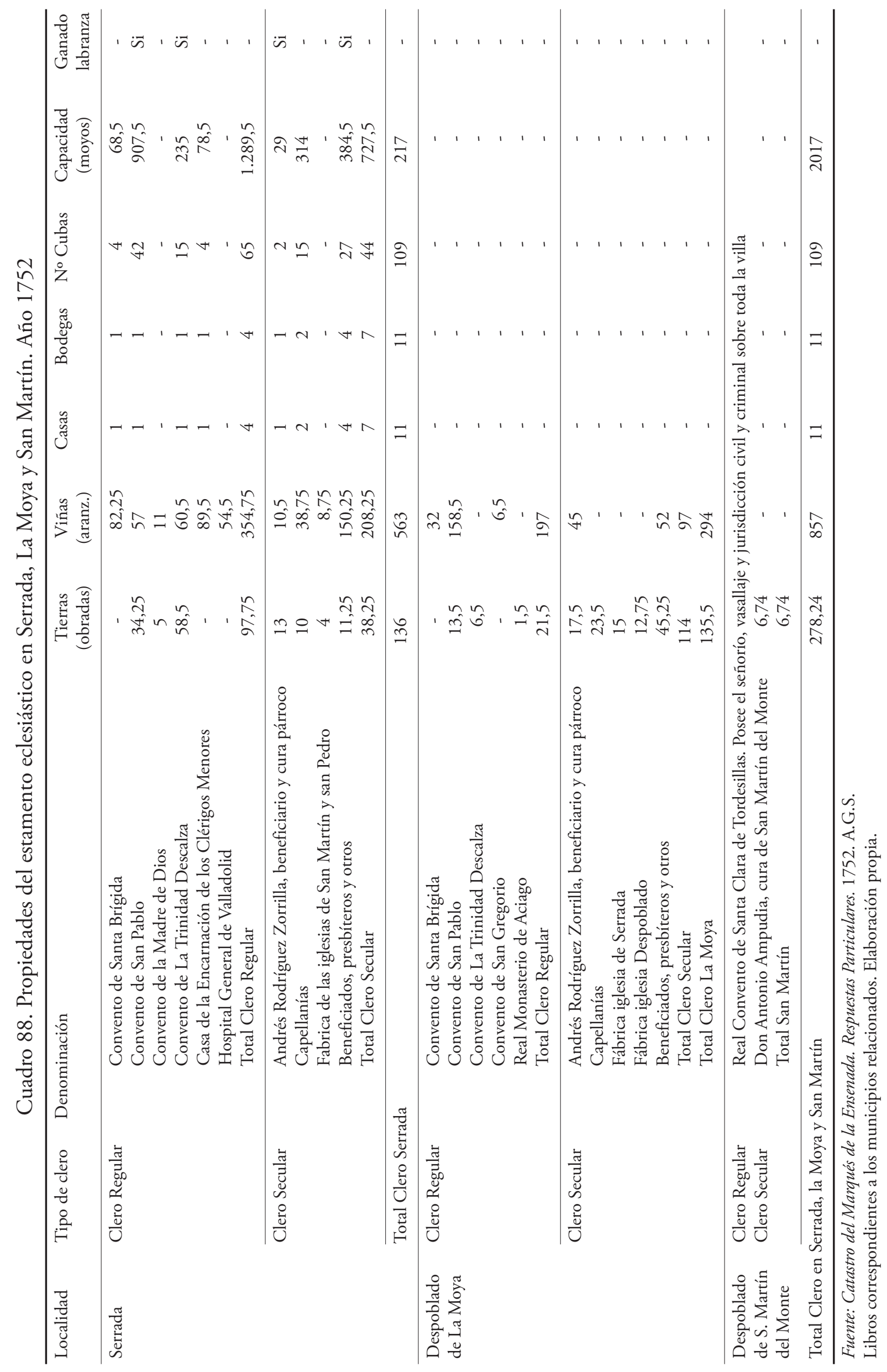




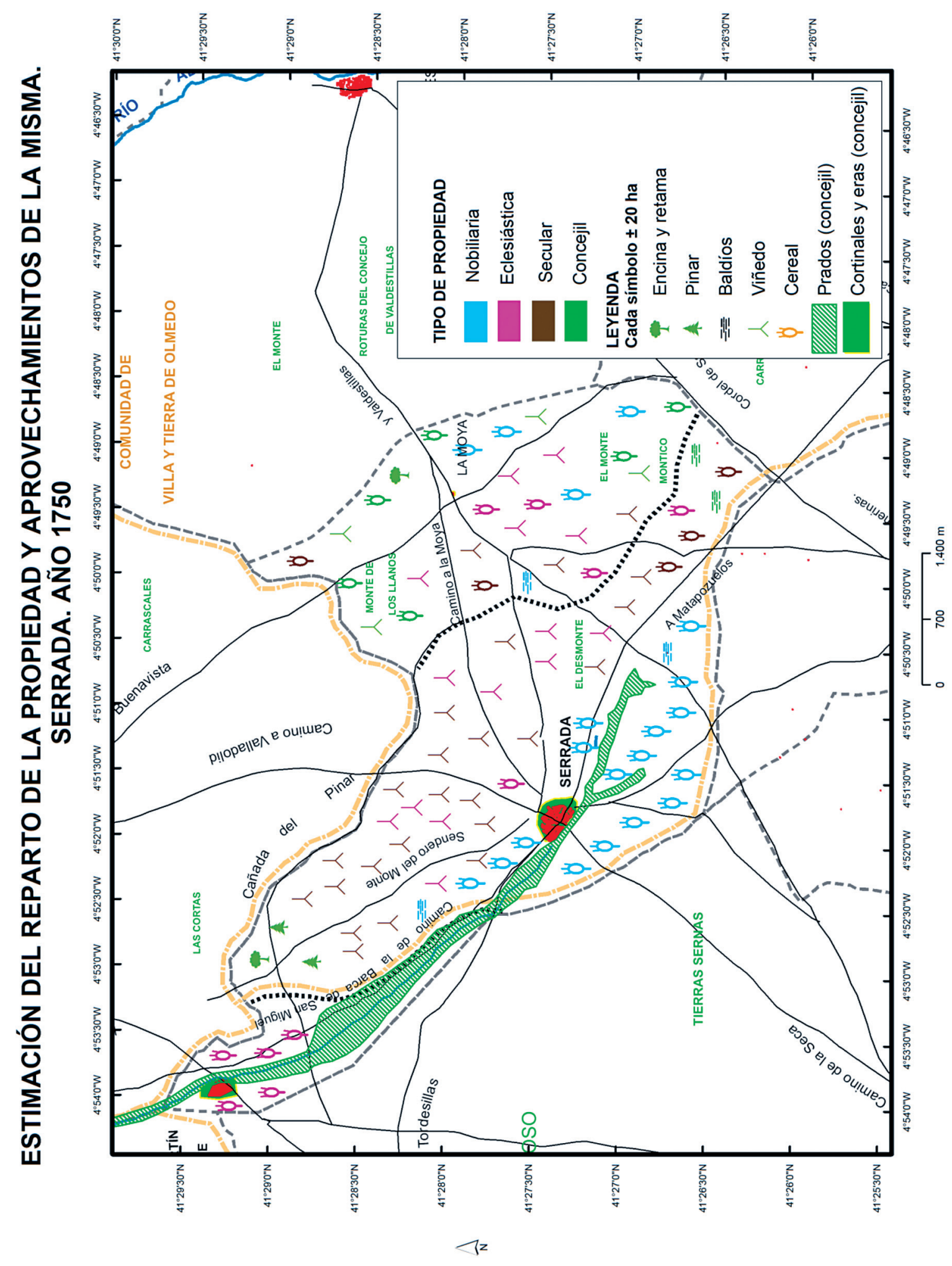


Los trabajos en las viñas y las operaciones sobre elaboración y tratamiento de los mostos son sus principales actividades. Basta asomarse al libro de cuentas de 1797 en la hacienda de la Casa de la Encarnación en Serrada para comprobar cómo todo lo centra el vino y las labores en los majuelos ${ }^{829}$ :

"Desmatar. En setenta y dos obreros que se han echado en las viñas a desmatar en los dos meses anteriores a dos reales cada uno, doscientos diez y seis reales.

En dos costales de tierra de la Nava para las cubas, diez reales.

En una sangría para dar claro a una cuba, nueve reales.

En el acovijo de ciento y diez y ocho aranzadas de vińa a tres reales cada una trescientos cincuenta y cuatro reales.

Arancia. A los aradores de la buelta de marzo que araron a quatro y a quatro, ciento y diez y ocho aranzadas de viña a quince reales cada una, mil setecientos setenta reales.

Vendimiadores. En trescientos treinta y siete jornales de vendimia y trota, pagados a tres reales con inclusión de el cachicán de vendimia, mil once reales.

Burras. En noventa y quatro jornales de burras para la trota pagados a tres reales, doscientos ochenta y dos reales. Carro. En catorze jornales de un carro que trotó catorze días a veintitrés reales por día, trescientos veintidós reales.

Espejuelo. En treinta y dos arrobas de espejuelo a dos reales y medio, setenta reales".

La crisis de final de siglo, la revolución francesa y la crisis vitícola que se vive en el primer tercio del XIX, hacen decaer sobremanera estas casas de labranza. Muchos majuelos se arriendan antes de que la desamortización los cambie de propietario. Entre las instituciones seculares es necesario apuntar, por último, las fábricas de iglesia de San Martín del Monte, la iglesia de San Pedro de Serrada y la iglesia del Despoblado. Suman 27,75 obradas de tierra en La Moya y 4 obradas y otras tantas aranzadas en Serrada. Es, sin duda, el clero regular quien detenta la mayor riqueza de la villa.

En el cuadro y mapa adjunto sobre el reparto de la propiedad y aprovechamiento de la misma, complementario del reproducido en el anterior capítulo, se observa con claridad cuanto hemos expuesto: el señor de la villa como poseedor de las mejores tierras de sembradura; la reducida, parcelada y dispersa propiedad de los labradores locales; la importante presencia del estamento clerical como propietario de vińedo y la existencia de prados, eras y tierras concejiles como elementos fundamentales para completar los recursos de los vecinos.

\section{- Rentas y diezmos como fuente de riqueza. Los dominicos como principales perceptores en Serrada}

Es sabido que la riqueza patrimonial de la Iglesia alcanza a mediados del XVIII niveles de acumulación difícilmente imaginables. Los excedentes de sus cosechas, vendidas hábilmente o administradas con eficacia, sobre todo en años de penurias, engrosan sus arcas. Las rentas de las arrendadas, que alivian la escasez de propiedad de renteros y pequeños labradores, contribuyen a acrecentar sus ganancias, pero es el vińedo y, en consecuencia el vino, su principal fuente de ingresos. En Serrada, el estamento religioso dispone en sus bodegas de 109 cubas y 15 cubetos con una capacidad de almacenaje de 2.017 moyos o, lo que es lo mismo, 32.272 cántaras (516.352 litros). A estos beneficios se deben añadir los producidos por las 271,5 obradas de pan llevar que declaran de su propiedad, cultivadas directamente la mayor parte y arrendadas aquellas de quienes o no tenían casa abierta, residen fuera de la villa o son propiedad de la iglesia de Serrada o del Despoblado. Producciones y rentas, pues, constituyen sus principales fuentes de ingresos. Estos, no obstante, también deben hacer frente a las obligaciones y cargas que gravan temporal o perpetuamente dichas haciendas ${ }^{830}$.

${ }^{829}$ A.H.N. Libro 17200, parte $1^{\text {a }}$, fol. 9 y ss.

${ }^{830}$ No es Serrada un ejemplo elocuente de ello, pues son escasos los censos a su favor y en su contra. Es el convento de la Trinidad Descalza el que debe hacer frente a dos censos en su contra, por valor de 22.000 reales de principal y 550 de réditos anuales, a favor de Don Francisco González, capellán de San Felipe Neri de Valladolid y de la iglesia de San 
Estos factores, junto con la aportación de limosnas y otros ingresos, fueron incrementando su patrimonio, de forma continuada y vinculada, hasta alcanzar un poder y presencia fuera de lo común. Entre todas las órdenes asentadas en la localidad, es la de los dominicos de San Pablo la más poderosa. Acaparan, además, un tercio del diezmo valorado en 6.327 reales y 18 maravedíes ${ }^{831}$.

Respecto a San Martín del Monte, el destinatario principal de estos diezmos es el Convento de Santa Clara de Tordesillas. Es dicha institución y los avatares históricos los que determinan el complejo reparto de las detracciones impositivas. En concreto, dicho convento era dueño de la citada villa con su señorío, vasallaje y jurisdicción civil y criminal. En cuanto al reparto del diezmo, un tercio lo recibía el cura párroco, equivalente a 275 reales, especificándose de forma exacta su cuantía en las distintas especies ${ }^{832}$.

Idéntica forma de concretar la distribución se sigue con las restantes partes ${ }^{833}$. Y el anteriormente mencionado. Antonio Ampudia, como representante del clero local, percibía también los primeros frutos que recogían todos los labradores con casa abierta en el pueblo, rememoración bíblica de los frutos iniciales que se otorgaban a los servidores de Dios y que con el nombre de primicia las iglesias locales habían generalizado a lo largo de los siglos:

\begin{abstract}
"Percive el expresado Don Antonio de Ampudia como tal veneficiado enteramente la primicia que pagan todos los labradores desta villa. Por la misma regulación, importa treze fanegas y quarenta y quatro quartillos, distinguidas así: tres fanegas y seis quartillos de zevada; tres fanegas y doze quartillos de zenteno; dos fanegas y treinta y quatro quartillos de garrobas, treinta y ocho quartillos de avena y veinte quartillos de garvanzos. Que al mismo precio que ban valuados los del diezmo suman ciento y treze reales y treinta y un maravedís al año."
\end{abstract}

Andrés de dicha ciudad. El resto, salvo los que recaen sobre los bienes patrimoniales de Andrés Rodríguez Zorrilla, tiene entre otros un censo en su contra de 17.233 reales, pero que, curiosamente, está a favor de la capellanía de la que es titular-, son pocos numerosos y de menor cuantía. Exceptuando estos dos casos, está saneada situación financiera demuestra la potencialidad de sus recursos, que no han necesitado sujetarse hipotecariamente a prestamistas o dadores de censos. Tampoco parece que estas entidades, beneficiados o capellanes se entregaran a dicha especulación monetaria que, como se verá, estaba en manos de personas ajenas a la villa. Sí disponen, en su contra, de cargas espirituales en forma de misas, responsos, aniversarios, etc., como pago de cantidades nada despreciables, apuntadas en los numerosos testamentos de sus fieles vecinos. Destaca el convento de San Pablo, de la orden de los dominicos, que declara como cargas anuales en su hacienda de Serrada "ochenta misas cantadas, veinte vigilias y treinta responsos cantados y noventa misas rezadas" por las ánimas de los fundadores de dichas memorias. Asimismo, sobre sus propiedades de La Moya "tiene la carga de quarenta misas; las veinte cantadas con vigilia, y las otras veinte rezadas, que se celebran en el referido convento de San Pablo por la prevención de los fundadores".

${ }^{831}$ El otro tercio diezmo real se dividía en tres novenos. Dos novenos iban a parar a la Universidad de Valladolid (4.218 reales y 12 maravedíes) y el restante a la iglesia de la villa. Del último tercio se sacaba la sexta parte para el Beneficiado de Grados, equivalente a 1.054 reales y 20 maravedíes. El resto se dividía nuevamente en tres novenos: dos para el Beneficiado de preste (3.481 reales y tres maravedíes) y el otro para el cura párroco (1.790 reales y 33 maravedíes) que, en estos ańos de 1752, recaían en la misma persona: Andrés Rodríguez Zorrilla.

832 "El referido Don Andrés Antonio de Ampudia, como veneficiado de la Iglesia de San Martín del Monte, perzive un tercio entero del diezmo de todo su término, que se paga de cada diez fanegas una de todas las especies de granos, y regulado por las tazmias que se han presentado, de que se halla puesto testimonio en los autos desta operación. Importa en cada un año treinta fanegas y treinta y ocho quartillos en esta forma: nueve fanegas y veinte y quatro quartillos de trigo, diez fanegas y un quartillo de zevada; seis fanegas y doze quartillos de zenteno; tres fanegas y quarenta y cinco quartillos de garrovas; treinta y cinco quartillos de avena; diez y siete quartillos de garbanzos...". (A.H.P.V. Catastro de Ensenada, Respuestas Particulares, caja 2549).

${ }^{833}$ Así, otro tercio se destinaba a las arcas del obispo de Valladolid importándose 226 reales y tres maravedíes. Del tercio restante se hacían tres novenos. El primero lo percibía la fábrica de la iglesia de San Martín, valorado en 85 reales y nueve maravedíes; otro noveno se hacía llegar a la Universidad de Salamanca como mitad del tercio diezmo real que totalizaba nueve fanegas y un cuartillo valorados en 74 reales y diez maravedíes. El último noveno y segunda mitad del tercio real quedaba en manos del convento de Santa Clara. Además, del tercio que se lleva el señor obispo y del que se hacen tres novenos, se saca un cuarto diezmo que es propio de la Universidad de Salamanca. (A.G.S. Catastro de Ensenada, Respuestas Generales, caja 649). 
Se hace difícil imaginar la forma de vivir de estos vecinos con las cosechas de apenas doscientas obradas de secano cultivadas mediante el sistema de año y vez, siendo además un tercio de segunda calidad y otro de tercera. Al diezmo debemos añadir otros impuestos eclesiásticos como el Voto de Santiago, consistente en media fanega de trigo al año por cada labrador de la villa, sin olvidar otras entregas menores. Todos los vecinos, como se recordará, por si no tenían bastante con las cargas citadas, tenían en contra un censo y foro perpetuo enfitéutico, a favor de dichas religiosas, al haber vendido estas al concejo de San Martín del Monte y a sus vecinos todo el término y aprovechamiento de pasto y labor, reservándose para sí la propiedad y su derecho de dominio, jurisdicción y vasallaje. El pago de su cuantía varía de acuerdo con las tierras labradas por cada vecino, pero en ningún modo son cifras que hay que despreciar: aproximadamente media fanega de centeno por obrada (una por obrada sembrada si tenemos en cuenta el sistema bienal), más otros once reales y seis maravedíes por cada labrador, a excepción del cura párroco, que sumaban un total de 99 fanegas de centeno, 110 reales y 60 maravedíes que, de forma conjunta, al precio regulado de siete reales la fanega de dicho cereal, sumaban 803 reales y 60 maravedíes.

\section{- Ejemplos y características de casas religiosas asentadas en la villa}

Los dominicos de San Pablo y los Trinitarios Descalzos fueron los que más se afanaron de forma directa en la dirección y trabajo de sus tierras y viñas, sobre todo en el segundo tercio del XVIII cuando, como se ha seńalado, muestran un mayor empuje comprador. Todas las órdenes religiosas, en cualquier caso, labraran directa o indirectamente sus propiedades, tenían en sus bodegas el producto clave para entender su asentamiento: el vino. De hecho, se puede unir el destino de estos religiosos al propio mercado vitícola. Las tierras de pan que adquieren y posteriormente plantan de vides a finales del primer tercio del XVIII testifican la recuperación del cultivo, beneficiado por el fin de la guerra de Sucesión y el incremento demográfico castellano. El alza de los precios del vino en relación con el trigo, experimentado desde 1715 a 1735, coincide con el incremento de las compras y la ampliación que estas órdenes llevan a cabo en sus bodegas y casas de labranza. ${ }^{834}$. En las épocas de retroceso que se registran a lo largo de este siglo, estabilizan su actividad compradora, a pesar de las exenciones fiscales que gozaban como estamento privilegiado. Igualmente, es de destacar su interés por adquirir propiedades contiguas para formar amplias parcelas, casas o bodegas, cuestión nada fácil pues los labradores extendían sus heredades por un sin número de minúsculas propiedades. Analicemos algunos ejemplos de estas haciendas religiosas.

\section{- La casa de la capellanía de Andrés Rodríguez Zorrilla}

Es raro el labrador con posibles que no anhela dar estudios de leyes o eclesiásticos a alguno de sus hijos. No pocos culminan su carrera ostentando algún cargo religioso en la localidad de procedencia, dejando a la Iglesia o a instituciones relacionadas con el mundo divino buena parte de su patrimonio. De ahí que muchas tierras y casas hayan llevado durante siglos cargas y réditos por razón de aniversarios, Misas o Memorias. En otros casos, se fundan sobre ciertos bienes de tierras, casas o censos determinadas instituciones religiosas, que quedan sujetas al mantenimiento de determinados cultos. Era el caso de las Capellanías fundadas por laicos o eclesiásticos y que, regidas por un capellán poseedor, administra y se beneficia, una vez atendido el mandato religioso del testador, los bienes adscritos. De alguna de ellas se tiene larga constancia a través de los intrincados pleitos por parte de quienes, siglos más tarde, se sienten con derecho al reparto de tales riquezas, una vez muerto el capellán poseedor.

${ }^{834}$ Ya se ha indicado que la orden de San Pablo suma a sus corrales un pedazo de las eras de propios en 1735 . Los Trinitarios Descalzos, por su parte, consolidan ya por estas fechas en torno a setenta aranzadas de majuelos. A.R.Ch.V. Pleitos Civiles, Quevedo (F), 3544.1, año 1737. 
La citada casa (véase imagen más adelante), hoy propiedad de la familia Rojo de Íscar, las casas adyacentes, bodega y buena parte de los corrales interiores eran propiedad, en 1760, de Andrés Rodríguez Zorrilla, preste y cura de la Parroquial de San Pedro. La había heredado de su padre Antonio Rodríguez y, en tal fecha, se la deja como único heredero a Remigio Rodríguez. En 1752 se catastra como sigue:

\begin{abstract}
"Don Andrés Rodríguez Zorrilla, beneficiado de Preste y cura párrocho de la Iglesia de esta villa de Serrada. Una casa situada en esta villa en el barrio de Pozo Bueno, con vivienda vaja, caballerizas, corral, pajar, lagar y bodega, propia del dicho Don Andrés Rodríguez. Tiene de frente treinta y siete varas y de fondo sesenta y uno. Se regulo su alquiler en ochenta y ocho reales de vellón al año. Confronta con calleja que llaman de la zilla y con corral de Simón Ruiz.

Cubas. En la bodega de la casa antezedente hay nuebe cubas y dos cubetos, de cabida de ziento y quarenta y nuebe moios y medio, que regulado el alquiler o renta de cada uno, según práctica de esta villa, a tres reales de vellón cada uno, importan quatrocientos y quarenta y ocho reales y medio de vellón.”
\end{abstract}

Cuando la legislación liberal del XIX regule el disfrute de estas figuras jurídicas, el control de sus bienes no estará exento de conflictos ${ }^{835}$. En febrero de 1834, casi un año después de que en mayo de 1833 León Rodríguez, presbítero y bisnieto político del fundador que gozaba dicha capellanía, hubiera sido degollado por su criado, el obispo de Valladolid llama a la obtención de la Capellanía a los descendientes de José Rodríguez y el tribunal eclesiástico la confirma en la persona de Pablo Obregón, al mantenerse la sucesión que privilegia el hijo al nieto, el mayor al menor y el varón a la hembra. Desde 1834 hasta las últimas sentencias de 1874 y 1875, transcurre casi medio siglo de costosos e intrincados pleitos por la división y goce de los bienes de dicha institución ${ }^{836}$.

\title{
- La casa de Francisco Cabo, canónigo de la Catedral de Valladolid
}

Similar destino tuvo la hacienda del doctor Requena, litigante con los Montalvo tiempo atrás. Sus bienes habían pasado a formar parte de la capellanía fundada por sus sucesores en la parroquia de San Miguel de Valladolid. En 1730, Francisco Gil de Reinoso, primer capellán poseedor, opta por la venta al mejor postor de los bienes sitos en Serrada ${ }^{837}$. Son rematados por Manuel Antonio Cabo. El nuevo propietario adquiere numerosos bienes rústicos en Serrada y en los pueblos limítrofes

${ }^{835}$ Los bienes adscritos a la capellanía son una cerca y lagar con bodega y 38 aranzadas y trescientas cepas. Los del aniversario o vínculo los forman una casa a la calle del Arroyo que lindaba por poniente con la calle de la Acilla y norte con casa y corral de Leandro Obregón y plaza de la villa. Dicha casa disponía de bodega, lagar y cubas, así como paneras, caballerizas y gallineros. La vivienda estaba acompañada por bienes raíces compuestos de una tierra en Valdelaíno de 5,75 obradas; otra en Valdesendero de 10 obradas; otra en Valdelacasa de 10 obradas, un majuelo en el mismo pago de 16 aranzadas y otro, donde llaman el Redondo, de 5 aranzadas.

${ }^{836}$ En el juzgado de primera instancia de Medina del Campo, de acuerdo a la ley de 19 de agosto de 1841, se adjudican dichos bienes a Da Agustina Rodríguez, viuda de Julián Obregón y a Da Micaela Alonso, hermana de Gregorio León Alonso e hija de María Rodríguez, representada por su marido Modesto de Castro, respetando el usufructo al capellán poseedor. Posteriormente, tras la prolongación de pleitos interminables y costosos, Gregorio León se adjudicará su mitad reservable por sentencia de 2 de octubre de 1873, que será reconocida en sentencia dictada el 20 de marzo de 1874 y que la sentencia de 29 de mayo de 1875 entre Gregorio León Alonso contra Patricio y Justo Obregón y Gregorio Juárez obligará a ejecutar.

${ }^{837}$ La casa era descrita en estos términos: "Una casa en la dicha villa de Serrada en la calle Real como se sale a esta ciudad de Valladolid a la mano izquierda, lindero por la parte de arriba con casa de Santos Moyano y por los corrales, por una parte, con corrales del convento de San Pablo de esta dicha villa y por otra con corrales de casa del licenciado Don Pedro Alonso del Arenal, beneficiado de Preste; y por parte de abajo con ejido de Diego García, vezino de la villa de San Martín del Monte, la qual dicha casa se compone de un portal, dos salas, dos alcobas, en la principal, una cozina, un cuarto pequeño con otra sala por lo alto sobre el portal con sus rejas de yerro grandes y medianas, y en la parte de arriba tres cuartos pequeños para recoger granos, y hazia el corral una caballeriza pequeña con sus pesebres y un cuarto pequeño y mediano a ella; con su lagar corriente y su pozo, con la bodega perteneciente a dicha casa y cubas a ella pertenecientes y demás que la toca y pertenece...”. (A.H.P.V. Pt.2967, fol. 121 y ss). 
por estas fechas. Sólo por la casa y las más de ochenta aranzadas de vińas de la capellanía llega a pagar 47.000 reales. La bodega se amplía conforme aumentan sus aranzadas. En 1752 son propiedad del canónigo Francisco Cabo. ${ }^{838}$ La calle de salida a Valladolid respiraba religiosidad por todas partes. Congregaciones de monjas disponen de casas al norte y sur de la estudiada con buenas bodegas. En estos años el religioso detenta 43,5 aranzadas en la Moya y 76,5 en Serrada. Así se describe la casa en el Catastro de Ensenada:

\begin{abstract}
"Don Francisco Cabo. Presbítero, vezino de la ziudad de Valladolid. Una casa situada en esta villa a la calle de Valladolid, con vivienda alta y baja, caballeriza, corral, pajar, lagar y bodega, propia de dicho Don Francisco Cabo. Tiene de frente treinta y cinco varas y de fondo quarenta y ocho. Se regulo su alquiler en ziento y diez reales de vellón. Cubas. En la referida bodega de la casa antecedente hay catorze cubas y dos cubetos, que hacen trescientos moios, que regulado el alquiler de cada uno a tres reales de vellón, importa nobezientos reales de vellón."
\end{abstract}

Una vez más se debe hacer constar el interés vitícola de estos poseedores foráneos. Sean o no religiosos. Los 300 moyos de capacidad de sus cubas (76.800 litros) lo hacían el segundo mayor elaborador de vinos de la localidad, sólo por detrás de los 907,5 moyos del convento de San Pablo. Pasado el esplendor religioso del XVIII, los bienes rústicos son vendidos y la casa que sirve de ejemplo permutada en 1854 por el cabildo de la catedral de Valladolid a Carlos Romero y su mujer Antonia Blanco por otra que estos poseen en dicha ciudad. Los testigos que dan fe en el acto y justifican la decisión del cabildo vallisoletano coinciden en que "la citada casa se halla muy mal conservada y que algunos años no produce cosa alguna, necesitando ahora un reparo de consideración ${ }^{339}$. Tras no pocas dificultades hipotecarias, los nuevos propietarios venden la casa en 1871 por 22.000 reales al propietario local Canuto de Castro que, junto con otras fincas, la lega, en 1908, a su hijo Melitón de Castro ${ }^{840}$.

\title{
- La casa convento de las monjas del Corpus Christi
}

Esta casa tiene un origen religioso similar a la anterior. Aunque se desconoce la fecha exacta, se sabe que dicha propiedad y otros bienes raíces adjuntos, sitos en Serrada y pueblos limítrofes, integran la dotación de dos capellanías fundadas por Juan de Zamora Cabrero en el convento del Corpus Crhisti, orden de Santo Domingo Extramuros, de Valladolid ${ }^{841}$. Este benefactor había ejercido como alguacil mayor del Santo Oficio de la Inquisición y regidor perpetuo. Dicho convento adquiere majuelos a favor de la capellanía a través de una Memoria fundada por Esteban Ybarra en $1738^{842}$. Los capellanes que gozan de estos bienes, vinculados al convento del Corpus, son Pedro Fernández Puras y Melchor Ruiz de la Peña ${ }^{843}$. Ambos figuran, si se suman sus bienes eclesiásticos y patrimoniales, como propietarios de 44,5 y 23 aranzadas, respectivamente, además de sendas casas por alto y bajo con bodega y cubas. Ambos bienes salen a subasta conjuntamente con sus bienes rústicos, tras la promulgación de las leyes desamortizadoras de 1 de mayo de 1855 y 11 de julio de 1856.

${ }^{838} \mathrm{Su}$ hacienda es administrada, en 1758, por Gregorio de Íscar, tal como se desprende de las obligaciones que firman varios vecinos de la villa en esta fecha. (A.H.P.V. Pt.8220, fol. 235 y ss).

${ }^{839}$ A.H.P.V. Pt.15832, fol. 319.

${ }^{840}$ A.RSP.M.C. Tomo 1064, Libro 131, Serrada, fol. 155.

${ }^{841}$ A.H.P.V. Pt. 8220, año 1768, fol. 37.

${ }^{842}$ A.H.P.V. Pt. 8226, Elvira Román, año 1738, fol. 43-46.

${ }^{843}$ El capellán Fernández Puras también gozaba de la capellanía fundada por Sebastián de Haro, dotada con algunas viñas en Serrada, si bien tenía "la carga de decir dos misas rezadas cada semana en dicho convento de Corpus Christi, y de asistir a los veniarios de todos los oficios dibinos que se celebren en la Iglesia de dicho convento, todo con arreglo a la fundación de la referida capellanía". Los bienes eclesiásticos del capellán Ruiz de la Peńa, por su parte, "tienen la carga de setenta y ocho misas, que a quatro reales de vellón, importan trescientos y doze reales de vellón" (A.H.P.V. Hacienda, Libro de Eclesiásticos, Serrada, fol. 107 y ss.). 


\section{- La casa del presbítero Pedro Alonso del Arenal}

Pedro Alonso del Arenal, presbítero de Serrada, deja sus bienes raíces y muebles, entre los que figuran casa y bodega, a sus sobrinos, y el encargo de la fundación de una capellanía con parte de los mismos al licenciado Manuel de Belandria. Al morir este sin ejecutar la fundación, los familiares venden la herencia a Miguel Moyano, también sobrino del religioso e importante hacendado local, como hemos estudiado ${ }^{844}$. Los herederos de Miguel Moyano y Beatriz Rodríguez repartieron esta hacienda tras el inventario hecho en $1801^{845}$. Las casas, sitas en la calle Real, con sus correspondientes corrales, lagares y bodegas, fueron el legado que dejaron a sus hijas y sobrinas. Rosa Moyano, casada con Lorenzo Villán, ya residía por entonces en la vivienda más antigua, adquirida a la muerte de sus anterior propietario, el citado presbítero Pedro Alonso del Arenal, fallecido en 1736. Su sobrina María Ana Moyano, por su parte, casada con el magistrado vallisoletano Gregorio Barahona, manda construir, tras el reparto, una nueva vivienda.

Tras el proceso de reparto, la casa que ocupaban Rosa Moyano y Lorenzo Villán "compuesta de portal, cuatro salas con sus alcobas, despensa, cocina, horno de pan, tres cuadras, desván, pajar sobre las cuadras, un patio en el fondo de la casa, dos lagares de viga, bodega subterránea compuesta de tres naves y dos vías con dos entradas...", será adjudicada a Rita Villán y Moyano tras la muerte de sus padres, menos el lagar conocido por "el viejo" y uno de los cañones de la bodega, que dicha señora adquirió por compra en 1846 a Domingo Contreras, marqués de Lozoya, adquiriente de dicho bien por compra en 1845 a Saturnino Villán. Al casar Rita Villán con su primo Manuel Victoriano Moyano (su bisabuelo común era el escribano Francisco Moyano, iniciador en Serrada de la familia de este apellido), los bienes serán heredados por sus hijos, el presbítero Francisco y el magistrado Manuel, ocupantes de importantes cargos en Sevilla, Barcelona y Zamora. Al morir ambos hermanos estos bienes son heredados por la familia Moyano Zamora quienes, después de utilizar y mejorar sus instalaciones como centro de sus labranzas, la venden en 1908 al propietario local Mariano Martin ${ }^{846}$. Dichos bienes son linderos de la casa que manda edificar el magistrado vallisoletano Gregorio Barahona, conocida hasta que fue derruida en 2005 como "la de Julita Hinojal". El conocido como "lagar del Obispo", ya mencionado anteriormente, sito a lo largo de la calle que sube a la iglesia desde la Calle Real, también pertenecía, por compra anterior, a esta pudiente familia. Así se describe en el inventario ${ }^{847}$ :

\footnotetext{
"Un lagar de viga con sus maderas y todo lo necesario para su servicio, incluso un conducto y cañones de ojalata para llebar desde la Pila el mosto a las cubas; un cubierto además, que tendrá de largo cien pies, en donde hay dos entradas para dicho lagar y la bodega, y además ésta, que se compone de un cañón sólo con nueve cubas de a diez y seis todas, enarcadas de yerro, su escalera, quatro zarzeras, y en una, que es la que enfrenta con la
}

${ }^{844}$ Tomás Labajo, curador del también heredero Cándido Alonso, exige la restitución de los bienes, iniciándose un complejo pleito entre partes. (A.H.P.V. Pt. 8227, fols. 169 y ss. y Pt.6411, fols. 513 y ss.).

${ }^{845}$ Se cree haber apuntado anteriormente que Miguel Moyano y Beatriz Rodríguez son los padres del ya renombrado obispo Buenaventura Moyano, Tomás Moyano, magistrado perteneciente a la audiencia de Su Majestad, oidor de la audiencia de Sevilla y ministro de Gracia y Justicia en tiempos de Fernando VII, y de Francisco Moyano, caballero maestrante de Ronda e importante hacendado comarcal. Sus hijas, igualmente, contrajeron matrimonio con importantes hacendados locales: Rosa Teresa con Lorenzo Villán; Catalina con Juan Antonio Díaz y Beatriz con Francisco Rodríguez. (A.H.P.V. Pt.8228, año 1801, fol. 61 y ss.).

${ }^{846}$ Tras la muerte de Manuel y Francisco Moyano Villán, estos bienes urbanos son heredados por los sobrinos de la familia Moyano Zamora. Mariano Martín compra estos bienes urbanos en 1908 a Francisco Moyano Zamora, dueño de 8/9 partes y a Claudio, Luis y Soledad Moyano Treviño el resto de la propiedad. Los nuevos propietarios son, igualmente, grandes hacendados. Mariano Martín Hinojal, hijo de Prudencio Martín y Trinidad Hinojal, sobrino del anterior comprador, será quien continúe en las bodegas de esta propiedad la elaboración de importantes cantidades de vino, actividad que continuará, como más adelante se estudiará, su hijo Juan Antonio Martín-Hinojal. En la actualidad dichos bienes urbanos son propiedad de la familia Alonso Renedo.

${ }^{847}$ A.H.P.V. Pt.8228, año 1801, fol. 61 y ss. 
puerta de la Iglesia un pozo, que sirve para dicha bodega y lagar. Linda el dicho cubierto, por el mediodia con corrales de la casa del señor marqués de Torreblanca, y una de las paredes de él es medianería con dicho solar; por norte con calle que ba desde la Iglesia a barrio nuevo, por oriente enfrente de la portada de aquella, y por poniente con la calle Real. El dicho cañón de bodega y la escalera es todo vosqueado de fábrica de cal y ladrillo a la mayor seguridad. Se tasa todo lo dicho, uno con otro alzadamente en veinte y quatro mil reales."

- La casa grande del Obispo

Esta importante edificación contribuye notablemente a la expansión del casco urbano a finales del XVIII, pues parte de ella se levanta en terreno no edificado y lleno de humedades, entre el núcleo más histórico, justo detrás de las casas de Concejo, y la cada vez más ocupada calle del Porro, lugar de asentamiento de la población con menos recursos. Como en el caso anterior, cabe explicar sus antecedentes en el interés de las familias más pudientes en dar estudios superiores a sus hijos. Cuando Francisco Moyano, nacido en La Seca, se instala en Serrada como escribano, sus bienes e influencia contribuyen de forma decisiva a que sus hijos sigan manteniendo importantes haciendas, agrandadas por matrimonios, desde las últimas décadas del XVIII hasta buena parte del siglo XIX. Uno de los hijos de su segunda mujer, Miguel Moyano, también titular como su padre de la escribanía de Serrada, al tiempo que se preocupa por incrementar sus heredades, sigue invirtiendo parte de la fortuna familiar en encauzar a los hijos en los estudios de leyes y eclesiásticos. Su hijo Tomás Moyano alcanza la cátedra de leyes en la Universidad de Valladolid, un acta de Diputado a Cortes y el ministerio de Gracia y Justicia en tiempos de Fernando VII. Buenaventura, hermano del anterior, fue canónigo de la catedral de Ávila y obispo auxiliar de Toledo, antes de alcanzar la titularidad de la sede obispal de Palencia en 1801. La vinculación con Serrada siempre fue constante, pues aquí reside su hermano Francisco, dueño de una de las mayores haciendas de toda la comarca ${ }^{848}$.

Fue su interés, fortuna personal y familiar, la que hizo posible la edificación de esta casa, en consonancia con la posición social. Nada mejor que reproducir las palabras que recoge el escribano al dictado del testamento de sus padres: ${ }^{849}$

\begin{abstract}
"Hemos tenido desde el dicho año, por encargo del referido nuestro hijo, la libre administración de todos los vienes anejos a uno y otro, percibido sus frutos según es notorio, y retenido en nuestro poder todo el valor y rendimiento liquido de ellos. Y con cuio caudal, por encargo así vien y cuenta del mencionado Don Buenabentura, le hemos hedificado la casa en que vivimos a el presente, con su lagar y demás ofizinas en el casco de esta villa y solares que ocupaban las carnecerías y matadero antiguo, y las casas propias de los herederos de María García, mujer que fue de Andrés Román y de los de Andrea Martínez, las quales compramos para ello con el mismo caudal..."
\end{abstract}

De esta manera se levanta en breve tiempo una de las viviendas más sólidas de la villa. Los terrenos sobre los que fue edificada habían sido ocupados por las carnicerías, matadero antiguo y corrales del concejo, que fueron subastados para proveerse de recursos con que hacer frente a la construcción del nuevo Ayuntamiento. Miguel Moyano remata en 1.540 reales los citados bienes, en el mes de diciembre de $1787^{850}$. La construcción no se hará esperar en los siguientes ańos. La temprana muerte del obispo Buenaventura y la llegada de la invasión napoleónica ocasionan no

\footnotetext{
${ }^{848}$ En concreto, consta su presencia en la iglesia de San Pedro, en el acto de Confirmación que se celebra el 28 de mayo de 1801, poco tiempo antes de su muerte, fechada el 7 de septiembre de 1802. Está sepultado en la capilla de Santa Lucia de la catedral de Palencia. Igualmente, la placa de agradecimiento que se coloca en su honor, sobre la puerta principal del nuevo Ayuntamiento, es otra distinción que le hacen sus vecinos: En ella puede leerse: "A Dios todopoderoso, en memoria del Ilustrísimo señor Buenaventura Moyano Rodríguez, obispo de Palencia en otro tiempo, natural de esta villa, su Concejo se preocupó de que se gravase esta inscripción y de que fuese colocada. Año 1803”.

${ }^{849}$ A.H.P.V. Pt. 8228, fol. 61.

${ }^{850}$ A.H.P.V. Pt. 8225, año 1787, fol. 206 y ss.
} 

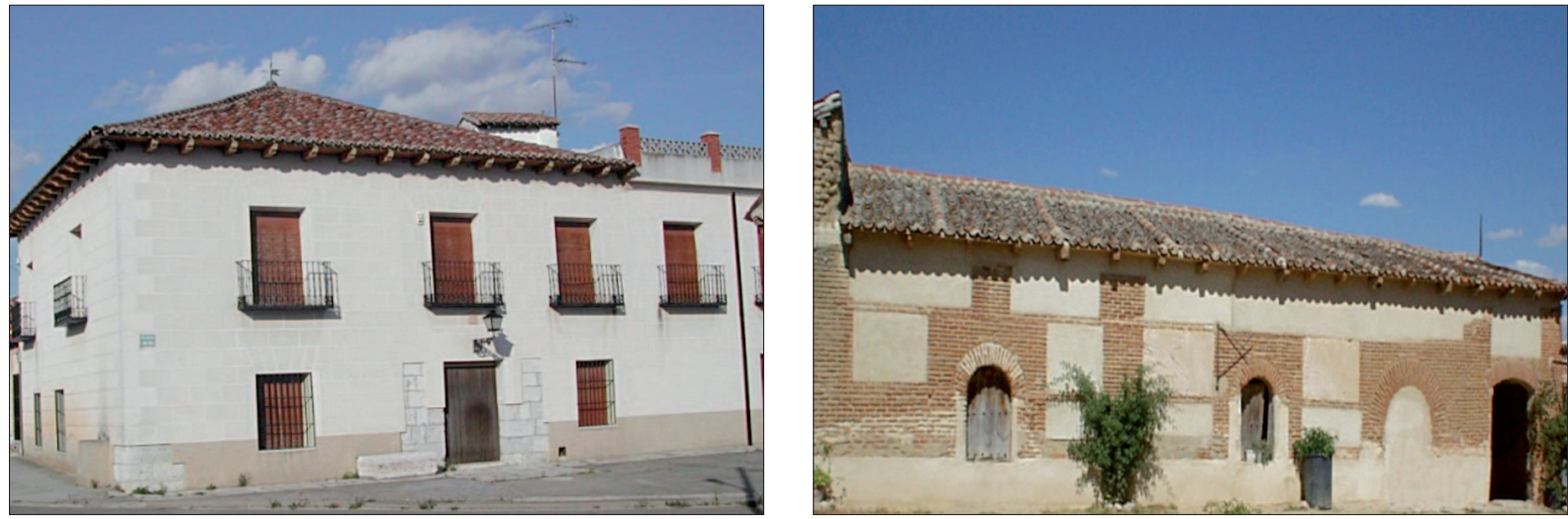

Izquierda: casa conventual de San Pablo, orden de los dominicos. (Hoy propiedad familia Gutiérrez Fernández) Derecha: lagar de la casa granja del Convento de la Trinidad. (Hoy propiedad familia Alonso Gutiérrez)
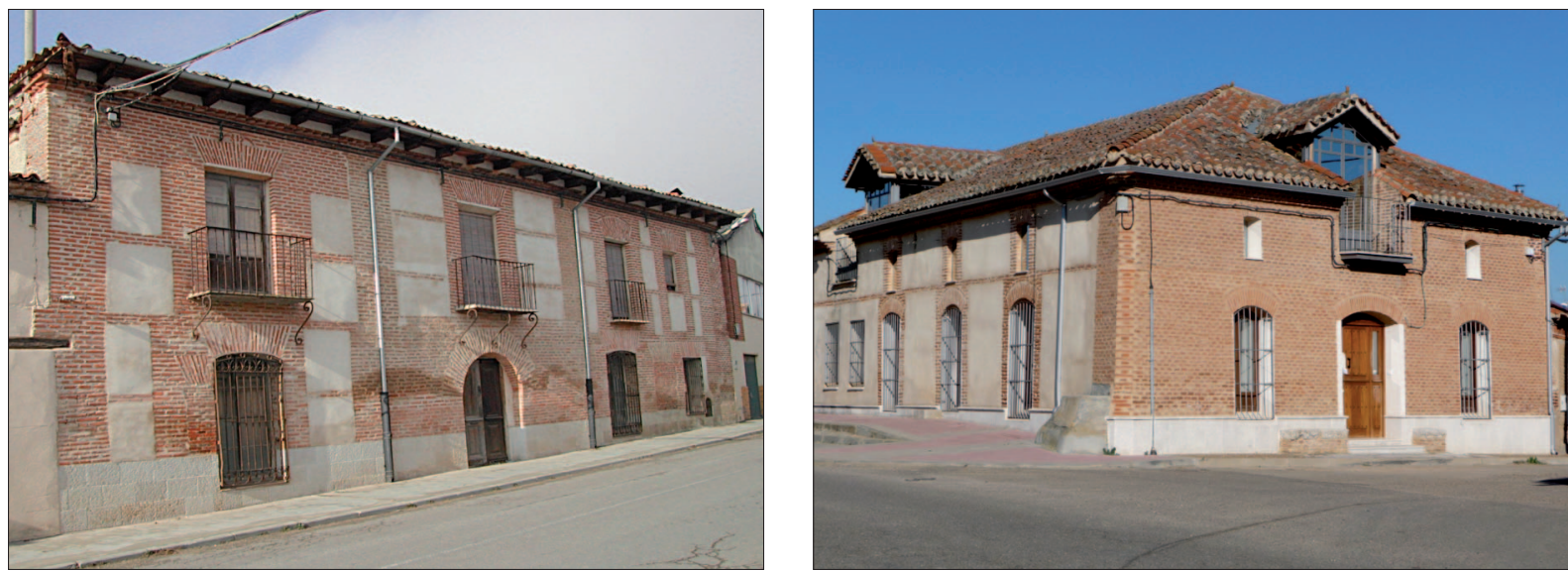

Izquierda: casa del presbítero Francisco Cabo. (Hoy propiedad de la familia Núńez de Castro) Derecha: casa conventual del Hospital de la Resurrección. (Hoy propiedad familia Alonso Moyano)
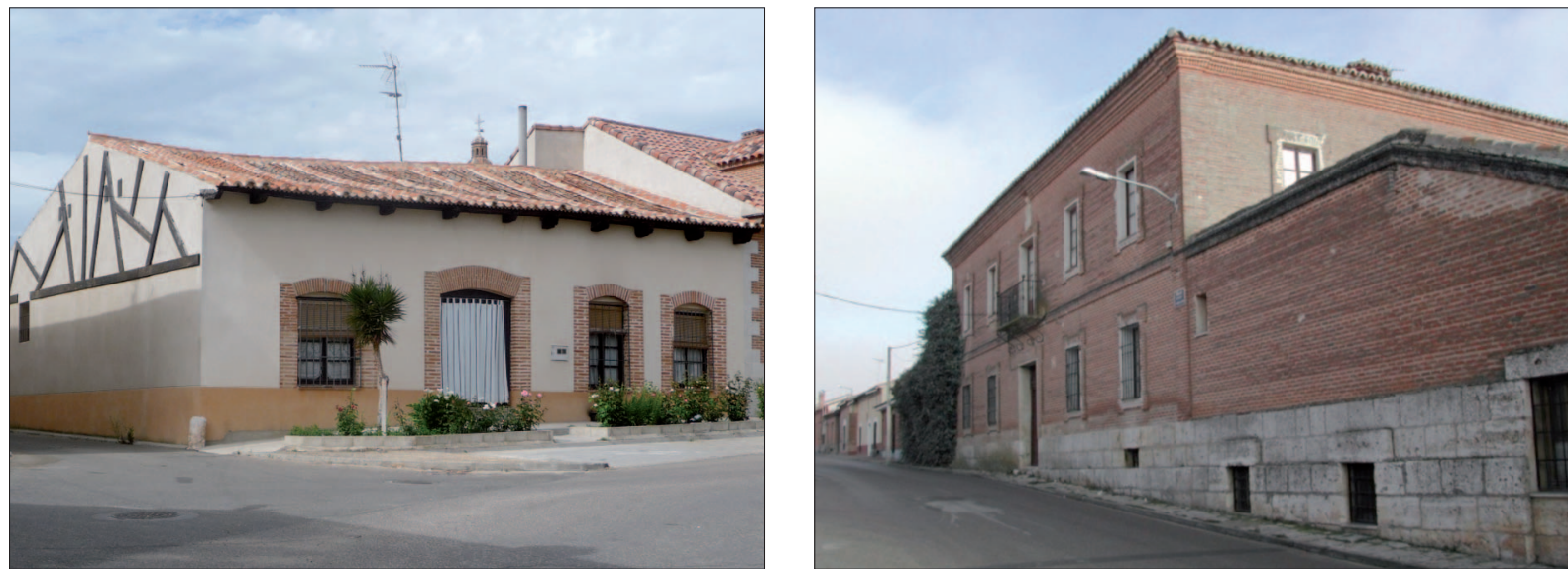

Izquierda: casa de la capellanía de Andrés Rodríguez Zorrilla (Hoy propiedad familia Rojo de Íscar) Derecha: casa del obispo Buenaventura Rodríguez Moyano. (Hoy propiedad familia Hinojal Medina)

Imagen 69. Ejemplos de casas religiosas con importantes haciendas vitícolas en el siglo XVIII, Serrada. Salvo la casa del presbítero Cabo, situada en la Calle Real, el resto se alzan a lo largo de la calle que subía al Pozo Bueno (actual Antonio Medina). 


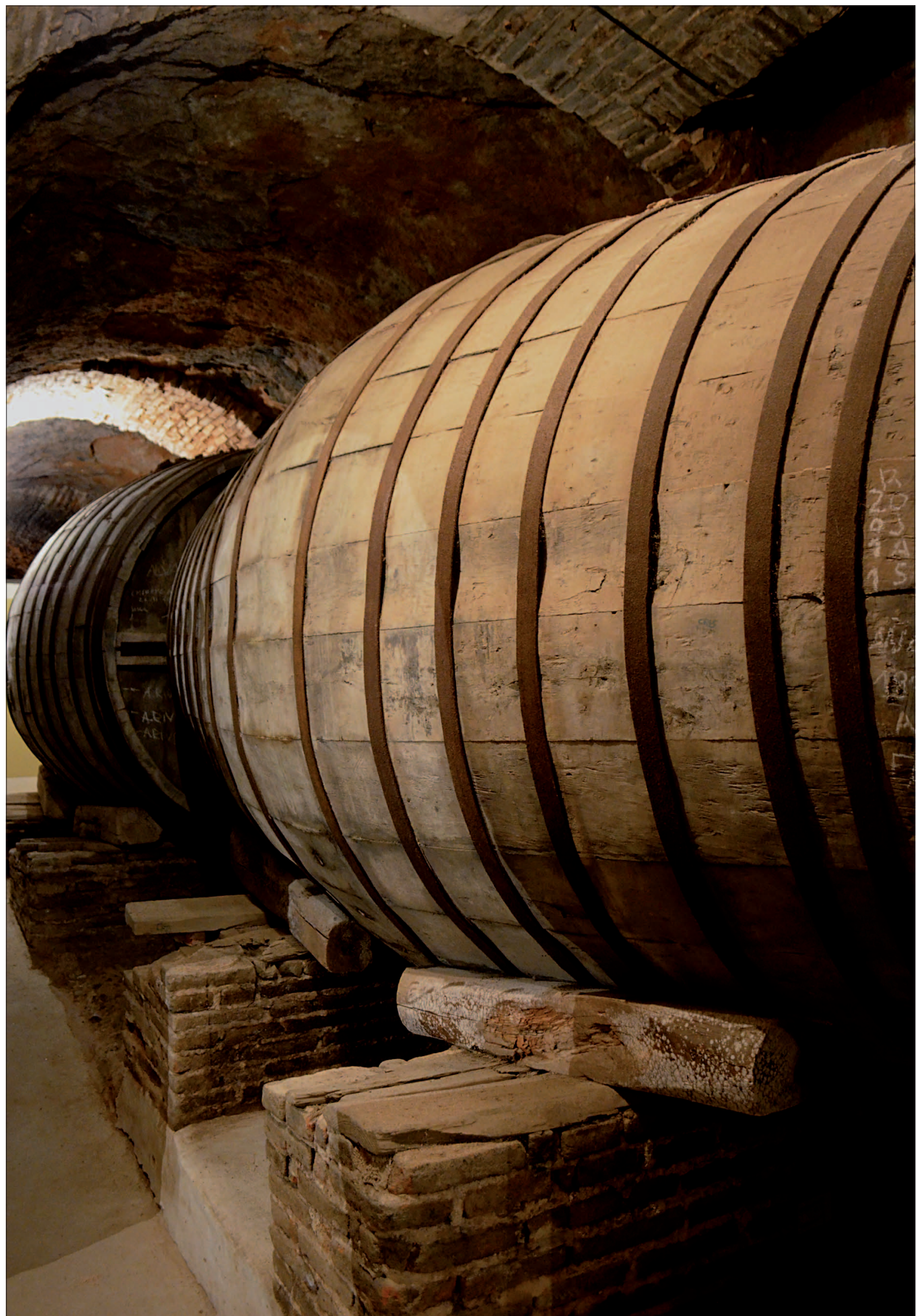

Imagen 70. Cañón de la antigua bodega de San Pablo, con cubas de roble tradicionales. Similar disposición y dimensiones tuvieron las que poseyeron los dominicos en el siglo XVIII. (Bodega Hijos de Alberto Gutiérrez, S.A. Serrada. Foto: 3/12/2014). La granja de San Pablo, en Serrada, fue una de las mayores haciendas vitívinícolas de la comarca, tanto en extensión de viñedo como en elaboración de vino. 


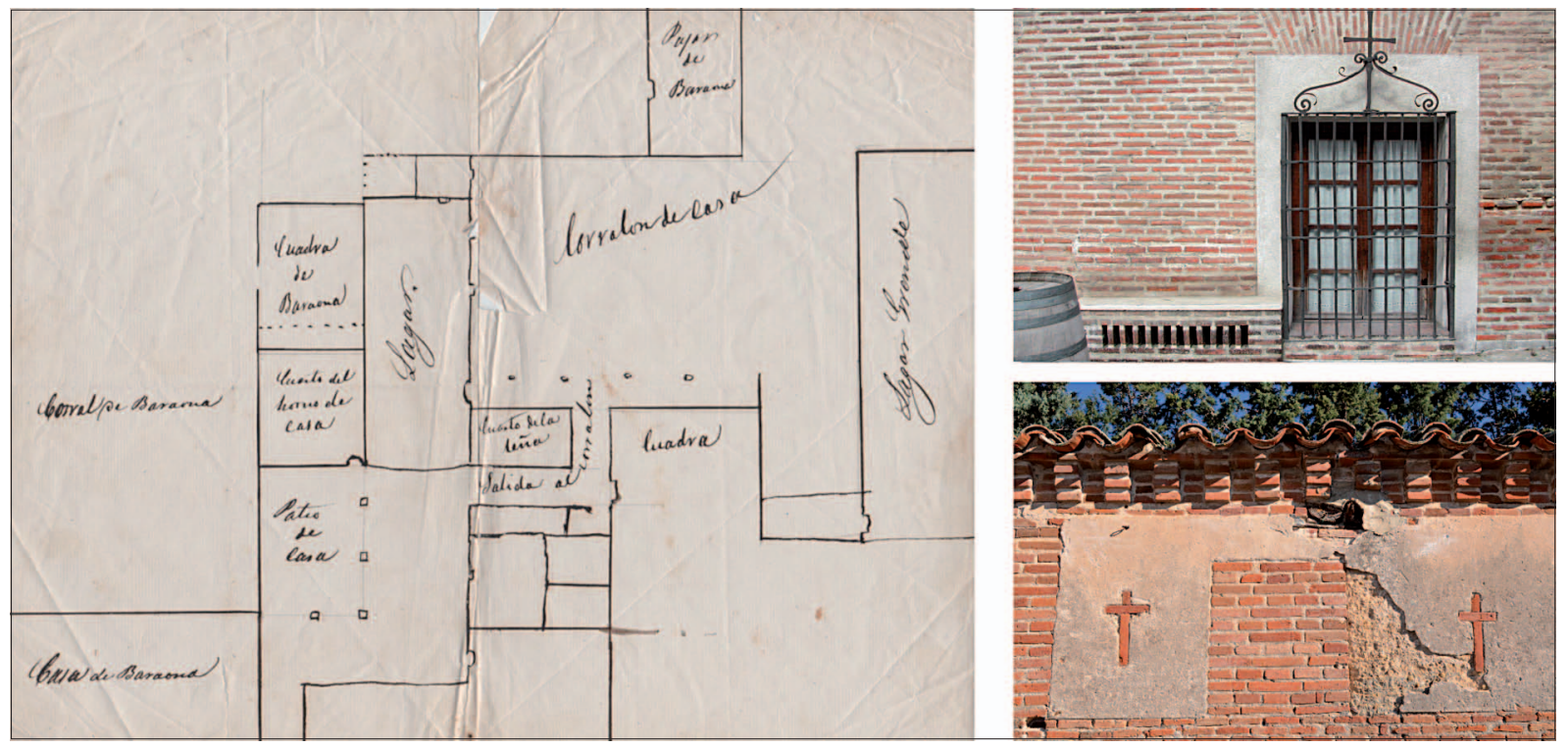

Plano de la casa del presbítero Alonso del Arenal (izquierda). Detalle de ventana en fachada delantera y muro exterior del lagar grande. Foto: 06/12/2014.

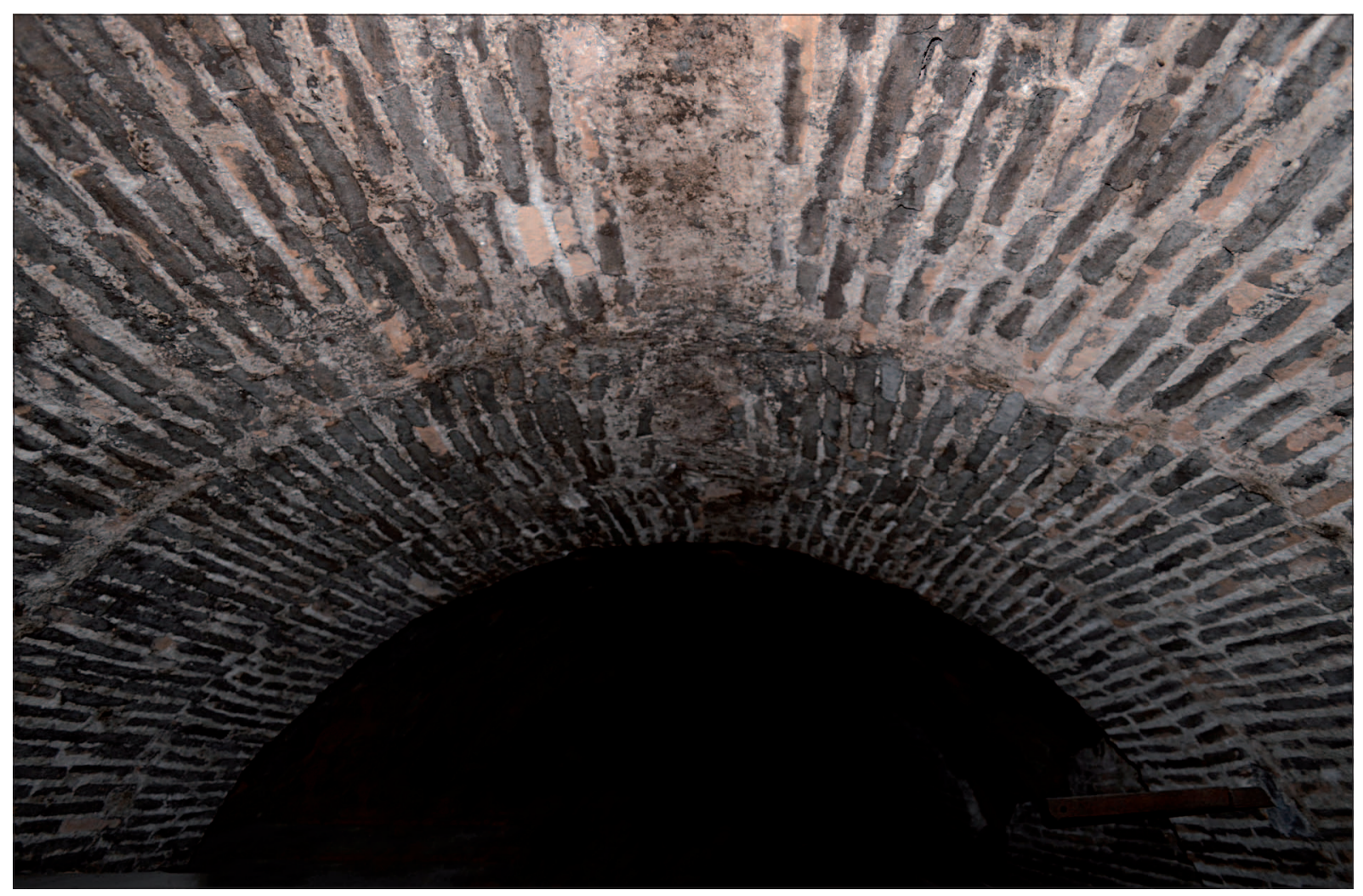

Detalle de la cimbra de uno de los cańones de la bodega situada bajo la vivienda. Foto: 06/12/2014.

Imagen 71. Plano de la casa, detalles constructivos y bodega del presbitero Alonso del Arenal. Serrada Siglo XVIII. (Hoy propiedad familia Laguna Renedo).

Como anteriormente se ha explicado, las haciendas vitícolas, fueran laicos o eclesiásticos sus propietarios, toda vez que pasan de unas manos a otras, se ordenan en torno al corral de la vivienda, desde donde se accede a las variadas dependencias que se necesitan tanto para la actividad agraria (cuadras, pajares, paneras), como la relacionada con la elaboración del vino: lagares y bodegas.

Obsérvese, en el plano adjunto, como a estas dependencias se accede por la parte interior, mejor guardada y atendida por dueños y criados que, en el caso de estos últimos, en las épocas de más actividad, dormían en las cuadras y pajares o cuartos habilitados a este fin. 
poco desasosiego y problemas a sus propietarios que, por lo demás, siguen ocupando altos cargos en la carrera administrativa y judicial, entroncando con familias de abolengo y adornándose con títulos nobiliarios ${ }^{851}$. En lo que respecta a su hacienda, los herederos la mantienen mediante arriendo durante varias décadas, pero sus titulares irán, poco a poco, desligándose de la vida local ${ }^{852}$.

\section{Las consecuencias espaciales del dinamismo agrario del siglo XVIII. Serrada como ejemplo}

Junto a nobles y clérigos no debemos olvidar a labradores, jornaleros y resto de la población que, a lo largo del tiempo, han ocupado y hecho suyo el terrazgo, unas veces en coyunturas favorables y otras bajo el peso de la desgracia. Hemos estudiado como, en el espacio tomado como ejemplo, el empuje del viñedo fue contenido hasta mediados del siglo XVII, en que se reparten a censo las 1.000 obradas de los Montalvo en Serrada y las 500 obradas de los Vega en La Moya para plantar vińas, evidencia del nuevo impulso vitícola que se desplaza de los pueblos meridionales de Medina a la zona de terrazas del norte comarcal ${ }^{853}$.

${ }^{851}$ Serán, sobre todo, los hijos del magistrado Esteban Moyano los que atesoren distintos títulos nobiliarios: Su hijo José Moyano Sánchez será adornado con el título de marqués de Caballero y conde de Villahermosa del Pinar; Luis de Arístegui, su hermano político, se titulaba conde de Mirasol y el citado Tomás Moyano Rodríguez de Toro, amén de ser marqués de Inicio, suma el de conde de Rebolledo que, por paradojas del destino, es el título que distinguía a la familia Bocos Quijada-Cano Cano, antepasados directos de César Medina, comprador de la citada casa del Obispo Buenaventura Moyano. Actualmente dicho título le posee, desde 1977, D. Tomás Moyano y Bonel.

${ }^{852}$ La vivienda comentada, por ejemplo, titulada escrituralmente como "la grande del Obispo", pasa a manos del magistrado Esteban Moyano, sobrino del obispo. A su muerte la hereda su hijo Pedro Moyano Sánchez, vecino de Madrid, casado con Josefa Rodríguez de Toro. En 1910, por no extenderse en más detalles, será Tomás Moyano Rodríguez de Toro, marqués de Inicio, hijo de los anteriores y también vecino de Madrid, el que se la vende a César Medina Bocos. Similar destino, tienen el resto de sus bienes rústicos y urbanos, sea mediante la venta a sus primos de la villa, sea, como ocurriera con "el lagar del Obispo" y otras heredades, a otros pudientes hacendados locales. El lagar y bodega "llamado del señor Obispo", sito en la calle de la iglesia, será adjudicado, tras la muerte del prelado, a su sobrina, hija de Francisco Moyano, María Ana Moyano, casada con Gregorio Barahona, también magistrado en Valladolid. Al no tener hijos, sus bienes se reparten entre sobrinos, correspondiendo este lagar y bodega a Francisco Ortiz de Paz Moyano, vecino de La Seca y, cuando este muere, a su sobrina Ma Carmen Moyano y Sánchez, en pago de haber sido una de las tres herederas del finado, que se lo vende a Canuto de Castro en el año 1892 y éste le adjudica en 1908, junto a otras fincas, a su hijo Benito de Castro Rueda. Tras la muerte de éste la propiedad familiar pasará a la familia de Castro Bocos quien la detenta hasta 2013 en que se la venden a la familia Esteban de Íscar (A.R.P.M.C.).

${ }^{853}$ En el norte de la Tierra de Medina, estos son los términos y lugares que se catastran en 1752: Término del Despoblado de La Moya: “..Dijeron llamarse este lugar de la Moya; hallarse despoblado; ser tierra y jurisdicción de la villa de Olmedo... Dijeron ser de realengo y el corregidor de la villa de Olmedo nombra a su alcalde.... Dijeron que este dicho lugar despoblado tiene de zircunferenzia quatro leguas y media; y de lebante a poniente una legua; y del norte al sur tres quartos de legua, a ora por legua... Dijeron que las espezies de tierras que en dicho lugar despoblado son de secano de pan llebar y viñedos, entendiéndose que las de secano lo son de al año y vez, con uno de intervalo de descanso, y las de viñedo sin intermisión...Dijeron que no hay arboleda alguna en dicho término..."

Término de San Martín del Monte: "Dijeron que se llama esta villa San Martín del Monte... Dijeron que esta villa es de señorio y perteneze al Real Convento de santa María la Mayor, horden de Santa Clara de la Villa de Tordesillas....Dijeron que tiene el término de la villa de levante a poniente medio quarto de legua, poco más o menos. $Y$ del norte al sur tiene media legua. Y de zircunferencia tendrá legua y media poco más o menos.... Dijeron que hay una obrada sembrada de ortaliza, y que las demás tierras son labrantías de secano..."

Término de Serrada: "Dijeron que esta poblazión se llama la villa de Serrada, tierra de la de Olmedo... Dijeron ser esta referida villa de señorío, y perteneze al marqués de Torreblanca, vezino de la ciudad de Valladolid... Dijeron que a su entender y juizio prudenzial, el término de esta villa tiene de zircunferencia quatro leguas; de zircunferenzia, digo, de lebante a poniente zinco quartos de legua, y del norte al sur media legua... Dijeron que las espezies de tierras de que se compone el término en esta expresada villa son de secano, tierras de pan llevar, viñedos, prados, un poco de pinar, heras, un poco de huerto de hortaliza, y un pedazito de minbreral, sin haber heriales, matorrales, ni otra espezie..."(A.G.S. Catastro de Ensenada, Respuestas Generales, cajas 648 y 649). 
Nava, Rueda y La Seca son los nuevos motores de este cambio. A diferencia de Serrada, sus vecinos labran amplias superficies de tierras sernas para plantarlas de vińedo. Por si fuera poco esta villa, salvo en La Vega y tierras adyacentes del marqués, los rendimientos de cosechas eran inferiores a las recogidas en los términos de Ventosa, Rodilana, La Seca, Pozaldez o Rueda, donde en sus mayores términos abundaban pagos de mayor calidad. Aunque en estos lugares buena parte del terrazgo está obligado al pago del correspondiente canon a Medina, la realidad fue que su cuantía no fue tan elevada como la exigida en Serrada por el señor de la villa. De hecho, la justicia absuelve en muchas ocasiones a sernistas de estos pueblos, tanto por plantaciones ilegales, como por impagos de rentas.

Estas consideraciones, entre otros factores, son vitales para entender el crecimiento del número de vecinos en estos lugares. Como se ha citado, el Censo que se lleva a cabo en Castilla en el año 1591, fija en La Moya cuatro vecinos; en San Martín del Monte quince; en Serrada 36 vecinos, de los que 32 son pecheros, 3 son hidalgos y el resto pertenece al orden clerical. Un crecimiento muy menguado en relación a principios del siglo, pero perfectamente explicado por cuanto se ha referido. La expansión que vive la Tierra de Medina en la primera mitad del XVI tan sólo parece llegar muy atenuada a este apartado lugar de Olmedo. La Seca, por ejemplo, alcanza en estas fechas 426 vecinos; Rueda, 251; Pozaldez, 231; Matapozuelos, 267 y Ventosa, 80 vecinos.

\section{a. El crecimiento de población y su reflejo en el casco urbano}

En la primera mitad del XVII Castilla se sumerge en una profunda crisis económica y demográfica. El hundimiento ferial medinense repercute en toda la Tierra. La primera mitad de centuria resulta catastrófica a nivel económico y demográfico. Es en la segunda mitad, especialmente en estos pueblos, donde el auge de plantaciones, al calor de la extraordinaria calidad y fama de sus blancos, sienta las bases de un nuevo despegue demográfico. Cuando en 1675 se lleva a cabo un padrón con motivo de la compra del derecho de villazgo por Diego Ruiz de Montalvo, se anotan en Serrada 76 casas abiertas y 242 almas que las habitan ${ }^{854}$. La recién titulada villa inicia, de esta manera, una proyección demográfica al alza que no tendrá vuelta atrás. El crecimiento de producción agraria es, sin duda, la base de la expansión demográfica. Piénsese que, en torno a 1680-1690, se recogen en la villa alrededor de 4.000 fanegas de cereales anuales, entre trigo, cebada y centeno; una década más tarde, se superan las $6.000 \mathrm{y}$, a finales del primer tercio del siglo XVIII, se mantienen unas cosechas superiores a las 8.000 fanegas anuales ${ }^{855}$.

El cultivo del viñedo refleja, con mayor intensidad, el crecimiento que se anticipó en el siglo XVIII. La expansión vitícola es verdaderamente espectacular. De hecho el vino hace caer la producción de centeno, al dedicar el terrazgo de tercera donde se asienta este cultivo al trigo. Valga señalar que, si entre 1700 y 1730 las cosechas de caldos se sitúan entre las 20.000 y 17.000 cántaras, en el último tercio del mismo, aun cuando se aprecia una contracción del cultivo en otras zonas, en Serrada se superan las 45.000 cántaras. La atracción por el cultivo influye en la llegada de nuevos vecinos, en la construcción de las importantes casas granjas regentadas por religiosos y, en consecuencia, en un importante crecimiento de la masa de jornaleros que trabajan tales heredades y que todos, cada uno en su medida, contribuyen a la expansión de la villa, reflejándose dicho crecimiento en la propia expansión del casco urbano.

Respecto al crecimiento histórico, las distintas aureolas de crecimiento tienen como centro la iglesia, a la plaza y las casas del concejo. Aunque en un principio se puede pensar que tal expansión se adapta a distintas cercas defensivas o de control mercantil, al no haber encontrado documentación al respecto, nos pronunciamos con cautela en este sentido. Lo que sí se puede apuntar es que, entre

${ }^{854}$ A.M.S. Privilegio de Villazgo, fol. 102-112.

${ }^{855}$ A. Marcos Martín: El crecimiento agrario castellano del siglo XVIII en el movimiento de larga duración. ¿¿Mito o realidad?, en "Estructuras agrarias y Reformismo Ilustrado en la España del siglo XVIII", Segovia, 1988, pág. 148. 
los ańos 1500 y 1600, Serrada crece de los veinte a los treinta vecinos aproximadamente, que en cifras totales, respectivamente, no van más allá de los 70 a 100 habitantes. De ahí la importancia que en líneas anteriores se seńalaba al computarse 242 almas en el recuento que se hace con motivo de la venta del privilegio de villazgo en 1675 . El crecimiento tendrá unas repercusiones directas en el propio casco urbano, limitado hasta entonces a las casas asentadas en torno a la casa del Concejo, la iglesia, la calle Real y la calle del Pozo Bueno. Como puede apreciarse en las figuras adjuntas, en las que se ha incluido su evolución hasta la actualidad, el casco inicial crece a costa de las eras del concejo desde la segunda mitad del siglo XX. Hasta entonces, y la imagen de la vista parcial del casco urbano de 1956 es muy ilustrativa, las casas se alineaban en torno a las calles dejando las salidas de corrales y pajares en la parte posterior, por donde entraban, por las traseras, tanto el ganado de labor como el fruto de las cosechas.

Como puede observarse, el espacio a las traseras de la calle Real fue ocupándose, de norte a sur, por el Barrio Nuevo, desde finales del XVII y durante el siglo XVIII, pero hasta entonces, al poniente, al norte y nordeste, se extienden importantes superficies de eras, propiedad del Concejo, que sirven tanto para ser aprovechadas para pasto por ovejas, cerdos o vacas como en el estío para el desgrane de mieses.

En este sentido, de acuerdo a escrituras notariales fechadas en 1575, se conoce que estas calles limitan en sus bordes exteriores, y en ocasiones, en su interior, con solares y cercas de los principales labradores. En dicho año, por ejemplo, Elvira de Rojas, viuda de Francisco de Rojas, vende a Francisco Blanco, una "tierra cercada de tapial que hará media obrada" y que linda con cercas de Juan de Elvira y de Juan de Íscar y Francisco Alonso; en 1598, por citar otro caso, Esteban Gutiérrez vende a Blas Blanco unas casas "con sus corrales" en la calle Real, "que tiene por linderos de la una parte casas de Francisco Blanco y por otra parte corrales de Alonso Casado y la calle que llaman de la Acilla". Es pues, desde la cabecera del Barrionuevo siguiendo la calle que corta la calle real dirigiéndose al Pozo Bueno hasta el camino de Valdestillas, el límite histórico septentrional; por el este, desde el último punto mencionado, bajando hasta la calle del Arroyo y la plazuela del Rollo, y dejando en los bordes del camino de Matapozuelos a Valdestillas, lugares más insanos y húmedos por la cercanía de prados y arroyos, el espacio donde la clase jornalera irá levantando humildes moradas en la calle del Porro o "camino que va a Matapozuelos" y la del "camino a Tordesillas". Se trata, pues, de un crecimiento diferenciado, tanto espacial como socialmente.

Las cifras antes apuntadas de cosechas de cereales y vinos no eran caprichosas. Parejas a su importancia se levantan nuevos casas, se aumentan los espacios de cuadras y paneras y se abren nuevas bodegas. Desde mediados del XVII a mediados del XVIII, se configura de forma plena un casco histórico que apenas varía en su estructura general hasta mediados del siglo XX. Es fácil señalar el perímetro dentro del cual han vivido los pequeños y medianos labradores. El subsuelo delata la expansión vitícola de la que se habla. Y los testamentos de sus hombres, el lugar que ocuparon sus bodegas, lagares, paneras y cubas. Francisco de Rojas deja, en 1592, una casa con su bodega, "dos cubas viejas, que hace una ocho moyos, y la otra cinco, que fueron tasadas en quatro ducados ${ }^{356 / 857}$. Deja también constancia, entre otros muchos bienes, de "cien cántaras de bino encubado que se vendió a cinco reales la cántara" y una casa lagar que tiene un poco de corral.

Desde estas tempranas fechas en Serrada, lo mismo que en la Seca, Matapozuelos, Rueda o tantos otros pueblos, abundan en los tratos escriturados las cubas, aranzadas, bodegas y vinos que se compran y se venden. En 1630, por poner otro ejemplo, entre los bienes que quedan de Juan Alonso se encuentran, amén de majuelos, bueyes y tierras, "una bodega soterrana que tiene nueve tinaxas pequeñas e grandes questa en este lugar que linda con casa de Juan Tomé...”. Desde estas fechas hasta 1750 aproximadamente, se levantan las principales casas que hoy se conocen y se horada la práctica totalidad de las bodegas con que cuenta la población.

${ }^{856}$ A.H.P.V. Pt. 11840 , fol. 257.

${ }^{857}$ A.H.P.V. Pt. 11836. 

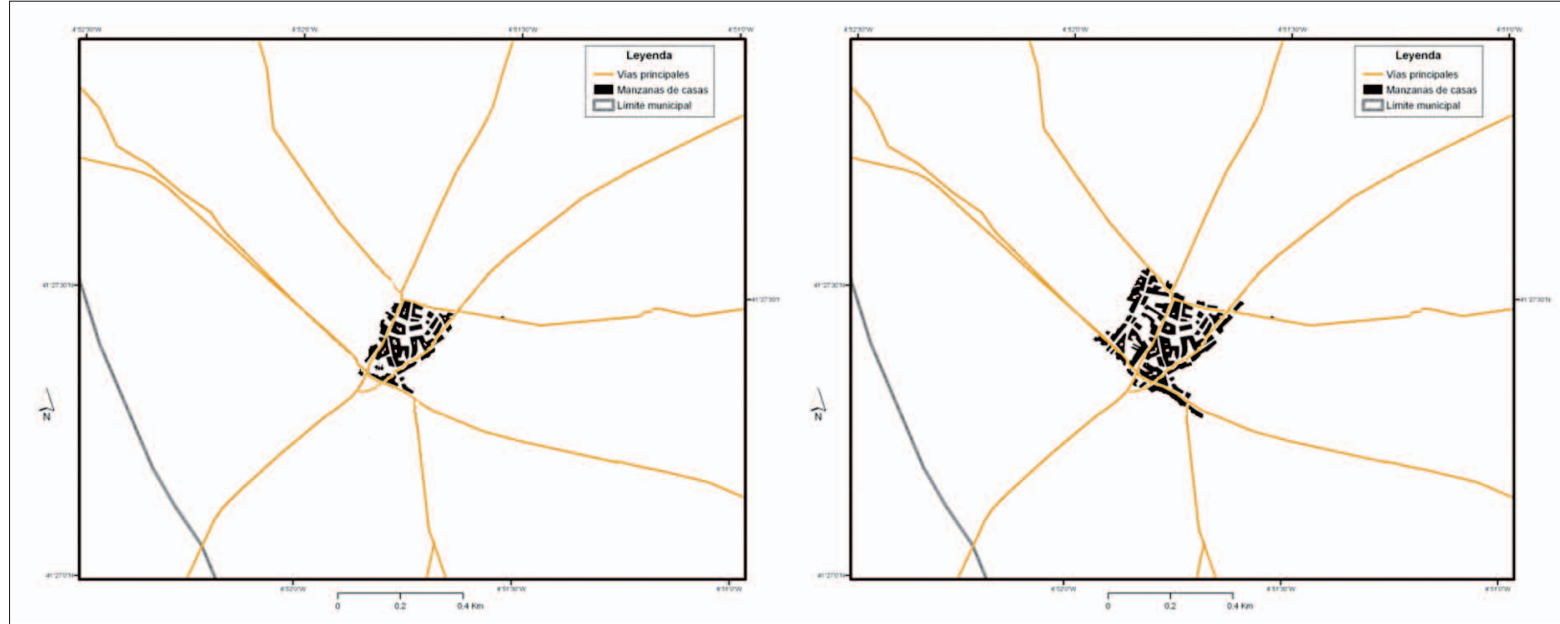

Estimación del casco urbano de Serrada a mediados del siglo XVII (izquierda) y XVIII (derecha).
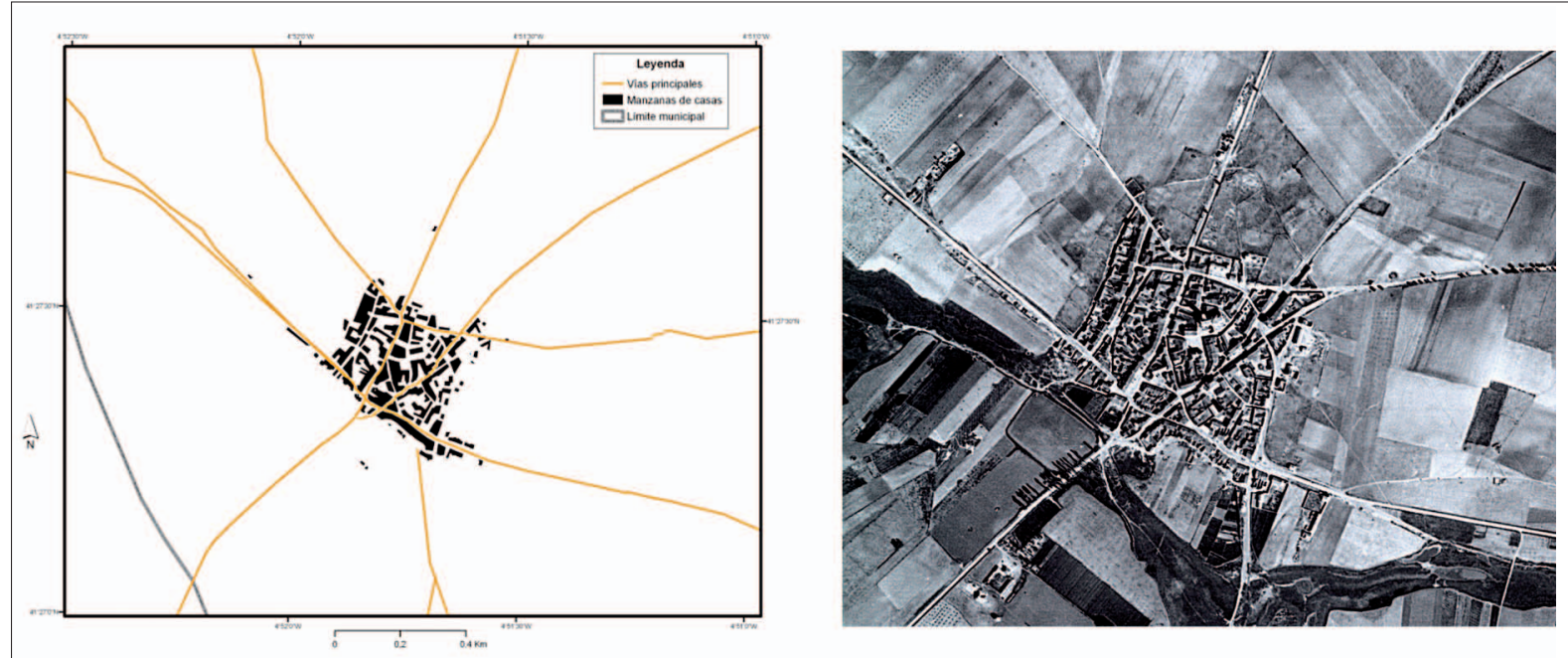

Estimación del casco urbano a mediados del siglo XX (izquierda) y foto aérea de 1957 (derecha).
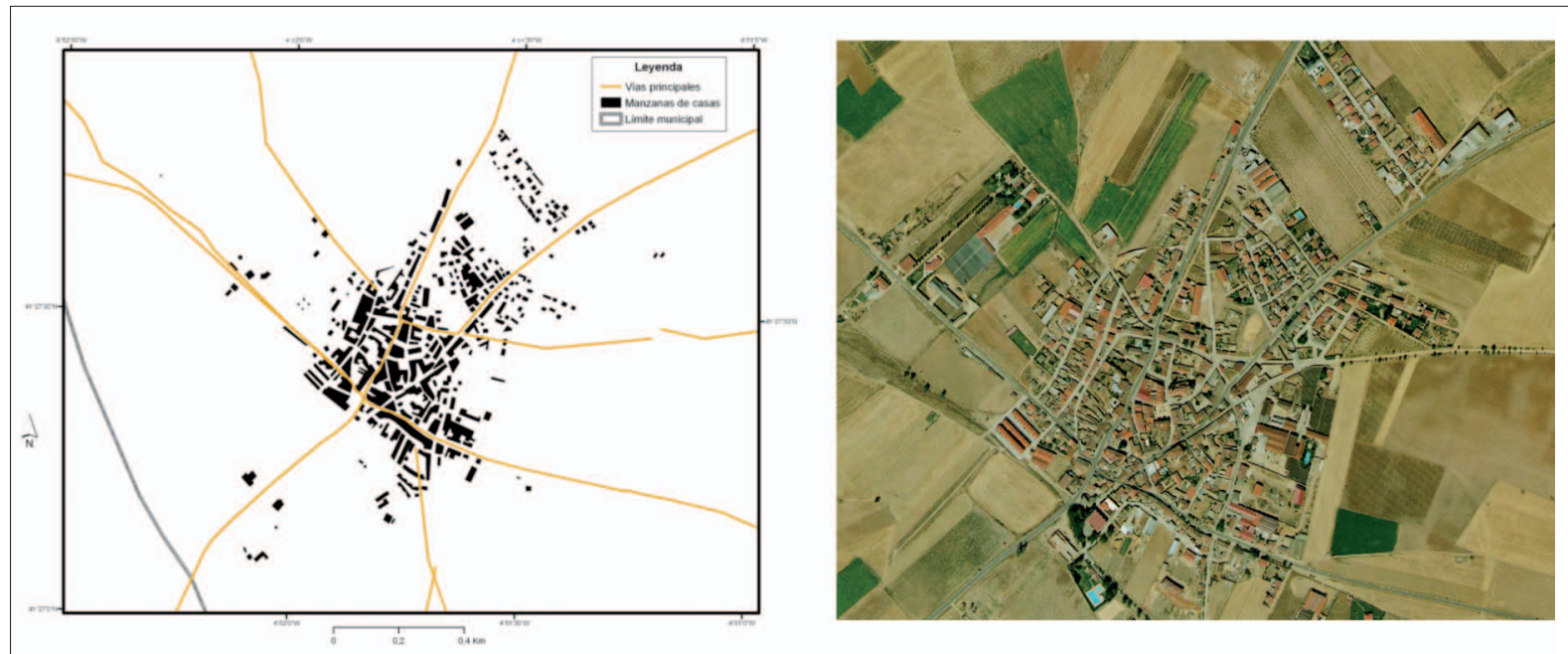

Casco urbano de Serrada en 2012 (izquierda) y foto aérea de 2000, (derecha, fuente: J.C. y L.).

Figura 27. Estimación del crecimiento del casco urbano de Serrada a mediados del siglo XVII, XVIII, XIX y en la actualidad. Fuente: Protocolos Notariales (A.H.P.V.); Catastro de Ensenada, Respuestas Particulares (A.G.S.); Planos y cartografia (A.M.S.). Elaboración propia. 


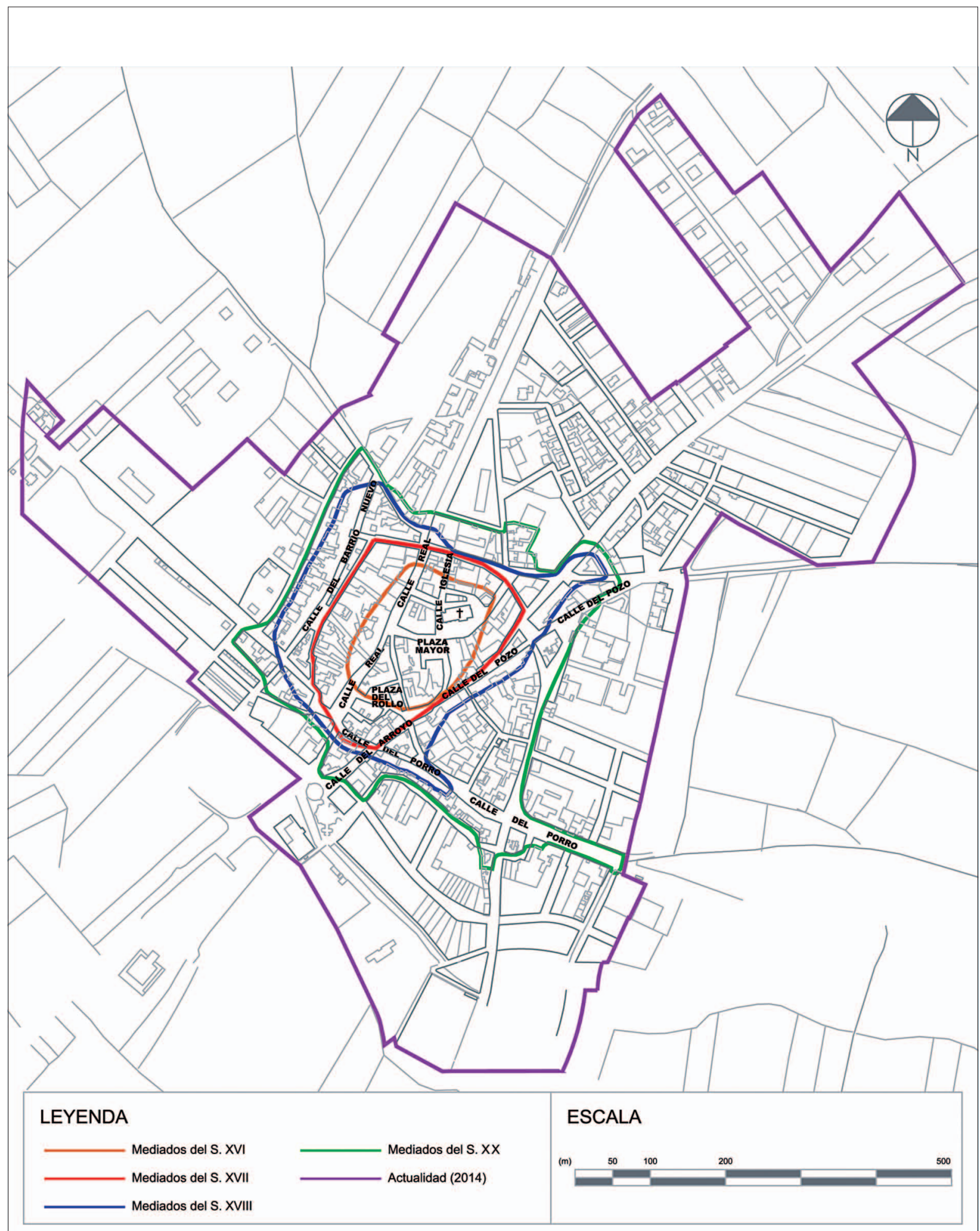

Figura 28. Detalle de las aureolas de crecimiento del casco urbano de Serrada sobre el plano actual. Analizando pormenorizadamente el crecimiento urbano local, en relación a las anteriores figuras, puede observarse que hasta mediados del siglo XX el espacio edificado se ordena de forma concéntrica en torno a la Plaza Mayor, dejando al norte y oeste amplios espacios de eras, imprescindibles para el desgrane de mieses hasta la llegada de la mecanización. En las últimas décadas del siglo XX, y en el presente siglo XXI, el crecimiento ha desbordado dicho terrazgo hasta englobar tierras de cultivo y prados, diversificando tipos de viviendas, usos de suelo y materiales utilizados en las distintas construcciones, tal como puede comprobarse en las imágenes que siguen. Agradecemos a Dolores Manso, arquitecto municipal de Serrada, su colaboración en la definición de la presente figura. 

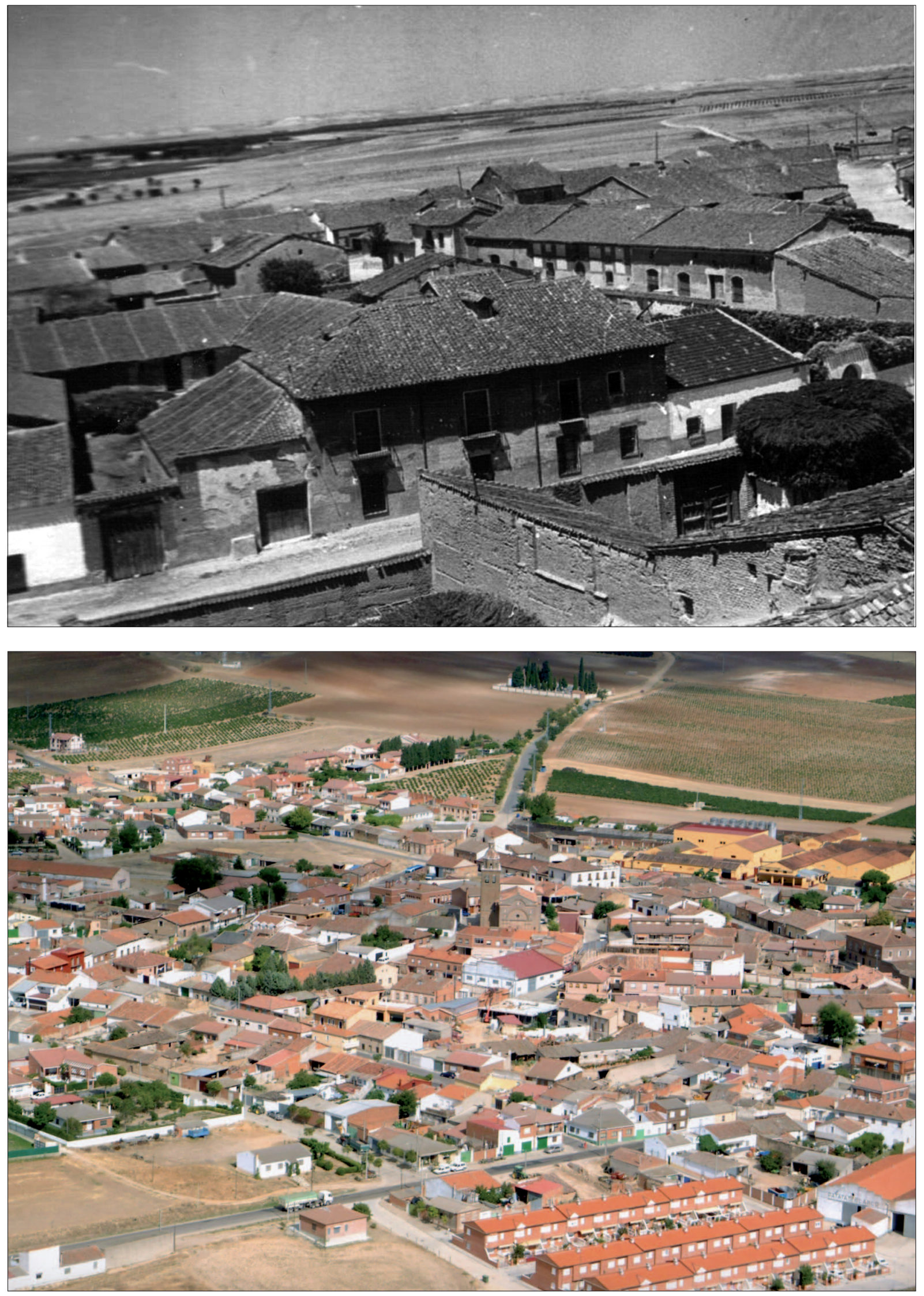

Imagen 72. Vista parcial del casco urbano de Serrada en el año 1956 (arriba, foto: familia Magro de Castro) y vista aérea en 2005 (abajo, foto familia Martín Santos). Hasta mediados del siglo XX la construcción y disposición de las viviendas apenas sufre modificaciones, más allá de las diferencias entre las clases sociales y actividades de sus propietarios. Obsérvese, en la imagen superior, las casas de los labradores, en las que paneras, cuadras, pajares y tenadas se ordenan en torno al corral situado tras la vivienda. 
El Catastro del Marqués de la Ensenada de 1752 es la mejor radiografía histórica de Serrada, de San Martín del Monte, La Moya y de tantas otras aldeas o villas castellanas. En esta fecha Serrada cuenta con 150 vecinos, de los que 24 son viudas y de ellas 13 pobres de solemnidad. La población se reparte entre 145 casas de las que 136 son habitables. El Censo de Floridablanca de 1787 eleva la población a la importante cifra de 842 almas. ${ }^{858} \mathrm{El}$ auge del vino ha conseguido triplicar el número de vecinos en poco más de un siglo. Las consecuencias sobre el espacio edificado no se han hecho esperar. A los labradores de siempre, se suman las casas conventuales que, desde fines del XVII, han comprado tierras para levantar casas y excavar bodegas, viviendas con lagares y cubas e importantes haciendas de tierras y viñas. Si los treinta labradores de esta fecha ocupan las calles que antes se han mencionado, los sesenta y seis jornaleros, los veintiséis mozos de labranza y los muchos pobres de solemnidad se han de conformar con ocupar los pequeńos huecos entre las casas de labranza, pero, sobre todo, atendiendo a sus posibilidades, ampliando casas y casuchas a lo largo de las también mencionadas calle que va a Matapozuelos, camino de Tordesillas, Arroyo, Cañadilla y sus transversales. Las figuras adjuntas son elocuentes por sí mismas. Basta comprobar el lugar de su emplazamiento, la superficie que ocupan, la existencia de colgadizos, sus paneras y demás infraestructuras.

Pero como ya se ha dicho, en Serrada, en esta época, catastran bienes el Convento de Santa Brígida, con su casa granja conventual en la calle Real, donde poseía una bodega con cuatro cubas; el de San Pablo, que en la segunda mitad del XVII había levantado una importante casa alta y baja y horadado una impresionante bodega con cuatro lagares, 42 cubas y seis cubetos; el convento de la Trinidad Descalza, con otras quince cubas en su casa y bodega al Pozo Bueno, la casa y bodega del Convento de la Encarnación en el mismo barrio... Si a esto se suman las importantes casas y haciendas de presbíteros, capellanes y otros religiosos, se comprende el gran cambio que se vive en términos económicos y demográficos a mediados del XVIII. El mercado del vino había despertado gran interés por cuanto tuviera relación con cepas y cubas. Aunque a continuación se tratará con detenimiento esta etapa, desde el punto de vista urbanístico, el casco urbano gana en solidez y presencia. No hay más razones que las que las que se derivan de vendimias bien fermentadas y de las sacas de vino a buenos precios que los arrieros llevan a la montańa o a los mercados comarcanos próximos.

Las casas, bodegas, paneras y símbolos adjuntos son el legado que ha dejado el pasado religioso y el próspero negocio de los caldos en esta villa. Detrás de cada una de ellas hay una historia diferente, hayan sido sus poseedores marqueses, clérigos o campesinos. Este trabajo podría extenderse sin límite estudiando cada una de las casas, bodegas, paneras o corrales y sorprendería la larga historia que atesoran, las variadas manos por las que han pasado o los cambios que han sufrido a lo largo del tiempo. Como tal empresa resultaría demasiado prolija, se ha optado por analizar algunos ejemplos como muestra de esta evolución, cuyas repercusiones llegan a nuestros días ${ }^{859}$.

\section{- Las casas, lagares, bodegas y paneras de los labradores locales}

Como las anteriores construcciones analizadas, las haciendas de los labradores son testigo de la propia evolución del casco urbano. Han crecido y, en ocasiones, también desaparecido, siguiendo el pulso de la propia historia ${ }^{860}$. En el siglo XVI y primera mitad del XVII, se hilvana todo un entramado de casas, corrales, paneras, lagares y bodegas que conforman lo que se puede llamar el núcleo más

\footnotetext{
${ }^{858}$ Censo de 1787 "Floridablanca”. INE, Submeseta Norte, parte occidental, pág. 2579 y ss.

${ }^{859}$ Para su mejor comprensión, se ha creído conveniente superar en el tiempo los límites cronológicos de esta Edad Moderna, pues el siglo XIX es determinante en esta evolución de la propiedad, por los efectos derivados del proceso desamortizador.

${ }^{860}$ Cuanto se está tratando en estos epígrafes podría conformar una publicación independiente, pero, de momento, basten estos ejemplos para darse cuenta del proceso de crecimiento del propio casco urbano, vinculado siempre a los avatares de las cosechas y de la propia vida.
} 
antiguo de la villa. A lo largo de la segunda mitad del XVII y primera mitad del XVIII, aprovechando la ya estudiada expansión vitícola, se extienden estas edificaciones por sus bordes, ocupando de norte a sur el "Barrio Nuevo" y los caminos de salida a Matapozuelos, La Seca y Tordesillas, para acabar de definir su crecimiento a lo largo del XIX. Las casas principales de las familias labradoras, aunque van ampliando sus instalaciones al tiempo que crecen sus labranzas y necesidades, permanecen, salvo excepciones, en torno a sus primeras ubicaciones, reedificándose sobre sí mismas o ampliándose en los espacios abiertos de sus corrales y ejidos anexos. El barrio en torno a la iglesia y el que se extiende desde esta al Pozo Bueno son sus lugares preferentes de ubicación. Las razones no son otras que sus saneadas condiciones para la edificación, libre de acuíferos superficiales y adecuado subsuelo para excavar bodegas. Un ejemplo entre muchos es el caso de Francisco de Rojas y de su mujer Agustina Recio. Cuando fallecen, a fines del siglo XVI, ya dejan, en la calle "que se lleba para la Iglesia," una casa con bodega y corrales, la mitad de un lagar, cuatro bueyes, cuatro yeguas, varias cubas y bienes raíces abundantes ${ }^{861}$. Este preferente asentamiento no impide que se vayan alzando otras edificaciones a las salidas de los caminos que conducen a los pueblos cercanos. Es el caso de las casas que compra Epocial López a Francisco Alonso en 1614, "que están en el dicho lugar, como se ba a la villa de Valdestillas..." "362. En 1630, Juan Alonso deja, a su muerte, una casa "que está en linde del camino real que ba deste lugar a la villa de Matapozuelos" $\$ 63$, pero en este caso, dada la cota topográfica más baja y la cercanía al arroyo y manto freático, la bodega y los caldos los mantiene en otro lugar más saneado ${ }^{864}$. De hecho, no faltan casos de cañones y lagares compartidos por unos y otros, que integran toda una laboriosa y compleja red subterránea de bodegas, que fueron evolucionando al tiempo que la demanda de caldos. La venta otorgada por el religioso de los clérigos menores Joseph Martín, a Manuel Alonso Navarro en 1741 es sólo un ejemplo: ${ }^{865}$

“...Un cañón de bodega y en él un vaso de roble usual y corriente, y hueco para otro questa en las casas de herederos de Pedro de Castro que lindan, por una parte, con casas del Beneficiado y, por otra, con casas de herederos de Simón de Castro y calle que va a la Iglesia, cuia bodega se divide en tres cañones de distintos dueños, con la entrada común para todos, y el que le vendo está a mano derecha de la escalera principal, con puerta de red, separado a dichos cañones según y cómo le compré a los herederos de Francisco de Pedrosa y María García, vecinos que fueron desta dicha villa, con todas sus entradas y salidas, usos, costumbres y servidumbres...".

Como tantas veces se ha repetido, es en esta segunda mitad del XVII y primeras décadas del XVIII, de la mano de la expansión vitícola, cuando se asiste a un crecimiento, sin precedentes, del número de casas, lagares y bodegas, sea por labradores locales o religiosos e inversores llegados de fuera $^{866}$. De hecho es el espacio a poniente, y de norte a sur, donde se entremezclan familias labradoras

${ }^{861}$ A.H.P.V. Pt. 11844, fol. 257.

${ }^{862}$ A.H.P.V. Pt. 11857, fol. 38.

${ }^{863}$ A.H.P.V. Pt. 14071 , fol. 2.

${ }^{864} \mathrm{El}$ testador manifiesta tener "una bodega soterraña que tiene nueve tinaxas pequeñas y grandes questa en este lugar que linda con casa de Juan Tomé y con corral de Juan Alonso." (Ibídem, fol. 4.)

865 A.H.P.V. Pt. 8215, fol. 217.

${ }^{866}$ Las particiones hereditarias y las compraventas de estos bienes generarán todo un complejo entramado de servidumbres y salidas o usos. Cuando en la actualidad surgen preguntas sobre la disposición de muchos de estos cańones o el encuentro de restos de construcciones subterráneas, nada mejor que acudir al pasado para explicar su procedencia. Un ejemplo es la venta que otorgó en 1747 Cristóbal Juárez, vecino de Serrada, a su hijo, en que se precisaban estas cuestiones: Se vendía "Un cañón de bodega, con una cuba de roble usual y corriente que tengo en la casa de mi morada y en la calle que va della al Pozo Bueno, y linda por una parte con casa de herederos de Joaquín Alonso, y por otra con casa del Convento del orden de la Trinidad Descalza de la ciudad de Valladolid, con todas sus entradas y salidas... y no queriendo usar de ellas, le daré puerta a dicha calle con la entrada separada a dicha bodega... en prezio y quantía de doscientos y cincuenta reales de vellón...” 
con pequeños propietarios necesitados de estos espacios ${ }^{867}$. A mediados del XVIII, salvando vacíos y cercas propiedad de los más pudientes, este crecimiento ya ha llegado al camino de Tordesillas. Nada mejor que conocer los términos de venta de una casa acordada en septiembre de 1755, entre Miguel Alonso y Carlos Aragón, para darse cuenta de esta expansión urbana ${ }^{868}$ :

"Una media casa que tengo mía propia en esta dicha villa y calle que llaman del Varrio Nuevo, que linda por una parte con otra mitad que corresponde a Antonio García, natural desta dicha villa; por otra con camino que va della a la de Tordesillas; por otra con la plazuela que llaman dela Fragua Vieja... en prezio y quantía de ziento ochenta y zinco reales de vellón...”

Por este tiempo, conforme avanza el siglo XVIII, sigue habiendo constancia de la ampliación de bodegas y de la construcción de nuevos lagares. Francisco Moyano acuerda en 1803, con un vecino de Rueda, la fábrica de uno de ellos para su hermana Rosa Moyano. Los términos del acuerdo son los siguientes ${ }^{869}$ :

"Un lagar de viga a Don Francisco Moyano, vecino de esta villa, que se ha de fabricar en el casco de ella y casa de Dońa Rosa Moyano, su hermana, compuesto de un cuerpo de veinte pies en quadro, algo más o menos, su lagareta y pilón, todo según la extensión con que se edifique, siendo de mi cuenta asentar con masilla dos vizmeras y una pilita en el pilón, todo de mi cuenta y riesgo, de piedra que también de mi quenta se sacará en la cantería de las canteras de Bercero a esta villa, labrado y asentado a toda satisfacción y buena usanza en estas obras, todo lo qual daré por concluido quince días antes de la próxima vendimia...”

En estos años de comienzos del XIX estas construcciones responden más a necesidades familiares por particiones y herencias que a la demanda del mercado, próximo a contraerse por la crisis que se vive en el primer tercio del nuevo siglo. De hecho, los hacendados que se acaba de mencionar, hermanos del obispo Buenaventura y el ministro Tomás Moyano, terminan de dividirse los bienes de sus padres Miguel Moyano y Beatriz Rodríguez, entre los cuales figuraba la casa y bodega principal, sita en la plazuela del Rollo, y que describen detalladamente, antes de proceder a su división en dos partes proporcionales ${ }^{870}$ :

"Una casa sita en esta villa y Plazuela, o calle que llaman del Rollo, con su lagar de viga, corrales, cuadras, paxar, orno, bodega, colgadizos y varias obras nuevas a la parte de entre oriente y norte. Linda por la puerta principal con dicha plazuela; por el costado derecho con calle que baxa a la cilla desde la calle Real, por el izquierdo con una callegita por donde se sale a la calle Real desde dicha Plazuela; y por la parte accesoria linda con dicha calle Real que ba, o es camino recto desde La Seca a Valladolid"

Los repartos hereditarios, sumados a las compraventas y demás transmisiones, van parcelando las propiedades iniciales para acomodo de distintos herederos, muchos de los cuales siguen teniendo

${ }^{867}$ Es en este "Barrio nuevo" donde abundan, junto a lagares de viga y piedra, otros "pequeños de mano".

868 A.H.P.V. Pt. 8218, fol. 76.

${ }^{869}$ A.H.P.V. Pt. 8228, año 1803, fol. 1.

${ }^{870} \mathrm{Si}$ se abunda en la reproducción de estos extractos documentales es porque reflejan con exactitud la evolución del crecimiento. De hecho, en este caso, se puede comprobar que toda una manzana o, a falta de precisar algún detalle, casi toda, bien ubicada en el conjunto urbano, pertenece a una de las familias más distinguidas del siglo XVIII, que, a su vez, se asienta y se había reedificado y engrandecido sobre otra más antigua. Baste comprobar los términos de la división que afectará a esta propiedad: "Esta casa se divide y a de dividir, para que puedan ser dos: una abaxo, que es la viexa; y otra arriba, en la parte o costado, que ba dicho; linda con la calle que baja a la cilla, la qual división se ha de hacer tirando una línea desde el punto en que remata por la parte del corral la pared de la despensa de la casa vieja entre su ventana y la puerta de una cuadra, que hay allí lindando hasta tropezar con el orno viexo, dexando salbo todo este para la parte de arriba, continuando la línea por donde está seńalado en la pared donde está el asiento de la artesa de cerner a salir a la calle Real...”. (A.H.P.V. Pt. 8228, año 1802, fol. 62 y ss.). 
la tierra como fuente de sustento, necesitando, por tanto, de paneras para guardar el trigo, cuadras donde cobijar ganados y bodegas donde fermentar mostos. Basta entrar, a modo de ejemplo, en alguna de estas casas de labradores de hace dos y tres siglos.

\section{- Ejemplos del acomodo de las familias labradoras}

En las figuras anteriores que reflejan el crecimiento del casco urbano la diferenciación socioeconómica y espacial de los vecinos que residen en sus calles es evidente. Las calles de la iglesia, la parte media y alta de la calle Real, el barrio del Pozo Bueno y la parte alta del Barrio Nuevo eran los emplazamientos más apetecidos por los labradores más pudientes. A los espacios edificados para vivienda se han de añadir dependencias adjuntas a toda buena labranza que se precie, tales como paneras, lagares, cuadras, pajares, palomares, tenadas y corrales, para guarda, recreo de ganados y otros usos.

En el Barrio Nuevo, al menos desde el siglo XVII, la familia del Castillo Alonso dispone de casa de labranza con bodega y lagar y a mediados del XVIII nos consta la vivienda y bodega de Francisco Hinojal; en la primera mitad del XIX, en fin, se traslada el pudiente Gregorio León Alonso para dar desahogo a las necesidades de su labranza... Su yerno Modesto de Castro, casado con su hija Micaela, suma, como ya se tendrá tiempo de comprobar en posteriores capítulos, no pocos bienes urbanos en la propia calle Real y Plaza Mayor. Las imágenes adjuntas testimonian la sólida y bella traza arquitectónica de las dos viviendas más distinguidas de las que fue poseedor ${ }^{871}$.

En el entorno de la iglesia, por citar otro espacio en que se alzan de forma temprana importantes casas labradoras, Juan Antonio Moyano y su mujer Bentura Alonso ocupan buena parte de la manzana que se extiende entre la calle de la iglesia saliendo a la eras y la calle Real ${ }^{872}$. Disponían por debajo de ella de "una bodega compuesta de tres cañones: el uno de sesenta pies de largo y treze de ancho $y$ alto; otro de veinte y nuebe de largo y doze de ancho y alto, y el otro de veinte y cinco de largo, doze de ancho y largo, con una zarzera en cada uno, con su escalera que se comunica a todos ${ }^{2873}$. La partición de los bienes que suma esta labranza se computa en 1788 en decenas de miles de reales. No es necesario apuntar lo abultado de sus bienes muebles y raíces.

A estas viviendas debemos añadir las levantadas, desde fechas muy tempranas, en las calles que suben al Pozo Bueno. Al tiempo que lugar de labradores, son también sitio preferente de asentamiento religioso. En los siglos XVII y XVIII, están en esta calle emplazadas las casas conventuales de los dominicos de San Pablo, Trinitarios Calzados, casa de la Encarnación, Hospital General, Trinitarios Descalzos y las casas de las capellanías de Rodríguez Zorrilla y Diego de Llanos ${ }^{874}$. La mayor parte de estas, o las tierras, cercas, solares, o casillas menores que ocupan estos terrenos habían pertenecido a jornaleros y labradores que serán los que las vuelvan a adquirir tras el proceso de desamortización que se vive a lo largo del XIX.

\footnotetext{
${ }^{871}$ La que se señala sita en la Plaza Mayor se corresponde con la propiedad actual de los herederos de Clímaco de Íscar. Esta casa, con bodega, lagar, paneras, cuadras y otras dependencias, será heredada en 1860 por Cástor de Castro, hijo de los anteriormente citados Modesto y Micaela y, cuando muere en 1871, es heredada por Fabián de Castro. Al instituir como única heredera a Mauricia Arranz y dividirse la propiedad por séptimas partes entre sus herederos, será adquirida posteriormente por la familia propietaria actual. La casa propiedad de los herederos de Víctor de Castro perteneció igualmente al mencionado Modesto de Castro y estaba compuesta, igualmente, por varias dependencias, bodega, colgadizos y corral. A su muerte la adquiere su hijo Canuto de Castro, que la lega a su heredero Víctor de Castro Rueda en 1909. Tras ser comprada por su hermano Benito de Castro, casado con Pilar Bocos, la vivienda pasará, al fallecimiento de esta en 1924, a propiedad de Víctor de Castro Bocos. (A.R.P.M.C.).

${ }^{872} \mathrm{La}$ casa fue tasada por sus herederos en el año 1788, en 16.275 reales y la bodega, en 2.280 , cifras veinte y treinta veces superiores a las anotadas en las compraventas de las casas jornaleras. (A.H.P.V. Pt. 8224, fol. 731 y ss.).

${ }^{873}$ Ibídem.

${ }^{874}$ A.H.P.V. Hacienda, Libros 278 y 279.
} 


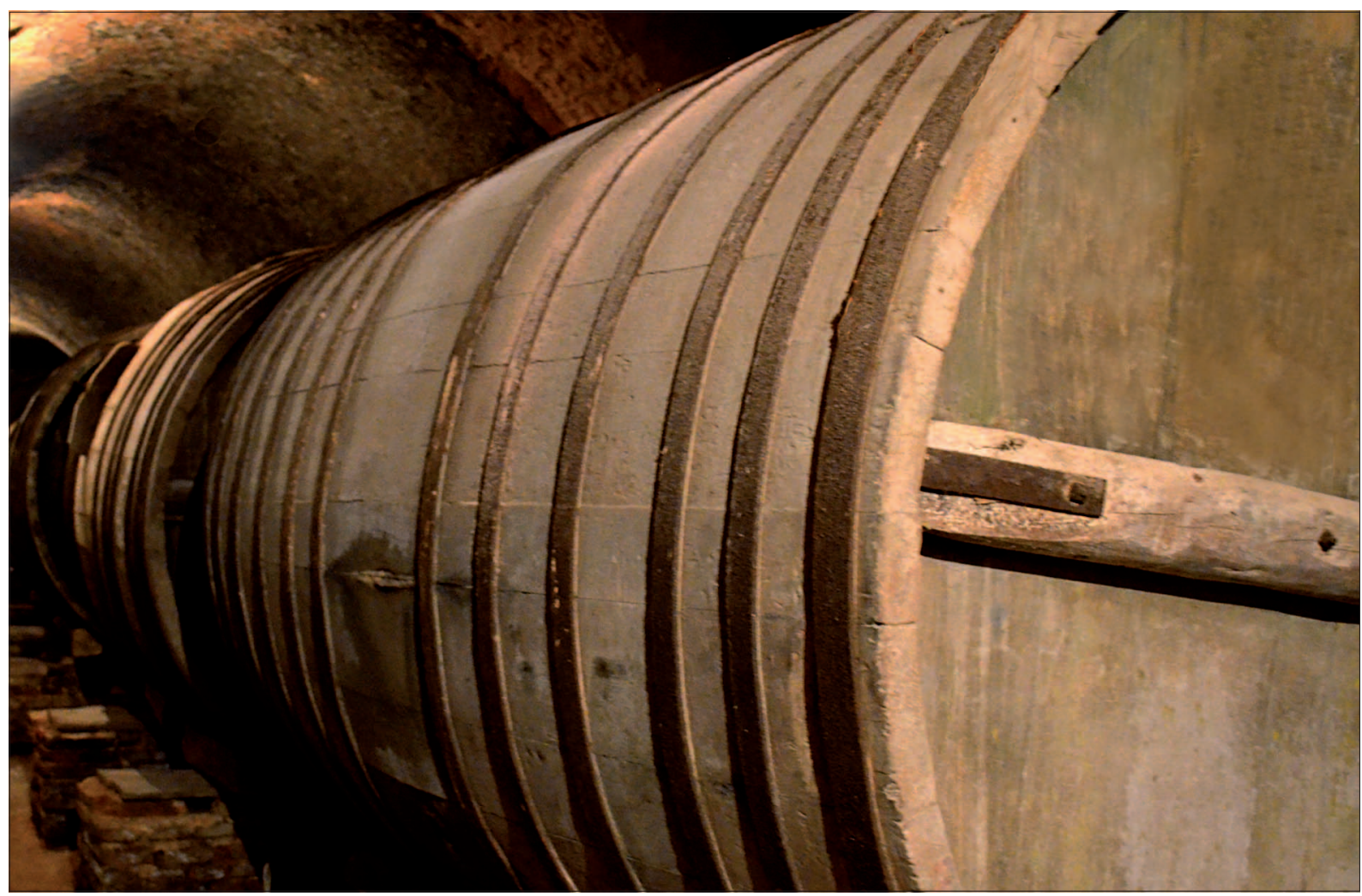

Imagen 73. Cuba de roble, enarcada de aros de hierro y asentada sobre poinos de madera, a la manera tradicional. Foto. 01/08/2014. El trabajo de los maestros cuberos, tanto en la construcción de las cubas como en su asentamiento en las bodegas ha sido muy cuidadoso y delicado, tanto en la selección de la madera como en el ensamblaje de la misma, al objeto de garantizar la buena fermentación y conservación de los mostos.

Unas u otras, en fin, son centro de importantes haciendas, con abundantes propiedades de tierras de pan y vino, fácil de advertir y comprobar tanto por su arquitectura como por sus abundantes bienes muebles, descritos de forma precisa en los inventarios particionales de sus propietarios. Otro ejemplo es la propiedad de la familia Alonso Capellán, también ubicada en la calle del Pozo (hoy Medina de Castro) que, a tenor de las trazas arquitectónicas de su lagar y bodega, no hay duda de que, fueran laicos o eclesiásticos sus propietarios, disponían de una sólida labranza. Como importante era en pasados siglos la labranza de la familia Moyano Zamora, moradores de la casa propiedad de la familia Díez Román ${ }^{875}$. Colindante por el mediodía, se extendían los Trinitarios Descalzos, compradores, como ya se ha estudiado anteriormente, de varias casas a la derecha de dicha calle del Pozo, actual Antonio Medina, conforme se sale a la plaza de San Pablo ${ }^{876}$. Estas propiedades, poseídas actualmente por la familia Alonso Gutiérrez, fueron desamortizadas y poseídas a lo largo de la segunda mitad del XIX por las familias Obregón Juárez y Fadrique Juárez ${ }^{877}$.

${ }^{875}$ Esta casa que, a mediados del XIX "linda por la derecha según se entra a poniente y por la espalda a mediodía con casa y corral de Patricio Obregón y por la izquierda a oriente con calle de la Cañadilla”, la hereda en 1855 y 1862 Petra Moyano Zamora de sus padres, Ventura Moyano e Inocencia Zamora. Avecindada en Valladolid, venderá la propiedad a su hermano Francisco Moyano Zamora, casado con Josefa Obregón Rodríguez, en 1881 (sus iniciales figuran aun en la puerta de entrada de dicha casa), y sus herederos acabarán vendiendo dicha propiedad en 1950 a Alberto Gutiérrez Estébanez. Heredada por Dalmacio Gutiérrez, será permutada por bienes rústicos a la actual familia propietaria. (A.R.P.M.C.)

${ }^{876}$ Se trata, en concreto, del sector urbano ocupado por las actuales viviendas de las familias Gutiérrez Alonso, Díez Román, Alonso Capellán, Gutiérrez Gutiérrez, Nieto Lubeiro, Maroto Aparicio y Gutiérrez Fernández.

${ }^{877}$ La subasta de estas casas, en los números catorce y quince de la calle del Pozo, tiene lugar en 1844. La ubicada en el no 14, por ejemplo, lindaba por el costado derecho con una casa que pertenecía al mismo convento de la Trinidad; por el izquierdo, con la casa de Buenaventura Moyano "y con calle de la Cañadilla a la que tiene puerta carretera y por su 

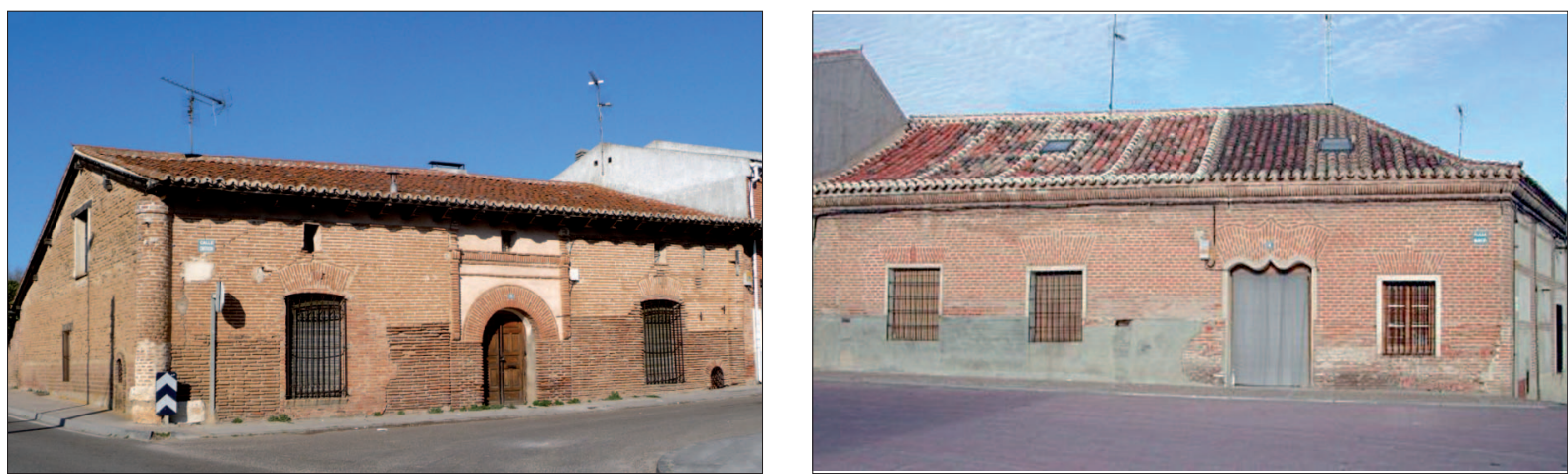

La Calle Real (izquierda, casa de la familia De Castro, hoy propiedad de las familia De Castro Bocos izquierda, y la Plaza del Concejo (hoy Plaza Mayor, casa de la familia De Castro, hoy familia De Íscar Alonso, derecha) fueron centro de la vida municipal desde el origen del pueblo.
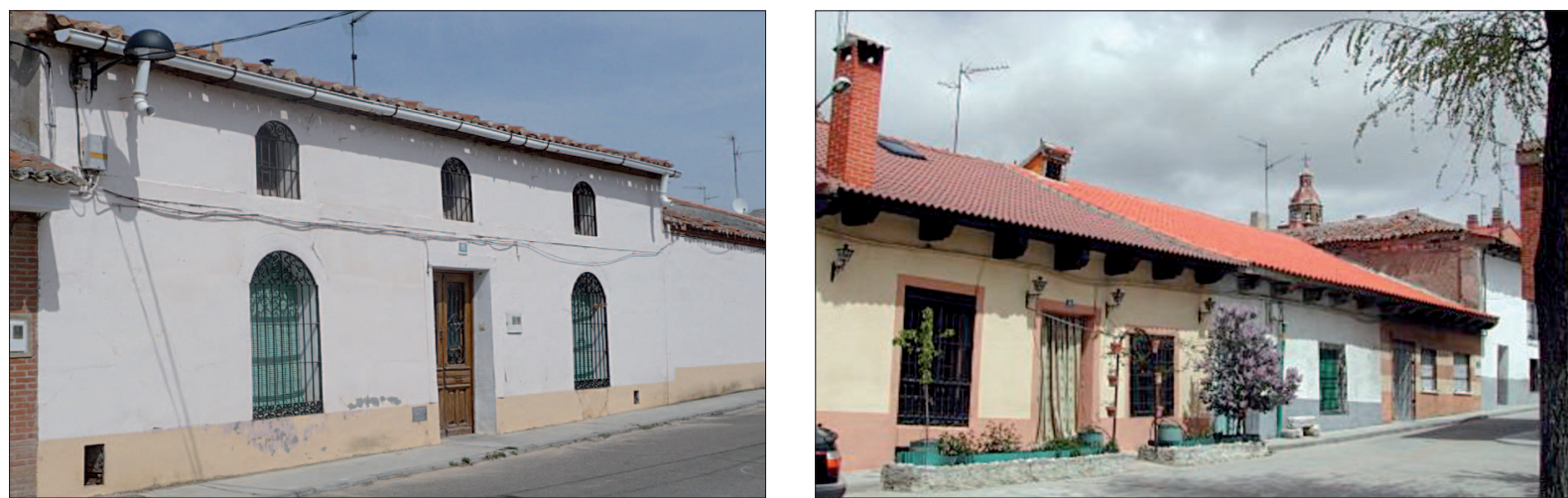

La calle de La iglesia (casa de la familia Alonso Moyano, izquierda) y la Plaza del Rollo, (casa de la familia Moyano Rodríguez, hoy familias De Îscar Obregón e Hinojal de Íscar) fueron ocupadas desde siglos muy tempranos.

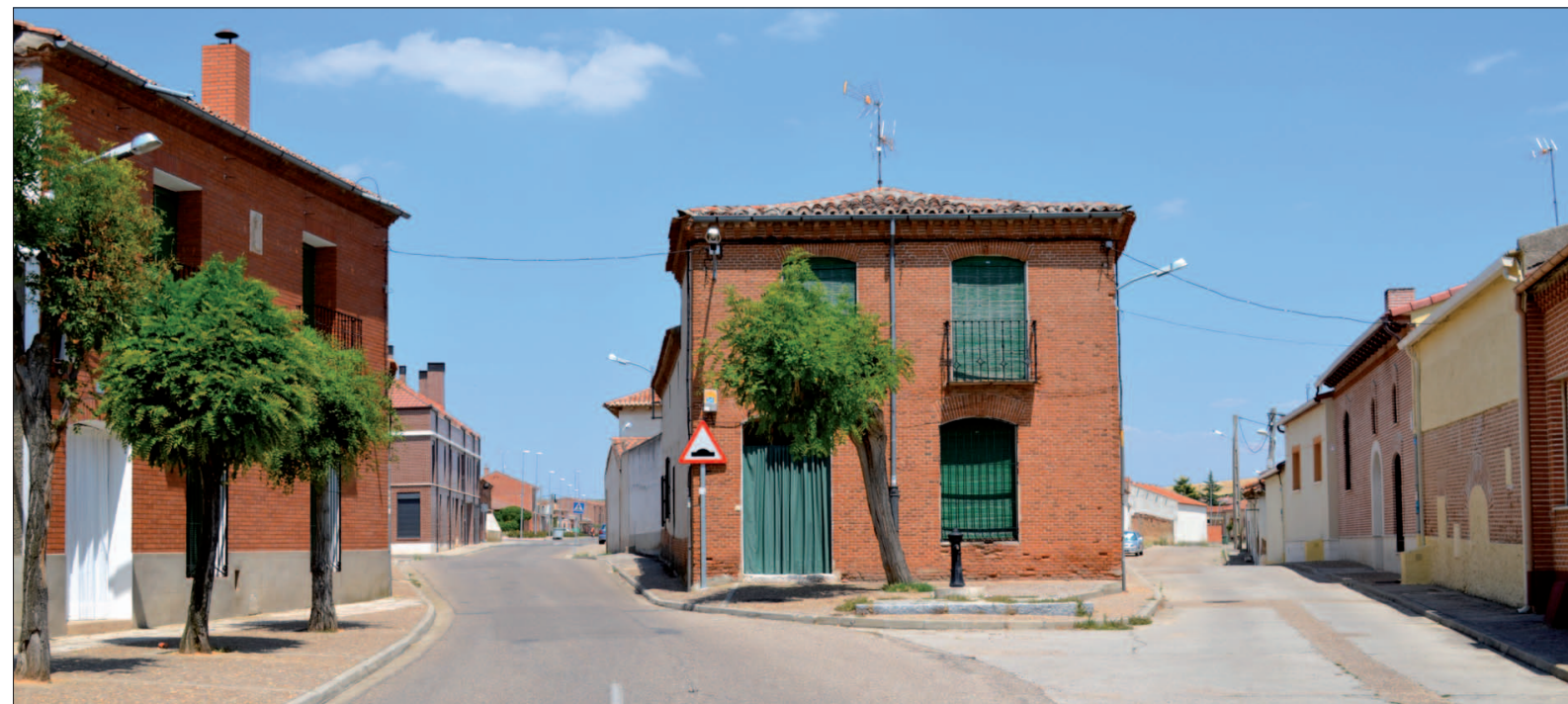

La calle del Pozo (hoy Antonio Medina), fue, además de asentamiento de casas conventuales, preferente ubicación de familias labradoras: casa de la familia Moyano, izquierda, hoy propiedad familia Gutiérrez Gutiérrez; familia Alonso, centro, hoy propiedad Alonso Capellán y Moyano Zamora y Obregón, derecha, hoy propiedad familia Díez Román. Foto: 25/07/2014.

Imagen 74. Ejemplos de viviendas del siglo XVIII, propiedad de familias labradoras, en Serrada. Obsérvese, en todas ellas, la existencia de zarceras que evidencian la existencia de bodegas asociadas a la actividad vitícola. 


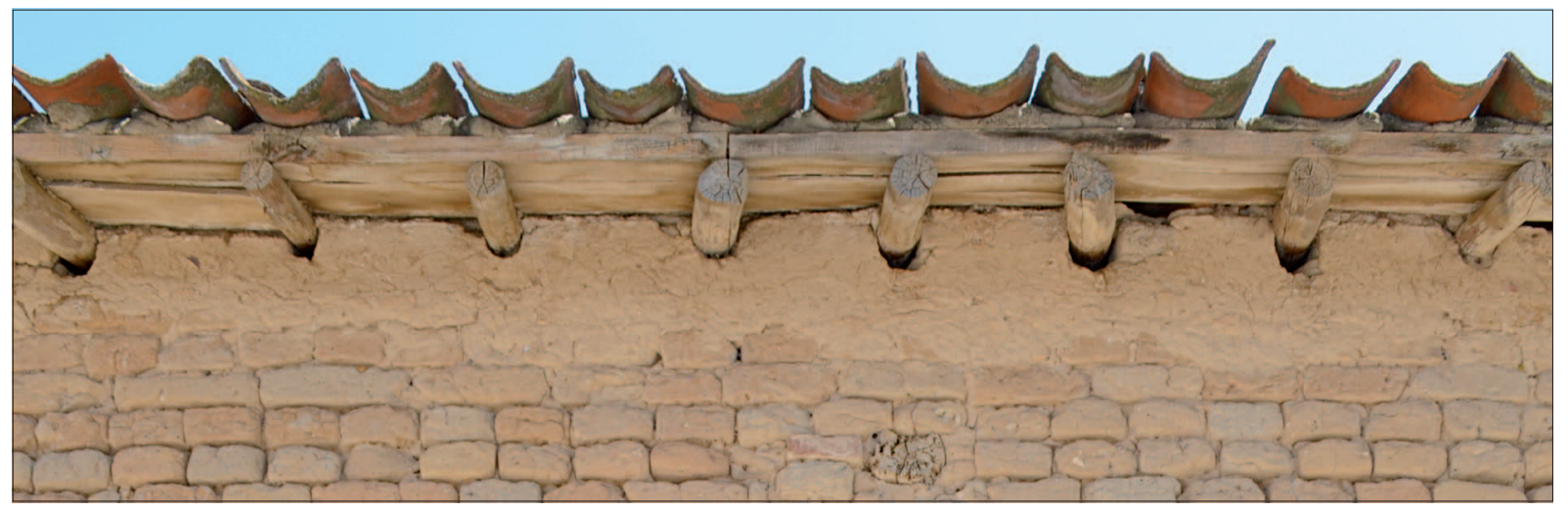

Detalle de la parte superior de un colgadizo en las traseras del Barrio Nuevo. Foto: 25/07/2014.

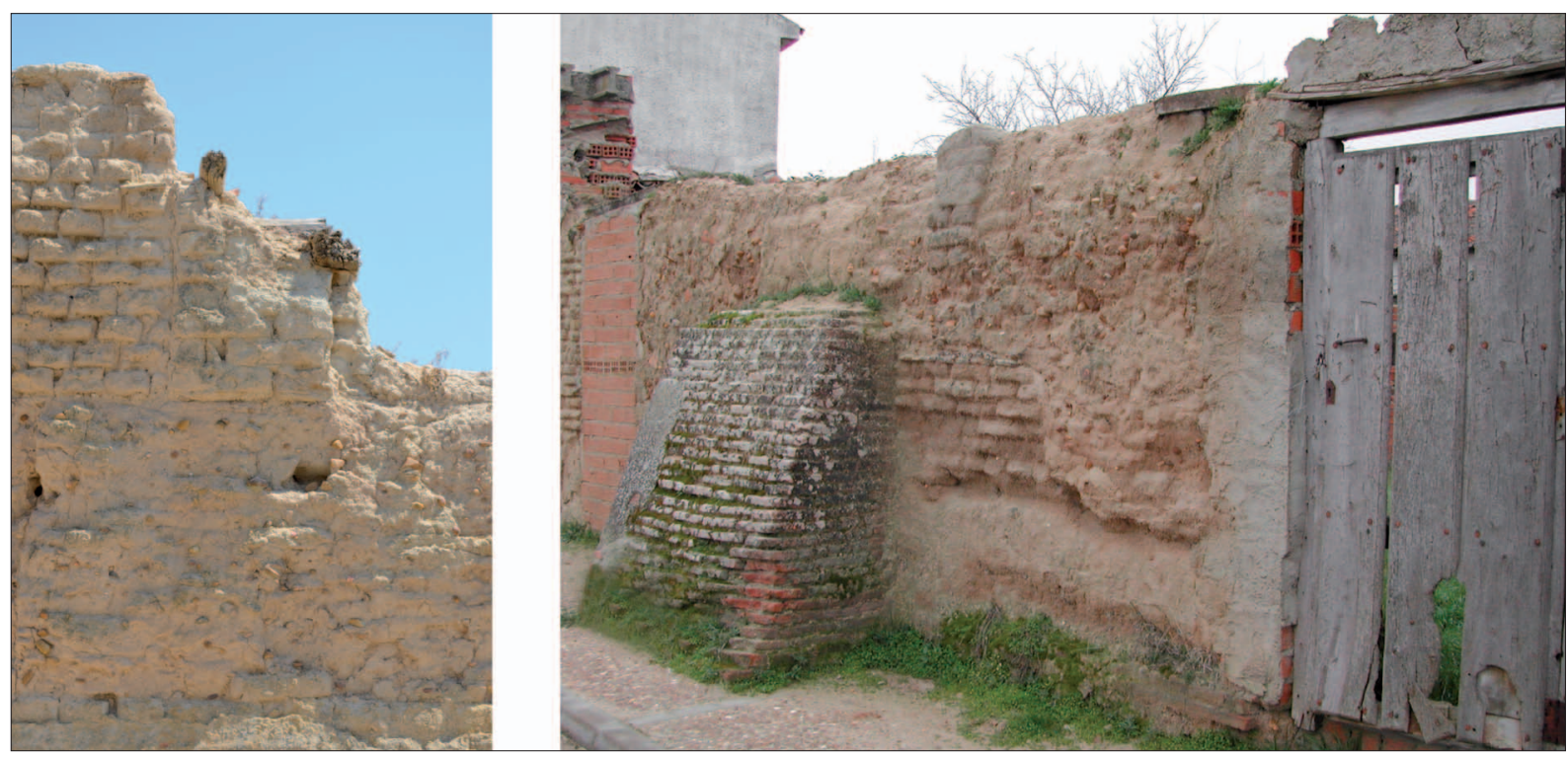

Pared de tapial y adobe (izquierda) y zarcera de bodega y puerta accesoria de corral en el Barrio Nuevo. (Fotos: 25/07/2014 y 23/01/2001).

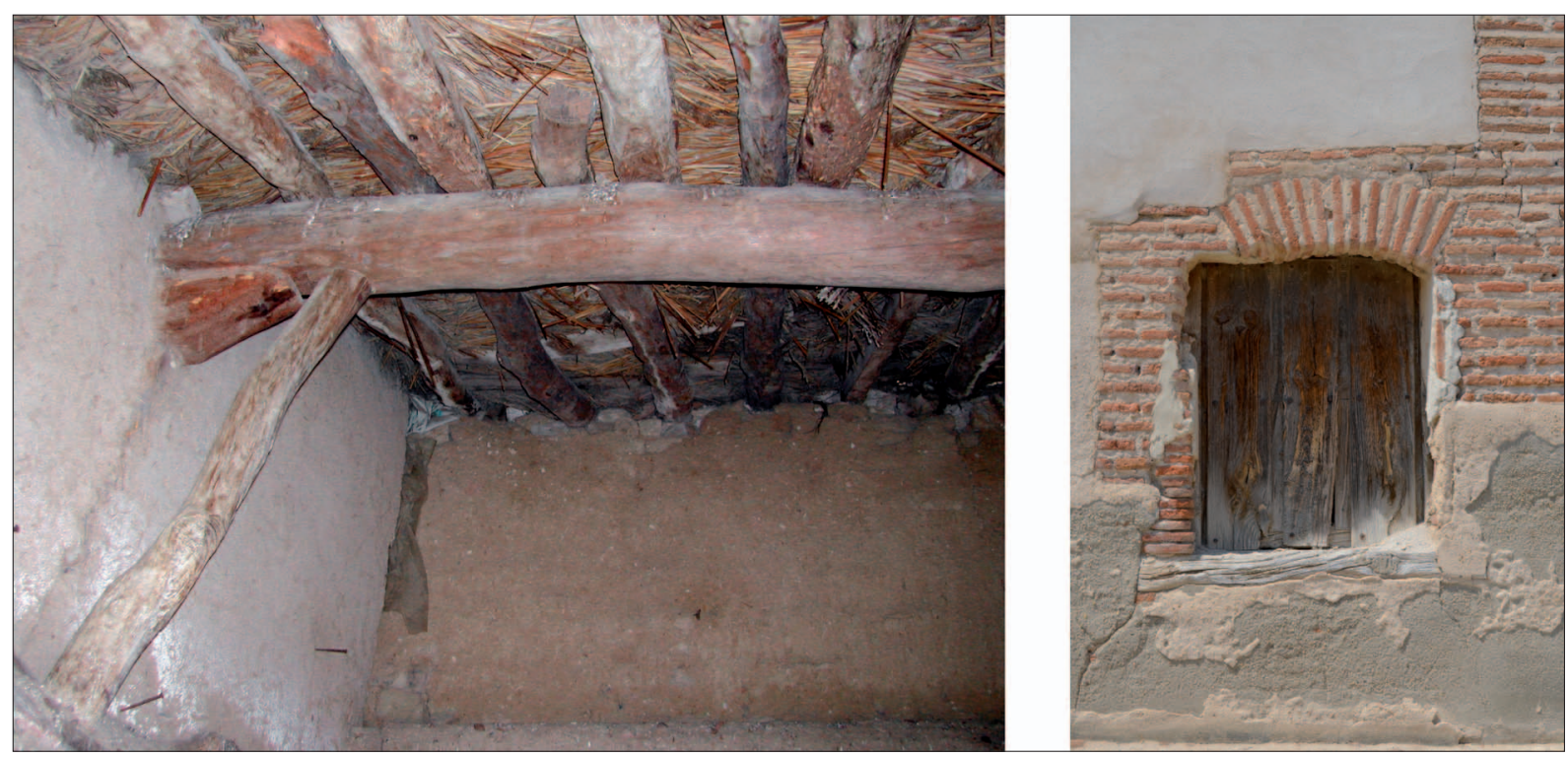

Pared de tapial y adobe (izquierda) y zarcera de bodega y puerta accesoria de corral en el Barrio Nuevo. (Fotos: 25/07/2014 y 23/01/2001).

Imagen 75. Ejemplos y detalles de construcciones con tapial, adobe, ladrillo y madera, elementos básicos en la construcción de estos siglos. 
El inventario de bienes dejado al fallecimiento de Patricio Obregón Román, marido de Petra Juárez Rodríguez, fechado en 1881, acerca con exactitud a las dependencias y bienes muebles de estas casas labradoras. Como ya es sabido, buena parte de su riqueza dormía en el silencio de sus cubas. En dicha fecha este labrador guardaba 1.500 cántaras de vino del año (24.000 litros), por un importe total de 3.375 pesetas). Así se tasan algunas de ellas: ${ }^{878}$

\footnotetext{
"Una cuba de catorce palmos, madera de roble, enarcada en hierro, en la bodega de la casa mortuoria, en el cañón grande de la derecha, la que toca con la cercera, tiene poínos de madera, valor doscientas cincuenta pesetas.

Otra cuba, la segunda del mismo seno, de catorce palmos enarcados en hierro, con poínos de madera, vale doscientas cincuenta pesetas...

Otra cuba, en el seno frente las escaleras, de catorce palmos enarcados en hierro, sobre poínos de madera, vale doscientas cincuenta pesetas..."
}

La riqueza que no eran caldos eran granos celosamente custodiados en las paneras. Como más adelante se tratará, conforme avance el siglo XIX los labradores se desesperaban al aguantar el trigo hasta el mes de abril y tener que venderlo sin apenas subida de precio. Los márgenes de ganancia, que tuvieron secularmente sus antepasados con estas estrategias, se desvanecen ante la revolución de los transportes y la llegada de granos extranjeros más baratos. Aun así, las paneras de la citada casa contenían las siguientes cantidades ${ }^{879}$ :

\footnotetext{
"Ciento veinticinco fanegas de trigo, tasadas a diez pesetas cada una; importan mil doscientas cincuenta pesetas. Setenta fanegas de cebada, tasadas a cinco pesetas cada una; importan trescientas cincuenta pesetas. Veinte fanegas de algarrobas, tasadas a cuatro pesetas, cincuenta céntimos cada una; importan noventa pesetas... Tres y media fanegas de garbanzos, a treinta pesetas cada una; importan ciento cinco pesetas.

Cien moyos de orujo empilonados, tasados cada uno a peseta, veinte y cinco céntimos; importan ciento veinte y cinco pesetas..."
}

Por si fuera poco, si importantes son las cubas y paneras, no menor valor tienen los animales de labor ${ }^{880}$ :

\footnotetext{
"Una mula llamada Comisaria, como de siete años de edad, pelo castaño, alzada la cuerda y dos dedos, vale setecientas cincuenta pesetas.

Otra mula llamada Leona, de la misma alzada, de dieciséis años de edad, pelo entrecano, vale doscientas cincuenta pesetas.

Una yegua llamada Mora, pelo negro, de dieciséis años de edad, alzada la cuerda, vale doscientas pesetas.

Un pollino viejo, capón de bastante alzada, pelo negro; vale sesenta y una peseta.

Un cerdo de cría, pequeño, vale cuarenta y una peseta."
}

Como vemos, las propias viviendas van en consonancia con la riqueza, distinción y propiedad de cada uno de sus dueńos, pero todas son descritas con su portal, salas, cocina, alacena, despensa y sobrado.

accesorio con tierra cercada que perteneció al mismo convento"(A.H.P.V. Hacienda, caja 1323, expediente 310). Su situación era de práctica ruina (B.O.P.V. de 8 de febrero de 1844, pág. 159), por lo que los primeros remates quedaron desiertos. La descripción de esta casa coincide de forma exacta con la que aparece registrada a nombre de Petra Juárez Rodríguez, por adjudicación y usufructo de su marido Patricio Obregón Román, a finales del siglo XIX. (A.R.P.M.C.). De hecho, su anotación registral es idéntica a la que figura en el cuaderno particional de los bienes dejados al fallecimiento del mencionado Patricio Obregón (A.H.P.V. Pt. 18037, año 1881, fol. 151.) por lo que, al coincidir distintas fuentes documentales escritas, no hay que dudar que se está ante las antiguas casas de licitada casa conventual.

\footnotetext{
${ }^{878}$ Ibídem, fol. 151.

${ }^{879}$ Ibídem, fol. 153

${ }^{880}$ Ibídem, fol. 151.
} 


\section{- Las viviendas de los jornaleros}

Adosadas a las anteriores, especialmente ocupando los requiebros de traseras, cercas y corrales, van levantándose las viviendas de la numerosa población jornalera. Conforme aumenta la población sus casas se asientan siguiendo los caminos de salida a Matapozuelos, La Seca y Tordesillas, toda vez que, por la parte norte, mucho más saludable para asentar casas, se extendían las eras del concejo, bien aireadas, muy soleadas y a salvo de escorrentías de tormentas veraniegas, reservadas, por todo ello, para la trilla en verano y el pasto el resto del año.

De esta manera, el espacio a lo largo de "la calle que va desta villa a Matapozuelos", por ejemplo, antes de ser nombrada como calle del Porro, será uno de los lugares de preferente y obligado asentamiento, sobre todo cuando se ocupen los márgenes inferiores del pequeño arroyo, que bajaba desde el camino de Valdestillas hasta el humedal del Soto, hoy ubicación del Parque del Encuentro y polideportivo ${ }^{881}$.

Tal como se señala en los gráficos adjuntos reproducidos en páginas anteriores, hay que imaginar este espacio libre de cualquier edificación, siguiendo el camino de Matapozuelos, lindante por el sur con la tierra del Bosque, propiedad del señor de la villa, entre el arroyo antedicho y la cańadilla, sujeto al ambiente insano de las charcas y arroyo principal. Por el norte, a su vez, llegaban las últimas cercas y corrales de los principales propietarios que se asentaban en la calle del Pozo, imponiendo, por tanto, un carácter marginal a este suelo. Piénsese, además, que las pequeñas casas que se fueron adjuntando con medianerías a lo largo de dicho camino se orientan al norte y no disponen de salida en su parte trasera, pues la servidumbre de El Bosque no se abre hasta los primeros años del siglo XX. Estas calles aparecen documentadas desde la segunda mitad del siglo XVII, a la par que la expansión vitícola. Sus dimensiones y valor en nada tienen que ver con las anteriores. Uno o dos cuartos, el portal y la cocina bastan para vivir a sus humildes propietarios que tienen, muchos de ellos, que meter al burro por el portal hasta llegar a la pequeńa cuadra en la parte trasera, ante la ausencia de puerta carretera en la parte del mediodía. Como ejemplos se pueden citar las ventas que acordaron en 1762 Francisco Hinojal en favor de su hermano Gregorio Hinojal y la casa que vende en 1763 Casilda de Mora a Gregorio Enrique ${ }^{882}$ :

"Una casa y corral que tengo mía propia y heredé de dichos mis padres, que está proindiviso con otra mitad propia de dicho comprador, sita en dicha villa y calle del Porro, que linda su puerta principal con dicha calle; por el costado derecho con casas de Manuel Díez; por el izquierdo con casa de Manuel Navarro, y por el corral con tierra llamada el bosque... por prezio y quantía de trescientos setenta reales."

"Una casa sita en el casco de esta villa, y calle que llaman del Porro, que linda por la puerta principal con la referida calle; por el costado derecho con casa de Juan Martín Navarro; por el izquierdo con otra de Gregorio Inoxal y por el corral con tierra llamada del bosque..."

${ }^{881}$ No se desea entrar, en esta obra de carácter general, en cuestiones toponímicas, pese al interés que pudieran suscitar. Como excepción, y en relación al nombre de las calles mencionadas, baste señalar que las denominaciones aluden siempre a usos del espacio, transito y ubicación espacial de lugares frecuentados. La "calle de la Iglesia", la "calle Real", la "calle del Pozo Bueno", "la plazuela del Rollo", la plazuela de San Pablo", "la calle de la cilla", la "calle de la carnicería", la "calle que sale a Matapozuelos", Tordesillas o Valladolid, la "calle que llevan los de la Seca a Valladolid", la calle que "sube del arroyo grande al Pozo Bueno" o "la que sale a Valdestillas", son las principales denominaciones. A mediados del siglo XVIII hay otras menores, de tránsito entre ellas, tales como "la calle de la golondrina", "calle de la fragua vieja" "calle que llaman del teso" o "la calle que llaman del troncho" donde si sitúan pequeñas viviendas de jornaleros. En 1755, por ejemplo, a la par que se encuentran casas que se compran y venden en la mencionada calle "que sale a Matapozuelos "o "llevan los de Tordesillas a Matapozuelos", aparecen otras con la denominación de "calle que llaman del Porro". Es el caso de la venta que otorga Casimiro Nieto a favor de Juan Martín, ambos vecinos de Serrada, en relación con "una casa nuestra propia, que tengo en esta dicha villa, y calle que llaman del Porro, en prezio y quantía de quinientos y sesenta reales...” (A.H.P.V. Pt. 8218, fol. 78).

${ }^{882}$ A.H.P.V. Pt. 8219, fols. 53-69. 
Sin precisar el número de jornaleros que las habitan, pues, por ejemplo, el catastro de 1752 anota muchos de ellos sin poseer vivienda alguna, son estas calles de El Porro y del Barrio Nuevo las que concentran la mayor parte ${ }^{883}$. A diferencia de las viviendas de los labradores, perfectamente inventariadas en los repartos hereditarios, en estas raras veces se anotan muebles o riquezas y, por el contrario, cuando sus titulares acuden ante el escribano, es casi siempre por lo forzado de la situación que atraviesan. El caso de Micaela Aparicio es un ejemplo, entre muchos, de pobreza jornalera: ${ }^{884}$

\footnotetext{
"Micaela Aparicio, biuda de Caetano Inojal, vezino que fue desta villa de Serrada, como madre tutora y curadora de mis hijos y del referido mi marido ante V.m.d., digo, soy pobre que no puedo alimentar a tres hijos que tengo de corta edad; y entre mis bienes que dicho mi marido dejó, es un solar de casa, lindero la que dejó el referido mi marido, y calle que va desta villa a la de Matapozuelos, y casa de Crisóstomo García, cuyo sitio le intento vender para socorrer a dichos mis hijos..."
}

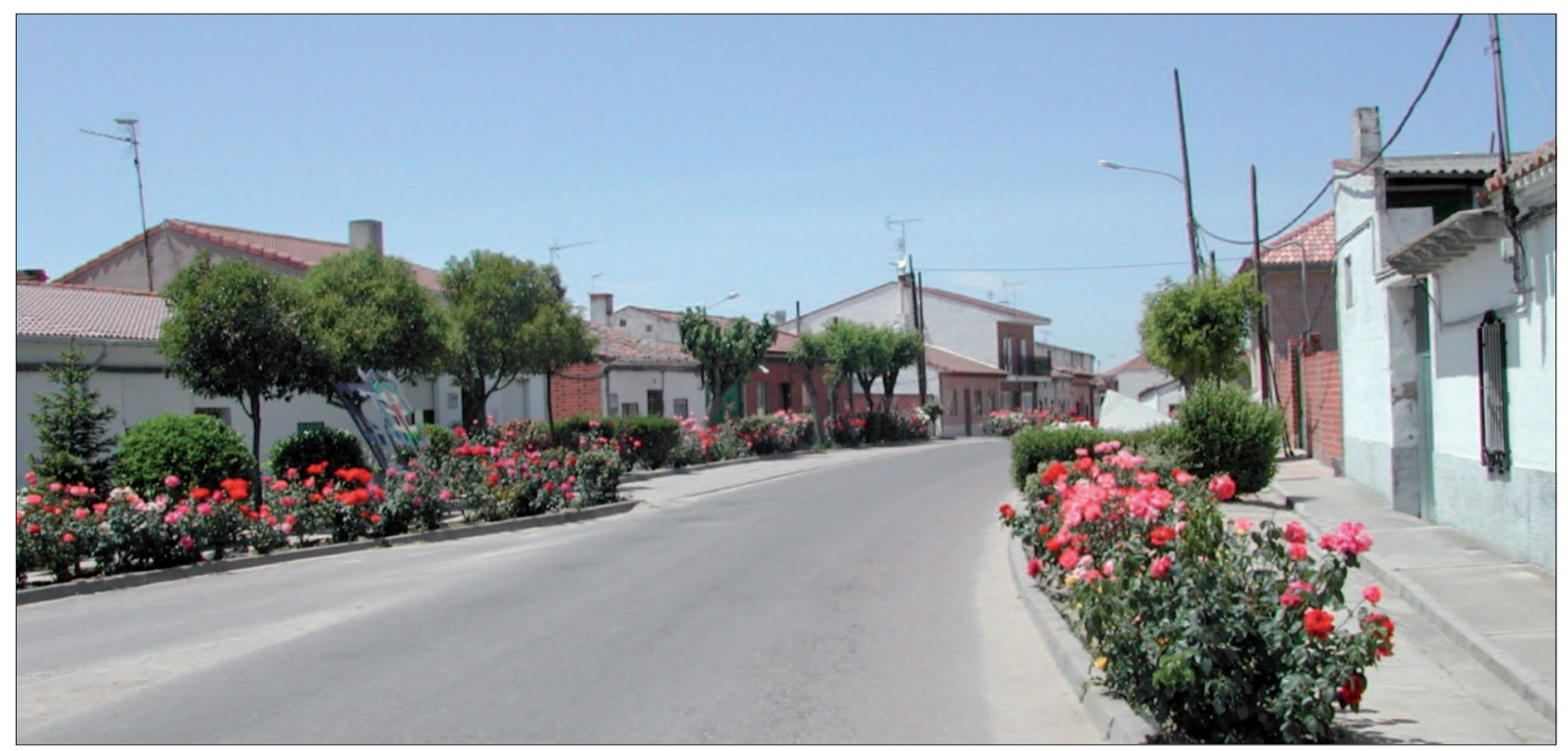

Imagen 76. Calle El Porro, de Serrada, tradicional asentamiento de familias jornaleras en el siglo XVIII, Foto: junio de 2006.

No es necesario apuntar, por último, que entre las dimensiones de las construcciones de los hacendados y estas últimas, existe toda una variedad de corrales, bodegas, paneras y viviendas. Todos los ejemplos derivan de repartos hereditarios, nuevas construcciones, pequeños labradores que van a menos o aquellos otros bendecidos por la suerte de buenas cosechas o matrimonios con posibles. Lo que sí es de destacar es que, sin poseer la villa normas escritas sobre construcción y urbanismo, todas ellas, fueran labradores o braceros sus titulares, guardan el alineamiento de las calles, bien parecido en materiales, alturas, muros, rejas y vanos. Todas crecen de forma armónica, protegiéndose unas a otras, y diferenciaban las partes principales de las puertas carreteras para comodidad tanto de sus vecinos como de los animales de labranza. Toda una lección para los tiempos que corren. Aunque se sale del tiempo tratado, si se observa el análisis del cuadro adjunto que detalla el aporte contributivo de cada vecino respecto al cupo del aguardiente, se puede distinguir claramente cuanto se lleva expuesto en este epígrafe ${ }^{885}$.

${ }^{883}$ En la calle del Porro son titulares de viviendas los jornaleros Antonio Casares, Antolín Rico, Francisco García, Francisco Gil, Fernando Montes, Gabriel Navarro, Julián Minguela y Manuel de Aragón. En la calle del Barrionuevo tienen casas Antonio Rico, Antonio Alonso, Bernardo Alonso, Gregorio de la Seca, Gregorio Lavajo, Mateo de Aragón, Manuel Rojo, Manuel Díez y Pedro Martín.

${ }^{884}$ A.H.P.V. Pt. 8217, fol. 64. 
Cuadro 89. Vecindad y repartos contributivos de la renta del aguardiente. Ayuntamiento de Serrada. Año $1832^{886}$.

\begin{tabular}{|c|c|c|c|c|c|c|c|}
\hline Barrio Nuevo & rs & Calle Real & rs & Calle del Arroyo & rs & Calle del Porro & rs \\
\hline Petra Jiménez & 4 & Tomás Monje & 4 & Luis Aragón & 10 & Gregorio del Pozo & 4 \\
\hline Bentura Hinojal & 4 & Dionisia de la Seca & 4 & Paulino del Río & 4 & Vicente Rojo & 4 \\
\hline Eleuterio Martín & 34 & Luis Conde & 4 & Fernando Barcenilla & 6 & Gregorio Díaz & 4 \\
\hline Gregorio Román Íscar & 18 & Gabriel Higuera & 14 & Segundo Barcenilla & 4 & Vicente Alonso & 4 \\
\hline \multicolumn{8}{|l|}{ (Alcalde) D.Gregorio } \\
\hline León Alonso & 38 & Valerio de Castro & 4 & Saturnino Mena & 4 & Fausto Alonso & 4 \\
\hline Plácida Rodríguez & 18 & José García & 4 & Bonifacio Román & 4 & Bentura Navarro & 12 \\
\hline Joaquina Moyano & 10 & Magdalena Cabo & 4 & Pablo Leonardo & 4 & Olayo García & 4 \\
\hline \multirow[t]{2}{*}{ Julián Román } & 4 & Manuel Alonso & & & & & \\
\hline & & Hernández & 26 & Eusebio Ribera & 6 & Patricio Rodríguez & 4 \\
\hline D. Cesáreo Moyano & 7 & Mariano Hernández & 4 & Tomás Martínez & 12 & Jerónimo García & 4 \\
\hline Eugenia Domínguez & 18 & Gabriel Cantalapiedra & 4 & Pedro Alonso & 4 & Guillermo de Castro & 4 \\
\hline Roque Leonardo & 10 & Baldomero Díaz & 4 & Silvestre Cabo & 4 & Francisco García & 4 \\
\hline Romana Gutiérrez & 2 & Gabriel Romero & 6 & Lorenzo de Íscar & 4 & Pablo Arranz & 4 \\
\hline María Román & 44 & Quintín Moyano & 6 & Blas Aparicio & 4 & Gregorio de Íscar & 4 \\
\hline D. Clemente Díaz & 4 & Félix Martínez & 76 & Pedro Hurtado & 8 & Eugenio Alonso & 4 \\
\hline Fermín Bastida & 4 & Fernando Alonso & 26 & & & Trifón Rodríguez & 4 \\
\hline Ignacio Fadrique & 4 & Da Agustina Rodríguez & $\mathrm{z} 12$ & Calle de Tordesillas & rs & Luciano Díaz & 4 \\
\hline D. Francisco Alonso & 8 & D. Eusebio Obregón & 14 & Francisco Martín & 4 & Ignacio Gaspar & 4 \\
\hline Policarpo de Castro & 4 & Bernardo García & 4 & Julián Fernández & 4 & Bentura Hernández & 4 \\
\hline Juan García Aparicio & 26 & D. Justo Obregón & 5 & D. José de Rojas & 4 & Gavino Ribera & 24 \\
\hline Manuel Baldomero & 6 & Crisóstomo de Íscar & 12 & Mariano López & 6 & Manuel Alonso & 4 \\
\hline Hermenegildo Alonso & 4 & Saturnino Villán & 12 & Jacinto Martín & 4 & Ángel García & 4 \\
\hline \multirow[t]{2}{*}{ Eustaquio Rojo } & 8 & Da Rosa Moyano & 6 & Anselmo Santos & 4 & Román García & 4 \\
\hline & & Leandro Alonso & 36 & Genaro Ribera & 4 & & \\
\hline \multicolumn{8}{|l|}{ Calle de la Cilla } \\
\hline y plaza del Rollo & rs & Modesto de Castro & 50 & Vicente Ribera & 4 & Calle de la iglesia & rs \\
\hline Celestino Martín & 4 & Mateo Higuera & 4 & Justa Navarro & 4 & Juan Antonio Leonardo & 10 \\
\hline Pablo de la Torre & 4 & Guillermo García & 12 & D. Gregorio Rojas & 4 & Eusebio Pérez & 4 \\
\hline Feliciano Martín & 60 & Aucunacia Leonardo & 4 & Nicolás Sanz & 4 & Diego Obregón & 2 \\
\hline Hdos. de Gabriel Navarro & 4 & Víctor Santino & 6 & Pío Puerta & 4 & Faustino Platón & 6 \\
\hline D. Francisco Rodríguez & 20 & Manuel Pérez & 24 & Donato Martín & 26 & Gabriel Pérez & 44 \\
\hline Melchor Moyano & 24 & Pedro Díaz & 6 & Calle Nueva & rs & Hilario Muñoz & 4 \\
\hline Blas Cisneros & 10 & Rafaela Martín & 10 & Alberto Juárez & 18 & D. Ignacio Fadrique & 12 \\
\hline Calixto Alonso & 4 & & & Ángel Román & 40 & Román Mata & 4 \\
\hline Marcelino Martínez & 10 & \multicolumn{2}{|l|}{ Hacendados forasteros } & D. José Román Abril & 14 & Elías Leonardo & 26 \\
\hline Félix Leonardo & 4 & \multicolumn{2}{|l|}{ D. Manuel Victoriano } & & & & \\
\hline & & Moyano & 34 & Ezequiel Pérez & 14 & Jacinto del Río & 26 \\
\hline Nicanor García & 4 & D. Gregorio Barahona & 60 & Venancio Colomera & 6 & & \\
\hline
\end{tabular}

Fuente: Archivo familia Alonso Moyano.

\footnotetext{
${ }^{885}$ Los Ayuntamientos elaboraban estos cuadernos cobratorios para cubrir en la tesorería de rentas nacionales de la provincia los cupos asignados a cada municipio. Se reflejan con claridad los medianos y grandes hacendados con propiedades de bodegas y cubas, además de quienes estaban relacionados con esta actividad, como elaboradores o comerciantes de aguardiente. Obsérvese el aplastante peso y presencia que tienen los jornaleros, gravados con cuatro reales, en la calle del Porro, de Tordesillas y del Arroyo. Es posible identificar el lugar de vivienda de unos y otros puesto que en la lista cobratoria los vecinos se anotan conforme se sitúan correlativamente en cada calle. En este primer tercio de siglo, como se podrá apreciar, no aparecen nombradas las distintas casas conventuales, pues, tras el desastre de la guerra de la Independencia y la crisis del sector vitícola, arriendan sus pertenencias a vecinos que ocupan sus casas como renteros. Los importantes hacendados forasteros que se reseñan tienen sus casas en la calle Real, junto a las que figuran a nombre de Rosa Moyano y Saturnino Villán.
}

${ }^{886}$ A.F.A.M. s/c. 


\section{- Las casas de artesanos, cirujanos, herreros y demás oficios}

Aunque su actividad era esencial para la marcha diaria de la villa y por ello se estudiarán sus oficios posteriormente, ni su número ni casas se apartan de la evolución que se viene tratando. Francisco y Cristóbal García, zapateros en 1752, vivían en la calle del Porro y Arroyo, respectivamente; el sastre Francisco Cabo y el carretero Simón García Bayón, en la calle Pública; el panadero Santiago Martín en la que va a Tordesillas, etc. Las fraguas y herrerías también evolucionaron a la par que lo hacen labranzas y ganados. En la citada en el Barrio Nuevo en pasados siglos con el nombre de "la plazuela de la fragua vieja”, se tiene constancia de la que regentó hasta 1759 Pedro Rodríguez ${ }^{887}$ y de la que desde comienzos del siglo XIX era propiedad de la familia Barcenilla, en el lugar conocido en 1827 como "sitio del herrero". 888 A la muerte de María Palacios, viuda de Andrés Barcenilla, la casa y fragua la heredará su hijo Segundo; entonces era descrita como sigue:889

"Una casa, su correspondiente corral y la fragua contigua, sita en el casco de esta villa y su calle del Arroyo; mediodía casa de herederos de Andrés Román; poniente calle de la fragua, y al norte con corral de esta testamentaria y que lleva ahora su hermano Fernando Barcenilla”

Igualmente, desde siglos anteriores, no faltaba la posada y mesón para dar servicio a tratantes, arrieros, carreteros y demás viajeros. Andrés Martínez se registra a mediados del XVIII como mesonero en "una casa mesón, situada a la calle de Valladolid... Tiene de frente nueve varas y de fondo treinta y una. Confronta con dich a calle y con casa de Joseph Román”. En este tiempo surgen, al calor de la actividad vinícola, otros mesones. Es el caso del que adquiere, un siglo más tarde, en 1857, Gregorio León Alonso a los testamentarios de Donato Martín y otros vecinos de la localidad. En 1887, adquiere la otra mitad de dicha vivienda a Dolores Alonso ${ }^{890}$. Se inicia una actividad ligada a la posada y a la botería que permite a sus descendientes, después de entroncar con familias hacendadas, sentar los cimientos de la industria vitícola a gran escala ${ }^{891}$.

\section{- La construcción del Ayuntamiento}

Por último, hemos de tratar los edificios más representativos. Si se observa la evolución del casco urbano, el crecimiento se organiza en varias aureolas en torno a un centro principal en que se ubica la iglesia, plaza mayor y casas del concejo. El viejo edificio del concejo no parece, a tenor de la documentación consultada, disponer de los espacios requeridos para atender las nuevas necesidades.

${ }^{887}$ La descripción del inventario de bienes la refiere como "Una fragua de herrería, que se compone de yunque, vigornia, fuelles, tres machos, un martillo, otro de peña, tres pares de tenazas, dos maneras y unas corbas, un yunque pequeño, un tornillo con nueve pinzas, tres punteros, uno grande y dos medianos; una piedra de amolar con su cigüeñal" (A.H.P.V. Pt. 8218, fol. 310).

888 A.H.P.V. Pt. 8230, año 1827, fol. 19.

${ }^{889}$ Ibídem, fol. 36.

${ }^{890}$ A.H.P.V. Pt. 19985, fol. 633.

${ }^{891}$ Gregorio León adquiere la casa mesón en diferentes porciones: En 1855 compra una parte a Francisco, Gregorio, Juliana y Joaquina Martín; en 1857 hace lo propio con Eugenio Aragón y Clotilde Trigueros, testamentarios del referido Donato Martín; en el mismo año suma otra porción a Clotilde Trigueros y, por último, a finales del mismo año, adquiere la última parte a Eustaquio Rojo, Luciano Leonardo, Tomás Cabo, Pedro de Íscar, Nicanor García y Juana García, herederos de otros poseedores. Al morir Gregorio León en 1877 deja la casa mesón por mitad a sus hijos Mariano y Dolores Alonso Ampudia. La escritura refiere la vivienda "con cuadras, corral y, en él, puerta accesoria carretera mirando entre el norte y oeste a la calle Real, local con máquina de espiritus y dos cubas enarcadas en hierro, y un cercado y plantío de olmos y álamos...". Esta propiedad está directamente relacionada con el mundo del vino, de los aguardientes y de los arrieros que allí paran. A la muerte de Gregorio León, dicha posada pasa en iguales partes a sus hijos Mariano, abogado, afincado en La Seca, y Dolores, casada en Serrada con Perfecto Moyano. Mariano Alonso vende su parte en 1882 a su convecino Pedro Gutiérrez López, casado, de veinte y ocho años y, según consta en la escritura, de oficio mesonero. (A.RSP.M.C. Libro 15, Serrada, fol. 54). 


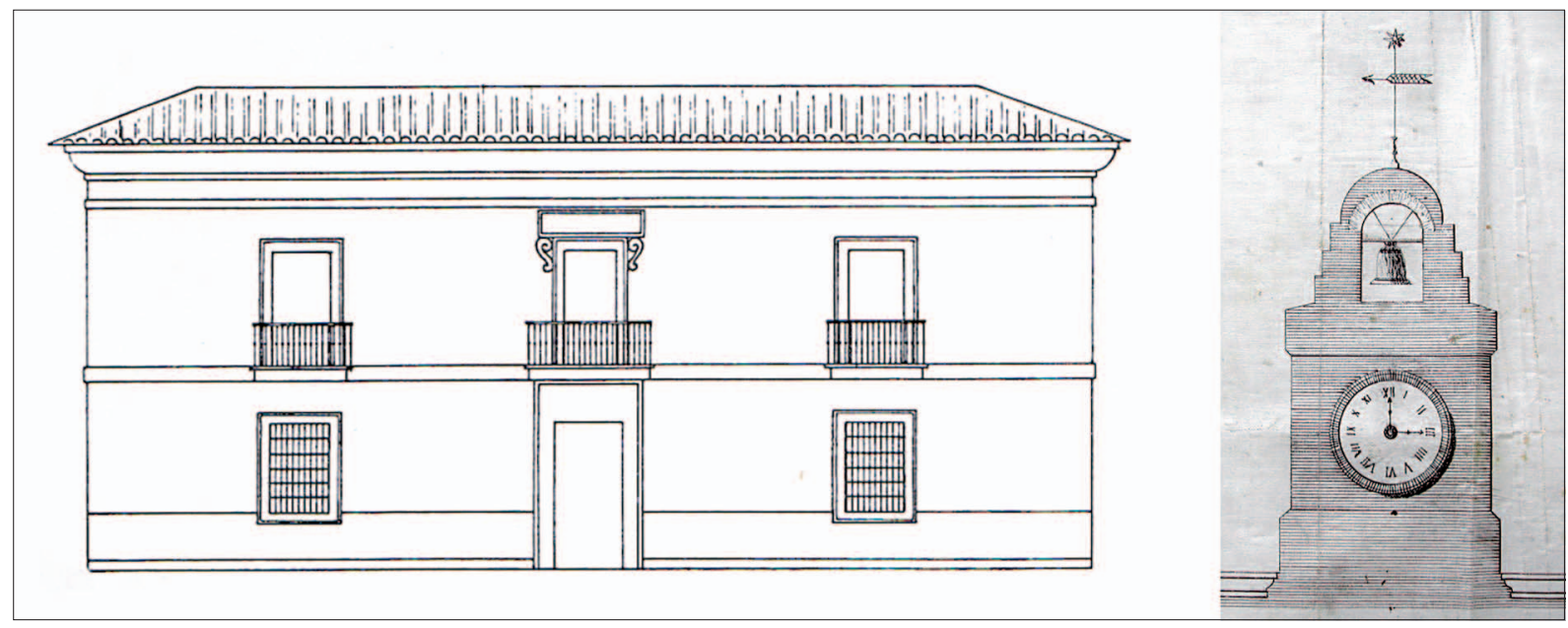

Figura 29. Ayuntamiento de Serrada, obra de Ventura Rodríguez, (reconstrucción ideal hacia 1885, según José Ma Pérez Chinarro) y espadaña posterior diseñada por el arquitecto Canuto Capdevila (A.M.S.).

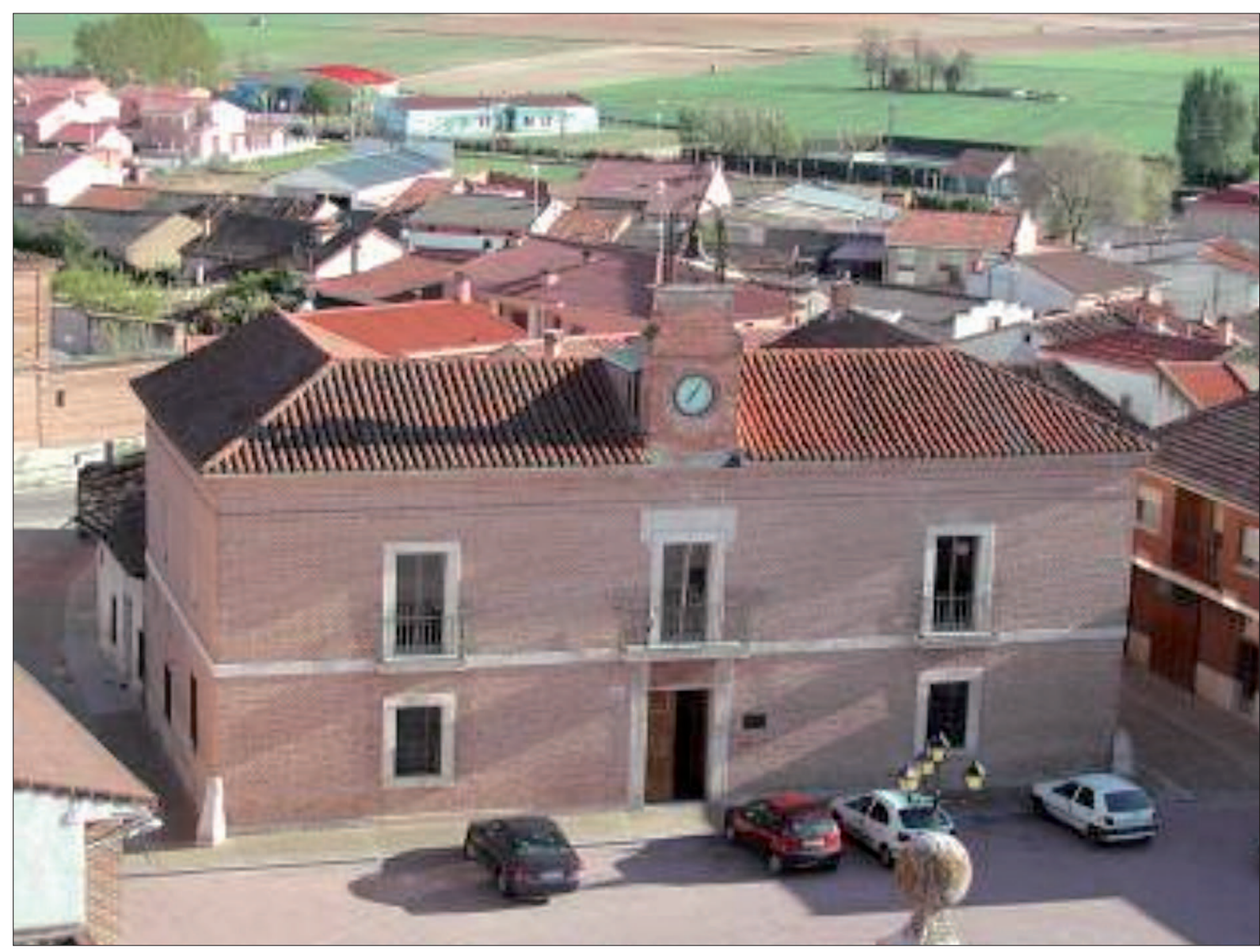

Imagen 77. Fachada del Ayuntamiento, Serrada. Foto: 02/05/2005.

La construcción del nuevo y actual Ayuntamiento se adjudica en 1784 al arquitecto Tomás Rodríguez, de acuerdo a las trazas propuestas por éste, completadas por Ventura Rodríguez. En principio, las obras deben ser sufragadas con los recursos de los bienes de propios del concejo, que se agotarían ante la envergadura del proyecto. De hecho, en 1786 se concede a la villa permiso para vender las carnicerías viejas y el corral del concejo que, como se acaba de ver, fue el lugar donde se edifica la casa del Obispo anteriormente descrita, de tal manera que, hasta 1790, no pueden finalizar las obras $^{822}$. Difícilmente hubieran podido acabar la edificación, si no hubiera sido por los nuevos aportes monetarios. La modificación que se hizo sobre el proyecto inicial, a petición del concejo, en relación 
con la modificación de la escalera de acceso a la planta noble, que reducía espacio a la sala de reuniones, incrementa el coste y dilata las obras ${ }^{893}$. Entretanto, las reuniones del concejo se realizan en la casa del Marqués de Torreblanca, situada justo enfrente del naciente edificio consistorial ${ }^{894}$ :

"En la villa de Serrada, a seis de mayo de mil setecientos ochenta y siete, estando juntos y congregados la Junta, Regimiento y vecinos como lo tienen de uso y costumbre en las casas del señor marqués de Torreblanca por estar construyendo de nueba planta las consistoriales...”

Por estas fechas el edificio iba muy avanzado y fiel en sus trazas al pensamiento de sus arquitectos. La fachada, de ladrillo, salvo el zócalo y los dinteles de ventanas y balcones, buscan una horizontalidad remarcada por la imposta intermedia entre la planta baja y la noble. La simetría en fachada es total, muy del gusto de Ventura Rodríguez. La espadaña y el reloj se ańaden más tarde, en concreto en 1884, de la mano del arquitecto Canuto Capdevila. En las imágenes que acompańan pueden verse estos detalles, como los del nuevo matadero, realizado en estos años de finales del XIX.

\section{b. La evolución dispar y situación de las iglesias de La Moya, Serrada y San Martín del Monte}

Capítulo aparte merecen las tres iglesias de los pueblos que conforman el centro de este estudio. Su importancia se confunde con la esencia misma de estas sociedades campesinas. Iglesias y ermitas han sido siempre centro vital, espacial y espiritual. Sus campanas albergan el honor de ser las primeras en dar testimonio de vida y de muerte, de guerra y paz, de venturas y de calamidades. Mala seńal era que dejaran de repicar. Si esto ocurría, era que el pueblo o la aldea habían pasado a mejor vida. Estas tres iglesias van parejas a los altibajos que sufren sus feligreses a lo largo del tiempo.

\section{- El poblado de la Moya y la iglesia de Santa María de los Remedios}

En el año 1346 servían a la Virgen Santa María de los Remedios de La Moya un Preste, un subdiácono y dos graderos. Limosnas, diezmos y donaciones enriquecen su patrimonio, conforme pasan los siglos. En 1589, estando de alcalde Francisco Martín, tiene lugar un apeo o reconocimiento de las propiedades de dicha iglesia, en que se detallan numerosas piezas de sembradura de las que se deducen, en parte, los caracteres del lugar ${ }^{895}$ :

\footnotetext{
"Los dichos apeadores fueron a otra tierra que está encima del Pozo Nuevo, junto a La Moya, la qual deslindaron por la dicha Iglesia, que haze cinco obradas, poco más o menos, que linda con el camino que ba a la Moya, junto a una casa que es de Dońa Juana de Sotomayor, vecina de Tordesillas, y por otra parte linda con tierra de Bartolomé de Moraleja...”
}

892 Puede leerse en la citada aprobación "El Consejo, en vista de recurso hecho por la justicia y Ayuntamiento de la villa de Serrada solicitando facultad para vender a dinero de contado las Carnicerías viejas y corral del Conzejo, y aplicar su balor a la nueba construcción de casa de Ayuntamiento, carnecería y demás Oficinas, que se están edificando de orden del Consejo de 22 de mayo de 1784 para su más pronta ejecución, por Decreto de 6 de este mes se ha servido conceder a la justicia y Junta de la referida villa de Serrada la facultad correspondiente para vender a dinero a contado las carnizerías viejas y corral de Consejo sacándolas a subasta y rematándolas en el mejor postor, destinándose su producto en parte de pago del coste general de las nuevas casas de Ayuntamiento, inclusa la Carnecería y demás oficinas comprehendidas en el plan aprobado". (A.H.P.V. Pt. 8224, fol. 203).

893 PÉREZ CHINARRO, J.M.: Edificios municipales en la provincia de Valladolid, pág. 159 y ss.

${ }^{894}$ A.H.P.V. Pt. 8224. Francisco Quintero, fol. 115.

${ }^{895}$ Es el caso también de esta otra tierra, que da pistas de dónde se encontraban las eras y otras viviendas: "Los dichos apeadores fueron a otra tierra que está junto del dicho lugar de la Moya... que está junto al camino que se lleba a Bentosa, que haze dos obradas poco más o menos, que linda con un sendero que se hace de Serrada para ir a las casas del dicho Don Antonio de Vega y con heras que están conjuntas a las dichas casas del dicho Don Antonio”. (A.H.P.V. Pt. 11837, fol. 736-37). 
En cualquier caso, la Virgen de los Remedios concita no sólo el fervor de su escaso vecindario, sino también el de los pueblos vecinos. En el testamento, fechado en 1591, de Antonia Mateo, viuda de Francisco de Rojas, vecina de Serrada, manda "se digan por mi ánima en la Iglesia de Nuestra Señora de los Remedios del lugar de la Moya una Misa rezada sin ofrenda, y la diga el cura de dicho lugar, y se le dé de limosna real y medio" "\$96. Sin embargo, conforme desciende el número de vecinos del lugar y pasan los ańos, el pequeño templo fue requiriendo mayores cuidados. El último de los que se tiene constancia se fecha en 1606. El mayordomo de la iglesia por aquel entonces, concierta, a instancias del provisor del obispado, con Mateo Blanco y Francisco de Casuso, obras de reparaciones que dejan importantes pistas de cómo era dicha iglesia ${ }^{897}$.

A partir de esta fecha, La Moya, como ya se ha explicado, entra en franco declive. Sus últimos vecinos abandonan el lugar en las primeras décadas del siglo XVII. La iglesia pasa a depender de Serrada y, recogiendo el fervor religioso hacia la Virgen, se constituye la cofradía de los Remedios o de la Moya, que tendrá su sede en esta villa. Los diezmos y cargas que su término rinde a la citada iglesia se pagan a la de San Pedro de Serrada, lugar por lo demás donde residen la mayor parte de los labradores que cultivan su terrazgo. De hecho, en 1697, el concejo otorga poder a Diego de Íscar, Pedro Navarro y Matías de Castro, vecinos de Serrada, para que, representando a esta villa, tomen y reciban en renta de la villa de Olmedo, a través de su Procurador General "el terrazgo del despoblado de la Moia, asi lo que se labra como lo que está inculto y por labrar, por los precios de granos y años y tiempo que se ajustaren... "\$98.

No obstante, la Virgen de los Remedios sigue conservando una enorme devoción entre los pueblos vecinos. En las romerías anuales se dan cita, junto a los de Serrada, numerosos romeros de los pueblos vecinos, especialmente de Villanueva, Matapozuelos, Ventosa y Valdestillas. El paso del

${ }^{896}$ A.H.P.V. Pt. 11839. Antonio de Medina, fol. 181.

897 "En la villa de Valdestillas, jurisdizión de la ciudad de Valladolid, a diez de setiembre de mil y seiscientos y seis años, por ante mí, Antonio de Medina, scriuano real y del número de la dicha villa, parecieron presentes mateo Blanco, vecino que dijo ser del valle de Oz y Francisco de Casuso, vecino de Billaberde, ambos del Balle y merindad de Trasmira, e oficiales de carpintería y albañilería, estantes en la dicha villa de Valdestillas, jurisdicción de la ciudad e Valladolid, y presentaron un mandamento del señor doctor Agüero, Provisor del Obispado de la dicha ciudad, con una notificación a las espaldas del ques del tenor siguiente.

Aqui entra y presentado el dicho mandamiento, que ba incorporado en la manera que dicha es, los dichos Mateo Blanco y Francisco de Casuso en su cumplimiento dixeron que estaban conbenidos y conzertados con Bartolomé de Moralexa, vecino del lugar de la Moya, y mayordomo de la Iglesia de nuestra Señora de los Remedios de dicho lugar, de hazer en dicha Iglesia la obra que esta mandada azer por el dicho señor Provisor en el arco de la Capillla Mayor de la dicha Iglesia con las condiciones siguientes:

Primeramente que los dichos Mateo Blanco y Francisco de Casuso y cada uno de ellos ynsolidum an de ser obligados a deshazer a su costa el arco de la dicha capilla mayor sin que a la dicha capilla se le haga ningún perjuicio en el edificio Della, posteando el dicho edificio en las partes de la dich a capilla y en el cuerpo de la dicha Iglesia de forma que todo haya de quedar y quede en toda firmeza y seguridad y que si algún daño resultare por no cumplir que los susodichos y cada uno de ellos hayan de estar y sean obligados a lo pagar luego que lo susodicho suceda o a lo bolbera hazer a su costa y esto a de quedar y queda a satisfación del dicho Bartolomé de Moralexa, mayordomo susodicho para que escoja lo que mas conbenga al aprovechamiento de la dicha Iglesia.

Yten, Que deshecho el dicho arco en la forma que ba declarado, luego le an de volver a azer de albañearía con su ladrillo cal y arena y yeso bien hecho y acabado en toda perfección de suerte que este y quede con toda firmeza para sustentar la carga de la dicha capilla y cuerpo de la dicha Iglesia, que todo lo a de sustentar el dicho arco y para le azer los dichos Mateo Blanco y Francisco de casuso an de poner las maderas necesarias y clavazón para las cimbras y andamios y postes para apoyar la dicha Iglesia y los demás materiales a de poner el dicho Bartolomé de Moralexa como son cal y arena y ladrillo y yeso todo ello al pie de la obra lo qual los susodichos an de aderezar y poner en perfección dando personas que lo hagan.

Yten. Con condición que los susodichos y cada uno de ellos han de trastesar toda la dicha Iglesia y torre del medio atras hazia el septrentión sea de texa rate y a doblada con su cal y aderezar los tabiques de la torre y los demás reparos que obiere en dicha Iglesia..." (A.H.P.V. Pt. 11854, fol. 291).

${ }^{898}$ A.H.P.V. Pt. 8213. Gutiérrez de Valdés, fol. 198. 
tiempo, sin embargo, deteriora el edificio de manera que, en 1732, se encarga un altar en la iglesia de San Pedro para la Virgen de la Moya, al tiempo que se traslada la cofradía del mismo nombre a esta iglesia. Sus cofrades arriendan el rebaño de ovejas propio de la misma durante largas décadas ${ }^{899}$. En lo que atañe al edificio, de lo que no cabe duda es de que, a mediados del XVIII, la ruina de iglesia y poblado es total. De nada sirven los buenos deseos del presbítero encargado de la parroquia despoblada para su reedificación. Para proveerse de fondos, solicita licencia en 1737 para vender una tierra de dos obradas perteneciente a su fábrica, pero todo queda en buenos deseos. En el Catastro de la Ensenada de 1752, se hacen constar con precisión sus restos. Se precisa que de las 1.200 obradas de su término, treinta corresponden a caminos y "entra una que ocuparan los paredones de la Iglesia" ${ }^{300}$. En las Respuestas Particulares, se hacen constar las que posee el convento de San Pablo, de la orden de los dominicos. Entre otras muchas se refiere "una viña... al pago de los Paredones. Dista del Despoblado cuatrocientos pasos... Consiste en cuarenta y cinco aranzadas. Confronta a levante con el camino que va de Matapozuelos a la Moya, al norte con el camino Real de las Carretas..." "\$o1. Los documentos consultados acerca de la localización exacta de la citada iglesia encierran no pocos interrogantes ${ }^{902}$. Nada mejor que el testimonio notarial realizado en 1792 sobre el terreno, y que transcribimos al pie, donde se precisan los restos que permanecen visibles en estas fechas ${ }^{903}$.

${ }^{899}$ En el año 1777 la cofradía otorga poderes al mayordomo Antonio Moyano, para que actúe contra Francisco Alonso, arrendatario del rebaño y "pague las menguas con que ha devuelto el ganado". (A.H.P.V. Pt. 8221. Año 1777, fol. 237).

${ }^{900}$ A.G.S. Respuestas Generales, caja 648.

${ }^{901}$ A.G.S. Libro de eclesiásticos, caja 279.

902 Por un lado, la tradición oral parece ubicarla, en la tierra de la imagen, propiedad de la familia Moyano Rojo, denominada también "La Ermita". Si bien es cierto que en ella se encuentran abundantes restos, no es menos cierto que muchos son de mosaico utilizado en viviendas distinguidas y que coinciden con la ubicación de lo que fue la casa principal del mayorazgo de los Vega en el citado lugar. Por otra parte, en el pago de los Paredones, y rara vez se equivoca la toponimia gestada en siglos pasados, se hallan numerosísimos restos de piedra caliza, empleada generalmente para construir sólidos cimientos, y coincide el lugar con la precisión del Catastro de 1752 cuando indica "los paredones de la iglesia”. Es de destacar, en el sentido apuntado, que, cuando Francisco Moyano, vecino de Serrada, adquiere a censo perpetuo a Manuel Pascual de Vega y Salcedo, vecino de Tordesillas y pertenecientes a su mayorazgo, los nueve solares donde se asentaba la población, no se hace mención concreta de la ubicación exacta de la iglesia y que, evidentemente, sobresaldría en espacio entre los restos de las casas y los ejidos. Es aquí donde radican las dudas de que la Iglesia se encontrara integrada en el poblado. (A.H.P.V. Pt. 8225, Francisco Quintero, fol. 742).

903 " $Y$ enterados de todo, su merced el señor Francisco Bermejo, alcalde de este Despoblado, tomó de la mano al referido D. Francisco Moyano y le entró en una porción de terreno que es sin duda el que se dice en la escritura fue el suelo de la Casa principal de este mayorazgo de Vega en tiempo de la población, pues, en efecto, linda por la parte del poniente con Camino que lleban los de La Seca a Valdestillas y queda a la izquierda, que es el mismo lindero al apeo, pues mirando desde dicho sitio hacia Matapozuelos, que es el que cita aquel, es lo mismo que a oriente, linda también otro terreno con el camino que lleban los de Matapozuelos a Villalba que se enuncia en el apeo y dize a la parte norte según refiere en la escritura, por el poniente, que es lo que en el apeo se dize, por la parte de la hermita, linda actualmente con ejido del despoblado que dice la escritura, el qual tiene bastante muestras de haber estado alli la cilla del lugar que dice en el Apeo si otro edificio, según los escombros y mayor altura del terreno que se nota: Y por el mediodia linda con más ejido que este va a confinar con majuelo que goza hoy Lorenzo Villán, vecino de Serrada, de modo que desde la casa del solar de que hablábamos por esta parte de mediodía hasta el majuelo de dicho Villán ay veinte y seis pasos naturales de travesía, que todo está ejido; y estando en este dicho terreno a los linderos señalados, según los vestigios que se notan en él, podrá contener, poco más o menos, los treinta y ocho estadales que señala el Apeo y escritura. Y dicho D. Francisco, en señal de posesión se paseó por él, echó la gente fuera e hizo otros actos de posesión.

$Y$ su merced le entró en otra porción de terreno que es el que el que contiene los tres solares siguientes que contienen la escritura de Apeo, lindantes en efecto por la parte de Norte con camino que lleban los de Matapozuelos a Villanueba, y quedan a la izquierda por el Poniente (que es lo que en el Apeo se dice a la parte de arriba) con otro terreno que hoy es exido, y como habia ciertas señales a que pudo ser alli el cementerio y prozesión de la Iglesia que se dice en dicho Apeo. Por el mediodía con mas ejido de este despoblado que va hoy también a lindar con el dicho majuelo de Villán. Y por el oriente lindan oy estos tres solares y se agarran con el solar de la Casa principal que va deslindada que es sin duda algún corral que habia en el Apeo y dice baldio de la Casa del Mayorazgo; Y estando a estos linderos puede haber en estos solares los dos cuarenta y cinco estadales que dize el Apeo y escritura. 


\section{- La falta de impulso de la villa de San Martín del Monte. De sus continuadas penurias a su abandono y hundimiento final}

Si algo se anota con frecuencia en la documentación histórica que se conserva de esta pequeña villa, dependiente de Santa Clara, no es sólo su corto número de vecinos, sino la pobreza que parece condicionar sus vidas. Sujetos al pago de unos foros que detraen rentas permanentes a sus cortas heredades, faltos de una mínima plena propiedad sobre un reducido terrazgo, que no rebasa las trescientas cincuenta obradas, de las que ciento cuarenta eran prados, tienen difícil sobrellevar las crisis de aquellos tiempos. En 1548, conciertan nueva escritura de censo perpetuo con las monjas de Santa Clara y tratan en todo momento de conseguir los favores de la comunidad religiosa para pastorear sus montes, "porque los vecinos del dicho lugar son pobres e la principal cosa que tienen para su sustentamiento es poder meter en el dicho monte las dichas tres bacas e bueies e nobillos o bestias de huelga..." La vinculación con Santa Clara se renueva en el año1552905.

Como también se ha tratado, San Martín defiende como suyos los prados y su aprovechamiento, aduciendo reales provisiones para poderlos arrendar, a fin de "reparos y obras de su Yglesia y casa de ayuntamiento y otras cosas... "y apela a la costumbre inmemorial en que la pequeña villa ha disfrutado de su aprovechamiento. Las dificultades de su iglesia por mantenerse en pie a lo largo de los siglos van a ser una constante, a decir de sus vecinos. Francisco Rodríguez, clérigo beneficiado de La Seca, deja ya escrito en su testamento de 1599 que "mando a la Yglesia de San Martín del Monte zinquenta reales de mis vienes para reparos della" ${ }^{306}$. Cuando en $1673 \mathrm{La}$ Seca gana sentencia dada por el Alcalde Mayor de la Mesta, que permite el pasto de su cabaña ganadera en los prados de Arriba y de Abajo prohibiendo, además, su arrendamiento por los vecinos de esta villa. San Martín, le muestra una

$Y$ también le entro su merced en un espacio de tierra alli luego, que es el mismo que se menciona en el Apeo y la escritura, comprende cinco solares que alli tenía este Mayorazgo; en efecto, linda oy esta porción de tierra por el norte (que el Apeo dize por la parte de abajo) con dicho camino que los de Matapozuelos lleban a Villanueva; (por el poniente (que el Apeo dice a la parte de arriba) con camino que viene de Valdestillas a Serrada y Tordesillas y quedan los solares a la izquierda; por el mediodía con majuelo de dicho Villán puesto en la tierra que menciona el Apeo era de Juan Alonso, vecino de Villanueva, la cual gozó después Bernardo Alonso, vecino de Serrada, y por Oriente linda este terreno con lo que pudo ser cementerio de la Iglesia (que se dize en dicho Apeo) según los escombros que se registran; y estando a los linderos mencionados, puede haber en este suelo deslindado la media obrada y setenta y dos estadales que señala el apeo y escritura. Y se advierte que en parte de este dicho suelo (la mayor de él) ha edificado ya el Don Francisco una caseta o cuadra para ganados de ochenta pies de larga y quinze de ancha y pegado a ella un corral a la parte de poniente de cien pies de largo y ochenta de ancho, poco más o menos, en todos los quales se paseo e hizo los mismos actos de posesión, quieta y pacificamente, sin protesta ni contradicción alguna...”. (A.H.P.V. Pt. 8225, Francisco Quintero, fol. 743). Aunque leyendo el texto queda medianamente claro cuánto se argumenta en torno a la distribución del poblado, se trata de una primera aproximación investigadora que en próximos años se intentará precisar.

${ }^{904}$ A.R.Ch.V. P.C. Quevedo (D), caja 442-2.

905 “... Otorgamos e conozemos por esta carta que damos a zenso perpetuo a vos Juan Gutiérrez e Juan de Luis e Juan Dominguez e Sebastián Gutiérrez e Bartolomé Gutiérrez e Francisco Lucas e Juan Guerra e Pedro Vecino e Francisco de Llanos e Miguel de Cuenca e Alonso Gallego e Juan Merino e Francisco Blanco e Rodrigo de Montealegre e Francisco García e Francisco de Montealegre e Leonor Rodríguez, viuda mujer de Alonso de Llanos, difunto, todos becinos e moradores del dicho lugar e a vos, Sebastián Gutiérrez, por virtud del poder que tenéis de todos los sobredichos, toda la heredad e termino del dicho lugar de San Martín, ansi tierras e prados e pastos y ejidos y era y azeras y casas y solares e guertas e palomares e aguas estantes e manantes e todo lo otro que nos pertenece en el dicho lugar de San Martín, ecepto el monte de enzinas que queda libre, y esenta para el dicho monasterio e conbento las tierras de Linares que ansimismo quedan para el dicho monasterio e conbento la casa que conpramos en el dicho lugar de San Martín de Gaspar de Harebalo e otra casa que compramos de Alonso de Balderas y el dicho suelo casa que conpramos y el suelo o casa en que solian bivir los merinos del dicho lugar. Que todo esto a de quedar e queda libre y esento para este dicho monasterio e conbento, lo qual todo e cada cosa e parte dello bos damos a censo para siempre jamás por veinte y siete cargas de zenteno e tres pares de gallinas en cada un año, lo qual habréis de dar e pagar por el día de Santa Maria de agosto de cada un año, puesto e pagados en este dicho monasterio e conbento de buestra costa e misión e riesgo e peligro en el patio del dicho monasterio e comienze la primera paga que nos abeis de hazer deste dicho censo e tributo el día de Santa María de agosto primera del año benidero del Señor de mil y quinientos e zinquenta e dos años... "(A.R.Ch.V. P.C. Quevedo (D), caja 442-2).

${ }^{906}$ A.H.P.V. Pt. 6471, fol.479 y ss. 
carta real, fechada el 27 de julio de 1674, en que se les otorga facultad para arrendar el prado de Arriba, para sufragar los gastos de reparación de su iglesia y construir una casa para reunión de su concejo $^{907}$.

San Martín, con tan sólo siete vecinos en aquel entonces, trata de cualquier manera de hacer valer sus intereses sin acudir a la justicia. Su pobreza le impide destinar recurso alguno a los siempre costosos pleitos. La precariedad de su iglesia y la falta de casa concejil manifiestan la difícil tesitura en que se encuentran en estos años. Es por ello por lo que, para evitar litigios y para que los prados, las vacas y sus ganancias no fueran a parar a manos de procuradores y de la Real Chancillería, se firma una escritura de concierto entre ambas partes el 8 de octubre de 1674, que pone fin a las desavenencias y regula el pasto en los prados de Arriba y de Abajo.

El Catastro de Ensenada de 1752 precisa con detalle sus vecinos, casas, calles y tierras. Este año la población cuenta con catorce vecinos, de los que siete son labradores, dos jornaleros, cuatro viudas y un guarda. La imagen adjunta, en que se representa a San Martín en 1777, con motivo del pleito ya estudiado, denota claramente cómo su casco urbano se apiñaba en torno a su iglesia. En el citado catastro se constata que sus trece casas de 1752 se reparten siguiendo la calle "que va a Tordesillas", la "calle que va camino de La Seca" o la "Plazuela que mira a la Iglesia" en que vive Francisca García. Andrés de Castro y Andrés Martín tienen sus casas respectivas "en la calle del Lagar" y, por poner un último ejemplo que permita imaginar su disposición, Alonso Ruiz, que vive en la calle que va a Tordesillas, tiene a levante la casa del concejo y a ponientes, ejidos del mismo común de vecinos.

A pesar de lo que pueda parecer, por entonces se advierte un futuro poco esperanzador para esta pequeña villa. A diferencia de los pueblos limítrofes, ni crece ni la expansión vitícola dinamiza su economía. Los últimos años del XVIII no se presentan buenos para nadie y menos para los más desfavorecidos en tierras y cosechas. Ya se analizará más adelante su situación económica. Sus vecinos y casas no son ajenos a esta situación. Los Libros de Cuentas de Fábrica de su iglesia testifican, en 1723 , las necesidades de un vecindario que carece de recursos para reparar el tejado "que tiene varias averturas por partes y el zielo que haze al altar mayor que esta de tablones... "o los lados del altar mayor que "están malparados"308. En 1736, la espadaña de la torre "se halla con necesidad precisa de reparo..." y, aunque en 1743 se encarga la realización de un San Martín de bulto, estofado y dorado, la situación causa alarma y casi escándalo cuando en 1745 , ante la falta de panera para guardar los granos del pósito común, "el cuerpo de dicha Iglesia y zerca del altar mayor Della sirve de panera de zilla común...".

En las últimas décadas del siglo, la iglesia, a tenor del relato de las múltiples necesidades que aquejan al templo, está más próxima a la ruina que a la esperanza de continuar en pie. El cielo raso puede contemplarse sin problemas cuando los vecinos entran en el templo. Tras las crisis de los últimos ańos del XVIII, en los primeros años del XIX se ha podido recomponer el tejado. Labor casi

\footnotetext{
${ }^{907} \mathrm{Al}$ margen de la búsqueda, por parte de unos y otros, de aquellos vericuetos judiciales para defender sus intereses o alargar los procesos, la facultad real permite conocer las penurias de sus vecinos "Don Carlos por la gracia de Dios, rey de Castilla, de León, de Aragón, de las dos Sycilias, de Gerusalén...etc, por quanto por parte de vos, el concexo, xusticia y regimiento de la villa de San Martín del Monte se nos yzo relazión que la fabrica de la Yglesia desa dicha villa, muy antigua, por cuya causa las paredes y texados amenazan ruyna por estar descubiertos, con que el sagrario estava con mucha yndefensión y los vezinos entravan a oir misa con riesgo evidente, y a lo referido se añadia la falta de ornamentos que tenia, y para remediarlo todo no tenia renta ni fábrica alguna dicha villa propios, por tener solo siete Bezinos y muy pobres y asimismo no tenía casa de concexo, y le azian en el portal de dicha Yglesia con notoria incomodidad, y esa dicha villa tenía un prado cuya mitad llamavan de avaxo con el qual los dichos becinos tenian pastos bastantes para sus ganados como todo constava de la ynformazión de que fagan presentación, para cuyo remedio nos pidió y suplico mandásemos conzeder a esa dicha villa lizenzia y facultad para poder arendar la mitad de dicho prado que llaman de Arriba para que con lo que procediese del dicho arrendamiento se reparase la dicha Yglesia y se fabricase la casa de ayuntamiento...”.(A.H.P.V. Pt. 6471, fol.479 y ss).

${ }^{908}$ A.G.D.V. Libro de Cuentas de Fábrica de San Martín del Monte. Citado en MIGUEL ÁNGEL MARCOS Y ANA Ma FRAILE: Catálogo Monumental de la Provincia de Valladolid, tomo XVIII, Diputación de Valladolid, 2003, pág. 446.
} 
estéril. Las correrías que llevan a cabo las tropas francesas, acantonadas en Tordesillas durante la Guerra de la Independencia, dictan la definitiva sentencia. Muchos de sus vecinos abandonan sus casas y se refugian con sus familiares en los pueblos cercanos. La visita de 1812 pone de manifiesto la situación límite que se vive estos años ${ }^{909}$ :

"Informado de don José Martín, Pro beneficiado cura de la única iglesia parroquial de san Martin del Monte, que los habitantes deste pueblo se habían desamparado sus casas y hogares a causa de las continuas invasiones de las tropas francesas que han aniquilado sus casas y haciendas por cuia razón se hallan avecindados en los pueblos inmediatos y el citado D. José tener que trasladar las alhajas, ornamentos, bestuarios y demás correspondiente a la iglesia de dicho pueblo a esta de Serrada..."

Cuadro 90. Vecinos y propiedades urbanas en San Martín del Monte, año $1752^{910}$

\begin{tabular}{|c|c|c|c|c|c|c|}
\hline \multirow{2}{*}{$\begin{array}{l}\text { Vecinos } \\
\text { (en varas castellanas) }\end{array}$} & \multirow[b]{2}{*}{ Actividad } & \multirow[b]{2}{*}{ Calle en que se sitúa } & \multicolumn{2}{|c|}{ Dimensiones } & \multicolumn{2}{|c|}{ Limita o confronta } \\
\hline & & & rente & Fondo & Levante & Poniente \\
\hline Andrés de Castro & Labrador & Calle del Lagar & 19 & 11 & $\begin{array}{l}\text { Hdos Nicolasa } \\
\text { García }\end{array}$ & Lagar de Diego García \\
\hline Andrés Martín Paz & Labrador & Calle del Lagar & 7 & 39 & $\begin{array}{l}\text { Hdos. De } \\
\text { Andrés Álvarez }\end{array}$ & Tierra del Convento \\
\hline Alonso Ruiz & Labrador & Calle que va a Tordesillas & 16 & 20 & Casa del Concejo & Ejidos del Concejo \\
\hline Beatriz García 911 & $\begin{array}{l}\text { Labradora } \\
\text { (viuda) }\end{array}$ & $\begin{array}{l}\text { Calle del camino } \\
\text { de La Seca }\end{array}$ & 31 & 40 & Andrés Castro & Ejido del Concejo \\
\hline Narciso Ruiz & Labrador & Calle que va a Tordesillas & 11 & 12 & Eugenio García & Ejidos del Concejo \\
\hline Eugenio García & Labrador & Calle que va a Tordesillas & 15 & 25 & Isabel de Castro & Narciso Ruiz \\
\hline Francisca García ${ }^{912}$ & $\begin{array}{l}\text { Labradora } \\
\text { (soltera) }\end{array}$ & $\begin{array}{l}\text { Plazuela que mira } \\
\text { a la iglesia }\end{array}$ & 42 & 17 & Arroyo de la villa & Calle que va a La Seca \\
\hline Francisco González ${ }^{913}$ & Jornalero & - & - & - & - & - \\
\hline Francisco Gaspar ${ }^{914}$ & Labrador & - & - & - & - & - \\
\hline Martín Ruiz ${ }^{915}$ & Labrador & Calle del Lagar & 9 & 9 & Tapia lagar & Ejido del Concejo \\
\hline María García & Viuda & Calle que sale a Tordesillas & 11 & 8 & Calle Pública & Alonso Ruiz \\
\hline $\begin{array}{l}\text { Menores de } \\
\text { Nicolasa García }\end{array}$ & - & Calle del Lagar & 10 & 13 & Andrés Martín & Andrés de Castro \\
\hline Isabel de Castro & Labradora & Cale que va a La Seca & 20 & 33 & Calle que va a La Seca & Eugenio García \\
\hline Casa del Concejo & - & Calle que sale a Tordesillas & 8 & 24 & Casa de María García & Casa de Alonso Ruiz \\
\hline
\end{tabular}

Fuente: Fuente: Catastro del Marqués de la Ensenada. Respuestas Particulares. 1752. A.G.S.

Libros correspondientes al municipio relacionado. Elaboración propia.

\footnotetext{
909 Ibídem, pág. 447.

${ }^{910}$ A.G.S. Catastro de Ensenada, caja 254.

${ }^{911}$ Beatriz García posee el 50\% de un lagar en la calle del mismo nombre, que tiene 14 y 10 varas de frente y fondo respectivamente. Confronta a Levante con casa de Andrés de Castro y a Poniente con tapias de Francisca García. En dicha propiedad posee al 50\% la bodega existente en el mismo.

912 Francisca García posee el 50\% del lagar y bodega antes referido. Hace constar la existencia de 5 cubas.

${ }^{913}$ Francisco González, jornalero, casado, de 32 ańos y con una hija "en casa", no figura como propietario de casa alguna. Se entiende que puede vivir con algún familiar.

${ }^{914}$ Francisco Gaspar labra su hacienda con los ganados de su suegra Isabel de Castro. Aunque no figura, es muy posible que viva igualmente en su casa.

${ }^{915}$ La casa anotada se concreta como una casa pajar.
} 
Aunque sea adelantarse en el tiempo, no se puede evitar anunciar su final. De sus quince vecinos sólo tres se mantienen en la villa. Imposible soportar el peso de contribuciones y foros que han de rendir ante Santa Clara. El 30 de enero de 1817, por escritura ante Pedro Ybero, escribano de Tordesillas, Gabriel Navarro, Isidoro Milla y Juan Antonio Hinojal, únicos vecinos en estas fechas, hacen dejación del útil aprovechamiento de los dos foros que tenían sobre todo el término a favor del Monasterio de Santa Clara. Se sienten obligados "porque arruinadas todas las casas de dicha villa en la guerra de la independencia, se despobló; y los tres únicos vecinos la abandonaron y se trasladaron a Serrada, hallándose imposibilitados de poder levantar las casas y pagar los muchos atrasos que debian por los indicados réditos" ${ }^{16}$.

La situación jurídica se presenta óptima para el monasterio. Los tres vecinos suplican que les admita la citada dejación con la condición de perdonarles todos los atrasos que deben y las consiguientes ejecuciones en curso para su cobro, además de permitirles el aprovechamiento del vuelo de los majuelos plantados en dicho término, "habiendo de hacer cada uno de sus poseedores las escrituras forales correspondientes y pagar sus réditos o canon”. De esta manera los dos dominios, el útil y el directo de San Martín del Monte y sus términos, dehesas, prados y eriales, quedan consolidados como único y absoluto en la citada institución monástica. Ninguna puerta volverá a abrirse en el citado lugar. La primera fecha que registra el lugar como Despoblado es de 16 de mayo de 1818. San Martín del Monte deja tras de sí más de quinientos años de historia ${ }^{917}$.

\section{- Las dificultades de Serrada por levantar su iglesia. La accidentada edificación de San Pedro de Serrada}

La iglesia de San Pedro corre pareja a las propias vicisitudes de población y sus cosechas a lo largo de los siglos. En los siglos XI y XII, a tenor de los documentos existentes, era poco más que una ermita. En líneas anteriores se constata que los encargados de su culto eran inferiores en número a su vecina en La Moya, Sta. Ma de los Remedios. Conforme fue creciendo la aldea, el recinto fue adaptándose a sus necesidades. Pronto empezaron obras de reparación o ampliación que dan pistas sobre su evolución. Los diezmos, las limosnas y donaciones que recogen las mandas testamentales sirven para afrontar estos gastos. En 1592, por ejemplo, es el propio Diego de Montalvo, vecino en

${ }^{916}$ A.F.A.M. Carp. de escrituras y varios.

${ }^{917}$ En ella José Obregón y Juan García Aparicio, vecinos de Serrada, otorgan escritura para servir a la administración de los efectos de propios del Despoblado. En el texto se señala que los citados tres vecinos se han trasladado a Serrada: "En la villa de Serrada a diez y seis de mayo de mil y ochocientos diez y ocho, ante mí el escribano único de su número Ayuntamiento y millones y testigos infraescritos, comparecieron Joséf Román y Juan García Aparicio, vecinos y labradores de esta dicha villa.... Dijeron: Que a consecuencia de carta orden del Señor Intendente de este Exército y Provincia como Jefe principal bajo del que rigen y gobiernan los efectos de propios... para la execución y cumplimiento a la Justicia y Junta de Propios de esta dicha villa de Serrada, encargándola nombrase sugeto lego, llano y abonado... para que administrase... los propios del Despoblado de San Martín del Monte, respecto a que la escriptura de defacción que habian otrorgado los tres únicos vecinos que habian quedado de dicho lugar y domiciliándose en este de Serrada en fabor del Real Convento de Santa Clara de la villa de Tordesillas como dueñas que espresaban ser de sus terrazgo, no podía ser válida por estar hecha por parte no legitima y sin autoridad para ello, ni perjudicar a los Propios de dicho Despoblado, quienes satisfacciendo a el citado Convento cinquenta y dos fanegas y quatro celemines de centeno y diez y siete reales $y$ diez $i$ seis maravedis anualmente que les corresponde pagar por el canon de ciento ocho fanegas, seis gallinas y cinquenta reales en dinero, no podía dicho Convento apropiarse del derecho útil de los Propios ni por consiguiente cobrar balores algunos por ellos, y consintiendo como consisten según nota que acompaño dicho señor Intendente a la notada su carta orden dichos propios del Despoblado de San Martín en la Dehesa titulada de Arriba: El Prado del Verral; el Pinar del Sotero y el Pinarillo, que todo hece ciento ochenta y quatro Obradas y doscientos treinta y tres estadales y medio. Se nombro por dicha justicia y Junta por tal Administrador de dichos efectos y valores a el espresado José Román.” (A.H.P.V. Pt. 8229, Serrada, Manuel Demetrio de Colomera, fol. 10, año 1818). Era el final. Es posible que el lector se haya encariñado con la pequeña villa por las desventuras de sus pocos habitantes a lo largo de los siglos. A quien esto escribe le ha sucedido lo mismo. Con el paso de los años, al tiempo que este estudio tomaba forma, ha pasado de contemplar los restos del Despoblado, desde la curiosidad del historiador por conocer su pasado,a la emoción de quien ve en aquellos restos de huesos, cerámica y piedras una parte de su memoria. Los huesos de las imágenes no son ajenos. Tienen nombres y apellidos y fueron enterrados cristianamente al amparo de San Martín para que reposaran 
Medina del Campo y titular del mayorazgo familiar de Serrada, el que se obliga con la iglesia de San Pedro a pagar "veynte y dos mil maravedis los quales debo y son por raçón de los frutos del nobeno pertenecientes a la dicha Iglesia en este año de la fecha ... los quales pagare a los dichos plaços y a cada uno de ellos con mas dos ducados en dinero para la colación que se ha de gastar en el dicho nobeno al año siguiente y más un quarterón de incienso y dos sogas y dos lías de dar y tomar para las campanas de la dicha Iglesia para el día de Pascua de Flores..... ${ }^{918}$.

María del Castillo, vecina de Serrada, deja en su testamento, como tantos otros escritos en estos siglos, mandas que acercan no sólo a la estrecha vinculación de los hombres con Dios y sus ministros, sino a lo frágil que resultaba la vida y al deseo, al menos, de acercarse lo más posible a lo espiritual como tabla de salvación y liberación terrenal ${ }^{119}$. El testamento anota misas y ofrendas que, cuantificadas en reales, van engrosando el patrimonio de la propia fábrica de la iglesia y de sus beneficiados. De hecho, fieles con menor fortuna, sabedores de lo costoso que resulta morirse, apartan determinados bienes para su subasta en almoneda pública y así costear entierro, misas y obras pías. A nadie se le escapa que, conforme la situación económica toma impulso, el crecimiento de Serrada se refleja en el empuje de la iglesia de San Pedro. Las imágenes adjuntas de San Pedro y de la Virgen con el Niño datan de este siglo XVI.

En este tiempo despega la riqueza vitivinícola del lugar y se acometen obras urgentes que salvan al templo de una ruina inminente. La documentación encontrada testifica que, desde comienzos del XVII, se llevan a cabo toda una serie de obras, reformas y ampliaciones. En 1606, se firma la escritura con Pedro de Casanueva para la edificación de la sacristía ${ }^{920}$. Desde estos muros de la capilla mayor se proseguirá, en las siguientes décadas, reparando y ampliando el viejo templo.

en paz de tantas fatigas vividas. Quizá no estaría de más, si las autoridades religiosas y municipales lo tuvieran por acertado,, recoger estos huesos, conforme afloran tras el paso de los arados, y depositarlos, con un breve y simbólico homenaje a su memoria, en el cementerio de esta villa que asumió en su día la jurisdicción sobre el citado Despoblado, siempre, claro está, con el permiso de quienes actualmente son los propietarios de aquellas tierras. Que todo sea por cumplir la principal manda testamentaria que aquellos hombres y mujeres dejaran escrita, a saber, descansar en la paz de Dios.

918 A.H.P.V. Pt. 11840, Antonio de Medina, fol. 397.

${ }^{919}$ Entre algunas de sus cláusulas religiosas, fechadas en este mismo año de 1592, puede leerse "Primeramente mando que quando la voluntad de Dios, nuestro Señor, fuere de me llevar desta presente vida, que mi cuerpo sea sepultado en la Iglesia del Señor San Pedro del dicho lugar, y si mi entierro fuese por la mañana se haga con misa de réquiem cantada; y si fuese por la tarde con vigilia de tres leçiones y al otro día siguiente se haga el dicho mi entierro, el qual se ofrende con siete quartales de pan con sus belas de zera, y de la demas zera necesaria conforme a la costumbre deste dicho lugar que se aze con las personas de mi estado, y se taña a la mor y se paguen los derechos acostumbrados.

Yten. Mando se me aga mi novenario rezado en nueve dias y en cada uno de ellos se diga por mi anima misa de requien, ofrenda de zera y se ofrende el dicho novenario con medio quartal de pan con su vela de zera y para el entierro y novenario se trayan quatro cirios del peso de una libra cada uno y el dicho novenario sea ofrendado de la demás zera necesaria y se taña a la mor y se paguen los derechos acostumbrados. Y es mi voluntad que para el día de mi entierro si no a tiempo de decir misa para este efeto y el ornato del, vengan tres clérigos de los pueblos deste contorno que ayuden al oficio que se hiciere y sea con ministros de diacono y subdiácono y que se les de de limosna dos reales a cada uno y el sustento necesario...". (A.H.P.V. Pt. 11840, Antonio de Medina, fol. 257).

${ }^{920} \mathrm{Su}$ lectura acerca a la situación que por entonces presentaba el primitivo edificio: "Primeramente con condición que esta dicha sacristía que se ha de azer se ha de fundar y plantar edificándola entre los dos estribos de la capilla mayor, al mediodia, la qual a de tener de hueco a la mano derecha distancia de diez y seis pies y otros doze de frente como se entra en la dicha sacristía que se entiende desde la pared de la capilla Mayor que agora esta hecha.

Yten. Con condición que para fundar esta dicha sacristía se ha de ahondar los cimientos donde se hiziere y ba declarado otro tanto como los de la dicha capilla Mayor de la dicha Iglesia, o a lo menos hasta allar tierra firme y suficiente conforme al edificio han de tener de grueso los dichos cimientos tres pies y han de yr hechos de buena albañilería con sus yladas de piedra asentada por sus tercios a cordel y a plomo y aniebladas.

Yten. Es condición que estos cimientos han de salir con este grueso hasta el pavimento de la tierra y alli se escogerán las dos paredes de las cabeceras de dos pies y medio y la pared frontera subiria de treze pies y todas estas dichas paredes con los gruesos declarados an de subir hasta diez pies de alto y alli se ha de dexar una dera desde donde se ha de eregir la bóveda de la dicha sacristía y desde alli y arriba subirán todas tres paredes de dos pies de grueso y han de subir hasta diez y seis pies de alto y encima destas paredes se ha de hazer un tejado bien ordenado con su ladrillo de yeso. 
Entre 1639 y 1645 , se arreglan los tejados y techumbres de la nave mayor; en 1650, se mejora la capilla mayor, que es reformada en 1650 por Antonio Cillero y cerrada con una media naranja, a la que sigue, meses después, la cubierta de la nave que, en aquel tiempo, tenía sólo tres ventanas ${ }^{921}$.

En la segunda mitad del siglo XVII, el pueblo crece en vecinos y en necesidades espirituales. El vino, como se ha escrito, mejora la situación económica de los serradenses y les aporta recursos suficientes para afrontar nuevas obras. De hecho, en 1660, se construye una nueva cilla en la calle del mismo nombre. Las cosechas de caldos dinamizan Serrada y sus pueblos limítrofes ${ }^{922}$. Entre 1657 y 1667 se llevan a cabo nuevos trabajos: se rehace el muro de la portada y se hace una nueva escalera para la torre. En la década de los ochenta del mismo siglo, se sigue componiendo la sacristía y se reparan tejados y cimientos. El edificio inicial parece más remozado que nunca. A la par de estas obras, se adquieren las tallas que los vecinos honran en sus devociones, como el Cristo procesional que parece fecharse en el siglo XVI. De 1606, año en que se realiza la sacristía, data una de las piezas de mayor valor de cuantas acoge el templo. Se trata, como puede advertirse en la imagen adjunta, de una representación de San Miguel Arcángel venciendo al demonio, obra de primera época del gran escultor barroco castellano Gregorio Fernández y, en la segunda mitad del siglo, destaca el retablo de la Inmaculada, donada en 1658 por el entonces alcalde Pedro Navarro.

La pequeña iglesia sufre, a lo largo del siglo XVIII, una profunda reforma hasta alcanzar las dimensiones y hechuras que hoy pueden contemplarse ${ }^{923}$. Para ello, en 1772, vuelve a plantearse la ampliación de la nave y, por tanto, debe replantearse nuevamente su trazado ${ }^{924}$. Al parecer, es la voluntad

Yte. Es condición que la bóveda desta sacristía a de ser de la hechura y forma que esta la de la moya con su arquitrabe, friso y cornisa y toda la demás labor sin discrepar de la hechura y traza y a de ser lucida de buen yeso y solada de ladrillo.

Yten. Es condición que el tejado desta dicha sacristía ha de ser armado a tres aguas con sus andabigas metidas en las paredes de la Capilla mayor bien forzadas en la dicha pared con yeso,; a de llebar el dicho tegado sus soleras, estribos, quadrales, todo bien asentado y edificado ha de ser tejado con teja doblada con su barro y todos los brocales y respaldar todo con buena cal.

Yten. Es condición que se a de romper una puerta en la pared de la capilla mayor junto a las gradas del Altar mayor. A de tener declaro tres pies y de alto siete pies en esta dicha puerta; se ha de asentar un postigo de buena madera, bien hecho y fuerte con su marco y gozneso fijas.

Yten. Es condición que para la luz desta sacristía se ha de hacer una ventana en la pared del mediodia; a de tener una quarta de ancho y una bara de alto; será rasgada por dentro y fuera...”. (A.H.P.V. Pt. 11854, fol. 291).

${ }^{921}$ MARCOS VILLÁN, M. A. Y FRAILE GÓMEZ, A, Ma: Antiguo Partido judicial de Medina del Campo. en Catálogo Monumental de la Provincia de Valladolid, tomo XVIII, Diputación de Valladolid, 2003, pág. 402 y ss.

${ }^{922}$ En Valdestillas, por ejemplo, distintos vecinos se obligan en 1611 a pagar distintas cantidades de mosto para costear las obras que también están haciendo en su iglesia. El cura Pedro de Medina da ejemplo, donando anualmente cien cántaras, Jerónimo Gutiérrez, un moyo; Pedro de Ortega, dos cántaras... (A.H.P.V. Pt. 11859, Antonio de Medina, fol. 239)

${ }^{923}$ Las obras no van a ser fáciles ni ajustadas al tiempo previsto. El arquitecto de Valladolid Matías Machuca es el encargado de trazar sus planos. Andrés Cillero, maestro de obras de Tordesillas, quien las ejecuta. El 22 de julio de 1723, día de Sta. María Magdalena, se dio principio la obra, acompañada de un desafortunado hecho: "En la villa de Serrada a 22 de julio de 1723 día de Vendita Sta. María Magdalena se dio prinzipio a la obra de esta iglesia por el licenciado Don Pedro Alonso de Arenal Presbitero y cura quien echó la primera errada de cal y primera esportilla de guijarro al zimiento de la iglesia... e después muchos otros vecinos Della siendo maestro de dicha obra Andrés Cillero vezino de la villa de Tordesillas, cuio día hubo fiesta de toros en la villa de Matapozuelos i a eso de la una de la tarde salio a ver la fiesta referida un oficial llamado Lorenzo natural de Ontiberos el qual luego que llego a dicha villa de Matapozuelos y entro en la plaza le dio una cornada un toro de la qual murió dentro de las pocas oras". La desgraciada muerte parecerá un presagio de cuantos problemas iban a sucederse. Dificultades con Cillero llevan en 1725 a Matías Machuca a proseguir las obras, edificando y cubriendo la cabecera con bóveda, asentando el retablo y acabando la nave de la iglesia. (MARCOS VILLÁN, M. A. Y FRAILE GÓMEZ, A, Ma: Antiguo Partido judicial..., ob. cit., pág. 417).

${ }^{924}$ Será Bernabé Domínguez, maestro arquitecto de La Pedraja quien traza y contrata la obra. En febrero de este año, el concejo de la Villa pide al obispado que destine los sobrantes de los beneficios de Preste vacantes a la obra de la iglesia. Se argumenta que el templo es "de cortísimo buque y con notoria necesidad de alargarse y extenderse para que con alguna comodidad quepan en ella sus vecinos". Por acuerdo del concejo tienen pensado "el ampliar dicha Iglesia Parroquial... a lo que jamás han podido arribar por los cortos medios que a todos asisten”. (A.H.P.V. Pt. 8220, Miguel Moyano, fol. 166). 
de todos por contribuir a dicha ampliación la que les hace dar un paso hacia delante. El mismo día de la Virgen de agosto de este ańo, los feligreses y Parroquial de San Pedro toman 6.000 ducados a censo al redimir para hacer frente a los gastos de la obra de "una nave para la iglesia" 225 . Nunca imaginaron que las cuentas y los tiempos previstos pudieran salir como salieron. Lejos de acabar las obras Bernabé Domínguez el día de San Miguel de 1774, como se había comprometido, se denuncia al arquitecto por no ajustarse a las trazas, ni emplear materiales de calidad, ni ejecutarla con las medidas convenidas ${ }^{926}$. Es Tomás Domínguez quien, en la década de los ochenta, levanta la torre, siguiendo las nuevas trazas de Vargas, y termina las obras principales. Unos años después, entre 1791 y 1792, se cierra el cementerio adjunto a la iglesia, se hace la bóveda de la sacristía y se embaldosa la iglesia ${ }^{927}$. Estaba acabando el siglo. A pesar del notable incremento del coste de unas obras que nunca acababan, conforme pasan los ańos, nuevos retablos e imágenes siguieron alentando el fervor popular. De 1712 data el retablo mayor realizado por Francisco Villota. Sus dimensiones se adaptan al ábside de la anterior iglesia que disponía de un antiguo retablo "con marcos de mucha talla y todo de la vida y martirio de San Pedro Apóstol" ${ }^{228}$. En 1732 se adquiere el retablo barroco que acoge a la Virgen de la Moya, trasladada desde el antiguo Despoblado por la ruina de su iglesia, si bien, a juicio de los expertos, dicha imagen data de la segunda mitad del siglo XVII. Con todo, es a lo largo de todo este siglo XVIII cuando retablos, pinturas, órgano, campanas y orfebrería conforman el importante legado artístico que alberga, con la adquisición de la cruz procesional en 1766 o, como se ha visto, de otras imágenes gracias a donación de devotos y pudientes serradenses ${ }^{929}$.

${ }^{925}$ Ponen como garantía del préstamo "los bienes, rentas y efectos que goza dicha Iglesia y eran valiosos y quantiosos... teniendo tratado con la Real Universidad de la misma ciudad de Valladolid, su mayordomo y apoderados la toma de sesenta mil reales de vellón a censo redimible..."(Ibídem, fol.188.

${ }^{926}$ Para colmo, con la torre empezada a los pies de la misma y sobre el coro, las críticas de los mismos maestros de obras sobre esta "ydea sin ejemplar y a todas luzes afirmada en la vanidad de una fantasía caprichosa sin reglas de arte" hacen que se revise el proyecto de la torre, se derribe lo que estaba construido y se levante una nueva, siguiendo las condiciones dadas en 1775 por José de Vargas. Antes, Domingo Rodríguez trata primero la posibilidad de continuación del proyecto para, después, dudar de su viabilidad: "Pliego de traza y condiziones que yo Domingo Rodríguez Maestro de Arquitectura y vezino de la villa de Fresno el Viejo Provincia de la Ciudad de Toro formo en fuerza andado por los Señores presidentes y oydores de la Real Chancillerí... Lo primero se habian de fabricar los dichos tres arcos baxo del piso de la tribuna el del medio y mayor para desemvarazo de la entrada de la iglesia y luego de los canceles revajado un pie en la forma que demuestra la traza que acompaña en la letra $A$ y los de los lados más pequeños de medio punto como se manifiesta por la letra $B$, cuios arcos se debian enrrasar de mazizo hasta el piso de dicha tribuna que el que señala con la letra $C . .$.

Que la fávrica de los referidos arcos y sus pilastras del diseño habian de tener de piedra de velilla u de otra misma casta cortada en sillares a regla y escuadra...

Que las pilastras que habian de rezivir el arranque del arco de medio punto sudio que son las que se demuestran por la letra $H$ se havian de adrajar cada segunda ylada en las paredes de la iglesia una tercia...

(...) Con cuias condiziones y del modo que va expresado y no de otro modo se devian formar y construir los rreferidos arcos .... Pero haviendo rrexistrado y reconocido nuevamente la rreferida obra torre y arco de punto subido .... con motivo de haver mediado cerca de quatro meses desde que se hizieron las últimas declaraciones ... se an aumentado las grietas ... por lo que soy de sentir que demoliendo lo favricado de dicha torre y el referido arco de punto subido se prosigue el texado y bóbeda hasta llegar al extremo de dicha fachada ... y fabrique una nueva torre firme y de la duración que corresponde en el sitio que mas conbenga ... Serrada y octubre 10 de 1774” (MARCOS VILLÁN, M. A. Y FRAILE GÓMEZ, A, Ma: Antiguo Partido judicial...., pág. 444 y ss).

927 Ibídem, pág. 404 y ss.

928 Ibídem, pág. 407.

${ }^{929}$ Es el caso, al margen del ya nombrado Pedro Navarro, de Buenaventura Moyano que, en 1790, antes de ser nombrado obispo de Palencia, dona un cáliz de plata, o de su hermano Tomás, consejero de Estado de S.M., que hace lo propio con otro en 1830. Mayordomos de la iglesia, fieles humildes o acaudalados hacendados fueron, al paso de los siglos, levantando el templo que hoy alberga, tanto al Apóstol titular, a la Virgen de La Moya, como a la tantas veces rezadas Virgen del Rosario. En 1812, por último, José Martín, cura de San Martín, ante las invasiones de tropas francesas y el abandono en que se haya el pueblo, decide trasladar "las alhajas, ornamentos, bestuarios y demás, correspondiente a la Iglesia de dicho su Pueblo, a esta de La Seca... (A.G.D.V. Libro de Fábrica de San Martín del Monte. Visita de 16 de septiembre de 1812). 


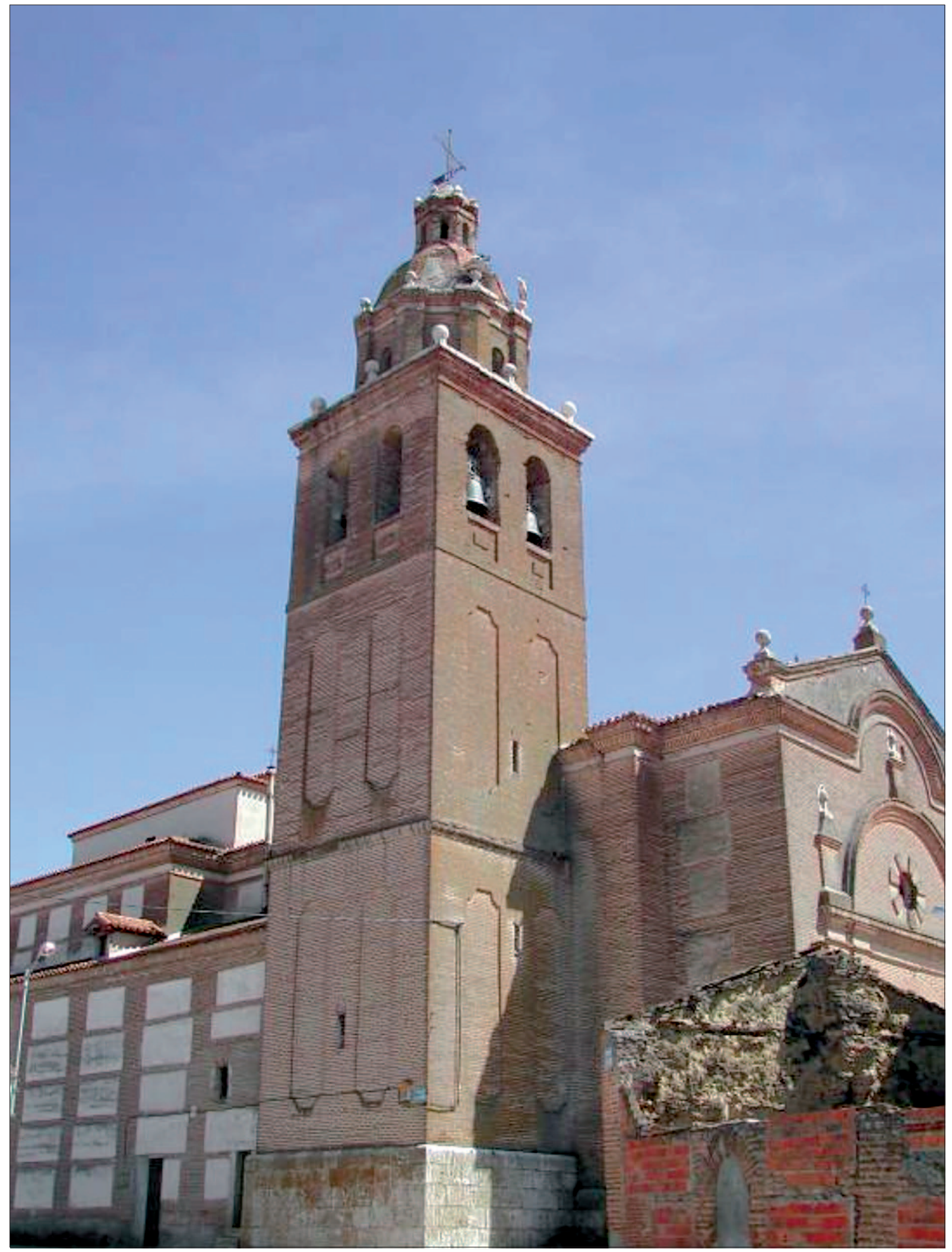

Imagen 78. Iglesia de San Pedro. Detalle de la torre, Serrada. Foto: 14/04/2005. 

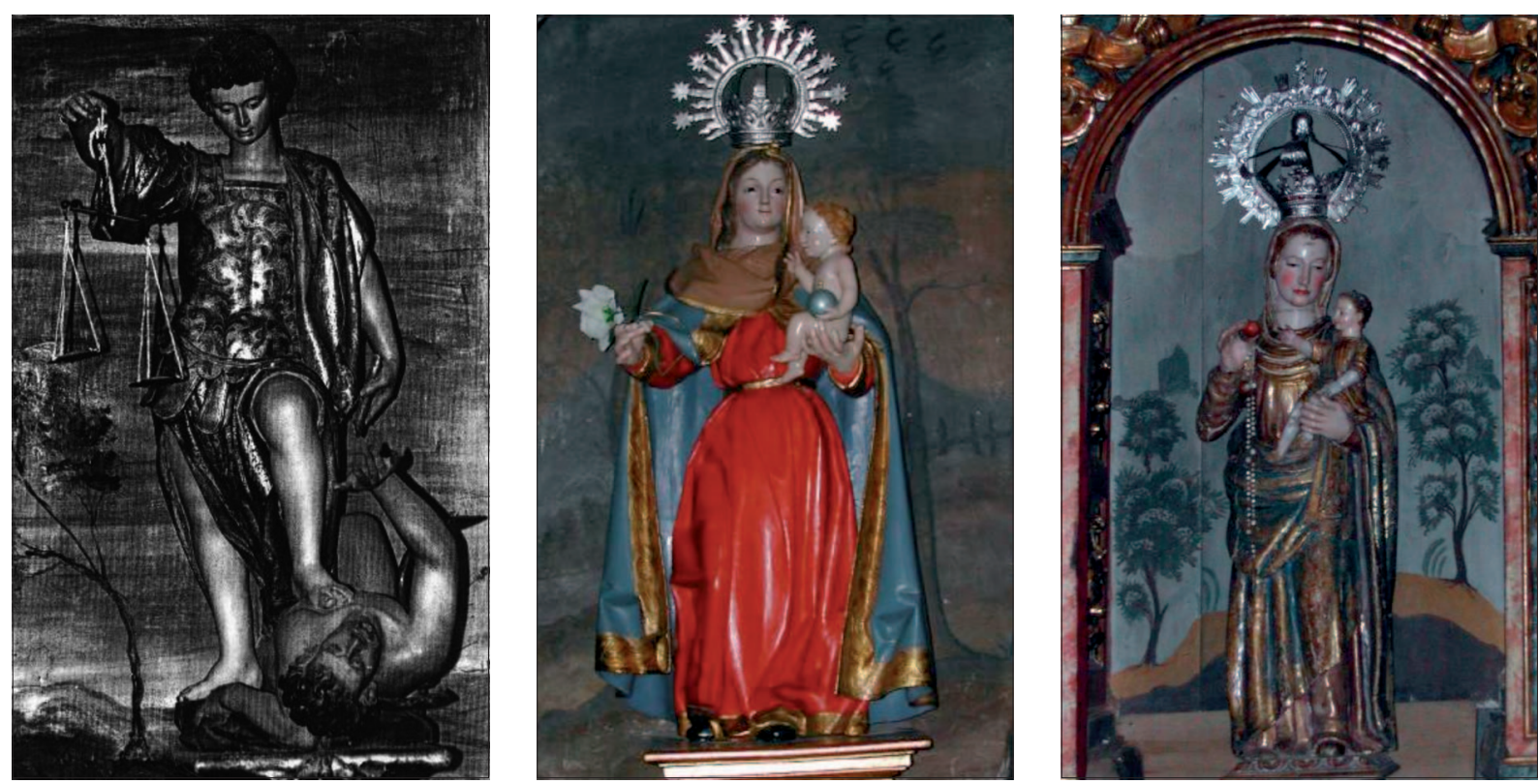

San Miguel Arcángel venciendo al demonio, (Gregorio Fernández, año 1606, izquierda), Virgen de Nuestra Señora de los Remedios de la Moya (centro) y Virgen del Rosario (derecha). Foto: 14/04/2005
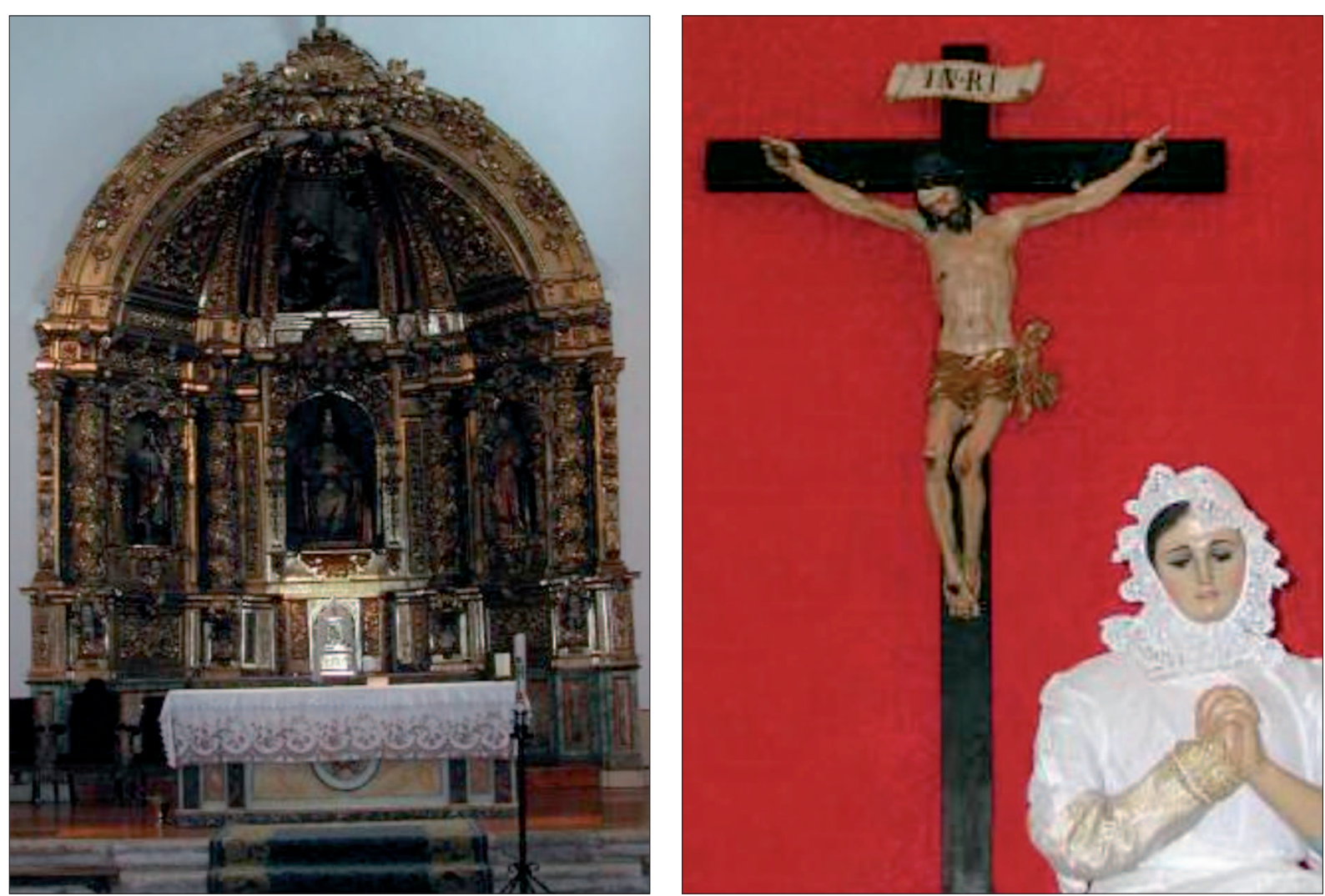

Retablo Mayor, de Francisco Villota, siglo XVIII, izquierda; Cristo Crucificado, siglo XVI, derecha. Foto: 14/04/2005.

Imagen 79. Imágenes y retablo de la Iglesia de San Pedro. Serrada. 


\section{La vida cotidiana. Una necesaria organización interna para garantizar la armonía entre vecinos}

El nacimiento y desarrollo de cuantos lugares tratamos va a la par de la vida de sus concejos. Estas instituciones, representativas de la comunidad campesina, administran los bienes de propios, hacen guardar el orden y convivencia entre vecinos, otorgan poderes para ser representados en pleitos, sacan a remate público alcabalas, abacerías o tabernas, son representados ante el tribunal de la Mesta o las villas cabeceras de las que depende su jurisdicción, conservan el monte, precisan los salarios y funciones de los maestros de primeras letras... La reunión concejil siempre es pública y previamente anunciada "a voz de campana tañida según lo avemos de uso y de costumbre de nos ajuntar" 930 . Las campanas sirven como eficaces instrumentos para convocar al vecindario de acuerdo con el toque dado, además de festividades religiosas u otros avisos. El sonido y la voz eran siempre más útiles que la letra impresa, dado el alto analfabetismo. Por ello tampoco falta en muchos concejos la figura del pregonero, que daba voz pública de los acuerdos o ponía al tanto de noticias o peticiones al pueblo entero.

Los concejos de estas villas presentan un dinamismo y participación más plural que sus cabeceras de Medina y Olmedo, controlados por los sectores oligárquicos y en manos de regidores y linajes que se reparten los cargos o simplemente los compran. La vida en estas pequeñas comunidades depende directamente del buen funcionamiento y ordenamiento de sus recursos ${ }^{931}$. A nadie se le escapa que los alcaldes, regidores y procuradores suelen ser los vecinos propietarios y con recursos, pero, en los pequeńos pueblos, la diferencia entre la vecindad no es tan acusada como en aquellas, donde el estamento nobiliario se eleva, sobre el resto, a niveles intocables. En ocasiones, no obstante, la labor de los alcaldes y regidores no es fácil, sobre todo en lo que respecta al cumplimiento de la justicia, especialmente cuando se trata de llevar a la cárcel a sus propios convecinos por incumplimiento de tratos o de normas de gobierno ${ }^{932}$. Palabras o hechos más graves ponen de manifiesto la difícil tarea de los alcaldes de estos pequeños pueblos de Castilla, tan llenos de pobreza como de diferencias y analfabetismo ${ }^{933}$.

${ }^{930}$ Así testimonia en 1741 el escribano Francisco Moyano el inicio de uno de los muchos concejos de vecinos que se celebran en Serrada y que se puede hacer extensible a cuantos lugares se reparten por la Tierra de Medina en estos siglos XVI, XVII y XVIII: "Sépase como nos, el Concejo, Justizia y Reximiento y vecinos Capitulares y particulares de esta Villa de Serrada, juntos a son de campana, según lo habemos de huso y costumbre en el sitio y parte acostumbrada en donde nos allamos, expecial y señaladamente Roque de Yscar, Alcalde ordinario; Gabriel Alonso y Santiago Martín, Regidores; Narciso del Castillo, Procurador general; Paulo Rodríguez, Joseph Alonso Rico, Marcos Román, Julián Minguela, Matheo Rodríguez....(siguen otros 49 vecinos), todos vecinos desta dicha Villa, que confesamos ser la mayor parte quienes por nos y por los demás ausentes e impedidos que no se an podido juntar, prestamos suficiente caución en forma sobre que estarán y pasaran por lo aqui contenido, so expresa obligación que hazemos de nuestras personas y vienes, y de los propios y Rentas de esta dicha Villa y todos Juntos con renunciazión que hazemos de las leies de la mancomunidad, con todas sus cláusulas, como en ellas y en cada una de ellas se contiene, dezimos que..."(A.H.P.V. Pt. 8215, fol. 172).

${ }^{931}$ Es obligación del común vigilar cada carga de retama que se corta, cada celemín de trigo que se presta, cada acuerdo suscrito entre vecinos, y el escribano da fe de ello. Como se verá, la cárcel está presta para los inobedientes de la justicia, los amigos de lo ajeno o los asiduos de las quimeras. El alcalde ordinario de cada villa era el encargado de impartir esta justicia, proceder criminalmente de oficio contra los infractores, encarcelar, si ha lugar, u otorgar fianzas carceleras hasta que la justicia mayor cumpla procedimientos y escuche a las partes en litigio. Alcaldes, regidores y procuradores representan el bien común y en algunas ocasiones, de acuerdo a lo que consta en los protocolos notariales, se acompañan de cargos menores como pueden ser el alcalde de la Santa Hermandad, encargado de la vigilancia y detención de los posibles malhechores para ponerlos a disposición de la justicia o diputados que también encabezan las reuniones del concejo en Serrada desde la segunda mitad del siglo XVIII.

932 No faltaron los regidores que, hartos de sus obligaciones, acusaban las tensiones vecinales y ocasionaron más de un conflicto. En el caso de San Martín, por poner un ejemplo, el regidor Vicente de Castro se negó a llevar las cuentas y dineros a Valladolid en el año 1785, lo que le valió ser encausado por su propio alcalde Damián de Blas, en un auto de oficio por inobediencia a la justicia y usurpación de su jurisdicción. Al parecer el fiel de los hechos lo requirió para 
A las anteriores obligaciones se deben sumar aquellas derivadas del buen aprovechamiento de los recursos concejiles, sean pastos, cortas de pinares, encinares o de la administración de tabernas o abacerías. En los múltiples juicios de residencia que tienen lugar se insiste en el control y vigilancia de la caja de caudales. Ante la inexistencia de entidades bancarias, lo aconsejables es guardar el dinero bajo llave. En la casa del concejo era preceptiva la existencia de un arca con tres llaves donde custodiar acuerdos, documentaciones y reales. Cuando las malas cosechas se repiten y el hambre aprieta, el control de quienes rematan tabernas, alcabalas, pampaneras o abacerías no es fácil. Y, si defraudan los arrendatarios, se resiente el vecindario. De ahí la rigidez en los registros de medidas, en la venta de los bienes y en el control del orden. La cárcel pública se frecuenta a menudo y el elevado coste de los pleitos puede arruinar a familias enteras. Regidores y vecinos son conscientes de lo que se juegan si tratan de burlar a la justicia.

\section{a. Las normas de buen gobierno}

Todos los hechos y acontecimientos se insertan en el marco de una legalidad preestablecida. Ningún aspecto económico o de la vida cotidiana está al margen de normas escritas o de costumbres ancestrales que garantizan la supervivencia durante siglos. Cuando las leyes se quiebran, la cárcel o los pleitos devuelven a cada una de las partes a su lugar natural. Solo así sobrevivieron estas sociedades a lo largo del tiempo.

que tomase las cuentas de propios y 143 reales y los llevara a Valladolid a la Contaduría del ramo y pagase los derechos debidos a la Real Hacienda. El regidor le respondió que no quería tomar el dinero ni llevar las cuentas, "que no quería ir, que mandara a otro". Por si esto fuera poco, se le imputaron enfrentamientos y usurpaciones de poder respecto al alcalde ordinario "en perjuicio de la Jurisdicción ordinaria de su ministerio para exigir penas o quererlas exigir blasonando y diciendo: Yo lo mando, aqui no hay mas Alcalde que yo. Si no sabe ser Alcalde, yo le enseñare." Estas palabras son ratificadas por varios testigos en el proceso incoado. Uno de ellos, Francisco Recio, vecino del lugar, ańade serias diferencias que evidencian desavenencias más profundas. Declara que el tal Vicente ha dicho "que en dicha villa no hay mas alcalde que el; que los meloneros se han de acordar de el y que no se han de aprovechar de los melonares.... que si ahora era regidor luego sería más, que el Alcalde se fuese a mandar a otra parte por no decir a la mierda; que ha querido quitar prenda a Brígida Recio su hija por dos veces; que es cierto no lo ha hecho estando cogiendo yerba en dicho garrobal..." Estaba medianamente claro que no congeniaban alcalde y regidor y que este tampoco tenía muchos amigos entre el vecindario. Pero dijo que no y que no. Prefirió acabar preso en la cárcel del concejo y encausado por la justicia, pero no fue y, como la hacienda apremiaba y la justicia se impacientaba, tuvieron que ir otros representantes de la villa con la mayor brevedad a entregar estas cuentas del concejo. (A.H.P.V. Sección Concejos, San Martín del Monte, SH 89/2, año 1785).

${ }^{933}$ Ejemplo de esta mayor gravedad y trascendencia, respecto a estas difíciles obligaciones de impartir justicia por parte de estos alcaldes, fueron los sucesos ocurridos en Serrada el 28 de enero de 1770. Las propias palabras del escribano Miguel Moyano, fiel de los hechos en aquellos años, que refieren el poder otorgado por el alcalde Simón Ruiz de Ríomayor a agentes y procuradores de la justicia de Valladolid, son muy elocuentes: "Enfermo en la cama por las heridas sufridas otorga poder a Don Pedro de Pedrosa y Don Antonio Andrés Cano, Agente y Procurador del numero de la Real Chancillería de la ziudad de Valladolid para que en su nombre parezca ante los señores gobernadores y Alcaldes del Crimen y actúen judicialmente en relación a los hechos ocurridos sobre las nueve y media de la noche del 28 de enero de este año, cuando por obligación de sus oficio y en compañia de Andrés García, vecino y Procurador sindico general se dirigian a la calle real a evitar ruidos y quimeras. Hallan poco más arriba de dichas mis casas a remigio Platón y Manuel Martín, solteros, naturales de ella, que juntos y en espía me estaban esperando, conjurados a quitarme la vida y sin otro que el de haberles recombenido se fuesen a recoger por ser ya ora para ello. Valiéndose de la obscuridad de la noche y sus sobradas fuerzas, ningún respeto a mi empleo y Persona, auxiliados el uno del otro, me acometieron por la espalda y descargaron en mi tan rezio y fuerte golpe con una cortante podadera del que me hirieron de muerte en la caveza. Y después de verme caido en el suelo y sin sentido, otros de los que hizieron otras heridas, fugándose y retirándose de dicho suelo con presteza, luego que lograron satisfacer su premeditada conjuración, machinada sin duda a instanzia y Consejo de Basilio Martín, vezino y obligado del Abasto de la abacería de este pueblo, Padre del referido Martín y tío del sobredicho Remigio, a causa de haver mandado en aquel mismo día poner y puesto preso al enunciado Basilio por falta de cumplimiento a la obligación de tal...". A los nominados Remigio Platón y al propio Basilio Martín se les puso presos en la cárcel local hasta su traslado a los calabozos de la Real Chancillería de Valladolid, no así al citado Manuel Martín que, al parecer, se dio a la fuga y no pudo ser encontrado. 
Para ello, las arcas de los concejos guardan cuantas normas escritas y de funcionamiento administrativo regulan la vida de las aldeas. Son pequeños archivos custodiados por los regidores, de acuerdo a pragmáticas reales y autos de la villa y tierra a la que pertenecen. La pérdida de este legado no sólo desarma al historiador, sino que borra la memoria colectiva de pueblos enteros. No obstante, para hacerse una idea de este conjunto normativo que regía la vida de La Moya, Serrada o San Martín, nos consta la documentación que se custodia en el arcas del concejo de esta última villa. Como ejemplo, en la residencia que se toma en 1759 por parte de Santa Clara a San Martín del Monte, San Miguel del Pino y Torrecilla de la Abadesa, todos ellos bajo su jurisdicción, el juez visitador Vázquez Dávila, hace fijar en las puertas de los respectivos concejos el bando que a continuación se reproduce al pie y que regula la vida de San Martín. Por su extensión reproducimos al pie las normas más importantes ${ }^{934}$.

${ }^{934}$ Son las que siguen: “...Primero. Lo primero que ninguna persona de qualquiera estado y calidad que sea, diga blasfemias, ni juren el nombre de Dios nuestro Señor, ni de la Virgen santa María su madre, señora nuestra, ni cosa sagrada, so las penas inpuestas por leyes destos reinos, que se ejecutaran imbiolablemente prozediendo en esto con todo rigor, especialmente contra los que dieren escándalo en plazas, calles o sitios públicos, en contabención a lo que ba prebenido.

Segundo. Que ninguna persona este emanzebada, ni sea alcabueta ni hechizero, y los que lo fueren, salgan de toda esta jurisdicción dentro del tercero dia, pena de cien azotes, y desde que se ejecutara en ellos la impuesta por la lei real. Y que el que fuese noticioso de tales excesos, me los partizipe explicando con toda verdad y pureza lo que haia entendido, y sepa, pena que al que asi no lo hiziese se le impondrá la consigna, considerándolo cohoperazión al exceso, y a que no se ebiten cosas tan perniciosas al bien público y particular.

Tercero. Que ninguna persona use del juego de naipes, taba, dados, ni otros prohibidos hasi en sitio público como en secreto, pena de trescientos maravedís, y tres días de cárzel por la primera vez, doblada en la segunda, y en la terzera se les ynpondrán las prebenidas por derecho y leies destos reinos.

Cuarto. Que a las diez horas dela noche en berano, y a las nuebe en ybierno, se recojan a sus casas, y no anden en quadrillas pena de prozeder contra los contrabentores como corresponda, como ocasionadores de la turbacion y paz y sosiego de la república.

Quinto. Que ninguna persona de día ni de noche use armas prohibidas, pena de ser castigados irremisiblemente como mandan las reales órdenes y pragmáticas.

Sexto. Que ninguna persona pueda comprar ni tome de hijos de familia moro ni mora de servicio, la más lebe cosa por ligera y tenue que sea, pena de prisión, y de prozeder contra las contrabentores según derecho y leies destos reinos.

Séptima. Que ninguna persona compre ni tome en empeño alhaja alguna que no sea de persona conozida, y en caso de haber alguna sospecha, sigilosamente darán parte a la justizia para providenciar lo combeniente, pena de ser responsables a los perjuizios y daños que de no lo ejecutar asi se originaren y de prozeder por todo rigor de derecho contra los contrabentores.

Octaba. Que todos los vecinos y moradores desta villa cada uno por lo que asi toca tengan limpias las portadas de sus pertenencias, pena de prozeder contra ellos a lo que haia lugar en derecho.

Novena. Que las personas que en esta villa usan de casas de posada no recojan ladrones, rufianes, bagamundos, ni mugeres de mal vivir, y en caso de tener algún género de sospecha, den quenta a la justizia pena de quatrocientos mrs por la primera vez que no lo hizieren, la segunda doblada, y por la terzera dos mil mrs y tres meses de destierro.

Décima. Que ningún ganadero que encierre sus ganados en esta villa lo pueda sacar de sus casas hasta tanto que haia salido el sol, y que los buelba a ellas de día, pena de seiscientos mrs por la primera vez, la segunda doblada, y en la terzera se prozeda contra ellos conforme a dercho, reales hordenes y hordenanzas desta villa.

Undécima. Que ninguna persona por si, sus caballerías y ganados de qualquiera especie que seian, baia ni entren en los sembrados, viñas, ni otras heredades, pinares, montes, alamedas, ni nuevos plantios y tallares, ni en las lindes, ni enzerradas durante haia sembrados y mieses, ni corten leña, ni arranquen árboles pena de pagar los daños a sus respectibos dueños, y de las impuestas en las reales órdenes y hordenanzas, que para ello tiene esta villa las que igualmente se exigirán a los dueños de las heredades que ejecutares lo referido, no llebando licencia de la justizia para qualquier cosa o parte de lo contenido en este capitulo.

Duodécima. Que todas las personas que usaren de pesos, pesas y medidas, las tengan aferidas y bien acondicionadas, y las traigan ha registrar a la audiencia de su merced, pena no lo executarán, si se hallaren defectuosas al tiempo de sus reconozimiento, se les exijiera la multa de quatrocientos mrs.

Decimotercera. Que todas las personas que usaren oficios de examen de qualquier genero o calidad que sea dentro dentro de tres dias primeros siguientes, presenten sus títulos y licencias para el uso y ejercicio de los tales oficios, pena que pasado dicho término, no lo habiendo hecho, se les impedirá el uso y exercicio de ellos, y prozederá contra cada uno de los sobredichos conforme a derecho.

Todas las quales dichas penas se aplican por terzeras partes a la real cámara, juez y denumpciador, y las de contrabención ha reales hordenes y hordenanzas desta villa, se obserbe lo en ellas contenido. Y para que todo lo referido se guarde, cumpla y obserbe imbiolablemente por todos y qualesquiera vecinos desta referida villa...”(A.H.P.V. San Martín del Monte, S.H., 83). 
Con ligeros matices, atendiendo al tiempo en que fue escrito y a las características particulares de estas villas eclesiásticas, estas normas pueden extenderse tanto a Serrada como a la mayor parte de las tierras de Castilla. Obsérvese el especial celo en regular y alentar la vida pacífica entre los vecinos, previniendo escándalos, relaciones no convenidas de acuerdo a la moral y costumbres de la época, juegos de los que se puedan derivar desavenencias, horarios desacostumbrados que turben el descanso y la quietud del vecindario campesino y armas que pongan en peligro la vida de unos y otros. Llama la atención la especificación y prevención que refleja la norma sexta sobre el trato respecto a moros y moras. E igualmente la condena del préstamo y la usura que registra la siguiente y que bien pudiera llevar una implícita alusión a los judíos conversos, siempre relacionados y acusados de estas prácticas. Ambas cuestiones acercan a la realidad intransigente y persecutoria hacia estas minorías que, desde tiempos de los Reyes Católicos, hasta la expulsión y deportación de los moriscos en 1568, fueron moneda corriente en la España de estos siglos.

Por último, se debe hacer notar la preocupación por el buen aprovechamiento de los bienes comunales, sean montes, prados o pinares, así como de la vigilancia de campos y ganados. Se mide con precisión cada actuación individual y colectiva, el registro de pesos y medidas, la legalidad de los distintos cargos y oficios. Sin embargo, como se leerá en las siguientes páginas, el azar de las cosechas, la enfermedad o penuria de los hombres pondrán al borde de la ley a muchos vecinos en busca de proveerse de lo más vital, aun sabiendo el riesgo de una ley poco generosa. No resultaba fácil vivir donde convivían quienes se morían de necesidad y aquellos que llevaban una vida placentera.

\section{b. La casa del concejo. La panera del pósito. La cárcel}

Se necesita un soporte físico para poder llevar a cabo cuanto se viene relatando. Un espacio común y de todos para reunirse, tomar decisiones, guardar escritos, vigilar penados, acudir prestos en caso de problemas... Eran las casas del concejo. En ellas se escribía la historia de todos y cada uno de los pueblos de Castilla. Surgen cuando estos inician su andadura y podrán ser de mayor o menor solidez, pero siempre albergan cuantos actos colectivos, exceptuando los religiosos, tienen lugar en estos pueblos. Eran los Ayuntamientos del ayer y, generalmente, ocupan el espacio sobre los que existen, normalmente en la plaza mayor, cerca de la iglesia y de cuantos edificios se necesitan para el buen gobierno.

Serrada se reunía en concejo "como lo tenemos de costumbre" desde hacía siglos. Y similares afirmaciones se pueden decir en lo referente a la cárcel y al pósito, si bien la regulación de cosechas y necesidades que este último proporciona a la población fuera de fechas más recientes. No obstante, alusiones al pósito o paneras del pueblo constan desde 1606, en que distintos vecinos expresan sus obligaciones de reintegrarle variadas cantidades de trigo, una vez recogida la cosecha por Nuestra Señora de agosto. Esta villa no se diferencia de los pueblos que salpican el centro de Castilla por estas fechas. Similares frases, en defensa de estas necesidades colectivas, se pueden decir en lo tocante a la cárcel pública existente en cada uno de los concejos. En Castilla siempre se ha recordado que "casa con dos puertas difícil es de guardar y concejo sin cárcel nunca tuvo lugar”. Analicemos brevemente, con las mayores luces documentales del siglo XVIII, cada una de estas dependencias que trataban de asegurar el buen ordenamiento de los recursos y vecinos en estos pueblos que estudiamos.

\section{- Localización y características de las casas del concejo en Serrada y San Martín del Monte}

Estas casas del concejo sirven de punto de encuentro de todos los vecinos y llevan anejas otras dependencias. En Serrada y San Martín, por las referencias archivísticas, se localizan en la manzana donde actualmente se sitúa el Ayuntamiento de la villa, ocupando el lugar de este y otros 
espacios aledaños ${ }^{935}$. No parece que fuera un espacio totalmente edificado a tenor de la documentación existente. Las casas del concejo disponen de corrales y ejidos, lindantes con casas y cercados de otros vecinos ${ }^{936}$.

Menor entidad, como no podía ser de otro modo por su reducido número de vecinos, tienen los bienes muebles de San Martín del Monte. En relación con la propia casa del concejo, localizada como refiere el catastro a "la calle que sale de esta Villa a la de Tordesillas", y que en 1752 se arrendaba a un vecino, nada mejor para enterarse de los pormenores, acompañando al juez visitador de $1759^{937}$ :

\footnotetext{
"Primeramente visitó su merced las casas que esta dicha Villa tiene suyas propias, en las que ha mano izquierda de su entrada hai un quarto don de la Justizia y vezinos se juntan ha zelebrar sus Acuerdos y demás actos de Concejo, en donde se halló una Arquita vieja de pino con tres zerraduras y llaves que por tener desgastada la tabla de sus tapadera por la parte de los pernios se halla sin uso...”.

"En otro quarto con su cozina, que sirve de cárcel. En dicha casa de conzejo se halló un zepo de Pino con dos barras de yerro, la una de una pinta, y la otra donde zierra; y una cadena de yerro con su arropea, y un candado grande con su llave con que se zierra el prezitado zepo y cadenas."
}

Se deja la descripción del pósito para el siguiente apartado, no sin antes apuntar que las anteriores dependencias públicas eran concurridas por los vecinos, aprobando acuerdos o solicitando cuanto podía beneficiar a la villa. El concejo era una institución dinámica que responde a las necesidades de unas poblaciones donde la subsistencia era un objetivo y la solidaridad, el buen reparto de los bienes y la administración de las rentas, una exigencia para poder seguir viviendo.

${ }^{935}$ La situación y caracteres, de acuerdo al Catastro de Ensenada de 1752, son las que siguen: En Serrada: "Una casa conzejo donde zelebran sus juntas de vezinos de esta dicha villa, que también sirve de cárcel, poseida por dicho Concejo. Se regulo su alquiler en quarenta y quatro reales de vellón al año. Tiene de frente veinte y cinco varas y de fondo nueve. Confronta con corral de Isavel Platón y con casa de Juan santos. Otra casa en esta dicha villa, con dos apartados y su corral, que sirve de carnizería y matadero, propia de dicho Conzejo. Se regulo sus alquiler en veinte y dos reales de vellón al año. Tiene de frente doze varas y de fondo treinta y dos. Confronta con casa de Pedro Martín y con casa de Don Andrés Rodríguez".

En San Martín del Monte: "Una casa situada en la calle que sale de esta Villa a la de Tordesillas. Su havitazión es por vajo, no está doblada. Tiene ocho varas de frente y veinte y quatro varas de fondo. Es propia del Conzejo de esta Villa y esta arrendada a Narziso Ruiz, quien la vive y paga de renta setenta y siete reales de vellón en cada un año. Confronta al lebante con casa de María García; al Poniente con casa de Alonso Ruiz". (A.H.P.V. Hacienda, Catastro de Ensenada. Serrada y San Martín del Monte: Libros de seglares, cajas 648 y 254).

${ }^{936}$ En una venta registrada en septiembre de 1755 entre Jerónimo Martínez, vecino de Valladolid y Casimiro Nieto, de Serrada se detallan las confrontaciones y está situada en la calle "que lleban los de la seca a la villa de Valdestillas", que lindaba con las carnicerías y matadero del concejo, con otras casas y con un cercado de pan llevar de Andrés Rodríguez Zorrilla. En el propio Catastro de Ensenada, el vecino Antolín Rico es propietario de una casa situada en la calle que va de Matapozuelos a Tordesillas que "confronta con calle que sale al ejido del concejo". Estos bienes municipales estaban inmediatos a las paneras y cilla de la iglesia de San Pedro, donde los vecinos llevaban sus diezmos. Gabriel Alonso Recio e Isabel Platón poseían casa en esta calle de la Cilla. La del primero confrontaba "con la calle que vaja del palazio del marqués de Torreblanca y con la plaza de dicha villa". Por último y para concluir esta localización aproximada, conviene anotar la ubicación de una casa vendida en marzo de 1868 “... en el casco de esta villa y calle que desde la Plazuela que llaman del Rollo sube a la villa de Matapozuelos, que linda por una parte con dicha plazuela, por otra con calle de la Cilla y Paneras de la fábrica de la Yglesia y otros notorios...". y que completa y avala cuanto se dice...". ${ }^{936}$ El lector se habrá percatado, a través de las citas anteriores, de un elemento asociado a la propia vitalidad del concejo: el rollo. En efecto, situado en la plaza que lleva su nombre, ratifica la voz pública, pregonando o fijando edictos, seguramente en algún poste o columna existente en estos tiempos, dando voz a las decisiones del concejo, a las sentencias de la chancillería o a las ejecuciones de las penas. Era algo más que el "tablón de anuncios" del antiguo régimen y que va abandonando sus funciones conforme las suple el pregonero o las propias puertas del Ayuntamiento muestran igualmente cuantos acuerdos habían ratificado sus vecinos.

${ }^{937}$ A.H.P.V. Sección Histórica, San Martín del Monte, SH 83. 


\title{
- La importancia de las paneras del pósito en la economía rural
}

Se ha mencionado anteriormente la existencia de estas paneras de trigo como bienes del concejo. Sin embargo, estos pósitos son algo más que reguladores de las necesidades de grano por parte de los vecinos. Eran verdaderas instituciones públicas, supervisadas por los Marqueses de Campo provinciales e intendentes generales de los pósitos del reino. En el siglo XVIII, existe toda una legislación que vela por el buen funcionamiento, vigilancia y cumplimiento de estas normativas. El interés de los reyes y por ende la necesidad de los estados es impedir a toda costa que las malas cosechas diezmen las poblaciones y desvertebren la débil estructura económica del país.

Las paneras de Serrada estaban situadas, por las escasas referencias que manejamos, a ras de suelo, como en la mayor parte de los pueblos comarcanos. Diferente es el caso de San Martín del Monte, donde, por falta de medios o economizar los recursos existentes, se localizaba en los sobrados de la casa del concejo, espacio, por lo demás, utilizado por buena parte de los labradores de Serrada y San Martín que de esta manera ponían a buen recaudo de humedades y amigos de los ajeno los sobrantes de las cosechas. Las características del pósito de San Martín del Monte no se diferencian de cuanto se viene relatando ${ }^{938}$.

\begin{abstract}
"Subiese a la panera del pósito que está en el sobrado de dicha casa del Conzejo. En la orillada y bien repartida, con su puerta nueba. Al subir de la escalera, en que hay dos candados con sus llaves. Que la una tiene dicho Alcalde, y la otra Thomás Hernández, su depositario, en que no se halló presente trigo alguno. Y los sobredichos declararon que las ziento treinta y dos fanegas y diez y ocho quartillos de que se al presente se compone su caudal fueron repartidas entre los vezinos de esta Villa para su sementera y recolección de los frutos pendientes, con la obligazión de reintegrarlas con un quartillo de crezes por fanega en el próximo benturo Agosto de este año, conforme a lo encomendado en las ordenes ha este fin expedidas por el señor Marques del Campo del Villar, Intendente general de los pósitos del Reino".
\end{abstract}

\section{- La cárcel}

¡Cuántos incumplimientos se pagan durmiendo en el calabozo hasta que sale algún familiar o vecino fiador respaldando al acusado! La ley y los edictos no se fijan en vano y la cárcel era considerada un mal necesario para garantizar el buen orden entre el vecindario. Sus muros guardaron desde rencillas de jóvenes bulliciosos hasta oscuros asesinatos. Pocas familias, a lo largo del tiempo, permanecen ajenas a los dictados de los alcaldes y alguaciles carceleros. Cuando se construyen los actuales Ayuntamientos, será una dependencia obligada. Así lo refiere el Amillaramiento de 1880. Serrada y San Martín del Monte tenían cárcel y, además, estaban obligados a mantener aquellas de la cabecera de la tierra a la que pertenecen. Palabras mayores eran las cárceles de la Real Chancillería de Valladolid. Algunos vecinos también fueron sus moradores al rebasar sus delitos lo que las justicias ordinarias podían abarcar, pero ni Serrada ni San Martín del Monte se caracterizan por presentar índices de criminalidad superiores a los pueblos del entorno. Buena parte de ellos derivan de los eternos conflictos entre labradores y ganaderos y no pocas veces unos y otros acaban con sus huesos entre rejas ${ }^{939}$.

En otros casos era el hambre y la pobreza la que encaminaba a los hombres al oscuro cuarto del concejo. Los robos, por pequeños que fueran, eran severamente castigados y mal vistos en estas economías donde la necesidad comparte las mismas estancias que los hombres ${ }^{940}$.

\footnotetext{
${ }^{38}$ A.H.P.V. Sección Histórica, San Martín del Monte, S.H., 83.
}

${ }^{939}$ Alonso Román fue apaleado en 1741 por Andrés Rivera al tratar de impedir, en palabras del primero, del "daño que me estaba aziendo con dicho ganado en un senbrado mí”. El conflicto derivará en querella y pleito criminal. El padre de Andrés Rivera, Antonio Rivera, tendrá que salir por su hijo en fianza carcelera. Similares procedimientos fueron los que enzarzaron a Bernardo y Urbán Leonardo, pastores de tradición familiar en todos los pueblos de la comarca que, también en la compañía del anterior Andrés Rivera, se encontraban presos en la cárcel de la villa por comer con sus ganados ovejunos dos tierras sembradas de centeno en el Despoblado de La Moya.

${ }_{940}$ A.H.P.V. Pt. 8216, Serrada, fol.189, año 1747. 
La pobreza generaba enormes diferencias a la hora de cumplir también el tiempo de presidio. Como en la agilidad de la justicia por encontrar a los culpables, caso de una vecina de pocos recursos de San Martín, desamparada cuando su marido, viniendo con ella, ya de noche, por la cańada de Villanueva, cayó muerto de un arcabuzado ${ }^{941}$.

En la mayor parte de las incidencias, no obstante, la cárcel del concejo se visitaba breves días por parte de los que eran amigos de broncas y discusiones, sobre todo si se saldan con algún herido. Asuntos dispares, jóvenes que se pasaban de la raya o abusaban del vino o rencores nunca olvidados suelen ser las causas de pasar varios días durmiendo a la sombra ${ }^{942}$. El quebrantamiento de las condenas o de los embargos podía llevar a nuevos autos y penas. Un ejemplo fue lo que le ocurrió a Alonso Navarro, que tuvo que sacar en fianza a su hijo de la cárcel, después de muchos días preso "por aber sustraido una mula suia que estaba enbargada y depositada en Ysidro Alonso, vecino de esta villa"43. El quebrantamiento de la prisión llevó a Isidro de Montes y su mujer Matilde Elvira a nuevos procedimientos por injurias a la justicia y se conoce el auto contra el regidor de San Martín del Monte por inobediencia a la justicia ${ }^{944}$.

No se van a relatar en estas páginas otros motivos de cárcel que también se han extraído de los protocolos consultados. Hacen referencia a la parte más escabrosa y morbosa del hombre y estos pueblos tampoco son ajenos. Escándalos públicos y tratos ilícitos entre hombres y mujeres eran muy mal vistos en estos tiempos; faltas de palabras de matrimonios en casos de embarazos y estupros, o malos tratamientos a mujeres que, como se ha constatado siglo tras siglo, han formado el eslabón más débil de la compleja historia del ser humano, son algunos de los casos omitidos. En el ejemplo que se transcribe una mujer de Serrada otorga poder para pleito a su padre para que, en su nombre, comparezca ante la justicia y denuncie los malos tratos que le ha dispensado su marido, vecino de La Seca y en cuya población vive. En la escribanía denuncia: ${ }^{45}$

“...malos tratamientos así de obra como de palabra y cruel vida que el nominado mi marido me ha dado, y da desde que contrage matrimonio con el susodicho. Me ha sido forzoso hazer una separazión a el presupuesto matrimonio, retirándome temerosa de su cruel genio me quitase la vida, a la casa del nominado Ambrosio, mi Padre, treinta días ha...".

${ }^{941}$ Ella no pudo distinguir bien a los embozados y la justicia, a pesar de hacer algunas detenciones, puso libre a los sospechosos y dejó en el mayor de los desamparos a la citada mujer del pueblo vecino. En escritura pública acaba poniendo a sus hijos en manos de personas curadoras y caritativas, asumiendo su desgracia: "La referida Nicolasa García, viuda de Andrés Álvarez, vecina de la villa de San Martín del Monte, como madre tutora y curada de Martin, Alonso y Felipe Álvarez, mis hijos y del dicho mi marido, digo que en los onze días del año pasado de mil setezientos quarenta y quatro, en el pinar y termino de Villanueva de Duero, siendo ya de noche y a mi presencia, dieron muerte a el referido mi marido a fuerza de un escopetazo, y aunque reconoci haber diferentes personas no conoci quienes heran, y por la justizia ordinaria de dicha villa de Villanueba se hicieron autos y prisiones de diferentes vecinos de dicha villa, y de la persona de Fhelipe Álvarez, hermano del dicho mi marido, que se hallaba en mi compañia, de cuio hecho y muerte biolenta di parte a los señores gobernador y alcaldes del crimen de la Real audiencia y Chancillería de la ciudad de Valladolid, quienes se sirbieron mandar despachar receptores a la aberiguazión de la referida muerte, y pareze no se justifico reo alguno ni menos se ha justificado en tan dilatado tiempo, y abiendo quedado como tal biuda y pobre con los referidos tres hijos que criar y alimentar solo con mi trabajo personal, y habiéndome aconsejado personas de graduazión el que aga apartamento de la dicha causa y muerte, y abiéndolo consultado con mi confesor, me ha esforzado a ello asi para bien mio y serbicio de Dios Nuestro Señor y para que su Magestad me perdone, y por quanto sin saber quien me da mil reales de vellón para mi remedio, alimentar y bestir a mis hijos, poniéndolos en una persona desinteresada para que me los entregue como en hefecto lo ha hecho...".

Por más recomendaciones que le hicieran, nadie como ella para saber que se le había caído en mundo encima. En este antiguo régimen las penas siempre se han multiplicado entre los más desvalidos. En este mismo apartado ya se ha anotado el intento de asesinato del alcalde Simón Ruiz en 1770 y cómo a los culpables se les puso camino del garrote. No fue el caso de lo ocurrido en el pago de la Raya en febrero de 1755. Juan y Jerónimo de la Cadena y Tomas Martínez, todos vecinos de La Seca, mataron a golpes a Manuel Alonso Navarro, vecino de Serrada. Sus hijos menores y su yerno debieron quedar igualmente en el mayor de los desamparos, pues, tras la solicitud de escritura de perdón por parte de los culpables, los familiares del fallecido les otorgan dicho perdón, a cambio de dos mil reales de vellón que servirán "para subvenir al gasto diario de nuestro alimento por ser como somos pobres" (A.H.P.V. Pt. 8218, fol.14). 


\section{c. Las rentas y la guarda de montes, campos y pastos}

No hay que olvidar que el control por parte de los concejos para tener bajo su autoridad cuantas actividades o aprovechamiento lleva anexos, ha sido siempre una obsesión en las distintas villas y lugares. Se aludía en el anterior epígrafe a que Serrada y La Moya luchan jurídicamente en 1590 por hacerse oír en lo referente al Monte de los Llanos y beneficiarse de los dos tercios de las rentas que se reparten los lugares que forman el cabildo de dicha tierra. En 1596 Serrada saca a subasta "la piña del pinar del concejo de esta dicha villa que esta mostrada" y las posturas por ella alcanzan los nueve ducados ${ }^{946}$. En 1602, ocho años después, Juan Alonso, el mozo, vecino de Serrada, se obliga con el concejo y con el que entonces era su mayordomo, Francisco Bizán, al pago de "veinte y cinco ducados los quales debo y son por razón de la leña de la retama que está en el pinar que el concejo tiene..." y a su vez otros vecinos se obligan con el anterior al pago de distintas cantidades por la retama que Juan Alonso ha cortado ${ }^{947}$.

Lo mismo sucede con la hierba de los prados. El citado Alonso ostenta en este tiempo el cargo de procurador del común y Serrada le otorga poder para tratar con Antonio de León "vecino de Tordesillas en razón de la hierba del prado deste dicho concexo que pretende pastar..". Retamas o hierbas que proporcionan sustanciosos ingresos a los concejos locales y generan trabajo, compras y ventas al resto de la población. Eran recursos vitales para unos y otros. De ahí la contundencia en las normas para su uso y disfrute. Aun así, siempre sorprende la estricta reglamentación que exhiben las partes en litigio. Un ejemplo se encuentra al otro lado del término, en la raya de San Martín del Monte. El convento de Santa Clara se enzarza en un enrevesado pleito con el concejo de La Seca por la fijación exacta de los límites que dividen ambas jurisdicciones. La espoleta fue la detención en 1777, por oficiales de Tordesillas, de dos hacheros de Valdestillas al servicio del concejo de La Seca tras cortar cuatro pinos. Seguramente fueron los pinos más caros de la Historia, a tenor del papel gastado, los procuradores pagados e incluso el magnífico óleo pintado por Antonio Navarro a este fin y que ya se ha mencionado en varias ocasiones. El pleito es, sin duda, muy interesante por cuanto remarca lo que se viene reiterando en relación con los aprovechamientos y recursos de uso común ${ }^{948}$.

\section{d. Las necesidades de abastos y otros servicios públicos}

No hay constancia del lugar donde los vecinos de San Martín se aprovisionan del aceite o la cera o en qué fragua arreglan sus carros o arados. Lo que sí consta es que carecen de taberna, abacería, fragua, barbería... No disponen de ningún servicio de abastos permanente en 1759. Consta únicamente la existencia de una fuente pública para abastecerse de agua, si bien era "usual y corriente, aunque es sin cubierto ni resguardo alguno para la defensa de las aguas llovedizas", en palabras del juez que los visita a mediados del XVIII. En esto se parece a los últimos moradores de La Moya, con la sal-

\footnotetext{
${ }^{942}$ Por poner un ejemplo que ha llamado la atención, se cita el ocurrido el 18 de diciembre de 1754 . La paliza que le dieron a Manuel Rojo debió de ser más que notable, pues hasta febrero del siguiente año no se otorgan las fianzas carceleras. Pero lo que más llama la atención es el número de los encausados. Salieron bajo fianza por hallarse entre los que le pegaron Leandro García; Luis y Gregorio García; Pedro y Blas Martín y Roque Casares y Miguel Pérez. Los golpes y heridas debieron de ser abundantes, a tenor del numero de encarcelados y del tiempo que estuvieron entre rejas. La Justicia, en cualquier caso, debía seguirse con todo rigor.

${ }_{943}$ A.H.P.V. Pt. 8216, fol. 226.

${ }^{444}$ A.H.P.V. Pt. 821, fol. 228.

${ }_{945}$ A.H.P.V. Pt. 8218, fol 42.

${ }^{946}$ A.H.P.V. Pt. 11844 , fol. 389.

${ }_{947}$ A.H.P.V. Pt. 11850 , fol. 367.

${ }_{948}$ A.R.Ch.V. P.C. Zarandona y Wals. (F), sig. C 3280.1, (leg. 682).
} 
vedad de que a estos les tocaba sacar el agua del "pozo nuevo", sito a un centenar escaso de metros del lugar poblado. Por el contrario, Serrada, como lugar más poblado y mejor comunicado, presenta lo largo de los siglos modernos unos niveles de servicios públicos bastante aceptables y que la equiparan a las villas medianas de la Tierra de Medina o de Olmedo.

\section{- Comprar en la abacería, beber en la taberna, adquirir carne o aprovisionarse de sal}

¡Qué difícil sería para una viuda o un jornalero enfermo reunir cuarenta maravedíes para comprar una libra de tocino! De ahí la importancia que los concejos locales mostraban por el control de los abastos y los precios de estos productos básicos, sin menoscabo, claro está, de velar por sus intereses recaudatorios. La abacería o lugar de venta "por menudo" de aceite o salazones era uno de los más frecuentados y sirve, además, de termómetro económico de los distintos hogares, de acuerdo a su capacidad de compra. Como sucede con la taberna o la carnicería, el concejo de Serrada saca a postura pública estos servicios de asistencia y negocio. Las licencias de aprovechamiento se otorgan al mejor rematador, previa aceptación de escrupulosas normas estipuladas por el concejo. Nos ha parecido de interés reproducir el remate de la abacería y taberna de Serrada de 1604 para conocer el nivel de precios de los alimentos de primera necesidad ${ }^{949}$. Los mercados de Medina y Tordesillas se señalan fijadores de los precios de los distintos productos. Adviértase igualmente la precisión y su variación en las distintas épocas del año, de acuerdo con su mayor o menor disponibilidad, así como los márgenes de ganancia que se estipulan para que dicha actividad sea rentable.

El concejo y justicia de la villa fijan asimismo el precio del vino, producto vital en las economías de estos pueblos; nada desdeńable es tampoco la cantidad que va a parar a sus arcas en forma de impuestos o al señor de la villa en concepto de alcabala y unos por ciento. Todo ello limita la capacidad de capitalización de estos pequeños comerciantes que, como sus vecinos campesinos, obtienen lo indispensable para subsistir.

${ }^{949}$ El remate lo efectúan Francisco Martín y Francisca de Montes, su mujer, ambos vecinos de Serrada. "Sépase como nos, Francisco Martín y Francisca de Montes, su mujer, vezinos desta villa de Serrada, con lizencia pedida, conzedida y azetada..., dezimos que oi, día de la fecha, se a rematado en mi el dicho Franzisco Martín las obligación del aceite, pescado, jabón, tozino, vino y demás a el contenido, para servirla este presente año de mil seiszientos y noventa y quatro, a los prezios de maravedies y por las cantidades y gravámenes siguientes:

- La libra de azeite todo el año a treinta y dos mrs.

-La libra de tozino, de aqui a año viexo a quarenta mrs; desde año viexo a San Miguel, a quarenta y ocho maravedies; desde San Miguel año nuevo a treinta y dos maravedies.

-La libra de queso asta San Martín, a quarenta maravedies; desde San Marcos a san Miguel, a beinte y quatro mrs; desde san Miguel asta a año nuevo a treinta y dos maravedies.

- La libra de jabón a quarenta y ocho maravedies, todo el año.

-La libra de pescado seco, todo el año a zinquenta y seis mrs.

- Lo mojado a quarenta maravedies todo el año.

En cada libra de sardinas se me a de dar de gananzia ocho mrs de a como valieren en las tablas de Medina del Campo y Tordesillas.

- El prezio del vino a de ser a boluntad de la justizia.

E de pagar por la sisa de los frescos veinte y quatro reales.

Para los Reales Servicios de sisas, setezientos y quinze reales en los terzios de fin de marzo y setiembre deste presente año y marzo del año que biene de noventa y zinco.

$E$ de pagar al conzejo desta villa doszientos reales a boluntad de la justizia y al señor delta lo que deviere dealcabalas y unos por zientos de las dichas obligazion, como dueño y señor de ellas o ajustarme con su merced.

$E$ de dar onze eminas de castañas y cantara y media de vino y la emina y media cantara que ya he dado hoy dicho dia al tiempo del dicho remate y la fanega y cantara de vino para el día de Pasqua Flores deste presente año(...).

Que he de traer de la villa de Olmedo y bender por menudo y por mayor en mi casa los dos terzios de la sal que son diez fanegas que está obligada esta villa gastar por encavezo y la cobranza y paga a de correr por mi quenta y riesgo con las costas que se causaren hasta la real paga, todo ello como consta del dicho remate y posturas a que nos referimos, el qual tenemos azetado y de nuevo acetamos...”. (A.H.P.V. Pt. 8213. Fol. 96. Año 1694). 


\section{- Hacer acopio de sal, comprar tabaco o disponer de nieve o hielo}

Puede que parezcan artículos menores, quizá algunos de ellos de lujo, pero no lo son tanto si se atiende a las necesidades de aquel tiempo. En cuanto a la sal, son constantes las referencias documentales sobre la necesidad de su acopio a lo largo del tiempo. Piénsese que, al margen de su importancia culinaria o alimenticia, se trata del conservante por excelencia de carnes y pescados, vitales para garantizar aportes proteínicos en las distintas épocas del año y sin riesgo de descomposición en los largos trayectos que, sobre todo en el pescado, impedían su consumo en fresco. Se puede decir que la sal era el frigorífico del Antiguo Régimen y su canalización desde las salinas hasta los concejos está rigurosamente reglamentada y sometida a las consabidas tasas. Así lo rubrica en 1740 el corregidor de Medina, que traslada la petición de Don Domingo Carranza, vecino de la villa de Madrid, como arrendador de las Reales Salinas. El concejo de Serrada otorga poder para el encabezo de dicho producto en la persona de Roque de Íscar, procurador síndico de Serrada, para que "ajuste nuebamente el acopio de las fanegas de sal que esta dicha villa a de consumir por el tiempo de los dichos seis años..." "550.

Caso distinto son el resto de productos nombrados, si bien todos ellos están sujetos a encabezo e impuestos. En febrero de 1755, el concejo de Serrada, ampliamente representado por sus vecinos, otorga poder a su alcalde Narciso del Castillo, para encabezar los derechos "del quinto y arbitrio y el de dos maravedies impuestos en cada una libra de nieve y yelo... "351. No consta que Serrada dispusiera de pozo de nieve, dada la cortedad de su vecindario, pero esta cita acerca a este producto almacenado en invierno y utilizado con fines médicos u otros más lúdicos. E igualmente de menor cuantía en cuanto a su consumo, es la compra de tabaco que, en manos de los estanqueros, era igualmente vigilada por la justicia a fin de que no eludieran las tasas correspondientes. Carnes, pescado, vino, sal... productos, en fin, que testimonian las necesidades alimenticias de cuantas gentes han vivido en estas tierras.

\section{c. Las necesidades del cuerpo y de la mente: los médicos, los maestros y el escribano}

Los vecinos de todos los lugares contaron, en mayor o menor medida a lo largo de su historia, con los servicios de cirujanos e instructores de las cuatro reglas. Otra cosa era la eficacia de sus remedios, en el primer caso, y la eficacia de sus enseñanzas en los más pequeños, en el segundo. Las penurias que caracterizan la vida en estos siglos pasados imponen su ley en ambos casos, si bien, a lo largo del siglo XVIII, se observa una mayor atención e interés por recibir estos servicios, conforme aumenta la población y los recursos.

\section{- La preocupación por la salud y los cirujanos sangradores}

Los concejos locales tratan por todos los medios de alejar las pestes y contagios de los lugares habitados y, en la medida de sus conocimientos, no escatiman esfuerzos a tal fin. Desde antiguo, el saneamiento de charcas palúdicas y la vigilancia y cuidado de fuentes y pozos públicos era una obligación de las justicias y regidores locales y pone de manifiesto la importancia de disponer de agua saludable para el consumo humano o animal. El concejo de Serrada firma escritura con Pedro Caballero y Antonio Carro para la obra de cauces en una fecha tan temprana como 1599, a fin de sanear y canalizar tanto las aguas llovedizas como las que fluían de manantiales y prados. Se trata a toda costa de impedir la propagación de enfermedades contagiosas o aquellas que se llevan por delante a cuantos consumen agua en mal estado ${ }^{952}$.

\footnotetext{
950 A.H.P.V. Pt. 8215, fol. 31.

${ }^{951}$ A.H.P.V. Pt. 8218, fol. 38.

${ }^{952}$ Esta preocupación será de tratamiento anual, como se verá cuando se llegue a tiempos contemporáneos. De momento, nada mejor que conocer las preocupaciones de los serradenses de hace más de cuatrocientos años: "En el lugar de Serrada, tierra y jurisdizión de la villa de Olmedo, el veinte e nueve del mes de diziembre de mil e quinientos e noventa e nuebe años, por ante my, Antonio de Medina, escrivano real y del numero del dicho lugar, parecieron presentes Pedro Caballero,
} 
Esta preocupación sanitaria por el buen saneamiento de prados y charcas no es exclusiva de Serrada, sino de cuantos pueblos eran sabedores de que la prevención de la enfermedad era siempre mucho mejor que el combate contra la misma. Serrada se aprovisiona de agua a través de pozos excavados en las principales casas de labranza y, sobre todo en lo que se refiere al agua para consumo humano, en aquellos que gozan de la aprobación de las justicias locales y del querer popular. El "Pozo Bueno" de Serrada, que da nombre al conjunto de casas y calles anexas, da fe de estas preocupaciones colectivas. Los últimos moradores de La Moya hacían lo propio en estos siglos XV y XVI al extraer agua en sus conocidos "pozo nuevo" o anteriormente en el denominado "pozo viexo". San Martín del Monte, como ya se ha comentado, se aprovisiona de agua del manantial que fluía en su fuente y alberca pública. A través del Catastro de Ensenada, se conoce su preocupación anual por su mantenimiento y cuidado, al tiempo que el concejo asigna igualmente una cantidad anual para la limpieza de las zanjas de los prados y dehesa de la villa. Todo ello sin menoscabo de que unos y otros aprovechen también el agua de cuantas fuentes y manantiales riegan el término y sus pagos aledaños. Conocida es, en este sentido, la Fuente de la Miel, sita a en el camino que llevaban los de Serrada a la villa de Tordesillas. Sin embargo, en no pocas ocasiones, estos empeños colectivos no impiden la llegada de la enfermedad, desgracia campesina más temida que la peor de las cosechas.

Cuando la enfermedad o la peste llega al vecindario, es el cirujano sangrador el encargado de combatirla. Caso contrario, el enfermo encomienda su alma a Dios y queda presto para la otra vida. La importancia de los lugares y la presencia de nobles o vecinos pudientes facilita la existencia de curanderos, boticarios o médicos, más o menos preparados. En el año 1600, hay notarialmente una escritura de postura por atender la barbería de Serrada que muestra las preocupaciones de cuanto se relata. Luis de Bonilla se obliga a atender para afeitar, pero también para "sangrar", a todos los vecinos del pueblo. Se cuantifican días de atención y salarios. La lectura del documento reproducido al pie indica que este servicio, en la medida de las posibilidades económicas del concejo, podía ser de mayor o menor calidad, pero que pocas veces faltaba. Otra cosa era la eficacia de estos métodos ${ }^{953}$.

vecino de Villadeanueva y Antonio Carro, vecino de la villa de Castromocho, estantes al presente en este lugar de Serrada... e dixeron quellos y cada uno de ellos se avian convenido y conzertado con los jueces del regimiento de dicho lugar, y en especial con Diego de Medina, alcalde ordinario en ley con Francisco Alonso, regidor, de hazer y que harán un cauze para que salga del de el lavaxo deque el dicho lugar se sirve que esta junto a las casas donde se sirve la fragua hasta el juncal do dizen Baldelayno, par que puedan correr y corran las aguas llovedizas y las demas aguas que curriern al dicho cauze, el qual a de llebar de ancho bara y media y de fondo una bara; el qual dicho sitio e parte donde el dicho cauze se oviera de hazer, el ha de ser señalado que es orilla del prado que llaman de arriba que es del concexo... Que en el largo de dicho cauze abra mil seiscientas baras, poco más o menos, poco o mucho... y que por cada bara de la que oviere de largo del dicho cauze se le ha de dar e pagar por el dicho concexo diez maravedies...”. (A.H.P.V. Pt. 11847, fol. 1177).

${ }^{953}$ Los términos del concierto son los que siguen: "En el lugar de Serrada, tierra e jurisdizión de la villa de Olmedo, a nueve días del mes de henero de myl e seiscientos años, por ante mí, Antonio de Medina, escriuano público y del numero y consejo del dicho lugar, paresció presente Luis de Bonilla e dixo que por esta postura de la barbería en el dicho lugar en este presente año deseiscientos hará e hizo la postura con las condiciones siguientes:

Primeramente se obligó a que servirá al dicho concejo e vecinos del dicho lugar con su persona y un criado todo el dicho año, y quea los vecinos y a sus mujeres e hijos afeitara todo el año y sangrará e colocará las bentosas que obiere menester y fuere necesario.

Yten. Que bendrá al dicho lugar a le visitar por su persona un día cada semana sin que sea necesario... y ha de ser el día que le fuere sentado e mandado por el juez... y que asimismo bendrá todas las beces que fuese llamado al dicho lugar a lo que fuere necesario y menester tocante al dicho su oficio.

Yten. Que se le ha de dar de salario al año por los vecinos del dicho lugar, todos los que tubieren senara e pan, ansí casados y biudas, diez celemines de trigo... y los demás que no coxieren pan ni tubieren senara, a tres reales cada uno de que se ha de hazer senara, y se le de por el mes de agosto deste presente ańo y los mozos de soldada que obiere lo que con ellos conzertare el dicho Luis de Bonilla.

Yten. Que las dichas tales quales condiciones se obligó de hazer y que bendrá con su persona a bisitar todos los juebes de cada semana...”. (A.H.P.V. Pt. 11848, fol. 48). 
Seguramente hoy evitaríamos tales sanaciones, pero a estos vecinos del XVII no les importa depositar sus esperanzas para vivir un poco más en la hoja de la navaja del citado Luis Bonilla. Llenos están los libros del siglo de oro de cuantas prácticas llevaban a cabo, a veces con temeridad, pero también con aciertos.

Siglo y medio después, encontramos documentación más precisa sobre estas necesidades de curación. En Serrada, en 1752, trataba de hacerlo Joseph Bermejo, "cirujano sangrador", que cobraba 1.300 reales por dicho trabajo anual, además de otros cien "de manos libres de apelaciones". Se está a medio camino entre la medicina científica y los barberos sangradores de antaño que, o bien curaban o bien mataban, pero no cabe duda de la buena remuneración recibida en estos oficios de alta consideración social. Los regidores locales tratan de contar con el mejor servicio sanitario para garantizar la menor incidencia de enfermedades o epidemias. Sin embargo, la fórmula de pago, a pesar de presentar una solidaridad entre el vecindario, pues los más pudientes pagan cuatro veces más que los más menesterosos, se resiente en lo tocante a la provisión de remedios o boticas para estos últimos. ¿Pasaría lo mismo en lo referente al aprendizaje de las cuatro reglas?

\section{- El maestro de primeras letras}

Aprender las cuatro letras no estaba al alcance de todos en estos primeros siglos modernos. El aprendizaje, en la mayor parte de los casos, se limita a saber firmar y a deletrear con dificultad algún escrito. Difícilmente el común se aventura con la enrevesada letra de muchos escribanos. Únicamente los más pudientes, entre los que se encontraban los hijos de los labradores con mayor desahogo, se desenvuelven con mayor acierto en el arte de la lectura o el cálculo. Era más importante en los zagales su pericia en iniciarse con la esteba, desgramar las viñas o manejar la caballería en torno a la parva. Los concejos locales, no obstante, siempre tuvieron la preocupación de acercar a los más pequeños la sabiduría de algún maestro. En 1752 Julián Alonso ejerce el magisterio en Serrada, ganando 650 reales al ańo, la mitad, por ejemplo, que el cirujano sangrador antes estudiado, pero con similares ganancias que muchos pequeños labradores.

A lo largo de este siglo XVIII, la preocupación de los concejos es creciente por contar con escuelas y maestros. No las hay en San Martín del Monte como tampoco en La Moya y la causa bien pudiera ser la cortedad de vecinos de ambos lugares. Sin embargo, en actas notariales de los siglos XVI y XVII, sí figuran las firmas de muchos de sus habitantes, al igual que en las ventas y obligaciones del vecindario de Serrada. En muchos casos, algún vecino firma en nombre de los que, asistiendo como testigos o presentes en los concejos, no saben firmar. Las últimas planas de las actas de los concejos donde figuran las firmas de los presentes son todo un ejemplo del aprovechamiento académico. Allí dejaron para la historia las firmas y rúbricas los que manejaron la pluma con acierto; los que no habían tenido demasiado entre las manos el papel y la pluma y aquellos otros que, por su desgracia o pobreza, sólo alguna temporada se habían acercado a la planta baja de la casa del concejo. La disponibilidad económica de este y de los propios vecinos condicionaba, en ocasiones, la contratación de los enseñantes. Generalmente el concejo aportaba un tanto del salario del maestro y el resto se reparte a derrama entre los que tenían hijos en la escuela. Por poco que fuera, a muchos hijos de jornaleros o viudas pobres les resulta prohibitivo, por el dinero y porque en dicho tiempo de aprendizaje sus niños ya acompañaban como zagales a segadores o criados. En el texto al pie, se recoge la escritura de obligación firmada el 19 de enero de 1749 entre el concejo de Serrada y Don Estanislao Manrique, maestro de primeras letras. Se señala, respecto a lo que se viene comentando, la obligación de enseñar "de limosna uno o dos niños pobres de solemnidad.", además de indicar las pautas que debe seguir en la educación de los escolares ${ }^{954}$.

954 "En la villa de Serrada, a diez y nuebe de henero de mil setezientos quarenta y nuebe, junto el concejo, justicia y regimiento y vecinos, juntos a son de campana según se tiene de uso y costunbre... decimos que nos obligamos con nuestras personas y vienes a que pagaremos setezientos reales de vellón en este presente año a Estanislao de Manrique, por maestro de primeras letras, pagados en esta forma: que todos los vecinos que tubieren hijos de hedad que puedan ir a la escuela, aian de pagar 
Como puede observarse, es una constante a lo largo de esta historia la simbiosis entre la educación y la doctrina de la fe. Los maestros deben procurar acercar a los niños a la iglesia, practicar con celo en las celebraciones y educarlos cristianamente. No se puede asegurar, ante la falta de documentación, que las niñas no tuvieran ninguna atención de primeras letras, oficial o en ámbitos familiares, pero distintos estudios ponen de manifiesto que, si el analfabetismo masculino alcanzaba tasas muy altas, el femenino resultaba abrumador. La contratación de los maestros tampoco era regular. La falta de escrituras hace temer por la continuidad de estos servicios y todo parece indicar que la irregularidad era la tónica dominante en estos pueblos.

En otros lugares se ha registrado el complemento o asistencia de vecinos letrados que, por impedimentos físicos o confianza del vecindario, interesan a los niños en el arte de la lectura o el cálculo. El concejo se implica en contar con instrucción para sus hijos, más que para las hijas, pero la dura realidad campesina obliga a muchos niños y niñas a ganarse unos maravedíes para disponer de una libra de tocino, antes que gastar cualquier real en aprender a garabatear. De hecho, los más pudientes procuran que alguno de sus hijos continúe la instrucción en niveles superiores, de la mano de alguna congregación religiosa. Y esta educación también era gravosa, a tenor del registro de censos e hipotecas por parte de sus familias, para que pudieran culminar con éxito sus estudios. De hecho, durante estos siglos, los ocupantes de cargos beneficiados de San Pedro son hijos del pueblo y el propio concejo litiga y solicita cuando quedan vacantes los cargos, para que sean ocupados por personas convenientemente formadas pero nacidas en la villa. E igualmente se constata en los ocupantes de la escribanía de Serrada. Francisco Moyano, Miguel Moyano y Juan Andrés de Íscar regentan la escribanía desde 1739 hasta 1779 .

\section{- El escribano}

Perdidos buena parte de los archivos municipales, han sido su testimonio o las copias y traslados de sus actas, guardadas en los archivos provinciales o nacionales, los que han iluminado buena parte del tiempo estudiado. Desde 1514, constan escrituras en Tordesillas en que las gentes de San Martín se acercaban a notificar sus contratos. De hecho, esta villa, al resultarle imposible mantener escribanía propia, dado su corto número de vecinos, declara en 1752, en respuesta general del Catastro de Ensenada, que pagan cien reales anuales al escribano Mateo Casado, que se acerca desde Tordesillas a satisfacer cuantos actos han de registrarse, al igual que pagan otros sesenta a José Bermejo, vecino de Serrada, por cumplir como fiel de los hechos. A La Seca también se encaminaban algunos vecinos de Serrada, sobre todo en aquellos casos de negocios con los vecinos de esta villa, pero donde sobre todo notificaban los vecinos de Serrada y La Moya sus quehaceres más notables es en la escribanía de Valdestillas y, en concreto, bajo la rúbrica de Antonio de Medina, regentador de la misma desde 1573 a $1604^{955}$. Muchas de estas operaciones se firmaban en Valdestillas, pero en ocasiones el propio escribano se trasladaba a Serrada a levantar acta de reuniones concejiles u otros asuntos. Tras su

quatro reales de vellón, y los quartos de los sábados y lo que faltase lo a de suplir la villa de los efectos más prontos como mejor obiere lugar. Y el referido Estanislao Manrique a de guardar y cumplir las condiciones siguientes:

Que dentro de tres meses a de presentar carta. Y no lo haciendo se le pueda apremiar y despedirle de dicho ministerio; que ha de enseñar de limosna uno o dos niños pobres de solenidad, habiéndolos los que la justicia le señalase; que aia de salir todos los días festibos a la misa maior, cantando la doctrina y los días de cuaresma a el rosario, además de todos los dias del año, con esta circunstancia, cuia cantidad a de ser dándoselo cobrado la justicia quees y en adelante fuese y cunpliendo con las dichas condiciones o no hemos de tener el adbitrio de habisarle que continúe o despedirle, y el pueda gozar de este beneficio y para que tenga efecto damos poder a las justicias de Su Magestad par que a ello conpelan y apremien por todo rigor de derecho como por sentencia definitiva...”(A.H.P.V. Pt. 8217, fol. 3).

955 Pocas escribanías como las de Antonio de Medina son tan fructíferas. En los miles de folios consultados, aparecen vecinos de Viana, Matapozuelos, Puente Duero, Villanueva, La Pedraja, Serrada, La Moya y, cómo no, los propio de Valdestillas, que dejan para siempre en sus folios los avatares de sus vida, al menos, de los hechos más trascendentes que quisieron alumbrar bajo ley. En ocasiones, la información es tan detallada como voluminosa. Sólo en el año 1600, por 
muerte, y ya desde finales del XVII y a lo largo del siglo siguiente, Serrada cuenta con escribanía propia. El catastro mencionado anota en 1752, en su respuesta treinta y dos, cuánto cobraba Francisco Moyano, escribano del número, ayuntamiento y millones del que consta su actividad desde 1739 a $1754^{956}$ :

"Hay un escribano del Número y Ayuntamiento y Millones llamado Francisco Moyano. Por la del Número se le regula de utilidad anual quatrozientos reales; por la de Millones ochozientos; por la de Ayuntamiento, doszientos. Son al año mil y quatrozientos."

Todos ellos gozarán de buena consideración social y notable posición económica, al margen de que los nacidos en la villa poseen haciendas familiares. Esto los implica aún más en los asuntos concernientes a los distintos avatares agroganaderos. De hecho, al propio Miguel Moyano el concejo le otorga en 1765 poder para que ajuste las operaciones de venta de las tierras del Despoblado propiedad de la villa y tierra de Olmedo. Unos y otros escribanos, en fin, además de dar fe pública de cuanto se dice, por su mayor preparación jurídica, vigilan y tratan de resolver cuantos asuntos espinosos envuelven a los concejos y a sus vecinos, que no son pocos ni de menor cuantía.

\section{- El pago de las contribuciones y el peso de los impuestos}

En capítulos anteriores se ha constatado como los años de cosechas menguadas sumergen a los más desvalidos en la pobreza y el hambre siempre presentes. Por si esto fuera poco, el carácter rentista de buena parte del terrazgo cultivado detrae vitales recursos que no sólo van a parar a manos ajenas, sino que estas en ningún caso revierten parte de sus beneficios en dicho terrazgo.

Pocos márgenes quedan a los regidores de Serrada o San Martín para saldar sus presupuestos con holgura. Alcabalas, servicios ordinarios o extraordinarios, penas de cámara, multas o derramas extraordinarias se encargaban de limitar cualquier holgura. Una de las regulares condenas que había que afrontar eran las multas de la Mesta. Es raro el ańo que no caminan hacia Medina varios cientos de reales; otro agujero es el derivado de las obligaciones de estos pueblos con sus núcleos cabeceros, especialmente de Serrada con respecto a Olmedo. Esta villa reclama en más ocasiones de las deseadas sumas de reales esgrimiendo concordias anteriores. Tampoco hay que olvidar, en virtud de pragmáticas reales, las contribuciones extraordinarias para las reparaciones de puentes, localizados, en ocasiones, en lugares lejanos. La ciudad de Toro, por ejemplo, reclama en 1743 derramas para "las obras y reparos de los puentes, el de dicha ziudady el de la Guareña", por las que se solicitan 6.888 maravedíes a repartir entre los vecinos. La resistencia de la villa esgrimiendo un menor número de vecinos y las dificultades por las que pasa estos años son bien amargas.

A estas dificultades han de añadirse aquellas que llegan del cielo. Cuando las sequías o los pedriscos anulan las cosechas, la petición de censos endeuda al vecindario y la ejecución de hipotecas no satisfechas deja en la calle a los más débiles. El propio concejo hace lo imposible por aliviar la penuria de sus vecinos, hasta llegar a implorar y solicitar exenciones fiscales a seńores y reyes. En 1707 se constata que el concejo de Serrada, presidido por su alcalde Antonio Rodríguez, otorga poderes el 29 de agosto a Alonso Román, alcalde de la Santa Hermandad y a Joseph Moyano, procurador

ejemplo, se rebasan más de mil folios y son muchos los años que superan sus legajos los 500 o 700 pliegos. Obligaciones de todo tipo, capitulaciones matrimoniales, testamentos, posturas, ventas inventarios de bienes, contratos de censo, arrendamientos, obras de reparación en las iglesias respectivas, etc. Todo cabe en sus veintiocho amplios legajos. Una de las últimas operaciones firmadas en relación con Serrada, próxima ya a su muerte, la rúbrica el 21 de enero de 1614 en que Fernando Alonso, vecino de Serrada, como curador de Francisco Alonso, menor, hijo de su hermano Juan Alonso, vende en nombre de este a Epocial López, vecino de San Martín del Monte, "unas casas que están en el dicho lugar, como se va a la villa de Valdestillas... por precio y quantía de veinte y cinco ducados...” A.H.P.V. Pt. 11861, fol. 38.

${ }_{956}$ A.G.S. Respuestas Generales, Serrada, caja 648. 
del común, para que acudan a la villa de Olmedo a una junta de los lugares de la tierra, a fin de tratar distintos temas u elevar peticiones y súplicas para que sean aliviadas las cargas fiscales, dado el estado de ruina que presentan las cosechas ante el devastador pedrisco caído en las anteriores fechas ${ }^{957}$ :

\footnotetext{
"Sépase como nos, el concejo, justicia y regimiento y vezinos desta villa de Serrada, juntos a son de campana tańida como se tiene de uso y costumbre... otorgamos que damos todo nuestro poder cumplido... a Alonso Román, alcalde se la Santa Hermandad y a Joseph Moyano Alonso, procurador general del común... para que los sustituyentes baian a azeer súplicas al excelentísimo señor marqués y representarle como esta villa y las demás de su partido contenido la esterilidad de aberse malogrado la maior parte de sus frutos apedreándose los campos, y en bista de dichas súplicas y representación que harán de todo ello ver si pueden conseguir con dicho señor algún alibio de la dichas contribuciones...”
}

En San Martín del Monte no hacía falta pedrisco. Padece la crisis económica de mediados del XVIII en toda su intensidad, hasta el punto que la sume en una total falta de recursos. En 1750 su concejo reconoce, ante las demandas de su cura beneficiado por cobrar sus honorarios, "la inposibilidad y cortedad de vezinos y los tiempos presentes no se pueden pagar los tributos reales ni menos contribuir con los expresados quinientos reales a el beneficiado quien solo le pertenecen los diezmos y primicias y demás emolumentos eclesiásticos...". 


\section{CAPÍTULO

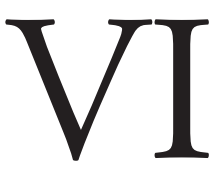

LA CRISIS DEL ANTIGUO RÉGIMEN Y LA OBRA DESAMORTIZADORA. CULTIVOS Y RENDIMIENTOS EN LA PRIMERA MITAD DEL SIGLO XIX 


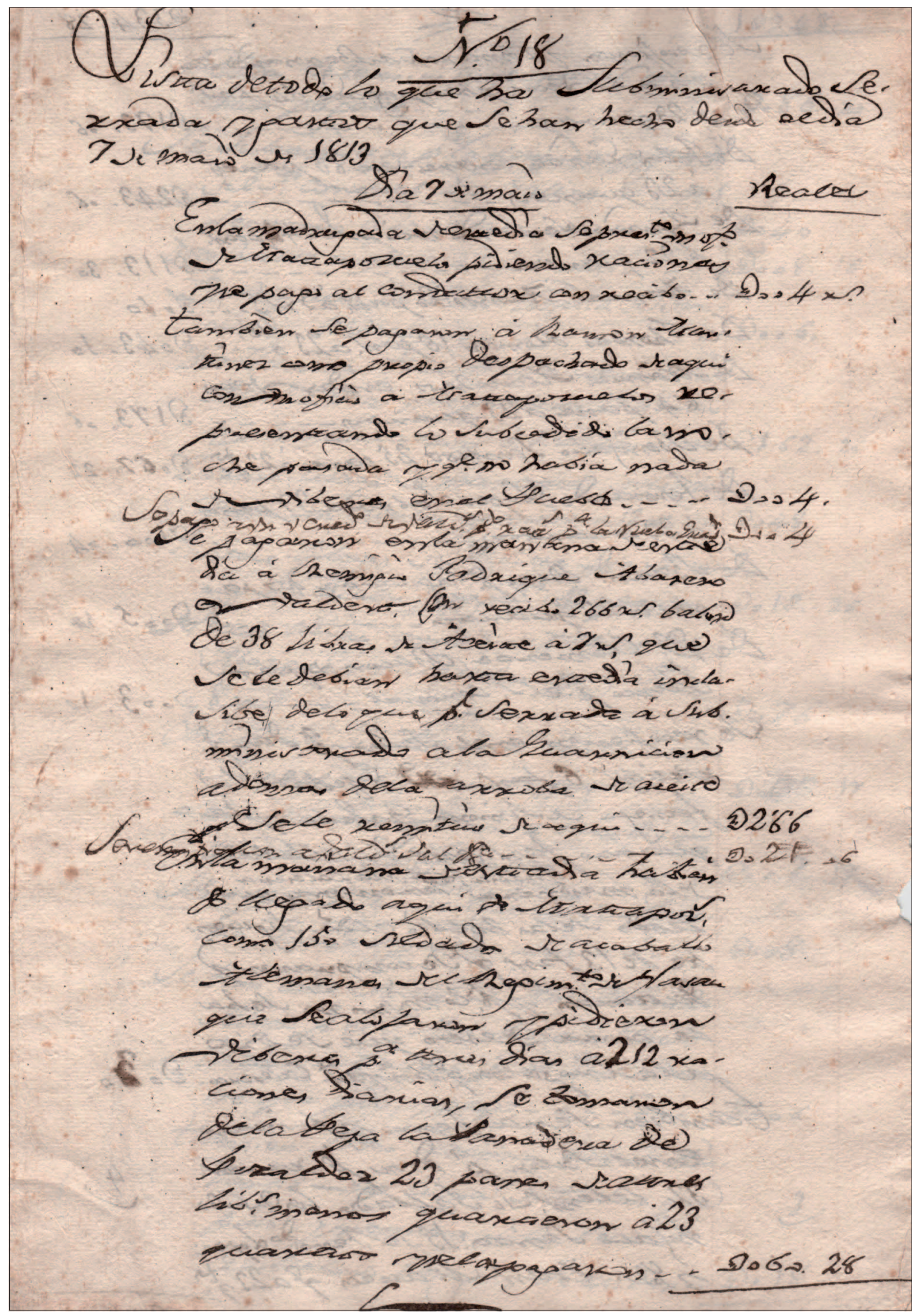

Imagen 80. Registro de los suministros a las tropas durante la guerra de la Independencia. Serrada, año 1813. Archivo familia Alonso Moyano. La crisis del Antiguo Régimen, al margen del desastre de la guerra, supuso toda una conmoción en las poblaciones campesinas del espacio que estudiamos, al alterar las estructuras socioeconómicas que habían mantenido durante largos siglos. 
En las últimas décadas del siglo XVIII, se inicia el desmoronamiento del sistema absolutista del Antiguo Régimen. Se abren las páginas del siglo XIX en unos momentos en que la revolución en Francia condiciona toda la política continental. La invasión napoleónica y la guerra de la Independencia llevan al país a la necesidad de adaptarse a los nuevos tiempos y dar acogida a las pretensiones de la burguesía liberal. Entre sus objetivos está el acceso al poder político y el control de la vida municipal, pero también hacer realidad su viejo sueño de conseguir tierra y propiedad urbana. De ahí que el proceso desamortizador, esto es, la venta en subasta pública de los ingentes bienes rústicos y urbanos del clero o de los municipios, lejos de transformar las estructuras de propiedad de la tierra, consolida un nuevo capitalismo agrario, controlado por sectores oligárquicos, dueños del juego político, ajenos en muchos casos al espacio local y poco interesados en la introducción de mejoras o nuevos cultivos. El arrendamiento fue mucho más numeroso que la explotación directa por parte de los nuevos propietarios, deseosos de incrementar las rentas para amortizar la inversión. La deficiente industrialización regional tampoco logra absorber el excedente de población campesina, provocando en estas tierras de Medina no pocas tensiones y contradicciones en un sistema que, lejos de limar las diferencias, sirve para ahondar el abismo que irá separando a los espańoles. No pocas transformaciones van a vivirse en este siglo.

\section{Del Antiguo Régimen al brusco despertar del siglo XIX. La Guerra de la Indepen- dencia}

Nada o muy poco parece cambiar en la vida de las comunidades campesinas del espacio estudiado. En el nuevo siglo, prosigue en todo su esplendor la vigencia de las estructuras estamentales y el peso de una sociedad campesina, fiel a los usos y costumbres de anteriores siglos. A San Martín del Monte apenas le quedaban cincuenta ańos de vida y Serrada apura la centuria, dependiendo de la regularidad de sus cosechas y de la saca del vino con destino a los mercados del norte.

Distinta era la vida de la nobleza propietaria de estas tierras que sigue emparentándose con altos linajes y disfrutando, en su vida cercana a la Corte, de las rentas derivadas de sus propiedades y posición ${ }^{958}$. La genealogía de los labradores y jornaleros es, sin embargo, otra. A tenor de la documentación consultada de fines del XVIII, abundan más las hipotecas y las deudas que los afanes por

${ }^{958}$ Luís de Montalvo Quadra y Avellaneda, señor de Serrada, que pleitea sobre el derecho de tanteo del concejo sobre su villa de Serrada en 1726, casa con Feliciana de Olmos Girón, II marquesa de Torreblanca y heredera de tal título en posesión de su padre Alejo de Olmos, casado con María Rodríguez de Eván, de la familia de los Evanes. De esta manera, los herederos de Diego Ruiz de Montalvo suman por matrimonio este título tan renombrado a su ya de por sí importante linaje. Alejo Manuel de Montalvo y Olmos, hijo de los anteriores, III marqués de Torreblanca y noveno señor de Serrada, como heredero de tales títulos, los otorga a su muerte a su hijo José-Nicolás de Montalvo y Álvarez. Este, como cuarto nieto en línea directa de Antonio Rodríguez de Eván, pasó a detentar, además de todos los bienes, incluido Eván de Abajo, el marquesado de Falces (1809), por ser el noveno nieto de Alonso Carrillo de Peralta (ÁLVAREZ MARTÍN, M.: Personajes en Tierra de Medina. Diputación de Valladolid, pág. 74 y BLANCO, A.: Esplandián Amadís 500 años. Valladolid, 1998). 
la modernidad. Como se ha estudiado, en 1772, Serrada aún no ha podido terminar su iglesia, evidencia de la falta de recursos que sufre el vecindario. El propio concejo se dirige al obispado para destinar los sobrantes, del beneficio de Preste vacante, a la citada obra. El concejo manifiesta "los cortos medios que a todos asisten", que pone sobre el tapete la precaria situación económica de la mayor parte de los vecinos, en el arranque del último tercio del siglo XVIII. No podía acabar el siglo sin penurias y crisis, pero tampoco sin que a estos caminos llegasen los ecos de nuevas ideas y de ciertos cambios.

\title{
a. La incidencia de la Ilustración y las crisis que anteceden a la invasión francesa
}

En sus viajes por España, era casi una obsesión en el clérigo ilustrado Antonio Ponz, su apuesta por la forestación como salida a la despoblación y a la pobreza. Le dolían, medio siglo antes que a la generación del 98, los problemas seculares de sus gentes y la inercia tradicional del campesinado castellano que veía en la resignación un escaso remedio para olvidar sus males. Escribía Ponz en este sentido ${ }^{959}$ :

\begin{abstract}
"Por lo regular se ara superficialmente con un mismo arado, y sin diferencia de rejas, quedándose por dicha causa las semillas expuestas a los efectos de frío, humedales extraordinarias, $\mathrm{y}$ a que se las lleven las aves escarbadoras, de que hay suma abundancia en Castilla. La desgracia en las cosechas, que en gran parte dimana de los referidos antecedentes, siempre se atribuye a falta o sobra de agua, a los yelos, etc., sin que haga fuerza ver en todas partes que poco terreno bien cultivado, y sin tanto ganado da mucho mas fruto que otros donde se ara mucho, y mal, perdiendo la simiente, el trabajo y la proporción de mantenerse del muchos vecinos en un territorio que apenas puede sustentar a uno...”.
\end{abstract}

No es cuestión en estos momentos de discutir las prácticas agronómicas, pero sí de constatar que las escrituras de arrendamiento que se han reproducido en la Serrada del XVI son semejantes a las que se analizarán a finales del XIX; el cultivo del cereal y los métodos de elaboración del vino son prácticamente idénticos: el mismo arado romano, los mismos débiles rendimientos... Parece que nada ha cambiado, que el tiempo apenas ha transcurrido en estos trescientos ańos. Por eso Ponz se rebela y se resiste a lo irremediable, con preguntas y alternativas que no siempre encuentran ecos y respuestas favorables. Se desea, por ejemplo, que la rubia, planta tintórea, fuera una alternativa al cultivo cerealista. Ponz se congratula al comprobar que son numerosos los pueblos del entorno donde ha arraigado este vegetal. Deja en el aire una pregunta clave para entender buena parte del pasado y futuro del país: “'Y quanto mayor sería el interés de la Nación, si los lienzos que se estampan, y tiñen con la rubia, en lugar de venir del Norte por Ostende, Amburgo, y otros puertos, se hilasen en España, como se podía conseguir, ocupando veinte mil hilanderas?" ${ }^{360}$. Se hace difícil imaginar que estos pensamientos fueran compartidos por el campesinado de estos pueblos conforme llevan en carros y costales, año tras año, las rentas al marqués, protegen con grandes acobijos sus cepas o dejan las tierras de la Vega en hojas de año y vez, para, entre otras cosas, cumplir los mandatos fijados en los seculares contratos de arrendamiento ${ }^{961}$. Camino de Tordesillas y Medina, Ponz descubre la realidad misma del éxito y fracaso de estas gentes, del paisaje desabrigado y del futuro poco abierto a las nuevas iniciativas. Escribe Ponz ${ }^{962}$ :

${ }^{959}$ VALDEÓN BARUQUE, J.: Castilla y León en el siglo XVIII. A través de los viajes de Antonio Ponz, pág. 72.

${ }^{960}$ Ibídem, pág. 55.

${ }^{961}$ En relación con el cultivo de la rubia, tan sólo se ha encontrado en una fecha tan tardía como 1803 un documento alusivo a dicho cultivo en Serrada, vinculado, por lo demás, al párroco beneficiado de la villa. ¿ Serían estas excepciones, vinculadas a las elites del poder, las que osaran introducir los nuevos cambios o al menos reflexionar sobre los problemas que acuciaban al campo castellano?

${ }^{962}$ Ibídem, pág. 113. 
"Hay una cuesta para baxar a Tordesillas, y desde lo alto se descubren Matapozuelos, Pozaldez, la Ventosa, la Seca, Rodilana, Serrada, Villanueva de Duero, Matilla de los Caños y otros Pueblos...(...). Se camina siempre por una llanura casi toda cultivada de viñas, como lo están igualmente las campiñas de otros pueblos circunvecinos en este territorio, de donde llevan el vino a Asturias, a la Montańa, y aun a Vizcaya. Rueda ha crecido (sin exemplo de otros) en esta parte de Castilla...”.

Acercándose a Medina, Ponz se lamenta de su presente, recordando su pasado963:

"No se puede entrar sin desconsuelo a hablar de la Villa de Medina del Campo, y mas quien tiene idea de lo que fue antiguamente, residencia de muchos monarcas, teatro de grandes sucesos, y población de catorce mil vecinos. Hoy está reducida a poco más de mil. Desaparecieron sus famosas ferias, sus muchas riquezas, la comodidad, y la limpieza de calles, y casas, y solo queda la apariencia de destrucción, y ruina...”

Esta inercia en la decadencia y prácticas campesinas es una pequeñez ante la llegada del pensamiento de las luces. Las minorías ilustradas apelan a la alfabetización y a la instrucción, como instrumentos para combatir la tradición y la ignorancia. Saben, no obstante, que siembran en campo poco abonado y con muchos enemigos. El viejo orden se aplica con severidad. Las denuncias, prohibiciones e inspecciones en relación con estas ideas que llegan de la mano de los filósofos franceses, ponen de manifiesto la fractura existente entre al Antiguo Régimen y los burgueses e intelectuales abiertos al nuevo pensamiento. Se señala, como detalle, el caso del fraile que acusa a Tomás González, geógrafo y archivero en Simancas, de poseer las peligrosas y prohibidas obras de Rousseau y, en relación con este trabajo, es reveladora la acusación formulada por un criado del marqués de Torreblanca, señor de Serrada, no sólo porque, mientras sirve a su amo "leía un libro en francés intitulado Obras de Voltaire", sino, y sobre todo, "porque se complacía en la leyenda" ${ }^{36}$.

La anécdota no carece de importancia. Lleva a pensar que, pese a las medidas "sanitarias" de los ministros de Carlos IV, las condenas inquisitoriales y las respuestas reaccionarias de quienes ven en lo extranjero al mismo demonio, su conocimiento estaba más extendido de lo que en un principio se puede imaginar. Otra cosa era su incidencia práctica en estos pueblos plegados sobre sí mismos. No obstante, hilvanando con alfileres cuantos detalles se esconden en testamentos, obligaciones y ventas entre los vecinos de Serrada y sus pueblos circundantes, se constata una mayor preocupación por la formación de sus hijos, por incrementar la producción de sus tierras y por aumentar la rentabilidad de sus ganancias. ¿Son consecuencia de las nuevas ideas? ¿Derivan de la propia evolución socioeconómica? ¿Testimonian una preocupación por insertarse con éxito en las inevitables estructuras capitalistas que ven llegar?

Es difícil responder separadamente a estas cuestiones y lo más prudente es afirmar que la conjunción de factores marca tanto el rumbo de Serrada como el de sus pueblos vecinos. Nunca fue fácil compaginar las letras con la besana y menos, con filosofías que rompen la tradición y la inercia de siglos. A lo largo de la investigación efectuada para escribir estos textos, han sido incontables los casos en que humildes campesinos excusan firmar por no saber y este menester, casi exclusivo de canónigos y hacendados, separa aún más, si cabe, la realidad campesina de los sueńos de Ponz y de tantos otros pensadores de finales del XVIII. Sin embargo, y es la otra cara de la moneda, también las ideas más vanguardistas e ilustradas calan en nacidos o avecindados en este espacio rural. Al menos en teoría. Es el inicio de un largo camino.

\footnotetext{
963 Ibídem, pág. 115.

${ }^{964}$ EGIDO LÓPEZ, T.: "La Ilustración en Castilla. Acogida, resistencias y fracaso”, en García Simón, A.(ed.): Historia de una Cultura. Junta de Castilla y León, vol. III, 1995, pág. 317.
} 


\section{- La llegada de ideas ilustradas. La familia Moyano Rodríguez como ejemplo}

Como se ha estudiado, desde 1739 a 1775, Francisco Moyano y Miguel Moyano, padre e hijo, regentan la escribanía de Serrada al tiempo que consolidan una buena hacienda de tierras y viñas. Tanto ellos como sus descendientes se preocupan tanto de incrementar sus heredades como de encauzar a sus hijos por la carrera eclesiástica o de leyes, caminos estos imprescindibles para escalar sólidas posiciones tanto en la administración como en la sociedad de la época ${ }^{965}$.

Bachilleres, canónigos, presbíteros y monjas salen a decenas de las principales familias labradoras de estos pueblos en esta segunda mitad del XVIII ${ }^{966}$. Pero pocos alcanzan tan altas distinciones como los citados escribanos ${ }^{967}$. En el caso de Tomás Moyano Rodríguez es su hermano Francisco Moyano, caballero maestrante de la Real de Ronda, casado en segundas nupcias con María Cantalapiedra Bayón, vecina de La Seca, y uno de los más grandes hacendados de Serrada, quien avala económicamente su carrera política y de leyes, así como sus costosos matrimonios. Tomás y Buenaventura Moyano maduran intelectualmente discutiendo las ideas de la Ilustración y las contradicciones de un sistema incapaz de adaptarse a las necesidades de su tiempo.

No se trata de exagerar los reflejos ilustrados que llegan a estos pagos por influencia de estos hijos ilustres o por las elites de poder de las cercanas ciudades, sino de verificar el cambio de tendencia de las dos últimas décadas del XVIII y que cristaliza en las llamadas Sociedades de Amigos del País, sean las fundadas en Valladolid (1783), Medina del Campo (1788) y Tordesillas (1787). Cuestión pendiente es la de investigar la resistencia o el apoyo que despertaron las nuevas ideas en el pensamiento de Buenaventura Moyano ${ }^{968}$. Se ignora si avalaría o aborrecería las tesis que acababa de publicar el Doctor Vicente Fernández Valcarce, canónigo de Palencia, poco antes de su llegada, pues los "Desengaños filosóficos, que en obsequio de la verdad, de la Religión y la Patria..." eran todo un alegato reaccionario contra la nueva filosofía ${ }^{969}$.

${ }^{965}$ Esta preocupación se refleja en el testamento que, con fecha de 28 de julio de 1792, otorgan Don Miguel Moyano y Dońa Beatriz Rodríguez: “Declaramos que habiendo destinado a nuestros hijos los doctores Don Buenaventura y Don Thomas Moyano a los estudios de Sagrada Teología y anbos derechos, habiendo contribuido a el primero con lo necesario para su manutención y subsistencia hasta que graduado de Doctor en las Unibersidades de Ábila y Valladolid, y obtenido cátedras de sagrada Teología de esta última, fue electo el año pasado de mil setezientos ochenta para la canongia de lectura de sagrada Escritura de la santa Yglesia Apostólica Catedral de dicha ciudad de Ábila, y habiendo higualmente contribuido lo mismo a el dicho Don Thomas para que haya seguido y siga con el lustre correspondiente su carrera en que ha obtenido siempre el grado mayor en derecho cibil por la Real Universidad de Valladolid, una de las Cáthedras de Instituta Cibil de ella, y que la Real Cámara de S.M. le haya consultado varias veces para plazas togadas de la Real Chancillería y Audiencia de estos Reinos de Castilla; no hemos ganado para todo esto más de lo necesario que exigían nuestras circunstancias y las de los referidos nuestros hijos. Y la educación que hasta aquí hemos juzgado y juzgamos más oportuna y conducente así para ellos como para conservar el lustre y honor de nuestra familia y hacerles útiles al estado, y con cuia ydea hemos señalado a los demás nuestros hijos los vienes competentes con cuyo producto se hayan mantenido según sus circunstancias, queremos y es nuestra voluntad que a ninguno de ellos se les impute ni deste ni por dicha razón cantidad alguna del respectivo haver de nuestras legitimas”. (A.H.P.V. Pt. 8225, fol. 544, año 1792).

966 Se encuentran, por poner algunos ejemplos en la segunda mitad del XVIII, a Julián de Íscar, presbítero, hijo de Blas de Íscar y Ana Alonso; a Melchor Moyano, hijo mayor de Juan Antonio Moyano y de Ventura Alonso; a Fernando Rodríguez, cura párroco en la parroquial de San Cipriano de Toledo y sobrino del presbítero de Serrada D. Remigio Rodríguez; al también presbítero D. Francisco del Castillo, tío de D. Juan Antonio, D. Cenón y D. Joseph Díaz del Castillo., etc., etc. (A.H.P.V. Pt. 8221, fols. varios).

${ }^{967}$ Alcanzar estas metas no era nada fácil en el tiempo estudiado. Además de la valía y buena disposición del interesado, era imprescindible estar respaldado por una buena hacienda. En este caso ambas cosas se unirán en la carrera de los hijos de este matrimonio. El doctor Buenaventura Moyano, nacido en Serrada el 13 de julio de 1755, alcanza el nombramiento de obispo auxiliar de Toledo, entre 1800 y 1801, y del obispado de Palencia desde el 23 de febrero de 1801 hasta su muerte, el 7 de septiembre de 1802. En relación con lo comentado, le hubieron de entregar hasta 30000 reales en dinero "y varios muebles y ropas que le embiamos para poner su casa y establecerse en Ábila después que fue electo para la dicha canóngia de lectura...”. En las mandas testamentarias consta cómo dicho Buenaventura, antes de ocupar tales distinciones, había sucedido en la capellanía fundada en la iglesia parroquial de Serrada a su tío el bachiller D. Andrés Rodríguez Zorrilla, beneficiado y cura párroco de la misma y propietario, como ya se ha estudiado en otro apar- 
Cuestión distinta es el caso del Doctor Tomás Moyano. Este serradense vive con intensidad su cátedra de leyes en la Universidad de Valladolid y conoce en profundidad las corrientes ilustradas que cristalizan en academias y sociedades. De hecho, defiende la utilidad de las nuevas ideas como el camino para mejorar en la práctica la difícil realidad que vive el país. Nada mejor en este sentido que reproducir al pie la repercusión que tuvo el discurso que pronuncia en la Universidad de Valladolid, el 5 de abril de 1787. El diario Pinciano, estandarte de esta cultura ilustrada, da cuenta de ello ${ }^{970}$. Merece la pena haberse extendido en la reproducción de las conclusiones que recoge el diario. Su lectura lleva a recordar las bases estrictas del Despotismo ilustrado, los grandes males que han retrasado al país y las cautelas que han de tomarse para evitar excesos. El hijo del escribano de Serrada parece ade-

tado de esta obra, de hasta 13 obradas de tierra y 10,5 aranzadas de majuelos, además de las rentas por los oficios que administraba.

La familia Moyano Rodríguez administraba estos bienes y rentas de las que, junto con su importante hacienda, derivará la construcción de la última gran casa solariega en Serrada, actualmente propiedad de la familia Medina. El escribano Francisco Quintero lo expresa certeramente, siguiendo las palabras que le dictan los testamentarios: "Hemos tenido desde el dicho año, por encargo del referido nuestro hijo, la libre administración de todos los vienes anejos a uno y otro, percibido sus frutos según es notorio, y retenido en nuestro poder todo el valor y rendimiento liquido de ellos. Y con cuio caudal, por encargo asi vien y cuenta del mencionado Don Buenabentura, le hemos hedificado la casa en que vivimos a el presente, con su lagar y demás ofizinas en el casco de esta villa y solares que ocupaban las carnecerías y matadero antiguo, y las casas propias de los herederos de María García, mujer que fue de Andrés Román y de los de Andrea Martinez, las quales compramos para ello con el mismo caudal..."

${ }^{968}$ Hay que tener en cuenta que, como tantos otros, este obispo procedía de la burocracia eclesiástica y del mundo capitular y, por tanto, estaría cercano a la institución de la monarquía tradicional del Antiguo Régimen. Antes de ocupar la diócesis palentina, se encontraba como auxiliar del obispado de Toledo. En concreto, será nombrado obispo titular de Sebastopol el 22 de diciembre de 1800, con encargo de auxiliar de Toledo y ascenderá a residencial de Palencia el 23 de febrero de 1801, ob. cit., MARRIO, M.: "Los obispos de Castilla y León durante el Antiguo Régimen (1556-1834). Junta de Castilla y León, Año 2000, pág. 75.

${ }^{969}$ EGIDO LÓPEZ, T.: La Ilustración en Castilla. Acogida, resistencias y fracaso. A. García Simón, (ed.) Historia de una Cultura, vol. III, Valladolid, pag. 320.

${ }^{970}$ Estos son algunos de sus fragmentos: "El día 21, presidió un Acto mayor de Derecho Público pro Universitate, el Doctor D. Tomás Moyano Rodríguez, del Gremio y Claustro de Leyes de esta Universidad, siendo su actuante Don Joseph Melo y Guilarte. La materia de este Acto es exquisita: las diez Conclusiones en que se extiende son de bello gusto, de singular erudición, de utilísima, y sólida doctrina...

Continuación de las Conclusiones doctor Moyano. En la quinta se dice: que las Sociedades establecidas para el progreso de las Ciencias y fomento de las Artes traen a la República una increíble utilidad; porque las luces se unen y multiplican, y la verdad se descubre más fácilmente quando los ingenios se comunican mutuamente sus pensamientos y reflexiones. Y como todo Cuerpo constituido en la República depende del Principe, como de su legitima Cabeza, y estas sociedades pudieran degenerar y convertirse en conventículos y juntas ilícitas, le toca al principe cuidar muy particularmente de ellas, dándoles reglas y constituciones para su gobierno, eligiendo individuos idóneos que las compongan, y nombrando Director o Presidente capaz de desempeñar este cargo... (...).

En la 8. Que poca o ninguna utilidad producirian a la República literaria los medios y auxilios pequeños, sino se pusiese cuidado en averiguar frecuentemente los adelantamientos de los Estudiantes y Doctores. Para lo qual son necesarios exámenes en las Escuelas de Primeras Letras, y en los demás Estudios, tanto para los que gozan de estipendios o pensiones, como para los que intentan recibir los Grados Académicos.

En la 9. Como el interés de la República no solo consiste en el explendor de las Letras, sino también en el exercicio y fomento de las Artes, es cosa clara que el Principe debe atender a unas y otras, y tanto más a estas quanto los hombres privados piensan menos en su perfección, y sus facultades son cortas para fomentarlas (...). Porque a la verdad, no hay Pueblo, ni Lugar alguno en que no se proporcionen mil ganancias y ventajas siempre que los vecinos conozcan y penetren las circunstancias, calidad $y$ naturaleza de su Pais. Mas como ha echado tantas raices en el vulgo la opinión de que en estas materias nada debe inovarse, y se tiene por temeridad querer saber más que los antiguos, no hay que esperar progresos algunos de la industria de los hombres, si el Príncipe no la excita con leyes, con premios y con privilegios... (...).

Finalmente asi como al cuidado del Principe pertenece todo quanto hay que hacer para los aumentos de las Ciencias y de las Artes, asi también a él toca apartar quantos impedimentos se opongan al logro de aquellos fines. Son innumerables los que podian mencionarse, pero ninguno más horrible y perjudicial que la EMBIDIA, que no cesa de perseguir, y poner asechanzas a la verdadera virtud...”. J. Marino Berón. Diario Pinciano, 1933, pág. 91 y ss. 
lantarse a su tiempo. Como certeramente señala el profesor Almuiña, "aunque en esta conferencia se cita a Rousseau, vemos ya cómo en 1787, o sea, dos años antes del estallido formal de la Revolución Francesa, en Valladolid, una de las personas más avisadas hace una llamada de atención sobre el posible arraigo en estos centros de las subversiones y doctrinas revolucionarias. La legitimidad y obligación de intervenir el poder para cortar todo posible desvío. Doctrina sintomática y de la más pura ortodoxia en la defensa de las esencias ilustradas: en lo cultural, las Academias como centros benéficos para la ciencia; en lo político, el intervencionismo del monarca, de acuerdo con el más puro despotismo ilustrado y, por último, el toque de atención ante el posible desbordamiento revolucionario" ${ }^{971}$.

Bajando de estas teorías políticas a la práctica local, puede preguntarse si llegaron a influir estos pensamientos en los vecinos y familiares más allegados y cultos que esta familia Moyano Rodríguez tiene en el pueblo. ¿Entrarían estos temas en las conversaciones familiares del padre Miguel Moyano con sus eminentes hijos? ¿Aplicarían algún aspecto de la nueva doctrina en la gestión de su labranza de Serrada? ¿Alentarían a los vecinos más letrados a conocer al menos las nuevas corrientes o a participar de los debates que se manifestaban en las citadas Sociedades de Amigos del País? A pesar de no haber encontrado documentación al respecto, se tratará de despejar algunos de estos interrogantes en las siguientes líneas.

\section{- Las luces y sombras de finales de siglo. Las crisis agrarias que anteceden a la invasión na- poleónica}

Aunque es conocida la recuperación económica que Espańa experimenta en la segunda mitad del XVIII, no es menos cierto que en la mayor parte de las pequeńas villas castellanas alternan ańos de saludables cosechas con otros que recuerdan las peores del crítico XVII. La Seca, Matapozuelos, Ventosa, Serrada y San Martín del Monte, entre otros lugares, profundamente campesinos, siguen sumidos, no sólo en las tradicionales crisis de subsistencia, sino también en las desequilibradas estructuras sociales y de propiedad que limitan cualquier posibilidad de mejora. Piénsese que de los 120 vecinos (450 habitantes, aproximadamente), que Serrada tiene en 1765, cien son jornaleros y del resto, 20 son labradores y 15 pegujaleros, que no se diferencian en años de escasas cosechas de la suerte que corren los primeros. La situación de necesidad de la inmensa parte del vecindario se torna incómoda, incluso, para la media docena de pudientes labradores, que no tienen ningún empacho en acudir a la justicia cuando sienten sus bienes comprometidos por el hambre de sus vecinos. Un ejemplo es la denuncia que sigue y que nos acerca a la realidad del campo castellano, bastante alejado de las ideas reformistas que se acaban de referir ${ }^{972}$ :

\footnotetext{
"Narciso del Castillo, vecino y labrador de esta villa de Serrada, doy todo mi poder cumplido... a Bernardo del Castillo Alonso, del número de la Real Audiencia y Chancillería de Valladolid, para que en mi nombre pueda parecer y parezca ante los señores Presidente y Oydores de dicha Real Chancillería y con relazión a componerse esta villa de ciento y veinte vecinos, los ciento jornaleros y los restantes labradores, aunque de estos los quinze pegujaleros, quienes por sí y su familia siegan y recogen los pocos frutos de pan que siembran; y con la de haverse dado por esta xusticia salvoconducto a trescientas personas que de día y de noche andan notoriamente espigando entre mis segadores y los de otros tres o cuatro vezinos que tienen sembrados, apoderándose de mis criados, a que se llega que los ganados abejunos así vien andan tras los mismos segadores, lo que jamás se ha experimentado en este pueblo, sin que hayan bastado ni vasten las amonestaciones christianas que he hecho a dichos mis segadores, para que no permitan entrar a sus mugeres, hijos y parientes en los rastroxos, hasta tanto que se haya lebantado el pan de la tierra, por quitar por este medio la presunción de lo que indevidamente cogen, pues se está evidenciando que trescientas personas que andan espigando..., poco menos que los labradores cogen ... que acabada que sea la siega, hazen por las enteras y no aguantando iguales excesos, los referidos segadores en descuento y venganza, validos de no tener vienes algunos, dexan la referida siega, dando lugar por este medio que los ganados obejunos lo rozen y talen todo, emanado de la ninguna providencia y castigo de la xusticia...”
}

${ }^{971}$ ALMUIÑA FERNÁNDEZ, C.: Teatro y Cultura en el Valladolid de la Ilustración. Ayuntamiento de Valladolid, 1974, pág. 32.

${ }^{972}$ A.H.P.V. Pt. 8219, fol. 246, año 1765. 
El texto aproxima de forma directa a las penurias que sufre el vecindario. Como en tantos otros casos, los ejemplos de Serrada se repiten en toda la Tierra de Medina. Casi todo un pueblo anda espigando por carecer del mínimo para subsistir. Estas situaciones se repiten invariablemente en los años de penurias. El ambiente social tampoco parece estar muy relajado. A las dificultades de los vecinos se suman las tensiones entre los distintos cargos que componen el concejo, nombrados por el marqués como dueño de la jurisdicción de la villa, y aquellos vecinos del estamento noble, en concreto Cenón y Josef Díaz del Castillo y Josef Obregón de Yscar, que exigen que se respeten sus derechos a formar parte de las justicias locales. En 1786, estallan nuevas protestas que acaban en la Chancillería por los parentescos entre cargos y la exclusión de estos hidalgos que ven como sigue sin cumplirse su participación legal en la mitad de los oficios ${ }^{973}$.

Aunque algunos de estos aspectos han sido tratados al analizar la vida cotidiana, en la Edad Moderna conviene recordarlos de cara a entender el siglo de los grandes cambios. La década de los ochenta parece mostrar un cambio de tendencia. La iglesia está terminada y, en junio de 1786, el concejo da licencia para la venta de las carnicerías viejas y el corral del concejo, al objeto de pagar parte de las obras del nuevo ayuntamiento ${ }^{974}$. En una de sus dependencias está la nueva escuela. Aunque ya se imparten las primeras letras, la real cédula de 1781 impone la enseñanza obligatoria en España, ratificando la educación como uno de los valores que hay que impulsar en esta centuria. Estas villas siempre se preocuparon por tener atendida esta labor, no exenta en ocasiones de conflictos entre vecinos, maestros y concejos. Y lo mismo se puede decir de la atención a la salud. En septiembre de 1791, se acuerda entre el médico Don Remigio García y el concejo de Serrada que el primero se obligue a "hacer dos visitas diarias a los enfermos; una por la mañana y otra por la tarde..."975. Estas preocupaciones por la salud llegan también a los enterramientos, que se sacan de la iglesia al nuevo camposanto. El testamento de Antonio Martín, fechado en 1803, da prueba de ello cuando manifiesta su deseo de ser enterrado "en el cementerio o camposanto que hay en esta villa, arreglo a Reales Órdenes, por no permitirse hacerlo en las Iglesias Parroquiales... "376.

Cambios o avances que no parece que se encuentren en los sistemas de trabajo y producción agraria, más allá de los retelos, el incremento de abonado y la siembra de leguminosas que se han estudiado en las últimas décadas del XVIII, que no es poco, a tenor de la tendencia del campesino castellano en estos siglos. Ya se ha manifestado el escaso éxito de los programas de forestación y que el cultivo de la rubia tampoco arraiga. Es de anotar, sin embargo, la excepción que se ha documentado en relación con este cultivo y que refiere la obligación, favorable al cura párroco de Serrada y la inclusión de una condición en los arrendamientos de pastos y rastrojeras de 1821, para evitar el pastoreo en aquellos sembrados de rubia que tuvieran menos de un ańo977. La patata, que a fines del XVIII también se siembra en otros pueblos cercanos, se encuentra, a comienzos del XIX, mezclada con harina para paliar las hambrunas ${ }^{978}$.

${ }^{973}$ A.R.Ch.V. Pleitos Civiles, Quevedo (OLV), caja 125.4.

${ }^{974}$ En reunión de concejo para tratar el anterior asunto, el escribano da fe del hecho y del lugar provisional en que se reúnen los vecinos: "En la villa de Serrada a veinte y uno de enero de mil setezientos ochenta y siete, y ora señalada en el decreto antezedente, juntos y congregados la Junta, Regimiento, conzejo y vezinos del estado general de esta villa en el Portal de la casa Palacio del Sr, marqués de Torreblanca, donde al presente, por estarse fabricando de nueba planta las Casas COnsistoriales...”. A.R.Ch.V. Pleitos Civiles, Quevedo (OLV), caja 125.4, fol. 16-17.

975 A.H.P.V. Pt. 8225, fol. 424, año 1791.

${ }^{976}$ A.H.P.V. Pt. 8228, fol. 33, año 1803.

977 En la citada obligación, se fija la cantidad de 1.020 reales a pagar por importe de 122 fanegas de rubia, por parte de Manuel de la Fuente, vecino de la villa de Íscar, a Félix Martín de la Vega, párroco de esta villa. A.H.P.V. Pt. 8227, Serrada, fol. 45, año 1798. En 1821, se registra la cláusula de respetar sus sembrados de menos de un año. A.H.P.V. Pt. 8228, fol. 27, año 1821 .

${ }^{978}$ Su primera mención escrita se documenta hasta 1832 en que Ramón Risco, vecino de Villanueva, hace testamento manifestando ser nacido en San Martín y feligrés de Serrada "por estar agregado el Despoblado de San Martin.... y declaro que tengo a medias con dicho señor alcalde Feliciano Martín tres muelares y mío propio un patatal en termino de este Despoblado de San Martin...” (A.H.P.V. Pt. 8230. Serrada, fol. 24, año 1832). 
La tradición vitícola y el carácter de arrendamiento de buena parte de las tierras de labor impiden aventuras inciertas. Las labores en los majuelos siguen idénticas a otros siglos y, en cuanto a la tracción animal, ya entonces era conocida la controversia entre los partidarios de bueyes o mulas. En Serrada alternan ambos, dependiendo del potencial hacendístico de sus dueños, pero el peso de los bueyes va en franco retroceso en las tareas de arado ${ }^{979}$. Pese a todo, Serrada se proyecta hacia el siglo XIX con cierto dinamismo. Nada mejor que analizar la evolución de las obligaciones y posturas con que los distintos vecinos rematan públicamente los servicios de correduría, taberna o alcabala del viento. Siendo prudentes y atendiendo a la variabilidad de las cosechas, se evidencia un incremento muy notable en cuanto al derecho de aguardiente, al tiempo que una cierta atonía en la taberna que refleja, como más adelante se analizará, la salida por destilación de parte de los excedentes vitícolas que, a partir de 1815/17, acusan el estancamiento general que vive el sector en todo el país. ${ }^{980}$

Cuadro 91. Remates públicos realizados por los vecinos de Serrada, año 1768-1814. (rs)

\begin{tabular}{lrrrrrrr}
\hline Años & 1768 & 1772 & 1776 & 1786 & 1795 & 1800 & 1814 \\
\hline Correduría del vino & 3.750 & 5.700 & 8.100 & 11.200 & 19.020 & 26.033 & 11.000 \\
Taberna y abacería & 3.300 & 4.000 & 4.000 & 3.700 & 5.200 & 2110 & 4.170 \\
Derecho de aguardiente & - & 400 & 400 & 570 & 610 & 600 & 1.200 \\
Pámpana de vińas & - & - & - & 780 & - & 1.000 & 1.500 \\
Alcabala del viento & 600 & - & 1.100 & 950 & 1.500 & - & 3.570 \\
\hline
\end{tabular}

Fuente: A.H.P.V. Protocolos Notariales. Libros correspondientes a los años relacionados. Serrada.

Las últimas fechas del XVIII y comienzos del XIX ponen fin a esta etapa de crecimiento. Una sucesión de malas cosechas sitúa al campo vallisoletano al borde de la quiebra: la langosta asuela los campos en 1798; los impuestos reales en forma de "donativo voluntario", arbitrados por Carlos IV, agravan la situación de los más débiles; las sequías de los primeros años del siglo traen consigo el hambre y, a partir de 1804, la enfermedad del "tabardillo pintado" acaba por oscurecer cualquier asomo de esperanza ${ }^{981}$. En 1803 el Concejo de Serrada "por no haber en esta villa pósito ni otro fondo para lances de escasez de granos como la presente" ${ }^{\prime 82}$ determina retener la quinta parte de todos los diezmos de granos y tomar cuatro mil reales de los propios "para aumento de un fondo para socorro de los

${ }^{979}$ Se conoce parte de la cabaña boyar de Serrada en estos años por los daños que ocasionaron en 1789 en un sembrado de D. Miguel Moyano, al salirse del Prado de Abajo en que pastaban. Ante la denuncia formulada, el guarda Justo Casado declara como reses causantes del daño dos bueyes de Fernando Lavajo; tres de Isidro Platón; dos de Manuela Bermejo; tres de José Díaz y, junto a ellos, los doce bueyes carretiles de Tomás Domínguez que, por no ser de la cabaña real, pastaban en los prados de Serrada al no dejárselos pastar en otros pueblos. (A.R.Ch.V. Pleitos Civiles, Pérez Alonso (OLV), caja 686.2). Excepción a su empleo como tracción, se encuentra en el caso de Tomás Domínguez, carretero avecindado en la villa. En su testamento refiere haber entregado a su hijo Rafael, cuando casó con María Labajo, 4 carretas, 9 bueyes y un caballo "y posteriormente le compré otro buey en setecientos reales, todo lo cual importo once mil trescientos reales”.(A.H.P.V. Pt. 8230. Serrada, fol. 15, año 1829).

${ }^{980}$ A falta de datos que cuantifiquen las cosechas, las posturas por la correduría están en relación con la producción y calidad de los vinos. El incremento de su cuantía parece asegurar el mantenimiento del empuje vitícola, amén de señalar las tasas a cobrar. En la obligación y fianza a favor de la villa, que otorgaron Santos y Narciso Martínez en 1774 , se afirma que "como rematadores de las rentas de correduría y aguardiente por todo este año de la fecha con barias condiciones, y entre ellas la de poder cobrar por cada cantara de vino, mosto y vinagre que se bendiese y saliese, quatro maravedis de vellón, y la de pagar a S.M. la quota fixa del encabezamiento desta villa por el derecho de aguardiente, poniéndole en quenta y riesgo en la ciudad de Valladolid...”. A.H.P.V. Pt. 8220. Serrada, fol.426, año 1774.

${ }^{981}$ El tabardillo es una variedad de tifus endémico contagioso, transmitido, generalmente, por piojos, y cuyos síntomas son dolores de cabeza, diarrea, pérdida de consciencia y alta fiebre.

${ }^{982}$ A.H.N. Consejos, leg. 2404, exp. 20. 
jornaleros en la presente carestía de pan" ${ }^{383}$. De hecho, se llega a socorrer diariamente a ciento veinte cabezas de casa, con una mezcla de harina y patatas que "según repetidos ensayos que hemos hecho al efecto resulta un pan excelente en su clase..." ${ }^{34}$. Esta acumulación de hechos se deja sentir "muy particularmente", en palabras de Francisco Moyano, en Serrada. Al descenso de producción y jornales sigue el temporal descenso de tierras cultivadas, lo que hace aun más acumulativo el descenso de vitalidad. Lo menguado de las cosechas y el alza de los precios hacen muy difícil la supervivencia de los más desvalidos. En 1804 el alcalde mayor de Tordesillas también se queja de las subidas abusivas del precio del trigo ${ }^{985}$ :

"Por momentos va subiendo el precio del trigo, van encareciéndose los vendedores, y los que tienen porciones sobrantes se han propuesto, a medida de su ambición (que no hay límites para ella), doblar aquél sin piedad del Consumidor".

Otro ejemplo que ilustra la situación que vive el campesinado es el que se precisa en el poder que otorga Francisco Moyano a los procuradores de la Chancillería de Valladolid, en fecha de 25 de mayo de 1807. Ya se han señalado tensiones en otros tiempos por la recogida de las cosechas, pero en este caso han sorprendido la situación y el tono de las palabras. ¿Participan del formalismo de la Ilustración y de la influencia del pensamiento de su hermano Tomás Moyano? Es muy posible pero, por encima de todo, testifican la posición distanciada de quienes, a lo largo del XIX, derivan a posiciones diferenciadas: los hacendados, interesados en mantener el control de los concejos locales y la prosperidad de sus haciendas, y los pobres y braceros sumidos en la temporalidad y en el azar de las cosechas. Pero no hay que adelantar las claves por las que discurrirá el nuevo siglo. Nada mejor que conocer las impresiones de uno de los mayores hacendados ${ }^{986}$.

"Don Francisco Moyano, caballero maestrante de la Real de Ronda, vecino desta villa de Serrada, rexidor decano en ella, otorgo que doy todo mi poder cumplido, el que de derecho se requiere, y es necesario.... y hagan relación de que soy en esta villa el acendado y labrador de mayor arraygo con siete y ocho pares de labor, y más de treinta hombres ocupados todo el año en los trabajos de vińas y tierras, pagando puntualmente a todos con los jornales más altos en el País, según que los tiempos se han presentado. Que tanto en las repetidas veces que he tenido los oficios de república como quanto no he tenido alguno, he procurado el provecho del común y de los particulares, especialmente de la clase de pobres y braceros con el maior conato y desprendimiento de mis intereses y comodidades. Que obserbo, y siempre e observado, con dicha clase de braceros, y con todos la conducta más positiva y compartida y caritativa, haciéndome de continuo muchos sacrificios por remediar sus necesidades; y para mediar en sus pendencias y disensiones, influyendo infinitamente en la quietud del pueblo, y en procurarle el mejor estado en todos los asuntos y ramos. Que lo espuesto es público y notorio, y yo me remito a los informes y pruebas que la Real Sala se dignare tomar..”

Poco más hay que añadir a las palabras del regidor decano del pueblo. Desde su posición de gran propietario y con un innegable paternalismo, testifica las enormes diferencias de clase y riqueza existentes entre sus vecinos. A fines del XVIII y comienzos del XIX, la miseria llevó a los primeros a iniciar, por primera vez, el camino de la emigración urbana, cuando no a ultramar, como una forma de huir de la pobreza. La guerra de la Independencia acaba por liquidar cualquier atisbo de esperanza. La situación no podía ser más crítica ${ }^{987}$.

983 Ibídem.

${ }^{984}$ Ibídem.

985 ANÉS, G.: Las crisis agrarias...., ob. cit., pág. 407.

${ }^{986}$ A.H.P.V. Pt. 8228, fol. 50, año 1807.

${ }^{987} \mathrm{El}$ relato por parte del hacendado es claro al respecto: "Que así bien lo es que de algunos años al presente, con ocasión de las miserias que se han padecido en general, y la falta de frutos que han causado, que en este pueblo ha sido aquella muy particular, me he visto con muchisimos trabajos para executar las lavores mas necesarias en los crecidos vienes que gozo; y por 
Se trata de una crisis de subsistencia propia del Antiguo Régimen. Dos o tres años de malas cosechas sumergen a los más débiles en el endeudamiento y la ruina, pero si, como es el caso, se alargan con una continuada falta de frutos, la desgracia y la miseria acaban por afectar a casi todos. Francisco Moyano sufre la "baratura de el pan y otros artículos", pero es de imaginar que buena parte del pueblo ni siquiera lo podría comprar a ningún precio, pues estaba en la indigencia más absoluta. Llama la atención su particular visión sobre la falta de braceros. Reclama la intervención de la justicia en la defensa de sus propiedades y bienes, a pesar de contravenir la libertad individual de los jornaleros. Tampoco cree en la capacidad de las juntas locales, desvitalizadas, si se comparan con el papel que en tiempos pasados jugaron los concejos locales en la resolución de los conflictos, entre las gentes de las aldeas. Es la antesala de las tensiones sociales entre la clase propietaria y las masas de braceros sin tierra, sin alimento y sin jornal regular. Una pena que no se puedan transcribir las amarguras de estos últimos, que constituían la otra cara de la moneda. Es en estos casos cuando más se lamenta la pérdida irremediable de la mayor parte de los archivos municipales.

\section{b. La Guerra de la Independencia. Repercusiones en Serrada y en San Martín del Monte}

Sabido es por todos que la Revolución Francesa (1789) trastoca el viejo orden europeo. Sus ideas reformistas fueron extendidas por los ejércitos de Napoleón desde que toma el poder en 1799. España iba a convertirse en una pieza más en el puzzle del gran corso, y los reyes, Carlos IV y Fernando VII, en frágiles marionetas, incapaces de contener al insaciable emperador. El tratado de San Ildefonso (1796) firmado con la España de Godoy, permite el paso de los ejércitos imperiales con el objetivo de ocupar Portugal y asegurar el bloqueo continental a Inglaterra. Las tropas francesas cruzan el Bidasoa el 18 de octubre de 1807; el 4 de noviembre, el general Junot pasa por Valladolid y, el 7 de enero de 1808, Dupont establece su cuartel militar en la capital del Pisuerga. Los franceses también venían a quedarse ${ }^{988}$. Valladolid y su provincia tendrán la "desgracia" de encontrarse en pleno corredor del Duero, encrucijada de caminos hacia Portugal y Galicia. Durante buena parte de estos años de ocupación estas tierras están sometidas y "gobernadas" por un general francés que hará de la rapiña y el expolio la norma de sus actuaciones. Se llamaba François Etienne Kellerman.

colmo del mal, sin operarios con que hacer la siega de las mieses, lo que me a forzado a haber aumentado más de doble la paga de este trabajo.

Que en el presente año me ha sucedido lo mismo todo él, a pesar de la baratura de el pan y otros muchos artículos que han bajado según que corrian dos y tres años hace; y ahora me hallo también con la penalidad de no tener operarios para la siega a ningún precio, porque forasteros aqui no bienen, y aunque para este trabajo sobran los que hay en el pueblo, respecto su cosecha, muchos se excusan a servir en él y se salen a hacerlo en otros, sin que ni los ruegos, ni los partidos más ventajosos que les he hecho por mi, y por mis cachicanes y encargados, basten a hacerles ceder de su empeño. Por manera que me veo en el mayor conflicto, y en términos de haver de dejar la mies en el campo, e impedido en delante de seguir la cultura de mis tierras. Esto e la confusión y amargura que esta situación dispone.

Que estoy llano desde luego a pagarles por dicho trabajo el mayor precio que se fije, no sólo en esta villa con senara y mieses del mismo estambre of fuerza, proporcionalmente, sino el que haya también más alto en los pueblos inmediatos que aun son de más cosecha de pan que éste. Y a cerca del mantenimiento, darles también las raciones mas crecidas, que se den a otros; ya sea sirviéndoles de mi casa, o que ellos quieran servirse tomando el dinero y artículos necesarios...

Que en estas circunstancias, y siendo ya tan efectivo el caso, me acojo a la protección de instancia superior pues aunque la Xunta de esta villa conoce muy bien la situación de los braceros, y lo justo que es proteger mi causa, la observo contenidos en el negocio; y ya tengo bastante experiencia de la poca energía con que prebee en estos asuntos. Y por todas las dichas razones, y lo demás que tengan por bien exponer, pidan y supliquen se despache Real Provisión para que supuestos los allanamientos que dejo espresados, y la verdad de quanto ba referido, no permita que salga ningún bracero del Pueblo al trabajo de la siega en tanto que yo no tenga los necesarios para hacer la oportuna y ordinariamnete la de mi senara y mieses... conminando a dicha xunta para que asi lo cumpla... y a los braceros con mayores y más rigurosas penas para que no quebranten el mandato de la Sala, y se puedan de una vez fixar los males indicados, que seguramente crecerán más cada día si la xusticia imbariable de la superioridad no les ataja....”. (A.H.P.V. Pt. 8228, fol. 50, año 1807).

${ }^{988}$ ALMUNIA FERNÁNDEZ, C.: "De la vieja sociedad estamental al triunfo de la "burguesía harinera”, en Valladolid en el siglo XIX. 1985, págs. 27 y ss. 
La resistencia popular convierte al país en un inmenso campo de batalla y Valladolid y su provincia sufren especialmente la avaricia y los excesos de la soldadesca gala. De las afrentas y humillaciones iniciales, el común pasa a la acción directa que trata de responder a cada saqueo, a cada agresión. La guerrilla nace, de esta manera, en esta Espańa desprotegida y humillada, donde pocos colaboran con el gobierno intruso y los más tratan de resistir, cuando no de actuar. Por estos pueblos pronto se empieza a oír hablar de Juan Martín, "El Empecinado", hijo de un labrador de Castrillo de Duero; de Saturnino Abuín, traidor del anterior y nacido en Tordesillas; de Félix de la Fuente, labrador de Nava del Rey, o de Jerónimo Saornil, natural de Calabazas y actuante por estas tierras de Medina y Olmedo. Sus vidas, como las de las partidas que dirigen, integradas en muchos casos por campesinos y jornaleros empobrecidos o afrentados, en algunos casos con delitos pendientes de la justicia, no son nada fáciles, pues, a pesar de contar con el apoyo de las poblaciones, están sometidas siempre al peligro de delaciones y traiciones. Con relación a ello, Saornil manifiesta: " $m i$ habitación, tanto de día como de noche, no ha sido otra que los áridos campos, sin haberme permitido las circunstancias haberme desnudado de mis vestidos una sola noche para descansar" 989.

Sin haberse producido choques de importancia ni matanzas en el espacio estudiado, queda fuera de toda duda el desgarro vivido en estos trágicos ańos que se encadenan, por si fuera poco, con los anteriores de penurias, escasez y hambre. Francisco Moyano, en un poder notarial fechado en 1815, en que trata de recuperar ante el Colector General de Expolios y vacantes del reino cuanto le dejó su hermano el obispo Buenaventura en su testamento, resume brevemente lo que aconteció en estos amargos ańos ${ }^{990}$ :

"Y de este modo llegó el año mil ochocientos ocho, la guerra, trabajos y obstrucción de todo, que es bien notorio, y su duración. Que con esta ocasión y aber abandonado su casa por dos años, fue ella y los contenidos maltratados, saqueado y extrabiado, como se dexa considerar, ya escondido en unos sitios, ya en otros, y siempre con el azar y presura consiguiente, de lo qual a resultado falta de muchos efectos, destrucción de otros, quiebra y desperdicio de otros...”.

El hermano del obispo no refiere sino lo que generalizan los cronistas vallisoletanos. El paso de las tropas francesas dejó un reguero de abusos y rapiña, acentuada por la escasez endémica y la ruina y abandono de los campos. A ello se ha de añadir la falta de brazos para el trabajo, bien porque no faltan quienes se integran en partidas de guerrilla o ejército, bien porque se intentaba escapar de tanta inseguridad. El propio y adinerado regidor había abandonado la villa. De sobra sabe que, al ser su casa y hacienda una de las más lustrosas de la comarca, no faltaría tiempo para que fuera objeto de contribuciones forzosas, amenazas o robos, en unos momentos en que la resistencia se paga con la vida. Pero la ausencia de vecindario, al hilo de los acontecimientos, afecta a todos, incluidas las mujeres. Al final de la guerra se constatan sus efectos. Así se manifiesta en un el testamento de Bernarda García, fechado en 1816, viuda de Gerónimo de Íscar Moyano ${ }^{991}$ :

"Declaro estuve casada legítimamente con dicho Gerónimo de Yscar, de cuyo matrimonio me dejó éste a su muerte por sus hijos y míos a Melchor, Crisóstomo, Simón y Thomasa, y que posteriormente a aquel fallecimiento falleció el Simón, y la Thomasa, en tiempo del gobierno yntruso, se ausentó de esta villa y se ignora su esistencia y paradero, por lo qual a el presente sólo tengo en mi casa y compañía a dichos mis hijos Melchor y Crisóstomo”.

Y si estas ausencias definitivas fueron frecuentes entre el vecindario, su repercusión no iba a ser menor en cosechas y labranzas. El ejemplo, en este caso, lo aporta Lázaro de Tiedra en 1813 como curador de la menor y sobrina carnal Rita Moyano ${ }^{992}$ :

\footnotetext{
${ }^{989}$ Ibídem, pág. 34.

990 A.H.P.V. Pt. 8229, fol. 59.

${ }^{991}$ A.H.P.V. Pt. 8229, fol. 14.

992 Será el vecino labrador Manuel Alonso quien les compre un majuelo de ocho aranzadas al pago del Pinar y alivie sus arruinadas arcas, pero cómo no imaginar la situación de quienes al borde de la ruina nada tenían que ofrecer ni vender.
} 


\begin{abstract}
"Que con el motivo de las actuales y pasadas ocurrencias de la Guerra, continuas y crecidas contribuciones y pedidos, destrucción de pan y vino que se experimentó en el año anterior por las tropas acampadas y transeúntes, experimento la casa de los Padres de mi menor los graves dańos que se pueden considerar, de forma que siendo como es público y notorio una de las más pudientes del Pueblo, ha benido por su desgracia a ser la casa más miserable y pobre de él, sin labranza, ganados, granos, vino y comestibles, y para haver podido cubrir parte de mis barbechos se ha visto en la precisión de buscar en empréstito y para redimirle y continuar en las labores de tierras y viñas, y manutención de la casa, compra de ganados y demás indispensable a su subsistencia, no se ha allado más arbitrio que la enajenación de alguna heredad...”.
\end{abstract}

Entre los documentos consultados se desprende por partes iguales tanto la ruina económica como la desgracia y angustia que vivieron todos. Similar pesadilla padecen las órdenes religiosas. Si sus sedes ubicadas en las capitales provinciales sufren la bárbara guerra hasta ver ocupados y saqueados sus bienes, muchas de sus casas granjas ya no levantan cabeza. El administrador del convento de San Pablo de Valladolid manifiesta, en la relación de bienes dictados con motivo del repartimiento del cupo de la nueva contribución de 1817, que tanto la casa como la bodega "con quarenta y un bastos de cubas y dos cubetos, de los quales en el dia de hoy se hallan útiles solamente siete, y los demás con vastantes desmejoras, como asi bien toda la casa, por las circunstancias ocurridas... "'93.

¡Qué decir del resto de granjas de menor entidad! Es, junto al decaimiento del viñedo en este primer tercio del XIX, el principio del fin. La guerra es una desgracia y una ruina económica para todos ${ }^{994}$. Valladolid es centro de operaciones y lugar de salida y llegada de contingentes de tropas, correos y pequeños destacamentos que van abasteciéndose sobre el terreno a costa de las poblaciones locales. En Serrada no consta que se fijaran acuartelamientos temporales como, por ejemplo, en La Seca, donde, en diciembre de 1808, se aloja en su recién estrenado Ayuntamiento una guarnición francesa, pero las fotografías adjuntas de balas de arcabuz, bayonetas y botones de guerreras militares francesas y españolas de este tiempo, testifican la guerra y saqueos a que se vieron sometidos todas estas poblaciones ${ }^{995}$.

Es difícil concretar la fecha de estos hechos, pero conviene tener en cuenta que, desde la llegada de Napoleón y sus tropas a Tordesillas y Valladolid en 1809, los saqueos franceses y la resistencia popular envenenan tanto los campos como las ciudades ${ }^{996}$. En noviembre de 1809, y fruto de estas tensiones, los franceses saquean Puenteduero, Valdestillas y Viana, "robándolo todo, hasta los vasos sagrados, y derramando las divinas formas".

${ }^{993}$ A.M.S., caja 72, carp. 891.

${ }_{994}$ Años después de la contienda, cuando la iglesia de San Pedro retome en 1817 el pago del censo otorgado en 1772 para finalizar su construcción, se hará observar la falta de liquidez y la escasez de diezmos recabados, prueba fehaciente, tanto de la crítica situación del antiguo impuesto a abolir, como del descenso de productos y cosechas de sus feligreses durante el llamado gobierno intruso: "Desde el qual (se refiere al año 1808) a ocasión de la Guerra, y que entre las causas de estorbo al pago que ella opuso, hubo la principal de haber mermado enormemente sus rendimientos consistentes en Diezmos, y también aber prestado a la villa en los apuros ocho mil reales. Se a atrasado en los réditos de modo que hasta el día d San Juan de junio de mil ochocientos diez y seis, suman los vencidos diez mil ciento beinte y cinco reales; seis mil setecientos cinquenta por cinco años que esta Provincia estubo ocupada por los franceses, y tres mil trescientos setenta y cinco por dos y medio que discurrieron desde que la ebaquaron hasta aquel dia...”.(A.H.P.V. Pt. 8229, Serrada, fol. 38, año 1817).

${ }_{995}$ En concreto, y por el número y forma de los adornos de círculos que diferencian a unos botones de otros, se puede determinar que aquellos que tienen un círculo abierto en la parte superior del botón con un punto son franceses. De ellos el que ostenta el numero 26 pertenece al regimiento del mismo dígito que combatió en la Península formando parte del $3^{\circ}$ y $4^{\circ}$ batallón, pertenecientes al $2^{\circ}$ cuerpo de ejército francés o ejercito de Portugal, combatiente en Orense y Ciudad Rodrigo; el 55 regimiento combatió en la Albufera; el 94, que también formó parte del ejército de Portugal, combatió en Espinosa y Alcalá: y el botón identificado con el número 100 se distinguió en Burgos y Zaragoza. La coincidencia en esta cercana villa, a tiro de piedra de Tordesillas, prueba lo estratégico de este paso y el repliegue o reforzamiento de unos batallones con soldados de otros, conforme obligaban las distintas circunstancias de la guerra. Por otra parte, y como ya se ha expuesto, el botón en el que pone REY, rodeado por un círculo, es del regimiento con este nombre perteneciente al ejército español.

${ }^{996}$ La bayoneta de la imagen, también encontrada en el término de San Martín, rubrica todo menos tranquilidad. Sin pruebas documentales, pero con una bien conservada tradición oral, se relacionan estos hechos y pruebas bélicas con los acaecidos en término de Serrada, al pago del camino del Pinar. Según permanece en la memoria colectiva, el 

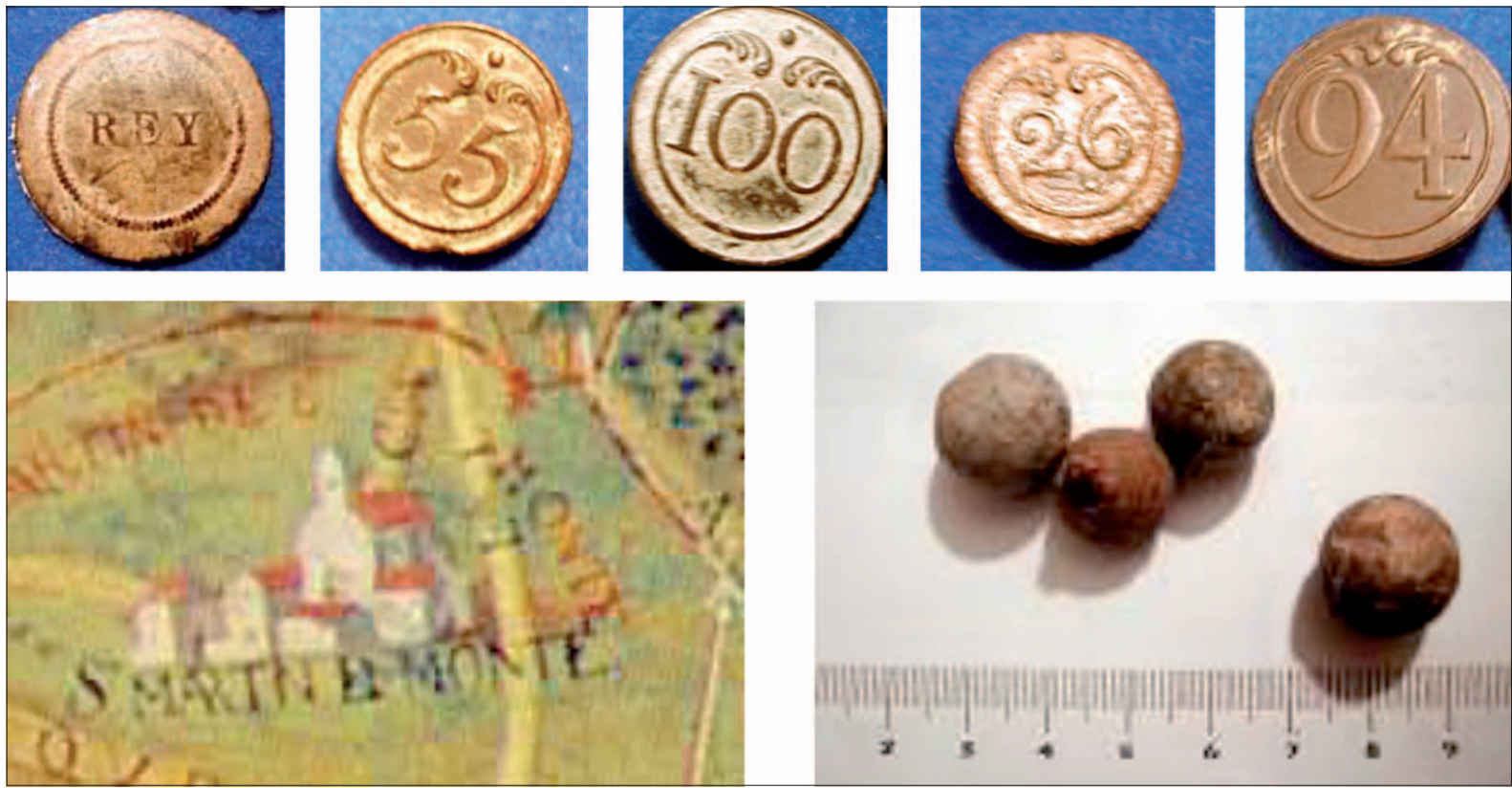

Botones de casacas militares encontrados en el despoblado de San Martín del Monte. Guerra de la Independencia. (Colecciones particulares, arriba). Detalle de la pintura de 1777 de la villa de San Martín (A.R.Ch.V., óleo 10), y balas de arcabuz halladas en el despoblado. (Colecciones particulares, abajo).

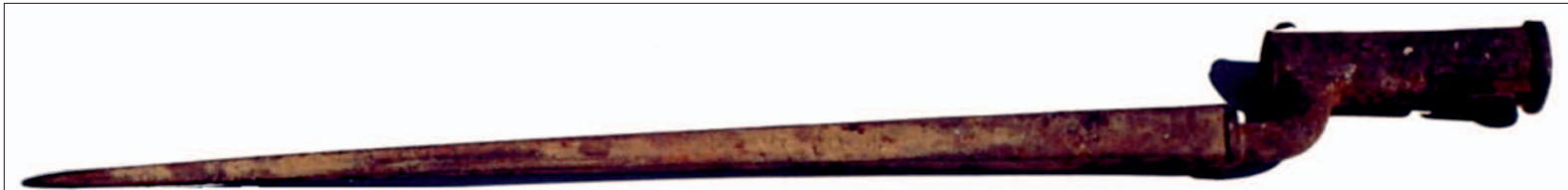

Bayoneta encontrada en el término de San Martín del Monte, (arriba). Base de columna de granito, placa grabada y otros restos del antiguo poblado (abajo).

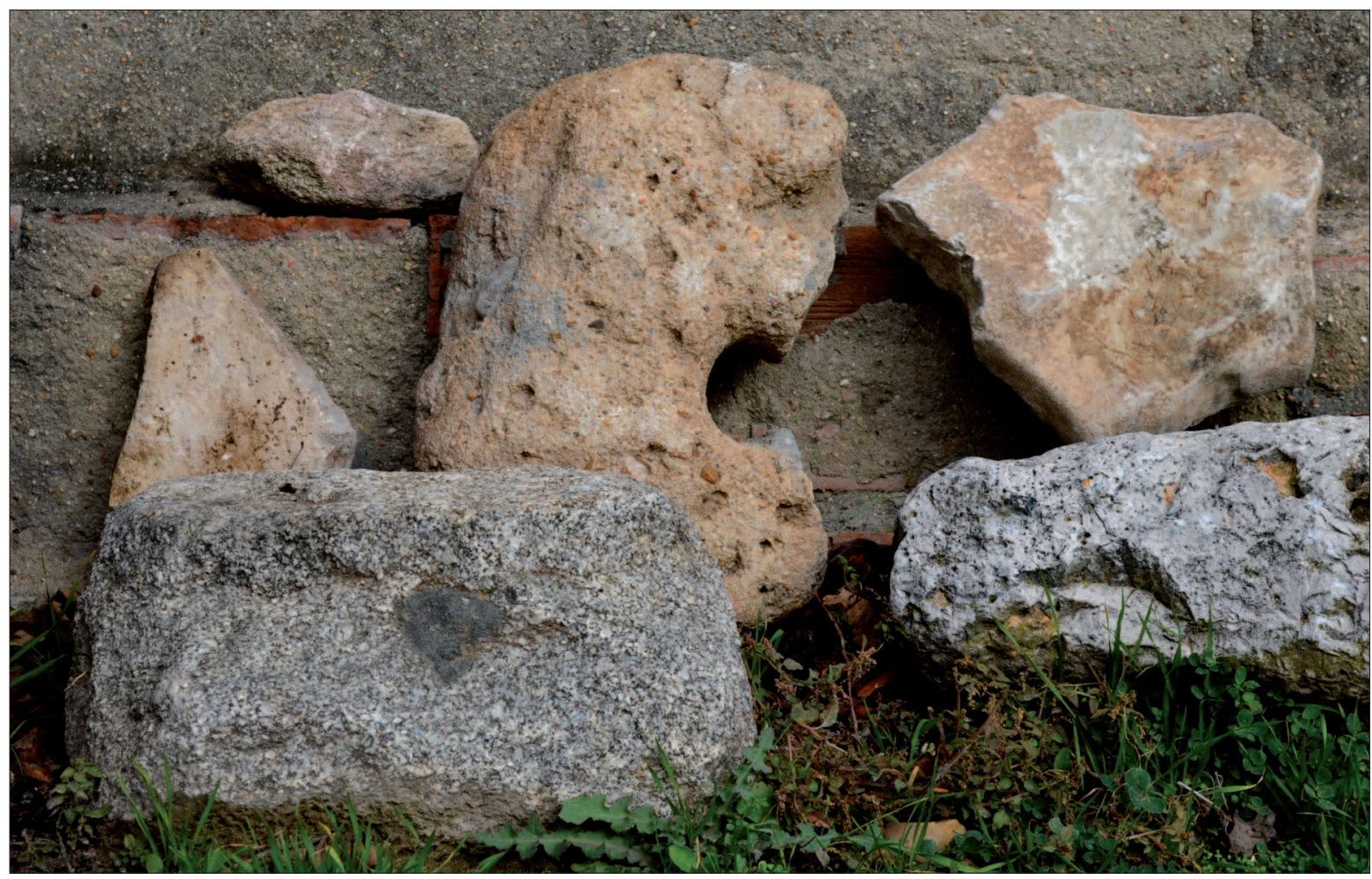

Imagen 81. Restos encontrados en San Martín del Monte correspondientes a la invasión napoleónica y otros materiales del citado despoblado. 
Un año después, la guerrilla campaba a sus anchas a pesar de las condenas ejemplarizantes de la Junta criminal, implacable siempre con los acusados o delatados por colaborador o formar parte de la resistencia. Al ambiente de inseguridad y la miseria que envuelve a buena parte de la población campesina, se unen las "compras" y "servicios" que solicitan las autoridades de ocupación, no siempre satisfechas convenientemente ${ }^{997}$.

No es un hecho aislado en esta comarca, como tampoco lo son las dificultades por las que pasan sus vecinos para satisfacer las demandas francesas de alimentos y abastecimientos para sus tropas. En ocasiones algunas villas elevan súplicas para que se repartan los suministros más equitativamente o, al menos, no se quebranten hasta la ruina los bienes del municipio. Matapozuelos, como Serrada, por pertenecer al partido de Olmedo, está obligado a suministrar a dicha plaza, conjuntamente con los pueblos que forman parte de la jurisdicción. Pero cuando otras guarniciones se asientan en estos pueblos el esfuerzo era difícil de soportar ${ }^{998}$. En ocasiones, a estas exigencias anteceden apercibimientos de posibles castigos, si son incumplidas. A cada lugar o villa, integrada con sus más cercanas en Juntas comarcales, se le asignaba un determinado coeficiente, de acuerdo con número de vecinos, para recabar las aportaciones exigidas. ${ }^{999} \mathrm{La}$ establecida en La Seca, por ejemplo, y que agrupa a varios pueblos vecinos debe hacer frente a la parte correspondiente del reparto que tiene que satisfacer por Medina. Sus integrantes han de acatar rigurosamente el 29 de agosto de 1811 "a que ponga en los almacenes de la ciudad de Valladolid quatro mil cántaras de vino que se piden de las diez mil que se han encargado al Partido de Medina, con barias comunicaciones y castigos"1000.

padre o abuelo de Apolinar Díaz, vecino de Serrada, y antepasado de la familia Hidalgo es uno de los coprotagonistas de los hechos. Señalan los relatos orales cómo varios podadores, estando trabajando las viñas de Manuel Alonso, bisabuelo del señor Valentín Alonso, todos vecinos de Serrada, atacaron a un correo francés del que se derivó la muerte del francés. Posteriormente, señalan los testimonios orales, habría otra agresión a un segundo correo, esta mediante engaño o simulación de socorro y ayuda, pero sin que de ella se derivara muerte alguna.

${ }^{997}$ Es el caso de Thomas Baion Pedrosa, vecino de La Seca, que relata las dificultades surgidas en enero de 1811 por uno de estos contratos llevados a cabo en junio de 1810: "Don Thomas Vaion Pedrosa, vecino de La Seca. Digo que en virtud y mandato de la xusticia y Ayuntamiento de esta villa, en los veinte y uno de junio del año próximo pasado, se me saco un carro y dos caballerías mulares para el servicio de las tropas francesas e hir de carruaje desde la villa de Medina del Campo a la ciudad de Valladolid, y desde esta, cargada de galleta, a la Ciudad Rodrigo. Que en su obedecimiento di dicho carro y mulas con su criado, que habiendo regresado este después de muchos días de ausencia de esta expresada villa, tan solo trajo una mula de las dos que llebo, informando que la otra se habia perniquebrado y muerto a poca distancia de dicha Ciudad Rodrigo, y por lo mismo, como no encontrase otra caballería, le fue forzoso el dejar también el carro, y siendo noticioso de que a a varios vecinos deste pueblo en iguales casos se les avían satisfecho sus respectivos importes... otorgo que doy todo mi poder para que en mi nombre... solicite... la percepción y rezibo de los juntos importes a que asciende el carro y mula...". (A.H.P.V. Pt. 6462, La Seca, fol. 15, año 1811).

${ }^{998}$ El 30 de enero de 1810 Matapozuelos pone de manifiesto las dificultades añadidas por el suministro que ha de hacer a la guarnición que se ha destacado en la ermita de Sieteiglesias, sin olvidar lo mandado a la guarnición de Valdestillas. Los alcaldes ordinarios de la villa manifiestan que respecto a Olmedo ya "se contribuye por esta villa con carruajes, los exija precisamente con arreglo a las pocas yuntas de labor a que a quedado reducida por los continuos serbicios que tiene hecho en este ramo y en los que se han estraviado y perecido muchas de las que habia, teniendo hecho además el servicio de diez y ocho mulas en la última repartición por la Real armada, supliendo por los demás pueblos que no las tenían de tan buena calidad para este serbicio, y algunas de las del Partido y otros agregados a el para el parque de carruajes tiene muchas más yuntas y contribuyen con mucho menos numero de carros..." (A.H.P.V. Pt. 10696. Matapozuelos, fol. 3, año 1810).

${ }^{999}$ En octubre de 1809 las autoridades francesas establecen la constitución de Juntas de Subsistencias que "normalizaran" las confiscaciones militares en los distintos pueblos. Dichas Juntas estaban integradas por los representantes o regidores más destacados de cada villa. Su misión, de acuerdo al vecindario y coeficiente establecido, era cubrir las necesidades de las guarniciones militares más cercanas. En Tordesillas, Olmedo y Medina del Campo no faltaban tropas estacionadas, estando la de Medina compuesta por 900 hombres. Al margen de satisfacer sus necesidades, habrán también de cubrir aquellos avituamientos que necesiten los destacamentos franceses instalados temporalmente en Matapozuelos, La Seca,Valdestillas o Ventosa. Todo ello sin menoscabo de lo que pudiera exigirse del de Valladolid que, como es sabido, era donde se concentraba el grueso del ejército napoleónico en nuestra provincia.

${ }^{1000}$ A.H.P.V. Pt 6462. La Seca, fol. 253, año 1811. 
Estos repartimientos se regulan por los precios que rigen en los mercados, aunque, como antes se ha dejado entrever, abundan los casos de impago o dilaciones en el mismo. A esto se deben ańadir las noticias luctuosas o trágicas que sumen a todos en el dolor. El dos de agosto de 1811, pocos días antes de la anterior comunicación, por ejemplo, se había ejecutado "a un sacerdote, exreligioso del orden de San Francisco, natural de la villa de La Seca, por haberlo cogido de capellán en la partida del comandante Saornil"1001. Faltan las palabras y sobra el odio al francés y a su gobierno. En este verano aún no se había olvidado el miedo que pasaron los vecinos de Valdestillas en la noche del 3 de enero, cuando soldados franceses que iban a pernoctar arrancaron el techo de una casa para hacer lumbre disparando sobre sus inquilinos ${ }^{1002}$.

Aún queda el final y las hambrunas de 1812. El camino de Medina a Valladolid por La Seca, Serrada, San Martín o Valdestillas sigue tan frecuentado de tropa francesa como peligroso de recorrer. El hambre se generaliza por toda la provincia. A los excesos aludidos se suman ahora la indigencia y la preocupación por no ser robado. Con todo, las tropas francesas siguen haciendo de las suyas a tenor de las incertidumbres por las que pasan los vecinos de La Seca en febrero de 1812, poco tiempo antes del acuartelamiento de un sector del ejército de Wellington, previo a la victoria hispanoinglesa de Arapiles ${ }^{1003}$ :

Los campesinos y concejos también sienten menguadas sus paneras cuando soldados o combatientes de partidas espańolas satisfacen sus necesidades sobre el terreno. Ya se ha indicado que el doce fue un ańo de escasez de alimentos y guerra social entre patriotas que regresan y afrancesados que huyen, sin olvidar los movimientos de tropa de uno y otro signo. Valladolid es final de Corte y camino de retirada y estos pueblos ven intensificar la presión de la resistencia. El propio Jerónimo Saornil y Moraleja, al mando de sus huestes y titulado coronel del escuadrón de caballería, se aloja en Valdestillas el 5 de julio de 1812. Es posible que participara en la expulsión temporal de los franceses de Valladolid, primera liberación de la mano de Wellington y Marquínez, aunque la alegría durara bien poco, pues los franceses vuelven a ocupar la capital el 14 de agosto ${ }^{1004}$. Sea como fuere, el caso es que de la presencia de las tropas se derivan no pocas diferencias vecinales ${ }^{1005}$.

${ }^{1001}$ ALMUNIIA FERNÁNDEZ, C.: ob. cit., pág. 103.

1002 SÁNCHEZ FERNÁNDEZ, J.: ob. cit., pág. 50.

${ }^{1003}$ Manifestaba su municipalidad en escritura de poder a favor de Pedro de Cuena: "Que por las notorias ocurrencias que a sucedido a este pueblo con motibo de crecido número de tropa francesa que han permanecido en él, hace pocos días que fuimos creados por miembros de dicha municipalidad, y entre ellos Don Manuel de Pedrosa Bayón, primer regidor, con el objeto de que este había de desempeñar su encargo con la puntualidad que en las actuales circunstancias se requiere. Dicho Don Manuel de Pedrosa, creiendo que en el concurrían, ha salido tan al contrario que se halla este vecindario disciplente de sus hechos y temeroso de que por su ignorancia se le sigan yrremediables perjuicios. Y para precaverles según desea, otorgan que dan todo su poder cumplido... a Don Juan Pedro de Cuena... para que en su nombre.... solicite ante el seńor Intendente... el que el referido Don Manuel cese en la función de su empleo de tal primer regidor y que su lugar se nombre otro sugeto experto y capaz de desempeñar el consavido empleo de tal primer regidor para por este medio evitar los males que puedan sobrevenir a este vecindario que tan afligido se halla”. (A.H.P.V. Pt. 6463, fol. 3).

${ }^{1004}$ ALMUIÑA FERNÁNDEZ, C.: ob. cit., pág. 109.

${ }^{1005}$ En ocasiones, tras su provisión y abastecimiento, los vecinos no se ponen de acuerdo a la hora de contribuir con los repartimientos. Un ejemplo es el del escribano Diego de Rojas, principal agraviado tras haberse quedado sin paja y cebada, quien pone el asunto en manos de la justicia. Los precios de los productos están por las nubes en este ańo de hambrunas y cada fanega vale un potosí. Merece la pena destacar un fragmento del poder otorgado para testimoniar la presencia del famoso guerrillero de Calabazas y, al tiempo, detallar el coste de producción del cereal. A fe que al escribano no se le escapaba ni un maravedí: "Sépase por esta publica escritura como yo, Don Diego de Rojas, vezino desta villa de Valdestillas, escribano del Numero y perpetuo del Ayuntamiento della, digo que en cinco de julio pasado deste año, abiéndose aloxado en la misma el Señor Coronel Don Gerónimo Saornil y Moralexa con el esquadrón de caballería de su comando, intimo a la justicia actual franquease las raciones competentes que de todas clases necesitaba para la subsistencia de su tropa, pero aquella, que se veía desprevenida de todo, ni hacer diligencias para prebenirlas, dio margen se extendiesen los soldados por 
Las propias Juntas de las distintas villas, abastecedoras de los distintos cuerpos de ejército, ponen especial celo en guardar los almacenes y vigilar los repartimientos. La Junta, sita en Valdestillas y que agrupaba a Matapozuelos, Ventosa y Villalba de Adaja, ya se había reunido el 20 de febrero del citado año con motivo de la presencia de "una guarnición de tropas imperiales acantonadas en ella" 1006 . Todos los pueblos resisten contribuciones y la misma guerra, pero apuntan hasta el último real o gallina suministrada a las tropas. La lista de aportes que hace Serrada el día 7 de mayo de 1813 es un ejemplo ${ }^{1007}$ :

“...En la mañana deste día habiendo llegado aquí de Matapozuelos como 150 soldados de a caballo del regimiento de Vasanquiz, se alojaron y pidieron víberes para unos días a 212 raciones diarias; se tomaron de la Pepa la panadera de Pozaldez 23 panes..., se recogieron y tomaron a Bernardo Montes en dos veces y han pagado 64 panes a 23 quartos... Se recogieron en el salón para dar ración 6 fanegas de cebada, la fanega de Simona García y las quatro fanegas y media de cebada de la mesonera Jerónima... Se suministró para la comida y cena del Sr. Coronel dos gallinas de Manuel Leonardo a 20 reales cada una; doce huebos recogidos a 6 quartos; un queso de libra y media de Bernardo Ribera, dos jamones traídos de la Seca de María Paz que pesaron 23 libras... Suma todo lo suministrado y gastado de este día y de que no dieron fondos la cantidad de tres mil seiscientos quarenta y cinco reales, veinte maravedíes. Serrada, 7 de mayo de 1813. Manuel Alonso (rubrica) Colomera (rubrica)".

Otra cosa será el cobro de tales aportaciones cuando el conflicto finalice. Para los quince vecinos de San Martín del Monte las contribuciones forzosas y la devastación francesa habían contribuido a escribir el final de su destino. Gabriel Navarro, Isidoro Milla y Juan Antonio Hinojal, únicos vecinos en estas fechas, hicieron dejación del útil aprovechamiento de los dos foros que tenían sobre todo el término, a favor del Monasterio de Santa Clara. Se sintieron obligados "porque arruinadas todas las casas de dicha villa en la guerra de la independencia, se despobló; y los tres únicos vecinos la abandonaron y se trasladaron a Serrada, hallándose imposibilitados de poder levantar las casas y pagar los muchos atrasos que debian por los indicados réditos"1008.

La situación jurídica se presentaba óptima para el monasterio. Los tres vecinos suplicaron que les admitiesen la citada dejación, con la condición de perdonarles todos los atrasos que debían y las consiguientes ejecuciones en curso para su cobro, además de permitirles el aprovechamiento del

donde estaban las mieses, y habiendo llegado a la mía que hera la primera con quien tocaron, en donde tenía una parba de cebada trillada, y en disposición de sacar el grano, producto de obrada y media de tierra de primera calidad, que para sembrarla supli doscientos y setenta reales por seis fanegas de cevada; doscientos y diez de siete huebras para alzar la tierra, abrirla y sembrarla; ochenta y ocho reales del gasto que hicieron en medio dia que la segaron diez hombres; noventa reales de tres huebras gastadas en llevarlo a la hera y trillarlo. Que todo importan seiscientos cinquenta y ocho reales, sin contar con la renta y diezmo correspondiente que hasta ahora no he podido pagar por no haverme quitado nada de ello...". No se reproduce el texto completo para no perderse entre tasaciones, repartos y diferencias internas. Mal día tuvo el escribano de Valdestillas aquel verano de 1812, pero en pocas ocasiones se ha encontrado un narración tan precisa del gasto y beneficio derivado de la labranza de la tierra. De sobra sabe Diego de Rojas el alto nivel de los precios en aquel año. Menos mal que le quedaban las retribuciones de la escribanía. La cebada, si la cobró, es fácil que se quedase entre los resquicios de la justicia. Lo cierto es que justo un año después, en julio de 1813, Valladolid está cercada por guerrilleros, soldados y hambrunas. La guerra toca a su fin en medio de un desabastecimiento y alza de precios alarmante y generalizado. (A.H.P.V. Pt. 11892, Valdestillas, Diego de Rojas, fol.14, año 1812).

1006 Tras los preceptivos bandos y avisos y para la buena administración y provisión de las tropas, se insta nombrar "una persona quien exerciendo las funciones de Guarda Almacén, recibiese de dichos pueblos las raciones detalladas a cada pueblo diariamente para dicha guarnición, y que para esta falta no padeciese ningún detrimento el Real servicio... a Agustín Ynaraja, becino de la expresada villa de Bentosa, le nombramos por tal Guarda Almacén para que permaneciendo en esta dicha villa de Valdestillas, reciba todas las raciones que bengan para la subsistencia de dicha guarnición, las distribuia y nos de buena quenta de su lexitima ynversión, pena de responsabilidad...”. (A.H.P.V. Pt. 11893, Valdestillas, fol. 7, año 1813).

${ }^{1007}$ A.F.A.M. (s/c).

${ }^{1008}$ Dicha dejación se lleva a cabo el 30 de enero de 1817, por escritura ante Pedro Ybero, escribano de Tordesillas, A.F.A.M. (s/c) 
vuelo de los majuelos plantados en dicho término, "habiendo de hacer cada uno de sus poseedores las escrituras forales correspondientes y pagar sus réditos o canon"1009. De esta manera los dos dominios, el útil y el directo de San Martín del Monte y sus términos, dehesas, prados y eriales, quedaban consolidados como único y absoluto en la citada institución monástica. Ninguna puerta volverá a abrirse en el citado lugar.

\section{c. Las consecuencias del desastre. El reinado de Fernando VII}

En junio de 1813, el general Castaños entra en Valladolid. El rey José y su séquito habían abandonado la ciudad el dos de junio. Los franceses, en su retirada, volaron el puente de Valdestillas. La guerra en estos pueblos había terminando, pero la paz en España tardará en llegar. El país, como en tantas ocasiones, hurga en sus propias heridas durante largo tiempo. Liberales, serviles y afrancesados siguen caminos opuestos. Fernando VII añade más leña al fuego, evitando tender puentes y apostando por los absolutistas más intransigentes. Hasta que "El Deseado" monarca sea liberado (Valençay, diciembre de 1813) y desapruebe lo legislado en Cádiz, pasan unos meses en los que las distintas instituciones locales y provinciales se afanan en el restablecimiento de la legalidad constitucional, emanada de la constitución de 1812. Tampoco esto será posible.

\section{- La participación de la familia Moyano Rodríguez en la restauración política}

En el nuevo contexto político, la familia Moyano Rodríguez juega un importante papel en el ámbito provincial. En la convocatoria para Cortes extraordinarias que deben de abrirse en octubre, le corresponden a Valladolid cuatro diputados y un suplente. La reunión de la primera Junta lleva fecha de 1 de agosto de 1813. Tras la preceptiva misa solemne en la catedral, salen electos para visar y censurar los poderes de todos los diputados, los señores Conde de Adanero, diputado del partido de Medina, Francisco Moyano, del de Olmedo y Miguel Biñe, presbítero del de Portillo. El 12 de agosto de 1813, tras no pocos debates, se procede al nombramiento de los Diputados a las referidas Cortes Extraordinarias. Después de aprobar los preceptivos poderes, se celebran "quince votaciones y cinco sorteos para el nombramiento de los cuatro Diputados y un suplente" que, como se ha dicho, correspondían a Valladolid. En el último sorteo entrará Tomas Moyano Rodríguez, natural de Serrada, exrector de la universidad de Valladolid y exconsejero del Consejo de Castilla. Dado lo eminente de la personalidad de este serradense, nombrado por Fernando VII ministro de Gracia y Justicia entre noviembre de 1814 y enero de 1816 , se deja a Basanta el relato de las reñidas votaciones en las notas al pie ${ }^{1010}$.

${ }^{1009}$ Ibídem.

1010 " 1 SORTEO PARA $1{ }^{\circ}$ DIPUTADO. = El Sr. D. Evaristo Pérez de Castro, natural de esta ciudad de Valladolid, suplente de esta probincia en las Cortes Generales anteriores. José Adánez Ortuña, cura párroco de la de Santiago de esta ciudad y el Sr D. Mateo Díaz de la Peña, cura párroco de Tordehumos. Salió electo $1^{\circ}$ Diputado el Dr D. José Adánez.

$2^{\circ}$ SORTEO PARA $2^{\circ}$ DIPUTADO. = En el $2^{\circ}$ sorteo entraron los Sres. D. Evaristo Pérez de Castro, D. Félix Calleja, natural de Medina del Campo, Virrey de Méjico y Dr D. Thomas Moyano, Consejero que fue en el extinguido de castilla, natural de la villa de Serrada y salió electo el Sr D. Evaristo Pérez de Castro.

$3^{\circ}$ SORTEO PARA $3^{\circ}$ DIPUTADO. = Entraron en suerte los Sres. D. Félix Calleja, D. Thomas Moyano y D. José Thomás Flores y salió electo D. José Thomás Flores, vecino de Morales de la Reyna y Diputado elector del Partido de Rioseco.

$4^{\circ}$ SORTEO PARA $4^{\circ}$ DIPUTADO. = Entraron en suerte los Sres. D. Félix Calleja, D. Thomas Moyano y D. José Ramírez Cid, vecino de Aguilar de Campos y salió electo el Sr D. Félix calleja, natural de Medina, Virrey de Méjico que hoy se halla en Cádiz.

$5^{\circ}$ SORTEO PARA SUPLENTE. = Entraron en suerte los Sres. D. Thomas Moyano, D. José Ramírez Cidy D. Francisco Antonio Mantilla, vecino de Almanza y salió electo por suplente el Sr D. Thomas Moyano."

Este autor relata cómo, en los solemnes actos en que procesionan a cantar el Te-Deum a la Catedral, una vez concluidas las votaciones, no se encuentra D. Tomas Moyano, pues únicamente acompaña al Obispo y al Jefe politico e Intendente de la ciudad el diputado elegido D. José Thomas Flores. 
Entretanto, los vecinos de Serrada están más pendientes de sus cosechas de pan y de la salida de su vino que de la agitada vida política del país o de la carrera política de sus distinguidos vecinos. Ello no es óbice para que todos los acontecimientos provinciales o nacionales tuvieran su eco en la localidad. Las recomendaciones al orden que llegaban mediante circulares o los pasquines defendiendo unas u otras ideologías los inclinan en uno u otro sentido. El represivo reinado de Fernando VII abona incluso el campo para lanzarse acusaciones sobre la mayor o menor simpatía que unos u otros tuvieron hacia la Constitución del 12, como una manera de ganarse a la justicia. El pleito entre el escribano Manuel Demetrio de Colomera y el concejo de Serrada es revelador en este sentido ${ }^{1011}$. Por si esta vinculación de Colomera fuera poco, el concejo también salpica a su familia ${ }^{1012}$. Hay que pensar que el concejo sólo trataba de apartar al escribano de la villa, porque tamańas acusaciones, en estos años, con Fernando VII volviendo a perseguir liberales, le hubieran llevado al destierro o al pelotón de fusilamiento.

Similares diferencias entre unos y otros se constatan unos años más tarde, cercano el fin de la ominosa década (1823-1833), cuando las partidas de realistas, defensores del absolutismo, chocan con los partidarios del constitucionalismo. Serrada también vive los ecos de estas diferencias políticas entre sus vecinos, que se saldan con heridos y encarcelados. Al parecer, entre los partidarios de unos y otros bastaba mencionar determinadas palabras o lemas para provocar un altercado, sin contar con aquellos integrantes de partidas realistas que, en estos años, se sienten respaldados por la autoridad y tienen facilidad para apretar el gatillo ${ }^{1013}$. Lo peor de los hechos, al igual que lo que sucede en tantos otros lugares, es que no será un caso aislado ${ }^{1014}$. La sangre no llega al río, pero lo expuesto al pie es revelador de las tensiones que se viven en la villa en estos últimos y aciagos años del tortuoso reinado de Fernando VII ${ }^{1015}$.

Aún faltaban las elecciones de Diputados a Cortes ordinarias. Nombrados los que corresponden a la ciudad, el 30 de agosto de 1813 se procede a elegir a aquellos que representan a la provincia. Como en el anterior proceso, se forma una Junta preparatoria donde está nuevamente presente el hermano del recién elegido diputado Moyano. La formaban "los señores D. José Berdones, canónigo de esta Santa Iglesia, Diputado del Partido de Valladolid; D. Francisco Moyano, del de Olmedo y D. Alonso González de la puebla, de Sanabria". Se vuelve a dejar a Basanta la narración del proceso electoral: "Concluida que fue la Misa los mismos Señores se regresaron a las Salas consistoriales donde formándose la Junta se pregunto por l Sr. Presidente si habia soborno o cohecho para que la elección cayese en personas determinadas y contestando que no se empezó la votación secreta y cada uno de por si de los Señores Electores y salieron en el primer escrutinio el Dr. D. Gabriel Ugarte y Alegría, Canónigo Penitenciario de esta Santa Iglesia, con catorce votos y el Licdo. D. Francisco Cortes, Canónigo Lectoral de la Santa Iglesia de Palencia con un voto: En el segdo. El Sr. Dr. D. Thomas Moyano, Exconsegero de Castilla natural de la villa de Serrada con catorce votos y el Sr. D. Gregorio Rodríguez, Mariscal de Campo de los Exércitos Nacionales y Gobernador de la Plaza de Badajoz, natural de Rueda con uno... Y quedaron electos por Diputados para esta Probincia para las Cortes generales ordinarias dichos Señores Sr. Ugarte, Sr. Moyano, Sr. González y por Suplente el dicho Sr. Ramírez, que es el numero que corresponde a esta Probincia por su población según el censo del año de 1797 y un Diputado por cada setenta mil almas...".

En la posterior elección a la Junta provincial, figura como candidato Francisco Moyano representando a Olmedo, pero no alcanzará el número de votos necesario para salir electo. Valladolid y sus pueblos habían festejado con júbilo tanto la salida de los franceses como la llegada de la normalidad constitucional. Sin embargo, será por poco tiempo. La derrota definitiva de Napoleón en Europa acelera el regreso de Fernando VII, (marzo de 1814) y con él la ruptura del nuevo marco legislativo en el que los diputados de Valladolid se iban a estrenarse cree que ni siquiera el serradense electo habría tenido tiempo de marchar a Cádiz. El golpe de estado que dirigirá el propio rey acabó con las reglas de juego que los españoles se dieron en dicha ciudad. España volvía, como buena parte de Europa, sus ojos al pasado. (Basanta, pág. 31).

${ }^{1011}$ El primero, titular de la escribanía desde 1793, reclama sea repuesto en el cargo en 1823, finalizado el Trienio Liberal y argumentando, en palabras de su procurador, que su apartamiento fue debido a que "se resistió al ejercicio en el Sistema Constitucional por ser muy desafecto a el...”. Versión totalmente distinta es la que exponen los representantes del concejo de Serrada, quienes, dejando aparte las numerosas denuncias sobre Colomera por su falta continuada de buen hacer, no desaprovechan la ocasión de insistir en lo político una vez caído el gobierno liberal y abjurada la Constitución por el rey. (A.R.Ch.V. Pleitos Civiles, Varela (OLV), caja 2883.7).

1012 Manifiesta "que habiendo sido nombrado ministro de Estado el año de ochocientos veinte Don Evaristo Pérez de Castro, su primo hermano, fue su celebridad de este echo notoria y exaltada, lo mismo que no haber perdonado diligencia ni medio para que le acomodara en algún destino emanante del sistema". O el caso de su hijo que "fue nombrado Miliciano de la Ley, y como en este lugar no hubiese ningun Voluntario de alisto tal con anuencia del padre en la villa de Simancas...". 
Sin embargo, desde la marcha de los franceses, la máxima preocupación de todos era volver a la normalidad de sus hábitos y trabajos. Cuestión esta nada fácil, dado el estado de ruina, abandono y deudas en que se encuentran todos, desde el más humilde bracero al más pudiente hacendado. Se ha apuntado la constancia documental en que se testifica el robo y saqueo de la casa del obispo. Es muy posible que otras muchas, y sobre todo las paneras de las casas conventuales y las del marqués de Torreblanca, así como cubas y bodegas diversas, sufrieran requisas forzosas. Pero no son sólo ellos. Como decimos, el estamento eclesiástico había sido igualmente profanado. Las arcas estaban vacías y había que recomponerlas. Una prueba de ello se encuentra en el escrito de la abadesa de la comunidad de Nuestra Señora de Santa Brígida de Valladolid, quien, dada la necesidad en que se halla el monasterio y "para el pago de una deuda que urge y gastos de bendimia", autoriza en 1813 la venta de un majuelo sito en la villa de Serrada, en término de Villanueva, "de cabida de cinco aranzadas"1016.

La iglesia de San Pedro y su fábrica también acusan el golpe. En líneas anteriores se aludía a su "grande necesidad y sin arbitrio" en que se encontraba para hacer frente al pago del censo contraído con la Universidad de Valladolid. La falta de aportaciones diezmales y préstamos al concejo durante la guerra la dejaron al descubierto ${ }^{1017}$. De estos tiempos de crisis y del posterior fenómeno desamortizador sale una nueva hornada de hacendados, que, en ocasiones, nada tendrá que ver con los pueblos donde radican sus propiedades. Por el contrario, otras pudientes y distinguidas familias quedan sumidas en la mayor postración. La guerra y la posterior revolución burguesa hacen a unos más ricos

${ }^{1013}$ De hecho, el 14 de noviembre de 1827 se otorga fianza por parte de Thomas Lavajo, "vecino y cosechero de vino de esta villa”, en relación con la causa criminal formada por el señor alcalde Tomas Román como encargado de la policía, "contra Felipe de Yscar, vecino de esta referida villa, sobre haber entrado en disputa con un voluntario realista y haber vertido públicamente la espresión de que antes de ocho días no habian de ser realistas, la cual tubo principio a las ocho de la mañana del día cinco del corriente mes por parte o queja dada por Saturnino Rico, uno de los voluntarios realistas, y Laecano Román, su comandante... "La testificación de los presentes, certificando la expresión en plaza pública, parece evidenciar, según el criterio de la autoridad, "los indicios que tiene de subversiba que cualquiera que la oye no sabe que sentido darla en las actuales circunstancias, teniéndose presentes las ordenes reserbadas que se han comunicado hace pocos dias con el objeto de contener las ideas de los rebolucionarios enemigos del altar y el trono..." (A.H.P.V. Pt. 8230, fol. 69 y ss., año 1827).

${ }^{1014}$ El 29 de diciembre del mismo año se encuentra otra solicitud de salir en fianza carcelera por estos asuntos, pero esta vez con hechos más graves. Simón Alonso otorga fianza para que salga de la carcelería que guarda en su casa Lorenzo Rodríguez, también vecino de Serrada. El sumario de los hechos que se citan en el registro notarial resume las divergencias políticas que existían entre el vecindario: "Que ante los dos Señores Alcaldes de ella y por mi testimonio pasa y pende causa criminal formada del Real oficio de Justicia contra Paulino Alonso, mozo soltero, natural de esta villa sobre desobediencia a la Justicia y ofensas hechas a la Real Jurisdicción con palabras obscenas... Y al practicar en la noche del siguiente dieciocho la segunda diligencia en busca del dicho Paulino con el auxilio de el comandante y realistas por lo ocurrido a el hirle a prender y haber sido herido de un valazo que le disparo uno de los voluntarios y haberse proferido grandes voces alarmantes y ofensivas a dicho Señor Alcalde Tomas Román e indibiduos del tercio de voluntarios realistas y con ellas proferido las espresiones ya le mataron; ya está aqui muerto; matarlos a todos, y a estos picaros realistas judios, y a este picaro Alcalde, con otras semejantes se formó como incidente pieza segunda, y tomada que fue declaración a dicho herido Paulino Alonso, prebio reconocimiento por el médico y cirujano...".

${ }^{1015}$ Los nuevos autos llevaron a prisión a Gregorio Román, Deogracias y Juan Antonio Ynojal, Ramón Román, Pascual Alonso e Isidro Matesanz. En la escritura de fianza, como en otra posterior otorgada por Gilberto Juárez a favor de Desgracias Ynojal, se hace mención a la declaración de Estéfana García quien, conjuntamente con Sebastiana Aparicio, guardaba en su propia casa la carcelería de los acusados. En las declaraciones indagatorias, señala la dicha Estéfana que "viniéndose para su casa se encontró en medio de la calle que bajaba de la suya, a la vuelta, con Lorenzo Rodríguez, quien la dijo: Tía Estéfana, callar y obrar, que a estos majos se les tira un balazo". (Ibídem, fol. 90-91).

1016 A.H.P.V. Pt. 8229, fol. 35.

1017 El 23 de junio de 1817, Antonio Moyano, mayordomo de su fábrica, expone la solicitud para la rebaja en los 6.750 reales de los réditos vencidos durante la contienda y que no han podido ser reintegrados. Otorga poder para que la justicia "an de suspender la dicha ejecución... o en otro caso que se la conceda moratoria por tres años" De poco valdrían tales súplicas. En septiembre de 1819, se venderá judicialmente "un majuelo, titulado de San Pedro, término de Serrada, de cabida de 2.201 cepas vivas,... en precio y cuantía de 11.010 reales”, como pago a la Real Universidad en relación al censo aludido. (A.H.P.V. Pt. 8229, Serrada, fol. 44, año 1819). 
que a otros. Es el caso del mayorazgo de los Vega de Tordesillas que extiende sus propiedades, entre otros pagos, por los términos de La Moya y Valdestillas. En junio de 1819, Dońa Josefa de Vega y Contreras otorga poder a D. Manuel Pescador, agente en los Reales Concejos, para conseguir facultad para la venta de bienes de su mayorazgo. Sus palabras son tan elocuentes que bien merecen ser reproducidas $^{1018}$ :

\begin{abstract}
"Dońa Josefa de Vega y Contreras... como poseedora del maiorazgo fundado por D. Hernando de vega, que fue del orden de Santiago... en virtud de posesión judicial que del tomo mediante haber recaído en mi, por fin y muerte de D. Manuel Pasqual de Vega y Salcedo, mi padre, quien le dejo y a su casa con crecidos empeños dimanados de los acontecimientos de la próxima pasada guerra con la Francia, que a dicho mi padre, por haber sido uno de los fidelísimos vasallos de S.M. le causaron superiores extorsiones, pues en el largo tiempo que permaneció el ejército francés en esta villa hicieron en su casa diferentes saqueos que le precisaron ausentarse de ella, abandonándola y todos sus efectos, como asimismo haber tenido que satisfacer muchas tiránicas contribuciones que le impusieron y exigieron, sin tener de donde cómodamente poderlas pagar."
\end{abstract}

Josefa de Vega sigue lamentando no solo de lo empeñadísimo que está el linaje familiar, sino también de la pérdida de cosechas que impiden reparar tan lamentable situación. Testifica incluso "no tener lo suficiente ni aun con mucho para mantenerme junto con Doña Teresa Sanz... mi hija unica..." y que "imposibilita la colocación de la referida mi hija", por lo que se plantea y otorga poder para que "se vendan y enajenen algunas fincas de las amaiorazgadas"1019. De hecho, aun después de muchos ańos, la guerra de la independencia sigue mostrando las secuelas del desastre. El propio Ayuntamiento de Serrada no se resigna a dar por perdidas las contribuciones y pagos realizados durante la contienda ${ }^{1020}$.

La guerra, en fin, se llevó cuantos pocos ahorros tenían unos u otros, dejando a muchas familias sin ingresos y en el mayor de los desamparos. Es de suponer que muchas regresan a su villa, reencontrándose con los suyos, con la azada, la yunta o la búsqueda de un amo a quien servir en aquel verano de 1813 . Una nueva campańa de siega inicia el retorno a la vida cotidiana ${ }^{1021}$.

1018 A.H.P.V. Pt. 5647, Tordesillas, Raimundo González, fol. 8, año 1819.

${ }^{1019}$ En relación con ello y debido a que muchas de sus propiedades en término de la Moya están sujetas a censo, la situación es compleja, dada la política de redención. De hecho, en septiembre de 1824, finalizado ya el trienio liberal, el vecino y hacendado de Serrada D. Francisco Moyano otorga poder sustitutorio en relación "a la devolución de 18.000 reales que le hizo en octubre de 1821 de cierto canon enfitéutico que ella gozaba (por Doña Josefa de Vega y Contreras) por unas tierras de su maiorazgo en término de la villa de Valdestillas y Despoblado de la Moya, que su difunto padre dio en censo perpetuo a D. Francisco Moyano, otorgante, lo que se ha declarado nulo por las últimas reales órdenes". (A.H.P.V. Pt. 8229, fol. 194, ańo 1824).

${ }^{1020}$ En fecha de 16 de mayo de 1845 se conserva un acuerdo municipal en que se manifiesta que "estando por liquidar las raciones y pedidos que esta precitada villa suministro a las tropas en tiempo de la Guerra de la Independencia y aun después, cuyos recibos fueron presentados al debido tiempo en las oficinas de la capital que lo es de la ciudad de Valladolid", se otorga poder a D. Luis de Rojas, representante de los hacendados forasteros y residente en la ciudad, para que obre en las instituciones de la capital a fin de "conseguir la liquidación y el abono de las cantidades a que asciende y haya y practique ante las autoridades y tribunales y oficinas competentes... las solicitudes y gestiones que conduzcan..." a la satisfacción de dicha liquidación. (A.M.S. Acuerdos de Ayuntamiento, fol., 11-12, año 1845).

1021 Se carece de documentación sobre aquellos que pudieron participar en las partidas de guerrilleros o encuadrados en los distintos cuerpos de ejército. Únicamente se ha encontrado en un testamento, fechado el 13 de enero de 1821 , que Florencio Ynojal, vecino de Serrada, manifiesta ser, en esta fecha, teniente agregado en el regimiento de Caballería del Príncipe, retirado en clase de disperso en Serrada. Este vecino, casado con Juliana Martínez, sin hijos, es posible que, por su edad y condición, participara en la contienda, pero, ante la ausencia de documentación fehaciente, no se puede afirmar con rotundidad. (A.H.P.V. Pt. 8229, Serrada, fol. 4, año 1821). 


\section{La pervivencia de estructuras precapitalistas en el primer tercio del siglo XIX. El mundo campesino al final del Antiguo Régimen en Serrada}

Por todos es sabida la importancia del siglo XIX como tiempo de cambio a todos los niveles. La radiografía de Castilla que deja Ensenada a mediados del XVIII pierde buena parte de su esencia. A pesar de la involución fernandina, se constatan elementos de no retorno. Un ejemplo es el pago del diezmo, que representaba una importantísima detracción de rentas a los cultivadores, que fue progresivamente abandonado. A partir de la muerte del rey en 1833, se inicia una obra legislativa de desmantelamiento definitivo del orden anterior y cuyo exponente máximo es la obra desamortizadora. A las viejas inercias y poderes anteriores se suman, al margen de la hecatombe que representa la invasión, las periódicas crisis de cosechas y precios que sumen a las sociedades rurales nuevamente al borde del colapso. La comarca medinense, en este primer tercio de siglo, se encuentra en una fase preindustrial y llena de inercias retardadoras de lo que será el naciente capitalismo agrario. Un ejemplo es el del marqués de Torreblanca y Falces, señor de Serrada y principal poseedor de su término y jurisdicción. Tan pronto marchan los franceses, inicia el reordenamiento de sus arrendamientos en la villa ${ }^{1022}$. El pago de deudas y el retorno de cuantos vecinos e instituciones permanecen ajenos durante la guerra testifica también el retorno a la "normalidad". La vida campesina se afana nuevamente en seguir haciendo producir a la tierra las cosechas de siempre con las técnicas de siempre. Los remates por parte de los vecinos de tabernas, abacerías o alcabalas así como las compras y las ventas siguen sirviendo de termómetro de la vida cotidiana.

Hasta el primer tercio del siglo XIX la agricultura cerealista se orienta al autoabastecimiento y, en el mejor de los casos, hacia los mercados locales. En palabras de Garrabou y Sanz Fernández, "los agricultores vendían en el mercado pero no producían para el mercado" ${ }^{1023}$. Las crisis de subsistencias que se han estudiado constatan la falta de un mercado estructurado a escala nacional y la pervivencia de frenos estructurales, propios del Antiguo Régimen, que imposibilitan cualquier cambio. A partir del decreto de 1820 por el que se prohíbe la introducción de granos extranjeros, comienza a articularse un mercado interior que encuentra en el ferrocarril el mejor aliado para integrar económicamente territorios que apenas tenían vías eficaces de conexión ${ }^{1024}$. Se inicia de esta manera la introducción del capitalismo en la agricultura cerealista castellana y es, en este contexto, donde mejor se entienden los afanes de la burguesía liberal y de negocios por tomar posiciones y alentar el fenómeno desamortizador.

La situación difiere en cuanto al viñedo. La especialización vitícola del norte de la Tierra de Medina necesita de un mercado próximo para el mantenimiento del cultivo. Los arrieros bajan de la montaña a La Seca, Rueda, La Nava o Serrada, como en anteriores siglos. El ferrocarril agiliza los intercambios, especialmente en el caso de mayoristas y grandes cosecheros, pero los carros siguen usándose hasta las primeras décadas del siglo XX. La revolución de los transportes amplía las posibilidades del mercado, pero también la competencia con otras regiones productoras.

\section{a. Las tierras de pan llevar. El predominio del arrendamiento, los flojos rendimientos y el cultivo de ańo y vez}

A finales del siglo XVIII, tal como señala Ricardo Robledo, "había en Castilla-León cerca de 120.000 arrendatarios, casi el doble de los que figuraban como labradores propietarios"1025. En los términos estudiados y, especialmente en Serrada, se puede decir que es raro el cultivador que no lleva alguna tierra en

1022 En noviembre de 1813, su apoderado y administrador es D. Josef Milla Cuéllar, vecino de Valladolid y procurador de la Real Chancillería, concreta y actualiza diferentes contratos de arrendamiento.

1023 GARRABOU, R y SANZ FERNÁNDEZ, J., (eds.): Historia agraria de la España Contemporánea. Expansión y crisis, vol. 2, Crítica, Barcelona, 1985, pág. 15.

${ }^{1024}$ Ibídem, pág, 51 y ss.

1025 ROBLEDO HERNÁNDEZ, R.: "Los arrendamientos castellanos antes y después de la crisis de fines del siglo XIX”, en GARRABOU, R. y SANZ FERNÁNDEZ, J., (eds.): Historia agraria..., ob. cit., pág. 369. 
arrendamiento. La importancia del mayorazgo de los Montalvo y las cuantiosas propiedades de unas órdenes religiosas en retirada explican la anterior afirmación ${ }^{1026}$. Sin embargo, la oligarquía local y la rancia nobleza acaban por despegarse definitivamente de sus raíces. En Serrada la casa palacio del marqués queda huérfana. Sus paneras, sin embargo, siguen recordando durante un siglo, gestionadas por administradores de confianza, quién sigue ostentando la propiedad y la jurisdicción en la villa. El tiempo apenas ha variado la relación entre señor y vasallos. Los contratos de arrendamiento siguen transcribiendo idénticos párrafos de siglos anteriores. Las tierras adscritas al mayorazgo se arriendan en rentas que abarcaban cuarenta obradas o "medias rentas de tierras que se componen de veinte dbradas a razón de diez cada oxa". La duración del arriendo se fija "por tiempo de ocho años y ocho pagas". Los renteros dan cuenta por Nuestra Señora de agosto de la renta estipulada en trigo, cebada o centeno "semental, puro, bueno, limpio y seco y bien acondicionado" al margen de cualquier "riesgo y ventura", con la condición de que, una vez pasado el tiempo establecido, el marqués pueda arrendar las tierras a quien mejor le pareciese ${ }^{1027}$.

Como única diferencia con los contratos anteriores, en este de 1813 se escrituran de forma personal rentas y renteros. Esta fórmula, más cercana al espíritu capitalista, sigue adoleciendo de la inclusión de cualquier aspecto que incite a la mejora de producciones o diversidad de labores o cultivos. Los lotes asignados parecen querer manifestar tanto la voluntad del marqués por no fraccionar en exceso las tierras de mayorazgo como la capacidad de los labradores por completar sus heredades. La no coincidencia de apellidos entre los renteros de 1813 y sus antecesores es engañosa. En la mayor parte de los casos son los matrimonios y herencias los que cambian las rentas de manos, pero no de sangre. Salvo abandonos anticipados o azares desgraciados de cosechas, que obligan a tirar la toalla a los más débiles, las rentas suelen seguir labrándose de generación en generación. Es interesante anotar los cambios de cuantía en las rentas. En 1709, por cada renta de cuarenta obradas, los renteros llevaban a las paneras de la casa palacio 32 fanegas de trigo y 4 de cebada, amén de los citados dos carros de paja a Medina. Hacia 1780/1800, la cuantía que se fija son 32 fanegas de trigo y 10 de cebada. En este año de 1813 se equiparan ambos cultivos con 18 fanegas por especie en cada renta, que totalizan 36 fanegas por cada cuarenta sembradas ( 0,9 fanegas por obrada arrendada en sistema de ańo y vez).

${ }^{1026}$ El cuanto a las tierras amayorazgadas, hay que anotar que el paso del tiempo hará que los señores de Serrada ya no sean únicamente "los Montalvo", regidores y vecinos de Medina del Campo. En 1786 se trata de Josep Nicolás de Montalvo Álvarez de Boorques, marqués de Falces y Torreblanca, vecino de Valladolid; en 1828, y no es una concesión decimonónica, Serrada pertenece a Dońa María de la Cabeza Tavira Montalvo, avecindada en 1828 en Aranda de Duero y en 1829 en Andújar. En 1861, el marqués de Falces es vecino de Madrid... No hará falta decir que en algo sí cambiarán los contratos de arrendamiento. Al menos a estos vecinos rentistas no les tocará ir cada año a llevar dos carros de paja a las casas del marqués en Medina del Campo. La villa de las ferias se quedaba pequeńa y con escaso lustre para servir de hogar a estos y tantos otros linajes que escogían el ámbito urbano para disfrutar de sus rentas y de círculos de amistades cercanos a la Corte o a la naciente burguesía industrial y de negocios.

1027 "En la villa de Serrada, a catorce del mes de Diciembre de mil ochocientos y trece, y según de la Constitución Política de la Monarquía española, ante mí, el escribano del numero de ella y testigos infraescriptos, parecieron presentes Gregorio Román y Pablo Román, vecinos desta dicha villa, y dexeron que por la presente y cada uno de por si otorgan que toman y reciben en renta y por arrendamiento del Seńor Marques de Torreblanca y de Falces, y en su nombre Don Joseph Milla Cuellar, vecino de la ciudad de Valladolid, su apoderado y administrador general en esta dicha villa, media renta de tierras que se compone de veinte obradas a razón de diez cada oxa de las que en este término y jurisdicción pertenecen a dicho señor marqués, la misma que tubo, labro y dejó a su muerte Benito García, vecino que fue de ella, cuias situaciones, cabidas y linderos son notorias a los otorgantes, y por lo mismo las dan aquí por espresas y relacionadas como si lo fuesen, tomando cada uno un quarto de renta por tiempo y espacio de ocho ańos y ocho pagas, que han de principiar estas desde el ms de agosto del ańo de mil ochocientos quince y en cada una de ellas se obligan con sus personas y vienes muebles y raíces, habidos y por haber, a dar y pagar que darán y pagarán a dicho señor marqués... de su quenta y riesgo en la panera que aquí tiene, nuebe fanegas de trigo semental, puro, bueno, limpio y seco y bien acondicionado, y otras nuebe fanegas de cebada de igual condición cada uno su mitad, las mismas que según el arreglo hecho para con los demás renteros corresponden a dicha media renta de tierras en lugar de las diez y seis fanegas de trigo semental y cinco fanegas de zebada que antiguamente se pagaban por ella, siendo la primera paga que corresponde y harán cada uno de su mitad para el día de Nuestra Señora de Agosto del año venidero de mil ochocientos quince...”. 
El propio texto hace mención a esta variación. Señala el cambio de fanegas en las especies de cereal que hay que entregar. Los renteros llevarán a las paneras las dichas nueve fanegas de trigo y nueve de cebada "en lugar de las diez y seis fanegas de trigo semental y cinco fanegas de zebada que antiguamente se pagaban por ella”. En 1752, esta villa tan sólo declaraba el 8\% (54 obradas frente a 378 de trigo) de las tierras de sembradura como propias de la cebada, mientras que el porcentaje exigido en la renta era del $23 \%$ equivalente, aproximadamente, a la superficie sembrada de este cultivo en otros términos. La equiparación de uno y otro en las rentas puede indicar tanto el avance de la cebada en el término como su mayor demanda en los mercados a nivel general ${ }^{1028}$. Al margen de criterios agronómicos, han de señalarse también otros factores, como la mayor seguridad de las redes comerciales y de abastecimientos en casos de malas cosechas. El inicio de una industria harinera en Valladolid posibilita la expansión triguera en otros términos más panificables y libera a los estudiados del autoabastecimiento de harinas en beneficio del viñedo. Ejemplos de esta evolución testimonian los inventarios y la tasación de bienes raíces de distintos labradores de Serrada que detallan, en ocasiones, la distribución de cultivos en sus barbecheras ${ }^{1029}$

Aunque no son extensibles estos porcentajes a otras labranzas, sí puede ser indicativo. En esta barbechera de 1801, el trigo representa el 56,25\%; la cebada el 25\% y el centeno el 18,75, cifras que no se pueden generalizar al no poder contrastarlas con otras superficies, pero certifican cuanto se viene diciendo si se comparan con la cosecha de granos en el Valladolid de 1791 en que el trigo, con 1.324.052 fanegas recolectadas, representaba el 44,2\% del total; la cebada con 894.152 el 29,8\%; dejando para el centeno el $25,4 \%$ con 761.391 y el 0,485 para la avena ${ }^{1030}$. Las fértiles tierras de la Vega y pagos limítrofes y las necesidades de los renteros parecen querer mejor la cebada que el trigo, aunque tanto este como el centeno siguen ocupando buenas proporciones, atendiendo a la idoneidad de los suelos. Si se observa el cuadro de arrendamientos de Serrada del ańo 1828, se aprecia cómo, a diferencia de las "rentas " de las tierras de la Vega y adyacentes, proliferan otras muchas sueltas en que su renta se fija sobre todo en centeno. Estas 103 obradas del marqués se encuentran en pagos tan dispares como el Viñazo, la Pellejera, el Lobo, Medianillas, la Golondrina, la Manca, Cotarros, Carretas,... y representan casi una cuarta parte del total detentado por el señor de la villa. En estas tierras sueltas, la renta se fija mayoritariamente en centeno, a una fanega por obrada arrendada ${ }^{1031}$.

${ }^{1028}$ Pueden ser varias las razones que expliquen este cambio en Serrada, la Moya o San Martín. En 1752, se justificaba el aplastante predominio del trigo por adaptarse mejor este cultivo que la cebada a la pobreza de estos suelos de gravas. La plantación de buena parte de ellos, por no decir casi todos los que faltaban, de viñedo a lo largo de la segunda mitad del XVIII y primeras décadas del XIX, deja las mejores tierras libres de estos condicionantes agronómicos y a la cebada, en óptimas condiciones para rivalizar con el trigo, dadas sus más altos rendimientos, pues duplican los de aquel y son muy necesarios para completar el alimento de la cabaña ganadera y de los animales de labor que cada década ven reducidos eriales y pastos en beneficio del viñedo. La cebada se adapta mejor y flexibiliza mas su calendario de sembradura en estas tierras fértiles y frescas de la Vega y pagos adyacentes, propios, por la demás, del citado marqués de Torreblanca.

1029 "Consistía la barbechera en doce obradas sembradas de cebada; veinte y siete y media de trigo y nueve de centeno. Se tasó todo en la actualidad en nueve mil reales...”. (A.H.P.V. Pt. 8228, Serrada, fol. 61, año 1801).

${ }^{1030}$ A.H.N. Consejos, leg. 4174, citado por Gonzalo Anés: Las crisis agrarias..., ob. cit., pág. 148.

${ }^{1031}$ Es el caso de Agustina Rodríguez, viuda de D. Julián Obregón, que continua con la media renta de su marido a cambio de 10 fanegas de trigo y otras 10 de cebada más otras dos de trigo los años pares por una tierra suelta al pago del Juncal. Rafaela Martín, viuda de Agustín Inojal, asumirá igualmente las de su marido, pagando otras 10 fanegas de cada especie y llevando otras cuatro obradas a la Pellejera. Plácida Rodríguez, por último, seguirá desde abril de 1834 la media renta de su marido Lorenzo Rodríguez, con otras 10 fanegas de renta. E idéntica responsabilidad adquiere en 1832 Eugenia Domínguez, viuda de Luis Moyano. Al parecer la estabilidad económica y las buenas cosechas hacen subir en una fanega por especie la renta al marqués que arrienda una tierra suelta para pasto al camino de La Seca a Donato Martín y Crisóstomo de Íscar por 140 reales al año.

Respecto a los renteros, sobresalen por encima del resto Modesto de Castro, que se incorpora en 1834 poseyendo 5/4 de renta e inicia, a partir de estos ańos, toda una serie de importantes compras; Ignacio Fadrique, rentero de 3/4 de renta, y Fernando Alonso cultivador de una renta. A estos ha de añadirse la familia Moyano Rodríguez, sea por parte de 







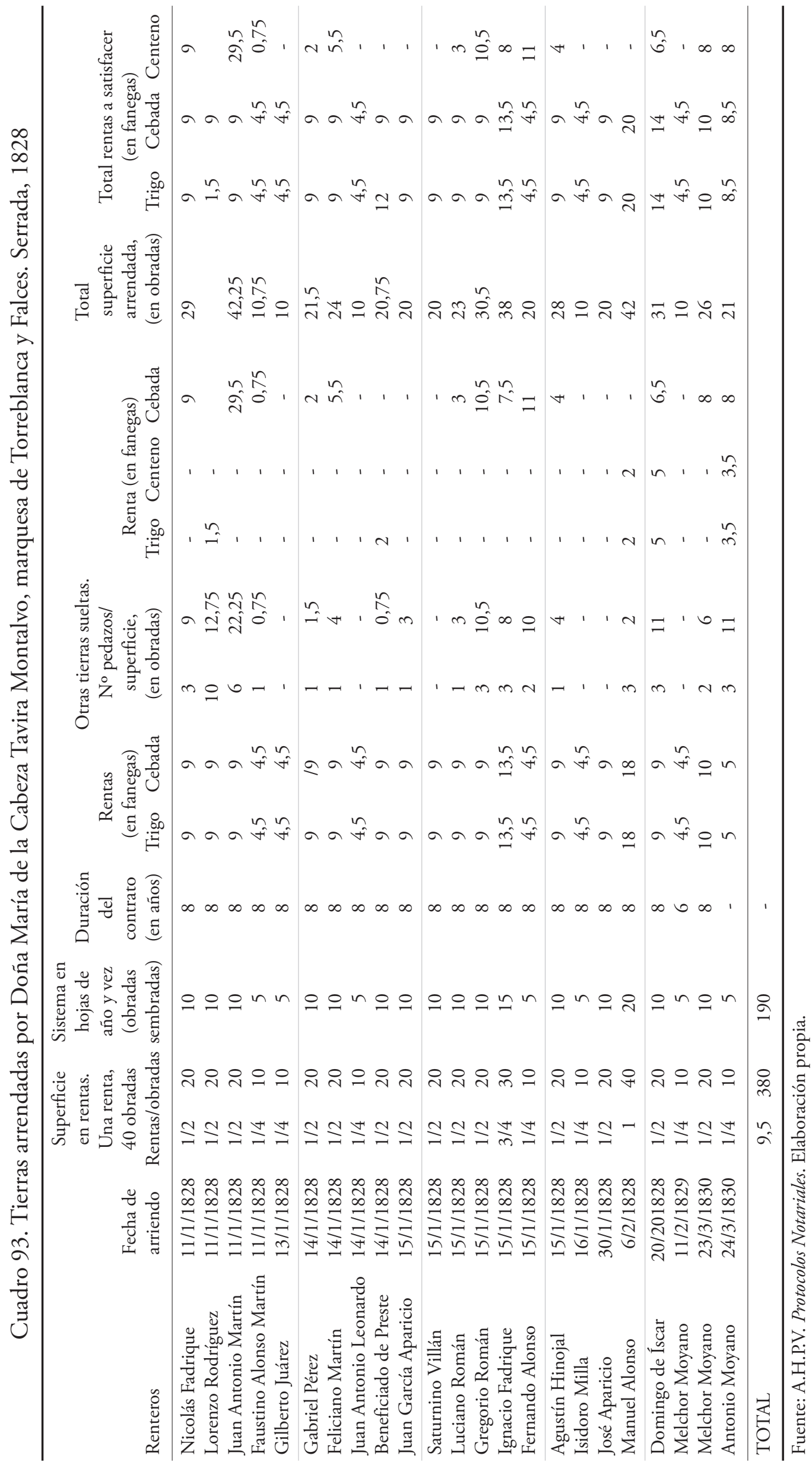


Junto a estos renteros restan otros pequeños o medianos labradores, que también necesitan tierras de pan toda vez que sus propiedades están plantadas de majuelos. Muchas órdenes religiosas han desistido de la explotación directa, que se acentúa tras la guerra hasta poder afirmar que es el inicio de su definitivo adiós. En 1817, continúan los arrendamientos del convento de la Trinidad Descalza ${ }^{1033}$ y, cuatro ańos más tarde, de la orden dominica. En marzo de 1831, arrienda 25 obradas "a dieciséis celemines por obrada de pan mediado" a Luciano Román, vecino de Serrada. Los dominicos repiten la renta señalando que "en cada año y paga lo hará a razón de dieciséis celemines por obrada en esta forma: mitad de trigo morcajo que ha de tener dos partes de trigo y una de centeno, y la otra mitad de cebada, limpio, seco y bien acondicionado...", lo que equivale a 1,33 fanegas por obrada ${ }^{1034}$. Parece que era la mejor manera de coger cosecha segura. Tampoco hacen la sementera en otras 25 obradas. En octubre de este mismo ańo se las arriendan a Luis Moyano. Es en la antesala del final del poder eclesiástico. Recuérdese cuando compraron en 1657 aquella media obrada para edificar casas y horadar bodegas. No les falta mucho tiempo para cerrar sus puertas en esta villa, después de haber brillado en ella 175 años $^{1035}$.

\section{- Rentas, producciones y beneficios en las tierras de pan llevar}

Se cifra, en líneas generales, en una fanega por obrada la renta, obligándose a tener bien abarbechada la otra hoja, lo que supone dos fanegas por obrada sembrada que entregar al marqués o dos y media de trigo morcajo a los dominicos de 1830. Estas rentas se deben relacionar con las producciones obtenidas. Desde mediados del XVIII constan en Serrada producciones de 16, 8 y 5 fanegas de trigo por obrada, según las tierras fueran de primera, segunda o tercera calidad respectivamente. Estos rendimientos no se superan hasta bien entrada la edad contemporánea, tanto en Serrada como en otras villas con mayores aptitudes trigueras. Piénsese que, avanzado el XVIII, un corregidor palentino, refiriéndose a la comarca de Campos manifiesta que "se dice que produce cada obrada ocho fanegas de trigo, que tales términos se considera cosecha más que decente”1036.

${ }^{1033}$ En marzo de este año, Juan y Agustín García arriendan 44 obradas de tierra de pan llevar, "la una al camino del Pozo de cabida de seis obradas; otra a el de la Mayorazga que hace once obradas; otra llamada la Larga, al pago de Valdelaino, de cabida de tres obradas; otra a la mano derecha del mismo camino que hace nuebe obradas y la otra de unos huertos que hace dos obradas... ajustada cada obrada a diez y ocho celemines, los nuebe de trigo semental, bueno y limpio, y los otro nuebe celemines de centeno...” (A.H.P.V. Pt. 8229, fol.45, año 1817).

${ }^{1034}$ A.H.P.V. Pt. 8230, fol.12, año 1831. Se recuerda que una fanega tiene doce celemines.

1035 "Sépase por esta publica escritura de arrendamiento, como yo, Luis Moyano, vecino de esta villa de Serrada, por la presente otorgo: Que tomo y recibo en renta y por arrendamiento del P. prior y Religiosos del Convento de San Pablo, orden de nuestro Padre Santo Domingo, de la citada ciudad de Valladolid, y en nombre del Padre Fr. Francisco Bernardo de Zaeros, depositario de dicho Convento, veinte y cinco obradas de tierra, mitad de cincuenta que en varios pedazos ha partido sin engaño con Luciano Román de esta vecindad, que él ha tomado también en renta, cuyas veinte y cinco obradas están a dos ojas por mitad a doce obradas y media cada una,... cuyo arrendamiento tomo y recibo por espacio de cuatro años, cuatro frutos y cuatro pagas que principian a correr y contar las primeras desde el día de Nuestra Señora, quince de agosto del año pasado de mil ochocientos treinta... y en cada año y paga lo hare a razón de dieciséis celemines por obrada en esta forma: mitad de trigo morcajo que ha de tener dos partes de trigo y una de centeno, y la otra mitad de cebada, limpio, seco y bien acondicionado. $Y$ asimismo recibo en renta y por separado por los mismos cuatro años una hera de pan trillar que pertenece a dicho Convento y Religiosos por la cantidad de sesenta reales anuales, pagaderos en la misma forma, advirtiendo que dichos sesenta reales les ha de pagar en paja a conforme valga cada año el carro de ello en esta villa... poniéndolo de mi cuenta, cargo y riesgo en la casa y panera que tienen en ella... en el día de Nuestra Señora, quince de agosto venidero...”. (A.H.P.V. Pt.8230, fol.46, año 1831)

${ }^{1036}$ A.H.N. Consejos, leg. 4173, citado por Gonzalo Anés: Las crisis agrarias en la España moderna. Taurus, 1970, pág. 368. 
En el juicio entre Miguel Moyano y Tomas Domínguez, por poner otro ejemplo de 1792, se tasa la producción de una obrada de centeno, que los ganados de este último comieron a la raya de la Seca, en doce fanegas, si bien hay que advertir la buena disposición del denunciado al pago y la notable insistencia del primero en asegurar lo bien presentada que estaba su cosecha ${ }^{1037}$. Aunque la mayor parte de las tierras de pan llevar se localizan en los pagos más feraces del término, las cosechas no dependen solo de brazos, suelo o arados. Los ańos de crisis se suceden en estos últimos años del XVIII y principios del XIX. A la crítica campaña de 1788/89 siguen las de 1794/95; 1797/98; $1801 / 02$ y sobre todo la de 1803/04 y 1804/05. A la escasez del cereal va unido lo elevado de su precio y la falta de cualquier "comprensión" por parte de los propietarios de las tierras. Sobradamente se han remarcado las condiciones en que se obliga al pago de las rentas, al margen de cualquier riesgo o desgracia. Los precios prohibitivos endeudan a los medianos labradores y aniquilan a los más pequeños ${ }^{1038}$.

La falta de registros continuados en Serrada y sus pueblos adyacentes hace tomar con extraordinaria cautela cuantos precios se han obtenido de las ventas entre particulares, pues a las fluctuaciones cíclicas se deben añadir las fuertes oscilaciones estacionales que, en ocasiones, doblan el precio de la fanega de grano en la mayor parte de los casos. Las cotizaciones de trigo en Tordesillas en el desastrosos año agrícola de 1803/04 registran 74,44 reales como mínimo estacional y 162 reales como máximo por fanega de trigo puesta en mercado. Al ańo siguiente, la fanega de trigo de buena calidad, en el mercado de los miércoles de Medina del Campo, oscila entre 58 y 65 reales y en el año 1806, por el contrario, baja a precios de 32 a 38 reales ${ }^{1039}$. Estas enormes oscilaciones permiten la especulación del grano por parte de los mayores hacendados. Muchos corregidores manifiestan al Consejo de Castilla cómo los labradores con posibles reservan sus granos en las paneras para venderlos en los años o temporadas de carestías, en detrimento de los más necesitados. A ello debe añadirse la falta de disponibilidad de moneda para hacer frente a las compras. Como testimonia el corregidor del partido de Olmedo en 1769, muchos comerciantes hacen acopio de granos "a cambio de vino, pescados, aceite, jabón, cera y otros géneros de sus tiendas”, por lo que no resulta fácil determinar los precios ${ }^{1040}$.

Cuadro 94. Precios de cereales y leguminosas pagados entre particulares en Serrada. $1752-1821$ (rs/fanega) $)^{1041}$

\begin{tabular}{lrrrrrrrrrrr}
\hline Años & 1752 & 1768 & 1771 & 1782 & 1797 & 1802 & 1810 & 1811 & 1813 & 1818 & 1821 \\
\hline Trigo & 14 & 14 & 20 & 20 & 24 & 40 & 32 & - & - & 24 & 30 \\
Cebada & 7 & 10 & 12 & 10 & - & 22 & 20 & 40 & 22 & 18 & 18 \\
Centeno & 8 & 12 & 13 & 10 & - & 26 & 24 & 60 & 23 & 20 & 16 \\
Algarrobas & 8 & - & - & - & 14 & 16 & - & - & - & 18 & - \\
Garbanzos & 30 & - & 50 & - & - & 65 & - & - & - & 60 & - \\
Guisantes & - & - & - & - & - & & - & - & - & 30 & - \\
Muelas & & & & & & 36 & & & 48 & & \\
\hline
\end{tabular}

Fuente: A.H.P.V. Protocolos Notariales. Elaboración propia.

${ }^{1037}$ A.R.Ch.V. Pleitos Civiles, Pérez Alonso (OLV), caja 686.2.

1038 Se pueden tomar, como referencia cercana, los precios alcanzados por los granos en la vecina Tordesillas. En 1794/95, alcanzó la fanega de trigo el precio de 50,04 reales como precio anual máximo, frente a 36,80 como mínimo de ciclo pagado en 1795/96. En los años de crisis de 1803/04, este cereal llega a superar, en esta plaza, los 100 reales por fanega, cifra muy alejada de los 29 y 28 reales a que se vende entre 1799/00 y 1806/07 respectivamente. Gonzalo Anés. Las crisis agrarias..., ob. cit., pág. 225.

${ }^{1039}$ A.H.P.V. S.H. Medina del Campo, caja 130.

${ }^{1040}$ ANÉS ÁLVAREZ, G.:. Las crisis agrarias..., ob. cit., pág. 368-373.

${ }^{1041}$ A.H.P.V. Protocolos varios de los años citados. 
Se hace difícil determinar las notables diferencias de los precios señalados en el cuadro adjunto con las cotizaciones, siempre más altas, publicadas por el Correo Mercantil, apuntadas por los corregidores del Consejo de Castilla y, en especial, con las vigentes en el mercado de Tordesillas. Como factores explicativos se debe tener en cuenta el coste del transporte incorporado en los precios de mercado y su relación a trigo "limpio y bien granado", condicionantes estos que se ignoran en el grano vendido entre particulares y anotado en los débitos testamentarios u obligaciones de pago entre vecinos.

Con todo, los precios referidos, a pesar de presentar siempre niveles cercanos a los mínimos estacionales, reflejan las fluctuaciones propias de la agricultura del Antiguo Régimen, elevándose los precios en los años de malas cosechas y alcanzando máximos prohibitivos durante la invasión napoleónica. La rentabilidad del cultivo queda muy mal parada por estas cíclicas oscilaciones. No siempre los precios del trigo superaban los 22 reales, cifra considerada por algunos entendidos de esta época de finales del XVIII como la necesaria para que el cultivo deje a los labradores beneficios.

El caso de las leguminosas es distinto. Se trata de cultivos minoritarios, con orientación de autoconsumo, que aprovechan las tierras que van de barbechera, reduciendo costes de cultivo y dejando el terreno nitrogenado para el siguiente año. En el último tercio del XVIII, se constataba cómo las labranzas más capitalizadas aumentan su superficie y variedad. Los garbanzos, por ejemplo, adquieren una mayor presencia en todos los libros de contabilidad en este primer tercio del XIX. Su producción en ańos normales suele ser de seis fanegas por cada una sembrada y la rentabilidad está condicionada por la calidad del producto y los precios del mercado. Así, en la granja conventual dominica de Serrada, están en 1801 a "65 reales fanega por ser de mala calidad" y en 1802 se venden 20 fanegas a cien reales "por ser de primera calidad"1042. Lo que siempre se cuida es su guarda, especialmente en las crisis agrarias de principios de siglo. En 1803, en la citada hacienda se pagan hasta "ciento dieciséis reales al guarda del garbanzal"1043. Estos gastos son desmesurados en relación con años normales, al igual que los salarios de hasta cinco reales por obrero y día, que tampoco pueden, por otra parte, hacer frente al ascenso especulativo de precios.

Con todo, y como puede apreciarse en el caso del ejemplo, que no se puede generalizar al no haberlo contrastado con otros casos y años, el beneficio que queda libre no es más que la simiente que al siguiente año se necesita, caso de repetir su siembra. De ahí que este cultivo siga siendo minoritario y se limite a alguna obrada en cada labranza trabajada con ganado y criados de casa para consumo interno.

Con el alto precio que alcanza el producto en su siembra, en 1803 se observa lo esmerado de la labor para que el desarrollo de la futura planta sea óptimo. Por lo general, estas leguminosas se siembran sobre tierras que han salido de pajas, una vez aradas con el arado romano, en enero y marzo, para evitar que se vaya el tempero. El que en este caso se precise que se han arado "a junto", esto es, dando una raya por el cerro y volviendo por la pestańa o "encía" del mismo, indica una esmerada labor o, dicho de otro modo, arado doblemente, dejando la tierra cual si de una labor de vertedera se tratare.

La siembra tiene lugar a finales de abril para evitar las heladas tardías. De hecho, entre los viejos labradores de estos lugares aún se recuerdan los dichos de generación en generación sobre el momento idóneo en que hay que sembrar el garbanzo. "Por San Marcos el garbanzal ni nacido ni por sembrar, y a la vieja que se lo decían a tres hojas ya le tenía", que recuerda, una vez más, el peligro de las heladas tardías en esta meseta castellana.

1042 A.H.N. Clero, Libro 1735, fol. 128-150.

1043 Ibídem. 
Cuadro 95. Coste y beneficios de una obrada de garbanzos, año $1803^{1044}$ (en reales).

\begin{tabular}{lr}
\hline Arar a junto & 93 \\
Volver a arar a huebras & 100 \\
Una fanega para siembra & 130 \\
Obreros y huebras para siembra & 130 \\
Seis obreros de escarde & 30 \\
Guarda del garbanzal & 116 \\
Obreros de coger la cosecha & 60 \\
Trilla y limpia más vino & 50 \\
\hline TOTAL GASTOS & 709 \\
\hline INGRESOS 6,5 fanegas, quitado diezmo, a 120 reales fanega & 780 \\
\hline TOTAL BENEFICIOS & 72
\end{tabular}

Fuente: A.H.P.V. Protocolos Notariales. Elaboración propia.

El cultivo estrella en las tierras de sembradura sigue siendo el trigo. En una memoria presentada a la Junta de Hacienda nombrada por la Comisión de Cortes en 1809, recogida por Gonzalo Anés, se precisa como el beneficio neto para el cultivador no sobrepasa el 10\% del total de ingresos en rendimientos de 7 fanegas de trigo por fanega de tierra sembrada. Por su detalle, parece oportuna su reproducción ${ }^{1045}$ :

Cuadro 96. Gastos e ingresos de 100 fanegas de tierra en un “año común”, año 1809

\begin{tabular}{lr}
\hline Gastos & En reales \\
Renta de 200 fanegas de tierra en año y vez, a 24 reales la fanega de tierra. & 4.800 \\
Valor de la semilla (100 fanegas a 45 reales) & 4.500 \\
Gastos de barbecho y cohecho, 400 jornales, a 15 reales & 6.000 \\
Gastos de sementera, 150 jornales, a 20 reales & 3.000 \\
Escarda y guardería & 1.000 \\
Siega /a 36 reales la fanega & 3.600 \\
Gastos de era & 2.200 \\
Contribuciones directas de millones, paja, repartimientos varios, etc & 100 \\
Costes totales & 25.200 \\
\hline Ingresos & En reales \\
\hline Producción: 700 fanegas, a 45 reales & 31.500 \\
\hline Beneficio: & 6.300 \\
\hline Ingresos-gastos & 3.150 \\
\hline Diezmo: 70 fanegas, a 45 reales & 3.150 \\
\hline Quedan para el cultivador & \\
\hline
\end{tabular}

Fuente: ANÉS ÁLVAREZ, G.:. Las crisis agrarias..., ob. cit. Elaboración propia.

Similares circunstancias de rentabilidad tiene el centeno. Orientado desde antiguo a las tierras de tercera, no rinde en la mayor parte de los casos más de cinco fanegas por obrada, echando una de simiente. En el ejemplo expuesto, hallado en la casa religiosa del Hospital de la Resurrección de Serrada en unos años de especulación, guerra y miseria, la rentabilidad, dando a hacer las labores, es muy re-

${ }^{1044}$ Ibídem. Todos los gastos de producción están obtenidos del libro de contabilidad de la citada hacienda de San Pablo en este ańo. La producción anotada se ha obtenido de las medias de estos ańos, dando por supuesto, dado el alto precio que se paga por la guarda del garbanzal, que la cosecha es buena. De ahí que se haya mantenido muy alto el precio de la simiente, aunque es muy posible que el precio medio del garbanzo de mediana calidad en este año sea sensiblemente inferior.

1045 ANÉS ÁLVAREZ, G.:. Las crisis agrarias..., ob. cit., pág. 294. 
ducida. Este año los salarios de los obreros llegan a cuatro reales día, las huebras, a 25 y 30 reales, el vino, a 25 rs/cántara, la cebada, a 37 y 42 reales... Buen año para quien labra sus tierras con ganado propio y tiene la suerte de no ser robado. En la citada granja, como puede observarse en el cuadro adjunto, aun sin contar los gastos de barbechera, ni las 14 cántaras de vino que consumen en las labores de recolección, las ganancias son mínimas, incluso estando por las nubes los precios de este cereal.

Cuadro 97. Labores, coste y beneficios en siete obradas de centeno.

Hospital de la Resurrección. Serrada, año 1711

\begin{tabular}{lr}
\hline Labores & Reales \\
\hline 21 huebras de arar, cubrir y sembrar a 30 reales huebra & 630 \\
Simiente: siete fanegas a 60 rs & 420 \\
Siega: siete obradas a 40 rs obrada, incluyendo comida & 280 \\
Dos huebras de acarreo & 60 \\
Doce huebras de trilla a 24 cada una & 288 \\
Obrero y comida de 16 días de ayudar a trillar, barrer, limpiar y meter. & 96 \\
\hline GASTOS & 1.774 \\
\hline Producción: 34 fanegas. (4,8 fanegas/obrada) Pago de tres por diezmo. & 1.860 \\
\hline INGRESOS: 31 fanegas a 60 reales & 86 \\
\hline INGRESOS NETOS & \\
\hline
\end{tabular}

Fuente. A.H.P.V. Hospital de la Resurrección. Elaboración propia.

En cuanto a la cebada, en estos años convulsos, nada mejor que acercarse a las cuentas que presenta el escribano de Valdestillas en 1812 sobre lo gastado en una tierra de este cultivo cuya cosecha, que ya se ha comentado, fue a parar a los estómagos de los caballos de la partida de Saornil ${ }^{1046}$ :

Cuadro 98. Coste y beneficios por obrada del cultivo de la cebada, año $1812^{1047}$

\begin{tabular}{lr}
\hline Labores & Reales \\
\hline Simiente: cuatro fanegas a 45 reales. & 180 \\
Labores: 4,5 huebras de alzar, cubrir y sembrar la tierra. & 140 \\
Siega: 3,3 jornales. & 58,6 \\
Acarreo y trilla: 2 huebras & 60 \\
Producción: 13,3 fanegas & 438,6 \\
\hline TOTAL GASTOS & 540 \\
TOTAL INGRESOS, pagado diezmo, 12 fanegas a 45 reales. & 101,4 \\
\hline TOTAL BENEFICIOS
\end{tabular}

Fuente: A.H.P.V. Protocolos Notariales. Elaboración propia.

Tampoco se pueden generalizar estos casos en la realidad de toda la comarca ni extenderlo en el tiempo, dado la excepcional de los precios que, durante la invasión napoleónica, alcanzan jornales y granos, pero es fácil advertir lo ajustado de gastos e ingresos que apenas dejan margen para recuperar la simiente sembrada. Solo si la producción de cebada por obrada es superior a 13 fanegas, el resultado es positivo. A mediados del XVIII, se constatan producciones superiores a las veinte fanegas por obrada, por lo que parece garantizada la rentabilidad del cultivo. Pero como antes se ha apuntado, a este supuesto beneficio neto se debe restar el aporte diezmal, que muchos autores cifran hasta en

${ }^{1046}$ A.H.P.V. Pt. 11892, fol. 14, año 1812.

${ }^{1047}$ Conviene tener en cuenta que lo elevado de los precios de las huebras, jornales o precios de las fanegas de cebada en este año, se debe a las carestías generadas en los últimos años de invasión francesa. 
el 50\% del producto neto, más los gastos que lleva la hoja abarbechada, por lo que el grano o los reales que el labrador recoge se presumen generosos sólo en el caso de abundantes producciones y precios altos, situaciones tan escasas como difíciles de hacer coincidir.

Difícilmente estas cantidades netas alientan a nadie a lanzar las campanas al vuelo. Si se estima el consumo por persona y año en cuatro o cinco fanegas, el mantenimiento del ganado y los cuantiosos débitos en forma de misas, aniversarios, deudas, réditos de censos, foros, etc., que tenía cada vecino, las malas cosechas pueden acabar con las mayores haciendas. Falta la sequía y el pedrisco, nunca eximente de los pagos y siempre eterno compañero de viaje del campesino. En estas primeras décadas del XIX, se detecta por primera vez una efectiva ayuda por parte de los incipientes ayuntamientos constitucionales y Diputaciones provinciales. Estas instituciones tratan de aliviar estas penurias de acuerdo a la capacidad económica de sus presupuestos. Así parece constatarse tras el pedrisco de $1822^{1048}$ :

“Domingo de Íscar, Nicolás Fadrique, Juan García Aparicio, Antonio Moyano, Gabriel Pérez y José Aparicio, alcalde, regidores y procurador sindico únicos que componen el Ayuntamiento... haviendo ocurrido en esta villa la desgracia de 1 perdida de todos los frutos de pan y vino en ella, única subsistencia de sus habitantes, por los temporales, pedriscos, acaecidos en los días seis y trece de junio del ańo ultimo por cuia desgracia recurrió el Ayuntamiento de esta villa a S.M. en diez de julio del mismo por conducto de S.E. la Diputación Provincial que remitió su informe a S.M. en tres de septiembre del mismo solicitando de la Real Beneficencia el auxilio de treinta y siete mil cinquenta reales; los diez y siete mil cinquenta para que los labradores de esta villa comprasen trigo y demás granos para su sementera, y los veinte mil para dar jornal a los jornaleros con utilidad de los propietarios...”.

En este sentido, a las rentas que hay que pagar se deben sumar los costes totales del cultivo que oscilan entre el 70 y el $80 \%$ del total ingresado, con producciones medias de 7/8 fanegas por obrada. En muchas ocasiones estos porcentajes se quedan cortos en años escasos de precios. En mayo de 1824 se conciertan en Serrada capitulaciones matrimoniales que detallan de forma precisa los costes de producción de cereales, viñedo y leguminosas ${ }^{1049}$.

Cuadro 99. Costes de producción, sin incluir recolección, en cereales, leguminosas y viñedo.

Serrada, año 1824

\begin{tabular}{|c|c|c|c|c|}
\hline $\begin{array}{l}\text { Forma de } \\
\text { aprovechamiento }\end{array}$ & Cultivo & Trabajos realizados & $\begin{array}{l}\text { Precio por obrada (cereal) } \\
\text { y aranzada (vid), en reales }\end{array}$ & Observaciones \\
\hline \multirow[t]{6}{*}{ Tierras de sembradura } & Trigo & Labores y simiente & 130 & - \\
\hline & Cebada & Labores y simiente & 200 & Se incorpora abono \\
\hline & Avena & Labores y simiente & 50 & - \\
\hline & Guisantes & Labores y simiente & 50 & - \\
\hline & Garbanzos & Labores y simiente & 90 & - \\
\hline & Algarrobas & Labores y simiente & 46 & - \\
\hline Barbechera & - & Dos vueltas arado & 30 & - \\
\hline Viñedo & Uva & $\begin{array}{l}\text { Excavo, } \\
\text { Arada de invierno y marzo }\end{array}$ & poda & _ $\quad$ acobijo. \\
\hline
\end{tabular}

Fuente: A.H.P.V. Protocolos Notariales. Elaboración propia.

Este año no parece que fuera un buen año en cuanto a precios. Se paga la cántara a 8 reales, la fanega de trigo a 18 y la de garbanzos a 34 reales. Aunque los datos pertenecen a un caso individual y no se puede generalizar como propios de toda la zona, no es probable que se aleje mucho de la realidad de cuanto se expone. Respecto al trigo, a 18 reales por fanega, solo por encima de cosechas

1048 A.H.P.V. 8229, fol. 15, año 1823.

${ }^{1049}$ A.H.P.V. Pt 8229, fol. 134, año 1824. 
superiores a ocho por obrada se libran costes de producción, excluyendo los gastos de siega, trilla y pago del diezmo. De ahí la observación de 22 reales por fanega y 8 fanegas por obrada como imprescindibles para asegurar una mínima rentabilidad del cultivo.

No se trata de cargar las tintas en cuantos aspectos negativos influyen en la vida campesina de hace doscientos años. De hecho el anterior texto rompe la inercia de la resignación respecto a anteriores desgracias, pero aún se está en un tiempo en que las cosechas dependen de sequías, humedades y pestes antes de ser llevadas a las eras o a las bodegas. Los precios, al final, son los que fijan las rentas y pocas veces satisfacen al campesino que cultiva directamente la tierra para ahorrarse gastos de producción y obtener beneficios por su trabajo personal. A nadie se le escapa que los factores que se han señalado son los causantes de la variabilidad que presentan unos ańos y otros. Es notorio su progresivo aumento desde las décadas finales del XVIII que llegan a duplicar los niveles de mediados de siglo. Las crisis de finales y principios del XIX duplican los precios, respecto a épocas anteriores, y el desabastecimiento y penurias durante la invasión francesa los eleva a niveles prohibitivos para su compra ${ }^{1050}$.

Para finalizar este mundo de pan llevar, es conveniente estudiar la distribución en hojas del terrazgo sembrado y su aprovechamiento ganadero. En Serrada y La Moya el vińedo dificulta la existencia de la hoja sembrada y barbechada, a diferencia de otros lugares trigueros con más uniformidad en suelo y cultivos. De hecho, conforme avance el siglo, la parcelación de los lotes y la identificación de las parcelas labradas será tan prolija que la expresión cultivo en hojas alude más a la forma de cultivo que a la distribución efectiva sobre el espacio.

\section{b. El cultivo del vińedo al final del Antiguo Régimen. La irregularidad de las cosechas y el estancamiento de los precios}

La explotación vitícola se manifiesta en el XVIII con un continuado aumento de aranzadas plantadas conforme se mantienen las salidas, tanto a los mercados del norte como otros más cercanos. La capital vallisoletana y las villas cerealistas del centro de la Meseta y las montańas del norte siguen manteniendo su fidelidad a estos vinos. Su aprecio es seńalado por el propio Jovellanos que recuerda su demanda por las tierras asturianas, a pesar del encarecimiento que representan los gastos del transporte. Campomanes reitera, tras su viaje por estas tierras en 1779, que el vino de La Nava, Rueda y La Seca tiene "gran saca para las montañas de Burgos y Santander"1051. Pero estos mercados, por llamativos que parezcan, no deben marginar las pequeńas pero numerosas sacas que taberneros y arrieros hacen a pueblos vecinos, hasta el punto de que, poco a poco, vacían las bodegas. Un ejemplo es el caso de Andrés Rodríguez, vecino de Serrada en 1786 ${ }^{1052}$ :

\footnotetext{
“Sépase como yo Balthasar Díez, vecino y tabernero obligado de la villa de Velliza, al presente en esta de Serrada, confieso que debo y pagare realmente y con efecto a Andrés Rodríguez, vecino desta dicha villa, y a quien en derecho representare en qualquier manera, trescientos sesenta y dos reales de vellón, valor de noventa cantaras y media de vino blanco que de su bodega he sacado para el consumo y abasto de dicha mi taberna, y las que me ha dado al fiado, a precio de quatro reales cada una, libres, a cuio respecto importa dicha cantidad"
}

${ }^{1050}$ La carestía de granos va unida en estos años a la de brazos. En las líneas anteriores se deben relacionar los distintos productos o bienes para poder cuantificar como altos o bajos estos precios. En 1752, cuando en Serrada se coge por obrada de primera calidad 16 fanegas de trigo, se venden a 14 reales cada una. Un jornalero gana al día dos reales, una cántara de vino se paga a cuatro. En 1815, se paga la fanega de centeno en Serrada a 23 reales y la cántara de vino a 10 reales, mientras que un jornalero cobraba 4 reales por podar o excavar una aranzada. Sólo adentrándose en los testamentos y particiones de bienes se puede hacerse idea del valor de cada real y lo escasos de ellos que estaban la mayor parte de pequeños labradores y jornaleros. Cuando se tasa hasta el último taburete viejo, es porque aún es valorado. Piénsese en la desgraciada vida de jornaleros o criados que, para comprar en este año de 1815 una fanega, deben tener siete o más días de jornal ¡Cómo para no apreciar una capa de pańo de Béjar tasada en cien reales!

${ }^{1051}$ Informe Campomanes, citado por Hilarión Pascual: Historia de Medina..., ob. cit. vol. II, pág. 676.

1052 A.H.P.V. Pt. 8223, fol. 398, año 1786. 
Estas ventas a localidades cercanas representan, en este final del XVIII y principios del XIX, buena parte del volumen comercializable del vino local, sea de pequeños productores o grandes hacendados. Asiduos taberneros se mantienen unidos a bodegas o viticultores y la mutua confianza permite las ventas al fiado, siempre peligrosas en unos tiempos en que los impagos son frecuentes y los pleitos muy costosos. De ahí que, para evitar riesgos, se escrituran mediante obligaciones de pago los tipos de moneda, las fechas de cobro o los salarios de gestiones que, por dilaciones u otras motivos, hubiera que realizar. He aquí un ejemplo fechado en $1826^{1053}$ :

\begin{abstract}
"En la villa de Serrada a nuebe de junio de mil ochocientos veinte y seis,... comparecieron Antonio y Luis Flórez, hermanos, vecinos y tabernero el primero de la villa de Torrelobatón y ambos juntos... Dixeron que por la presente... otorgaban y se obligan con sus personas y bienes... a dar y pagar en monedas usuales y corrientes y en ninguna manera en papel ni vales reales a Don Francisco Moyano, vecino de esta villa de Serrada, la cantidad de dos mil nobecientos nobenta y siete reales de vellón, que confiesan deberle importe y valor de quatrocientas cantaras de vino blanco que le han comprado al fiado y el susodicho les ha bendido a precio de ocho reales menos quartillo cada cántara, cosecha del año próximo pasado, consumo al presente de la fecha, y que ya an dado principio a embasar y han tomado de la cuenta y riesgo con los desbotes competentes que ya quedan deducidos... cuia cantidad la darán y pagaran en una sola vez y plazo para el día de Natividad de Nuestra Señora de septiembre...”.
\end{abstract}

A pesar de estos actos notariales, las deudas se dilatan en el tiempo. No siempre las compraventas tienen final feliz ni los mercados están próximos. Importantes sacas son llevadas a cabo por arrieros de las montañas de León, Asturias, la montaña santanderina o las sierras al norte de Madrid ${ }^{1054}$. A esta tradición de consumo ha de añadirse la apertura del puerto de Santander al comercio americano desde 1765. Representa una salida natural a los productos castellanos en que el vino ocupa un lugar de primer orden. Los blancos de Medina, Rueda, La Seca o Nava, nombres por los que son conocidos, inician el paso del Atlántico, altamente valorados y cotizados en los mercados indianos, sin olvidar el alivio que producen estas remesas en años excedentarios ${ }^{1055}$. Eran estas situaciones de cubas llenas, difíciles de vender en años de abundancia y contracción de mercados, y con riesgos de mermas de calidad, una de las mayores preocupaciones de los cosecheros.

Las superficies plantadas en Serrada, La Moya o pueblos vecinos dan cuenta de su importancia. Los protocolos notariales de las últimas décadas del XVIII y primeras del XIX, testifican las numerosas compras y ventas de majuelos, lagares y bodegas. El pulso económico de estas y otras localidades viene dado por el permanente interés de los vecinos en rematar las posturas de tabernas o corredurías de vinos y aguardientes, sin olvidar aquellas que rematan los diezmos del mosto y menudos correspondientes a las fábricas de sus iglesias ${ }^{1056}$.

${ }^{1053}$ En este caso, el escribano anota al margen su cancelación "por recibo dado escrito y firmado por el Sr. D. Esteban Moyano y hermanos, vecino de Valladolid, su fecha veinte y tres de octubre de este año, comprehensibo de la cantidad de cuatrocientos catorce reales, por resto de lo que estaban debiendo, y a continuación de otros recibos de esta escritura y otra posterior otorgadas en su razón, que se mandara cancelar, como se hace hoy primero de diciembre de mil ochocientos veinte y ocho." (A.H.P.V. Pt. 8230, fol. 26, año 1826).

${ }^{1054}$ Constancia de estas ventas a zonas de montaña, a tenor de la huella que dejan en litigios por conflictos o impagos, se encuentran, por ejemplo, en la Rueda de 1806, donde Catalina Pérez, viuda de Nicasio Fontecha, encargado del abastecimiento del vino a Fontiveros (Ávila), pleitea con los alcaldes de dicho lugar. Asimismo, son numerosas las ejecuciones de bienes que se llevan a cabo entre compradores por las denuncias por impago. En 1806 se ejecutan bienes a distintos compradores de vino de Hijas, en Cantabria, denunciados por Francisco Garrido; en1807, hace lo propio Agustín Rodríguez con Luis Martínez, vecino de Requejo de la Vega (León), etc. (A. R. Ch. V. Pl. C. Pérez Alonso (F), caja 3702.3; Pérez Alonso (OLV), caja 904.1 y 913.4 respectivamente).

1055 VALERA MARCOS. J.: El inicio del comercio castellano con América. Diputación de Valladolid. 1999.

${ }^{1056}$ La parroquial de Serrada otorga obligaciones con los vecinos en cantidades superiores a los 4.000 reales anuales, cifras que prueban el dinamismo de los caldos. La celebrada en junio de 1789 no tiene desperdicio. Se inicia en tres mil reales y acaba alcanzando, tras numerosas pujas, los 5.123 reales: "En la villa de Serrada, a veinte y quatro días de junio 
Corredores y arrieros tratan de hacerse con las mejores partidas a precios asequibles. En 1792, se encuentra una obligación entre Juan García de Castro y Santiago Aragón con el corredor José Martín. Es natural de Rueda, avecindado en La Seca y tiene la correduría de Serrada. Representa uno de los muchos casos de estos "hombres de negocios" que especulan con los caldos y abastecen los mercados con vinos de la comarca. Sus operarios no dejan nada al azar en el contrato que firman para la saca del vino de las bodegas ${ }^{1057}$.

Ajustadas las cántaras entre corredores, cosecheros y compradores, Serrada, La Seca, Rueda y tantos otros pueblos de esta comarca son un trasiego continuo de carreteros y vino. A través del pleito entre Lucia Martín, viuda, vecina de Serrada, con Ignacio Barrero, tabernero y vecino de Villanubla, sobre la satisfacción de 800 reales, resto de mayor cantidad de vino vendido en 1794 , se puede recrear este constante trajín ${ }^{1058}$. Al parecer, el citado tabernero, tras la compra y saca de vino en Serrada, adeuda a la demandante "algunas sumas por entero y llebando otras a el fiado, de que resulta haber benido a serme deudor de dich a cantidad de ochocientos reales". Aunque en ocasiones el vino es pagado conforme se suben los pellejos de las cubas, en la mayor parte de los casos se dan distintas cantidades a cuenta para, una vez concluida la saca, concluir o escriturar las cantidades pendientes de pago. El detalle de la cuenta, en este caso, aproxima a estas ventas de hace dos siglos ${ }^{1059}$ :

de mil setecientos ochenta y nuebe, estando juntos los Sres. Curas y beneficiados de la iglesia Parroquial d San Pedro Apóstol de ella a la Puerta principal, según costumbre a fin y efecto de admitir las posturas para el arriendo y remate de los menudos y mosto que corresponden a dicha iglesia en la cilla común de Diezmos por su Noveno... admitieron las Posturas siguientes: Don Canon Diez del Castillo, de esta vecindad hizo postura en tres mil reales y vista la mandaron admitir, y admitieron; y publicada que fue Inocencio Lajo dixo la mejoraba y mexoró en quinientos reales con la condición de afianzar a contento y satisfacción de dichos señores y Francisco Quintero, mayordomo de fabrica, y de dar diez cantaras de mosto al tiempo de el reparto de este efecto en la Pila para las misas, y admitió; y publicada que fue se mexoró hasta quatro mil reales por Remigio Platón, y en este estado la mexoró Felipe Alonso, vecino de esta villa en quinientos reales mas, vaxo de dichas condiciones, la que se público, y por dicho remigio Platón se pujo y mejoro en cinquenta reales mas... Inocencio Lajo la mexoró hasta quatro mil y seiscientos reales, y en este estado por el citado Julián Recio se mejoro hasta la cantidad de cinco mil y treinta reales, cuia mejora se mando admitir y admitió, y publicada que fue se mexoró por Toribio Alonso de esta vecindad hasta cinco mil y noventa reales y dicho Julián Recio puxo diez reales mas, cuia mejora se admitió, y público, y Don Cenón Díaz de esta vecindad dixo la mejoraba en diez reales mas y dicho Julián dixo pujo otros diez reales mas... e no habiendo resultado otro alguno mayor ni mejor postor dichos señores dieron por rematada...”. (A.H.P.V. Pt. 8224, fol. 551, año 1789).

${ }^{1057} \mathrm{~A}$ cambio de 1.400 reales anuales, ambos se comprometen a "sacar el vino de las vodegas; las hezes de las cubas; labar estas, embasar o en liar las cargas a los harrieros y demás que nos mandase dicho José Martín, quien habrá de percibir los intereses de embagar o enlucir las cargas, los de las hezes y demás corresponda al derecho de correduría..." La falta de previsión en la mayor o menor saca también se precisa para evitar malos entendidos. Así "si algún día ocurriere haber mucha saca, como suele acontecer, y no fesemos vastantes nos los otorgantes para el despacho de los arrieros, que en este caso el dicho José Martin ha de poner de su quenta un hobrero que hayude a sacar sin que por esto nos rebaje cosa alguna." Por el contrario, en aquellos días de poca saca se ofrecen en "ocupar en lo que nos mandare" pero matizan "a excepción de hir a cabar las viñas". No dejan nada al azar cuando hacen constar que "si hiziesemos algún trabajo estraordinario a los harrieros, y por vien serbicio estos dieren alguna cosa de gratificación que llaman regularmente para tabaco, esto ha de ser para nosotros dos.". (A.H.P.V. Pt. 8225, fol. 464, año 1792).

1058 A.R.Ch.V. Pleitos Civiles, Pérez Alonso (F), caja 3544.2.

${ }^{1059}$ Escuchados los testigos de las partes, la Audiencia confirma la sentencia a favor de la vecina de Serrada en enero de 1795. Ignacio Barrero debe abonar tanto los 790 reales del vino como otros 472 en concepto de costas. En el detalle de la operación se puede apreciar además, tanto el volumen del vino vendido (5.440 litros), representativo de muchos cosecheros, como las distintas calidades y precios de las cubas (a 16 reales la cántara la primera y a trece la segunda). Recuérdese que se trata de unas añadas de muy altos precios. La casa de San Pablo vende las cosechas de 1795, 1796 y 1797, a una media de 13,55 reales, el mayor precio en tres ańos consecutivos de todas sus elaboraciones en el siglo XVIII. Por último, hay que anotar que los arrieros acarrean entre 33 y 41 cántara por viaje (528 y 656 litros), lo que explica los costes y penalidades de un transporte que no se abarata hasta la mejora de la red caminera y la aparición del ferrocarril. 
"Cuenta con Ignacio Barrero, vecino y tabernero de la villa de Villa Nubla, en el agosto de nobenta y uno, de barias partidas de bino que llevo de mi casa Lucia Martin, vecina de la villa de Serrada, a precio de dieciséis reales. Primer biaje.

Treinta y tres y medi 918,02 reales

Segundo biaje. Quarenta y media 626,14 reales

Terzero biaje. Treinta y quatro y media 933,21 reales

Quarto biaje. Treinta y tres y media 918,04 reales

Quinto biaje. Treinta y tres y media, con mas de seis y media

que presto a el tabernero de Ziguńuela, importa todo sesto biaje catorze 618,22 reales

Partidas de dinero que tiene entregadas:

Primeramente quinientos reales 500 reales

Ytem. Quinientos nobenta y dos reales 592 reales

Ytem. Quinientos quarenta y seis reales 546 reales

Ytem. Doscientos sesenta reales 260 reales

Total 898 reales.

Ytem. Doscientos sesenta y ocho reales 268 reales

Ytem. Quatrocientos reales 400 reales

Ytem. Ciento treinta y cinco reales 135 reales

Ytem. Doscientos y cinquenta reales 250 reales

Total 2.951 reales.

Otra cuba, a precio de trece reales cántara:

Primer biaje. Quarenta y una y media 521,1 reales Segundo biaje. Quarenta y siete 590 reales

Tercer biaje. Quarenta y una 515 reales

Quinto biaje. Beinte y nuebe 564 reales

Total $1.099,1$ reales.

Partidas de dinero que tiene entregadas:

Primeramente doscientos y cinquenta 250 reales Ytem. Quatrocientos nobenta y ocho reales 498 reales Ytem. Trescientos ochenta y seis reales 386 reales Ytem. Ciento quarenta y ocho reales 148 reales

Total 1.282 reales

Y par que conste lo firma a mi ruego un testigo. Manuel Alonso Martin. (rúbrica)

Resumen.

Las seis primeras partidas del vino que llebo a precio de 16 reales cantara importan ...... 3031,15

Las otra quatro de vino que llevo a precio de trece reales 1997,11

Dinero entregado.

A cuenta de las primeras partidas según quedo por menor referido

A cuenta por las segundas

Estas diferencias en el precio de las cántaras de un mismo productor y bodega, que llegan a alcanzar diferencias muy notables en una misma campaña y villa, nos ha llevado a interesarnos por el proceso de producción vinificación en el periodo tratado. Por lo que dicen y callan las escrituras, hay que inclinarse por la continuación de la tradición en el tratamiento de las vendimias, mostos y encubados. Sin embargo, en estos tiempos de cambio y sin olvidar el poso científico que deja la Ilustración, se hace conveniente analizar tanto las prácticas agronómicas como los procesos de transformación. Los cosecheros hacen frente a no pocos contratiempos, sean las nuevas competencias de otras zonas vitícolas, la bajada generalizada de precios o la merma de calidades por acumulaciones de cosechas no vendidas. No todos ven la luz una vez acabado el largo túnel. 


\section{- La labranza de las vińas. Labores, producciones y rentabilidad}

Como antes se ha comprobado en el cereal, en este tiempo no es fácil determinar precios, producciones y rentabilidad más allá de cada añada. Dada la variabilidad de factores que inciden en el cultivo, los márgenes de ganancias o pérdidas se tornan tan aleatorios como el sinnúmero de factores que inciden en la calidad final del vino. A mediados del XVIII, no obstante, se estima en 0,89 moyos/aranzada, equivalentes a 6 hectolitros por ha, la producción media en estas tierras de la meseta superior. Este rendimiento se obtiene de una producción de 329,6 kilos de uva por aranzada o $863,3 \mathrm{~kg} / \mathrm{ha}$. Recuérdese, en épocas anteriores, lo difícil que era superar la media del moyo de uva por aranzada, equivalente a $6,7 \mathrm{hl}$ por ha. Dependiendo de la calidad del terreno, sigue siendo difícil superar los 8 o $10 \mathrm{hl}$ a final de siglo ${ }^{1060}$. La casa conventual de San Pablo, con viñedos en plena producción, entre 1768 y 1784, registra una media de 1,39 moyos por aranzada, equivalentes a 9,3 hl/ha, para bajar entre 1785 y 1801 a 1,14 moyos por aranzada, equivalentes a 7,6 hl (1.099 kg/ha).

A los múltiples condicionantes de suelo, labores, edad de la cepa y estado general de la viña se suman las repercusiones de las favorables o adversas coyunturas vitícolas que repercuten en un mayor o menor esmero en los majuelos, con el consiguiente reflejo en los rendimientos por aranzada. Poco tienen que ver los majuelos bien labrados de principios de siglo, en que la cepa se cotiza hasta 4 y 5 reales, con los que abundan gramosos y descuidados entre 1825 y 1830, pagados a poco más de dos o tres reales por cepa. Las 115 aranzadas (43,92 ha) que posee en propiedad Miguel Moyano en 1801 son, además de una de las más extensas labranzas, un ejemplo de esmerada atención vitícola ${ }^{1061}$.

Los tasadores que elaboran el inventario de bienes de los citados vecinos de Serrada cifran la última cosecha en 2.700 cántaras, lo que significa unas producciones de 23,47 por aranzada o, si se quiere, 61,43 cántaras o 9,83 hl por ha ${ }^{1062}$. Para llegar a estas cifras de vino se necesitan 1.413 kilos de uva por ha, cantidad que se estima superior a las cosechas medias en este tiempo.

Cuadro 100. Explotación vitícola de Miguel Moyano y Beatriz Rodríguez.

Serrada, año 1801. (115 aranzadas)

\begin{tabular}{lccc}
\hline Pago o nombre del majuelo & No de cepas & Precio tasado por cepa (en reales) & Valor de venta (en reales) \\
\hline Valdesuero & 10.163 & 8 & 81.304 \\
Valderramos & 11.750 & 5 & 58.750 \\
Bolo & 3.770 & 5 & 18.850 \\
Moya & 5.908 & 4 & 23.632 \\
Blanquizal & 4.173 & 7 & 29.211 \\
Gigante & 2.127 & 4 & 8.508 \\
Pinar & 1.498 & 4 & 5.992 \\
Colgadero & 1.744 & 3 & 5.232 \\
Valondo & 7.181 & 3 & 21.543 \\
\hline TOTAL & 48.314 & 5,23 & 253.022 \\
\hline
\end{tabular}

Fuente: A.H.P.V. Protocolos Notariales. Elaboración propia.

1060 PAN-MONTOJO, J.: La bodega del mundo. La vid y el vino en España (1800-1936). Alianza, 1994, pág. 385.

${ }^{1061}$ A.H.P.V. Pt. 8228, fol. 61, año 1801.

${ }^{1062}$ En realidad, se trataría de cifras ligeramente superiores si se atiende a los majuelos en producción, pues el consignado al pago de "el Gigante," de 2.127 cepas, es una vińa nueva de 5/6 hojas y está iniciando su ciclo productivo. Los datos, como los siguientes aportados, deben enmarcarse en periodos excepcionales, pues no se debe olvidar que el Catastro de Ensenada refiere producciones de 20 cántaras en aquellos majuelos de primera calidad; 14 en los de segunda y tan sólo 8 en los de tercera. 
Cifras similares se encuentran en 1824. En una venta para satisfacer mandas testamentarias, Catalina Martínez vende un majuelo de 1.074 cepas vivas (alrededor de una hectárea) a Gabriel Román ${ }^{1063}$. Al estar el fruto pendiente, se estima en 68 cántaras de mosto $(10,88 \mathrm{hl})$, derivadas de una producción aproximada de 1.564 kilos de uva. La tasación de cada cepa a 4,5 reales, en unos años en los que la tónica dominante es de precios sensiblemente inferiores, viene a confirmar estos rendimientos cercanos a los $10 \mathrm{hl}$, derivados de producciones aproximadas de 1.500 kilos de uva por hectárea. Son propios de ańos excepcionales o majuelos de elevada calidad que salen a 1,5 moyos por aranzada ${ }^{1064}$. No se puede ignorar, por otra parte, la otra cara de la moneda. En los años en que agoniza el Antiguo Régimen, el viñedo en estas zonas no presenta su mejor coyuntura. La labranza a continuación estudiada es un claro ejemplo de ello.

- El ejemplo de una explotación vitícola en crisis a finales del Antiguo Régimen

La hacienda que se deshace a la muerte de Manuel García y Gregoria Alonso se compone de 7 majuelos, que suman 11,1 aranzadas y 4 tierras eriales de antiguas viñas con cerca de diez obradas en pagos de segunda y tercera ${ }^{1065}$. Es probable que estos "majuelos eriales y ya sin cepas" o la "viña erial... con cepas perdidas" o aquella "poblada de pimpollos" hubieran sido replantados si no fuera por el estancamiento vitícola que vive el sector en estos ańos. No es necesario apuntar que estos eriales, que vuelven a ser dominio de pimpollos en los pagos de "Las Cortas" o "Arenosas", representan las máximas roturaciones que en la segunda mitad del XVIII extienden el viñedo por terrenos casi estériles. Como en tantos otros ciclos, estas circunstancias llevan a muchas haciendas de pequeños campesinos a la desaparición, o al límite de su viabilidad, en la mayor parte de los casos. Los últimos años de lo que se puede entender como el final de Antiguo Régimen, coincidente con la segunda mitad del reinado de Fernando VII, acusan la reducción de los precios y sólo hacendados con posibles pueden iniciar el liberalismo económico con garantías de seguir adelante. El caso que ocupa es representativo de los primeros. Dispone de 35 aranzadas de viñedo en propiedad y algunas tierras arrendadas al poder señorial o eclesiástico de la villa, a tenor de las distintas fanegas de yeros, guisantes, cebada o morcajo, "malo y con mucho bon", que se tasan en el inventario de bienes ${ }^{1066}$.

La heredad es labrada por un par de bueyes "pequeños de labranza," vendidos para pagar deudas por 850 reales y "una pollina vieja" que, con sus buches de cría, aportarían algunos reales a la bolsa familiar. Un lagar de mano al Barrio Nuevo y una cuba en la bodega debajo de su vivienda en la calle la Cilla completan, amén de otros bienes específicos para el trabajo de los majuelos, como "un azadón de pico pequeño", "un arado viejo con su reja pequeña" o "un legón," los bienes muebles propios del trabajo de las cepas. En cuanto a las viñas, estas son sus extensiones y tasaciones.

1063 A.H.P.V. Pt. 8229, fol. 1195-197, año 1824.

${ }^{1064}$ Recuérdese que un moyo de mosto o vino son 16 cántaras de 16 litros cada una, que hacen 256 litros o 2,56 hl para producir esta cantidad de vino se necesitan 368,34 kilos de uva, siguiendo la equivalencia de que de cada dos arrobas (23 kilos) se obtiene una cántara (16 litros), con un rendimiento de la uva del 0,695\%. Cuando se manifiesta durante buena parte del XVII y XVIII que los viñedos vienen a dar a moyo por aranzada, se deben tener presentes estas cantidades que son indicativas de unas producciones que no llegan al kilo por cepa, pues se quedan en 0,87 kilos cada una.

${ }^{1065}$ La situación familiar no es fácil: su hija Antonia ha muerto, el hijo varón ha emigrado a la Habana y, por cuestiones que se desconocen, la hacienda no la labra Juan García, marido de la también hija María García. (A.H.P.V. Pt. 8229, fol. 6-14, año 1821).

1066 El "bon" o carbón y tizón del trigo es una enfermedad causada por hongos que se controla en la actualidad mediante fungicidas aplicados a las semillas. Es la primera mención de esta enfermedad del cereal que se encuentra en estos siglos, y que prueba su existencia al tiempo que alerta de las posibles disminuciones de producción, caso de no sulfatar convenientemente el grano que sembrar. 
Cuadro 101. Localización, extensión y tasación de los bienes raíces de Antonio García y Gregoria Alonso. Serrada, años 1817-21

\begin{tabular}{lllrcc}
\hline Propietarios & Pagos & Término & No de cepas & $\begin{array}{c}\text { Precio por } \\
\text { cepa } \\
\text { (en reales) }\end{array}$ & $\begin{array}{c}\text { Valor } \\
\text { en venta } \\
\text { (en reales) }\end{array}$ \\
\hline Antonio García y Gregoria Alonso & Pinar & Serrada & 1.449 & 2.5 & 3.622 \\
Antonio García y Gregoria Alonso & Mercader & Serrada & 651 & 1.5 & 976,5 \\
Antonio García y Gregoria Alonso & Mercader & Serrada & 872 & 2 & 1.724 \\
Antonio García y Gregoria Alonso & Mercader & Serrada & 1.070 & 2.5 & 1.675 \\
Antonio García y Gregoria Alonso & Raya & Serrada & 800 & 1.5 & 1.200 \\
Antonia García. (hija difunta) & Mercader & Serrada & 685 & 2 & 1.370 \\
Antonia García. (hija difunta) & Retamal & Ventosa & 1.081 & 3.243 \\
Antonia García. (hija difunta) & Las Cortas & Villanueva de Duero & Viña erial 7 obradas & - & 1.050 \\
Antonia García. (hija difunta) & Las Cortas & Villanueva de Duero & Viña erial 3 obradas & - & 450 \\
Antonia García. (hija difunta) & Arenosas & Villanueva de Duero & Viña erial 3 obradas & - & 60 \\
\hline TOTAL & - & 6.608 & 2,3 & 15.370 \\
\hline
\end{tabular}

Fuente: A.H.P.V. Protocolos Notariales. Elaboración propia

A tenor de los precios pagados por cepa, conviene advertir que los majuelos, valorados a 1,5 reales, o son viejos -así se hace constar en el citado al pago del Mercader de 651 cepas- o de escasa producción. En estos años, el precio oscila entre 2 y 2,5 reales por cepa, lejos de los 3,5 y 4 reales que constan en ventas efectuadas desde 1797 a 1816. Tanto los majuelos abandonados, propiedad de Antonia García, como la inexistencia de nuevas plantaciones que los sustituyan, parecen certificar la crítica situación y rentabilidad por la que pasa el cultivo en estos años, a pesar de encontrarse algunas de las plantaciones del ejemplo tomado en terrenos de escasa calidad. Estas circunstancias y la debilidad de las cosechas obtenidas, impiden generalizar los rendimientos al resto de heredades vitícolas, pero los distintos trabajos efectuados en ellas, durante una serie continuada de cinco años, acerca a la verdadera dimensión del cultivo en estas villas al norte de Medina.

En el cuadro adjunto puede comprobarse cómo, entre 1818 y 1821, a siete reales cántara, o se cosecha a 0,6 moyos aranzada (221 kilos/aranz. o $577 \mathrm{~kg} / \mathrm{ha}$ ) o los gastos superan a los ingresos, toda vez que los jornales se han incrementado notablemente respecto a los existentes un cuarto de siglo antes ${ }^{1067}$. Se vuelve a demostrar que, si la cosecha no llega al moyo por aranzada (388 kilos de uva/aranz. o $964 \mathrm{~kg} / \mathrm{ha}$ ), solo en ańos de altos precios se obtienen beneficios. Este ejemplo recuerda al de Pedro de Íscar, un siglo antes, con majuelos en similares pagos y escasas producciones por aranzada, en las que del viñedo sólo se saca el jornal que cada cual invierte en su propiedad.

El cuadro, no obstante, refleja de primera mano cuántos trabajos continúan vigentes a comienzos del XIX. Desde los excavos a partir de noviembre hasta las tardías vendimias de octubre, los majuelos siempre necesitan abundante laboreo de legón o arado, prueba evidente de cómo la expansión del viñedo fue unida a la demográfica y a la económica. En los variables precios de las cántaras se ponen todas las esperanzas de una vida más desahogada, aunque pedriscos, heladas o vinos invendibles se encarguen en muchas campañas de que sólo sea un deseo de cara a la siguiente cosecha. Pero lo cierto es que el viñedo, en esta villa, mantiene a la población laboriosa, desde la media docena de grandes hacendados, la otra media de medianos labradores o los cien jornaleros que viven trabajando en las tierras y vińas de estos propietarios.

${ }^{1067}$ Recuérdese que, en la primera mitad del siglo, el podador cobraba 2,5 reales/día y un obrero de azadón o vendimiador salía por dos reales. En la segunda mitad, especialmente en el último tercio, el podador ya se ajustaba, generalmente, a tres reales y los obreros no bajaban, en la mayor parte de los casos de los casos, de los 2,5. Tras la crisis y guerra ya estudiadas, los jornales se sitúan, a partir del segundo tercio del XIX, en torno a los tres y cuatro reales, dato muy a tener en cuenta en el incremento de los costes de producción. 


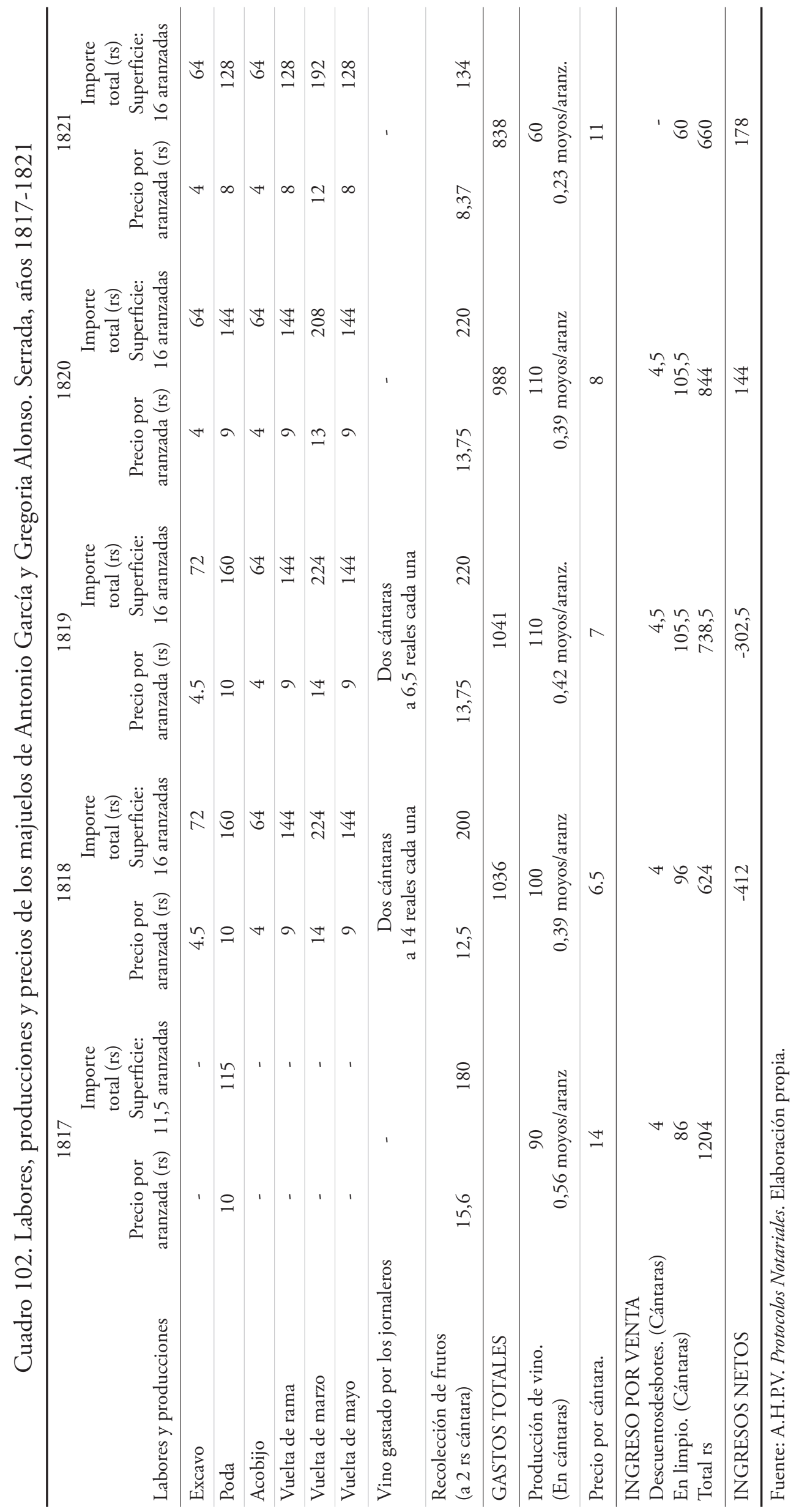


Las labores siguen fieles a la costumbre y al saber de los antiguos ${ }^{1068}$. Iniciados los primeros fríos invernales, se alumbran o excavaban las cepas para acto seguido proceder a su poda y posterior acobijo. ${ }^{1069}$ Estas tareas eran especialmente duras y exigentes en mano de obra. El salario de 4 y 4,5 reales, pagado por aranzada en excavo y acobijo, viene a coincidir regularmente con una día de trabajo, mientras que la poda de sarmientos, realizada con la podadera, no suele bajar en majuelos verdejos, con abundantes cortes por cepa, de dos a dos días y medio por aranzada. Las tres vueltas de arado, realizadas en diciembre/febrero, marzo y mayo, representan la llave para obtener una buena $\operatorname{cosecha}^{1070}$.

En el caso tratado, a tenor del precio tasado, estas labores fueron hechas por yunteros que cobran, teniendo en cuenta el precio y superficie labrada, el doble de un jornal, dada la aportación de brazos, arados y animales. Aunque se carece de documentación sobre la reglamentación y acuerdos entre las partes contratantes, se cree que estas labores complementan los ingresos de sus labranzas, sin descartar que algunos de ellos labren a jornal o con otro tipo de acuerdos, en los que puede entrar la pisa de sus mostos. Estos pequeños labradores, como en décadas anteriores, alquilan sus yuntas en las vińas de las órdenes religiosas o particulares laicos o eclesiásticos que no llevan directamente el laboreo de sus propiedades.

En el anterior epígrafe se cifraban en el año 1824 en 40 reales por aranzada los trabajos de excavo, poda, arada de invierno y de marzo, cifra idéntica a la reflejada en el cuadro anterior si se descuenta la vuelta de rama, que por otra parte no siempre se daba, a tenor de la documentación consultada. Salvo los grandes hacendados que superan las cien aranzadas y los jornaleros que nunca

${ }^{1068}$ Recuérdese que, con esta labor, denominada también alumbramiento y realizada generalmente en diciembre, se rompía el castro de las cepas, dejando al descubierto larvas e insectos, saneándola de las malas hierbas otoñales y generando una pequeña poza en torno a la misma que favorecía el filtrado máximo de las aguas invernales, óptima reserva para el arbusto en los periodos de aridez estival. La labor era especialmente dura si la primavera había sido lluviosa y el verano y otońo seco, pues la aspereza y endurecimiento de las gravas hacían especialmente difícil introducir el legón por debajo de sarmientos y varas para descubrir el pie en todo su alrededor. La llamada vuelta de rama, que en el cuadro figura posterior al acobijo, pero que se ejecutaba antes de la poda, solía hacerse en el mes de diciembre. Consistía en la traza de dos surcos con cerro en medio, siguiendo los ahitines o interlíneos oblicuos que forman los líneos de cepas plantados a marco real. Perseguía romper el terreno para facilitar la penetración de las aguas invernales y removerlo para posteriores laboreos. Esta tarea era especialmente dura en majuelos generosos de leńa, al enredarse al paso del arado con caballerías y hombres. Estos debían protegerse las piernas con pańos recios y cueros para no dejar pantalones y pellejos entre las varas de las cepas.

1069 Como en anteriores siglos se ha estudiado, la poda del arbusto se realizaba con la podadera manual. Su manejo necesitaba de la pericia del podador, amén de experiencia y técnica en la ejecución de los cortes. El jornalero sujetaba con una mano el sarmiento a la par que con la podadera lo cortaba. Las cepas verdejas, con abundantes y enredados vástagos, dificultaban la operación, dado que estos sólo podían ser seccionados con dicho instrumento uno a uno. La vuelta de marzo se ejecutaba a dos manos y tres o cuatro rayas por calle, dejando, por tanto, tres cerros en aquellas en que se pasaban cuatro rayas. Tras esta labor, se procedía al acobijo de las cepas que perseguía protegerlas mediante la acumulación de tierra en torno a las mismas. En ocasiones tan solo quedaban las varas y pulgares al aire. Por último, la vuelta de mayo se realizaba, como las anteriores, a dos manos. El arado rajaba los cerros existentes, dejando, en el caso de calles con tres cerros, dos tras el paso de las mulas o bueyes. Pero las labores de legón o azada podían perfectamente proseguir, pues con los pámpanos alargándose se efectuaba el reacobijo, en el que se repasaba el acobijo para evitar en lo posible evaporaciones estivales que mermaran la disponibilidad hídrica, al tiempo que se anulaba el crecimiento de forraje. Legones, arados y brazos debían tener mullido el terreno y libre de malas hierbas. Entre estas era la grama la principal enemiga de cepas y cavadores. Por lo que relatan obligaciones testamentarias, el desgramado de las viñas era tan difícil como costoso, y en las ventas en que se especifica el estado gramoso en majuelos, la tasación o venta de ellos dista mucho de presentar los valores medios de sus linderos bien labrados.

${ }^{1070}$ Es de observar que la vuelta de rama y la de mayo se tasan a 5 reales menos por aranzada que la vuelta de marzo. Se explica porque el arado debía hacer menos rayas en cada calle, pues, como ya se ha explicado, en la vuelta de mayo únicamente se abrían los cerros formados en marzo Esta vuelta, sin embargo, se obligaba como la más completa, arándose los majuelos con tres o cuatro rayas por calle. 
rebasan la docena, predominan las pequeñas propiedades vitícolas como la analizada, donde sus titulares son sus trabajadores directos. Manuel García no podría atender, con su pareja de pequeños bueyes, más allá de las treinta y cinco aranzadas que explotaba en propiedad ${ }^{1071}$. Piénsese que, como se ha estudiado en el siglo XVIII, las labores de brazo, incluida vendimia, llevaban 7,7 jornales aranzada y año. Si se añaden las vueltas de arado de noviembre a junio, cada aranzada lleva entre 8 y 9 jornadas de trabajo. La mayor parte de estas pequeńas heredades suelen llevar algunas tierras de pan y barbecheras que también han de atender en estos meses. Aunque algún hijo desde temprana edad sigue el camino del padre, el recurso a jornaleros o familiares con menos aranzadas es obligado en los meses de mayor actividad ${ }^{1072}$. El vińedo, mientras mantiene la salida de sus caldos, ocupa en esta comarca a una numerosa población, sea propietaria o jornalera, con escasas semanas de paro estacional, pues los meses en que las cepas no requieren cuidados, las tierras de pan y la época de siega y trilla reclama obligatoriamente a jóvenes y adultos.

Aunque sea una cuestión menor, llama la atención el gasto de dos cántaras de vino por parte de los jornaleros. En ocasiones, se obliga el propietario a este abastecimiento y en otras, aquellos prefieren que se les reintegre su importe en el jornal. Por lo anotado, ambas circunstancias concurren en este caso, dado que en los años 1820 y 1821 no se especifica vino alguno. De la misma manera es interesante la consignación de los gastos de vendimia, tasados a dos reales la cántara. Se explica por tratarse de una labranza sin presencia de titular directo, en que estas operaciones se encomendaban al cuidado de algún otro labrador, sin descartar la contratación de cuadrillas del norte al cargo de mayorales que se responsabilizan de toda la labor de recogida, pisado y encubado de los mostos, sin descartar los acuerdos entre familias labradoras para realizar la vendimia y pisado de forma conjunta y repartirse, posteriormente, gastos y mostos ${ }^{1073}$.

${ }^{1071}$ Ya se ha referido en otros apartados la eterna disputa con los bueyes y mulas como protagonistas. En 1771, un campesino de la Armuña (Salamanca) manifestaba: "no es posible arar con yunta de bueyes mas alla de 25 aranzadas de tierra, si bien pueden alargarse a 40 aranzadas si se utilizan yuntas de mulas". (A.H.N. Consejos, leg.: 1841, citado por Margarita Ortega: La lucha por la tierra en la Corona de Castilla. M.A.P.A., 1986, pág. 177). En esta comarca ninguna familia labradora careció de alguna pareja boyal hasta finales del XIX en que los mulos, aunque notoriamente presentes desde el XVIII, acabaron por dominar enteramente la tracción animal en lo que respecta al trabajo de la tierra. A comienzos del XX, son contadas las parejas de bueyes que siguen tirando del arado en las tierras más recias de estos términos. $Y$ en relación con la superficie cultivada por unos y otros, hay contrastados testimonios de que, aun a comienzos de los ańos cuarenta del siglo XX, se labraba con las tres vueltas citadas y experimentados jornaleros o afanosos labradores llegaban a arar hasta sesenta y setenta aranzadas de viña, aunque lo más generalizado era no sobrepasar las cincuenta aranzadas aradas con ganado mular.

1072 Distintos estudios coinciden con los datos analizados al estimar entre 25 y 30 días el número de jornales que puede llevar una hectárea de vińa en el antiguo régimen de diciembre a junio. Con estas cifras un solo titular labraría con bueyes de 6 a 7 ha y buena parte de los medianos y grandes labradores deberían recurrir a jornaleros y criados para completar el déficit de brazos existentes en las familias propietarias, en que la existencia de hijos varones se tornaba fundamental para proseguir la labranza. De todas maneras no conviene olvidar que lo importante no era lo mucho o poco que cada cual podía abarcar con su yunta, sino la disponibilidad de tierra en propiedad o renta que cada labrador de hecho poseía. Con todo, se estima que entre 750.000 jornales eran necesarios para atender debidamente las 30.000 ha de vińas que aproximadamente se extendían por esta comarca en la segunda mitad del siglo XVIII, dando trabajo a más de 4.000 jornaleros. Hilarión Pascual Gete: "Viñedos de la antigua Tierra de Medina del Campo". Tesis de Licenciatura, inédita, copia consultada en A.H.P.V., sig. 2108. Tanto en estos aspectos como en los anteriores, tratados de labores y prácticas de cultivo pueden consultarse, además de la obra citada: A.M.D. "De la agricultura del partido de Medina del Campo”, Semanario de Agricultura y Artes dirigido a los Párrocos, ańo 1801, no 259 (tomo X); García de la Puerta, Agustín: Tratado práctico del cultivo de la vid o arte de hacer el vino. Valladolid, 1836-1842, 2 vols.; Huetz de Lemps, Alain: Vignoles et vins du nord-ouest de l'Espagne. Institut de Géographie. Faculté de Lettres, Bordeaux, 1967, 2 tomos.

${ }^{1073}$ Estas prácticas solían ser habituales entre los pequeños propietarios, pegujaleros o jornaleros con algunos bienes. Tanto en las vendimias como en las siegas se echaban mutuamente una mano, colaborando en las distintas tareas y utilizando de forma común eras o lagares. En el caso de las vendimias y pisados de los mostos, estas tradiciones colectivas prosiguieron hasta entrado el siglo XX en que la mecanización y la comercialización de las uvas pusieron fin a la transformación propia de los mostos. 
Los relativos a la propia vendimia son difíciles de concretar en reales por aranzada, pues a la variabilidad de cosechas que cada una de estas produce según su estado, se suma el propio carácter familiar que presenta esta tarea en las pequeñas propiedades. No obstante, el apunte de dos reales por cántara es un dato que hay que valorar y del que se derivan unos 12.5 reales por aranzada en las tareas de recogida y pisado de la uva ${ }^{1074}$. Estudios que han valorado estas tareas en estos ańos finales del viejo régimen consignan salarios de 2 reales diarios entre los vendimiadores vallisoletanos hasta 1809 y entre 3 y 4 reales, en la tercera década del XIX ${ }^{1075}$.

- La atonía del sector vitícola a fines del primer tercio del siglo XIX

A diferencia de las tierras de pan en las que se han registrado tímidos avances como el abonado o el incremento de leguminosas, en el vińedo continúan los trabajos sin apenas variaciones. Muchas de estas fragilidades comienzan en las mismas vendimias, realizadas por muchos pequeños productores conforme a su capacidad de tiro, brazos y transporte, lo que ocasiona que la uva pueda estar más de un día en los cestos a la espera de su acarreo a los lagares. Abundan también los pequeños lagares de mano, distantes de las bodegas, donde los mostos reposan más tiempo del aconsejable, en perjuicio de una buena fermentación ${ }^{1076}$.

Tanto en estos, como en las nuevas construcciones de aquellos de viga, directamente conectados a las bodegas y cubas, por lo general en manos de los grandes hacendados, no se expresan innovaciones o cambios. En 1803, Francisco Moyano, por ejemplo, concierta la construcción de uno de estos lagares ${ }^{1077}$. Era imprescindible que estas construcciones estuvieran preparadas antes de la vendimia. Esta actividad ponía en pie a toda la población de estas villas, desde niños a ancianos, para acabar lo más pronto posible la recogida de la cosecha y evitar que las lluvias y fríos de octubre perjudicaran el fruto, lo cierto es que, desde siglos anteriores, se concertaba con jornaleros foráneos parte de estos trabajos. Tanto en la vendimia como sobretodo en la mostería o pisado y trasiegos de los mostos, son conocidos los conciertos con caporales de las montañas del norte que proveían cuadrillas enteras que ellos gobernaban y dirigían, de acuerdo las necesidades de los grandes cosecheros. Dada la seguridad que unos y otros deben tener en unas semanas críticas, se pactan y escrituran en ocasiones tareas y conciertos, generando no poca agitación cuando o se retrasan las partidas de mosteros o existe falta de acuerdos.

Similar continuidad se observa en las bodegas y cubas. Muchas economías no dan para la renovación de la madera y las cubas, en ocasiones, distan de presentar su mejor cara. Proliferan las de 12, 14 o 16 palmos, pero tanto en sus ventas como en la tasación que se hace de ellas en repartos de herencias, existen diferencias de precio entre unas y otras del $500 \%{ }^{1078}$. En la mayor parte de los casos, suele indicarse su mayor o menor grado de vejez o deterioro. Aun faltan muchas décadas para que se inicien concentra-

${ }^{1074}$ En 1814, por poner una fecha coetánea del ejemplo analizado, Domingo Caunello, vecino de Almaraz, concejo de Miranda, en el Principado de Asturias, da poder escritural el 29 de septiembre en Serrada denunciando que "estando... cinco años a esta parte... como mayoral de la tira del mosto en la recolección de vendimias en la villa de Matapozuelos, sin causa ni razón alguna, la actual xusticia de dich a villa a querido despojar y despojado al otorgante al dicho cargo..." (A.H.P.V. Pt. 8229, Serrada, fol. 68).

1075 LLOPIS AGELÁN, E.: "Algunas consideraciones acerca de la producción agraria castellana en los veinticinco últimos años del Antiguo Régimen”, en Ángel García Sanz y Ramón Garrabou, eds.: Historia agraria de la España contemporánea, vol. 1, Ed. Crítica, 1985, pág. 149-150.

${ }^{1076}$ Estos lagares de mano se ubicaban en corrales o sotechados propiedad de pequeños productores o jornaleros que pisaban su uva y trasladaban posteriormente los mostos a sus bodegas o a cubas alquiladas. Con un poco de corral no rebasan en venta más allá de 1.500 reales de 1815 .

1077 A.H.P.V. Pt. 8228, fol. 1, año 1803. 
ciones comerciales y productoras que incorporen nuevos sistemas de prensado, encubado y filtrados de los mostos. Consecuencia de todo ello son las diferencias de precio que se han encontrado en distintas partidas en el mismo lugar y año, en torno al 30 y $40 \%$, descontando los casos en que vinos picados arruinan cualquier expectativa de venta. La estabilidad en los precios se torna así prácticamente utópica en tanto factores como la mayor o menor abundancia de cosecha, calidad del añejamiento y coyuntura económica, hacen subir o bajar el precio de las cántaras. A la variabilidad de los precios, de acuerdo a los factores apuntados, se debe añadir el estancamiento general que sufren en las últimas tres décadas del XVIII, contribuyendo a la decadencia del cultivo en las áreas más panificables de la Tierra de Medina.

La Pragmática de 1765 que liberaliza el precio de los granos acentúa el desequilibrio entre los precios de las fanegas de trigo y las cántaras de vino. Pero en estas villas, a pesar de la bajada de precios y de los problemas excedentarios que afectan al sector, es difícil cambiar de rumbo. Las distintas posturas y remates públicos, recogidos en la gráfica adjunta, tienen al vińedo como centro de atención, sea en las tabernas o corredurías, sea en el pasto de sus hojas y pámpanas. Tras las desorbitadas subidas que se detectan durante la invasión napoleónica, los precios se mantienen bastante altos durante casi un quinquenio, duplicando incluso el de algunas campańas de los primeros ańos del siglo, pero sólo es un espejismo. Desde 1815, el descenso de precios y de rendimientos netos es generalizado y, en los primeros ańos de la segunda década, los precios del vino se hunden a niveles de décadas pasadas. El descenso de los precios continúa hasta 1830-32 en que parece acabarse esta etapa de crisis ${ }^{1079}$. No es casualidad, como se apuntaba páginas atrás, que, en el análisis de las distintas posturas y remates de la taberna y aguardientes, estos últimos experimentan un notable crecimiento después de la guerra de la Independencia. Frente a los remates de las tabernas que apenas superan los 4.000 reales en 1814, manteniendo valores similares a décadas anteriores, los derechos del aguardiente, que generalmente no rebasaban los 600 reales, se cotizan en 1814 en 1.200 , prueba fehaciente de la búsqueda de nuevas salidas y mercados que alivien la difícil coyuntura.

Las comarcas catalanas son, en este sentido, un ejemplo de cómo la especialización vitícola, el espíritu capitalista y las ventajas del comercio colonial transforman en riqueza lo que en otras zonas representaba un freno al desarrollo ${ }^{1080}$. En nuestro caso no se alcanzará ni mucho menos tal grado de superación de la adversidad, pero la crisis tampoco acaba con estos viñedos a pesar de que el vino, como el trigo, baja de precio de forma notable en toda esta vieja Castilla, según testifican los datos sacados a la luz del Convento de San Joaquín y Santa Ana de Valladolid o la fabrica de la iglesia de Fuentelcésped, por poner ejemplos relatados en solventes estudios ${ }^{1081}$.

Esta atonía se refleja, como no puede ser de otra manera, en el precio de cada aranzada vendida. A pesar de las dificultades en determinar precios medios, dados los múltiples condicionantes de suelo, edad, conservación y productividad de cada una de sus cepas, se ha constatado que, si en buena parte de la segunda mitad del XVIII se vende cada cepa a dos y tres reales ( 840 y 1.260 reales por aranzada respectivamente), en los quince primeros del XIX abundan compras que suben a 3,5

${ }^{1078}$ La mayor parte de los "vastos o cubas" son de roble, asentados sobre basas o "poínos" de pino, además de cubetos u otros depósitos menores. Las cubas se diferencian en cuanto a su distinta capacidad y estado. Una cuba usada de diez palmos, que se tasa con una cavidad de doscientas cántaras (3.200 litros), puede variar su precio entre los 420 reales o los escasos 200. En 1815 se encuentran tasaciones de otras más grandes, de catorce y dieciséis palmos, reforzadas con "tres arcos de yerro" y que igualmente oscilan entre 370 y 500 reales. (A.H.P.V. Pt. 8230, Serrada).

1079 PAN-MONTOJO, J.: La bodega del mundo. La vid y el vino en España (1800-1936). Alianza, 1994, pág. 49.

${ }^{1080}$ LLOPIS AGELÁN, E.: Algunas consideraciones acerca de la producción agraria castellana en los veinticinco últimos años del Antiguo Régimen, pág., 129 y ss. En "Historia agraria de la España contemporánea. 1. Cambio social y nuevas formas de propiedad (1800-1850)”, eds. Ángel García Sanz y Ramón Garrabou, Editorial Crítica, 1985.

${ }^{1081}$ Ibídem. 
y 4 reales por cepa, para descender a precios de dos, dos reales y medio y tres desde 1817 a 1830 . Si a esto se une que el precio de los salarios se mantiene en niveles de 4 y cinco reales diarios, duplicando los dos y tres de décadas pasadas, la situación de las pequeñas heredades vitícolas es tan crítica que muchas de ellas no llegan a ver la muerte de Fernando VII.

Cuadro 103. Ejemplos de precios de venta de vino entre particulares Serrada.

1797-1830. En reales por cántara

\begin{tabular}{lcccccccccccccc}
\hline Años & 1797 & 1813 & 1815 & 1816 & 1817 & 1818 & 1819 & 1820 & 1821 & 1823 & 1825 & 1826 & 1829 & 1830 \\
\hline Reales & $8 / 10$ & 30 & $10 / 16 / 18$ & 14 & 14 & $6.5 / 11 / 14$ & $6.5 / 7$ & $5 / 8$ & 11 & 8 & 8 & 8 & 10 & 9.5 \\
\hline
\end{tabular}

Fuente: A.H.P.V. Protocolos Notariales. Elaboración propia.

Cuadro 104. Posturas y remates públicos en Serrada, ańos 1799-1835. En reales

\begin{tabular}{|c|c|c|c|c|c|c|c|c|c|c|}
\hline Años & $\begin{array}{r}\text { Ramo } \\
\text { de la } \\
\text { taberna }\end{array}$ & $\begin{array}{r}\text { Ramo } \\
\text { del } \\
\text { aguardiente }\end{array}$ & $\begin{array}{r}\text { Correduría } \\
\text { y fiel } \\
\text { medidor }\end{array}$ & Abacería & $\begin{array}{r}\text { Cabezas } \\
\text { de } \\
\text { rastreado }\end{array}$ & $\begin{array}{r}\text { Arriendo de } \\
\text { las hierbas } \\
\text { de las eras }\end{array}$ & $\begin{array}{r}\text { Noveno } \\
\text { del mosto y } \\
\text { menudos }\end{array}$ & $\begin{array}{r}\text { Alcabala } \\
\text { del } \\
\text { viento }\end{array}$ & $\begin{array}{l}\text { Pámpana } \\
\text { y hoja de } \\
\text { las vińas }\end{array}$ & $\begin{array}{r}\text { Pastos } \\
\text { dehesa de } \\
\text { San Martín }\end{array}$ \\
\hline 1799 & - & - & - & - & - & 280 & - & - & 1.700 & - \\
\hline 1800 & 2.050 & 600 & 26.033 & 5.200 & 1.500 & 330 & & 2600 & 1.000 & 3.025 \\
\hline 1801 & 1.600 & 550 & 25.120 & 4.050 & 1.525 & 400 & 3.100 & 2.200 & 1.300 & 3.025 \\
\hline 1802 & 2.350 & 400 & 23.020 & 3.500 & 1.460 & - & 5.100 & 2.000 & 750 & 3.025 \\
\hline 1803 & 2.460 & 750 & 23.050 & 4.020 & 1.350 & 330 & - & 2000 & 900 & 3.025 \\
\hline 1804 & 2.160 & 720 & 29.000 & 3.500 & 1.170 & - & - & 2900 & - & - \\
\hline 1805 & - & - & - & - & - & - & 3.950 & - & - & - \\
\hline 1806 & - & 1.690 & 25.000 & 2.800 & - & - & 2.570 & - & - & - \\
\hline 1807 & 1.200 & 600 & 19.000 & 3.000 & 920 & - & - & 2.110 & 1.025 & - \\
\hline 1808 & 1.240 & 620 & 16.000 & 3.100 & 890 & - & - & 1.950 & 900 & - \\
\hline 1809 & - & - & - & - & - & - & - & - & - & - \\
\hline 1810 & - & - & - & - & - & - & - & - & - & - \\
\hline 1811 & - & - & - & - & - & - & - & - & - & - \\
\hline 1812 & - & - & - & - & - & - & - & - & - & - \\
\hline 1813 & - & - & - & - & - & - & - & - & - & - \\
\hline 1814 & 1.000 & - & 17.700 & 960 & 850 & - & - & 1.450 & - & - \\
\hline 1815 & 1.840 & 1.200 & 11.000 & 2.330 & 112 & - & - & 3.550 & 1.500 & - \\
\hline 1816 & 1.800 & 2.500 & 14.050 & 3.220 & 1.270 & - & - & 1.700 & 1.950 & - \\
\hline 1817 & 820 & 1.050 & - & - & - & 505 & - & 1.050 & 1.600 & - \\
\hline 1818 & - & - & 16.500 & 2.520 & - & - & - & - & 1.700 & 2.800 \\
\hline 1819 & 1.580 & 620 & - & - & - & - & - & - & 1.700 & 1.670 \\
\hline 1820 & 920 & 700 & - & - & - & - & - & - & - & - \\
\hline 1821 & & - & 14.021 & - & - & - & - & - & - & - \\
\hline 1822 & - & - & - & - & - & - & - & - & - & - \\
\hline 1823 & - & 1.000 & 12.440 & - & - & - & - & - & 1.100 & - \\
\hline 1824 & 663 & 320 & 21.000 & 710 & - & - & - & - & - & - \\
\hline 1825 & 800 & - & 25.200 & 1.230 & - & - & - & 2.000 & - & - \\
\hline 1826 & 1.420 & - & - & 3.000 & 1.220 & & 2.210 & 2.010 & 1.180 & - \\
\hline 1827 & 1.420 & - & 18.620 & & 820 & - & 2.360 & 2.505 & - & - \\
\hline 1828 & 1.900 & - & 13.770 & 1.800 & 1.210 & - & - & 2.510 & 800 & - \\
\hline 1829 & 1.040 & - & 19.210 & 1.990 & - & - & - & 2.300 & - & - \\
\hline 1830 & 730 & - & 16.365 & 2.300 & - & - & 1.260 & 2.000 & - & - \\
\hline 1831 & 1.300 & - & 11.810 & 2.960 & - & - & - & 1.815 & - & - \\
\hline 1832 & 805 & - & 1.6550 & 2.400 & - & - & - & 1.013 & - & - \\
\hline 1833 & - & - & - & - & - & - & - & - & - & - \\
\hline 1834 & - & - & - & - & - & - & - & - & - & - \\
\hline 1835 & - & - & 16.700 & - & - & - & - & - & - & - \\
\hline
\end{tabular}

Fuente: A.H.P.V. Protocolos Notariales. Elaboración propia 
No se quiere, sin embargo, cargar las tintas profundizando en más dificultades. Si ya se ha indicado que Medina-Alaejos reduce las plantaciones en beneficio del cereal, Serrada, Rueda o La Seca siguen apostando por el viñedo como centro de sus quehaceres. Son las cubas, las cántaras de vino y los majuelos los principales bienes que hacen subir las anotaciones que llevan a cabo tasadores de inventarios y herencias. El viñedo es el cultivo dominante en todas las propiedades particulares ${ }^{1082}$. Pese a las limitaciones que impone la tradición, la pobreza o la ausencia de nuevas técnicas en lo tocante a prensas, filtrados, clarificación y conservación, se está al final de un camino y en el inicio de nuevas expectativas. Se ha dejado deliberadamente para este final, antes de pasar a otro capítulo, la exposición de los fascinantes debates que, al final de este Antiguo Régimen, también se daban en torno al vino. La sabiduría ancestral frente a las nuevas ideas y saberes; los debates encontrados en torno al mosto que enfrentan a hacendados, médicos, farmacéuticos o físicos y que completan cuanto se ha comentado de estos vinos de hace doscientos ańos.

- Ni el huevo que flota ni el dichoso glaucómetro: Mis mostos son los mejores

El interés de los cosecheros por aumentar sus cosechas y la vigilancia de corredores y arrendatarios por evitar engańos han sido una constante durante siglos. Al final del Antiguo Régimen los deberes en las entregas diezmales inician un camino de progresivo deterioro hasta que sean definitivamente abolidas ${ }^{1083}$. Hasta entonces no son pocos los conflictos que acaban en las salas de justicia. El que se libra en la Chancillería de Valladolid en 1830 no tiene desperdicio ${ }^{1084}$. Acerca a las vendimias, fermentaciones y graduaciones que se hacen en esta comarca en este tiempo. Los testimonios encontrados de unos y otros testifican los debates entre la tradición y los nuevos avances que, como en tantos otros campos, también afectan al vino.

El proceso se inicia ante las sospechas de Sotero Rodríguez, arrendatario de los diezmos de Rueda, de los mostos que Carlos Bayón entrega tras la vendimia. Experimentados catadores, farmacéuticos, químicos y médicos se dan cita argumentando a favor y en contra, acercando a las teorías más avanzadas de la época sobre los procesos de fermentación. El propio médico de Serrada Juan Francisco Zamora, emparentado con importantes cosecheros de esta villa, y se supone buen conocedor de los procesos de vinificación, testifica en el litigio. Las palabras de los primeros alguaciles del juzgado testimonian las fundadas dudas de Sotero y las prácticas de los expertos por determinar si los mostos están o no aguados:

${ }^{1082}$ En el inventario realizado en 1777, a la muerte de Andrés García, se hacen constar entre sus bienes raíces 27,41 aranzadas y tan sólo 3,5 obradas de tierra; en 1791, al hacer lo propio con la hacienda de Baltasara Rodríguez y Manuel Moyano, una de las más importantes de la villa, se anotan hasta 20 majuelos que suman 160 aranzadas. Como tierras de sembradura figuran 23,5 obradas que, por lo demás, "son propias del dicho señor marqués de Torreblanca". A principios de siglo, en 1808, se tasan las heredades del otro "grande labrador" Miguel Moyano, tío por parte de padre del anterior y padre de los ya citados Buenaventura, Tomás y Francisco Moyano. Constan 115 aranzadas y nueve pedazos de tierra que suman 26,5 obradas.

A la muerte de José Obregón y María de Íscar Moyano, ocurrida en 1813 y 1815, se reparten sus bienes que agrupan 81,4 aranzadas de vińedo. Como los anteriores, obtenían la cebada y el trigo en las tierras arrendadas al marqués de Torreblanca. Y si esta es la tónica dominante entre los grandes hacendados, los porcentajes apenas varían en la mayoría de pequeños y medianos campesinos. Todos prefieren ver sus tierras plantadas de cepas y sembrar las ajenas de cereal, dependiendo de la fuerza de sus yuntas y de sus posibilidades económicas.

${ }^{1083}$ Las aportaciones decimales percibidas por la iglesia en un 70\%, dado que el Estado se quedaba con las tercias reales (2/9 partes), el excusado (importe de la mayor casa diezmera) y el noveno decimal (novena parte del diezmo, incorporada en 1800) tendrán sus días contados. A la tradicional resistencia a su pago se unirá la reducción a la mitad aprobada en Cortes de 1821. Anulada la medida en la reacción absolutista, su cobró se volverá en ocasiones difícil de ejecutar. A las leyes abolicionistas de los progresistas de Mendizabal sucedían las restauradoras de los moderados hasta que, considerado un anacronismo por casi todos, fueran abolidos sus restos en 1841 y sustituidos los ingresos eclesiásticos por partidas presupuestarias y contribuciones destinadas a satisfacer las necesidades del clero secular y de monjas. CANALES, E.: “Diezmos y revolución Burguesa en España”, en Ángel García Sanz y Ramón Garrabou, (eds.), Historia Agraria de la España Contemporánea, vol. I, Ed. Crítica, 1985, págs. 245-267.

${ }^{1084}$ A.R.Ch.V. Pleitos Civiles, Pérez Alonso (OLV), caja 1063.1. 


\begin{abstract}
"Dijeron haber hecho en la citada noche del mosto contenido en los jarros, el cual podía ser distinto del de los pellejos, se redujeron a las que podía suministrar el paladar, y a la observancia de que la espuma o balago quedaba sin deshacerse, de la cual dedujeron un argumento contrario acaso a los principios y reglas de la química que nunca habían saludado. Pero a la mañana siguiente que fue cuando se uso el graduador para cotejar dicho mosto con otra porción que se había cogido del pilo de Don Carlos Bayón, y de lo que corría por la viznera, notaron que esto último tenia, respectivamente, trece grados y medio y catorce, y lo primero solamente siete. Repitieron la operación del huevo, o por mejor decir la hicieron de nuevo; graduaron también el mosto de la cuba que conservaba lo diezmado por Manuel Delgado y por mi parte, y vieron que solo tenía cinco grados....”
\end{abstract}

El paladar de catadores, las verdades del glaucómetro y el tradicional e infalible método del huevo parecen corroborar el fraude. Aunque Carlos Bayón deja caer sobre el arrendatario que pudiera haber echado "ya de antemano alguna porción de agua", las preguntas que se formulan ante los procuradores elevan a mostos y vinos a lo más avanzado de la física y química del momento:

\footnotetext{
“¿De que el huebo echado en el mosto de mi diezmo se hundiese rápidamente, podrá deducirse en buena física que estaba mezclado con agua o que era de inferior calidad? ¿Está probado en debida forma que mientras que el mosto no esté mezclado con agua ha de resistir precisamente la sumersión de un huebo? ¿Las partículas o moléculas compactas que, según el contrario, resisten la sumersión del huebo, son de esencia para probar la bondad del mosto? ¿Sera malo precisamente el mosto que no las tenga?...

Las partículas o moléculas compactas, o lo que es lo mismo, las heces, el entrojamiento y la pócima que el mosto saca ordinariamente de la prensa serán, si se quiere, requisitos indispensables para formar un mosto que resista la sumersión del huebo per nunca podrán serlo para formar su bondad. Cuanto más puro y mejor es un liquido, menos resiste la sumersión de los cuerpos sólidos. En un espíritu de vino que tenga cuarenta grados calara el huebo al fondo con la mayor rapidez; en una de aguardiente que solo tenga veinte penetrara con mas pausa; en un vino común bajara con más lentitud; en un mosto que no tenga ni una gota de agua pero que se halle todo lo limpio posible se sumergirá necesariamente, aunque con menos precipitación. Y solo en un mosto que se halle sucio por la hez o pócima de que abunde será donde no penetre al fondo de la vasija...”
}

Nunca se sabrá si Bayón defendería lo contrario caso de no ser el acusado. Testigos relevantes opinan sobre el particular. Roque Alonso, profesor de farmacia, explica cómo el glaucómetro o graduador de mostos suele "bundirse con mayor facilidad en estos líquidos cuanto más densidad tengan o cuando contengan materias propias a la fermentación viscosa”. Juan Cipriano García, beneficiado parroquial, repara en los conflictos derivados de las entregas diezmales; el médico Andrés Albarrán reflexiona sobre las leyes de la hidrostática en relación con la inmersión del huevo; el cirujano de Serrada, anteriormente citado, manifiesta al respecto que "el mosto en cuestión hera muy inferior en grados a los otros con que fue cotejado y, si se quiere, que contenía mucha más porción de uno de los elementales principios cual es el agüero", y apunta como procedimiento exacto para determinarlo "el unico a propósito según el dicho de un sabio para saber y averiguar las cualidades del mosto que es el de ponerlo al tormento del fuego hasta descubrir sus elementales principios"1085.

Ante tales afirmaciones, el alegato en su defensa que hace Carlos Bayón, a lo largo de veinte largos folios de menuda letra, bien pudiera formar parte de un tratado de vinificación o del imposible arte de transformar el agua en vino. Postula con vehemencia que el mayor o menor hundimiento del huevo y del glaucómetro en sus mostos debe atribuirse "a que sin embargo de ser el mío mejor que los otros, no habia empezado la fermentación en estos y se hallaba avanzada en aquel”. Manifiesta que, al estar su mosto iniciando la fermentación, pasó a un estado más fluido y perdió la consistencia de sus azucares, provocando el hundimiento del huevo. Lo ratifica preguntándose sobre las tesis acusatorias: “No dice el mismo (por el médico Albarrán) que el mosto se adelgaza al paso que se va convirtiendo en vino y que el glaucómetro baja en la misma proporción?" 086 . Añade cuantos aspectos fortalecen sus tesis, pero, en lo que interesa, ilustra sobre las condiciones de vendimia y fermentación ${ }^{1087}$ :

\footnotetext{
${ }^{1085}$ Ibídem, fol. 18.

${ }^{1086}$ Ibídem, fol 141-143.

1087 Ibídem.
} 
"La vendimia del año treinta se hizo con un tiempo tan caluroso que podía compararse con los mejores del verano y que por este motivo era tal el calor que, traída la uba desde las viñas, que principiaba el mosto a fermentar desde el momento que se los exprimía..."

Añade que su lagar tiene la puerta orientada al mediodía, cubierto el pilo con una trampa de madera y que "estuvo desde la madrugada del cuatro de octubre hasta el mediodía del cinco que fue cuando Sotero lo retuvo en los pellejos y después estuvo hasta el día seis en que lo reconocieron. "Continúa su defensa, tratando de desmontar la declaración del médico y reflexionando sobre la existencia o no de "vahos" en el proceso de fermentación. Afirma que esta necesita de la presencia del aire y que, aunque los pellejos estaban cerrados, al no ir llenos "sino con el vacio de media cántara para poder ser llevados sobre los hombros y cabezas de los mosteros", la transformación de los azúcares no se interrumpiría, cuestión esta que podía hacerse extensible a los pilones y lagares dado "que no hay en los lagares máquinas neumáticas que verifiquen su extracción"1088.

Sotero adeudará a su procurador 1.494 reales y Bayón, otros 1.466, pero sus testimonios, en estas últimas décadas del Antiguo Régimen, nos testifican vendimias tardías, mostos con graduaciones de 13 y 14 grados que arrancan pronto a fermentar y vinos con viso y color dorado que se añejan bien caso de no venderse en el año. Como en siglos anteriores las uvas son trasladadas en cestos y carros a los lagares donde se pisan y prensan. No siempre lagares y bodegas están en una misma casa, por lo que los mostos desde los pilos son envasados en pellejos y trasladados a cubas propias o arrendadas, sitas en las numerosas bodegas de las distintas villas. Los procesos de clarificación y trasiegos a cubas limpias y desinfectadas por la quema de pequeñas muestras de azufre, dependerá del potencial económico del cosechero. En el delicado proceso de "dar claro" se jugaban los labradores buena parte de los ingresos ${ }^{1089}$. Esta labor se lleva a cabo en muchos casos por manos expertas, mezclando pausadamente los caldos de las cubas con sangre de vacuno o tierra de La Nava o ambas productos a la vez. El vino pierde así las sustancias en suspensión, quedando limpio de impurezas y a la espera de la demanda de los arrieros de la montaña y los taberneros de las comarcas vecinas. Estas prácticas habían garantizado la calidad y fama de estos blancos hasta estas fechas, a la espera de cambios productivos y de comercialización que trataremos en capítulos posteriores.

\section{c. Los ganados y el aprovechamiento de los pastos a finales del viejo régimen}

El desmembramiento de las comunidades de villa y tierra deja en manos de los regidores locales la administración de la justicia de estos bienes comunales, pero ello no impide que se sigan desencadenando enfrentamientos. Muchos de los que se han analizado en estos términos, a lo largo del siglo XVIII, suman la tensión añadida del desequilibrio causado por la expansión vitícola, que ha ocupado baldíos, montes y eriales.

La actitud hostil de aquellos que no pueden ver una oveja en sus viñas y la búsqueda de pasto por parte del ganado que, cuando tiene hambre, no atiende a lindes ni límites jurisdiccionales, continúa generando conflictos en las últimas décadas del Antiguo Régimen. Recuérdese que los procuradores de Matapozuelos prohíben la entrada del ganado lanar de Serrada en sus majuelos, o los

${ }^{1088}$ Las declaraciones de unos y otros dan las claves de la vinificación en 1830. Aunque se detectan novedosas teorías explicativas, no siempre son aceptadas de buen grado. Hipólito Gómez, en nombre de Sotero, manifiesta, tras las declaraciones de los físicos y médicos "como la vulgar experiencia de la inmersión del huebo hizo conocer el fraude que se estaba cometiendo y la intolerable adulteración con que se traía aquel licor por mas que sean (estas prácticas vulgares del huevo) poco cientificas y se expliquen en castellano tan claro como desconocido en el vocabulario de los químicos...". (Ibídem, fol. 26).

${ }^{1089}$ En 1815, D. Guillermo Obregón da cuenta, en la relación de cargos, de los efectos que habían entrado en su poder procedentes de la testamentaria d D. Josef Obregón y Da María e Íscar de "quarenta reales para dar claro a una cuba de vino". Es de suponer que entrarían las sustancias o productos antes aludidos, que, junto con las operaciones efectuadas para la buena mezcla, dan idea del coste de la operación, equivalente, por lo demás, al salario de diez jornales. (A.H.P.V. Pt. 8230, Serrada. Inventario de bienes de D. Josef Obregón, fol. 34). 
pleitos entre los vecinos de San Martín ante el concejo de La Seca que considera las hierbas de la pequeña villa como pasto común de la Tierra de Medina ${ }^{1090}$. En 1786, los concejos de Serrada y Matapozuelos acuden a la Chancillería de Valladolid para pleitear contra el concejo de Valdestillas por impedir esta villa el pasto en "el Montico" a todos ganados forasteros, toda vez que este pago era el acordado desde tiempo inmemorial como pasto común, abrevadero y descanso de los ganados lanares de todos estos lugares de la tierra de Olmedo ${ }^{1091}$.

\title{
- La hoja de las viñas y las rastrojeras al final del Antiguo Régimen
}

Los terrazgos colectivos tienen sus días contados. Los procuradores denuncian las retenciones y embargos de reses en unos y otros pueblos pero, por encima de la concordia y costumbre, está la necesidad de aumentar la disponibilidad de pastos y obtener de ellos el mayor beneficio en los remates públicos. El aumento de la población y la presión ganadera sobre los recursos naturales arrumba estas viejas tradiciones a la memoria colectiva. De la misma manera, las nuevas necesidades regulan anualmente, y al alza, las condiciones de la entrada de ovejas en las viñas, a pesar de contar con vecinos reacios a su acatamiento ${ }^{1092}$. En 1796, el concejo de Serrada, en palabras de José Obregón, apoderado del “Cuerpo o gremio de hazendados viñeros de todo el término del lugar despoblado de la Moya", manifiesta ${ }^{1093}$ :

\begin{abstract}
"En virtud de acuerdo o Junta general zelebrada por aquellos en doze de abril del año próximo pasado de 1795... solicita que dicho Supremo Tribunal (Supremo Consejo de Castilla) mande no se les ympida pastar en las vińas y rastroxeras de todo el partido lebantados frutos, conforme a la costumbre, todo con el fin de entrar libremente... sin dejar de pagar como ha sido el estilo y contraviniendo a lo mismo que en dicho ańo próximo pasado de setecientos y nobenta y cinco practicase dichos ganados en consecuencia lo acordado por el citado gremio de vińeros y azendados de la Moya, relativo a este punto y fue que anualmente se arrendase la pámpana y ojas de las viñas, con otros artículos y reglas de buen gobierno para aquel termino despoblado.."
\end{abstract}

En sus palabras se observa tanto el peso de conflictos pasados como el interés de estos hacendados, poseedores de tierra y algunos de ellos también de ganado lanar, que desean arrendar para el pasto el terrazgo de viñedo. Décadas más tarde, cuando se asiente plenamente el sistema liberal burgués, serán ellos individualmente quienes dicten condiciones y se reintegren como propietarios los ingresos de hoja y pámpana. Hasta entonces, son los concejos quienes regulan, a través de posturas y remates públicos, el aprovechamiento de los majuelos. Estos, juntamente con eras, prados, rastrojeras, tierras de labor y eriales conforman los espacios donde el ganado de cerda, las ovejas y las bestias de labor pastan, de acuerdo al calendario agrario y las hojas del terrazgo labrado.

${ }^{1090}$ A.R.Ch.V. Pleitos Civiles. Alonso Rodríguez (OLV), caja 666.4 y Quevedo (F)., caja 3544.1 respectivamente.

${ }^{1091}$ En el acuerdo se expresa con exactitud la forma y manera del aprovechamiento por el ganado de estos pastos: "Sépase como nos Ysidro Platón, vecino y procurador sindico general y del Común de esta villa... y Don Antonio de Neira Diez, vecino e ygual Procurador General y del Común que soy de la de Matapozuelos,... otorgamos todo nuestro poder cumplido... a Don José Milla Cuellar, agente en la Real Chancillería de Valladolid,... con relación de que desde el tiempo en que la villa de Valdestillas se eximio de la pedanía y jurisdicción de la de Olmedo, de cuia tierra y partido lo son las nuestras, que son pasados más de doscientos ańos, entre los pactos y concordias que la de Valdestillas y tierra de Olmedo hicieron, fue uno el quedar los pastos de la dicha de Valdestillas y tierra de Olmedo comunes a todas, como hantes lo avían estado con solo la qualidad de no poder los de la tierra de Olmedo ni los de Valdestillas pastar más que de sol a sol, sin poder pernoctar en unos ni otros términos, y con la condición también de quedar siempre para pasto común, abrebadero y descanso de los ganados lanares de todos, el pago y terrazgo llamado el Montico, sito dentro del término y jurisdicción de la citada de Valdestillas y linde la raya de la tierra de Olmedo...”. (A.H.P.V. Pt. 8223, fol. 375, año 1786).

${ }^{1092}$ Recuérdese que en 1739 los ganaderos de ovejuno, que sumaban hasta 800 cabezas, otorgan poderes para que se defienda en la Chancillería "la costumbre que a abido de inmemorial tiempo a esta parte de pastar las viñas desta jurisdicción después de haber lebantado el fruto” y hacer frente así a la prohibición ganada por Francisco Hinojal de impedir dicho pasto a los ganados lanares, así como a los "vacunos y yeguerizos". (A.H.P.V. Pt. 8226, fol. 39).

1093 A.H.P.V. Pt. 8227. fol. 79. 
Cuadro 105. Remates públicos relacionados con prados y pastos.

Serrada, años 1800-1828. En reales

\begin{tabular}{|c|c|c|c|c|c|c|c|c|c|c|c|c|}
\hline Años & 1800 & 1813 & 1814 & 1815 & 1816 & 1817 & 1818 & 1819 & 1821 & 1823 & 1826 & 1828 \\
\hline $\begin{array}{l}\text { Pámpana y } \\
\text { hoja de las viñas }\end{array}$ & 1.000 & 1.600 & - & 1.500 & 1.200 & 1.600 & 1.700 & 1.700 & 1.180 & 1.100 & 1.180 & 800 \\
\hline Hierba de las eras & - & - & - & - & 753 & 505 & - & - & - & - & - & - \\
\hline $\begin{array}{l}\text { Rastrojeras, } \\
\text { barbecheras y eriales }\end{array}$ & $s$ & - & - & - & - & - & - & - & - & 1.900 & - & - \\
\hline $\begin{array}{l}\text { Prados y dehesa } \\
\text { de San Martín }\end{array}$ & 3.025 & 3.025 & 3.025 & 3.025 & - & - & 2.800 & 1.670 & - & - & - & - \\
\hline
\end{tabular}

Fuente: A.H.P.V. Protocolos Notariales. Elaboración propia

Las hojas de las viñas y la otoñada que crían los majuelos tras la vendimia alcanzan importantes sumas en las posturas celebradas entre los ganaderos de la villa, más si se tiene en cuenta que el tiempo de pastoreo no solía exceder de dos a dos meses y medio. En ocasiones, como en 1813, el remate iba unido al "herbaje de su rastrojera, heriales y baldios de dicho su término, pinar y prados", si bien se diferencian las fechas en unos u otros. Así, estos últimos "solo desde San Andrés Apóstol hasta Candelas y lo demás desde la conclusión de vendimia y rebusca hasta primeros de marzo"1094. En muchos casos, dada la importancia del cultivo en la economía de la comarca, se precisan cuidados y formas de pasto. Manuel Martín y Eusebio Ribera se obligan en 1817 a no meter otros ganados que no sean suyos y a respetar en las viñas "los ballados que muchos dueños tienen hechos para la custodia y resguardo de sus viñas, ni caerlos sopena de satisfacer el coste de su reparación"1095. Con el tiempo, la duración del aprovechamiento se hace más flexible ${ }^{1096}$.

Un factor explicativo a esta mayor duración de los contratos y del progresivo descenso de las posturas a partir de 1817, es el estancamiento vitícola, que provoca el abandono de aquellos majuelos de débiles rendimientos y la menor labor en muchos otros, con el consiguiente aumento del pasto. En el pasado epígrafe dedicado al viñedo, se han probado sobradamente los muchos majuelos que se dejaban perder y las muchas tierras eriales, antiguas vińas, donde el pasto crece sin cortapisas. Como consta en el remate de 1828, Manuel Martín y sus consortes manifiestan "que todos los ganaderos que quieran tener parte y meter los ganados en los pastos han de entrar en la escritura de obligación" siempre que satisfagan la parte correspondiente. En este campaña el disfrute es, como decimos, desde "dos días concluida la vendimia y rebusca hasta el dia principio de marzo del año próximo... ${ }^{1097}$.

${ }^{1094}$ A.H.P.V. Pt. 8229, fol. 61.

${ }^{1095}$ A.H.P.V. Pt. 8229, fol. 57.

${ }^{1096}$ Si en 1773 tan sólo se permitía el pastoreo en los meses de noviembre y diciembre, el rematante Gabriel Ruiz rentabiliza sus 1.100 reales de 1823 , desde principios de noviembre hasta primeros de marzo. La mayor duración en tiempo facilita los acuerdos entre distintos pastores, ganando las ovejas en terrenos y herbajes. Las condiciones pactadas tratan de garantizar el respeto a las tierras de sembradura y la salvaguarda de las cepas: "Que el postor a quien quedasen rematados dichos pastos no habia de entrar a disfrutarlos hasta después de concluida la vendimia y rebusca, tuviese licencia de dicha Justicia para pastarlos y concluiría el disfrute en primero de marzo del año próximo venidero de mil ochocientos veinte y quatro. Que no habian de entrar a pastar mas cavezas de ganado que las que proporcionalmente puedan mantenerse en dichos pastos a a juicio pericial, caso necesario y no sin número excesibo que destruya el viñedo. Que los ganados dormirán en el pueblo como antiguamente lo habian y en caso de dormir en el campo, situaran los corrales en parajes bien retirados del viñedo, a fin de que las entradas y salidas diarias del ganado y los emparejos no destrozen las cepas. Y últimamente que la cantidad en que queden rematados los pastos la pagara el postor y pondrá en poder del mayordomo de propios de esta villa en dos plazos iguales...". (A.H.P.V. Pt. 8229, fol. 32.

${ }^{1097}$ A.H.P.V. Pt. 8229, Serrada, Manuel Demetrio de Colomera, ańo 1828. 
Pero el tiempo y los nuevos cambios políticos marginan tradiciones en beneficio del interés particular. Son los propios hacendados los que dictan las normas de quiénes, cómo y por cuánto entran las ovejas en sus vińas ${ }^{1098}$.

Similar evolución se encuentra en el resto de aprovechamientos ganaderos. Los prados de Arriba, Abajo y Pradejón son aprovechados por el ganado de labor, vacuno y ovino, según las estaciones y la vigilancia de los guardas. Las hierbas de las eras que rodean la villa al norte y noreste eran cotizadas por su abundancia y cercanía a los cobertizos donde guardan el ganado. Al igual que los anteriores pastos, salen a remate y se fija tanto el número como la calidad de las cabezas ${ }^{1099}$ :

"Eusebio Ribera, vecino y ganadero de ganado lanar obejuno de esta villa... remató en el día de ayer (7 de enero de 1717) la yerba de las heras de esta dicha villa, que he de pastear hasta fin de marzo de este dicho año con solo corderos de cría, no entrando en dichas heras mas que únicamente diez obejas..."

Con todo, la cortedad del término impone la necesidad de buscar sustento fuera del término. Los ganados de Serrada, como los vecinos de La Seca, tienen en los prados y dehesas de San Martín una solución a sus escaseces. Un ejemplo lo representa en octubre de 1800 Ana Joaquina Hinojal, viuda, que arrienda los pastos de invierno de la citada dehesa al concejo de la referida villa que preside su alcalde Gabriel Martín "por tiempo de quatro años, pagando en cada uno la cantidad de tres mil veinticinco reales vellón”. En el informe previo, la justicia y Junta de Propios del lugar manifiesta, de cara al contrato, que cumpla con la necesidad de "no arrendar las yervas de primavera ni verano para que las haya en la inbernia"1100. La importante cantidad pagada da buena cuenta de lo cotizados que están los pastos durante el invierno. El resto del ańo y hasta que se levanten las cosechas los ganados lanares, aprovechan las rastrojeras que no han sido alzadas y la naciente yerba primaveral de aquellas levantadas de forma temprana, ya que las hojas sembradas están vedadas a la entrada del ganado. El cierre y vallado de los accesos, vigentes hasta entrado el siglo XX, tratan de evitar, como también sucede en los majuelos, no solo descuidos sino malas intenciones. Si el ganado de labor pace secular y ordenadamente en los distintos prados del concejo de Serrada, el ovino alivia sus penurias en los pastos de San Martín, una vez despoblada la pequeña villa.

En 1821, se encuentra por primera vez un arrendamiento conjunto de barbecheras y rastrojeras de los tres términos y que, a partir de esta fecha, se considera único. Recuérdese que, con fecha de 16 de mayo de 1818, se otorga escritura para la administración de los efectos de propios del Despoblado.

${ }^{1098}$ Aunque sea adelantarse unos años, merece la pena observar los términos en que se conciertan los nuevos contratos:"En la villa de Serrada a diez y siete de octubre de mil ochocientos cincuenta y siete, ante mi, el escribano... comparecieron D. León José Moyano, D. Canuto de Castro, D. Félix Martínez, D. Feliciano Martin y D. Ezequiel Pérez, y demás que subscriben que componen el numero de la mayor parte de los vecinos hacendados y labradores de esta dicha villa y dijeron: Que en el campo y termino de la misma poseen el vińedo que respectivamente les corresponde, el cual se halla con los pastos de pámpana y oja. Que con el objetivo de qualos productos destos redunden legítimamente y justamente en beneficio de sus respectivos dueńos y propietarios, han resuelto estos arrendar su aprovechamiento hasta el día de San Andrés, o sea, el treinta de noviembre próximo de este año, y al objeto de autorizar persona de su confianza que lo verifique, y poniéndolo en ejecución de su libre y espontanea voluntad, obligan: que dan y confieren todo su poder cumplido... a D. Leandro Obregón, vecino y hacendado labrador de esta villa para que a nombre de los otorgantes proceda de la manera, modo y forma que sea conveniente a el arrendamiento de los pastos de pámpana y oja de los majuelos correspondientes a la propiedad d los otorgantes... con la persona o personas que se interesen en su aprovechamiento por el tiempo espresado y por el precio y plazos para su pago que convenga. Para poder cobrar y recaudar el total precio del arrendamiento que no llegan a cinco mil reales, con la condición de que llegado el caso de hacer efectiva esta cantidad ha de ser distribuida por el D. Leandro entre los otorgantes a prorrata de las aranzadas de vińedo que cada uno tubiere..." (A.H.P.V. Pt. 15958, fol. 108, año 1856).

${ }^{1099}$ A.H.P.V. Pt. 8229, fol. 9, año 1817.

${ }^{1100}$ A.H.P.V. Pt. 8229, fol. 45, año 1800. 
El contrato que gestiona Serrada, arrendando el término a sus ganaderos de lanar, acerca nuevamente a la naciente explotación capitalista de los recursos tratados. También aquí se está al final de un viejo camino. En las líneas al pie se anota lo detallado del aprovechamiento ${ }^{1101}$.

Como se advierte en el texto, son los ayuntamientos constitucionales que sustituyen a los antiguos concejos quienes organizan los aprovechamientos comunales. Estos otorgan competencias en su gestión, y también en el aprovechamiento de sus beneficios, a los propios interesados, especialmente a la clase propietaria. Son estos hacendados, agrupados en gremios de labradores y vińeros, quienes se benefician proporcionalmente de los bienes que detentan. Es de destacar la precisión con que se detallan los caminos y pagos por donde debe transitar el ganado, a fin de salvaguardar las hojas de sembradura y barbechera repartidas por el término. La permanencia de éstas, condicionadas por el viñedo, añade un nuevo elemento que respetar, salvo en el tiempo de disfrute de la pámpana y hoja. Con todo, se está a pocas fechas del fenómeno desamortizador que introducirá una dinámica monetarista que ya no tendrá vuelta atrás ${ }^{1102}$.

1101 "En la villa de Serrada a ocho días de abril de mil ochocientos veinte y uno, ante mi, el escribano del numero della y testigos infraescritos, comparecieron Manuel Alonso Martín, Isidro Milla, Gabriel Pérez, Manuel Mateos y Tiburcio Peláez, vecinos y ganaderos de ganado lanar obejuno de esta villa, y todos firmemente y de mancomún a voz de uno, y cada uno de por sí,... Dijeron que por la presente otorgan que toman y reciben todos cinco en renta y arrendamiento de los Apoderados del gremio de labradores y vecinos propietarios de esta dicha villa de Serrada, el a saber todo el herbaje y pasto de los tres términos y jurisdicciones de esta dicha villa, y el de los Despoblados de San Martín del Monte y la Moya, barbechera, rastrojera y heriales que se dirán, el qual hacen y toman desde principio del presente mes hasta fin de septiembre benidero de este año, por precio y quantía de mil y nobecientos reales en que fueron rematados dichos pastos como y mejor postor en dicho Isidoro Milla, en nombre y representación de los demas ganaderos, y que pagaron a los Apoderados en dos plazos y pagas iguales por mitad, el primero el día de San Juan Bautista benidero del presente año, y el segundo el último día del mes de agosto benidero deste dicho próximo año, bajo la pena de ejecución y costas de la cobranza, cuio arrendamiento hacen los otorgantes bajo los pactos y condiciones siguientes:

$1^{\circ}$ Con condición que los otorgantes arrendadores harán de mancomún escritura formal a su vista y espresa obligación de responder de todo el daño que se cause en viñas, panes y legumbres con ganado lanar.

$2^{\circ}$ Que la cantidad del remate sea pagado a los Apoderados en dos plazos iguales, primero el dia de San Juan Bautista del presente año ultimo el día de agosto del dicho año, por mitad y dichos apoderados se lo entregaran a el Depositario nombrado.

$3^{\circ}$ No entraran a pastar mas número de cabezas maiores lanares en los heriales, barbechera y rastrojera que mil y doscientos y los corderos que tengan estas, pero no los que pudieran comprar en adelante o aora.

$4^{\circ}$ Tienen facultades todos y la mayor parte de los Apoderados para secuestrar el ganado lanar que hubiese pastado entendiéndose que si pasan de cinquenta cabezas arriba mas, además de pagar el duplo serán lanzadas y hechadas fuera inmediatamente.

$5^{\circ}$. Que en los rubiales de un año no entraran a pastar hasta pasado el día de todos los santos.

6. Están excluidos del arriendo los heriales que no tengan entrada, y son en termino de esta villa los de Sison, los de Hipólito, el Tuimbas, Monsu y Pancilla; en la Moya la de Cuesta Blanca..

7o Entradas que contienen para los tres términos: Para la de Serrada, de Malinas por Pela; para el Hibitero por la Cañada del Pinar bajando derecho; en los de Juambrín por los de Malinas; y para las Carretas por el camino del Pozo, entrando por orilla del majuelo del Marqués y senda de las Fuentes, sin pasar más adelante por dicho camino.

8. Para la Moya por el camino llamado de Valdestillas; camino de Valladolid, y camino de las Carretas, y no por las demás sendas y abiaderos que haia en dicho termino.

9 Para los de San Martín por la cañada del Pinar de esta villa abajo hasta el dicho termino.

10. Últimamente el ganado de cerda del pueblo entraran en dichos pastos y rastrojeras fue en el año pasado y costumbre en los anteriores, y todo ganado no entrar a la rastrojera hasta segarse todos los troges.

Con cuias condiciones declaran y aseguran los otorgantes hacen en derecho arrendamiento y se obligan con sus personas y vienes habidos y por haber a la obserbancia y cumplimiento dellas y a responder según la primera dellas de todo daño que se cause en viñas, panes y legumbres con ganado lanar, y a dar y pagar como darán y pagaran realmente y con efectos la cantidad del en los dichos plazos señalados.” (A.H.P.V. Pt. 8229, fol. 27, año 1821).

${ }^{1102}$ Un ejemplo se tiene en las dehesas y prados del citado despoblado. Ya no son sus hombres quienes escriben el futuro de sus tierras, dehesas y prados. Los arrendamientos y ventas que llevan a cabo los nuevos propietarios, tras la subasta desamortizadora, suman una nueva página en el discurrir de su historia: "En la Villa de Serrada a primero de abril de mil ochocientos cincuenta y nueve; ante mí, el escribano... comparecieron... por una parte, D. José Manuel Gómez de Hor- 
Después de tantos siglos recorridos, cuesta abandonar las posturas que pastores o labradores hacían en las casas del concejo o en el soportal de sus iglesias, pero, en estas fechas, ya no era una novedad el arriendo del pasto común entre particulares ni el reintegro de los dineros por los propietarios de las viñas y prados. A la legislación agraria del Trienio Liberal siguen las reformas del liberalismo isabelino que, como se verá, están protagonizadas por otras instituciones y otros intereses ${ }^{1103}$. Hasta entonces, y una vez detallados los campos donde pastan los ganados, debemos dedicar unas líneas a pastores y rebaños.

- Los pastores y el ganado lanar a comienzos de siglo

El Catastro de Ensenada anotaba en Serrada cinco pastores y 670 ovejas, excluyendo borregos, corderos y carneros que sumaban otros 431 animales. En el arrendamiento de la rastrojera de 1821, se limita el número de cabezas lanares con derecho a pasto a 1.200 cabezas, lo que se traduce en un importante incremento de la cabaña ganadera y da pie a pensar en un mayor número de reses. Es muy posible que la incorporación al terrazgo de Serrada del Despoblado de San Martín, junto con la estudiada decadencia del viñedo y el aumento de majuelos descuidados y hechos eriales, contribuyera a este aumento, dada la cortedad de prados, montes y barbecheras aprovechables hasta este

nillos, vecino de la ciudad de Valladolid, y de la otra León Adanero, Gumersindo Morejón, que son de la Pedrajas de San Esteban, y Remigio Arranz de Iscar, y dijeron que el D. José Manuel ha tomado y lleva por varios años el arrendamiento el campo y termino del despoblado de San Martin del Monte, jurisdicción de esta villa, propio del Real Monasterio de Santa Clara de la villa de Tordesillas..

Los referidos D. José Manuel, León Adanero, Gumersindo Morejón y Remigio Arranz otorgan que el D. José Manuel da y el León y consortes recibe en arrendamiento los prados que produzcan la referida desa titulada de San Martin... bajo las condiciones siguientes:

$1^{\circ}$ Que el arriendo es únicamente estensivo al aprovechamiento de pastos, no comprendiendo los del prado titulado del Verral...

$2^{\circ}$ Que el tiempo y duración... es solamente desde el día primero de noviembre de este presente año y concluirá en ocho de mayo del próximo que viene...

$3^{\circ}$ Que por los dichos pastos y tiempo espresado han de pagar al D. Jose Manuel Gómez de Hornedo la cantidad de nueve mil cuatrocientos reales..

$4^{\circ}$ Que el aprovechamiento de dichos pastos se ha de verificar precisamente por ganado vacuno y no de otra clase.

$5^{\circ}$ Es de cuenta de los arrendatarios León y consortes el pago de pastores, guardas, vaqueros o mayorales que necesiten para el cuidado y custodia de las reses...". No es menester ser más prolijo en la reproducción documental. En los frescos prados de San Martín, importantes cabañas vacunas, ajenas a la villa de Serrada, aprovecharán sus pastos a lo largo del XIX y buena parte del XX. Los arrendamientos requieren ampliar las cuadras y corrales existentes, así como habilitar viviendas para vaqueros o mayorales. En el contrato, además de la preocupación para la guarda del ganado, se precisa que todo el abono o estiércol que produzcan las reses será como propio del Sr. Gómez de Hornedo; que los arrendatarios correrán con los trabajos de ampliación y cuidado de las instalaciones, que deben "limpiar y poner corriente la fuente titulada de los lobos", etc., etc.

(A.H.P.V. Pt. 15958, Serrada, Domingo Duque, fol. 31, año 1869).

${ }^{1103}$ La amplia potestad de los concejos, en lo tocante a sus bienes comunales, será ahora controlada por las Diputaciones Provinciales que, a través de las Contadurías de Propios, supervisan la gestión de los Ayuntamientos. En el caso del herbaje del Despoblado de San Martín, es aquella la que otorga conformidad a la actuación de la Junta Local de Serrada. En un papel adjunto al arrendamiento realizado en 1819 por Rafael Domínguez, se ratifican las condiciones que hay que cumplir entre la que se encuentra "abrir a su costa un cauce para recoger y dar espediente a las aguas que tienen inutilizados los pastos en mucha parte, cuya longitud ha de ser la de 7200 y mas varas; dos de anchura y una y media de profundidad en el sitio mas apropiado; limpiar y reparar los cauces existentes a igual anchura y profundidad, y reparar el corral con todo cuanto sea necesario”. (A.H.P.V. Pt. 8229, Serrada, fol. 33-38 ). Son los Intendentes provinciales quienes en última instancia aprueban o no la gestión de los Ayuntamientos, respetando las formas y usos derivados de la costumbre. En el arriendo que hace en 1823 Sabino Rivera, el Ayuntamiento de Serrada propone a la Diputación utilizar este recurso para levantar en parte el encabezo con la real Hacienda, pero el Intendente provincial recordará que el pago del encabezo debe hacerse según lo que regula la Instrucción de Millones y, en cuanto a la rastrojera, podrá usar de su arriendo "siempre que su valor haia de serbir para cubrir las cargas del reglamento de propios". (A.H.P.V. Pt. 8229, Serrada, fol. 17 , año 1823). 
momento. En las primeras décadas del XIX, pujan por los pastos en los remates públicos las familias de los Rivera, Herrero, Milla, Pérez, Alonso, Peláez, Domínguez y Mateos. Padres e hijos que tienen en los rebańos ovejunos la esperanza de vivir ajustadamente.

Los mercados de Medina y Tordesillas siguen siendo la salida natural de carneros, ovejas o corderos, cifrándose el precio de estos, a finales del XVIII, en 36, 18 y 12 reales respectivamente, toda vez que la venta de lana había dejado hace tiempo de ser el producto estrella de los encuentros feriales. Aunque constan ventas de lana a 35 reales la arroba, no era este producto el principal recurso del que obtienen sus ingresos los ganaderos de Serrada. Lo reducido de sus rebaños obliga a completar sus quehaceres con algunas aranzadas de majuelo y, como tantos otros labradores con sus vinos, no faltan pleitos por acabar de cobrar sus ventas por fiado a compradores forasteros ${ }^{1104}$.

Aunque se trata de ganado y no suele ser frecuente, en ocasiones se acude al arrendamiento para completar rebaños y redimensionar aprovechamientos. Hasta no hace mucho tiempo eran órdenes religiosas o presbíteros con propiedades quienes arrendaban sus ganados y pastos, sin faltar cofradías que mantenían hatos de ovino ${ }^{105}$. En las primeras décadas del XIX, en cambio, hay particulares relevando a los anteriores en estos contratos, pero los conflictos no varían en el tiempo ${ }^{1106}$.

\section{El desmantelamiento del Antiguo Régimen: La obra desamortizadora}

Manifiesta Olavide en su Informe sobre la Ley Agraria que "uno de los mayores males que padecemos es la desigual repartición de tierras y que las más de ellas están aún en pocas manos...", y que lo que conviene al Estado es la existencia de muchos labradores que cultiven con esmero y trabajo sus propiedades, pues uno de los males de estas propiedades tan inmensas es que "la demasiada extensión de la labranza previene que las tierras se cultiven mal y no se cultivan todas". Si estuvieran más repartidas, mantiene, "se sembraría todos los años, se estercolaría, se araría bien...". Palabras que

${ }^{1104}$ En 1817, Eusebio Ribera, pastor y vecino de Serrada, otorga poder a D. Francisco Ortega, vecino de Astudilo, para que "a su nombre y representación acuda ante la justicia real ordinaria... y con presentación haga de un papel de obligación hecha a favor del otorgante por Manuel Reynoso Pérez, vecino de dicha villa de Astudillo, su fecha en esta de Serrada, veinte y cinco de julio de mil ochocientos diez y seis, por la que confeso quedarem en deber de la porción de arrobas de lana que expresamente compro, la cantidad de mil doscientos cinquenta reales." (A.H.P.V. Pt. 8228, Serrada, Manuel Demetrio de Colomera, fol.67, año 1817).

${ }^{1105}$ Un ejemplo ocurre en septiembre de 1770, cuando D. Fernando del Castillo, presbítero, arrienda a Luis Pérez, vecino de Serrada, "veinte y seis ovejas emparejadas con sus esquilmos por tiempo y espacio de quatro años... en prezio y quantía de ziento y treinta reales en cada uno de los quatro años...". Como decimos, dado lo delicado del ganado, se notifica ante escribano el estado en que han de devolverse los ganados. En este caso "buenas, sanas y sin lesión alguna, como yo se las arriendo”. (A.H.P.V. Pt. 8220, Serrada, Miguel Moyano, fol. 79, ańo 1770) En cuanto a pastos, y aunque ya se ha tratado, se debe destacar la administración de D. Francisco Moyano, en nombre y como apoderado de su hermano político D. Manuel Cantalapiedra, presbítero en La Seca, de las hierbas del Monte de Nuestra Señora de la Paz de La Seca. En el año 1803, se arriendan a Agustín Conde Leonardo y Manuel Lorenzo Leonardo, vecinos de La Seca y a Rafael de Castro, vecino de Pozaldez, por 4.500 reales "desde el día de San Andrés... hasta el día veinte y cinco de marzo del inmediato año de mil ochocientos cinco... en la cantidad de quatro mil y quinientos reales..." (A.H.P.V. Pt. 8228, Serrada, Miguel Moyano, fol. 81, año 1803).

${ }^{1106}$ Un ejemplo es el derivado del arrendamiento, firmado en junio de 1820, por Leonarda Román, a favor de su marido Isidoro Milla. Ambos toman "por termino de cuatro años sesenta y ocho obejas de leche y diez y seis cancinas propias de Juan Guridi, vecino de la villa de Laguna y obligarse a la paga y satisfacción de seis reales cada una de renta en cada un año" y como se manifiesta en obligación de 6 de agosto de 1824, un día después del anterior contrato se habían añadido otras "ciento cuatro reses lanares hembras en que se incluyeron cuatro marrones en esta forma: cuarenta y seis reses de dos partos; once de tres partos; tres de cuatro partos, y de primer parto ocho, y las treinta y dos restantes borregas... ". Concluido el contrato, el vecino de Laguna no recibe ni rentas ni ovejas entre otras cosas porque estas ya no existían. En obligación firmada el seis de agosto de 1824, este matrimonio de Serrada se obliga a pagar a Juan Guridi 3788 reales, procedentes de su valor y renta. Por unos u otros motivos y una vez más, los ganados, en estas tierras de labradores, seguían en boca de todos. (A.H.P.V. Pt. 8230, año 1820). 
testimonian una preocupación gubernamental por el tema agrario desde la segunda mitad del XVIII, por el fomento del desarrollo rural. En este sentido, la construcción de canales navegables en Castilla fue una cercana actuación que casi atañe al norte de Medina, pues el proyecto del canal de Segovia, que partía desde el río Eresma y desembocaba en Villanueva de Duero, que al final no fue ejecutado al privilegiar los canales de Campos, hubiera potenciado este espacio tanto agrícola como comercialmente. Con todo, es muy posible que estos vecinos sí tuvieran conciencia de hallarse en una encrucijada de cambios irreversibles, conforme se iniciaba el nuevo siglo y no sólo por las secuelas de la conmoción napoleónica. En 1833 moría Fernando VII dejando al país en un mar de contradicciones internas.

La naciente sociedad burguesa desea para su propio beneficio la implantación de un régimen constitucional restringido, que les permitiera el acceso a los resortes de un poder y a una propiedad que desean liberar de tantas ataduras jurídicas y feudales. En el Trienio Liberal (1820-23), ya se había iniciado una primera desamortización, limitada a los bienes del clero regular que el retorno absolutista obligó a restituir. Pero hacía tiempo que la monarquía absoluta había entrado en crisis de la mano de su propia hacienda. El déficit era insoportable desde las guerras de Carlos IV y la invasión francesa. En 1814, la situación era insostenible y, durante el reinado de Fernando VII, sólo se logró alargar la agonía. El restablecimiento de una economía capitalista era incompatible con el mantenimiento de los privilegios y estructuras de otro tiempo y la desamortización o conversión de la propiedad de la tierra en propiedad privada, particular y enajenable, será uno de los principales objetivos de los gobiernos progresistas a lo largo de buena parte del nuevo siglo.

Recuérdese que en 1752 se encontraban vinculadas a órdenes religiosas, mayorazgos y concejos locales en los términos que sirven de ejemplo 2.291,66 obradas, que representaban el 66,25\% de los términos conjuntos del Despoblado de La Moya, San Martín y Serrada. Bien es verdad que parte de ellas estaban en manos de los mayorazgos de Torreblanca (602,5 obradas) y de Don Manuel Joaquín de Vega (117,5 obradas), que no serán vendibles como buena parte de las anteriores, aunque perderán la vinculación o indivisibilidad que llevaban consigo. Los decretos desamortizadores y la legislación liquidadora del Antiguo Régimen transformarán el dominio señorial en una nueva propiedad libre, individual y divisible, no ajena al mercado y más cercana, en teoría, a la introducción de mejoras y nuevos cultivos. Distinto es el caso de las propiedades de la iglesia. Tierras de pan llevar, vińas y casas saldrán a pública subasta y el abultado patrimonio clerical (en este caso 278 obradas, 857 aranzadas de majuelos y parte de las mejores casas, corrales, lagares y bodegas) pasarán a manos de labradores acomodados o ricos burgueses ajenos a la localidad. E idéntica suerte correrán los bienes del concejo de San Martín, ya que los prados de Serrada se librarán de la subasta. ¿Contribuirán estos hechos a cambiar la estructura social española en la que el 56\% de la población rural en 1860 eran jornaleros y el 11\% arrendatarios?

\section{a. Las primeras medidas desamortizadoras llevadas a cabo durante el Trienio Liberal (1820-23)}

El paréntesis revolucionario durante el absolutismo de Fernando VII inicia un proceso reformista imposible de culminar por las tensiones y divisiones políticas de los propios liberales, la intransigencia reaccionaria del rey y el enfrentamiento con la cúpula eclesiástica por la desamortización y reducción del diezmo, la reacción señorial por la abolición de su régimen, el crónico déficit hacendístico, el descontento de los pueblos por el retraso de las medidas de reparto de terrenos, el aumento de las exenciones que anulaban la "ventaja" de la reducción diezmal y, en fin, la mala cosecha de 1822. No obstante, la obra desamortizadora del Trienio, que cerraba conventos de menos de 24 miembros o suprimía los inferiores a 12, subastando sus bienes como "nacionales" al mejor postor, dejó en Serrada, como ejemplo del espacio estudiado, el primer expediente documentado. Se trata de la subasta de fincas pertenecientes al suprimido Colegio de San Gregorio, de la orden de Santo Domingo, radicadas en los términos de Valdestillas y Despoblado de La 
Moya, fechada en 1821. No es en absoluto significativo, ni cualitativa ni cuantitativamente, respecto a la posterior labor subastadora, pero es la primera medida liberalizadora de la que se tiene constancia escrita ${ }^{1107}$.

\section{b. La desamortización de Mendizábal. Serrada como ejemplo}

La mayor parte del proceso desamortizador que se llevará a cabo se gesta a lo largo de los años cuarenta del XIX y, en concreto, durante la primera mitad de la década. Se concreta en ventas masivas que se generalizan por todo el territorio nacional y serán conocidas por el nombre del ministro progresista que desde su gabinete de Hacienda las fue proponiendo: Mendizábal. El Real Decreto de 19 de febrero de 1836, que se completa con el de marzo del mismo año, dictamina la desamortización de los bienes del clero regular.

En lo que respecta a esta villa saldrán a subasta, procedentes del clero regular, 385,6 obradas y 176,3 aranzadas, pertenecientes a las distintas granjas conventuales asentadas en la localidad, además de sus casas, corrales y bodegas. Los decretos de suspensión habían conducido al descuido de sus instalaciones y producciones vitivinícolas, toda vez que, aunque no todas ellas aparecen en manos de renteros, en los distintos expedientes de subasta se constata el estado ruinoso de varias de sus casas de labranza y la dejadez que presentaban cubas y lagares. La invasión napoleónica y la crisis vitícola del primer tercio del XIX fueron determinantes en este sentido. Un ejemplo de ello es la casa de los Trinitarios Calzados que traía en renta el vecino de Serrada José Milla, pues no paga cuota alguna a cambio de cuidar y mantener las instalaciones. Más elocuente es el peritaje de la casa conventual que perteneció a los Trinitarios Descalzos. La lectura de su expediente aproxima al deterioro y devaluación que sufrieron muchos de estos bienes muebles que no resisten el transcurrir del tiempo desamortizador, no tan lejano a sus pasados días de gloria ${ }^{1108}$.

Distinto es el caso de los bienes urbanos del Convento de Monjas Brígidas. Se trataba de su casa compuesta por diferentes habitaciones, lagar con su correspondiente máquina, pajar, corral cercado con puertas carreteras, pozo y pila y una bodega con 8 cubas y un cubeto, de las cuales dos estaban inútiles. Como en anteriores remates, quedaron desiertas las primeras pujas, repitiéndose la historia de la casa de los Trinitarios Calzados y, en esta ocasión, además, con un hermano del anterior otorgante: Modesto de Castro, vecino de Serrada, labrador acomodado y, como ya se verá, activo comprador en todo este proceso.

1107 Se trata, en concreto, de "una tierra de muy mala calidad, perdida y hecha herial, que en lo antiguo fue maxuelo, sita en el pago de la Moya" de una cabida de 2.277 estadales y con un valor de venta, de acuerdo a la tasación efectuada en Serrada el 28 de agosto de 1821, por el perito Gregorio Román, de 200 reales. Esta tierra sale a subasta con otras cuatro fincas que suman 15.284 reales de valor en venta. No acude ningún rematador a la primera subasta celebrada en Olmedo el 1 de julio de 1822. Y así quedó para mejor ocasión porque Cándido Sáez, vecino de Matapozuelos y adquiriente del resto del lote, se vio, sin comerlo ni beberlo, inmerso en un litigio jurídico al decretar las Cortes, el primero de octubre de 1823, la nulidad de esta medida desamortizadora. El decreto implicaba devolver los bienes a sus anteriores poseedores. Eran los primeros momentos y, como puede advertirse, nada sólidos, de un proceso a caballo entre la agonía del absolutismo fernandino y el reformismo del progresismo liberal. (A.H.P.V. Desamortización, Clero regular, caja 1340, Tordesillas).

1108 "Linda por poniente con casa de Bentura Moyano, por el mediodía con corral de la misma casa y cañadilla; por el oriente con calle del Pozo; por el norte, calle del Pozo... Su armadura es de tabla en mala situación puesto que el edificio se halla en gravísima ruina pues parte del cañón de la bodega se halla arruinado, y lo demás del en gravísima ruina. Tiene la casa de fachada cincuenta y siete pies y de fondo cuarenta y cinco. Que sus lados comprenden dos mil quinientos sesenta y cinco pies cuadrados superficiales y el corral tiene cincuenta y siete pies de largo y treinta y seis de ancho que compone una superficie de dos mil novecientos cuarenta pies cuadrados y el lagar tiene cuarenta y ocho pies de largo y diez y siete de ancho, que componen ochocientos diez y seis pies cuadrados, pero parte de este está arruinado. Tiene viga de pino millo y piedra en mediano estado. La bodega tiene de largo noventa y ocho pies y doze de ancho que compone una superficie de mil ciento y seis pies cuadrados y la fabrica es de tierra. La bodega se halla parte arruinada y lo demás ruinosos. Los que escriben tasan todo el edificio en la cantidad de tres mil cuatrocientos reales de vellón" Firmado. Don Trifón Hernández, maestro alarife, vecino de la Villa de Olmedo, nombrado por el Sr. Intendente de Hacienda pública”. A.H.P.V. Hacienda, Desamortización, Clero regular, Serrada, caja 1323, exp. no 969. 
- La desamortización de la Hacienda del Convento de San Pablo, de la orden de los dominicos.

El 23 de junio de 1840 se ponía en marcha de forma legal el proceso de peritaje y capitalización de una de las mayores haciendas religiosas del norte de la comarca ${ }^{1109}$.

El precio fijado alcanzaba la cifra de 50.182 reales, a pesar de que estaba hundida la bodega y deteriorado el edificio. Sin duda era un precio excesivo para las arcas de la mayor parte del vecindario, no sólo de Serrada sino de los pueblos vecinos. Por estos ańos las labranzas no generaban tales excedentes monetarios y, si en alguna ocasión se aproximaban, la primera inercia del campesino era adquirir más tierra. Y esto podía aplicarse tanto para los labradores de una yunta como a hacendados de más de dos pares. Por ello se insiste en lo alejado que estaba este proceso burgués de enajenación de bienes del interés ilustrado por generar un entramado de "medianos y laboriosos labradores".

En este caso, los dominicos habían amasado una buena heredad de tierras y viñas, sin olvidar los compromisos y mandas testamentarias que les encargaban sus vecinos u otros fieles ajenos a la localidad. En 1817 la hacienda de Serrada tiene unas cargas afectas de memoriales de misas, dotación de capillas, etc., de 42.362 reales $^{1110}$. Como hemos estudiado la casa granja y la propia explotación agropecuaria eran muy notables ${ }^{111}$. Luís de Rojas, vecino de Valladolid, eleva al Intendente Provincial su voluntad de allanar el valor más alto adquiriendo todos los bienes urbanos. Este hacendado y capitalista liberal vallisoletano, director de la Sociedad de Seguros Mutuos de Incendios de Casas, y dueño del parador de diligencias de Santa Ana, amasa, a lo largo de su vida, una inmensa fortuna. Tras su muerte en 1849 sus hijos heredan sus negocios y siguen negociando préstamos, comprando

${ }^{1109}$ Epifanio Martínez de Velasco, arquitecto de Valladolid, titular de Arbitrios y Francisco Javier Berben, arquitecto nombrado por el Procurador Sindico del Común de Serrada, reconocieron y peritaron los bienes urbanos. Se trataba de la casa conventual de San Pablo, de la orden de los dominicos. Se describe en los términos que siguen: "Una casa lagar que en el casco de esta Villa correspondió a la Comunidad de Frailes de San Pablo de Valladolid, que linda por la fachada principal con la Plazuela de San Pablo; por el costado derecho como en ella se entra linda con calle del Pozo a la cual tiene puerta de carros; por el izquierdo con camino que va a Valdestillas, y por lo accesorio con calle del Pozo Nuevo, cuya casa que dejamos deslindada consta de abitaciones altas y bajas; dos lagares con quatro máquinas de pisar uba; Paneras, cuadras, cubertizos, pajar y dos pozos con dos pilas, y Bodega con diez y nuebe cubas. Esta se allá hundida en gran parte y el edificio muy deteriorado y su figura es la de un polígono irregular de siete lados, compuesta por las líneas cuyas dimensiones son las siguientes: la fachada principal señalada con el $\mathrm{n}^{\circ} 4$ tiene cinquenta y un pies desde la que sale otra cuia fuera de beinte y cinco y medio pies, desde cuyo estremo parte otra paralela a la fachada hacia a la derecha de beinte y dos pies, en cuyo estreno o límite, y formando ángulo recto, continua la finca que forma la parte accesoria de treinta y un pies. Desde esta se divide una de las del costado izquierdo formando con la anterior ángulo octuso qu tien doscientos diez pies, continuando otra que también forma con esta ángulo octuso y es la que cierra el perímetro de la figura en ángulo recto con la fachada de doscientos quarenta y nuebe y medio pies, en cuyo polígono están comprendidas quarenta y cinco mil doscientos ochenta y tres pies cuadrados de superficie, de los cuales diez y siete mil quatrocientos beinte y dos corresponden a los edificios y los restantes beinte y siete mil ochocientos sesenta y uno a los corrales, y dando valor a todos sus pies cúbicos y cuadrados superficiales, la tasamos en la cantidad de cinquenta mil ciento ochenta y dos reales de vellón en venta, y en renta en la de dos mil reales cuia tasación hemos hecho con arreglo a el arte que profesamos y ordenes vigentes. Y para que conste damos esta que firmamos en Serrada a 20 de octubre de 1839."Epifanio Martín de Velasco (rubrica). Francisco Javier Berben (rúbrica).

${ }^{1110}$ A.M.S. Caja 72, carp. 891.

${ }^{1111}$ Merecen destacarse, entre otras, las tierras de pan sitas en el Picón del Bao y el Sendero del Montico (nueve obradas cada una); la Cuesta de los Muertos (once obradas); la grande de La Moya (diecinueve obradas) o las treinta y cinco que sumaban las limítrofes de las Fuentes y los Tintos. Eran buenas tierras. De segunda calidad muchas de ellas y productoras de regulares cosechas de trigo o de morcajo. Con todo, la Casa Granja ya no era ni mucho menos lo que había sido unas décadas antes. Pero quien tuvo, retuvo. Una vez arrancadas 165 aranzadas, el lote de majuelos es aún importante. Los mejores son valorados a 20 reales la renta cada aranzada y en 630 reales su valor de venta. Siete aranzadas se encuentran en Pelagallos Y otras doce en Matarillón, en el camino de Matapozuelos a Villanueva. De categoría y precio inferior son los situados en el Horcajillo (una aranzada y cuatrocientoas seis cepas); en el Picón de las Olmas (cuatro aranzadas a 10 reales en renta cada una de ellas y 315 su venta) o las Raposeras, que hace casi cinco aranzadas y vale cada una de ellas 13 reales en renta y 420 en venta. Se puede imaginar la cara que debieron poner los arrendatarios y labradores de Serrada que sońaban algún día con ser propietarios de las tierras que trabajaban. 
y vendiendo tierras, y revendiéndolas tarde o temprano ${ }^{1112}$. El caso de la heredad dominica de Serrada será uno más entre ellas, pero hasta entonces se cerraba una etapa clerical al tiempo que se abrían las puertas del liberalismo burgués a todos los efectos.

Cuadro 106. La desamortización de Mendizábal en el norte de la Tierra de Medina ${ }^{1113}$

\begin{tabular}{lrrrrrrrrrrrr}
\hline & \multicolumn{1}{c}{ No de ha catastradas y samortizadas } & \multicolumn{1}{c}{ y } \\
Municipio & 1 & 2 & 3 & 4 & 5 & 6 & 7 & 8 & 9 & 10 & 11 & 12 \\
\hline La Seca & 6.617 & 57 & 1 & 6 & 88 & 44 & - & 13 & - & 71.265 & 71.290 & 100 \\
Matapozuelos & 5.019 & 119 & 2 & 12 & 89 & 101 & 17 & - & - & 92.000 & 94.968 & 103 \\
Serrada & 2.495 & 380 & 15 & 22 & 135 & 248 & - & 133 & - & 125.926 & 177.220 & 141 \\
\hline Valdestillas & 3.632 & 374 & 10 & 18 & 142 & 191 & 30 & 151 & 2 & 231.576 & 449.115 & 194 \\
Ventosa de la Cuesta & 1.599 & 79 & 5 & 10 & 100 & 79 & 30 & 151 & 2 & 90.050 & 100.175 & 111 \\
Villanueva de Duero & 3.728 & 640 & 17 & 33 & 235 & 364 & 224 & 52 & - & 441.474 & 679.050 & 154 \\
\hline
\end{tabular}

Fuente: Germán Rueda: La Desamortización de Mendizábal en Valladolid.

Conceptos Expresados: 1: ha catastradas; 2: ha desamortizadas; 3: \% de las ha desamortizadas respecto a las catastradas; 4: $\mathrm{n}^{\circ}$ de heredades o lotes desamortizados en subasta; $5: \mathrm{n}^{\circ}$ de las parcelas desamortizadas, 6: ha de labor desamortizadas; 7: ha De vińedo desamortizadas; 8: ha de huerto y otros terrenos desamortizadas; 9: ha de monte, pinares y eriales desamortizadas; 10: valor total de a tasación (en rs). 11; valor total del remate o venta (en rs); 12: cotización (tasación = 100).

- Los Conventos de Monjas Brígidas y de Trinitarios Descalzos. Un paso más en la desamortización del clero regular

El convento de monjas Brígidas atesoraba 33 obradas de tierra y 108 aranzadas de vińas y los Trinitarios Descalzos suman 126 obradas de tierras, todas ellas en manos de arrendatarios locales. A diferencia del caso anterior, la heredad se lotifica y pueden dar orden de puja de acuerdo con sus posibilidades económicas El arrendatario Feliciano Martín se pondrá en manos del apoderado López Morales y no dejará escapar la suerte de menor cuantía; su vecino Gabriel Pérez hará lo propio para adquirir la quinta suerte de 22 obradas; el resto, 78 obradas divididas en tres suertes serán rematadas igualmente por Morales para cedérselas a Modesto de Castro. A diferencia del caso de los dominicos, la heredad de los Descalzos se repartía entre los labradores más pudientes del pueblo.

No sucederá lo mismo un ańo después, en 1842, cuando se inicia el expediente del convento de monjas Brígidas. La tasación pericial ascendía a 18.305 reales que acogían 33 obradas y 108 aranzadas. Ante el primer anuncio oficial, el propio apoderado López Morales solicitará tasación de bienes. Estos, como los anteriores, estaban repartidos por todo el término ${ }^{1114}$. La tasación era igualmente asumible en relación a la calidad de los bienes: entre 1.659 y 3.677 reales. Pero las subastas nunca fueron para jornaleros ni aparceros. Acabaría quedándose con ellas Luís de Rojas. La desamortización del clero regular testificó en Serrada lo que en tantos otros pueblos.

- La subasta de los bienes seculares. Adiós al patrimonio de curas, cofradías e iglesias

De menor importancia que los anteriores, los bienes seculares en Serrada estaban en su mayor parte en manos del Cabildo de la Catedral de Valladolid, que poseía en la villa 42 obradas de tierra y 98 aranzadas de majuelo. El resto no alcanzaba en conjunto las 10 obradas de tierra que se repartían entre la Fábrica de la Iglesia, el beneficio de Preste y el cura párroco. En cuanto a los majuelos,

1112 RUEDA, G.: La Desamortización..., ob. cit., pág. 259.

1113 RUEDA, G.: La Desamortización ..., ob. cit., pág. 457.

${ }^{1114}$ Las tierras de pan llevar eran de reducida cabida: 4 obradas en las Carretas, 6 en las Olmas y en Cuesta Redonda, 4 obradas en las Olmas,... Los majuelos presentaban mayores dimensiones: 16 aranzadas en la Moya, 13 en el camino del Pinar, 9 en los Senderillos, 12 en los Cuarterones..., que salieron en seis lotes, de los cuales cinco tenían una cabida de 14 obradas. El que abría el primer remate se extendía en 18 obradas. 
saldrán a subasta únicamente tres aranzadas que no tendrán rematador, pertenecientes a la Cofradía de Nuestra Señora del Refugio. En 1842, salió también a subasta media obrada de la iglesia, al pago de los Cotarros. La llevaba en renta Feliciano Martín que pagaba por ella "una fanega de pan mediado que importaba dieciocho reales". No pujará por ella, a diferencia de Modesto de Castro que solicitará y allanará el valor más alto, rematándola en agosto de 1842. E igualmente actuará con las dos obradas del beneficio de preste de la iglesia. Estas estaban repartidas en cuatro pedazos en el camino de Ventosa y la Vega. Como en el anterior caso ningún vecino pujó por ellas. Porque no quisieron o porque sabían que no podrían con Don Modesto. Modesto de Castro tampoco podía con los que eran más poderosos que él, a pesar de estar bien respaldado económicamente. Venido de Pozaldez, había realizado un extraordinario matrimonio al casar con Micaela Alonso, hermana de Gregorio León Alonso, uno de los mayores hacendados de la comarca en estas décadas centrales del siglo, hijos a su vez, de Manuel Alonso y María Rodríguez. Es posible que los arrendatarios, que pagaban sólo seis reales la aranzada, consideraran excesivo pagar a plazos la renta de varias décadas, sabiendo que el nuevo propietario, si era foráneo, les iba a dejar seguir labrando dichos bienes, aunque fuera la renta un poco más elevada. Tampoco las paneras andaban sobradas, pese a que a otros les hubiera gustado incrementar su patrimonio. ¡Qué caras han sido siempre las tierras para los que nunca tuvieron dinero! No obstante, para algunos, habrá una última oportunidad.

- La redención de censos y cargas. El foro del Monte de La Moya y la hacienda del Hospital de la Resurrección

Junto a la obra desamortizadora, no se debe olvidar el proceso de redención de censos y cargas que gravaban a perpetuidad o en plazos casi eternos a buena parte del terrazgo estudiado ${ }^{1115}$. En Serrada constan abundantemente tanto en pequeńos como grandes labradores y, como ocurre en la actualidad, en ocasiones se renegocia sobre otro censo, ampliando los bienes que avalan la deuda del censatario. Mayor importancia posee el llamado censo enfiteútico, que hipotecaba eternamente a quienes tomaban tierras incultas de mayorazgos, conventos o concejos. A cambio de la preceptiva autorización y escritura, los beneficiarios adquirían el dominio útil y el usufructo, previo pago de una renta en dinero o especie. La muerte del contrayente no rompía el vínculo de obligaciones jurídicas que se transmitían sine die a sus respectivos herederos. En caso de compraventa por parte de los censatarios, estos se obligaban al pago de determinados derechos al tiempo que el censualista podía romper el vínculo jurídico, haciéndose retornar el dominio útil mediante el derecho de tanteo.

En Serrada, La Moya o San Martín este tipo de censos alternan con el llamado foro, variedad del anterior y cuyos ejemplos más notables son los que unían a estos campesinos con el Convento de Santa Clara de Tordesillas o con la llamada Universidad y Tierra de Olmedo ${ }^{1116}$. Como en los bienes rústicos o urbanos, la redención llegará de la mano de Mendizábal, aun cuando el debate sobre su vigencia y liberación empezase antes, incluso, de la obra gaditana de 1812. Junto a estos censos redimidos, otras muchas cargas permanecerán ligadas al dominio útil de sus tenedores por largo espacio de tiempo, aun cuando su legalidad fuera más que dudosa. Un ejemplo es el del foro de las monjas de Santa Clara de Tordesillas. Este gravamen ha vinculado buena parte del terrazgo del despoblado de San Martín del Monte al mencionado Convento, desde que se otorgara la escritura de dejación del dominio útil en 1817, hasta hace pocas décadas. Los cultivadores, como anterior-

1115 El censo era un contrato realizado entre dos partes (censualista y censatario) por el cual se obliga al pago de un rédito anual por el goce de un bien rústico o urbano o la entrega de un capital. El caso más sencillo es el censo redimible al quitar en que señores, conventos, particulares o instituciones diversas otorgaban a particulares o colectivos cantidades pactadas y avaladas como un préstamo hipotecario actual.

1116 GARRIDO REDONDO, J. J.: "Aproximación al estudio de la desamortización de censos de regulares en las comarcas vallisoletanas de Tierra del vino y Tierra de Medina. Etapa de Mendizábal (1836-1853)", en "Historia de Medina.... ", ob. cit., vol. III., pág. 79 y ss. 
mente ya se ha analizado, debían anualmente entregar al citado monasterio cuatro celemines de centeno por cada obrada de tierra y tres, por cada aranzada de majuelo. A pesar de las distintas disposiciones redencionistas de este tipo de vinculaciones, a lo largo de todo el siglo XIX las escrituras entre particulares anotarán estas obligaciones. De hecho, distintos vecinos de Serrada aún conservan entre sus escrituras, con fechas tan tardías como noviembre de 1960, justificantes de pago "de réditos de un censo impuesto a favor del Patronato de Santa Clara de Tordesillas, que gravita sobre las fincas expresadas al dorso del presente recibo..." 1117 .

Otro ejemplo de censo que las leyes y la actitud pasiva de los otorgantes acabarán por liquidar es el llamado "foro del Monte" o censo enfiteútico, que se había otorgado en marzo de 1766 sobre las tierras incultas situadas en el término Despoblado de La Moya, pertenecientes al común de su concejo y extensibles a la Universidad, de pueblos de la Tierra de Olmedo. Los pagos en que se repartían las roturas, efectuadas por los vecinos de Serrada, no eran pocos ${ }^{1118}$

"Pagos de los majuelos de Monte en la Moia. Pago del Sendero de las Fuentes, Pago de la Calabazaza, Valdesuero, Valondo, Raposeras, Subida del Monte, Cañada del Monte, Sisón, camino de Valladolid, Valdesendero, Valdelacasa, Rancho, Cañada de Valderramos, Cerbiguera, Cañada de Valdelperro, Pradera, Pobres, Picón de la Cańada, Barco de la Moia, Cañada de los Cotos, pago de la Cruz, pago del Colgadero.”

Se pueden recordar al respecto, en una escritura tomada al azar, las obligaciones contraídas por sus tenedores. En 1802 María Moyano vendía a Tomás Cermeño, ambos vecinos de Serrada, cuatro aranzadas al pago de los Pobres por valor de 4.200 reales $^{1119}$ :

"Tiene a favor de la Universidad de la Tierra de Olmedo como uno de los majuelos y heredades que en dicho término y jurisdicción de la Moya llaman del Monte, por el que se pagan a dicha tierra en cada uno de réditos mil quinientos diez reales que reparte la xusticia de esta villa a prorrata entre los tenedores y posehedores y toca cada aranzada a veinte y dos quartos. Para poder formalizar la debida escritura o correr con relaciones de todo al procurador más antiguo de dicha tierra solicitando que no queriendo dicho majuelo por el tanto, me concediese la necesaria lizencia para su enajenación, allanándome a la satisfacción de veintena...”

Estas cuatro aranzadas formaban parte de las más de cuatrocientas obradas que múltiples cultivadores habían ocupado con anterioridad y que, de forma mayoritaria, fueron plantando en la segunda mitad del XVIII. El tiempo jugaba en contra de cualquier restablecimiento de rentas y privilegios por parte de las antiguas y desmembradas comunidades de Villa y Tierra, más cuando estos censos habían sido abolidos por la Ley de Cortes de julio de 19 de julio de 1813 y restablecida en 29 de enero de 1837. El sistema foral y censal se apaga en Serrada y en esta Tierra de Medina, si bien las redenciones no sobrepasarán una tercera parte de los censos de regulares subastados ni los campesinos mostrarán gran interés por redimirse de tales $\operatorname{cargas}^{1120}$, y menos por aceptar contribuciones a antiguas jurisdicciones de las que dependieron. De hecho, a la enésima convocatoria que Olmedo convoca a los pueblos que considera deudores (Hornillos, Matapozuelos, Villanueva de Duero, Valdiviadero y Serrada), la respuesta de esta última población con fecha de 27 de febrero de 1846 es elocuente: "No existiendo en el día la que fue Universidad de la Tierra de Olmedo, tampoco esta villa es el caso de autorizar a ninguno de sus capitulares para los fines que indica el presente oficio circular"1121.

\footnotetext{
${ }^{1117}$ A.F.A.M. y otros.

1118 Ibídem.

1119 A.H.P.V. Pt 8228.

${ }^{1120}$ GARRIDO REDONDO, J. J.: Aproximación al estudio de la desamortización de censos..., ob. cit., pág. 101.

${ }^{1121}$ A.M.S. Caja 22, carp. 878.
} 
El foro del Monte se extingue y la disputa con Olmedo toca a su fin. La nueva división administrativa en provincias, partidos y distritos administrativos, gestada en la década de los treinta, había integrado a Serrada y al despoblado de La Moya en el partido de Medina del Campo. Una página más se cerraba en la Historia de estas tierras.

Distinto es el caso de la hacienda del Hospital de la Resurrección en Serrada. Se componía dicha heredad en 1843 de 49 aranzadas y 43 obradas, de las que once estaban eriales, además de casa, lagar, bodega y cubas. La casa, como se ha estudiado en páginas anteriores, fue levantada por el mercader de joyería vallisoletano José Núnez, tras comprar en 1736 al marqués de Torreblanca cuarta y media de tierra al camino del $\mathrm{Pozo}^{1122}$. En el expediente de enajenación se describía con las siguientes características ${ }^{1123}$ :

"Una casa titulada del Hospital, que linda por el lado derecho como en ella se entra con calleja del Pozo; por la izquierda con tierra correspondiente a la Hacienda de dicho Hospital, y por la fachada con camino de Valdestillas. Dicha casa consta de un alto con bodega o cueba, y en ella cinco cubas, y un corral grande, cuya figura es la de un trapezoide, en el cual están comprendidos treinta mil pies cuadrados superficiales..."

Como el resto de las casas conventuales de la localidad, su potencial vitícola estaba muy mermado respecto a tiempos anteriores. Por entonces muchas de sus cubas ya estaban inservibles. Lejos quedaba la campańa 1790-91 en que se vendimiaron 88 aranzadas de majuelos. La venta o enajenación será mediante la figura de censo reservativo, redimible al tres por ciento del valor en que se tase el conjunto de la propiedad. El mencionado centro piadoso y asistencial estaba acelerando la enajenación de otros bienes en la propia capital y en pueblos de la provincia. Será el rico propietario y alcalde Gregorio León Alonso quien se haga con el control de dicha hacienda ${ }^{124}$.

Los cambios políticos y las leyes liberales iban a jugar a su favor ${ }^{125}$. El 14 de diciembre de 1855, extiende diez pagarés al tesoro Público correspondientes a los diez plazos "del importe líquido de veinte y cuatro mil novecientos reales en que he redimido el censo impuesto sobre varias fincas en Serrada, Villanueva de Duero y Valdestillas a favor del Hospicio de esta ciudad"1126. Un ejemplo más de la ingente cantidad de bienes que habían de ser enajenados.

${ }^{1122}$ A.H.P.V. SH. Hospital de Resurrección, caja 4, leg.1, nº 16.

${ }^{1123}$ A.H.P.V. Pt. 15786, fol. 341.

${ }^{1124}$ A diferencia de los anteriores sistemas de subasta, en este caso se remata el disfrute al aprovechamiento de unos bienes que se capitalizan el año 1844 en 39.567 reales. El posible pujador ha de rematar al alza, tal como se detalla en el pliego de condiciones, el pago anual de los 1.187 reales derivados de aplicar el rédito indicado anteriormente, sin olvidar el cuidado anual y las reparaciones que pueda necesitar la casa, las labores de costumbre asociadas a los cultivos y la reposición de las cepas conforme lo requieran el estado de los distintos majuelos. La Junta de Beneficencia de Valladolid anuncia la subasta en el Boletín de la Provincia en marzo de dicho ańo. El 24 del mismo mes se celebra la subasta en las Casas Consistoriales. Gregorio León Alonso, vecino y alcalde de Serrada en estos ańos, inicia la puja ofreciendo 1.245 reales de réditos. Manifiesta aceptar las condiciones "a excepción de la cuarta que expresa que contribuciones hayan de ser de cuenta del Postor, pues estas pasaran sobre el Hospital, y no sobre el tenedor de dicha Hacienda”. ${ }^{1124}$ Fue la única puja. La Junta aceptó su condición sobre las contribuciones. Gregorio León aumentaba de forma considerable su patrimonio.

${ }^{1125}$ Aunque sea adelantarse al epígrafe siguiente, el censo contraído no iba a tardar en ser prontamente redimido. Entre las cargas redimibles conforme a la ley de 1855 se encontraba el estudiado censo reservativo de 1.245 reales de réditos, otorgado el 30 de diciembre de 1844 ante Pío Cernuda. La nueva ley que declaraba en estado de venta todos los bienes pertenecientes al Estado, al Clero, a las órdenes militares, a los Propios y Comunes de los pueblos, etc., concedía en su título II a los censatarios la facultad de redimir los censos declarados en venta. Gregorio León no se lo pensará dos veces. También tenía dinero para ello.

${ }^{1126}$ A.F.A.M. (s/c). 


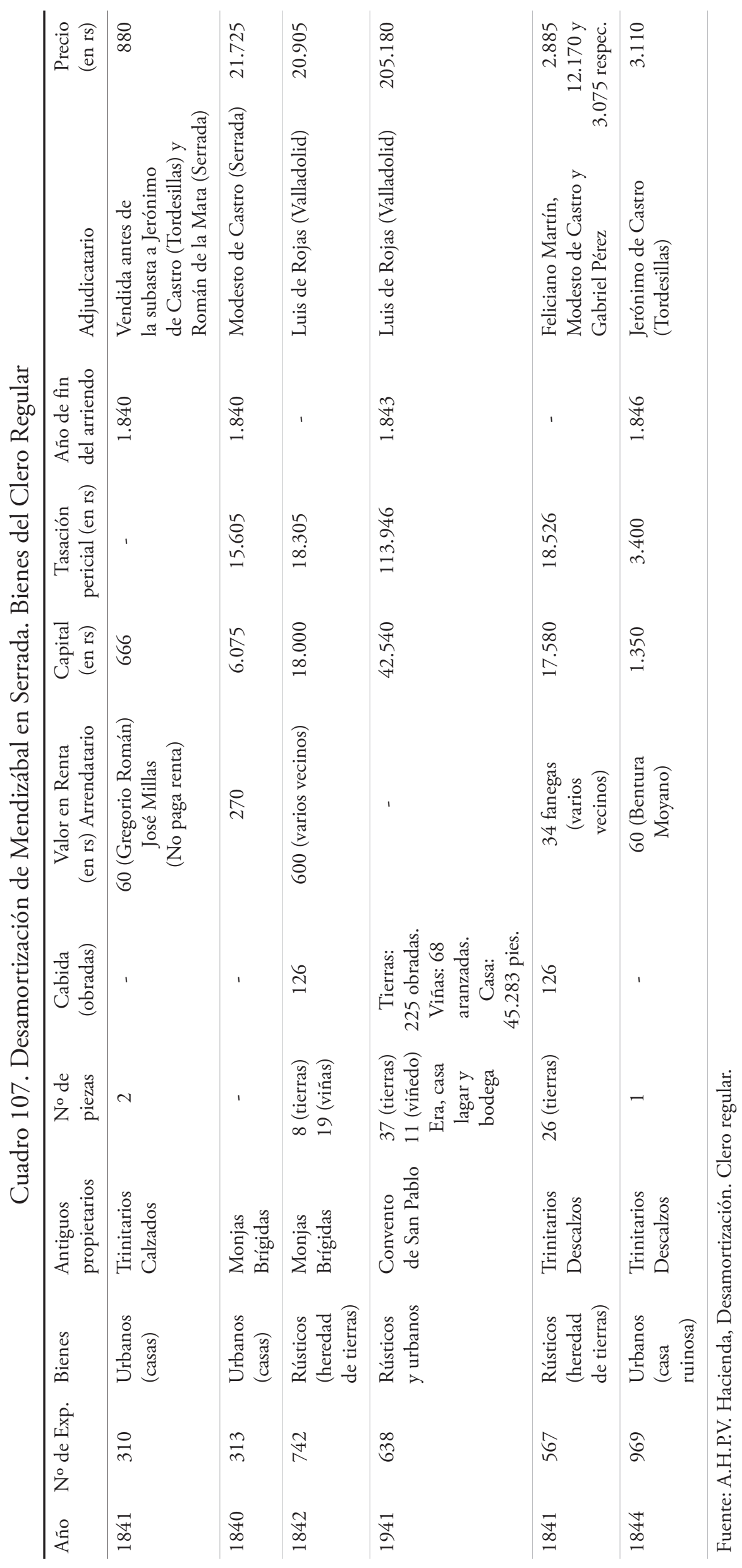




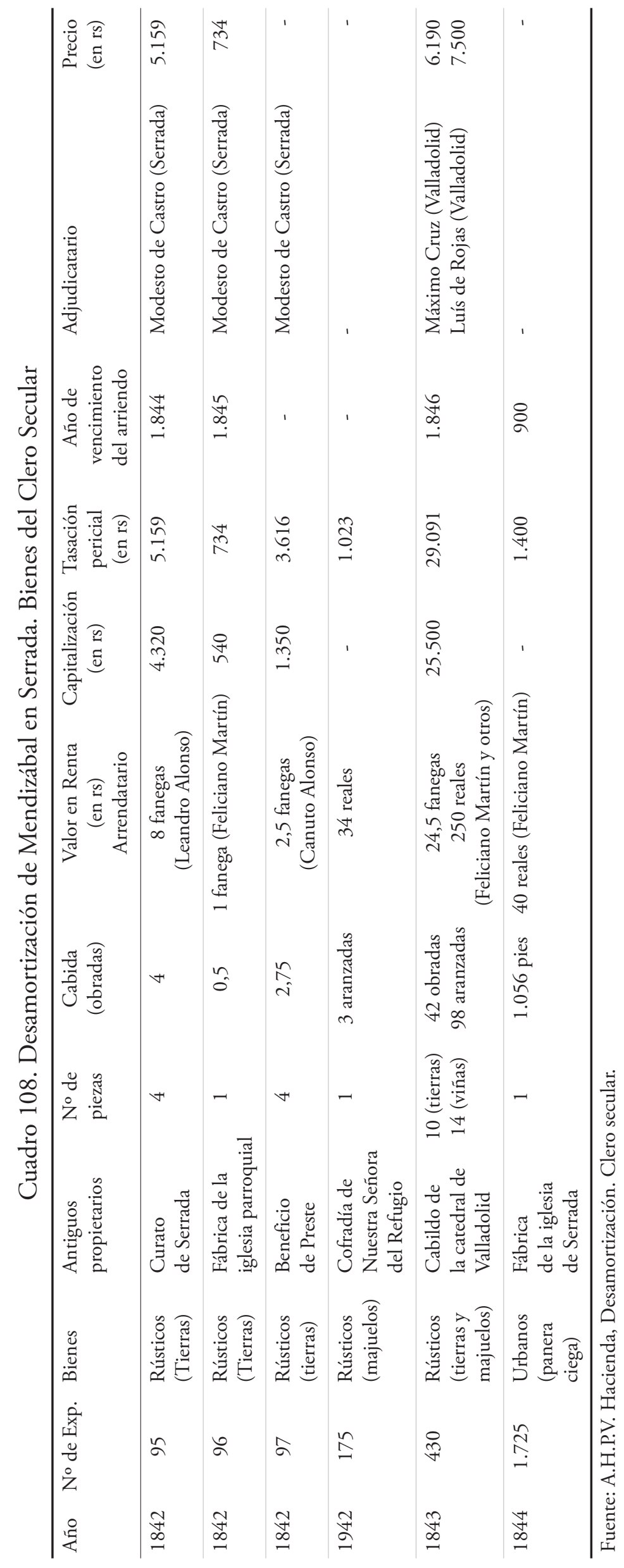




\section{c. La desamortización de Madoz}

Tras la década moderada de Isabel II, nuevamente los progresistas del Bienio (1854-56) prosiguieron la labor desamortizadora con la Ley de 1 de mayo de 1855. Completaba las anteriores "declarando en estado de venta todos los predios rústicos y urbanos, censos y foros pertenecientes al Estado, al clero, etc., y cualesquiera otros pertenecientes a manos muertas". Los bienes del clero secular que faltaban por vender y los bienes de los municipios tenían sus días contados en pro de los mismos intereses confesables e inconfesados de los tiempos de Mendizábal. Los mismos pueblos habían rechazado, tras consulta gubernamental, la venta de sus bienes concejiles. Las fuerzas políticas moderadas y algún sector progresista se opondrán a las medidas y el propio Joaquín Costa criticará "la guerra loca de la Nación contra los municipios". Si la desamortización de Mendizábal benefició fundamentalmente a los hombres más ricos, la de Madoz perjudicará a los más pobres, a aquellos que completaban sus recursos aprovechando pastos comunes, montes y bosques o labrando pequeños lotes o suertes municipales ${ }^{127}$. Serrada, como muchos otros pueblos, luchó lo indecible para salvar del proceso sus bienes comunales, pero no todos se libraron de las subastas. Desaparecido San Martín del Monte y reabsorbido su término por Serrada, sus dehesas y prados saldrán a la venta, al igual que su limítrofe monte de Nuestra Señora de la Paz, de La Seca, el Rebollar de Nava del Rey, la Rinconada de Castronuño, el Montico de San Miguel del Pino o tantos otros. En cambio, los prados de Serrada quedarán al margen del proceso. La vecina Villanueva de Duero se librará también de nuevos propietarios, muy dados a introducir el hacha y el arado, en sus montes y pimpolladas. Un total de 472 ha permanecerán indemnes en el citado municipio, al igual que los extensos montes del Común y Escobares de Nava, Molinillo y la Vega de Tordesillas... ${ }^{1128}$.

- Los bienes rústicos y urbanos de la comunidad del Sancti-Spíritus ${ }^{129}$

$\mathrm{Al}$ margen de estos bienes civiles comentados, en Serrada aún subsistían propiedades religiosas. Se trataba de los bienes de las monjas del Sancti-Spíritus. No iban a ver proclamar la primera República. Los años 1867 y 1869 saldrán a pública subasta. Esta comunidad religiosa había conseguido reunir en Serrada una mediana propiedad, cercana a las treinta obradas, que acogían, además de tierras de pan, 34 aranzadas de majuelos. Y todo ello presidido por su casa de labranza que, en virtud de las citadas leyes de $1^{\circ}$ de mayo de 1855 y 11 de julio de 1856, será rematada, en agosto de 1867 previo anuncio en el boletín de Ventas de Bienes nacionales de Valladolid, fecha de 11 de junio de $1867^{1130}$ :

\footnotetext{
"Una casa, en el casco del pueblo de Serrada, procedente de las Monjas de Sancti-Spíritus de Valladolid, situada en la calle Real, señalada con el numero 5; linda al N. casa de D. Canuto de Castro, S. y O. casa de herederos de Manuel Moyano y E. con dicha calle; comprende una superficie de dos mil trescientos cinco pies cuadrados la parte edificada, equivalente a una área y setenta y nueve centiáreas; y mil ciento veinte pies cuadrados de corral, o sea por edificar, equivalente a ochenta y siete centiáreas; la bodega tiene mil ciento treinta y tres pies cuadrados, equivalentes a ochenta y ocho centiáreas; ha sido capitalizada por la renta de veinticuatro escudos, que gradúan los peritos en cuatrocientos treinta y dos escudos, y tasada para la venta en setecientos cincuenta escudos, tipo para la subasta."
}

${ }^{1127}$ PALACIO ATARD, V.: “La España del siglo XIX”. Espasa Calpe, SA., Madrid, 1978, pp 294.

${ }^{1128}$ DÍEZ ESPINOSA, J. R.: "La Desamortización de Madoz en la Tierra de Medina (1855-1868)”, en "Historia de Medina y su Tierra”. Ayuntamiento de Medina y otras instituciones, 1986, pág. 31-32.

${ }^{1129}$ Aunque se ha verificado y constatado la coincidencia de estos bienes de la comunidad del Sancti-Spíritus con los de las monjas del Corpus Cristi, se ha mantenido la diferencia terminológica de su titularidad de acuerdo a la distinta identificación de los documentos consultados.

${ }^{1130}$ A.H.P.V. Hacienda, Desamortización, caja 1373. 
Núm. 992.

\section{POOVISEAA DE VALEAOOLIO.}

\section{COMISION PRINGIPAL.}

Por disposicion del Sr. Gefe de la Administracion Económica de esta provincia y en virtud de las Leyes de 1. de Mayo de 1855 , 11 de Julio de 1856, é Instrucciones para su cumplimiento, se sacan á pública subasta en el dia y hora que se dirán, las fincas siguientes :

Remate para el dia 13 de Febrero de 1872, que dará principio á las doce en punto del dia en las Casas Consistoriales de esla Capital, ante el Sr. Juez de primera instancia del distrito de la Plaza y Escribano D. Victor Mora.

Bienes DEL PATRIMONIO QUE FUE DE LA CORONA, CONSIDERADOS PARA SU ENAGENACION COMO DE

Rústicas en Serrada.-Remate en Madrid, Valladolid y Medina del Campo.

\section{MAYOR CUANTIA}

\section{$195-278$}

EXPEDIENTE número 11.299; del inventario general 8.094 y del particular de la Direccion general del ramo 2.-Quiñon compuesto de dos dehesas en término de Serrada, procedentes de las Monjas de Santa Clara de Tordesillas, deslindadas por el práctico de labranza D. Ignacio Gaspar Moyano y tasadas por el Agrimensor Don Gerónimo Gervás, en esta forma:

1." Una dehesa, titulada de San Martin, al pago de su nombre, de primera calidad; linda 0. camino de la Barca de San Miguel, P. baldío de la Seca y N. cañada: la divide el arroyo que pasa por medio de ella en toda su longitud: tiene de superficie ciento ochenta obradas y setenta estadales, equivalentes á sesenta y una hectáreas, veinte y dos áreas y cuarenta y seis centiáreas; componiéndose la obrada de cuatrocientos estadales de trece y medio pies de lado, produce sanos y abundantes pastos; $y$ vale en renta ochocientas setenta pesetas y en venta veinte y un mil seisEientas noventa pesetas.

2.a Otra dehesa-prado titulado el Berral, al pago del mismo nombre, de primera y segunda calidad; linda, 0 . monte de Calderon, M. cañada, P. terreno conocido por del despoblado y camino de la Barca de San Miguel á la Seca y N. monte de Calderon: le divide el camino de Rueda á Valladolid y el que de esta villa vá á la Barca de San Miguel, por el P. baja el arroyo que entra en parte de la finca: produce sanos y abundantes pastos y tiene de superficie cuarenta y siete obradas, dos cuartas y ocho estadales, equivalentes á veinte y seis hectáreas, ochenta y nueve áreas y cincuenta y una centiáreas: vale en renta trescientas ochenta pesetas y en venta nueve $\mathrm{mil}$ cuatrocientas ochenta pesetas.

De manera que las dos fincas referidas componen en junto la cabida de ciento cincuenta y cinco obradas; dos cuartas y setenta y ocho estadales. equivalentes á ochenta y ocho hectáreas, once áreas y noventa y siete centiáreas: han sido capitalizadas por la renta anual de mil doscientas cincuenta pesetas, que marcan los peritos en veintiocho mil ciento veinte $y$ cinco pesetas y tasadas para la venta en 31.170 pesetas, tipo para la subasta.

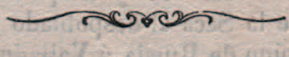

Imagen 82. Anuncio en el Boletín Oficial del expediente de desamortización de las dehesas y prados de San Martín, hasta entonces propiedad del convento de Santa Clara de Tordesillas. Desde la desamortización de Mendizábal el estar bien informado, contar con los contactos oportunos y disponer de capital para hacer frente a los pagos será imprescindible para adquirir las numerosas propiedades que salen a subasta. Como hemos expuesto, la mayor parte de los pequeńos y medianos labradores quedarán al margen de este importante trasvase de propiedad. Archivo familia Alonso Moyano. 
El remate final será para el propietario local León José Moyano que, en calidad de cesión, se la vende a su hermano Perfecto Moyano en $1868^{1131}$. Entre los bienes rústicos de esta congregación destaca un quińón de majuelos que suman 31 aranzadas repartidas en cuatro piezas: la Raya (23 aranzadas), en la Mayorazga (4 aranzadas), en el Gigante (otras cuatro más cien cepas) y "un majuelo de cuarta clase al pago del Lobo... Tiene una cabida de 710 estadales". Todas estas fincas, junto con un erial en los Redondos de 99 áreas, serán rematadas en primera subasta celebrada en Medina del Campo por Eleuterio Martín, vecino de Serrada, como mejor postor, en 3.500 escudos. Tomás Moyano Domínguez, por su parte, se quedará, después de aportar otros 250 escudos, con las tierras eriales de dicha comunidad y será el adquiriente de los últimos majuelos que se desamortizan en Serrada y en buena parte de la provincia. El patrimonio concejil será igualmente subastado. Una buena parte -seis obradas y media- serán rematadas por Balbino Alonso en 3.601 escudos ${ }^{132}$.

\section{- Llegó la hora de prados y montes}

Habían jugado un papel fundamental en las economías de subsistencia durante largos siglos. Los propios concejos regulaban su aprovechamiento, la entrada del ganado o la concesión de roturaciones. El Ayuntamiento de Serrada echará, como tantos otros pueblos, el resto por la defensa de sus prados. Los vecinos no dejaron de preocuparse hasta que conocieron la exclusión de los prados de Abajo y de Arriba, así como del Pradejón, todos ellos en término de Serrada, del proceso de enajenación que se lleva a cabo en estos años de la segunda mitad del XIX. No ocurrió lo mismo con los pastizales de San Martín. Tanto su dehesa, de primera calidad y con una cabida de 180 obradas (101 ha) como la Dehesa-prado del Berral, de 47 obradas (26,59 ha), tendrán desde febrero de 1872 un nuevo propietario: Cayo Pombo ${ }^{1133}$.

No podía finalizar la desamortización de Madoz sin sustraer al concejo de Serrada algo más: su pinar. A pesar de no ser nunca bien valorado, no dejaba de ser un espacio de aprovechamiento común. Confinado en las rayas de San Martín y Villanueva, en tierras de tercera poco aptas para

${ }^{1131}$ Como en los anteriores casos esta propiedad pasa por distintos titulares. Será heredada por Eustaquia Moyano, casada con Zacarías Alonso, quien la legará a sus seis hijos tras su muerte en 1922. Felipe Alonso Moyano será quien se haga con la totalidad de su propiedad antes de ser vendida en 1938 a César Medina Bocos. (A.R.P.M.C., tomo 133, Libro 5, Serrada, finca 363).

${ }^{1132}$ Se anota la trascripción por la importancia de estos espacios concejiles en el desarrollo de la vida campesina tradicional. Si se recuerda las figuras del caso urbano, reproducida en páginas anteriores, estos bienes dedicados al desgrane de mieses y al pastoreo en primavera, se encontraban situados al norte de la población, en lugar bien venteado y a salvo de posibles inundaciones o escorrentías por tormentas veraniegas. La localización exacta de la era es la que sigue: "Una era de pan trillar, en el expresado Serrada y de igual procedencia, al pago de las Eras, de primera calidad; linda O. Camino de la calle del Pozo a Valdestillas, M. era y bodega de D. Pedro Moyano, camino del Pozo, era de Tomas Moyano Díaz, servidumbre de la casa de Tomas Moyano Domínguez y camino del pinar, P. Campo Santo y N. Eleuterio Alo nso; hace seis obradas y doscientos quince estadales, equivalentes a tres hectáreas, cuarenta y un áreas y setenta centiáreas, componiéndose la obrada de cuatrocientos estadales de trece pies y medio de lado.

El camino que divide esta finca, es servidumbre publica y sale desde la calle Real para Valladolid, atravesando la era desde el límite que linda con la casa de Canuto de Castro, siguiendo la dirección del N. hasta el opuesto que linda con la era de Celestino Alonso y Canuto de Castro, cuyo camino es de diez metros de anchura en toda su longitud. Tiene además otra servidumbre para la puerta accesoria de la casa de Tomas Moyano Domínguez, en una longitud de cuatro metros y cincuenta centímetros que separa la casa de la era, a contar desde el ángulo posterior del edificio que confina al N. y en esta dirección, siguiendo el accesorio de la casa de Canuto de Castro, al P. hasta entrar en el camino citado de Valladolid. Estas servidumbres que se consignan en la certificación constan hasta ahora solamente por declaración del regidor sindico D, Celestino Alonso. Llevan en renta para la estación veraniega Canuto de Castro, vecino de Serrada y para la de pastos, Juan Rivera, no constando la renta que satisfacen al Ayuntamiento: ha sido deslindada por el práctico de labranza D. Pedro Hinojal, tasada por el Agrimensor del ramo D. Victoriano González Meléndez, según certificación expedida en 19 de agosto del presente año, en mil escudos, y capitalizada por la renta de setenta que marcan los peritos en mil quinientos setenta y cinco escudos, tipo para la subasta.”.

(A.H.P.V. Hacienda, caja 373, Boletín 24-9-1869).

${ }^{1133}$ DÍEZ ESPINOSA, J. R: "La Desamortización en Valladolid..., ob. cit., pág. 230. 


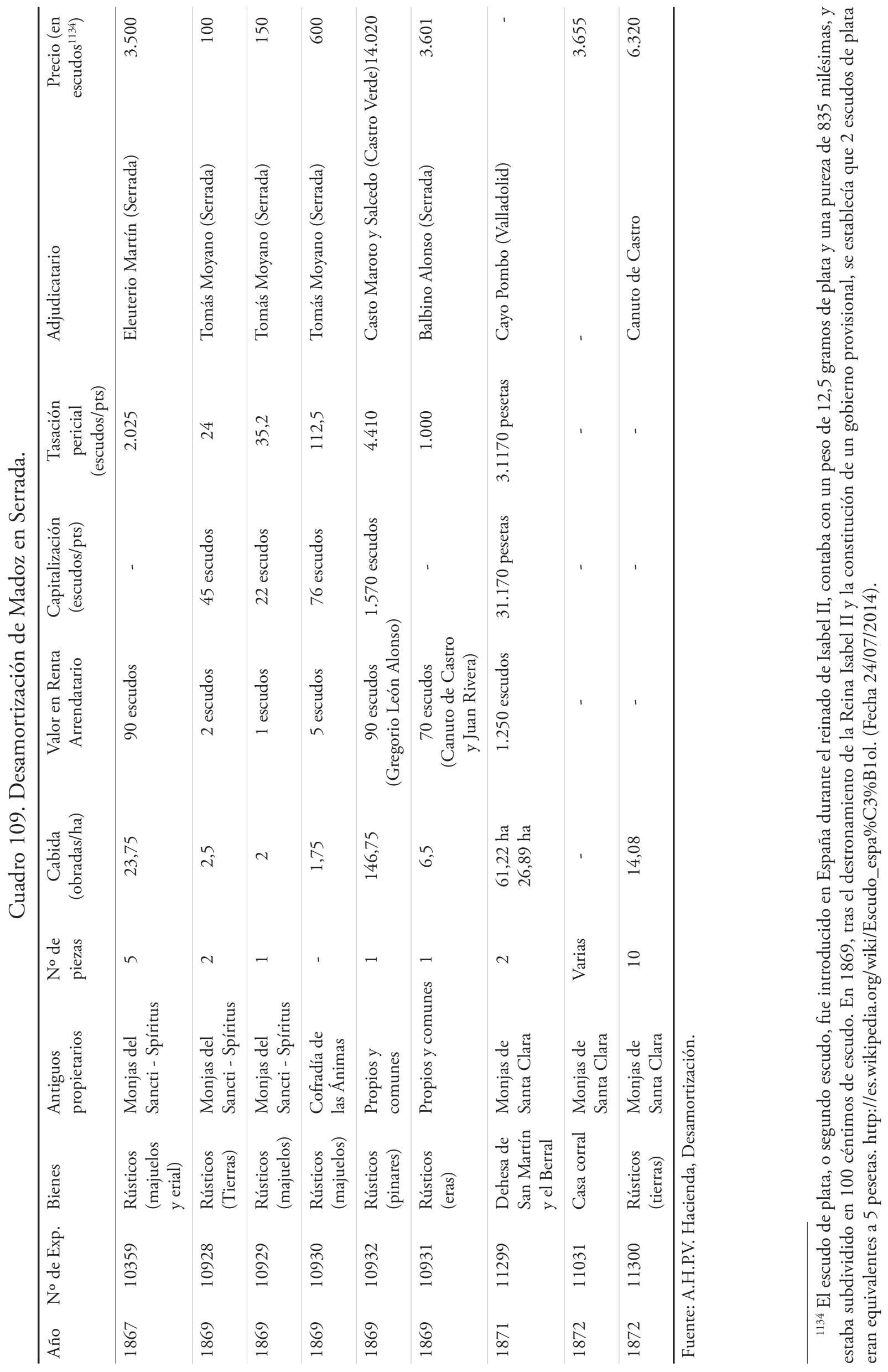


pan, se encontraba un tanto descuidado a mediados del XIX. El propio anuncio de su remate señalaba que "se compone de pinar albar en mal estado y bastante abierto el arbolado y algunas matas de encina”. También tendrá rematador forastero en la persona de Casto Maroto y Salcedo, vecino de Castroverde, previo pago de 14.020 escudos. El proceso desamortizador tocaba a su fin. ¿Había cumplido los objetivos que alentaron los ilustrados y esperaron los liberales?

\section{d. Las consecuencias del proceso desamortizador}

Se inició el estudio desamortizador recordando las preocupaciones ilustradas por superar los frenos que impedían a la agricultura iniciar caminos más productivos. En menos de medio siglo, los labradores y renteros de Serrada verán cambiar de manos 745,25 ha, una vez sumadas a las anteriores cifras los pinares y prados sacados a subasta por Madoz, equivalentes al 29,89\% del término municipal. Tan sólo podrán adquirir 96,24 ha. Ni la Desamortización, como tantas veces se ha repetido, constituyó nunca una reforma agraria ni los hechos facilitaron, aunque esta cuestión sí figuraba entre quienes idearon las distintas leyes, el acceso a la propiedad a los vecinos de los pueblos que labraban las tierras desde siglos.

A ello, o quizá fuera un factor que impidiera cumplir los anteriores deseos, se debe añadir la falta de capitalización que se observa en las economías de los pequeños y medianos labradores, a quienes les resultaban inalcanzables los precios de las tasaciones y las pujas de las subastas, controladas, como ya se ha relatado, por especuladores y hombres de negocios. Si esto caracterizaba a los poseedores de tierra, la atonía vitícola que se vive en el primer tercio del siglo alejaría del todo a los eternos renteros de lanzarse a aventuras crediticias por conseguir las granjas y bodegas de dominicos o brígidas que, por otra parte, se encontraban en franca retirada, como se refleja del abandono que presentan sus casas, bodegas y cubas. Subastados los bienes, continuarán pagando similares rentas a los nuevos y ricos propietarios como Luís de Rojas, principal comprador de cuantos se interesan por Serrada. Adquiere 98 aranzadas de viña y más de 350 obradas de tierra. A este agente de negocios, que adquiere con Mendizábal más de 900 ha en la provincia de Valladolid, se unen en el interés por esta villa en la época Madoz Casto Maroto y Salcedo, comprador de las 146 obradas del pinar del común, o Cayo Pombo, adquiriente de las 127,7 ha de la dehesa de Arriba y del Berral. Se convertirán así en los mayores propietarios de la villa, acompañando al marqués de Torreblanca y Falces, que, con sus 340 ha de inmejorable calidad, sigue siendo el mayor hacendado y comparte con los anteriores el carácter absentista de sus haciendas. En Serrada tan sólo se distingue Modesto de Castro y su hijo Canuto de Castro como adquirentes de bienes rústicos y urbanos durante la época de Mendizábal. Modesto de Castro se quedará con 78 obradas de las 126 que componían los bienes de los Trinitarios Descalzos, además de otras 7,25 procedentes del curato, fábrica y beneficio de Preste de la iglesia Parroquial. Junto a este comprador, adquirente igualmente de varios bienes urbanos en la localidad, el resto de los compradores labradores de Serrada es poco significativo en relación con los volúmenes de tierra subastada. Tan sólo cabe destacar, como pequeños labradores que completaban la escasez de sus propiedades con tierras a renta, a Feliciano Martín y a Gabriel Pérez que acompańaron, comprando un lote de en torno a 22 obradas cada uno, a Modesto de Castro en la compra de los trinitarios y, ya en la desamortización de Madoz, a Eleuterio Martín que se hizo con las 23,75 obradas de las monjas del Sancti Spíritus.

El resto de compradores locales en cuanto a volumen de bienes adquiridos es insignificante. No representan sino una pequeña parte $(21,33 \%)$ de las adquiridas por los ya citados Máximo Cruz, Luís de Rojas, Maroto y Salcedo y Cayo Pombo, que suman la mayor parte $(78,6 \%)$ de las tierras que se desamortizan en Serrada, totalizando 867,7 obradas que van a parar a manos ajenas a la villa y a conformar nuevos arrendamientos, dado que ninguno de estos compradores foráneos abrirá, a diferencia de sus antiguos y religiosos poseedores, casa de labranza en la localidad. 
Junto a estos factores, que en nada contribuyeron a resolver la desequilibrada estructura de la propiedad de la tierra, Serrada y su despoblado de San Martín del Monte perderán, además, otras 160 ha de sus comunes de prados y montes, lo que supondrá, como abundantes estudios sobre el particular ya han demostrado, otro serio revés para las economías rurales que obtenían de estas tierras no cultivadas buenas rentas (caso de los frescos pastizales de San Martín) o un complemento a la cabaña ganadera local, nunca sobrada de eriales o baldíos, dada la importancia del terrazgo vitícola, sin olvidar el perjuicio a labrantines y jornaleros que siempre vieron en estas tierras y espacios comunes una posibilidad de combatir escaseces o ampliar sus reducidos bienes.

Por todo ello se puede concluir que son los propios labradores medios o pudientes los que adquieren la mayor parte de los bienes enajenados. En lo que respecta a los terrazgos de la Moya, Serrada y San Martín del Monte, la Desamortización no evitará la secular salida de rentas a manos totalmente ajenas a la localidad ${ }^{1135}$. Y este fenómeno, ya de por sí importante a lo largo de los siglos pasados, será vital en esta segunda mitad del XIX. La fortaleza de las labranzas será fundamental a la hora de afrontar con garantías la crisis de final de siglo. A ello se debe ańadir, aunque en nada tenga que ver con el proceso de enajenación, el mantenimiento del marqués de Falces como principal hacendado a lo largo de todo la centuria y que hará de Serrada, con 810 ha arrendadas de un total de 2.495 ha que componen el término, $(32,46 \%)$, un singular ejemplo de dependencia externa en lo tocante al régimen de propiedad y de consiguiente descapitalización productiva en relación a cada una de las haciendas. A finales de siglo la crisis de la filoxera y la caída de precios del cereal encontrarán campo abonado para que se acentúen las tensiones sociales de cara a las primeras y tensas décadas del siglo XX.

${ }^{1135}$ RUEDA, G.: La desamortización... en Historia de Medina...., ob. cit., vol. III., pág. 14-17. 


\section{CAPÍtULO VII}

LOS CAMBIOS DERIVADOS DE LA REVOLUCIÓN LIBERAL. EL INICIO DE UN CAPITALISMO AGRARIO MONOPOLIZADO POR LA CLASE PROPIETARIA EN LA SEGUNDA MITAD DEL SIGLO 


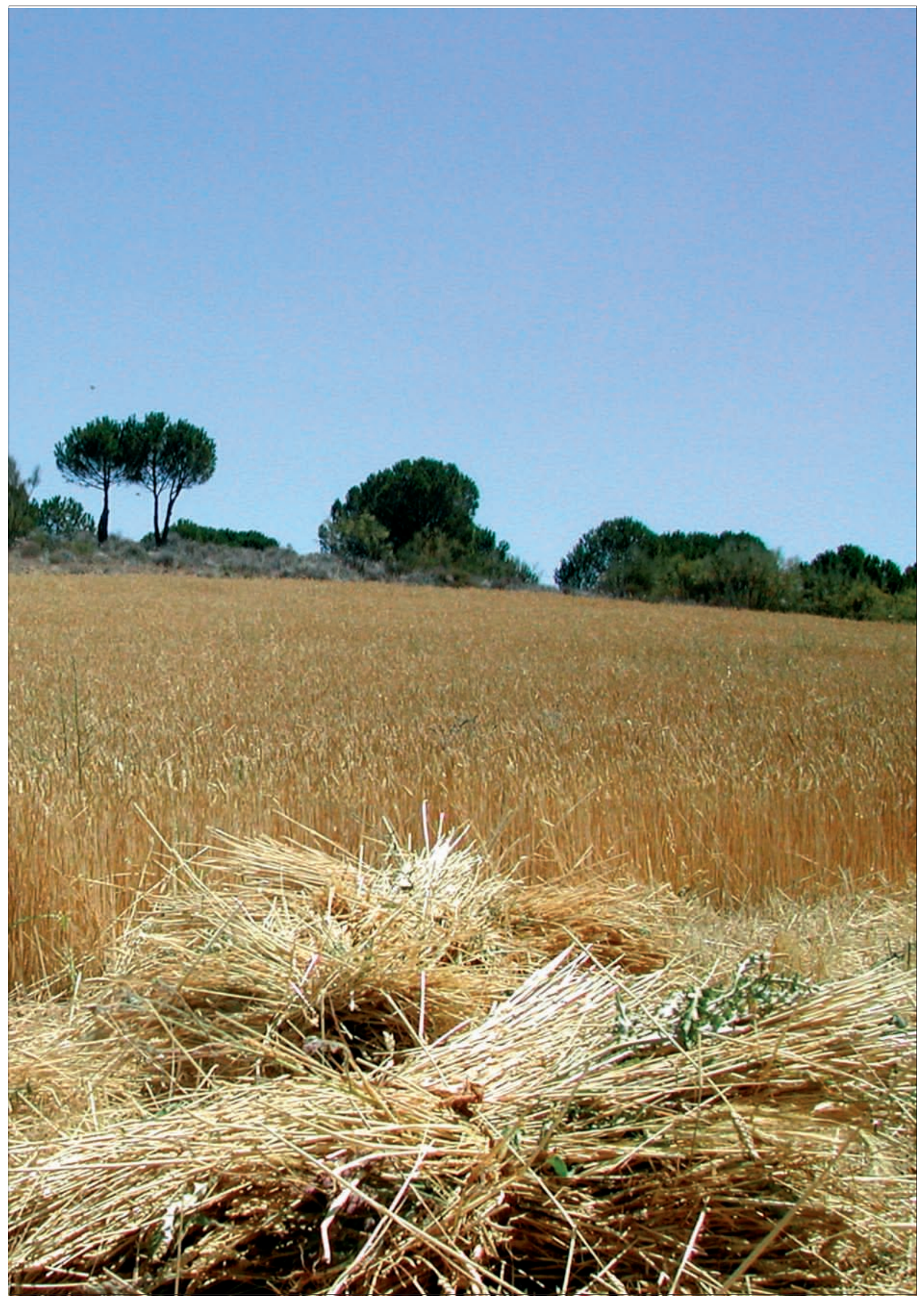

Imagen 83. Haces de trigo segado y atado a la manera tradicional. Serrada. (Foto: 16/07/2005). El cultivo del trigo, fomentado por los intereses de la industria harinera y la política proteccionista, centrará los afanes de los labradores de mediados del siglo XIX. Las buenas cosechas, acompañadas de altos precios, explican el dinamismo agrario que se vive en las décadas centrales de esta centuria. 
Como se ha analizado, en el proceso político de toma del poder por parte de la burguesía el sector agrario se verá notablemente afectado. La tierra, que había sido a lo largo de los siglos el soporte básico de poder, monopolizada por los estamentos privilegiados, se convierte en una preciada mercancía, regulada por los principios del liberalismo económico. Suprimidas sus ataduras diezmales, vinculaciones institucionales o usos colectivos que limitaban su explotación y modernización, va a convertirse en una de las piezas angulares sobre la que descansa la política económica espańola del segundo tercio del XIX ${ }^{1136}$. La Desamortización abre definitivamente la puerta a un capitalismo que, en estas primeras décadas, deja sentir sus efectos en las nuevas relaciones de propiedad, en el control por las emergentes clases propietarias de las vidas municipales y en la salida de estas entidades de su tradicional plegamiento sobre sí mismas.

La comarca medinense no va a permanecer ajena a unos cambios que, graduados en distintas fases, acaban por modificar radicalmente las estructuras propias del antiguo régimen. El fenómeno no tiene lugar de la noche a la mañana, pues viejas inercias campesinas persisten un siglo más. De hecho, hasta finales del XIX, la agricultura castellana y española en general se encuentra en una fase preindustrial en la mayor parte de los casos. Sólo en las explotaciones más avanzadas del último cuarto de siglo se detectan innovaciones de cultivo, mecanización o transformación y comercialización de productos, que indican su transición a la agricultura mecanizada, industrial y moderna que se generaliza desde la segunda mitad del siglo XX. Pero hasta entonces son notables los cambios que han de superar las comunidades campesinas estudiadas, no sólo por su propia evolución, sino en cuanto se integran, cada vez más intensamente, en las estructuras administrativas y económicas de la comarca medinense que, como no puede ser de otra forma, sigue las pautas de los distintos procesos de cambio e implantación del liberalismo de la España del siglo XIX.

\section{La incidencia de la nueva organización administrativa en tierras vallisoletanas}

El ordenamiento administrativo y territorial que se inicia con la legislación de Cádiz, culmina en la reforma provincial de Javier de Burgos de 1833 y en el establecimiento de los partidos judiciales en 1834 que tratan de racionalizar la anacrónica y dispar estructura existente en España. Otra cosa bien distinta era acabar con las eternas disputas que se traían entre manos las distintas villas y aldeas por la delimitación exacta de sus términos municipales ${ }^{1137}$. Cuestión de mayor trascendencia tienen

\footnotetext{
${ }^{1136}$ Conviene recordar que el nuevo régimen agrario representa toda una revolución respecto al sistema tradicional. A la estudiada desamortización eclesiástica y civil, se debe añadir la paulatina desaparición de los aportes diezmales, la reducción de la vigencia o redención de censos, la abolición del régimen señorial que conllevaba importantes derechos y percepciones de rentas, paso de puentes, privilegios o pagos en los aprovechamientos de pastos o molinos, etc., etc. Muy valiosa en este sentido es la aportación de Ángel García Sanz: Historia agraria de la España contemporánea, vol. 1, ed. Crítica, 1985, pág. 7-99.

1137 Aún en 1822 Serrada y Matapozuelos solicitan "a que términos corresponden los pagos del Picón y Casa Balandrán con el objeto de conciliar los ánimos e intereses de dichos pueblos". Hasta que se aclare la cuestión, ambos pueblos convienen que no se hagan novedades en los repartimientos de la contribución y que los propietarios de las heredades en disputa paguen en el pueblo de su vecindad. A.D.V. L.A.D., 16 de marzo de 1822.
} 
los Despoblados que se reparten por las extintas comunidades de villa y tierra. El Catastro de la Ensenada de 1752 asignaba a muchos de ellos pleno carácter jurídico. El Despoblado de La Moya, vinculado a Serrada, es una prueba de ello. A pesar de quedar abandonado desde principios del XVII, se siguen nombrando alcaldes por Olmedo durante buena parte del siglo y son sus gremios de labradores o hacendados vińeros los que gestionan su terrazgo durante el siglo XVIII.

El caso de San Martín del Monte es distinto. Hemos estudiado cómo se cierran definitivamente sus puertas en 1818. La última oportunidad de ser nuevamente habitado se malogra en 1820, cuando fracasan los intentos de repoblación emanados desde la secretaría de gobernación y las instancias al Ayuntamiento de Tordesillas para que "ayude a los que pretenden repoblar a San Martín del Monte"1138. Su término se integra en el de Serrada. La administración tributaria y los arrendamientos de sus bienes comunales serán vigilados por la nueva institución de la Diputación Provincial. Aunque en estas primeras décadas del XIX existen decretos e instrucciones que permiten la incorporación de términos o municipios en otros, San Martín del Monte seguirá conservando una identidad propia durante buena parte del siglo. En los repartimientos que hace la institución provincial en 1845, 1859 o en los cupos de contribución de inmuebles, cultivo y ganadería correspondiente a 1860, por poner algunos ejemplos, se individualiza la riqueza imponible a San Martín del Monte, si bien en el resto de cupos y recargos aparecen unificados con los de Serrada ${ }^{1139}$. Idéntico trámite administrativo se constata con despoblados como Sardoncillo (vinculado a Sardón), Descarga María (Carpio), San Llorente (Salvador), cotos como La Espina (adscrita a Castromonte), Bernardos (Balbuena de Duero) o las llamadas granjas como Quiñones y San Andrés (a San Martín de Valvení) o Mombiedro (a Quintanilla de Arriba).

\section{a. La Diputación Provincial como nuevo órgano de gestión, vigilancia y control de la vida municipal}

Los liberales de Cádiz fueron conscientes del peligro que entrańaba dejar en manos apegadas a la tradición los concejos y ayuntamientos locales. La creación de la institución provincial sirve para extender y defender el nuevo régimen liberal hasta los últimos rincones del país. La provincia se ordena entre la Diputación como entidad corporativa, formada por representantes de la comarca, y el jefe Político como representante del poder central del que deriva posteriormente la figura del subdelegado de Fomento y gobernador civil ${ }^{1140}$.

A pesar de la temporal anulación por Fernando VII del nuevo sistema o de la mayor o menor dependencia que tendrá la provincia respecto al poder central en décadas posteriores, se aprecia desde las primeras décadas del XIX un acogimiento favorable entre los municipios vallisoletanos, toda vez que dicha institución asume un papel protector en los momentos de desgracias colectivas. La Diputación socorre a los pueblos cuando estos pierden sus cosechas, se extienden por ellos epidemias o sus casas son devoradas por el fuego, sea en forma de reducción de contribuciones, en metálico o en especie. Las primeras actas provinciales muestran peticiones de pueblos afectados por las contribuciones a tropas nacionales o las requisas efectuadas por los franceses. En febrero de 1814, la contaduría provincial aprueba fondos para "la reparación de los puentes de Simancas, Villanueva de Duero y Quintanilla de Abajo en el año próximo anterior y el de Valdestillas en el de 1812" y, en noviembre de 1820, distribuye para socorro de labradores 30 fanegas de trigo, 30 de morcajo y 40 de cebada a Valdestillas; 34 de morcajo y 34 de cebada a Serrada; 40 fanegas de trigo, 50 de morcajo y 50 de cebada a Matapozuelos, 60 fanegas de morcajo y 40 de cebada a Tordesillas, etc. ${ }^{1141}$.

${ }^{1138}$ A.D.V. L.A.D., 21 de septiembre de 1820.

${ }^{1139}$ A.D.V. L.A.D., 30 de septiembre de 1845 y 6 de diciembre de 1859.

1140 PASTRANA MORILLA, H.: La Diputación Provincial de Valladolid. 1875-1930. Política y gestión. Ed. Diputación Provincial de Valladolid, 1997, pág. 9.

${ }^{1141}$ A.D.V. L.A.D. Actas de 1814 a 1820. 
A pesar de ser el nuevo órgano recaudatorio, de ordenación y gestión de recursos de los bienes municipales, estas actuaciones facilitan su implantación institucional, reforzada a lo largo del XIX por los propios componentes de las comisiones provinciales. Al proceder de las más distinguidas familias de las distintas comarcas, se sentirán mediadores o voceros de los problemas de las demarcaciones que representan y tratan de influir tanto en las cuestiones domésticas de los municipios como, en la medida que puedan, presionar para la resolución de problemas generales al Jefe Político, correa transmisora del gobierno central. Sirva como ejemplo la solicitud formulada por varios pueblos del partido de Olmedo para que se prohíba la introducción de rubia extranjera por la amenaza que supone para el cultivo e industria nacional ${ }^{1142}$.

\begin{abstract}
"A consecuencia de una exposición hecha por los cosecheros y fabricantes de rubia de diferentes pueblos del partido de Olmedo, solicitando se prohíba la introducción que de aquel artículo hacen los extranjeros en el reyno, atendiendo a la grande decadencia que se halla por esta razón dicho ramo de industria en los expresados pueblos, se acordó que se recomiende al Gobierno la solicitud, manifestándole que cuando se tubiere por oportuna la general y absoluta prohibición de que se introduzca rubia extrangera, disponga al menos que subsista esta introducción mientras que el precio de la molida no exceda de ochenta reales arroba".
\end{abstract}

Esta actividad inicial se refuerza, como se irá viendo en los siguientes epígrafes, no solo en lo tocante al fomento de la actividad agraria (proyecto de la Granja Modelo, mecanización del campo, ferias agrícolas, lucha contra la filoxera...), sino también en aportaciones y estudios de proyectos para el tendido de la red ferroviaria y trazados de caminos o carreteras vecinales, aspectos que, unidos a los citados, la sitúan de forma inmejorable en la primera línea del control político y electoral que caracteriza a los ámbitos rurales durante el periodo de la restauración borbónica.

\title{
- La nueva adscripción de Serrada al partido de Medina y la definitiva fijación de límites en su término municipal
}

La racionalidad administrativa va acompañada de similares intenciones en el campo judicial. No son pocos los pueblos que se quejan de las distancias que hay que recorrer, en caso de declaraciones y pleitos, cuando existen salas de justicia a escasas leguas. En junio de 1834 la regente $\mathrm{M}^{\mathrm{a}}$ Cristina manda publicar en el Boletín Oficial, en nombre de la futura reina Isabel, el Real Decreto que establece la división de la provincia de Valladolid en partidos judiciales. El legislador apela a la urgencia de acometer cuanto antes la reforma "por los grandes beneficios que han de resultar a los pueblos de la más pronta administración de justicia”. De esta manera, las nuevas provincias quedan subdivididas en partidos judiciales, al frente de los cuales se encuentra un juez letrado que asume buena parte de las funciones que antes tenían los alcaldes ordinarios. La provincia vallisoletana se divide en los partidos de Medina del Campo, Mota del Marqués, Nava del Rey, Olmedo, Peñafiel, Rioseco, Valoria la Buena, Valladolid y Villalón de Campos. Ermitas, barrios y Despoblados se distribuyen de la mano de sus cabezas rectoras en las nuevas demarcaciones. Serrada y el despoblado de La Moya ponen fin a la dependencia de Olmedo, largamente señalada por ajetreos judiciales.

El despoblado de San Martín del Monte, aun cuando su término se funde con el de Serrada, se integra, de la mano de La Seca, si se sigue el documento oficial, en el nuevo partido medinense. Está integrado por 27 pueblos que suman 18.848 almas y, como se puede apreciar en el cuadro adjunto, se encuentra en una posición intermedia tanto por el número de municipios que lo forman como por el volumen de población que tiene adscrita ${ }^{1143}$.

${ }^{1142}$ A.D.V. L.A.D. Actas, sesión 11 de 3 de abril de 1821.

${ }^{1143}$ Los 27 pueblos que componen el partido de Medina del Campo son, siguiendo el orden que figura en el propio B.O.P.V de 3 de junio de 1834, Bobadilla, Brahojos, Campillo, Carpio, Carrioncillo, Cervillego de la Cruz, Dueńas de Medina, Foncastín y el despoblado de Herreros, Fuente el Sol, Fuente la Piedra, Gomeznarro, La Seca y el despoblado de San Martín del Monte, Lomoviejo, Medina del Campo y el despoblado de Orcilla, Moraleja de las Panaderas y el despoblado de Hornillejo, Pozal de Gallinas, Rodilana, Romaguitardo, Rubí de Bracamonte, Rueda de Medina, San Vicente del Palacio, Serrada, Torrecilla del Valle, Velascálbaro, Villanueva de Duero y el Monasterio de Aniago, Villanueva de las Torres y Villaverde. 
Esta se beneficiará de la cercanía a la sede judicial medinense, debido a que la mayor parte de los municipios se encuentran a menos de $20 \mathrm{~km}$ de la antigua villa de las ferias. Su localización central le reportará añadidas atracciones económicas y poblacionales, incrementadas notablemente una vez que se convierta en nudo ferroviario y despegue como centro de servicios e industrial.

Cuadro 110. Resumen de los nuevos partidos judiciales de Valladolid. Año 1834

\begin{tabular}{lccc}
\hline Partidos judiciales & Total de pueblos & Total de vecinos & Total de habitantes \\
\hline Medina del Campo & 27 & 4.647 & 18.848 \\
Mota del Marqués & 39 & 6.249 & 23.918 \\
Nava del Rey & 10 & 3.953 & 15.786 \\
Olmedo & 39 & 4.887 & 19.568 \\
Peńafiel & 36 & 3.951 & 14.211 \\
Rioseco & 30 & 6.481 & 25.433 \\
Valoria la Buena & 30 & 3.311 & 12.687 \\
Valladolid & 22 & 8.285 & 32.838 \\
Villalón & 41 & 5.729 & 21.358 \\
\hline TOTAL & 274 & 47.493 & 184.647 \\
\hline
\end{tabular}

Fuente: Boletín Oficial de la provincia de Valladolid, 1834. Elaboración propia.

El proceso de puesta en marcha del nuevo sistema judicial requiere de ajustes y consensos por los intereses creados en épocas anteriores. Aunque rebasa el marco de este estudio, baste reseñar que en 1838, aun cuando en el Real Decreto figura su integración, el alcalde de Rubí de Bracamonte solicita "que se segregase este Pueblo del cantón de Olmedo y admitiese a destinar como en un principio al de Medina del Campo, en atención a la mucha distancia que le separaba del primero y proximidad que tenía con el segundo". Similares demandas se anota Rodilana aunque parece más que evidente la administración de su justicia por la sala de Medina ${ }^{1144}$. Es el final del largo proceso de asunción de términos, despoblados y cotos de unas entidades por otras, sea por vía judicial o de administración territorial. Y todo ello asumiendo el estado contemporáneo las antiguas estructuras rurales. De hecho, la proliferación municipal española arranca desde las Cortes de Cádiz de 1812, que establecen, en su artículo 310 que "se pondrá Ayuntamiento en los pueblos que no lo tengan y en que convenga lo haya, no pudiendo dejar de haberlo en los que por sí o con su comarca lleguen a 1.000 almas". En las "Instrucciones para el gobierno económico-político de las provincias" de 3 de febrero de 1823, se posibilita su establecimiento en entidades menores, si bien se fijan normas para alterar términos municipales. Todo ello conlleva que en 1857 haya en España 9.315 Ayuntamientos, más del doble que cincuenta años antes ${ }^{1145}$.

La propia legislación liberal, consciente de la variabilidad de las innumerables circunstancias administrativas que pueden afectar a tantos enfrentamientos sobre términos y jurisdicciones, ordena, por decreto de 23 de diciembre de 1870, el señalamiento de los términos municipales españoles. Serrada, La Moya y San Martín del Monte van a ser amojonados como un mismo territorio sobre el que Serrada ejerce sus funciones y competencias municipales. En este último tercio de siglo y primeros años del XX, se fija definitivamente la raya con Matapozuelos. Recuérdese que, al comienzo de este mismo apartado, se señalaba el interés por conciliar los ánimos entre Serrada y esta villa en relación a límites entre pagos. De hecho, en junio de 1844 se lleva a cabo un "Apeo y deslinde de las rayas que dividen este término alcabalatorio del de la villa de Matapozuelos, a instancia de este último

${ }^{1144}$ A.D.V. Libro de Actas de 19 de junio de 1838.

${ }^{1145}$ CASTELAO RODRÍGUEZ, J.: El término municipal. Extensión y alteraciones”. Publicaciones Abellá, 1994, pág. $35-39$. 
pueblo" que va a reavivar viejos rescoldos históricos ${ }^{1146}$. En 1887, se procede al deslinde de las servidumbres pecuarias que radican o discurren por el término municipal, de acuerdo a lo que previene el Real Decreto y Reglamento de ganadería de 3 de marzo de 1877. Aunque son controladas por Visitadores nombrados por la Asociación de Ganaderos del Reino, en esta ocasión el proceso se inicia a petición de los ganaderos, tras la falta de acuerdo con los propietarios, al no permitirles dilatar los plazos en los pastos de invernia ${ }^{1147}$. Por fricciones con los cultivadores, los ganaderos tratan de aumentar los desmanes del arado en las cañadas y cordeles existentes a fines del XIX ${ }^{1148}$.

${ }^{1146}$ A.M.S. Libro de Actas de 21 de junio de 1844. El conflicto resurge cuando se procede al deslinde de los citados municipios. La Corporación municipal de Serrada se encuentra con representantes de los respectivos pueblos de la Cuesta del Orcajo, en la que se unen y dividen las cuatro rayas de los términos de Serrada y su despoblado de La Moya, Valdestillas y Matapozuelos. Las actas municipales recogen que el límite con Valdestillas "no ha ofrecido nunca la más leve dificultad, (...), especialmente desde el otorgamiento de la escritura de concordia celebrada entre los procuradores de la estinguida Universidad de la Tierra de Olmedo, alcaldes y vecinos de Valdestillas, en diez y seis de marzo del año de mil seiscientos noventa y dos". El apeo y deslinde, de acuerdo a dicha escritura, se fijaba "descendiendo para ello desde dicha Cuesta al camino Real que va desde la villa de Valdestillas a la de Medina del Campo hasta tocar via recta por él con la raya divisoria de la de Ventosa de la Cuesta a la que está unida la de esta de Serrada, desde la cual ha de volverse a la indicada Cuesta de Orcajo".

Distinta es la relación con Matapozuelos. Los representantes de Serrada denuncian que en dicho acto sus vecinos "pisaban y tuvieron el atrevimiento de atravesar los sembrados y viñas contiguas al camino titulado del Orcajo para señalar a su antojo". Matapozuelos argumentaba a su favor un "Privilegio concedido por la merced de Su majestad Don Felipe Segundo en la ciudad de Toledo el ańo de mil quinientos y tantos”. Serrada presenta en su favor la Carta Ejecutoria de 1632 que contiene el apeo y deslinde general de términos, expedida por la Real Audiencia y Chancillería de Valladolid (Traslado de copia en A.M.S., caja 72, carp. 891), donde se perfila el término con insuficiente claridad: "Que de coto en coto hasta llegar a un coto que esta junto a un camino que va de dicho lugar de la Serrada a dar al Camino Real que viene de Valdestillas al dicho lugar de la Ventosa el cual dicho camino sale de un camino que dicen de las Carretas que va de Serrada a la fuente de Siete Iglesias e a Matapozuelos la atraviesa el dicho camino Real que va desde Valdestillas a Ventosa en la cual dicha raya la que se apartó de dicho camino que va de la Ventosa a Tordesillas hasta llegar al dicho camino..." No obstante, la parcialidad, a decir de los vecinos de Serrada, del juez tomando como validas ciertas opiniones y documentos de Matapozuelos e invalidando otros de Serrada, así como la forma en que la parte de Matapozuelos trataba a la de Valdestillas de "atraerles a sus ideas", decidirá al Ayuntamiento de esta villa a elevar instancia a organismos superiores para que supervisen el conflicto para así ponerle definitivo orden y remedio.

${ }^{1147}$ Quien dirige el proceso es el propio Visitador de Cańadas D. Francisco Pozaco, nombrándose como comisionados en el municipio a D. Ambrosio Román, D. Celestino Alonso y D. Claudio Román.

${ }^{1148}$ Los ganaderos reclaman que se revise la anchura de estas vías, dado que en muchas veredas malamente pasaban, decían, los carros. Su descripción, no obstante, sirve para explicar su distribución que unos ańos más tarde se detallará cartográficamente, tal como recoge el plano adjunto. Entre las citadas servidumbres pecuarias, se diferenciaban las veredas, de anchura de 20,83 metros, los cordeles (más estrechos) y las coladas. Entre las primeras se encuentran las llamadas Vías Directas entre las que estaban las que conducían desde la villa a Valdestillas; el camino Real de Valladolid, por el que se estaba construyendo en el citado ańo de 1888 la carretera del mismo nombre; el camino del Pinar; el camino de la Barca a San Miguel del Pino, el de San Martín; el de Tordesillas; el de La Seca o prolongación del Real a Valladolid; el de Rodilana, el de Ventosa, igual al anterior en toda su extensión; el de Valondo y el Pozo, que "es servidumbre de aguas y sirve para el aprovechamiento de los pastos de las fincas colindantes", y el de Matapozuelos, que "es continuación de la de Tordesillas y Galicia a Madrid, y atraviesa la cañada de Madrid a Valladolid estando Ocupado en una extensión de 600 metros por el camino vecinal de esta villa a Matapozuelos, construido en 1868 y siguientes" y que, en decir de los escritos ganaderos, ocupaba en el mismo sitio una anchura de 30 metros, excepto en un trecho que está "tan cerrado que ni los mismos labradores que en colonia labran las tierras colindantes, no se respetan mutuamente pues al arar las tierras en un lado que está de barbecho, se arriman tanto al otro que levantan con el arado los sembrados...".

Entre las llamadas vías transversales, se encuentran el camino de Rueda a Valladolid, que atravesaba una de las dehesas del marqués de Casa Pombo (cerrado en la fecha totalmente para la ganadería lanar);el cordel del Pinar, que se perdía al desembocar en el camino a Valdestillas, el cordel de los Espinos de la Moya, límite de la jurisdicción de Villanueva de Duero; el camino de las Carretas, que se dirige al puente de Valdestillas y que, siguiendo las denuncias de los ganaderos, de 20 metros de anchura en nuestro término "está tan cercenada que no es más que un sendero..." y la raya de La Seca, "que corre entre el viñedo de uno y otro lado y tiene una anchura de 15 metros, fuera de este sitio no existe más que una linde..."

Existen, por último, numerosas vías estrechas, no usadas por los ganados ovinos por causar al paso daños en las fincas colindantes. Son, fundamentalmente, el sendero del Coto, el Senderillo, el sendero del Sisón, el sendero de los Tintos y el sendero de los espinos o Cachapera. (A.F.A.M. Carp. de escrituras y varios). 
Sin embargo, como se desprende del acta que a continuación se reproduce, las citadas vías pecuarias se encuentran por estas fechas en buen estado de conservación. Falta por llegar la mecanización y la segunda mitad del siglo $\mathrm{XX}^{1149}$.

Estos apeos y deslindes se completan con los amojonamientos que se llevan a cabo en el año 1889 en todas las rayas y pueblos limítrofes de este término municipal. Se inicia el 4 de noviembre del citado año con la raya entre Tordesillas y Serrada donde las comisiones y peritos, sin ninguna contradicción, señalan "cuatro mojones, tres de tierra y uno de piedra, ésta antigua, en una longitud del primero al último mojón de seiscientos ochenta y seis metros..." "I50. Se sigue con idéntica conformidad con las rayas de Villanueva donde se acotan 52 mojones; Valdestillas con otros 16, Ventosa con 8 y la Seca con 11 pero, como casi podía adivinarse, el amojonamiento con Matapozuelos, reabre viejas diferencias. Nada mejor que entresacar algunos fragmentos del acta firmado el 9 de noviembre de 1889, que relata el momento de iniciar las comisiones de los respectivos pueblos el deslinde de la raya partiendo del mojón primero que divide estos términos y el de su vecina Valdestillas en el lugar conocido como "cantón o piedra de las tres rayas"151.

"En este estado se suscitó discusión entre ambas Comisiones sobre la verdadera dirección de la raya divisoria de ambos términos; y no resultando conformidad, la de Matapozuelos tomó la dirección del oeste, a sea, hacia Serrada, y la de esta última villa, o sea, la de Serrada, emprendió el deslinde en dirección a Ventosa de la Cuesta, o sea, al sur..”.

Serrada hace constar sus protestas al levantar las actas del amojonamiento. El tema parece eterno e irresoluble ${ }^{1152}$. En el segundo hito se repite la desavenencia. En 1914 constan actas del desencuentro, si bien poco o nada afectan a la vida administrativa o al aprovechamiento agropecuario de ambos pueblos. No se puede por menos que reproducir los resultados de estos trabajos cartográficos que se plasman tanto en el plano del término de Serrada como en el mapa provincial de $1905^{1153}$. Es la última ocasión en que algunas entidades, como el Despoblado de San Martín del Monte, figuren en cartografías de uso común.

${ }^{1149}$ Merece la pena su transcripción: “DESLINDE de la vereda denominada del "Pinar”. Equivalente a 20,83 metros de anchura. En la villa de Serrada a trece de octubre de mil ochocientos ochenta y siete, reunida la comisión deslindadora en la Casa Consistorial a las siete de la mañana, bajo la presidencia del Señor Alcalde D. Toribio del Río, con asistencia del Visitador de ganaderías y Cañadas D. Francisco Pozaco, se emprendió la marcha para el deslinde de las jurisdicciones de La Seca y de esta villa, que es este de donde viene la vía pecuaria citada, y constituidos todos los Sres. Citados en el referido punto, se procedió a su apertura y deslinde, la que se encontró en perfecto estado de conservación.

DESLINDE de otra vereda denominada de "Las Cruces". Equivalente a 20,83 metros de anchura. Seguidamente la propia Comisión se constituyó en la vereda denominada de las Cruces, y se procedió a su deslinde y reconocimiento. Hallándola en toda su longitud en perfecto estado de conservación, excepto algunas pequeñas intrusiones las que se amojonaron y no se hace mención de ellas por insignificantes.

DESLINDE de otra vereda denominada Camino Real de Valladolid, anchura 20,83 metros. A continuación la repetida Comisión se trasladó a la vereda citada, y reconocida que fue en su parte longitud y latitud se encontró en su anchura legal, únicamente en la actualidad se está construyendo una carretera provincial en el centro de la misma, y sería conveniente que por la Excma. Presidencia de la Asociación general de Ganaderos del Reino, se hagan las gestiones que sean conducentes a fin de salvar los intereses de la ganadería, puesto que el corte es longitudinal e impide completamente el tránsito de los ganados. En este estado el Sr, Presidente con el Sr, Visitador que asiste a esta operación interrogaron a los peritos si tenían conocimiento existiese alguna servidumbre pecuaria más que las que van deslindadas, manifestando que no, dando por terminada la operación y firmando la presente acta los Sres. Concurrentes, de que certifico. Toribio del Río, Francisco Pozanco, Celestino Alonso, Eladio Román, Ambrosio Román, Federico A. Altamirano”.

A.M.S. Caja de planos.

${ }^{1150}$ A.M.S. Caja 72, carp. 891.

${ }^{1151}$ Ibídem.

${ }^{1152}$ En los trabajos que el propio Instituto Geográfico lleva a cabo en 1904 sobre líneas divisorias y señalamientos, en cumplimiento de la ley de 27 de marzo de 1900, sobre la formación del Catastro de la riqueza territorial, nuevamente, en el primer mojón que se trata de fijar entre las comisiones de Serrada y Matapozuelos, se hace constar en el acta que "no hubo conformidad entre las comisiones presentes en la situación de este mojón, por lo cual no se describe. Debia ser común a los términos municipales de Serrada, de Matapozuelos y de Ventosa de la Cuesta”. A.M.S. Caja 72, carp. 882. 

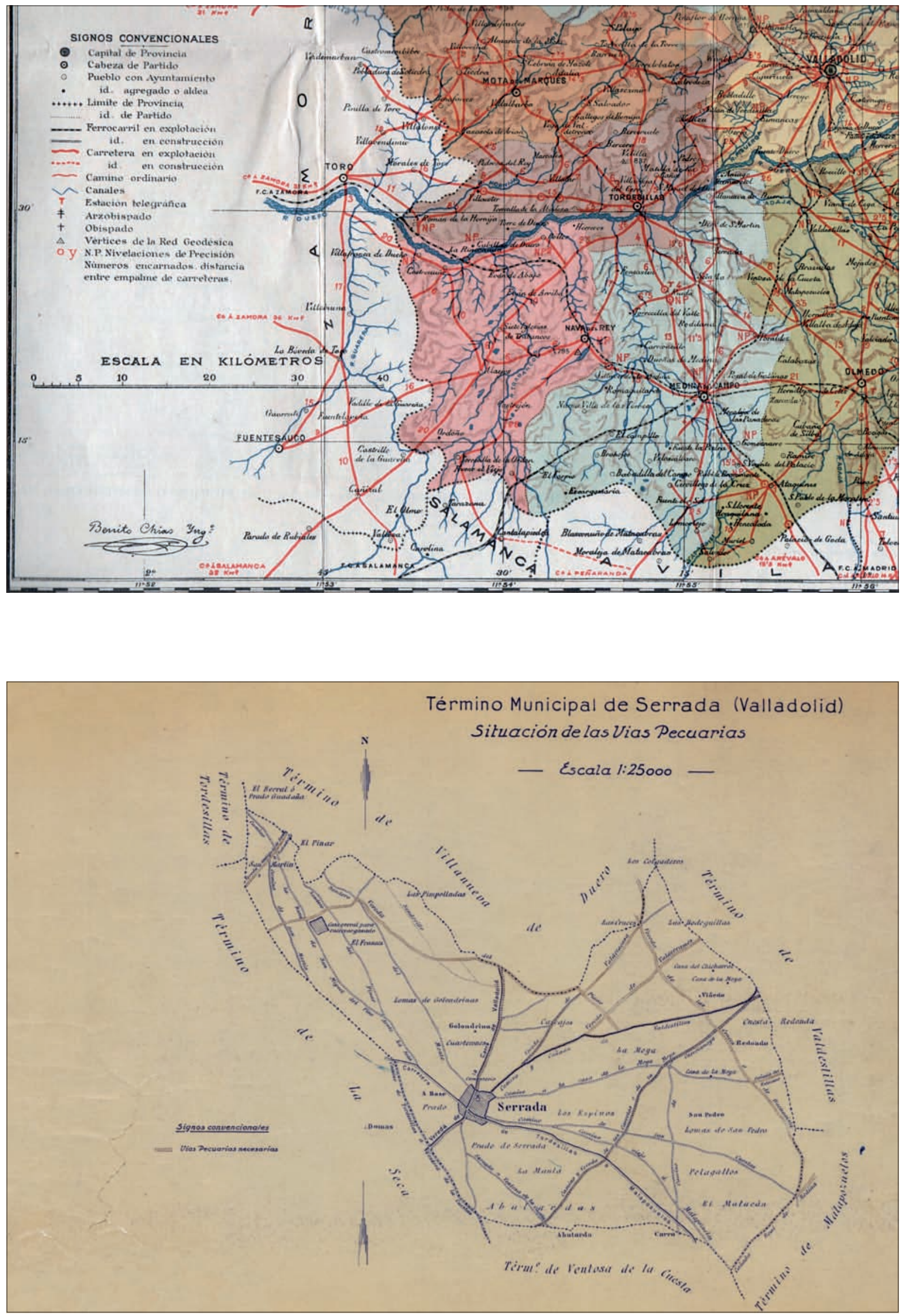

Figura 30. Mapa de la provincia de Valladolid (arriba, sur provincial, Benito Chías, 1905, según datos del Instituto Geográfico Catastral). Pañoleta del término de Serrada, incluido el terrazgo de los despoblados de La Moya y San Martín del Monte, abajo, A.M.S., año 1905. 

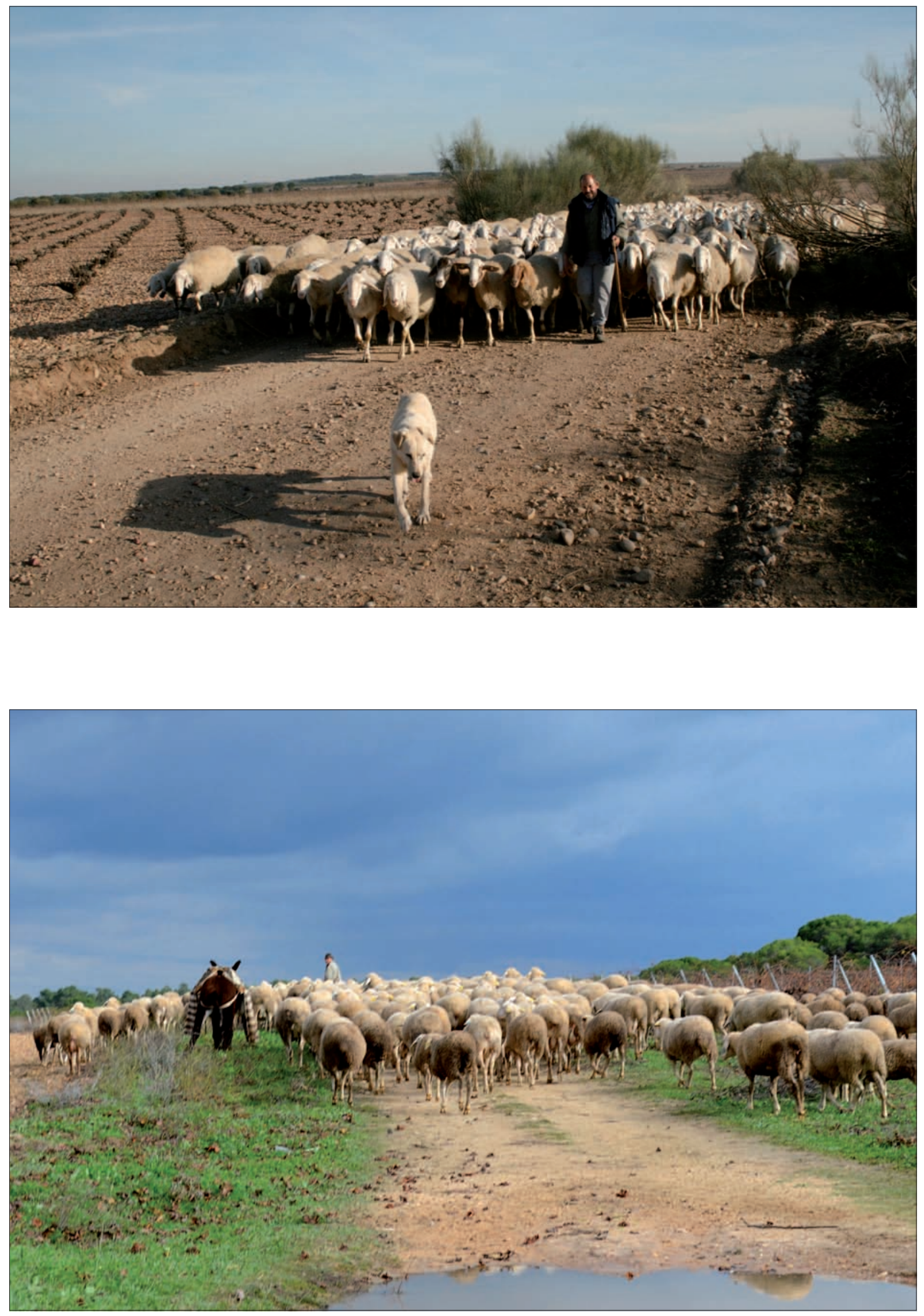

Imagen 84. Las cañadas y veredas fueron, además de importantes vías pecuarias, espacios de pastoreo para el ganado ovino. En la actualidad, la ambición del arado las ha reducido, en muchos tramos, a meros caminos, (arriba, rebaño en la Caña de Buenavista, Serrada, foto: 10/01/2008; abajo, rebaño aprovechando la hierba otońal en el camino de Rueda a Valladolid. La Seca. Foto: 4/12/2014). 


\section{Los escasos cambios en las estructuras de propiedad y cultivo de la tierra. El predo- minio del arrendamiento como principal forma de tenencia}

Si en otras ocasiones se ha señalado la común sintonía de Serrada con el resto de la comarca, en lo que respecta a los resultados del proceso desamortizador conviene recordar la singularidad de este enclave. A diferencia de los pueblos limítrofes y del resto de la provincia donde la explotación directa avanza tras el proceso de venta, en Serrada continúa el arrendamiento como forma predominante de explotación de la tierra en la segunda mitad del siglo XIX. Recuérdese que, frente a porcentajes del $67 \%$ de extensión desamortizada en manos del 82\% de propietarios labradores en los totales provinciales ${ }^{154}$, en esta villa sólo son tres los labradores que acceden, casi en su totalidad, a la reducida cifra del $21,33 \%$ de la tierra que se subasta en el término municipal. Si a ello se suma, como ya se ha apuntado, que, a diferencia de otros lugares donde ceden o casi desaparecen las grandes superficies nobiliarias, en esta villa el marqués de Torreblanca y Falces sigue siendo el principal propietario, tanto en cantidad como en calidad. El proceso del trasvase de la propiedad a sus directos cultivadores se alarga en Serrada casi un siglo y estas formas indirectas de explotación explican las dificultades por constituir explotaciones capitalizadas, que tomen el relevo a las influyentes granjas conventuales del siglo XVIII.

\section{a. Un terrazgo cultivado por medianos y pequeños labradores}

Pocos cambios estructurales, como se viene diciendo, van a caracterizar el reparto de la propiedad en este término y en sus aledaños. Los compradores foráneos sustituyen a las extintas órdenes religiosas y un reducidísimo grupo de potentes hacendados locales, adquirientes en mayor o menor grado de bienes desamortizados, comparten los primeros puestos con los herederos de la pudiente y extensa familia de los Moyano que, bien desde el exterior o como labradores con casa abierta, siguen ocupando lugares distinguidos. Unos y otros sienten el peso recaudatorio de unos gobiernos liberales que, desde las reformas fiscales de1845, tienen a la agricultura como el sector más cargado, tanto en términos absolutos como relativos ${ }^{1155}$. Aunque en las tierras arrendadas los cultivadores no están obligados al pago de las cargas tributarias, en la mayor parte de los casos los propietarios absentistas estipulan en los contratos de arrendamientos que el peso de las contribuciones recaiga sobre los sufridos colonos. No en vano la nueva burguesía propietaria deseaba rentabilizar al máximo sus recientes adquisiciones de tierra. ${ }^{1156}$ En los arrendamientos que firman los numerosos renteros de Serrada en 1860, ante el nuevo propietario José María de Rojas, este hace constar que "será de cuenta y cargo de los colonos el pago de toda clase de contribuciones, asi ordinarias como extraordinarias que se impusieren a las tierras arrendadas..."1157. El marqués de Torreblanca hace lo propio a partir de esta fecha y estas cláusulas se repiten invariablemente en buena parte de los contratos que se firman en toda la Tierra de Medina ${ }^{1158}$.

${ }^{1153}$ En cuanto al plano del término de Serrada, es muy posible, dadas las precisiones topográficas tan cercanas a los apeos tratados, que, pese a llevar fecha de 1941, esta reproducción pueda ser copia de una anterior elaborada en estos años de finales del XIX, en que se precisan límites y cańadas con notable y definitiva exactitud. El interés por la conservación de estas vías pecuarias llevará, unas décadas más tarde, a una nueva clasificación en la que se precisan límites y linderos con el objetivo de una mayor y necesaria conservación.

${ }^{1154}$ DÍEZ ESPINOSA, J.R: “Desamortización y economía agraria..., ob. cit., pág. 357.

1155 VALLEJO POUSADA, RS: Reforma tributaria y fiscalidad sobre la agricultura en la España liberal, 1845-1900. Ed. Prensas Universitarias de Zaragoza, 2001, pág. 81.

1156 Ibídem, pág. 89.

1157 A.H.P.V. Pt. 15958. Serrada, Domingo Duque, año 1860, fol. 119.

${ }^{1158}$ En los contratos de arrendamiento consultados en la segunda mitad del XIX en distintas localidades de la comarca, se señalan, junto a las estipulaciones comunes sobre rentas y plazos, nuevas precisiones en relación con el mantenimiento de la fertilidad de las tierras y la obligatoriedad del pago de las contribuciones a cuenta del colono. Un ejemplo es el arrendamiento acordado en Medina del Campo entre Mariano de la Devesa Toribio y Dionisio Nieto, labrador de Moraleja de las Panaderas. (A.H.P.V. Pt. 18084. Medina del Campo, Gil Terradillos, año 1874, fol. 686-689). 
Sin embargo, son los repartimientos individuales que forman los Ayuntamientos con relación a los cupos de contribución asignados a cada pueblo, de acuerdo a la riqueza imponible derivada del amillaramiento hecho al efecto, los que acercan, de forma pormenorizada, tanto a los contribuyentes como a los bienes por los que contribuyen. Especialmente interesante resulta la valoración del producto imponible por bienes territoriales, pues da una idea bastante exacta de las distintas labranzas ${ }^{1159}$. Piénsese que sólo la foránea familia De Rojas acapara el 9,5\% del total de riqueza imponible territorial por las 350 obradas que tiene en propiedad y que, junto a las 440 obradas del marqués de Torreblanca y Falces, componen buena parte del terrazgo arrendado a los labradores de esta localidad ${ }^{1160}$.

La desigualdad en el reparto de la riqueza es la característica más sobresaliente. Piénsese que 140 propietarios, que representan el 61,9\% del total, tan solo suman el 7,1\% de la riqueza imponible, frente a 14 hacendados que, con más de 5.000 reales cada uno, alcanzan el 49,9\% del cupo asignado a la villa. Estos registros son igualmente válidos en lo tocante a las aportaciones por el concepto de territorial. Su potencial económico, basado fundamentalmente en el viñedo, los lleva a necesitar tierras de sembradura, que arriendan al marqués de Falces, aun cuando algunos de ellos ya superan las 50 ha en propiedad ${ }^{1161}$. Sin embargo, son los medianos y pequeños cultivadores los que superan los 500 reales, pero no sobrepasan los 5.000 los que forman el grueso de las labranzas ${ }^{1162}$. Si esto que se apunta con relación al producto imponible de territorial se aplica a la riqueza urbana, de colonia, renta o ganadería y su distribución entre vecinos y forasteros, se obtienen unos resultados similares a los ya expuestos.

${ }^{1159}$ El conjunto de cambios que configuran la llamada revolución burguesa liberal trae consigo la necesaria revisión fiscal en Espańa. Por un lado, la liberación por el proceso desamortizador de una ingente cantidad de riqueza territorial permitirá a la Hacienda pública la fijación de contribuciones donde hasta entonces reinaba la exención fiscal. Asimismo, la liquidación del orden anterior, vía supresión de señoríos, desvinculación de mayorazgos o la eliminación definitiva del diezmo en 1841, hará necesaria una convergencia tributaria hacia un único modelo impositivo para todo el Estado, que se concretara a partir de la reforma e 1845. Llevada a cabo de acuerdo con los intereses de la clase oligárquica, la nueva contribución, denominada de inmuebles, cultivo y ganadería, gravará fundamentalmente a rentistas, pequeños propietarios, cultivadores y ganadería, siendo la contribución territorial el impuesto más importante en estas décadas centrales de siglo. El estudio citado de Vallejo Pousada resulta básico para entender todo este complejo proceso de reforma fiscal. En los repartos que se llevan a cabo en 1852, en plena fase de expansión agrícola y ganadera, como en las listas que se publican de los mayores contribuyentes de la provincia, se encuentran, junto a las tradicionales familias propietarias, nuevos hacendados. De hecho, es la familia De Rojas, residente en Valladolid y heredera de la fortuna del activo comprador y hombre de negocios Luis de Rojas, la mayor contribuyente de Serrada en producto imponible de territorial, al sumar 16.176 reales. Le siguen Modesto de Castro con 13.610 y Gregorio León Alonso con 10.517 reales. La espectacular ascensión del señor de Castro, llegado de Pozaldez y conocido por todos como importante comprador durante el proceso desamortizador, se explica por su matrimonio con Micaela Alonso, hermana de Gregorio León, y herederos de la importante hacienda de la familia Alonso Rodríguez. El propio marqués, con residencia en Madrid, ocupa el quinto lugar entre los contribuyentes totales, alcanzando en concepto de contribución por rentas la importante cantidad de 13.212 reales. Tras ellos se encuentran, situándose a la mitad de los anteriores, pero con cifras muy importantes para la época, los herederos de Melchor, Manuel y Francisco Moyano que, bien afincados y labradores en Serrada, bien residentes en Valladolid, Sevilla u otros municipios, siguen detentando una parte importante del terrazgo labrado en la localidad. Si a la lista anterior se incorpora a Pablo Obregón (6.292 reales de territorial) y a Feliciano Martín (3.730 reales), este último también comprador durante la etapa Mendizábal, hay catorce contribuyentes que, representando tan sólo el 9,7\% del total, alcanzan el 53,9\%, del cupo impuesto al municipio en este concepto. Salvo los primeros, que bien pueden ser calificados como grandes hacendados, el resto, sea por el reparto hereditario o por el carácter rentista de algunos titulares, se integra entre las medianas y pequeñas haciendas que caracterizan a la mayor parte del agro comarcal según avanza el siglo.

${ }^{1160}$ Recuérdese que, en las conclusiones de la incidencia de la Desamortización en este municipio, se apuntaban 810 ha de las 2.495 ha que se catastran en el término (32,46\%), como las que por distintos motivos estaban en manos absentistas y eran tomadas por los vecinos cultivadores en arrendamiento.

${ }^{1161}$ Son, por este orden, Modesto de Castro, la familia De Rojas, Gregorio León Alonso, herederos de Melchor Moyano, Marques de Falces, Feliciano Martín, Ventura Moyano, Pablo Obregón, Gregorio Barahona (yerno de Francisco Moyano), Eleuterio Martín, Félix Martínez, Herederos de D. Manuel Moyano, Cipriano Platón y Ezequiel Pérez.

${ }^{1162}$ En este año de 1852, cincuenta y ocho titulares, de los que 40 son vecinos de Serrada, suman hasta el 54,4\% del total imponible en concepto de territorial. Suelen ser labradores de uno o varios pares de mulas que, como Manuel 
Un reducido número de grandes propietarios territoriales dispone de la mayor riqueza urbana (23 propietarios con el 52,1\% de la riqueza, frente a la 82 jornaleros que suman poco más de una cuarta parte). O como 15 propietarios, de los cuarenta que son rentistas, que llevan en colonia casi tres cuartas partes de los arrendamientos. O los cinco rentistas que acaparan el 83,55 del producto imponible por rentas...

Las cuotas contributivas derivadas de estos bienes imponibles, en fin, que indican la riqueza de unos y otros, sirven también para diferenciar sus privilegios en un siglo en que el derecho electoral y el ejercicio político está regulado por la propiedad o las capacidades alcanzadas. Aunque se tratarán estos aspectos más detenidamente cuando se aborde la vida municipal, conviene adelantar, por ejemplo, que, en la formación de los distritos electorales para el nombramiento de Diputados a Cortes, la Real Orden de 21-11-1846 tan sólo asigna a Serrada 15 electores, prueba de la limitada potencia económica de sus habitantes ${ }^{1163}$. En este sentido, es revelador del potencial hacendístico de los pueblos vecinos el número de electores que en ellos tienen derecho de voto: 64 en La Seca, 40 en Pozaldez, 48 en Rueda, 7 en Rodilana, 4 en Villanueva de Duero, 7 en Ventosa de la Cuesta... ${ }^{1164}$. En el Real Decreto que publica el Boletín Oficial de Valladolid en febrero de 1850, por ejemplo, entre las cualidades necesarias para poder ser diputado provincial figura la de tener una renta anual, procedente de bienes propios, que no baje de 8.000 reales o pagar al menos 500 reales de contribuciones directas, cantidades que sólo son propias de los más fuertes labradores de cada municipio. Las listas electorales delatan la repetición de apellidos que controlan los terrazgos y las vidas municipales de la comarca tanto en este siglo XIX como en buena parte del siguiente XX: Los Pimentel, Arévalo, Gimeno, Monsalve o Gómez de Bonilla en Rueda; Los Bayón, Pedrosa, Lorenzo, Platón o Ampudia en La Seca; los Arévalo o Ruiz en Matapozuelos; Inaraja o Toro en Ventosa, Cantalapiedra en Pozaldez...

\section{b. El marqués de Torreblanca y Falces como principal rentista de la villa}

Como se viene explicando, pocas repercusiones van a tener las reformas liberales sobre las mejores tierras de Serrada. Como manda la tradición y una vez finalizados los contratos, el veinte de octubre de 1851 se rubrican una vez más los arrendamientos entre los labradores de Serrada y José Félix de Orturas, apoderado de Pedro Manuel Velluti, marqués viudo de Falces y del sucesor en los mayorazgos de este marquesado y de sus agregados ${ }^{1165}$.

Pérez o Leandro Obregón, también completan sus heredades con tierras de marqués o de la familia De Rojas, caso de Gregorio Román, Guillermo García, Gregorio Juárez o Jorge Martínez. Entre ellos se encuentran veinticinco pequeños labradores que ingresan a la Hacienda pública entre 500 y 1.000 reales. A pesar de su reducido potencial, no se encuentran en estos ańos incrementando su superficie con tierras en renta y se les supone en dificultades cuando se tuercen cosechas o precios. A tenor de la cuantía territorial que se les asigna, la mayor parte están encuadrados entre 500 y 700 reales de riqueza imponible, mayoritariamente ocupadas sus tierras por vińedo y en las que el trabajo personal constituye la clave para asegurar la viabilidad de sus reducidas heredades. En este año de 1852, se encuentran, de mayor a menor, entre 1.000 y 500 reales totales de riqueza imponible y, por este orden, los siguientes propietarios vecinos de Serrada: Celestino Alonso, Elías Leonardo, Felipe Herrera, Pedro de Íscar, Ángel Román, Dionisio de Íscar, Paulino del Río, Ignacio Fadrique, Víctor García, Herederos de Da María Obregón (Astorga), Monasterio del Corpus Christi, (Valladolid), Manuel Alonso Mateos, Julián Román, Marcelino Alonso, Leandro Alonso, Pedro Hinojal, Nicanor García, Blas Cisneros, y José García.

${ }^{1163} \mathrm{Si}$ se sigue la cuota anual de contribución y recargos publicada en junio de 1852 (B.O.P.V. Suplemento $\mathrm{n}^{\circ} 24$, fecha 12 de junio de 1852), se encuentran con cuota superior a 400 reales y de mayor a menor, a lo siguientes propietarios avecindados en Serrada: Modesto de Castro, Gregorio León Alonso, Herederos de Melchor Moyano, Feliciano Martín, Ventura Moyano, Pablo Obregón, Eleuterio Martín, Félix Martínez, Cipriano Platón, Ezequiel Pérez, María Rodríguez, Castor de Castro, Manuela Rodríguez y Martina Gaspar.

${ }^{1164}$ B.O.P.V., 15 agosto de $1850, \mathrm{n}^{\circ} 97$.

1165 A.H.P.V. Pt. 10559. Víctor Rodríguez, año 1851, fol. 259-263. Don Pedro Manuel de Velluti López de Ayala, Ponce de León, Caballero de la Real Maestranza de Caballería de Granada, había casado con Dońa María de la Cabeza, marquesa de Falces y Torreblanca, señora de Serrada y de Eván de Abajo entre otras distinciones. (ÁLVAREZ MARTíN, M.: Personajes en Tierras de Medina..., ob. cit., pág. 75). 
Cuadro 111. Tierras arrendadas en Serrada por el marqués de Falces, año 1851

\begin{tabular}{|c|c|c|c|c|c|c|c|}
\hline \multirow{2}{*}{$\begin{array}{l}\text { No de } \\
\text { Orden }\end{array}$} & \multirow{2}{*}{$\begin{array}{l}\text { Pago en que } \\
\text { radican }\end{array}$} & \multicolumn{2}{|c|}{ Cabida } & \multirow[b]{2}{*}{ Norte } & \multicolumn{2}{|c|}{ Linderos } & \multirow[b]{2}{*}{ Poniente } \\
\hline & & obradas & estadales & & Mediodía & Oriente & \\
\hline 1 & Gigante & 3 & & $\begin{array}{l}\text { Majuelo de D. } \\
\text { Leandro Obregón }\end{array}$ & $\begin{array}{l}\text { Camino de S. } \\
\text { Miguel del Pino }\end{array}$ & - & - \\
\hline 2 & $\begin{array}{l}\text { Camino de } \\
\text { Tordesillas }\end{array}$ & 13 & 50 & Prado de Abajo & Prado de Abajo & - & Prado de Abajo \\
\hline 3 & Prado de Abajo & 32 & 236 & Prado de Abajo & - & $\begin{array}{l}\text { Camino de } \\
\text { La Seca }\end{array}$ & Prado de Abajo \\
\hline 4 & $\begin{array}{l}\text { Huerto } \\
\text { de la Virgen }\end{array}$ & 32 & 200 & Prado de Arriba & - & $\begin{array}{l}\text { Camino de } \\
\text { Rodilana }\end{array}$ & - \\
\hline 5 & $\begin{array}{l}\text { Camino } \\
\text { de Ventosa }\end{array}$ & 10 & 250 & $\begin{array}{l}\text { Camino de } \\
\text { Ventosa }\end{array}$ & - & $\begin{array}{l}\text { Tierra de } \\
\text { Modesto de Castro }\end{array}$ & - \\
\hline 6 & Vega y Varela & 129 & 364 & $\begin{array}{l}\text { Prados de Arriba, } \\
\text { Estacada y Baldío }\end{array}$ & $\begin{array}{l}\text { Prado del } \\
\text { Pradejón }\end{array}$ & - & $\begin{array}{l}\text { Prado de los } \\
\text { Cotarros }\end{array}$ \\
\hline 7 & Maricastilla & 6 & 50 & $\begin{array}{l}\text { Camino de } \\
\text { Matapozuelos }\end{array}$ & Prado de Arriba & Prado de Arriba & \\
\hline 8 & $\begin{array}{l}\text { Molineras } \\
\text { y Lastras }\end{array}$ & 45 & 50 & - & $\begin{array}{l}\text { Camino de } \\
\text { Matapozuelos }\end{array}$ & $\begin{array}{l}\text { Camino de } \\
\text { las Carretas }\end{array}$ & $\begin{array}{l}\text { Camino de } \\
\text { Matapozuelos }\end{array}$ \\
\hline 9 & $\begin{array}{l}\text { Cerrajero y } \\
\text { Picón del Vado }\end{array}$ & 49 & 350 & - & $\begin{array}{l}\text { Camino de } \\
\text { Matapozuelos }\end{array}$ & $\begin{array}{l}\text { Majuelo de } \\
\text { Ventura Moyano }\end{array}$ & $\begin{array}{l}\text { Camino de } \\
\text { las Carretas }\end{array}$ \\
\hline 10 & Casillas & 35 & 250 & $\begin{array}{l}\text { Camino } \\
\text { del Baldío } \\
\text { a Matapozuelos }\end{array}$ & $\begin{array}{l}\text { Tierras de la } \\
\text { jurisdicción } \\
\text { de Ventosa }\end{array}$ & $\begin{array}{l}\text { Tierra de } \\
\text { Valentín } \\
\text { Cantalapiedra }\end{array}$ & $\begin{array}{l}\text { Camino de } \\
\text { las Carretas }\end{array}$ \\
\hline 11 & $\begin{array}{l}\text { Frontero al } \\
\text { Baldío de Arriba }\end{array}$ & $a$ & 0 & $\begin{array}{l}\text { Camino de } \\
\text { Matapozuelos }\end{array}$ & $\begin{array}{l}\text { Camino } \\
\text { del Baldío } \\
\text { a Matapozuelos }\end{array}$ & $\begin{array}{l}\text { Camino de } \\
\text { las Carretas }\end{array}$ & Prado Baldío \\
\hline 12 & Cuartillos & 76 & 0 & $\begin{array}{l}\text { Camino de } \\
\text { Matapozuelos }\end{array}$ & $\begin{array}{l}\text { Camino } \\
\text { del Baldío }\end{array}$ & $\begin{array}{l}\text { Camino a } \\
\text { Matapozuelos }\end{array}$ & $\begin{array}{l}\text { Camino de } \\
\text { las Carretas }\end{array}$ \\
\hline TOTAI & & 435 & 1.800 & & & & \\
\hline
\end{tabular}

Fuente: A.H.P.V. Protocolos Notariales. Elaboración propia.

Salvo tierras sueltas que no constan y los majuelos que no se consignan como lotes, se está ante las mismas tierras que labraron los abuelos y tatarabuelos de los que ahora suscriben los contratos ${ }^{1166}$. En esta escritura aparece de forma pormenorizada la división en "rentas" de la superficie adscrita al mayorazgo y que, aunque se desmenuzan en pedazos, siguiendo el aprovechamiento y división en hojas de sembradura y barbechera que llevan a cabo los renteros, siguen vigentes pese al tiempo transcurrido ${ }^{1167}$ :

"Cuyos doce deslindados trozos de tierra que componen cuatrocientas cuarenta obradas poco más o menos, se hallan subdivididas desde muchos años, para su comodidad, en porciones de cuarenta obradas poco más o menos en diversos sitios y en diferentes pedazos, y se designan con el nombre de rentas, y en porciones de veinte obradas en la misma forma que se llaman medias rentas; y en porciones, en fin, de diez obradas por el mismo orden que se titulan cuartos de renta, y de cuyas tierras, sus sitios, linderos y cabidas son ciertos y sabedores por haberlas estado labrando los mas, años há”

Tampoco existen apenas diferencias en cuanto al origen de las familias labradoras que se interesan por ellas. O son los mismos que se anotó en el arrendamiento de 1828 o son sus hijos los que, una vez dividida la hacienda familiar, continúan con similares porciones de tierra del marqués. Los prin-

\footnotetext{
1166 Ibídem.

${ }^{1167}$ Ibidem.
} 
cipales compradores de bienes desamortizados, Modesto de Castro, Feliciano Martín y Gabriel Pérez, siguen como poseedores de estas fértiles tierras. Unos y otros completan las tierras de pan arrendando una renta, caso de los mayores labradores como Gregorio León Alonso o Canuto de Castro, hijo del anterior Modesto de Castro, o media o cuarta si se trata de medianas o pequeñas haciendas.

Cuadro 112. Renteros y rentas a pagar. Serrada. Año 1851

\begin{tabular}{|c|c|c|c|}
\hline \multirow[b]{2}{*}{ Renteros } & \multirow{2}{*}{$\begin{array}{c}\text { Superficie en rentas } \\
\text { (Una renta }=40 \text { obradas) }\end{array}$} & \multicolumn{2}{|c|}{ Renta en especie a satisfacer (en fanegas) } \\
\hline & & Trigo & Cebada \\
\hline Ramón Román & Media renta & 13 & 13 \\
\hline Cipriano Platón & “ & “ & “ \\
\hline Feliciano Martín & “ & “ & “ \\
\hline Ezequiel Pérez & “ & “ & “ \\
\hline Benito Fadrique & “ & “ & “ \\
\hline Ventura Moyano & “ & “ & “ \\
\hline Eleuterio Martín & “ & “ & “ \\
\hline Manuel Pérez & “ & “ & “ \\
\hline Tomás Moyano & “ & “ & “ \\
\hline María Rodríguez & “ & “ & “ \\
\hline Joaquina Moyano & “ & “ & “ \\
\hline Aquilina Rodríguez & “ & “ & “ \\
\hline Eugenia Domínguez & “ & “ & “ \\
\hline Martina Gaspar & “ & “ & “ \\
\hline Modesto de Castro & Cinco cuartos & 32,5 & 32,5 \\
\hline Gregorio León Alonso & Una renta & 26 & 26 \\
\hline Ezequiel Moyano & Tres cuartos & 19,5 & 19,5 \\
\hline Fernando Alonso & Un cuarto & 6,5 & 6,5 \\
\hline Lucia Martín & Un cuarto & 6,5 & 6,5 \\
\hline Félix Martín & Media renta & 14 & 14 \\
\hline TOTAL & 11 & 287 & 287 \\
\hline
\end{tabular}

Fuente: Fuente: A.H.P.V. Protocolos Notariales. Elaboración propia.

La cuantía de las fanegas que pagar pasan de las 36 por renta de cuarenta obradas en 1828 a las 52 fanegas de 1851, lo que supone un 44,4\% de incremento respecto a la primera fecha e indica la bonanza cerealista de estos años de mediados de siglo, tanto en producciones como en precios. No puede ser de otro modo para poder entregar 2,6 fanegas de trigo o cebada por obrada sembrada, ya que, como consta en la escritura de arrendamiento, se exige el cultivo de ańo y vez en que los renteros "no han de poder trashojar ni subarrendar las porciones de terreno que por virtud de esta escritura reciben a renta". En cuanto a las especies en que han de pagarse las rentas, se registra la cebada manteniendo una presencia equivalente al trigo, lo que viene a ratificar el continuo ascenso de este cultivo desde comienzos de la centuria como cereal importante en las tierras de primera calidad. No obstante, serán las diversas circunstancias por las que pasa el cultivo y comercio de granos las que hagan variar las fanegas por obrada que entregar, amén de las distintas calidades de tierra acordadas en los arriendos, factores todos que inciden en la cuantía que se firma en los contratos.

Se dice esto porque, a diferencia de otras escrituras de arrendamiento, esta se hace por tiempo indeterminado "o hasta que el administrador formalice desahucio o las dejen cualquiera de los arrendatarios", cuestión que la diferencia de tiempos anteriores o posteriores donde los administradores fijan con precisión los tiempos de vigencia, la cuantía que percibir o se encuentren integradas en las llamadas rentas o en tierras sueltas. Un ejemplo de ello son los contratos firmados en 1861, justo una década después de los anteriores ${ }^{168}$ :

${ }^{1168}$ A.H.P.V. Pt. 11975. Serrada, Cenón Martínez, año 1861. 
Cuadro 113. Tierras arrendadas por el Marqués de Falces en Serrada, año 1860

\begin{tabular}{|c|c|c|c|c|c|c|c|}
\hline Rentero & $\begin{array}{l}\text { Superficie Renta } \\
=40 \text { obradas }\end{array}$ & $\begin{array}{l}\text { No de } \\
\text { piezas }\end{array}$ & $\begin{array}{c}\text { Total } \\
\text { obradas rentas }\end{array}$ & $\begin{array}{l}\text { Otras tierras } \\
\text { No de piezas }\end{array}$ & $\begin{array}{l}\text { Total obradas } \\
\text { tierras sueltas }\end{array}$ & $\begin{array}{c}\text { Total renta } \\
\text { (Fanegas de trigo) }\end{array}$ & $\begin{array}{c}\text { Total obradas } \\
\text { arrendadas }\end{array}$ \\
\hline Marcelino Alonso & $1 / 4$ & 9 & 8,25 & 17 & 25 & 33,25 & 15 \\
\hline Celestino Alonso & $1 / 4$ & 13 & 10,25 & - & - & 10,25 & 9 \\
\hline Cesáreo Moyano & $1 / 4$ & 9 & 9,37 & - & - & 9,37 & 9 \\
\hline Vicente Rojo & - & - & - & 3 & 12 & 12 & 4 \\
\hline Manuel Alonso & - & - & - & 4 & 7 & 7 & 3 \\
\hline Eusebio Obregón & - & - & - & 2 & 2,5 & 2,5 & 2,5 \\
\hline Braulio Martín & - & - & - & 3 & 9,25 & 9,25 & 3,5 \\
\hline Agustín Martínez & & - & - & 2 & 4 & 4 & 1 \\
\hline Paula Díaz & $1 / 2$ & 18 & 18,5 & - & - & 18,5 & 18 \\
\hline Benito Fadrique & $1 / 2$ & 30 & 18,5 & - & - & 18,5 & 18 \\
\hline Martina Gaspar & $1 / 2$ & 19 & 20 & 8 & 26 & 46 & 29,5 \\
\hline Gregorio León & 1 & 28 & 35 & 3 & 2 & 37 & 37,5 \\
\hline Canuto de Castro & $5 / 4$ & 31 & 55 & - & - & 55 & 48 \\
\hline Tomás Moyano & $1 / 2$ & 17 & 20 & 1 & 3 & 23 & 19,5 \\
\hline Eleuterio Martín & 1 & 36 & 35 & 3 & 13 & 48 & 42 \\
\hline Valentín Martín & - & - & - & 10 & 30,75 & 30,75 & 12 \\
\hline Manuel Pérez & $1 / 2$ & 20 & 20 & - & 4 & 24 & 20 \\
\hline Leandro Obregón & $1 / 2$ & 13 & 18,75 & 1 & 0,75 & 19,5 & 19,5 \\
\hline Joaquina Moyano & $1 / 2$ & 18 & 18,75 & 3 & 7,5 & 26,25 & 24 \\
\hline Ezequiel Pérez & $1 / 2$ & 22 & 19 & 1 & 1,5 & 20,5 & 19 \\
\hline Feliciano Martín & $1 / 2$ & 16 & 20,5 & 1 & 4 & 24,5 & 20 \\
\hline Inocencia Zamora & $1 / 2$ & 22 & 20,75 & - & - & 20,75 & 18 \\
\hline Ezequiel Moyano & $1 / 2$ & 34 & 29,5 & - & - & 29,5 & 30 \\
\hline León José Moyano & $3 / 4$ & 24 & 20,125 & - & - & 20,125 & 22 \\
\hline Félix Martínez & - & - & - & 15 & 20 & 20 & 19,5 \\
\hline TOTALES & 10,25 & 379 & 397,24 & 77 & 172,25 & 569,49 & 463,5 \\
\hline
\end{tabular}

Fuente: Fuente: A.H.P.V. Protocolos Notariales. Elaboración propia.

En este año 1861 vuelven a concretarse de forma individual piezas y calidades con notable precisión. Se acortan a cuatro ańos los contratos y se fijan normas que en nada dejan entrever cambios en los cultivos ni modificación del sistema de año y vez. Ni la más leve indicación de ruptura con la tradición. En nada se diferencian de los rubricados doscientos años atrás ${ }^{169}$.

Aunque no coincide, salvo excepciones, la superficie de cada renta con su equivalencia exacta en obradas, se vuelve a fijar en torno a una fanega por obrada como renta anual. La diferencia estriba en que el grano de cómputo se fija exclusivamente en trigo. Esta indicación expresa de que sean todas las fanegas en "trigo nuevo, bien granado, seco y bien azarandado y limpio..." sin ninguna mención a la cebada, aun cuando parte de las tierras iban a ser echadas de este cultivo, hace pensar en las repercusiones tanto de las crisis de precios que se viven en estas décadas como en el naciente dinamismo del mercado triguero y harinero a nivel nacional. Una cosa era la necesidad de los labradores de contar con cebada para el alimento de sus ganados y otra muy distinta el interés del apoderado del marqués por hacer rendir al máximo las posesiones de su seńor. No se olvide que, desde mediados de siglo, la mejora de las comunicaciones, el canal de Castilla y, posteriormente, la aparición del ferrocarril revolucionan el comercio interior de granos, con la consiguiente subida del precio del trigo amparado por la política proteccionista de estos ańos ${ }^{1170}$.

1169"Las referidas tierras se reciben por cuatro años, cuatro pagas y cuatro frutos o siembra de la parte y porción de tierras que en cada un año corresponda estar en barbecho. En cada un año y para el quince de agosto se obligan a pagar sin descuento ni moderación alguna. No podrán subarrendar el todo ni la más pequeña parte de las tierras, ni ceder su cultivo y disfrute por ningún otro concepto, ni tampoco trashojar ni mudar las lindes, ni poner ninguna de las tierras a un surco con otras, ni consentir intrusión, ni permitir menoscabo o cavar y extraer tierra de ninguna de ellas. Será de su cuenta pagar todas las contribuciones ordinarias generales, provinciales y municipales... por las referidas tierras y con el deber de entregar al administrador los recibos al fin de cada año...” (A.H.P.V. Pt 11957, fol. 58, año 1861). 
El desarrollo de la burguesía harinera de la segunda mitad de siglo, de la que Orturas no estaba alejado al comercializar el trigo de su señor, acaba de explicar la preferencia por esta especie como pago en las escrituras de arrendamiento. De hecho, en el contrato de arrendamiento que firma Gregorio León Alonso el 20 de octubre de 1873, "se paga de renta por las cincuenta obradas de tierra aquiñonadas cien fanegas de trigo todos los años", lo que ratifica y consolida tanto la preferencia por el trigo en el pago de las rentas como la subida de estas por la expansión que viven los mercados en todo el país ${ }^{1171}$.

Cuadro 114. Ejemplos de la cuantía y productos fijados como pago en los arrendamientos del Marqués de Torreblanca y Falces en su mayorazgo de Serrada. 1657-1877

\begin{tabular}{lccccc}
\hline Ańos & $\begin{array}{c}\text { Renta estipulada por cada } \\
\text { Trigo }\end{array}$ & $\begin{array}{c}\text { obradas (fanegas) } \\
\text { Cebada }\end{array}$ & Total fanegas & $\begin{array}{c}\text { Fanegas por } \\
\text { obrada arrendada }\end{array}$ & $\begin{array}{c}\text { Fanegas por } \\
\text { obrada sembrada }\end{array}$ \\
\hline 1657 & 32,75 & & 32,75 & 0,81 & 1,63 \\
1709 & 32 & 4 & 36 & 0,90 & 1,8 \\
1785 & 32 & 10 & 42 & & 1,8 \\
1813 & 18 & 18 & 36 & & 2,6 \\
1828 & 18 & 26 & 36 & 0,90 & 1,84 \\
1851 & 26 & - & 52 & 1,3 & 2,5 \\
1861 & 37 & - & 37 & 0,92 & 3 \\
1873 & 50 & & 50 & 1,25 & 1,5 \\
1877 & 60 & 60 & & & \\
\hline
\end{tabular}

Fuente: Fuente: A.H.P.V. Protocolos Notariales. Elaboración propia.

Como puede apreciarse en el cuadro adjunto, es en la segunda mitad del XIX cuando las rentas se incrementan por encima de la tradicional fanega por obrada, al calor del desarrollo triguero y de mercados. Otra cosa bien distinta es la predisposición de los renteros a su pago ${ }^{1172}$. En septiembre de 1869 Juan José de Orturas, administrador del marqués de Falces, dirige una carta a Gregorio León Alonso, principal hacendado de la villa, expresando su disgusto por el impago de rentas sin que existan motivos para su incumplimiento ${ }^{1173}$ :

\begin{abstract}
"Para salir del compromiso en que me hallo con el Sr. Marqués de Falces por los descubiertos de rentas que tienen los renteros de la posición de Ud. me es imprescindible hacerles presente la imperiosa necesidad de demandar como procede para el pago, de no realizarle lo más pronto posible, mediante a lo mucho que ha favorecido la buena cosecha recolectada, y por lo tanto y porque no hallo medio decoroso para disculpar la falta de pago por parte de Ud. de la cosecha de 1868 y de la que acaba de vencer, espero se servirá Ud. ponerlas ambas sin demora en esa panera o en la que aquí recibo los granos para evitarme el disgusto de tener que tomar las medidas del caso...”.
\end{abstract}

${ }^{1170}$ Aunque todos estos hechos se estudiarán en detalle cuando se aborden el análisis de los cultivos y sus rendimientos a mediados de siglo, conviene apuntar a lo ya constatado como factores explicativos de estos cambios de rentas y especies en 1851 y 1861, tanto el incremento productivo que vive el campo vallisoletano en estos ańos, como el descenso del precio del trigo que acusan los mercados en los años de 1848 a 1855 y el pico ascendente que registran cuando se firma la escritura de 1860. (Sobre estas fluctuaciones, registros de precios y dinamismo de mercados puede seguirse a Ramón Garrabou y Jesús Sanz Fernández: Historia agraria de la España contemporánea...., ob. cit., pág. 41).

${ }^{1171}$ A.F.A.M. Contrato de las "Tierras que lleva en colonia del Señor marqués de Falces D. Gregorio León Alonso".

1172 A.M.S. caja 1, carp. 14, fol. 14, año 1868. A las siempre difíciles relaciones de muchos renteros con el apoderado del marqués, se van a unir en los años sesenta diferencias municipales con dicho administrador en relación con el barrero donde el vecindario se aprovisionaba de adobes y que se localizaba en tierras del antiguo seńor de la villa. El administrador del marqués de Falces solicita al Ayuntamiento el saneamiento de los pantanos y excavaciones hechas por los vecinos, pese a haber recibido pagos por dicha extracción con cargo a las arcas municipales.

${ }^{1173}$ A.F.A.M. Correspondencia entre Gregorio León Alonso y Juan José de Orturas. 

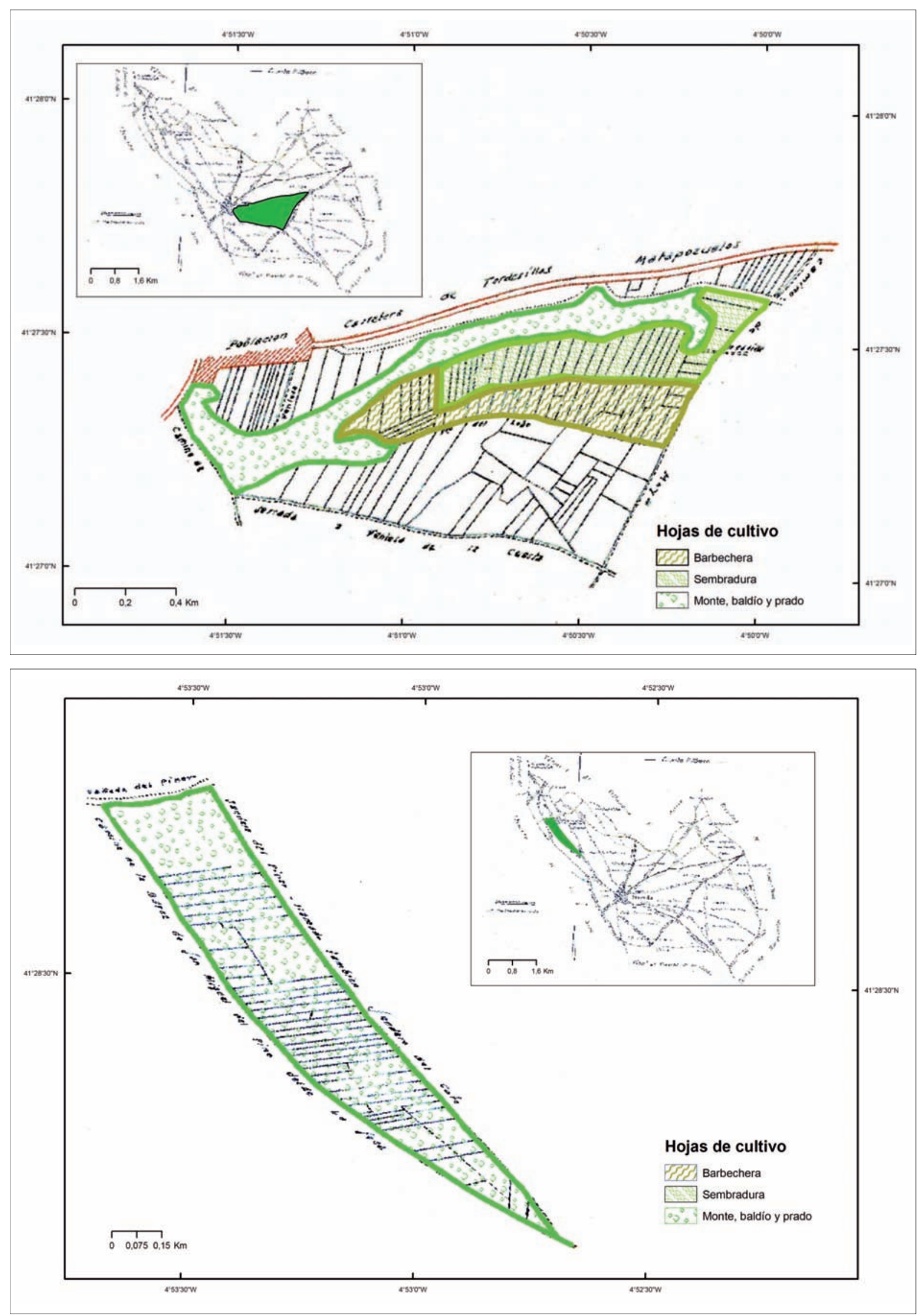

Figura 31. Estimación parcelaria y de hojas de cultivo en las tierras de mayorazgo del marqués de Torreblanca, a mediados del siglo XIX. La Vega (arriba) y Las Medianillas (abajo). Obsérvese la extraordinaria parcelación, en los polígonos escogidos por representativos, del espacio agrario, resultado de la ocupación y usos a lo largo de los siglos. Fuente: Avance catastral (A.M.S.), Protocolos notariales (A.H.P.V.). Elaboración propia. 

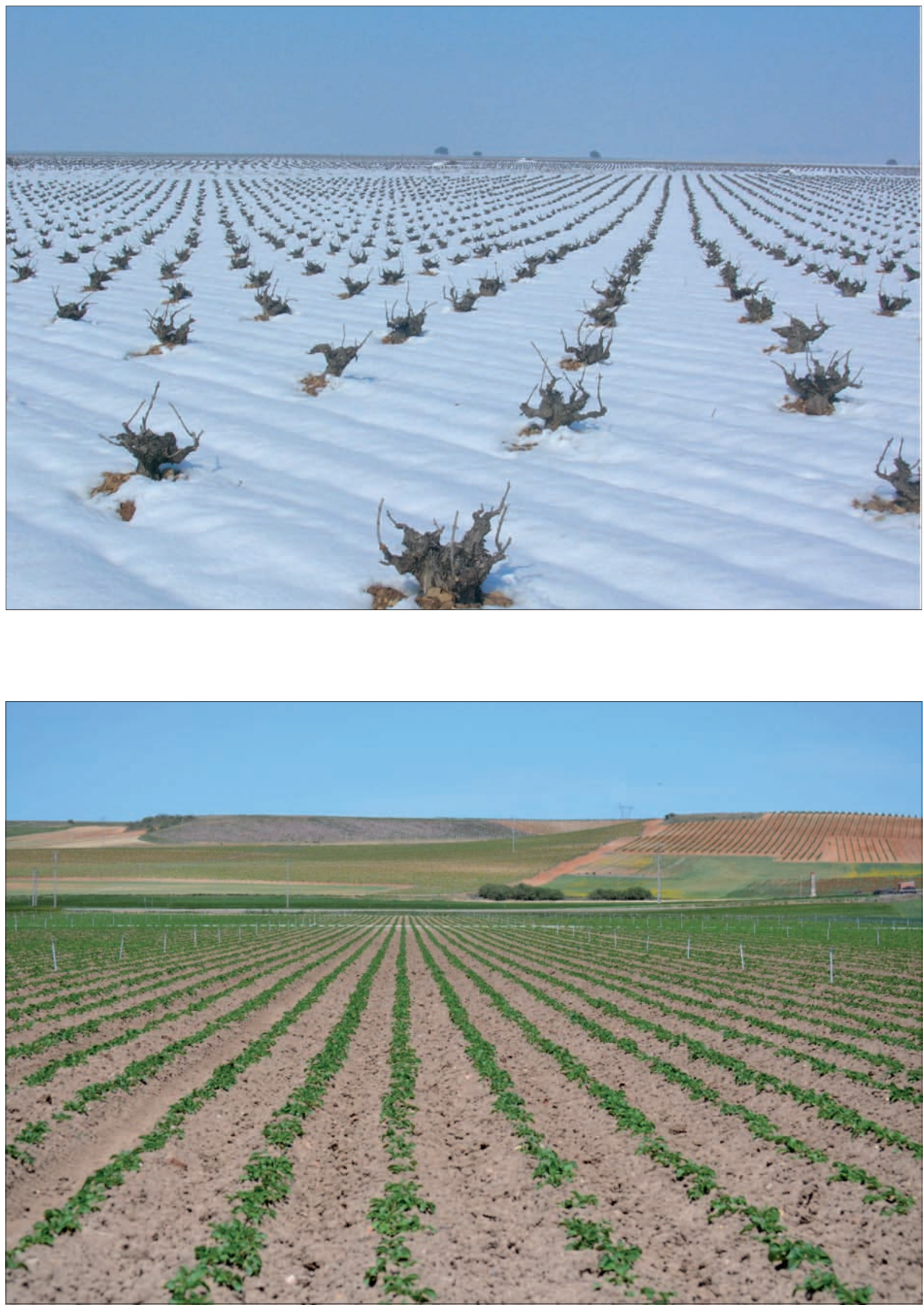

Imagen 85. Terrazas de gravas y tierras de vega han sido cultivadas desde siglos atendiendo a los condicionantes edáficos, necesidades de los hombres y rentabilidad de los cultivos. (Arriba, viñedos en término de La Seca, foto: Pedro Vázquez de Prada, 27/02/2006; abajo, pago de La Vega, en Serrada, foto: 03/05/2014). La parcelación que estudiamos atiende, amén de estos factores, a la ocupación del espacio a lo largo de los siglos, a la división en hojas, tipo de propiedad y repartos hereditarios. 

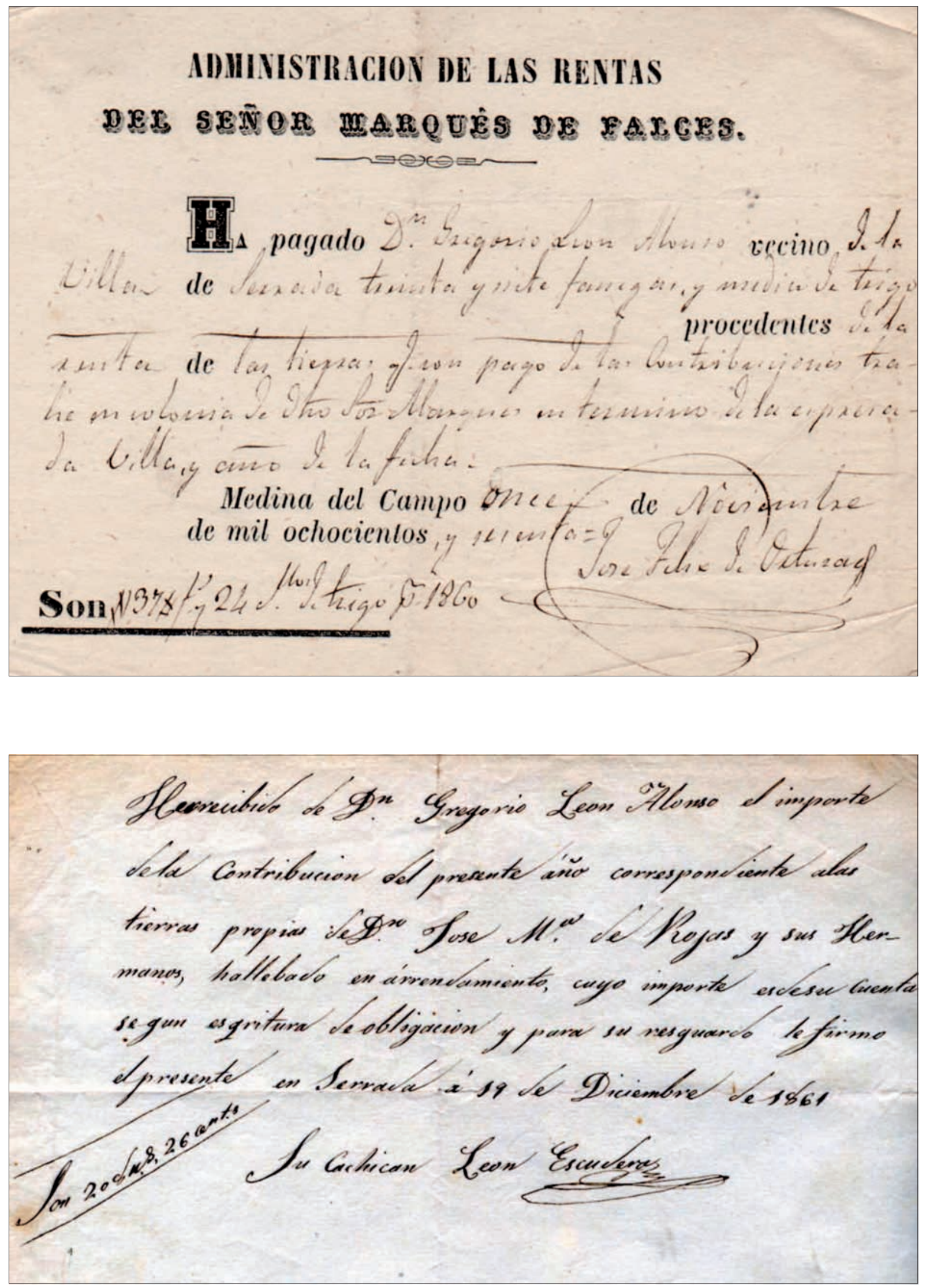

Imagen 86. Recibos de pago de arrendamientos rústicos del Marqués de Falces (arriba) y de la familia Rojas (abajo). Serrada, 1860 y 1861. (Archivo familia Alonso Moyano). La administración de los bienes rústicos y urbanos en Serrada y en otros municipios de la provincia, pertenecientes a la nobleza o la burguesía decimonónica, generalmente absentista, fue llevada por administradores ajenos al espacio local. Los retrasos en los pagos, generalmente por malas cosechas, fueron causa de litigios y enfrentamientos. 
La pérdida de las cosechas del año 68 había sido general en el campo vallisoletano. Ni el marqués perdona rentas ni los renteros tienen sobrantes en sus paneras. A ello se ańaden las tensiones que hacendados pudientes, como el citado o el vecindario en general, tienen con dicho administrador, pero ya se han relatado ejemplos de renteros desahuciados por impagos o la situación de otros que ceden al marqués alguna propiedad como pago de rentas atrasadas ${ }^{1174}$.

Por último hay que detenerse en la extraordinaria parcelación que se observa en el terrazgo cultivado, pese a que en origen se trata de doce "trozos" que suman 440 obradas ${ }^{1175}$. En 1860 y en lo que respecta al terrazgo de rentas propiamente dicho, se escrituran 397,24 obradas. El resultado es un mosaico irregular de 379 diminutos pedazos, repartidos en las distintas hojas en que se divide el terrazgo cerealista, con una extensión media de tan sólo 1,04 obradas por parcela. En la escritura, de cinco cuartos de renta (50 obradas) que firma Gregorio León Alonso en 1873, se anotan hasta 29 pedazos con una extensión media de 1,72 obradas por parcela. Esta extraordinaria fragmentación, que incrementa notablemente los costes de explotación de la tierra, es característica no sólo del terrazgo arrendado sino de todo el cultivado en Serrada y en buena parte de la comarca, aspecto este, por lo demás, propio de los sistemas tradicionales de cultivo y, en lo que respecta al espacio estudiado, por distintas circunstancias que ya se valorarán, presente hasta nuestros días.

En la estimación adjunta de la división parcelaria y las hojas de cultivos, vigentes hasta este siglo, podemos apreciar esta atomización parcelaria, tanto mayor cuanto es la calidad de la tierra. En ambos pagos representados es evidente la forma de ocupación del espacio labrado, su reparto teniendo en cuenta la pendiente del terreno, la red caminera, la proximidad a los prados, etc. En el pago de la Vega, por ejemplo, se aprecia con claridad cómo el sendero que divide el pago en dos mitades permite, al tiempo, el paso de los animales de labor y disponer de parcelas a uno y otro lado, asegurando la cosecha en cada campańa, dada la feracidad de estos suelos ${ }^{1176}$. Hasta las primeras décadas del siglo XX el sendero de acceso se tapaba con tierra en su inicio para impedir el paso del ganado a las sembradura e, igualmente, los vallados que limitan con los prados se realzaban evitando las intromisiones del ganado lanar o mular.

Sin extendernos en más consideraciones, las tierras sueltas que conforman el pago de Las Medianillas, camino de San Martín del Monte, fueron roturadas y ocupadas siguiendo esta dirección, con salidas a los caminos lindantes del pago que, en la estimación representada, corresponden a la hoja de sembradura y reflejan, como en el anterior caso, unas roturaciones y ocupaciones iniciales que apenas rebasan la obrada o, lo que viene a ser lo mismo, el terreno que podía labrar una yunta en una jornada.

${ }^{1174}$ A.F.A.M. En el caso de Gregorio León Alonso, no parece que sean circunstancias de falta de liquidez las que demoren las rentas que entregar, dado que por estas fechas la hacienda que dirige es una de las más importantes de la comarca. El retraso en los pagos parece deberse a otras razones, relacionadas con su papel de alcalde de la villa y el distanciamiento vecinal y de algunos renteros con dicho administrador. (ver nota anterior). Además, y a título personal, a tenor de la correspondencia consultada, se advierten escasas simpatías, por parte de Gregorio León, con el administrador medinense. Las diferencias más notables se registran en 1842, cuando el seńor Alonso solicita al marqués el arrendamiento de sus majuelos, la bodega, la casa y el lagar. Su negativa o la influencia que ejerce el señor Orturas en el arrendamiento de la casa, manifestando que "no quería que cuando fuese a dar una vuelta a sus granos le pusiesen mala cara", la insistencia de Gregorio León en ello al necesitarla por "la estrechez en que vivo en la mía” y la negativa del administrador insistiendo en el deseo de su señor de no arrendarla, contribuirán a agriar las relaciones entre las partes.

1175 Muchos contratos se firman conjuntamente por distintos componentes de una misma familia, aun cuando se especifican las parcelas asignadas a cada uno, pero que anteriormente formaban parte de un mismo lote arrendado por el antecesor de todos ellos. Así, el 13 de diciembre de 1861, comparecen ante el escribano y el administrador "conjuntamente Doña Inocencia Zamora, D. Ezequiel Moyano Díaz y D. León José Moyano, vecinos de esta referida villa...” y que no son sino componentes todos de la familia de labradores descendientes de Melchor Moyano y su mujer Doña María Díaz. (Ezequiel es hijo, Inocencia nuera -casó con Ventura Moyano- y León José el hijo primogénito de estos, que casará con Feliciana Moyano). Buena parte de las diminutas parcelas asignadas a unos y otros son linderas de familiares directos e indirectos e integrantes todas de las que anteriormente llevara el antedicho D. Melchor Moyano.

${ }^{1176}$ La división parcelaria tomada como base es la reflejada en el avance catastral de comienzos del siglo XX, tanto en el pago de la Vega como en el de Las Medianillas. A pesar de la deficiencia del croquis indicativo, hemos creído conveniente sacrificar la claridad por respetar el material gráfico original, tanto de parcelas como de indicaciones de senderos y pagos. 


\section{c. La familia De Rojas como gran propietaria absentista y arrendataria}

La desamortización de Mendizábal cambia la estructura de la propiedad de Serrada respecto a las mayores haciendas. En cierta manera, la decadencia de las casas religiosas de la villa, que en sus últimas décadas arriendan buena parte de sus propiedades, encuentran el relevo en Luis de Rojas. Este agente de negocios vallisoletano adquiere en Serrada 98 aranzadas de majuelos y 350 obradas de tierras procedentes de la hacienda de las monjas Brígidas y del Convento de San Pablo. Como se ha estudiado, buena parte de los majuelos estaban pidiendo su arranque por descuidados, gramosos y faltos de tareas. Seguramente no era el fin sońado por los religiosos ni tampoco por los labradores de la villa, pero buena parte de ellos vuelven a ser tierras de pan llevar, de flojos rendimientos, dada la escasa calidad de la tierra sobre la que se asientan y que sólo por la favorable coyuntura triguera de las décadas centrales del siglo son tomados en arrendamiento por los labradores, faltos, como siempre, de tierra en sus labranzas. Luis de Rojas y sus herederos se convierten en los grandes rentistas de la comarca, puesto que también gestionan el arrendamiento del Despoblado de San Martín del Monte. De hecho, en 1852, los herederos del comprador (José Manuel Gómez de Hornedo, Julián y José María de Rojas) figuran como principales contribuyentes entre los hacendados forasteros, superando notablemente a todos los propietarios. La influencia de sus propiedades arrendadas es, agrícolamente hablando, mucho menor que la que se ha analizado del antiguo señor de la villa, no sólo por su temporalidad, dado que no alcanzan a ver el nuevo siglo, sino fundamentalmente por la baja calidad de sus suelos, como constata el documento encontrado en el archivo de la familia Alonso Moyano y que se resume en el cuadro adjunto ${ }^{1177}$ :

Cuadro 115. Colonia de Luis de Rojas. Mediados del siglo XIX. Serrada

\begin{tabular}{|c|c|c|c|c|c|c|c|}
\hline \multirow{2}{*}{$\begin{array}{l}\text { Nombre de } \\
\text { los colonos }\end{array}$} & \multirow{2}{*}{$\begin{array}{c}\text { No de } \\
\text { pedazos }\end{array}$} & \multicolumn{5}{|c|}{ Clases de calidad. (Obradas) } & \multirow{2}{*}{$\begin{array}{l}\text { Total } \\
\text { obradas }\end{array}$} \\
\hline & & $1^{\text {a }}$ calidad & 2a calidad & $3^{a}$ calidad & $4^{a}$ calidad & $5^{\text {a }}$ calidad & \\
\hline Cipriano Platón & 8 & - & - & 7 & 12,33 & 8,5 & 28,83 \\
\hline Eugenio Aragón & 6 & - & 5 & - & 9 & 13 & 27 \\
\hline Ezequiel Pérez & 7 & - & 3 & 5 & 10,5 & 26,25 & 44,75 \\
\hline Feliciano Martín & 5 & - & - & 5 & 9 & 3 & 17 \\
\hline Fernando Alonso & 2 & - & - & 8 & 8,5 & - & 16,5 \\
\hline Félix Martínez & 10 & - & - & 10 & 15 & 14 & 39 \\
\hline Gabriel Pérez & 1 & 0,5 & - & - & - & - & 0,5 \\
\hline Gregorio Román & 5 & - & - & 2 & 13 & 15 & 30 \\
\hline Guillermo García & 11 & - & - & 12 & 14 & 9,5 & 35,5 \\
\hline Gregorio Juárez & 2 & - & - & - & 4 & 5,5 & 9,5 \\
\hline Jorge Martínez & 6 & - & - & 7 & 2 & 16 & 25 \\
\hline Pablo Obregón & 3 & - & - & 21,5 & 8 & - & 29,5 \\
\hline Manuel Pérez & 6 & - & - & 5 & 4 & 6,5 & 15,5 \\
\hline Modesto de Castro & 4 & - & - & 12 & 5 & 1,5 & 18,5 \\
\hline Simón Bayón & 4 & - & - & 20 & 4 & - & 24 \\
\hline TOTAL & & & & & & & 361,08 \\
\hline
\end{tabular}

Fuente: Archivo familia Alonso Moyano. Elaboración propia.

Son tierras para plantar majuelos, esté boyante o decaído el mercado del vino, pero la nueva burguesía propietaria invierte su dinero para hacerlo producir. Estas tierras, eriales en parte por su escasa aptitud cerealista, son puestas en el mercado de arriendos para extraer de ellas hasta el último celemín. El novedoso detalle de su clasificación, por calidades, es una prueba de una racionalidad nunca vista hasta ahora y su división en "quiñones," con rentas diferenciadas, en que hasta la paja va a ser pedida como parte de las rentas, otro elemento que ańadir en el nuevo tiempo de la segunda mitad del siglo XIX ${ }^{1178}$ :

1177 A.F.A.M. Papel suelto, colonia de Luis de Rojas.

1178 A.H.P.V. Pt. 15958, Serrada, Domingo Duque, fol. 119, año 1860. 
A pesar de la escasa calidad de muchas de ellas, la renta media asciende a 0,87 fanegas por obrada, amén del carro de paja a la mayor parte de los renteros, que, teniendo en cuenta precios en torno a 20 reales por cada uno de ellos en estos ańos, vienen a equivaler a otra media fanega de trigo por quiñón ${ }^{1179}$. El abogado y propietario vallisoletano no deja nada al azar. Los contratos están sujetos a tiempos precisos de entrega de rentas (del 15 de agosto al 30 de septiembre), a plazos fijos de duración de los contratos (ocho años en la mayor parte de los casos) y a las costumbres tradicionales de cultivo dado que las tierras "han de ser labradas y cultivadas conforme al estilo agrícola del pais, es decir, a dos ojas, sin que puedan subarrendarlas, ni trashojar ninguna de ellas, para cuyo efecto van senaladas las que cada uno tiene de pajas"1180.

Cuadro 116. Arrendamientos de José Ma de Rojas en Serrada, año 1860

\begin{tabular}{|c|c|c|c|c|c|c|c|}
\hline \multirow[b]{2}{*}{ Rentero } & \multirow[b]{2}{*}{$\begin{array}{l}\text { Número } \\
\text { de quiñón }\end{array}$} & \multirow[b]{2}{*}{$\begin{array}{l}\text { Localización } \\
\text { en pago }\end{array}$} & \multirow[b]{2}{*}{$\begin{array}{l}\text { Número } \\
\text { de piezas }\end{array}$} & \multirow[b]{2}{*}{$\begin{array}{l}\text { Superficie } \\
\text { (En obradas } \\
\text { y estadales) }\end{array}$} & \multicolumn{3}{|c|}{ Renta a satisfacer } \\
\hline & & & & & $\begin{array}{l}\text { Celemines } \\
\text { de trigo } \\
\text { por obrada }\end{array}$ & $\begin{array}{c}\text { Total } \\
\text { fanegas } \\
\text { de trigo }\end{array}$ & $\begin{array}{c}\text { Número } \\
\text { de carros } \\
\text { de paja }\end{array}$ \\
\hline Celestino Alonso & $1^{\circ}$ & Enredosos & 6 & 32,376 & 12,02 & 32,96 & 1 \\
\hline Guillermo García & $2^{\circ}$ & - & 6 & 33,218 & 10,50 & 29,35 & 1 \\
\hline $\begin{array}{l}\text { Felipe Moyano } \\
\text { y Melitón Moyano }\end{array}$ & $3^{\circ}$ & $\begin{array}{l}\text { Cuesta de } \\
\text { los Muertos }\end{array}$ & 7 & 37,140 & 10,50 & 32,40 & 1 \\
\hline Cesáreo Moyano & $4^{\circ}$ & Vallejo & 6 & 33,083 & 10,50 & 29,05 & 1 \\
\hline \multirow[t]{2}{*}{$\begin{array}{l}\text { Pedro Alonso } \\
\text { y Aureliano del Río. }\end{array}$} & $5^{\circ}$ & $\begin{array}{l}\text { Fuentes, Tintos } \\
\text { y C. Muertos }\end{array}$ & 7 & 28,388 & 12 & 28,97 & 2 \\
\hline & $11^{\circ}$ & Moya & 14 & 26,292 & 7,5 & 16,70 & 2 \\
\hline Jorge Martínez & $6^{\circ}$ & Colgadero, & & & & & \\
\hline \multirow[t]{2}{*}{ Fuentes y Tintos } & 5 & 31,037 & 12 & 31,09 & 1 & & \\
\hline & $7^{\circ}$ & & 3 & 15,255 & 12 & 15,55 & 1 \\
\hline \multicolumn{7}{|l|}{ Florentino Martín } & 1 \\
\hline \multirow[t]{2}{*}{ Gregorio Román } & $9^{\circ}$ & Bodeguilla & 5 & 30,004 & 7,5 & 18,75 & - \\
\hline & Era & - & 1 & 0,180 & & 24 & 2 \\
\hline \multirow[t]{2}{*}{$\begin{array}{l}\text { Eugenio Aragón } \\
\text { y Mariano García }\end{array}$} & $10^{\circ}$ & La Rosa & 6 & 30,232 & 7,5 & 19,11 & 1 \\
\hline & Tierra & - & 1 & 8 & 12 & & \\
\hline Pablo Obregón & 12 & Carretas & 3 & 21,234 & 7,5 & 13,49 & - \\
\hline Mariano López & 13 & Carretas y Orcajillo & 9 & 31,212 & 6 & 15,765 & - \\
\hline Mateo Martínez & - & - & 7 & 7,028 & 6 & 3 & - \\
\hline \multirow[t]{2}{*}{ Juan Matisán } & - & - & 4 & 9,108 & & 11 & \\
\hline & Majuelo & - & 1 & 2,5 aranzadas & - & & \\
\hline TOTAL & & & 94 & 347,67 & 9,70 & 304,515 & 14 \\
\hline
\end{tabular}

Fuente: Fuente: A.H.P.V. Protocolos Notariales. Elaboración propia.

Similar detalle, aunque se carece de fuentes documentales, se puede imaginar en las piezas de majuelos arrendadas y cuyo estado, como se ha estudiado, había aconsejado arrancar. En las que se han localizado la cuantía de la renta también es en trigo, lo que invita a pensar que los herederos de

${ }^{1179}$ En estos años de 1860 a 1862 se tasa en Serrada la fanega de trigo a 41 reales; la de centeno, a 25; la de cebada, a 23; los guisantes, a 28 reales la fanega y las algarrobas, a otros 20 reales. Cada carro de paja suele pagarse, como queda referido. a veinte reales cada uno.

${ }^{1180}$ Ibídem. 
Luis de Rojas tampoco apostaron por la transformación de mostos, labor imposible de llevar con eficiencia, si no se está a pie de cuba, contribuyendo así a que cese, durante buena parte de la segunda mitad del XIX, el apogeo vitivinícola en las antiguas haciendas de dominicos y brígidas, ahora de su propiedad. Únicamente se tiene constancia del arrendamiento de los lagares y cubas que se conservaban en uso.

Pero no por ello esta familia rentista se despreocupa de su inmensa propiedad. Al contrario, son los hijos y yernos del propio hacendado los que llevan directamente la gestión administrativa, la firma de las escrituras de arriendo y, en ocasiones, la supervisión de las tierras o ciertas tareas ligeras que aquellas necesitan ${ }^{1181}$. Se tiene constancia de la residencia temporal de Gómez de Hornedo en la villa en juicios de conciliación por la cobranza de rentas de tierras y de ocupación de cubas en su bodega. Como negociantes y rentistas, los herederos de Rojas aprovechan cualquier ocasión para ampliar su campo de actuación ${ }^{182}$. La oportunidad les llega en 1851 cuando se hacen con el arrendamiento completo del Despoblado de San Martín del Monte, siempre vinculado a Serrada, pero que por su complejidad e interés bien merece epígrafe aparte.

\section{d. El arrendamiento y gestión del Despoblado de San Martín del Monte}

Aunque agregado a Serrada, San Martín de Monte continúa dependiendo del monasterio de Santa Clara de Tordesillas. Como se ha estudiado, sus últimos tres vecinos se fueron a vivir a Serrada en 1817 renunciando al dominio útil y de aprovechamiento de su término ${ }^{1183}$. San Martín, aunque sin vecinos, sigue siendo centro de interés, tanto por parte de quienes labran sus tierras, como por quienes desean aprovechar los pastos de sus dehesas. A partir de la citada fecha se abre un paréntesis en que Santa Clara, dueña y poseedora de dicho terrazgo, organiza los pagos de rentas con los cultivadores que, aun habiendo acordado su derecho a aprovechar el vuelo de los majuelos que poseen, o no han realizado las correspondientes escrituras forales para legalizar la nueva situación, o se retrasan y excusan año tras año en el pago de sus réditos ${ }^{1184}$. A mediados de siglo el monasterio, como tantas órdenes religiosas, no anda sobrado de recursos. La desamortización de Mendizábal no ha pasado en balde y falta que Cayo Pombo remate sus dehesas, aprovechando la legislación de Madoz.

La comunidad clarisa no se cruza de brazos ante tantos retrasos e impagos de tantos pequeños cultivadores. Con fecha de 28 de abril de 1851 y ante Román Rodríguez, se inicia una gestión rentista y capitalista de cuantos recursos atesora la despoblada villa. Al frente del proceso se encontraban los

${ }^{1181}$ En un borrador de carta fechado el 29 de noviembre de 1873, Gregorio León Alonso comunica a José María de Rojas el remite de la escritura de subarriendo del Despoblado de San Martín del Monte y cómo le observó, cuando salió con el pretexto de dar un paseo a ver si le veía para proporcionarle la escritura y resolver ciertos problemas, que se pasó la tarde "a las huebras... quemando los cardos... gastando la tarde en esta operación..." (A.F.A.M., apunte de correspondencia)

${ }^{1182}$ En el repartimiento de la contribución de 1852, figuran como contribuyentes de esta villa José Manuel Gómez de Hornedo, Julián y José María de Rojas, todos ellos avecindados en Valladolid y titulares conjuntos de las propiedades sitas en Serrada. Es este último el que administra directamente y como apoderado de su hermana Micaela de Rojas Ovejero, tanto la hacienda de la villa como el arrendamiento del Despoblado de San Martín del Monte, iniciado por Gómez de Hornedo en 1851 y que continúan los hermanos mencionados, a partir de 1862. Falta confirmar, aunque para nada incide en la presente investigación, el parentesco entre el señor Gómez de Hornedo y los hermanos de Rojas, aunque todo hace pensar que se trata de su hermano político.

${ }^{1183}$ Recuérdese que, por escritura ante Pedro Ybero de 30 de enero de 1817, Gabriel Navarro, Isidoro Milla y Juan Antonio Hinojal, únicos vecinos tras el desastre napoleónico, renuncian a los dos foros que tenía dicha villa con el monasterio de las Claras de Tordesillas, ante los múltiples atrasos y la imposibilidad de poder afrontarlos.

${ }^{1184}$ En certificación que expide Vicenta Adánez, Presidenta del Real Monasterio en 1851, en que ratifica que al monasterio le corresponde el total dominio y propiedad del Despoblado, tan solo refiere ocho escrituras de otros tantos propietarios acogidos a escritura foral, en virtud de los acuerdos de 1817. Se trata, en concreto, de propiedades de Isidoro Milla, Feliciano Martín, Félix Martínez, Bernardo Rico, Luis Aragón, José Lorenzo Moyano y Basilio Labajo, estos dos últimos vecinos de La Seca. (A.F.A.M. Documentación del subarriendo de San Martín del Monte). 
propietarios rentistas tantas veces aludidos, José Manuel Gómez de Hornedo y José María de Rojas, y el hacendado local Gregorio León Alonso. Los capitales no sólo se invierten en tierra sino en gestionar y hacer producir al máximo cuanto de ella se deriva. Nada tienen que ver estas nuevas escrituras con las que los antiguos vecinos de San Martín acordaron con las religiosas ${ }^{1185}$ :

“Don José Manuel Gómez de Hornedo, vecino de la ciudad de Valladolid, estante al presente en la Grada del Depósito de este Real Monasterio de Santa Clara de esta villa de Tordesillas Digo: Que tomo y recibo en renta y arrendamiento de este dicho Real Monasterio y en su nombre, de las Señoras Presidenta, depositarias de maravedíes y graneras del mismo de quienes se compone su Junta de Gobierno, todo el término de su Despoblado de San Martín del Monte, de pastos, censos en trigo y centeno, y tierras labrantías; y todo lo demás que contiene todo ello propio de este mismo Real Monasterio, por tiempo y espacio de ocho años que principian a contarse en diez del próximo mes de mayo de este año de mil ochocientos cincuenta y uno... y en cada uno de dichos ocho años me obligo a dar y pagar, y daré y pagaré realmente y con efecto ocho mil reales en dos plazos iguales por mitad..."

De esta manera, las monjas cambian las incomodidades que representan las morosidades de los pequeños arrendatarios por una gestión más eficaz y acorde con los nuevos tiempos. Es un paso más en el naciente capitalismo agrario que empieza a dibujarse en la segunda mitad del XIX. Hornedo, a cambio de pagar puntualmente los 8.000 reales y las contribuciones del citado lugar, tiene las manos libres para "disfrutar con mis ganados los pastos de la Dehesa y Prados y labrar todas las tierras labrantías de dicho término, y heriales que haya y que no estén arrendadas por la Comunidad, y también he de poder subarrendar todo o parte de lo referido a la persona o personas que mas me acomodare..."1186/1187. Los codiciados pastos de San Martín se abren al mercado comarcal y extracomarcal. Grandes hacendados y pequeños labradores dejan en ellos su ganado boyal, desde el primero de noviembre al diez de mayo, en que se fija el tiempo de aprovechamiento ${ }^{1188}$. He aquí la oportunidad y el negocio de esta burguesía capitalista que toma, por sus contactos y oficio, la tajada más cómoda y rentable y cede la que requiere más fatiga a quien por su posición e influencia puede sobrellevarla, al margen de la rentabilidad económica que del subarriendo se derive ${ }^{1189}$.

1185 A.F.A.M. Carp. de San Martín del Monte Copia de escritura del arrendamiento de San Martín. Escribano: Román Rodríguez, Tordesillas 28 de abril de 1851.

${ }^{1186}$ Ibidem, fol. 17-18.

${ }^{1187}$ Medio año después, estas últimas palabras tenían nombre propio. El 21 de septiembre del mismo año se firma escritura de subarriendo a favor de Gregorio León Alonso, a cambio de otros 8.000 reales e idénticas obligaciones ${ }^{1187}$. Falta decir, para poder entender la operación, que Hornedo, aunque deja pastar en las dehesas los ganados del señor Alonso, se reservaba su arriendo. Ello consta documentalmente por una escritura de mayo de 1859, último año del contrato, en que Gómez Hornedo arrienda los pastos a favor de León Adanero y otros, en una cuantía de 9.400 reales. (A.H.P.V. Pt. 15958, Serrada, Domingo Duque, fol. 31, año 1859).

${ }^{1188}$ En concreto, se fijaba para el prado del Berral, "que esta contiguo al Corral que se halla en la casa de dicha Dehesa" hasta "incuenta o sesenta reses, número que es permitido pastar en dicho prado" y que representaba, aproximadamente, la tercera parte de la ganadería potencial que podían acoger las citadas dehesas (Ibídem, fol. 98).

1189 A.F.A.M. Carp. de San Martín del Monte. La característica general de quienes labran terreno en el Despoblado es la reducida extensión de sus parcelas inferiores, por lo general, a dos Has. Destacan como mayores labradores del citado lugar Félix Martínez con 17 aranzadas, Feliciano Martín con 25 aranzadas y 15 obradas; los herederos de F. Román Abril con 12,5 aranzadas y Modesto de Castro, que amillara 24 aranzadas de vińa. Todo ello se deduce porque la frase entresacada en cursiva del primer arrendamiento de Hornedo, y que no parecía tener ninguna aviesa intención, iba a desatar no pocos recelos y litigios entre arrendadores, subarrendadores y cultivadores. ¿En qué situación quedaban los majuelos escriturados con gravamen de foro que habían pasado a terceras personas sin realizar las debidas formalidades legales? ¿ ¿Se hacía extensible a todos los majuelos plantados en 1817 la concesión foral otorgada por el monasterio, si no todos los habían escriturado? ¿Y los majuelos plantados con posterioridad sin consentimiento del monasterio, pero que pagaban su cuota de canon o renta...? Difícil se hacía conciliar el espíritu de las antiguas leyes con los nuevos tiempos. Y más en un San Martín del Monte donde, de acuerdo con el padrón de riqueza de 1851, figuraban hasta cincuenta propietarios que asumían el cultivo de 199,5 aranzadas de majuelos y 32,5 obradas de tierra. 
Según las escrituras mencionadas, debían de pagar anualmente "cuatro celemines de centeno por cada obrada de tierra o tres celemines de la misma especie por cada aranzada de majuelo radicantes en dicho termino del Despoblado por el aprovechamiento de su vuelo que le concedió la Comunidad propietaria en atención a la dimisión que hicieron del dominio útil' 190.

Pese a ello, renueva tales compromisos por escritura de 1869, en que se hace nuevamente subarrendador del término y de los descubiertos de los foros en una cuantía de 825 escudos anuales, idéntica cantidad contraída por el arrendador, en este caso no el señor Hornedo, sino José María de Rojas Ovejero ${ }^{1191}$. Desde la fecha de la nueva escritura se encuentra, por último, al propio Alonso como arrendador de las dehesas de San Martín y del Berral, hechos estos que lo llevan a ser continuamente requerido por el Patronato para el pago de sus rentas, lo que indica que ni los rendimientos obtenidos por tanto trajín subarrendador eran, por aquellos años, tan boyantes, ni la situación de su hacienda en sus últimos años de vida rendía para abarcar tantos frentes. Un dato en este sentido es la obligación hipotecaria que contrae en 1865, a favor de Josefa Bosquet y Sobiet de Valladolid, por valor de 22.000 reales al objeto de "dar más impulso a las operaciones agricolas de sus propiedades", y que tendrá que ser cancelada por sus herederos tras su muerte ${ }^{1192}$. Es muy posible que Pombo, cuando remata las citadas dehesas, supiera de cuantos hechos se han referido. El convento de Santa Clara pierde esta riqueza tan preciada, pero San Martín del Monte y sus foros siguen estando vivos entre sus cultivadores, contribuyendo a reforzar la dependencia rentista de la práctica totalidad de los labradores locales y, como ya se ha insistido cuando se trataron los arrendamientos del marqués de Falces, nada positivo de cara a la crisis agropecuaria que se estaba gestando.

${ }^{1190}$ Se acababa la paciencia de la Junta de Gobierno del Monasterio con los débitos de las "bastantes fanegas de trigo y centeno procedentes de majuelos y tierras que han labrado en su término del Despoblado de San Martín del Monte desde el Agosto del año de mil ochocientos diez y siete hasta el de mil ochocientos cincuenta, sin que a pesar de las diligencias que se han practicado se haya hecho efectiva cobranza". Relacionados estos aspectos con cuanto antes se ha manifestado respecto al subarriendo y sobradamente acostumbrado a defender en pleitos su hacienda e intereses, con fecha de 16 de febrero de 1852, la Junta de Gobierno de Santa Clara otorga pública escritura a favor del citado Gregorio León, para la cesión y venta de todos los débitos antedichos, a cambio de 1500 reales que hay que pagar en tres plazos de 500 reales, corriendo este con cuantos gastos y acciones judiciales fueren necesarias para tal fin. Si no tenía bastante con la defensa de su importante hacienda, y aun le sobraba tiempo tras el dedicado a la vida municipal, el subarriendo de San Martín le costará más de un pleito y disgusto. Aunque como ya se ha manifestado este hacendado estaba acostumbrado a la defensa jurídica de cuanto creía conveniente a sus intereses, el subarriendo de San Martín y sus débitos le enfrentarán judicialmente a distintos labradores de San Martín, sea por cuestión de atrasos, sea por impago de rentas. En 1859, llegará a celebrar a su petición un acto conciliatorio con el señor Gómez de Hornedo, lo que demuestra las tensiones y conflictos derivados de tan complejos arrendamientos que lleva hasta el final de sus días. Parte de la vinculación que adquiere con San Martín y, por tanto, con el propio monasterio de Santa Clara puede atribuirse a razones personales, debido a que en el citado centro profesó su hija Juliana. De hecho, en la correspondencia que se conserva con el administrador del Patronato, al margen de problemas de retrasos de rentas u otras cuestiones, siempre están presente los afecto personales, aun cuando en 1877, aquejado ya de distintas dolencias y en el que será último año de vida, se le reclamen rentas y se anoten diferencias con Rojas por cuestión del arrendamiento de las dehesas. (A.F.A.M. Carp. de San Martín del Monte. Correspondencia con Patronato).

${ }^{1191}$ Ibídem. Copia escritural de 6 de octubre de 1869 ante Francisco Cantalapiedra, notario residente en La Seca. A Rojas se le supone el nuevo arrendador desde la expiración del contrato de aquel, ya que, en octubre de 1862, firma por sí y como apoderado de su hermana Micaela de Rojas un nuevo contrato de arrendamiento de las dehesas, por valor de 9800 reales, con los anteriores citados vecinos de Pedrajas de San Esteban, D. León Adanero y D. Gumersindo Morejón. (A.M.S. Pt. 11957, Serrada, Cenón Martínez, fol. 96, año 1862).

1192 A.F.A.M. Carp. de San Martín del Monte. Escritura de 25 de marzo de 1868 de crédito hipotecario ante Timoteo González Salamanca y escritura de carta de pago de 5 de mayo de 1879, ante Ambrosio Padilla. 


\title{
3. El dinamismo agrario de mediados de siglo
}

Como se ha señalado a lo largo de las páginas anteriores, el peso abrumador del arrendamiento representa, más que una singularidad, un pesado lastre para la capitalización de las pequeñas y atomizadas explotaciones agrarias. Este problema era el denominador común de la agricultura española. A pesar de ello, el agro castellano vive, salvo contadas crisis, un dinamismo sostenido en el segundo tercio del siglo XIX, en que se une la expansión demográfica con el aumento de producciones y el desarrollo ganadero. Es posible decir, siguiendo términos ampliamente aceptados, que las décadas centrales del siglo ven pasar al sector agrario del centro de la meseta, de una situación preindustrial a una protoindustrial, que sienta las bases para que la agricultura y ganadería se orienten definitivamente al mercado en los albores del siglo $\mathrm{XX}^{1193}$. La introducción de nuevas técnicas, rotaciones y cultivos señalan el camino para afrontar con éxito los retos que impone el fin de siglo. Se analizarán, antes de que lleguen otros acontecimientos, los factores desencadenantes del nuevo impulso agrario y que ponen punto final al proceso de liquidación del antiguo régimen.

\section{a. Los factores que alientan el despegue: La integración de las producciones en los mercados, la revolución de los transportes y la política proteccionista}

Desde hacía siglos era un secreto a voces el camino para resolver los problemas de subsistencias y atrasos que presentaba la agricultura y ganadería española. Lo imposible hasta mediados del XIX era romper este nudo gordiano. Nada mejor que leer el "Informe sobre la Ley agraria" de Jovellanos en el año 1795 para darse cuenta de la conciencia e interés de los ilustrados de fines del XVIII en superar las barreras que impiden el desarrollo agrario ${ }^{1194}$. El equilibrado e ilustre gijonés, además de denunciar cuantos factores tradicionales sumen en el inmovilismo al sector, propone la enseñanza desde la escuela de los métodos, labores y utillaje como fórmula para aumentar la productividad y romper la inercia de la tradición, insistiendo en la necesidad de eliminar los "estorbos de la circulación," facilitar el transporte cuando sea posible e incentivar la producción y comercio de las cosechas. Sus palabras, en lo que se refiere al principal cultivo de estas tierras, están bien documentadas ${ }^{1195}$ :

\begin{abstract}
"Los hechos confirmarán esta observación. El mayor consumo, por exemplo, del vino de castilla de los fértiles territorios de Rueda, la Nava y la Seca se hace en el principado de Asturias, y no habiendo camino carretero entre estos puntos, el precio ordinario de su conducción a lomo es de 80 reales en carga, lo que hace subir estos vinos tan baratos en el punto de su cultivo, desde 36 a 38 reales la arroba en el de su consumo: a los quales agregado el millón que se carga sobre su último valor, resulta un precio total de 44 a 46 arroba, que es el corriente en Asturias."
\end{abstract}

Cuanto manifiesta del vino y de estos pueblos lo hace extensible a los trigos, harinas y demás productos. Sus ojos no verán las transformaciones que soñaba, pero qué duda cabe de que había puesto el dedo en la llaga. Medio siglo después, la Junta de Comercio de Santander se felicita del potencial e inagotable granero castellano como depósito para un comercio exportador que enriquece a sus puertos. Señala en 1840 cómo "las Castillas yacían también en el abandono más lastimoso, despreciados sus campos, despreciados sus ricos frutos y pereciendo de necesidad los labradores en medio de la abundancia" y ahora, a mediados de la centuria, "el tráfico harinero comenzó a desarrollarse y todo cambió de aspecto"1196. Una década más tarde, en 1850, la "Memoria de la Junta de Calificación de los productos de la Agricultura, Industria y Artes presentados a la primera exposición pública de Valladolid"

${ }^{1193}$ Hilarión Pascual..., ob. cit., vol. III, pág. 105.

${ }^{1194}$ Gaspar Melchor de Jovellanos: "Informe sobre la Ley Agraria”. Prólogo de Valentín Andrés Álvarez. Instituto de Estudios Políticos, Madrid, 1955.

1195 Ibídem, pág. 257.

${ }^{1196}$ GARRABOU, R. y SANZ, J.: "Historia agraria..., vol..2, ob., cit., pág. 39, cita textual. 
incide en estos aspectos de mejora de comunicaciones, desarrollo de la industria harinera y subida del precio del trigo por la política proteccionista, factores, junto a la estudiada desamortización, que arrancaron la agricultura de su letargo secular ${ }^{1197}$.

En efecto, son unas décadas en que se observa un inusitado interés, por parte de los Ayuntamientos locales, por no quedarse al margen de carreteras, caminos o ferrocarriles como remedio mágico para solucionar sus problemas. Si Medina del Campo cambia el rumbo de su actividad agraria por otra más diversificada gracias al ferrocarril, La Seca, Rueda, Serrada, Villanueva, Valdestillas, Matapozuelos o Tordesillas, se afanan por crear comisiones, debatir y solicitar aquí y allá ramales férreos por donde drenar sus producciones y evitar quedar aislados.

Cuando el sueño del ferrocarril se evapore, vuelven sus ojos a la Diputación Provincial, solicitando comunicaciones tanto para conectar con las estaciones más cercanas, como para aliviar, ya en el último tercio del XIX, la penosa situación de un cada vez más abundante paro obrero. Aunque estas infraestructuras serán analizadas en posteriores capítulos, baste señalar que los Ayuntamientos y sus vecindarios son conscientes del tren que pueden o no tomar, del cambio que se está gestando, de la encrucijada, en fin, que representan estas décadas. Serrada, por ejemplo, protesta por la modificación del proyecto de la carretera de Tordesillas a Mojados, aprobado en 1864, porque se ha "variado la dirección del camino de una manera inconveniente con notabilisima desventaja para los intereses del municipio"II98 o se suma al proyecto de construcción de un tranvía que propone La Seca como una necesidad de conectar directamente con los mercados del norte y facilitar la llegada de sus vinos ${ }^{1199}$ :

\footnotetext{
"En la villa de Serrada a doce de enero de mil ochocientos setenta y tres, reunido el Ayuntamiento en la Sala capitular bajo la Presidencia del Sr, Alcalde D. Agapito de Íscar,... por consecuencia de haber concebido la Corporación municipal de la Seca el proyecto y propósito decidido de construir en tranvía que partiendo de dicha villa enlace con la línea general del Norte, en la Estación de Valdestillas, para cuya construcción se ha ofrecido una casa inglesa costeando todos los gastos pero a condición que este pueblo de su parte coopere en aquello que este de su parte, enterado el Ayuntamiento de las explicaciones dadas por dicha comisión... con cuyo tranvía se ha de aumentar el tráfico y se desenvolverán las artes e industrias,... se acordó acceder a tan buenos deseos y elevado pensamiento, ofreciendo esta Corporación todo su apoyo moral pero sin comprometer en nada los intereses materiales, públicos ni privados...”
}

En la mente de todos están las positivas repercusiones de la llegada del ferrocarril a Medina del Campo en el verano de 1860. Serrada, La Seca, Nava y Rueda quieren ver en los caminos de hierro la salida fácil y rápida a sus caldos y de ahí sus últimos intentos por enganchar con lo que entonces representa el camino del progreso. No en vano desde 1850, las distintas autoridades, con publicaciones periódicas en los Boletines Oficiales de la provincia, insisten en lo indispensable de tal avance. En febrero de 1850, Mariano Miguel de Reinoso, al frente de la Comisión Regia para la Inspección General de la Agricultura del Reino, exalta la importancia de estas obras públicas. Manifiesta que "El porvenir de esta Castilla al norte del Guadarrama, depende principalísimamente del ferrocarril de Santander" y que con ello "tendrá superioridad en todos los mercados, hasta sobre los surtidos de Odesa y de los Estados Unidos; pero sin ese ferrocarril, Castilla se verá reducida antes mucho de cultivar únicamente pan que ha de comer en sus provincias centrales, pues que las de la costa lo recibirán más barato del extranjero" ${ }^{1200}$.

${ }^{1197}$ RUEDA HERNANZ, G.: “Del antiguo régimen a la primera expansión industrial (1808-1864)”, en Valladolid en el siglo XIX. Historia de Valladolid, vol. VI, 1985, pág. 272.

${ }^{1198}$ A. M. S., caja 1, carp. 12, sesión de 18 de marzo de 1866.

${ }^{1199}$ A. M. S., caja 1, carp. 19, fol. 1, año 1873.

${ }^{1200}$ B.O.P.V., no 23, 21 de febrero de 1850. 
Hay que hacer mención, por último, del proteccionismo del que goza el sector agropecuario en estos años, clave para entender tanto el impulso triguero como el desarrollo de la industria y burguesía harinera vallisoletana. El sector cerealista siempre estuvo protegido por barreras arancelarias, pero es en estos ańos de incremento del comercio mundial cuando su defensa es más notoria. La prensa local y regional se hace eco de las controversias entre proteccionistas y librecambistas, acusándose mutuamente de perjudicar los intereses del país. Los proteccionistas, manteniendo el peligro que corre la independencia nacional si Espańa pusiera su alimentación a cargo de extranjeros, y sus antagonistas, desconfiando del patriotismo alegado que no es, dicen, sino "o la máscara de la codicia, que quiere conservar el monopolio, o la más lastimosa ignorancia de las leyes del derecho y de la economía social", ponen el caso inglés como el ejemplo de una nación ajena a tales prácticas y situada a la cabeza de las potencias europeas ${ }^{1201}$.

La realidad de su práctica será un motor de despegue, sin duda, aunque sólo temporal, ya que la reducción de los costes del transporte a nivel mundial y el aumento sostenido de las producciones en los nuevos países colocará contra las cuerdas, tarde o temprano, al viejo continente ${ }^{1202}$. Y si esto constituye un mazazo a finales de siglo, las apariencias de prosperidad de estos años 50 y 60 tampoco deben llevar, a nivel local, a un exceso de optimismo. Prueba de ello es la constante preocupación de los pueblos por hacer frente a sus abundantes descubiertos y aliviar la penuria tanto de los pequeños labradores como de los empobrecidos jornaleros.

El desarrollo de la industria de transformación y comercialización de productos agrarios, que se está expandiendo en estos años, separa al productor del consumidor, dejando en medio unos márgenes de beneficios que van a parar a un sin número de almacenistas, especuladores y fabricantes de licores o harinas que florecen en las áreas urbanas. Como se advierte, al tiempo que se corrigen unos problemas estructurales, otros se perfilan como claves para entender su futuro.

Ello es así porque, a través de la abundante documentación municipal y de archivos particulares que se han consultado, son más las quejas y penas que manifiestan los habitantes rurales y urbanos que el aparente dinamismo con que se han titulado estas décadas. De hecho, esta problemática, que comienza a envenenar la quietud de muchos pueblos y ciudades, es fuente de preocupación para las autoridades nacionales. En una comunicación al ministerio de la guerra por parte de la autoridad vallisoletana en 1857 , a pesar de la buena cosecha general, se valora la incidencia que pueda tener el descenso del precio de la cebada recién cosechada en el precio posterior que pueda tener el trigo, con la consiguiente consecuencia en los demás productos, dado que "los precios de las demás subsistencias alimenticias se hallan subordinadas a los que aquel tiene"1203. La preocupación del informante es asegurar la quietud de la sociedad y nada mejor que esta pueda acceder con bajos precios a abundantes granos. De ahí la alarma ante lo que está sucediendo ${ }^{1204}$ :

“De algunos años a esta parte se ha interpuesto entre el productor y el consumidor un intermediario osado, avaro e inmoral que todo lo abarca y monopoliza, que se enriquece rápida y prodigiosamente, y que con voluntad omnipotente determina de este país la abundancia o escasez, la baratura o la carestía.

Me refiero, Exmo. Sr. A los compradores de granos, pocos en número, con lo que más fácilmente se ponen de acuerdo; compran y venden las cosechas antes de saber si existen, las transportan obteniendo grandes primas y hacen de los granos un juego de bolsa tanto más inmoral y lucrativo cuanto que en sus tratos no existe intervención alguna legal, ni otras reglas que dependan de su voluntad”

${ }^{1201}$ El Norte de Castilla, sábado 12 de mayo de 1860.

${ }^{1202}$ GARRABOU, R.: La crisis agraria española de finales del siglo XIX, en "Historia agraria...”, ob. cit., vol. II, pág. 477.

${ }^{1203}$ A.F.A.M. Comunicación al Ministerio de la Guerra, 15 de julio de 1857, sin firma.

${ }^{1204}$ Ibídem. 
El comunicante centra su interés, más allá de si estos hechos contribuyen a generar una mayor o menor riqueza, en el problema eterno de las subsistencias, debido a que la especulación y la carestía "han llegado a producir en estos últimos años un malestar y una sobreexcitación en los ánimos tan inusitada" que pone en peligro la quietud del pueblo. La situación, insiste el interlocutor ministerial, tiene "uno de sus principales orígenes, en la falta de moralidad en el tráfico de los vulgarmente conocidos con el nombre de harineros y la envidia que produce el fabuloso alarde de sus improvisadas riquezas". Termina, por último, acusando a estos especuladores de ser los causantes de que "en el último año arrastraron a las masas al robo de las casas de los especuladores de granos y al incendio de las fábricas de harinas en las que, ebrios de venganza contra aquellos que a su juicio producian la carestía, redujeron a cenizas lo que habia de servir de alimento a sus propios hijos"1205.

Es evidente que las inmejorables condiciones que proporciona la guerra de Crimea (18541857), a las exportaciones harineras (recuérdese el dicho alusivo a la bonanza exportadora: "Lluvia y sol y guerra en Sebastopol'), no eran vistas ni sentidas por igual entre las diferentes clases sociales, que inician, y es este otro de los aspectos que se debe tener en cuenta, una lucha social y política por la defensa de sus legítimos intereses, cuestión que hay que considerar al valorar en conjunto la evolución de las sociedades agrarias que se están analizando.

Se puede, pues, concluir que cuantos factores y cambios estructurales se han estudiado hasta ahora tiene como consecuencia, coincidiendo con el reinado isabelino, (1844-1868) un periodo de sostenido crecimiento económico y el aumento de la producción agraria. Se pone fin así a la crisis con que acababa el siglo XVIII como a la hecatombe que supuso la guerra de la Independencia. Consecuencia directa es que, desde 1814 a 1829, el cultivo de las tierras se duplica. Las estadísticas estatales, aún distando de ser fiables, vienen a confirmar que, desde 1797 a 1857, el terreno cultivado en España se ha triplicado. La demografía siente este aliento benefactor. La población agrícola en España, que se fijaba en 1797 en 5.700 .000 habitantes, se eleva en 1857 a 9.328.000. Sólo así se explican que, del primer año mencionado a este de 1857, la superficie cultivada pase de 8,5 a cerca de 20 millones de hectáreas ${ }^{1206}$. Participando de esa tónica general que vive el país, tanto la agricultura castellana como los pueblos asentados al norte de Medina, integrados en su mayoría en el partido judicial del mismo nombre, experimentan similares crecimientos agrarios y demográficos. Se alejan de las crisis de subsistencia de finales del XVIII y primer tercio del XIX.

La bonanza de cosechas y precios sirve para estabilizar las economías agrarias a mediados de siglo. El incentivo que supone la política proteccionista y la demanda propiciada por la creciente población, que alentaron la subida de precios, hacen el resto. Sólo así se puede explicar que Serrada, con un exiguo término municipal, y condicionantes severos de suelo, estructura y tenencia de las propiedades, aumenta su población un 28\% entre 1842 y 1863 (627 y 870 habitantes respectivamente). Para que esto pueda ocurrir y, sobre todo, para que durante varias décadas pueda mantener dicha población sin recurrir a la emigración, la rentabilidad de los cultivos, única fuente de ingresos de sus vecinos, tuvo que experimentar un notable crecimiento en relación con épocas pasadas. El mapa adjunto recoge la estimación del terrazgo labrado en 1850 en Serrada. Puede comprobarse que, por estas fechas, los antiguos montes ya han sido reemplazados por las vińas en los terrenos de gravas y los cereales en los pagos de mayor calidad. Nos encontramos ante un terrazgo completamente labrado y, como venimos constatando, con una presencia del cereal desmedida en tierras de mediocre calidad pero justificada por el alto precio del producto en esta mitad de centuria.

1205 Ibídem.

${ }^{1206}$ GARCÍA BARRASA, A.: La Agricultura en España, cap. XIV. La Asociación Agrícola por la Iniciativa Privada. Revista de Agricultura, Valladolid, 1869-1874, tomo IV, pág. 269-270. 


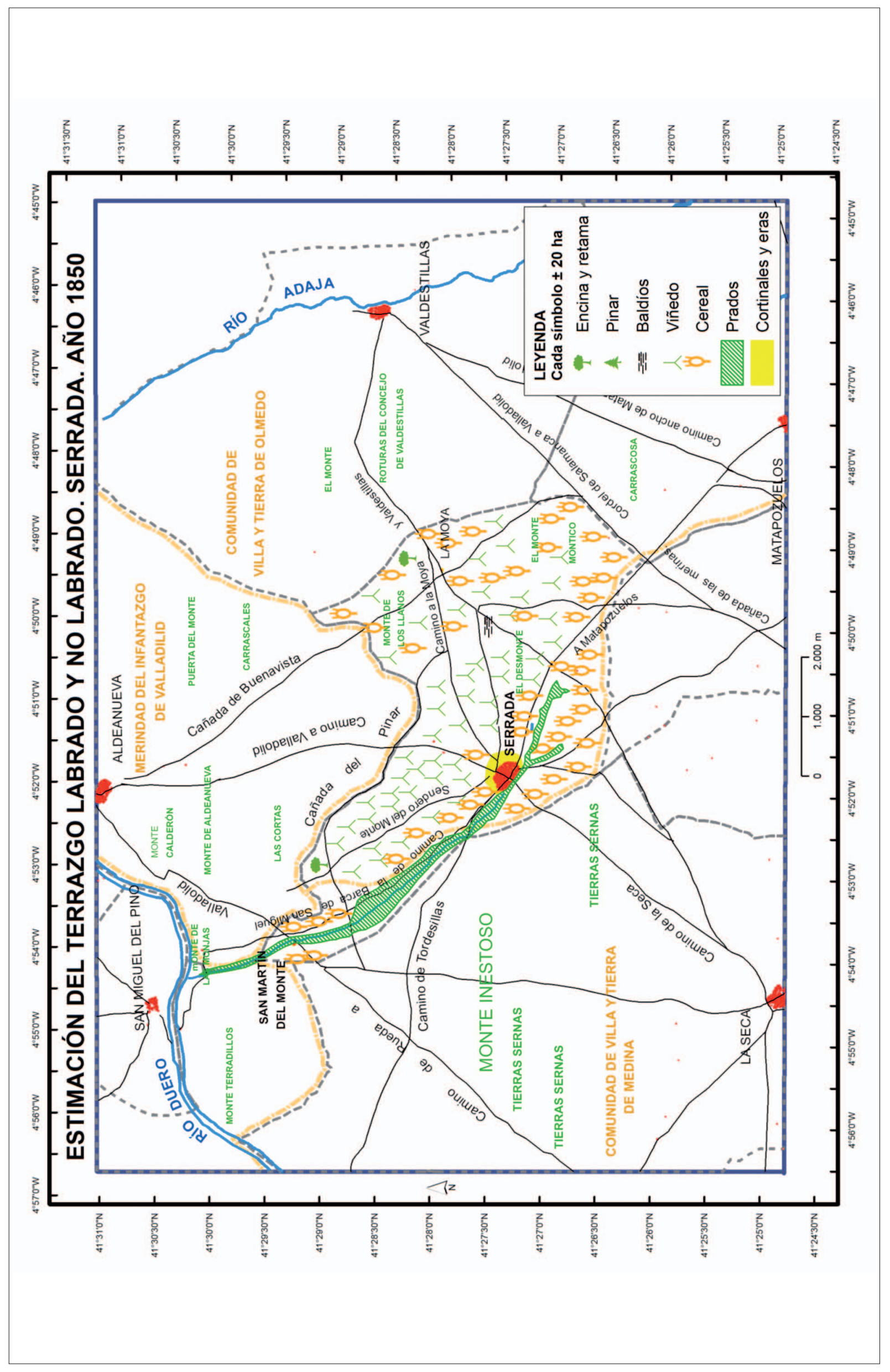



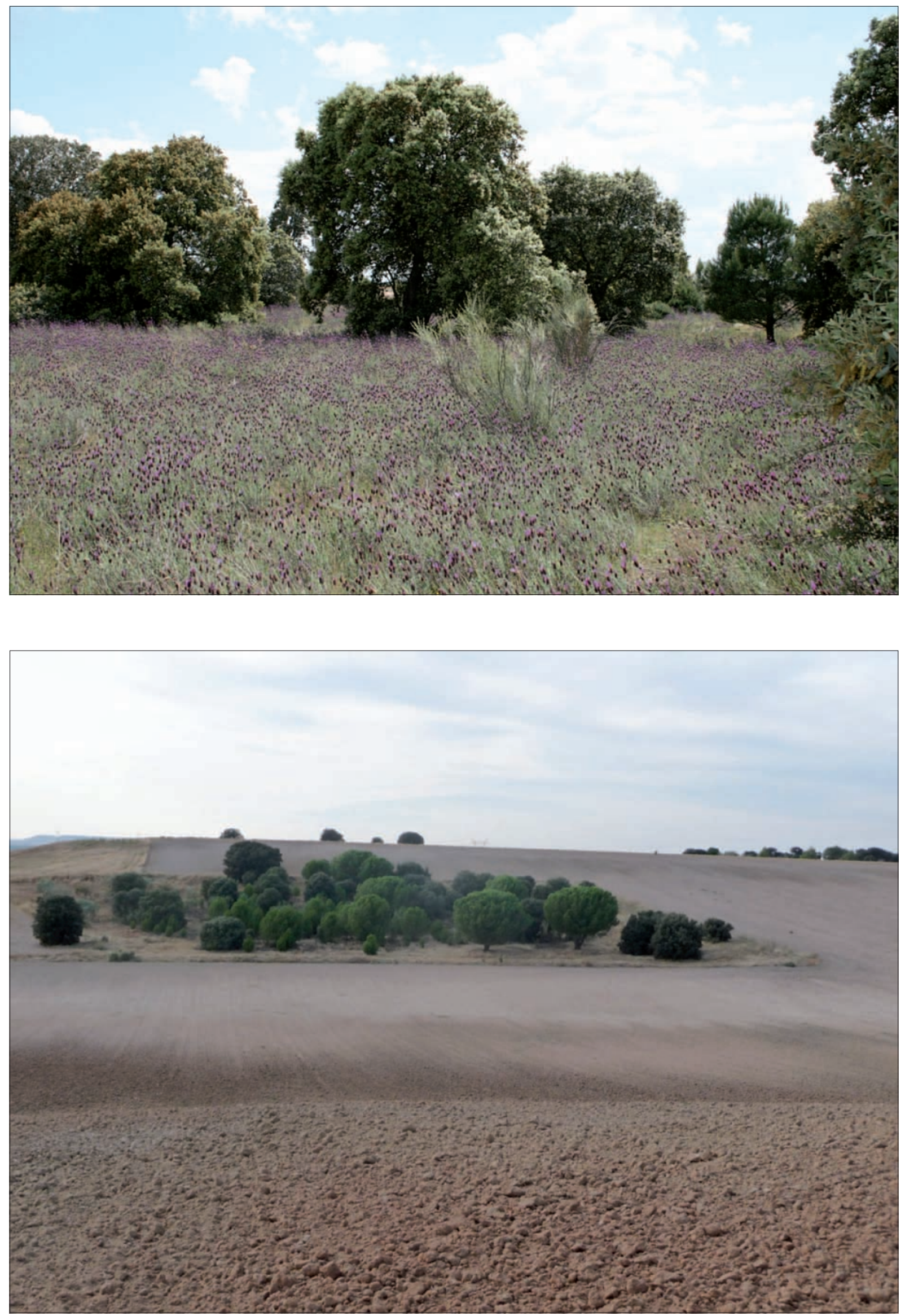

Imagen 87. Pinos, encinas y retamas colonizan en el siglo XX los escasos baldios existentes. Salvo excepciones, como la de la imagen (arriba, cańada Buenavista, Villanueva, foto: 18/05/2008), desde mediados del siglo XIX el terrazgo labrado ocupa la práctica totalidad del espacio estudiado, (abajo, pago de Valtropín, Villanueva, foto: 26/09/2013). 


\section{b. Evolución y caracteres de los aprovechamientos agrarios en la segunda mitad del siglo XIX}

A diferencia de otras localidades provinciales donde el arado tuvo más posibilidades de aumentar el terrazgo labrado a costa de montes desamortizados y superficies incultas, en Serrada no había más cera que la que ardía en 1752. El Catastro de Ensenada constata que el término estaba plenamente roturado, la superficie de pasto cubría las necesidades del ganado y los escasos pinares, confinados en suelos fríos y sin sustancia. La dispar calidad de la tierra condicionaba los cultivos en tiempos de crisis por sus escasos rendimientos. Así se anota al final del primer tercio del XIX cuando por unas $\mathrm{u}$ otras circunstancias muchas tierras y majuelos están tomados por la grama y la maleza. Es ahora, a mediados de la centuria, cuando son escasas las cuartas por labrar y el trigo es rentable donde antes apenas lo era el centeno.

Cuadro 117. Distribución de cultivos en relación a la calidad de los suelos. Serrada, año 1752

\begin{tabular}{lcccccc}
\hline $\begin{array}{l}\text { Clase } \\
\text { de tierra }\end{array}$ & $\begin{array}{c}\text { Tierras } \\
\text { de sembradura } \\
\text { (obradas) }\end{array}$ & $\begin{array}{c}\text { Viñedo } \\
\text { (aranzadas) }\end{array}$ & $\begin{array}{c}\text { Prados } \\
\text { (obradas) }\end{array}$ & $\begin{array}{c}\text { Pinares } \\
\text { (obradas) }\end{array}$ & $\begin{array}{c}\text { No productivo } \\
\text { (obradas) }\end{array}$ & $\begin{array}{c}\text { TOTAL } \\
\text { (obradas) }\end{array}$ \\
\hline $1^{\text {a }}$ Clase & 268 & 340 & & & & \\
$2^{\text {a } \text { Clase }}$ & 528 & 825 & & & & 3.681 \\
$3^{\text {a } \text { Clase }}$ & 766 & 495 & 116 & 155 & \\
\hline TOTAL & 1.562 & 1.660 & 188 & & & \\
\hline
\end{tabular}

Fuente: A.H.P.V. Catastro de Ensenada. Respuestas Particulares. Elaboración propia.

Cuadro 118. Distribución de cultivos en relación a la calidad de los suelos. Serrada, año 1857

\begin{tabular}{lcccccc}
\hline $\begin{array}{l}\text { Clase } \\
\text { de tierra }\end{array}$ & $\begin{array}{c}\text { Tierras } \\
\text { de sembradura } \\
\text { (obradas) }\end{array}$ & $\begin{array}{c}\text { Viñedo } \\
\text { (aranzadas) }\end{array}$ & $\begin{array}{c}\text { Prados } \\
\text { (obradas) }\end{array}$ & $\begin{array}{c}\text { Pinares } \\
\text { (obradas) }\end{array}$ & $\begin{array}{c}\text { No productivo } \\
\text { (obradas) }\end{array}$ & $\begin{array}{c}\text { TOTAL } \\
\text { (obradas) }\end{array}$ \\
\hline 1a Clase & 103,75 & 60 & - & - & - \\
2a Clase & 189 & 167 & - & - & - \\
3a Clase & 673 & 575,5 & - & - & - \\
4a Clase & 1.138 & 1.035 & - & - & 116 & $3.915,87$ \\
\hline TOTAL & $2.103,75$ & $1.837,5$ & 170 & 148 & \\
\hline
\end{tabular}

Fuente: Catastro de Ensenada. Respuestas Particulares. Elaboración propia.

Como se puede apreciar en los cuadros adjuntos, el vińedo no ve reducida su superficie. A diferencia de otros términos con pagos mejor dotados para el trigo, en Serrada o La Seca resulta un suicidio arrancar cepas por más que la fanega de trigo supere los 40 reales y la cántara de vino solo se pague a 16 reales. Bastante es que Serrada en 1857 compute 266,25 obradas más de tierras de sembradura que de majuelos cuando cien años antes era el viñedo el que tenía 98 obradas más que aquellas. Piénsese que en 1833 se destinan al cultivo de cereales en España 10.274.000 ha, mientras que en 1857 la cifra se eleva a 15.957.441 ha ${ }^{1207}$.

El mantenimiento a niveles aceptables de los precios del cereal es una de las principales causas del incremento del terrazgo de sembradura en Serrada, en Tierra de Medina o en Campos. Caso contrario, la familia de Rojas no hubiera podido arrendar muchas de las tierras de tercera ni a la mitad de la renta que exigía. La presión demográfica del XIX hace el resto. Pero hay que insistir en el proteccionismo estatal y en el despegue de la industria harinera en la región. De lo contrario, los medianos y grandes hacendados no hubieran mandado a sus criados a arar y barbechar tierras inseguras y pagar

${ }^{1207}$ Ibídem, pág. 285. 
de renta una fanega por obrada. Otra cosa hubiera sido que la cántara de vino estuviera a 20 reales en vez de a los 12 contabilizados en 1857 o los 5 reales que figuran en campañas de pésimas sacas. Ya se vería entonces qué frutos darían las 673 obradas de $3^{\text {a }}$ calidad o las 1.138 de cuarta que se destinaban al año y vez.

Nada mejor avalan estas palabras que los datos de 1881. La favorable coyuntura triguera ha terminado y el viñedo vive una gran expansión, gracias a las salidas de caldo por la filoxera francesa. Los precios del trigo bajan por la competencia del grano barato de los nuevos países productores. Consecuencia de ello, es que los majuelos vuelven a superar a las tierras de sembradura, aumentando 175 obradas respecto a las que ya existen en 1857 . Por el contrario, las obradas para panes se reducen de 2.103 obradas, en 1857, a 1.996 obradas en 1881. Estas circunstancias y porcentajes son similares a las que registra el sur de la provincia. Medina del Campo siembra, por poner un ejemplo significativo, 5.257 ha en 1751 y 6.852 ha en $1860 / 70$ para descender a 6.644 ha en 1881 . En cuanto al viñedo, ve reducida su extensión en $1860 / 70$ a 1.113 ha respecto a 1751 (1781), pero, como el sector norte de su comarca, manifiesta un nuevo empuje hasta tener plantado en 18811.724 ha $^{1208}$. Aunque la recuperación vitícola será efímera, dado el retroceso ya definitivo de este cultivo en las campiñas de Medina-Alaejos en beneficio del cultivo de granos.

\section{c. Los pastos y el ganado como soporte básico de la actividad agraria}

Pastos y ganados siempre fueron necesarios, pero en este tiempo se tornaron aun más imprescindibles. La intensificación del cultivo del cereal y el mayor esmero en las labores dadas a los majuelos, en la segunda mitad de siglo, requerirán una potencia de labor nunca vista hasta entonces. El incremento del ganado mular, más ágil que los pesados bueyes, venía siendo una constante desde finales del XVIII, pero ahora es uno de los factores que caracterizan este dinamismo. Para hacer las sementeras a tiempo, se necesitaban más yuntas y más criados. El buen estado de los pastos era ahora una cuestión esencial para poder soportar una mayor carga ganadera. Aunque el incremento de los cereales pienso y las algarrobas contribuía a paliar lo reducido de aquellos y a mantener el ganado de labor más cuidado que antes, a los labradores siempre les costó sacar grano de la panera para llenar el pesebre cuando las bestias no trabajaban. Otra cosa era tener bien cumplimentada la cebadera en las arancias de mayo o en tiempo de sementera. Por ello, siempre se aprovecharon al máximo los pastizales naturales. Sobre todo en los meses de huelga. Y aquí aparece en la mayor parte de los pueblos de la comarca un problema de difícil solución: pocos pastos y mucho ganado; ganado de labor frente a ganado ovejuno; pastos comunales frente a Ayuntamientos deseosos de su arrendamiento para aliviar sus presupuestos...

Las soluciones no se presentaban ni cómodas ni fáciles para intereses tan encontrados. Se ha puesto de manifiesto en páginas anteriores que estos pueblos se dejan ríos de tinta para evitar la venta por parte del Estado de lo que consideraban vital para su sustento. Se consiguió lo que se pudo y el aumento de las bestias, ante las reducciones de superficie que ocasionaron las subastas vendedoras, hizo necesaria una definitiva ordenación de recursos. Para ello se hizo necesario desempolvar los viejos legajos que conservaban los archivos municipales sobre titularidad y aprovechamiento de prados y bienes colectivos. Todo fuera por mantener la quietud entre vecinos un siglo más.

\section{- La ordenación de los pastos atendiendo a las necesidades de los cultivos y del ganado de labor}

Conviene recordar que atrás quedaron capítulos y siglos sembrados de pleitos, en que los concejos defendieron sus derechos al dominio y disfrute de los pastizales y las aguas que recorrían sus términos. La desamortización de las dehesas de San Martín privó a Serrada de un buen puñado de obradas de pasto, aunque sabido era su arrendamiento al mejor postor desde hacía tiempo. Esta villa

${ }^{1208}$ PASCUAL GETE, H.: “La evolución de la agricultura...” en Historia de Medina..., ob cit., vol. III pág. 110. 
veía cómo, a pesar de ver incrementado su término, se reducían los pastos de diente. Aunque hay que tener en cuenta el aprovechamiento de las eras, de la hoja y pámpana y del careo de pajas por las ovejas, el ganado de labor necesitaba de pastos abundantes y bien conservados. Pero a la subasta liberal sobrevenían los agobios financieros de los Ayuntamientos locales. Al margen de las indicaciones de la Diputación en las primeras décadas del siglo sobre la forma y manera de cubrir los presupuestos, Serrada no tiene más remedio en 1846 que arrendar al mejor postor sus prados comunales, para cubrir los 5.366 reales de déficit municipal. De otra manera tendría que elevar el repartimiento al vecindario. El acuerdo de 5 de enero del citado año se inclina por lo primero dado "lo gravoso de esta medida y tanto más sobre un vecindario misero y abrumado con los gravosos tributos que sobre el mismo pesan". ${ }^{1209}$ Y todo ello a pesar del carácter comunal de estos y otros bienes ${ }^{1210}$.

Estaba claro que cada concejo interpretaba la costumbre y las leyes según las necesidades del momento. ${ }^{1211}$ De ahí que, cuando los mas agraviados protesten ante la justicia, hayan de conciliarse las posiciones para evitar gastos añadidos a las partes. Ya sucedió en los años veinte cuando el labrador y ganadero Manuel Alonso litiga contra el concejo por un motivo similar. En los años 40 y 50 los arrendamientos acogerán bienes comunales y de propios sin distinción, ocasionándose dificultades jurídicas a la hora de decidir si era o no procedente determinar la enajenación de unos u otros ${ }^{221}$. Al final, los prados de Serrada se libraron de la subasta, a diferencia de las ricas dehesas de San Martín y los pinares del concejo. Pero es que, además, son estas décadas de mediados de siglo cuando más hace falta la hierba.

Consecuencia de todo ello será un nuevo reglamento que no va a tardar en ver la luz ${ }^{1213}$. Es el resultado del cambio de coyuntura que vive el sector agrario castellano desde mediados de los cuarenta hasta pasados los setenta. El fragmento entresacado al pie resume, tanto la marginación durante siglos que ha vivido el ganado ovino, como los derechos preferentes que siempre gozó el de labranza.

${ }^{1209}$ A.F.A.M., carp. de acuerdos y varios, acuerdo de 5 de enero de 1846 para arrendar pastos, fol. 3 .

1210 "Dijeron así bien que supuesto que en el reglamento de propios de esta referida villa librada a la misma por los S.S. del Concejo en 9 de mayo de 1764 aparecen enclavados como fincas de aquellos, entre otras, un terreno de cabida de 140 obradas que fue pinar y hoy se halla herial el cuasi todo por haberse cortado rasamente en el año 1837, previa licencia de la Excma. Diputación Provincial, y cuatro pedazos de prado que hacen en junto la total cabida de 37 obradas nada mas, justo y laudable es proceder al arrendamiento de su pasto, el cual, si hasta el día se ha aprovechado por los ganados del vecindario a titulo de común aprovechamiento, tal regalía y su origen es en todo caso ignorada puesto que ningún documento existe de ello que legalmente así lo acredite; antes, por el contrario, en el mismo Reglamento se prebiene sea una de las partidas del cargo el producto de estas fincas siempre que le tengan, razón por cual, y la de haberse egecutado algunos arriendos del pasto de ellas, según documentos existentes en esta Secretaria, estaban en el caso de proceder a verificarle igualmente en el presente año como único medio más análogo o compatible con las grandes dificultades que ofrece un repartimiento vecinal..." (Ibídem).

${ }^{1211}$ En este caso se procederá al arriendo en público remate de los pastos del pinar y prados para aprovechamiento con ganado ovino, desde el 5 de enero, fecha del acuerdo, hasta el 8 de marzo, previa autorización del jefe político de la Provincia.

${ }^{1212}$ Se trató este tema cuando se estudió la defensa de su exclusión tras los decretos desamortizadores de Madoz. Al continuar su arrendamiento en la segunda mitad de los cuarenta y pese al decreto de la Diputación Provincial de 10 de noviembre de 1842 declarándolos como comunes, el Ayuntamiento de Serrada los tuvo pendientes de un hilo en los años sesenta cuando se iba a dictar su futuro. El vecindario apelaba a que eran "las únicas fincas que producen, aunque con escasez, el pasto para los ganados de labor del vecindario, sin cuyo recurso y auxilio visto es que con graves perjuicios perecería la clase agrícola y ramo de agricultura tan recomendado por nuestro ilustrado Gobierno". (A.M.S., caja 1, carp. 7, sesión ordinaria de 1 de septiembre de 1856).

${ }^{1213}$ Las denuncias de algunos vecinos ante el alcalde en 1861 Celestino Alonso, sobre la forma y manera de proceder al aprovechamiento de los prados, le hacen apuntar a pie de firma la siguiente consideración testifical: "Que nunca ha oydo decir a persona alguna que para aprovechar los prados haya régimen especial autorizado.

Que por igual razón ha oydo decir que en la época anterior al año 1846 se arrendaron, y que después se han aprovechado por todo el ganado lanar y de labor sin pagar nada. 
En los años sesenta se volverá a privilegiar, dada la creciente demanda de tiro en las tierras de sembradura y viñedos. El peso aplastante de los mayores labradores contribuyentes, dueños también de importantes rebaños, reducirá aun más el número de cabezas lanares en los pastos de Serrada. Antonio Castilla, Jefe de Administración Civil y Secretario del Gobierno Civil que por entonces presidía Cástor Ibánez de Aldecoa, reconocía el derecho de los vecinos a disfrutar del pasto del común "en proporción a los beneficios que reportan y las cargas que levantan en el municipio"1214. Semejante afirmación pondrá a las ovejas contra las cuerdas una vez más.

La nueva reglamentación, basada en la legislación municipal de 8 de enero de 1845, será desarrollada por el Ayuntamiento que preside en 1861 Cesáreo Moyano y demás asociados contribuyentes, siguiendo el criterio antes señalado y, al parecer, "que la distribución de beneficios debe hacerse en primer lugar para el ganado de labor, en segundo para las caballerías de los jornaleros y tercero, y último, para el ganado lanar obejuno." Son dicen, y por este orden, quienes levantan las cargas del municipio. La nuevas bases y disposiciones a observar por todos se aprueban en acuerdo de Ayuntamiento de 27 de abril de 1861 y se autoriza por el gobernador de la provincia con fecha de 26 de octubre del mismo año ${ }^{1215}$.

Que en el año citado de 1846 se arrendaron pastos de conformidad del Ayuntamiento y vecinos para atender a necesidades del pueblo con su producto y barios años después también se hizo en igual forma, y otros aprovechados sin régimen alguno.

Que efectivamente antes del año 1846 no podía ser tan necesario el pasto de los prados para las labranzas como lo ha sido posteriormente y hasta el día, teniendo en cuenta el aumento que en ellas a ocurrido.

Que también es efectivo el que los labradores de cortos productos sufrirían grabe perjuicio una vez privados sus ganados del pasto de los prados.

Que a no dudar el ganado lanar perjudica más que favorece a los prados si en ellos pasta.

Ser de notoriedad pública y voz común el que en el país y poblaciones que se encuentran en iguales circunstancias que lo está esta Villa siempre ha tenido y tiene preferencia el ganado de labranza sobre el lanar para los aprovechamientos comunes.

Que anteriormente los ganados lanares no solamente aprovechaban los prados sin régimen alguno alternando con los de labor sino que también y con la misma libertad han utilizado hasta hace pocos ańos las propiedades de dominio particular del término.

Que con efecto en todo tiempo hayan estado en arriendo o sin él los prados siempre se ha reserbado una parte mayor del año para pasto del ganado de labor, y que cuando la ganadería ha entrado en el inbierno en los mismos prados nunca ha tenido día fijo para salir. Que es cuanto sabe”. (Archivo familia Alonso Moyano. Carp. de acuerdos y varios. Comunicación de D. Celestino Alonso a todos los vecinos. 9 de marzo de 1861).

${ }^{1214}$ Ibídem, carp. de acuerdos y varios. Reglamento especial competente autorizado por el Sr. Gobernador Civil, 26 de octubre de 1861 .

${ }^{1215}$ El perito síndico avalará el informe que será aprobado por el Ayuntamiento presidido por el teniente de alcalde D. Celestino Alonso y en unión de los mayores contribuyentes. Únicamente se ańadirá a lo reglamentado el derecho a quien ostente el surtido de carnes al municipio a introducir cuatro reses vacunas y que "no expresándose tampoco por los peritos el número de reses de labor y huelga que pueden apacentarse, creen y convienen que pudieran serlo en número de sesenta, esto sin perjuicio de que el aprovechamiento se haga en un todo, conforme a lo reglamentado".

"Primero. Los labradores y jornaleros tendrán el derecho de apacentar sus ganados de labor y caballerías en los prados del común en todos los días del año a excepción de aquellos a que el titulado de arriba este vedado o cerrado para toda clase de ganado.

Segundo. Se permitirá entrar a pastar 300 cabezas de ganado lanar ovejuno solamente en el prado de abajo desde el día 20 de noviembre hasta el 17 de enero siguiente, ambos inclusive y de ninguna manera en el de arriba mediante a que teniendo que estar vedado este para aprovecharle de primavera por el ganado de labor, y teniendo en cuenta los pocos pastos que hay en esta villa le causarían grandes dańos y cuyo resultado sería perecer las labranzas y demás clases a que se ha atendido.

Tercera. A todo vecino se le permitirá por cada yunta de labor una res de huelga con su cría y así en proporción el que tenga dos o más yuntas.

Cuarta y última. El prado de arriba se vedara para todo ganado el día 18 de enero y no se abrirá hasta el 20 de mayo del mismo año, ocho días más o menos según el año, quedando como siempre a juicio del Ayuntamiento. Es cuanto tienen que proponer en cumplimiento del cargo que se les ha conferido. Serrada, 10 de abril de 1861. Pedro de Íscar, Leandro Obregón, León José Moyano”. (Ibídem, fol. 2). 
Quedaban claros los intereses de labradores sobre los ganaderos. Lo mismo que la escasez de pastos en la mayor parte del centro de Castilla. De otra manera no se entendería que, al reclamo de los anuncios del Boletín Oficial de la provincia, anunciando las dehesas de San Martín con "su yerba abundantísima, con buenos bebederos y además un grandioso corralón con buenos colgadizos" ${ }^{216}$, acudieran caballerías de sitios dispares o que, en algunos años, como ha quedado descrito, fueran arrendadas por importantes sumas a hacendados y hombres de negocios ajenos al entorno comarcal. Unas décadas más tarde, cuando tocaba a su fin el empuje agrario en estas tierras, los pastizales parecían haber encontrado la regulación definitiva. Estos eran los que se catastran en el amillaramiento de 1881217:

Cuadro 119. Superficies y características de los prados en Serrada. Año 1881

\begin{tabular}{|c|c|c|c|c|c|}
\hline Nombre & Propietario & obradas & Linderos & $\begin{array}{r}\text { Valor } \\
\text { (pts) }\end{array}$ & $\begin{array}{r}\text { Renta } \\
\text { (pts) }\end{array}$ \\
\hline $\begin{array}{l}\text { Prado } \\
\text { de Abajo }\end{array}$ & $\begin{array}{l}\text { Común de vecinos. } \\
\text { Administra. Valentín de Íscar Alonso, } \\
\text { alcalde constitucional de la villa. }\end{array}$ & 37,85 & $\begin{array}{l}\text { Norte. Camino de San Martín y tierras } \\
\text { del marqués de Falces; este: entradas de } \\
\text { servidumbre; sur Tierra del marqués; } \\
\text { oeste: raya de La Seca }\end{array}$ & 3.600 & - \\
\hline $\begin{array}{l}\text { Prado } \\
\text { de Arriba }\end{array}$ & $\begin{array}{l}\text { Común de vecinos. } \\
\text { Administra. Valentín de Íscar Alonso, } \\
\text { alcalde constitucional de la villa. }\end{array}$ & 25,03 & $\begin{array}{l}\text { Norte: camino de Matapozuelos; } \\
\text { este: prado del Pradejón; } \\
\text { sur Tierras del marqués; } \\
\text { oeste: camino de La Seca. }\end{array}$ & 2.400 & - \\
\hline Pradejón & $\begin{array}{l}\text { Común de vecinos. } \\
\text { Administra. Valentín de Íscar Alonso, } \\
\text { alcalde constitucional de la villa. }\end{array}$ & 5,05 & $\begin{array}{l}\text { Norte, este y sur: tierras del marqués } \\
\text { de Falces; oeste: prado de Arriba }\end{array}$ & 200 & - \\
\hline $\begin{array}{l}\text { Dehesa de } \\
\text { San Martín }\end{array}$ & $\begin{array}{l}\text { D. Juan Pombo, marqués de casa Pombo. } \\
\text { Administra: Teodosio Alonso Pesquera, } \\
\text { vecino de Quintanilla de Abajo. }\end{array}$ & 180,19 & $\begin{array}{l}\text { Norte: cańada; oeste: camino de } \\
\text { la barca,poniente: baldío de La Seca. }\end{array}$ & 62.121 & 2.170 \\
\hline $\begin{array}{l}\text { Dehesa de } \\
\text { El Berral }\end{array}$ & $\begin{array}{l}\text { D. Juan Pombo, marqués de casa } \\
\text { Pombo. Administra: Teodosio Alonso } \\
\text { Pesquera, vecino de Quintanilla } \\
\text { de Abajo. }\end{array}$ & 47,52 & $\begin{array}{l}\text { Norte y poniente. Monte de Calderón; } \\
\text { Mediodía y sur Cañada, terreno conocido } \\
\text { por el "Despoblado" y camino de la barca } \\
\text { de San Miguel. }\end{array}$ & & \\
\hline TOTAL & & 295,64 & & 68.321 & 2.170 \\
\hline
\end{tabular}

Fuente. A.H.P.V. Hacienda. Amillaramiento de 1881. Elaboración propia.

Los espacios comunales habían sido, a lo largo de los siglos, demandados por todos los vecinos. El arriendo de las dehesas de San Martín por el tantas veces nombrado Gregorio León Alonso no hace sino confirmar las nuevas necesidades. Los subarrendasteis de Pedrajas de San Esteban, Justo y León Adanero, pagaban 95 reales por cada una de las 25 reses que introducían en las citadas dehesas, desde el día de Todos los Santos hasta el 11 de mayo. Gregorio León se reservaba el derecho de introducir animales vacunos hasta llegar a la cifra de 120, pues al ganado lanar también le estaba vedada la entrada. Aunque constan vecinos pudientes como clientes de los arrendatarios, no todos podían pagar por mantener su ganado. El negocio de los subarriendos se gesta al tiempo que la expansión triguera. De hecho, el citado vecino también subarrienda de forma continuada en la década de los 50 el prado de La Fuente de la Miel, lindero a los anteriores ${ }^{1218}$.

1216 B.O.P.V. No 158, fecha: 11 de julio de 1868.

1217 A.H.P.V. Hacienda, Serrada, Amillaramiento de 1881, caja 1166.

1218 Gregorio León toma en arrendamiento, a lo largo de la década de los 50, el prado de la Fuente de la Miel al Ayuntamiento de La Seca. En enero de 1854, al haberlo tomado inicialmente Rafael Ampudia, se lo coge como subarriendo a este. En la obligación entre partes se menciona la localización y el importe: "el prado de la Fuente de la Miel, sus aguas y las de la fuente que se llama de la Miel de la pertenencia de esta Villa, cuyas propiedades lindan con dehesa de San 
En esta época los pastizales iban a ser una inversión al tiempo que una necesidad para el ganado boyal y, sobre todo, mular. La cabaña de Serrada se estima superior a la cuantificada un siglo antes y totalizaba 32 reses vacunas, 17 mulos, 32 de caballar, 118 pollinos y 45 bueyes. Entre los datos apuntados para elaborar la estadística de consumos a mediados de los años cincuenta, se apuntan 100 caballerías de mayor y 80 reses vacunas, pero es indudable que estas cifras crecerían unos años más tarde. Piénsese que sólo el citado señor Alonso, aunque no es representativo dado su poder económico, tenía en 1845 cincuenta y cinco reses vacunas. He aquí un factor que explica la introducción de las leguminosas pienso en las rotaciones de cultivo.

\section{- Las dificultades del mantenimiento de la ganadería lanar}

Hemos estudiado cómo el término de Serrada, respecto a tierras de sembradura y viñedo, alcanzó un máximo histórico con métodos tradicionales a mediados del XIX. Ahora se asume idéntica afirmación en cuanto a ganados. Las 2.219 cabezas de lanar documentadas en diciembre de 1854 duplican las existentes un siglo antes, tocando el techo de las posibilidades en estos pagos ${ }^{1219}$. A las dificultades y quejas de tiempos anteriores, se debe ańadir la reducción de pasto en pinares y prados. Eso sin contar la reducción de baldíos y majuelos perdidos que completaban su sustento. De ahí que no sea osado decir este ganado estaba al borde del colapso.

La crisis de fin de siglo arranca palabras desesperadas a estos pastores. Entretanto, las dificultades por conciliar ganados y cultivos seguirán en aumento. Aun así, todos demandaban la basura de sus corralones para mantener la producción de cebadas y trigos, pero, a la hora de darlas de comer, todo el mundo las cerraba caminos y aprovechamientos. O las relegaba, bajo pago por arrendamiento, a los confines del término. En 1859, cuando el trigo se acercaba a 40 reales la fanega y el arado trataba de hacer fértiles las gravas y arenas más pobres, los rebaños lanares debían aprovechar pastos comidos ocasionalmente en otros tiempos. El Ayuntamiento, entre los arbitrios a ingresar para el ańo 1860, poseía la facultad, de acuerdo a la resolución favorable del gobierno de la provincia de fecha $14 \mathrm{de}$ junio de 1853, de sacar al mejor postor el pasto de los bienes comunes.

En idéntica fecha y por semejantes disposiciones se hace lo propio con "el pasto de las eras pertenecientes al común de vecinos", al igual que "el pasto de los terrenos baldios que goza esta referida villa..., teniendo presente las disposiciones que establece la Instrucción de 21 de junio de 1852" con el objeto, como los anteriores, de "componer el presupuesto de ingresos y gastos del Ayuntamiento"1220. Nada era gratis, como tampoco lo fue nunca la entrada en las viñas para aprovechar su hoja y pámpana, pero ahora, con el estado tan precario en que se hallaban las arcas municipales, se cobraba a las ovejas hasta la última brizna de hierba que comían. Junto a estos arrendamientos los regidores que componen el Ayuntamiento, unidos a los vocales de la Junta nombrada por el Gremio de Propietarios y Labradores, acuerdan cada año las condiciones y tiempos del arrendamiento de los pastos de primavera, rastrojera, hoja e invernia de las propiedades de los asociados al citado gremio. Los aprovechamientos acordados en marzo de 1878 seguían el calendario agrícola:

\footnotetext{
Martín del Monte y camino que conduce desde la villa de Serrada a la de Tordesillas, por la cantidad de mil setenta reales". La obligación se firma ante los testigos Ramón Román de Serrada y Pedro Álvarez de La Seca el 5 de enero del citado año 1854. Es muy posible que, aunque no se ha consultado documentación al respecto, siguiera con tal aprovechamiento a lo largo de la década de los sesenta, pues sigue con el arrendamiento de las dehesas de San Martín. De hecho, así consta en 1873, cuando el citado prado, que se supone ya desamortizado, está en propiedad de Mariano Gimeno de Homar que lo arrienda por un año y en la cantidad "de dos mil cuatrocientos reales, o sean, seiscientas pesetas" (A.F.A.M., carp. de acuerdos y varios, arriendo prado de la Fuente de la Miel).

${ }^{1219}$ Recuérdese que, en 1752, el cómputo de ganado ovino que anota el libro de seglares del Catastro de Ensenada sumaba 1.156 cabezas.

${ }^{1220}$ Ibídem.
} 

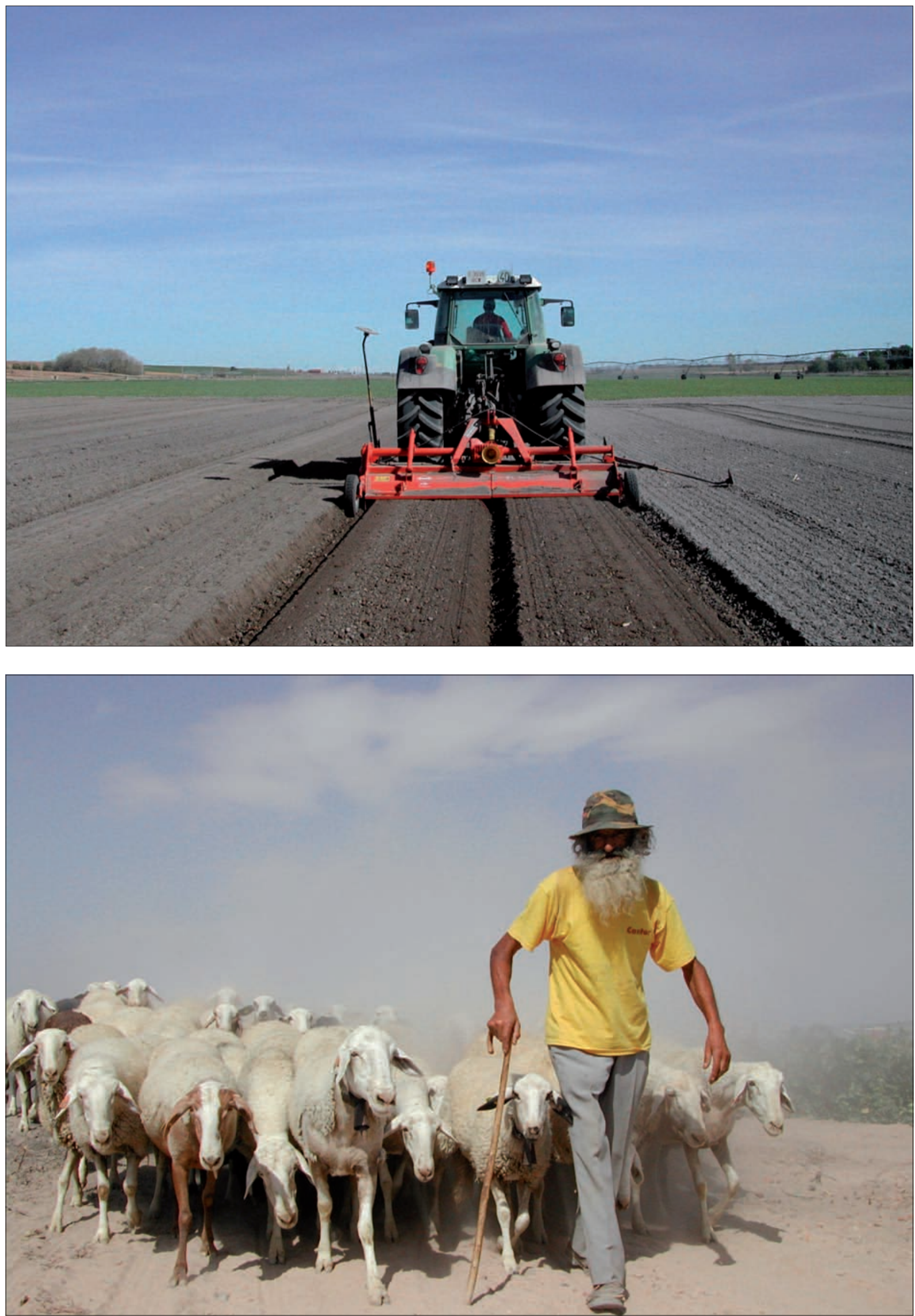

Imagen 88. La dehesa y pastos de San Martín fueron aprovechados como tales hasta finales del siglo XX, en que fueron roturados, (imagen superior, foto: 30/04/2005). En contraste con estas últimas roturaciones sirva la imagen del pastoreo tradicional: Chencho saliendo de mañana a aprovechar rastrojos y barbechos, siguiendo la costumbre de los siglos que estudiamos, (imagen inferior, foto: 20/09/2003). 

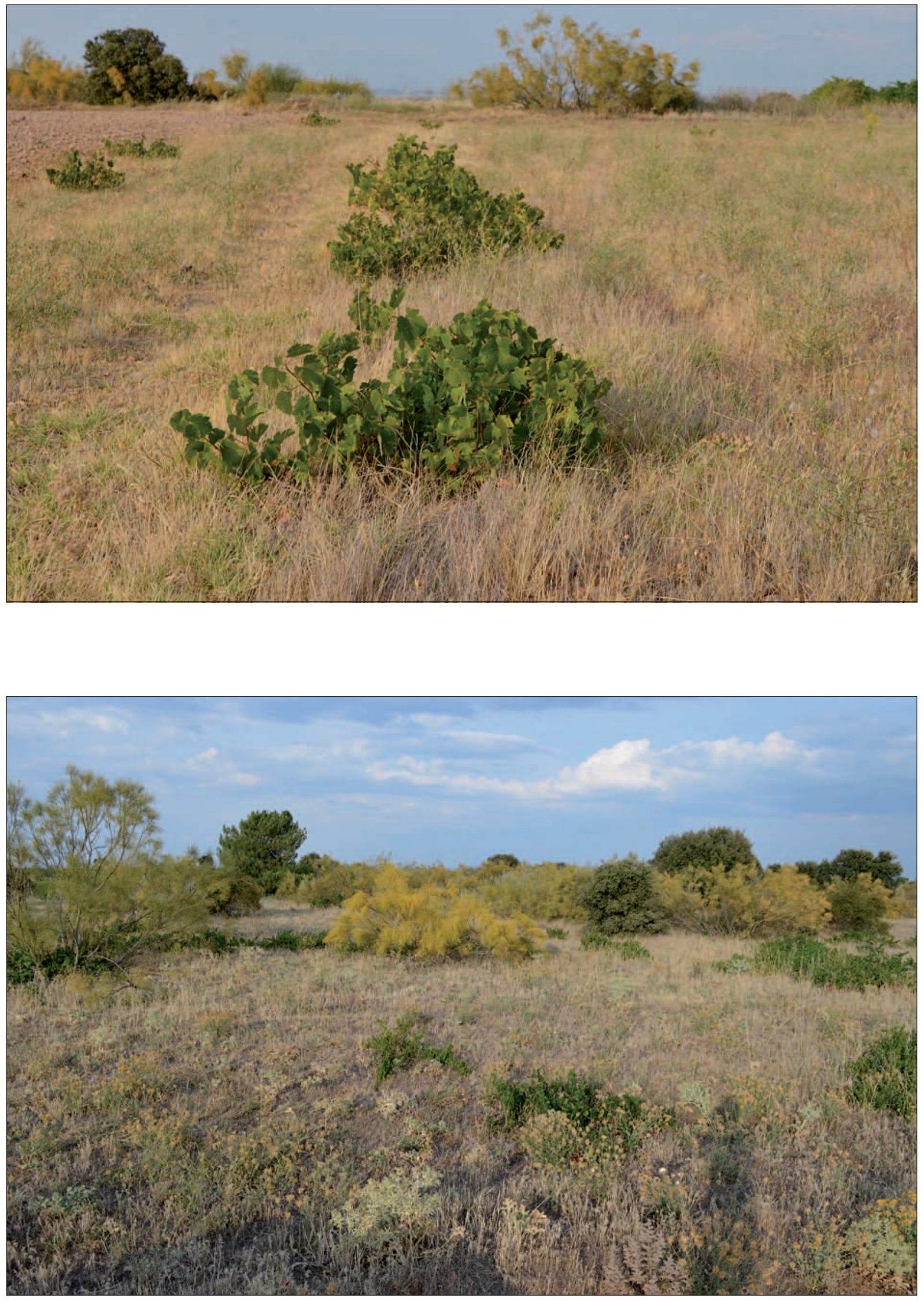

Imagen 89. Las crisis vitícolas que se dieron a lo largo del tiempo propiciaron la existencia de eriales, muy apreciados por la ganadería ovina. Obsérvese, en ambas imágenes, especialmente en la inferior, la colonización del terrazgo, anteriormente cultivado, por la vegetación natural. Bastan unas décadas de falta de cultivo para que carrascas y retamas se adueñen de estos pagos que, en otro tiempo, ocuparon ampliamente. El menor aprovechamiento por el ganado ovino y la falta de interés por este tipo de leńa pueden convertir a estos baldíos en retamares impenetrables. (Foto: 18/08/2014). 


\begin{abstract}
"Que referidos pastos se arrienden por término de un año que dará principio el día en que sea adjudicado el remate en el mejor postor, y terminará precisamente el día 15 de abril del año inmediato de 1879 bajo el tipo de dos mil seiscientas setenta y cinco pesetas divididas en la forma siguiente:

Por los pastos de primavera, quinientas pesetas, comprendidos desde el quince de abril, último día de remate hasta el día quince de junio inmediato. Los pastos de rastrogera principiaran desde el día que se levantan las mieses o legumbres hasta el día veintinueve de septiembre... El aprovechamiento de la hoja se extenderá por el tiempo que medie desde el cuarto día de terminada la vendimia y dada la rebusca hasta el 30 de noviembre, cuyo aprovechamiento esta apreciado en ochocientas setenta y cinco pesetas. El aprovechamiento de invernia se extenderá desde el día 18 de abril actual hasta el 15 de abril próximo de 1879 en que termine este arriendo, sujetándose a las condiciones establecidas en los arriendos que por conceptos separados han servido de base en los últimos ańos."
\end{abstract}

Solo los ganaderos que lleguen a acuerdos entre sí y se queden con todas las pujas tenían asegurados pastos en cualquier mes del ańo. El resto o pujaba por aquellos del común de los vecinos o verían peligrar el sustento de sus animales, sometidos siempre a un estrecho control para evitar dańos en los cultivos. Si era sabida la prohibición del paso del ganado por los prados de veda, o que anden sueltas o sin cebadera las caballerías por los sembrados o vińedos podados, en marzo de 1875 se prohíbe también "que del mismo modo se prohiba que los ganados lanares transiten ni pasen por caminos que no tengan tres metros de anchura, para evitar que a su paso hagan daño en las heredades abiertas que lindan con los caminos citados..."1221. Cada arrendamiento se concretaba en dinero y tiempos según viniera el ańo. En junio de 1876 se acordaba la rastrojera y el espigueo ${ }^{1222}$.

Cuadro 120. Arrendamiento de pastos de baldíos en Serrada, año 1850

\begin{tabular}{lcc}
\hline Ganaderos de lanar & Número de reses & Renta a pagar (rs) \\
\hline Gregorio León Alonso & 624 & 68,32 \\
Modesto de Castro & 351 & 38,28 \\
Ezequiel Moyano & 358 & 39,20 \\
Crisóstomo de Íscar & 266 & 29,16 \\
Pablo Rivera & 5 & 0,22 \\
\hline TOTAL & 1604 & 177,16 \\
\hline
\end{tabular}

Fuente: Fuente: Archivo familia Alonso Moyano

Cuadro 121. Arrendamiento de pastos de prados y baldíos en Serrada, año 1854

\begin{tabular}{lcc}
\hline Ganaderos de lanar & Número de reses & Renta a pagar (rs) \\
\hline Crisóstomo de Íscar & 160 & 43,14 \\
Feliciano Martín & 260 & 80,10 \\
Ezequiel Moyano & 340 & 105 \\
Pablo Obregón & 210 & 64,29 \\
Modesto de Castro & 300 & 92,22 \\
Jorge Martínez & 80 & 24,24 \\
Cesáreo Moyano & 189 & 58,13 \\
Gregorio León Alonso & 680 & 210 \\
\hline TOTAL & 2.219 & 685,10 \\
\hline
\end{tabular}

Fuente: Fuente: Archivo familia Alonso Moyano

${ }^{1221}$ A.M.S., caja 2, carp. 21, año 1875.

${ }^{1222}$ Los textos de los acuerdos y condiciones son claros al respecto: "Primero. El arriendo tendrá lugar en subasta pública y previos los anuncios de costumbre y edictos que se fijaran en esta villa y las inmediatas...

Segundo. El arriendo se hace por el tiempo que medie desde el diez y ocho del corriente en que termina el de campaña o época en que se levantan las algarrobas hasta el treinta de septiembre próximo venidero, pero los disfrutantes no podrán introducir su ganado al pasto hasta que pasen doce horas de haber levantado los dueños las mieses o legumbres de sus heredades. 
Cuadro 122. Arrendamiento de pastos de rastrojera en Serrada, año 1857

\begin{tabular}{lcc}
\hline Ganaderos de lanar & Número de reses & Renta a pagar (rs) \\
\hline Juan Rivera & 360 & 259,200 \\
Feliciano Martín & 300 & 216 \\
Luciano Román & 22 & 15,84 \\
Canuto de Castro & 300 & 216 \\
Cesáreo Moyano & 280 & 201,60 \\
Gregorio León Alonso & 510 & 367,20 \\
\hline TOTAL & 1.772 & $1.275,84$ \\
\hline
\end{tabular}

Fuente: Fuente: Archivo familia Alonso Moyano

Cuadro 123. Arrendamiento de pámpana y hoja en Serrada, años 1855, 1857 y 1861

\begin{tabular}{|c|c|c|c|c|c|c|}
\hline \multirow[b]{2}{*}{ Ganaderos de lanar } & \multicolumn{2}{|c|}{1855} & \multicolumn{2}{|c|}{1857} & \multicolumn{2}{|c|}{1861} \\
\hline & No de reses & Renta (rs) & No de reses & Renta (rs) & No de reses & Renta (rs) \\
\hline Gregorio León Alonso & 657 & 548,18 & 510 & 461,55 & - & - \\
\hline Cesáreo Moyano & 167 & 139,12 & 280 & 253,40 & 194 & 239,59 \\
\hline Canuto de Castro & 265 & 221,18 & 300 & 271,50 & - & - \\
\hline Pablo Obregón & 236 & 197,06 & - & - & - & - \\
\hline Feliciano Martin & 152 & 126,50 & 300 & 271,50 & 335 & 413,72 \\
\hline Ezequiel Moyano & 187 & 156,06 & - & - & - & \\
\hline Juan Rivera & 190 & 158,24 & 360 & 325,80 & 331 & 408,78 \\
\hline Felipe Hidalgo & - & - & - & - & 654 & 807,69 \\
\hline TOTAL & 1.854 & $1.546,34$ & 1.750 & $1.583,75$ & 654 & 807,69 \\
\hline
\end{tabular}

Fuente: Fuente: Archivo familia Alonso Moyano

Cuadro 124. Arrendamiento de pastos del pinar en Serrada, años 1853 y 1855

\begin{tabular}{lcccc}
\hline \multirow{2}{*}{ Ganaderos de lanar } & \multicolumn{2}{c}{1853} & \multicolumn{2}{c}{1855} \\
Gregorio León Alonso & No de reses & Renta a pagar (rs) & No de reses & Renta a pagar (rs) \\
Cesáreo Moyano & 150 & 54 & 680 & 140 \\
Modesto de Castro y Hdos. & - & - & 189 & 38,31 \\
Pablo Obregón & 530 & 191,12 & 300 & 61,26 \\
Feliciano Martin & - & - & 210 & 43,8 \\
Ezequiel Moyano & 300 & 108,24 & 260 & 53,18 \\
Sebastián Rivera & 200 & 72,14 & 340 & - \\
Jorge Martínez & 50 & 18 & - & 16,16 \\
Crisóstomo de Íscar & - & - & 160 & 32,38 \\
\hline TOTAL & 1.230 & 444,16 & 2.219 & 455 \\
\hline
\end{tabular}

Fuente: Archivo familia Alonso Moyano

Tercero. El disfrute del pasto dicho se hará por ganado lanar ovejuno o cabrío mezclado en pequeña proporción; y por lo que respecta a servidumbres de ganadería se guardaran exactamente las prescripciones de los reglamentos vigentes...

Cuarta. Se fija como tipo para la subasta la cantidad de quinientas cincuenta pesetas...

Quinta. El valor en que definitivamente se arriende... se entregara por el rematante... a D. Patricio Obregón, individuo de la Junta y Depositario nombrado para este objeto...

Sexta. El pasto objeto de este arriendo es solo el de los rastrojos que pertenecen a los agremiados, siendo obligación de los disfrutantes respetar los predios acotados plantados o pendientes de recolección, y será el arrendatario o participes del arriendo responsable de los daños que se causen en las heredades contiguas...”. (A.M.S., caja 2, carp. 22, año 1876). 
Con todo, como puede apreciarse en los cuadros adjuntos, a las ovejas no les quedaba más remedio que salir al campo y pagar, si querían comer, las tasas que, paradójicamente, imponían sus dueños, dado que la mayor parte de los mismos integraban los ayuntamientos. De ahí que, aunque el lamento de los ganaderos en las últimas décadas sea de alarma, en estas décadas centrales de siglo dejan beneficios a todos, especialmente a los que disponían labranza y podían conjugar la alimentación en tierras propias con los remates públicos ${ }^{1223}$.

Ante estos ejemplos de pagos, una cuestión llama poderosamente la atención. La práctica totalidad de los ganaderos son labradores. Entre ellos se encuentran los mayores hacendados de la villa. Algunos explotan la cabaña con personal propio, pero la mayoría recurre a la cesión de las reses a mayorales, previa firma de contratos de arriendo. Es significativo que familias tradicionalmente ganaderas, aunque lleguen a poseer rebańos importantes, no siempre entran en los arrendamientos como sus homólogos labradores ${ }^{1224}$. Con todo el terrazgo arrendado no faltaban ovejas aprovechando el pasto de caminos y cañadas. De ahí a comerse lo de otros distaba un paso. En abril de 1873 el Ayuntamiento ha de tomar cartas en el asunto ante el "abandono que se nota por los sembrados del término jurisdiccional, pues constantemente están invadidos de ganados que los destruyen y aniquilan, sin que haya sido bastante a detener estos excesos el bando publicado a este intento y las multas exigidas..." 1225 Similares atropellos parece que también se producen en los prados. La presencia de un guarda, que por motivos económicos no era contratado desde hacía tiempo, se hacía más necesaria que nunca. ${ }^{1226}$ La situación propicia tratos de intercambio de reses y ventas por parte de ganaderos y contratos que especifican las obligaciones de propietarios y mayorales. ${ }^{1227}$ Para acercarse al entresijo de quehaceres reproducimos al pie uno de esos $\operatorname{contratos}^{1228}$.

${ }^{1223}$ A.F.A.M. Carp. de acuerdos y varios.

${ }^{1224}$ Un ejemplo es Juan Rivera. Seguramente para estos ganaderos de siempre no todos los años se podía entrar en todos los repartos El mencionado Juan Rivera era dueño de un rebaño de 310 cabezas en 1865, pagador de 654 reales de los 2.024 que costaron en aquella campańa los pastos de pámpana y hoja. Estaba acompañado por dos grandes: Gregorio León Alonso, que metió ese año 234 reses, y Félix de Castro, poseedor de otras 416. Las cifras del reparto apuntan a dos reales con once céntimos por cabeza. (A.F.A.M. Carp. de acuerdos y varios. Repartimiento de pámpana y hoja, año 1865).

${ }^{1225}$ A.M.S., caja 1, carp. 19, fol. 5-6, año 1873.

${ }^{1226}$ Aunque se sale propiamente de lo estudiado, en relación con los daños que ocasionan los animales en los sembrados, no se puede dejar de señalar, para arrancar una sonrisa al lector y aliviar el texto de seriedad, la denuncia presentada en 1891 por Pedro Ampudia a María de los Santos, dueña de un monte sito en Villanueva de Duero y colindante con un majuelo nuevo que poseía en San Martín. Al parecer, los conejos provenientes del citado monte ocasionaron unos daños valorados en 225 pesetas en las dos aranzadas largas del citado Alonso Ampudia. Hasta ocho testigos suscriben haber visto a los conejos llevándose más de la cuarta parte del valor de los trabajos efectuados en las cerca de mil cepas recién plantadas. Y, según se desprende del papel en que se hace el borrador de la denuncia, en virtud del artículo 1906 del código civil vigente en la citada fecha, es el dueńo del monte y, por tanto, de la caza que en él se refugia y vive quien debe abonar los perjuicios que ocasiona. Un precedente, quizá, de la compleja legislación que hoy acompańa a los cotos de caza.

1227 Aparte de ventas, se han documentado contratos de intercambio de reses que cuantifican tanto el valor como las condiciones de los acuerdos. Estos se hacían "a ley de ganadería, obligándose a su sanidad durante los noventa días que aquella fija”. Caso de mostrar enfermedad los animales o producirse por ella la muerte del ganado, se fijan los precios de cada res en los contratos. Para hacerse una idea de los precios que rigen en 1867 en ventas efectuadas en Serrada en este ańo, constan borregos a 27 reales, corderos a 18, cancines de desecho a 13 y carneros a 27.

1228 "Decimos nosotros, Gregorio León Alonso, vecino de esta villa de Serrada, y José Domínguez de la de La Seca, que en el día de la fecha, hemos convenido yo, el Gregorio León Alonso como ganadero el entregar al José para su custodia, y con el carácter de mayoral, ciento treinta y cuatro ovejas, diez y ocho carneros Padres y ciento diez y nueve borregos con sesenta y nueve corderos, hasta el día de igual fecha del año venidero de mil ochocientos cuarenta y cuatro; y yo el José Domínguez me doy por entregado de las referidas reses y bajo las condiciones a que respectivamente nos obligamos a cumplir.

Primera. Pagaré yo el Gregorio León Alonso al José como mayoral del ganado que queda espresado, la cantidad de cuarenta y dos reales mensuales de soldada; doce reses orras de todo gasto, quedando a mi beneficio el abono y leche 


\section{La evolución y rentabilidad de los cultivos en la segunda mitad del siglo XIX}

A diferencia de las tierras de sembradura, los majuelos siempre fueron una inversión acumulada de esfuerzo. Se extendieron por las superficies de gravas por el hambre de tierra de pequeños y medianos campesinos que, como se ha manifestado, se mantuvieron firmes frente a no pocas vicisitudes. Estos factores y el propio carácter de la cepa verdeja, espartana en sus necesidades y generosa en sus virtudes, explica en Serrada la presencia de las 1.817 aranzadas de producción (1.362 obradas o, si se quiere, $771 \mathrm{ha}$ ) del año $1857^{1229}$. Habrá que esperar a la filoxera francesa para verlo resurgir, antes del mazazo que supondrá su llegada a tierras peninsulares. Resultado de ello son las 2.074 aranzadas que se amillaran en 1881. Aunque hay que tener en cuenta los aumentos de superficie catastrada en los distintos términos, las cifras respecto a mediados del siglo XVIII y a las tierras de sembradura son significativas.

Cuadro 125. Ejemplos de distribución de tierras y viñedo en el norte de Medina

\begin{tabular}{lcccc}
\hline \multirow{2}{*}{ Municipios } & \multicolumn{2}{c}{ Año 1752} & \multicolumn{2}{c}{ Año 1881 } \\
& $\begin{array}{c}\text { Obradas de } \\
\text { sembradura }\end{array}$ & $\begin{array}{c}\text { Aranzadas } \\
\text { de viñedo }\end{array}$ & $\begin{array}{c}\text { Obradas de } \\
\text { sembradura }\end{array}$ & $\begin{array}{c}\text { Aranzadas } \\
\text { de viñedo }\end{array}$ \\
\hline La Seca & 5.220 & 5.000 & 2.940 & 9.250 \\
Matapozuelos & - & 2.280 & 2.795 & 2.775 \\
Serrada & 1.562 & 1.660 & 1.786 & 2.074 \\
Ventosa de la Cuesta & 3.000 & 600 & 1.155 & 1.715 \\
\hline
\end{tabular}

Fuente: A.H.P.V. Hacienda. Catastro de Ensenada y Amillaramiento de 1881. Elaboración propia.

Desde comienzos de siglo no corren buenos tiempos para este cultivo. Muchos están descuidados de labor, la grama crece entre las cepas a finales del primer tercio, y los precios, el eterno caballo de batalla indicador de su rentabilidad, estuvieron muy por debajo de lo que se esperaba. Los arranques de cepas son continuos en los pueblos de la comarca que poseen tierras de primera calidad para cereal. Y si a este, como así sucedió, le acompañaban los precios, a los majuelos se les fue arrinconando en los peores pagos con el consiguiente descenso de rendimientos y el carácter menor que, a partir de entonces, tendrá su cultivo. En el norte de Medina, sin embargo, Rueda, La Seca

que estas produzcan; una cordera soldadesca? en dinero con el aumento de dos reales al precio medio que resulten en los mercados de mayo de dicho año de mil ochocientos y cuarenta y cuatro, seis pellejos y dos días de leche. Asimismo y en la propia forma me obligo yo, el José Domínguez al cuidado y conservación de las citadas reses con el esmero y delicadeza que exigen, no faltando de su vista sino con licencia de mi amo el Gregorio; también responderé de las reses que falten al hacer la entrega con otras de igual clase, así como de las que aparezcan muertas de golpe de lobo, manifestando en tiempo que pueda probarse y en este caso no seré responsable de su abono. Las denuncias de yerba que ocurran serán de cuenta del amo, así como las entradas a sitios que no tengan paso lo haré con su conocimiento y, en este caso si acarrease denuncia será cuenta del mismo amo, y respecto de las reses que por todos conceptos desaparezcan se llevará una cuenta en esta misma obligación que firmamos por duplicado, sentándolas en el acto que se haga la entrega o se de noticia de ella. Al cumplimiento de esta obligación, en la parte que a cada uno corresponde, con todos nuestros vienes habidos y por haber, en la forma más solemne que de derecho se requiere. Serrada, diez de junio de mil ochocientos cuarenta y tres, siendo testigos Gregorio Llanos, Fernando Calderón y Gregorio Díaz de esta vecindad y por no saber firmar el José Domínguez lo hace a su ruego un testigo. Firma a ruego: Pedro Román Martín (rúbrica). Noticia de las reses que por todos conceptos van desapareciendo de las comprendidas en esta obligación: ovejas, cuarenta y cuatro; carneros, dos; borregos, tres; corderos, doce; borregas, tres.”. (A.F.A.M. Carp. de acuerdos y varios. Carta de arrendamiento y custodia de ganado lanar, año 1843).

${ }^{1229}$ Anteriormente se ha citado como cifra de este año 1857 la cantidad de 1834,5 aranzadas. Las 1817 que se acaban de señalar, ligeramente inferiores a la anterior, son las que apunta como productivas en el citado ańo D. Gregorio León Alonso al alcalde presidente Leandro Obregón. (A.F.A.M. Interrogatorio y respuesta de Serrada a la Junta permanente de estadística del partido de Medina del Campo). 
y la Nava siguieron siendo el corazón del que salían los afamados blancos hacia Asturias, la Montaña o Galicia. La aparición del ferrocarril y la mejora de los caminos y carreteras fueron las nuevas arterias que salvaron al cultivo de la competencia triguera. El sostenimiento de la producción en 1854 así lo constata ${ }^{1230}$.

Cuadro 126. Ejemplos de producción de vino en el partido de Medina y términos de su influencia, año 1854

\begin{tabular}{lrlr}
\hline Pueblos & $\begin{array}{r}\text { Producción } \\
\text { (cántaras) }\end{array}$ & Pueblos & $\begin{array}{r}\text { Producción } \\
\text { (cántaras) }\end{array}$ \\
\hline Medina del Campo & 71.294 & Castrejón & 7.129 \\
Rueda & 249.532 & Rubí de Bracamonte & 4.277 \\
La Seca & 242.402 & Bobadilla del Campo & 5.703 \\
Nava del Rey & 356.474 & El Carpio & 1.425 \\
\hline Torrecilla & 14.258 & Fresno el Viejo & 5.703 \\
\hline Alaejos & 57.035 & Villaverde & 28.517 \\
\hline Siete Iglesias & 42.776 & Resto de pueblos & 86.817 \\
\hline Cantalapiedra & 7.129 & TOTAL & 118.0471 \\
\hline
\end{tabular}

Fuente: Archivo Municipal de Medina del Campo. Elaboración propia.

Como se desprende de la relación que refiere Medina, se está hablando de un importante volumen de producción. Conviene destacar cómo los tres municipios que antes mencionados acaparan el $71 \%$ del total. De ahí que los blancos de la Tierra de Medina se hayan identificado con el nombre de "blancos de La Seca, Rueda o la Nava". La población que mantienen es muy abundante y los numerosos mesones y posadas que albergan en esta época dan cuenta del buen número de arrieros que bajan del norte a por sus caldos.

Serrada presenta cifras menores. En 1857 su producción alcanza las 19.255 cántaras y, aunque la relación anterior bien pudiera pecar por exceso, dado el fin para el que estaba destinada, lo cierto era que en estos años su término no daba para mucho más. La gráfica adjunta es el mejor testimonio del cultivo en estos ańos ${ }^{1231}$ :

Cuadro 127. Caracteres, producciones y precios del viñedo en Serrada, año 1857

\begin{tabular}{|c|c|c|c|c|c|c|}
\hline Tipo de uva & $\begin{array}{l}\text { Calidad } \\
\text { de la tierra }\end{array}$ & No de aranz & $\begin{array}{c}\text { Producción } \\
\text { aranzada } \\
\text { (cántaras) }\end{array}$ & $\begin{array}{l}\text { Producción total } \\
\text { (cántaras) }\end{array}$ & $\begin{array}{c}\text { Precio } \\
\text { cántara (rs) }\end{array}$ & $\begin{array}{l}\text { Ingresos } \\
\text { brutos (rs) }\end{array}$ \\
\hline \multirow{4}{*}{$\begin{array}{l}\text { Uva blanca } \\
\text { (verdeja) }\end{array}$} & Primera Clase & 50 & 40 & 2.000 & 12 & 24.000 \\
\hline & Segunda Clase & 120 & 24 & 2.880 & 12 & 34.560 \\
\hline & Tercera Clase & 600 & 12 & 7.200 & 12 & 86.400 \\
\hline & Cuarta Clase & 1.025 & 7 & 7.175 & 12 & 86.100 \\
\hline Uva Tinta & - & 22 & 9,09 & 200 & 12 & 2.400 \\
\hline TOTAL & - & 1.817 & - & 19.455 & - & 233.460 \\
\hline
\end{tabular}

Fuente: Archivo familia Alonso Moyano

${ }^{1230}$ A.M.M. “Estado que demuestra la recolección... en la villa de Medina del Campo y demás pueblos... para alimentar el ferrocarril del Norte...”. Año 1857. En la citada relación, dado su destino a servir de mercancías transportadas por ferrocarril, las distintas cantidades estaban anotadas en arrobas. Para facilitar la comprensión, dado que el vino se mide de forma usual en cántaras, se ha llevado a cabo su conversión, teniendo en cuenta que en Tierra de Medina una arroba equivale a $11,502 \mathrm{~kg}$ y una cántara 16,128 litros.

${ }^{1231}$ Ibídem. 
Cada aranzada es reflejo de siglos de historia. Llama la atención la mediocre calidad de los suelos sobre los que se asienta la mayor parte del terrazgo vitícola. El 56,41\% de las aranzadas están plantadas en suelos de cuarta, con unos rendimientos de tan sólo 7 cántaras o 0,43 moyos (161 kg de uva/aranzada o $422 \mathrm{~kg} / \mathrm{ha}$ ) ${ }^{1232}$. Las 50 aranzadas de primera (2,75\% del total), en cambio, presentan una producción de 40 cántaras o 2,5 moyos/aranzada $(920 \mathrm{~kg} /$ aranzada o $2.411 \mathrm{~kg} / \mathrm{ha})$ dejando importantes beneficios a 12 reales la cántara.

\section{Cuadro 128. Evolución del rendimiento del viñedo en Serrada ${ }^{1233}$}

\begin{tabular}{lcc}
\hline & Año 1752 & Año 1857 \\
Calidad de la plantación & Rendimientos (En cántaras por aranzada) & Rendimientos (En cántaras por aranzada) \\
\hline Primera clase & 20 & 40 \\
Segunda clase & 14 & 24 \\
Tercera clase & 8 & 12 \\
Cuarta clase & - & 7 \\
\hline
\end{tabular}

Fuente: Fuente: Archivo familia Alonso Moyano

A partir de los datos aportados, es notorio un aumento de rendimientos por unidad de superficie, respecto a los que refiere el Catastro de Ensenada, pero, en última instancia, son las coyunturas vitícolas las que acentúan o hacen disminuir los rendimientos, atendiendo a los cuidados que se les dispensa y al precio que cada año tienen los mostos ${ }^{1234}$. Hay que recordar que en 1801 la producción estimada de las 115 aranzadas que cultivaba Miguel Moyano y Beatriz Rodríguez era de 23,5 cántaras de media; entre 1817 y 1826, cuando ni el viñedo pasaba por una buena coyuntura ni la situación de Antonio García y su mujer Gregoria Alonso tampoco, sus 16 aranzadas apenas llegaban a las 7 cántaras. En 1872, por último, los majuelos de la capellanía que se analizará sacan de la bodega una media de 15 cántaras por aranzada vendimiada.

Otra cuestión no menos importante son los precios. Por bajos y por irregulares. Frente al trigo, que se vende de 1850 a 1875 a precios que oscilan entre los 35 y 40 reales, duplicando en muchos ańos los precios pagados a comienzos de siglo, los vinos no rebasan los 16 reales la cántara y, aun siendo superiores a las medias que rigieron en décadas anteriores, sólo consiguen el mantenimiento del cultivo. No porque con dicho precio no se obtengan beneficios, sino porque no toda la producción se vende. He aquí el tercer factor que tiene la llave de la expansión o retroceso de los majuelos. Piénsese que, en el citado año de 1857, se apuntan hasta 3.000 cántaras de vinagre que se vende a 12 rs y 600 de aguardiente a un precio de 20 rs.

${ }^{1232}$ Es conveniente anotar que, aunque se trata de cifras muy bajas, son cifras medias. En ellas entran tanto los majuelos de cuarta en plena producción como los más viejos y medio perdidos que tiran hacia abajo de los porcentajes globales. En cualquier caso, se entiende mejor que nunca la existencia de tantos majuelos perdidos, derivados de la crisis vitícola de finales del primer tercio del siglo. O la precaria situación de quienes tuvieron que arrancar estas tierras al monte con azadas o burros para, tras sacarles un poco de centeno el primer año, invertir posteriormente un más que generoso esfuerzo para vender unas cántaras y conseguir unos reales. O consumirlas y de esta manera evitar la compra del caldo.

${ }^{1233}$ La relación estadística de 1857 divide el terrazgo viñero en cuatro clases diferentes, por lo que los datos aportados deben juzgarse atendiendo a este factor. En 1852 únicamente se diferencian tres tipos de calidades, coincidiendo parte del terrazgo de tercera con lo que un siglo más tarde se clasificaría como de cuarta. Por la importancia y detalle de estos datos para el fin buscado, no sabe este autor a quién debe estar más agradecido: si a D. Gregorio León Moyano, por cumplimentar con tanta meticulosidad la citada estadística, o a sus bisnietos Pedro y María, por conservar y dejar consultar estos viejos papeles.

${ }^{1234}$ No se desea, bajo ningún concepto, citar unas u otras cifras como rendimientos medios. De hecho, cada pueblo aporta cifras distintas en los mismos años. De todos es sabido que cada año tiene distintas producciones dictadas por la variable meteorológica y las variables circunstancias que rodean a la planta. 
Los resúmenes estadísticos, a diferencias de los inventarios de bienes, no hablan de partidas perdidas, pero es una evidencia que, si el vino tiene buenos precios, la saca es rápida y no llega ni a avinagrarse ni a ser destilado para ser vendido su espíritu a 20 reales. En esta tesitura, sólo contados propietarios dan pasos con iniciado afán capitalista para vender sus caldos. Gregorio León es uno de ellos. A través de su correspondencia, se puede comprobar que tiene hijos al frente de la comercialización en zonas de consumo, acuerdos con almacenistas y distribuidores de vinos o contactos, en fin, que puntualmente le informan del estado de los mercados nacionales e internacionales. Así, a comienzos de 1858, su amigo y pariente Pablo Calvo Madrigal le pone al tanto, desde Salamanca, del complicado mercado portugués y de las buenas expectativas de la industria harinera ${ }^{1235}$ :

\begin{abstract}
"Fregeneda, febrero, 15 de 1858
Mi querido tío D. José:

...Sobre el negocio del espíritu: Primero Que no establezca sin mi aviso la fabrica (de aguardiente)... en razón a que este negocio se habrá paralizado en Portugal y amigos míos se encuentran con grandes existencias sin poderlas dar salidas; ya por las grandes precauciones fiscales en Portugal y lo difícil de su introducción hoy; ya también porque escaseando la cosecha de vino por el oídium, el consumo de aguardiente ha disminuido.

Segundo: Que se cree salga una ley en Portugal admitiendo con derechos la entrada de espíritu, y si tal sucede, y se aprueba, entonces será asunto fijo, y los españoles podremos llevar y vender, lo que no sucede hoy, que en Portugal nada podemos hacer porque la introducción es de contrabando y el asunto es casi suyo esclusivo en aquel Reyno.

Tercero: Que de tener espíritu allí, D. Gregorio o algún amigo no haga más contratos con los portugueses, que ajuste al contado, pues en general hay mala fe.

Hoy no sé nada fijo de precio así como el coste de maquinaria por ser asunto que no he querido comprender, pero en breve daré a usted noticias circunstanciadas, pues son amigos casi todos los que se dedican a este negocio y me han invitado varias veces. Por supuesto que las máquinas necesarias se le proporcionarían de Oporto, de donde las traen todos, pero repito suspenda por ahora, y si llega día en que sea conveniente, descanse que le avisaré en tiempo y tendrá todos los datos...

Nosotros estamos haciendo una fabrica harinera en Tejares y para junio próximo creemos deba funcionar. Para su inauguración avisaré a Ud. si gusta acompañarnos a los demás socios y a mí. La Sociedad se titula marqués de BihaAlcázar, Torres y Calvo. Es colectiva y por los apellidos de la razón social comprenderá Ud. que uno de los socios es dicho marqués. Torres es amigo mío, de Oporto. D. Félix Fernández de Torres y Compañía, y el último el que suscribe. Llevamos un tercio cada uno a diferencia que yo tengo dividida mi tercera parte con otro amigo mío. Van gastado ya 27.000 duros, sin contar con 17.000 duros que costó la pesquera y propiedades y por lo mismo diga Ud. a José que hasta concluir con la obra nada puedo ofrecerle, pues ignoro lo que me será necesario....

Pablo Calvo Madrigal. (Rúbrica)
\end{abstract}

Se ha reproducido parte de la misiva porque la entendemos representativa de las distintas coyunturas del vino y del trigo por estas fechas. Ya no se está ante los labradores del XVIII. Se ha apuntado repetidas veces cómo, desde mediados de siglo surgen, escasos en número pero muy dinámicos, labradores hacendados con espíritu capitalista y de empresa. ¿Era una necesidad ante la difícil salida de algunas producciones y la pérdida de dividendos en el mercado por la actuación de los intermediarios? ¿Es el seguimiento a una burguesía de negocios que se enriquece rápidamente? Sea como fuere, estos pueblos tratan de dar salida a los vinos dentro o fuera de las fronteras, en mostos o en aguardiente. El señor Alonso acaba por instalar la fábrica en su "Casa del Hospital" de Serrada donde, en la segunda mitad de los sesenta, aparte de destilar parte de su cosecha, arrienda las instalaciones a distintos vecinos y, como sucede entre los grandes labradores de estos pueblos, aprovechan la formación dada a sus hijos para estar al tanto de las leyes y de la evolución de los mercados ${ }^{1236}$.

${ }^{1235}$ Ibídem. Carpeta de correspondencia.

${ }^{1236}$ Ibídem. Carpeta de correspondencia. Con fecha de 18 de febrero de 1869, se firma un contrato entre el mencionado hacendado de Serrada y su convecino Braulio Martín. En él, el primero le vende el orujo de la cosecha del 68, "cediéndole el local de la fábrica de la Casa del Hospital para su elaboración y quema, depositándose el aguardiente que produzca en dicho local, dándose venta en el mismo, y recibiendo, a medida que se vaya vendiendo, la mitad del importe de los cántaros que se vengan, hasta hacerme el completo pago de los mil seiscientos reales en que ha sido ajustado..." En papeles adjuntos donde constan distintos débitos, se refiere el alquiler de la alquitara a tres reales diarios. Aunque sólo sirva para comprender la rentabilidad y precios de unos u otros productos, el trigo se vende en el citado ańo de 1869 a 40 reales. 

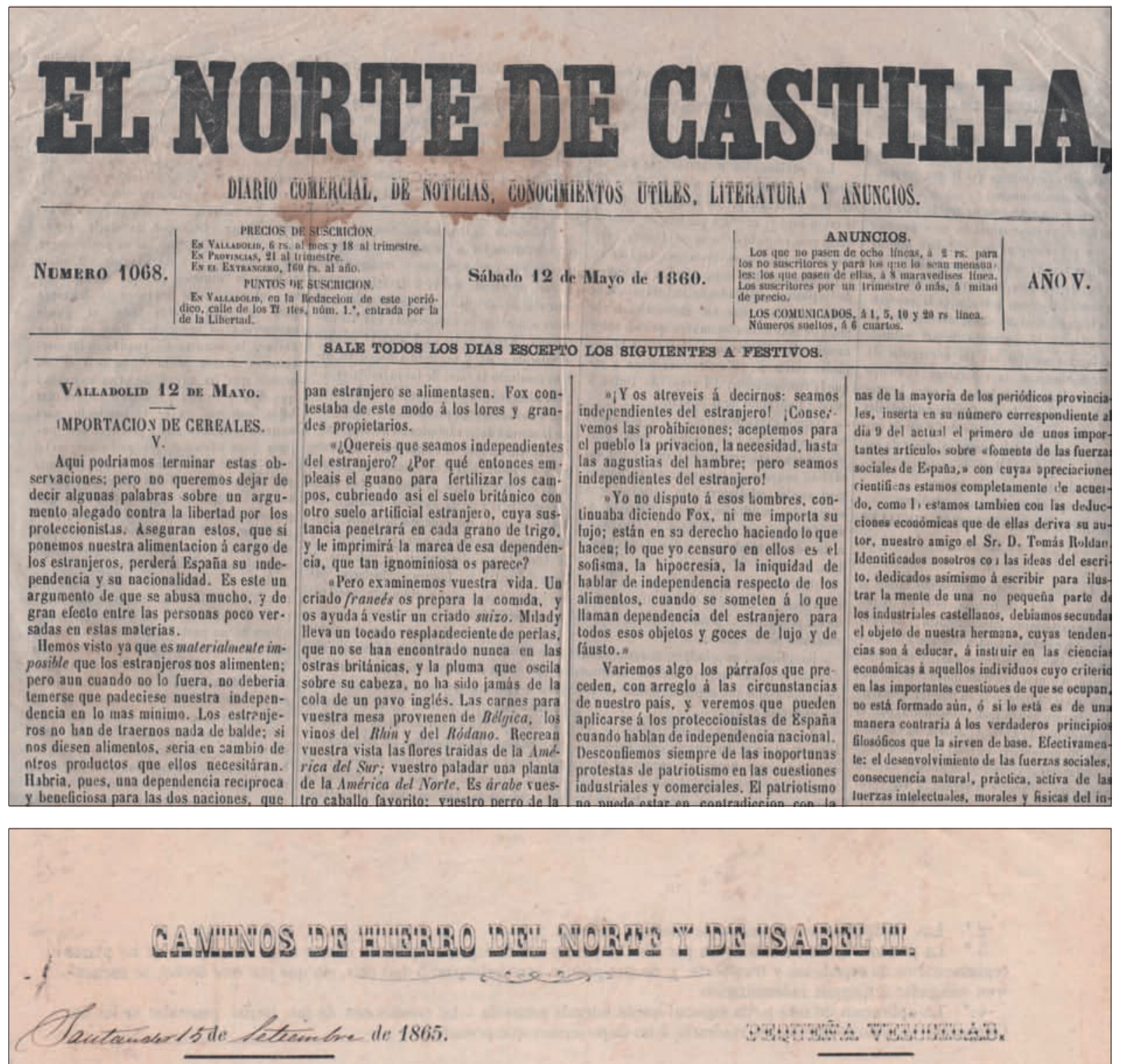

XAIFA ESPRIA

Série X. Y, nimero 5.

Vinos y aguarilientes dei Reino en pipas, en pellejos y en botellas eneajonadas: emhalages vacios de retorno.

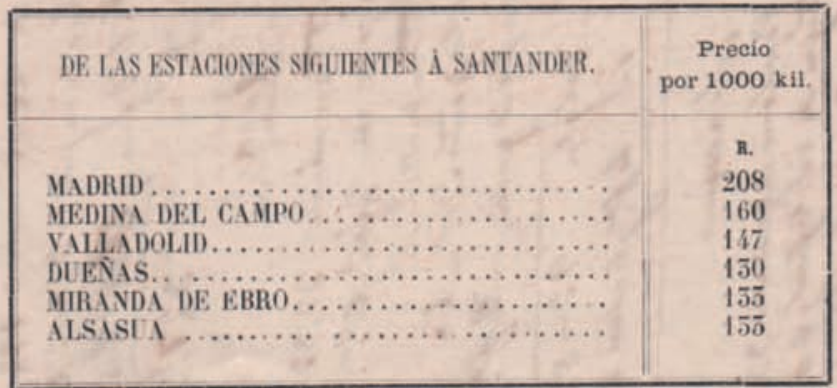

Imagen 90. Artículo sobre importación de cereales publicado en El Norte de Castilla de 12 de mayo de 1860 (arriba), y tarifas de transporte de vinos por vía férrea a Santander en 1865 (abajo). Archivo familia Alonso Moyano. Los alegatos proteccionistas que diariamente recoge la prensa reflejan los intereses de una clase propietaria que ve peligrar su posición privilegiada ante la competencia de importaciones de cereal a precios más bajos. 
A diferencia del trigo que aguanta en las paneras, el vino depende de su calidad para su conservación y de que lleguen los carros de los arrieros o el correo de los almacenistas interesándose por las partidas. La salida de vinos espańoles con destino a Francia en los ańos sesenta y setenta alivia a estos blancos de la Nava o La Seca. En esta villa no hay constancia de salidas al exterior, pero sí una mayor facilidad para ser vendido en los mercados regionales. En 1865 se vende a 16 reales presionando a 17 reales y, en septiembre de 1875, la demanda parece satisfacer a los productores. Así lo manifiesta Pedro Alonso, hijo del anterior, quien desde el almacén de vinos de Apelio Unzúe, en Azadinos (León), escribe a su padre en los siguientes términos ${ }^{1237}$ :

"León 27 de agosto de 1875.

Querido Padre: ayer recibí su grata con el talón, la leí por tres veces y con mucha detención para enterarme. En estos días hemos perdido por vender mucho vino y mańana sábado sé que vienen seis carros y regularmente, como no habrá llegado el vino no querrán cargar las setenta u ochenta cántaras que hay en el almacén. Me alegro que tengan Uds. tan buena saca y precios pues eso aquí influirá mucho, pues de aquí han bajado algunos carros a La Seca.

Hoy quedaré lavadas y corrientes diez pipas.

Mañana le enteraré a Ud. de lo que me diga Cabo pues anoche estuve a verle y no le encontré.

Sin más por hoy reciba Ud. expresiones para todos y Ud. mande a su hijo.

Pedro (Rúbrica)

11, septiembre, 1875

Querido Padre. En estos dos días no ha venido nadie más que José Conde y llevó seis cantaras; hoy sábado no se que habrá. Si sigue así no podré ir a esa. Desde mañana daré una vuelta a la estación para sacar el vino en cuanto llegue; en cuanto haré lo suficiente para pagar el porte.

Si viene Patrón que me traiga la capa vieja y la chaqueta de Sta. María pues aquí va refrescando. Nicolás el mozo me dice que le mande traer un puchero de arrope, que le traiga Patrón.

Vuelvo a encargarle a Ud. que si puede venda Ud. ahí a cualquier precio pues esto no puedo asegurar ni a favor ni en contra.

En la Magdalena, cuatro leguas más arriba de aquí dan vino bueno a 16 reales cántara.

Ayer a la nochecer llegó Antonio. Va para esa. Pero le detengo hasta que traiga los pellejos para que me ayude. Sin más por ahora mande Ud. como guste a su hijo. Pedro Alonso Ampudia (Rúbrica)

Aunque el ferrocarril y el correo acortan las distancias, los arrieros seguirán bajando a por vino a la Tierra de Medina durante varias décadas más. Los pequeños productores no tienen posibilidades para acercar el vino a los centros consumidores. Los conciertos con los almacenistas, los gastos del transporte, el salario de mozos y pensiones y lo más importante, el estar fuera de la labranza durante un tiempo hacen imposible tal aventura comercial. Para la familia Alonso Ampudia, sin embargo, que ya posee en 1855 en propiedad 133,5 aranzadas de majuelo, pero que por estas fechas mantiene en producción la abultada cifra de 301 aranzadas, era tanto una inversión como la imperiosa necesidad de dar salida anual a tan importante volumen de vino ${ }^{1238}$. Todo ello, claro está, respaldado por su sólida posición económica.

La mayoría de pequeños y medianos labradores de esta comarca debían esperar a corredores, tratantes y arrieros antes de llamar a los sacadores del pueblo. De ahí su presión a los Ayuntamientos para que estos exijan a la Diputación o al gobierno el arreglo o trazado de caminos y carreteras que enlacen con las estaciones del ferrocarril o con las zonas tradicionales de consumo. Les iba parte de cada cosecha en ello. Quedarse al margen del abaratamiento de los portes que generarán los nuevos sistemas de transporte, o aislados sobre el terreno, hubiera sido su perdición. En estos años 60 y 70 de fiebre vendedora y de llegada del vapor, hasta el más reacio campesino hubiera dado su vida por defender el sueńo ilustrado.

${ }^{1237}$ Ibídem. Carpeta de correspondencia.

${ }^{1238}$ Ibídem. Carpeta de testamentos e inventarios de bienes. En el resumen de los siete lotes (Hipólito, Pedro, Balbino, Alberta, Mariano, Dolores y Claudia) en que se reparte la herencia de D. Gregorio León Alonso, ya que su esposa murió en 1855, los majuelos suponen, como queda dicho, 301 aranzadas con 26 cepas, con un valor total de 215.418 reales. A ello han de sumarse las 200 obradas en propiedad, cuya tasación se fija en 81371. Asciende el valor total de estos bienes raíces a la importantísima suma de 296.790 reales. 
Faltará el tiempo. Desde los mismos cimientos de las estructuras agrarias se están gestando no pocas contradicciones que los nuevos países productores y las comunicaciones que todos anhelaban van a poner en evidencia. La política proteccionista no puede mantenerse por más tiempo. Por si fuera poco el oídium en las viñas había entrado por Portugal y la filoxera seca las cepas de los valles más cercanos a los Pirineos. Se está en los albores de la llamada gran crisis agropecuaria de fin de siglo.

\section{a. La importancia del terrazgo vitícola. El análisis de una explotación vitícola}

Dada la carencia de registros, es difícil proponer un modelo de explotación agraria en estas fechas $^{1239}$. La explotación tomada como ejemplo corresponde a los bienes integrantes de un Aniversario de Misas, fundado con fecha 4 de noviembre de 1760, por Andrés Rodríguez Zorrilla ante el escribano de Serrada Miguel Moyano y adjunto, de acuerdo a las condiciones impuestas por el testador, a la Capellanía que funda el 27 de enero de 1757 ante el escribano de Valladolid Joaquín Balleste$\operatorname{ros}^{1240}$. Las leyes de desvinculación promulgadas desde 1820, así como el fallecimiento del capellán poseedor, generan una tremenda batalla legal entre herederos por hacerse con los bienes citados, lo que obliga a los tenedores a ser escrupulosos con la administración de unas riquezas pendientes de repartos y litigios ${ }^{1241}$. La conservación de estos apuntes ha permitido un acercamiento preciso a las labores, producciones y rendimientos de este aniversario de bienes, que se reparte de forma definitiva entre 1874 y 1875 y que afecta tanto a majuelos como a tierras cerealistas ${ }^{1242}$. Se trata, en concreto,

${ }^{1239}$ Acercarse en detalle y adentrarse en las labores, producciones y rendimientos de una hacienda de comienzos del último tercio del XIX no ha sido tarea fácil. Una vez más se agradece a María y Pedro Alonso Moyano haber puesto a disposición cuanta documentación conservan de este tiempo.

${ }^{1240}$ Archivo familia Alonso Moyano. Carp. de escrituras y varios. Los bienes adscritos a la capellanía son una cerca y lagar con bodega y 38 aranzadas y trescientas cepas. Los del aniversario o vínculo los forman una casa a la calle del Arroyo que lindaba por poniente con la calle de la Acilla y norte con casa y corral de D. Leandro Obregón y plaza de la villa. Parte de la misma correspondería a la actual vivienda de la familia de Román Íscar. Dicha casa disponía de bodega, lagar y cubas, así como paneras, caballerizas y gallineros. La vivienda estaba acompańada por bienes raíces compuestos de una tierra a Valdelaíno de 5,75 obradas; otra en Valdesendero de 10 obradas; otra en Valdelacasa de 10 obradas, un majuelo en el mismo pago de 16 aranzadas y otro, donde llaman el Redondo, de 5 aranzadas.

${ }^{1241}$ Ibídem. A la falta de acuerdos entre las partes, se suman los cambios legislativos que van surgiendo en la España del XIX, conforme se alargan los procesos judiciales, especialmente los que interesan a estas capellanías colativas familiares, sean las leyes de agosto de 1841, el Concordato de 1851, los decretos de abril de 1852, febrero de 1855, noviembre de 1856 u otras posteriores. De hecho, el conflicto tiene sus antecedentes en febrero de 1834 cuando fallece D. León Rodríguez, presbítero y bisnieto político del fundador que gozaba de dicha capellanía. El obispo de Valladolid llama a la obtención de la Capellanía a los descendientes de José Rodríguez y el tribunal eclesiástico la confirma en la persona de Pablo Obregón, al mantenerse la sucesión que privilegia el hijo al nieto, el mayor al menor y el varón a la hembra.

${ }^{1242}$ Archivo familia Alonso Moyano.

Desde 1834 hasta las últimas sentencias de 1874 y 1875, transcurre casi medio siglo de costosos e intrincados pleitos por la división y goce de los bienes de dicha institución. En el juzgado de primera instancia de Medina del Campo, de acuerdo a la ley de 19 de agosto de 1841, se adjudican dichos bienes a Agustina Rodríguez, viuda de Julián Obregón, y a Micaela Alonso, hermana de Gregorio León Alonso e hija de María Rodríguez y representada por su marido Modesto de Castro, respetando el usufructo al capellán poseedor. La sentencia definitiva de 15 de julio de 1846 adjudicará los bienes como de libre disposición a las anteriores, como parientes con preferente derecho a suceder en ellos por mitad, sin perjuicio del legítimo poseedor de la Capellanía, el presbítero Pablo Obregón.

Gregorio León Alonso, hermano de la citada Micaela, entabla demanda contra la familia Castro Alonso y la familia Obregón, hijos estos de Agustina, para que se declarase con igual derecho que aquellas, lo que le confirma el Tribunal Supremo de justicia de 14 de octubre de 1864. Gregorio León había sentido menoscabados sus intereses en la medida en que era nieto de José Rodríguez y de más edad que Leandro y los hijos de Modesto de Castro, a la sazón biznietos de José Rodríguez. Se sentía, por tanto, con derecho preferente y exclusivo a la mitad de los bienes reservados del aniversario adjunto a la capellanía, dado que es sucesor inmediato del último poseedor. Posteriormente, tras la prolongación de pleitos interminables y costosos, Gregorio León se adjudicará su mitad reservable por sentencia de 2 de octubre de 1873 y que será reconocida en sentencia dictada el 20 de marzo de 1874, que la sentencia de 29 de mayo de 1875 entre Gregorio León Alonso contra Patricio y Justo Obregón y Gregorio Juárez obligará a ejecutar. 
de 10 obradas de sembradura y 30 aranzadas de majuelo que, si bien son cultivadas como parte integrante de haciendas de mayor entidad, pueden ser representativas del tamańo medio de buena parte de las haciendas de este espacio en esta segunda mitad del XIX ${ }^{1243}$.

Los datos manejados acercan a la difícil realidad de la agricultura española en los primeros años del último tercio del siglo XIX, previos a la severa crisis agrícola y pecuaria que se desata a partir de 1887. En este caso, no obstante, se deben anotar los condicionantes del suelo a los que tantas veces se ha aludido y que en estos momentos ponen contra las cuerdas, si es que no lo estuvieron siempre, a buena parte del terrazgo cerealista del norte de la Tierra de Medina.

El viñedo en estos años de 1870 y 80 vive buenos tiempos, dado que aprovecha las salidas de caldos por la filoxera francesa, si bien sufre la contracción de la demanda cuando las viñas galas se rehacen y el insecto llega a tierras de Castilla. A principios de los noventa, la sobreproducción hunde los precios y la invasión filoxérica aterra a todos estos pueblos dependientes de sus mostos. Hasta entonces siempre había visto ganada la batalla al cereal, sea trigo, cebada o centeno. Las valoraciones que hacen las partes sobre los bienes del aniversario tratado así lo constatan ${ }^{1244}$ :

\footnotetext{
"Majuelo titulado el viejo, hoy tierra. Vale la obrada 250 reales. Esta misma tierra, si estuviera plantada de majuelo valdría 1.100 cada una de las aranzadas.

Otro majuelo, titulado Redondo, hoy tierra. Vale cada una obrada a 300. Esta misma tierra, plantada de majuelo valdría cada aranzada a 1.200 reales.

(...) Otro pedazo de dicho majuelo que linda por el norte con la partida anterior, mediodía con majuelos de León Moyano y otros; poniente con el pedazo de 500 cepas ya deslindado y solano con majuelo de herederos de Roque de Íscar, que atendida su falta de valor hoy vale nada más que 1.000 reales la aranzada, si estuviera corriente sin la falta de labores que se observa valdría a $1.300 . . . ”$
}

Los mil reales que diferencian una misma tierra, caso de estar de viñedo, no son sino una segura y productiva inversión durante décadas, puesto que los beneficios netos obtenidos están por encima de las fatigas que proporcionan las tierras de año y vez, eternamente condenadas a bajos rendimientos en estos pagos de gravas y arenas. El viñedo, como se ha reiterado, además de su mayor rentabilidad, proporciona una subsistencia más llevadera a la numerosa masa de jornaleros de estos pueblos hasta ser el principal dinamizador de la demografía comarcal.

Aunque se ha puesto de manifiesto la aparición de un cierto capitalismo agrario avanzada la segunda mitad de siglo y, desde los ańos cincuenta, se observa una apertura y modernización en la gestión de las labranzas tradicionales, buena parte de la práctica diaria y trabajos en los cultivos se siguen realizando conforme a las viejas tradiciones. Nada mejor que comparar los cuadros siguientes con las labores y producciones estudiadas. Conviene señalar, sin embargo, que estos años de la década de los 70 son los últimos en el mantenimiento de estas inercias. La llegada del oídium, del mildiu y la filoxera transformarán parte de las prácticas vitícolas vigentes hasta la fecha. La llegada de los tendidos ferroviarios y la cercanía a los mercados que supone la revolución de las comunicaciones nacionales e internacionales hará que, al menos, a los ojos de los coetáneos, ya nada sea lo mismo.

\footnotetext{
${ }^{1243}$ Antes de cualquier valoración de los datos que recogen las gráficas adjuntas, para evitar generalizaciones erróneas, extensibles al resto de la agricultura comarcal, se debe tener en cuenta que dichos bienes estaban labrados por un administrador que, al no ser propiamente su dueño, como se anota en papeles sueltos adjuntos a la documentación manejada, es muy posible que las aranzadas de majuelo hubieran sufrido atrasos de labor en ańos anteriores y, por tanto, acusen rendimientos menores que las llevadas directamente por sus propietarios. Las tierras de sembradura, por su parte, corresponden a pagos de segunda y tercera calidad y, como se verá por sus rendimientos, no pueden compararse con aquellas otras tierras de primera, sitas en La Vega y adyacentes, arrendadas por el marqués de Falces y de mayores producciones por obrada.
}

${ }^{1244}$ A. F. A. M. Carp. de escrituras y varios. 


\section{- La plantación y crianza de las cepas en los primeros ańos}

Desde la plantación hasta la vendimia, o desde el manejo de los mostos hasta el lavado de las cubas, son incontables las operaciones manuales que se requieren. En el cuadro adjunto se detalla el coste del plantío y crianza del viñedo en haciendas y fechas representativas de este tiempo y espacio ${ }^{1245}$ :

Tanto este ejemplo como el que sigue son representativos de los trabajos y costes de plantación antes de la llegada de la filoxera y la introducción de plantones americanos. Gregorio León era rentero de 20 obradas del marqués en 1861 por las que pagaba 20 fanegas de trigo. Su patrimonio consistía, al margen de algunas tierras de sembradura, en la posesión de 97 aranzadas de viñedo. Las labores de arado y picadura son constantes en los primeros años. En este caso la entrega de vino no es un gasto menor, pues se consumen 177 litros/ha el primer año. Hasta que la plantación no tenga cuatro o cinco hojas, la inversión es muy importante. De ahí el incremento del valor de la tierra, caso de estar plantada de viñedo. Sin contar con las tareas preparatorias de la tierra y sin anotar los plantones, cada hectárea se acerca a los mil reales en el primer ańo.

Cuadro 129. Coste del plantío y crianza de 7,66 aranzadas de majuelo en Serrada. Hacienda de León José Moyano. 2a mitad s. XIX

\begin{tabular}{|c|c|c|c|c|c|}
\hline \multicolumn{3}{|l|}{ Primer año } & \multicolumn{3}{|l|}{ Segundo año } \\
\hline Trabajos realizados & Detalle & Coste (rs) & Trabajos realizados & Detalle & Coste (rs) \\
\hline \multicolumn{3}{|l|}{ Vuelta de arado } & \multicolumn{3}{|l|}{ Vuelta de arado } \\
\hline Señalo y ahoyo & Cuatro personas & 500 & Seńalo y ahoyo & 18 obreros & 54 \\
\hline Rehoyo & - & - & \multicolumn{3}{|l|}{ Rehoyo } \\
\hline Vino gastado & 15 cántaros & 105 & \multicolumn{3}{|l|}{ Vino gastado } \\
\hline Relleno & 13 obreros & 39 & Relleno & 5 obreros & 15 \\
\hline Destape y recorte & - & - & Destape y recorte & Vino, atollo y destape & 40,5 \\
\hline Atollo & 13 obreros & 39 & Atollo & 18 rs/aranz. (Abril) & 135 \\
\hline Vuelta de arado & $18 \mathrm{rs} / \mathrm{aranz}$. & 135 & Vuelta de arado & 18 obreros & 54 \\
\hline Picadura & 20 obreros & 60 & Picadura & 18 rs/aranz. (Mayo) & 135 \\
\hline Vuelta de arado & 18 rs/aranz. & 135 & Vuelta de arado & 14 obreros & 42 \\
\hline Picadura & 25 obreros & 75 & Picadura & 3 cántaras & 30 \\
\hline \multicolumn{2}{|l|}{ Vino gastado } & 31,5 & \multicolumn{3}{|l|}{ Vino gastado } \\
\hline Picadura & 20 obreros & 60 & \multicolumn{3}{|l|}{ Picadura } \\
\hline Vuelta de arado & $18 \mathrm{rs} /$ aranz. & 135 & \multicolumn{3}{|l|}{ Vuelta de arado } \\
\hline Picadura & & 35 & \multicolumn{3}{|l|}{ Picadura } \\
\hline Vuelta de arado & 18 rs/aranz. & 135 & \multicolumn{3}{|l|}{ Vuelta de arado } \\
\hline Picadura & 15 obreros & 45 & \multicolumn{3}{|l|}{ Picadura } \\
\hline Vino gastado & 2,5 cántaros & 17 & Vino gastado & Dos vueltas. Agosto & 270 \\
\hline Vuelta de arado & Tres vueltas & 405 & Vuelta. de arado & Dos veces. (12 obreros) & 36 \\
\hline Picadura & 30 obreros & 90 & Picadura & 5,5 cántaros & 55 \\
\hline Vino gastado & 12 cántaros & 96 & Vino gastado & 18 rs/aranz. (Mayo) & 135 \\
\hline Vuelta. de arado & 18 rs/aranz. (Octubre) & 135 & Vuelta. de arado. & 4 obreros & 12 \\
\hline Tapadura de invierno & 6 obreros & 18 & Tapadura invierno & 2 cántaros & 20 \\
\hline Vino gastado & 3 cántaros & 30 & & & \\
\hline \multicolumn{3}{|l|}{ TOTALES } & \multicolumn{3}{|l|}{ TOTALES } \\
\hline \multicolumn{3}{|c|}{ Total primer año } & \multicolumn{2}{|c|}{ Total segundo ańo } & $1.033,5$ \\
\hline \multicolumn{2}{|c|}{ Total una aranzada primer año } & 302,9 & \multicolumn{2}{|c|}{ Total una aranzada primer año } & 134,9 \\
\hline \multicolumn{2}{|c|}{ Total equivalencia hectárea } & 793,3 & \multicolumn{2}{|c|}{ Total equivalencia hectárea } & 353,3 \\
\hline
\end{tabular}

Fuente: Archivo familia Alonso Moyano. Elaboración propia.

1245 A.F.A.M. Carp. de escrituras y varios. Los cuadros que siguen han sido confeccionado tomando como base este archivo familiar. En relación a las unidades de superficie conviene recordar que la aranzada de vińedo en estas tierras la conforman 420 cepas plantadas a marco real, equivalentes a una superficie de 0,4244 ha. La obrada o medida de terreno de sembradura se extiende hasta 0,5659 ha viniendo a ocupar una aranzada tres cuartas partes de una obrada. Ateniéndose a las medidas utilizadas a mediados del XIX entre los labradores de estos pueblos, la concreción es mucho más precisa. Así, en la obrada de 400 estadales de 13,5 pies de lado o de 18 palmos cada uno y contiene una superficie de 72.900 
En el nacimiento de estas cepas está la clave de la vitalidad de Serrada y sus pueblos vecinos. No hay otra cosa que una acumulación extraordinaria de esfuerzo humano. Es esta inversión la que consigue hacer producir frutos a una tierra casi estéril, abandonada al monte hasta la llegada del verdejo. Piénsese que, si estas obradas son valoradas a 200 o 300 reales de 1875, es porque, invirtiendo otros 1.300 reales en trabajos de azada y arado, pueden convertirse en vińas productivas y rentables. Si no hubiera asentado el viñedo sus raíces en estos pagos, es muy posible que este terrazgo siguiera ocupado por montes, retamares o pinares. Ha sido la propia inversión de trabajo la cosecha que se ha cogido año tras año, caso de madurar el fruto adecuadamente y el caldo hacer lo propio en las cubas. Si se echan cuentas, pocos años quedan beneficios más allá del esfuerzo invertido. Esto no es poco y también la clave para entender el sueño de los más desheredados que labran alguna aranzada con burros o azadas.

La crianza de las viñas, pese a estar a finales del XIX, apenas ha variado en sus labores desde los siglos XV y XVI. Tras el conveniente barbechado de la tierra el año anterior y dependiendo del terreno, una aranzada puede llevarse el primer año más de 75 jornales, sin contar las vueltas de arado ${ }^{1246}$.

Cuadro 130. Coste del plantío y crianza de una aranzada de majuelo. Serrada. Año 1875

\begin{tabular}{|c|c|c|c|c|c|c|c|c|}
\hline Trabajos realizados & $\begin{array}{l}\text { Primer año } \\
\text { Labor }\end{array}$ & (rs) & $\begin{array}{l}\text { Segundo año } \\
\text { Labores }\end{array}$ & (rs) & $\begin{array}{l}\text { Tercer año } \\
\text { Labores }\end{array}$ & (rs) & $\begin{array}{l}\text { Cuarto año } \\
\text { Labores }\end{array}$ & (rs) \\
\hline Señalo y ahoyo & - & 100 & - & - & - & - & - & \\
\hline $\begin{array}{l}\text { Majuelos, zarollo, } \\
\text { relleno y acorrullo }\end{array}$ & - & 36,5 & - & - & - & - & - & \\
\hline Rehoyos & - & - & $\begin{array}{l}\text { Primer rehoyo, } \\
\text { hoyas, relleno, } \\
\text { recorte y tapada }\end{array}$ & $\begin{array}{l}17 \\
50\end{array}$ & $\begin{array}{l}\text { Segundo rehoyo. } \\
\text { hoyas, majuelos, } \\
\text { rellenos, tapado } \\
\text { y recortado }\end{array}$ & $\begin{array}{r}8, \\
25\end{array}$ & $\begin{array}{l}\text { Tercer rehoyo, } \\
\text { majuelos, relleno, } \\
\text { recorte y tapadura }\end{array}$ & 4 \\
\hline Vueltas de arado & $\begin{array}{l}8 \text { vueltas } \\
\text { de arado }\end{array}$ & 160 & $\begin{array}{l}8 \text { vueltas de arado. } \\
\text { (A ocho por las } \\
\text { calles y a cinco } \\
\text { por los saetines) }\end{array}$ & 160 & $\begin{array}{l}8 \text { vueltas de } \\
\text { arado a } 20 \text { reales. } \\
\text { (A } 8 \text { por calle y } \\
\text { a } 5 \text { por saetines) }\end{array}$ & 160 & $\begin{array}{l}6 \text { vueltas de arado. } \\
\text { A } 16 \text { reales }\end{array}$ & 96 \\
\hline Picaduras & 7 & 98 & 6 & 35 & 6 & 24 & $\begin{array}{l}5 \text { picaduras y recorte } \\
\text { de podadera }\end{array}$ & 34 \\
\hline Tapadura de invierno & & 2 & - & 2 & - & 2 & - & - \\
\hline $\begin{array}{l}\text { Vino gastado } \\
\text { por los jornaleros }\end{array}$ & - & 56 & - & 18 & - & 12 & - & 12 \\
\hline rs /aranz. & & 452,5 & & 232 & & 206 & 14 & 46 \\
\hline rs/ha & & $1.185,5$ & & 607,6 & & 539,5 & & 82,3 \\
\hline
\end{tabular}

Fuente: A.H.P.V. Protocolos Notariales, Archivo familia Alonso Moyano. Elaboración propia.

pies cuadrados. Se plantan 729 cepas de a 10 pies, 669 a 10,5 pies y 602, si la distancia entre ellas fuera a 11 pies. En ocasiones se hablará de cuartas (una obrada: cuatro cuartas) o en otros términos de fanegas como unidad de superficie (una fanega igual a 450 estadales de 4,5 varas el estadal equivalentes a 0,5030 ha). Se hace necesario conocer entonces las medidas de longitud. Las más básicas son el pie (0,278 metros), la vara castellana (equivalente a tres pies o 0,836 metros) y la cuarta (equivalente a 4 varas o 3,345 metros).

Para mayor información pueden consultarse las medidas y equivalencias que recoge en un apéndice Hilarión Pascual Gete: El viñedo en Tierra de Medina. Memoria de licenciatura, inédito, copia en A.H.P.V., sig. 2108.

${ }^{1246}$ Aunque el valor de los jornales puede variar en relación con la abundancia o escasez de jornaleros y la coyuntura económica, en esta época y comarca oscilan entre los 3 y 4 reales diarios, que se pagan en trabajos de azada, sean de excavo o acobijo. En las vendimias, oscilan notablemente atendiendo a la actividad: Tres reales para los vendimiadores, 3,5 para los cargadores, 8 para los cachicanes, etc. Además, son múltiples los factores que pueden subir o bajar estas cifras, desde el tipo de terreno y cepas hasta si el ajuste lleva o no vino del amo para bebida de los operarios. 
Piénsese que sólo los 100 reales que se anotan de ahoyo representan hasta el 50\% del capital tierra. Al consistir la preparación previa en un mero pase de arado romano, pues no consta en estos pagos la realización de desfondes como aconsejaban los ilustrados de la época, se precisan ahoyos muy anchos y profundos con el fin de mullir la tierra en profundidad, para facilitar el enraizamiento y mantener el tempero. En terrenos cascajosos, la tarea puede ocupar la actividad de cinco obreros durante una semana. El resto de operaciones, una vez metidos los majuelos seleccionados, consisten básicamente en picar y mover los acorrullos para que guarden el tempero y estén libres de malas hierbas. A ello se añaden las vueltas de arado para guardar la humedad y que el mes de agosto no se lleve por delante todo el trabajo realizado. En suma, hasta 452,5 reales consumidos sólo el primer año, que no todas las haciendas podían pagar, pero sí llevar a cabo pequeńos o medianos labradores en sus labranzas, caso de disponer de alguna obrada de sembradura en pagos de tercera o cuarta.

Los dos primeros años son fundamentales para garantizar el futuro de la plantación. Asegurado el agarre inicial y los rehoyos en las faltas, el majuelo será proporcional a la calidad del suelo y al trabajo que se invierta. Antes, en 1875 y hoy. La plantación y crianza siempre exige esmero y dinero. En 1891, en una tasación de daños por conejos en un majuelo de dos años, propiedad de Pedro Alonso Ampudia, aparece un nuevo detalle de estas operaciones. Los trabajos son algo más reducidos, pero los costes proporcionalmente similares: ${ }^{1247}$

Cuadro 131. Coste de crianza de 1.000 cepas. Labores durante dos campańas. Serrada, ańo 1891

\begin{tabular}{lcc}
\hline Labor realizada & Caracteres y coste & Precio total (en reales) \\
\hline Ahoyo & - & 200 \\
Relleno & - & 30 \\
Vueltas de arado & 7 vueltas a 40 reales cada una. & 280 \\
Picaduras & 6 picaduras a 4 obreros cada una. & 108 \\
Reoyo & - & 100 \\
Relleno & - & 22 \\
Atraso & - & 160 \\
TOTAL & - & 900 \\
\hline
\end{tabular}

Fuente: A.H.P.V. Protocolos Notariales, Archivo familia Alonso Moyano. Elaboración propia.

El resto de los años los gastos se reducen notablemente. Si el primer año se lleva el 43,6\% y el segundo el 22,38\% del coste total cuatrienal, el tercer y cuarto año ya sólo representan el 19,8\% y $14 \%$ respectivamente. Con todo, en el citado majuelo de 1875 tan sólo se anota un recorte de podadera al cuarto año, lo que pone de manifiesto la necesidad de algunos años más para que del nuevo plantío los ingresos superen a los gastos. Si las sacas de vinos no van a buenos precios, casi mejor no pensar en los trabajos e inversiones llevadas a cabo.

\section{- De las labores de producción a la entrada de los mostos en las bodegas}

No se tiene intención de convertir estos epígrafes en un tratado agronómico del siglo XIX. Se espera que la exposición ordenada de las labores sirva, a quienes no estén familiarizados con estos términos, un acercamiento a los trabajos que requieren las cepas. Se dice esto porque el viñedo y el vino llevan consigo un componente cultural que no poseen las tierras de sembradura. Las mil variantes que tiene la poda; la forma, profundidad y tiempo en que deben realizarse los excavos, acobijos y reacobijos; la guarda de las vińas; el componente humano de las vendimias...

${ }^{1247}$ A.F.A.M. Carp. de escrituras y varios. Apunte de denuncia a presentar al Sr. Juez de la villa de Serrada, año 1891. 
En relación con los ejemplos analizados en el siglo anterior, es fácil observar que las tareas se repiten de forma idéntica. Se remite a aquellas páginas a quienes no recuerden con exactitud en qué consisten las distintas labores ${ }^{1248}$.

Cuadro 132. Labores, producciones y beneficios en majuelos en Serrada, año 1872

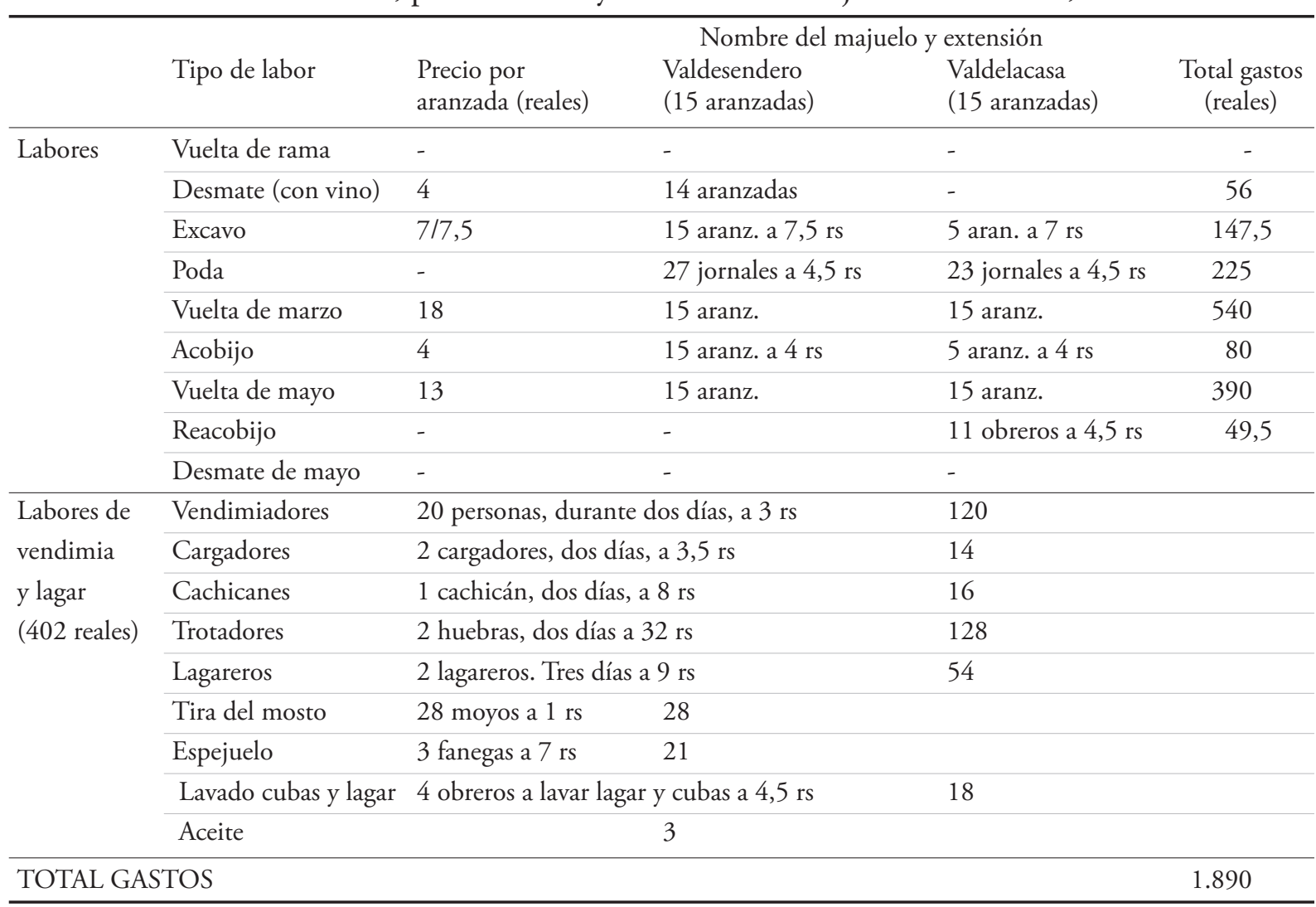

Producción 28 moyos a 16 cántaras cada uno: 448 cántaras.

y venta Cuba trinitaria chiquita: 128 cántaras Cuba del cañón hondo: 320 cántaras

del vino Segunda mitad de febrero. Venta del vino Segunda quincena de abril:

a 10 reales cántara

130,5 cántaras a $10,5 \mathrm{rs} / \mathrm{c}: 1.370,25 \mathrm{rs}$

Desbotes y tragos: 1,5 cántaras $\quad 147$ cántaras a $10,25 \mathrm{rs} / \mathrm{c}: 1.506,75 \mathrm{rs}$

En limpio 126,5 cántaras 31 cántaras a 10 rs/c: 310 rs

TOTAL: 1.265 rs $\quad 8$ de escurriduras a $10 \mathrm{rs} / \mathrm{c}: 80$ rs

En total, exceptuando desbotes y tragos

se venden 316,5 cántaras.

TOTAL: 3.267 reales

TOTAL INGRESOS

Contribuciones territoriales y repartimientos:

537,25

Contribución de 1872 a 1873: cinco talones: 444,5

Repartimientos vecinales: cuatro talones: 92,75

Fuente: A.H.P.V. Protocolos Notariales, Archivo familia Alonso Moyano. Elaboración propia.

${ }^{1248}$ Repetirlas resultaría redundante. No obstante, se observará una característica común y que ya se ha tratado: el importante trabajo manual que es necesario para hacer producir cada ańo unos racimos a cada cepa. Aunque dependerá del majuelo, terreno, cuidados dados anteriormente, año meteorológico, etc., las labores de producción exigen estar pendientes permanentemente. Como puede apreciarse en el cuadro, no todos los años se realizan todas las labores que convienen al cultivo. Su estado o la falta de tiempo pueden hacer que la vuelta de rama de invierno sea sustituida por el desmate (limpieza de hierbas o excabucheo a final de otońo). O que el propio excavo y acobijo no se haga a la totalidad de las aranzadas, sino a las que están más gramosas o, en caso del acobijo, a aquellas partes de los majuelos que requieran una mayor protección ante los rigores invernales. Es el caso de estos majuelos. Y en todo ello un factor fundamental es la disponibilidad de tiempo y de dinero. 
EVOLUCIÓN HISTÓRICA Y TRANSFORMACIONES RECIENTES DE LA AGRICULTURA EN TIERRA DE MEDINA

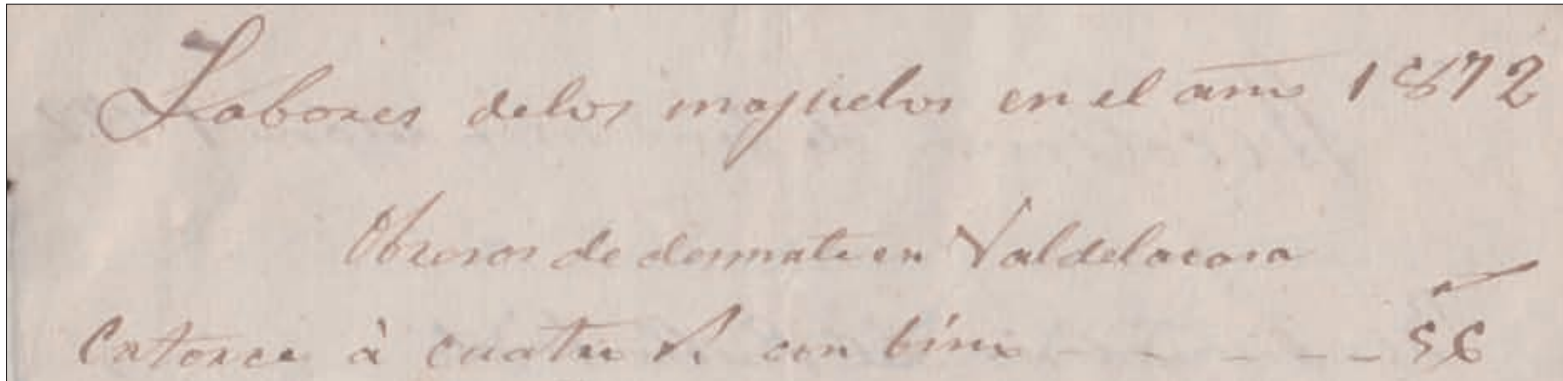
Ecabo à néten conbino

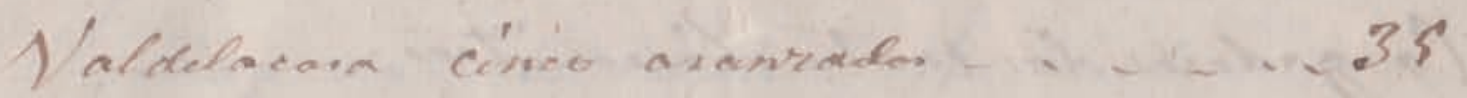

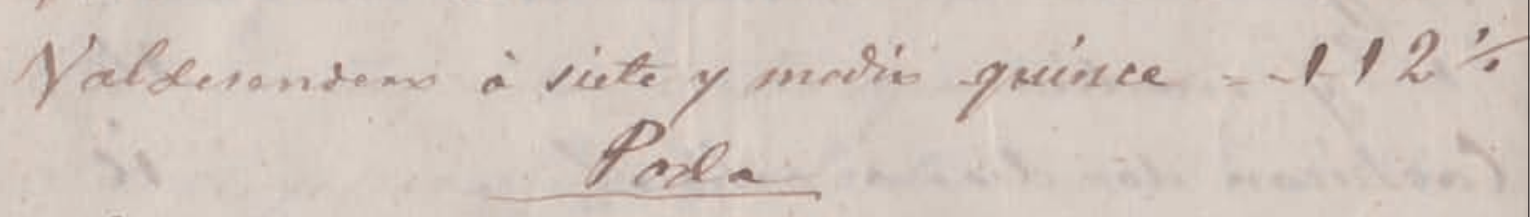
Yaldebacora acintey tren ybexos

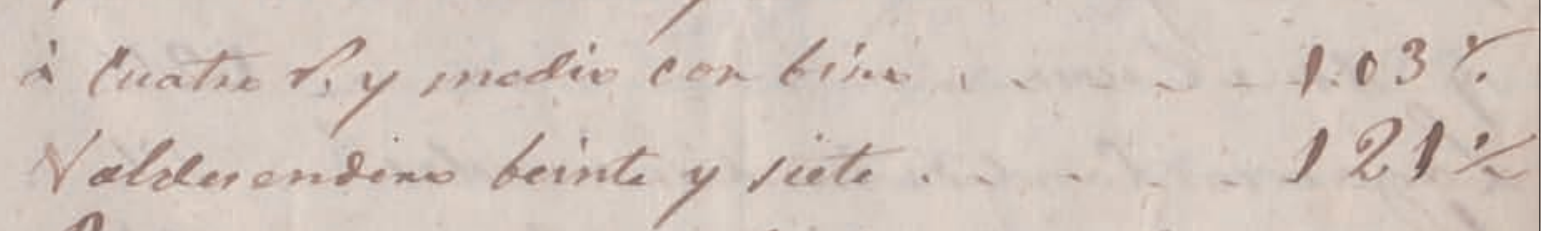

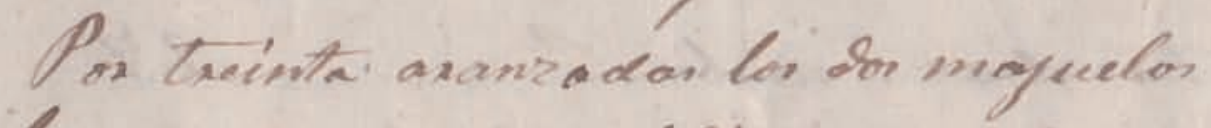

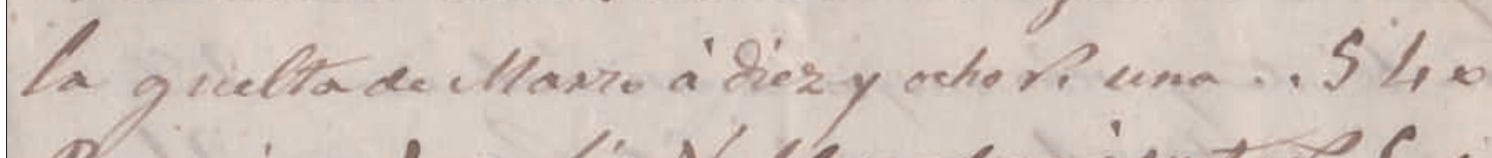
Pox quince de acobijo Yalderendero i euntros. 6 o

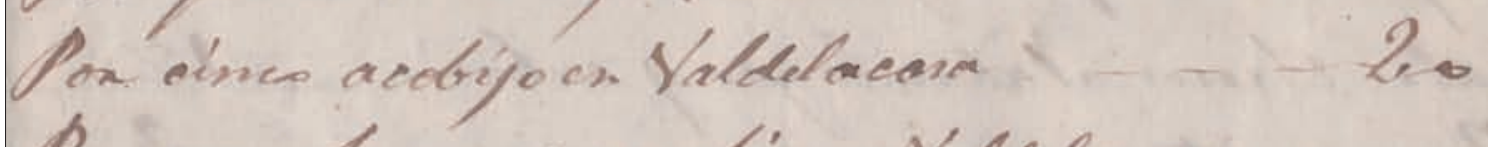

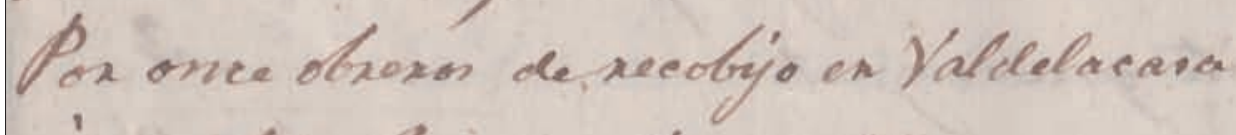

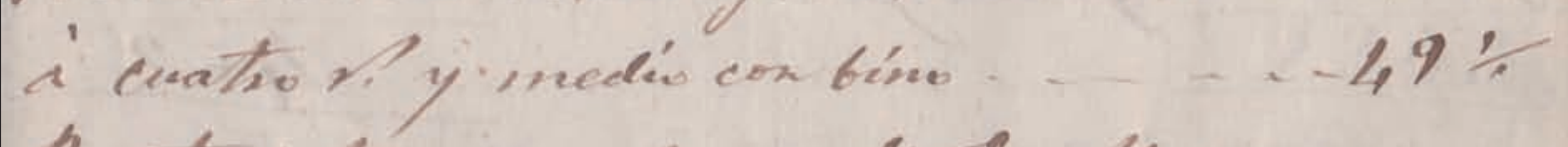
Patucinta amareades quelta de llayo

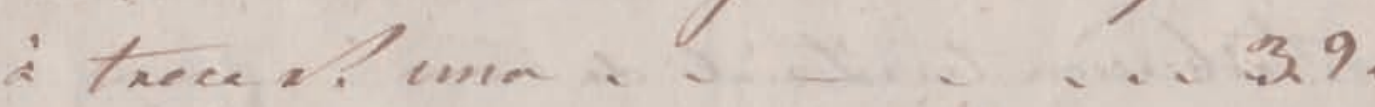
Pon el cuarto trimer tue de tersitoside

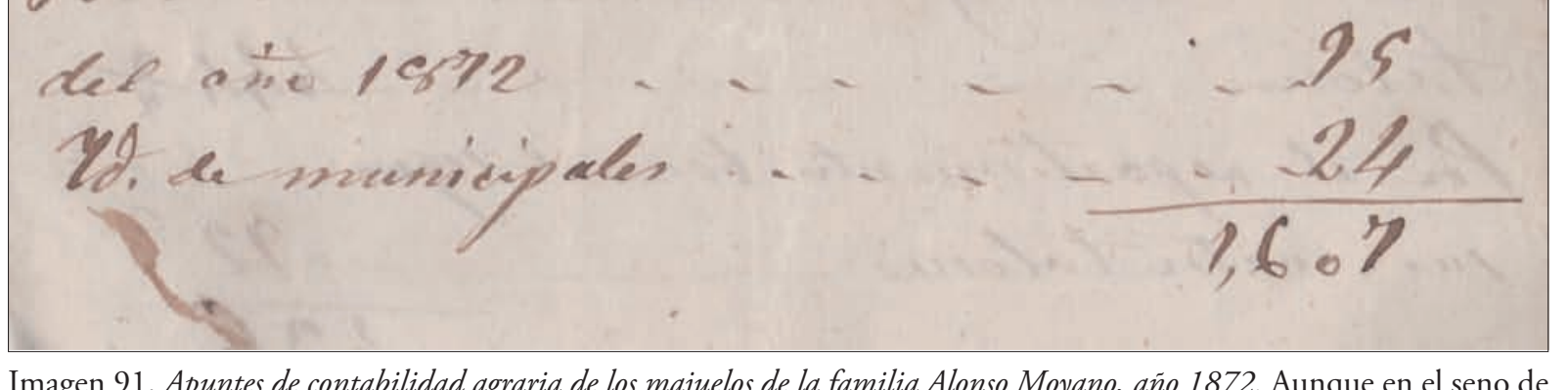

Imagen 91. Apuntes de contabilidad agraria de los majuelos de la familia Alonso Moyano, año 1872. Aunque en el seno de las grandes familias de labradores siempre se llevó la contabilidad de las labores de forma precisa, en la segunda mitad del XIX observamos una especial preocupación, toda vez que la presión fiscal, especialmente el pago de las contribuciones territoriales, puede llevar, en años de mala cosecha, a más de una labranza a situaciones de falta de liquidez o ruina.

$-560-$ 
Cuadro 133. Labores, producciones y beneficios en majuelos. Serrada. Año 1873

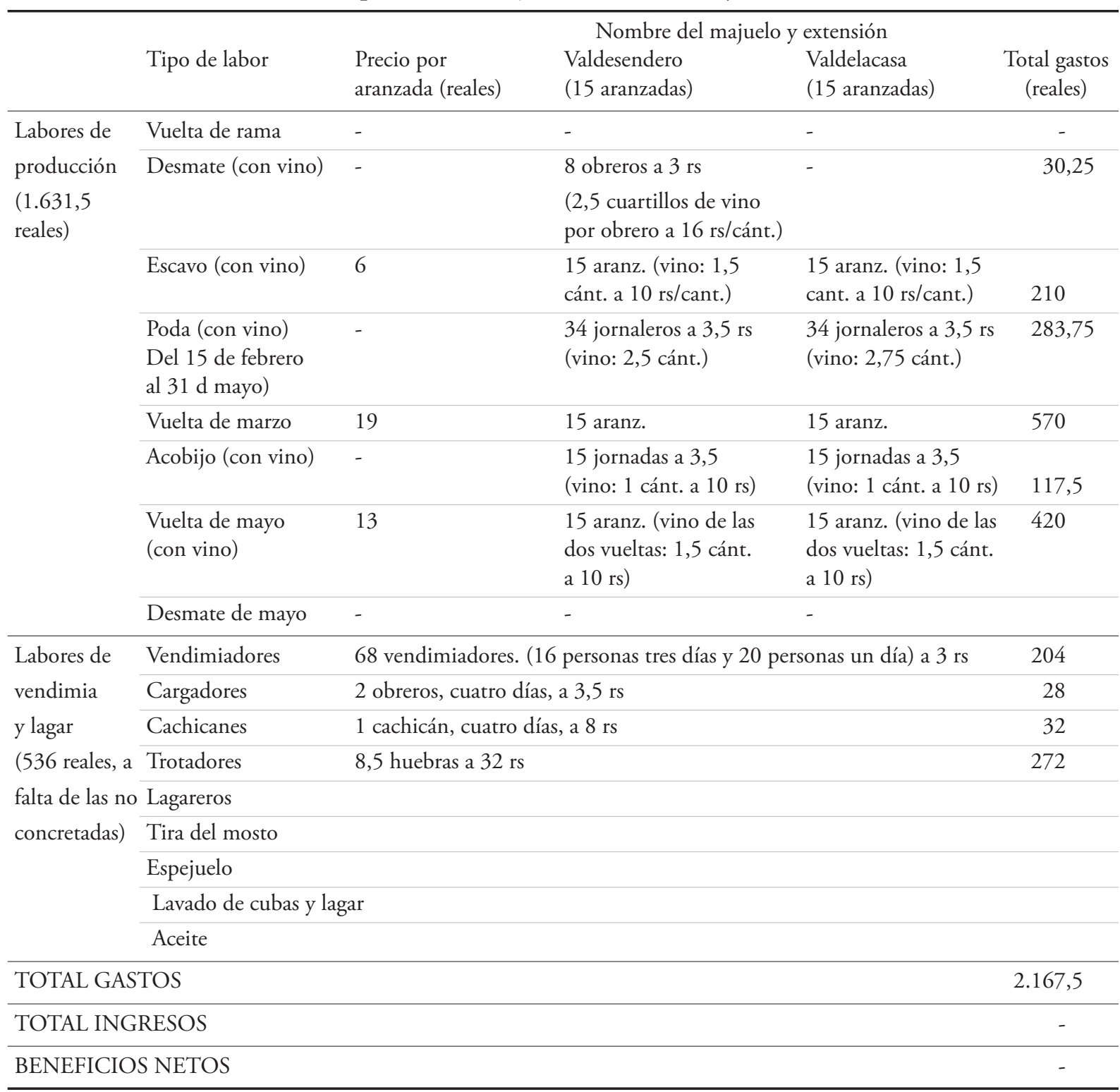

Fuente: A.H.P.V. Protocolos Notariales, Archivo familia Alonso Moyano. Elaboración propia.

Como antaño, la coyuntura por la que atraviese la salida del vino y su precio es fundamental a la hora de explicar por qué en los pagos de viñas abunda la grama o están al día de labor. Recuérdese el precio y estado de muchas aranzadas a finales de la década de los veinte. Avanzada la segunda mitad de siglo, cuando los excedentes salen a encabezar los vinos franceses atacados por la filoxera, los precios impulsan el cultivo y las viñas se trabajan con esmero. Más, cuando existe una abundante masa de jornaleros con salarios de 3 y 4 reales diarios, similares a los que se pagaban en 1833. Salvo los grandes hacendados, con suficiente liquidez para tenerlos bien labrados aunque no venga bien el ańo, la mayor parte de los cultivadores tratan de evitar jornales y realizar las labores familiarmente.

Con todo, la exigencia de mano de obra mantiene ocupada a la clase jornalera en los meses de invierno y primavera. Sólo la poda de las cerca de 1.800 aranzadas de majuelos que hay en Serrada llevaría más de 2.000 jornales de trabajo. Manejen la podadera los pequeños y medianos cultivadores o la lleven los jornaleros. Si a ello se suma el resto de labores y vueltas de arado, se explica la ausencia de emigración en los términos donde abundan las vides hasta que llegue la mecanización. La cifra teórica de aranzadas que un activo, sea mediano labrador o trabaje como "criado" de un hacendado, suele labrar en un año se estima entre 30 y 40, aunque los cálculos teóricos resultan siempre inexactos 
hablando de cosechas y labores campesinas. En este siglo muchos titulares propietarios sólo van detrás de la yunta ocasionalmente, teniendo en cuenta, además, que las labores de los majuelos se entrelazan con las operaciones que requieren las tierras de sembradura.

Cuantas labores de azada, podadera y arado se han comentado suponen, un año con otro, unos gastos de producción de 49,6 reales por aranzada, equivalentes al 78\% del total de gastos. De estos, aun no dando la vuelta de rama como es el caso y reflejan los cuadros adjuntos, la mayor parte se la llevan las yuntas con 31 reales por aranzada (62,5\%) frente a las labores de brazo (18,6 reales o $37,5 \%)$. Piénsese que sólo la vuelta de marzo, en el ejemplo de 1875 , suma 540 reales $(28,5 \%)$. De nada serviría hacer una buena poda si se descuidan las arancias de marzo y mayo ${ }^{1249}$.

Si se puede o el majuelo lo requiere, se reacobija, sobre todo las cepas más jóvenes. De ahí que los jornaleros casi enlazan estas tareas con la siega de la cebada, pero no todos se emplean en el término. Cuando se estudió el siglo XVIII, se documentó que muchos marchan a los pueblos más cerealistas del sur de Medina a buscar siega. A los animales, sin embargo, no les sobra el tiempo hasta llegado el verano. La vuelta de mayo coincide con la última que se daba a los barbechos, a poder ser, antes de Santiago. La comunidad agraria ya había hecho todo por sus cepas. Ahora se las dejaba a merced del calor y de las tormentas de agosto. Recogida la cosecha de pan, no tarda en llegar la vendimia.

Cuando las heladas de primeros de mayo no han sido dañinas y Santa Bárbara ha protegido el fruto, todos se afanan por tener prestas las cubas y apalabrados los lagares, caso de no poseerlos, contratados a vendimiadores, lagareros o tiradores. Pero hasta que no estuvieran vendimiados los majuelos, nada era seguro En agosto de 1870, por ejemplo, una nube se llevó la cuarta parte de la cosecha. Menos mal que por esas fechas buena parte del cereal ya estaba recogido ${ }^{1250}$ :

\begin{abstract}
"Que el pedrisco que descargó en el término de este pueblo la tarde del día catorce anterior, había causado bastante daño en el viñedo... Se observó la dirección de la nube y ha llegado a persuadirse de que el daño causado excede en bastante de la cuarta parte de la cosecha... por lo que para acordar la construcción del expediente y optar al perdón colectivo de la contribución del pueblo, ha considerado necesaria la reunión del Ayuntamiento en sesión extraordinaria para no dejar pasar el breve término de ocho días que conceden las instrucciones para reclamar el perdón."
\end{abstract}

En julio de este mismo año 1872, muchos majuelos quedaron sin vendimiar. El propio Ayuntamiento vuelve a tomar cartas en el asunto ${ }^{1251}$ :

\begin{abstract}
"En la Villa de Serrada, a veinte y seis de julio de mil ochocientos setenta y dos, el Señor Alcalde, Don Agapito de Yscar, asociado de los Seńores concejales cuyos nombres se anotan al margen, se constituyeron en la sala Consistorial en sesión extraordinaria, a la que fueron convocados por cédula ante día, y así constituidos el Señor Alcalde tomó la palabra y dijo: Que por efecto del pedrisco que había tenido lugar el día de ayer, como a la una de la tarde, se hallaba el pueblo, según de público se sabía, verdaderamente consternado y esperando un desgraciado porvenir por la miseria a que quedaba reducido. Que ante tanta calamitosa desgracia no podía permanecer impasible e indiferente y buscaba cuantos medios pudieran conducir a hacer más soportable su angustiosa situación...”
\end{abstract}

$\mathrm{Al}$ igual que sucede en 1847 o unos años antes, el Ayuntamiento trata de que, al menos, se le perdonen al municipio las contribuciones públicas. En aquella época poco más se podía esperar. Respecto a las rentas que había que entregar al marqués de Falces o al señor de Rojas, todos saben que tienen que pagarlas. Ese verano también la vendimia iba a ser más corta y menos alegre ${ }^{1252}$.

${ }^{1249}$ Recuérdese: cuatro surcos formando tres cerros y arado a las dos manos, esto es, cruzando las calles que forman el interlineado de las cepas. Aunque no menor importancia tiene la última vuelta dada en mayo o principios de junio, pero en ésta, ya con las rastras del verdejo caídas al suelo, sólo podía meterse el arado tres veces por calle; de ahí su menor precio.

${ }^{1250}$ A.M.S. Caja 1, carp. 16, fol. 20, 16 de agosto de 1870.

${ }^{1251}$ A.M.S. Caja 1, carp. 18, 26 de julio de 1872.

${ }^{1252}$ No se sabe si ya habrán reparado los lectores, al comparar los datos de los cuadros seleccionados, que con idénticas 30 aranzadas en 1872 se necesitaron 40 jornales para su vendimia, mientras que al ańo siguiente hicieron falta 68 
La vendimia, en cualquier caso, siempre representó en estos pueblos del norte de Medina la culminación de todo el trabajo del año y la esperanza de finalizar el pago de deudas o alcanzar las sumas necesarias para comprar alguna tierra. Nadie quedaba en casa, fuera cual fuera su edad. Lograda una óptima maduración de los racimos, cuanto antes se pisaran, mejor saldrían los vinos.. Por otra parte, nada bueno se derivaba de dilatar el inicio de recogida de las cosechas, una vez estuvieran bien maduras. El descenso de ingresos y el cada vez mayor número de familias empobrecidas había acentuado la costumbre de hacerse demasiado amigo de lo ajeno, en lo tocante a panes y racimos. En 1874, el Ayuntamiento ha de nombrar dos guardas hasta que se termine de recoger la uva ${ }^{1253}$. No debió ser suficiente a tenor de lo que se escuchó en el Pleno tres años más tarde ${ }^{1254}$ :

"En la Villa de Serrada a las once de la mañana del día doce de agosto de mil ochocientos setenta y siete,...se manifestó por el Sr. Síndico D. Florentino Martín, que no habiendo ya frutos de cereales o legumbres en el campo se nota ya que se dirigen todos los ataques contra el viñedo, ya introduciendo caballerías al pasto y con el pretexto causando dańos con las mismas, ya con el de cortar forraje y escobas causando daño en el fruto y arrancando este sin madurar con fines demasiado escandalosos y criminales, pues de años anteriores se sabe por oídas que varios vecinos a quienes ni una cepa se les reconoce propia, han dado por pienso a los cerdos uva durante la época de madurez y recolección, siendo necesario que el Ayuntamiento, de acuerdo con la Junta de Propietarios y Labradores tome serias providencias y vea el mejor medio de hacer respetar sus disposiciones..."

Sobra reproducir en su totalidad el texto. Aparte de redoblar la vigilancia mediante los guardas que al efecto estaban para este fin, se escribe al Gobernador de la provincia "suplicando se digne mandar una pareja de la benemérita Guardia Civil fije aqui su residencia o acantonamiento como así lo concedió en el año próximo pasado con cuyo auxilio se logró ver respetados el principio de Autoridad y las Propiedades".

Al margen de las uvas, se entrevé el comienzo de unas tensiones sociales que ya no tendrán freno. Por lo que toca a la vigilancia de los frutos del campo, las denuncias entre unos y otros fueron el pan de cada día entre vecinos. De ahí la estricta regulación de las distintas tareas agrícolas, sobre todo del espigueo en las tierras de pan y del comienzo de la vendimia y las normas para el rebusco en los majuelos. La fecha de comienzo fue haciéndose coincidente para evitar desagradables sorpresas en majuelos situados entre las rayas de los términos. El inicio se fijaba tras acuerdo del Ayuntamiento y posterior fijación de bandos en los sitios de costumbre. El cuatro de octubre del último año citado se acordó su principio para el 12 del mismo mes ${ }^{1255}$.

durando la recogida un día más. ¿Cómo era posible que, si en el primer año los jornaleros cobraban 4,5 reales diarios, al año siguiente, aunque fueran compensados con vino, sólo se llevaron a casa 3,5? ¿Por qué cargadores y cachicanes fueron contratados el doble de días? La explicación hay que buscarla mirando al cielo. El nublado menguó las arcas a los que más tenían, vació los bolsillos de los más pequeños y quebró las esperanzas a todos. Piénsese que, siendo las labores de vendimia de 1873 al menos un 25\% más caras (536 reales a falta de anotar importantes partidas no anotadas, frente a los 402 reales de 1872), sin embargo el coste total de producción se redujo en un 12.8\%. La piedra del 26 de julio. Una pena que no se hayan conservado los datos de producción de uva y transformación y venta de los mostos. Aunque dicha falta es un aliciente para seguir investigando, no tiene mérito haber deducido que el precio de la cántara en 1873 se pagó a 10 reales en Serrada, mientras que la de un año antes sólo atendió a 7. La reducción de la cosecha hizo subir los precios.

${ }^{1253}$ A.M.S., caja 2, carp. 20, fol. 29, año 1874.

${ }^{1254}$ A.M.S., caja 2, carp. 23, 12 de agosto de 1877.

${ }^{1255}$ Esta fecha, coincidente con la Virgen, se repite en numerosas ocasiones. En 1876, por ejemplo. Este año, además de no haber apedreado, regresaron muchos de los que se hallaban formando parte de los ejércitos que pacificaron en febrero las Provincias Vascas y Navarra. Aparte del toque de campanas y dulzaina de La Seca, D. León Adanero, dueño de la vacada que pastaba en la antigua dehesa de San Martín, ahora de D. Juan Pombo, ofreció una suelta de vaquillas. Pero no se flexibilizaron las precauciones de las tareas de vendimia por la alegría. La sesión del 7 de octubre no deja sombra de dudas. (Ibídem). 


\begin{abstract}
"Se declara dar principio a la vendimia general del término el día doce del corriente, y dos días antes puedan vendimiar los que no teniendo lagar presenten en debida forma el parte a la autoridad, previo el aviso de los linderos según lo dispuesto en varias Reales Ordenes sobre vendimia. También por unanimidad se acordó que por el Sr. Alcalde se fije el Bando de costumbre a fin de impedir desmanes y la introducción de fruto clandestino así como todas las demás faltas y atropellos contra la propiedad".
\end{abstract}

Las autoridades de estos pueblos tratan de evitar a toda costa conflictos entre el vecindario. No hay que olvidar que en estas semanas toda esta comarca medinense estaba llena de cientos de vendimiadores comarcanos y del norte de Castilla, Asturias y la Montańa. Los primeros como vendimiadores, los segundos como lagareros y tiradores de mosto. Si en 1873 se necesitaron 2,26 jornales para vendimiar una aranzada y, de acuerdo a las aranzadas en producción, se cifrarían en torno a 4.500 jornales sin contar a cargadores, trotadores, tiradores de mosto y demás operarios. Era imprescindible, por tanto, la estancia de un buen número de forasteros en todos los pueblos del contorno. De hecho, para garantizar la llegada anual de estos contingentes de trabajadores, en sesión de 30 de septiembre de 1877 el Ayuntamiento de Serrada acuerda socorrer con 50 cts de peseta diarios a los mozos "de Asturias que es costumbre inmemorial reclamar para el servicio del vecindario, los cuales por una equivocación imposible ya de remediar se han presentado en esta villa antes del día señalado para dar principio a la vendimia”256. Corriendo el riesgo de ser reiterativos, es conveniente reproducir al pie en su totalidad las normas de vendimia del año $1878^{1257}$.

Nada queda al azar en estos días de actividad febril. Los lagares y las cubas han sido preparados y todos los majuelos, recorridos y vigilados en el último tiempo de maduración. El Ayuntamiento nombra una comisión de reconocimiento, encargada de inspeccionar los distintos pagos, antes de proceder a discutir la fecha general en que ha de "principiar" la vendimia. Los propios bandos municipales como el que se entresaca son reveladores del interés municipal en evitar conflictos entre el vecindario, daños a majuelos o personas o perjuicios producción de vino local. En el acta municipal del 12 de octubre de 1879 en que se acuerda la vendimia para el día 16, se apunta incluso como primer apartado de las normas de vendimia "Que antes y durante la vendimia, nadie podrá introducir uva en aguaderas o cabanillas para colgar o tender, ni aún bajo el pretexto de alegar ser de su propiedad, sin licencia por escrito de la autoridad, en la población"1258. Todo sea, como se repite unos ańos tras otros, "a fin de impedir desmanes y la introducción de fruto clandestino asi como todas las demás faltas $y$ atropellos contra la propiedad"1259.

${ }^{1256}$ A.M.S., caja 2, carp. 23, fol. 36, año 1877.

1257 "Primero. Que se anuncie al vecindario por los medios de costumbre que el día siete del próximo octubre es el designado para dar principio a la vendimia.

Segundo. Que aquellos que por no tener lagar o por otra cualquier causa le fuere de reconocida necesidad verificar la recolección de las uvas antes del día prefijado, podrán hacerlo el cinco y seis del dicho mes, siempre que, cuarenta y ocho horas antes, por lo menos, lo participen a esta Alcaldía por escrito y duplicado, y además cumplan respecto a los colindantes con las disposiciones dictadas sobre la vendimia.

Tercero. Que el que así no lo haga así incurra en la multa de dos pesetas, cincuenta céntimos, que satisfará en el papel creado al efecto sin perjuicio de aplicarle las accesorias...

Cuarta. Que antes de dar principio a esta nadie podrá introducir vino en la población, ni aun bajo el pretexto de alegar ser de su propiedad, sin licencia por escrito del Alcalde o quien autorice.

Quinta. Todo el fruto que se coja antes de salir el sol y después de puesto será decomisado y considerado como de mala procedencia, siendo los contraventores puestos a disposición del Juez Municipal para su inmediato castigo.

Sexta. Nadie podrá dar principio a la rebusca sin que se haya terminado por completo la vendimia, y sin que preceda en publicación señalando día por medio del oportuno bando que dictará la Autoridad para conocimiento del vecindario.

Séptimo. Los pastores o ganaderos no podrán introducir en el viñedo sus ganados hasta tres días después que se haya terminado la rebusca.

Octavo. Se prohíbe correr a otro paso que el regular caballerías o carruajes por las calles de la población y caminos concurridos, yendo al efecto los mozos de mulas puestos sobre ellas y los de los bueyes delante.

Noveno. Y por último, que los infractores de la anteriores disposiciones serán castigados con la multa de tres a diez pesetas." (A.M.S., caja 2, carp. 24, fol. 38, 28 de septiembre de 1878). 
A partir de este momento, son los propietarios de las viñas los que dictaminan en qué majuelos empezar, de acuerdo con el grado de maduración, riesgo de podredumbres o proximidad entre las piezas. La disponibilidad de lagares o la colaboración en estas tareas entre los pequeños y medianos labradores es otro factor relevante. El hecho de conceder licencia, anticipando la vendimia a aquellos que carecen de lagares, es un claro indicador. Se trataba de recoger la uva, una vez madura, en el menor tiempo posible y aprovechando todo el potencial humano de la villa. Es claro que, recogida y pisada la uva de los pequeños pelucheros, estos se pondrían al servicio de los grandes propietarios. Piénsese que el deseo de obtener mostos con altos contenidos de azúcares en estas vendimias tardías de octubre podría venirse abajo, caso de ponerse el tiempo de lluvias, sin olvidar, además, que la sementera estaba ya abierta. De ahí la concentración de todos los activos en estas tareas.

Si se atiende al detalle de las labores anotadas en los cuadros anteriores, cada operación se valora de forma distinta con relación a la cualificación, fuerza física o aporte de caballerías que cada trabajador lleve a cabo. Pero los vendimiadores serán siempre los que reciban menor salario. Repartidos en cuadrillas en las haciendas de mayor tamańo, son los cachicanes los que regulan tanto la intensidad de su trabajo como el buen orden entre los componentes. De ahí que saber estar, el conocimiento de los majuelos, sus lindes y caminos de acceso y la experiencia acumulada sea valorada hasta alcanzar la nada despreciable suma de ocho reales diarios. Por lo demás, la corta y recogida de la uva sigue la rutina de pasados siglos. Hombres y mujeres se afanan en ello a lo largo de todo el día. Distintos apuntes de contabilidad de estos jornales, guardados en archivos particulares, señalan de forma indistinta a su sexo a vendimiadores locales o comarcanos. La presencia infantil debía de ser más frecuente en las cuadrillas familiares donde toda ayuda era poca. Informes vinícolas provinciales de estos años hacen constar como "mujeres y niños de diez años en adelante... recogen el fruto en cuévanos de mimbre..." 1260.

Los cargadores ayudan a los vendimiadores a llevar los cuévanos a los cestos, pero su principal función consiste en la subida y colocación de dichos recipientes en los carros para el traslado del fruto. Cargadores y trotadores se ajustan con las grandes haciendas, donde se hacía necesario el rápido traslado de los carros a los lagares. Eran semanas en que los pequeños yunteros, una vez recogida su cosecha, al ser reclamados por sus vecinos más pudientes, se ganaban unos días de huebras, a la nada despreciable suma de 32 reales.

En el momento en que la uva entraba por las lagaretas al lagar, se iniciaba el proceso de pisado y prensado de la uva. Los 9 reales diarios pagados a los lagareros es un indicador tanto de la necesaria cualificación como del intenso trabajo que requerían estas labores. De ahí que fueran realizadas por los criados de confianza, los jornaleros experimentados del pueblo y los llegados un año tras otro de las montańas del norte. Los lagareros se encargaban del pisado y prensado de la uva, al tiempo que los tiradores transportaban o hacían conducir el mosto a las cubas donde iniciaba el proceso de fermentación. Se iniciaba el último pero más importante y delicado proceso: hacer con las uvas un buen vino.

\section{- Del pisado de la uva a la transformación de los mostos}

Cuando se estudiaba el cultivo del viñedo al final del Antiguo Régimen e incluso en épocas anteriores, se indicaban, de forma pormenorizada, las labores que exigían los majuelos así como las características de los caldos. En cierta manera los sistemas de producción y elaboración apenas han cambiado en estos siglos. De ahí que estos apartados no sean sino una continuidad con respecto a aquellos tiempos, que en muchos aspectos continuarán hasta bien entrado el siglo XX. De hecho y

${ }^{1258}$ A.M.S., caja 2, carp. 26, fol. 14, año 1879.

1259 A.M.S., caja 2, carp. 22, fol. 35, año 1876.

1260 A.M.A. Leg. 87, exp. no 45: “Información vinícola de la provincia de Valladolid”. (Citado por Hilarión Pascual Gete: "La Tierra de Medina. Siglos XVI al XVIII. Los viñedos de la antigua Tierra de Medina". Memoria de licenciatura, 1973, Inédito. A.H.P.V., sig. 2108). 
desde tiempos lejanos, todos estos pueblos se habían cuidado de que la uva verdeja entrara por las lagaretas bien cargada de azúcares para garantizar buenas fermentaciones. Todavía los más mayores recuerdan el regreso a diario de mujeres y niños, tras la jornada de vendimia, con bolsillos y fardeles llenos de uvas pasas que se cogían a puñados. O cómo a algunos el agua del pozo les servía para acabar de llenar las cubas o rematar los pellejos ante mostos tan azucarados. El juicio estudiado en la Rueda de 1830 es un claro ejemplo que indica, además, la pervivencia de prácticas vitivinícolas ancladas en la tradición, junto a saberes científicos modernos que trataban de imponerse en el arte de elaborar vino. Los 13,5 y 14 grados que se apuntaban en los mostos del citado conflicto, que se creen comunes en la mayor parte de las partidas de uva de todo este tiempo, eran la consecuencia lógica de las anteriores prácticas vitícolas. La vendimia rara vez empezaba antes del día del Pilar y casi siempre se alargaba ocupando toda la segunda quincena de octubre. De ahí que, alcanzado este alto punto de maduración, se hiciera esencial exprimir cuanto antes el racimo.

Estas tareas de lagar y bodega han sido siempre las más delicadas y secretas. Lo siguen siendo hoy. Con idénticas uvas pueden salir vinos totalmente dispares, atendiendo a cubas, bodegas, manos y paladares. En estos ańos de 1870 y 1875, aún no constan innovaciones en los sistemas de prensa o movimientos de los caldos que diferencien a grandes o pequeños labradores. El sistema común de pisado y prensado sigue girando en torno al lagar de viga y piedra o prensa romana, descrito en anteriores capítulos. A partir de estas fechas, sin embargo, no tardarán en introducirse tolvas y cilindros metálicos manuales que exprimen los racimos en primera instancia, sustituyendo al primer y tradicional pisado de la uva ${ }^{1261}$.

En estas tareas se afanan en jornadas agotadoras los lagareros. Recibían por las lagaretas los cestos, transportados desde el majuelo por los trotadores, para, de forma inmediata, proceder a su estrujamiento con pies, mazos y palas. El primer mosto de yema discurría por la canaleta que comunicaba el piso de piedra del lagar con el pilón donde se recogía el mosto. En muchos casos bastaba el desnivel dado al piso para que el zumo discurriera por sí sólo. Acto seguido, procedían a colocar hollejos, pulpa y rampojos al pie de la viga, pudiéndose acumular, de acuerdo a las dimensiones de esta y del lagar, hasta 50 cargas de uva en cada pie, del que se derivaba por carga entre 4 y 6 cántaros de mosto. La colocación y nivelación de los tablones, puentes y marranos debajo de la viga, así como el manejo del husillo para subir la piedra y que ejerza la presión, eran labores que llevaban a cabo los lagareros más experimentados, bajo la atenta mirada de los dueńos de los lagares. Finalizado el primer prensado, había que bajar la piedra, desmontar el castillete, picar el pie y volver a prensarlo hasta conseguir extraer el último mosto. Como indican los apuntes de contabilidad resumidos en los anteriores cuadros, para pisar y prensar 28 moyos (448 cántaras obtenidas de 10.300 kilos de uva), se empleaban a fondo 2 lagareros durante tres días a 9 reales diarios, salario tres veces superior al de un vendimiador y que indica tanto la cualificación como la fatiga que reclamaba la uva para poder ser transformada en mosto.

Pero aquí no se acababa la tarea. En realidad empezaban las más delicadas e importantes. Antes de iniciarse la fermentación, los tiradores llenaban los pellejos en los pilos o pilones donde se acumulaba el zumo para su traslado a hombros a las cubas o cocederas donde debía fermentar. En ocasiones, existían conducciones desde los pilos a las cubas pero no siempre la uva que se pisaba en un lagar era de su titular por lo que debía ser trasladado a la bodega del propietario. Otras veces la insuficiencia de cocederas en la bodega donde se hacía el prensado hacia necesario el traslado a cubas sitas en otros lugares. Recuérdese también la anticipación de la vendimia dos días para aquellos que,

${ }^{1261}$ Por estas fechas y a través de exposiciones, publicaciones o distribuidores de máquinas agrícolas, se intensifican las recomendaciones para la adquisición de artefactos que economicen esfuerzos y tiempos en las distintas tareas. (La Asociación Agrícola por la Iniciativa Privada. Revista de Agricultura. Valladolid, 1869-1874, tomo I, abril 1869-marzo 1870, pág.41). 
no teniendo lagares, debían utilizar aquellos con cuyos dueños se conviniesen. En cualquier caso, el traslado se hacía en pellejos a hombros de asturianos y leoneses que se contrataban, mediante acuerdos, con caporales de dichos lugares por las distintas poblaciones.

La llegada de estos trabajadores nos consta desde al menos el siglo XVII, en que los distintos concejos y caporales suscribían obligaciones mutuas para tener garantizada la labor de mostería. Cuando el Ayuntamiento de Serrada socorre las necesidades de estos mozos asturianos que llegaron en 1877 antes de tiempo, no duda en manifestar tanto la "costumbre inmemorial de reclamarles para el servicio del vecindario" como la labor que realizan dado "que el servicio de dichos mozos en una época tan afanosa como la vendimia redunda en beneficio de todos los cosecheros de vino, los cuales les necesitan unos más que otros, sin que sea fácil fijar la proporción de beneficio que cada uno de estos haya de recibir de los expresados mozos de tira"1262. De ahí que su paga sea en relación a moyos trasladados, sea desde el pilón a las cubas, sea también el traslado del vino añejo no vendido a otros recipientes, para hacer hueco a la nueva cosecha. Organizados por el caporal o responsable de la cuadrilla, buen conocedor por la experiencia acumulada año tras año de las bodegas y necesidades de cada cosechero, se trataba de que los mozos a su cargo realizaran la labor en el menor tiempo posible, para evitar que la fermentación se iniciara antes de que el mosto llegara a la cuba.

No es necesario apuntar los desvelos porque el mosto no entrara en contacto con yesos y cal de paredes o suelos, hierros u otras sustancias. El trasvase de malos sabores al futuro vino podía arruinar o desprestigiar a cualquier cosechero. De hecho, la limpieza de cubas y lagares tiene ocupado en este ejemplo a 4 obreros. En estos años, sin embargo, se echa a las uvas, en el momento de su pisado, un espolvoreado de espejuelo en cantidad de una fanega cada nueve moyos aproximadamente. El uso de estos terrones de yeso, para tratar de conseguir fermentaciones homogéneas y completas, es característico de este último tercio del XIX por parte de muchos cosecheros de Tierra de Medina que tratan por todos los medios de evitar pérdidas en sus cosechas y comienzan a incorporar los tratamientos que recomiendan distintos tratados enológicos. ${ }^{1263}$ De hecho, el espejuelo ha seguido utilizándose hasta avanzada la década de los 30 del siglo XX. Otra práctica que se alienta por los entendidos es el azufrado de las cubas, tanto para su conservación después de ser lavadas, como para evitar el deterioro de los vinos en la operación del trasiego. ${ }^{1264} \mathrm{El}$ empleo del azufre será general a fines del siglo XIX, si no en los trasiegos, pocos numerosos, sí a la hora de desinfectar cubas o mermada alguna pipa por la venta de parte de su contenido. De cualquier manera, desde estas fechas el azufre va a convertirse en uno de los aliados más eficaces de todo cosechero. No se olvide que, al margen de la utilización mencionada, el producto se había revelado como indispensable en el combate contra el oídium, enfermedad criptogámica que alarmará a estos labradores a comienzos de este último tercio del XIX y antes de que comenzara a hacer estragos la filoxera. ${ }^{1265}$

${ }^{1262}$ A.M.S., caja 2, carp. 23, fol. 36, año 1877.

${ }^{1263}$ Distintos autores como A. García de la Puerta, en su Tratado práctico del cultivo de la vid o arte de hacer el vino (Valladolid, 1836-1842, 2 vols.), recogen y actualizan las distintas formas de elaboración. El ingeniero Teodosio Lecanda, por ejemplo, colabora de forma habitual con la Revista de Agricultura de la "Asociación por la Iniciativa Privada" con resúmenes de las distintas operaciones de elaboración de los caldos para que puedan ser seguidos por los lectores cosecheros de los distintos pueblos de la provincia. En 1869 (tomo I, pág. 41-4), advierte a los lectores que la falta de tonicidad y el sabor seco que tienen nuestros vinos blancos es una de las principales causas por las que son poco apreciados por los extranjeros. Recomienda incluso que, para corregir y mejorar la tonicidad, se vendimie más temprano o se adicione agua al mosto con el fin de que no pasen de 11 por ciento de alcohol y quede alguna cantidad de azúcar sin descomponer. El uso de espejuelo o yeso para ayuda de la fermentación puede verse igualmente en la "información vinícola” del A.M.A. de 1885 (leg. 87, exp. no 45. Citado por Hilarión Pascual... El viñedo..., (ob. cit., pág. 169-170).

${ }^{1264} \mathrm{El}$ azufrado de las pipas se realiza introduciendo en ellas un platillo con una mecha de azufre ardiendo, hasta que esta deja de arden por falta de oxígeno. Acto seguido, se retira, evitando que caigan restos de azufre en el fondo, y se tapona la pipa con celeridad. (T. Lecanda. Sobre Vinificación..., ob. cit., pág. 27).

${ }^{1265}$ En julio de 1875, la Junta Provincial de Agricultura publica una circular en el Boletín de la Provincia en que se hace eco de la alerta y amenaza que está suponiendo la extensión de la filoxera en los viñedos europeos. Se inicia el 
Sin adelantar acontecimientos, conviene advertir que esta última y letal enfermedad ya afectaba en 1875 a distintos países europeos y también, desde la cuenca del Duero portuguesa, avanzaba recorriendo el valle hacia la frontera española. ${ }^{1266}$ Los nuevos tratamientos y técnicas de vinificación resultarán fundamentales para asegurar la rentabilidad del cultivo a pequeños o grandes cosecheros, antes de que la plaga filoxérica haga tabla rasa a finales de siglo con la mayor parte de la superficie plantada.

Pero los mostos de 1872 y 1873 estaban a punto de cocer en las cubas. Los labradores cosecheros de vino ya habrían pagado individualmente al caporal los moyos "tirados" por los mosteros ${ }^{1267}$, en tanto en la oscuridad de la bodega solo rompía levemente el silencio el burbujear de los azúcares conforme van transformándose por la acción de las levaduras. En el ejemplo de la gráfica, la producción está repartida en una cuba de 128 cántaras (2.048 litros) y otra mayor de 320 (5.120 litros), que representan en general las capacidades medias de las cubas destinadas a fermentar y conservar los vinos en esta comarca. Distintos estudios coetáneos señalan tanto las ventajas de estas grandes capacidades, que abrevian la primera fermentación tumultuosa, como el inconveniente para la segunda fermentación o fermentación latente, dado que no permite que el vino desarrolle todos los principios que contiene. Igualmente se seńalan los perjuicios de estas cubas tan grandes a la hora del azufrado, limpieza y trasiego. Para esta última labor se señala como aconsejables la preferencia por pipas de 15 a 30 cántaros, aunque se necesiten locales mayores, así como la utilización de la madera de roble, preferentemente del norte de Europa y de los Estados Unidos ${ }^{1268}$.

Pero una cosa eran las recomendaciones de los ingenieros agrónomos y otra la práctica cotidiana que se llevaba a cabo en las bodegas. La mayor parte de las cubas no se reponían, conforme mandaban los estudios teóricos, porque las cosechas y precios no daban para tantos lujos. Otro tanto ocurría con el desaconsejable uso de la pez para que las cubas más deterioradas fueran tirando. Aún a comienzos del siglo XX, era rara la bodega que no disponía de una tinaja conteniendo dicho producto. $\mathrm{O}$ los tres trasiegos que se recomendaba hacer en diciembre, febrero y marzo. La tradición secular los reducía a uno sólo tras el proceso de clarificación, realizado generalmente con sangre de toro o de buey ${ }^{1269}$. La tradición chocaba con la modernización de forma constante en este último tercio del XIX. Nuevos métodos tratan de mejorar el producto de cara a un mercado cada vez más exigente,

escrito aludiendo al oídium, dominado gracias al azufre, pero temiendo que la nueva calamidad pueda tener unos efectos devastadores en estos campos, la dirección de Agricultura llama la atención a los viñeros dejando entrever la importancia de salvar las cepas a tiempo, pues "la ruina de las viñas extranjeras puede acrecer de un modo fabuloso el valor de los vinos españoles, de sí tan estimados”. (B.O.P.V., año 1875,fecha: 15 de julio de 1875)

${ }^{1266}$ Ibídem, pág. 4.

${ }^{1267}$ En apuntes de contabilidad de 1880, el vecino de Serrada Mariano Martín hace constar la paga a los mosteros de ciento veinte y tres moyos, que vienen a ser el equivalente de una cosecha en torno a 31.488 kilos de uva. Mariano Martín Navarro dirige una buena hacienda de viñedo y de tierras de sembradura, propias y arrendadas. El Amillaramiento de 1881 lo sitúa como décimo mayor propietario de Serrada con 46,19 ha en propiedad, de las que 72,5 son aranzadas de vińedo. Según los apuntes del Archivo de la familia Martín Santos sobre los moyos recogido en 1883, se obtuvo una producción media aproximada por aranzada de 434 kilos de uva por aranzada en caso de que todos los majuelos sean de producción. El señor Martín Navarro se casa con Gregoria Moyano y Moyano en Valladolid en enero de 1883. Fueron padrinos José Alonso Fadrique y Gabriela Moyano Zamora y testigo Perfecto Moyano, todos pertenecientes a la clase propietaria y pudiente de Serrada.

${ }^{1268}$ La Asociación Agrícola por la Iniciativa Privada. Revista de Agricultura. Valladolid, 1869-1874, tomo I, Abril 1869- marzo 1870, T. Lecanda. Sobre Vinificación..., ob. cit., pág. 26.

${ }^{1269}$ De forma tradicional, los vinos en este siglo XIX seguían clarificándose con clara de huevo, pero, sobre todo, dadas las grandes cantidades que producía la comarca, con sangre de toro o buey. No tardarán en comercializarse productos gelatinosos, derivados del pescado o la propia sangre del vacuno en seco, para conseguir arrastrar todas las impurezas de los caldos y hacerlos con la mejor presencia, de cara al mercado. El proceso consistía, en caso de hacerse con clara de huevo, en batir una clara con un poco de vino por cada cántara que se quiera clarificar y luego verter la mezcla, removiendo al tiempo el contenido del tonel. La sangre de vacuno macho será la más utilizada hasta las primeras décadas del XX. Su empleo, caso de ser en fresco, se realizaba de forma inmediata, es decir, antes de que se coagule y en la proporción de un cuartillo para cuatro cántaras, mediante el mismo proceso que el descrito para las claras. (La Asociación agrícola..., ob cit., vol. II, año 1870, pág. 258). 
a la vez que las viejas prácticas tratan de remediar los viejos males o las imperfecciones de una elaboración que no tardará en sufrir transformaciones definitivas. Hay que referirse al uso de tierra de La Nava para corregir la acidez o el picado de los vinos, al cabeceo mediante vino añejo o alcohol de destilación para prevenir el avinagramiento, al echado de arrope en las cubas y al calentamiento del caldo "cuando el vino perdía liquidez y formaba hebra como el aceite".

No se quiere entrar en el detalle de tamaños males. Pese a las importantes pérdidas que se derivaban de las viejas prácticas, la uva verdeja y sus azúcares habían ganado la partida durante siglos a estas imperfecciones de elaboración, aun cuando, a finales de siglo, se conocían sobrados métodos para remediarlas. Pero la adquisición, por ejemplo, de azufradores, tolvas metálicas, bombas de trasiego, mangas de lona o goma o filtros para los pasos, aunque estaban a la venta en la misma capital vallisoletana, en los años 1860 y 1870, sólo fueron entrando en los lagares y bodegas de los mayores hacendados y cosecheros conforme avanzaba el último tercio del siglo. En Serrada no hay constancia de ellas hasta entrado el siglo XX. Los grandes cosecheros de la comarca asistían a concursos y exposiciones provinciales y estaban al tanto de las novedades y nuevas técnicas que se mostraban en los distintos depósitos de maquinaria y publicaciones sobre el particular, pero no siempre las incorporaron a sus haciendas. Sin embargo, gracias a los premios o a las menciones honoríficas sobre los vinos que presentaban a concursos, se conocen con precisión las cualidades de estos caldos de hace casi siglo y medio.

Entre los premiados por la Diputación de Valladolid en la "Exposición Castellana” celebrada en septiembre de 1860, se encuentran algunos de los grandes cosecheros de la comarca. ${ }^{1270}$ A Vicente Pimentel, de Rueda, premian con medalla de plata tanto sus "vinos blancos graves y espirituoso" como su "vinagre superior y aromático". De esta misma localidad reciben medallas o menciones honoríficas Mariano Jimeno, por sus vinos blancos espirituosos; Manuel de Guillamas, por sus blancos; Pedro Bayón, por sus blancos secos, y Jorge Ruiz, por su espíritu de vino superior a 40 grados. Estaba claro que los ańejamientos de la comarca eran muy estimados en este tiempo y que el alto grado alcohólico, derivado de los mostos verdejos, permitía buenas conservaciones. A Josefina Delayen, de La Seca, se le hace lo propio con su espíritu de vino y a Dionisio Arias, de Nava del Rey, se le premian en este año de 1860 vinos añejos de 1851 y 1853, que prueban la resistencia de estos caldos. Estos premios no deben tampoco engańarnos. En ocasiones el ańejamiento no era sino una consecuencia obligada de la falta de ventas, ya que, por otro lado, las partidas propensas al avinagramiento se destilaban para poder ser vendidas como aguardiente.

No es el caso de las 448 cántaras de 1872 que se estudian. Su venta se inicia a 10 reales en la segunda mitad de febrero y terminan de vaciarse las cubas a finales de abril, aunque, como anteriormente se ha puesto de manifiesto, al haber sido un año de reducida cosecha en Serrada a causa del pedrisco, es probable que el vino elaborado tuviera una mejor saca. Desde mediados de siglo, se constata un incremento de los caldos que se destilan, sea para encabezar otros, sea para evitar el deterioro y pérdida del contenido de alguna pipa picada. Esta labor se realiza mediante alquitaras o pequeñas instalaciones que se prestan, dejan o arriendan entre cosecheros vecinos, Así, por ejemplo, "el catorce de enero de 1874 llevo el Sr. Gregorio Alonso la alquitara para empezar a quemar; el quince la llevaron Patrón y Francisco el sacador. La trajeron Patrón y Pascual Alonso el día 26 de febrero de 1875 a la nochecer"1271.

Con todo, se observa una preocupación cada vez mayor por dar gusto a las nuevas exigencias de los mercados y un afán de ser competitivos en el exterior. Al tiempo que se siguen elaborando los tradicionales vinos blancos con elevada graduación, surgen experiencias nuevas. Ha resultado una novedad conocer que a los señores Pimentel y Bayón se les concede la medalla de oro, en la citada exposición de 1860, por sus "vinos espumosos, tinto clarificado, aguardiente, cognac y vinagres. Por la superior calidad de

1270 B.O.P.V. Boletín no 8, año 1860. Fecha: 17-1-1860.

${ }^{1271}$ A.F.M.S. Carp. de escrituras, s/c. 
los vinos espumosos, elaborados al modo de Champagne, su baratura, y la importancia de esta industria en el país, apreciando los esfuerzos de los espositores" ${ }^{\prime 272}$. Nada mejor en este sentido, para finalizar este epígrafe dedicado al vino, que transcribir de forma literal las observaciones realizadas por el jurado de Asociación Agrícola de Valladolid en el concurso y estudio de 200 muestras de vino remitidas por distintos cosecheros españoles, en el año 1871. De las conclusiones publicadas sobre las muestras, se desprenden tanto las inercias tradicionales en los procesos de elaboración, las innovaciones que de forma progresiva se van incorporando, como el interés por la calidad y el gusto de la época para hacer posible su exportación ${ }^{1273}$.

Don Marcelo del Río. Bodega de Villanueva de Duero. Valladolid.

Muestra número 1. Este vino contiene 15,2 por 100 de alcohol. Su color es un poco verde, y para evitar esto es preciso ponerle más subido, si él no lo coge de suyo, con un poco de azúcar quemado. Además, está poco limpio, y por ello urge mucho clarificarlo con cola de pescado disuelta en agua (gelatina), añadiéndole una cucharada de tanino por cada dos cántaras. De esta forma, se activa su clarificación. El vino en cuestión es bueno y tiene un gusto agradable. El cosechero debe hacer fermentar el mosto en un pilo de madera, pues los lagares de piedra quitan mucho color. Esta práctica es la única necesaria para hacer una buena vinificación. Lo que llevamos dicho se hace extensivo a las muestras número 2 y 3 y nos parece, sin embargo, que el vino de la cosecha del $6^{\circ}$ se hizo con uva poco madura, así que, recomendamos a este cosechero que vendimie siempre, a pesar de todo, que el fruto haya llegado a su completa madurez, para traerlo al lagar. En el estado en que se encuentra hoy este vino, no puede exportarse al extranjero; solo si tiene salida para el N. De la Península. Ha merecido un diploma de $2^{\text {a }}$ clase, que podrá recoger abonando un franco de medio real.

\section{b. Las tierras de sembradura. Cultivos, rendimientos y precios}

Si los condicionantes edáficos y la importante superficie arrendada marcan el binomio cereales/viñedo, la variedad de cultivos en las tierras de sembradura ha de pagar similares tributos. Los labradores del XIX, como sus antecesores, podían obligar a las tierras de segunda a dar trigo, si los arrendatarios preferían este grano como pago en sus rentas; echar las tierras del marqués de lo que gustasen dada su feracidad, pero nunca contrariarían a la naturaleza sembrando cebada en los cascajos o trigo en las peores tierras. Tenían por cierto que aquel año no segaban. De ahí que, hasta que el siglo XX no aporte masivamente nuevas técnicas, abonado, maquinaria y agua, los rendi-

1272 B.O.P.V. Boletín no 8, año 1860. Fecha: 17-1-1860.

${ }^{1273}$ Junto a la mención transcrita anteriormente, las que siguen ofrecen toda una completa información sobre los gustos de la época y atenciones que requiere el vino, tanto al norte como al sur de la Tierra de Medina:

-Señor Don Julián García. Pozaldez. Valladolid. El vino de este Sr. Contiene 11,7 por 100 de alcohol. Para esta clase de vinos es muy poco, y si no se ha conseguido más, es por haber hecho la recolección de la uva demasiado temprano. El producto de que nos ocupamos aparece algo turbio, y es menester trasegarlo y clarificarlo añadiéndole una cucharada de tanino por pipa. Además, se necesita azufrarlo, y sería también muy conveniente encabezarlo hasta 16 grados con alcohol de vino, pues entonces, sería un vino riquísimo y susceptible de conservación. En el estado en que hoy día se encuentra, solo puede tener salida en el país. Ha obtenido el cosechero un diploma, que podrá recoger remitiendo un sello de medio real.

-Don Antonio Sánchez. Nava del Rey. Valladolid. Estos vinos contienen respectivamente 14,15 y 15,7 por 100 de alcohol. Son vinos blancos y la calidad de las seis muestras que ha presentado si no fuera por la diferencia de grados, sería poco más ó menos la misma. Entre los vinos blancos, pocos se han mandado mejores al concurso, y así se comprende, cuanto observamos que la elaboración se ha hecho con mucho esmero. Sin embargo, hemos reparado que existen posos de una materia calcárea que nos hace suponer que el vino ha sido clarificado pocos días antes de embotellarlo, o que el producto mineral que ha servido para la clarificación, no era muy limpio. En un vino tan bueno, esto es un defectillo, que aconsejaríamos se corrigiera. En su tiempo se indicará el momento de emplear esta materia calcárea que puede dar mejores resultados, aun cuando se la eche encima de una primera clarificación con gelatina o materias albuminosas. Para concluir; estos vinos son excelentes. Se comprende que el cosechero es inteligente y observador, pero no por eso debe descuidar de clarificar el producto otra vez; y con frecuentes trasiegos, verá su conservación mucho tiempo, teniendo la satisfacción dentro de poco de poderlo entregar al comercio extranjero. La Asociación además de felicitarle cumplidamente, le concede un diploma de $1^{\text {a }}$ clase, y le recomienda a todos los vinícolas como muy entendido en la elaboración de esta clase de vinos. 
mientos seguirán dependiendo más del cielo que de la voluntad del ser humano. Y por más que se han examinado inventarios y repartos de bienes de los vecinos de Serrada según avanzaba el siglo, no se encuentra ninguna novedad técnica, ningún nuevo artefacto mecánico. Ni siquiera entre las familias más pudientes que se supone son conocedoras de las distintas exposiciones que organiza, por estas fechas, la Diputación Provincial ${ }^{1274}$.

Cuadro 134. Producciones anuales de cereal y leguminosas en Medina del Campo, su partido judicial y otros pueblos limítrofes, año $1854^{1275}$

\begin{tabular}{|c|c|c|c|c|c|c|c|}
\hline PUEBLOS & $\begin{array}{r}\text { Trigo } \\
\text { (en fanegas) }\end{array}$ & $\begin{array}{r}\text { Centeno } \\
\text { (en fanegas) }\end{array}$ & $\begin{array}{r}\text { Cebada } \\
\text { (en fanegas) }\end{array}$ & $\begin{array}{r}\text { Avena } \\
\text { (en fanegas) }\end{array}$ & $\begin{array}{r}\text { Algarrobas } \\
\text { (en fanegas) }\end{array}$ & $\begin{array}{r}\text { Garbanzos } \\
\text { (en fanegas) }\end{array}$ & TOTAL \\
\hline Medina del Campo & 36.000 & 4.000 & 38.000 & 1.000 & 4.000 & 1.500 & 84.500 \\
\hline Rueda & 24.000 & 3.000 & 27.000 & 800 & 3.000 & 1.000 & 58.800 \\
\hline La Seca & 18.000 & 2.000 & 19.000 & 500 & 2.000 & 500 & 42.000 \\
\hline Nava del Rey & 50.000 & 4.000 & 46.000 & 2.000 & 10.000 & 4.000 & 116.000 \\
\hline Torrecilla & 36.000 & 4.000 & 38.000 & 1.000 & 4.000 & 1.500 & 84.500 \\
\hline Alaejos & 50.000 & 4.000 & 46.000 & 2.000 & 10.000 & 5.000 & 117.000 \\
\hline Siete Iglesias & 25.000 & 2.000 & 23.000 & 1.000 & 5.000 & 2.500 & 58.500 \\
\hline Cantalapiedra & 50.000 & 4.000 & 46.000 & 2.000 & 10.000 & 3.000 & 115.000 \\
\hline Castrejón & 20.000 & 2.000 & 20.000 & 1.000 & 3.000 & 1.000 & 47.000 \\
\hline Rubí de Bracamonte & 20.000 & 2.000 & 20.000 & 1.000 & 3.000 & 800 & 46.800 \\
\hline Bobadilla del Campo & 20.000 & 2.000 & 20.000 & 1.000 & 3.000 & 800 & 46.800 \\
\hline El Carpio & 16.000 & 1.000 & 8.000 & 500 & 1.000 & 300 & 26.800 \\
\hline Fresno el Viejo & 25.000 & 4.000 & 23.000 & 1.000 & 5.000 & 1.500 & 59.500 \\
\hline Villaverde & 16.000 & 1.000 & 16.000 & 500 & 1.000 & 500 & 35.000 \\
\hline $\begin{array}{l}\text { Los pueblos restantes } \\
\text { del Partido }\end{array}$ & 154.000 & 22.000 & 140.000 & 3.000 & 25.000 & 3.000 & 347.000 \\
\hline TOTAL & 560.000 & 61.000 & 530.000 & 18.300 & 89.000 & 26.900 & 1.285 .200 \\
\hline
\end{tabular}

Fuente. A.M.M.C. Estado que demuestra la recolección de fanegas de trigo. Elaboración propia.

Podía más la inercia de la costumbre, la baratura de los jornales y que muchas de las tierras de pan eran ajenas a novedades técnicas no suficientemente contrastadas. El pago de rentas era otro aspecto que detraía aportes de capital a pequeñas y medianas labranzas que hubieran podido ser más madrugadoras en estos aspectos. De ahí que hay que situarse en niveles continuistas, tanto en los porcentajes de siembra de los distintos cultivos, como en la evolución de sus rendimientos.

Ello lleva a plantearse no pocos interrogantes. ¿Cómo explicar el sostenido aumento de producciones que tiene la agricultura de sembradura medinense si no se observa una revolución en cuanto a los rendimientos por obrada? Un factor, ya apuntado en el anterior epígrafe, fue el incremento de la superficie. Pero los porcentajes, sin embargo, no acaban de explicar el sostenido incremento de productos que se generan para el mercado foráneo. Hay otro elemento fundamental que rompe la inercia de siglos del campesinado castellano. Es el cambio progresivo que se produce en el sistema de rotación de cultivos. Hasta ahora se ha constatado el aplastante dominio de la distribución del terrazgo en hojas de año y vez, dejando al barbecho blanco enseńorearse de la mitad del terrazgo de sembradura. Sin embargo, en la Tierra de Medina se constata, a partir de mediados de siglo, un considerable

${ }^{1274}$ En el año 1860, la Diputación entrega los Premios en la categoría de material agrícola tras la celebración de una magna exposición en la ciudad. Figuran entre otras novedades premiadas un rodillo desterronador, una sembradora montada en la esteva de un arado, un arado de reja triangular con vertedera de chapa, etc. (B.O.P.V., ańo 1860).

1275 A.M.M. "Estado que demuestra la recolección de fanegas de trigo y demás productos agrícolas en la Villa de Medina del Campo y demás pueblos de su partido judicial y otros limitrofes, calculados en un año común; su movimiento mercantil y otras cosas que se acumulan, para alimentar al ferrocarril del Norte por la línea de Ávila y su tránsito por esta villa, remitido hoy por el Sr Alcalde al Gobierno de S. M. con exposición a la Reyna (27 de marzo y 12 de abril de 1854)". 
incremento de la superficie y producción de leguminosas que entran en rotación con los cereales, sean algarrobas, guisantes o garbanzos. Este crecimiento de las leguminosas, que representa un 9,01\% de la producción total y porcentajes superiores en cuanto a la superficie sembrada, ya que sus rendimientos por obrada son inferiores a los cereales, constituyen una de las grandes novedades de la agricultura comarcal en este periodo. Por un lado, contribuirá a solucionar el problema crónico de la alimentación ganadera que estaba viendo disminuir la superficie de pasto derivado del proceso desamortizador. Las leguminosas grano, y consta también su aprovechamiento en verde, unidas al centeno y a la cebada como productos de alimentación animal, incentivan a escala general una expansión de la cabaña ganadera, su mayor integración en el espacio agrario y, de paso, el incremento del número de las obradas estercoladas cada año, aspecto fundamental en todo el proceso ${ }^{1276}$. Al mismo tiempo, conocido su efecto mejorador sobre el terrazgo, contribuyen, si no a aumentar los rendimientos de los cultivos con los que entraban en rotación, dada la reducción de la superficie barbechada, al menos a mantenerlos, con el consiguiente aumento general de la producción.

De unos y otros aspectos derivarán estos importantísimos y sostenidos incrementos de la producción, clave para entender el dinamismo agrario de la comarca, sostener el ya referido aumento demográfico e impulsar el desarrollo de otros sectores. No en vano el alcalde de Medina, en la relación que envía a S. M. del "Estado que demuestra la recolección de fanegas de trigo y demás productos..." para "alimentar el ferrocarril del Norte por la línea de Ávila y su tránsito por esta Villa" y de paso convencer a las autoridades gubernamentales de la apuesta de ésta como un importante nudo ferroviario, hace constar no sólo la existencia de un importante excedente comercializable sino también de su constante crecimiento. Añadidas a las cifras de la cuadro anterior la concurrencia de los aportes de Zamora y Salamanca al mercado medinense, y restadas las cantidades locales consumidas, "da por resultado un sobrante de seis millones, dos mil arrobas castellanas, y, según el aumento progresivo de los frutos en relación con las mejoras que constantemente se suceden en las operaciones agricolas, puede suponer un aumento actual de quinientas mil arrobas por término medio" 1277.

Esta generalizada apuesta por las leguminosas estará en Serrada, sin embargo, condicionada por el vińedo, los suelos, la tenencia de la tierra y la atomización de explotaciones. Aunque no consta el desarrollo de la rotación leguminosas/cereales sí la existencia de similares excedentes de producción que los pueblos del partido. La explicación la proporciona la protesta elevada en mayo de 1868, por un grupo de vecinos y propietarios, ante las inexactitudes de los trabajos que llevó a cabo la junta pericial del Ayuntamiento y que pudieran perjudicar administrativamente a la villa ${ }^{1278}$ :

\begin{abstract}
"Los que subscriben, vecinos y propietarios de la misma, habiendo visto y examinado detenidamente loa trabajos hechos por la junta pericial, no pueden menos de reclamar de agravios por las ocultaciones que en ellos se hallan, y que según creen los exponentes perjudican a la riqueza en general cuando menos en un dos por ciento. Consisten dichas ocultaciones en haber puesto todas las tierras como sembradas con un año de intermisión, siendo público y notorio que hay sembradas sin esta más de cien obradas de primera y segunda calidad...”
\end{abstract}

${ }^{1276} \mathrm{El}$ estiércol se convertirá en un producto muy demandado por los principales cultivadores. De hecho, y a diferencia de tiempos anteriores en que entre los ganaderos no abundaban los grandes poseedores de tierra, es ahora cuando estos se hacen con grandes rebaños. En los contratos de arrendamiento o cesiones de estos se especifica la obligación de la basura como uno de los elementos que retribuir al dueńo de las reses. En el convenio entre Gregorio León Alonso como ganadero y José Domínguez como mayoral del rebaño de su propiedad, consistente en 134 ovejas, 18 carneros, 119 borregos y 69 corderos, se rubrica que ha de quedar "a mi beneficio el abono... que estas producen".(A.F.A.M. Carp. de acuerdos y varios. Convenio entre Gregorio León Alonso como ganadero y José Domínguez. Año 1843). Igualmente, en los arrendamientos que firma D. José María de Rojas en 1863, respecto a los pastizales de San Martín, con los ya mencionados vecinos de Pedrajas, se hace constar en su cláusula séptima "Que todo el abono, basuras o estiércol que produzcan las reses quedara como propio del D. José." Estaba claro que un hombre de negocios, avecindado en Valladolid, no quería el estiércol para llevárselo a casa. De sobra sabía la fuerte demanda que tenía el producto por aquellas fechas. (A.H.P.V. pt. 11957, Serrada, Cenón Martínez, fol. 151, año 1863.

1277 Ibídem.

${ }^{1278}$ A.F.A.M. Instancia de protesta. A los ” Sres. Presidente e individuos del Ayuntamiento de esta Villa.” Año 1868. 
He aquí la explicación de por qué en este término tan sólo se anotaran en 1857 veinte obradas de garbanzos y ocho de guisantes, sin que conste ninguna de algarrobas. No obstante, la presencia de ellas para completar la alimentación del ganado fue creciendo. Los granos recolectados que se apuntan en los inventarios de bienes dan fe de ello. En el que se ejecuta en 1862 a la muerte de Sebastiana Aparicio, casada con Justo Obregón, se refieren 28 fanegas de trigo, 14 de centeno, 14 de cebada, 7 de algarrobas y 5 de guisantes ${ }^{1279}$, Cuando las sementeras lo permitían, muchas tierras de primera y segunda se retelan de cebada o trigo, dejándolas descansar al tercer año.

Este hecho parece dejar en papel mojado las rigurosas prohibiciones que reflejan los contratos de arrendamiento en lo tocante a la mudanza de las hojas, tanto en Serrada como en toda la comarca. ${ }^{1280}$ Es el principio del fin de la tradicional división en hojas de año y vez. Hasta entonces y aunque se ocultan por motivos fiscales, siempre hubo algunas obradas ocupadas por melonares, garbanzales u otras leguminosas, pero siempre fueron minoritarias y destinadas completamente al autoconsumo. Ahora, en cambio, y a tenor de las cifras que proporcionan las primeras reseñas estadísticas, los valores de superficies y producciones indican que se está ante una nueva encrucijada. Piénsese que, en el caso de Serrada, cien obradas de primera o segunda calidad, aunque tan solo representan la décima parte de la superficie sembrada, pueden equivaler hasta un 30\% o 40\% respecto a la producción global, dadas las diferencias entre rendimientos de estas con respecto a las de tercera y cuarta.

En la contestación del Ayuntamiento en sesión de 31 de mayo a la anterior instancia, se atribuye tal falta a los propios cultivadores que no declaran tales aprovechamientos cuando "debieran de signar las fincas en qué consiste la ocultación, como igualmente los Dueños, ora como propietarios, ora como colonos y cultivadores". Estas nuevas prácticas fueron posibles, tal como se viene insistiendo, por la conjunción de los factores mencionados: mayor población, mayor demanda de productos, aumento del ganado de tiro y disponibilidad jornalera. Son el aumento de esfuerzo humano y animal y el incremento de la superficie sembrada, más que las innovaciones técnicas, las causas directas del crecimiento de las cosechas, amparadas, como ya ha quedado expuesto, por la favorable coyuntura del mercado harinero y los efectos de las medidas liberales que afectaron al campo español.

La expansión triguera que vive Castilla y se hace sentir en toda la comarca se refleja de forma notable en Serrada, alcanzando las 700 obradas y acaparando el 66,03\% de la superficie total de cereales. Este altísimo porcentaje, en un término en que las tierras de primera y segunda no rebasan el $14 \%$ del total de sembradura, pasará factura a los labradores de la villa a la hora de recoger la cosecha, pues no superarán las 6 fanegas por obrada. La explicación son los altos precios del cereal, que duplican a los que posee el resto de cultivos cerealísticos, que inclinan a los labradores a su siembra, repitiendo en muchas ocasiones su cultivo, y a los arrendatarios a exigir la renta en esta especie.

1279 A.H.P.V. Pt. 11957, Serrada, Cenón Martínez, año 1862, fol. 6.

${ }^{1280}$ Una de las cláusulas obligadas en todo contrato de arrendamiento era la prohibición de mudar las hojas, estando estas determinadas por su ubicación en el terrazgo. El incremento de siembras de leguminosas sobre pajas provoca, en ocasiones, la reacción de los propietarios que no dudan en incluir de forma expresa precisiones a este respecto. En Serrada y en toda la comarca. Cuando D. Mariano de la Devesa, propietario de Medina del Campo, arrienda en 1874 ocho obradas a Dionisio Nieto, labrador de Moraleja de las Panaderas, por ocho fanegas de trigo, pagando además el arrendatario todas las contribuciones, precisa en el contrato que las fincas estén "bien cultivadas, a ley de buen labrador y a dos hojas, sin poderlas sembrar de legumbres a desoja”. (A.H.P.V. Pt. 18084, Gil Terradillo, Policarpo. Medina del Campo, fol. 686-689). Unos años más tarde, cuando se siente cercana la crisis, muchos propietarios tratan de velar por la fertilidad de sus tierras arrendadas, incluyendo cláusulas al respecto. En 1881, en el arrendamiento que se firma en Medina del Campo entre D. Ignacio Pérez y el propietario D. Ramón Bocos Quijada y Marza se estipula "Que el D. Ignacio Pérez Felipe ha de labrar y cultivar las cinco tierras que recibe en renta a ley de buen labrador y a dos hojas, dándolas las labores y vueltas necesarias, estercolarlas y sin rebujar las varbecheras para evitar que se esquilmen, sin poder tampoco destruir lindes, mojones...”. (A.H.P.V. Pt. 18113, Medina del Campo, Gil Terradillos, año 1881, fol. 1413). 
Las cifras lo dicen todo. El trigo, a 32 reales fanega, aunque sólo se obtenga 6 fanegas por obrada, logra unos rendimientos brutos totales del $67,25 \%$ del total del total de los ingresos de cereal. El riesgo de forzar a dar trigo a pagos que no estaban dotados para ello merecía la pena. La ambición la pagarían el centeno y la avena que, arrinconados en las tierras de cuarta, con rendimientos que estaban al límite de la rentabilidad, no conseguían, pese a representar el 26,41\% de lo sembrado, superar el $7,1 \%$ en el computo total de rendimientos. Algo de culpa tenía la cebada que, sembrada en las mejores tierra de vega y con producciones por encima de muchos pueblos comarcanos ( 40 fanegas obrada), cuadruplicaba con 51.200 reales de beneficios brutos a sus hermanos de pienso, ocupando tan sólo el 7,5\% del terrazgo. Gracias a ella, se podía asegurar la alimentación del ganado en las épocas en que los prados estaban acotados.

Cuadro 135. Cultivos, rendimientos y precios en tierras de sembradura. Serrada. Año 1857

\begin{tabular}{|c|c|c|c|c|c|c|}
\hline \multirow[b]{2}{*}{ Cultivo } & \multicolumn{2}{|c|}{ Superficie } & \multirow{2}{*}{$\begin{array}{c}\text { Rendimientos } \\
\text { (fanegas/obrada) }\end{array}$} & \multirow{2}{*}{$\begin{array}{l}\text { Producción total } \\
\text { (fanegas/obrada) }\end{array}$} & \multirow{2}{*}{$\begin{array}{c}\text { Precio } \\
\text { fanega (rs) }\end{array}$} & \multirow{2}{*}{$\begin{array}{c}\text { Ingresos brutos. } \\
\text { Total (rs) }\end{array}$} \\
\hline & Obradas & $\%$ & & & & \\
\hline Trigo & 700 & 66,03 & 6 & 4.200 & 32 & 134.400 \\
\hline Cebada & 80 & 7,54 & 40 & 3.200 & 16 & 51.200 \\
\hline Centeno & 250 & 23,58 & 3 & 750 & 16 & 12.000 \\
\hline Avena & 30 & 2,83 & 5 & 150 & 15 & 2.250 \\
\hline Total cereales & 1.060 & 100 & & 8.300 & & 199.850 \\
\hline Algarrobas & - & - & - & - & - & - \\
\hline Guisantes & 8 & - & 5 & 40 & 15 & 600 \\
\hline Garbanzos & 20 & - & 6 & 120 & 70 & 8.400 \\
\hline Total leguminosas & 28 & - & - & 160 & & 9.000 \\
\hline Patatas & - & - & - & - & - & - \\
\hline Rubia & 4 & - & $\begin{array}{r}100 \\
\text { (arrobas) }\end{array}$ & $\begin{array}{r}400 \\
\text { (arrobas) }\end{array}$ & $\begin{array}{r}5 \\
\text { (arroba) }\end{array}$ & 2.000 \\
\hline Total otros cultivos & - & - & - & - & - & - \\
\hline TOTAL & - & - & - & - & - & 210.850 \\
\hline
\end{tabular}

Fuente: Archivo familia Alonso Moyano. Elaboración propia.

Escasamente significativa, para finalizar, como puede apreciarse en el cuadro, es la presencia de rubia. Pasado el impulso ilustrado, la competencia de tintes extranjeros y la localización de la industria textil fuera de este ámbito pondrán fin al sueño de Ponz y los suyos. De la misma manera, de haber seguido vivos, hubieran sufrido tremendamente al ver las resistencias de la población a aceptar el cultivo de la patata. La propaganda oficial no lograba evitar la resistencia de la sociedad a este cultivo. Asturias es un buen ejemplo de ello, aunque el cultivo logra un impulso extraordinario en las montañas de Burgos mediada la década de los $70^{1281}$. En el caso de estas tierras, salvo contados años en que se ha detectado sembrada en Serrada y en San Martín del Monte, tendrá que esperar a final de siglo, aun cuando hubiera sido gran aliviadora de las penurias alimentarias en que casi siempre estaban sumidas las clases más débiles.

\section{- El análisis de una explotación cerealista}

Es fácil advertir que nadie en esta comarca vivía de forma exclusiva de las tierras de sembradura. Las 20 obradas que tomamos de ejemplo pertenecen al aniversario y vínculo detallado en líneas anteriores. La ausencia en ellas de la cebada se explica por la calidad mediana e inferior de las distintas piezas. Con todo, dado lo pormenorizado de las labores que se detallan, las hace representativas del cultivo cerealista en este tiempo. Si el barbecho continuaba enseñoreándose a mediados del XIX de la

${ }^{1281}$ GARCÍA FERNÁNDEZ, J.: Sociedad y organización del espacio en Asturias. Biblioteca Julio Somoza. Temas de investigación asturiana, 1980, pág. 112-118 y ORTEGA VALCÁLCER, J.: La transformación de un espacio rural. Las Montañas de Burgos, Universidad de Valladolid, 1978, pág. 165. 
mayor parte de estos campos medinenses, en estas tierras su práctica es indispensable hasta bien entrado el siglo XX. En este sentido, el ingeniero agrónomo Francisco Arranz, al examinar el estado del cultivo vallisoletano en 1860 señalaba que "pretender que el barbecho desaparezca instantáneamente sería una utopía, y al que tal propusiera, muy bien podría calificarse de poco conocedor de las cosas del campo"1282.

Para liberarse en la medida de lo posible de tamaña inercia, propone el enterrado en verde de los cereales y las leguminosas para abono y, sobre todo, la alternancia de estas con los cereales, prácticas que se estaban extendiendo tanto en las tierras de Campos como en las de Medina. Aun así, como se ha reiterado, el cultivo de cereales en Castilla tendrá por base la alternativa bienal o barbecho de año y vez. Las nuevas prácticas empezarán a borrar de forma tímida la tradicional separación de hojas en que se dividía el terrazgo de la mayor parte de los municipios. No obstante, muchos pueblos del sur de la comarca medinense, como de otros sectores de Castilla, mantendrán esta separación durante buena parte del primer tercio del siglo XX. En Serrada, sin embargo, esta división en hojas de sembradura y barbechera continuará solo en algunos pagos los primeros años del nuevo siglo. La presencia del viñedo y la generalización del retelo en las tierras de primera calidad harán olvidar su práctica. Hoy sólo los mayores recuerdan o han oído comentar el tapado del camino de acceso a las tierras de La Vega, para impedir la entrada del ganado en los pagos de sembradura y preservarlos de posibles dańos.

No se va a abundar en lo explicado. Era la calidad del suelo la que dictaminaba en Serrada dónde y cómo debían sembrarse el trigo y la cebada. Las exigencias alimentarias hacían el resto. De ahí que cualquier ejemplo tenga un sinnúmero de condicionantes que le impidan convertirse en regla general, sea por la dimensión de la explotación, la política arancelaria, la mayor o menor extensión de viñedo en su haber, las rentas a pagar, caso de ser las tierras arrendadas, los precios o la dispar calidad de sus suelos. A mediados de siglo, como se ha estudiado, el cultivo mayoritario es el trigo. Se puede comprobar si se compara el anterior cuadro de cultivos y rendimientos generales de Serrada con el cuadro adjunto de una explotación cerealista tipo en Tierra de Campos. Obsérvese que, exceptuando la cebada, se consiguen también mayores rendimientos por unidad de superficie. ${ }^{1283}$

Cuadro 136. Distribución de cultivos y producciones en una explotación tipo de Tierra de Campos, año 1860

\begin{tabular}{|c|c|c|c|c|c|c|}
\hline \multirow{2}{*}{$\begin{array}{l}\text { Planta } \\
\text { cultivada }\end{array}$} & \multirow[b]{2}{*}{ Extensión (ha) } & \multirow[b]{2}{*}{ Simiente (ha) } & \multicolumn{2}{|c|}{ Producción por hectárea } & \multicolumn{2}{|c|}{$\begin{array}{l}\text { Producción total } \\
\text { de las hectáreas sembradas }\end{array}$} \\
\hline & & & Fanegas & Arrobas & Fanegas & Arrobas \\
\hline Trigo & 44 & 2 & 19,5 & 73 & 858 & 3.186 \\
\hline Cebada & 6 & 6 & 60 & 152 & 360 & 1.860 \\
\hline Garbanzos & 2 & 2 & 8 & 30 & 16 & 60 \\
\hline Guisantes & 2 & 2,5 & 30 & 110 & 60 & 220 \\
\hline Muelas & 2 & 2,5 & 25 & 94 & 50 & 188 \\
\hline Totales generales & 56 & - & - & - & 1.344 & 5.514 \\
\hline Paja & 56 & - & - & 120 & - & 6.720 \\
\hline
\end{tabular}

Fuente: Revista de Agricultura de la Asociación por la Iniciativa Privada. Elaboración propia.

${ }^{1282}$ ARRANZ, F.: Examen del actual cultivo, en Revista de Agricultura..., ob cit, pág 225.

1283 Ibídem, pág. 239. La explotación tomada como ejemplo labra 100 hectáreas y barbecha 50. En la tras-hoja cultiva 6 ha de leguminosas, por lo que siembra en total 56. Las producciones medias que se anotan para un quinquenio son de 6,5 fanegas por 1 de simiente para el trigo; 10 por uno para la cebada; 4 por uno en garbanzos; 12 por uno en guisantes y 10 por uno en muelas. Si se reducen las producciones seńaladas por hectárea a obradas, y se comparan con las apuntadas por Serrada en 1857, haciendo media con las más bajas que se señalan en su "Demostración de cereales que hay en la villa a mediados de siglo", que ya se comentará, la comarca de Campos es netamente superior en rendimientos de trigo (8,2 fanegas de Campos frente a 5,25 en Serrada) e inferior en cebada (25,4 frente a una media de 30 por obrada en esta villa) aunque muy similar a los que recoge Medina a mediados del XIX (8,5 fanegas de trigo y 28,7 fanegas por obrada de cebada). 
Sin embargo, no se desea entrar en más detalles en lo que a rendimientos medios respecta. Las condiciones atmosféricas de cada campaña desvalorizarían cualquier afirmación. Baste decir que en la explotación que se analizará en detalle, donde las tierras distan de ser de calidad, en el año 1872 recogieron 6,2 fanegas de trigo por obrada (4 a 1 por fanega sembrada) y en 1873, por el contrario, la producción llegó a la estimable cifra de 14,1 fanegas de trigo por obrada (relación de 9,4 a 1 por semilla), lo que satisfaría a los más exigentes cultivadores de la comarca.

\section{- De la preparación de la tierra al tapado de la simiente}

Entre los labradores de las distintas épocas, pocos axiomas han sido tan unánimemente aceptados como que una buena sementera era la esperanza de una buena cosecha. Sabido es por todos, además, que el sistema bienal llevaba consigo tener bien labradas las tierras de barbechera, dados los condicionantes edáficos y climáticos que imperaban en este sector norte de la Tierra de Medina.

Las labores en los majuelos retrasaban hasta finales del invierno el alzado de las pajas, salvo las que en septiembre se hubieran echado de algarrobas, cereales para alcacer o morcajos ${ }^{1284}$. Todas estas labores se realizaban con arado romano, aunque no tardan en aparecer novedades técnicas como el arado de vertedera que permite una mayor profundidad, aireación y volteo de la tierra ${ }^{1285}$. El tiro lo llevaban de forma mayoritaria yuntas de mulas y, si algunos autores en esta época seguían mostrando preferencia por los bueyes para hacer entrar la reja a mayor profundidad, estos hacía tiempo que habían perdido el protagonismo ante paso más ligero del ganado mular ${ }^{1286}$.

${ }^{1284}$ En anteriores épocas históricas, el morcajo o mezcla no regulada de trigo y centeno se sembraba en tierras de bajos rendimientos. En este tiempo y hasta los años 40 del siglo XX, el término, en pueblos al sur de Tierra de Medina, designa también a la mezcla indeterminada de cereales, algarrobas y otras leguminosas que se sembraban en septiembre en los alrededores de los pueblos, con el objeto de ser aprovechadas en verde en la primavera por el ganado mular y caballar.

${ }^{1285}$ En estos años, a tenor de los inventarios de bienes consultados, se puede asegurar que en Serrada apenas se habrían adquirido los nuevos arados u otras máquinas que ya se anunciaban y premiaban en las distintas exposiciones agrícolas. Entre ellos, destacan como novedades en estos años de 1870-75 el arado de vertedera Howard, las gradas articuladas de dos y tres cuerpos, los nuevos rodillos desterronadores o el arado de vertedera Chanu. Estos arados de vertedera y demás artefactos serán aceptados de forma lenta por los labradores castellanos, en las últimas décadas del XIX. Aunque la vertedera con la misma fuerza de tiro profundiza mucho más que el arado romano en la labor de alzado de las rastrojeras, los reacios a su uso argumentaban el menor avance en las labores de arada por la menor anchura de la reja respecto al tradicional romano. Leandro de Blas, veterinario y labrador, en un artículo que publica la Revista de Agricultura de la Asociación por la Iniciativa Privada en 1869 titulado "Máquinas agrícolas"..., ob. cit., pág. 375-379) estudia en detenimiento las labores, profundidades y anchuras que permiten los nuevos modelos, en comparación con el tradicional romano, y no duda en recomendarlos (en especial el arado Chanu, construido por su constructor residente en Valladolid y dada su eficacia en las tareas a realizar en las barbechera). La realidad será, sin embargo, bien distinta en muchos de estos pueblos. Hasta bien entrado el primer tercio del XX, la inmensa parte de las tierras de sembradura se alzan, binan y tercian con el tradicional romano, aun teniendo en los colgadizos el nuevo de vertedera.

${ }^{1286}$ Daniel de Cortázar señala en su "Descripción.... de la provincia de Valladolid. Memorias de la Comisión del Mapa Geológico de España. Madrid, pág. 187, año 1877”, que los alzados con bueyes consiguen un "trabajo más igual y sobre todo más profundo" (citado por Hilarión Pascual. El viñedo.... ob. cit.). El paso del siglo jugaba en su contra, pese a que el ganado boyal tenía no pocos defensores entre los ilustrados de la época. El anterior autor citado, Leandro de Blas, en otro artículo que publica en la Revista de Agricultura de la Asociación por la Iniciativa Privada ("Animales de trabajo preferentes". Valladolid, vol. I, año 1869, pág. 94-96) señala las acusaciones injustas con que ha cargado el buey desde el primer tercio del XIX. Amén de considerar como injustas las acusaciones realizadas por parte de sus detractores de lentitud y pereza, señala, entre otros factores que puedan hacer entender el cambio, la excesiva fragmentación del terrazgo cultivado y las continuas distancias que recorrer que lo situaban en desventaja frente a la sobrias y más ágiles mulas. Añade, incluso, como factor de su postración, la actitud de gañanes y mozos de labranza que se sienten más cómodos a lomos del nuevo ganado y con más tiempo en la holganza personal que si sirvieran atendiendo como se merecen a los denostados bueyes. 
El alzado de los rastrojos, en fin, se constituía como la primera labor en las barbecheras para levantar, airear y sanear una tierra apalastrada por las lluvias otońales, los rigores invernales y el pisar del ganado lanar que, falto de pastos, aprovechaba muchas campañas hasta marzo lo que quedaba por arar en las hojas de sembradura ${ }^{1287}$.

La segunda vuelta, que se realizaba durante los meses de abril y mayo, era la bina. Su ejecución en tiempo dependía de cuando se hubiera realizado la alzadura, la muestra de hierba que la primavera estuviera gestando y el tiempo disponible. No se olvide que en estos meses no se podía retrasar la vuelta de marzo en las viñas, reacobijar alguna aranzada y aricar o realizar algún escarde en las tierras de sembradura que lo necesitasen. Quien más quien menos tenía que sembrar, por si fuera poca tarea, alguna obrada de garbanzos o alzar aquellas otras sembradas de alcacer o morcajos en verde, una vez acabaran de ser aprovechadas por el ganado. Técnicamente la bina perseguía, como sus compañeras de barbechera y en palabras de 1870, "la necesidad de poner en contacto las moléculas terrosas del suelo con los agentes atmosféricos aumentando su permeabilidad'. ${ }^{1288}$ Los mozos de mulas dejaban explicaciones a un lado y se limitaban a abrir los cerros con la reja. Como mucho, tal como se relata al pie, se cambian transversales o de forma oblicua los cerros en algunas parcelas. Todavía hoy nietos de aquellos labradores recuerdan la necesidad, entre los consejos recibidos desde niños por sus antecesores, de "binar los barbechos para matar la hierba y terciarles para atemperarles de cara al verano." Y es que estos consejos fueron llevados por ellos al pie de la letra hasta los ańos cuarenta. No será necesario advertir la referencia a estas líneas una y otra vez en tiempos posteriores.

Faltaba redondear la barbechera con la tercia, vuelta esencial de cara al estío. Se procuraba hacerla tras las últimas lluvias primaverales, desde mediados de junio hasta Santiago. Las yuntas, que salían al alba para aprovechar la fresca y los calores de la tarde, se encargaban de matar la hierba movida por la reja, dejando el barbecho limpio y atemperado el resto del verano.

Estas labores podían coincidir con las primeras siegas de cebada que algunos años se iniciaban por San Antonio, dependiendo de cómo hubieran venido los calores de junio. La distinta capacidad de tiro de cada hacienda ejecutaba la tercia conforme podía, pero siempre tratando de que estuviera finalizada el 25 de julio. Se dice esto porque por estas fechas la mayor parte de los labradores estaban metidos de lleno en la siega del trigo. Si las tres labores, por el contrario, se hubieran anticipado en exceso o la segunda quincena de junio fuera lluviosa, podía llevarse a cabo un cuarteo o último pase de arado, poco aconsejable entre los entendidos que estimaban mejor llevar a cabo un escarde manual. En 1873, sin ser el caso, este escarde emplea en las 10 obradas a dos obreros durante un día. Su labor consistiría en quitar algún tipo de malas hierbas (sardinetas en 1873) crecidas, suponemos, por el tiempo en que son cortadas, en algunos corros de las citadas tierras.

Con todo, estas tres vueltas a los barbechos se llevaban 48 reales por obrada, que equivalen al $20 \%$ del total de gastos anuales de las tierras de sembradura. Unos gastos que no dejan de ser una inversión a largo plazo, pues hasta un año después no se siembra en esta hoja y, en cambio, se pagan rentas y contribuciones. De ahí que, en la medida de lo posible y en esta segunda mitad del XIX, en que son continuas las quejas de los labradores por la excesiva presión fiscal, se procure aumentar los sembrados evitando los barbechos en las tierras de calidad. Para compensar el repetido esquilmo, el estercolado comenzará a ser una práctica habitual.

${ }^{1287}$ Mediante la labor de alzado se abrían los cerros o lo que quedaba de ellos con el arado común romano. Sobre el hoyo del cerro salido de pajas, la reja y orejeras del arado volteaban los lomos de los contiguos formando uno nuevo. No faltan ingenieros agrónomos de esta época que critican tanto lo somero de la labor como lo imperfecto de la operación, al dejar la banda longitudinal del hoyo del cerro anterior prácticamente sin tocar. (Leandro de Blas. "Máquinas agrícolas..., ob, cit., pág. 377). Se aconseja, en todo caso, que las labores se hagan transversalmente a la disposición de los cerros anteriores, pero ni esto será regla general ni tenido en cuenta cuando entren en juego condicionantes tales como tierras muy estrechas o laderas acusadas.

${ }^{1288}$ Ibídem, pág. 376. 
El abono animal, sin embargo, no es barato. Los Ayuntamientos venden cada carro de légamo al efectuar la limpieza de cauces, arroyos y charcas, tarea esta que es especialmente cuidadosa en el último tercio del XIX, para evitar el cólera morbo. Los muladares que rodeaban a las poblaciones y crecían conforme se sacaban las basuras de cuadras, las cenizas de las lumbres y los desperdicios que se amontonaban en los corrales, se esparcían antes de la sementera por aquellas tierras de barbecho que lo necesitaran, pero, sobre todo, por las que iban a ser reteladas. La basura que se esparce en la obrada de los Redondos el año 1872 es tasada en 200 reales. Si se echan cuentas antes de la siembra y a 50 reales que en dicho año se vende el trigo, son ya 4 fanegas las que se han invertido. De ahí que, como se apuntaba, en el análisis del ganado, muchos hacendados mantuvieran buenas cabañas de ovino para aprovisionarse de este imprescindible abono si querían producir todos los años en las mejores tierras o, al menos, reducir el barbecho en aquellas que juzgaran menester ${ }^{1289}$. En caso contrario, se acudía a la compra de estiércol a los ganaderos sin tierra o a quien tuviera arrendada la saca de los corralones de ganado del Despoblado de San Martín. Era el caso del hacendado Mariano Martín Navarro. En enero de 1881 consta al menos la saca de 31 carros. El testimonio escrito del esparcimiento en el mes de enero, que por otra parte no se cree general, indica su uso para estercolar tierras salidas de pajas antes de su alzadura, que se efectuaba, como se ha dicho, a lo largo de los meses de diciembre, enero, febrero y marzo ${ }^{1290}$ :

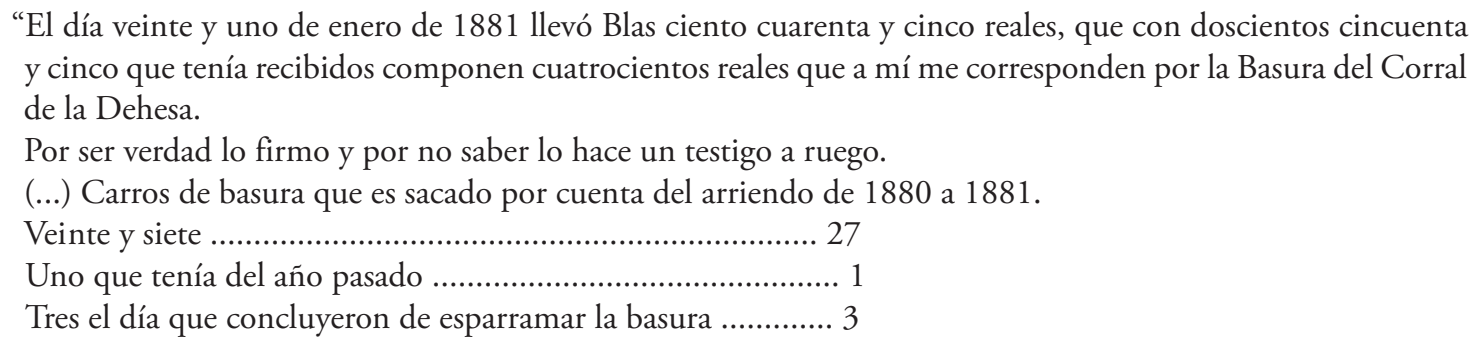

En las barbecheras o en las tierras segadas, también se estercolaba mediante el sistema de redileo conforme se aprovechaba el pasto. Consistía en hacer pernoctar y descansar al rebaño en rediles situados en aquellas tierras que se deseaban abonar e ir corriendo la red por toda la superficie de la pieza ${ }^{1291}$ :

\footnotetext{
"Sacó Juan la rede el once de Abril de 1880. La lleve a las Vacas. Estuvo abonando hasta el día cuatro de mayo inclusive. Perdió una noche de aguas con ciento cincuenta y siete cabezas. El catorce de julio volvió Juan abonar. El día 10 de mayo saco Juan la rede. La llevó al Aragón con ciento treinta y una hasta el 24 inclusive y veinticuatro mas que son ciento cincuenta y cinco...

El 21 de junio llevó Juan la rede al Cerrajero y durmió en ella la primera noche...”
}

En estos años las labores en las tierras de sembradura tienen un precio considerable. En 1873 una obrada sembrada en año y vez lleva, contando los gastos inherentes a otra de barbechera, 238 reales. Si se comparan estas cifras con las que estudiadas estos mismos años en los majuelos (84 y 96 reales por obrada plantada), se aprecia que son netamente superiores (una aranzada viene a corresponder a tres cuartas de obrada). De ahí que la reducción del barbecho se persiga en la medida de lo posible, tanto para evitar costes, como para incrementar los sembrados pero, exceptuando las mejores tierras, su práctica de ir acompańada de abonado si no se quiere esquilmarlas en breve tiempo ${ }^{1292}$.

${ }^{1289} \mathrm{El}$ "Semanario de Agricultura y Artes" de 1801 recomendaba como adecuado en las tierras de Medina el reparto entre 10.000 y 15.000 kilos de estiércol por hectárea. (A.M.D.: “de la Agricultura del Partido de Medina..., pág. 386. Citado por Hilarión Pascual: "Los viñedos...., ob. cit.).

${ }^{1290}$ A.F.M.S. Carp. de escrituras y varios, Serrada, año 1881.

1291 Ibídem.

1292 Como se ha precisado en anteriores cuadros de costes y producciones, buena parte de las labores son realizadas por los propios labradores o miembros de la familia, por lo que estos "gastos" son un salario "pagado" a su propio trabajo. 
Cuadro 137. Labores, costes y producciones en tierras de pan llevar 20 obradas en hojas de año y vez, año 1872

\begin{tabular}{|c|c|c|c|c|c|c|c|}
\hline \multirow[b]{2}{*}{ Labores } & \multirow[b]{2}{*}{$\begin{array}{l}\text { Precio } \\
\text { por obrada } \\
\text { (reales) }\end{array}$} & \multicolumn{2}{|c|}{ Barbechera (10 obradas) } & \multicolumn{3}{|c|}{ Hoja de pan (10 obradas) } & \multirow[b]{2}{*}{$\begin{array}{l}\text { TOTAL } \\
\text { GASTOS } \\
\text { (reales) }\end{array}$} \\
\hline & & $\begin{array}{l}\text { Valdelaíno } \\
\text { (6 obradas) }\end{array}$ & $\begin{array}{l}\text { Valdelacasa } \\
\text { (4 obradas) }\end{array}$ & $\begin{array}{l}\text { Valdelacasa }(7,5 \text { obradas }) \\
\text { TRIGO CENTENO } \\
6 \text { obradas } 1,5 \text { obradas }\end{array}$ & $\begin{array}{l}\text { Redondo } \\
\text { TRIGO } \\
1 \text { obrada }\end{array}$ & $\begin{array}{c}(2,5 \text { obradas }) \\
\text { CENTENO } \\
1,5 \text { obrada }\end{array}$ & \\
\hline Siembra y tapado & 16 & - & - & 4 vueltas & 4 vueltas & 4 vueltas & 736 \\
\hline Simiente & - & - & - & $\begin{array}{cc}9 \text { fanegas } & 1,5 \text { fanegas } \\
\text { a } 50 \text { rs } & \text { a } 24 \text { rs }\end{array}$ & 1,5 fanegas & 1,5 fanegas & 637 \\
\hline Abono & - & - & - & - & A carro & - & 200 \\
\hline Arique & 16 & - & - & - & - & - & 112 \\
\hline $\begin{array}{l}\text { Arancias y vueltas } \\
\text { en barbechera }\end{array}$ & - & - & - & - & - & - & - \\
\hline Escardes (Quitar sardinetas) & as) - & - & - & - & - & - & - \\
\hline Vino gastado & - & - & - & - & - & - & - \\
\hline Siega & $15 / 16$ & - & - & $\begin{array}{c}\text { A } 16 \text { reales } \\
\text { A } 15 \text { reales } \\
\text { obrada obrada }\end{array}$ & $\begin{array}{l}\text { A } 16 \text { reales } \\
\text { obrada }\end{array}$ & $\begin{array}{l}\text { A } 15 \text { reales } \\
\text { obrada }\end{array}$ & 157 \\
\hline $\begin{array}{l}\text { Arrastre de la mies } \\
\text { en carros }\end{array}$ & - & - & - & 9 carros de trigo y 3 de cer & ntenoa 6 rea & ales cada uno & 72 \\
\hline Vino gastado & - & - & - & - & - & - & - \\
\hline $\begin{array}{l}\text { Trillar, tornar y barrer } \\
\text { Limpia de grano }\end{array}$ & - & - & - & 7 huebras & s a 24 rs & & 168 \\
\hline \multicolumn{2}{|l|}{ Meter pan y paja } & & & Labores a brazo: $\mathrm{M}$ & leter grano y & y paja & 40 \\
\hline \multicolumn{4}{|c|}{ GASTOS TOTALES PRODUCCIÓN } & & & & 2.122 \\
\hline Producción de grano & - & - & - & \multicolumn{3}{|c|}{$\begin{array}{l}44 \text { fanegas de trigo a } 42 \text { reales } \\
16 \text { fanegas de centeno a } 24 \text { reales } \\
1,5 \text { fanegas de terrero a } 38 \text { reales }\end{array}$} & 2.289 \\
\hline \multirow{2}{*}{$\begin{array}{l}\text { Producción de paja } \\
\text { BENEFICIOS BRUTOS }\end{array}$} & - & - & - & \multicolumn{3}{|c|}{9 carros de paja a 31 real cada carro } & 279 \\
\hline & \multicolumn{7}{|c|}{ BENEFICIOS BRUTOS OBTENIDOS2.568 } \\
\hline \multicolumn{5}{|c|}{ BENEFICIOS NETOS (excepto pago de contribuciones e impuestos municipales) } & 446 & & \\
\hline
\end{tabular}

Fuente: A.H.P.V. Protocolos Notariales, Archivo familia Alonso Moyano. Elaboración propia.

Finalizado agosto y encerrado el grano y la paja, se comenzaba una nueva sementera. En estos años de 1860 y 1870 el incremento de leguminosas y retelos obligaba a no embobarse en estos pueblos donde la segunda quincena de octubre la consumían las vendimias. Bien es verdad que las algarrobas podían sembrase en septiembre y en seco con pases someros de arado. Quizá por eso a nadie sorprendían sus escasos rendimientos ${ }^{1293}$. Estas mayores siembras de leguminosas sobre pajas representan el principio del fin de la tradicional división en hojas. Cuando se incrementen y los retelos de cereal aumenten, el paisaje se modificará sin remedio. De hecho, estos cambios obligan a matizar las normas del pastoreo sobre la hoja de barbechera. En las condiciones fijadas en 1875, se acuerda que estos retelos, llevados a cabo sobre la hoja de barbechera, sean considerados de cara al pastoreo como propios de la rastrojera ${ }^{1294}$ :

\footnotetext{
${ }^{1293}$ La siembra de algarrobas, yeros, guisantes o cereales y leguminosas mezclados, para consumir en verde por el ganado en primavera, se efectuaba en las hojas que salían de pajas. Tanto si acababan por segarse como si eran aprovechadas en verde y alzadas al acabar la primavera, formaban parte de la hoja de barbechera que al año siguiente se sembraba enteramente. De esta manera, a pesar de no dejar descansar la tierra, la fijación de nitrógeno por estas especies ejercía un efecto mejorador que permitía la supresión del barbecho, al tiempo que rendían, o bien cosecha, o bien alimentación en verde para el ganado.
}

${ }^{1294}$ A.M.S., caja 2, carp. 23, ańo 1877. 


\begin{abstract}
"El arrendatario, o los disfrutantes del pasto a quienes dieren participación, no podrán aprovechar el pasto de lo garrobales ni otras legumbres que por necesidad se sieguen o arranquen antes del día fijado para la terminación de este arriendo, pues que en el mismo solo se comprende el pasto de las heredades que se hallan sin sembrar de cualquiera especie de semilla, entendiéndose que el pasto de las heredades de legumbre o retelo pertenece al arriendo de rastrojera, y sólo en el caso de ser arrendatarios o disfrutantes de dicho pasto podrán entrar a su disfrute pasado el día octavo y previo parte que se dará a la Alcaldía para su conocimiento, todo bajo la multa gubernativa con arreglo a las vigentes disposiciones o denuncia en su caso al Tribunal de Justicia como atropello de la Propiedad."
\end{abstract}

La sementera se hacía enteramente manual, a pesar de la introducción de las primeras sembradoras por los grandes hacendados de la comarca. La abundancia de jornaleros y los escasos rendimientos que se obtenían de muchas de estas tierras de sembradura apenas si fueron incentivos para esta incipiente mecanización. Piénsese que todavía en el primer tercio del siglo XX los labradores de esta villa y alrededores seguían llevando la sembradera al hombro de forma mayoritaria. Sobre los mismos cerros salidos de las pajas o puestos en las tercias, si los sembrados iban en la hoja de barbechera, el sembrador esparcía la semilla contando trece o, si eran más delgados, catorce caballones, tirando alternativamente el puño de semilla longitudinal y transversalmente, según marcaba los pasos, al andar por el anteúltimo cerro de cada mano ${ }^{1295}$. Llegado a la linde de la tierra, volvía realizando la misma operación para cubrir la melga o banda antedicha, procurando que la distribución de la semilla quedara con la mayor igualdad posible. La pericia del sembrador solía ser tal que, cuando apuntaba el sembrado, no se notaba si este había sido sembrado en días de viento o de calma. Esta siembra a manta o voleo era la generalizada desde siglos en las tierras de sembradura castellanas ${ }^{1296}$.

Después se abría el surco con el mismo tipo de arado para tapar la semilla. A veces, cuando apuntaban, se arrastraban con la cańiza para redondear un poco el cerro y permitir que naciera la simiente que había quedado a mayor profundidad. Las primeras lluvias otonales hacían nacer con prontitud estos cereales tempranos que, a comienzo de la primavera y cuando estaban bien presentados, se aricaban para matar las malas hierbas nacidas en el hoyo de los surcos, al tiempo que se acorpaban un poco las plantas nacidas en el lomo del cerro.

En cuanto al tipo de semilla, es dominante el trigo candeal y la cebada común. Entre los productos premiados en la Exposición Castellana de 1860, el candeal no deja de recibir medallas y menciones honoríficas en buena parte de los pueblos de la Tierra de Medina, desde San Vicente del Palacio o Carpio al sur, hasta Nava del Rey al norte. Es la semilla rey en esta comarca y, en general, en toda Castilla por estas fechas. En las provincias limítrofes el candeal tiene como compañero al trigo rojo, al barbilla y, poco a poco, al mocho que comienza a introducirse en algunos pueblos, como Alaejos, para ir extendiéndose, de forma progresiva, por sus mayores rendimientos y su siega más temprana ${ }^{1297}$. El candeal, en cualquier caso, es la especie dominante en el último tercio del XIX y persistirá como tal, dada su rusticidad, en los pagos menos feraces hasta mediados del siglo XX.

1295 La anchura de la melga que había que sembrar cada mano variaba el número de cerros, atendiendo solo a la fuerza física y al tamaño del puño o pericia del sembrador, pues lo fundamental era que la semilla quedara regularmente repartida por toda la pieza.

${ }^{1296}$ Este sistema de siembra ya suscitaba serias críticas entre los entendidos de la época. Se consideraba como vicioso al afirmar que se tiraba la semilla al acaso, sin la certeza de un enterrado homogéneo y que hiciera posible la nascencia de todos los granos. Leandro de Blas y Rodríguez afirmaba en 1860: “QQuedan todas las semillas a una profundizar conveniente de la superficie de la tierra...? Seguramente que no, pues muchas quedan en la superficie, y desde esta a una profundidad de veinte centimetros (siete pulgadas) están todas a distancias diversas de la superficie. ¿Qué igualdad puede esperarse para la germinación del grano, vegetación y fructificación de las plantas con una sementera tan a falta de razón?" (En "Sementera de trigo y cebada”. vol. II, año 1870, pág. 266)

1297 A.M.D.: “De la agricultura del partido de Medina del Campo", en Semanario de Agricultura y Artes dirigido a los Párrocos. Año 1801, no 259, tomo X, pág. 386. (Citado por Hilarión Pascual: El viñedo...) El trigo mocho o chamorro carece su espiga de arista (de ahí su denominación). 
Cuadro 138. Labores, costes y producciones en tierras de pan llevar 20 obradas en hojas de año y vez, incluidas labores en barbechera, año 1873

\begin{tabular}{|c|c|c|c|c|c|c|}
\hline \multirow[b]{2}{*}{ Labores } & \multirow[b]{2}{*}{$\begin{array}{c}\text { Precio } \\
\text { por obrada } \\
\text { (en reales) }\end{array}$} & \multicolumn{2}{|c|}{ Hojas de pan (10 obradas) } & \multicolumn{2}{|c|}{ Barbechera (10 obradas) } & \multirow[b]{2}{*}{$\begin{array}{c}\text { TOTAL } \\
\text { GASTOS } \\
\text { (en reales) }\end{array}$} \\
\hline & & $\begin{array}{c}\text { Valdelaíno } \\
\text { (6 obradas) } \\
\text { TRIGO }\end{array}$ & $\begin{array}{c}\text { Valdelacasa } \\
\text { (4 obradas) } \\
\text { CENTENO }\end{array}$ & $\begin{array}{l}\text { Valdelacasa } \\
(7,5 \text { obradas })\end{array}$ & $\begin{array}{c}\text { Redonda } \\
(2,5 \text { obradas })\end{array}$ & \\
\hline Siembra y tapado. & 16 & Cuatro vueltas & Tres vueltas & - & - & 640 \\
\hline Simiente & - & $\begin{array}{l}9,5 \text { fanegas } \\
\text { a } 42 \text { reales }\end{array}$ & $\begin{array}{l}4,5 \text { fanegas } \\
\text { a } 24 \text { reales }\end{array}$ & - & - & 507 \\
\hline Arico & 16 & Una vuelta & - & - & - & 96 \\
\hline Arancias y vueltas en barbechera & 16 & - & - & Tres vueltas & Tres vueltas & 480 \\
\hline Escardes (Quitar sardinetas) & - & - & - & - & $\begin{array}{l}2 \text { obreros } \\
\text { a } 3,5 \text { reales }\end{array}$ & 7 \\
\hline Vino gastado & - & - & - & - & 2 & 2 \\
\hline Siega & $16 / 18$ & $\begin{array}{c}18 \text { reales } \\
\text { obrada }\end{array}$ & $\begin{array}{c}16 \text { reales } \\
\text { obrada }\end{array}$ & - & - & 172 \\
\hline Traslado de la mies en carros & - & $\begin{array}{l}14 \text { carros } \\
\text { a tres reales }\end{array}$ & $\begin{array}{l}3 \text { carros } \\
\text { a } 6 \text { reales }\end{array}$ & - & - & 60 \\
\hline Vino gastado & & & & & & 20 \\
\hline Trilla & & $\begin{array}{l}9 \text { huebras } \\
\text { a } 24 \text { reales }\end{array}$ & $\begin{array}{l}2 \text { huebras } \\
\text { a } 24 \text { reales }\end{array}$ & & & 264 \\
\hline Trillar, tornar y barrer los suelos & - & 7 obreros & 1 obrero & - & - & 72 \\
\hline Limpia de grano & - & 9 obr & reros & & & 36 \\
\hline Meter pan y paja & - & Una h & uebra & - & - & 24 \\
\hline TOTAL GASTOS & & & & & & 2.380 \\
\hline Producción grano & $\begin{array}{r}85 \text { faneg } \\
\text { a } 38 \\
1,5 \text { faneg. } \\
\text { a } 31\end{array}$ & $\begin{array}{l}\text { as de trigo } \\
\text { reales } \\
\text { s de terrero } \\
\text { reales }\end{array}$ & $\begin{array}{l}17 \text { fanegas } \\
\text { de centeno } \\
\text { a } 24 \text { reales }\end{array}$ & & & 3.727 \\
\hline Producción paja & & $\begin{array}{l}14 \text { carros } \\
\text { a } 31 \text { reales }\end{array}$ & $\begin{array}{l}3 \text { carros } \\
\text { a } 31 \text { reales }\end{array}$ & & & 527 \\
\hline TOTAL INGRESOS & & & & & & 4.254 \\
\hline TOTAL BENEFICIOS (a falta d & de pago de $\mathrm{c}$ & ntribuciones) & & & & 1.874 \\
\hline
\end{tabular}

Fuente: A.H.P.V. Protocolos Notariales, Archivo familia Alonso Moyano. Elaboración propia.

La sementera ocupaba a pequeños y grandes labradores en las semanas anteriores y posteriores a la vendimia. En la segunda quincena de septiembre y primera de octubre, debía encontrarse buena parte del cereal temprano sembrado, a tenor de la reglamentación sobre el paso de las caballerías para entrar a los majuelos y las penas a pagar por dańar los sembrados. "El trigo por octubre y la cebada por los Santos" o "siembra temprano y cogerás paja y grano" han sido frases que la tradición oral ha conservado de generación en generación. Desde las haciendas de tres y cuatro pares de mulas hasta los que sembraban sus pequeñas propiedades con pequeños burros, todos se afanan en estas siembras tempranas que trataban de asegurar así parte de la futura cosecha. Un sembrador podía sembrarse cuatro obradas y media en cada jornada (2,5 ha), necesitándose para su tapado tres yuntas, si bien, en la mayor parte de las medianas haciendas, son sus titulares, acompañados por algún mozo de mulas, los que van alternándose para hacer a la par ambas operaciones.

Estos trabajos varían también según el estado de la barbechera, la calidad de la tierra y el tipo de cereal o leguminosa. Bastaba un pase de arado, abriendo el surco formado en la tercia, para enterrar semillas y basura, caso de haberse estercolado. Atendiendo a la calidad del suelo, puede también aumentarse o no, la simiente. En estos años vienen a echarse 1,5 fanegas de trigo por obrada, o tan 
sólo una, si la tierra es centenera. En La Vega, sin embargo, la tierra admitía mayores porciones, llegando en la cebada hasta las 4 fanegas. Recuérdese que el Catastro de Ensenada de 1752 fijaba en Serrada que "en las referidas tierras que se siembran de trigo, siendo de la primera calidad corresponde echar en ellas de sembradura dos fanegas de dicha especie; y de zebada una carga que son quatro fanegas, $y$ de garbanzos una fanega. En las de segunda, que solo se siembran de trigo, fanega y media. Y en las de terzera, que solo se siembran de zenteno, garrobas y avena, una fanega de cada especie... "2298.

Con todo, el coste de las labores de sementera, entre arancias y semillas, pueden llegar a casi la mitad de los gastos anuales que llevan estas tierras de sembradura (114,7 reales de 1873 por obrada o el $48 \%$ del coste total por unidad de superficie en el caso tratado). ${ }^{1299}$ Cifras similares son las que se manejaban a comienzos del XIX. En 1824, simientes y labores de sementera alcanzaban en Serrada 130 reales en las sembraduras de trigo y 200 reales, en las de cebada. De ahí que, cuando se suceden varios ańos con precios bajos, las peores tierras de sembradura queden abandonadas como eriales a la espera de tiempos mejores.

\section{- De la siega y trilla a la guarda del grano en las paneras}

Junto con la vendimia, hacer el verano era la otra gran actividad comunitaria en los campos castellanos hasta que llegue la mecanización en el siglo XX. Como aquella, los trabajos de mayor exigencia física eran propios de hombres, pero tanto en la trilla como en barrer las eras y preparar paneras y pajares participaban también mujeres y niños. Estos últimos grupos, además, formaban cuadrillas de espigueo que recorrían los campos detrás de los segadores, cuando las ordenanzas lo permitían. Unas u otras labores se iniciaban a mediados de junio en las cebadas tempranas.

Como sucedía en los meses que anteceden a la vendimia, desde primavera los labradores vigilaban los campos para evitar robos y daños en las futuras cosechas ${ }^{1300}$. La falta de recursos en los Ayuntamientos del XIX era tan crónica como el incremento de familias pobres entre sus vecinos. Con la excusa de recoger forraje en caminos y linderas, animales y brazos se adentraban en los sembrados. $\mathrm{Y}$ es que, de finales de mayo hasta San Antonio en que volvían a relucir las hoces y llenarse las eras de parvas, muchos braceros vivían de jornales sueltos y de la caridad pública ${ }^{1301}$. El Ayuntamiento, sabedor de quejas y para evitar conflictos, regula la actividad al comienzo de cada campaña veraniega. Mediante bandos públicos, se establece el tránsito de los carros por la población, el paso de los segadores por los sembrados, el espigueo o el cuidado que han de tener los dueños de ganados ${ }^{1302}$.

${ }^{1298}$ A.G.S. Catastro de Ensenada, Respuestas generales, Serrada.

${ }^{1299}$ Es muy posible que, en este segundo cuadro en que figuran en siembra y tapado tres y cuatro vueltas de arado, se refieran a las tres dadas el año anterior como preparatorias del barbecho (no declaradas en el cuadro primero), más la obligada del tapado de la semilla. Al entender que la rentabilidad del cultivo bienal tiene que tener en cuenta al menos dos años consecutivos, se opta por mantener los apuntes del contador, dado que no alteran en absoluto la valoración del cultivo.

${ }^{1300}$ En abril de 1873, justamente el mismo ańo del ejemplo estudiado, el Ayuntamiento de Serrada acuerda poner un guarda al campo, siempre que los labradores cedieren el pasto de la campiña para sufragar su pago: “...Con este motivo recordó el abandono que se nota por los sembrados del término jurisdiccional, pues que constantemente están invadidos de ganados que los destruyen y aniquilan, sin que haya sido bastante a detener estos excesos el bando publicado a este intento y las multas exigidas por consecuencia de la infracción de aquel. Por cuyas razones creía que el medio más eficaz además de emplear por su parte todos los que la ley le autoriza era el de poner un guarda, tan necesario en esta época, para que vigile el campo, pero que no teniendo el Ayuntamiento recursos para subvenir a los gastos que ha de ocasionar, había creído conveniente... toda vez que del acta de veinte de marzo próximo pasado resulta que los pastos de rastrojera, o sea, espigadero y hoja de vińas, fueron cedidos al Ayuntamiento para llenar las atenciones del presupuesto municipal, con solo la obligación de poner dos guardas durante la recolección del verano y tres desde quince de septiembre hasta terminada la vendimia..., que se ponga un guarda que vigile el campo desde ahora hasta la época en que hayan de ponerse los dos para que le autorice el acta de veinte de marzo del año ultimo...”. (A.M.S., caja 1, carp.19, fol. 5, año 1873).

${ }^{1301}$ Como se tratará al abordar el funcionamiento del poder local en este siglo, son constantes en la segunda mitad del XIX las preocupaciones por atender a la cada vez mayor cantidad de vecinos necesitados, sea para procurarles asistencia médica gratuita, sea para dar trabajo publico a los braceros desocupados. 
Pocas cosas quedan al azar en las épocas de recolección de frutos. En las semanas previas los braceros, por medio de mayorales, multiplican contactos con los hacendados de pueblos del sur de Medina para concertar tiempos y precios de siega, toda vez que las obradas de sembradura de Serrada no alcanzan para todos en estos meses. A los labradores de Serrada les bastaba con parte de los jornaleros del pueblo, con quienes se ajustan a principios del verano, una vez tanteados precios y visto como se presentaba la cosecha. Así lo manifiesta en sus apuntes de contabilidad de 1879 el señor Martín Navarro ${ }^{1303}$ :

"He ajustado la siega en el año de 1879 en seiscientos reales y me salió la obrada a diez y seis reales la obrada. Lo segaron en treinta y seis días dos de ellos, treinta y seis obradas."

En palabras de los labradores de más edad entrevistados, y que han seguido los consejos de sus mayores, "lo regular era empezar en la segunda quincena de junio por la cebada, coger las pocas algarrobas o guisantes que se tuvieran, seguir por el centeno y dedicar las ultimas semanas de julio y la primera quincena de agosto al trigo". Sirva como ejemplo el siguiente apunte familiar de $1881^{1304}$ :

${ }^{1302}$ Como ocurría en las vendimias, todo un conjunto de normas obligaba a la población durante la recogida de mieses: "En la villa de Serrada, a veinte y tres de junio de mil ochocientos ochenta y dos, previa convocatoria especial, se reunieron en la sala consistorial y bajo la presidencia del Sr. Alcalde D. Mariano Martín, los concejales al margen nombrados. En sesión extraordinaria se aprobó el acta de la anterior y declarado esta abierta, el Presidente puso a discusión si era conveniente publicar un bando de policía rural, según costumbre, con motivo de las operaciones de recolección de mieses, a fin de prevenir, antes que castigar abusos tan frecuentes, como se suelen cometer durante dicha época. Oído por los Señores capitulares, y después de haber hecho uso de palabras varios de ellos, por unanimidad acordaron se publique por la Alcaldía y se haga respetar y cumplir un bando, bajo las siguientes bases:

Primera. Que tanto al entrar en caminos concurridos y atravesándose heredades con frutos pendientes de recolección procuren los mozos de mulas ir sobre ellas y los de bueyes delante.

Segunda. Que los segadores y espigadoras no lleven más que una caballería por cuadrilla a los rastrojos y si alguna mas llevasen las tengan estacadas donde no causen dańos de los que serán responsables sus dueños.

Tercero. Los segadores no atravesaran los sembrados de unos a otra tierra a pie $\mathrm{n}$ ia caballo, haciéndolo por las lindes y caminos para evitar perjuicios a los propietarios, y cuando regresen a sus casas por la noche no introducirán manadas bajo pretexto de ser de sus mujeres ni de cualquiera persona.

Cuarta. Las espigadoras no saldrán del pueblo hasta después de sol salido, volviendo a las diez de la mañana, y por la tarde saldrán a las tres y regresaran a la postura del sol, bajo apercibimiento de perder lo espigado que será entregado a los dueños si son conocidos y, en otro caso, destinadas las manadas a usos benéficos, sin perjuicio de las penas correspondientes.

Quinta. Los dueños de los ganados de cerda los tendrán recogidos mientras no estén al cuidado del guarda, evitando su abandono por los sembrados y heras.

Sexto. Se prohibirá espigar en los domingos y demás días festivos.

Séptimo. Teniendo en cuenta que después de levantadas las mieses, desde tiempo inmemorial. Se ha consentido a los pobres y jornaleros espiguen en las primeras horas siguientes, se haga entender a los ganaderos lo conveniente que seria, a la vez que humanitario, previniesen a los mayorales de las respectivas piaras, se abiniesen de introducir los ganados en los rastrojos hasta pasadas las primeras horas en que se hubieren espigado.

Octava. Y últimamente, que los infractores de las antedichas disposiciones, excepto la séptima, incurrirán en la multa por primera vez de una a dos pesetas, según los casos; doble por la segunda y si reincidiesen por tercera vez serán sometidas a el tribunal correspondiente.

No siendo otros los asuntos de la convocatoria, se levanto la sesión firmando el acta como el Presidente los concurrentes a ella, de que certifico.

El presidente: Mariano Martín (rúbrica) Domingo Juárez, Ambrosio Román, Toribio del Río, Juan Moyano (rúbricas) Vicente G. Hervada (rúbrica). (A.M.S. caja 2, carp. 28, año 1882).

1303 A.F.M.S. Carp. de escrituras y varios, Serrada, año 1879.

${ }^{1304}$ Ibídem. 


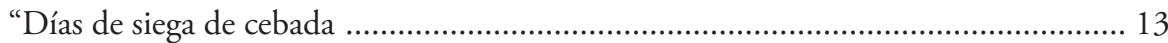

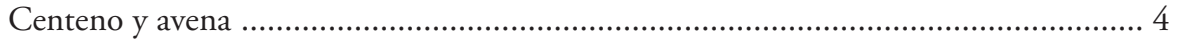

El 12 de julio empezaron el trigo. Concluyeron el 15 de agosto. Días:

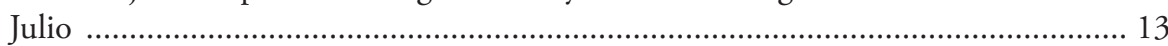

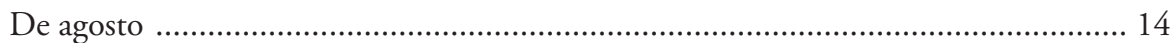

TOTAL: ................................................................................................................. 44

(División al pie: 620 (reales) entre 44 (días) igual a 14 reales."

$\mathrm{Al}$ tiempo que se segaban los cereales, se cogen algarrobas y garbanzos. Aunque estos últimos eran especialmente guardados por la autoridad pública, la situación precaria de muchos vecinos llevaba a algunos dueños a vigilar de forma particular sus cosechas. Así lo hace en 1881 el señor Martín Navarro pues "el día 3 de julio empezó Melitón a cuidar los garbanzales a cuatro reales el día. Concluyó el 9 de agosto" 1305 .

Fueran los daños debidos a la necesidad o al temor a tormentas y pedriscos, el caso es que todos ansiaban llevar cuanto antes el grano a las paneras. $\mathrm{O}$ al menos que estuviera en las eras aunque ello no impidiera mermas por culpa de veranos lluviosos. La penosa tarea de la siega era llevada a cabo por cuadrillas de segadores al servicio de los labradores que les daban comida y alojamiento en colgadizos, cuadras o pajares. En Serrada, donde la explotación cerealista siempre fue complementaria de la vitícola, los segadores forasteros siempre fueron escasos. Bastaban los braceros de la villa para la realización de estas tareas y, como se relataba a finales del XVIII, eran muchos jornaleros del pueblo los que, aun teniendo algunos días de siega en la localidad, preferían marchar a los pueblos del sur de Medina, donde el predominio cerealista les garantizaba dos meses de jornal ${ }^{1306}$.

Todas estas labores alcanzan el 27,2\% de los gastos totales. En este ańo 1873, salió la obrada a 64,8 reales. A pesar de lo que en un principio puede parecer, no es la siega el trabajo que se lleva la mayor parte. Aunque los segadores cobraban ocho reales diarios, podían quitarse una obrada en dos días, de tal manera que la siega de las 10 obradas de este ejemplo (172 reales) tan sólo representa el $26 \%$ de estos gastos o el 7,25\%, si se atiende al total de gastos en estas tierras de panadeo. Son las huebras de las yuntas encargadas de la trilla las que, tasadas a 24 reales, alcanzan el $40 \%$. El traslado de la mies, la limpia y el barrido se llevan el resto.

En el cuadro anterior se fija como salario diario en la trilla y torna 9 reales diarios, y 4 en las tareas de limpia. Hay que aclarar, sin embargo, que no todas estas cantidades salían en moneda contante y sonante de las arcas de los labradores. Excepto los grandes hacendados que pudieran necesitar algún par, son las caballerías de cada uno las que transportan la mies y trillan el grano. Los jornales se pagan en la medida en que se necesitan y abunda la cosecha, pero en la mayoría de las pequeñas y medianas labranzas todos los miembros de la familia trabajan de sol a sol. Con todo, los trabajos se trilla, torna y limpia del grano son especialmente fatigosos y caros si hay que contratar yuntas a otros vecinos ${ }^{1307}$. En este ejemplo se llevan 37,2 reales por obrada sembrada o, lo que es lo mismo, una fanega menos de lo que esta haya producido.

\section{Ibídem.}

${ }^{1306}$ De los pueblos vitícolas del norte de Medina salían regularmente segadores a sus limítrofes del sur o a la tierra de Peñaranda y Madrigal. En estas campiñas del sur del Duero eran numerosas las cuadrillas de segadores gallegos encargadas de segar la mies. La llegada del ferrocarril a Medina del Campo facilitó este importante movimiento de trabajadores hasta la generalización de las máquinas agavilladoras, en el segundo tercio del siglo XX. Los mayorales o segadores experimentados eran los encargados de negociar con los labradores tanto el ajuste de la siega como las cantidades y calidades de la comida y los alojamientos, condiciones estas que, en algunos casos, distaban de ser las más adecuadas para llevar a cabo un trabajo tan exigente y penoso como lo era la siega.

${ }^{1307}$ Desatados y desbaratados hacillos y haces de mies, una vez descargadas de los carros, se extendían formando una parva donde se echaban los trillos tirados por mulas para el trillado. Realizada la labor, se recogía paja y grano en un montón, parvero o pajero. Normalmente cada dos parvas se hacía el montón, muchas veces alargado en los lados de las eras por la acumulación de distintas parvas trilladas. Acabada la siega y trilla, se iniciaba la torna y limpia. Con bieldos se lanzaba contra 
Las parvas y muelos se extendían, como en todos los pueblos de la comarca, por las eras que rodeaban las poblaciones, fueran particulares, producto de la Desamortización, o continuaran en manos del común de los vecinos. El Ayuntamiento de esta villa, para evitar déficits presupuestarios, poseía licencia del gobierno de la Provincia desde 1853 para "arrendar la era que al común de los vecinos pertenece para la trilla y elaboración de mieses de la cosecha pendiente... "1308. No pocos preparan algún espacio propio para su trilla, generalmente utilizando cantos para su nivelación y empedrado y que, cuando toman cespedones del prado común, desatan de forma inmediata las denuncias públicas ${ }^{1309}$ ¡ ¡Cuántos sudores y reales para conseguir una fanega de trigo! De ahí que cada cual fuera celoso en la guarda de sus montones de grano y paja. En 1882, el señor Navarro los tenía repartidos, en su media obrada de era propia, de la siguiente manera ${ }^{1310}$ :

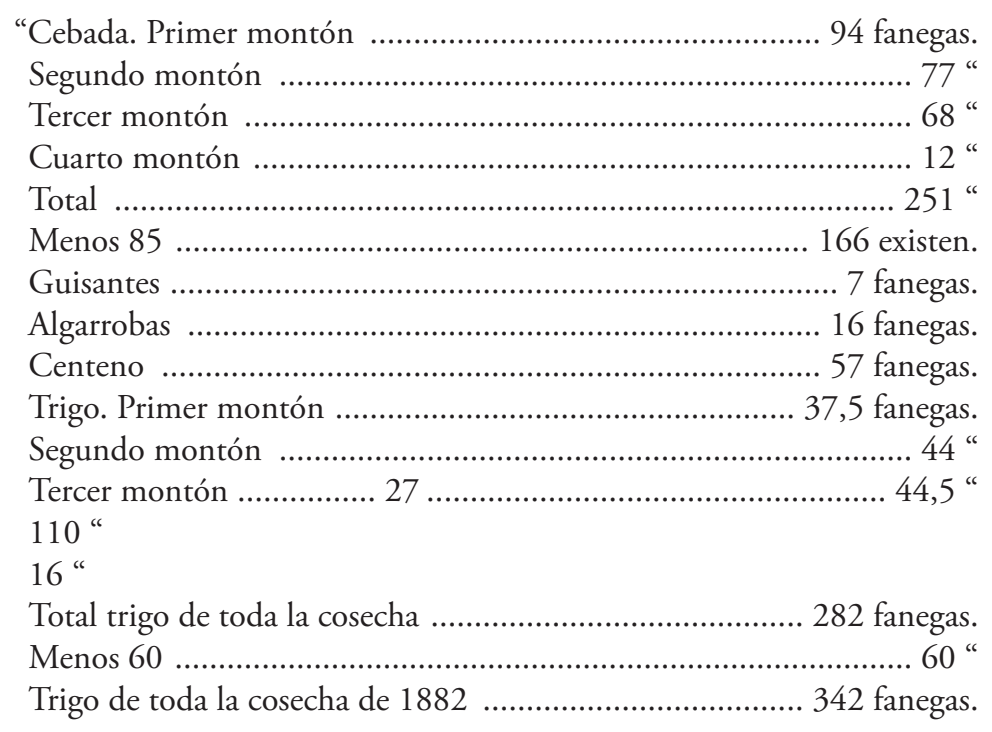

el viento paja y grano, provocando la separación de los dos elementos por su gravedad y peso. En este último tercio del XIX, buena parte de los grandes hacendados comienza a adquirir las primeras aventadoras manuales que ahorraran tiempo y esfuerzo. No parece que sea el caso ni se tiene constancia de su adquisición en Serrada en estos años por ningún vecino. De hecho, la explotación tomada como ejemplo pertenece a fuertes hacendados de la localidad y en ningún momento se recogen testimonios sobre máquinas aventadoras u otros artefactos. Recogida la paja tirándola para atrás, se recogía el trigo limpio y los bordes o colmillos más sucios se pasaban por arneros, azarandándolo y separando definitivamente grancias y granos. Conforme se procedía a esta operación, se llenaban los costales para su transporte a las paneras. Apartadas las rentas en especie que pagar, caso de que se llevaran tierras arrendadas, los grandes labradores, siempre que tuvieran excedentes monetarios, guardaban parte o toda la cosecha esperando los siempre más altos precios que regían en los mercados de primavera. El trigo de los montones limpios se echaba en costales a fanega y media por lo general. Era dado y acordado que la marca del peso del trigo candeal era de 43 kilos y cuarto por fanega. Si en vez de guardarlo se llevaba a los compradores y harineros de Matapozuelos (familia Ruiz), Medina o Valdestillas, los costales se llenaban a dos fanegas o lo que es lo mismo 86,5 kilos, peso solo resistido por las espaldas de los más fuertes y experimentados mozos y criados. El año que el trigo alcanzaba esta marca de peso era buen año, pues por lo general era frecuente el asurado o arrebatado en el mes de junio.

${ }^{1308}$ A.M.S., caja 1, carp. 9.

${ }^{1309}$ Entresacamos un fragmento de una denuncia al efecto: "Que habiendo tenido noticia que el Don Felipe Moyano estaba sacando céspedes para la construcción de una hera, próximo a la entrada del prado de Arriba... se le hizo presente que no podía continuar extrayendo céspedes de aquel sitio...

Que... podía utilizar los céspedes del punto donde el pueblo se provee de varro para sus construcciones, cuyo punto era al camino viejo de Matapozuelos, hoy que no es necesario toda vez que se ha hecho otro camino nuevo...

Y por último. Si los céspedes del sitio que se le señalo no llenaban las condiciones de su deseo, hubiera seguido el ejemplo de otros vecinos que también están haciendo heras y las hacen con cantos antes que perjudicar los intereses procomunales... y que de tolerar semejantes abusos vendrían a redundar en grave perjuicio de los mismos, mayormente en la escasez que se siente de heras por haberse vendido las de propios...”. (A.M.S., caja 1, carp.16, fol. 5-7, año 1870).

${ }^{1310}$ El Amillaramiento de 1881 asignaba al seńor Martin Navarro una explotación de 25,5 obradas de sembradura, 72,5 aranzadas de viñedo, media obrada de era y 1,25 de pinares. En total 46,18 ha. Es notorio, a la luz de las treinta y 
Limpio el grano, se apartaban las rentas y débitos en especie, se medía por fanegas y se llevaba en costales a las paneras. Unos años eran malos, otros medianos y la mayor parte regulares. Incluso teniendo buena cosecha y altos precios, cuando se echaban cuentas, caso de descontar el trabajo personal, apenas quedaban beneficios en la mayor parte de las tierras de sembradura ${ }^{1311}$. Valga como ejemplo el que analizamos. A pesar de los buenos precios del trigo en 1872, no se cogió ni para pagar la simiente. Se cree que, al menos en dicho año, la Diputación perdonaría parte de las contribuciones por el pedrisco que afectó a las cosechas. Al año siguiente, los 187,4 reales por obrada sembrada (la mitad si se suman las dejadas de barbecho) tampoco hicieron salir a nadie de pobres. Faltaban las contribuciones y, como ya se ha manifestado, en el cuadro de apuntes no se han computado ni gastos de conservación, ni desgracias en ganados ni, no se olvide, las numerosas rentas a que estaban abonados los renteros desde hacía siglos.

Las quejas amargas en este sentido son permanentes en las publicaciones de temas agrarios de la época, tanto por parte de pequeños como de mayores propietarios. Pocas crisis se han anticipado tanto como la que ven llegar los labradores en estos años. Todos coinciden en el ahogo contributivo que el Estado les estaba ocasionando. Hasta los labradores de Campos, por ejemplo, de regulares cosechas, braman contra un gobierno capaz de gravar con 1.500/2.000 reales de territorial y consumos a cualquier labranza que tuviera una yunta y que, no bastándole con ello, "celosa en demasía por el aumento de la riqueza imponible, ha obligado a la mayor parte de las localidades, a elevar la clasificación de sus fincas para obtener lo bastante a cubrir su cupo, siempre creciente... "1312, hasta hacer parecer "que el ominoso diezmo ha vuelto ya de su viaje, y está sobre nosotros aun más sofocante..."

¿Qué no sentirían los de estas labranzas de esta comarca con menores rendimientos! Hasta las familias más pudientes deben ajustar sus presupuestos para atender a tan onerosas cargas. Así, en abril de 1877, cuando desde la ciudad de León Hipólito Alonso Ampudia escribe a su hermano Pedro, se congratula del "acuerdo tomado respecto al Sr. Portero y de la prórroga concedida por este. Me parece bien, pues supongo que habrá sido para poder atender mejor a necesidades más urgentes y apremiantes, como la de las contribuciones" 1314 .

No escapa Serrada a estos gastos que limitan el rendimiento final. En las gráficas anteriores de majuelos se recogen contribuciones de 17,9 reales por aranzada. Aunque se desconoce la cuantía exacta de los impuestos sobre las tierras del ejemplo analizado, se cree cercana a los 18-20 reales por obrada. Sirva, para concluir estos aspectos, el siguiente resumen de lo que produce una obrada de cereal en Tierra de Campos ${ }^{1315}$ :

No es objetivo de este trabajo analizar técnicamente los valores que se fijan en concepto de rentas de capital y otros gastos, pero todos los cultivadores, sean de donde sean, expresan sus temores ante el futuro que se les viene encima. Al final, todo el mundo vuelve los ojos al precio en que se cotiza cada ańo la fanega de trigo. Distintos estudios en estos ańos lo estiman en torno a 32 reales y, teniendo en cuenta los 40 reales a que la venden por estos años, aseguran que sólo con rendimientos de 48 fanegas hectárea, o lo que es lo mismo, un milagro, la agricultura es rentable ${ }^{1316}$.

seis obradas que declara tener sembradas en 1879 y de la cebada que trilla, pero que no figura como cultivo en el citado Amillaramiento, que llevaba en renta tierras del marqués. Distintas cantidades de pagos a su administrador así lo confirma en estos ańos.

${ }^{1311}$ Reiteramos que en todos los cuadros realizados sobre gastos de producción y beneficios se anotan todas las tareas a los precios reales del año y explotación. Como es sabido, en la mayor parte de las pequeñas y medianas labranzas, buena parte de estos gastos lo realiza la propia familia.

${ }^{1312}$ Revista de Agricultura... por la Iniciativa Privada..., Valladolid, vol. I, pág. 132-133, año 1869.

1313 Ibídem, pág. 97.

${ }^{1314}$ A.F.A.M. Carp. de escrituras y varios, año 1877.

${ }^{1315}$ Revista de Agricultura... por la Iniciativa Privada..., ob. cit., vol. I, pág. 132, año 1869.

${ }^{1316}$ Revista de Agricultura... por la Iniciativa Privada... Valladolid, vol. II, pág. 287, año 1870. 
Es evidente que se está en plena recesión. Los lamentos de estos grandes propietarios que firman las páginas de la Asociación Agrícola vallisoletana no confirman sino la crisis del modelo cerealista. Menos mal que en estos años setenta la positiva evolución del mercado exterior de vinos abría una puerta a la esperanza a los convecinos del norte de la Tierra de Medina.

Cuadro 139. Rendimientos obtenidos en una obrada de trigo. Tierra de Campos, año $1869^{1317}$

\begin{tabular}{lccr}
\hline Labores realizadas & Numero de labores o precisión de las mismas & Reales por unidad & Total (rs) \\
\hline Simiente & 2 fanegas & 40 & 80 \\
Labores de arado & 4 vueltas & 25 & 100 \\
Siega & 3 peones & 10 & 30 \\
Recolección & 5 reales fanega & 12 fanegas & 60 \\
Abono para conservación de la finca & 5 carros por igualada & 16 & 80 \\
Contribución & - & 18 & 18 \\
Por el 7\% del capital adelantado, menos la renta & - & 40 & 12 \\
Rentas de capital & 2 fanegas & & 80 \\
\hline Total de gastos & 12 fanegas & 460 \\
\hline Total de ingresos & - & 40 & 480 \\
\hline Beneficio & - & 20 \\
\hline
\end{tabular}

Fuente: Revista de Agricultura de la Asociación por la Iniciativa Privada. Elaboración propia.

Alejándose de la queja permanente del labrador, las tierras del ejemplo estudiado, sitas en los pagos de Valdelaíno y Valdelacasa en 1873 dieron rendimientos aceptables. Aunque el centeno de esta última solo salió a 4,25 fanegas la obrada, en las seis de Valdelaíno se cosecharon 14,16 fanegas de trigo. Y para estar en 1873 los precios del trigo seguían altos. Con todo, muchas tierras de sembradura de Serrada, exceptuando las de primera calidad del marqués, eran de mediocres rendimientos. Se finaliza su estudio transcribiendo las referencias a los precios de los granos que puntualmente en cada carta hacía llegar en 1859 Hipólito Alonso a su padre Gregorio León ${ }^{1318}$ :

"Medina del Campo, 17 de Abril de 1859

Querido Padre:...

...La cebada ha estado de 34 a 35 y el trigo de 40 a 44 . He ofrecido las 300 fanegas que Ud. me dice y me ha contestado uno que paga las 92 libras a 40,5 reales. Ud. me dirá si está limpio el trigo y que peso podrá tener; o más bien, advierto a Ud. Que el ofrecimiento es a calidad de estar limpio..."

Medina del Campo, 3 de julio de 1859

Querido Padre.

...La cebada está de 24 a 28 reales fanega. El trigo creo que de 36 a 37...”

Medina del Campo, 29 de agosto de 59

Querido Padre: recibí la de Ud. que trajo Facundo ayer, por el que pude contestarla, si bien le encargue se enterara de los precios de los granos. Yo creo que el trigo bueno pudo estar a 30 o 31 reales fanega, y la cebada a 18 o 19 ...”

Como se aprecia, el seguimiento de los mercados era muy importante en este tiempo. Sobre todo para los grandes hacendados, capaces de guardar toda la cosecha, evitando el descenso de precios durante el verano y sacándola de la panera al final de la primavera. Si entonces ya se ponía un ojo en los mercados, el otro seguía sin quitarse del cielo. La cosecha de uva dependía de las noches estrelladas y la de trigo, de si las nieblas de febrero y marzo acababan por "sacar agua". Se finalizan tantos desvelos reproduciendo estas inquietudes, según palabras escritas en abril de 18771319:

1317 Ibídem. La obrada del ejemplo presenta idéntica superficie a las de Tierra de Medina: 400 estadales con 18 cuartas por lado. Se anotan como simiente 2 fanegas de trigo por obrada y producirá de forma regular unos años con otros 12 fanegas, estimando su valor en 40 reales fanega.

1318 A.F.A.M. Carp. de escrituras y varios.

1319 A.F.A.M. Carp. de escrituras y varios. 

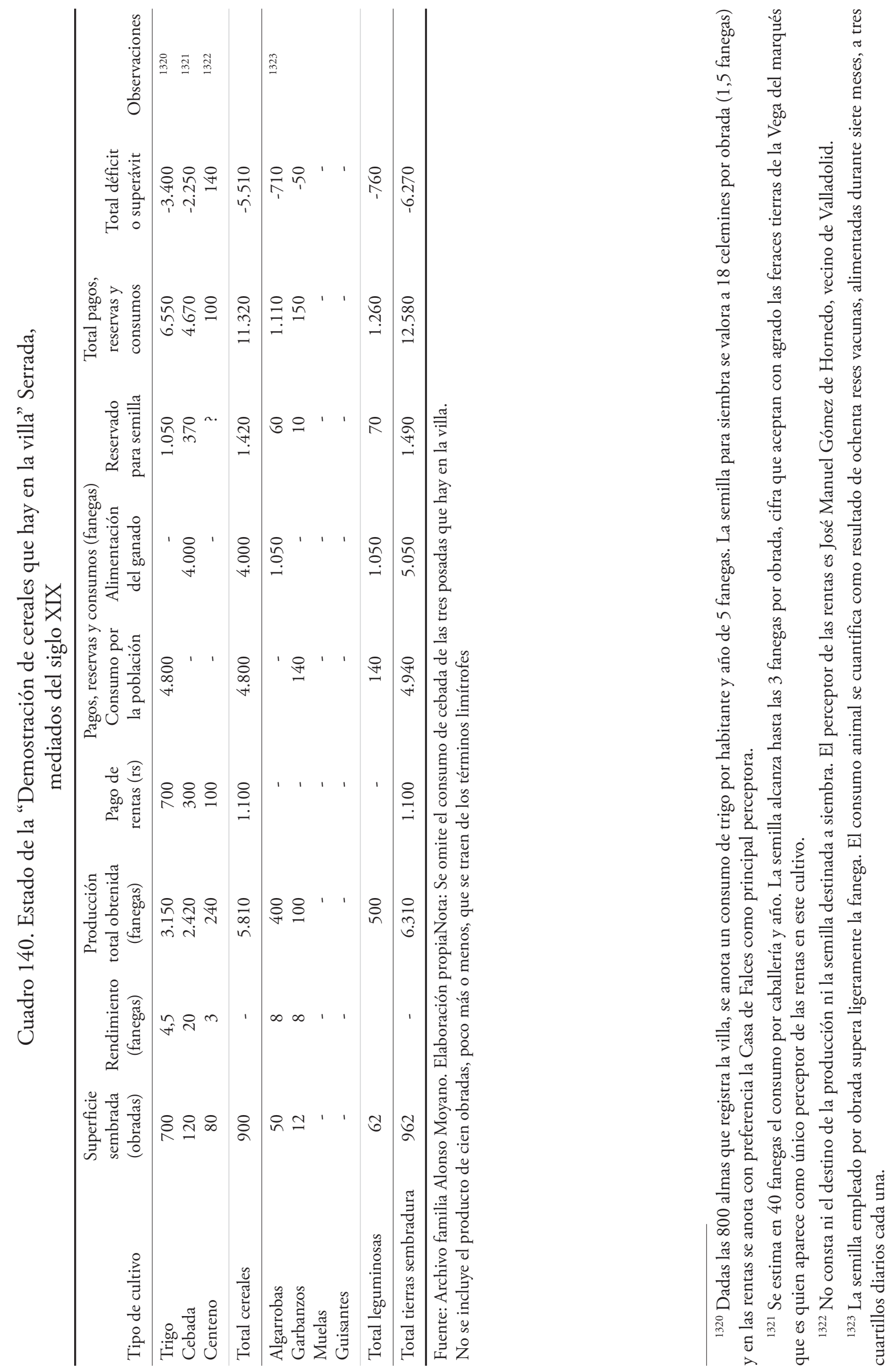
“...Aquí también ha estado el temporal de aguas; pero estos últimos días ya se va despejando y aun hace frío con viento. Dios quiera que el campo continúe ofreciendo esperanzas halagüeńas y nos de buen resultado, sin excluir las tierras que se siembran de garbanzos...”.

Hay que hacer un esfuerzo para evitar la influencia de los escasos rendimientos que se anotan en la cosecha que se registra y que pueden llevar a conclusiones erróneas. Las 4,5 fanegas por obrada en trigo y las 20 de cebada, obtenidas en las tierras de primera del marqués, son rendimientos propios de ańos de condiciones meteorológicas adversas. Cuando se han estudiado estos aprovechamientos, se han constatado cosechas regulares que superaban ampliamente estas cifras. De hecho, en estos años, la cifra media que señala la Administración para efectuar el cálculo de contribuciones y repartimientos es de 7,5 fanegas de trigo por obrada. En distintos pueblos de la Tierra de Medina se señalan producciones de cebada entre 32 y 40 fanegas. Es importante recordar estos valores porque entonces se duplicarían prácticamente las producciones brutas obtenidas con la consiguiente desaparición del déficit de grano final.

Entre los protocolos notariales o los apuntes que han conservado familias labradoras de este tiempo, las partidas de trigo o cebada al exterior son insignificantes. Dejando aparte, claro está, las rentas que salieron regularmente durante siglos, por la falta de titularidad de quienes labraban la tierra. Piénsese en la importancia de este factor estructural. En años de malas cosechas, como es el caso del ejemplo, sólo la renta suponía casi el 20\% del volumen total de la producción. Y si los gastos de producción la propia Administración los seńala en torno al 45\%, es evidente el efecto devastador que unas décadas atrás podían ocasionar a pequeños y medianos labradores una sucesión de malas cosechas.

No se quiere acabar esta primera reflexión abandonándose al azar de los precios y los mercados para dictaminar la rentabilidad o no de las explotaciones, pero, alejados de cualquier afán economicista, la política de protección arancelaria que se vive en este tiempo, aunque pudiera ser pan para hoy y hambre para mañana, fue un factor de impulso fundamental para explicar los cambios que se producen en el terrazgo de sembradura castellano. El predominio aplastante del trigo iba a subordinar a todos los cultivos, incluido al mismo trigo, como ya se ha analizado, a pagos poco adecuados. Sólo así se explica que, para tratar de mantener esas 700 obradas, que buscan, más que altas producciones, la suerte de tener excedentes y poderlos vender a 45 o 40 reales, la cebada y el centeno se mueven en un baile de cifras poco estables: 120 obradas de cebada y 80 de centeno en el año no determinado de la gráfica y 80 obradas de cebada, 30 de avena y 250 de centeno en los datos de 1857.

La importancia de asegurar la alimentación de la creciente cabańa ganadera, indispensable para lograr está expansión cerealista, necesitaba el soporte de los cereales y leguminosas pienso, si no en cuanto al número de obradas sembradas, pues estas representan el 27,23\%, sí en cuanto al volumen de alimento que han de disponer, dado lo exiguo de los pastos. De hecho, su cosecha equivale al $50 \%$ del total y, aunque en este año deficitario sólo cubre el 62,5\% de las necesidades alimenticias del ganado, en años de cosecha regular es muy posible que se pudieran atender sus necesidades. No sobra un solo celemín. ¡Cómo para que no marginen a las ovejas de los mejores pastos!

Por otra parte, los datos apuntados al pie y asimismo extraídos del citado cuadro estadístico, ayudan a completar estas valoraciones finales. Las cinco fanegas de consumo de trigo por persona y año, aun cuando se sabe lo difícil que es valorar la ingesta de grupos dispares en siglos diferentes, supera en una fanega las estimaciones que distintos estudios apuntan como cantidad consumida un siglo antes. He aquí uno de los factores de la expansión demográfica del XIX. Que Serrada pueda garantizar 4.000 fanegas anuales de trigo para la alimentación de sus 800 habitantes a mediados de siglo es un logro que hay que tener en cuenta. Cincuenta años más tarde, su imposibilidad reducirá el número de vecinos al tiempo que tensará las relaciones sociales. Otro tanto se puede decir del esfuerzo que se requiere para alimentar a las 80 reses vacunas que se refieren. $\mathrm{O}$ las 4.000 fanegas que han de consumir los animales de labor, si luego se les quiere exigir tirar del arado adecuadamente. 
A la luz de los precios que alcanzan la cebada y el trigo en estos ańos, no faltaban labrantines o jornaleros arrancando forraje en lindes y caminos para ahorrar a diario algunos reales.

El resultado final es una recuperación lenta, pero sostenida, de la producción global agraria. La Administración lo aprovechará en su beneficio, exigiendo porcentajes de contribución en torno al $12 \%$ del total de la riqueza valorada anualmente. Los registros que se han conservado y detallan las distintas partidas indican que, en esta villa, la riqueza se equilibra entre las tierras de sembradura y un viñedo que no pasa por su mejor momento. En sendos ańos no determinados de la década de los cincuenta, esta era la riqueza que los distintos comisionados asignaron a Serrada, de acuerdo con las bases que fijaba la Administración: ${ }^{1324}$

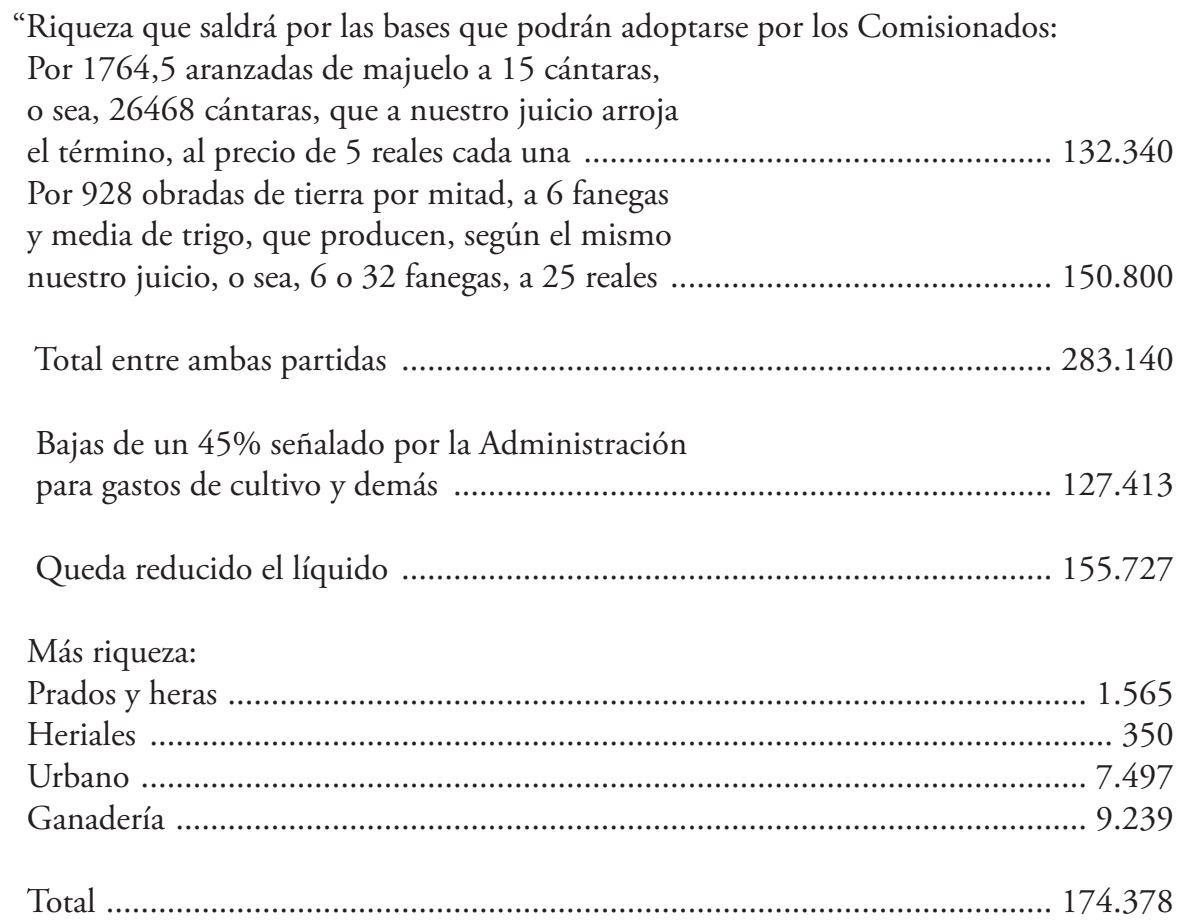

Corresponde a estos millares, al 12\%, 20.925 reales”

El mayor o menor porcentaje que ocuparán cereales o viñedo depende de las coyunturas de cosechas y precios. En el anterior ejemplo, los porcentajes de riqueza de majuelos y cereales son de $46,7 \%$ y $57,3 \%$ respectivamente, pero a nadie se le escapa que el precio medio de la venta del vino fue muy bajo. La recuperación de este cultivo, avanzada la centuria, invertirá estos valores, ya que en el último cuarto del mismo cesa el auge de la expansión triguera. Con todo, son estos los aprovechamientos que conforman la mayor parte de la riqueza estimada. Deducidos a riqueza líquida, sembradura y majuelos suponen el 89,30\% del total, aunque a estas alturas resultaría ocioso manifestar el predominio aplastante del componente agrícola frente al ganadero. La riqueza global, en fin, se verá crecer de forma continuada estos años. En la mayor parte de la década de los cincuenta, Serrada superará los 200.000 reales de riqueza imponible, llegando en 1852 a 296.978 reales. No obstante, los pueblos vecinos, con más término y más población, la superarán ampliamente. En 1859, cuando se asigna a Serrada una riqueza de 207.120 reales, La Seca alcanza 865.920 reales, Valdestillas 196.600 reales y Matapozuelos 313.950 reales, por poner algunos ejemplos de pueblos limítrofes ${ }^{1325}$.

${ }^{1324}$ A.F.A.M. Carp. de acuerdos y varios.

${ }^{1325}$ B.O.P.V., años 1852 y 1859. 
No hay que extenderse en la valoración de los datos aportados. Son elocuentes por sí mismos y, cuando se trate la vida municipal, tiempo habrá de profundizar en ellos. El crecimiento que se observa es el resultado del conjunto de factores que ya se han descrito y, al final de los sesenta, de la mano de la fragilidad estructural sobre la que se asienta buena parte de tal crecimiento, llegará la crisis de fin de siglo.

\section{Valoración y resultados de la intensificación agraria. La superación definitiva del sistema económico del Antiguo Régimen}

No por avisados dejará de sorprender el cambio de coyuntura tras este tiempo de expansión. Analizaremos si la fragilidad estructural del campo castellano encuentra responsables a los campesinos o a los desaciertos institucionales, pero hasta entonces no se duda en valorar estas décadas centrales, entre mediados de los cuarenta y avanzados los 60, como el tiempo en que se produce un cambio de rumbo definitivo, que aleja al campo castellano de las antiguas y endémicas crisis de subsistencia, anticuadas estructuras productivas y onerosas ataduras estamentales. Es cierto que los nubarrones que se avecinan dejan a labradores y jornaleros con las paneras vacías y muchas carencias, pero nunca los devolverán, ni al siglo XVIII, ni a la crisis del primer tercio de la centuria.

Cuantos factores se han estudiado, todos bajo el común denominador del liberalismo burgués isabelino, pudieron adolecer de atrevidos, ser acusados de foráneos, transitorios o apegados al interés de propietarios, hombres de negocios y rentistas, pero garantizaron al menos el alimento a una población que creció de forma extraordinaria en estas décadas y otorgó cierta solidez a las pequeñas y medianas explotaciones que en otro tiempo apenas sobrevivían entre escaseces y deudas. Que se hubiera necesitado un mayor cambio en las estructuras de la propiedad, en la introducción de mejoras técnicas, en la comunión entre ganadería y agricultura, en los repartos por herencias, en la llegada a los mercados de los productos y del agua a los secanos, parece extemporáneo manifestarlo ahora, a mediados del XIX, cuando tan sólo unos años antes dominaba en todo su esplendor el llamado Antiguo Régimen. No por casualidad el término "revolución industrial" se ha extendido y utilizado con mayor predicamento frente al apenas escrito "revolución agraria".

Pese a todo, parece innegable el mantenimiento en este tiempo de una neta y creciente producción destinada al mercado no sólo de los mostos, cuya transformación tenía ese fin prioritario, sino también de los productos cerealísticos y ganaderos. Avanzada la década de los cincuenta, esta tónica productiva nacional es también común a toda la comarca de Medina. Anteriormente se expusieron los abultados sobrantes que esgrimía su Ayuntamiento para alimentar al ferrocarril del norte. El nudo ferroviario medinense facilita tanto la salida de excedentes como la llegada de artículos procedentes de las provincias del Norte y de Andalucía y Extremadura, prohibitivos tan sólo unos años antes. En cuanto a Serrada, siempre se ha sido prudente en cuanto a los volúmenes de excedentes de cereales y leguminosas que comercializar, si se exceptúan las importantes sumas de las fanegas que alcanzaban las rentas pagadas al marqués o las familias De Rojas y Hornedo. La existencia de tantos pagos de tercera y esta falta de tierra en propiedad se constituían en factores que restaban muchos reales en las cuentas que se echaban a final de verano. Condicionada por su suelo, pese a vivir la expansión triguera, nunca abandonó la especialidad vitícola. El cuadro anterior, que recoge la "Demostración de las existencias de cereales que hay en la Villa”, es la mejor prueba radiológica del estado de las paneras de estos labradores en los años cincuenta ${ }^{1326}$. No obstante, se hará su análisis con la mayor de las cautelas, pues, a su carácter de documento elevado por una parte interesada a la Administración, se une la irregularidad de cosechas y precios que alteran notablemente, de un ańo para otro, la cuenta de resultados y dificultan la generalización de valoraciones, más allá del periodo y espacio a que aluden.

${ }^{1326}$ A.F.A.M. Carpeta de acuerdos y varios. 



\section{CAṔ́TULo VIII}

LA CRISIS AGRÍCOLA Y PECUARIA DE FINALES DE SIGLO. LA VIDA MUNICIPAL EN EL SIGLO XIX 


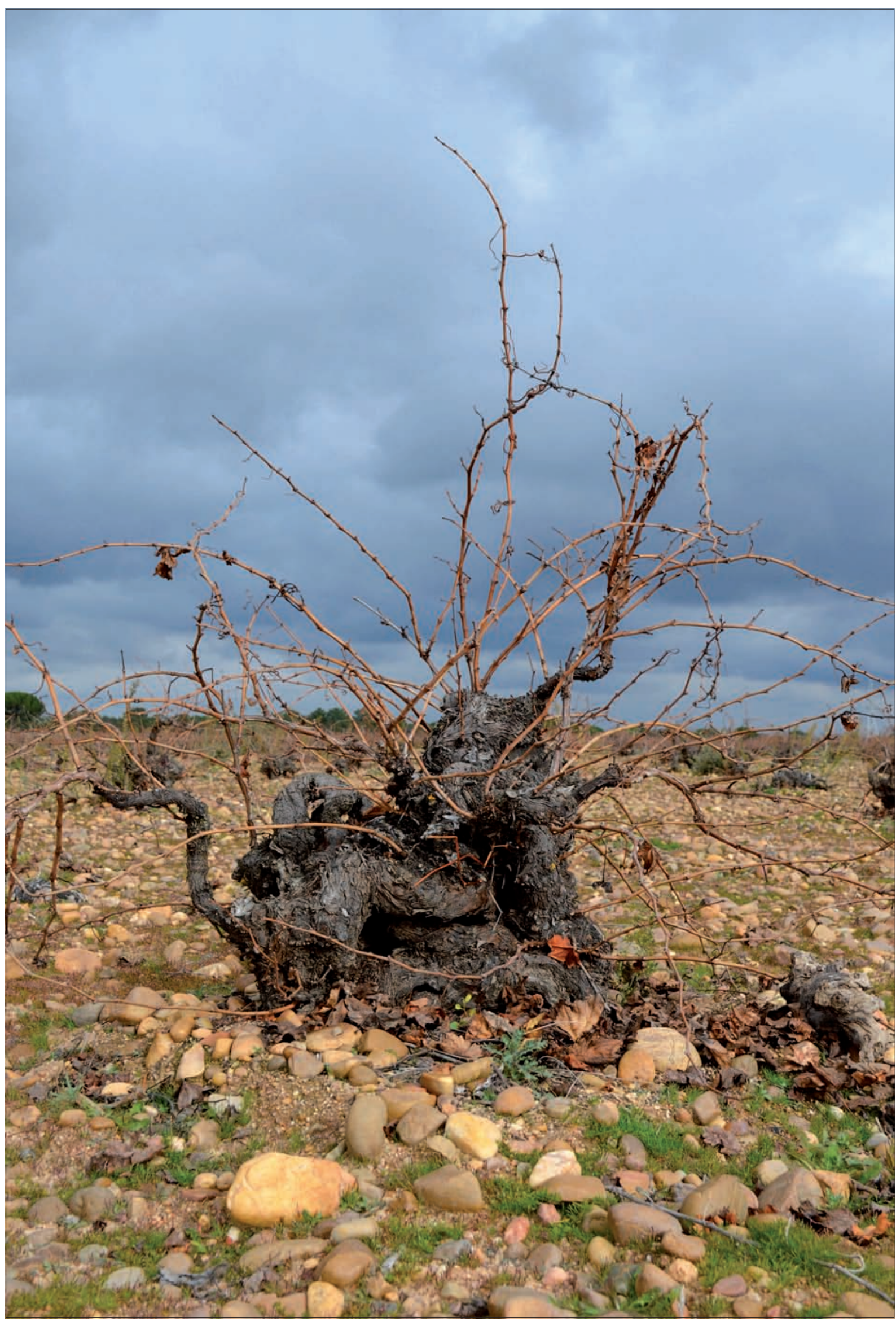

Imagen 92. Cepa verdeja prefiloxérica plantada en la segunda mitad del XIX. La Seca. Foto: 03/12/2014. La plaga de la filoxera destruyó la principal riqueza sobre la que se cimentaba la economía de estos pueblos. Cepas como las de la imagen son una excepción, toda vez que el insecto destruyó la práctica totalidad del viñedo. 
Aunque es un hecho incuestionable el aumento demográfico y de producción agraria que experimenta el país en el siglo XIX desde los años cuarenta hasta entrados los sesenta, los labradores castellanos nunca lanzaron las campanas al vuelo. Al contrario, siguen temerosos de la llegada de las tradicionales calamidades que asuelan cosechas y poblaciones. Después de la catastrófica cosecha de 1868, los más grandes y pudientes labradores vallisoletanos ponen de manifiesto, en la Asociación y Revista de Agricultura fundada por ellos mismos, que el crecimiento tenía más de artificio que de solidez. Denuncian que el periodo que atraviesa España es similar al que "pasó la Francia hace veinte años, la Alemania hace setenta y algunos más la Inglaterra”, reclamando la agrupación de las fuerzas productoras, la modernización técnica del campo español y una política favorecedora de los intereses de los productores nacionales ${ }^{1327}$. Si esto manifiestan los que tienen sobradas fuerzas para hacer frente a situaciones críticas, se puede imaginar la situación de los pequeños propietarios y renteros. La desamortización de Madoz acababa de hacer perder a todos, pero especialmente a estos últimos, el usufructo de montes y pastos comunales.

Como en otros muchos pueblos de la Tierra de Medina, los labradores de Serrada exponen a su alcalde en 1861 lo exiguo de los pastos con relación al aumento que han experimentado sus labranzas desde 1846. Los cultivadores privilegian su ganado de labor sobre el resto, al tiempo que solicitan a los ganaderos el estiércol para tratar de conseguir mayores rendimientos en unas tierras cada vez más esquilmadas. La fiebre productora había logrado arrancar a la tierra cosechas de grano por encima de sus posibilidades. Aprovechando la favorable situación, los gobiernos liberales, dada la agónica situación de su Hacienda, tampoco perdieron la ocasión de elevar la presión fiscal hasta límites asfixiantes. Poco tardan los nuevos y ricos propietarios o la nobleza rentista que aún conserva sus patrimonios, en defenderse de tales cargas, derivando el pago de las contribuciones a sus renteros, al tiempo que incrementan las fanegas de trigo que entregar en concepto de renta. Al final, los presagios se hicieron realidad. "Donde quitan y no pon, pronto se llega al hondón", argumentaba, siguiendo el refranero hispano, en febrero de 1871, Fernández Soba en una conferencia "Sobre los progresos realizados recientemente en Agricultura” 1328 . Lo que este ingeniero de minas de la Asociación de Amigos del País de León aplica, con relación a la necesidad de abono para corregir unos esquilmos abusivos, se puede aplicar a la acumulación de capital logrado en estos años de bonanza, por parte de los grandes hacendados y propietarios absentistas y que canalizan hacia otros sectores, como la deuda pública o las acciones ferroviarias.

El campo se descapitalizaba desde hacia muchas décadas ${ }^{1329}$. Si se extiende el dicho al gobierno de la nación, puede imaginarse la angustiante situación de muchos labradores ante el pago de con-

${ }^{1327}$ La Asociación agrícola..., ob. cit., vol. I, pág. 1-3, año 1869.

${ }^{1328}$ Ibídem, vol. III, pág. 1-2, año 1971.

${ }^{1329}$ Ello sin contar, como en ocasiones se viene refiriendo, los importantes recursos procedentes del campo que medianos y grandes hacendados destinaban a la formación y acomodo de sus hijos que, una vez colocados en la administración del estado y recibida la herencia familiar, también se convertían en arrendatarios de sus antiguos vecinos. Es el caso, a comienzos de siglo, de parte de la familia Moyano o, en el último tercio del XIX, de algunos hijos del hacendado Gregorio León Alonso. 
tribuciones, en unas décadas (1840-1870) en que el gasto público desborda a los ingresos ordinarios y la emisión continua de deuda agranda el círculo vicioso en que el ahorro agrícola es absorbido por el Tesoro. Los labriegos, endeudados, ven subir los intereses de sus préstamos año tras año ${ }^{1330}$. La debilidad estructural de la propiedad agraria para hacer frente a la competencia de los nuevos productores es igualmente un factor de primer orden. A diferencia de crisis anteriores, nos encontramos ante una crisis de sobreproducción, provocada por la llegada a los centros de consumo europeos de producciones agrícolas y ganaderas externas a precios más bajos que los que demandan estos labradores para rentabilizar sus explotaciones. No siempre, como se verá en esta comarca, era posible efectuar transformaciones para que la empresa agraria fuera competitiva, ya sean cambios de cultivo, mejoras técnicas, eliminación de rentas, etc. La revolución de los transportes y las leyes capitalistas del mercado comenzaban a regular los precios, más allá del volumen y calidad de producciones locales y regionales ${ }^{1331}$. Junto a ello no se puede olvidar la debilidad industrial interna que no absorbe el excedente de braceros o pequeños cultivadores. Si a estos factores se suman los anteriores, se obtienen los ingredientes necesarios para explicar la delicada situación que atraviesa el campo español. Para que no falte de nada la filoxera es el último golpe que podían esperar los cosecheros del norte de Medina y la pobreza y el cólera, en fin, la dura realidad en unos pueblos donde la miseria se hace difícil de sobrellevar.

\section{Los síntomas de la crisis y el agotamiento agroganadero de finales de siglo}

El aumento de superficies cultivadas y producciones que caracteriza las décadas centrales de siglo, tanto en Tierra de Medina como en el campo castellano en general, nunca supera los límites que marca el sistema tradicional. El análisis que se ha llevado a cabo del cultivo en tierras de sembradura y en majuelos en los años 70 era similar al analizado un siglo antes y al vigente cincuenta años después. De hecho, las malas cosechas y la crisis de subsistencia que se viven en 1857 y 1868 son un serio aviso de la fragilidad del sector que ve cómo las tierras se agotan, los precios descienden y, por el contrario, se disparan rentas, contribuciones e intereses de deuda.

Como se ha indicado y Serrada es un ejemplo elocuente, los capitales acumulados y las rentas derivadas de la actividad agraria rara vez se reinvirtieron en mejoras técnicas y productivas en unos momentos en que el desarrollo del capitalismo a escala mundial, la revolución industrial y de los transportes hacen llegar a los mercados nacionales trigo a precios más baratos que los productores castellanos pueden producir ${ }^{1332}$. Consecuencia directa de esta falta de competitividad de la agricultura vallisoletana es la ofensiva proteccionista que, desde 1875, labradores y harineros llevan a cabo, utilizando a la Diputación Provincial para la defensa de los intereses regionales, fuere quienes fueran los diputados y partidos de la nueva etapa de la Restauración ${ }^{1333}$. La Asamblea Regional de Diputa-

${ }^{1330}$ GONZÁLEZ PORTILLA, M.: “Acumulación de capital y crisis en el sector agrícola”, pág. 31-98. En: La Cuestión Agraria en la España Contemporánea. VI coloquio de Pau. M. Tuñón de Lara, Gonzalo Anés, Antonio Elorza y otros. Ed. José Luis García Delgado, Madrid, 1976.

${ }^{1331}$ GARRABOU, R. y ROBLEDO, R.: La crisis agraria de finales del siglo XIX, en La economía agraria en la Historia de España. Propiedad, explotación, comercialización, rentas. Gonzalo Anés Álvarez, Antonio Bernal Rodríguez, Jesús García Fernández, Emilio Giralt Raventós, Pierre Vilar y otros. Alfaguara, pág. 76-77.

1332 GARRABOU, R y SANZ, J.:, eds., Historia Agraria de la España Contemporánea, Expansión y crisis. 1850-1900, vol. 2, Ed. Crítica, Barcelona, 1985, pág. 177. Sobre los precios agrícolas y la crisis triguera: Grupo de Estudios de Historia Rural (G.E.H.RS), "La crisis agrícola en Castilla la Vieja y Andalucía: Los casos del trigo y del olivar" en: La crisis agraria de fines del siglo XIX, R. Garrabou, ed., edit. Crítica, Barcelona, 1988.

1333 Sobre el particular son imprescindibles los estudios de Celso Almuiña: La Prensa vallisoletana durante el siglo XIX (1808-1894); su estudio "Empresarios y Empresariales. La burguesía harinera castellana: un nuevo tipo de empresario. Número 4 de la revista de Anales de Estudios Económicos y Empresariales. Universidad de Valladolid, pág. 85-101 y su Historia de Valladolid, Siglo XIX... 
ciones, que se convoca a instancias del presidente vallisoletano Luis Alonso en 1884, trata de cerrar las filas regionalistas en torno al arancel triguero. En 1890 la institución no duda en contestar a la Comisión creada por Cánovas al efecto que "No ve esta Diputación otro remedio que la protección arancelaria, gravando los trigos extranjeros con 2,80 ptas. los $100 \mathrm{~kg}$ a más de lo que hoy pagan, y subiendo los de las harinas a 17 ptas los $100 \mathrm{~kg}{ }^{1334}$. La Diputación habla por boca de sus diputados provinciales. En la Tierra de Medina es unánime el mismo sentir. En 1887 la Junta de Agricultura, Industria y Comercio de la villa de las ferias, en contestación a la encuesta nacional que se lleva a cabo sobre el particular, manifiesta que "La causa inmediata originaria de la crisis y del estado de inminente ruina de esta región agricola es la importación de cereales y legumbres extranjeros, favorecidos por condiciones de tributación y transporte que no concurren en los nacionales, los cuales no pueden sostener la competencia establecida por la disminución del regulador arancelario ${ }^{1335}$.

El semanario "El Medinense", que nace también en este año 1887, recoge el debate nacional en torno al librecambismo/proteccionismo y en sus páginas abundan los sectores más catastrofistas. Martínez Maroto publica en 1896 un tratado sobre la crisis y, al tiempo que denuncia las estériles discusiones políticas, defiende a la "clase agrícola" como motor de la industria y el comercio e insta a las instituciones públicas a la defensa de los intereses de los productores, al fomento de los mercados y a la reducción de contribuciones entre otros factores ${ }^{1336}$. En realidad, algunos de los propietarios de la capital y provincia vallisoletana, que fundaron en 1869 la Asociación por la Iniciativa Privada, expusieron estos deseos. Aunque acompańados por otros que ven en las contribuciones todos los males y en el férreo proteccionismo la única salida, muchos defienden entonces, entre otras medidas, la modernización técnica y dimensional de las explotaciones como forma de competir en los mercados, o el impulso de los cotos redondos frente a la excesiva parcelación del terrazgo, como el camino que hacía tiempo habían recorrido Inglaterra o Francia para conseguir un sector rural competitivo $^{1337}$.

La contracción agropecuaria era general en estos años, pero los productores de granos del interior se llevan la peor parte. Pese a todo, al norte de Medina, donde el terrazgo de sembradura no era el fundamento de la economía rural, los años 70 y 80 coinciden con regulares salidas de vino y cierto fortalecimiento del cultivo. La filoxera francesa representa un momentáneo respiro dada la importante exportación de vinos españoles. A finales de siglo, cuando la plaga inicie la destrucción de los viñedos medinenses, la desolación será total.

\section{a. La toma de posiciones ante la crisis. El abandono de los hombres de negocios. El caso de José María de Rojas}

En contraste con las importantes familias nobiliarias que mantienen sus propiedades a lo largo del XIX, de las que el marqués de Torreblanca y Falces es un notable ejemplo, la situación general de crisis llevó a muchos hombres de negocios e inversores vallisoletanos a replantarse sus inversiones. La tierra dejaba de ser rentable y era hora de abandonar el barco antes de que se hundiera. A José

${ }^{1334}$ PASTRANA MORILla, H.: la Diputación Provincial de Valladolid. 1875-1930. Politica y Gestión. Ed. Excma. Diputación Provincial de Valladolid, 1997, pág. 305-314.

${ }^{1335}$ La crisis agrícola y pecuaria. Sucesores de Rivadeneyra, 1887-1889, 8 vols. Contestación de la Junta de Agricultura, Industria y Comercio de Medina del Campo (tomo 2, pág. 308-312) y Contestación de los productores de la zona militar de Medina del Campo (tomo 5, pág. 182-188). Citado y estudiado por Hilarión Pascual Gete: "La evolución de la agricultura medinense durante los siglos XIX y XX. De la opción cerealista al gran impulso dado al regadío, en Historia de Medina del Campo..., vol. III, ob. cit., pág. 152 y ss.

${ }^{1336}$ MARTINEZ MAROTO, S.: La crisis agricola y pecuaria y sus verdaderos remedios. Valladolid, 1896.

${ }^{1337}$ Un ejemplo del debate sobre el problema de la parcelación múltiple de las propiedades y del camino seguido en otros países puede verse en las páginas 37-39 del volumen I, Valladolid, año 1869. 
María de Rojas no le dio tiempo ${ }^{1338}$. En 1875 se deshace su importante hacienda de Serrada entre deudas y préstamos. No hacía veinticinco años que su padre Luis de Rojas había comprado en subasta la hacienda de brígidas y dominicos en esta localidad. Haciendo balance del proceso desamortizador, el profesor Díez Espinosa lo sitúa como el undécimo mayor comprador en la provincia (916 ha), representativo de la burguesía de negocios deseosa de adquirir importantes patrimonios ${ }^{1339}$.

Tras su muerte en 1849, sus hijos Julián, Micaela y José María heredan y gestionan directamente estos bienes rústicos al margen de otros negocios comerciales. Sus bienes en Serrada suman 106 fincas y la casa lagar dominica que se adjudican por terceras partes. Al margen de la gestión de esta importante hacienda gestionan el arrendamiento del Despoblado de San Martín del Monte desde la década de los cincuenta. José María de Rojas Ovejero mantiene abierto domicilio en Serrada en la misma casa lagar que rematara su padre, procedente de los frailes de San Pablo. En 1864, compra a su hermana Micaela la parte que le había correspondido de estos bienes, una vez fallecido su hermano Julián y su cuñado José Manuel Gómez de Hornedo, esposo de la citada Micaela de Rojas ${ }^{1340}$ :

"Que no conviniendo a la Doña Micaela conservar dicha mitad de fincas se ha convenido y concertado en enajenarlas... y otorga y vende a su hermano dichos bienes... por precio en que han convenido de 300.000 reales..,. importe de las ciento ocho fincas".

Sea por el enorme esfuerzo económico, sea por la mala marcha de otros negocios, el hecho es que su situación económica a finales de esta década se torna crítica. En mayo de 1871, la citada hermana le presta 67.000 reales a devolver el 18 de agosto de ese mismo ańo ${ }^{1341}$. No es suficiente. El 25 junio del mismo año vende con pacto de retro y arrendamiento 50 fincas en Serrada al conservador y rico propietario vallisoletano Eusebio Alonso Pesquera. El hijo del pudiente agente de negocios se vuelve por tres años rentero de unas tierras que jamás volverán a ser suyas ${ }^{1342}$ :

“D. José María de Rojas... otorga que vende a D. Eusebio Alonso Pesquera las cuarenta fincas deslindadas... por el precio de 8.000 escudos o sean 20.000 pts..

Que el vendedor podrá detraer o volver a adquirir las fincas... devolviendo el precio de veinte mil pesetas... dentro del término de tres años... con más las rentas vencidas... El D. José de Rojas recibe en arrendamiento las fincas que enajena por este contrato por la renta anual o colonia de 1.800 pts o sean 720 escudos...

Serán adeudados de cuenta de D. José $\mathrm{M}^{\circ}$ de Rojas todos los pagos que haya que hacer a la Hacienda pública...”.

El endeudamiento era tal que, meses después, un majuelo del lote le será embargado para el pago de un crédito a Rafael Casado Berceruelo, por lo que tendrá que compensar al señor Pesquera con otras vińas por valor similar al tasado. El plazo de revertir dinero y tierras expira sin que le sobre ningún escudo. Para rematar los disgustos, en abril de 1875 le embargan una cuba de vino por impagos en la contribución de consumos ${ }^{1343}$.

1338 José María, Julián y Micaela de Rojas Ovejero son hijos del ya conocido D. Luis de Rojas, hacendado liberal vallisoletano y director de la Sociedad de seguros de Incendios, y dueńo del parador de diligencias de Santa Ana, casado con Dońa Ramona Ovejero. Su hijo José María contrae matrimonio, en diciembre de 1862, con Patrocinio Castilla y Martínez y su hermana Micaela hace lo propio con el también mencionado José Manuel Gómez de Hornedo, que heredan, todos ellos al ser los únicos herederos, los bienes del tercer hermano mencionado Julián de Rojas Ovejero.(A.H.P.V. pt. 16570, Valladolid, Manuel Martín de Lezcano, fol. 435 y 500, año 1864.).

${ }^{1339}$ DÍEZ ESPINOSA, J. R.: Revolución liberal en Castilla. Tierra, nobleza y burguesía. Valladolid. Secretariado de Publicaciones, Universidad de Valladolid, 1987, pág.111.

${ }^{1340}$ A.H.P.V. Pt. 16570, Manuel Martín de Lezcano, Valladolid, fol. 435, año 1864.

${ }^{1341}$ A.H.P.V. Pt. 18724, Cándido Santos García, Valladolid, fol. 642, año 1875.

${ }^{1342}$ A.H.P.V. Pt. 16419, Felipe Redondo Muñoz, Valladolid, fol. 375, año 1871.

1343 Sus quejas por la falta de reforma en el procedimiento del reparto es, tanto una muestra de la resistencia que muestran muchos propietarios ante la agobiante presión fiscal, como de la situación que viven sus haciendas. Decimos esto porque el 
Cuadro 141. Fincas rústicas adquiridas por Balbino Alonso Moyano a Eusebio Alonso Pesquera, procedentes de la familia Rojas Ovejero. Serrada, año 1875

\begin{tabular}{|c|c|c|c|c|c|c|}
\hline No & Tierra/majuelo & Localización & $\begin{array}{l}\text { Superficie en } \\
\text { obradas/aranzadas }\end{array}$ & $\begin{array}{c}\text { Equivalencia } \\
\text { en ha }\end{array}$ & Calidad & $\begin{array}{c}\text { Precio } \\
\text { (en pesetas) }\end{array}$ \\
\hline 1 & Tierra (antes majuelo) & Moya (Velasco) & 10 aranz. 350 cepas & 5,0768 & 2 & 540 \\
\hline 2 & “ & Moya (Calabazana) & 3 aranz. 388 cep. & 1,8423 & 2 & 180 \\
\hline 3 & “ & Moya (Higuera) & 5 aranz. 208 cep. & 2,6607 & 2 & 300 \\
\hline 4 & “ & “ & 8 aranz. 51 cep. & 3,8121 & 3 & 90 \\
\hline 5 & “ & Moya (Las nueve) & 9 aranz. 60 cep. & 4,2926 & 3 & 600 \\
\hline 6 & Majuelo & Moya (Las Siete) & 7 aranz. 382 cep. & 3,7136 & 3 & 540 \\
\hline 7 & “ & Moya (Atanasio) & 3 aranz. 25 cep. & 1,4366 & 2 & 300 \\
\hline 8 & “ & Moya (Las Seis) & 6 aranz. 49 cep. & 2,8720 & 2 & 630 \\
\hline 9 & Tierra & Moya (Viña el Ciego) & 2 obrad. 342 est. & 1,6158 & 3 & 300 \\
\hline 10 & “ & Moya (Rosa Pequeña) & 6 obrad. 218 est. & 3,7609 & 3 & 330 \\
\hline 11 & “ & Moya (Cuadrado) & 2 obrad. 218 est. & 1,4979 & 3 & 750 \\
\hline 12 & “ & Moya (Cepas Altas) & 6 obrad. 74 est. & 3,5005 & 3 & 1.000 \\
\hline 13 & “ & Moya (Cuesta Redonda) & 6 obrad. 325 est. & 3,8557 & 3 & 1.000 \\
\hline 14 & Majuelo & Moya (Cepas Altas) & 16 aranz. 48 cep. & 7,5665 & - & 1.250 \\
\hline 15 & Tierra, anres majuelo & Moya (Zapatero) & 4 aranz. 110 cep. & 2,4110 & 3 & 350 \\
\hline 16 & Majuelo & 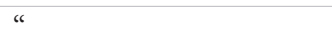 & 3 aranz. 108 cep. & 1,5293 & 3 & 180 \\
\hline 17 & Tierra & Moya (La Grande) & 19 obrad. 65 est. & 10,8455 & 3 & 1.950 \\
\hline 18 & “ & Moya (Montico) & 9 obrad. 300 est. & 5,5182 & 3 & 1.000 \\
\hline 19 & “ & Moya (Carretas) & 6 obrad. 204 est. & 3,6845 & 2 & 540 \\
\hline 20 & “\# & Moya (Herredosos) & 9 obrad. 16 est. & 5,1164 & 2 & 300 \\
\hline 21 & “ & Moya (Ponce) & 1 obrad. 200 est. & 0,8489 & 3 & 300 \\
\hline 22 & “ & Moya (Tintillos) & 4 obrad. 200 est. & 2,5468 & 2 & 685 \\
\hline 23 & “ & Moya (Cañarroyo) & 6 obrad. & 3,3958 & 3 & 650 \\
\hline 24 & "Tierra & Moya (Ventosilla) & 2 obrad. 200 est. & 1,4149 & 2 & 900 \\
\hline 25 & “ & Moya (Vallejo) & 8 obrad. 100 est. & 4,6693 & 2 & 900 \\
\hline 26 & “ & Moya (Rosagrande) & 9 obrad. 300 est. & 5,4182 & 3 & 240 \\
\hline 27 & “ & Moya (Chinchorral) & 3 obrad. 300 est. & 2,1224 & 3 & 240 \\
\hline 28 & “ & Goya (la Higuera) & 3 obrad. & 1,6979 & 2 & 600 \\
\hline 29 & “ & Moya (hundido) & 2 obrad. 100 est. & 1,2734 & 2 & 700 \\
\hline 30 & “ & Moya (velasco) & 8 obrad. 100 est. & 4,6692 & 3 & 180 \\
\hline 31 & “ & Moya (Atanasio) & 2 obrad. 100 est. & 1,2734 & 3 & 725 \\
\hline 32 & “ & Moya (Tras en Cuba) & 4 obrad. 200 est. & 2,5868 & 3 & 330 \\
\hline 33 & “ & Moya (Fuentes) & 30 obrad. 165 est. & 18,6177 & 2 & 2.050 \\
\hline 34 & “Tierra & Idem. & “ & & 2 & 1.000 \\
\hline 35 & “ & Moya (Bartolillo) & 3 obrad. Y 298 est. & 2,1195 & 2 & 350 \\
\hline 36 & Majuelo & Moya (Orcajillo) & 1 aranz. 406 cep. & 1,2000 & 2 & 180 \\
\hline 37 & “ & Moya (Fuentes) & 4 aranz. 365 cep. & 2,2861 & 2 & 1.955 \\
\hline 38 & “ & Serrada (Olmas o Sisón) & $4 \operatorname{aranz}$ & 1,8782 & 2 & 300 \\
\hline 39 & “ & Serrada (Praderas) & 3 aranz. 372 cep. & 1,8245 & 2 & 210 \\
\hline 40 & “ & Serrada cam. Valladolid) & 7 aranz. 120 cep. & 2,9139 & 2 & 205 \\
\hline 41 & “ & Serrada (Raposeras) & 5 aranz. 390 cep. & $2,33,92$ & & 170 \\
\hline \multicolumn{2}{|c|}{ TOTAL } & & & 139,36 & & 25.000 \\
\hline
\end{tabular}

Fuente: A.H.P.V. Protocolos Notariales. Elaboración propia.

comisionado ejecutor sale de su domicilio para entrar en la casa del pudiente Balbino Alonso y después en la de Gregorio león, padre de este último. Encabezaban la lista de "otros doce o catorce deudores." Al parecer la resistencia vecinal derivaba" del perjuicio que causa al contribuyente con no haber reformado el repartimiento de consumos, según orden superior" en la que se posibilita al Ayuntamiento a disminuir el gravamen sobre la riqueza amillarada del doce por ciento al cuatro autorizando al Ayuntamiento a que, "cobre el semestre vencido por el actual reparto haciendo después de reformado, una liquidación con cada uno de los que sufran alteración en sus cuotas." (A.H.P.V. Pt. 18031. Francisco de Ávila, Rodilana, fol. 67, año 1875). 
Las razones a que aluden las escrituras con relación a estos trasvases de propiedad son sólo el principio de la crisis que arruinará a otros muchos ${ }^{1344}$ :

"Que la escasez de cosechas y productos de la fincabilidad del Don José en los ańos últimos, y especialmente en el corriente, han imposibilitado al Don José devolver a la Dońa Micaela las diez y seis mil quinientas pesetas... y la propuso la venta y enajenación de... una casa, situada en el casco de Serrada, en la Plazuela de San Pablo..."

Era el final. Seis años más tarde vende la casa al hacendado local, comprador de casi todos sus bienes en Serrada, Balbino Alonso ${ }^{1345}$. Se deshace como un azucarillo una de las mayores labranzas de la comarca gestada en tiempos de Mendizábal. Una vez más, lo precipitado de las ventas, el control hipotecario de los bienes por acaudalados caciques y prestamistas foráneos y la difícil situación que vivían los pequeños propietarios locales, impiden el reparto de las propiedades entre los pequeños y medianos labradores.

El definitivo trasvase de propiedad también se lleva a cabo en este vertiginoso mes de noviembre de 1875. El día 24 Eusebio Alonso Pesquera vende las 41 fincas adquiridas al señor de Rojas a Balbino Alonso, vecino propietario de Serrada, por una cantidad "que en junto suman 100.000 reales, lo mismo que 25.000 pesetas"1346. Balbino Alonso, hijo del hacendado Gregorio León, se convierte, tras el marqués de Falces, en el mayor hacendado de la villa. El cuadro adjunto, que detalla superficies, calidades y precios, da una idea de la situación del mercado de la tierra al comienzo de la crisis.

\title{
b. Del endeudamiento de los labradores a las exigencias de los arrendatarios
}

Antes de 1870 sobran hechos en las distintas villas al norte y al sur de Medina que reflejan la recesión que se avecina. Desde los años sesenta, pequeños labradores arruinados solicitan préstamos a los mayores hacendados. La obligación hipotecaria por valor de 2.000 reales que firman Ignacio Gaspar y Damiana Alonso a favor del pudiente Canuto de Castro en noviembre de 1861 es sólo el inicio de un endeudamiento de mayor alcance ${ }^{1347}$ :

\begin{abstract}
"Que necesitando para atender y cubrir sus necesidades la suma de dos mil reales vellón, buscaron a su convecino D. Canuto de Castro, y haciéndole un pequeño bosquejo de los motivos que les ha impulsado a buscar dichas sumas, le rogaron se la prestase o facilitase. Que más generoso de lo que pudieron figurarse se lo prometió y entregó antes de este acto en monedas de oro y plata, y con la condición que les había de pagar un seis por ciento el tiempo que tarden el hacerle pago de los expresados dos mil reales cada un ańo... Y por lo mismo se obligan con sus personas y todos sus bienes muebles y raíces... a reintegrarles y devolvérseles y pagárseles los dos mil reales..."
\end{abstract}

${ }^{1344}$ El 30 de octubre de este año, vende a Canuto de Castro "un majuelo tinto... al pago de la Cuesta de los Muertos, que de plantio hace quince aranzadas y media..." por 5.375 pts El 3 de noviembre hace lo propio a su convecino Balbino Alonso "por precisar metálico para sus negociaciones... los vinos y vinagre anejos, así como también los vinos y líquidos nuebos que están en fermentación, todo encerrado en la casa y bodega del D. José, situada en Serrada, en la Plaza de S. Pablo" por 2.805 pesetas ${ }^{1344}$. Cuatro días después, vende 36 ha repartidas en 14 fincas a Valentín de Íscar, en precio de 8.000 pesetas. Como los anteriores bienes citados habían sido adquiridos por herencia y compra a sus hermanos Julián y Micaela de Rojas Ovejero. Este lote estaba hipotecado por un empréstito de 5.000 pesetas contraído en 1869 ante Mr. Desiderio Petit, de nacionalidad francesa y avecindado entonces en Valladolid. En estos días adeudaba anualidades vencidas por valor de más de 2.000 pts. A su hermana tampoco la iban bien los negocios o, como sucedía a su hermano, no parecía que la prudencia contara gran cosa en la asunción de créditos y riesgos. En febrero de este año 1875, firma un crédito de 5.000 pesetas al 6\% "para cubrir sus necesidades y de su familia" depositando como aval "una casa en que habita, situada en calle Nueva del Teatro... que lindaba y linda... con otra del D. Julián y D. José de Rojas...” y en noviembre, sin embargo, compra a su hermano por 10.000 pesetas la casa y bodega de los dominicos. (A.H.P.V. Pt. 19314, Manuel Martín de Lezcano, Valladolid, vol. 45, año 1875).

1345 A.H.P.V. Pt 18724, fol. 642, Cándido Santos, año 1875 y Pt. 18480, fol. 2217, Bonifacio Oviedo, año 1881, respectivamente.

1346 Ibídem. Fol. 319.

1347 A.H.P.V. Pt. 15957, Serrada, Cenón Martínez, fol. 20, año 1861. 
Unos años más tarde, en 1864, el mismo hacendado presta a las familias Romero Villarejo y Blanco Herrero la suma de 14.000 reales al ocho por ciento ${ }^{1348}$. Conforme la crisis avance, y de acuerdo a las necesidades de unos y la avaricia de otros, los intereses pueden llegar al 20 por ciento, caso del préstamo firmado en La Seca en 1893 entre Clemente Pérez y Cecilia de Ávila a favor de Francisca García por valor de 500 pesetas $^{1349}$. Hasta el gran propietario Gregorio León solicita en 1865 una obligación hipotecaria por valor de 22.000 reales, para impulsar su labranza, y tiene dificultades para el pago de sus rentas entre los años 1872 y 1874 . El Patronato de Santa Clara, muy a su pesar dadas las amigables relaciones que mantenían, pero abrumados por "la situación tan precaria en que se encuentran todas las obligaciones de esta fundación", se ve obligado a iniciar acciones judiciales para el cobro del arrendamiento de las dehesas de San Martín que lleva el citado vecino de Serrada "pese al mal efecto que siempre produce la acción de embargo y la presencia de curiales" 1350 .

La coyuntura no es fácil para nadie cuando a la irregularidad de las cosechas se une lo azaroso de los mercados. El trigo sube y baja desconcertando a todos y disponer de una buena información mercantil, cercana a la especulación con que obran los almacenistas, es clave para decidir su venta. En 1877 León José Moyano escribe a sus tíos dando cuenta de estos precios ${ }^{1351}$ :

"El trigo ha bajado, pues un obrero de casa que estuvo en Tordesillas, dice que no pasó de los 40 reales; y esta mañana me han asegurado que unos de San Miguel que llaman los berceruelos, se volvieron de Valladolid ayer mismo con su trigo en los carros, pues no se lo pagaron más que a 35 reales".

Como puede imaginarse, si el labrador no vende bien la cosecha, difícilmente paga a tiempo sus rentas. De hecho, en estos ańos se observa, en la correspondencia privada, que cobrar la renta a renteros que siempre habían sido solventes se torna más que difícil. Las cartas que se cruzan en 1877 estas familias propietarias dan testimonio de ello ${ }^{1352}$ :

\footnotetext{
"Respeto a Julián Rodríguez debe los años 68 y 70, pero atendiendo a que era el que mejor cumplía, que nunca me molestó para cobrarle, al decirle que me daban 30 fanegas por las tierras, me contestó: es un disparate, pero no quiero que pierdas mucho, yo también te las doy, pero haces el favor de no hacerme gastos de escrituras y cumpliré con las treinta como hasta aquí lo he hecho con las veintidós. Conformándome por el buen comportamiento que había tenido, así lo hizo en el año 66, pero vino el año fatal de 68 y le fue imposible; y desde entonces empezó a estar mal. Le dije: déjeme usted las tierras, aún cuando no le he desahuciado en su tiempo, y me contesto: no las dejo, ni pienso dejarte en deber nada, como a los demás. Vino el 70 y hasta aquí me dijeron: "es imposible que te pague, pues si ha sembrado será muy poco...". Desde entonces digo lo de nuestro tío Antonio: no hay que fiarse de nadie".
}

1348 Ibídem, fol. 91, año 1864.

1349 A.H.P.V. Pt. 20012, La Seca, Santiago Nogal del Castillo, fol. 267, año 1893.

1350 A.F.A.M., carp. de escrituras y varios.

${ }^{1351}$ A.F.E.I.

${ }^{1352}$ A.F.E..I. Al igual que ocurrió con la familia de Rojas, en el último tercio del XIX distintos miembros de la pudiente familia de los Moyano que ocupaban puestos en la administración en el mundo urbano regional o extra regional, acaban vendiendo sus propiedades en Serrada. Luis Moyano, médico en Madrid, remite una carta a sus tíos de Serrada en enero de 1897 en los siguientes términos: Mi querido tío: Si no estoy equivocado y usted me rectificara, las fincas que poseo en esa son próximamente veintiséis aranzadas de majuelos y once obradas y media de tierra blanca, una cuba en la bodega del tío Antonio, la parte correspond iente de la capellanía y el vino de la última cosecha sino se ha vendido. Pues bien, teniendo en cuenta que ustedes pagaron a mi tía Pepita sesenta y nueve o setenta mil reales por sesenta y tantas aranzadas de majuelo, una bodega sin cubas y mala y un solar y el fruto de los majuelos, yo fijo como precio a todo lo enunciado en el primer párrafo de mi carta en nueve mil pesetas al contado o en doce en $\operatorname{diez}$ ańos..." 
Huelga decir que muchos pequeños propietarios perderán parte de su hacienda cuando malas cosechas o bajos precios impidan hacer efectivo el pago de intereses o capitales. La escasez de estos provocaba el encarecimiento del dinero en todo el país ${ }^{1353}$. Se han detectado casos en que, a cambio de dinero "para sus urgencias y lebantar las cargas de su casa", se han entregado cosechas enteras previa valoración antes de la siega. Santiago Conde vende en mayo de 1878 en Calabazas los siguientes sembrados: ${ }^{1354}$

"Ocho obradas de trigo valoradas cada una a 216 reales... Como nuebe obradas de sembrado de algarrobas, en cuatro pedazos... tasado cada una obrada a 126 reales... Siete obradas de centeno, cada obrada a 80 reales... Obrada y media de garbanzos en 200 reales...”.

En relación con esta inseguridad económica, los contratos de arrendamiento tienden a reducir su vigencia y a estipular aun más, si cabe, las obligaciones y sujeciones de los renteros, no sólo en lo que atañe a contribuciones y rentas, dada la incertidumbre por la que pasaban los mercados trigueros, sino también para asegurar la fertilidad de las tierras, capital fundamental en unas décadas en que el intenso esquilmo de décadas atrás las había dejado al borde del agotamiento edáfico. El importante arrendamiento que se firma en La Seca en 1877, entre Manuel Bayón Cantalapiedra y Pedro Fernández Recio sobre 105 obradas de tierra y 53 aranzadas de majuelo, además de casa, corral, bodega, cubas y lagar, se firma por dos ańos. En estos casos de acuerdos entre partes muy pudientes o instituciones públicas, se comienza a ver que la renta no se estipula en especie sino en "buenas monedas" 1355 . Otro ejemplo tiene lugar en la misma localidad, cuando su Ayuntamiento arrienda, en 1892, a Fermín B. Bayón, 27 fincas pertenecientes a sus propios, por tres años a razón de 6.992 pesetas ${ }^{1356}$. O las 16 aranzadas de majuelo y 3,5 obradas de tierra que arrienda en 1883 el vecino de Serrada Perfecto Moyano y al de La Seca Braulio Mena por 300 pesetas anuales ${ }^{1357}$.

No es el caso del marqués de Falces, que sigue arrendando sus propiedades a los labradores de la villa siguiendo repartos anteriores y especificando la renta en fanegas de trigo. En los contratos que firma su apoderado Mariano Moyano en 1877, la renta se sitúa en fanega y media por obrada en contratos de "cuatro pagas, cuatro frutos o siembra de la parte y porción de tierra que cada año corresponda estar de barbecho...". Entre las nuevas condiciones que figuran en las escrituras de arriendo, nunca expresadas hasta ahora, está la prohibición de "no trashojar más que cuatro obradas por cada renta de cuarenta obradas", lo que viene a confirmar, tanto la práctica de los retelos ya estudiada, como la preocupación de los propietarios por evitar un excesivo esquilmo en sus propiedades. Otra

1353 GONZÁLEZ PORTILLA, M.: "Acumulación de capital y crisis en el sector agrícola”, en La cuestión agraria..., ob. cit., pág. 45 .

${ }^{1354}$ A.H.P.V. Pt. 18034, Francisco de Ávila, Rodilana, fol. 213, año 1878. Llama la atención el riesgo que corre el comprador al asumir una venta de frutos mostrados al final de la primavera y "a todo riesgo y ventura". En un contrato similar que firman labradores de San Vicente del Palacio ante el notario de Rodilana en 25 de julio de 1873, se hace constar que "confiesa que hace más de un mes, cuando se perfeccionó el contrato, recibió los importes en que convinieron, o sean, cinco mil treinta y seis reales". Como en el anterior caso los precios a los que se ajustan son "los corrientes del país." El trigo en todos estos contratos sigue siendo el cultivo dominante. En la hacienda de San Vicente, de las 38,75 obradas sembradas y repartidas en 31 pedazos, 3,75 obradas están sembradas de algarrobas; 2,5 de cebada; 1,5 de centeno; 29,5 de trigo y 1,5 de garbanzos. (A.H.P.V. Pt.18030. Francisco de Puebla. Rodilana. Fol. 97. Año 1873.)

$1355 \mathrm{El}$ mencionado arriendo se firma "por el precio cada obrada de tierra de diez pesetas y cada una aranzada de majuelo el de doce pesetas y media; el de veinticinco pesetas el corral; el de setenta y cinco pesetas el lagar; el de cincuenta pesetas el hueco de bodega y el de ciento doce pesetas y media las tres cubas, importando las dos rentas reunidas de tierras y majuelos en los dos disfrutes por que se arriendan, asi como lo demás espresado en los dos años, todo reunido, la cantidad de tres mil novecientas setenta y tres pesetas y setenta y cinco céntimos..."(A.H.P.V. Pt. 18064, La Seca, Francisco Rodríguez Cantalapiedra, fol. 176, ańo 1877).

${ }^{1356}$ A.H.P.V. Pt. 20017, La Seca, Santiago Nogal del Castillo, fol. 85, año 1892.

1357 A.H.P.V. Pt. 18039, Rodilana, Francisco de Ávila, fol. 95, año 1883. 
nueva obligación adscrita a los renteros será la de estar a disposición del señor cuando desee comercializar el grano depositado en sus paneras de Serrada. La revolución de los transportes y mercados conllevaba en este caso un trabajo adicional para los labradores de Serrada: ${ }^{1358}$

"Que los citados D. Luis y D. Hilario se comprometen a llebar, libres de todo gasto de porte, impuesto y demás que se establezcan para el señor marques, desde la panera que este tiene en Serrada a la estación de Matapozuelos, la renta entregada el día en que se les ordene por el D. Mariano...”

Las distintas familias labradoras siguen con las rentas de sus antepasados o con aquellas dejadas por quienes, por reducción de sus labranzas o por acumulación de herencias, dejan de llevar tierras del marqués. Baste señalar, como ejemplo, las escrituradas en Medina del Campo en el año 18771359:

Cuadro 142. Ejemplos de arrendamientos del marqués de Falces en Serrada, año 1877

\begin{tabular}{|c|c|c|c|c|c|}
\hline Rentero & Antiguo rentero & $\begin{array}{l}\text { Superficie } \\
\text { arrendada }\end{array}$ & $\begin{array}{l}\text { Duración } \\
\text { del contrato }\end{array}$ & $\begin{array}{l}\text { Cuantía a entregar } \\
\text { (fanegas de trigo) }\end{array}$ & Fanegas/obrada \\
\hline Luis e Hilario Fadrique & $\begin{array}{l}\text { Padre de los } \\
\text { anteriores }\end{array}$ & $\begin{array}{l}\text { Media renta } \\
\text { (20 obradas) }\end{array}$ & 4 años & 30 & 1,5 \\
\hline Patricio Obregón Román & Félix Martínez & $\begin{array}{l}\text { Media renta } \\
\text { y tierras sueltas } \\
\text { ( } 27,5 \text { obradas })\end{array}$ & “ & 37,5 & 1,36 \\
\hline $\begin{array}{l}\text { Mariano y Florencio } \\
\text { Martín Navarro }\end{array}$ & $\begin{array}{l}\text { Joaquina Moyano } \\
\text { y Feliciana Martín }\end{array}$ & $\begin{array}{l}\text { Una renta y } \\
\text { tierras sueltas } \\
\text { ( } 48 \text { obradas) }\end{array}$ & “ & 48 & 1 \\
\hline Agapito de Íscar Román & $\begin{array}{l}\text { Mariano Fadrique } \\
\text { y Celestino Alonso }\end{array}$ & $\begin{array}{l}\text { Media renta } \\
\text { (20 obradas) }\end{array}$ & “ & 30 & 1,5 \\
\hline $\begin{array}{l}\text { Valentín de Íscar Alonso } \\
\text { y Nicolás Hinojal Román }\end{array}$ & $\begin{array}{l}\text { Manuel Alonso } \\
\text { y Vicente Rojo }\end{array}$ & $\begin{array}{l}\text { Una renta y } \\
\text { tierras sueltas } \\
\text { ( } 42,5 \text { obradas })\end{array}$ & “ & 72,5 & 1,70 \\
\hline Gregorio Juárez Rodríguez & Manuel Pérez & $\begin{array}{l}\text { Media renta y } \\
\text { tierras sueltas }\end{array}$ & ( 21,5 obradas) & “ & $31,51,46$ \\
\hline
\end{tabular}

Fuente: A.H.P.V. Protocolos Notariales. Elaboración propia.

Sin embargo, cuando el señor, a través de su administrador, se entiende con pocos renteros, como sucede en 1880 en sus propiedades de Eván de Abajo, no duda en fijar la renta en dinero y en precisar las restricciones que se vienen apuntando ${ }^{1360}$.

${ }^{1358}$ A.H.P.V. Pt. 18124, Medina del Campo, Ramón Rodríguez Pérez., fol. 95, año 1877.

${ }^{1359}$ Ibídem.

1360 “Que el D. Juan Flores Martín, el D. Blas Alonso Flores y el D. Esteban Alonso de Oyague, juntos y de mancomún... reciben en renta de dicho Excmo. Sr. Marques de Falces y Torreblanca, y en nombre de su apoderado D. Mariano Moyano López, el terrazgo, prados, casas, horno y palomar, y un cercado y una hera, que corresponden al repetido Excmo. Sr. Marqués en el pueblo y término de Eván de Abajo, tierras labrantías y demás..., incluso la tierra denominada del Gatuñal... que hace aproximadamente cuarenta y seis obradas...

Que el arriendo será por seis años...y en cada uno de los seis años pagarán el primero de septiembre la cantidad de veinte y un mil reales de renta que los mismos pondrán de su cargo, cuenta y riesgo en monedas de oro y plata... en la Villa y Corte de Madrid, en la casa y poder d dicho Excmo. Sr. Marqués...

Que las tierras de pan llevar se disfrutarán a dos hojas y no podrán los arrendatarios subarrendar ni trashojar más que sesenta u ochenta obradas...

Que los arrendatarios se obligan a pagar todas las contribuciones ordinarias y extraordinarias provinciales y municipales...

Será de cuenta y riesgo de los arrendatarios dejar en tan buen estado de conservación los edificios y era que se recibe en arrendamiento cuando este concluya conforme el inventario...”. (A.H.P.V. Pt. 18128, fol. 1140, año 1880). 
Por estas fechas y conforme avance la crisis, las rentas tienden a bajar, pero ello no debe llamar a engaño, pues en estos años se fijan como condiciones obligatorias para los renteros "el pago de todas las contribuciones ordinarias, provinciales y municipales, y cuantas se impongan a las tierras objeto de este arrendamiento" ${ }^{1361}$. A partir de los años 80 , los contratos que se firman en la comarca medinense rara vez superan rentas de 1,25 fanegas por obrada, situándose muchas por debajo de la unidad ${ }^{1362}$. La bajada generalizada de precios reduce la rentabilidad en unas tierras que ya venían sobreexplotadas de tiempo atrás. La peor parte la lleva la propia tierra toda vez que la crisis ganadera, el alto precio y la carestía del estiércol llevan a los renteros a un esquilmo abusivo. Para evitar este agotamiento, sobre todo en contratos superiores a cuatro ańos, los propietarios de esta comarca no dejan nada al azar. El que a continuación se anota, firmado en 1881, es un buen ejemplo ${ }^{1363}$ :

"Que el D. Ignacio Pérez Felipe ha de labrar y cultivar las cinco tierras (nueve obradas y 100 estadales) que recibe en renta a ley de buen labrador y a dos hojas, dándolas las labores y vueltas necesarias, estercolarlas y sin rebujar las barbecheras para evitar que se esquilmen, sin poder tampoco destruir lindes, mojones...

Que... por esta razón, de renta en los seis años por el que se hace el arrendamiento entregará setenta y dos fanegas de trigo, o sean, doce fanegas de trigo en cada uno de los seis ańos y en los días quince de agosto...”

Son unos momentos en que, como sucedía en el viñedo, las tierras de sembradura se estiman tanto por su calidad natural como por las prácticas agrícolas invertidas en ellas. Recuérdense los gastos que conllevaba hacerlas producir en 1872 y 1873 . Hacia 1875 y por lo que se hace constar en distintos inventarios de bienes de la Tierra de Medina, solo las labores y estercolado pueden superar el 25\% del valor total de la tierra. Un ejemplo de estas apreciaciones se encuentra en el inventario practicado dicho año por Teodoro Hernández, en que la obrada de tierra oscila, según su calidad, entre las 75 y 150 pesetas. La fanega de trigo se cotiza en este tiempo a 34 reales y el cántaro de vino a 2 pesetas ${ }^{1364}$ :

"Vueltas y abonos.

Ítem. Por veinte y dos obradas de tierra, vinadas a tres pesetas cada una y vuelta, importan 132,5 pesetas.

Ítem. Por once obradas y media de tierra, terciadas a tres pesetas cada una y vuelta, importan 103,50 pesetas. Ítem. Por dos obradas y media de tierra, cuarteadas a tres pesetas cada una y vuelta, importan 30 pesetas. Ítem. Por cinco obradas de tierra, abonadas a quince pesetas cada una importan 75 pesetas.

Ítem. Por el basurero tasado en 15 pesetas.

Ítem. Por veinticuatro aranzadas y tres cuartas de majuelo, tasadas a veintiséis reales cada una, importan 157,5 pesetas..."

${ }^{1361}$ A.H.P.V. Pt. 18124, fol. 203.

${ }^{1362}$ A falta de un estudio más pormenorizado sobre el particular, se hace difícil establecer criterios generales al respecto. Las diferentes calidades de tierra y la dispar situación de renteros y propietarios son un factor a tener en cuenta. A ello se debe añadir que en muchos de los contratos estudiados se incluyen casas, eras o bodegas, sin que se especifique la renta en unas y otras partidas, sin olvidar las numerosas escrituras en que, por continuar el contrato entre las partes, no se concreta el número de obradas. Con todo, sí se puede afirmar esta tendencia a la baja. En el año 1881, por ejemplo, hay arrendamientos que fijan la renta por obrada en 1,29, 0,62, 0,87, 0,65, 1, 1,25, o 0,70 fanegas de trigo en distintos pueblos de la comarca medinense. (A.H.P.V. Medina del Campo. Pt. 11813, 18129, 18079, 18126 y 18128). En 1883 el Hospital General de Medina arrienda 20,5 obradas en Fuentelsol por 29 fanegas de trigo (1,41 fanegas por obrada). (A.H.P.V. Pt. 18132); en 1885 el marqués de San Felices arrienda en término de San Salvador de Zapardiel 183 obradas por 122 fanegas anuales (1,5 fanegas por obrada) o Nicanor Alonso Munumer, en nombre de su madre, vecina de Dueñas (Villaverde) hace lo propio con 89 obradas por 100 fanegas de trigo (1,12 por unidad) (A.H.P.V. Pt. 20008).

${ }^{1363}$ A.H.P.V. Pt. 18113, Medina del Campo, Policarpo Gil Terradillos, fol. 1413, año 1881.

${ }^{1364}$ A.H.P.V. Pt. 18087, Medina del Campo, Policarpo Gil Terradillos, fol. 1127, año 1875. 
A partir de estas fechas el pago de las contribuciones por los cultivadores es un hecho generalizado. Es raro el contrato de arrendamiento en toda la Tierra de Medina en que no se precise tal obligación, sea por parte de particulares o por instituciones ${ }^{1365}$. Distintos autores señalan la importancia de estos gravámenes que se incrementaron en un 74,6 \% entre 1850 y $1870^{1366}$. Vallejo Pousada recoge numerosos ejemplos con la consiguiente repercusión en la economía doméstica del campesinado. La Junta de Agricultura de Palencia manifiesta tras la desastrosa cosecha del $1868^{1367}$ :

"Hoy el propietario no recibe sus rentas, por que el colono no puede pagarlas. El colono no puede sostenerse, ni siquiera sostener sus ganados de labor, y menos puede satisfacer los impuestos. El bracero, con fuerzas para trabajar, no encuentra quien le dé ocupación. El mercader no vende porque no hay quien compre, y el menestral no gana ni aun lo necesario para su sustento."

El desastre del citado año supone un serio quebranto para muchos labradores de la Tierra de Medina. Las contribuciones atrasadas pasan a formar parte de las hijuelas de deudas testamentales $y$, aunque no era una novedad, a los propios municipios les falta tiempo para solicitar su perdón cuando pedriscos o sequías los introduzcan en el mismo precipicio ${ }^{1368}$. Tras el pedrisco que se lleva la cosecha de uva de Serrada en 1893, se solicita a la Diputación el perdón de las contribuciones, al tiempo que se insta a la Comisión nombrada al efecto para que "solicite ser recibida por el Sr. Gobernador Civil e interese del mismo los auxilios y socorros necesarios para en su día poder atender al sostenimiento de la clase jornalera en los meses de invierno"1369. En plena crisis agrícola y pecuaria, a los condicionantes estructurales se sumaban las contingencias meteorológicas. Las desgracias nunca vienen solas. Su repetición en estos años hace más daño de lo que las economías campesinas pueden soportar. Al margen de sequías y heladas, hay constancia de importantes pedriscos en los años de $1870,1872,1893$ y $1899^{1370}$. Este último, acaecido el 10 de junio dejó a todo el vecindario en la ruina: ${ }^{1371}$

\footnotetext{
"Todos... contemplasteis ayer la extraordinaria calamidad que vino sobre nosotros destruyendo nuestros viñedos y sembrados, el pedrisco que a las doce y cuarenta minutos de la tarde comenzó a descargar sobre nuestro término municipal. Aquellas piedras cuyo tamaño llegó a alcanzar en algunas partes hasta el de un huevo pequeño de gallina y en la mayor parte el de un huevo de paloma, que en un metro cuadrado contaron de este volumen hasta el número de cuarenta y las innumerables de más pequeño bulto habréis observado que rompieron la mayor parte de los tallos de los viñedos..., así como también destrozó los sembrados, muy especialmente las cebadas, que hallándose ya en su completa madurez, fueron descabezadas y desgranadas hasta el punto de que apenas se ven cabezas en ellas, y esto en mucha proporción en todos los pagos del término, sin que por esto haya quedado sin daño el trigo, centeno y las legumbres. ¿Y cómo no había de suceder así cuando la piedra que caía hirió a infinidad de personas, mató en el campo infinidad de aves, entre ellas una cigüeńa, como también conejos, liebres y otros bichos?”.
}

${ }^{1365}$ Es una cláusula común en todos los arrendamientos que, firmados en esta época, se acuerden en los pueblos al norte o al sur de la Tierra. En el caso del caso del importante arrendamiento citado que se firma en La Seca en 1892, entre el Ayuntamiento y D. Fermín B. Bayón, sobre 27 fincas rústicas en precio de 6992 pts, se hace constar, "que el arriendo de las tierras y viñas pertenecientes a los propios de esta villa se hace por término de tres años..." y que "serán también de cuenta de dicho rematante el pago de la contribución territorial..." (A.H.P.V. Pt. 20017, La Seca, Santiago Nogal del Castillo, fol. 85, año 1892).

1366 GONZÁLEZ PORTILLA, M.: Acumulación de capital..., en “La Cuestión agraria...”, ob. cit., pág. 69. Ángel García Sanz analiza de forma exhaustiva el problema en su obra: "Renta territorial y patrimonio de una casa nobiliaria en la Castilla del siglo XIX: los marqueses de Lozoya, 1808-1896”, en Pegerto Saavedra Fernández y Villares (eds.), 1991.

1367 Citado por Rafael Vallejo: Reforma tributaria y fiscalidad..., ob. cit., pág. 302.

1368 A.H.P.V. Pt, Pt. 20002, La Seca, Nogal del Castillo, fol. 247, año 1891.

${ }^{1369}$ A.M.S., caja 3, carp. 38, acta se sesiones de septiembre y octubre de 1893.

${ }^{1370}$ A.M.S., caja 1, carp. 16; caja 1, carp. 18 ; caja 3, carp. 38 y caja 3, carp. 45, respectivamente.

${ }^{1371}$ A.M.S. caja 3, carp. 45, fol. 7, año 1899. 


\section{c. Una estructura de la propiedad insuficiente para hacer frente a la competitividad que exigen los mercados}

Si no bastan las quejas que exponen los labradores del XIX, he aquí uno de los grandes problemas estructurales de la agricultura española y que las desamortizaciones liberales dejaron sin resolver. Aún hoy este epígrafe continúa vigente. La "globalización" de finales del XIX recuerda lo que sigue siendo un interrogante. ¿Cuáles son las dimensiones adecuadas para que una explotación agrícola o ganadera se pueda considerar moderna y competitiva? ¿Depende únicamente del tamańo de la propiedad? ¿De su gestión? ¿De los repartos hereditarios? ¿Del trabajo que en ella inviertan sus titulares? ¿De los mercados? ¿De la política agraria del gobierno o desgobierno de turno? ¿De San Isidro y Santa Bárbara?

¿Cómo explicar, entonces, la decadencia de tantas labranzas a fines del XVIII y del XIX? Quien haya seguido las páginas anteriores es posible lance al aire dos preguntas maliciosas: ¿Es que va a ser la propiedad absentista y amayorazgada de los Montalvo la única rentable y duradera desde que nace en 1506 hasta que la venden en 1916? ¿Hubieran seguido obteniendo beneficios las granjas religiosas de no haber sido por la conmoción napoleónica y la política desamortizadora?

No es la amortización de tierras y su vinculación jurídica lo que garantiza la rentabilidad agraria. Una cosa es la pervivencia y el carácter privado de la propiedad, otra la rentabilidad y otra muy distinta el carácter social que las comunidades agrarias han dado a la tierra y a sus frutos. Los contemporáneos de Ensenada, a mediados del XVIII, como los de Mendizábal y Madoz en el XIX, no debaten tanto el número de obradas por hacendado como los métodos de producción, transformación y venta de los productos producidos, pero, aun siguiendo estos consejos con las mejores intenciones, la atomización parcelaria y de la propiedad que viven muchos de estos pueblos es un obstáculo demasiado grande para alcanzar una rentabilidad duradera.

A mediados del XVIII se constata en la mayor parte de las villas que las explotaciones entre diez y cincuenta hectáreas, cuyos activos viven enteramente de la actividad agraria, no representan más allá de un 20-25\% del total de vecinos propietarios, detentando tan sólo entre un 15-25\% de la propiedad. Sólo acudiendo al arrendamiento dimensionan unas labranzas que en pocas ocasiones superan las treinta hectáreas. En La Seca los 130 vecinos que están dentro de este umbral tan sólo poseen 940 ha propias (7,23 ha de media) y han de ser las tierras sernas las que les aporten 1.981 ha para alcanzar una media de 22 ha por explotación. En Serrada los seglares poseían el 43\% de la propiedad (559 ha), dada la importancia de las órdenes religiosas y del señor de la villa que acaparan el resto (739 ha). Dieciséis vecinos, que representan el 17,5\% de los seglares, se declaraban propietarios entre 10 y 50 ha alcanzando una media de 14,46 ha que incrementaban, como es sabido, con parte de las 334 ha del marqués de Torreblanca.

Los desequilibrios en el reparto de la tierra son generales tanto en este espacio como en sus aledaños. Un ejemplo es el estudiado por Pedro Caballero en un sector del suroeste vallisoletano. En 1879 los propietarios de más de 100 ha representan en 2,5\% del total de propietarios y detentan el $55 \%$ de la superficie total, si bien el predominio de la pequeña propiedad es palpable: las explotaciones locales de menos de diez hectáreas y que representan el 60\% de los propietarios, tan solo suman el $25 \%$ de la superficie labrada ${ }^{1372}$.

Como se puede comprobar en los cuadros adjuntos, correspondientes a los amillaramientos de 1881, la situación poco ha mejorado ciento treinta años después. Si se atiende al cuadro que refleja la estructura de la propiedad de los propietarios residentes en Serrada en el año 1881, en el que está incluida la propiedad que poseen en otros pueblos y que, por tanto, refleja con exactitud la realidad, 35 labradores, poseedores de entre 10 y 50 ha, que representan el 21,1\% del total de propietarios, se reparten 875 ha y alcanzan una media de 25 ha por explotación. Los cuadros adjuntos de La Seca y Villanueva, en los que no se entra en detalles por no resultar repetitivos, reflejan cifras similares, si bien, en esta última villa, 16 vecinos residentes poseen el $60 \%$ de la propiedad, lo que, sin acudir al arrendamiento, tienen una propiedad media de 25,68 ha.

${ }^{1372}$ CABALLERO FERNÁNDEZ-RUFETE, P.: Propiedad y explotaciones..., ob. cit., pág. 67. 

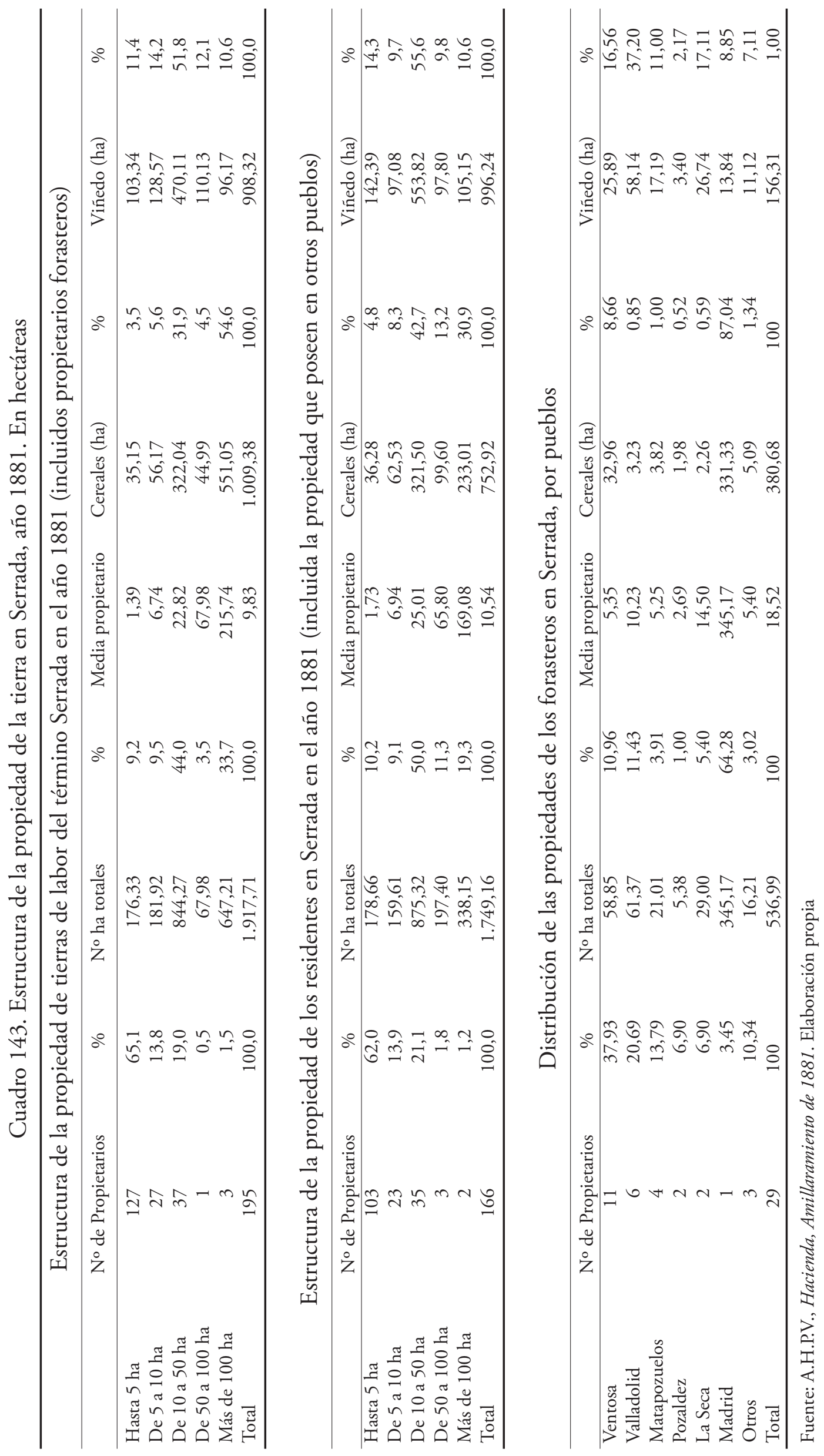


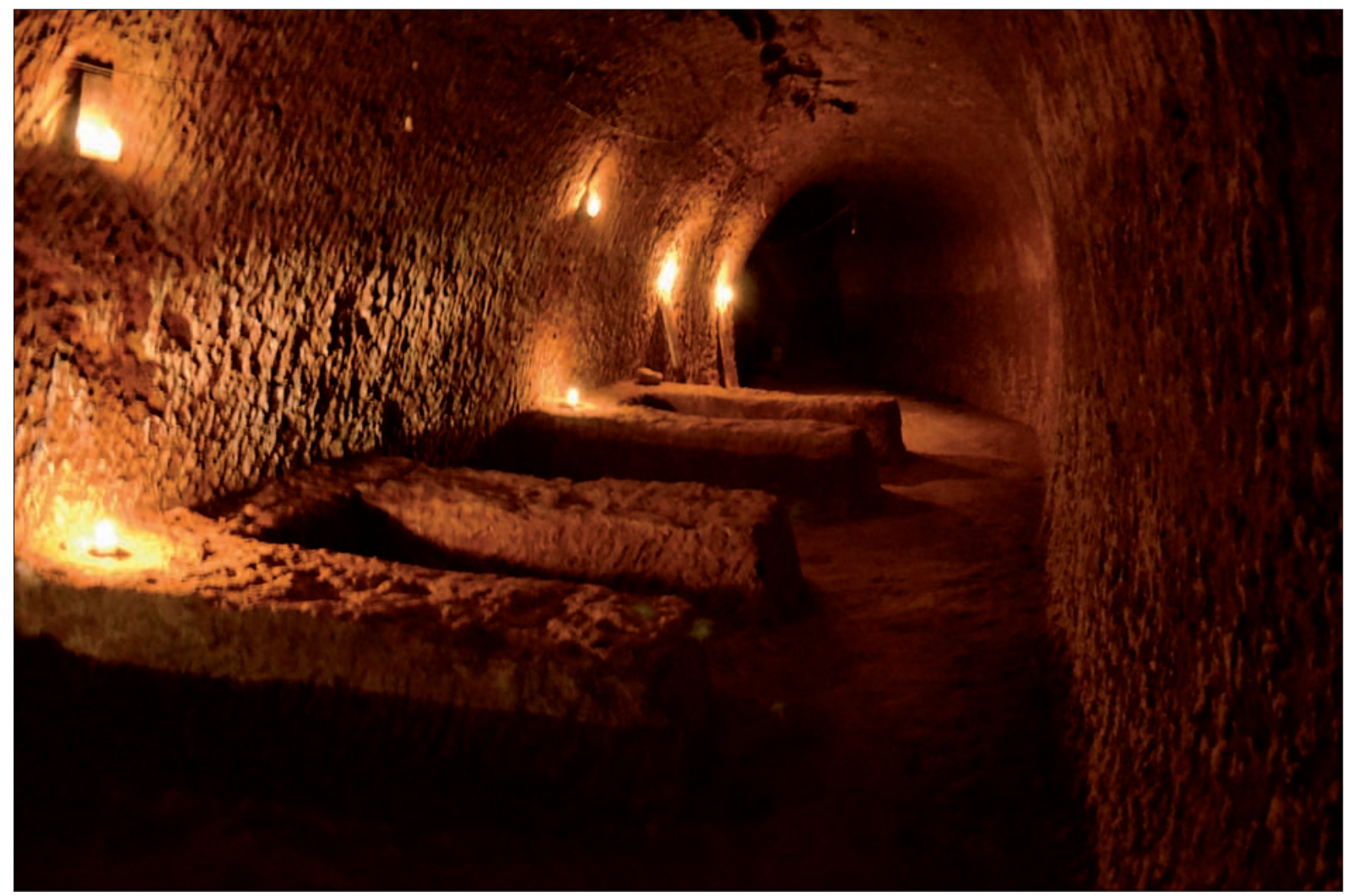

Imagen 93. Cañón de bodega y poínos excavados en la propia roca, La Seca. Foto: 26/10/2014. La localización de esta inmensa bodega, hoy propiedad de la familia Vidal, fuera del casco histórico de la población, y el tipo de construcción, nos lleva a pensar fue mandada horadar por la pudiente familia Obregón Pedrosa en la segunda mitad del siglo XIX, aprovechando la expansión vitícola.

En todos los ejemplos son numerosos los pequeños propietarios con alguna obrada y aranzada en propiedad. Si se toma el cuadro de Serrada y los propietarios con menos de cinco hectáreas, su porcentaje no es significativo en el conjunto, pues no llegan al $8 \%$ del total de la propiedad, pero sí en cuanto a su número, pues son 118 propietarios los que representan el 59,6\%. Todo lo contrario puede decirse de los que poseen más de 100 ha. Dejando aparte las 190 ha de comunales, entre el marqués de Falces ( 346 ha), el marqués de casa Pombo (128 ha) y los propietarios citados Balbino Alonso (183 ha) y Canuto de Castro (154 ha), suman 811 ha, que representan el 29\% del total de tierras en manos de propietarios de Serrada.

Otro factor interesante, toda vez que desde las grandes roturaciones del XVI y XVII no se ha vuelto a tratar, es la vecindad de los propietarios respecto a las tierras que cultivan. Las viejas costumbres de labrar a rejas vueltas han conformado una propiedad a medida de aquellos principios. La racionalidad hace que la mayoría de los vecinos labre las tierras que posee en cada término y, en aquellos casos con propiedades en otros, las tierras se anotan en los pagos más cercanos al lugar poblado. Llevar y traer a diario mulas y bueyes con sus pertrechos a más de una legua $(5,5 \mathrm{~km})$ de sus cuadras acarrea costes muy altos, así como el tiempo que gastan los jornaleros en desplazarse a pie o en burros a sitios alejados. El porcentaje de las tierras de labor de los vecinos de Serrada en el término, en relación con el total de sus propiedades, es del 78,9\%, que se incrementa notablemente si se descuenta la propiedad del marqués de Torreblanca y Falces. De hecho, en aras a conseguir la mayor rentabilidad, los nuevos hacendados que en Serrada se hacen con la labranza de los dominicos, situada en su mayor parte en el despoblado de La Moya, levantan una casa con su era para desgranar la mies y evitar a diario esa legua de ida y de vuelta en los meses de mayor actividad. 

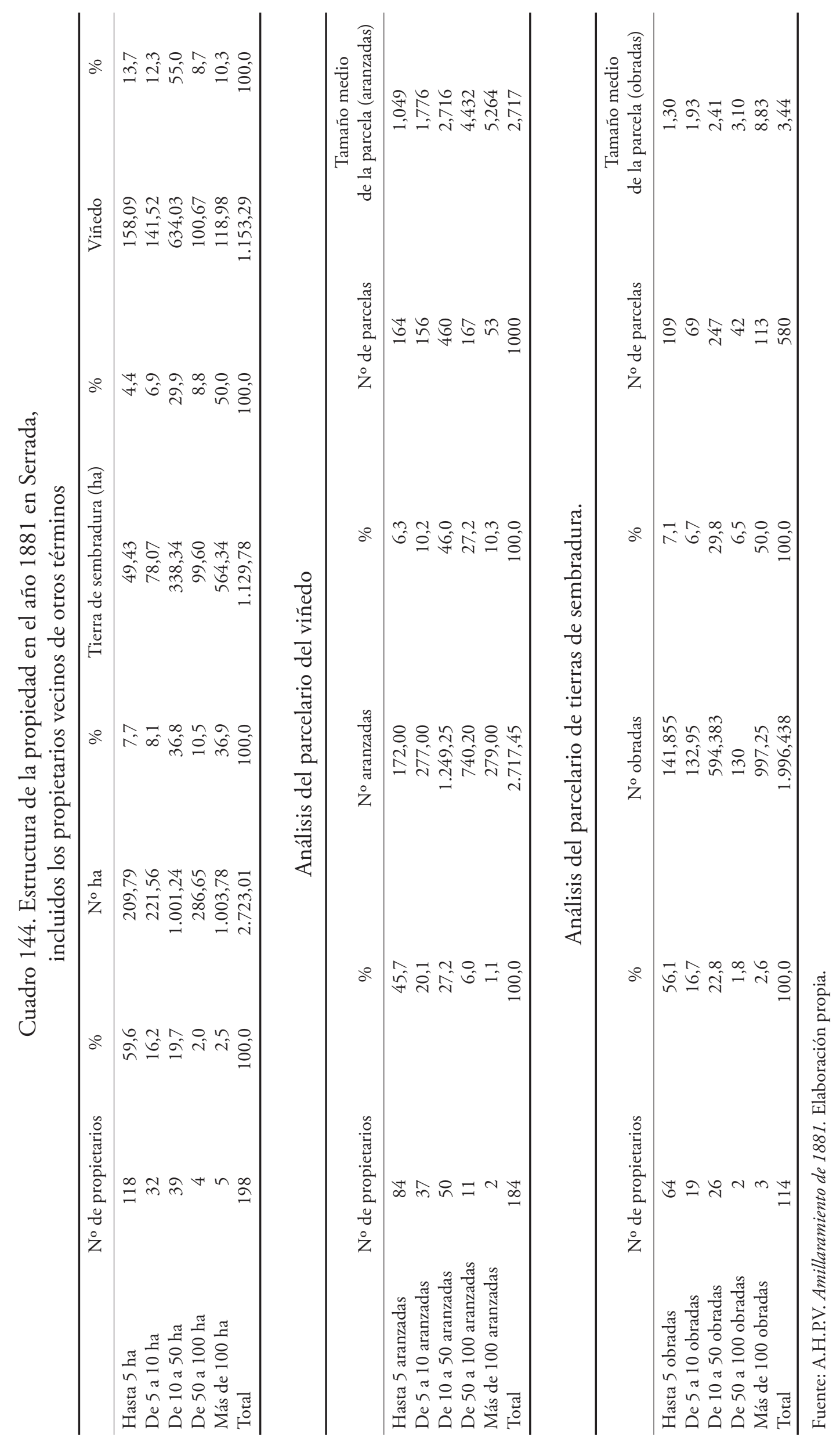
En el análisis del parcelario de las tierras de sembradura apenas se producen mejoras respecto a siglos anteriores. Son un rosario de minúsculas parcelas que se reparten por los distintos pagos de Serrada, La Seca o Villanueva, como ejemplo de lo que acontece en el resto de la comarca. En 1752, la superficie de las tierras de sembradura de los propietarios con menos de 5 ha es de 1,12 obradas $(0,63$ ha) y, en 1881 , de 1,30 obradas (0,73 ha). Aquellos encuadrados entre las 10 y 50 ha, si se trata de seglares, tienen una media por parcela de 1,48 obradas ( 0,83 ha) en 1752 , y de 3,73 obradas en 1881 $(2,11 \mathrm{ha})$, si son eclesiásticos. Entre estos labradores medianos, la media por parcela labrada en 1881 alcanza 2,41 obradas (1,36 ha), siendo la media global de 3,44 ha. Como se puede imaginar la excepción es el marqués de Falces, aunque no por ello sus parcelas se labran en unidades mayores ${ }^{1373}$.

A mediados del XIX, tal como refleja el cuadro en la renta y cuarta que lleva en 1861 Canuto de Castro, la parcelación y ocupación ha alcanzado su máximo histórico desde que se tiene constancia de renteros a finales del siglo XV. Por necesidad de tierra, de reparto en hojas y limitación de riesgos, caso de pedriscos en algún pago del término. Ahora bien, y dejando al margen su extraordinaria feracidad, ¿seguirá por mucho tiempo siendo rentable esta extraordinaria y minúscula parcelación?

Cuadro 145. Ejemplo de arrendamiento del Marqués de Falces a Canuto de Castro. Serrada, año 1861. 5/4 de renta y una tierra suelta. Total superficie: 56,375 obradas (31,9 ha)

\begin{tabular}{lcclcc}
\hline \multirow{2}{*}{ Pagos } & \multicolumn{2}{c}{ Superficie } & & \multicolumn{2}{c}{ Superficie } \\
& Obradas & Cuartas & Pagos & Obradas & Cuartas \\
\hline Gigante & 1 & 2 & La Vega & 1 & 2 \\
C. Tordesillas & 3 & 2 & La Vega & 2 & 0 \\
Prado de Abajo & 1 & 2 & La Vega & 2 & 0 \\
Chopo & 0 & 1 & Varela & 1 & 2 \\
C. Rodilana & 4 & 3,5 & Varela & 1 & 3 \\
C. Ventosa & 0 & 1,5 & La Frontera & 0 & 0 \\
C. Ventosa & 1 & 2 & Cuartillos & 2 & 0 \\
C. Ventosa & 0 & 3 & Cuartillos & 2 & 2 \\
Pradejón & 1 & 2 & Cuartillos & 2 & 1 \\
Pradejón & 1 & 2 & Cuartillos & 2 & 3 \\
Estacada & 1 & 2 & Cuartillos & 0 & 2 \\
Lastras & 1 & 2 & Picón Vado & 1 & 2 \\
Molineras & 2 & 2 & Casillas & 1 & 2 \\
Molineras & 1 & 1 & Casillas & 2 & \\
Cerrajero & 1 & 2 & Casillas & & 2 \\
Casillas (Tierra suelta) & 5 & 2,5 & & & \\
\hline
\end{tabular}

Fuente: A.H.P.V. Protocolos Notariales. Elaboración propia.

Como puede apreciarse en los cuadros adjuntos, respecto al viñedo existe un mayor equilibrio. En 1881, su posesión está vinculada a su laboreo y apenas existen viñedos arrendados. Entre los vecinos residentes de Serrada, La Seca y Villanueva, incluyendo sus propiedades en otros términos, sobresalen los labradores entre 10 y 50 ha como los más importantes en relación al viñedo poseído. De 4.345,9 ha de viñedo entre los tres pueblos controlan más del 50\%, representando el $21 \%$ del total de labradores. En el polo opuesto están los 451 propietarios con menos de 5 ha, que representan el $61 \%$ del total y labran 614,75 ha $(14 \%$ del total).

${ }^{1373} \mathrm{Su}$ mayorazgo, como se ha reiterado, lo forman 41 tierras de sembradura que suman 560 obradas y 5 viñedos que totalizan 40 aranzadas. Aplicar la estadística en este caso induciría a confusión, pues se tendría que hacer media de fincas tierra inmejorable como La Vega, que suma 135 ha, con otras de menor tamańo como las 28 obradas de las Casillas, 76 en los Cuartillos, 38 en el Cerrajero, y otras sueltas y dispersas mucho menores que enmascararían la verdadera dimensión de este gran propietario. 


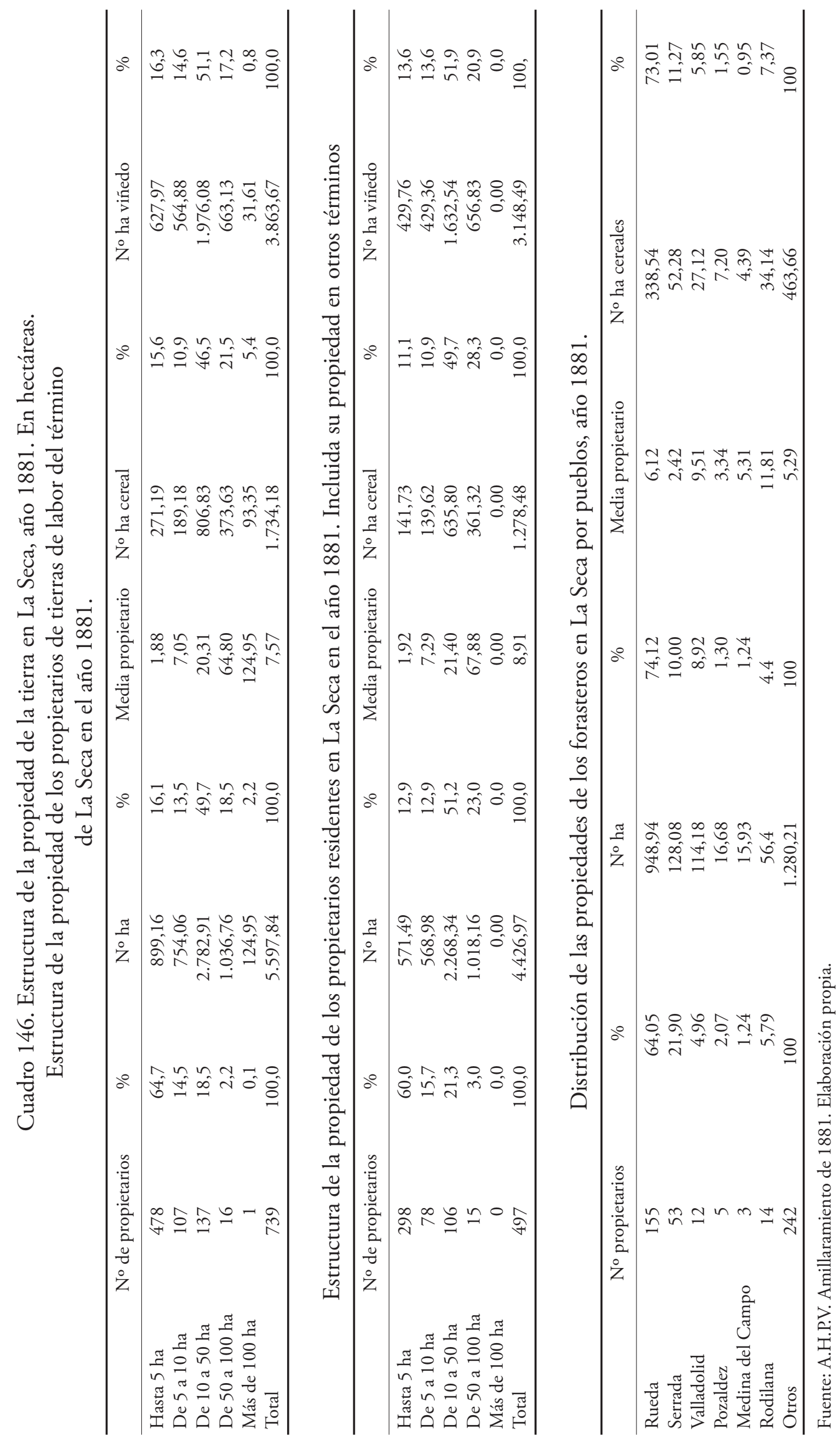




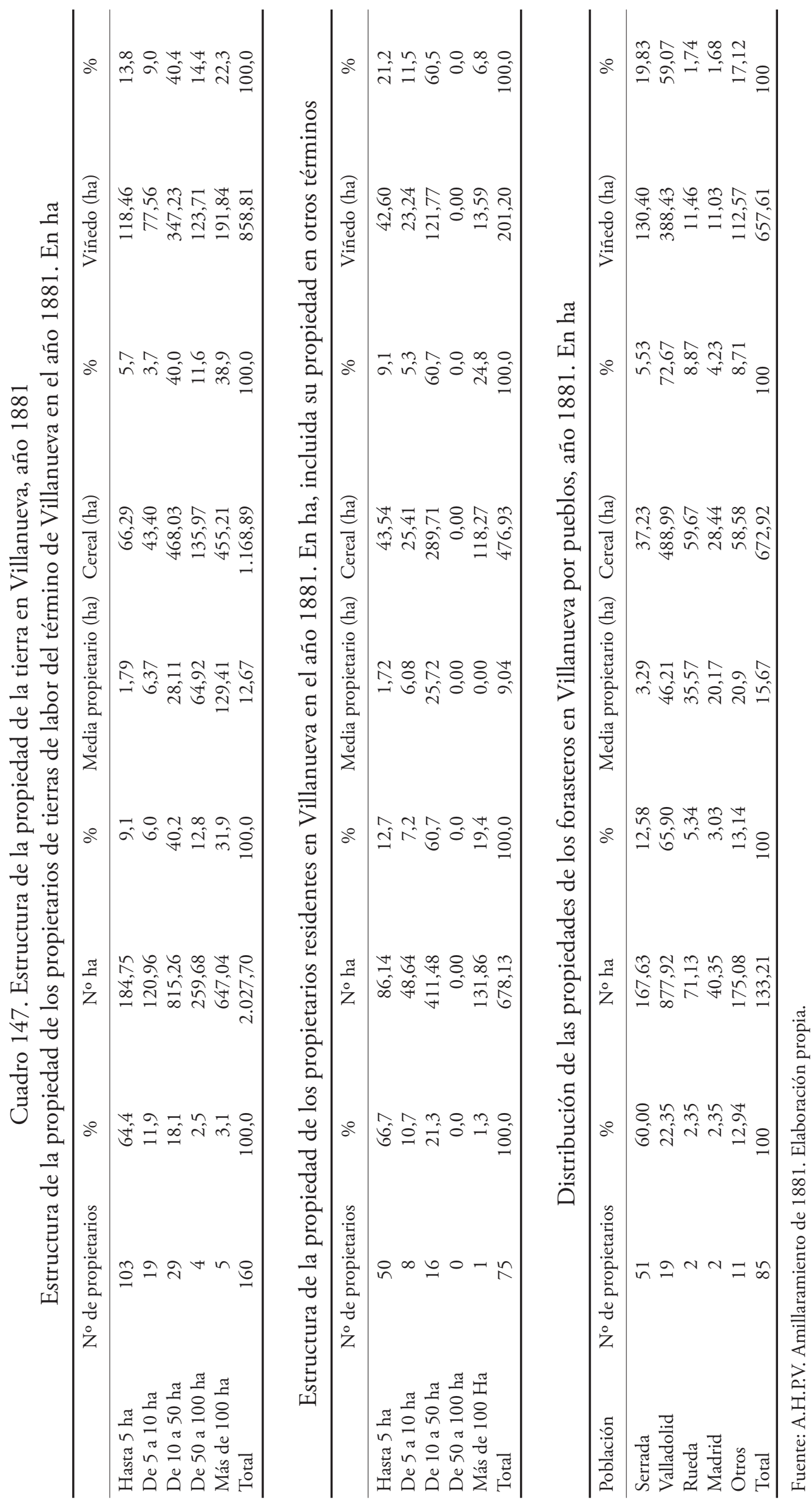


La dimensión de las parcelas, como en el caso de las tierras de sembradura, se caracteriza por su pequeño tamaño. En Serrada los propietarios menores de 5 ha tienen en una media de 1,04 aranzadas; los comprendidos entre 5 y 10 ha, 1,77 aranzadas; los que poseen entre 10 y 50 llegan a 2,71 aranzadas para subir a 4,43 aranzadas los propietarios encuadrados entre 50 y 100 ha. El tamaño medio de las parcelas en Serrada es de 2,71 aranzadas que vienen a ocupar 1,03 ha, lo que reafirma la atomización parcelaria del terrazgo vitícola en todas estas villas.

La mayor laboriosidad que lleva este cultivo y el valor añadido que suma al valor tierra retrasarán la apuesta por el aumento de la superficie por parcela. De hecho, en este sector norte estudiado, donde el vińedo continúa ocupando importantísimas superficies, los propios labradores lo excluirán del proceso de concentración parcelaria vivido entre los ańos 50 y 80 del siglo XX, aun cuando el proceso era reclamado para las tierras de sembradura. Será después, al amparo de la D. O. Rueda, y cuando se acometa el profundo proceso de reestructuración de fines del XX y comienzos del siglo XXI, cuando las reducidas parcelas sean en sí mismas un lastre para conseguir la máxima eficiencia y rentabilidad. Con todo, hay que dar tiempo al tiempo. En esta década de los años ochenta del XIX, al tiempo que se viven añadas muy buenas y mercados muy prósperos por la filoxera en Francia, ya se presagiaba entre los labradores la desgracia que se avecinaba.

\section{d. Las dificultades de las labranzas en la última década del siglo: la caída de los precios y la pérdida del valor de la tierra}

Al comienzo del presente capítulo se indicaba que, a diferencia de anteriores crisis de subsistencia en que una o varias malas cosechas consecutivas llevaba a las poblaciones al hambre, ahora no suben los precios de trigos o centenos, aunque a estos se los lleve el pedrisco o la sequía. Al ofrecer los mercados internacionales cereales a precios muy competitivos, los labradores de la meseta quedan desamparados en sus estrategias tradicionales de producción y comercialización, tanto en años buenos como malos. Como certeramente ha seńalado Ramón Garrabou, aunque el precio del trigo desciende notablemente desde 1879 a 1895 (en Valladolid de 23,08 pts/hl a 18,34 pts/hl en la última fecha), es en el descenso tremendo que experimenta la diferencia porcentual entre el precio máximo y mínimo de cada ciclo donde se encuentra una de las claves para entender la desesperación de los productores ${ }^{1374}$.

Hasta entonces los labradores hacendados compensan las malas cosechas guardando el cereal en sus paneras y vendiendo el producto cuando este alcanza cotizaciones elevadas. Se ha relatado la costumbre de sacar al mercado el trigo en los meses de abril y mayo, aprovechando la tendencia alcista que invariablemente, se observa a finales de primavera. En estos años, por el contrario, las importaciones compensan los déficits y moderan los precios hasta el punto que la diferencia entre el precio máximo y mínimo es tan sólo del 15,9\% entre 1883-1887 o del 12,6\% entre 1899 y 1905. Nada que ver, por tanto, con el 196,6\% de amplitud porcentual que se alcanzaba en Valladolid entre 1847-1857 1375. Se trata, pues, ante un fenómeno general y estas depreciaciones que sufren los cereales provocan que muchos sectores de ambas Castillas y Aragón apenas sean competitivos ${ }^{1376}$.

${ }^{1374}$ GARRABOU, R.: la crisis agraria española de finales del siglo XIX. Una etapa del desarrollo del capitalismo, en "Historia agraria de la España contemporánea", Vol. 2. Expansión y crisis (1850-1900). Ramón Garrabou y Jesús Sanz, eds., Ed. Crítica, Barcelona, 1985, pág. 511-515.

1375 Ibídem.

${ }^{1376}$ Las repercusiones de la bajada de los precios serán proporcionales al desarrollo agrario de los distintos países, pero su descenso será acusado en todos ellos. En Inglaterra, los precios de los trigos y harinas descienden un 40\% en tan sólo diez años; en Bélgica, el trigo baja de 30 franco el $\mathrm{Hl}$ en 1877 a 11 en 1895; en Francia, se inicia la baja en 1893 y la importante cosecha de 1891 convierte a este país en exportador en vez de importador, agravando el proceso. Martínez Maroto señala a este respecto, refiriéndose a la difícil competitividad de los precios que en enero de 1896 se venden los trigos extranjeros en estas costas "al insignificante precio de 19 reales fanega" por lo que, más pesimista que convencido del resultado argumenta que dado que "casi no existe el factor que antes más cohibia el tráfico de productos agrícolas que era la distancia, lo verdaderamente práctico y conveniente por ahora es aumentar la producción...”(Santiago Martínez Maroto: La crisis agrícola..., ob. cit., pág. 302). 
Frente a estos hechos, el labrador castellano se vuelve proteccionista a ultranza. No puede entender que los granos bajen de precio en plena primavera y se volatilicen sus expectativas de ganancia. En mayo de 1890 escribe Pedro Alonso Ampudia a su hermana política avecindada en León ${ }^{1377}$ :

"No me habías dicho nada respecto a la venta del trigo. Yo sí que te anuncié que convendría no se vendiese hasta mayo, y sea por causa de las importaciones extranjeras o porque los campos en toda esta región han mejorado muchísimo, hasta el punto de prometer por hoy esperanzas tan satisfactorias como pocos años, ha bajado y se observa deseo de vender. Hasta la cebada ha bajado, pues de 27 reales que ha llegado a costar, hoy se coge hasta 24 y siguiendo así el tiempo bajará aún más...”.

Pese a lo que en principio se pudiera suponer, el precio del vino no compensa las pérdidas cerealistas. Tan sólo en 1889, cuando tuvieron un "verano corto", se carteaban felicitándose de que "el vino tomase el precio que tomó, pues a 12 reales ya es agradable vender." En abril del año siguiente, con "un campo grande y hermoso", aunque con "los majuelos parados por efecto del temporal", las quejas se centran en los caldos, ya que "el precio hasta ahora no ha pasado de 10 reales, y hay regular saca, y buenas sacas, aunque no todas"1378.

Aunque en la forma no disten demasiado las quejas de los labradores de hoy respecto a las de hace más de un siglo, la progresiva pérdida de rentabilidad de las explotaciones se hará notar. El endeudamiento de muchos pequeños y medianos labradores es un hecho que refieren abundantemente los protocolos notariales en estos años, en los que se disparan las obligaciones hipotecarias y las ventas de propiedades. Sólo en la notaria de La Seca se registran en 1892 setenta y seis escrituras de compraventa de tierras o majuelos $^{1379}$. La situación lleva a muchos renteros a replantearse la continuación de los contratos de arrendamiento. Observan que sus trabajos rinden menos que si el esfuerzo y dinero que invierten en esas tierras lo destinaran a echar huebras para otros. La situación alcanza incluso a los labradores acomodados. El propio Pedro Alonso desea dejar las tierras que lleva en arrendamiento de su hermana política, a pesar, como refieren, de que "tengan que pasar a manos ajenas". A finales de 1893, la rebaja de 45 a 40 duros no será suficiente. De hecho ni siquiera acepta "labrar por este año sin renta alguna pero con la condición de dejar la mitad de las tierras de barbecho, con la obligación de pagar por mi cuenta la contribución de todas ellas y el foro", prueba evidente del importante coste que llevan las tierras de sembradura, así como de la falta de expectativas que aqueja a las labranzas castellanas por estos años. Singular y sincero testimonio es el que se hace llegar a la propietaria a finales de febrero de 1884 en relación a su rentabilidad ${ }^{1380}$ :

1377 A.F.A.M. carp. de escrituras y varios. Tras la muerte de D. Gregorio León Alonso en 1877, sus hijos, no sin dificultades por disparidad de criterios, se reparten la herencia familiar. Pese a las dificultades económicas que tuvo que afrontar en sus últimos años, sus herederos se reparten casas, tierras y viñedos en siete lotes que suman un valor de tasación de 296.790 reales, cifra importantísima para la época. Sus hijos Hipólito, Pedro, Balbino, Alberta, Mariano, Dolores y Claudia siguen, de esta manera, detentando importantes labranzas en el final y comienzos del nuevo siglo, pues al caudal de sus bienes (entre 25 y 30 ha del capital paterno) han de sumarse aquellos aportados por matrimonios o compras. En el amillaramiento de 1881destaca Balbino (casado con María Martín, de Matapozuelos), que se alza como el mayor propietario de la villa tras el marques de Falces. Tiene en propiedad 190,17 ha. Su hermano político Perfecto Moyano (casó con Dolores) se sitúa en octava posición con 57,87 ha. Le sigue Pedro Alonso Ampudia (casado con Cirila Sánchez, de Pozaldez) con 41, 06 ha. Con menor cantidad, entre 25 y 30 ha, se encuentran el resto de los hermanos, de los cuales Hipólito, como se ha dicho, vive en León, Mariano (en La Seca) y Alberta (casa en Serrada con Victoriano Obregón). Los que se encuentran avecindados en Serrada, como es el caso de Pedro, llevan las tierras de quienes se encuentran fuera, tal es el caso de su hermano Hipólito, registrador en León. En la década de los noventa,, una vez fallecido este, es su viuda Constantina Álvarez Enríquez, residente en Celanova (Orense), la encargada de cobrar rentas y estar al tanto de los bienes que le corresponden por parte de su difunto marido. La conservación de la correspondencia entre ambas partes, en la que la marcha de la cosecha anual es uno de los temas prioritarios, permite conocer de primera mano la problemática agraria de este fin de siglo en Serrada y, por extensión, en la Tierra de Medina.

1378 Ibídem.

${ }^{1379}$ A.H.P.V. Pt. 20017, La Seca, Santiago Nogal del Castillo.

${ }^{1380}$ A.F.A.M. Carp. de escrituras y varios. 
"Dices que no crees que quiera comparar el producto que me dan las tierras que he sembrado con los trabajos y labores de las tres fincas que dejo en barbecho; vaya, pues si tan en lo cierto crees que estás, yo te cedo el producto, págame las labores y después verás quien gana.”

Constantina Álvarez deseaba que, a cambio de "cuatro duros" por obrada de las catorce que irían de algarrobas y centeno, le dejase la otra mitad "de barbecho, o sea, labradas en disposición de dar trigo al año que viene y además con obligación por mi parte la contribución...”. En unos años en que los precios de los cereales parecían no tocar fondo, la respuesta del labrador no puede ser más clara $^{1381}$ :

"El barbecho de estas 14 obradas que no se ha de hacer con menos de tres vueltas a cada una arroja un coste no menor de 600 a 700 reales a huebras de destajo, que a mí me cuesta más haciéndolo para mí. Entre contribución y foro no son menos también de 380 reales, sin contar que el precio del centeno pueda ser como puede de 30 reales fanega, y sin contar también que la contribución de Villanueva y La Seca no se paga en Serrada y el foro tampoco. Por consiguiente, sin pagar, o sea, sin querer tú renta ninguna, pretendes que satisfaga de mi cuenta 1.100 reales poco más o menos, o sea, en números redondos, como suele decirse.

Labradas las tierras en esa forma resulta que al año que viene se encontrará favorecido cualquiera que con sus manos lavadas las coja. Vuelvo a repetirte que no me conviene tu proposición."

La suerte estaba echada. Para estas y para otras muchas heredades. Los precios de la tierra descendían año tras año y, aunque sus propietarios trataban de hacerlas valer, la numerosa oferta provocaba el descenso de los precios. Sin contar con aquellas que año tras año salían a subasta por impagos de contribuciones ${ }^{1382}$. En enero de 1894 se pusieron al público las tierras citadas anteriormente. El cuadro recoge sus características y la imagen adjunta lo que leyeron en los postes públicos, y no compraron, los vecinos de la comarca ${ }^{1383}$ :

Cuadro 148. Lote y valoración de tierras de sembradura y era puestas a la venta pública Serrada, familia Alonso Moyano, enero de 1894

\begin{tabular}{|c|c|c|c|c|c|c|}
\hline $\begin{array}{l}\text { Nombre de las fincas } \\
\text { Pago }\end{array}$ & Nombre & $\begin{array}{c}\text { Cabida } \\
\text { (en obradas) }\end{array}$ & $\begin{array}{c}\text { Primera } \\
\text { Precio } \\
\text { por obrada } \\
\text { (en pesetas) }\end{array}$ & $\begin{array}{c}\text { Precio } \\
\text { total }\end{array}$ & $\begin{array}{l}\text { Segunda } \\
\text { Precio } \\
\text { por obrada } \\
\text { (en pesetas) }\end{array}$ & $\begin{array}{c}\text { Precio } \\
\text { total }\end{array}$ \\
\hline Valera & Varela & 1,5 & 100 & 150 & 90 & 134,50 \\
\hline Picón del Vado & Arroyo & 0,75 & 100 & 75 & 90 & 67,50 \\
\hline Cuesta redonda & Velasco & 2,6 & 125 & 325 & 100 & 260 \\
\hline Cuesta Redonda & Los Pobres & 4,86 & 125 & 608,12 & 100 & 486,50 \\
\hline Valdelacasa & Redondo & 1,75 & 40 & 70 & 30 & 59,50 \\
\hline Pinar & Cañarroyo & 5,53 & 100 & 553 & 75 & 414,38 \\
\hline San Martín & Fuente los Lobos & 2,12 & 100 & 212,50 & 75 & 159,38 \\
\hline San Martín & Recio & 0,49 & 10 & 49 & 5 & 22,50 \\
\hline La Coma Baja (La Seca) & Manuel Martín & 1,48 & 75 & 111,87 & 75 & 111,87 \\
\hline El Valle (Villanueva de Duero) & Giralda & 4 & 125 & 511,25 & 100 & 409 \\
\hline Hera & Las Heras & & & 338 & & \\
\hline TOTAL & & 21,08 & & $2.999,74$ & & 2.350 \\
\hline
\end{tabular}

Fuente: Archivo familia Alonso Moyano.

\footnotetext{
${ }^{1381}$ A.F.A.M. Carp. de escrituras y varios.

1382 A.H.P.V. Pt. 19979, Rodilana, Francisco de Ávila Puebla, fol. 72, año 1895; Pt. 19999, fol. 239, año 1885, etc.

1383 A.F.A.M. Carp. de escrituras y varios.
} 
EVOLUCIÓN HISTÓRICA Y TRANSFORMACIONES RECIENTES DE LA AGRICULTURA EN TIERRA DE MEDINA

Ventac

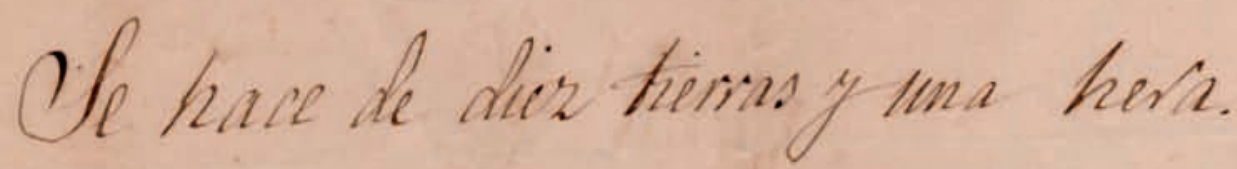
Vuma, titulada Planta.

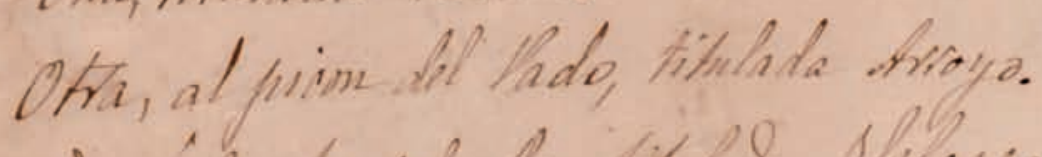

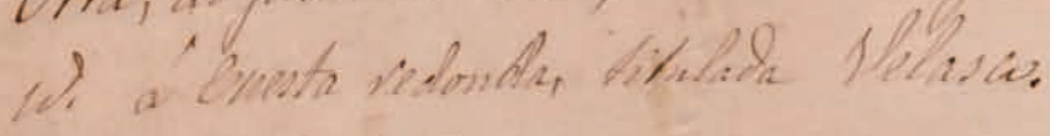
at al haye de los piotien.

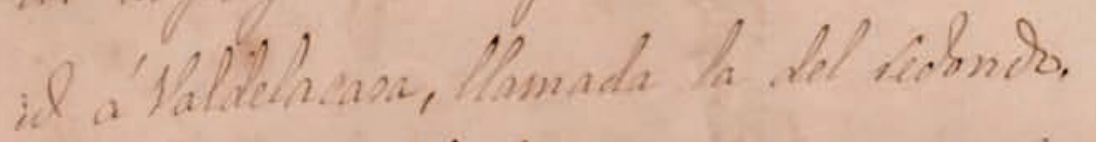

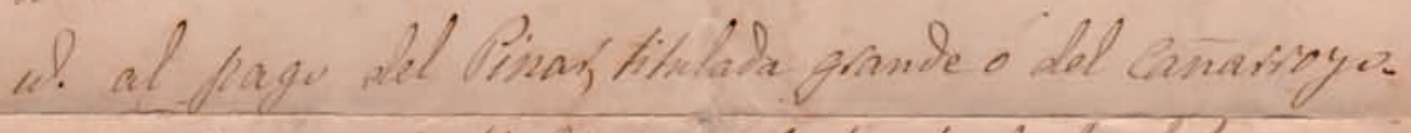

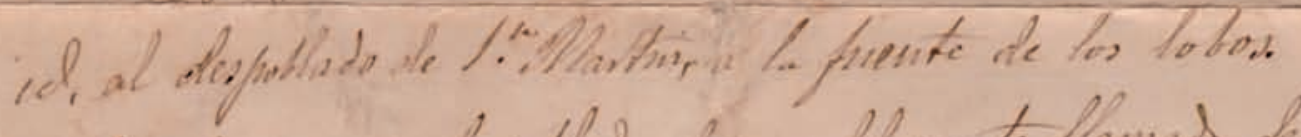

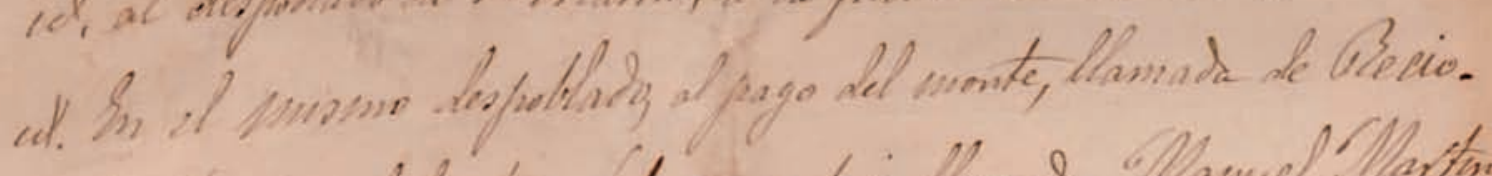

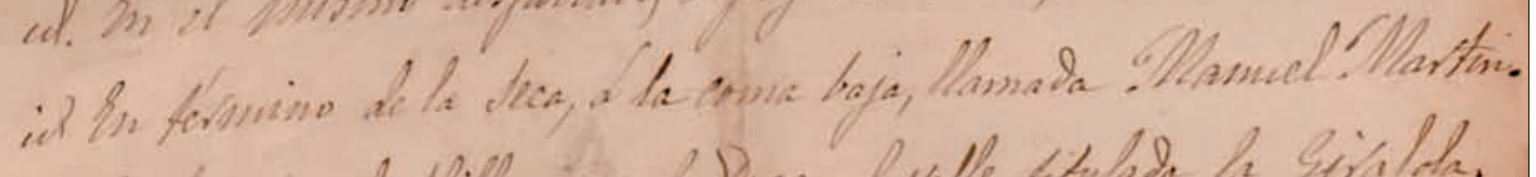

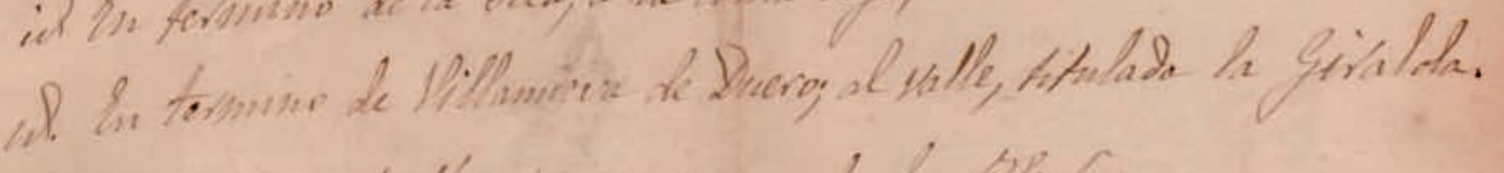

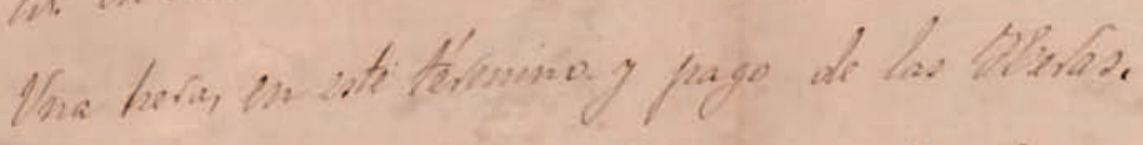

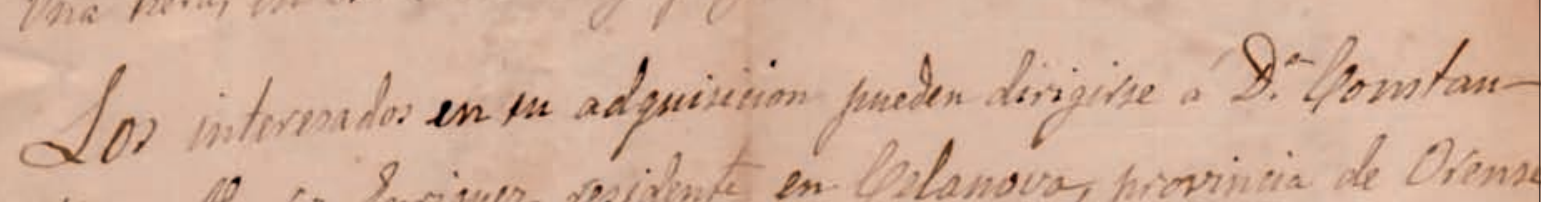

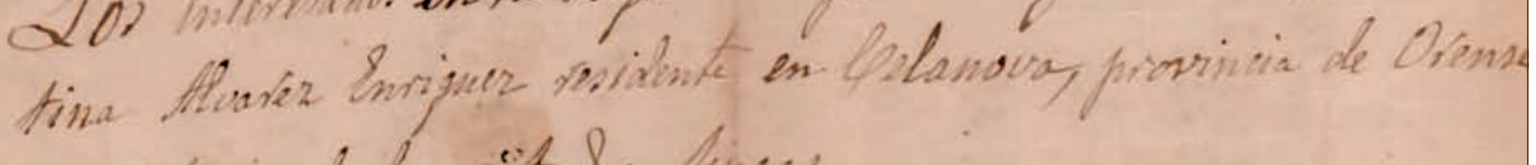
provintaria de las citalas fences.

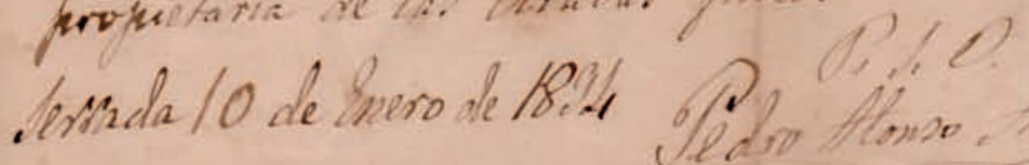

Imagen 94. Anuncio público de venta de tierras y era en Serrada, año 1894, (Archivo familia Alonso Moyano). El sacar las tierras a la venta pública ha sido considerado siempre una pérdida muy dolorosa para las familias labradoras, aun cuando distintas circunstancias lo hicieran aconsejable. Hasta hace unas décadas, antes de proceder a exponer en los postes vecinales tal intención, se acostumbraban a reunirse los parientes más allegados, por si alguno deseaba quedarse con los bienes vendibles.

$-616-$ 
Como unos años antes había sucedido con sus majuelos, estas tierras se quedarán entre la familia en un precio inferior al que hubiera querido su propietaria. A finales de junio de 1894 escribía Pedro Alonso ${ }^{1384}$ :

"Yo no aprecio hoy por hoy las tierras más que en 1.500 pts, reservándome para otra ocasión la manera de pagarlas; y las condiciones han de ser: títulos cumplidos y corrientes sin que yo tenga que hacer nada más que firmar la escritura."

La situación económica prevalecía por encima de los lazos de sangre y, aunque acabarán realizando la operación, la propietaria se aferraba al valor de tasación realizado veinte años antes y fijado en 3.100 pts, esperanzada de "que según tengo oído la depreciación en el precio de los trigos desaparecerá sin tardar mucho y, claro es, subiendo éste, las tierras tendrán mayor precio"1385. No le faltaba razón. Es posible que también tuviera constancia de la situación de los mercados Pedro Alonso, que sube su oferta a 2.750 pts en los primeros meses de 1897 . Este año los precios de los trigos en España experimentan una notable recuperación que pone fin a la caída iniciada en 1882. La cebada, aunque de forma más lenta, también buscará unos valores medios más altos ${ }^{1386}$. Nunca propietarios y labradores habían estado tan al tanto de cuantos factores intervenían en la formación de los precios, fueran aranceles, precios internacionales, cotización de la peseta o volumen de cosechas y mercados interiores. Era el principio del fin de la agricultura tradicional.

\section{- La precaria situación de la ganadería lanar}

Si estas décadas no son nada fáciles para los medianos labradores, qué decir de los ganaderos, acostumbrados a ser los hermanos pobres del mundo campesino. Tampoco en esta época parecen encontrar comprensión por parte de labradores y autoridades locales. Este es un factor difícil de entender en esta segunda mitad de siglo, en que todos estaban de acuerdo en la importancia de los abonos como uno de los elementos básicos para aumentar producciones y competir en los mercados. Los preocupados por conciliar posiciones tratan, con escasez de resultados, de reforzar sus tesis, actualizando viejos adagios como "la oveja con la reja" o "antes sin orejas que sin ovejas"1387. La realidad era bien distinta. Un ejemplo es el de Serrada en 1887. Los ganaderos elevan, en noviembre de ese ańo, al Ayuntamiento y a los seńores apoderados de los pastos arrendados, una súplica que resume certeramente la situación que viven unos y otros ${ }^{1388}$.

${ }^{1384}$ Ibídem.

1385 Ibídem.

${ }^{1386}$ Grupo de Estudios de Historia Rural: los precios del trigo y de la cebada, 1874-1906, en Ramón Garrabou: la crisis agraria..., vol. 2, ob. cit., pág. 320 y ss.

${ }^{1387}$ MARTÍNEZ, S.: "La crisis agrícola..., ob. cit., pág. 337.

1388 Poco se puede añadir a lo que ya expresan con tanta desesperación: "Los que suscriben, vecinos ganaderos de esta dicha villa, exponen: Que próximo a espirar el plazo del aprovechamiento de pámpana u hoja, y estando obligados por el contrato de arriendo a no aprovechar los pastos de las propiedades cedidas durante la temporada de invernia, viéndose en la imposibilidad de vender sus ganados por lo exiguo del precio a que hoy valen, y siendo poco menos que imposible el encontrar dehesas para rebaños tan cortos como son los que tienen los exponentes, y aún encontrándolos, saben por esperiencia propia que el auxilio que estas prestan puede considerarse como nulo en sus efectos, pues sería necesario mantener a los ganados con pienso diario, y como esto es por lo demás costoso e imposible de sostener, a fin de conciliar los intereses de todos, y teniendo en cuenta que precisamente en esta temporada de invierno es en la que menos perjuicios se ocasionan por los ganados lanares en las fincas vedadas del término, y no negándose de ninguna manera y en ningún caso los esponentes a indemnizar los daños que pudieran ocasionarse por cualquier motivo, sea causados intencionalmente o por descuido o negligencia, y que invernando los ganados en el término ayudan a proporcionar aumento a uno de los elementos más necesarios a la agricultura, hoy que tan necesitada se haya de ayuda, redundando dicho aumento en beneficio de todos cedentes y ganaderos, se ven estos en la necesidad de recurrir a Uds. para que interpongan sus buenos oficios cerca de los demás señores propietarios cedentes, haciéndoles presentes los perjuicios que sobrevienen del cumplimiento de la condición referente a la invernia, tratando en su consecuencia de ver conseguir la permanencia de los ganados lanares en el término durante dicha temporada, acordando para ello las 
La situación de las cabañas de ovino del resto de la comarca presenta similares dificultades. Parte de los ganaderos firmantes eran también propietarios influyentes. Las razones ni parecen descabelladas ni reflejan otra cosa que la apurada situación que viven. Sin embargo, dos días después, en contestación del Ayuntamiento por escrito de su alcalde Toribio del Río, se evade cualquier competencia, argumentando que tal solicitud está prohibida "terminantemente por las condiciones $1^{\circ}$ y $8^{\circ}$ del expediente de arriendo", por lo que se les devuelve el expediente para, si lo creen conveniente, seguir otros medios. Llovía sobre mojado ${ }^{1389}$. Buena parte de los ganaderos firmantes estaban emparentados con la parte propietaria, pero en estos tiempos de crisis y a pesar de argumentar este factor como uno más entre los expuestos para llegar a un acuerdo, prevalecía más el "sálvese quien pueda". El caso derivó por caminos insospechados. Los ganaderos, tras escuchar la negativa en idénticos términos por parte de los propietarios, pero firmes en la defensa de "los intereses y derechos de la ganadería lanar, la cual... atraviesa una crisis ruinosísima", solicitan, a fin de aliviarla en lo posible, la apertura de todas las servidumbres pecuarias que discurren por el término municipal. Se entiende la reacción como una forma de protesta y presión más que conseguir pastos por esta vía, aun sabiendo que las intrusiones y usurpaciones del arado a lo largo del tiempo eran un hecho incuestionable. De ahí la existencia de toda una legislación al respecto ${ }^{1390}$. La respuesta negativa del alcalde encenderá a los ganaderos que solicitan, en enero de 1888, la apertura y el deslinde de las servidumbres al gobernador civil y a la Asociación General de Ganaderos del Reino. Se reabrían los enfrentamientos entre la oveja y el arado. La disputa por algunos metros de pasto en determinados sectores de cańadas o coladas, donde la reja se había sobrepasado por la escasez de tierra para conseguir un celemín más de trigo, evidencia la precaria situación que viven todos. La solicitud de los pastores tratando de esgrimir razones en su defensa así lo evidencia ${ }^{1391}$ :

"Hoy más que nunca se hace necesaria su conservación por la crítica situación que atraviesa aquella (la ganadería), y no es menor la que aqueja a la agricultura; y como tal situación en que en parte es motivada por la carencia de abonos y estos son proporcionados por la ganadería de aquí el que sea necesario procurar su desarrollo y fácil sostenimiento, aun sin tener en cuenta otras razones, por las que se puede juzgar que la ganadería es una de las principales fuentes de riqueza de la nación..”

El conflicto servirá más para poner al día las vías pecuarias que para satisfacer a los demandantes ${ }^{1392}$. Los ganaderos solicitan, igualmente, la revisión de la prohibición del pasto ovino en aquellas partes de los prados en que, hasta comienzos de los 70 , se permitía la entrada dos meses de la temporada de invernia.

condiciones que se crea oportuno estipular respetando los derechos e intereses de todos. Es favor que de Uds. Esperan y piden dispensen con la benevolencia que a Ud. Caracteriza por lo que anticipadamente los firmantes dan las gracias más cumplidas.

Serrada, 25 de noviembre de 1887. Firmantes: Pedro Alonso Ampudia, Tomás Ynojal, Dimas Obregón, Florentino Martín y Florentino Rivera. (rúbricas)" (A.F.A.M., carp. de escrituras y varios).

1389 En 1884 el Ayuntamiento que presidía D. Francisco Moyano Zamora había acordado por unanimidad señalar para que la ganadería pudiera pastar sin perjudicar al terrazgo sembrado los caminos siguientes: camino de Valladolid, de La Seca, de Matapozuelos, de Valdestillas, de Tordesillas, del Pinar y el camino del Pozo hasta las Carretas. Este seńalamiento se hacía dadas las quejas que los propietarios habían elevado a la alcaldía por el perjuicio que sentían que estaban haciendo las ovejas en los sembrados. (A.M.S., caja 2, carp. 29, fol. 31, ańo 1884.

${ }^{1390}$ A lo largo del siglo XIX se publican distintas disposiciones con escaso resultado en relación con la conservación de vías pecuarias (Ley de 21 de octubre de 1820; R. D. de 23 de septiembre de 1836, R. O. de 24 de febrero de 1839 y 13 de octubre de 1844).

${ }^{1391}$ A.F.A.M. Carp. de escrituras y varios.

1392 El R. D. De 3 de marzo de 1877 establecerá reglas claras para el deslinde de las vías pecuarias con objeto de evitar abusos. Como complemento se publica el 13 de agosto de 1892 el reglamento que fija las anchuras de las diferentes vías. El artículo 12 es claro al respecto. Las vías pecuarias necesarias para la conservación de la Cabaña española y el tráfico de reses son: cañadas, cordeles, veredas, coladas, abrevaderos, descansaderos y pasos ( 45 varas); la extensión de las veredas es de 20,39 metros (25 varas) y la de las coladas, así como la de los abrevaderos, indeterminada. Los pasos son las servidumbres que tienen algunas fincas para que por ellas, levantados los frutos, puedan cruzar los ganados". (Tomado de Santiago Martínez Maroto: La crisis agrícola y pecuaria y sus verdaderos remedios. Valladolid, 1896, pág. 337 y ss.). 
La falta de sensibilidad de los labradores hacia sus problemas les hacen, incluso, sentirse humillados en tanto que no les dejan meter sus ovejas en los descansaderos y abrevaderos que existen al comienzo de los pastizales cuando, como manifiestan, "paran de tránsito por esta localidad gitanos que sueltan y pastean sus ganados en estos sitios, sin que hasta la fecha se haya oido se impusiera una multa por tal hecho, ni a gitanos, ni a los criberos que también hacen igual uso"1393. No podía acabar peor el siglo.

\section{La llegada de la filoxera y la ruina de las explotaciones vitícolas}

La evolución del cultivo del vińedo en Serrada es similar a la registrada en los pueblos vecinos. Aunque las 1.660 aranzadas que esta villa registra en 1752 pasaron por malos momentos en el primer tercio del XIX, a la par que cerraban sus puertas las órdenes conventuales y tocaban fondo los precios del vino en todo el país, en 1857 se detecta una importante recuperación vitícola, alcanzando la superficie plantada 1.817 aranzadas. Este sostenido impulso se incrementa cuando cesa la expansión triguera y mejoran los mercados de caldo en la década de los setenta como consecuencia de la filoxera francesa. Entre la devastación que ocasiona el insecto en Francia desde finales de los sesenta y la merma de producción por culpa del mildiu, los vinos españoles, italianos y portugueses van a encontrar una coyuntura excepcional. Conscientes de la catástrofe que se vive en Europa, las autoridades nacionales y las distintas Juntas Provinciales de Agricultura no tardan en reaccionar. En julio de 1875, la Junta vallisoletana difunde en el Boletín de la Provincia una circular emanada de la Dirección General de Madrid en que, al tiempo que se declara la guerra con todos los medios conocidos hasta entonces al "enemigo insidioso" de la "Phylloxera Vastatrix", difunde precisas instrucciones para reconocerlo y no esconde las formidables perspectivas que pueden abrirse para los labradores viñeros nacionales ${ }^{1394}$ :

La Dirección de Agricultura, Industria y Comercio, que vela siempre por los intereses de los ramos confiados a su cuidado, no puede menos de llamar seriamente la atención de los viñeros de España, para que estén alerta y se preparen oportunamente a rechazar la plaga exterminadora, que tan de cerca vuelve a amenazar sus propiedades, cuya salvación sería de tanta importancia para el país, cuanto que la ruina de las viñas extranjeras puede acrecer de un modo fabulosos el valor de los vinos espańoles, se sí tan estimados."

La estabilidad política que proporciona el sistema de la Restauración une a las distintas fuerzas provinciales en este asunto. Alonso Pesquera promueve medidas para favorecer la enología y, en diciembre de 1875, se acuerda abonar los gastos que ocasionen técnicos de Burdeos y de Jerez para que enseñen a los bodegueros provinciales sus métodos de vinificación. La propia Diputación corre con los gastos de transporte e instalación de muestras que los bodegueros envían a la Exposición Nacional Vinícola, celebrada en Madrid en $1877^{1395}$. Empiezan ańos de gloria. O al menos esa es la euforia que parece desprenderse de los discursos inaugurales en la citada exposición, en que se habla de España como "bodega del mundo". Pan-Montojo toma precisamente esta idea como título y arranque introductorio en su obra sobre la vid y el vino ${ }^{1396}$.

\section{a. La década dorada de las buenas sacas a regulares precios, 1877-1887}

Las buenas expectativas creadas no tardan en hacerse realidad. El auge exportador es incontestable tras el acuerdo arancelario con Francia de 1877 que reduce los aranceles sobre el vino español hasta igualarlos con Italia y Portugal. En 1882, un nuevo convenio por diez años asegura a los caldos

${ }^{1393}$ Ibídem.

${ }^{1394}$ B.O.P.V. 15 de julio de 1877.

1395 PASTRANA, H.: La Diputación Provincial..., ob. cit., pág.328.

1396 PAN.MONTOJO, J.: La bodega del mundo. La vid y el vino en España (1800-1936). Alianza Universidad, M.A.P.A, Madrid, 1994, pág. 11. 
españoles una posición de privilegio. Las exportaciones de vino común al país vecino pasan, de un índice 100 en 1865 y 134,1 en 1876, a 615,3 en 1878, 1988, 1 en 1880 y 3360,6 en $1888^{1397}$.

Consecuencia de ello es el reactivamiento comercial vinícola que vive, como el resto de las zonas productoras, la Tierra de Medina. En este caso no tanto por la exportación, como por la subida general de precios. Los comerciantes franceses demandan vinos tintos y espesos que posibiliten las mezclas, dejando los vinos blancos en un segundo plano. A pesar de ello, los verdejos viven buenas sacas en estas décadas. Un factor clave ya estudiado es la conexión ferroviaria con el norte y noroeste, zonas tradicionales de consumo. La estaciones de Medina, Pozaldez y Valdestillas juegan un papel de primer orden en la expedición de caldos aunque, como se recordará por las cartas que se cruzan en 1875 Gregorio León y su hijo Pedro Alonso, desplazado a León para colocar y vender los vinos directamente, los arrieros siguen bajando durante muchos años más al sur del Duero. Prueba del activo comercio son las líneas que escribe Hipólito Alonso Ampudia, avecindado en León, a su hermano Pedro en abril de $1877^{1398}$ :

"Celebro que se vaya vendiendo vino y haciendo dinero, aunque no me gusta que baje el precio; pero no por esto se debe dejar de vender lo que se pueda."

La coyuntura favorable beneficia a todos, especialmente a los grandes cosecheros con contactos con especuladores o comerciantes al por mayor. Sólo teniendo en cuenta estos factores, puede explicarse, por ejemplo, que el vecino de Serrada Balbino Alonso, hermano de los anteriores, pueda dar salida tanto a su propia cosecha como a la que compra en el citado ańo de 1875 a José María de Rojas ${ }^{1399}$ :

\footnotetext{
"Que llebando adelante el convenio, en la forma que más haya lugar a derecho, el espresado D. José María de Rojas: Otorga: Que vende al D. Balbino Alonso los líquidos, a saber: Como mil cántaros de mosto o vino nuevo lo que hubiere, valorados en dos mil pesetas; como doscientas cántaras de vinagre lo que hubiere, valorado en doscientas cincuenta pesetas; como trescientas cántaras de vino añejo lo que hubiere, valorado en cuatrocientas cincuenta pesetas; lo que hubiere, valorado en ciento cinco pesetas.

Que los líquidos vendidos hay blanco y tinto encubado en bastos mayores y pipas... y valen en junto once mil doscientos veinte reales..."
}

Nueve meses después el vino ya se había vendido y entregadas las llaves de la bodega a su dueño, prueba de las excelentes ventas por estas fechas ${ }^{1400}$. Hasta entonces los cosecheros bastante tuvieron con vender el vino propio y cobrarlo sin demoras. Aunque es sabida la mala situación financiera del vendedor, no puede pasar desapercibido el interés de estos hombres de negocios por hacerse un hueco en lo que parecía el nuevo "Dorado", tras el decadente negocio de trigos y harinas ${ }^{1401}$. De hecho, el señor de Rojas, que carecía de trayectoria vitivinícola, mediante alquileres y negocio propio, recupera parte de la capacidad de la extinta y casi arruinada bodega dominica que contaba, en su época de esplendor, con cuatro lagares y 42 cubas. En 1864, al tasarse para su primera venta, se

${ }^{1397}$ Ibídem, pág. 139 y ss.

${ }^{1498}$ A.F.A.M. Carp. de escrituras y varios.

${ }^{1499}$ A.H.P.V. Pt. 18031, Francisco de Ávila Puebla, fol. 281, año 1875.

${ }^{1400}$ A.H.P.V. Pt. 18032, Francisco de Ávila Puebla, fol. 213, año 1876.

${ }^{1401}$ A diferencia del trigo, que puede esperar en las paneras, el vino debe venderse y la espera siempre está envuelta en un manojo de nervios y especulaciones por parte de vendedores y compradores. La correspondencia privada consultada así lo atestigua, por encima de coyunturas favorables o desfavorables. En 1877, por ejemplo, puede leerse en la de la familia Moyano: "En cuanto a la venta de vino sigue lo mismo, sin saca en La Seca, en Ventosa y Matapozuelos, y todos con deseo de vender; y aquí la mujer de Patricio Alonso está vendiendo una cuba añeja a 10,5 reales, y se la pagaron a 16 reales, y me ha dicho Perfecto que está tan buena que cree que ha de llamar saca": (A.F.I.M.). 
hacen constar dos lagares con sus máquinas y diecinueve cubas. En 1881, cuando Micaela de Rojas se la vende a Balbino Alonso, los recipientes han sido renovados. No consta, sin embargo, la existencia de ninguna novedad técnica, sean lagares mecánicos o prensas modernas que comenzaban ya a ser adquiridos por los cosecheros más pudientes, pero, cuando en la bodega hay cubas nuevas, es señal de que el vino tiene buena venta ${ }^{1402}$ :

"Que también han convenido en que se comprenda en esta venta cuatro cubas nuevas de diez y seis palmos, tres viejas también de diez y seis; siete cubas en buen uso de catorce; dos de a doce, otras dos de diez; dos cubetos, ocho pipas de roble, dos baños de embase y una artesa de limpieza de bodega que han evaluado para celebrarle en tres mil trescientas sesenta y dos pesetas y cincuenta céntimos."

Conforme crecen las exportaciones en la segunda mitad de los setenta y primeros ańos de los ochenta, muchos productores de blancos incrementan la superficie de sus viñedos con cepas tintas, ya que este vino se exporta fácilmente y a mejor precio. Hasta entonces, su presencia en el terrazgo del norte de la Tierra de Medina había sido escasa (22 aranzadas de un total de 1817 en la Serrada de 1857), pero, si el mercado ya ha modificado sistemas de cultivo a mediados de siglo, no va a quedar al margen el viñedo en este tiempo de euforia. En 1884 Nava exporta a Francia 200 hl de tinto y Villanueva de Duero hace lo propio con otros 1300 hl. Son cantidades simbólicas con relación a los totales vendidos (Nava produce en el citado año $30.440 \mathrm{hl}$ ), pero la imparable exportación de los tintos activa nuevas plantaciones en todos estos pueblos ${ }^{1403}$. En 1888 se plantan cepas de Tinto Aragonés en el pago de La Lastra de Nava del Rey y, tanto en ventas de majuelos en 1875, como en inventarios de bienes de 1892 en Serrada, se hacen constar igualmente estas nuevas cepas tintas ${ }^{1404}$ :

"Un majuelo tinto, situado en jurisdicción del mismo Serrada, al pago de la Cuesta de los Muertos, que de plantío hace quince aranzadas y media, y ocupa de tierra diez obradas trescientos veinte y seis estadales, equivalentes a seis hectáreas, doce áreas y once centiáreas."

"Una tierra... de una hectárea, diez y ocho áreas y sesenta y nueve centiáreas... al pago de la Moya, titulada Zapatero, hoy Tinto... que se ha plantado de majuelo tinto... y vale ciento cincuenta y seis pesetas y cinco céntimos..."

"Una tierra plantada en parte de majuelo... al pago de Valdesuero o las Fuentes y los Tintos, de cabida de 18,6178 hectáreas... conteniendo plantadas siete mil cuatrocientas veinte y ocho cepas de tinto..."

¡Quién no iba a plantar algún majuelo de tinto cuando llegan noticias cada ańo de que los comerciantes franceses agotan las bodegas riojanas pagando elevados precios! Es un fenómeno general. En Valladolid y en sus provincias limítrofes. Entre ellas sobresale Zamora que, como señala Huetz de Lemps, es una de las que más ven crecer la superficie vitícola en la segunda mitad del XIX, al pasar de 33.557 ha en 1857 a 48.885 ha en 1879 , llegando a las 64.492 ha en $1888^{1405}$. Hasta la nobleza rentista desea subirse al nuevo tren. En esta misma provincia, por ejemplo, la condesa de Mollina, marquesa viuda de San Felices, cuando arrienda en 1892 una dehesa de 309 ha por cinco años y 50.000 pesetas, hace constar que "nueve obradas se hallan plantadas de vacillos o viñedo nuevo", pero lo más sorprendente es que los renteros "quedan obligados a plantar de su cuenta y a su costa en el año de 1883 en tiempo oportuno y siempre antes del mes de mayo 10.000 bacillos de viñedo en el terreno de la dehesa, contiguos a los 6.000 ya puestos, siendo de su cuenta y coste también el darles las labores de cultivo necesarias... ${ }^{1406}$.

${ }^{1402}$ A.H.P.V. Pt. 18724, Valladolid, Cándido Santos García, fol. 642, año 1881.

${ }^{1403}$ HUETZ DE LEMPS, A.: Vinos y viñedos..., ob. cit., tomo I, pág. 283 y ss.

${ }^{1404}$ A.H.P.V. Pt. 20017, año 1892.

${ }^{1405}$ HUETZ DE LEMPS, A.: Vinos y viñedos..., ob. cit., tomo I, pág. 284.

${ }^{1406}$ A.H.P.V. Pt. 18131, fol. 571, año 1882. 
Las cifras lo dicen todo. Serrada contaba en 1881 con 2.074 aranzadas de viña; La Seca, con 9.250 aranzadas (frente a las 5.000 de 1752); Matapozuelos, 2.775; Villanueva, 2.037; Ventosa, $1.715 \ldots$ El norte de la Tierra de Medina no escapa, en fin, a la tónica general que se vive en las diferentes regiones españolas. A. Huetz de Lemps constata, a pesar del baile de cifras que ofrecen las distintas fuentes, este aumento de superficie en las provincias del Duero entre 1857 y $1889^{1407}$. En 1752, estima la superficie de viñedo en la provincia de Valladolid en 53.000 ha, cifra ligeramente inferior a la que anota para 1857 (51.519 ha), pero muy por debajo de las 77.507 ha que recoge el "mapa de la filoxera" de 1877, aun cuando el resumen estadístico del Ministerio de Agricultura otorga la abultada cifra de $91.185 \mathrm{ha}^{1408}$. A pesar de este problema administrativo, la importante presencia de la vid, en los distintos partidos judiciales de la provincia, es indiscutible ${ }^{1409}$ :

Cuadro 149. Extensión del viñedo por partidos judiciales en la provincia de Valladolid

\begin{tabular}{lcccc}
\hline Partidos judiciales & $\begin{array}{c}\text { Según avance } \\
\text { estadístico de 1889 }\end{array}$ & $\begin{array}{c}\text { Según García } \\
\text { Salmones, año 1892 }\end{array}$ & $\begin{array}{c}\text { Según Ortega } \\
\text { Rubio año 1892 }\end{array}$ & $\begin{array}{c}\text { Según mapa } \\
\text { filoxera año 1889 }\end{array}$ \\
\hline Medina del Campo & 14.668 & 11.847 & 13.387 & 14.421 \\
Medina de Rioseco & 5.200 & 2.311 & 2.863 & 3.188 \\
Mota del Marqués & 9.980 & 3.387 & 3.073 & 3.456 \\
Nava del Rey & 8.839 & 8.708 & 12.153 & 14101 \\
Olmedo & 15.500 & 8.127 & 10.234 & 9059 \\
Peńafiel & 10.600 & 9.163 & 5.551 & 4.450 \\
Tordesillas & 3.018 & 3.690 & 3.708 & 4.770 \\
Valoria la Buena & 9.395 & 4.326 & 4.281 & 7.180 \\
Valladolid & 11.885 & 7.528 & 6.033 & 5.207 \\
Villalón & 2.110 & 3.402 & 4.249 & 77.507 \\
\hline TOTAL & 91.185 & 62.489 & 65.532 & \\
\hline
\end{tabular}

Fuente: Publicaciones varias citadas en el presente cuadro y capítulo. Elaboración propia.

Como puede apreciarse, los partidos judiciales de Medina del Campo y Nava se alzan con 28.522 ha (si se atiende al vińedo que consta en el mapa de filoxera de 1889), que suponen el 36,7\% del total provincial. La Nava, Rueda y La Seca, a pesar de quedar al margen del mercado exportador, siguen siendo puntos de referencia vitivinícola a escala nacional y, al lado de ellos, otras villas menores como Serrada, Villanueva, Matapozuelos, Pozaldez o Rodilana, tienen en los majuelos, sobre todo en aquellos que extienden sus términos por los sectores de gravas, el principal recurso económico, tanto para los grandes hacendados, como, sobre todo, para pequeńos labradores y braceros que tienen en ellos jornales una buena parte del ańo. La crisis, sin embargo, estaba a la vuelta de la esquina.

\section{b. La crisis, el descenso de precios y la adulteración de los vinos}

La superficie vitícola vallisoletana alcanza la mayor extensión de su historia, pero los factores que propician tan extraordinario avance comienzan a volatilizarse. La recuperación de los viñedos franceses y el fin de los tratados comerciales con el país vecino provocan una subida de aranceles con la consiguiente caída de las exportaciones españolas a partir de 18921410/1411.

${ }^{1407}$ HUETZ DE LEMPS, A.: Vinos y viñedos..., ob. cit., tomo I, pág. 286.

1408 Ibídem, pág. 270-285.

${ }^{1409}$ Ibídem, pág. 362-363.

${ }^{1410}$ GARCÍA FERNÁNDEZ, J.: El comercio exterior de exportación en la economía española, 1850-1914. Anales del CUNEF. 1980-81, pág. 124-132.

${ }^{1411}$ PAN MONTOJO, J.: La bodega del mundo..., ob, cit., pág. 252 y ss. 
Por otro lado, la devastación paulatina que ocasiona la filoxera en las distintas provincias desanima a gobiernos y diputaciones ante la falta de remedios preventivos para combatirla, sumiendo a todos en el mayor de los desasosiegos. En los años de 1886 y 1887, el mildiu eleva los gastos de producción y hace descender la producción. Para que no falte de nada, se asiste en estos años a una pérdida de credibilidad de los caldos españoles, tanto por las prácticas de adulteración que se llevan a cabo por parte de defraudadores, como por las polémicas entre lo que deben ser vinos naturales y $\operatorname{artificiales}^{1412}$.

El resultado final no puede ser más desalentador. A la reducción de las exportaciones se une la bajada generalizada de los precios. En Tierra de Medina, a pesar de ser lugar predominante de blancos, la contracción de la demanda es muy notable. Las cosechas se almacenan año tras año y los precios se hunden. Si en 1865 o 1875 el vino sale de las cubas de Serrada a 16 y 17 reales la cántara y con buenas sacas, testimonios escritos en 1890 refieren que "el precio del vino por hoy no pasa de los 10 reales", a lo que hay que sumar los gastos de saca y, en caso de expedición, la inversión en pipas y el precio de los portes. Sirvan como ejemplo las cuentas tomadas en Serrada en mayo de 1893 en un envío desde la estación de Valdestillas a la estación de Orense, facturadas en la modalidad de pequeña velocidad ${ }^{1413}$ :

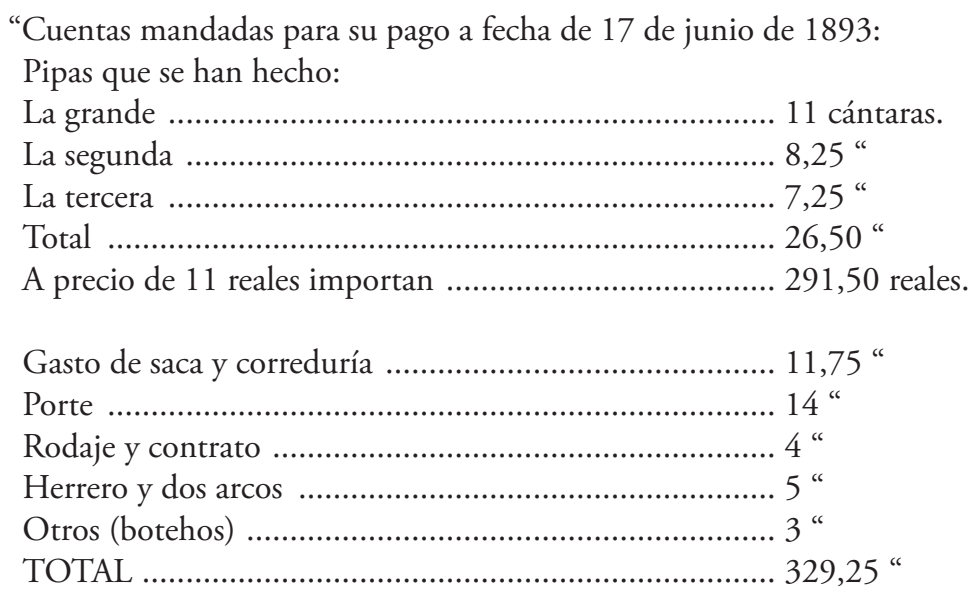

Sin contar con la inversión en pipas, que usadas costaban en 1875 unos sesenta reales cada una, se anotan unos gastos de expedición y portes de 1,42 reales por cántara o, lo que es lo mismo, 8,90 reales el hl. Son horas bajas. En tan sólo dos años el precio del vino en Matapozuelos desciende un $33 \%$ y en Medina del Campo un 25\% ${ }^{1414}$. Como sucediera con la crisis triguera, los contemporáneos desean desterrar la resignación secular del labriego que sintetiza su escepticismo en el adagio "viva la gallinita, y viva con su pepita", hacia posiciones más combativas que permitan aunar las fuerzas de la clase labradora en un Partido Agrícola Español en que "agricultores todos, liberales y conservadores, carlistas, integristas y republicanos defiendan sus intereses" siguiendo el ejemplo ofrecido por agricultores franceses y alemanes ${ }^{1415}$.

En cualquier caso, la situación del vino no parece fácil. En septiembre de 1894, la prensa se hace eco de esta escasez de transacciones y de que "los cosecheros de casi todos los pueblos de Aragón se ven precisados a tirar sus cosechas por la falta absoluta de compradores", tal como sucede en muchos pueblos de la ribera del Duero y en otras importantes comarcas productoras ${ }^{1416}$.

\footnotetext{
${ }^{1412}$ Ibídem, pág. 280 y ss.

1413 A.F.A.M. Carp. de escrituras y varios.

${ }^{1414}$ HUETZ DE LEMPS, A.: Vinos y viñedos..., ob. cit., tomo I, pág. 281.

${ }^{1415}$ MARTÍNEZ MAROTO, S.: La crisis agraria..., ob. cit., pág. 195.

1416 Ibídem, pág. 238.
} 
Sin ser un hecho generalizado, los mayores de Serrada recuerdan haber oído contar a sus padres que el vino del señor Zacarías corría por la calle Real abajo conforme vaciaban los pellejos sacados de la bodega del Lagar del Obispo. Pese al ejemplo, en Medina la contracción no es tan acusada porque nunca se dependió en tan alto grado de la exportación, pero la crisis llevará a muchos labradores al endeudamiento y a muchos braceros, al hambre. Los blancos de Castilla continúan saliendo hacia las montañas de León, Asturias y Santander, abasteciendo a las comarcas vecinas y manteniendo el mercado en tierras segovianas, pero pese a las ventas, en abril de 1896, todos rezaban por un cambio de coyuntura ${ }^{1417}$ :

"Deseando mucho que siguiese la venta de vino y tomase mayor precio. Por ésta (Orense), mucho vino hubo y sin salida."

Es difícil precisar hasta qué punto estos blancos de Castilla sufrieron más las consecuencias de los mercados y las políticas arancelarias internacionales que la depreciación derivada de las prácticas fraudulentas que se llevan a cabo en el mercado del vino por estas fechas. La adición de agua al vino era pecata minuta ante las denuncias por envenenamientos con vinos artificiales o mezclas con alcoholes alemanes. Mientras se formalizan entre 1892 y 1895 las prohibiciones del empleo de alcoholes industriales en el encabezamiento de los vinos o la elaboración de vinos artificiales, el perjuicio que se hace a los productores es irremediable.

Se está, en cualquier caso, ante unos momentos en que se inicia una nueva regulación jurídica de lo que ha de entenderse por vino, las características que han de guardar las comarcas con denominaciones de prestigio o los niveles que han de tener como máximo por hectolitro determinadas sustancias empleadas en el proceso de elaboración. Recuérdese, por ejemplo, que el enyesado de los mostos antes del proceso de fermentación o después para su clarificación fue una práctica común desde siglos tanto en los vinos de Jerez como en los de Castilla. Cámaras de Comercio, Diputaciones o Asociaciones de labradores van tomando posiciones para la defensa de sus intereses en los primeros años del nuevo siglo. En 1903, la Asociación de Cosecheros de Valladolid solicita al Ayuntamiento que, además de recoger muestras que eviten el fraude, suprima las banderas de expedición de vinos a aquellos vendedores ajenos a la Asociación de cosecheros y propietarios de viñas. De este modo, indican, se ejercerá un mejor control sobre la pureza de vinos y vinagres. Todo sirva para "la persecución de los vinos artificiales y adulterados... pues si bien... se ha discutido... la necesidad de higienizar la población de España, de poco serviría... si industriales sin conciencia y comerciantes de mala fe adulteran los artículos alimenticios" 1418 .

Bastaba un caso de envenenamiento o una denuncia para provocar el descrédito y la pérdida de confianza en un mercado que ya andaba a trompicones en estos últimos ańos de centuria. La desconfianza había llegado a las zonas de aprovisionamiento. La correspondencia de la familia Alonso Moyano que se ha conservado sobre el particular muestra, en distintos meses de 1893, tanto la preocupación por recibir un vino que estuviera aguado, como, y esto es más grave, que hubiera sido adulterado y pusiera en peligro la vida del consumidor. En tiempos de crisis era lo peor en que podía verse envuelto el cultivo rey de nuestra comarca $^{1419}$ :

“Celanova, 28 de mayo de 1893.

Te remito tres pipas para que me hagas el fabor de llenarlas de bino blanco del mejor, si lo tienes tú de esta clase, como creo, lo prefiero al de ninguna otra bodega, y en caso contrario, procura que sea de un cosechero de confianza que venga sin agua, pues como no es para gastar al momento, se echaría a perder, además de que perdería el mérito...”

1417 A.F.A.M., carp. de escrituras y varios.

1418 A.M.V., sig. 495-19.

${ }^{1419}$ A.F.A.M. Carp. de escrituras y varios. 
“Celanova, 23 de diciembre de 1893.

Muy caro me saldrá el vino puesto en ésta pero si tú lo tienes de toda confianza en tu bodega, o en otra, caso puedes conseguirlo de otro cosechero de toda confianza, te mandaría una pipa de las que ya fueron a esa para que me la mandases llenar, y con él iría pasando hasta marzo que estuviese en disposición de comprar el del presente año. En ésta hay vino de Castilla y nada caro pero tememos que tenga alguna composición, y como la salud de Casto, que es para quien se dedica el vino, requiere que sean puros, de hay que prefiero sea desa, aunque caro."

\section{c. La llegada de la filoxera}

Desde que se escriben las líneas anteriores hasta la invasión filoxérica de la provincia faltan tan sólo cuatro años. Desde 1882 avanza imparable desde Portugal por tierras gallegas, leonesas, salmantinas y zamoranas ${ }^{1420}$. Favorecido por los vientos dominantes, el insecto llega a los viñedos vallisoletanos en abril de 1897. Roales, Mayorga y Monasterio son los primeros núcleos afectados. El avance es espectacular: en mayo ya hay cepas con el insecto en Gatón, Tamariz y Palacios; en agosto se detecta en Nava, Pozaldez y Rodilana. Un año después, en 1898, toda la provincia es pasto de la terrible plaga. Por entonces se han prácticamente abandonado cuantos métodos preventivos y curativos se habían ensayado en Francia y en otros lugares. A diferencia de otras provincias o regiones donde el gobierno y las Diputaciones gastan infructuosamente importantes sumas en tratamientos con sulfuro de carbono, desde comienzos del nuevo siglo todos los esfuerzos se concentran en la replantación del viñedo con pies americanos, inmunes al insecto. A diferencia del oidium y del mildiu, enfermedades criptogámicas vencidas, o al menos paliadas, conforme llegan a Europa en esta segunda mitad del XIX, mediante azufre y sulfato de cobre (caldo bordelés) respectivamente, el nuevo inquilino, perteneciente al género de los Aphidiae, no parece encontrar barreras. Nunca un insecto ha provocado tanta conmoción internacional y ha hecho correr tantos ríos de tinta.

La filoxera se suma, con sus efectos, a la profunda crisis que vive el campo castellano en el último tercio del XIX y primeras décadas del XX. El gobierno de la nación, tras no poca legislación preventiva, por ley de 18 de junio de 1885, trata de hacer frente al problema, creando un fondo solidario que las distintas diputaciones se encargan de recaudar. La Diputación Provincial, para el año económico 1880-81 ya ha puesto un repartimiento de 25 céntimos de peseta sobre cada hectárea de viñedo con destino al fondo de defensa contra la filoxera, en virtud de la ley de 30 de julio de 1878 . Por estos años la provincia de Valladolid registra 52.927 ha y serán estos pueblos al sur del Duero los que concentran casi la mitad de su superficie ${ }^{1421}$.

La Diputación trata de adelantarse a un problema que todos ven llegar creando un fondo "con destino a satisfacer los gastos que hubiere necesidad de hacer para combatir y extinguir la filoxera en el caso de que desgraciadamente esta provincia o las limitrofes fueran objeto de esta calamidad"1422. No siempre los Ayuntamientos aceptan con agrado un impuesto que se añade a los que ya agobian a sus vecinos. En abril de 1889 el Ayuntamiento de Serrada, para afrontar el pago de 426,50 pesetas "sobre defensa contra la filoxera, a razón de 50 céntimos de peseta por hectárea", impone el recargo máximo del $100 \%$ en el impuesto de consumos y sube al $50 \%$ el de cédulas personales ${ }^{1423}$. En junio de 1893 , sin embargo, el Ayuntamiento de La Seca se adhiere a los acuerdos que tomen las Cámaras Agrícolas de Medina para que no se exija dicho impuesto ${ }^{1424}$.

${ }^{1420}$ En la propagación de la filoxera en España se pueden distinguir tres focos: el que se inicia en Gerona desde 1878, procedente de Francia, y que destruye todo el viñedo catalán y aragonés; el foco andaluz derivado de la importación de pies americanos en Málaga en este mismo ańo, que se extiende por toda Andalucía, y el que desde Portugal va arrasando por el norte y oeste desde 1882 los majuelos gallegos y castellanos. Para un conocimiento más amplio de esta crisis Alain Huetz de Lemps. Vinos y viñedos..., ob. cit., tomo I, pág. 295 y ss. y Juan Pan Montojo: La bodega del mundo..., ob, cit., pág. 122 y ss.

${ }^{1421}$ B.O.P.V., año 1880 , no 251.

${ }^{1422}$ B.O.P.V. No 262, pág. 3, año 1880.

${ }^{1423}$ A.M.S., caja 3, carp. 32, fol. 31.

${ }^{1424}$ SUÁREZ ALÁEZ, A.: Historia de la villa de La Seca. Diputación de Valladolid, 1997, pág. 121. 
Cuadro 150. Superficie de viñedo en la comarca de Medina, año 1880

\begin{tabular}{lrlr}
\hline Municipios & ha & Municipios & ha \\
\hline Alaejos & 849 & Pozaldez & 1.222 \\
Ataquines & 95 & Ramiro & 29 \\
Bobadilla del Campo & 97 & Rubí de Bracamonte & 40 \\
Brahojos de Medina & 141 & Rueda & 2.587 \\
\hline Campillo (El) & 133 & Salvador de Zapardiel & 17 \\
Carpio & 275 & San Pablo de la Moral. & 15 \\
Castrejón de Trabancos & 131 & San Vicente del Palacio & 84 \\
Cervillego de la Cruz & 104 & Seca (La) & 3.515 \\
\hline Fresno el Viejo & 317 & Serrada & 641 \\
Fuente el Sol & 98 & Siete Iglesias de T. & 746 \\
Lomoviejo & 20 & Torrecilla de la Orden & 127 \\
Matapozuelos & 1.377 & Valdestillas & 779 \\
Medina del Campo & 1.049 & Villanueva de Duero & 754 \\
Moraleja de las Panaderas & 2 & Velascálvaro & 42 \\
Muriel & 40 & Ventosa de la Cuesta & 378 \\
Nava del Rey & 3.536 & Villaverde de Medina & 578 \\
Nueva Villa de las Torres & - & Zarza (La) & 43 \\
Pozal de Gallinas & 576 & TOTAL & 23.194 \\
\hline
\end{tabular}

Fuente: Diputación Provincial. Boletín Oficial de la Provincia. Elaboración propia.

Al tiempo que la propia Diputación Provincial gasta energías en tratar de cobrar las distintas partidas a sus municipios, estos excusan con dispares argumentos el pago, al tiempo que el insecto devora viñas y los años pasan sin que se activen medidas para recuperar al sector. Las circulares que publica la Comisión provincial de defensa contra la filoxera son más informativas que efectivas. Se forman comisiones municipales y se prohíbe a los pueblos la introducción de sarmientos procedentes de provincias infectadas. El viñedo se hunde y los vecindarios con é ${ }^{1425}$. Las tensiones sociales, derivadas del alarmante incremento del número de braceros en paro, no se hacen esperar. Se asiste, a tenor de los datos de la gráfica adjunta, a una paralización y a un desánimo administrativo difícil de justificar, pero general en la mayor parte del país. Como señala Teresa Carnero, si en Francia la filoxera favorece el inicio de un proceso de modernización, en España el temible insecto acentúa los graves problemas existentes ${ }^{1226}$. Y lo peor es que no puede decirse que la plaga les pille desprevenidos. En 1893 García Salmones ya había puesto el dedo en la llaga. Sus palabras podían pecar de duras, pero no de ambiguas ${ }^{1427}$ :

\footnotetext{
"En lo hecho por nuestros gobernantes, veremos que todo se ha reducido a nombrar Comisiones de defensa contra la plaga, sin medios para llevar a cabo los trabajos que proyectaran y a dictar leyes inspiradas en muy buenos deseos, aun cuando no siempre en armonía con las nuevas corrientes que de día en día toma la viticultura, resultando de todo ello, que el agricultor ninguna utilidad ha podido sacar hasta hoy, y a decir verdad, si en algo conoce, que se legisla en cuestiones de tan vital interés para el país, es sólo en los impuestos con que esa legislación grava sus productos...”
}

Sea por falta de recursos, de capacidad o de energía el caso es que la filoxera se propaga por la provincia vallisoletana ante la indiferencia general. "Aqui nadie se interesa en tomar medidas, todas mis quejas se pierden en el vació", se queja el Perito de Vigilancia en julio de $1890^{1428}$. Diez años después los focos filoxéricos se extienden por estos pagos campando a sus anchas. En 1897 y 1901, la propagación

${ }^{1425}$ B.O.P.V. En septiembre de 1890 las provincias más infectadas son Barcelona, Tarragona, Gerona, Málaga, Granada, Salamanca, León, Zamora, Orense y Almería, (año 1890, pág. 511, sección cuarta, no 3514).

${ }^{1426}$ CARNERO I ARBAT, T.: Expansión vinícola y atraso agrario, 1870-1900. Ed. Servicio de publicaciones agrarias, 1980, pág. 180.

${ }^{1427}$ Ibídem, citando a Nicolás García de los Salmones: La invasión filoxérica en España y las cepas americanas. T. I. Barcelona. Tipolitografía de Luis Taso, 1893, pág. 14-19. 
del mildiu reduce la cosecha en distintos pueblos del norte de Medina. En 1892 apedrea en La Seca; en 1893, 1899 y 1904, en Serrada. La filoxera sigue matando vides al tiempo que los obreros suplican trabajo e inician las primeras huelgas a comienzos de siglo. En abril de 1911, el Ayuntamiento de La Seca, en sesión ordinaria, estudia solicitar una reducción de la contribución en aquellas fincas que han dejado de ser majuelos por la filoxera. Es el mismo trámite que se seguía cuando caían pedriscos o heladas, pero el contexto era otro. El insecto pone en peligro la frágil estructura rural del campo castellano sin que la reacción vaya más allá de la constatación de los hechos ${ }^{1429}$ :

\begin{abstract}
"Teniendo en cuenta que la plaga filoxérica biene causando cada día mayores extragos en el viñedo de este término municipal, viniendo la invasión a concluir con un benero de riqueza muy estimable, teniendo en cuenta que dedicarse los terrenos que aquellos ocupan al cultivo de cereales, el cual ofrece escasos rendimientos, dado que estos no reúnen condiciones favorables a la producción del nuevo cultivo a que se dedican, por unanimidad acuerda la Corporación que por el Secretario de este Ayuntamiento se estudie la legislación vigente para solicitar de quien corresponda la rebaja de la contribución atribuida a las fincas que hasta ahora han dejado de dedicarse al cultivo del viñedo por la invasión filoxérica."
\end{abstract}

En estas líneas se observa la propia labor del insecto. A diferencia de otras comarcas más arcillosas, en estas terrazas de gravas y arenas la destrucción de las cepas se prolonga varias decenas de años. Este hecho, sin embargo, alarga la agonía, retrasa la labor replantadora y, como manifiestan los ediles lasecanos, hace perder buena parte de la riqueza a estos núcleos tradicionalmente vitícolas, ya que buena parte de sus pagos, arrancadas las cepas, son de escasos rendimientos si se siembran de cereal. La propia Diputación Provincial de Valladolid estima que de las 43.092 ha destruidas en 1909 y que eran susceptibles de replantación, tan sólo unas 12.000 ha vienen a ser aprovechadas para el cultivo de cereales ${ }^{1430}$. La propia institución es consciente en 1917 tanto de la gravedad del problema como de su magnitud, toda vez que el manejo de las cifras de ha destruidas era muy superior a las manejadas anteriormente en las estadísticas oficiales, pues muchos municipios reducen administrativamente sus extensiones de viñedo ante el impuesto filoxérico ${ }^{1431}$. De hecho, en 1917 , de las 86.000 ha que se estiman destruidas, 12.000 ha se dedican al cultivo de cereales y 74.000 ha están pendientes de repoblación. Aunque la producción de estos viñedos es más bien baja, tan sólo 7,68 hectólitros cada una (1,14 moyos/aranzada), como valor medio de producción de mosto (con referencia al ańo 1911) representa una riqueza anual de 22.732 .800 pesetas. Si a la citada cantidad se suman otros 13,5 millones que dejan de gastarse en jornales, se está ante un problema de una magnitud desconocida. Pocas veces, estos pueblos, estuvieron tan desvalidos.

\title{
d. Una población no exenta de crisis periódicas y que acusa las dificultades agrarias
}

A finales del siglo XVIII el equilibrio entre población y recursos llega al límite, como ponen de manifiesto las distintas crisis de subsistencia que tienen lugar en sus últimos años. Conviene recordar que Serrada figura en el Censo de Floridablanca de 1787 con 842 habitantes, muy superiores a los 37 de San Martín del Monte, pero pocos si se comparan con La Seca (3.702 habitantes) o Nava

${ }^{1428}$ Ibídem, cita textual procedente del Archivo del Ministerio de Agricultura. Valladolid, filoxera, expedientes sobre los estados de los viñedos, comisiones..., 1890, M. S., leg. 21, exp. n 9; 1878, M.S. leg. 21, exp. 8, y 1890 y 1898, M. S., leg. 21 , exp. $\mathrm{n}^{\circ} 9$.

${ }^{1429}$ A.M.L.S. Libro de Actas, 19 de abril de 1911.

${ }^{1430}$ DIPUTACIÓN PROVINCIAL DE VALLADOLID, (1917) Antecedentes y acuerdos adoptados por la Excma. Diputación Provincial de Valladolid para la reconstitución del viñedo de su provincia, Valladolid, Imprenta Castellana, pág. 55.

${ }^{1431}$ Ibídem. En el citado informe se manejan como datos recientes aportados por el Jefe del servicio Agronómico, Sr. Marqués de la Solana, las siguientes cifras: 122.760 ha dedicadas al cultivo de la vid en la provincia; 23.025 ha que conservan vińedo antiguo; 13.735 repobladas y 86.000 ha destruidas por la filoxera. En estos datos de 1815/1817 se encontraban repobladas 13.735 de las que 2.735 estaban en producción. 
(4.710). Estos municipios superan incluso a la villa de las ferias que, en horas bajas, no pasa de los 3.454 habitantes. Pozaldez cuenta con 1.166 habitantes, Rodilana con 1.284, Matapozuelos con 1.233, Valdestillas con 856 y Ventosa y Villanueva con 396 y 770 habitantes. respectivamente.

Todos estos municipios han crecido, beneficiados por la expansión agraria de mediados de siglo y al calor de su vińedo, necesitado siempre de abundantes brazos para hacerlo producir. En Serrada, por ejemplo, este factor, unido a la escasa propiedad y entidad del término, es la causa de la existencia de tan sólo 39 labradores, de los que ocho son nobles, frente a los 105 jornaleros y 11 criados vecinos de la villa. Se reflejan estas cifras porque también aquí hay diferencias. En La Seca, por ejemplo, a la inexistencia de propiedad nobiliaria en forma de grandes mayorazgos hay que sumar la abundancia de tierras sernas y un notable término municipal. El Censo de Floridablanca cifra en 543 los labradores y en 316 los jornaleros, elevándose el número de hijosdalgo hasta la importantísima cifra de 620 que, como es de imaginar, distinguen desde braceros empobrecidos a pudientes labradores.

Todos y cada uno de estos pueblos han padecido las crisis de finales del XVIII, la Guerra de la Independencia, y la crisis vitícola del primer tercio de forma notable. El descenso demográfico alcanza en mayor medida a las entidades menores. Serrada, por ejemplo, ha visto descender el número de sus habitantes en una cuarta parte y no supera las 627 almas en 1842. El dinamismo triguero, la bonanza de los precios y las buenas sacas de los caldos vuelven a aumentar el número de matrimonios y bautizos, aunque, como se podrá imaginar, son también muchos los entierros que se celebran cada mes. A pesar de la revolución industrial y de los transportes, de los avances médicos y sanitarios y, en fin, del avance inexorable del siglo XIX, se trata de un modelo demográfico tradicional con escasas variaciones respecto a pasados siglos. La mortalidad es altísima, con cifras que superan el 34 por mil.. Los párvulos se entierran a decenas cada año. Los primeros años del XIX son terribles en este sentido. En 1804 se entierran en Serrada sesenta y un niños párvulos; en 1805, veintidós; en 1806, doce; en 1807, dieciséis... En el resto del siglo la situación tiende a mejorar, pero no son pocos los episodios en que la enfermedad se lleva a muchos vecinos en la plenitud de su vida. Las anotaciones que dejó escrito Eleuterio Martín sobre su familia y que reproducimos al pie son valiosísimas en este sentido $^{1432}$.

${ }^{1432}$ En algunos archivos particulares se conservan apuntes sobre los nacimientos y defunciones de la familia. El caso que sigue es ilustrativo de cuanto venimos estudiando: "Eleuterio Martín y Ulpiana Fadrique. En el ańo de 1830 nos casamos (el 5 de junio). Cura párroco, D. León Rodríguez, interino. Familia que hemos tenido:

-El 17 de enero del 31 nació Antonia, sin tiempo, a las 12 del día. Padrinos: Lorenzo Rodríguez y su mujer Plácida Rodríguez. Se acristianaron el 18. Cura párroco en propiedad, D. José Lino Gutiérrez. Nació en la casa Barrio Nuevo.

(Nota al margen). Murió el 27 de enero. Se enterró en la iglesia.

-El 14 de febrero del año de 1832 nació Valentín Martín Fadrique, a las cuatro de la mañana. Padrinos D. Saturnino Villán y Plácida Rodríguez. Se bautizó el 16 del mismo. Cura párroco, D. José Lino Gutiérrez. Sacristán, Luis Mato, y en la anterior nació.

-En el día 17 de enero de 1834 nació Antonia, en la casa de Dábila, a las tres de la mañana. Padrinos: Ramón Alonso y Paula Fadrique. El cura, D. José Lino Butérrez. Sacristán, Blas Cisneros.

(Nota al margen). Murió el 14 de julio del mismo año. Se enterró en el Cementerio.

-El día 29 de noviembre de 1836 nació Saturnina Martín Fadrique a las ocho y media de la mañana. Padrinos, Manuel Román y Baldomera Fadrique. El señor cura párroco, D. José Domínguez. Sacristán, Blas.

-(Nota al margen). El día 7 de julio nació Fermina en Tordesillas. Llevó agua de socorro. Murió a las cuatro de la mañana siguiente. Se enterró en San Pedro.

-El día 12 de febrero de 1939 nació Eugenia a las 4 y media de la mañana. Padrinos Guillermo García y Juliana Martín. El Sr. Cura, D. José Domínguez. Sacristán, Blas.

(Nota al margen). Murió el 24 de febrero de 1861.

-El 30 de diciembre de 1842 nació Jacoba a las 4 de la mañana, padrinos D. Patricio Alonso y su mujer Anacleta Fadrique. Se acristianó el 3 de enero siguiente. Cura ecónomo, D. Antonio Perona, sacristán Blas.

-El 28 de noviembre de 1945 nació Gregorio a las tres de la mañana. Se acristianó el 30 mismo. Padrinos, Marcelino y Eulogia Ríos. D. Antonio Perona, cura ecónomo. Sacristán, Blas.

(Nota al margen). Murió el 23 de septiembre de 1859.

-El día 18 de febrero de 1848 nació Eladio a las 4 y media de la tarde. Se acristianó el 21 del mismo. Cura ecónomo, 
Es difícil imaginar lo que pensaría este vecino conforme llena, año tras año, su cuaderno familiar con las anotaciones de tantos hijos nacidos y muertos. En su casa no faltaba el pan, pues era un labrador mediano pero la muerte llamó numerosas veces a su puerta. Las malas cosechas, las epidemias y la pobreza se llevan a la tumba a buena parte de los que nacen sin apenas tiempo al agua de socorro. Ello explica los porqués de tantas obras y limosnas en busca de Dios, salud o salvación. Las malas cosechas traen siempre del brazo hambres y mortandades. La de 1868 fue pavorosa en Serrada. Murieron setenta y dos personas de las que catorce eran párvulos. Sólo las fiebres tifoideas se llevan a treinta y una, y en conjunto fallecen cuarenta y dos habitantes de entre 15 y 50 años $^{1433}$. Casi una décima parte de la villa se fue para siempre en tan sólo doce meses. La muerte era fraternal compañera de viaje y sólo una elevada natalidad podía conseguir aferrar a los hombres y mujeres a este mundo. Nada mejor que un ejemplo: si en 1858, cuando Serrada tenía 862 habitantes murieron 30 personas, la mayor parte párvulos, este mismo año nacieron 34. Las circunstancias no eran fáciles para muchos $y$, en ocasiones, los recién nacidos, abandonados, eran encontrados colocados en las ventanas de alguna casa del pueblo. Su camino era ser llevado por el administrador de expósitos al hospicio de Valladolid. En julio de 1806 se dejó escrito en el Libro de bautizados de San Pedro de Serrada ${ }^{1434}$

"En la parroquial de San Pedro Apóstol de esta villa de Serrada, en quince de julio de mil ochocientos y seis, yo, el infraescripto, cura ecónomo de ella hize el exorcismo cathequismo, puse los Santos óleos y crisma y bautizé solemnemente sub conditione a una niña que apareció en el mismo día por la mañana, metida en un cuévano y enbuelta en unos trapos y colgada en el mismo cuévano que lo estaba de una ventana vaxa de una casa de esta villa, sin saberse sus Padres ni quien la hubiere puesto allí. Tenía puesto y pegado al cuébano un Papelito en que decía haber nacido en el día catorze del mismo mes, día de San Buenaventura y que tenía agua de socorro. Pero sin embargo le bauticé sub conditione, como lo prescriben los moralistas. Fueron Padrinos Juan García y María Cruz Cueto de esta vecindad, a quienes advertí el parentesco y demás obligaciones. Testigos: Felipe García. Bernardo Hinojal. Y lo firmé dicho día, mes y año. Fr. Pedro de la Asunción. (Rúbrica)”.

No era nada fácil vivir ni crecer en estos tiempos. Ya se ha relatado lo caro que también resultaba morirse o, para ser más exactos, ser enterrado. En ocasiones se advierte una resistencia por parte del vecindario a hacer efectivas tantas cargas piadosas a la iglesia. A principios de siglo, por ejemplo, al revisar las partidas de defunciones de Serrada, el cura Beneficiado de San Martín del Monte, Manuel Seco, detecta estas inercias. Manifiesta en relación a las mandas piadosas ${ }^{1435}$ :

“... pero esto no lo ha logrado ni en adelante lo conseguiría a causa de que en nada se entienden con el cura los interesados del difunto sino con los beneficiados de Preste, los que le entierran queriendo y, como quieren, se enteran de lo piadoso, cobran de ellos misa, entierro y demás. Y aunque el cura reconvenga a los interesados

D. Isidoro Rodríguez, de La Seca. Padrinos, Florentino y Rufina Martín. Sacristán, Blas Cisneros.

(Nota al margen). Murió el 10 de junio de 1850.

-El 4 de noviembre de 1850 nació María En la casa del Sr. Marqués. Se acristianó el 9 del mismo. Padrinos, Valentín

Martín y Luciana. Cura ecónomo, D. Bruno Cantalapiedra, de La Seca. Sacristán, Blas.

(Nota al margen). Murió el 6 de enero de 1851.

-El primero de abril de 1852 nació Catalina de Siena A las 12 y cuarto del día. Se acristianó el 4 del mismo. Padrinos, Nicolás Inojal y su mujer Fermina Fadrique. El Sr. Cura ecónomo, D. Francisco. Sacristán, Blas.

-El primero de julio de 1854 nació Casto Simeón a las 11 de la noche. Se acristianó el 4 del mismo. Padrinos Nicolás Inojal y Saturnina Martín. Cura párroco D. Roque Melchor y Mayor. Sacristán, Blas Cisneros.

(Nota al margen). Murió el 20 de enero de 1855.

-El diez de abril de 1858 nació un niño muerto.

-El día 7 de enero de 1859 murió Ulpiana a las 4 de la tarde.

-El 22 de septiembre de 1844 se confirmaron en Villanueva de Duero, Valentín, Eugenia, Jacoba y Saturnina. Obispo, el Ilmo. Sr. D. José Riba de Neira. A.F. Martín Santos, cuaderno familiar (s/c).

1433 A.G.D.V. Difuntos, Libro 6, año 1868.

${ }^{1434}$ A.G.D.V. Bautizados, Serrada, Libro 5, fol. 27.

${ }^{1435}$ A.G.D.V. Difuntos, Serrada, Libro 3, fol. 46. 
sobre que le den el tanto del testamento o certificado de lo piadosos, lo pagan con buenas o malas razones, lo que no sucediera si los Prestes no pasasen a enterrar al difunto asta aguardar recado del cura de tener cumplido todo esto los interesados...”.

Pese a todo, pagando más o pagando menos, todos son enterrados. Y cuando se llene la nueva iglesia o lleguen nuevas disposiciones, se descansa fuera del templo. En diciembre de 1804 una nota señala "hasta aqui los enterrados en la Iglesia de esta villa; los restantes en el Campo Santo"1436. Sea por "tumores y calenturas", sea por "tabardillo", sea por "fiebres pútridas" o "tifoideas", el caso es que es rara la semana que o hay entierro en el pueblo o misa de aniversario ${ }^{1437}$.

Cuadro 151. Población según padrón de 1942 y censo de 1877 en la comarca de Medina ${ }^{1438}$

\begin{tabular}{|c|c|c|c|c|c|}
\hline Municipios & Año 1842 & Año 1877 & Municipios & Año 1842 & Año 1877 \\
\hline Alaejos & 3.352 & 3.664 & Pozaldez & 1.743 & 2.139 \\
\hline Ataquines & 732 & 1.292 & Ramiro & 107 & 206 \\
\hline Bobadilla del Campo & 232 & 656 & Rubí de B. & 310 & 566 \\
\hline Brahojos de Medina & 200 & 418 & Rueda & 2.467 & 4.427 \\
\hline Campillo (El) & 190 & 581 & Salvador de Z. & 94 & 318 \\
\hline Carpio & 800 & 1.195 & San Pablo M. & 100 & 338 \\
\hline Castrejón de T. & 414 & 757 & San Vicente P. & 268 & 514 \\
\hline Cervillego de la Cruz & 255 & 420 & Seca $(\mathrm{La})$ & 3.450 & 3.394 \\
\hline Fresno el Viejo & 1.051 & 1.441 & Serrada & 627 & 792 \\
\hline Fuente el Sol & 200 & 419 & Siete IglesiasT. & 1.097 & 1.656 \\
\hline Lomoviejo & 272 & 598 & Torrecilla O. & & 544 \\
\hline Matapozuelos & 1.216 & 1.459 & Valdestillas & 450 & 918 \\
\hline Medina del Campo & 3.017 & 5.123 & Velascálvaro & 100 & 227 \\
\hline Moraleja de las P. & 100 & 120 & Ventosa de C. & 213 & 479 \\
\hline Muriel & 302 & 621 & Villanueva D. & 351 & 482 \\
\hline Nava del Rey & 4.396 & 5.986 & Villaverde M: & 492 & 840 \\
\hline Nueva Villa de T. & - & - & Zarza (La) & 184 & 303 \\
\hline Pozal de Gallinas & 465 & 604 & TOTAL & 29.247 & 43.497 \\
\hline
\end{tabular}

Fuente: Padrón de 1942 y censo de 1877. Elaboración propia.

A pesar de estas crisis, como puede advertirse en el cuadro respecto a datos de población anteriores, el siglo XIX es un siglo de notable crecimiento demográfico. Con la prevención debida en los datos ofrecidos por los municipios, la comarca de Medina pasa de 29.247 habitantes en 1842 a 43.497 habitantes en 1877 , alcanzando un crecimiento del 32,7\%. Serrada, por ejemplo, ve aumentar su población un 28\% entre 1842 y 1863 (627 y 870 habitantes respectivamente). Para que esto

${ }^{1436}$ A.G.D.V. Difuntos, Serrada, Libro 4, fol. 25.

${ }^{1437}$ En ello también las diferencias, limosnas y cargas eran proporcionales al nivel social y riqueza del finado: "Se enterró en esta parroquia con entierro doble, nobenas, honras y cabo de año. Otorgo su testamento ante Luís Sanz Martín, escribano de Rodilana en que mando celebrar en esta iglesia dos misas cantadas en los días cinco de enero y catorce de julio... Mando se dijesen por su anima y de su hijo D. Melchor Moyano cuatrocientas misas rezadas con la limosna de tres reales cada una..., y se mando enterrar en numero octavo de sepulturas, valiendo a la fabrica ochenta y ocho reales y medio. Quedo por herederos a sus hijos legítimos Miguel, cecilia, Catalina, María, Inés y a los hijos de Manuel Moyano su hijo y a jerónimo de Íscar y María de Íscar Moyano sus nietos. Mejoro en dieciocho aranzadas de viña a sus dos hijas: María e Inés Moyano y manda la ofrenda en estas con ofrenda doble y responso cantado por espacio de un año...”

"En esta villa a cuatro de julio murió Benito de Castro, mi feligrés, y marido que fue de Manuela Crespo, ya difunta. Recibió el sacramento de la penitencia y, sin más lugar a mas, al instante espiro. Se enterró en esta parroquial y en sepultura de pobres por serlo el susodicho, y lo firmé. Juan Manuel Obregón de Íscar, (rúbrica).” (A.G.D.V. Difuntos, Serrada, Libro 4, fol. 25).

${ }^{1438}$ B.O.P.V. Año 1842 , no 114 y año 1880 , no 376. 
pueda ocurrir y, sobre todo, para que durante varias décadas se pueda mantener dicha población sin recurrir a la emigración, la rentabilidad de los cultivos, única fuente de ingresos de sus vecinos, tuvo que experimentar un notable crecimiento.

Similares afirmaciones, aun con condicionantes y características diferenciadas, se pueden hacer de los términos vecinos. Salvo La Seca apenas crece entre las citadas fechas, pero mantiene una altísima población (3.450 habitantes en 1842 , 3.552 en 1870 y 3.394 en 1877), el resto de localidades como Rueda, Nava, Villanueva, etc., crecen entre un 25 y 40\%, y sólo se apaga esta dinámica cuando el fantasma de la crisis finisecular se acerca y el sector agropecuario ha de esperar tiempos mejores. De hecho, desde 1865 el rumbo de la agricultura castellana y española en general parece torcerse. Las malas cosechas que se suceden entre dicho ańo y en 1868 provocan la ruina de muchos labradores, un descenso de las salidas de los principales productos agrarios y, por el contrario, la subida de la presión fiscal que, al tiempo que atenaza a los cultivadores, sume en la miseria a jornaleros y pequeños campesinos ${ }^{1439}$. Se acaban las esperanzas de los pequeños por hacerse grandes. Los medianos y grandes labradores se despiden de los beneficios que obtenían en años anteriores y la situación de la clase jornalera queda comprometida ante la falta de jornales.

El futuro de las labranzas y de la clase propietaria se tambalea. La población, también. El censo de 1877 otorga a Serrada 783 habitantes y 3.353 a La Seca, evidenciando que el estancamiento y la crisis del sector agropecuario paralizan también la dinámica demográfica. Ambos municipios pierden población respecto a 1860 . Se inicia la emigración ante la falta de capacidad de un mundo rural incapaz de alimentar a sus habitantes. De hecho, en el censo de 1887 Serrada registra 892 habitantes, pero su vecina La Seca, con 3.095 habitantes, pierde casi un tercio de su población. En el año 1900 Nava del Rey, Pozaldez, Rueda, La Seca o Ventosa con 6.148, 2.168, 4.466, 2.970 y 527 habitantes respectivamente, marcan el techo demográfico de todo el siglo XX y, en la mayor parte de los casos, de toda su historia. Pero esta deparará no pocas transformaciones a todos los niveles.

\section{La vida municipal en el siglo XIX. Labradores y jornaleros}

Desde sus inicios el régimen liberal trata de generar un sistema municipal que resuelva racionalmente los problemas de los viejos concejos. La Constitución de Cádiz sienta las bases del gobierno interior basándose en el Ayuntamiento, obligatorio en todas las poblaciones de más de mil almas y compuesto por el alcalde, los regidores y el procurador síndico, nombrados por el vecindario con derecho a voto. En el nuevo marco del sistema político liberal, muy pronto, como se puede imaginar a tenor de lo estudiado, los Ayuntamientos, las Diputaciones y el resto de instituciones del Estado, son monopolizados por las clases propietarias que hacen del poder, en cualquiera de sus formas, un instrumento para la defensa de sus intereses.

Por lo demás, la vida de estas villas no se diferencia en exceso del siglo anterior. La revolución industrial y de los transportes afecta a la salida y entrada de productos, a la intensificación de cultivos, a la rentabilidad de explotaciones y al movimiento migratorio, pero, al margen de estas cuestiones ya tratadas, la vida cotidiana sigue sujeta a las mismas preocupaciones por regular los caudales públicos, hacer frente a contingencias o calamidades que afectan a sus vecinos, preocuparse por la salubridad de las aguas, disponer de maestro de primeras letras o cirujano, sacar en subasta de arrendamiento los distintos puestos o servicios a la población, vigilar los campos y velar por la quietud del vecindario.

\section{a. El control político por la clase propietaria}

La desaparición del viejo orden y la consolidación del liberalismo burgués sitúan a la clase propietaria en un lugar de privilegio tanto en ciudades como en villas y aldeas. Bien es verdad que en los ámbitos rurales siempre lo habían ocupado. Con el nuevo régimen, sea la vieja nobleza terrate-

${ }^{1439}$ VALLEJO POUSADA, RS: Reforma tributaria y fiscalidad..., ob. cit., pág.246-247. 
niente, los nuevos hombres de negocios o los grandes labradores tradicionales, el caso es que las distintas constituciones y leyes electorales les garantizan el control político, económico y social que ejercen sin cortapisas, estén adscritos a las filas de los partidos conservadores o progresistas. Unos y otros gozan y monopolizan, a través del sufragio censitario, el poder ser tanto electores como elegibles a cargos municipales. A pesar del vaivén legislativo que regula el derecho de voto en las constituciones de 1837,1845 o 1856, el caso es que la representatividad nunca superó el 5 por ciento de la población. Dicho de otro modo: sólo los muy pudientes podían presentarse a las elecciones y no todos tenían el derecho a poder votarles. Si se toma, por ejemplo, el Boletín Oficial de Valladolid del 12 de febrero de 1850, donde se publica el Real Decreto mandando que se proceda a renovar en su mitad las Diputaciones provinciales, en su artículo séptimo, como cualidad necesaria para ser Diputado Provincial se señala "Tener una renta anual procedente de bienes propios que no baje de 8.000 reales de vellón o pagar 500 de contribuciones directas" 1440 .

La constitución de 1845 y las leyes electorales derivadas del periodo isabelino certifican muy a las claras quiénes son los que mandan y controlan ciudades y pueblos. La publicación de la lista de electores que toman parte en las distintas votaciones a Diputados a Cortes es reveladora de este liberalismo doctrinario ${ }^{1441}$. Basta comprobar las listas electorales de estas villas comarcales para darse cuenta al instante. Los apellidos Monsalve, Pérez, Bayón, Moro o Pimentel se repiten en Rueda; Mena, Bayón, Lorenzo, Pedrosa o Cantalapiedra en La Seca; Inaraja o Fernández en Ventosa... ${ }^{1442}$. Coinciden, evidentemente, con las listas de los mayores contribuyentes de dichos municipios ${ }^{1443}$. Y lo que los legisladores liberales estipularon para Cortes y Diputaciones, también lo hicieron extensivo a los propios municipios. En 1860, por ejemplo, se señalan mediante parte oficial y conforme a la ley electoral quiénes tienen derecho a participar en la renovación de los Ayuntamientos.

En Serrada, de los 197 vecinos (862 habitantes), tan sólo son electores 73 y pueden ser elegidos 48. A mediados de la década de los cuarenta era Alcalde Gregorio León y regidores Crisóstomo de Íscar, Ezequiel Moyano y Modesto de Castro; en 1857, los electores distinguieron a Leandro Obregón como Alcalde y a Balbino Alonso, Canuto de Castro, Tomás Moyano y Jorge Martínez regidores. Es muy posible que alguno se esté preguntando a qué partidos pertenecían unos u otros. En realidad a ninguno. Y menos a escala tan local. A escala provincial se puede hablar de clientelas, llenas de intereses familiares o económicos que pueden variar si se les facilita un acta de diputado, la promesa de una carretera para su distrito de procedencia o intereses semejantes. En estas fechas se sientan las bases del favoritismo de la Restauración. Los grandes propietarios con posibles entran en el juego político del momento, tanto porque son necesarios a los principales líderes provinciales para ganarse apoyos en sus demarcaciones, como para conseguir de éstos, caso de salir en las elecciones, beneficios

${ }^{1440}$ B.O.V. Na $19,12 / 2 / 1850$.

${ }^{1441}$ En Serrada tuvieron derecho a voto y lo ejercieron, por ejemplo, en la votación a Diputados a Cortes del 31 de agosto de 1850 Gregorio León Alonso, Ventura Moyano, Ezequiel Moyano, Leandro Obregón, Cipriano Platón, Pablo Obregón, Crisóstomo de Íscar, Fernando Alonso, Ezequiel Pérez, Modesto de Castro, Félix Martínez y Feliciano Martín. En el distrito de Medina del Campo los candidatos que obtuvieron más votos fueron Vicente Pimentel, Joaquín María Belloso y Joaquín María Montalvo.

1442 B.O.V. Na 19,fecha: 5/9/1850.

${ }^{1443}$ En el reparto de la contribución de Serrada del mismo año Gregorio León Alonso tenía fijada una cuota de contribución de 3.128 reales; su cuñado Modesto de Castro 3.211 reales, los Hnos. de Melchor Moyano 1.494; Cástor de Castro 1.031; Ventura Moyano 950; Feliciano Martín 853... Qué mejor indicador que estas listas para comprobar la riqueza de unos y la pobreza de la mayoría. Baste señalar algunos nombres y cuanto pagaban para hacerse una idea y dejar constancia de sus vidas. Antolín García, Blas Aparicio, Benito Alonso, Fausto Alonso, Estanislao Barcenilla, Florentino Mena, Francisco Martínez, Félix Leonardo, Juan Ribera, Luciano Díaz, Marcelino Román, Trifón Rodríguez o Hilario Muñoz, por citar algunos, no llegaban ni a 10 reales, trescientas veces menos, por tanto, que los más ricos. De sobra se imagina que sus escasos bienes no iban más allá de la casa en que moraban y esta, a tenor de la cuota asignada, era tan humilde como sus dueños. 
para los pueblos en que ocupan cargos municipales. Son favores debidos. Situarse fuera del juego político era perder la posibilidad del perdón de las contribuciones en caso de pedriscos, olvidarse de los subsidios para los más pobres, no conseguir la construcción de un camino vecinal o no poder solicitar la recomendación para algún familiar.

La participación política interesa a los hacendados en la medida de estas variables y la opinión política se fundamenta en estas cuestiones. A esto se debe añadir un cada vez más áspero enfrentamiento entre moderados y progresistas entre 1840 y 1868. La revolución liquida el régimen de Isabel II, pero mantiene el fraude, las manipulaciones electorales y la injerencia del ejército en la vida política en lo que resta de siglo. Hipólito Alonso Ampudia, hijo de León Alonso que, como ya se ha referido, es uno de los más poderosos e influyentes hacendados en estos años, escribe a su padre desde el Madrid de 1864 donde trataba de buscar acomodo ${ }^{1444}$.

Unos años más tarde, como puede apreciarse en la carta que reproducimos, su padre Gregorio León escribe al diputado electo por la circunscripción de Mota del Marqués, Pedro Moyano Sánchez, para que le busque acomodo. La respuesta de este, en marzo de 1868, no puede ser más positiva en tanto el diputado le asegura a su pariente que "si dentro de mi posición política, y de presupuesto como cuestión capital para el pais, puedo hacer algo por Hipólito, no dude de mi un momento que ayudaré a conseguir su colocación, mejor dicho, su reposición..."1445.

Las circunstancias políticas tan cambiantes no favorecían a quien estaba avalado por buenas recomendaciones. La misiva merece su reproducción por su lucidez en el análisis político de aquellos años. Cuando acabe el sexenio y retornen los Borbones en 1876, lo antes expuesto será como un juego de niños. Es el tiempo de Gamazo, Muro, Alonso Pesquera, Alba... Se leía sobre Gamazo en el periódico La Libertad en $1881^{1446}$ :

"Nada se mueve sin su voluntad; y hasta creemos que el sol no sale en esta nueva Ínsula Barataria, sin pedir permiso al tronante Júpiter del oficialismo castellano. Nombra todos los alcaldes, los jueces municipales, los estanqueros, los peatones, todos los empleados en las diferentes dependencias...”

¡Como para no tratar de estar próximos a los nuevos detentadores del poder provincial! ¡Y más con Gamazo que llegaría a ser ministro de Ultramar en 1885, de Hacienda en 1892 y de Fomento en 1898! Sus partidarios de Serrada y estos pueblos se cartean con él desde 1875, apoyándolo electoralmente, pero dejando claro recibirían algunas contrapartidas, unas más confesables que otras.

${ }^{1444}$ Con tantos cambios políticos es difícil posicionarse a tiempo. Nadie mejor que él para referir cuanto sucedía en la capital del reino: "Madrid, 25 de Diciembre de 1864. Fui a casa del señor Conde por la noche; estuve un buen rato con toda la familia, y el Conde manifestó que se encontraba mal en estas circunstancias; que ni en los nombramientos de alcaldes de La Seca, Medina y Portillo a que se limitaban sus aspiraciones políticas podría conseguir, y respecto del juicio de tío Tomás, que sabía por Judas, no podía ser otra su actitud que la de partidario de Unión Liberal u Odonelista, a no reñir con D. Leopoldo, sin el cual nada puede hacer ni ser él. Por esto devuelvo a Vd. la solicitud de renuncia de Perfecto.

El discurso de la Corona del 22 a nadie ha satisfecho, pues los mismos periódicos moderados le juzgan poco favorablemente, comentándole en algunos puntos, como el relativo a la cuestión de Italia, en sentido contrario. Los unionistas tienen grandes esperanzas por las diversas cuestiones de reconocida importancia pendientes de resolución, y creen que en las primeras sesiones del parlamento ha de haber crisis. En la votación de Presidente del Congreso decían que la habría, por salir derrotada la candidatura del gobierno, pero se equivocaron. Los acontecimientos políticos son los que menos pueden preverse, y así no se puede pronosticar todavía, con alguna probabilidad, la suerte del actual gabinete, aunque se dice que está herido de muerte a causa de la última crisis.

D. Javier Istúriz no se anduvo con chiquitas, pues se proponía formar una situación exclusiva de unionistas, declarándose desde entonces afiliado a ese partido; y se cree que será el intermediario para colocar a O’Donnell en el poder...

D. Carlos O’Donnell tampoco tiene partido con el Gobernador de Valladolid...”

1445 A.F.A.M. s/c.

${ }^{1446}$ ALMUIÑA, C., PALOMARES, J. Ma, SANZ, J. y otros: Liberalismo y Caciquismo (Siglo XIX). Historia de Castilla y León, ed. Ámbito, tomo IX, 1986, pág. 124. 
EVOLUCIÓN HISTÓRICA Y TRANSFORMACIONES RECIENTES DE LA AGRICULTURA EN TIERRA DE MEDINA

CONGRESO

DELOS

DIPUTADOS

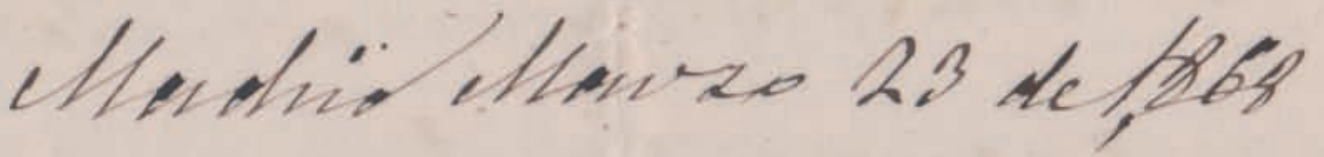

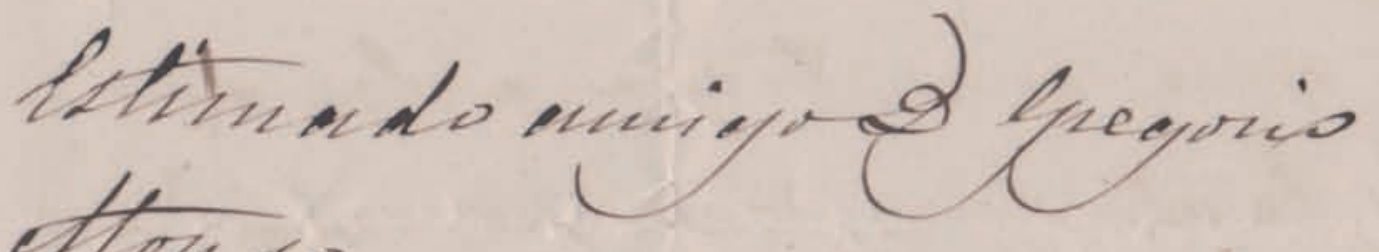

Qli dewtus de mi fusticion-

politieny de juexufuestor

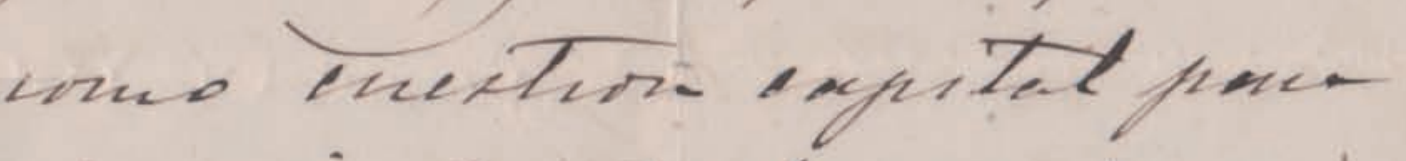
epain jusdo hacen aloy fern Hijuolito, noducle le un ume numento fre ayculare

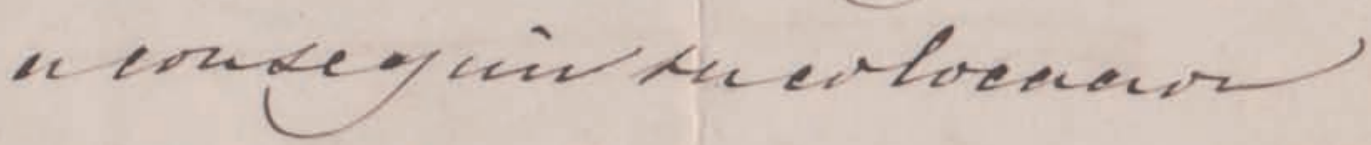
nejor ducher denefuatieus

teruxo devile, ope enouto

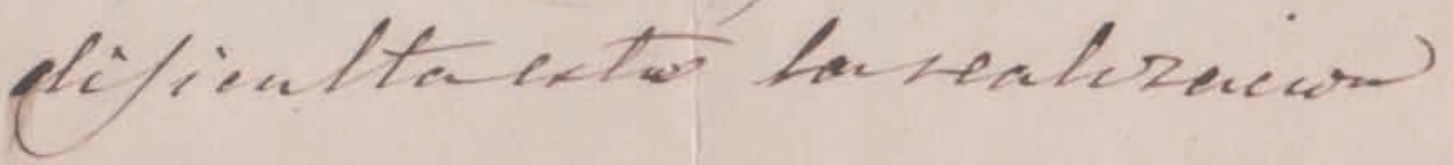

Imagen 95. Carta del diputado Pedro Moyano en 1868 a Gregorio León en relación a la solicitud de recomendación para su
hijo Hipólito Alonso Ampudia. Archivo familia Alonso Moyano. Las familias de hacendados del siglo XIX tratan de colocar hijo Hipólito Alonso Ampudia. Archivo familia Alonso Moyano. Las familias de hacendados del siglo XIX tratan de colocar de formación e imagen ante sus vecinos, sino también para estar bien informados y posicionados ante los negocios comerciales y agrícolas. Como hemos tratado, era costumbre dar estudios a alguno de los hijos para que trataran de alcanzar
estas posiciones de privilegio. En el caso que nos ocupa por ejemplo, la familia Alonso Ampudia tiene a su hijo Pedro, en régimen interno, en el Colegio del Sagrado Corazón, en Carrión de los Condes en los años 1864-1865.

$-634-$ 


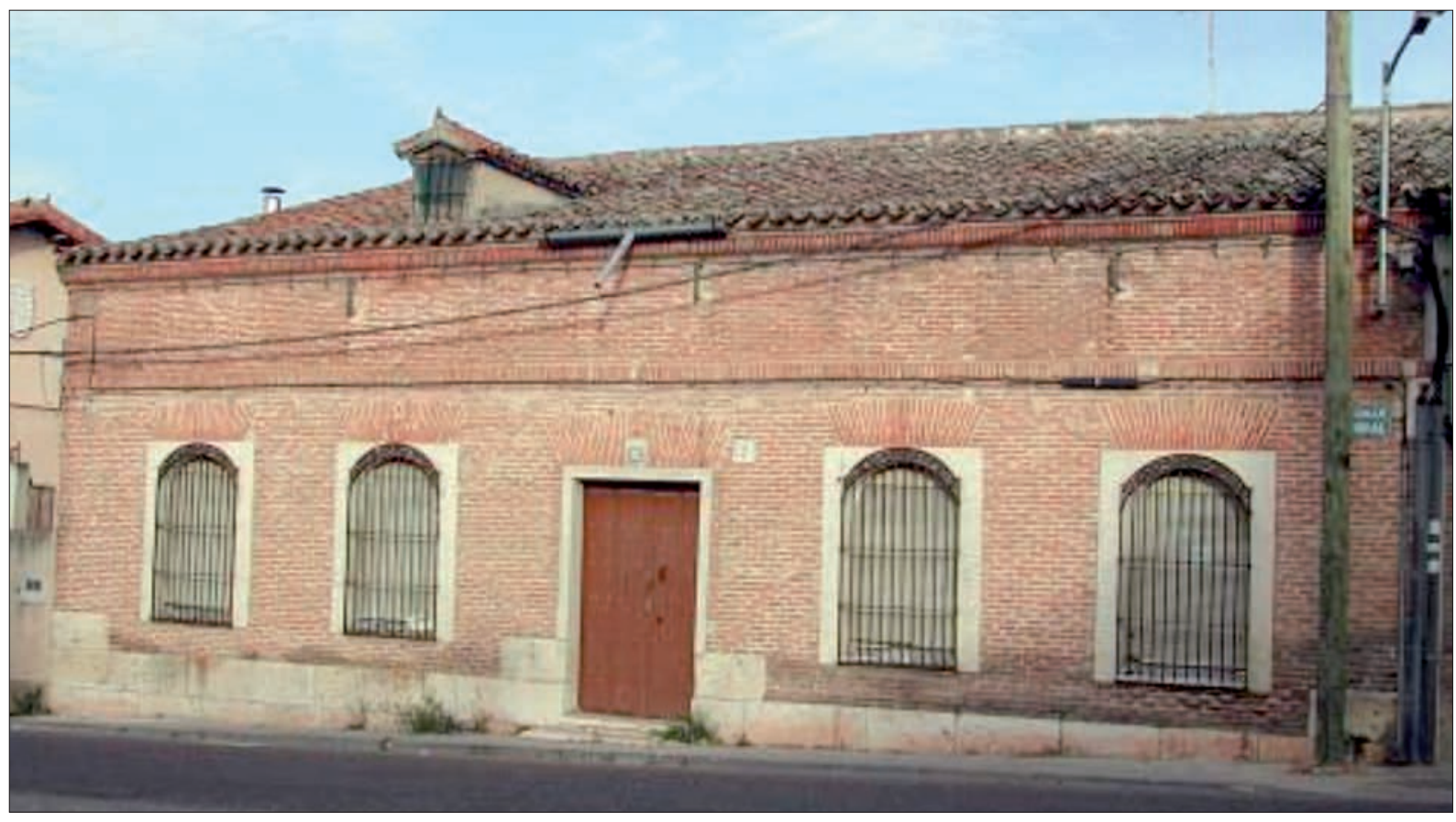

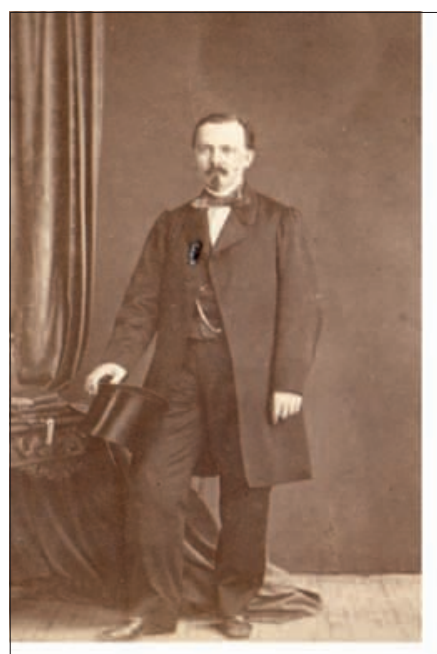

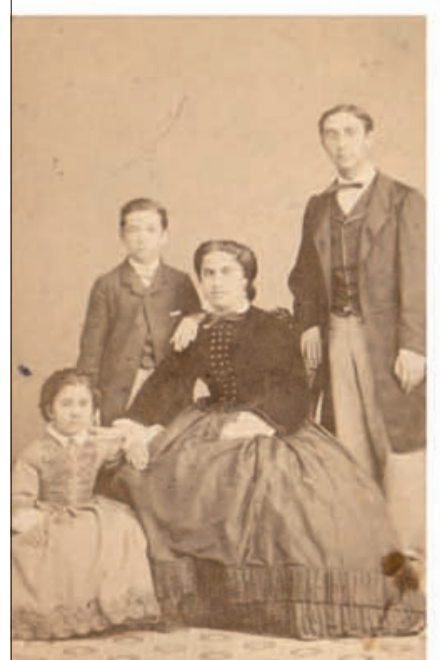

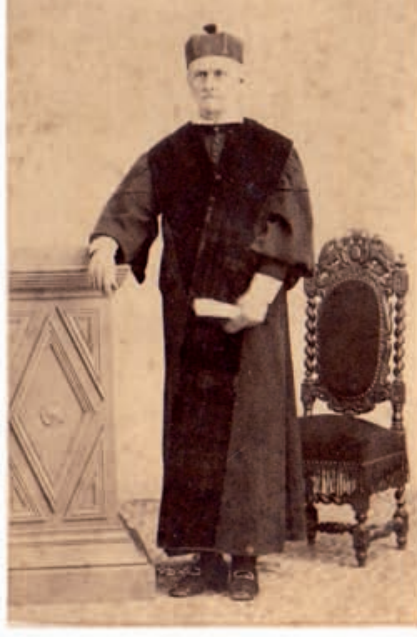

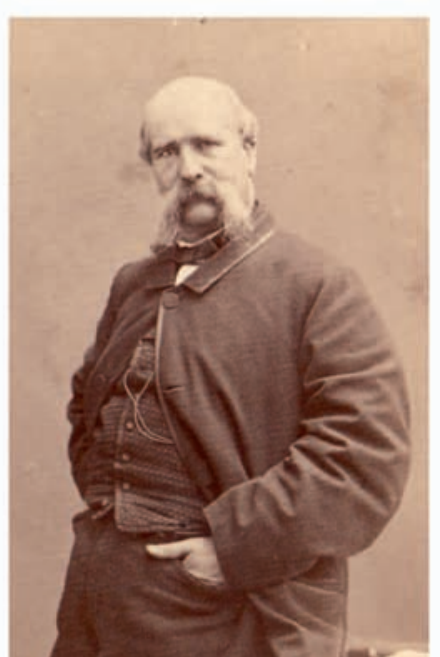

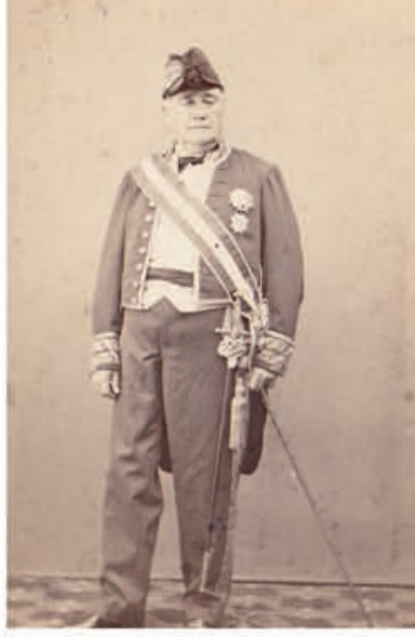

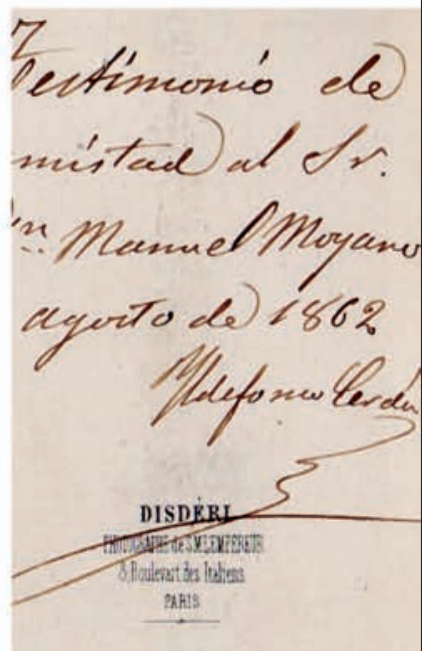

Imagen 96. Casa, ya desaparecida, mandada construir en la Calle Real por el magistrado vallisoletano Gregorio Barahona, tras emparentar con la familia Moyano. Foto: 06/05/2005. Además de grandes hacendados, la familia Moyano ocupó importantes cargos en la administración en Valladolid, Madrid, Sevilla o Barcelona, gozando de buenas relaciones. Sirva como ejemplo la foto y dedicatoria autógrafa de Idelfonso Cerdá (abajo, imágenes central y derecha). Fotos fechadas en las ciudades citadas en los años 1861 y 1862. Archivo familia De Íscar Martínez. 
Eran las reglas del juego político del momento. Los diputados a elegir estaban predeterminados y pactados para que saliesen. De eso ya se encargaban los gobernadores civiles y las autoridades locales. Baste citar un ejemplo anterior a la propia Restauración borbónica: el 3 de abril de 1872 se celebraron elecciones a diputados en Serrada. El candidato era Sebastián Fernández Miranda, personalidad magna del gamacismo vallisoletano ${ }^{1447}$. Tomaron parte en la elección 30 electores en Serrada. El candidato no pudo quejarse en modo alguno. Tuvo ¡treinta votos!

En este tiempo, Gamazo era Gamazo. Su influencia era indiscutible entre los propietarios rurales. Era raro el municipio donde no se colocaba una placa en su honor o donde no lo nombraban hijo predilecto. En La Seca lo nombran hijo adoptivo y predilecto y ponen su nombre a la Plaza de la Olma en $1895^{1448}$. En Serrada se le rinde agradecimiento en 1893. En septiembre una "fuerte tormenta y horroroso pedrisco" se llevó parte de la cosecha de uva. El Ayuntamiento acuerda "se proceda sin demora a instruir expediente" para solicitar perdón de contribuciones. Las súplicas encuentran eco en instancias superiores. Todo parece "arreglarse" ${ }^{1449}$. Cientos de peticiones se agolpan en las mesas de los Gobernadores civiles y de los Diputados provinciales, reclamando favores debidos. En estos pueblos, como en las décadas pasadas, los distintos alcaldes proceden de idénticas familias propietarias: Agapito de Íscar, Celestino Alonso, Valentín de Íscar, Mariano Martín, Francisco Moyano, Perfecto Moyano... A escala provincial o nacional, se asiste a la consolidación de sagas familiares que se perpetúan en Diputaciones y Parlamentos y caracterizan al sistema de la Restauración de final de siglo $^{1450}$.

En este sentido, en esta Castilla interior apenas parece pasar el tiempo. Ni siquiera durante los sucesos revolucionarios de 1868 se detectan movimientos por parte de los excluidos del sistema. De hecho, los miembros del Ayuntamiento, constituidos en sesión de 14 de octubre de 1868 en Junta Provisional Revolucionaria, con el fin de proceder al nombramiento de la Junta definitiva por medio de sufragio universal, manifiestan que "el pueblo se mostró impasible y tranquilo sin que un solo individuo se acercase a emitir su sufragio..." $" 451$.

En el acta de posesión y juramento de los nuevos concejales electos por sufragio universal, tomando a Serrada como ejemplo y que bien puede extenderse al resto de la comarca, cesan Mariano Martín, Valentín de Íscar, León José Moyano, Celestino Alonso, Melitón Moyano y Pedro Díaz y juran el nuevo cargo, León José Moyano como Alcalde y, como regidores, Patricio Obregón, Mariano Martín, Celestino Alonso, Melitón Moyano, Valentín de Íscar y Pedro Díaz. Efectivamente. Son los mismos. El sistema liberal había generado unas estructuras que permanecen estables durante todo lo que resta de siglo y, por encima de los acontecimientos revolucionarios nacionales, las preocupaciones e intereses locales, se centran más en facilitar la salida de los vinos y trigos locales, mejorar las

${ }^{1447}$ PASTRANA MORILLA, H.: La Diputación Provincial de Valladolid 1875-1930. Politica y gestión. Diputación Provincial de Valladolid, 1997, pág. 410.

${ }^{1448}$ SUÁREZ ALÁEZ, A.: Historia de la Villa de La Seca..., ob. cit, pág. 123.

${ }^{1449}$ El acta dela reunión de Ayuntamiento de 8 de octubre de 1893 dice textualmente: "El Secretario dio lectura de una carta del Excmo. Sr. D. Germán Gamazo, en la cual incluye o adjunta otra que le remitió el Sr. Gobernador Civil de la provincia... de la cual también se dio lectura, ... y en prueba de reconocimiento al interés que dicho Excmo. Sr. demuestra hacia esta localidad se acordó contestarle dando las gracias... Acto seguido se acordó interesar de los Sres. Diputados provinciales D. Tomás Bayón, D. García Lorenzo, D. Segundo Cantalapiedra y D. Atanasio Bachiller, los cuales representan este distrito, interpongan su valiosa influencia y propongan en la Excma. Diputación provincial la construcción de la Carretera proyecto de esta villa a Valdestillas, de que tan necesitada se halla esta localidad, y con el fin de que los vecinos de la misma encuentren colocación con el objeto de subsanar a las necesidades de sus familias en vista del invierno calamitoso que es de esperara consecuencia del destrozo causado en este término por la tormenta del día 15 de septiembre último, y que hace de carecer la mayor parte del tiempo de jornales con cuyo producto puedan mantener a sus familias...”. (A.M.S., caja 3, carp. 38).

${ }^{1450}$ Ibídem, pág. 98 y ss.

${ }^{1451}$ A.M.S., caja 1, carp. 14, fol. 27. 
comunicaciones o garantizar la asistencia médica al vecindario que en dirimir guerras internas contra quienes, al fin y al cabo, se ven cada día detrás de una yunta, eran vecinos, familiares, linderos o les proporcionaban jornales para seguir viviendo.

A finales de siglo siguen siendo los hijos de los citados los que componen el Ayuntamiento ${ }^{1452}$. Como decimos, se habrá observado una coincidencia extraordinaria de apellidos y lazos familiares, que puede hacerse extensiva a la España de la segunda mitad del XIX, como ejemplo del control municipal por la clase propietaria. Otra cosa será cuando desde finales de siglo la filoxera y la crisis general que viva el mundo agrario sitúe a los labradores contra el tablero y suma a los braceros en el hambre permanente. Pero eso alcanzará su cenit en las primeras décadas del XX. Entonces los equilibrios locales y la quietud municipal comenzarán a resentirse.

Tal vez el exceso de propietarios locales ha dificultado entender el complejo mundo de la política del siglo XIX. Se tratará de compensarlo analizando a quienes les bastaba "almuerzo, cuando lo dan; comida, cebolla y pan; y a la noche, si no hay olla, vuelta al pan y a la cebolla"1453. Es momento de acercarse a los más desfavorecidos.

\section{b. La clase jornalera. De la pobreza secular a la desesperación de finales de siglo}

No es fácil rastrear en detalle a quienes, a pesar de ser los más numerosos en las sociedades analizadas, apenas dejaron huella de su existencia. En su mayoría carecieron de propiedades más allá de sus casas, no ocuparon cargos municipales en que las actas pudieran expresar sus pensamientos y apenas dejaron nada escrito. Ni sabían firmar la mayoría ni tuvieron necesidad de hacerlo. Sin embargo, se contaban por cientos en estos pueblos. Al comienzo de este epígrafe se señalaba la existencia a finales del XVIII de 105 jornaleros en Serrada y 316 en La Seca. Conforme el siglo XIX intensifique cultivos y producciones, los brazos van a necesitarse más que nunca y, habiendo jornales regulares, su número crecerá de forma notable a lo largo de la centuria.

Con todo, aquellos que testaban relatan sus vidas. Por lo que dicen y por lo que callan. Anteriormente ya se ha hecho constar la falta de ofrendas, misas o limosnas que caracterizaban sus entierros. No era por falta de fe. Era por una absoluta falta de recursos. A nadie le agrada ser enterrado en una sepultura de pobres. Cuando en 1822 testa Bernardo Rivera, viudo de Eustaquia Alonso, y marido en segundas nupcias de Lucia Nieto, hace constar que "de mi primera mujer no dejó esta bienes algunos más que unos cortos muebles". Lo peor, sin embargo, no era la pobreza sino que la enfermedad o la edad pudieran condenarlos a la invalidez. Declara el susodicho que "haze más de dos años que por mi avanzada edad y achaques que padezco no pudiendo trabajar me ha estado manteniendo dicha mi actual mujer Lucia Nieto, haciendo esta trabajos extraordinarios del campo para ganar y asegurar la subsistencia de ambos" ${ }^{1454}$. Se trata sólo de un ejemplo, pero se cuentan por cientos los casos como el suyo en la comarca. De ahí que la ayuda prestada por familiares o vecinos sea fundamental para sobrellevar épocas de penuria o enfermedad. En 1864, Doroteo Rico, hijo de Tomás Rico y Vicente Álvarez, soltero, de cincuenta y tres años, sin heredero forzoso y de oficio bracero, dicta al escribano de la villa que "mando a Modesta Peláez, mi convecina, la casa que habito..." 1455.

\footnotetext{
${ }^{1452}$ En 1890 acompañan al citado alcalde Valentín de Íscar, Germán Juárez, Pedro Alonso Ampudia, Joaquín Moyano, Mariano Alonso Hinojal, Luis Fadrique y Toribio del Río. Lo mismo sucede con los mayores contribuyentes que en este año tienen derecho a emitir sufragio. Los diez mayores y por este orden son: Canuto de Castro, Balbino Alonso, Perfecto Moyano. Mariano Martín, Domingo Juárez, Florencio Martín, Fabián de Castro, Ambrosio Román, Agapito de Íscar y Galo González.

${ }^{1453}$ ALMUIÑA, C., PALOMARES, J. Ma, SANZ, J. y otros: Liberalismo..., ob. cit., pág. 156.

${ }^{1454}$ A.H.P.V. Pt. 2829, Serrada, Manuel Demetrio de Colomera, fol. 5.

1455 A.H.P.V. Pt. 11957, fol. 213.
} 
En líneas anteriores se han hecho constar pedriscos y sequías que arruinan a los labradores. Huelga decir que tales calamidades sitúan a los jornaleros al borde mismo de la muerte. Si no trabajan, no entran en casa jornales y no comen. De la extrema necesidad al hurto en majuelos, garbanzales o melonares dista un paso. Los Ayuntamientos, a través de los guardas del campo, reforzados por otros en las épocas de madurez de los frutos, velan por evitar pillajes en las cosechas que pongan en peligro la quietud en la villa, pero siempre, propietarios y regidores, se muestran solidarios con las necesidades de los más necesitados. El Ayuntamiento, por ejemplo, auxilia en 1861 con el fondo de beneficencia a Jorge Domínguez, "siquiera en la parte de medicamento para atender a la curación de la herida casual que se halla padeciendo en la pierna derecha desde hace tres meses por haber agotado los pocos recursos con que contaba" ${ }^{1456}$. No es el único caso. Desde mediados de siglo se asiste a la preocupación de los Ayuntamientos por dar trabajo y asistencia sanitaria a la población jornalera que carezca de recursos. Año tras año se revisan las condiciones de dicha asistencia y se publican las listas de familias pobres que tienen derecho a recibir asistencia facultativa. En este año de 1861, la lista de vecinos pobres la componen 26 vecinos. Cuando en 1866 se nombra como "profesor de medicina y cirugía" para atender tales necesidades a D. Manuel Benito, vecino de Villaflores, se hace constar que los 2.000 reales anuales que se han de pagar salgan "de los fondos municipales de esta villa."

Conforme avanza el siglo y crecen estas necesidades, los Ayuntamientos tratan de resolver con sus recursos estas penurias. En mayo de 1861, se asiste en Serrada a una sesión extraordinaria en que se acuerda la concesión de cédulas de empadronamiento gratuitas teniendo en cuenta la situación social y "atendiendo los perjuicios que pudieran seguirse" a tales vecinos "y considerando que en esta localidad es bastante crecido el número de vecinos que pertenecen a la clase menesterosa y proletaria"1457.

Malos tiempos corrían para todos en aquellos años, pero especialmente para los que se acaban de citar y que pueden ser representativos de la clase jornalera de toda la comarca. Sólo ellos saben las penalidades que pasaron para poder criar a sus hijos en unos años donde lo peor aún no había llegado. Para que no faltara de nada, al año siguiente, un pedrisco se llevó parte de la cosecha y los jornales, ya menguados, escasearon todavía más. Como un acto reflejo, en los años siguientes fue constante la preocupación de las autoridades por evitar el paso por los prados, que las caballerías anduviesen sin cebadera y sueltas por los sembrados, que los ganados lanares no transitaran por caminos estrechos, que se redoblara la vigilancia de guardas en siegas y vendimias...

${ }^{1456}$ A.M.S., caja 1, carp.10, fol. 13.

${ }^{1457}$ Se entresaca un fragmento del acta acordada por los regidores que presidía el entonces alcalde León José Moyano: "Considerando la situación que representan en la sociedad, por unanimidad acordamos se reparta cedula de empadronamiento de gratis a los sujetos que como vecinos comprende la lista puesta a continuación, y mayores de catorce ańos que de cualquiera manera dependan de estos mismos o se hallen independientes, a menos que no conste de una manera pública y notoria que tienen bienes o utilidades suficientes para no ser considerados pobres, a saber: Anselmo Martín, Alejandro Alonso, Aquilino Alonso, Alejo de la Cruz, Alejo Martín, Bonifacio Román, Basilio Puerta, Carlos de Íscar, Benito Díaz, Basilio Fadrique, Epifanio de Castro, Fermín Alonso, Gregorio Díaz, Ignacio Gaspar, Ignacio Alonso, Luciano Díaz, Martín Leonardo, Mariano Alonso, Pascual Alonso, Pablo Arnaz, Sebastián Rivera, José Arnaz, Pablo García, Saturnino Huerta, Evaristo Martín, Manuel Pérez, Sinforiano Rivera, Felipe de Rojas, Aquilino Rivero, María Rodríguez, Ventura Román, Vicente Martín, Francisco García, Regino Rodríguez, Marcos Alonso, Mauricio Fadrique, Melitón de la Torre, Marta del Río, Sebastián Matilla, Sermes Rico, Rufino Alonso, Paulino del Río, Pedro Martínez, Alejandra Alonso, Francisco Leonardo, Francisco González, Doroteo Santos, Alejandro Santos, Ramón Bayón, Toribio Gaspar, Toribio Rojo, Sandalio Carrasco, Maximina Carrasco, Sandalio Luján, Martina García, Inés Martínez, Valentina García, Cándido Alonso, Cándido García, Eusebio García, Mateo Domínguez, Zacarías Higuera, Juan Montes, Gregorio Martín, Francisco Cubero, Bonifacio de Rojas, Cesáreo Martín, Felipe Moyano, Florentina García, Basilia García, Alejandro Díaz. Formada la presente lista de los vecinos que por su posición considera el Ayuntamiento que tienen opción a recibir cedula de empadronamiento gratis, el Alcalde Presidente expuso a los señores que la Administración solamente le había entregado diez cedulas de gratis, número muy escasísimo comparado con la necesidad de la localidad; teniendo en cuenta que los individuos que comprende la precedente lista, aunque pobres, son ciudadanos y muy bien tendrán alguna acción que ejercer ante los tribunales y autoridades...”. (A.M.S., caja 1, carp. 17, fol. 6). 
Claro que había vecinos que por estas fechas ni siquiera podían hurtar un fardel de garbanzos. La tercera guerra carlista se había llevado al frente norte a otro puñado de jóvenes para desesperación de sus familias. Muchos regresaron. Otros no. El 29 de febrero de 1876, el Alcalde Celestino Alonso convoca sesión extraordinaria para dar cuenta de "la terminación tan deseada de la guerra civil y la pacificación completa de las Provincias Vascas y Navarra después de haber pasado la frontera Franco-Española D. Carlos de Borbón y sus más tenaces defensores" 1458 . Se acababa el sexenio democrático de Amadeo de Saboya, de la constitución de 1869 y de la primera República española. Se inicia la Restauración borbónica con fiesta y toros ${ }^{1459}$. La banda de música de La Seca, los adornos en la plaza y toques de campanas y luminarias hicieron el resto. La paz siempre trajo sosiego a unas villas donde los cupos de soldados y las guerras se cebaban, sobre todo, con los más humildes.

El último tercio del siglo tampoco iba a ser fácil para nadie. Ya en 1878, cuando se trata en sesión extraordinaria de Ayuntamiento la necesaria aportación vecinal para las necesarias obras de reparación en la iglesia, se pone de manifiesto "que con dinero les es un imposible contribuir a tan laudable fin, a consecuencia de la situación tan crítica por que atraviesa este vecindario, abrumados con tantos y tan onerosos impuestos como se le exigen y escasos rendimientos de las cosechas, tanto de cereales como de vino" ${ }^{1460}$. La crisis general de fin de siglo comienza a resquebrajar la tradicional estabilidad vecinal. Se discute y se muestran diferentes pareceres entre quienes poseen distinto grado de riqueza. Los repartos y contribuciones son tan altos en relación con los estancados ingresos que desesperan a todos. Labradores, yunteros, criados y braceros se entremezclan en las siguientes discusiones sobre un más justo reparto de impuestos ${ }^{1461}$.

Si venían malos tiempos para los labradores es fácil imaginar cómo estarían los braceros. El invierno de 1880 se iba a recordar por sus intensos fríos y nieblas. En Serrada, en La Seca, en Rueda... El 14 de enero se celebra en el Ayuntamiento sesión extraordinaria de carácter urgente. El alcalde, Valentín de Íscar, no se anda con rodeos:

${ }^{1458}$ A.M.S., caja 2, carp. 22, fol. 5.

${ }^{1459}$ Acordaron aquel día que: "A las primeras palabras del Sr, Presidente, la Corporación, que por los periódicos ya tenía noticia de tan fausta nueva, prorrumpió en un acalorado viva, al que siguieron otros muchos contestados con frenético entusiamos por el vecindario que llenaba la plaza ansioso de saber lo que el Ayuntamiento acordaría en virtud del extraordinario Boletín recibido, así como se regocijaba al ver terminada una lucha tan insensata y contar con la esperanza mas segura ya de abrazar a los muchos hijos de esta villa que se hallaban formando parte del ejército vencedor... A continuación el Sr. Alcalde hizo presente que en repetidas ocasiones y esperando este día se habían presentado varios grupos de vecinos pidiendo que se celebrase la paz con una corrida de novillos; que a este fin y para tener algo prevenido había expresado este deseo a D. León Adanero, vecino de Pedradas de san Esteban que tiene una vacada en término de esta villa y dehesa de D. Juan Pombo, cuyo ganadero, con patriótico desprendimiento había puesto a disposición del Ayuntamiento su ganado ofreciendo gratis una corrida para este fin; y también que se habían presentado a su autoridad comisionados por otros varios vecinos D. Mariano Martín, D. Agapito de Íscar y D. Florentino Martín haciendo presente que entre varios vecinos asociados habían determinado costear otra corrida de novillos...”. (A.M.S., caja 2, carp. 22, fol. 5).

${ }^{1460}$ A.M.S., caja 2, carp 24, fol. 44.

1461 "Después de una detenida discusión acordaron por unanimidad no aprobarle puesto que le consideran arbitrario a causa de la desigualdad de categorías en primer lugar, y en segundo que después de gravar la mayor parte sobre la clase media, se encuentran que los mayores contribuyentes, es decir, los más ricos, son los más beneficiados en atención a que divididos los contribuyentes en once categorías para dar lugar a la extensión de cuotas, resulta que computados los sirvientes por una categoría igual, se encuentra que el sirviente de un contribuyente de clase baja se le grava con igual cuota que a otro de los mayores contribuyentes, cuando estos les ocupan más días, les vigilan más, y haciéndoles trabajar más, tienen que darles mejor trato o, lo que es lo mismo, consumir más, y sobretodo, que si para laborear, por ejemplo, doscientas aranzadas se necesitan doce obreros, para diez, por mucho que se quiera, no se necesita uno, resultando además que unos, los más ricos, tienen no sólo el laboreo de viñas, sino verano en grande, mientras que los demás están sin él y si tienen algún dependiente es temporero y en el invierno, por todo lo cual se tiene por mal girado el citado repartimiento...". (A.M.S., caja 2, carp 22, fol. 38). 


\begin{abstract}
"No entraré en las muchas consideraciones que podría hacer, concretándose únicamente a exponer lo que todos saben y es, que a consecuencia del largo tiempo en que los obreros en su mayor parte no han tenido trabajo, por los intensos fríos y densas nieblas, se ven reducidos a la miseria, lo que ha motivado la presentación en colectividad a mi Autoridad, hasta el número de doce, sin contar los que lo han verificado individualmente; todos me demandan de algún socorro para no perecer de necesidad y poder proporcionar un pedazo de pan a sus ateridos y extenuados hijos y esposas, habiendo hecho las manifestaciones en el sentido más pacífico y humilde, sin que la exigencia ni imposición se haya advertido en ninguna de sus palabras y acciones. Ante actitud tan marcada de necesidad y seguridad de los hechos expuestos, me he creído en el deber de reunirles a fin de atajar de una manera prudente los males que en mencionada clase podía producir la crueldad del tiempo, en la forma que los fondos municipales y situación económica del Municipio lo permitan...”
\end{abstract}

Los últimos textos seleccionados sitúan ante un nuevo umbral histórico. Más allá del equitativo reparto de dineros que se lleva a cabo atendiendo a la situación concreta de vecinos sin jornal, obreros sin propiedades o matrimonios sin recursos, o de los "humanitarios sentimientos impelidos por la caridad cristiana" que hacen compadecerse a los regidores locales, se está en un callejón de difícil salida. $\mathrm{Ni}$ el país dispone en estas décadas de un desarrollo industrial capaz de dar trabajo a los braceros hambrientos, ni los labradores de excedentes monetarios que impulsen sus explotaciones, ni los Ayuntamientos de suficientes recursos con que atender tales necesidades. En una España interior empobrecida, la miseria ambicionaba hasta el último grano de trigo ${ }^{1462}$.

Sean fríos, sequías, excesos de lluvia o pedriscos, contingencias que abundaron en estos últimos años del XIX y primeros del XX, el caso es que la situación de jornaleros y criados se torna cada vez más crítica. La filoxera acaba desbordando la pobreza contenida paternalmente por las instituciones y el caciquismo imperante en el país, controlado, como bien es conocido, por los gobernadores civiles, Diputaciones y autoridades locales. Hasta entonces apenas tuvieron eco en el mundo rural las ideas proletarias, sean socialistas o anarquistas que se manifestaban rupturistas con el sistema en las ciudades o regiones industriales. Se clamaba contra las contribuciones, contra las contingencias atmosféricas, contra los acaparadores, pero no contra el sistema. En las décadas anteriores, a decir de Valera Ortega, "oír hablar de socialismo por estas fechas en Castilla la Vieja, como detallaba Prósper Merimée a la condesa de Montijo, era tanto como escuchar que el emperador de la China se había hecho monje" 1463 . En estas villas del centro de Castilla habrá que esperar a finalizar el siglo, pero la adversa situación por las que pasa el campo castellano genera las primeras protestas colectivas y huelgas de jornaleros. En Serrada tuvieron lugar tras el duro invierno de 1904. Obreros y propietarios dejaron entrever dos mundos distintos, más allá de la mayor o menor subida de los jornales que los $\operatorname{separan}^{1464}$ :

"En la villa de Serrada, a diez y seis de marzo de mil novecientos cuatro... bajo la presidencia del señor Alcalde Don Víctor de Castro Rueda, ... se hizo saber a los Señores Concejales que el objeto de la convocatoria era ver la manera de solucionar la huelga de obreros de esta localidad; que por consiguiente su parecer era proponer tanto a los obreros como a los propietarios unas formulas de arreglo en la cual no se perjudicaran los intereses

1462 Prueba de ello vuelve a ser la publicación de especiales normas de vigilancia y aprovechamiento de los campos: "Que los segadores y espigadoras no lleven más de una caballería a los rastrojos...

Las espigadoras no saldrán del pueblo hasta después del sol salido, volviendo a las diez de la mañana, y por la tarde saldrán a las tres y regresarán a la postura del sol...

Los dueños de los ganados de cerda los tendrán recogidos mientras no estén al cuidado del guarda...

Se prohíbe espigar los domingos y demás días festivos...

Teniendo en cuenta que después de levantar las mieses, desde tiempo inmemorial se ha consentido a los pobres y jornaleros espiguen en las primeras horas siguientes, se haga entender a los ganaderos lo conveniente que sería, a la vez que humanitario, previniesen a los mayorales de las respectivas piaras, se abstuviesen de introducir los ganados en los rastrojos hasta pasadas las primeras horas en que ya hubiesen espigado...”. (A.M.S., caja 2, carp 28, fol. 51).

${ }^{1463}$ ALMUIÑA, C., PALOMARES, J. Ma, SANZ, J. y otros: Liberalismo..., ob. cit., pág. 115.

${ }^{1464}$ A.M.S., caja 4, carp. 48, fol. 25. 
de unos ni otros; y al efecto le parecía, salvo el parecer de los Señores concurrentes, que el mejor medio sería que ante el Ayuntamiento compareciera una comisión de obreros y otra de propietarios y proponerlos tanto a unos como a los otros, el adquirir datos de los pueblos limítrofes a esta villa, con objeto de enterarse del jornal que ganan los obreros, horas de trabajo, leña que les dan sus amos además del vino, etc., y viendo lo que resultaba en unos y otros pueblos, adoptar el término medio...”

Era el comienzo de un siglo en que los problemas estructurales y las graves diferencias que caracterizan a todo el país no se iban a resolver precisamente con consensos. Población, recursos, propietarios y braceros no encuentran caminos compartidos desde finales de los años sesenta. Los vecinos de La Seca expusieron el problema en 1888 de forma muy precisa en reunión de Ayuntamiento. En pocas ocasiones hay conclusiones tan atinadas ${ }^{1465}$ :

\begin{abstract}
"Teniendo a la vista las cedulas del censo recogidas en primero del corriente, la copia de la hoja remitida en marzo del referido año para el Nomenclátor, el Censo de 1877 y los Padrones con posterioridad tomados en este distrito municipal, se observa que dicho Censo desciende considerablemente en esta localidad de uno a otro año, debido sin duda alguna a las circunstancias nada favorables por que viene atravesando la población desde hace largos años, en que la riqueza viene recargada por la gran paralización de las transacciones mercantiles y escasa demanda en los productos vinícolas, principal riqueza de que se sostienen sus habitantes, faltas de vías de comunicación para sus transportes y otras mil vicisitudes que no se ocultan al público en general; han motivado la emigración constante de muchas familias que malvendiendo sus fincaza, dejando arruinar sus casas y desalquiladas otras, han fijado su residencia en distintos puntos por no poder soportar las más y más perentorias necesidades que les aquejaban y de aquí el que el Censo de población en esta localidad disminuya con extrańeza al parecer, pero obligado por las circunstancias."
\end{abstract}

Los viñedos secándose, los braceros emigrando, los vinos con escasos compradores, reemplazos de jóvenes muriendo en ultramar... El siglo concluye con muchos problemas y amarguras en esta Tierra de Medina. Los Ayuntamiento habían tratado en estos años de estirar sus ingresos para dar "plus" a los obreros y aliviar a los más necesitados, pero las estructuras que generaban tan severos problemas siguen intactas. En el nuevo siglo la creación de sociedades por parte de obreros o labradores, vinculadas a las ideologías del momento, tratarán de defender intereses particulares. El siglo XIX no puede acabar con peor cara y con una moral hundida tras el desastre colonial de Cuba y Filipinas. El sistema político, cada vez más decadente y cuestionado, sobrevivirá un par de décadas inmerso en no pocas contradicciones internas. En el siglo XX ya nada será lo mismo y todo estará por decidir.

\title{
c. La vida cotidiana. De la solución de los problemas a los problemas sin solución
}

Excede de los límites de este trabajo adentrarse en el entramado jurídico que regula la vida de los Ayuntamientos en este siglo. No limitaremos en conocer el funcionamiento municipal de Serrada como ejemplo comarcal y de sus preocupaciones básicas en este siglo XIX, ya que, como se ha dicho, muchas de las actuaciones apenas variaron respecto a tiempos anteriores y han sido tratadas. Conviene, sin embargo, conocer cómo organizaban su vida doméstica, cuáles fueron sus principales preocupaciones, sus logros o desaciertos en una centuria donde, quien más y quien menos, se vio desbordado por tan importantes transformaciones.

\section{- La cabeza rectora: el Ayuntamiento de la villa}

A comienzos de cada ańo, en sesión inaugural, los miembros del Ayuntamiento, conforme a la ley vigente, proceden a la renovación y elección de cargos. El alcalde ostenta la representación municipal y dirige las deliberaciones en las sesiones de Ayuntamiento, pero para que se tome un acuerdo es necesaria la coincidencia mayoritaria de los distintos regidores en el tema objeto de discusión.

${ }^{1465}$ A.M.L.S. Libro de Actas. 6 de enero de 1888, fol. 56. 
El alcalde como presidente se acompaña de los regidores y del procurador síndico que componen el constitucional ${ }^{1466}$. Salvo el secretario, velador y testigo de las distintas sesiones, que está obligado a reflejar de forma precisa en el Libro de Actas y recibe un emolumento anual pagado por el municipio, el resto de cargos, incluido el alcalde, no reciben ningún dinero municipal salvo aquellos que por razón de sus desplazamientos o gestiones derivaran gastos personales.

Las amplias participaciones derivan, por lo general, en una rápida y eficaz gestión de los problemas, ya que su resolución concreta se encomienda a quienes por sus conocimientos, ocupaciones o relaciones pueden hacerlo con eficacia. Para ello, caso de proceder, se otorgan poderes para ostentar la representación de la villa y gestionar a la mayor brevedad el negocio encomendado. En 1857, por ejemplo, se otorga poder a Tomás Moyano y Díaz, magistrado y residente en la corte de Madrid, para que gestione y liquide las acciones pertenecientes a los propios de la villa depositados en el banco de San Fernando ${ }^{1467}$. Quién mejor que él para atender a cuestiones tan alejadas de quehacer diario de sus vecinos. O quien mejor que Luis de Rojas para en 1845 consiga "la liquidación y el abono de las cantidades a que asciende... las raciones y pedidos que esta precitada villa suministró a las tropas en tiempo de la guerra de la Independencia..., y haga y practique ante las autoridades y tribunales y oficinas competentes" ${ }^{\prime 1468}$. O aprovechar la presencia en 1910 como diputado por el distrito de César Medina Bocos para que interceda, junto a José Gutiérrez, administrador de la marquesa de Falces en Serrada y compañero político, en la resolución favorable de la solicitud de apertura e servidumbre "capaz de dar el paso de labranzas desde la Cañadilla a la calle del Arroyo, por la parte accesoria de las casas de la calle del Porro"1469.

Conforme avance el siglo, no obstante, la mayor complejidad de los asuntos administrativos hace traspasar su gestión a profesionales que ofrecen sus servicios a las entidades locales. Así, en 1878, los miembros que componen la municipalidad acuerdan "nombrar agente de negocios en la capital de provincia a D. Victoriano González Menéndez... para representar a esta Corporación en los diferentes negocios... ${ }^{1470}$. Ya por estas fechas la gestión municipal va desbordando tanto la capacidad como el tiempo disponible de los regidores electos ${ }^{1471}$.

${ }^{1466}$ A mediados de siglo, en 1857, por ejemplo, el alcalde de Serrada era Leandro Obregón; los regidores, Balbino Alonso, que ejercía las funciones de teniente de alcalde, Canuto de Castro, Tomás Moyano y Jorge Martínez, siendo procurador síndico Joaquín Román. Junto a ellos otros vecinos de su confianza, experiencia o capacidad los asistían en las distintas tareas administrativas y de buen gobierno de la villa. En dicho año el depositario de los fondos municipales era Cesáreo Moyano; el recaudador de la contribución de consumos con cargo de hacer entrega del importe a la Tesorería de Rentas de la provincia lo desempeñaba León José Moyano y los apreciadores de daños que se causaban por unos u otros motivos, en los sembrados, viñedos y arbolados, correspondían a Patricio Obregón y Marcelino Román. Junto a ellos, además, colaboraban distintos vecinos como peritos repartidores en los distintos repartimientos y contribuciones al vecindario, miembros de distintas comisiones, sean para seguir la instrucción de las primeras letras, sea liquidadores de bulas, sean representantes de los hacendados forasteros, etc.

1467 A.M.S., caja 1, carp. 8, fol.7.

1468 A.M.S., caja 1, acta de 16 de mayo de 1845.

${ }^{1469}$ A.M.S., caja 4, carp. 52, fol. 3.

${ }^{1470}$ A.M.S., caja 2, carp. 24, fol. 9.

${ }^{1471}$ Alfredo Velasco, agente de negocios encargado de gestionar estos asuntos en 1879, tenía entre otras, las siguientes tareas encomendadas por el Ayuntamiento de Serrada: "Que practique la liquidación de la tercera parte del 80\% de propios en la Caja de Depósitos; recoja las cartas de pago que se expidan; haga las concesiones que sean necesarias, cobre y perciba los intereses que haya devengados y en lo sucesivo los depósitos y valores de este Ayuntamiento; perciba o retire el Capital, ya en metálico, ya en otra forma que nuevas disposiciones lo exijan y calcule el impuesto personal según está prevenido. También le autorice este Ayuntamiento a dicho señor Velasco para que gestione en la dirección de la deuda la emisión de las Imagens e inscripciones intransferibles por las dos terceras partes del 80\% de propios, las convierta a títulos al portador, cobre los intereses devengados y que devenguen en lo sucesivo, domicilie el pago de las mismas en la Tesorería...”. (A.M.S., caja 2, carp. 25). 
Los tiempos estaban cambiando. El texto seleccionado al pie es ilustrativo del funcionamiento de una administración cada vez más compleja y que necesita de expertos que la gestionen. Es evidente que para otros menesteres se encargaban aquellos que estaban a diario detrás de una yunta. Distinto es, por ejemplo, cuando se trata de decidir sobre la maduración de la uva para dar principio a la vendimia. En este caso son los propietarios los encargados de asesorar a los distintos regidores, por lo demás, cosecheros en su mayoría. El Ayuntamiento aprueba sin dilación las normas que deben seguirse para que la actividad más importante y trascendente de la villa resulte satisfactoria para todos.

Las autoridades de estos pueblos tratan de evitar a toda costa conflictos entre el vecindario. No se debe olvidar que en estas semanas a la comarca medinense llenan cientos de jornaleros de pueblos vecinos y del norte de Castilla, Asturias y la Montańa. Los primeros como vendimiadores, los segundos como lagareros y tiradores de mosto. De hecho, para garantizar la llegada anual de estos contingentes de trabajadores, en sesión de 30 de septiembre de 1877 el Ayuntamiento de Serrada acuerda socorrer con $50 \mathrm{cts}$. de peseta diarios a los mozos "de Asturias que es costumbre inmemorial reclamar para el servicio del vecindario, los cuales por una equivocación imposible ya de remediar se han presentado en esta villa antes del día señalado para dar principio a la vendimia"1472. Por la importancia de esta actividad reproducimos al pie las normas de vendimia del año $1878^{1473}$.

La vendimia es una de las épocas más cruciales del año. El Ayuntamiento nombra una comisión de reconocimiento, encargada de inspeccionar los distintos pagos, antes de proceder a discutir la fecha general en que ha de "principiar" la vendimia. Para evitar conflictos, robos o daño en los pagos colindantes entre términos, continuará el interés de los distintos municipios en hacer coincidente esta fecha, amén de redoblar la vigilancia a través de guardas viñeros. En el acta municipal del 12 de octubre de 1879 en que se acuerda la vendimia para el día 16, se apunta incluso como primer apartado de las normas de vendimia "Que antes y durante la vendimia, nadie podrá introducir uva en aguaderas o cobanillas para colgar o tender, ni aún bajo el pretexto de alegar ser de su propiedad, sin licencia por escrito de la autoridad, en la población"1474. Todo sea, como se repite unos ańos tras otros, "a fin de impedir desmanes y la introducción de fruto clandestino asi como todas las demás faltas y atropellos contra la propiedad"1475.

1472 A.M.S., caja 2, carp. 23, fol 36, año 1877

1473 "Primero. Que se anuncie al vecindario por los medios de costumbre que el día siete del próximo octubre es el designado para dar principio a la vendimia.

Segundo. Que aquellos que por no tener lagar o por otra cualquier causa le fuere de reconocida necesidad verificar la recolección de las uvas antes del día prefijado, podrán hacerlo el cinco y seis del dicho mes, siempre que, cuarenta y ocho horas antes, por lo menos, lo participen a esta Alcaldía por escrito y duplicado, y además cumplan respecto a los colindantes con las disposiciones dictadas sobre la vendimia.

Tercero. Que el que así no lo haga así incurra en la multa de dos pesetas, cincuenta céntimos, que satisfará en el papel creado al efecto sin perjuicio de aplicarle las accesorias...

Cuarta. Que antes de dar principio a esta nadie podrá introducir vino en la población, ni aun bajo el pretexto de alegar ser de su propiedad, sin licencia por escrito del Alcalde o quien autorice.

Quinta. Todo el fruto que se coja antes de salir el sol y después de puesto será decomisado y considerado como de mala procedencia, siendo los contraventores puestos a disposición del Juez Municipal para su inmediato castigo.

Sexta. Nadie podrá dar principio a la rebusca sin que se haya terminado por completo la vendimia, y sin que preceda en publicación señalando día por medio del oportuno bando que dictará la Autoridad para conocimiento del vecindario.

Séptimo. Los pastores o ganaderos no podrán introducir en el viñedo sus ganados hasta tres días después que se haya terminado la rebusca.

Octavo. Se prohíbe correr a otro paso que el regular caballerías o carruajes por las calles de la población y caminos concurridos, yendo al efecto los mozos de mulas puestos sobre ellas y los de los bueyes delante.

Noveno. Y por último, que los infractores de la anteriores disposiciones serán castigados con la multa de tres a diez pesetas”. (A.M.S., caja 2, carp 24, fol. 38, fecha: 28 de septiembre de 1878).

${ }^{1474}$ A.M.S., caja 2, carp. 26, fol. 14, año 1879.

1475 A.M.S., caja 2, carp. 22, fol. 35, año 1876. 
Similares dictados regulan la siega, trilla y espigueo. Mayores dificultades encierra el aprovechamiento del término para los ganados ${ }^{1476}$.

Cada año, en fin, se discute cuanto acontece en la villa y preocupa a los vecinos. A diferencia de tiempos lejanos, donde cada uno era dueño de su esfuerzo y esclavo de sus debilidades, Serrada, como tantas centenares de villas en Castilla, ha de asumir que los horizontes se amplían y sus intereses son trastocados por mercados europeos o transoceánicos, por políticas arancelarias que apenas entienden, por desamortizaciones que los desbordan, por miedos que desconocen... Se acaba el tiempo de sentirse dominadores de sus términos y, aunque los más pudientes, trataban de tomar posiciones, seguían sin entender que los trigos guardados durante siglos en las paneras hasta el mes de abril, seguían estancados y no subían... Quién iba a decir a los viticultores y a sus regidores que iban a estar tan pendientes de la cosecha de uva que se avecinaba en Francia, o de la renovación o no del arancel vitícola, como del proceso de fermentación del mostos en sus cubas. En dos generaciones habían vivido más cambios que decenas de los que les antecedieron. Era el precio de una transformación sin retorno en que nuevas necesidades debían encontrar nuevas soluciones.

\section{- La relación entre vecinos. Negocios y trabajos. Alegrías y penas}

$\mathrm{Al}$ igual que en siglos anteriores, entre el campesinado de estas llanuras al sur del Duero hubo ricos y pobres; salud y enfermedad; fríos y calores; cosechas abundantes y pedriscos devastadores. Sólo en una cosa coincidían y eran iguales los vecindarios: en morirse. En otras ocasiones se ha tratado sobre lo frágil que era la vida. Bien es verdad que para unos más que para otros. La lectura de los libros de difuntos de estos siglos son siempre una lección de humildad en cualquier época o circunstancia. Pero no todo eran penas y calamidades. También había fiestas y negocios florecientes.

${ }^{1476}$ En el caso de los prados se regula conforme lo requieran las circunstancias y necesidades de unos y otros. Las denuncias de algunos vecinos ante Celestino Alonso, alcalde en 1861, sobre la forma y manera de proceder al aprovechamiento de los prados hace que un nuevo reglamento no tarde en ver la luz. Será el resultado del cambio de coyuntura que vive el sector agrario castellano desde mediados de los cuarenta hasta pasados los setenta. El peso aplastante de los mayores labradores contribuyentes, dueńos también de importantes rebańos, reducirá aun más el número de cabezas lanares en los pastos de Serrada. Antonio Castilla, Jefe de Administración Civil y Secretario del Gobierno civil que por entonces presidía Cástor Ibáńez de Aldecoa, reconocía el derecho de los vecinos a disfrutar del pasto del común "en proporción a los beneficios que reportan y las cargas que levantan en el municipio” (A.F.A.M. Carp. de acuerdos y varios). Semejante afirmación pondrá a las ovejas contra las cuerdas una vez más. La nueva reglamentación, basada en la legislación municipal de 8 de enero de 1845, será desarrollada por el Ayuntamiento que preside en 1861 Cesáreo Moyano y demás asociados contribuyentes, siguiendo el criterio antes señalado y el parecer "que la distribución de beneficios debe hacerse en primer lugar para el ganado de labor, en segundo para las caballerías de los jornaleros y tercero, y ultimo, para el ganado lanar obejuno"Son dicen, y por este orden, quienes levantan las cargas del municipio. La nuevas bases y disposiciones a observar por todos se aprueban en acuerdo de Ayuntamiento de 27 de abril de 1861 y se autoriza por el gobernador de la provincia con fecha de 26 de octubre del mismo ańo: "Primero. Los labradores y jornaleros tendrán el derecho de apacentar sus ganados de labor y caballerías en los prados del común en todos los días del año a excepción de aquellos a que el titulado de arriba este vedado o cerrado para toda clase de ganado.

Segundo. Se permitirá entrar a pastar 300 cabezas de ganado lanar ovejuno solamente en el prado de abajo desde el día 20 de noviembre hasta el 17 de enero siguiente, ambos inclusive y de ninguna manera en el de arriba mediante a que teniendo que estar vedado este para aprovecharle de primavera por el ganado de labor, y teniendo en cuenta los pocos pastos que hay en esta villa le causarían grandes daños y cuyo resultado sería perecer las labranzas y demás clases a que se ha atendido.

Tercera. A todo vecino se le permitirá por cada yunta de labor una res de huelga con su cria y así en proporción el que tenga dos o más yuntas.

Cuarta y última. El prado de arriba se vedara para todo ganado el día 18 de enero y no se abrirá hasta el 20 de mayo del mismo año, ocho días más o menos según el año, quedando como siempre a juicio del Ayuntamiento.

Es cuanto tienen que proponer en cumplimiento del cargo que se les ha conferido. Serrada, Abril, 10, de 1861. Pedro de Íscar, Leandro Obregón, León José Moyano”. (Ibídem, fol. 2). 


\section{- Los negocios entre vecinos}

Los Ayuntamientos regulan la práctica totalidad de los aprovechamientos del término de tal manera que los trabajos de los vecinos no escapan al control de sus regidores. El calendario agrícola obliga a regular y arrendar al mejor postor los pastos de primavera (desde mediados de abril a mediados de junio); los de rastrojera (desde que se levantan las mieses o legumbres hasta el veintinueve de septiembre); el aprovechamiento de la hoja y pámpana de los majuelos (desde el cuarto día después de la vendimia y, dada la rebusca, hasta el treinta de noviembre); los pastos de invernia, el aprovechamiento del pinar... En enero todos los vecinos se echan sus cuentas y suben o no las pujas de partida que fija el Ayuntamiento. Pero no sólo en lo tocante a estos menesteres. El Ayuntamiento arrienda los llamados arbitrios de peso y medida, denominados vulgarmente corredurías, los de rodaje y peaje, los locales de matadero y carnicería, los consumos... ${ }^{1477}$. Está en juego la prosperidad y la salud del vecindario. También el que los ingresos presupuestados puedan hacer frente a los salarios de maestros, secretario, policía urbana y rural, beneficencia municipal, contribuciones y obras.

Entre los más importantes se encuentra la mencionada correduría, vigente desde siglos. Consiste en el arrendamiento al mejor postor de la muestra de vinos, vinagres y aguardientes en cuanto a líquidos, y de granos en cuanto a sólidos, cosechados en el municipio. El rematante, por encargo de los cosecheros, muestra los frutos que estos tienen en sus bodegas o paneras a aquellos arrieros o tratantes que llegan a la villa y que así se lo encargan. Convenida la venta entre comprador y vendedor, el corredor presta su servicio con mozos de saca, lía y carga previamente contratados, envasando el producto vendido y acondicionándolo en los carros de los arrieros. A cambio de este servicio, cobra la cantidad estipulada por el Ayuntamiento por cántara expedida y, una vez liquidada con la institución municipal la postura efectuada, el resto le queda como beneficio. El Ayuntamiento, en relación con las cosechas, dinamismos de los mercados o situación económica de sus arcas varía a lo largo del siglo la cuantía de estos arbitrios ${ }^{1478}$.

Idéntico tratamiento tienen otros productos. Conviene recordar que, ya desde antiguo, estos gravámenes ayudan a los concejos tanto a soportar el peso de los impuestos como a homogeneizar y regular la venta de las mercancías en el municipio. El arbitrio de rodaje y peaje consiste en este año en cobrar diez reales por cada cabeza de tiro, tres por cada caballería mayor de carga y dos por las de menor que extraigan de la población los indicados frutos y granos, así como productos que se vendan fuera, géneros de distinto tipo, etc. La crisis vitícola y la mecanización de lagares y bodegas acaban, en el primer tercio del siglo XX, con muchos de estos oficios y actividades seculares. Unos años antes, en 1910, cuando la crisis filoxérica y el paro jornalero rompe también la tradicional llegada de asturianos para la mostería, son los naturales de Serrada los que se encargan, en su mayoría, de la tira del mosto ${ }^{1479}$.

1477 Todos ellos están sujetos a un estricto control y regulación desde siglos. En 1814, Pedro de Íscar remata por 3.550 reales la alcabala del viento; Rafael Domínguez, por 11.000 la correduría y por 1.200 la del aguardiente; Fernando López se hizo con la abacería por 2.330 reales; Bernardo Montes, con la taberna por 1840. (A.H.P.V. Pt. 8229, Manuel Demetrio de Colomera, fol. 3 y ss).

${ }^{1478}$ En 1879, por ejemplo, se fijaron los que siguen: "Primero. El de seis y cuatro céntimos de peseta; o sea, un cuartillo de real por cada diez y seis litros o cántaro de vino, vinagre, aguardiente y mosto o sus semejantes, que se expendan para fuera de la población, y el de doce céntimos y medio de peseta, o sea, medio real por cada carga de uva que por vecinos y hacendados forasteros con casa abierta se extraigan de la población para la venta, (o se introduzca por forasteros solamente para verificarla en esta localidad); esto en cuanto a los frutos líquidos o caldos y uva); y por los respectivos a los áridos o granos y demás productos, un real por arroba de lanas y tres cuartillos la de queso; el de un real por fanega de garbanzos; medio real por fanega de trigo; un cuartillo las de otras semillas como cebadas, centeno, algarrobas, guisantes, avena y demás granos o legumbres que se extraigan de la población, exceptuando las que saquen los labradores para sus usos agrícolas....”. (A.M.S., caja 2, carp. 25).

${ }^{1479}$ Eran en este año "Calisto Extremo, Juan Santos, Antonio Leonardo, Braulio Sanz y Juan Puerta de esta localidad más dos de Bercero, uno de Pedrajas y otro de Rodilana y como en total sean nueve los elegidos se acordó admitir otros dos más. " 1479 Pedro de Eván dirigía en 1898 a los mozos de tira y que eran, en este año, Deogracias de San José, Jorge Calderón, Calisto Extremo, Andrés Alonso y Pedro Gaspar. Parte de ellos seguirán el resto del año al mando de quien se haga con la puja de la mencionada correduría. 
El Ayuntamiento también fija el precio "a que se han de vender las especies de consumo". En 1879, los precios de la exclusiva en las ventas al por menor quedaron fijados de la siguiente forma ${ }^{1480}$ :

\begin{abstract}
"Cuartillo de vino y vinagre, cinco cuartos; aceite de oliva a veintidós cuartos cuartillo; aguardiente de veinte grados, quince cuartos cuartillo; libra de carne de vaca, a diez y seis cuartos; tocino añejo a treinta cuartos libra; el tocino nuevo a veintidós cuartos libra; longaniza curada a treinta y cuatro cuartos libra; longaniza y lomo a veinte y cuatro cuartos libra; oveja y carnero en los meses de julio a diciembre inclusive a doce cuartos libra; jabón duro y blando a doce cuartos libra; petróleo a doce cuartos cuartillo; jamón curado a treinta y cuatro cuartos la libra de callos limpios, cuatro cuartos; libra de bofes a ocho cuartos..."
\end{abstract}

La quietud del vecindario exige un cumplimiento riguroso de los dictados, sobre todo en estos ańos finales del XIX cuando la falta de jornales o su reducida cuantía lleven al límite de la subsistencia a muchos vecinos. A comienzos del último tercio del XIX, por ejemplo, en las labores de los majuelos, los precios se cifran en siete reales el excavo de una aranzada y la poda, a siete y medio, teniendo en cuenta que el jornal del podador se sitúa en torno a cuatro reales y medio; dar a arar una aranzada en marzo salía a 18 reales; en mayo, a trece... Los vendimiadores cobran tres reales diarios; los lagareros nueve reales... ${ }^{1481}$. En 1893, en el mercado de Medina se vende el trigo a 34 reales la fanega; la cebada, a 18 reales; las algarrobas, a 19 reales y los garbanzos, a 90 reales. Eran precios bajos en relación a años anteriores. Los labradores, se lee el cuatro de noviembre en "El Castellano" "están justamente alarmados no sólo de ver el bajo precio a que han llegado a cotizarse los trigos y demás granos, si no de la marcada tendencia a la baja que se nota en la mayoria de los mercados" 1482 .

Sólo adentrándose en la vida cotidiana de los trabajos, productos y precios se pueden entender las quejas o alegrías de unos u otros. Los jornaleros tratan de estirar sus jornales para poder comer un trozo de carne los domingos y los labradores, cada primavera, siguen apurando en la panera el trigo a ver si sube un cuartillo para conseguir cierto beneficio. Es en este contexto en el que se ha de entender la vida de los castellanos de hace siglos. Teniendo presente, además, que en estos años ochenta y noventa del XIX, por ejemplo, sembrar diez obradas de trigo con sus vueltas correspondientes venía a salir por 375 pesetas; hacer lo propio con tres obradas de trigo, más abonarlas, costaba 135 pesetas, dos obradas y media de centeno treinta pesetas... Los braceros, porque no alcanzaban a comprar los productos, y los labradores, porque la crisis agrícola les había sumido en la mayor de las desesperaciones, el caso es que, por estos años, los lamentos apenas dejaban tiempo y ganas para fiestas.

\title{
- Momentos de celebraciones y alegrías
}

Estos momentos, que compensaban a los anteriores, se celebraban asociados a las buenas cosechas, a la Virgen de la Moya, a la Virgen del Rosario, a la suelta de novillos, celebrando bodas y bautizos, festejando vivas a los reyes, cantando el fin de guerras y el regreso de los mozos... El paso del tiempo y de cada una de las generaciones que se suceden dejan constancia de estas alegrías. Sirvan algunos ejemplos. La sementera en seco que se hace en 1856 apenas gusta a nadie. En diciembre,

${ }^{1480}$ A.M.S., caja 2, carp. 25.

${ }^{1481}$ A finales de siglo, por ejemplo, se contrató a Félix Hinojal como guarda temporero de viñedo en 1897 y su sueldo diario era de una peseta y veinticinco céntimos; el mismo sueldo cobraron en 1898 los vigilantes nocturnos Nicomedes Díez, Evaristo Sanos, Desgracias de San José y Andrés Alonso.

${ }^{1482}$ Los inventarios de bienes alumbran con nitidez cada siglo y en este del XIX siguen dando cuenta de productos, beneficios, casas o deudas. En el que se lleva a cabo en 1881 por el fallecimiento de Patricio Obregón, marido de Petra Juárez, se fija el precio de su mula "Comisaria" en 750 reales; el de su compañera "Leona”, en 250; un cerdo de cría, en 41 reales; siete cubas que oscilan entre sesenta reales la más barata y 250 las de mayor precio; sembrados de centeno, a cuatro fanegas; otras de cebada, a treinta y dos fanegas la obrada; otros de trigo, a ocho fanegas; 1500 cántaras de vino, a nueves reales cada una; obradas de tierra y aranzadas de majuelos, a cien pesetas cada una... (A.M.M. Diario "El Castellano". 4/11/1894). 
sigue sin llover y el vecindario empieza a encomendarse más a la Virgen del Rosario que a buscar nubes en el horizonte. Los rezos y novenas se suceden. Llueve en enero y febrero. Llueve en abril y en mayo. En septiembre, el propio Ayuntamiento, como pueblo agradecido, sabe estar a la altura de tan divina concesión. No ha sido la primera vez ni será la última ${ }^{1483}$ :

\begin{abstract}
"Que constando cual consta a los demás Sres. Capitulares el beneficio dispensado a este vecindario por el Todopoderoso, habiendo interpuesto el mismo por intercesora a maría Santísima, venerada en esta población bajo el título del Rosario para que se dignase conceder la lluvia que tan necesaria era ya en diciembre del año último, la que efectivamente fue concedida y con ella una abundante cosecha de cereales, veía dicho Sr. Que nada más justo en acción de gracias que solemnizar de una manera extraordinaria la festividad del Santísimo Rosario a costa de los fondos municipales... Se acordó se solemnice la indicada función con los actos solemnes de Misa y sermón y que, además, se de un baile de dulzaina al vecindario, todo lo cual se solvente de los fondos municipales..."
\end{abstract}

Todo era poco para honrar a la Virgen del Rosario. Pero en Serrada también se guarda especial devoción por la Virgen del Refugio que, como la del Rosario, dispone de altar en la capilla mayor del templo. Al igual que la Santa Vera Cruz tienen cofradía y muchos devotos ${ }^{1484}$. Por encima de todos los actos festivos sobresalen aquellos en que se honra a la Virgen Santa María de los Remedios de La Moya. Desde la ruina de su iglesia y traslado de la imagen a Serrada, su devoción y culto aparece fijado en los días de 9 y 10 de mayo. Su cofradía es numerosa y entre sus bienes disponen de un rebaño de ovejas que arriendan a los ganaderos de la villa. El Ayuntamiento contribuye a los gastos "de función" ${ }^{1485}$. El Ayuntamiento acuerda en sesión el 6 de mayo de 1888 cuánto se necesita para honrarla, aunque tampoco olvida, sobre todo conforme avanza el siglo, que el orden presida todas las celebraciones ${ }^{1486}$ :

"El Señor Presidente interesó a sus compañeros la asistencia a los actos religiosos que en los días 9 y 10 del corriente han de celebrarse con motivo de la función de la Moya; y que con motivo de esta función se oficie al Comandante del puesto de la Guardia Civil de Rueda a fin de que se persone en esta una pareja de Guardias al objeto de evitar alborotos y desórdenes."

Si ya se ha comentado que en siglos pasados la romería al lugar de La Moya congrega a romeros devotos de los pueblos vecinos, en las décadas finales del XIX va tomando regular consistencia la celebración de actos lúdicos a la par que los religiosos. Así, en abril de 1903 la corporación municipal acuerda acompañar con festejos populares esta fiesta, tan solemne para sus vecinos ${ }^{1487}$ :

${ }^{1483}$ A.M.S., caja 1, carp. 8, fol. 14.

${ }^{1484}$ De esta última hay constancia, al menos, de su existencia desde 1772 , y son numerosos los hermanos que la componen. En 1774 participan en la elección de cargos hasta 141 vecinos y acuden a los distintos actos religiosos que tienen lugar, en especial durante la Semana Santa, el Corpus y en el 5 de mayo, día de la festividad. Las celebraciones religiosas congregan, al margen de los actos religiosos, a los cofrades en reuniones particulares para la gestión de los bienes adscritos. En ellas los vecinos aprovechan para intercambiar pareceres, olvidar rencillas, que los jóvenes traben amistades y que los mayores concierten o den el visto bueno a los matrimonios de sus hijos.

${ }^{1485}$ En concreto en 1843 la inversión alcanza 70 reales. Equivale, para hacerse una idea, a lo que cuestan dos fanegas de trigo, diecisiete jornales o algo menos de una arroba de tocino salado. En dicho año, por ejemplo, se gastan otros 12 reales en cohetes y demás conmemorando la proclamación de la reina Isabel II. Son cantidades menores en comparación con los 180 reales que se pagan al orador en Semana Santa o los 20 reales dedicados a misas votivas, pero todo es bueno si contribuye a alegrar al vecindario.

${ }^{1486}$ A.M.S., caja 2, carp. 31.

${ }^{1487}$ Desde entonces, y aunque anteriormente se había ya detectado, es una constante en las actas municipales el tratamiento en la segunda quincena de abril de los actos del día de la patrona. Y en la fiesta, año tras ańo, no falta la dulzaina, sea de La Seca, sea de otros pueblos vecinos. Comenzando el siglo XX, además, se ańade a la dulzaina la contratación de otras músicas para amenizar un baile nocturno en el salón del Ayuntamiento. En 1908, por ejemplo, alcalde 


\begin{abstract}
"Se manifestó que era necesario acordar lo conveniente para la función que con el título de Virgen de la Moya se celebre anualmente en este pueblo, y enterados los seńores reunidos acordaron que el Sr. Alcalde Presidente, se encargue de buscar dulzainero y música para el baile de la noche, dentro de la consignación en presupuesto, y que tenga todo lugar en la misma forma que en años anteriores."
\end{abstract}

Junto a estas festividades, conforme se despierta el siglo XX, nuevas inquietudes culturales se asocian a los actos festivos. Las fiestas más solemnes, además de músicas, bailes, bollos y vino, van acompańadas de representaciones teatrales que llevan a cabo los propios vecinos. Al margen de la tradición oral, las actas municipales lo hacen constar en sus sesiones ${ }^{1488}$ :

"También por la Presidencia se manifestó que los actores que habían actuado en el Salón de sesiones de estas Casas Consistoriales el día de ayer, solicitaban del Ayuntamiento la concesión del dicho salón, con el objeto de dar en el mismo otra función de teatro el día veinticinco del actual mes, a beneficio como la anterior de la sociedad de obreros de esta villa, titulada la Paz Social, y que a su parecer, como quiera que trabajaban con un fin tan saludable, se les debía de ceder dicho local."

Los novillos son siempre símbolo de la fiesta popular. No todos los años se sueltan. A decir verdad, los hay pocas veces a lo largo del siglo XIX. O al menos no se tiene constancia escrita de su regularidad. Revisadas las actas del Ayuntamiento, es difícil o casi imposible que se hayan olvidado de hacerlos constar. Sí lo manifiestan, como se ha anotado, en 1876, cuando varias sueltas de estos animales festejan el fin de la guerra carlista ${ }^{1489}$. Para ver novillos con regularidad anual hay que irse a los pueblos vecinos, sea La Seca, Tordesillas o Matapozuelos, donde disponen de más recursos y población para poder afrontar su lidia. Recuérdese lo que le pasó al oficial albañil en la suelta de novillos de Matapozuelos el día que dio principio la reedificación de la iglesia de San Pedro. Tras cogerlo un toro, el hombre se desangró en la misma plaza. En Serrada, en realidad, hasta principios del XX no se tiene constancia de cierta frecuencia en estos festejos en que el Ayuntamiento, en ocasiones, cede a las manifestaciones y presiones de los vecinos más que a sus deseos de organizar estos festejos, en unos ańos, por lo demás, en que los recursos son reducidos. Las actas municipales de 1922 reflejan lo siguiente ${ }^{1490}$ :

"En la villa de Serrada a nueve de septiembre de mil novecientos veintidós, bajo la Presidencia del Sr. Alcalde de la misma, Don Prudencio Martín Moyano ... se manifestó que se habían dirigido a ella varios jóvenes de la localidad pidiendo se les diera licencia para celebrar dos corridas de vacas en la plaza de esta villa, y que

y regidores acuerdan que "por unanimidad se escribiera a Asterio Alonso para que venga a tocar los días nueve y diez por la noche en el baile del Salón en la cantidad y condiciones que a manifestado por carta" ${ }^{\text {"487. }}$. La Moya es la fiesta, con mayúsculas, de la villa de Serrada. Y si la Virgen ha traído agua a los campos y salud a sus vecinos, se va con más alegría a correr el bollo por las casas, con más esperanza de encontrar pareja en el baile, de mayores preparativos para la ocasión...En 1912 la festividad y alegría que concita la Virgen hace que el Ayuntamiento no repare en gastos. Melitón de Castro, como alcalde, manifiesta en reunión plenaria: "Que como quiera que se aproxima la función del pueblo era de necesidad, como en años anteriores, de buscar dulzaina y música único festejo que en dicho día existe desde tiempo inmemorial, y que en cuanto a dulzaina había dos pretendientes... Los seńores capitulares... acordaron por unanimidad que esta escriba al dulzainero de Portillo aceptando la proposición y al de Velliza diciéndole que este Ayuntamiento ya tiene compromiso y en cuanto a la música que ha de tocar en el baile de la noche se encargue el señor Presidente de organizarla, bien sea la de viento de Rueda, o bien la de Pozaldez." (A.M.S., caja 1, carp.52, fol. 32).

A.M.S., caja 4, carp. 48, fol. 6.

${ }^{1488}$ Ibídem.

${ }^{1489}$ Además las campanas repican durante tres días a las nueve de la noche y, según dicta el Boletín Extraordinario publicado al efecto, durante "los dos siguientes se iluminarán a un tiempo todas las casas". El Ayuntamiento, en estas ocasiones, tarda poco en ponerse en contacto con la dulzaina de La Seca "para que amenizase la fiesta y fuese esta ordenada al parque solemne en lo posible por no haber en esta instrumentos ninguno de aire". (A.M.S., caja 1, carp. 10, fol. 51).

${ }^{1490}$ A.M.S., caja 5, carp. 56, fol. 4. 
como carezcan de recursos para ello, solicitaban se les concediera la plaza para la construcción de tablados, así como el salón de actos de la Casa Consistorial para que su producto y lo que del pueblo pudieran recoger, satisfacen los gastos que las vacas pudieran ocasionar."

De todas las maneras, como en otras poblaciones y siglos anteriores, los mozos del pueblo hacían la fiesta por su cuenta. Las fiestas de guardar o los días de diario. En siglos pasados se estudia como la cárcel del concejo se ocupa a menudo por los amigos de quimeras o de excesos con el vino. El Ayuntamiento tuvo que ponerse firme en estos años. En 1886 muchos vecinos se quejaron de tanta juerga nocturna. El 22 de octubre de dicho año, en sesión ordinaria, se trató sobre el cierre de los establecimientos públicos de bebidas ${ }^{1491}$. Seguramente la medida no se cumplió de forma tajante porque su intención no era tanto impedir festejos como prevenir conflictos, que también los hubo ${ }^{1492}$.

Especial alegría en estas comunidades agrarias tienen las celebraciones matrimoniales. Los libros de Casados y Velados son testigos de innumerables momentos de regocijo entre el vecindario. Hay que pensar en la mayor parte de estas pequeñas villas medio pueblo está emparentado. De hecho, muchos de los contrayentes deben contar con licencias eclesiásticas por parentesco ${ }^{1493}$. En otros casos llegan nuevos apellidos de La Seca, Pozaldez, Valdestillas, Villanueva, Bercero, Astorga... A pesar de lo relatado, el pueblo crece y las bodas siempre llenan la plaza de familiares y vecinos que muestran su alegría en estas celebraciones. Al igual que muchos viudos y viudas que, como Crisóstomo y Teresa en 1772 , inician una nueva andadura ${ }^{1494}$ :

\begin{abstract}
"Yo, el Infraescripto Presbítero, vecino de esta villa, habiendo leído las moniziones Conciliares en los días de santiago y Santa Ana y Dominica octava Post Pentecostés a los Ofertorios de sus misas mayores, para contraer matrimonio Crisóstomo García, vecino, natural de esta villa, y viudo de Isabel García, natural de la villa de San Martín del Monte, vicaria de Medina del Campo, con Theresa de Íscar, viuda de Justo Obregón, natural de la villa de La Seca, vicaria de Medina del Campo, vecina y natural de esta villa... despose por palabras de presente que hicieron verdadero matrimonio y vele según forma de Nuestra Madre Iglesia."
\end{abstract}

1491 "El Sr Presidente hizo entender a la Corporación las diferentes quejas que por algunos vecinos de esta localidad se han dado de que los establecimientos públicos de bebidas se hallan abiertos al público a horas bastante avanzadas y cuando la mayoría de este vecindario descansa de sus faenas agrícolas, los jóvenes que se albergan en dichos establecimientos, con especialidad en el de Cesárea Martínez, turban el sosiego de esta localidad; y como estas asociaciones pudieran alterar en parte el orden público, y a fin de evitar el que las consecuencias fueran más graves, ... esta Alcaldía acordó: Que toda clase de establecimientos públicos de esta localidad se cierren a las nueve de la noche como viene haciéndose en años anteriores durante los meses de invierno y hasta el mes de marzo inclusive. Que se haga entender así a los dueńos de dichos establecimientos como más inmediatos responsables de cualquier transgresión que puedan cometer, autorizando al Sr. Alcalde para la imposición de las multas que sean necesarias imponer y cualquier otra acción necesaria, según los casos, que necesite deducir en derecho, haciendo responsables también a los padres de las infracciones, que sus hijos menores de edad puedan cometer". (A.M.S., caja 2, carp. 30., fol. 44).

${ }^{1492}$ Nos han llamado la atención los versos que Laureano Recio dedicó a la villa a mediados de siglo. Servía en el ejército y fue ascendido a segundo de batallón. Al parecer por estos años de 1840 y 1850 hubo algún conflicto vecinal y no desaprovechó la cercanía de la Navidad para mandar la "Enhorabuena a la unión de los vecinos de la villa de Serrada”. Aunque este tipo de asuntos se dejan para otra ocasión, no se puede dejar de entresacar algunas estrofas. Así cantaba el primer poeta popular del que se tiene noticia la reconciliación entre sus vecinos: "Si hemos de hablar con ver$\mathrm{dad} /$ sin hacer más argumentos,/todos estamos contentos/día de Natividad./Después de una revoltosa/cuestión entre vecinos,/se hicieron amigos finos/en su noche misteriosa/.A muchos les fue azarosa,/en las Villas y ciudades/por algunas nimiedades,/pero en Serrada grandiosa./Alegrose el más tenaz,/vivan en paz y alegría/los de Serrada este día,/pues ha nacido la paz./Esa paz tan deseada/nunca debe ser perdida/atendiendo a que es debida/al Sr. Cura de Serrada/.

${ }^{1493}$ En 1796 a Félix Leonardo y a Teresa Díaz les "fue dispensado por Su Santidad el tercero grado de consanguinidad en que los dos susodichos se hallaban parientes". (A.G.D.V. Casados y Velados, Libro 3, fol. 184).

${ }^{1494}$ A.G.D.V. Casados y velados, Libro 3, fol. 87. En el primer tercio del XIX se constata en los libros de Casados de San Pedro la absorción de San Martín del Monte por Serrada. Es evidente que sus vecinos proceden en muchos casos de Serrada. Sus vecinos, sea en este pueblo, en La Seca, en San Miguel del Pino o Villanueva es donde fraguan noviazgos y matrimonios. Así, por ejemplo, en 1816 se casa el labrador Feliciano Martín con Juliana Navarro, hija de Gabriel Navarro y Gertrudis Álvarez "natural de San Martín del Monte y residente en esta villa hace ocho años". Las correrías y saqueos franceses les hacen refugiarse en Serrada. (A.G.D.V. Casados y velados, Libro 4, fol. 43). 
En este sentido, es interesante comprobar los matrimonios de unos y otros a lo largo de los siglos. Si la nobleza dispuso del mayorazgo que transmite todos los bienes al primogénito varón e impide la atomización de su riqueza, las familias labradoras tratan, a través del matrimonio de sus hijos, buscar la suma y no la resta en sus heredades. De hecho, disposiciones reales así lo reconvienen. En abril de 1776 se recibe en Serrada la Real Pragmática de Carlos III dictada al objeto de contener los desórdenes "por haber sido frecuente el abuso de contraer matrimonios desiguales los hijos de las familias, sin esperar el consejo y consentimiento paterno o de aquellos deudos o personas que se hallen en lugar de Padres... "1495. La Pragmática dispone que, desde esta fecha en adelante, los que celebren contrato de esponsales, o tienen los obligados consentimientos o, además de perder derechos civiles, que se olviden de recibir bienes por herencia o dote. No pocas familias hacendadas pueden seguir siéndolo a lo largo del siglo gracias al matrimonio de sus hijos e hijas con pudientes labradores de La Seca, Matapozuelos o Ventosa, por ejemplo. Caso contrario, la división hereditaria divide los bienes hasta acabar proletarizando a antiguos labradores y eso los podía apartar de ser contribuyentes con derechos electorales, de la presencia en la vida municipal, etc. De ahí que estas sociedades tengan, en ocasiones, unas reglas no escritas sobre la forma en que sus hijos e hijas deben o no acudir a los actos públicos, estar o no presentes, hablar más o menos ante determinadas visitas...

- La otra cara de la moneda. Momentos de dolor y de luto. La impotencia ante la ignorancia, el dolor y la muerte

No se puede finalizar este apartado sin hacer referencia a los otros compañeros de viaje. Si algo sobrecoge cuando se investiga el pasado, es el inmenso dolor que encierran los centenares de legajos consultados, sean pleitos civiles o criminales, libros de difuntos o protocolos notariales. Todos certifican una vida campesina que lucha, siglo a siglo, por superar mil penurias para sobrevivir ${ }^{1496}$. A ello hay que añadir la pobreza, la indigencia y la enfermedad, no pocas veces aliviada por la solidaridad entre vecinos. En julio de 1862, por ejemplo, Toribio Santos suplica al Ayuntamiento "se le socorra a domicilio con la cantidad que tenga a bien... para atender al remedio de sus cargos y padecimientos que hace largo tiempo le tienen en la mayor indigencia postrado en una cama"1497.

¡Pero cuántas veces dejan peor a los que aquí quedaron, viudas o huérfanos, desvalidos y sin nada que llevarse a la boca! De ahí que son constantes las segundas y terceras nupcias entre viudos para recomponer familias o arreglarse para seguir viviendo, siempre, claro está, con el peso de una moral y costumbres que la pobreza y la ignorancia se encargan en acentuar. El caso de Marciana Rico es sobrecogedor. Se había quedado viuda y con un niño que alimentar. En una noche de 1834, asistida por su cuñada, da a luz otro niño. Aunque la cuñada la reconviene que bien "le atete", o bien le lleve de expósito al cura de San Pablo, la desgraciada mujer, confundida y enferma, se niega y manda a su cuñada que meta al recién nacido en un arca de la cocina, no fuera a ser que su hijo lo oyera llorar y saliera a la calle "a parlarlo." Al día siguiente, los alcaldes de la villa, Saturnino Villar y Cipriano Platón han de dar cuenta a la justicia. El niño está muerto. Las dos mujeres acaban en la cárcel, una por encubridora y Marciana por culpable.

${ }^{1495}$ A.G.D.V. Casados y Velados, Libro 3, abril de 1776.

${ }^{1496}$ Es difícil permanecer impasible ante muertes mensuales de 10 y 20 párvulos, en 65 años de los 85 años que median entre 1800 y 1885 en una villa, como Serrada, cuya población se situaba entre 600 y 900 habitantes. Se hace difícil ponerse en lugar de Bernarda García. ¿Qué pensaría de la vida después de perder en 1790 a su niña Quintina; en 1800, a Dionisia, en 1801, a María y en 1802, a Florentín? Claro que peor lo tuvo que pasar Lorenza Moyano. En 1834 perdió a su nińa María; en 1840, a Fausto; en 1842, a Lorenza, ya mocita, y, para que no le faltaran más desgracias, ese mismo año se murió, con 34 años, su marido. No son casos escogidos. Era la regla general que se da en todos los pueblos de Castilla. Mujeres que fallecen en los partos o jóvenes que la muerte visita cuando menos lo esperan. Entre 1850 y 1885 , por ejemplo, en Serrada fallecen 107 personas que cuentan entre 20 y 40 ańos de edad.

${ }^{1497}$ A.M.S., caja 2, carp. 22, fol. 5 y ss. 
Sin duda, este tipo de hechos, por salirse de la normalidad y por muy dura que esta fuera, siempre conmocionan a las poblaciones. En este XIX, como en otros anteriores, sin ser muy frecuentes, las desgracias también se repiten. Unas casuales y otras intencionadas. Entre las primeras baste citar el caso de Pedro Casarejos, de catorce años, hijo de Agustín y Estefanía del Barrio, guardas de la dehesa del Despoblado de San Martín del Monte. El 23 de abril de 1850 fue enterrado toda vez que su "cadáver fue hallado en el dia de ayer en el regato de aguas que baja por dicha dehesa". ${ }^{1498}$ A finales de siglo también son enterrados Bernardo Ruano, Cirilo Torres y su hijo Anastasio Torres, naturales de San Miguel del Arroyo y que, según el facultativo, "fallecieron en el día diez y seis del corriente mes de una asfixia tóxica" ${ }^{\prime 499}$.

Las delictivas devuelven al lado más terrible y oscuro del ser humano. Baste señalar que a Juan Moyano, marido de Lucía Gutiérrez, en mayo de 1811, unos ladrones disfrazados violentan su casa, le roban y le sacan al campo. Al día siguiente aparece medio enterrado en el camino del Pinar ${ }^{1500}$. En 1833 "Don León Rodríguez, presbitero, beneficiado de la parroquial de Serrada y Capellán de la fundada en la misma por D. Andrés Rodríguez Zorrilla fue hallado en la madrugada del cinco degollado en su habitación..." "1501. El brutal asesinato es perpetrado por su criado Ricardo Monje, al que el 17 de junio de dicho año dan garrote vil en la Plaza Mayor de Valladolid. Su cabeza es traída a Serrada y su brazo derecho, llevado al camino de Madrid, fuera del Campo Grande de la ciudad. De poco le valen sus oraciones y actitudes serenas ante el verdugo. En enero de 1873 Blas Álvarez, natural de la provincia de Oviedo y accidentalmente en esta villa "murió de mano airada... a la edad de treinta y seis años..." "1502. En 1890 dos vecinos del pueblo matan, detrás de iglesia, a Julián Moyano, hijo del entonces alcalde Perfecto Moyano. En el periódico semanal "El Medinense" de 13 de octubre de 1890, con el título "El crimen de Serrada", se dicta todo un alegato contra dicho acto criminal ${ }^{1503}$.

Para acabar estas tragedias, qué decir de las guerras que se llevan, sobre todo en la segunda mitad del siglo, a mozos del pueblo a sitios lejanos y por razones y causas demasiado alejadas de sus oficios, mentalidades y vidas. A pesar de ello, el servicio de armas hizo destacar a algunos de ellos como, por ejemplo, Gabriel Alonso, condecorado en 1840 con la Cruz de distinción María Isabel Luisa por los servicios y méritos contraídos durante la primera guerra carlista, especialmente en la batalla de Peracamps ${ }^{1504}$. Pero no siempre el oficio de la guerra trae consigo oficios y méritos. La paz de la tercera guerra carlista, como antes se ha relatado, es celebrada por todo el pueblo con toros. Al parecer hay muchos hijos del pueblo en los campos de batalla. El desastre de Cuba y Filipinas, o las guerras en África de finales de siglo y primeras décadas del XX, sumen a muchas familias de estos pueblos comarcanos en la mayor de las desesperaciones. En muchas ocasiones son los más pobres los más afectados. En algunos casos porque nunca tuvieron posibilidad de encontrar recomendaciones que los apartaran de los frentes de batalla; en otras porque tuvieron que ir como sustitutos de los más pudientes. Siempre, en cualquier caso, la guerra conmociona al vecindario ${ }^{1505}$.

\footnotetext{
${ }^{1498}$ A.G.D.V. Difuntos, Libro 5, fol. 41.

${ }^{1499}$ A.G.D.V. Difuntos, Libro 6, fol. 187.

${ }^{1500}$ A.G.D.V. Difuntos, Libro 4, fol. 107.

${ }^{1501}$ A.G.D.V. Difuntos, Libro 5. fol. 5vto.

1502 A.G.D.V. Difuntos, Libro 6, fol. 139.

${ }^{1503}$ A.M.M. El Medinense, año IV, no161, fecha: 13/10/1890.

${ }^{1504}$ A. F. H. R. s/c.

${ }^{1505}$ Los años de 1897 y 1898 son difíciles. A Juan Díaz, por ejemplo, se le cae el mundo encima. Tiene a su hijo Celestino sirviendo en el ejército de la isla de Cuba y trata, argumentando su pobreza, de evitar que su otro hijo, Marcos Díaz de Rojas, sea alistado como soldado. Lo mismo argumenta Perfecto Rebollo. También tiene a otro hermano sirviendo en Cuba; Raimundo Santos también alega ser hijo de viuda pobre y tener a su hermano Juan sirviendo en caballería. En el expediente, por último, de Julián Martínez puede leerse: "Resultando probado la pobreza de su madre Tomasa Higuera
} 


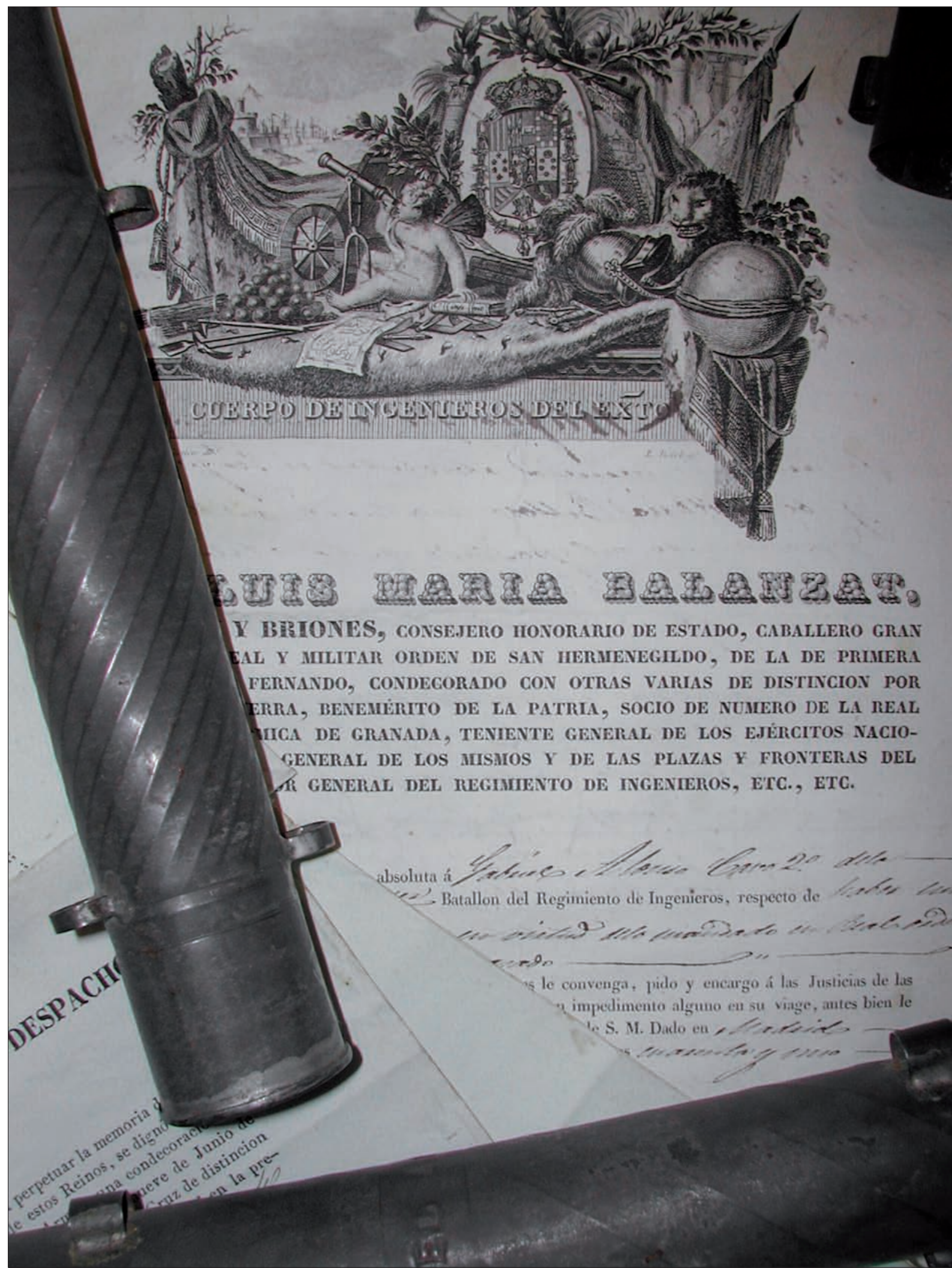

Imagen 97. Despacho de condecoración al vecino de Serrada Gabriel Alonso por sus méritos en la batalla de Peracamps, en la primera guerra carlista. (Archivo familia Hidalgo Román). Salvo excepciones, como el despacho que reproducimos, la participación obligatoria de jóvenes que debían integrarse en el ejército trajo consigo desasosiego y dolor, al margen de la pérdida de jornales al seno familiar, siempre vitales en el caso de jornaleros y pequeños propietarios. 


\section{d. Mirando al futuro. La necesidad de carreteras y la importancia del agua y de la salud}

Hay que insistir, una vez más, en las ganas de vivir del vecindario de todos los pueblos de la comarca. Si algo se repite constantemente es la capacidad de estos pueblos de Castilla de no rendirse ante fracasos, malas cosechas o muertes difíciles de aceptar. Siempre fue una constante, pero en este siglo XIX, especialmente en su segunda mitad, la preocupación por la salud pública y tratar de combatir las posibles causas que pudieran llevarse a los suyos es permanente. Como lo fue la necesidad de contar con buenas comunicaciones con el exterior.

\section{- Caminos y carreteras. El malogrado intento por conectarse a la red ferroviaria}

En los Ayuntamientos constitucionales del siglo XIX fue continua la existencia de comisiones encargadas de velar por el buen estado de los caminos vecinales comprendidos en cada término. En estas tierras del norte de Medina la saca del vino necesitaba de buenas comunicaciones y todas las facilidades que pudieran darse a los arrieros para que llegasen con comodidad a estos pueblos eran pocas. No obstante, la llegada del ferrocarril iba a revolucionar el transporte de mercancías y Serrada, La Seca, Rueda o Tordesillas se iban a afanar por no quedarse atrás de los nuevos sistemas de transporte. Hasta entonces había sido costumbre inmemorial de los concejos o Ayuntamientos el velar por el buen estado de caminos y calles. Salvo casos excepcionales, las reparaciones de estas vías se llevaban a cabo por turnos, previa aprobación por el Ayuntamiento, generalmente en las madrugadas de algunos días festivos fijados en pleno, aportando las yuntas y carros los labradores y esparciendo y afirmando los materiales los braceros locales.

En las distintas décadas de la segunda mitad de la centuria se observa un inusitado interés por parte de los Ayuntamientos y Diputaciones por no quedarse al margen de las nuevas carreteras, mejora de los viejos caminos y petición de nuevos trazados de ferrocarriles, como remedio para solucionar sus problemas. Si Medina del Campo cambia el rumbo de su actividad agraria por otra más diversificada gracias al ferrocarril, La Seca, Rueda, Serrada, Villanueva o Tordesillas, se afanan por crear comisiones, debatir y solicitar aquí y allá ramales férreos por donde drenar sus producciones y evitar quedar aislados. Cuando el sueño del ferrocarril se evapore, volverán sus ojos a la Diputación Provincial, solicitando comunicaciones tanto para conectar con las estaciones más cercanas como para aliviar, ya en el último tercio del XIX, la penosa situación del cada vez más abundante paro obrero.

Los Ayuntamientos y sus vecindarios son conscientes del tren que pueden o no tomar, del cambio que se está gestando, de la encrucijada, en fin, que representan estos ańos. Serrada, por ejemplo, protesta por la modificación del proyecto de la carretera de Tordesillas a Mojados e Íscar, aprobado en 1864, porque se ha "variado la dirección del camino de una manera inconveniente con notabilísima desventaja para los intereses del municipio", 1506 o se suma al proyecto de construcción de un tranvía que propone La Seca como una necesidad de conectar directamente con los mercados del norte y facilitar la saca de sus vinos ${ }^{1507}$ :

"En la villa de Serrada a doce de enero de mil ochocientos setenta y tres, reunido el Ayuntamiento en la Sala capitular bajo la Presidencia del Sr, Alcalde D. Agapito de Íscar,... por consecuencia de haber concebido la Corporación municipal de la Seca el proyecto y propósito decidido de construir en tranvía que partiendo de dicha villa enlace con la línea general del Norte, en la Estación de Valdestillas, para cuya construcción se ha

García, de estado viuda a la que mantiene, no teniendo más hermanos que otro llamado Cipriano sirviendo por su suerte en el Batallón expedicionario de Burgos, no 35, en el Ejército de la Isla de Cuba, el Ayuntamiento ... le considera comprendido en el caso $3^{\circ}$ del artículo 87 de la Ley, pero como quiera se halle pendiente de la certificación de existencia de su mencionado hermano... le declara Soldado a reserva de lo que la comisión mixta resuelva en su día...”

A.M.S., caja 3, carp. 44, fol. 13 y ss.

1506 A. M. S., caja 1, carp. 12, sesión de 18 de marzo de 1866.

${ }^{1507}$ A. M. S., caja 1, carp. 19, fol. 1, año 1873. 
ofrecido una casa inglesa costeando todos los gastos pero a condición que este pueblo de su parte coopere en aquello que este de su parte, enterado el Ayuntamiento de las explicaciones dadas por dicha comisión... cuyo tranvía se ha de aumentar el tráfico y se desenvolverán las artes e industrias,... se acordó acceder a tan buenos deseos y elevado pensamiento, ofreciendo esta Corporación todo su apoyo moral pero sin comprometer en nada los intereses materiales, públicos ni privados...”

En la mente de todos estaban las positivas repercusiones que generó la llegada del ferrocarril a Medina del Campo en el verano de 1860. Serrada, La Seca, Nava y Rueda ven en los caminos de hierro mayores posibilidades para expedir sus caldos y de ahí sus esfuerzos por enganchar con lo que entonces representa el camino del progreso. No en vano desde 1850 las distintas autoridades, con publicaciones periódicas en los Boletines Oficiales de la provincia, han insistido en lo indispensable de tal avance. En febrero de 1850, Mariano Miguel de Reinoso, al frente de la Comisión Regia para la Inspección General de la Agricultura del Reino, había exaltado la importancia de estas obras públicas. Manifiesta que "El porvenir de esta Castilla al norte del Guadarrama, depende principalísimamente del ferrocarril de Santander" y que con ello "tendrá superioridad en todos los mercados, hasta sobre los surtidos de Odesa y de los Estados Unidos; pero sin ese ferrocarril, Castilla se verá reducida antes mucho de cultivar únicamente pan que ha de comer en sus provincias centrales, pues que las de la costa lo recibirán más barato del extranjero"1508.

Alcaldes, diputados provinciales y prohombres regionales ven en estos proyectos de comunicaciones la mejor solución para impulsar las economías locales, dar trabajo en los meses invernales a los braceros parados y satisfacer por encima de todo a sus electores. Otra cosa es la falta de presupuestos que retrasan muchos de los caminos vecinales proyectados o la falta de viabilidad de tantos proyectos ferroviarios sońados. Baste señalar que en 1872 los regidores locales denuncian los retrasos en las obras de la carretera de Serrada a Tordesillas que "desde el año 1868 ha que están paralizadas con grave perjuicio de los pueblos obligados a transitar por dicha carretera"1509. Hasta 1875 el informe provincial no recoge como construida la carretera de Matapozuelos a Tordesillas por Serrada. Otro tanto sucede en 1893 con el proyecto de carretera Serrada-Valdestillas. Como ocurre en la mayor parte de los pueblos de la comarca, a la necesidad ya comentada de dotarse de buenas comunicaciones se une, en estos últimos ańos del siglo, la acuciante necesidad de contar con jornales en invierno para paliar el hambre de los braceros sin trabajo ${ }^{1510}$.

Otro tanto ocurre con los nuevos proyectos ferroviarios propuestos por la Diputación Provincial en 1888, muchos de los cuales todavía siguen como proyectos en 1904. El interés de Tordesillas, Rueda o La Seca por conectarse con la red nacional vuelve a ponerse de manifiesto. En octubre de 1904 Serrada llega a ofrecer de forma gratuita a la Diputación los terrenos necesarios para la línea Valladolid-Toro y 3.000 pts por cada kilómetro que discurra por el término. Era demasiado tarde.

\section{- La preocupación por la salud pública. La importancia del agua. El alejamiento de los cementerios de las poblaciones}

Los concejos locales siempre velaron por el buen uso de fuentes, pozos y lavajos públicos. El agua fue fundamental para cosechas, ganados y poblaciones. Los cementerios estaban llenos de vecinos por el mal estado de las aguas o la falta de salubridad del municipio. La reunión de Ayuntamiento de 1846, en sesión de tres de enero, parecía seguir la máxima de que es mejor prevenir que curar ${ }^{1511}$ :

${ }^{1508}$ B.O.P.V. no 23, fecha: 21 de febrero de 1850.

${ }^{1509}$ A.M.S., caja 1, carp. 18, fol. 19.

${ }^{1510}$ El Ayuntamiento de Serrada, en octubre de ese año, se dirige a los diputados provinciales del distrito, a saber, Tomás Bayón, García Lorenzo, Segundo Cantalapiedra y Anastasio Bachiller, con objeto de impulsar la construcción antes citada, argumentando tanto las ventajas de tan necesaria obra, como la ayuda a los braceros que previsiblemente carecerán de jornales durante el invierno a consecuencia del pedrisco que había destrozado el viñedo un mes antes. (A.M.S., caja 1, carp. 3, fol. 38).

${ }^{1511}$ A.M.S., caja 1, acta de 3 de enero de 1846. 
"Atendiendo al poco orden que se observa por el vecindario tanto en verter estiércol y aguas de todas las clases en las calles del pueblo, así como también en el amontonar dicho estiércol dentro del radio y en las inmediaciones de la población, en perjuicio notorio de la salud, se acordó limpiar las calles, quitar los basureros y hacerles a distancia de doscientos pasos del pueblo, no contándose para ello con las fincas de propios pues estas han de quedar también enteramente limpias como las calles y caminos...”.

Toda precaución era poca. En febrero de 1856, por ejemplo, el Ayuntamiento acuerda "se fijen bandos en los sitios de costumbre prohibiendo de labar las ropas de todas clases en el labajo titulado Balondo de esta jurisdicción para evitar los perjuicios que puede sobrevenir a los ganados... "\$112. Este año también se acuerda crear un partido de médico y otro de cirujano y "medicinas necesarias para los pobres”. Aunque siempre hubo distinciones en la atención que prestaban médicos o cirujanos, según se tratase de pudientes hacendados o menesterosos braceros, y notables diferencias entre unos y otros en sus posibilidades por proveerse de medicinas, lo cierto es que desde la segunda mitad del siglo los municipios, ante la falta de fondos, regulan y reparten entre el vecindario las cargas de estos servicios. Los 8.000 reales de 1857 que costaba la plaza de médico cirujano de Serrada se pagaban aportando los fondos municipales 2.000 reales y el vecindario, los 6.000 reales restantes "con exclusión de la clase pobre"1513. Pero como se puede deducir de lo comentado, ya entonces se seguía el aforismo de que es mejor prevenir que curar. Tanto Serrada como San Martín del Monte fueron siempre conscientes de lo valioso de sus prados, pero también de lo peligroso para la salud de las insanas charcas que albergaban. La limpieza de cauces, zanjas de desagüe y lavajos fue siempre una de sus máximas preocupaciones ${ }^{1514}$.

Los informes sanitarios son vigilantes de las condiciones higiénicas del matadero, de la carencia de aguas potables al estilo de las nuevas canalizaciones y surtido de aguas en las pujantes ciudades; de la necesidad de vigilar alimentos, de la conveniencia de no abusar de las bebidas alcohólicas, de la falta de oficina de farmacia,... ${ }^{1515}$. No tardan los responsables municipales en atender estas deficiencias. En 1883 se acuerda la construcción de un nuevo matadero, toda vez "que el que hoy existe no reúne las condiciones de salubridad e higiene que deben tener esta clase de establecimientos" 1516.

${ }^{1512}$ A.M.S., caja 1, carp. 7, fol. 10.

${ }^{1513} \mathrm{El}$ Ayuntamiento formalizaba para su cobro igualas anuales subdividiendo a los vecinos en siete clases que pasaban de los 70 reales anuales que aportaban los siete vecinos más pudientes que formaban la primera, hasta los 22 reales que satisfacían los 22 vecinos de séptima clase o los 12 reales que debían pagar las últimas viudas en la lista por el Ayuntamiento. El resto del vecindario, consignado en lista de familias pobres con derecho a asistencia facultativa gratuita, también debía atenderse a cargo de dichos fondos municipales.

${ }^{1514}$ A finales del XIX, Serrada sigue cuidándose mucho de tales peligros. El informe al efecto que elabora en septiembre de 1879 Enrique Rodríguez, médico titular de la villa, y del que se da lectura en sesión plenaria, bajo presidencia de Valentín de Íscar, vuelve a incidir, como principal causa de insalubridad del municipio, la existencia de charcas de aguas detenidas y descompuestas que influyen fatalmente en el curso de las dolencias comunes y desfavorablemente en la salud en general. El relato del médico es claro al respecto: "Numerosas son las causas de insalubridad existentes en esta localidad... La más grave de todas, la que con invariable constancia influye perniciosamente en la salud de todos los habitantes (es) la existencia de pantanos o charcas de aguas detenidas y descompuestas, causa eficiente de la enfermedad palúdica en sus variadas formas... (También) Se hace preciso que por su Autoridad se dicten las oportunas órdenes para impedir el fácil acceso por las calles del pueblo de las aguas de lluvia, evitando su estancación...

Es indispensable la construcción de un local en el cementerio con destino a depósito de cadáveres y sitio de autopsias. Debe de existir método y orden en el modo de verificar las inhumaciones, sujetándose a medidas fijas las aberturas de fosas.

Los cadáveres de animales ya que no sepultados colóquense lejos de poblados, idénticas reglas deben seguirse en la situación de estercoleros y muladares.

Es uno de los datos que sirve para medir la cultura de un pueblo la existencia de plantaciones, dispone esta villa de privilegiados terrenos para arbolado; consiguiéndose el doble objeto de sanear aquellos y purificar el aire...”. (A.M.S., caja 2, carp. 26, fol. 12).

1515 GIGOSOS, P. y SARAVIA, M.: El surtido de aguas a Valladolid: de la concesión a la municipalización (18641959). Ayuntamiento de Valladolid, 1992.

${ }^{1516}$ A.M.S., caja 2, carp. 29, fol. 22 y ss. 
$\mathrm{Al}$ año siguiente, dada cuenta de la circular del Gobierno Civil al respecto, se acuerda el inicio de gestiones para alzar un nuevo cementerio, dado que el existente carece de "las condiciones higiénicas por hallarse situado a menos de medio kilómetro de esta localidad," al tiempo que se crea una plaza de sepulturero y se dictan normas precisas en relación a entierros y sepulturas ${ }^{1517}$.

A pesar de estas actuaciones y esfuerzos, los siguientes ańos no van a ser nada buenos. Muchos proyectos tardarán décadas en concretarse. A la crisis agrícola y pecuaria que se extiende por todo el país, sembrando de parados y mendigos campos y ciudades, se unirá el estrago general que causa el llamado cólera morbo. Todas precauciones son pocas. A la par que el Boletín de la Provincia difunde circulares preventivas y avisos sanitarios, las autoridades locales se cuidan de que no existan basuras en las inmediaciones de la población, de que se ponga "una puerta trampa al pozo de aguas buenas" para evitar riesgos, se adquieran desinfectantes y se difundan bandos para cuidar al máximo la higiene personal. La muerte, como tantas veces se ha relatado, seguía presentándose de improviso y con demasiada frecuencia en la mayor parte de las familias.

Aunque la ciencia había extendido notablemente sus prácticas médicas en este siglo XIX, la vida seguía pendiente de un hilo en la mayor parte de las poblaciones. De ahí el celo de autoridades y vecinos por alejar en lo posible cualquier riesgo. En 1890 siguen, como en anteriores épocas, acordando "dar principio los trabajos de limpieza y saneamiento de las zanjas de los prados del común de vecinos”, bien es verdad que acompañando estas prácticas con un gusto por el embellecimiento del entorno que anteriormente no se había detectado ${ }^{1518}$ :

\footnotetext{
"Acto seguido se acordó la plantación de arbolado en las orillas de los prados e inmediaciones de las zanjas de los mismos, con objeto ver si por este medio se consigue mejorar las condiciones higiénicas de esta localidad, tan propensa al desarrollo del paludismo, al propio tiempo que contribuirá al embellecimiento y ornato de las afueras...”
}

A comienzos de 1891, y para cumplir el anterior acuerdo, se solicita a la Comisión Provincial árboles para llevar a cabo la plantación "en las cuatro salidas de las dos carreteras que cruzan esta villa". El once de marzo de este año y en relación con las continuas quejas del vecindario sobre los peligros que entrańaba la cubierta y pilares que protegían al secular Pozo Bueno, tan frecuentado por todos para aprovisionarse de agua, se decide remozar la vieja estructura que le protegía de la intemperie ${ }^{1519}$ :

\footnotetext{
"Seguidamente se acordó, en vista del estado inminente de ruina en que se encuentra la cubierta y pilares que cubren el pozo de aguas potables de que se surte este vecindario, y con el fin de evitar que ocurra alguna desgracia en las personas que de citado pozo concurren con el objeto de sacar agua, se proceda al derribo de indicados pilares y cubierta, reconstruyéndoles... con toda la solidez posible...”
}

Unos días más tarde se adjudicaban las obras en sesión ordinaria para llevar a cabo el anterior acuerdo $^{1520}$

\footnotetext{
"Seguidamente se acordó ordenar a los maestros albañiles Domingo de la Fuente y Hermógenes Herrero, procediesen sin pérdida de tiempo a la demolición de los pilares y cubierta del pozo de aguas potables de que se surte este vecindario así como a la reconstrucción de los mismos.”
}

La salud de los vivos también depende de cómo y dónde estén enterrados los fallecidos. Distintas disposiciones reales sacan los cementerios de las iglesias y los alejan definitivamente de las poblaciones, con objeto de evitar la propagación de posibles contagios. En 1857, para dignificar el camposanto

\footnotetext{
${ }^{1517}$ A.M.S., caja 2, carp. 29, fol. 84.

1518 A.M.S., caja 3, carp. 34, fol. 16.

${ }^{1519}$ A.M.S., caja 3, carp. 35, fol. 15.

${ }^{1520}$ A.M.S., caja 3, carp. 35, fol. 16.
} 
construido fuera del casco urbano, en el camino al Pinar y que, en palabras de los regidores locales, se hallaba en un estado deplorable, se acuerda destinar distintos derechos y rentas municipales para su arreglo. Como en otras ocasiones, la aportación colectiva en dineros y trabajos es fundamental. En este año serán "los labradores y braceros del campo... a que por turnos contribuyan los primeros con sus ganados y carros para el acopio de materiales y los segundos con sus personas y herramientas en los días que durase la obra... "1521. La movilización del pueblo nunca se hizo esperar en lo tocante a los principios religiosos y de moralidad propios de cada época. La recogida de las cruces de las eras del Calvario es otro ejemplo ${ }^{1522}$.

Similar preocupación observamos en estas décadas por conservar el paisaje que formaban campos, prados, fuentes y arboledas y dejar intactos a sus hijos los caminos, veredas y cańadas por las que transitaron sus antepasados. Debemos, en este sentido, citar la reunión extraordinaria de Ayuntamiento del nueve de junio de 1883 en que se mostraba el más hondo pesar por la pérdida en incendio de una monumental olma situada al pago del mismo nombre. O las denuncias y juicios por extraer piedras y materiales en los antiguos despoblados. Se desvivieron por mantener intacto el legado histórico de sus antepasados y, en este final de siglo, se constata un especial interés por aquellos aspectos festivos y de ocio que, desde entonces, se caracterizan por su regularidad. Ejemplos de ello es la construcción en 1894 de las dos aletas del frontón o juego de pelota "para facilitar mayores ventajas a tan saludable e higiénico juego... "1523, las contrataciones de dulzaineros para alegrar la función de la Virgen de la Moya, las representaciones teatrales a cargo de los jóvenes de la villa, etc., etc. ${ }^{1524}$.

\section{- El permanente interés por disponer de maestro de primeras letras. La escuela de nińas}

Aunque no siempre los fondos públicos albergaron dineros para tantos gastos, siempre los regidores trataron de que no faltaran recursos para atender el aprendizaje de las cuatro reglas. El aumento de vecindario y el cambio de costumbres en este siglo XIX trajeron consigo nuevas necesidades. En 1856, siendo alcalde Guillermo García, el Ayuntamiento siente "de la mayor necesidad la creación de una escuela pública de Instrucción primaria para educar las niñas en esta villa". Al parecer, las anteriores corporaciones municipales no habían podido culminar la "ilustrada" idea del gobierno por falta de recursos, local y fondos. Este año se solicita para tal propósito "el local que hay

${ }^{1521}$ A.M.S., caja 1, carp. 8, fol. 15.

${ }^{1522}$ Recibían este nombre por albergar las cruces de piedra del Vía Crucis existente en dichas eras que, como ya se ha dicho, pertenecían a los propios del concejo. El itinerario sagrado se iniciaba, saliendo desde la iglesia Parroquial, en la cruz hoy existente en la era del señor Valentín Alonso, a la salida del camino a Valdestillas, enfrente de su casa del Hospital de la Resurrección y mirando al convento de San Pablo. Continuaba por dicho camino hasta tomar, girando a la izquierda, el sendero que, entre las eras y sembrado de cruces, atravesaba el camino a Valladolid. En este lugar se levantaba la estación de las Tres Cruces o Calvario propiamente dicho, para continuar, por detrás de las eras, hasta el viejo cementerio. En 1874 se recogen de forma solemne y tras reunión de Ayuntamiento: "Acordaron que se recojan las Cruces de piedra o los restos que de ellas existan procedentes de un Calvario o Vía Crucis que alrededor de las eras que pertenecieron a estos Propios se hallan diseminadas y cuyas cruces o sus restos sean depositados en el cementerio de esta villa o atrio de la única iglesia Parroquial como sitios de reverencia por el sagrado carácter de que se hallan investidos, y en cuanto a las peanas o sustentáculos queden colocadas en sus respectivos sitios como recuerdo de la piedad de nuestros padres en anteriores siglos...”. (A.M.S., caja 2, carp. 20, fol. 36).

${ }^{1523}$ A.M.S., caja 3, carp. 39, fol. 13.

${ }^{1524} \mathrm{El}$ final del texto entresacado anteriormente vela, igualmente, por la conservación de la memoria y las tradiciones de sus padres y abuelos. Si volvieran a la vida, es muy posible que dijeran respetuosamente que sigue siendo posible la convivencia entre el progreso y la tradición. Que ellos ya lo hicieron. Y que cada vez que se corta un árbol centenario que ellos plantaron, cada vez que se tiran fachadas de buena fábrica que ellos levantaron, cada vez que se roban metros a cańadas, pinares o prados que ellos tanto defendieron, cada vez que no se restauran debidamente los campos tras la extracción de gravas..., no son ellos ni los actuales moradores los que pierden. Dirían que van a ser los jóvenes los que más van a sentirlo. Advertirían de que serán los descendientes de los que ahora viven los que pedirán explicaciones de lo que hoy no se ha sabido conservar debidamente. 
en el casco de esta población y su calle del Pozo, el cual lo es una panera titulada la Cilla, que perteneció a la Fábrica de su unica Iglesia Parroquial, hoy del Estado, por virtud de la Ley de Desamortización de $1^{\circ}$ de mayo último..." ${ }^{1525}$ Por fin, en el Boletín Oficial pudo leerse ${ }^{1526}$.

"Se ha creado escuela de niñas en Serrada, con la dotación de mil cien reales anuales, casa, y las niñas pagan mensualmente cincuenta céntimos las de primeros conocimientos; un real las de leer y costura y dos las que reciban mayor instrucción. Valladolid, 30 de junio de 1857".

Los regidores locales aceptarán la única solicitud presentada para ocupar tal plaza. Serrada también tendrá maestra ${ }^{1527}$. Tomado el acuerdo, se avisaba anticipadamente a los profesores y a la Junta local de Instrucción Primaria para su conocimiento. Pero a pesar de todo, y como por entonces era característica general en todo el país, el analfabetismo era muy elevado, especialmente entre las clases más pobres, cuyas hijos debían atender primero a las penurias de las familias y después a las bondades de la ilustración. De ahí que el Ayuntamiento, a instancias del Cura Párroco de la villa, y "amante de la instrucción de sus convecinos y teniendo en cuenta los beneficios que ha de reportar a la cultura de esta localidad" acuerde ceder el Salón de Sesiones para que se establezca una "Escuela Pública católica nocturna de adultos" ${ }^{1528}$. Con todo, y como consecuencia del aumento de población, se tratará en 1893 y 1894 sobre la ampliación de las escuelas o la construcción de unas nuevas. Tras no pocas deliberaciones, se acordará en julio de este último año, siendo alcalde Perfecto Moyano Zamora, solicitar la construcción de un nuevo edificio, adquiriendo para ello las eras de Mercedes Martín, viuda de Juan Paulino Moyano, hermano del citado alcalde y situadas "en la parte más elevada e higiénica de la localidad"1529/1530. La falta de presupuesto, sin embargo, dilatará estas y otras necesidades. En las primeras décadas del siglo XX, buena parte de lo expuesto en este epígrafe, continuará debatiéndose entre la necesidad y la falta de recursos para llevarlo a cabo, sean las escuelas, el cementerio o el camino a Valdestillas.

Cuanto se trata, en fin, es norma general en la mayor parte de los pueblos castellanos de final de siglo. Y cuantas necesidades y proyectos tratan de acometerse deben enmarcarse en un contexto general de crisis que se alarga en las primeras décadas del siglo XX sin encontrar una salida satisfactoria para ninguna de las partes. Es el principio del fin del mundo rural tradicional, a las puertas de un nuevo siglo.

${ }^{1525}$ A.M.S., caja 1, carp. 7, fol. 24.

${ }^{1526}$ B.O.P.V. no 130 y A.M.S., caja 1, carp. 8, fol. 11.

1527 Se llama María Cruz Platón. Previa autorización del gobernador provincial, la instrucción en estos años era pagada y controlada por los propios ayuntamientos, encargados de facilitar local, materiales y casa a los maestros. En ocasiones, como sucede en 1865, y para evitar el pago de rentas, se habilitará una habitación como casa junto al salón de plenos del mismo ayuntamiento al maestro de niños y el celo por parte de alcaldes y concejales, en relación al aprendizaje de los escolares, lleva, tal como sucede en 1889, a acordar municipalmente la realización de exámenes para comprobar los conocimientos adquiridos por los niños. (A.M.S., caja 3, carp. 32, fol. 35).

${ }^{1528}$ A.M.S., caja 3, carp. 36, fol. 3.

${ }^{1529}$ A.M.S., caja 3, carp. 39, fol. 26 y ss.

${ }^{1530}$ A.M.S., caja 3, carp. 41, fol. 1. 